UNITED STATES DEPARTMENT OF THE INTERIOR-

J. A. Krug, Secretary

- GEOLOGICAL SURVEY

W. E. Wrather, Director

Water-Supply Paper 992

BIBLIOGRAPHY AND INDEX OF

PUBLICATIONS RELATING TO GROUND WATER

PREPARED BY THE GEOLOGICAL SURVEY

AND COOPERATING AGENCIES

By

GERALD A. WARING and OSCAR E. MEINZER

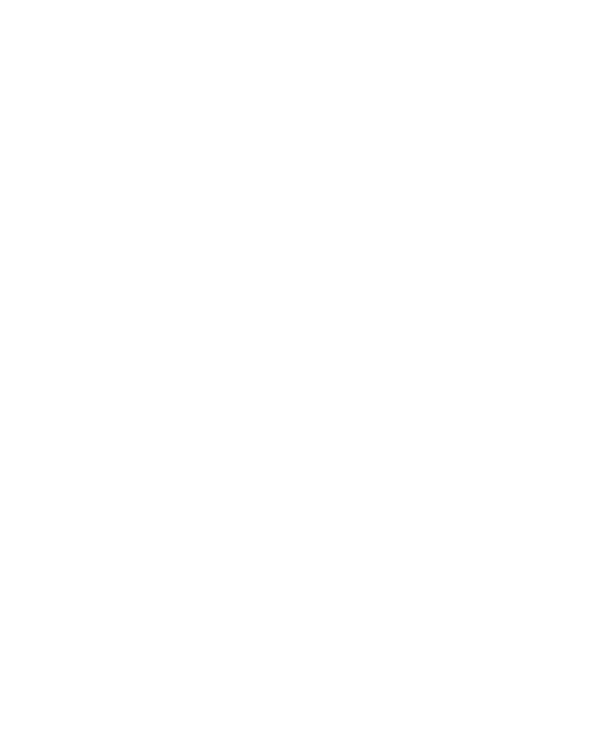

UNITED STATES

GOVERNMENT PRINTING OFFICE

WASHINGTON : 1947 


\section{CONTENTS}

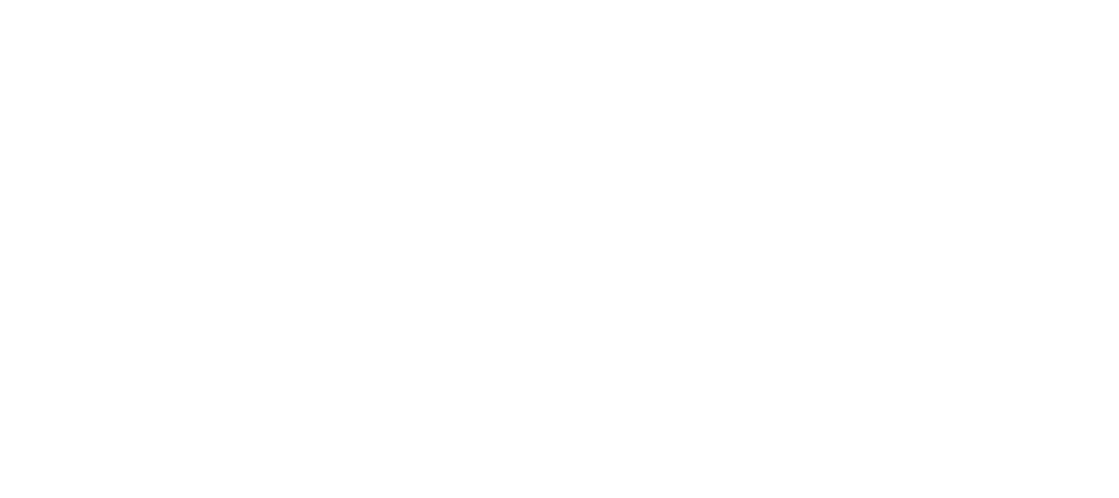

II 


\title{
BIBLIOGRAPHY AND INDEX OF PUBLICATIOI'S RELATING TO GROUND WATER PREPARED BY THE GEOLOGICAL SURVEY AND COOPERATING AGENCIES
}

\author{
By Gerald A. WARING AND OSCAR E. MEINZER
}

\section{INTRODUCTION}

The work of the Geological Survey includes investigations of the natural water of the United States, both that which occurs above and that which oceurs below the land surface. The water below the surface' is known as subsurface, subterranean, underground, or ground water. According to the present usage of the Geological Survey the water that occurs below the surface in zones of saturation is called ground water; this is the water that is recovered through wells and springs. It is to this water trat the present bibliography applies.

In 1885 the Geological Survey published a paper by T. C. Chamberlin entitled "The requisite and qualifying conditions of artesian wells." Aside from this well-known paper it published practically nothing on the subject of ground water during the first 10 years after its organization in 1879 except "Lists and analyses of mineral springs," by A. C. Peale; annual statistics on t] $1 \cong$ production of mineral water, by - A. C. Peale; and papers on the hot springs of Yellowstone National Park, by W.H. Weed and by F. A. Gooch and J. E. Whitfield.

In 1888, by act of Congress, the Geological Survey undertook irrigation investigations in the arid regions of the United States, which soon led to the problem of irrigation with artesian water. The Eleventh Annual Report, published in 1891, contains a section on artesian irrigation on the Great Plains and records of wells in seven western States. In the Thirteenth Annual Report, published in 1893, there is a discussion by F. H. Newell on the occurrence and quantity of ground water in arid regions, with statiștics on artesian wells and irrigation with well water in the United States. The need for more detailed information on the ground water of the country became evident and resulted in a number of investigations. The first report dealing exclusively with eastern conditions was a paper by W J McGee entitled "Potable witers of eastern United States," published in $\mathbf{1 8 9 3 .}$ 
In 1895 Congress made the first of the annual "Stream gaging" appropriations, which include provision for "the investigation of underground currents and artesian wells." Systematic surveys of the ground-water resources of the United Stater were begun soon after the enactment of the first of these appropriations. In 1903 the Division of Hydrology was organized to conduct the ground-water work. It was a division in the Hydrogrephic Branch. N. H. Darton was placed in charge of the work in the West and M. L. Fuller in charge of the work in the East. In 1906 the $\mathrm{Hy}$ drographic Branch became the Water Resources Branch, and the Division of Hydrology became the Ground Water Division. From 1908 to 1912 the Ground Water Division was in charge of W. C. Mendenhall, and from July 1, 1912, to December 1, 1946, it was in charge of 0 . E. Meinzer. Since that time it has beer in charge of A. N. Sayre.

In 1905 a paper entitled "Bibliographic review and index of papers relating to underground waters published ky the United States Geological Survey, 1879-1904," by M. L. Fuller, was issued as Water-Supply Paper 120.

In 1918 a more extensive compilation entitled "Bibliography and index of the publications of the United States Goological Survey relating to ground water," by $\mathrm{O}$. E. Meinzer, was issued as Water-Supply Paper 427. Like Fuller's bibliography, this includes for each paper listed a brief abstract or notation of its references to ground water. At the time this bibliography was issued a total of 609 papers containing information on the subject of ground water had been published by the Geological Survey in 454 volumes. Of these, 307 papers, in 171 volumes, relate primarily to that subject.

Since 1918 there has been a progressive increase in the funds annually made available for ground-water investigations and a corresponding improvement in the quality of the technical work done. The demand came first from the States, which supplied funds for cooperation. Since 1929 Congress has recognized these needs by making increased appropriations but has restricted the major part of the funds for cooperation with State and municipal governments.

The present volume lists a total of 1,777 papers. including all listed in Water-Supply Paper 427 and 1,168 additicnal papers issued through January 1946. It is therefore in effect a second edition of the 1918 bibliography. Most of the additional papers are based on work done in cooperation with State geological surveys, State engineer offices, and other State agencies concerned with water 
resources. The present volume contains the titles of 919 r'blications of the Geological Survey, about half of which relate primarily to ground water. It also includes the titles of 276 cooperative ground-water reports published by the various States, the Territory of Hawaii, and the Governments of Antigua and Haiti; 209 short reports on ground water, reproduced by the Geological Survey by mimeographing or other duplicating process; and 373 articles relating to ground water written by members of the Geological Survey and published in various scientific, technical, and trade journals.

The preparation of this volume was supervised by 0 . F. Meinzer. Abstracts of the water-supply papers that contain information on ground water from Nos. 427 to 640 , inclusive, were prepared by K. E. Anderson; abstracts of bulletins that contain ground-water information from Nos. 661 to 900 , inclusive, were prepared by C. L. McGuinness; and abstracts of a number of reports issued during 1942-45 were prepared by Miss J. M. Berdan. Nearly all the other abstracts of publications by the Geological Survey issued since 1918 and abstracts of the reports published by cooperating agencies, duplicated reports, and journal artic' ${ }^{\prime}$ s were prepared by G. A. Waring, who also prepared the index with the help of C. E. Jacob. 


\section{HIBLIOGRA PHY}

\section{WATER-SUPPLY PAPERS}

1. Pumping water for irrigation, by H. M. Wilson. 1896. 57 pp., 9 pls.

Describes various pumps and curious and antiquated lifting devices usad chiefly in India and Egypt; engines, windmills, water wheels, and other devices for producing power for lifting water; and storage reservoirs for holding pumped water until needed for irrigation.

2. Irrigation near Phoenix, Ariz., by A. P. Davis. 1897. 98.pp., 31 pls.

Describes ehiefly irrigation with surface waters but also contains some well data and discusses briefly the quantity of underflow (pp. 86-92). For more comrrehensive reports on the region see Water-SupplyPapers 136 and 375-b.

4. A reconnaissance in southeastern Washington, by I. C. Russell. 1897. 96 pp., 7 pls.

Describes the geography and geology, gives some well data, and discusses the artesian eonditions and the irrigation prospects of an indefinite region in southeastern Washington.

5. Irrigation practice on the Great Plains, by E. B. Cowgill. 1897. 39 pp., 12 pls.

Contains directions for constructing reservoirs for pumped well water (rp. 14-19).

6. Underground waters of southwestern Kansas, by Erasmus Hawortl . 1897. 65 pp., 12 pls.

Covers a rectangular area comprising all of Meade County, nearly all of Seward, Haskell, and Gray Counties, and parts of Ford and Finney Counties. Deseribes the physiography, geology, water supplies, and irrigation developments of the area. Discusses the waters of the Dakota sandstone and of the Tertiary formations.

7. Seepage water of northern Utah, by Samuel Fortier. 1897. 50 pp., 3 pls.

Describes the water supplies of Cache Valley and the seepage waters in Ogden Valley. Diseusses the loss of ground water by evaporation, transpiration, an seopage.

8. Windmills for irrigation, by E. C. Murphy. 1897. 49 pp., 8 pls.

Describes the apparatus and methods used in making tests of windmi"ls during the summer of 1896 in the vicinity of Garden City, Kans. Gives the result a of these tests and draws conclusions.

9. Irrigation near Greeley, Colo., by David Boyd. 1897. 90 pp., 21 pls.

Describes the water supplies, irrigation developments, and agricultural practice in the 'valley of Cáche la Poudre River, a tributary of the South Platte. Discusses the legislative and judicial control of the water supplies (including grourd water), the source and disposal of ground water, the use of ground water, the effects of alkali water on soil, pumping of ground water, and artesian wells.

10. Irrigation in Mesilla Valley, N. Mex., by F. C. Barker. 1898. 51 pp.. 11 pls.

Describes primitive methods of irrigation and agriculture employed in the valley of the Rio Grande between Fort Seldon, N. Mex., and El Paso, Tex. Describes pumping for irrigation with windmills and steam engines.

12. Underground waters of a portion of southeastern Nebraska, by N. H. Darton. 1898. $56 \mathrm{pp} ., 21$ pls.

Covers an area that includes Lancaster, Seward, York, Fillmore, Hamilton-Clay, Hall, Adams, Buffalo, Kearney, and Phelps Counties and parts of Salin?, Gosper, and Dawson Countiès. Describes the physiography, geology, and ground waters of the area. and discusses briefly the prospects for obtaining water from deep-seated formations. 
13. Irrigation systems in Texas, by W. F. Hutson. 1898. 68 pp., 10 pls.

Describes and discusses irrigation works and projects in Texas, considering both surface and ground waters as sources of supply. Superseded by Water-Supply Paper 71.

14. New tests of certain pumps and water lifts used in irrigation, by $0 . P$. Hood. 1898. 91 pp., 1 pl.

Discusses the mechanics and efficiency of reciprocating pumpr and of water lifts of various other types.

17. Irrigation near Bakersfield, Calif., by C. E. Grunsky. 189,. 96 pp., 16 pls.

Describes irrigation with surface water and contains also a statement on early pumping from wells for irrigation at Lindsay, San Joaquin Velley, Calif. (p. 94).

18. Irrigation near Fresno, Calif., by C. E. Grunsky. 1898. 94 pp., 14 pls.

Describes irrigation with surface water and contains a brief discussion of the loss of water from Kings River and Fresno Canal and its effect on the water table (pp. 71-79).

20. Experiments with windmills, by T. O. Perry. 1899.97 pr., 12 pls.

Gives data and discusses results of numerous laboratory expnximents with winddriven wheels. Describes the apparatus and methods used.

21. Wells of northern Indiana, by Frank Leverett. 1899. 82 pp., 2 pls.

Gives well data by counties for the northern part of the State and contains two maps of Indiana and western Ohio, showing the character and depth of the glacial drift and its relation to water supplies.

25. Water resources of the State of New York, Part II, by C. W. Rafter. 1899. pp. 105-200, 12 pls.

Discusses chiefy water storage and power and canal project but also contains data in regard to seepage from canals (pp. 159-160, 173-178) and quantities of water yielded by the sand deposits of Long Island (pp. 191-198).

26. Wells of southern Indiana, by Frank Leverett. 1899. 64 pp.

Gives well data by counties for the southern part of the State.

27. Operations at river stations, 1898, Part I, (F. H. Newall, chief hydrographer; B. M. Hall, district engineer, Florida.) 1899. pp. 1-100.

Contains discharge measurements of Silver, Kissingen, Bli' $e_{r}$ and Ichatuckneo Springs, Fla. (p. 45).

28. Operations at river stations, 1898, Part II. (E. H. New grapher; T. U. Taylor, district engineer, Texas.) 189 . pp. 101-200.

Contains discharge measurements of Barton Spring near Arstin, Tex. (p. 130).

29. Wells and windmills in Nebraska, by E. H. Barbour. 189. 85 pp., 27 pls.

Describes home-made windmills, various other water-lifting devices, salt-water wells, and blowing and freezing wells; gives well data and other information in regard to ground water.

30. Water resources of the Lower Peninsula of Michigan, by A. C. Lane. 1899 99 pp., 7 pls.

Discusses the use of water and the effects of quality with respect to the various uses. Describes the geology and ground-water conditions in the area covered.

31. Lower Michigan mineral waters, by A. C. Lane. 1899. 97 pp., 4 pls.

Discusses the economic value of mineral waters and the interpretation and classification of water analyses; contains analyses of water from various geologic formations and generalizations in regard to them: also diseusses squitary conditions of drinking waters. 
34. Geology and water resources of a portion of southeastern South Dakota, by J. E. Todd. 1900. 34 pp., 10 pls.

Covers a rectangular area that includes parts of Turner, Hutchinson, Bmhommo, Yankton, and Clay Counties. Describes the geology and the surface and ground waters with special reference to the artesian water in the Dakota sandstcne, Contains a geologic map and maps showing depths to bedrock, depths to the water at the base of the till, and depths to the artesian water. This area is als covered by Geologie Folios 96 and 97 .

36. Operations at river stations, 1899, Part II. (F. H. Newell, chief hydrographer; B. M. Hall, district engineer, Georgia.) 1900. pp. 101-198.

Contains discharge measurements of 14 springs in Georgia (pp. 147, 148).

37. Operations at river stations, 1899, Part III. (F. H. Newell, chief hydrographer; T. U. Taylor, district engineer, Texas.) 1900. pp. 19^-298.

Contains discharge measurements of Las Moras and San Felipe Springs, Tex. (p. 277).

41. The windmill; its efficiency and economic use, Part I, by E. C. Iurphy. 1901. $72 \mathrm{pp} ., 14 \mathrm{pls}$.

See also Water-Supply Paper 42.

42. The windmill; its efficiency and economic use, Part II, by E. C. Murphy. 1901. pp. 77-147, 2 pls.

Nos. 41 and 42 give a classification of windmills, describe early experirents with windmills and tests made by the writer, describe the apparatus and methods used in making these tests, and discuss the results of the tests.

45. Water storage on Cache Creek, Calif., by A. E. Chandler. 1901. 48 pp., 10 pls.

Contains data in regard to wells and irrigation with ground water near Woodland, Sacramento Valley, Calif. (pp. 23-26).

50. Operations at river stations, 1900, Part IV. 1901. pp. 296-387.

Includes a section on "Computations of seepage in Colorado," pp. 299-306, in which are given data on seepage, chiefly seepage into rivers, and conclusions as to the relation of irrigation to seepage.

52. Operations at river stations, 1900 , Part VI. 1901. pp. 495-575.

Contains a section entitled "Construction of wells in southern Califo-nia," pp. 497-498.

53. Geology and water resources of Nez Perce County, Idaho, Part I, by I. C. Russell. 1901. 86 pp., 10 pls.

See also Water-Supply Paper 54.

54. Geology and water resources of Nez Perce County, Idaho, Part II, by I. C. Russell. 1901. pp. 87-141.

Nos. 53 and 54 relate to an indefinite area in western Idaho including a part of Nez Perce County and to adjacent areas of Washington and Oregon. Ther describe briefly the physiography, geology, soils, water supplies, and mineral resources of the region.

The information on ground water, all of which is given in Water-Surply Paper 54, includes meager data with recommendations in regard to springs, "horizontal wells" or infiltration tunnels, and artesian wells. No. 54 also contairs a short bibliography , of artesian waters.

55. Geology and water resources of a portion of Yakima County, Wash, by G. O. Smith. 1901. 68 pp., 7 pls.

Describes the geography, geology, and surface and ground waters $o^{f}$ an area comprising about 50 square miles in the vicinity of Yakima. Discusses the artesian basins in detail and gives well data. The part of this area west of Yakina is also 
55. Geology and water resources of a portion of Yakima Ciunty, Wash.Continued.

eovered by Geologic Folio 86, which contains a more detailed geclogic map and also contains a discussion of the artesian and other ground-water eonditions.

57. Preliminary list of deep borings in the United States, Pert I (AlabamaMontana), by N. H. Darton. 1902. $60 \mathrm{pp}$.

See also Water-Supply Papers 61 and 149.

58. Storage of water on Kings River, Calif., by J. B. Lippincott. 1902. 101 - pp., 32 pls.

Contains discussions of ground water for irrigation and of alkali conditions and includes records of 854 wells (pp. 22-24, 53-88). Contains map (pl. 5) showing locations of wells listed in the table.

59. Development and application of water near San Bernard:no, Colton, and Riverside, Calif., Part I, by J. B. Lippincott. 1902. 95 pp., 11 pls.

See also Water-Supply Paper 60.

60. Development and application of water near San Bernardino, Colton, and Riverside, Calif., Part II, by J. B. Lippincott. 1902. pp. 96-141.

Nos. 59 and 60 give descriptions of pumping plants and of ground-water supplies. No. 60 contains records of 412 wells in Redlands quadrangle snd of 478 wells in San Bernardino quadrangle. No. $59^{\circ}$ includes a topographic man showing contours of water table, areas of artesian flow in 1897 and 1900, irrigated areas and locations of wells for which records are given.

61. Preliminary list of deep borings in the United States, Part II (NebraskaWyoming), by N. H. Darton. $1902.67 \mathrm{pp}$.

Nos. 57 and 61 contain tabular data in regard to wells and other borings more than 400 feet deep. They give information as to the depths, diameters, and yields of the wells, the head, temperature, and quality of the water, and purposes for which the boring was done. The data are given by States, and the States are arranged alphabetically. The States from Alabama to Montana, inclusive, are covered by No. 57, and the States from Nebraska to Wyoming, inclusive, by No. 61. A revised edition for all States was published in 1905 as Water-Supply Paper 149.

62. Hydrography of the southern Appalachian Mountain region, Part I, by $H$. A. Pressey. 1902. 95 pp., 25 pls.

Contains a paragraph on large springs in the Watauga River basin (p. 82).

66. Operations at river stations, 1901, Part II. $1902.188 \mathrm{pp}$.

Contains a brief description of the springs, flowing wells, and ground-water conditions in the vicinity of Carrizo Springs, Tex. Includes an analysis of the Carrizo Springs mineral water (p. 63).

67. The motions of underground waters, by C. S. Slichter. 1902 . 106 pp., 8 pls.

Discusses the origin, depth, and amount of ground waters the porosity and permeability of rocks and soils; the causes, rates, and laws of the movements of ground water, the surficial and deep zones of circulation, the recovery of water by wells, and the shape and position of the water table. Gives simple methods of measuring the yield of flowing wells. Describes artesian wells at Savannah, Ga.

70. Geology and water resources of the Patrick and Goshen Hole quadrangles, in eastern Wyoming and western Nebraska, by G. I. Adams. 1902.50 pp., 11 pls.

Describes the geology and contains some information on spring: and wells in these quadrangles.

71. Irrigation systems of Texas, by T. U. Taylor. 1902.137 F., 9 pls.

Discusses the principal irrigation systems, giving special attertion to the irrigation of rice. Contains data in regard to numerous springs and artesinn and other wells. 
75. Report of progress of stream measurements for the calendar year 1901, by F. H. Newell.' 1903.246 pp., 13 pls.

Contains records of diseharge of 33 flowing wells in Moxie Valley, near Yakima, Wash. (pp. 204, 205).

77. The water resources of Molokai, Hawaiian Islands, by Waldemar I indgren. 1903. 62 pp., 4 pls.

Describes the geography, geology, and water resources of the island of Molokai, ineluding springs and wells. Describes the occurrence of water in lava and its quality as affected by the sea. Contains a discussion and estimate of the quantity of ground water available for irrigation.

78. Preliminary report on artesian basins in southwestern Idaho ard southeastern Oregon, by I. C. Russell. 1903. 55 pp., 2 pls.

Deseribes briefly the geology of a part of the Snake River plains in Cinyon and Owyhee Counties, Idaho, and Malheur and Harney, Counties, Oreg. Discusses the conditions on which artesian flow depends and describes springs and wolls in the Lewis, Otis, Harney, and Whitehorse artesian basins. Describes artesian wells in alluvial deposits and discusses the size of drill holes, the methods of casing, the preservation of well records, and the importance of laws to govern the use of artesian waters. Gives a list of publications bearing on artesian waters.

84. Report of progress of stream measurements for the calendar year 1902, by F. H. Newell. (T. U. Taylor, hydrographer, Texas.) Part III, Western Mississippi River and western Gulf drainage. 1903. $200 \mathrm{pp}$.

Contains a brief description of Barton Springs, near Austin, Tex. (pr, 152-153). See also Water-Supply Papers 132 and 174.

85. Report of progress of stream measurements for the calendar year 1902 , by F. H. Newell. (N. S. Dils, hydrographer, Idaho; L. H. Taylor, hydrographer, Nevada) Part IV, Interior Basin, Pacific Coast, and Hudson Bay drainage. 1903. $250 \mathrm{pp}$.

Contains 7 discharge measurements of 4 springs in Nevada (p. 126) and discharge measurement of a group of springs in Idaho (p. 216).

89. Water resources of the Salinas Valley, Calif., by Homer Hamlin. 1904. $91 \mathrm{pp}, 12$ pls.

Includes data in regard to ground water and pumping plants, and a m?p showing the area of artesian flow and the areas irrigated with water obtained from wells.

90. Geology and water resources of part of the lower James River Vralley, S. Dak., by J. E. Todd and C. M. Hall. 1904. 47 pp., 23 pls.

Describes the geology, surface waters, and artesian and other ground waters of a rectangular area comprising Davison, Hanson, Sanborn, Beadle, and Miner Counties and parts of Kingsbury, Jerauld, Aurora, and McCook Counties. Includer a geologic map of the area and maps showing areas of artesian flow, depths to Diakota sandstone, head of artesian water, depths to bedrock, and depths to water at the base of the till. The area is also described in Geologic Folios 99, 100, 113, ard 114.

91. The natural features and economic development of the Sandusky, Maumee, Muskingum, and Miami drainage areas in Ohio, by B. H. and M. S. Flynn. 1904. $130 \mathrm{pp}$.

Includes descriptions of numerous public water supplies obtained from wells and springs (pp. 58-124).

98. Report of progress of stream measurements for the calendar yizar 1908, by J. C. Hoyt (M. R. Hall, district hydrographer, Alabama), Part II, Southern Atlantic, eastern Gulf of Mexico, and eastern Micsissippi River drainage. 1904. $313 \mathrm{pp} ., 1 \mathrm{pl}$.

Contains discharge measurements of Big Springs, near Tuscumbia, Alr. (p. 293). 
99. Report of progress of stream measurements for the calendar year 1903, by J. C. Hoyt (E. Johnson, Jr., hydrographer, Missouri; W. G. Russell and G. H. Matthes, hydrographers, Oklahoma), Part III, T'estern Mississippi River and western Gulf of Mexico drainäge. 1904,422 pp, 1 pl,

Contains a description and discharge record of Meramec Spring, near Meramec, Mo. (pp. 235-237) and the discharge records of 16 springs in Okl thoma (p. 321).

101. Underground waters of southern Louisiana, by G. D. Harris, with discussions of their uses for water supplies and for rice irrigation, by M. L. Fuller. 1904. 98 pp., 11 pl.

Describes the geology and ground-water conditions of the area, gives data in regard to artesian wells, and outlines methods of well drilling, pumping, and rice irrigation. Includes 23 analyses of ground water.

102. Contributions to the hydrology of eastern United States, 1903; M. L. Fuller, geologist in charge. 1904. $522 \mathrm{pp.}$

Contains a list of publications of the United States Geological Survey relating to ground water, with special reference to springs. Gives ań account of the organization and of the work of the division of hydrology (ground water). Contains notes on wells, springs, and general water resources, arranged by counties, in the following States:

Maine, by W. S. Bayley, pp. 27-55: Contains records of 224 wel' and 130 springs and analyses of 3 well waters and of 3 spring waters.

New Hampshire, by J. M. Boutwell, pp. 56-72. Contains recorcs of 35 wells and 107 springs and analyses of 9 well waters and 12 spring waters.

Vermont, by G. H. Perkins, pp. 73-93. Contains a table giving data in regard to the water supplies of Vermont towns, contains also 111 partial analyses of waters from wells, springs, streams, and lakes and records of 44 wells and 90 springs.

- Massachusetts, by W. O. Crosby and Laurence LaForge, pp. 94-118. Contains records of 162 wells and 40 springs and analyses of 7 well watiors and 17 spring waters.

Rhode Island, by W. O. Crosby, pp. 120-126. Contains records of 24 wells and 12 springs and analyses of 2 well waters and 3 spring waters.

Connecticut, by H. E. Gregory, pp. 127-168. Contains records of about 470 wells and 84 springs and analyses of 19 well waters and 19 spring waters.

New York, by F. B. Weeks, pp. 169-206. Contains records of 371 wells and 228 springs and analyses of 14 well waters.

Georgia, by S. W. McCallie, pp. 207-237. Contains a table giving data in regard to water suppies of cities and villages in the State. Contains records of 90 wells and 100 springs and a table giving the yields of 14 springs. Includes analyses of water from 1 well and 1 spring.

Florida, by M. L. Fuller, pp. 238-275. Contains records of 242 wells and 43 springs and analyses of 11 well waters and 9 spring waters. Gives the yields of some very large springs.

Alabama, by E. A. Smith, pp. 276-331. Contains notes on nvmerous wells by counties.

Mississippi, by L. C. Johnson and E. C. Eckel, pp. 332-357. Contains records of 265 wells.

Tennessee, by L. C. Glenn, pp. 357-367. Contains records of 78 wells.

Kentucky, by L. C. Glenn, pp. 369-373. Contains records of 16 we'ls and 2 analyses of artesian water.

Arkansas, by A. H. Purdue, pp. 374-388. Contains records of 96 wells and 33 springs and analyses of 3 well waters.

Missouri, by E. M. Shepard, pp. 389-440 Contains records of 105 wells and 112 springs and analyses of 13 well waters and 34 spring waters. Inc'udes brief papers on wells of Joplin and vicinity, by W. S. T. Smith, pp. 404-40?, and the water supply of Livingston County, by R. Hawkins (pp. 410-416).

Minnesota, by C. W. Hall, pp. 441-448. Contains records of about 800 shallow wells, about 200 deep wells, and 76 gprings; includes an analysis of water from a spring at Mankato.

Lower Michigsn, by W. F. Cooper, pp. 489-512. Contains reccrds of 198 wells and 31 springs and analyses of 11 well waters and 15 spring waters. 
104. The underground waters of Gila Valley, Ariz., by W. T. Lee. 19^4. 71 pp., 5 pls.

Describes the topography and geology of the Gila Valley between The-Buttes, 12 miles east of Florence, and the mouth of Salt River; treats of the source, amount, and quality of water in the valley fill and the methods of recovering this water; includes well data and water analyses.

105. The water powers of Texas, by T. U. Taylor. 1904.116 pp., 17 p's.

Gives data regarding Hackberry Springs, 2 miles northwest of Toyah Lake, and Santa Rosa Spring, near Santa Lucia, in Pecos County (pp. 14, 15).

106. Wâter resources of the Philadelphia district, by Florence Bascom. 1904. 75 pp., 4 pls.

Describes the geology and the streams, springs, wells, and public water supplies of an area comprising the Germantown, Norristown, Philadelphia, and Chester quadrangles. Discusses artesian conditions and prospects in the crystallina racks, the Triassic formations, and the formations of the Coastal Plain. The area is also described in Geologic Folio 162, which contains considerable information on ground water.

108. Quality of water in the Susquehanna River drainage basin, by M. 0 . Leighton, with an introductory chapter on physiographic features, by G. B. Hollister. 1904. 76 pp., 4 pls.

Contains analyses of ground waters and discussions of the quality of these waters.

110. Contributions to the hydrology of eastern United States, 1904; M. L. Fuller, geologist in charge. 1905. 211 pp., 5 pls.

Contains the reports in the following list. Most of those covering specific areas do not include any maps.

Description of underflow meter used in measuring the velocity and direction of underground water, by Charles S. Slichter, pp. 17-31.

. The California or "stovepipe" method of well construction, by Charles S. Slichter, pp. 32-36.

Approximate methods of measuring the yield of flowing wells, by Charles $S$. Slichter, pp. 37-42.

Corrections necessary in accurate determinations of flow from vertical well casings, from notes furnished by A. N. Talbot, pp. 43-44.

Experiment relating to problems of well contamination at Quitman, Ga.. by $\mathrm{S}$. W. MeCallie, pv. 45-54.

The new artesian water supply at Ithaca, $N$. Y., by F. L. Whitney, pp. 55-64.

Drilled wells of the Triassic area of the Connecticut Valley, by W. H. C. Pynchon. pp. 65-94.

Triassic rocks of the Connecticut Valley as a source of water supply, br M. L. Fuller, pp. 95-112.

Spring system of the Decaturville dome, Camden County, Mo., by E. M. Shepard, pp. 113-125.

Water resources of the Fort Ticonderoga quadrangle, Vt. and N. Y., by T. N. Dale, pp. 126-129.

Water resources of the Taconic quadrangle, N. Y., Mass., and Vt., $F$ F. B. Taylor, pp. 130-133.

Water resources of the Watkins Glen quadrangle, N. Y., by R. S. Tarr, pp. 134-140. The ground-water conditions of this quadrangle are described mcre fully in Geologic Folio 169.

Water resources of the central and southwestern highlands of New Je-sey, by Laurence La Forge, pp. 141-155.

Water resources of the Chambersburg and Mercersburg quadrangles, Pa., by G. W. Stose, pp. 156-158. The ground-water conditions of these quadrangles are deseribed more fully in Geologic Folio 170.

Water resources of the Curnwensville, Patton, EHensburg, and Barnesboro quadrangles, Pa., by F. G. Clapp, pp. 159-163. The ground-water conditions of the Barnesboro and Patton quadrangles are also briefly described in Geologic Filio 189 , and those of the Ebensburg quadrangle in Geologic Folio 133. The ground waters of 
110. Contributions to the hydrology of eastern United States, 1904-Continued.

the Curwensville, Barnesboro, and Patton quadrangles are alsc briefly described in Bulletin 531 d.

Water resources of the Elders Ridge quadrangle, Pa., by $R$. W. Stone, pp. 1C4, 165. The ground-water conditions of this quadrangle are also described in Bulletin 256 (with geologic map) and in Geologic Folio 123.

Water resources of the Waynesburg quadrangle, Pa., by R. W. Stóne, pp. 166, 167. The ground-water conditions of this quadrangle are also cescribed in Geologic Folio 121.

Water resources of the Accident and Grantsville quadranfles, Md., by G. C. Martin, pp. 168-170. The ground-water conditions of these quadrangles are also described in Geologie Folio 160.

Water resources of the Frostburg and Flintstone quadranglez Md. and W. Va., by G. C. Martin, pp. 171-173.

Water resources of Cowee and Pisgah quadrangles, N. C., by H. S. Gale, pp. 174-176. The ground-water conditions of the Pisgah quadrangle are described also in Geologic Folio 147.

Water resources of the Middleboro-Harlan region of southesstern Kentucky, by G. H. Ashley, pp. 177-178.

Summary of the water supply of the Ozark region in northern Arkansas, by G. I. Adams, pp. 179-182.

Notes on the hydrology of Cuba, by M. L. Fuller, pp. 183-200.

111. Preliminary report on the underground waters of Washington, by Henry Landes. 905. 85 pp., 1 pl.

Describes briefly by counties the deep wells, springs, and municipal water supplies of the State.

112. Underflow tests in the drainage basin of Los Angeles River, by Homer Hamlin. 1905. 55 pp., 7 pls.

Describes in detail the methods and apparatus used in m7king measurements of the rate and volume of underflow and gives the results of underflow tests made in the valley of Los Angeles River in 1902 and 1903.

113. The disposal of strawboard and oil-well wastes, by R. L. Sackett and Isaiah Bowman. 1905. 52 pp., 4 pls.

The second part of this paper describes briefly the geology and ground waters of the region about Marion, Ind., and the contamination of rock wells and streams by waste oil and brine.

114. Underground waters of eastern United States; M. L. Frller, geologist in charge. 1905. 285 pp., $18 \mathrm{pls}$.

Contains a paper entitled "Occurrence of underground waters," by M. L. Fuller, pp. 18-40, in which are discussed the source, quantity, and temperature of ground waters, the permeability and storage capacity of water-bearing formations, the recovery of water through springs and wells, the conditions that produce artesian flow and the general ground-water conditions in eastern United States.

Contains also brief reports on ground water in the following States, each of which includes a bibliography.

Maine, by W. S. Bayley, pp. 41-56. Includes analyses of 35 spring waters.

New Hampshire, by M. L. Fuller, pp. 57-59.

Vermont, by G. H. Perkins, pp. 60-67. Includes a sketch map of the State, showing water-bearing deposits and analyses of 3 spring waters.

Massachusetts and Rhode Island, by W. O. Crosby, pp. 68-75.

Connecticut, by H. E. Gregory, pp. 76-81. Includes a sketch map of the State, showing the rock formations.

New York, by F. B. Weeks, pp. 82-92. Includes a sketch map of the State, showing the rock formations.

New Jersey, by G. N. Knapp, pp. 93-103. Includes a sketch map of the State, showing the ground-water provinces, and 5 geologic sections, showing the waterbearing formations of the Coastal Plain.

Pennsylvania, by M. L. Fuller, pp. 104-110. Includes a sketch map of the State, showing the main geologic systems.

Delaware, by N. H. Darton, pp. 111-113. Includes geologic sections showing waterbearing formations. 


\section{Underground waters of eastern United States-Continued.}

Maryland, by N. H. Darton and M. L. Fuller, pp. 114-123. Includes-geologic sections showing water-bearing formations.

District of Columbia, by N. H. Darton and M. L. Fuller, pp. 124-126. Includes geologic sections showing water-bearing formations.

Virginia, by N. H. Darton and M. L. Fuller, pp. 127-135. Includes Peologic sections showing water-bearing formations.

North Carolina, by M. L. Fuller, pp. 136-139.

South Carolina, by L. G. Glenn, pp. 140-152. Includes geologic sections showing water-bearing formations.

Georgia, by S. W. McCallie, pp. 153-158. Includes a sketch map of the State showing areas of artesian flow.

Florida, by M. L. Fuller, pp. 159-163.

Alabama, by E. A. Smith, pp. 164-170. Includes a sketch map of the State showing ground-water conditions.

Mississippi, by L. C. Johnson, pp. 171-178. Includes a geologic sketch map of the State.

Louisiana and southern Arkansas, by A. C. Veatch, pp. 179-187. Includer sketch maps showing ground-water conditions.

Northern Arkansas, by A. H. Purdue, pp. 188-197. Includes a geologic sket.eh map and sections of the area.

Tennessee and Kentucky, by L. C. Glenn, pp. 198-208.

Missouri, by E. M. Shepard, pp. 209-219. Includes sketch maps showing the geology and ground-water conditions of the State.

Iowa, by W. H. Norton, pp. 220-225.

Minnesota, by C. W. Hall, pp. 226-232.

Wisconsin, Northern Peninsula of Michigan, and the portion of Illinois north of of the Carboniferous deposits, by Alfred $R$. Schultz, pp. 232-241. Includes a sketch map of the region showing the outcrops of the "Potsdam" and St. Peter sardstones.

Lower Michigan, compiled from report by A. C. Lane, pp. 242-247. Insludes a geologic sketch map and a section of the area.

Illinois, by Frank Leverett, pp. 248-257. Includes a geologic sketch maj and a section of the State.

Indiana, by Frank Leverett, pp. 258-264. Includes sketch maps of this : State, showing the geology, the depth of the glacial drift, and the relation of wells to depths of drift.

Ohio; by Frank Leverett, pp. 267-270. Includes sketch maps of the State showing the geology, the depths of the glacial drift, and the relation of wells to the depth of the drift.

West Virginia, by M. L. Fuller, pp. 271-272.

116. Water problems of Santa Barbara, Calif., by J. B. Lippincott. 1905. 99 pp., 8 pls.

Deals chiefly with surface waters but contains data on deep city wells and collecting tunnel and analysis of tunnel water (pp. 33-42, 57).

118. Geology and water resources of a portion of east-central Washing ${ }^{+}$on, by F. C. Calkins. 1905. 96 pp., 4 pls.

Describes briefly the geology of the Columbia Plains and the Kittitas Valley, gives information in regard to the streams, springs, and wells, and discusses the artesian prospects.

120. Bibliographic review and index of papers relating to underground waters published by the United States Geological Survey, 1879-1904, by M. L. Fuller. 1905. $128 \mathrm{pp}$.

Lists all papers that contain information on ground water. Gives brief abstracts of these papers in regard to ground water, with page references for papers dealing mainly with other subjects. Contains an index of the papers listed in so far as they relate to ground water.

122. Relation of the law to underground waters, by D. W. Johnson. 1975. 55 pp.

Defines and classifies ground waters and gives common-law rules and $S$ ate leg$\therefore$ islative acts relating to their use. 
123. Geology and underground water conditions of the Jornada del Muerto, N. Mex., by C. R. Keyes. 1905. 42 pp., 9 pls.

Superseded by Water-Supply Paper 188.

127. Report of progress of stream measurements for the calendar year 1904, by M. R. Hall and J. C. Hoyt, Part IV, Southern Atlantic and eastern Gulf of Mexico drainages. 1905. 192 pp., 2 p!s.

Contains discharge measurements of Big Springs, near Albany, Ga. (p. 120), and Cave Spring, Ga. (p. 175).

130. Report of progress of stream measurements for the calendar year 1904, by C. C. Babb and J. C. Hoyt, Part VII, Hudson Bay and northern Mississippi drainage. 1905. 204 pp., 2 pls.

Contains discharge measurement of Giant Springs, near Great Falls, Mont. (p. 192).

131. Report of progress of stream measurements for the calendar year 1904, by M. C. Hinderlider and J. C. Hoyt, Part VIII, Platte, Kansas, Meramec, Arkansas, and Red River drainages. 1905. 203 rn., 2 pls.

Contains a description and discharge record for Meramec Spring, near Maramec, Mo. (pp. 123-125), and Greer Spring, Mo. (pp. 178-179).

132. Report of progress of stream measurements for the calendar year 1904, by T. U. Taylor and J. C. Hoyt, Part IX, Western Gulf of Mexico and Rio Grande drainages. 1905.132 pp., 2 pls.

Contains descriptions of the following springs in Texas: Lipan and Kickapoo Springs near San Angelo (p. 43) ; Barton and Mormon Springs near Austin (pp 44, 45): Toyah Spring, at Toyahville (pp. 121, 122); and Santa Rosa Spring near Fort Stockton (p. 122). Gives discharge of 20 big springs in Texas (p. 127).

133. Report of progress of stream measurements for the calendar year 1904, by M. C. Hinderlider, G. L. Swendsen, and A. E. Chandler, Part X, Colorado River and Great Basin drainages. 1905. 384 pp., 2 pls.

Contains discharge measurements of Heitman's and Monfrena Springs, Nev. (p. 358), and Big Spring, Utah (p. 364).

135. Report of progress of stream measurements for the calendar year 1904, by D. W. Ross, J. T. Whistler, and T. A. Noble, Part XII, Columbia River and Puget Sound drainage. 1905. 300 pp., 2 pls.

Contains discharge measurements of 18 springs in Idaho (pp. 271-273).

136. Underground waters of Salt River Valley, Ariz., by W. T. Lee. 1905.196 pp., 23 pls.

Describes the geology of that part of the valley in which Phcanix and Mesa are situated. Gives well records and discusses the quantity and chemical character of the ground waters, the duty of water for irrigation, and the cost of pumping. Contains maps showing the geology and the position of the water table.

137. Development of underground waters in the eastern coastal-plain region of southern California, by W. C. Mendenhall. 1905. 140 pp., 7 pls.

Describes the geology of that part of the valley in which Phoonix and Mesa are and Santa Ana quadrangles in Los Angeles and Orange Courties. Discusses the effects of development and drought on ground-water levels, contains records of 2,765 wells, and includes maps showing original areas of artesian flow, areas of artesian flow in 1904, ground-water levels, irrigated lands, and locations of wells and pumping plants. Includes also a general map of the "Valley of southern California," showing contours of the water table, original arear of artesian flow. and areas of artesian flow in 1904. 
138. Development of underground waters in the central coastal-plain rogion of southern California, by W. C. Mendenhall. 1905. 162 pp., 5 pls.

Describes the ground-water conditions and the irrigation systems in th a Downer and Las Bolsas quadrangles, in Los Angeles and Orange Counties. Dircusses the effect of development and drought on ground-water levels, contains recorcs of 3,323 wells, and include maps showing original areas of artesian flow, areas of artesian flow in 1904, ground=water levels, irrigated lands, and locations of wells and pumping plants. Contains also the general map mentioned tinder Water-Supply Paper 187.

139. Development of underground waters in the western coastal-plain region of southern California, by W. C. Mendenhall. 1905. 105 pp., 8 pls.

Describes the ground-water conditions and the irrigation systems in the Santa Monica and Redondo quadrangles, in Los Angeles County. Discusses the effects of development and drought on changes in ground-water levels, contains records of 2,097. wells, and includes maps showing original areas of artesian flow, areas of artesian flow in 1904. ground-water levels, irrigated lands, and locations of wells and pumping plants. Contains also the general map mentioned under Water-Supply Paper 187.

140. Field measurements of the rate of movement of underground waters, by C. S. Slichter. 1905.122 pp., 15 pls.

Discusses the capacity of sand to transmit water, describes the under-flow meter devised by the author and laboratory experiments on the flow of water thrmigh sands and gravels, and gives results of measurements of underflow in Rio H-ndo, San Gabriel, and Mohave River Valleys, Calif., and on Long Islánd, N. Y. Discusses specific capacities of wells, gives results of tests of wells and pumping plants in the Rio Grande Valley in New Mexico and Texas and the Arkansas Valley in Kansas, and describes the "stovepipe" method of well construction.

141. Observations on the ground waters of the Rio Grande Valley, by C. S. Slichter. 1905. 83 pp., 5 pls.

Describes investigation of the underflow in the valley of the Rlo Grande in Texas and New Mexico, gives details of tests of pumping plants near El Pasc, Tex., in Mesilla Valley, N. Mex., and near Berino, N. Mex., and gives analyses of well waters and data concerning wells at and near El Paso.

142. The hydrology of San Bernardino Valley, Calif., by W. C. Merdenhall. 1905. 124 pp., 12 pls.

Describes the source, circulation, quantity, temperature, and chemical character of the ground water, gives records of 890 wells, and contains maps showine changer in areas of artesian flow and in ground-water levels, and locations of wells pumping plants, and irrigated lands. This paper, like Nos. 137, 138, 139, and 219, also contains a general map of the "Valley of southern California," showing contours of water table, original areas of artesian flow, and areas of artesian flow in 1904.

144. The normal distribution of chlorine in the natural waters of New Jork and New England, by D. D. Jackson. 1905. 31 pp., 5 pls.

Discusses the content of sodium chloride in coast and inland waters and its value in indicating pollution of streams and wells. Describes the solvtions and methods used in determinations of chlorine. Containg maps showing tl $;$ normal distribution of chlorine in surface and ground waters in the New England States and New York, and tables giving data on which the maps are based.

145. Contributions to the hydrology of eastern United States, 190E; M. L. Fuller, geologist in charge. 1905.220 pp., 6 pls.

Contains the reports in the following list. Most of those covering sperific areas do not include any maps.

Hydrologic work in eastern United States and publications on ground waters, by M. L. Fuller, pp. 9-29.

The drainage of ponds into drilled wells, by R. E. Horton, pp. 30-39.

Two unusual types of artesian flow, by M. L. Fuller, pp. 40-45.

Construction of so-called fountain and geyser springs, by M. L. Fuller, pp. 45-50.

A convenient gage for determining low artesian heads, by M. L. Fuller, pp. 51, 52. 
145. Contributions to the hydrology of eastern United States, 19C5-Continued.

Water resources of the Catatonk area, N. Y., by E. M. Kindle, pp. 53-57. The ground-water conditions in this quadrangle are also described in G inlogic Folio 169.

Water resources of the Pawpaw and Hancock quadrangles, $W$. Va., Md., and Pa., by G. W. Stose and G. C. Martin, pp. 58-63. The ground-water conditions in these quadrangles are also described in Geologic Folio 179.

Water resources of the Nicholas quadrangle, W. Va., by G. H. Ashley, pp. 64-66.

Water resources of the Mineral Point quadrangle, Wis., by U. S. Grant, pp. 67-73. The ground-water conditions in this quadrangle are also des rribed in Geologic Folio 145.

Water resources of the Joplin district, Mo.-Kans., by W. S. T. Smith, pp. 74-83. The ground-water conditions in this quadrangle are also described in Geologic Folio, 148, but analyses are given only in the water-supply paper.

Water resources of the Winslow quadrangle, Ark., by A. H. Purdue, pp. 84-87. The ground-water conditions in this quadrtngle are also described in Geologic Folio 154

Water resources of the contact region between the Paleozoic and Mississippi embayment deposits in northern Arkansas, by A. H. Purdue, pp. 88-119.

Water resources of the Portsmouth-York region, N. H. and Maine, by G. O. Smith, pp. 120, 128.

A ground-water problem in southeastern Michigan, by M. L. F rller, pp. 129-147. Water supplies at Waterloo, Iowa, by W. H. Norton, pp. 148-155.

Wa'er supply from glacial gravels near Augusta, Maine, by G. O. Smith, pp. 156-160. ..

Water-supply from the delta type of sand plain, by W. O. Crosby, pp. 161-178. Waters of a gravel-filled valley near Tully, N. Y., by G. B. Hol'ister, pp. 179-184.

Notes on certain hat springs of the southern United States, by W. H. Weed, pp. $185-206$.

Notes on certain large springs of the Ozark region, Mo. and Ark., compiled by M. L. Fuller, pp. 207-210.

146. Proceedings of second conference of engineers of the Reclamation Service, with accompanying papers, compiled by F. H. Newell, chief engineer. 1905. 267 pp.

Contains a brief account of the organization of the hydrographic (water resources) branch, including the division of hydrology (ground water). Inclides the following papers relating to ground water, drilling methods, and pumping for irrigation.

Pumping underground water in southern California, by F. C. Finkle.

Diamond-drill methods, by G. A. Hammond.

Underground waters of southern California, by W. C. Menderhall.

Cost of power for pumping irrigating water, by H. A. Storrs.

148. Geology and water resources of Oklahoma, by C. N. Gorld. 1905. 178 pp., 22 pls.

Covers only the original Territory of Oklahoma, not the eatern part of the State. Describes the topography and geology and the streams, strings, and wells; discusses artesian conditions, outlines the water supplies by counties; treats of irrigation from reservoirs, springs, and wells; and gives 154 analyses of well waters and a table containing records of 261 wells. Includes a giologic map.

119. Preliminary list of deep borings in the United States (second edition, with additions), by N. H. Darton, 1905. $175 \mathrm{pp}$.

Gives location, depth, diameter, yield, water level, and other available information concerning wells 400 feet or more in depth; includes all well in Water-Supply Papers 57 and 61. Contains some data in regard to every St-te in the United Statés, arranged alphabetically by States and counties. Mentions principal publications relating to deep borings.

150. Weir experiments, coefficients, and formulas, by R. E. Horton. 1906.189 pp., 38 pls.

Superseded by Water-Supply Paper 200.

151. Field assay of water, by M. O. Leighton. 1905.77 pp., 4 pls.

Describes apparatus, reagents, and methods for rapid field determinations of turbidity, color, iron, hardnęss, carbonates, bicarbonates, sulfates, chlorides, and calcium in water, 
152. A review of the laws forbidding pollution of inland waters in. the United States (second edition), by E. B. Goodell. 1905. 149 pp.

Includes laws relating to wells and springs.

153. The underflow in Arkansas Valley in western Kansas, by C. S. Slichter. 1906. 90 pp., 3 pls.

Discusses the origin and extent of the underflow, the fluctuation of rround-water level, and the chemical composition of the water. Gives results of underflow measurements and tests of the rate of evaporation of ground water. Gives summaries and details of pumping tests and analyses of river and well waters.

154. The geology and water resources of the eastern portion of the Panhandle of Texas, by C. N. Gould. 1906. 64 pp., 15 pls.

Describes the topography and geology and the streams and springs, discusses the ground-water conditions and irrigation, and gives detailed data by counties. Includes a geologic map.

155. Fluctuation of the water level in wells, with special reference to Long Island, N. Y., by A. C. Veatch. 1906.83 pp., 9 pls.

Gives data on ground-water levels and discusses flunctuations due to rainfall, evaporation, barometric changes, temperature changes in rivers, changes in lake levels, tidal changes, irrigation, the construction of dams, ground-water developments, deforestation, cultivation of the soil, drainage, and other causes.

157. Underground water in the valleys of Utah Lake and Jordan River, Utah, by G. B. Richardson. 1906. 81 pp., 9 pls.

Describes the geology and the ground-water conditions and gives numerous well records. Includes maps showing depths to ground water and areas of artesian flow.

158. Preliminary report on the geology and underground waters of tro Roswell artesian area, N. Mex., by C. A. Fisher. 1906. 29 pp., 9 pls.

Describes the geology and ground-water conditions of the artesian basin which extends along Pecos River from Roswell to Lake McMillan. Discusses the area and extent of the artesian basin, the source, quantity, pressure, cuality, and conservation of the artesian water, and the irrigation with this water. Gives well records and analyses and contains maps showing the area of artesien flow and the intake area.

159. Summary of the underground-water resources of Mississippi, by A. F. Crider and L. C. Johnson. 1906. 86 pp., 6 pls.

Describes the geology and the ground-water conditions of the State. Gives notes on wells by counties, records of deep wells, and chemical analyses. Includes a geologic map (pl. 1) and a map showing ground-water conditions (pl. 5).

160. Undergroúnd-water papers, 1906; M. L. Fuller, geologist in charge. 1906. 104 pp., 1 pl.

Gives an account of work done in 1905 and lists of publications ${ }^{\circ}$ relating to ground waters; also contains the following reports:

Significance of the term "artesian," by M. L. Fuller, pp. 9-15.

Representation of wells and springs on maps, by M. L. Fuller, pp. 16-18.

Occurrence of water in crystalline rocks, by E. E. Ellis, pp. 19-28.

Flowing-well districts in the eastern part of the northern peninsula of Michigan, by Frank Leverett, pp. 29-53.

Drainage of wet lands in Arkansas by wells, by A. F. Crider, pp. 54-58.

Total amount of free water in earth's crust, by M. L. Fuller, pp. 59-72.

Use of fluorescein in the study of underground waters, by R. B. Dole, pp. 73-85.

Peculiar mineral waters from crystalline rocks of Georgia, by M. L. Fuller, pp. 86-91.

,Problems of water contamination, by Isaiah Bowman, pp. 92-95.

Instances of improvement of water in wells, by M. L. Fuller, pp. 9f-100. 
163. Bibliographic review and index of underground-water litersture published in the United States in 1905, by M. L. Fuller, F. G. Clapp, and B. L. Johnson. 1906. $130 \mathrm{pp}$.

Lists practically all papers that contain any information on ground water: includes brief abstracts with respect to ground water, giving pege references for reports dealing mainly with other subjects; contains index with respect to groundwater subjects of papers listed.

164. Underground waters of Tennessee and Kentucky west of Tennessee River and of an adjacent area in Illinois, by L. C. Glenn. 1906. 173 pp., 7 pls.

Describes the topography and geology, discusses mineral waters and artesian conditions, and outlines the water resources by counties. Contains maps showing the geology and the head of the artesian water.

168. Report of progress of stream measurements for the calendar year 1905, by M. R. Hall and J. C. Hoyt, Part IV, South Atlantic ard eastern Gulf of Mexico drainages. 1906. 164 pp., $1 \mathrm{pl}$.

Contains discharge measurement of Blue Springs, Ga. (p. 98), and three measurements of Warm Springs, Ga. (p. 101).

170. Report of progress of stream measurements for the calerdar year 1905, by R. E. Horton, F. W. Hanna, and J. C. Hoyt, Part VI, Great Lakes and St. Lawrence River drainages. 1906. 116 pp., 1 pl.

Contains a description and a one-year record of discharge of Reeds Springs near Albion, Mich. (pp. 24, 25).

173. Report of progress of stream measurements for the calendar year 1905, by M. C. Hinderlider, J. M. Giles, and J. C. Hoyt, Part IX, Meramec, Arkansas, Red, and lower western Mississippi River drrinages. 1906. 105 pp. 1 pl.

Contains a description and discharge record of Meramec Sprin\%, near Meramec, Mo. (p. 17).

174. Report of progress of stream measurements for the calendar year 1905 , by T. U. Taylor and J. C. Hoyt, Part X, Western Gulf of Mexico and Rio Grande drainages. 1906. 113 pp., 1 pl.

Describes Barton Springs, near Austin, Tex. (pp. 30, 31).

177. Report of progress of stream measurements for the calen lar year 1905, by W. B. Clapp and J. C. Hoyt, Part XIII, The Great Besin and Pacific Ocean drainages in California. 1906. 273 pp., 1 pl.

Contains discharge measurements of Fish and Little Shasta Syrings, Calif. (pp. 85, 245).

181. Geology and water resources of Owens Valley, Calif., 1, W. T. Lee. 1906. 28 pp., 6 pls.

Outlinew the geology and ground-water conditions, gives well records, and discussen briefly the artesian prospects, the utilization of ground waters by installation of pumping and power plants, reservoir sites, and the significance of undrained lakes as registers of climate. See also Water-Supply Paper 294.

182. Flowing wells and municipal water supplies in the southern portions of the southern peninsula of Michigan, by Frank Leverett and others. 1906. 292 pp., 5 pls.

See alsq Water-Supply Paper 183.

183. Flowing wells and municipal water supplies in the middle and northern portions of the southern peninsula of Michigan, by Frank Leverett and others. 1907.393 pp., 5 pls.

Nos. 182 and 183 describe in general the geology and ground-woter conditions of the areas covered and give details by counties concerning flowing walls and municipal 
183. Flowing wells and municipal water supplies in the middle and northern portions of the southern peninsula of Michigan-Continued.

supplies. They contain numerous analyses and several geologic and artesinn-water maps.

184. The underflow of the South Platte Valley, by C. S. Slichter and H. C. Wolff. 1906. $42 \mathrm{pp}$.

Describes investigations of velocity, direction, and quantity of underflow at Ogalalla, Nebr., gives chemical analyses of the water, and discusses disadrantages of underflow canals or infiltration ditches. Describes also investigations st North Platte, Nebr., and gives suggestions for the construction of small pumping rlants.

188. Water resources of the Rio Grande Valley, N. Mex., and their derelopment, by W. T. Lee. 1907. 59 pp., 10 pls.

Describes the topography and geology, reservoir sites, and the water reso"rces of the valley. Gives the well data and outlines the ground-water conditions in the Santa Fe, Albuquerque, Belen, Jornada, La Mesa, and Mesilla districts. Discussed the origin, course, and quantity of the ground water, its character, and its utilization by means of wells and infiltration ditches. Contains several analyses of river and well waters and includes a topographic map of Mesilla Valley, showing d ypths to ground water.

190. Underground waters of the Coastal Plain of Texas, by T. U. Taylor. 1907. 73 pp., 3 pls.

Describes the ground waters by counties; gives many well records and analyces; includes a map showing locations of artesian wells.

191. The geology and water resources of the western portion of the Panhandle of Texas, by C. N. Gould. 1907. 70 pp., 7 pls.

Describes the topography and geology, the springs, streams, and shallow and deepseated ground waters, and the utilization of the waters for irrigation. Gives detailed information by counties and includes a geologic map.

193. The quality of surface waters in Minnesota, by R. B. Dole and F. F. Wesbrook. 1907. 171 pp., 7 pls.

Relates chiefly to surface waters but contains scattered notes on wells ised-for public supplies throughout the State, a table of data in regard to these wells. (pp. 146-149), and a brief discussion of the comparative value of surface and ground waters (pp. 151-153).

195. Underground waters of Missouri, their geology and utilization, by E. M. Shepard. 1907. 224 pp., 6 pls.

Describes the topography and geology of the State and discusses the water supplien by districts and counties; gives statistics of city water supplies, analyses of water, and many well sections and records; includes a map of the State, showing tie locations of flowing and non-flowing deep wells.

197. Water resources of Georgia, by B. M. and M. R. Hall. 1907. 342 pp.. 1 pl.

Containg description and several discharge measurements of Blue Spring (7. 236), Warm Springs (p. 241), and Cave Spring (p. 302).

199. Underground water in Sanpete and central Sevier Valleys, Utah, by G. B.: Richardson. 1907. 63 pp., 6 pls.

Describes the geology of the area and the sources, distribution, recovery, and quality of the ground waters; gives detailed descriptions and tabulated data concerning springs and wells; includes a map showing the geology and the depths to ground water.

200. Weir experiments, coefficients, and formulas, by R. E. Horton. 1907. 195 pp., 38 pls.

Revision of Water-Supply Paper 150 . tablea and eurvea based on experiments.

A treatise on the theory of weir?, with 
204. Surface water supply of southern Atlantic and eastern G-alf States, 1906;

M. R. Hall, district hydrographer. $1907.110 \mathrm{pp} .5 \mathrm{pls}$.

Contains discharge record of Silver Springs at Silver Springa Fla. (p. 50).

209. Surface water supply of lower western Mississippi River drainage, 1906, by R. I. Meeker and J. M. Giles. 1907. 79 pp., 2 pls.

Contains a description and discharge record of Meramec Spring, near Meramec, Mo. (pp. 21, 22). See also Water-Supply Papers 99, 131, and 173 Contains discharge records of Antelope, Buffalo, and Sulphur springs, near Sulphu-, Okla. (p. 74).

212. Surface water supply of the Great Basin drainage, 1906; E. C. LaRue, Thomas Grieve, and Henry Thurtell, district hydrographers. 1908. 98 pp., 2 pls.

Contains discharge measurements of 10 springs in Utah (p. 92).

213. Surface water supply of California, 1906, by W. B. Clar n, with a section on ground-water levels in southern California (by W. C. Mendenhall). 1907. 219 pp., 4 pls.

Gives the results of a series of measurements of water levels in wells made during 1904, 1905, and 1906 (pp. 189-205). Wells widely distributed over the various basins of southern California were selected in order that the data would give a basis for conclusions as to the fuctuations of the water table in each of these basins.

214. Surface water supply of the north Pacific coast drairage, 1906; J. C. Stevens, Robert Follansbee, and E. C. LaRue, district hydrographers. 1907. 208 pp. 3 pls.

Contains discharge measurement of Warm Springs at Warm Springs Agency, Oreg. (p. 154).

215. Geology and water resources of a portion of the Missouri River valley in northeastern Nebraska, by G. E. Condra. 1908. 59 pp., 11 pls.

Describes the geology, streams, springs, and shallow and ar'osian wells in Boyd, Knox, Gedar, Dixon, and Dakota Counties, and in a part of $\mathbf{F}^{\top}$ olt County ; includes maps showing the geology and the artesian-water conditions; contains information on "blowing wells."

216. Geology and water resources of the Republican River Valley and adjacent areas, Nebraska, by G. E. Condra.- 1907. 71 pp., 13 pls.

Describes the geography, geology, and surface and grourd waters in Dundy, Hitchcock, Redwillow, Furnas, Harlan, Franklin, Webster, Nuckolls, Thayer, and Jefferson Gounties : includes a geologic map ; contains information on "blowing wells."

217. Water resources of Beaver Valley, Utah, by W. T. Lee. 1.908. 57 pp., 1 pl.

Describes the geography, geology, streams, springs, and siepage waters of the eastern part of Beaver County. Gives data in regard to deep wells in the Beaver, Greenville, Adamsville, Minersville, and Milford districts, and at railroad stations between Beryl and Lynn. Discusses possible developments of additional irrigation supplies from surface and underground sources. Describes the quality of the water and contains field assays and laboratory analyses.

219. Ground waters and irrigation enterprises in the footl ill belt, southern California, by W. C. Mendenhall. 1908. 180 pp., 9 p] .

Covers the Pasadena, Pomona, and Cucamonga quadrangles, which lie south of the San Gabriel Mountains between Los Angeles and San Bern 7 rdino. Describes the geography, geology, and ground-water conditions, discusses fuctuation in groundwater levels and the conservation of the water supply, and gives the results of measurements of water levels in 1904, 1905, and 1906. Describes irrigation systems and gives records of 1,044 wells. Contains maps showing original areas of artesian flow, areas of artesian flow in 1904, ground-water levels, irrigated lands, and locations of wells and pumping plants. Contains also the general map that is described under Water-Supply Paper 142 and is included with Water-Sumply Papers 137, 138, and 139. 
220. Geology and water resources of a portion of south-central Oreron, by G. A. Waring. 1908. 86 pp., 10 pls.

Describes the geography and geology, and the streams, lakes, and ground waters in the valleys of Goose Lake, Abert Lake, Chewaucan Marsh, Summer Lal*B, Silvei Lake, Christmas Lake, Alkali Lake, and in Warner Valley and several smalline valleys lying chiefly in Lake County. Gives analyses of waters and of alkali in soil and includes a geologic map.

221. Geology and water resources of the Great Falls region, Mont., by C. A. Fisher. 1909. 89 pp., 7 pls.

Describes the geography and geology, and the surface waters, ground waters, and artesian conditions in an irregular area comprising parts of Cascade, Teton Fergus, Chouteau, and Lewis and Clark Counties. Discusses municipal water supplies, the chemical character of the water, water powers, irrigation, and agricultan; gives analyses of water; includes maps showing the geology, the locations of artesian wells, etc.

222. Preliminary report on the ground waters of San Joaquin Valley, C-lif., by W. C. Mendenhall. 1908. 52 pp., 1 pl.

Describes the geography, geology, and surface and ground waters of the entire valley. Discusses the origin, circulation, quantity, accessibility, and develonment of the ground waters; gives notes on the water supplies by counties; and includes a map showing areas of artesian flow and contours of the water table. S iperseded by Water-Supply Paper 398 .

223. Underground waters of southern Maine, by F. G. Clapp, with records of deep wells, by W. S. Bayley. 1909. 268 pp., 24 pls.

Covers an area that lies almost entirely south of the 45th parallel. Describes the physiography, drainage, water-bearing rocks, the quantity, source, disposition, and temperature of the ground waters, and the recovery of water from springs, collecting galleries, tunnels, and wells. Discusses well-drilling methods and costs, municipal water supplies, and the quality of the ground waters. Gives detailed data for each county and records of deep wells. Includes a geologic map of southern Maine, and several diagrams showing the relative composition of waters from different kinds of rock.

224. Some desert watering places in southeastern California and southwestern Nevada, by W. C. Mendenhall. 1909. 98 pp., 4 pls.

Describes the physical features of the region, gives hints on desert traviling and on finding water in desert places, describes main routes of travel, and gives detailed descriptions of springs, wells, and other watering places. Includes a map' of the region showing roads and watering places.

225. Ground waters of the Indio region, Calif., with a sketch of the Colorado Desert, by W. G. Mendenhall. 1909. 56 pp., 12 pls.

Describes the geography, geology, precipitation, and drainage, and tha source, character, and development of ground waters in the Colorado Desert, with special reference to the Indio region, which is the name applied to the artesian basin extending from the vicinity of Indio to the Salton Sea. Contains a table of well data and a map of the Indio region showing areas of artesian fiow, irrigated liads, and: locations, of wells and pumping plants.

227. Geology and underground waters of South Dakota, by N. H: Darton. 1909. 156 pp., 15 pls.

Describes the geology and water horizons of the State, and discusses by counties the deep wells and well prospects. Gives notes on the construction and indriagement of artesian wells. Includes maps showing the geology and the artesian con'titions.

230. Surface water supply of Nebraska, by J. C. Stevens. 1909 . 251 pp., 6 pls.

Contains discharge measurement of Paxton Spring (p. 160). 
231. Geology and water resources of the Harney Basin region, Oreg., by G. A. Waring. 1909. 93 pp., 5 pls.

Describes the geography, geology, surface waters, ground weters, and artesian conditions of the Harney, Catlow, Alvord, Whitehorse, and Mal'ieur River basins, which lie chiefly in Harney County. Discusses the conservation of the water supply, the temperatures of ground waters, and well drilling methods and costs. Includes a geologic map of the area.

232. Underground water resources of Connecticut, by H. E. G "egory, with a study of the occurrence of water in crystalline rocks, by E. E. Ellis. 1909. 200 pp., 5 pls.

Describes the physiography and geology, and the circulation, quantity, temperature, quality, and contamination of the ground water of the State. Discusses the water in the crystalline rocks, and Triassic sandstones and traps, and the glacial drift. Discusses also the methods of constructing wells and the character and use of the springs. Gives records of wells and springs and analyses of ground waters. Includes detailed descriptions of the towns of Warren, North Haven, and Branford Point.

233. Water resources of the Blue Grass region, Ky., by G. C. Matson, with a chapter on the quality of the waters, by Chase Palm?r. 1909. 223 pp., 3 pls.

Describes the physiography, geology, soils, and water resources cf an area covering 30 counties in the north-central part of Kentucky. Discueses the source, occurrence, quantity, and recovery of ground water, the artesian conditions, the collection and storage of rain water, and the municipal water supplies, the industrial uses and comparative hardness of the ground waters, and the various medicinal and table waters. Contains detailed data in regard to each county, and numerous well records and water analyses. Includes a geologic map of the area.

234. Papers on the conservation of water resources. $1909.96 \mathrm{pp} ., 2$ pls.

Contains a paper on underground waters by W. C. Mendenhall.

236. The quality of surface waters in the United States, Part I, Analyses of waters east of the one hundredth meridian, by R. B. Dole. 1909. $123 \mathrm{pp}$.

Contains analyses of surface waters exclusively, but includer a description of analytical methods, an outline of methods for expressing analytisal results, and a disctssion of the probable accuracy of analyses that are applicablis to ground waters as well as to surface waters. Describes methods for the following determinations: Turbidity, total suspended solids, total dissolved solids, silica, iron, calcium, magnesium, sodium and potassium, carbonates, bicarbonates, sulfates, chlorine, nitrates, total acidity, and total iron. Also gives directions for the preparation of the necessary solutions.

240. Geology and water resources of the San Luis Valley, Colo., by C. E. Siebenthal. 1910. 128 pp., 13 pls.

Describes the geography and geology and the artesian and other waters of the valley. Gives detailed data regarding the springs and the flowing and nonflowing wells and discusses adequacy and permanence of the artesian suoply, variations in flow, and temperature, quality and uses of the water, well-drilling methods and costs, and approximate methods for measuring the discharge of flowing wells. Contains several analyses and a map showing the area of artesian fow, the gas fields, and the area of colored water.

242. Surface water supply of the United States, 1907-8, Part II, South Atlantic coast and eastern Gulf of Mexico, by M. R. Hall and R. H. Boltser. 1909. 226 pp., 3 pls.

Contains discharge record of Silver Springs at Silver Springs. Fla., 608 sec-ft.; and White Springs, Fla., 72 sec-ft. (pp. 132, 136).

247. Surface water supply of the United States, 1907-8, Part VII, Lower Mississippi basin, by W. B. Freeman, W. A. Lamb, and R. H. Bolster. 1910. 124 pp., 2 pls.

Contains discharge measurements of Antelope and Buffalo Springs near Sulphur, Oklă, (p. 118). 
250. Surface water supply of the United States, 1907-8, Part X, T: : Great Basin, by E. C. LaRue and F. F. Henshaw. 1910. 151 pp., 6 r's.

Contains discharge measurements of Roaring Springs, Oreg. (p. 143).

251. Surface-water supply of the United States, 1907-8, Part XI, Crlifornia. 1910. 363 pp., 7 pls.

Contains a section (pp. 338-348) on "fluctuations in ground-water lerels in the valley of southern California, by W. C. Mendenhall, in which are giver measure-1 ments of depths to the water level in typical wells during 1907-8. Thesi? measure ments were a continuation of the work reported in Water-Supply Paper 213. Contains also records of the discharge of springs as follows: Fish Springs, Seelew Springs, and Black Rock Springs, Calif. (p. 333); Bettles Rest Springs, Oreg. (p. 337) ; Fords Springs, and Olene Springs, Calif. (p. 338).

252. Surface water supply of the United States, 1907-8, Part XI*. North Pacific coast, by J. C. Stevens and F. F. Henshaw. 1910.418 rn., 9 pls.

Contains discharge measurement of unnamed spring in Oregon (p. 284).

254. The underground waters of north-central Indiana, by S. R. Capp , with a chapter on the chemical character of the waters, by R. B. Dol?. 1910. 279 pp., 7 pls.

Covers the following 19 counties: Boone, Carroll, Cass, Clinton, Elkha "t, Fulton, Grant, Hamilton, Hancock, Hendricks, Howard, Kosciusko, Madison, Marion, Marshall, Miami, St. Joseph, Tipton, and Wabash. Describes the geography ard geology, the sources, movements, occurrence, and quantity of ground water and th methods of constructing wells and of lifting water. Describes in detail, for each county, the ground-water conditions and the water supplies for cities, villages, and rural districts. Discusses the methods of making water analyses and of expressing the results, the mineral constituents of natural waters, the influence of these constitvents upon domestic, industrial, and medicinal uses of the water, and methods of purification. Compares the chemical composition of the waters in different geologic formations in the area and gives numerous analyses and field assays. Contains maps showing the distribution of rock formations and surface deposits, the thickness of the surface deposits, and the areas of artesian flow.

255. Underground waters for farm use, by M. L. Fuller, 1910 . 58 pp . 17 pls. Diseusses the various kinds of water-bearing formations and the relativ $?$ safety of supplies from each. Describes different types of springs and their protection from pollution. Discusses dug and drilled wells with respect to their location, yield, cost, and safety from pollution. Discusses also cisterns and combination wells ard cisterns.

256. Geology and underground waters of southern Minnesota, by C. W. Hall, O. E. Meinzer, and M. L. Fuller. 1911. 406 pp., 18 pls.

Covers Bigstone, Swift, Kandiyohi, Meeker, Wright, Anoka, and Washington Counties and all of Minnesota south of these counties. Discusses the physiography. geologic history, geologic formations and their water-bearing capacities, artesian conditions, mineral quality of the ground waters, types of wells, methods of finishing wells in sand, methods of drilling in quartzite, "blowing" and "breathing" of wells, freezing of wells and other phenomena due to variations in atmospheric pressure, drainage into wells, and municipal water supplies. - Gives detailed data, br counties, concerning the yield, head, and quality of water. Includes numerous analyses of water and maps showing the thickness and character of surface deposits, the depths to granitic rocks and Sioux quartzite, the distribution of water-bearing formations, the areas of artesian flow, and the quality of ground waters; also diagran's showing geographic variations in the quality of the waters from surface deposits and bedrocke.

257. Well-drilling methods, by Isaiah Bowman. 1911. 139 pp., 4 pls

Discusses briefly ground water in the United States and water-bearing formations : gives a history of well drilling in Asia, Europe, and the United States; and described the various methods of drilling and the machinery used. Discusses the difficultien encountered in sinking wells, the flooding of oil wells, the contamination of water wells and methods of preventing contamination, the capacity of wells and methods of testing capacity, methods of measuring the depth of wells and of detecting the defection of drill holes, and the cost of sinking wells. 
258. Underground-water papers, 1910, by M. L. Fuller, F. G. C`app, G. C. Matson, Samuel Sanford, and H. C. Wolff. 1911. 123 pp., 2 pls.

Contains the following papers:

Drainage by wells, M. L. Fuller, pp. 6-22.

Freezing of wells and related phenomena, by M. L. Fuller, pp 23-31.

- Occurrence and composition of well waters in the slates of Maine, by F. G. Clapp, pp. 32-39.

1 Occurrence and composition of well waters in the granites of New England, by F. G. Clapp, pp. 40-47.

Pollution of underground waters in limestone, by G. C. Matsor, pp. 48-56.

Protection of shallow wells in sandy deposits, by M. L. Fuller, pp. 57-65.

Composition of mineral springs in Maine, by F. G. Clapp, pp. 66-74.

Saline artesian waters of the Atlantic Coastal Plain, by Samue' Sanford, pp. 75-86.

Magnetic wells, by M. L. Fuller, pp. 87-93.

Underground waters neax Manassas, Va,, by F. G. Clapp, pp. 94-97.

The utilization of the underflow near St. Francis, Kans., b" H. C. Wolff, pp. 98-119.

259. The underground waters of southwestern Ohio, by M. L. Fuller and F. G. Clapp, with a discussion of the chemical character of the waters, by R. B. Dole. 1912. 228 pp., 9 pls.

Coyers the following counties: Adams (western half), Brown, Butler, Clark, Clermont, Clinton, Darke (southern part), Greene, Hamilton, Highl ind (western half), Miami (southern part), Montgomery, Preble, and Warren. Describes the topography and geology, the water-bearing formations, the source, occurrence, and head of the water, and the municipal water supplies. Gives detailed information in regard to ground-water conditions by counties. Discusses methods of maring water analyses and of expressing the results, mineral constituents of natural weter and their effects with respect to its use for domestic, industrial, and medicinal purposes, and methods of purifying water. Gives numerous analyses and field asse vs. Ineludes maps showing the rock formations, the surface deposits, the thickness of surface deposits, structure contours, and areas of artesian flow. The chapter on the chemical character of the water is nearly the same as the chapter on the same subjoct in Water-Supply Paper 254.

260. Preliminary report on the ground waters of Estancia Valley, N. Mex., by 0. E. Meinzer. $1910.33 \mathrm{pp}$.

Describes briefly the ground-water conditions in the valley and discusses the use of ground water for irrigation. Includes analyses but no maps. This report is superseded by Water-Supply Paper 275.

271. Surface water supply of the United States, 1909, Part XI, California, by W. B. Clapp and F. F. Henshaw. 1911. 256 pp., 6 pls.

Contains discharge measurement of Beetle's Rest Spring near Klamath Agency sawmill (p. 242).

273. Quality of the water supplies of Kansas, by H. N. Parkes, with a preliminary report on stream pollution by mine waters in scutheastern Kan-sas, by E. H. S. Bailey. 1911. 375 pp., 1 pl.

Describes the geology, ground water, and artesian basins of the-State; discusses the significance of mineral constituents and classification of water: gives details concerning quality of ground water by counties and surface water by drainage basins; contains numerous assays and analyses of surface and ground"waters; includes a geologic map of the State.

274. Some stream waters of the western United States, with chapters on sediment carried by the Rio Grande and industrial app'ication of water analyses, by Herman Stabler. 1911. 188.pp.

Contains analyses of surface waters exclusively, but the dis?ussion of industrial application of water analyses which it includes is as pertinent for ground waters as for surface waters. This discussion introduces "reacting coefficients" and "reacting values" and develops formulae for calculating, from analysis, the soap-consuming 


\section{Some stream waters of the western United States-Continued.}

power of the water, the amount of softening constituents that it requires the extent of foaming, priming, and corrosion that it will produce in boilers, the amount of scale and the hardness of the scale that it will deposit in boilers, and it quality for irrigation.

275. Geology and water resources of Estancia Valley, N. Mex., with notes on ground-water conditions in adjacent parts of central New Merico, by O. E. Meinzer. 1911.88 pp., 14 pls.

Describes the physiography, geology, soil, and climate of the valley, and discusses the source and disposal of ground water, the water table, artesian conditior $\$$, yields of wells, quantity of ground water available, quality of ground water, storage of storm-waters, use of ground water for irrigation, types of wells, windmills, cost of pumping, and the alkali problems. Contains tables giving depths to water level in wells and analyses and assays of water from wells and springs. Contains also brief reports on physiography, geology, soil, ground water, and irrigation in Encino and Pinos Wells basins, and notes on wells at Vaughan. Includes maps showing physiography and Pleistocene and Recent geology, depths to the water table, and amount of chlorides and sulfates found in the ground waters.

276. Geology and underground waters of northeastern Texas, by C. H. Gordon. 1911. 78 pp., 2 pls.

Covers an area comprising Bowie, Camp, Cass, Delta, Franklin, Hopkins. Lama, Morris, Red River, and Titus Counties. Describes the geography and geol $r y$, and the artesian and other waters found in the various formations. Describes the water resources by counties. Gives tables of well data and analyses of ground waters and includes a geologie map of the area.

277. Ground water in Juab, Millard, and Iron Counties, Utah, by O. E. Meinzer. 1911. 162 pp., 5 pls.

Describes briefly the physiography, geology, precipitation, soil. vegetation, streams, and industrial development, occurrence of water in bedrock and in uncorsolidated sediments, artesian conditions, springs, the quality of ground waters, irrigation, construction of wells, and watering places on routes of travel. Describes in mre detall Juab, Round, Little, Sage, Dog, Fernow, and Tintic valleys, the Tintic mining district, Pavant and Lower Beaver valleys, Old River Bed, Cherry Creek, the Drum, and Swasey Wash regions, Sevier Desert, Wah Wah Valley, Sevier Lake bottoms, White, Fish Springs, Snake, Parowan, and Rush Lake valleys and the Escalante Desert. Contains several water analyses.

278. Water resources of Antelope Valley, Calif., by H. R. Johnson. 1911. 92 pp., 7 pls.

Describes the drainage, climate, and physiography, and the water-bearing and non water-bearing formations of an area in Kern, Los Angelès, and San Bernardino Counties. Discusses the artesian and other ground waters, the chemical character of the ground waters, certain fallacies as to the drigin and quantity of artesian water, and the present and future development of the underground supplios. Contains a table of well data and a few chemical analyses, and artesian flow.

288. Surface water supply of the United States, 1910, Part VIII, Western Gulf of Mexico, by W. B. Freeman and J. G. Mathers. 1911. 149 pr., 3 pls.

Contains discharge measurements of Hancock, Hanna, and Barton Springs, Tex. (p. 185).

289. Surface water supply of the United States, 1910, Part IX, Coloradn River basin, by W. B. Freeman, E. C. Larue, and H. D. Padgett. 1912, 233 pp., 4 pls.

Contains discharge measurements of artesian well and Every Spring, near Las Vegas, Nev. (p. 220).

293. Underground-water resources of Iowa, by W. H. Norton, W. S. Hendrixson, H. E. Simpson, O. E. Meinzer, and others. 1912.994 pp., 18 pls.

Describes the topography, climate, and geology of the State, the oecurrence of water in the various geologic formations, the artesian phenomena and the yielde of 
293. Underground-water resources of Iowa-Continued.

artesian wells, the chemical composition of the ground waters, tha municipal, domestie and industrial water supplies, and methods of drilling wells. Discusses corrosion of well casings and boilers and the deposition of scale in boilers. Gives a classification of mineral waters. Contains numerous sections of wells and about 400 water analyses. Gives detailed information concerning ground waters and city and village supplies by districts and counties. Includes maps showing the glacial and rock geology, structure contours of water-bearing formations, locatiors of deep wells, head of artesian water, and quality of ground water. Also includes numerous geologic sections showing depths to the principal water-bearing formations. Describes a method of casing deep wells with cement (p. 562). See also cooperative report 137 .

294. An intensive study of the water resources of a part of Owens Valley, Calif., by C. H. Lee. 1912.135 pp., 30 pls.

Relates to the Independence region, a segment of Owens Valley that is relatively isolated with respect to water supplies. Describes the undergrcund reservoir of this region and the drainage basin tributary to it. Presents quantititive data on precipitation, stream flow, percolation into the underground reservoir from precipitation, streams, irrigation, and flood waters, evaporation and transpiration from soils in experimental tanks with various depths to water level, fiuctuations of the water table, height of capillary rise of ground water, areas with specified depths to the water table within the range of capillary rise, and discharge frcm springs. Analyzes the data and calculates the annual intake and discharge of the underground reservoir and the available supply of ground water. Includes maps showing depths to ground water and other hydrologic features and also includes numerous diagrams. The results of the tank experiments and their application in estimating the discharge of ground water in closed desert basins are of general interest.

298. Water resources of California, Part I, Sacramento Rivem basin, by H. D. McGlashan and F. F. Henshaw. 1912. 411 pp., 8 pls.

Contains 9 discharge measurements of Dotta Spring in Biץ Meadows, Calif., 50 to 122 sec. ft., (p. 390).

300. Water resources of California, Part III, Stream mearurements in the Great Basin and Pacific coast river basins, by H. I. MeGlashan and H. J. Dean. 1913. 956 pp., 4 pls.

Gives discharge records of springs and wells in California as follows: Grover Hot Springs (p. 198), Black Rock Springs (p. 393), Seeley Sprin 7 (p. 394), Slanson well (p. 680), Shasta Little Springs (p. 913), Anna Creek Spring (p. 914), Bettles Rest Springw (p. 915), Barclay Springs (p. 915), Fords Sprin (p. 917), and Olene Springs (p. 918).

310. Surface water supply of the United States, Part X, Tho Great Basin, by F. F. Henshaw, H. D. McGlashan, and E. A. Porter. 1913. 210 pp, 4 pls.

Contains discharge measurements of Roaring. Threemile, Thompson, and Knox Springs, in Oregon (p. 196).

314. Surface water supply of Seward Peninsula, Alaska, by F. F. Henshaw and G. L. Parker. 1913. 317 pp., 17 pls.

Contains discharge measurement of spring in Fish River Basin (p. 81), and spring in Grand Central River Basin (p. 173).

315. The purification of public water supplies, by G. A. Johnson. 1913.88 pp., 8 pls.

Includes a brief discussion of ground waters for municipal s'pplies; also information on methods of purification that are more or less applicable to ground waters.

316. Geology and water resources of a portion of south-certral Washington, by G. A. Waring. $1913.46 \mathrm{pp} ., 1 \mathrm{pl}$.

Covers an area of about 5,000 square miles comprising Benton County and parts. of Franklin. Grant, Yakima, and Klickitat Counties. Describer the climate, vegetation, physiography, and geology; discusses shallow and artesian water and irrigation enterprises in Sunnyside and Reservation valleys, Horse Hearen Plateau, and the Columbia River plains, and irrigation along lower Yakima $\Gamma$ 'ver; gives tabulated data concerning wells and springs; include a geologic map. 
317. Geology and underground waters of the Wichita region, north-central Texas, by C. H. Gordon. 1913.88 pp., 2 pls.

Covers Archer, Baylor, Clay, Foard, Hardeman, Haskell, Jack, Knox. Montague, Throckmorton, Wichita, Wilbarger, and Young Counties. Describes the physiography and geology, the occurrence and quality of ground waters and their relation to rock structure, the effects of barometric changes on water levels, and the water-bearing formations; gives detailed information by counties; contains numerous sections of wells and water analyses; includes a geologic map.

318. Water resources of Hawaii, 1909-1911, by W. F. Martin and C. F. Pierce. 1913. 552 pp., 15 pls.

Describes chiefly surface-water supplies, but contains brief notes on ground-water supplies and data on the discharge of springs, infiltration tunnels, floring wells. and pumped wells on several islands, as follows: Kauai, pumped wells (p. 144) ; Oahu, springs, pumped wells, and flowing wells (pp. 163, 187-196); Mari, pumped wells (pp. 258, 331-332); Hawaii, springs and infiltration tunnels (p. 408). Gives sections of wells on Oahu (pp. 191-193).

319. Geology and ground waters of Florida, by G. C. Matson and Samnel Sanford. 1913. $445 \mathrm{pp} ., 17 \mathrm{pls}$.

Describes the characteristic upland, lowland, and coastal features of the Statethe springs, lakes, caverns, sinkholes, natural bridges, terraces, sand dines, coral reefs, bars, inlets, tidal runways, pine lands, swamps, keys, and ocean currents. Describes in detail the geologic formations, the source, quantity, depth, circulation, and recovery of artesian and other ground waters. Gives detailed information concerning ground-water conditions and water supplies by counties. Contains nurerous well sections and tables of well data and includes maps showing the geolow and the Pleistocene terraces of the State.

320. Geology and water resources of Sulphur Spring Valley, Ariz., by O. $\mathbf{B}$. Meinzer and F. C. Kelton, with a section on agriculture, ly R. $\mathbf{H}$. Forbes. 1912., 231 pp., 15 pls.

Covers Sulphur Spring Valley and contains a small amount of information on San Pedro: San Simon, and San Bernardino valleys. Describes the physiorraphy, the drainage, the geology, with special reference to the Quaternary deposits in the valley, the seasonal and geographic distribution of the precipitation, the occurrence and level of the ground water, the flowing and nonflowing wells, the quality of ground waters with relation to derivative rocks, water levels, and underground circulation, the effects of quality on irrigation and other uses, the distribution of al'ali In the soil, the relation of the alkali to the water table and to the drainage, and the relation of zones of vegetation to water supply and other geographic controls. Contains detailed data in regard to tests of 20 pumping plants and describes a portable welr used in making these tests. Gives the history of agriculture in the valley and discusses agricultural methods. Contains analyses of water and of al in the soil and includes maps showing the geology, vegetation, depths to gro'nd water. elevation of the water table, quality of water, and alkali in soil.

326. Surface water supply of the United States, 1912, Part VI, Misso"ri River basin, by W. A. Lamb, Robert Follansbee, and H. D. Padgett. 1914. 375 pp., 2 pls.

Contains discharge measurement of Buckholtz Springs, Mont. (p. 864), and Giant Springs, Mont. (p. 365).

331. Surface water supply of the United States, 1912, Part X, Pacific coast basins in California, by H. D. McGlashan and G. C. Stevens. 1914. 442 pp., 2 pls.

Contains records for 1909 to 1912, inclusive, of water levels in the series of wells for which water-level data are given in Water-Supply Papers 213 and 2f 1, with an introductory note by W. C. Mendenhall (pp. 425-434). 


\section{Surface water supply of the United States, 1912, Part XII, North Pacific} drainage basins; F. F. Henshaw, G. C. Baldwin, and W. A. Lamb, district engineers. 1916. 748 pp., 2 pls.

Contains three measurements of discharge of Drumheller Springs. Wash. (p. 275).

333. Ground water in Boxelder and Tooele Counties, Utah, by Everett Carpenter. 1913. 90 pp., 2 pls.

Covers all of Boxelder County and Tooele, Rush, and Skull valleys in Tooele County. Describes briefly the geography, geology, water in bedrock and in unconsolidated sediments, artesian conditions, springs, and quality $o^{*}$ ground waters; gives detalled information by valleys; contains numerous assays $o^{*}$ water; includes a guide to watering places on routes of travel and maps showing locations of flowing and nonflowing wells, springs, and roads.

335. Geology and underground waters of the southeastern part of the Texas Coastal Plain, by Alexander Deussen. 1914. 365 pp., 9 pls.

Covers that part of the Coastal Plain of Texas occupied by the ortcrop of Cenozoic rocks east of Brazos River and south of a line extending east and west through Jefferson, in Marion County. Describes the physiography, stratigraphy, geologic structure, occurrence of ground water, springs, artesian systems, and quality of water with reference to various uses and in relation to the geologic formations; gives detailed information by counties; contains numerous well sections and water analyses; includes maps showing the geology of the region and the structure contours and areas of artesian flow for the seven principal artesian reservo: $t$.

336. Water resources of Hawaii, 1912, by C. H. Pierce and G. K. Larrison. 1914. 392 pp.

Relates chiefly to surface waters, but contains data in regard to pumpage of wells and seepage of ditches on the Isiand of Kauai (p. 99), dis ?harge of springs and flowing wells and fluctuations of water levels in wells on th Island of Oahu (p. 128); pumpage of wells on the Island of Maui (pp. 209-211), and of springs on the Island of Hawaii (p. 381).

338. Springs of California, by G. A. Waring. 1915.410 pp., $1 \hat{i}$ pls.

Deseribes the physical features of California and discusses natural waters with respect to mineral analyses, source and amount of dissolved substances, therapeautic and other properties, temperature, and classiflcation. Gives detailiad descriptions of springs, particularly those which yield mineral waters or are ured as centers of recreation or health resort. Contains numerous analyses and includes maps showing the geology of the State and the locations of hot, carbonated, and sulfur springs.

340. Stream-gaging stations and publications relating to water resources, - 1885-1913, by B. D. Wood. 1916. 195 pp.

Consigts chiefly of lists of publications on stream gaging, but gives supplementary list of 87 titles of hydrologic reports of general interest, most of which deal with ground water (pp. 169-178).

341. Underground waters of the Coastal Plain of Georgia, by T. W. Stephenson and J. O. Veatch, and a discussion of the quality of the waters, by R. B. Dole. 1915. 439 pp., 21 pls.

Describes the physiography and geology, the source, quantity, and disposition of water supplies, the artesian and nonartesian waters, the quality and use of water from springs and wells, and the stratigraphic distribution of the ground water. Gives detailed information by counties. Discusses the quality of the water in relation to industrial, domestic, and medicinal uses, the purification of water, and the composition of surface waters, and of ground waters in relation to geologic formations, geographic position, and depth. Contains many well sertions and water analyses and includes maps showing the geology, the areas of artesian flow and the locations and depths of wells.

343. Geology and water resources of Tularosa Basin, N. Mex., by O. E. Meinzer and R. F. Hare. 1915. 317 pp., 19 pls.

Covers a large area in south-central New Mexico between this Rio Grande and 
343. Geology and water resources of Tularosa Basin, N. Mex-Contir red:

Pecos Valleys, and also contains data in regard to the vicinity of IM Paso, Tex. Deseribes the physiography and geology and gives data on precipitation and its seasonal and geographic distributions. Discusses the water in the valley fill in regard to intake zones, occurrence, disposal, yield, artesian head, methods of constructing wells, and quality of the water in relation to derivative rocks, water table, and water-bearing beds and with respect to its use for drinking, cooking, washing, steam making, and irrigation. Discusses likewise the water in Cretaceous end Carboniferous strata and in igneous rocks. Describes the soil and native vegetation in relation to water supplies, the irrigation from streams, springs, flood waters, and wells, the railroad and public water supplies. Contains a guide to watering rlaces on routes of travel, and tables of well data, analyses of water and soil, and distances between watering places. Includes maps showing the geology, vegetation. depths to water, contours of the water table, and locations of watering places and connecting roads.

345. Contributions to the hydrology of the United States, 1914; N. C. Grover, chief hydraulic engineer. 1915. $225 \mathrm{pp}$., $17 \mathrm{pls}$.

(a) Preliminary report on ground water for irrigation in the vicinity of Wichita, Kans., by O. E. Meinzer, pp. 1-9.

(b) Ground water for irrigation in the vicinity of Enid, Okla., by A. T. Schwennesen, pp. 11-23, pl. I. Includes a note on ground water for irrigation on the Great Plains, by o. E. Meinzer.

(c) Underground water of Luna County, N. Mex., by N. H. Darton, pn. 25-40, pl. 2. Includes the results of five pumping tests made by $A$. T. Schwenneser.

(d) Ground water for irrigation in the valley of North Fork of Carídian River near Oklahoma City, Okla., by A. T. Schwennesen, pp. 41-51, pli 3. .

(g) The water resources of Butte, Mont., by O. E. Meinzer, pp. 79-125. pls. 7-8.

(h) Ground-water resources of the Niles cone and adjacent areas, Calif., by W. 0 . Clark, pp. 127-168, pls. 9-17.

All except No. 345a include maps showing ground-water conditions. No. $345 \mathrm{~h}$ contains numerous records of water levels in' wells and an estimate of groundwater recharge in 1912-13 and 1913-14 based on fluctuations of the water table. It includes a series of graphs showing fluctuations of the water table and the source of the ground water.

358. Water resources of the Rio Grande Basin, 1888-1913, by Robert Tollansbee, H. J. Dean, W. W. Follett, and G. A. Gray. 1915.725 pp,, 3 pls, Contains data on seepage of water into and out of streams and discussions of the data (pp. 679-694).

359. Surface water supply of the United States, 1913, Part IX, Coloradn River basin; Robert Follansbee, E. A. Porter, and G. A. Gray, distrint engineers. 1915.260 pp., 2 pls.

Contains discharge measurement of Hunts Springs near Central, Utah (p. 255).

360. Surface water supply of the United States, 1913, Part X, The Great Basin; E. A. Porter, H. D. McGlashan, F. F. Henshaw, and G. C. Baldwin, district engineers. 1916. 293 pp., 2 pls.

Contains discharge measurements of 2 springs in Utah, 4 springs in Nevada, and 1 spring in Oregon (pp. 285-287).

362. Surface water supply of the United States, 1913, Part XII, Nortl Pacific basins; G. L. Parker, W. A. Lamb, G. C. Baldwin, and F. F. Henshaw, district engineers. 1917. 764 pp., 2 pls.

Contains discharge measurement of Intermittent Spring, Wash. (p. 749).

364. Water analyses from the laboratory of the United States Geologinal Survey, tabulated by F. W. Clarke. 1914. $44 \mathrm{pp}$.

Contains 203 miscellaneous analyses of waters from rivers, lakes, wells. springs, and mines, which were made at various times in the chemical laboratony of the United States Geological Survey. Includes analyses of waters from wells, springs, or mines in the following 25 States: Arkansas, Arizona, California, Colorado, Florida, Illinois, Iowa, Kentucky, Maine, Michigan, Mississippi, Missouri, Montana, Nevada, New Mexico, North Carolina, Oklahoma, Pennsylvania, South Carolina, Tennessee, Texas, Utah, Virginia, West Virginia, and Wyoming. 
365. Ground water in southeastern Nevada, by Everett Carnenter. 1915. ' 86 pp., 5 pls.

Covers an area of about 17,000 square miles in Clarw, Lin?oln, White Pine, and Nye Counties, including the vicinities of Geyser, Lund, Barne?. and Duckwater, on the north, and the vicinities of Sharp, Hiko, Alamo, and Indian Springs, on the west. Describes briefly the geography, geology, water in bedrock and in unconsolidated deposits, artesian conditions, springs, and quality of wa+er. Gives detailed information regarding water supplies in the Las Vegas drainage basin, Duck, Ursine, and Meadow valleys, White River drainage basin, Muddy ant Virgin valleys, and Bristol, Delamar, Coal, Garden, Dry Lake, Indian Spring, and Railroad valleys. Contains water analyses, a guide to watering places on roites of travel, and a table of distances between watering places. Includes maps shcwing Pleistocene lake beds, areas of artesian flow, and locations of watering places.

370. Surface water supply of Oregon, 1878-1910, by F. F. Henshaw and H. J. Dean. 1915. 829 pp., 1 pl.

Contains discharge measurements of 9 springs in Oregon (pp. 811-821).

373. Water resources of Hawaii, 1913, by G. K. Larrison. $1915.190 \mathrm{pp}$.

Relates chiefly to surface waters, but contains data on the discharge of springs, tunnels, and flowing wells on the island of Oahu (p. 103), springs on the island of Maui (p. 151), and springs on the island of Hawaii (p. 174).

374. Ground water in the Hartford, Stamford, Salisbury, Willimantic, and Saybrook areas, Conn., by H. E. Gregory and A. J. Ellis. 1916.150 pp., 13 pls.

Covers the towns of Bloomfield, Canaan, East Hartford, East Windsor, Essex, Franklin, Greenwich, Hartford, Manchester, Newington, Nortl Canaan, Old Lyme, Salisbury, Saybrook, Stamford, South Windsor, Westbrook, West Hartford, Wethersfield, Windham, and Windsor. Discusses the origin, circulation, quantity, and quality of the waters in stratified and unstratified drift, crystallive rocks, traps, Paleozoic limestones, and Triassic sandstones. Discusses ground water for municipal use and the construction of drilled, driven, and dug wells, and infiltration galleries. Describes the municipal pumping plants at Brookline, Mass., Brooklyn, N. Y., and Plainfield, N. J. Describes the ground-water conditions in detail, by towns. Contains numerous tables of well data and water analyses, and includes maps showing water-bearing formations, depths to water, locations of wells, and woodlands.

375. Contributions to the hydrology of the United States, 1915; N. C. Grover, chief hydraulic engineer. 1916. $181 \mathrm{pp} ., 9 \mathrm{pls}$.

(a) Ground water for irrigation in the Sacramento Valley, Calif., by Kirk Bryan, pp. 1-49, pls. 1-2.

(b) Ground water in Paradise Valley, Ariz., by O. E. Meinzer and A. J. EMlis, pp. 51-75, pls. 3-5.

(d) Ground water in Big Smoky Valley, Nev., by O. E. Me'nzer, pp. 85-116, pis. 6-7.

(g) Ground water in La Salle and McMullen Counties, Tex., by Alexander Deussen and R. B. Dole, pp. 141-177, pls. 8-9.

All of these papers include maps showing ground-water conditions. No. 375 a contains statistics on irrigation with ground water in Sacremento Valley and a discussion of problems relating to the construction of wells and to pumping for irrigation. No. 375 d contains data on ground-water intake and discharge and on irrigation with ground water. No. $375 \mathrm{~g}$ discusses water in the various geologic formations, especially with reference to its quality and quantiir for irrigation, and contains tables of well data and water analyses.

380. The Navajo country-a geographic and hydrographic reconnaissance of parts of Arizona, New Mexico, and Utah, by H. E. Gregory. 1916. 219 pp. 29 pls.

Covers the Navajo and Hopi Indian Reservations in northeastern Arizona, northwestern New Mexico, and southeastern Utáh, and some adjasent areas. Gives an outline of the history of the region; describes the geographic provinces, climate, soil, flora, fauna, and geology; describes also the streams and discusses factors 


\section{The Navajo country-Continued.}

influencing stream flow, irrigation with surface waters, storage of rain and surface water for domestic and stock use, and water powers; discusses ground-v'ater reservoirs, quality of ground water, artesian water, springs, and wells; gives data on watering places and recommendations for prospecting for water in various geographic provinces. Includes maps showing the geology, the locations of watering places, roads, and trails, and the areas covered by forests.

389. Surface water supply of the United States, 1914, Part IX, Colorido River basin; N. C. Grover, chief hydraulic engineer; Robert Follansk se, E. A. Porter, C. C. Jacob and G. A. Gray, district engineers. 19?7. 198, xxxiii pp., 2 pls.

Contains discharge measurements of Toquerville and Hunts Springs ir Utah and Stone Cabin and Ash Meadows Springs in Nevada (pp. 191-192).

390. Surface water supply of the United States, 1914, Part X, The Grent Basin; N. C. Grover, chief hydraulic engineer; E. A. Porter, H. D. McGlashan, F. F. Henshaw, and G. C. Baldwin, district engineers. 1917. 306, xxxiii pp., 2 pls.

Contains discharge measurements of Upper and Lower Mollen Springs in Utah, Preston Spring and an unnamed spring in Nevada, and Parsnip Springs and Ana River Spring in Oregon (pp. 297-299).

391. Surface water supply of the United States, 1914, Part XI, Parific slope basins in California; N. C. Grover, chief hydraulic enginenr; H. D. MeGlashan and F. F. Henshaw, district engineers. 1917. $3^{\wedge} 4, \mathbf{x x \times v i}$ pp., 2 pls.

Contains discharge measurements of Big Spring and Roger Spring, Oreg. (p. 328).

393. Surface water supply of the United States, 1914, Part XII, B, Snake River basin; N. C. Grover, chief hydraulic engineer; G. C. Baldwin and F. F. Henshaw, district engineers. 1916. 248 pp., 2 pls.

Contains five discharge measurements of Warm Springs, Idaho (p. 241).

394. Surface water supply of the United States, 1914, Part XII, C, Lower Columbia River and Pacific drainage basins in Oregon; N. C. Grover, chief hydraulic engineer; F. F. Henshaw and G. L. Parker, district engineers. 1917. 180, xlix pp., 2 pls.

Contains discharge measurements of two large unnamed springs in Oregon, Intermittent Springs, Wash., and the combined flow of three springs near Parksdale, Oreg. (pp. 173-174).

397. Ground water in the Waterbury area, Conn., by A. J. Ellis, und $x$ the direction of H. E. Gregory. 1916. 73 pp., 4 pls.

Discusses the water in glacial drift and crystalline rocks, ground water for private and municipal uses, and methods of developing ground-water supplies. Describes the municipal pumping plants at Brookline, Mass., Brooklyn, N. Y., and Plainfield, N. J. Describes in detail the water-bearing formations and water suphlies in the towns of Ansonia, Beacon Falls, Middlebury, Naugatuck, Oxford, Seymorr, Thomaston, Waterbury, and Watertown. Contains tables of well data and water analyses and includes a map showing areas underlain by stratified drift, rock outcrops, woodlands, and locations of wells and springs.

398. Ground water in San Joaquin Valley, Calif., by W. C. Mendenl all, R. B. Dole, and Herman Stabler. 1916. 310 pp., 5 pls.

Describes the development of irrigation in the Southwest and gives an outline of the geography and geology of the San Joaquin basin. Discusses briefly the origin, circulation, quantity, and availability of ground water and its use fo- irrigation. Describes the quality of the surface and ground waters, the standards for classifications, the methods of purifying water, and the effects of quality on use. Explains the variations in the quality of the water with its depth below the surface and 


\section{Ground water in San Joaquin Valley, Calif.-Continued.}

with its geographic and geologic relations. Gives details of 55 pumping tests and summarizes and discusses thé results. Gives numerous well records and water analyses and detailed descriptions by counties. Includes maps shoving areas of artesian flow, contours of the water table, quality of ground water, and locations of the pumping plants investigated.

399. Geology and ground waters of northeastern Arkansas, by L. W. Stephenson and A. F. Crider, with a discussion of the chemical character of the waters, by R. B. Dole. 1916. 315 pp., 11 pls.

Covers an area of about 13,250 square miles extending from Mississippi River west to the Ozark province and from Missouri south to Arkansa; River. Describes the physiography, geology, surface waters, stratigraphic distrizution of ground waters, springs, artesian waters, and uses of ground water, especially in irrigating rice. Gives detailed descriptions, well sections, and tables of well data by counties. Discusses chemical standards of classification, methods of purification, and the quality of the waters in relation to the strata in which they occur, their geographic positions, and their depths below the surface. Includes numerous analyses and maps showing the geology, the areas of artesian flow, and the locations and depths of wells.

400. Contributions to the hydrology of the United States, 1916; N. C. Grover, chief hydraulic engineer. 1917. $108 \mathrm{pp} ., 7 \mathrm{pls}$.

(b) Artesian water for irrigation in Little Bitterroot Valley, Mont., by 0 . E. Meinser, pp. 9-87, pls. 1-4.

(e) Ground water for irrigation in the Morgan Hill area, Calif., by W. O. Clark, pp. 61-106, pls. 5-7.

Both papers include maps showing ground-water conditions. No. 400 e contains numerous well sections and records of water levels in wells and an estimate of the annual ground-water supply, based chiefly on fluctuations of the water table and porosity of the water-bearing deposits.

416. The divining rod, a history of water witching, with a biblingraphy, by $A$. J. Ellis. 1917, 55 pp.

Gives an outline of the history of the popular delusion known as "water witching" and points out fallacies in so-called "mechanical water finders." Advises the public against expending money "for the services of any water witch or for the use or purchase of any machine or instrument devised for locating underground water or other minerals." Lists numerous papers on the subject from 1532 to the present time.

418. Mineral springs of Alaska, by G. A. Waring, with a chapter on the chemical character of some surface waters of Alaska, by P. B. Dole and A. A. Chambers. 1917. 114 pp. 9 pls.

Describes hot springs in 48 localities, carbonated springs in 12 localities, and sulfur springs in 13 localities, also iron springs and salt springs. I'scusses the chemical charaeter of the waters of Yukon, Tanana, Lowe, Copper, Stikine, and other rivers. Contains 32 analyses of spring waters and 38 analyses of surface waters. Includes a map of Alaska showing the locations of 108 groups of mineral springs in relation to volcanoes.

422. Ground water in Animas, Playas, Hachita, and San Luis basins, N. Mex., by A. T. Schwennesen. 1918. 152 pp., 3 pls.

Covers the southern part of Grant County. Describes the physiog aphy and geology and the ground-water conditions in each basin with respect to the occurrence, depth, quantity, quality, artesian conditions, and irrigation prospects. Gives well data, analyses of water, and analyses of the water-soluble contents of th soil. Contains a map of the area showing depiths to the water table and other feat'res.

423. Geology and water resources of Big Smoky, Clayton, and Alkali Spring Valleys, Nev., by O. E. Meinzer. 1917. 167 pp., 15 pls

Describes the physiography and geology with special reference to Quaternary events ; gives data on precipitation, stream flow, seepage, springs, and wells ; estlmates intake and discharge of ground water; discusses criteria for recogni-ing shallow-water 
423. Geology and water resqurces of. Big Smoky, Clayton, and Alkali Spring Valleys, Nev.-Continued.

areas; discusses the quality of the water with reference to the geologic source of the valley fill, geographic provinces, and use; describes public water sup rlies and discusses irrigation with ground water; contains analyses of water and of alkali in soil; includes maps showing Pleistocene lake features, depths to grourd water, areas of ground-water intake and discharge, and locations of watering planes.

425. Contributions to the hydrology of the United States, 1917; N. C. Grover, chief hydraulic engineer. 1918.

(a) Ground water in San Simon Valley, Ariz., by A. T. Schwennesen with a chapter on agriculture by R. H. Forbes, pp. 1-35, pls. 1-3. Describes the physiography and geology of the valley, the upper water horizon, and the deeper artesiar horizon of the San Simon and Bowie areas, the ground water in the Rodeo and Artesia valleys, and the irrigation supplies from flowing and non-flowing wells; contains 39 analyses of well and spring waters, numerous records of deep wells and maps showing areas of artesian flow, depth to water table, and lands irrigated with well water; also includes a chapter by R. H. Forbes on soil, vegetation, and ag:icultural prospects.

(b) Ground water for irrigation in Lodgepole Valley, Wyo.-Nebr., kp $\mathbf{0}$. $\mathbf{E}$. Meinzer, pp. 37-69, pls. 4-6. Describes the physiography and geology of Indgepole Valley and the adjacent region and the water in the alluvial gravel ant in the Tertiary and. Cretaceous formations; discusses irrigation with ground watir ; gives well data and analyses of 20 well waters and 2 samples from Logdepol ? Creek; contains maps showing the geology and the depths to the water table; also includes data on the cost of pumping for irrigation in western Nebraska, by H. C. Diesem, U. S. Department of Agriculture.

(d) Ground water in Reese Valley and adjacent parts of Humboldt Rive" Valley, Nev., by $\dot{G}$. A. Waring, pp. 95-129, pls. 7-12. Describes the physiography, geology, ground-water conditions, and irrigation prospects. Contains well and spring data and analyses of ground waters. Includes a map showing the geology, shall $2 w-w a t e r$ areas, and areas of artesian flow.

(e) Ground water in Quincy Valley, Wash., by A. T. Schwennesen ard 0 . $E$. Meinzer, pp. 131-158, pls. 13-14. A preliminary report, which outlines the physiographic features, climate, and agricultural conditions of Quincy Valley and adjacent regions; describes the character and distribution of the Yakima basalt, Pleistocene lake beds, and Pleistocene outwash gravels and discusses quantity, quality, and head of water in each of these formations; discusses present and prospentive irrigation with ground water. Contains a sketch map showing contours of the water table.

427. Bibliography and index of the publications of the United States Goological Survey relating to ground water, by O. E. Meinzer. 1918. 169 pp., 1 pl .

Includes all publications of the Geological Survey prior to 1918 that contain information on ground water, with page references to reports that deal mainly with other' subjects. Gives a brief abstract of each paper, an index, and a map showing areas covered by reports.

428. Artesian waters in the vicinity of the Black Hilis, S. Dak., by N. JT.- Darton. 1918. 64 pp., 13 pls.

Describes the geology and artesian-water conditions in areas covered in previous reports but in the light of additional data. Discusses the artesian prospects of the Dakota, Minnelusa, and Deadwood sandstones. Contains a map showing the geology and the depths to the water-bearing sandstones.

429. Ground water in the San Jacinto and Temecula Basins, Calif., br G. A. Waring. 1919. 113 pp., 14 pls.

Describes the irrigation systems, physiography, geology, and ground-water conditions, including artesian conditions and quality of water. Includes well data and water analyses and a chapter on pumping tests, by Herman Stabler. Contains maps showing areal geology, irrigated areas, depth to ground water, and artesian areas. 
-

430. Surface water supply of Hawaii, July 1, 1913, to June 30,$1915 ; \mathrm{N}$. C. Grover, chief hydraulic engineer; C. K. Larrison, district engineer. 1917. 329 pp.

Contains data on the discharge of springs, tunnels, and flowing wells on the Islands of Oahu and Maui (pp. 205-207 and 308).

440. Surface water supply of the United States, 1916, Part X, Tre Great Basin; N. C. Grover, chief hydraulic engineer; E. A. Porter, C. C. Jacob, H. D. McGlashan, F. F. Henshaw, G. C. Baldwin, and Robsrt Follansbee, district engineers. 1919. 331, xxxviii pp., 2 pls.

Contains discharge measurements of 5 springs in Utah (pp. 319-321), 4 springs in Nevada (p. 325), and 10 springs in southeastern Oregon (p. 32?).

441. Surface water supply of the United States, 1916, Part XI, Pacific slope basins in,California; N. C. Grover, chief hydraulic engineer; H. D. McGlashan and F. F. Henshaw, district engineers. 1918. 330, xxxvi pp., 2 pls.

Contains discharge measurement of Big Springs, at Mayten, Calif. (p. 324).

445. Surface water supply of Hawaii, July 1, 1915, to June $₹$, 1916; N. C. Grover, chief hydraulic engineer; G. K. Larrison, district engineer. 1917. 224 pp.

Contains discharge records for springs near Kailua, Oahu (pp. 97-99), for Kahoma development tunnel, near Lahaina, Maui (pp. 156, 157), and springs near Lahaina (p. 201).

446. Geology and ground waters of the western part of San Diego County, Calif., by A. J. Ellis and C. H. Lee. 1919. 321 pp., 47.pls.

Discusses the detailed physiography and geology of the area, precipitation, and evaporation. Describes occurrence of water in major and minor valleys with reference to valley fll, water table, well yield, methods of well sinking. quality of water, and pumping tests. Includes tables giving well records and anal rses of water and maps showing general geology, fluctuations of the water table. contours on the water table, principal water-bearing formations, and mean annual precipitation.

449. Ground water in the Meriden area, Conn., by G. A. Waring. 1920.83 pp., 7 pls.

Cover parts of Hartford, New Haven, and Middlesex Countier Conn. Describes occurrence and availability of ground-water supplies, methods of well construction, and quality of ground water. Contains descriptions of towns with reference to geology, surface water, ground water, records of wells and surings, and water analyses. Includes maps showing areal geology, extent of glarial deposits, and forested areas.

450. Contributions to the hydrology of the United States, 1919; N. C. Grover, chief hydraulic engineer. 1921. iv, 86 pp., 11 pls.

(a) Geology and water resources of the Gila and San Carlos Valleys in the San Carlos Indian Reservation, Ariz., by A. T. Schwennesen, pp. 1-27, pls. 1-4. Covers parts of Gila, Pinal, and Graham Counties, Ariz. Describes the investigation of possible use of ground water for irrigation. Includes physiography, geology, extent of irrigation, occurrence, quantity, and quality of shallow ground water, and possible sources of artesian water. Includes analyses of water and maps showing geology, local vegetation, and extent of arable land.

(b) Ground water in Lanfair Valley. Calif., by D. G. Thomps?n, pp. 29-50, pls. 5-6. Covers the east-central portion of San Bernardino County, Crlif. Describes the geology, climate, vegetation, and source, occurrence, and quality of ground water. Includes analyses of water and records of wells and springs.

(c) Ground water in Pahrump. Mesquite, and Ivanpah Valleys, Nev. and Calif., by G. A. Waring. pp. 51-86, pls. 7-11. Covers parts of Nye ard Clark Counties, Nev., and Inyo and San Bernardino Counties, Calif. Describes the geography and geology of the region and the ground-water conditions in each valley with reference to springs, artesian water, water table, quality of water, and trigation. Includes tables of well and spring records and water analyses. 
452. Surface water supply of the United States, 1917, Part II, South Atlantic slope and eastern Gulf of Mexico basins; N. C. Grover, chief hydraulic engineer; G. C. Stevens and W. E. Hall, district engineers. 1920. 64, xxviii pp., 2 pls.

Contains discharge measurements of 8 springs in Florida (p. 61).

456. Surface water supply of the United States, 1917, Part VI, Missouri River basin; N. C. Grover, chief hydraulic engineer; W. A. Lamb and Robert Follansbee, district engineers. 1921. 242, xlii pp., 2 pls.

Contains discharge measurement of South Spring, Wyo. (p. 238).

460. Surface water supply of the United States, 1917, Part X, The Great Basin; N. C. Grover, chief hydraulic engineer; C. C. Jacob, H. D. McGlashan, F. F. Henshaw, G. C. Baldwin, and Robert Follansbee, district engineers. 1921. 277, xl pp., 2 pls.

Contains discharge measurements of 4 springs near Park Gity, Utah (p. 264), Warm Springs near Scotts, Calif. (p. 270), and 8 springs in the Harney Lake Basin, Oreg. (p. 271).

463. Surface water supply of the United States, 1917, Part XII, North Pacific slope drainage basins: B, Snake River basin; N. C. Grover, chief hydraulic engineer; G. C. Baldwin, G. L. Parker, and F. F. Henshaw, district engineers. 1922. 168 pp., 2 pls.

Contains discharge measurements of Alpine Hot Springs and Hanser Springs, Idaho (p. 163), and Indian Rock Springs, Idaho (p. 164).

466. Ground water in the Southington-Granby area, Conn., by H. S. Palmer. 1921. 219 pp., 7 pls.

Covers parts of Litchfield, New Haven, and Hartford Counties, Conn. Discusses physiography, geology, water-bearing formations, artesian conditions, sprirgs, means of recovery of ground water, ground water as a source of public supply, and quality of water. Describes towns individually with reference to local aquifers, quality of water, public water supply, and well and spring records. Includes, tables of analyses and a geologic map.

467. Exploratory drilling for water and use of ground water for irrigation in Steptoe Valley, Nev., by W. O. Clark and C. W. Riddell, with an introduction by 0 . E. Meinzer. 1920. 70 pp., 6 pls.

Covers parts of White Pine and Elko Counties, Nev. Discusses exploratory drilling done by the United States Geological Survey in the area; the physiograply and the surface-water supply; and the ground water, with reference to oćcurrense, source, depth to water table, discharge, quantity, quality, and springs. Describes test wells of the United States Geological Survey and the irrigation program in the region. Includes a map showing land under irrigation, areas of ground-water discharge, and estimated depths to water.

468. Records of water levels in wells in southern California, by F. C. Ebert. 1921. 156 pp., 4 pls.

Discusses causes of fluctuation of the water table and describes general rater-table conditions as shown by the records. Contains data on depth to water from 135 nonflowing wells and head of some flowing wells. Most of the measurements cover the period 1900-1920.

470. Ground water in the Norwalk, Suffield, and Glastonbury areas, Conn., by H. S. Palmer. 1920. 171 pp., 12 pls.

Covers parts of Fairfield and Hartford Counties, Conn. Discusses the physiography, geology, water-bearing formations, artesian conditions, springs, means of recovery of ground water, ground water for public supplies, and quality of water. Describes the towns individually with reference to local aquifers, quality of water, public water supply, and well and spring records. Includes tables of analyses ard geologic map of the area. 
473. Surface water supply of the United States, 1918, Part III, Ohio River basin; N. C. Grover, chief hydraulic engineer; A. H. Hcrton and C. G. Paulsen, district engineers. $1922 . \quad \mathrm{v}, 115 \mathrm{pp}, 2 \mathrm{pls}$.

Contains 3 discharge measurements of Tuscumbia Spring. Tenn. (p. 112).

479. Surface water supply of the United States, 1918, Part IX, Colorado River basin; N .C. Grover, chief hydraulic engineer; Robart Follansbee, C. C. Jacob, A. B. Purton, and C. E. Ellsworth, district engineers. 1922. v, 189 pp., 2 pls.

Contains discharge measurement of Hunt's Spring, near Central, Utah (p. 185).

480. Surface water supply of the United States, 1918, Part X,'The Great Basin; N. C. Grover, chief hydraulic engineer; C. C. Jacob, A. B. Purton, H. D. MeGlashan, F. F. Henshaw, G. C. Baldwin, and Robert Follansbee, district engineers. 1922. vi, 271 pp., 2 pls.

Contains discharge measurements of Haveter Spring, near Park City, Utah, 3.1 sec.-ft. (p. 260), and of 7 springs in Harney Lake Basin, Oreg. (p. 266).

483. Surface water supply of the United States, 1918, Part XII. North Pacific drainage basins: B, Snake River basin; N. C. Grover, chief hydraulic engineer; G, C. Baldwin, G. L. Parker, A. B. Purton, and F. F. Henshaw, district engineers. 1922. v, 171 pp., 2 pls.

Contains several discharge measurements of Alpine Springs, Hansen Springs, and Indian Rock Springs, all in Idaho (pp. 167, 168).

489. The occurrence of ground water in the United States, with a discussion of principles, by $\mathrm{O}$. E. Meinzer. 1923 . xi, 321 pp., $31 \mathrm{pl}$-.

A comprehensive treatment of the principles of the occurrence of ground water and a systematic description of the rock systems in the United States with respect to their water-bearing properties. The first section includes discuision of porosity, forces controlling water movement, and zones of saturation ard aeration. The second section describes water-bearing properties of all rock types. The third section discusses structural features of rocks and their influence on ground water. The last section discusses the water-bearing formations in each of the geologic systems, with tables for geologic formations and their value for water supply in each part of the country. Includes a map of ground-water provinces and a discussion of occurrence of ground water in each of these provinces.

490. Routes to desert watering places in California and Arizona.

(a) Routes to desert watering places in the Salton Sea region, Calif., by J. S. Brown. 1920. pp. i-v, 1-86, pls. 1-7. Covers Imperial County and parts of San Diego and Riverside Counties in southeastern Cálifornia.

(b) Routes to desert watering places in the Mohave Desert ragion, Calif,, by D. G. Thompson. 1921. pp. i-vii, 1-4, 87-269, pls. 1-4, 8-18. Covers San Bernardino County and parts of Kern and Los Angeles Counties in southern California.

(c) Routes to desert watering places in the lower Gila region. Ariz., by* C. P. Ross. 1922. pp. i-iv, 1-4, 271-315, pls. 1-3, 19-22. Covers Yuma and western Maricopa Counties in southwestern Arizona.

(d) Routes to desert watering places in the Papago region, Ariz., by Kirk Bryan. 1922. pp. i-vi, 1-4, 317-429, pls. 1-3, 16, 23-28. Covers parts of Yuma, Maricopa, Pinal, and Pima Counties in southwestern Arizona.

These four papers describe the physical features of the region and give suggestions for desert travel, lists of main roads, and complete road logs, with an index to watering places. Each report includes shaded topograph': maps showing roads and watering places. Papers $490 \mathrm{c}$ and $490 \mathrm{~d}$ also describe the types of roads.

494. Outline of ground-water hydrology, with definitions, by $O$. E. Meinzer. 1923. iv, $71 \mathrm{pp}$.

Gives an outline of the concepts of ground-water hydrology, with classification of many of the concepts. Assigns terms for these concepts, many o* which are new. Discusses water of the earth, atmospheric water, surface water, and subsurface water with reference to origin, occurrence, water tables, movement, absorption, and discharge. Includes a section on wells and their classification. 
495. Geology and ground-water resources of Sacramento Valley, Calif., by Kirk Bryan. 1923. xi, 285 pp. 19 pls.

Covers the north-central part of California. Deseribes the physiography, geology, water-bearing formations, water table, intake and discharge of ground water, quantity of water, artesian conditions, quality of water, well and pumping problems, deep wells, and irrigation. Discusses the valley subdivision with reference to water table, wells, quality of water, and public supplies. Includes well records, water analyses and maps showing contours on the water table, depth to water table, and.irrigated areas.

496. The industrial utility of public water supplies in the United Strtes, by W. D. Collins. 1923. iv., 59 pp., 1 pl.

Discusses sources, treatment, and analyses of public water supplies in the United States. Includes tables of analyses of surface and ground water used for public supplies in 307 principal cities. See also Water-Supply Paper 658.

497. The Salton Sea region, Calif., a geographic, geologic, and hydrolngic reconnaissance, with a guide to desert watering places, by J. S. Brown. 1923. $\mathrm{xv}, 292$ pp., 19 pls.

Covers Imperial County and parts of San Diego and Riverside Counties in southexstern California. Gives information on the geology, source of water, and cceurrence and quality of water in addition to information on watering places of this area contained in Water-Supply Paper 490 a. Includes analyses of water, wel records, logs, detailed deseriptions of routes of travel, and maps showing geclogy and watering places.

498. The lower Gila region, Ariz., a geographic, geologic, and hydrol ngic reconnaissance, with a guide to desert watering places, by C. P. Ross. 1923. xiv, 237 pp., 23 pls.

Covers central Yuma and western Maricopa Counties, Ariz. Gives information on the geology, surface-water supply, afd irrigation in addition to information on the watering places of this area contained in Water-Supply Paper 490-C. Inclutes water analyses, well reeords, and maps showing geology and watering places.

499. The Papago country, Ariz., a geographic, geologic, and hydrologic reconnaissance with a guide to desert watering places, by Kirk Bryan. 1925. xviii, 436 pp., 27 pls.

Covers part of Yuma, Maricopa, Pinal, and Pima Counties in southwestern' Arizona. Deseribes the geology and physiography of the area and discusses the surface water supply, indicators of ground water, quality and mode of occurrence of ground water, and springs. Describes ground-water conditions by areas. Incluces water analyses and the description and guide to watering places of the area cortained in Water-Supply Paper $490 \mathrm{~d}$.

500. Contributions to the hydrology of the United States, 1921; N. C. Grover, chief hydraulic engineer. 1922. iv, $74 \mathrm{pp} ., 4 \mathrm{pls}$.

(b) Ground water for irrigation near Gage, Ellis County, Okla., by D. G. Thompson, pp. 33-53, pl. 4. Discusses possible sources of ground water for irrigation and describes the geology, physiography, artesian conditions, and water-bearing horizons. Includes well records and water analyses.

508. Surface water supply of the United States, 1919-20, Part VIII, Testern Gulf of Mexico basins; N. C. Grover, chief hydraulic engineer; C. E. Ellsworth, district engineer. 1922 . iv, 136 pp., 2 pls.

Contains discharge record of Barton Springs, Tex. (p. 64), and discharge measurements of San Solomon, Griffin, Saragosa, and Fort Stockton Springs, Tex. (p. 134).

510. Surface water supply of the United States, 1919-20, Part $X$, The Great Basin; N. C. Grover, chief hydraulic engineer; A. B. Purton H. D. McGlashan, F. F. Henshaw, C. G. Paulsen, and Robert Follansk æe, district engineers. $1923 . \quad$ vi, 348 pp., 2 pls.

Contains discharge measurement of Hauter Spring, Utah (p. 331), and "00" Springs, Oreg. (p. 341). 
513. Surface water supply of the United States, 1919-20, F rt XII, North Pacific slope drainage basins: B, Snake River basin; N. C. Grover, chief hydraulic engineer; G. C. Baldwin, G. L. Parker, C. G. Paulsen, A. B. Purton, and F. F. Henshaw, district engineers. 1924. vi, 318 pp., 2 pls.

Contains discharge measurement of Oakden Spring, Idaho (p. 307), and 5 measurements of Limestone Springs, Idaho (p. 308).

514. Surface water supply of the United States, 1919-20, Fart XII, North Pacific slope drainage basins: C, Lower Columbia $F^{*}$ ver basin and Pacific slope drainage basins in Oregon; N. C. Grover, chief hydraulic engineer; F. F. Henshaw and G. L. Parker, district engineers. 1924. v, 204 pp., 2 pls.

Contains discharge measurement of springs near Benham Falls, Oreg. (p. 197).

518. Ground water in Musselshell and Golden Valley Counties, Mont., by A. J. Ellis and O. E. Meinzer. 1924. vi, 92 pp., 5 pls.

Describes the physiography, water-bearing properties of rock formations, effect of structure on water supply, artesian conditions, and quality of viater with reference to geologic horizon and depth. Includes descriptions of ground-water conditions by townships, water analyses, and a geologic map of the area.

519. Ground water in Santa Clara Valley, Calif., by W. O. Clark. 1924. vii, 209 pp., 19 pls.

Covers Alameda, Santa Clara, and San Benito Counties, Calif. Describes the physiography, geology, precipitation, and surface water. Discusses absorption, groundwater levels, methods used to determine quantity of ground water, artesian conditions, and water supplies for irrigation and municipal, domestic, and industrial use. Includes data on pumping plants and water levels in wells, well logs, and maps showing contours of water table, fluctuations of water table, and area of artesian flow.

520. Contributions to the hydrology of the United States, 1923-24; N. C. Grover, chief hydraulic engineer. 1925. iv, 129 pp., 12 pls.

(b) Additional ground-water supplies for the city of Enid, Okla., by B. C. Renick, pp. 15-26. Describes the geology and the source and occurrence of ground water; discusses present water supplies, annual recharge of ground we.ter, and quality of water; and makes recommendations for increasing the ground-water supply.

(d) Base exchange in ground water by silicates as illustrated in Montana, by B. C. Renick, pp. 53-72, pis. 3-5. Discusses the natural softening of water that takes place in the Lance and Fort Union formations in Rosebud County, Mont. Clay minerals soften the hard water as it percolates downward. Includes water analyses and petrographic descriptions of the water-bearing formations.

(e) The artesian-water supply of the Dakota sandstone in North Dakota, with special reference to the Edgeley quadrangle, by $O$. E. Meinzer and H. A. Hard, pp. 73-95, pls. 6-7. Discusses early artesian drilling, decline in artesian head and shrinkage of area of artesian flow, decline in yield of wells, rate of recharge, the removal of water from the Dakota sandstone and compression of the formation, and the conservation program of North Dakota. Includes well records and analyses of water.

(f) Temperature of water available for industrial use in the United States, by W. D. Collins, pp. 97-104, pls. 8-11. Discusses the relation of temperatures of ground water, surface water, and air. Includes tables showing correlation between air and surface water temperatures and a map showing average ground.water temperatures in nonthermal wells 30 to 60 feet deep.

526. Surface water supply of the United States, 1921, Part VI, Missouri River basin; N. C. Grover, chief hydraulic engineer; W. A. Lamb, Robert Follansbee, E. D. Burchard, R. C. Rice, and E. L. V'illiams, district engineers. 1925. vii, 331 pp., 2 pls.

Contains discharge measurement of Hahatonka Spring, Mo. (p. 325). 
528. Surface water supply of the United States, 1921, Part VIII, 'Nestern Gulf of Mexico basins; N. C. Grover, chief hydraulic engineer; C. E. Ellsworth, district engineer. 1923 . iv, 96 pp., 2 pls.

Contains 4 discharge measurements of Mill Spring, Tex. (p. 93).

529. Surface water supply of the United States, 1921, Part IX, Colorado River basin; N. C. Grover, chief hydraulic engineer; Robert Follansbee. A. B. Purton, and R. C. Rice, district engineers. 1925. v, 181 pp., 2 pls. . Contains discharge measurement of Hunts Springs, Utah (p. 178).

530. Surface water supply of the United States, 1921, Part X, Tho Great Basin; N. C. Grover, chief hydraulic engineer; A. B. Purton, H. D. McGlashan, and F. F. Henshaw, district engineers. 1926. v, 194 pn., 2 pls. Contains discharge measurement of "00" Spring, Oreg. (p. 190).

533. Surface water supply of the United States, 1921, Part XII, Nortl Pacific slope drainage basins: B, Snake River basin; N. C. Grover, chief hydraulic engineer; G. C. Baldwin, G. L. Parker, C. G. Paulsen, A. B. Purton, and F. F. Henshaw, district engineers. 1925. vi, 292 pp., 2 pls.

Contains discharge measurements of principal springs, and inflow, on rorth side of Snake River from Milner to Bliss, Idaho (p. 283-286).

535. Surface water supply of Hawaii, July 1, 1920, to June 30, 1921; N. C. Grover, chief hydraulic engineer; J. E. Stewart, district engineer. 1924. iv, $151 \mathrm{pp}$.

Contains discharge measurement of Punahou Springs, near Honolulu (p. 66), and of four branches of Big Springs (p. 83).

537. A study of coastal ground water, with special reference to Conrocticut, by J. S. Brown. 1925 . viii, 101 pp., 7 pls.

Discusses the subject of coastal ground water, with special reference to the New Haven, Conn., area. Describes the geology, physiography, and ground-water conditions in the New Haven coastal area, with a discussion of the Ghyben-Herzberg theory of fresh and salt water relationships, contamination by salt water, effects of pumping and tides on contamination, and the nature of the fresh and salt wate contact. Includes a geologic map, water analyses, descriptions of wells, springs, and pumping plants in the New Haven area, and a bibliography of coastal ground water.

538. The San Juan Canyon, southeastern Utah, a geographic and hydrcripraphic reconnaissance, by H. D. Miser. 1924 . v, 80 pp., $22 \mathrm{pls.}$

Primarily a geographic reconnaissance of the area. Describes the geology and geography of the canyon and gives descriptions of San Juan River and of tributary springs and streams. Includes a geologic map.

539. Geology and ground-water resources of Townsend Valley, Mont., by J. T. Pardee. 1925. iv, 61 pp., 2 pls.

Includes parts of Lewis and Clark and Broadwater Counties, Mont. Describes the geology, physiography, and ground-water conditions with reference to public water supplies, water table, quality of water, and artesian conditions. Includes water analyses, well records, and a geologic map.

540. Ground water in the New Haven area, Conn., by J. S. Brown. 1928. vi, 206 pp., 15 pls.

Covers New Haven County and part of Middlesex County, Conn. Dissusses the geology and physiography of the area and the ground-water resources $w^{i} h$ respect to occurrence, quality, and methods of recovery. Describes the public water supplies and gives records of wells and springs in the several towns, with water analyses. Includes a geologic map.

547. Surface water supply of the United States, 1922, Part VII, Lower Mississippi River basin; N. C. Grover, chief hydraulic engineer; E. L. Williams and Robert Follansbee, district engineers. 1925. iv, 106 pp., 2 pls.

Contains discharge measurement of Alley Spring at Alley, Mo. (p. 103). 
548. Surface water supply of the United States, 1922, Part VIII, Western Gulf of Mexico basins; N. C. Grover, chief hydraulic engineer; C. E. Ellsworth, district engineer. 1925. iv, 124 pp., 2 pls.

Contains numerous discharge measurements of Mill Spring, near Austin, Tex., and discharge meàsurements of Fleming, Sloans, San Solomon, Comanche, Goodenough, and San Felipe Springs and Troy's Johnson Well No. 1 and Grants-Devlin Well No. 4. (pp. 120, 121).

549. Surface water supply of the United States, 1922, Part IX, Colorado River basin; N. C. Grover, chief hydraulic engineer; Robert Follansbee, A. B. Purton, and R. C. Rice, district engineers. 1927. v, 175 pp., 2 pls.

Contains discharge measurements of Ashley Spring, and Hurt's Spring. Utah (p. 170).

553. Surface water supply of the United States, 1922, Part XII, North Pacific slope drainage basins: B, Snake River basin; N. C. Grרver, chief hydraulic engineer; G. C. Baldwin, G. L. Parker, C. G. Paulsen, A. B. Purton, and F. F. Henshaw, district engineers. 1926. vi, 295 pp., 2 pls.

Contains discharge measurements of several artesian wells in Id tho (p. 287, 288).

557. Large springs in the United States, by O. E. Meinzer. 192.7. vii, $94 \mathrm{pp.,}$ 17 pls.

Discusses the distribution and character of large springs and gives a proposed elassification with respect to size. Describes in detail the large springs from each part of the United States as to origin, size, fluctuations of discharge, relation to rock structure, and character of the water. Includes maps of several areas showing the relation of springs to geologic structure.

559. Relations between quality of water and industrial devel ppment in the United States, by W. D. Collins. 1926. iv, 43 pp., 5 pls.

Discusses requirements of water for various industrial uses, purification of water, public water supplies, and location of typical industries with special reference to quality of water. Lists factors affecting the movement of industrial centers.

560. Contributions to the hydrology of the United States, 1925; N. C. Grover, chief hydraulic engineer. 1925. iii, 134 pp., 2 pls. (Published in March, 1926.)

(b) Chemical character of ground waters of the northern Great Plains, by $\mathbf{H}$. B. Riffenburg, pp. 31-52. Describes the general geology of the rerion; the general character of ground water; and the changes that take place throurh base exchange, absorption of base and acid, and reduction of sulfate. Discusses the character of water from the several geologic formations of the region and give typical analyses of water from the principal formations.

(c) Index of analyses of natural waters in the United States, by W. D. Collins and C. S. Howard, pp. 53-85. A bibliography of publications, chieqy of Federal and State bureaus, containing water analyses arranged by States.

(d) Preliminary report on the geology and water resources of the Mud Lake basin, Idaho, by H. T. Stearns and L. L. Bryan, pp. i-iv, 87-134, pls. 1-2. Gives a summary of surface-water supplies, describes the ground-water table in the several parts of the area, and presents an inventory of the water supply, with dat on minor lakes. ground water, and artesian conditions. Discusses quality of water and gives a table of analyses of water from 12 wells, 4 lakes, and Lidy Hot Spring. Contains a map showing contours of the water table. See also Water-Supply Paper 818.

566. Surface water supply of the United States, 1923, Part VI, Missouri River basin; N. C. Grover, chief hydraulic engineer; W. A. Lamb, C. G. Paulsen, Robert Follansbee, J. B. Spiegel, E. L. William , H. B. Kinni- son, and H. C. Beckman, district engineers. 1927. viii, 395 pp.

Contains discharge measurement of Bennett Spring, Mo. (p. 857). 
567. Surface water supply of the United States, 1923, Part VII; Lovrer Mississippi River basin; N. C. Grover, chief hydraulic engineer; E. L. Williams, H. C. Beckman, Robert Follansbee, and H. B. Kinni ₹on, district engineers. 1926. iv, 122 pp., 3 pls.

Contains discharge measurements of Roaring River, Mill, Round, and Blue Springs, Mo. (p. 96).

568. Surface water supply of the United States, 1923, Part VIII, Western Gulf of Mexico basins; N. C. Grover, chief hydraulic enginee:. 1927. iv, 168 pp., 3 pls.

Contains several discharge measurements of Mill, San Solomon, Giffin, Comanche, Goodenough, and San Felipe Springs, Tex. (pp. 143, 144).

570. Surface water supply of the United States, 1923, Part X, TF? Great Basin; N. C. Grover, chief hydraulic engineer; A. B. Purton, H. D. McGlashan, F. F. Henshaw, C. G. Paúlsen, and Robert Follan\$̧bee. district engineers. 1927. $\mathrm{v}, 183 \mathrm{pp}$.

Contains 4 discharge measurements of Formation Springs, Idaho (p. 147).

573. Surface water supply of the United States, 1923, Part XII, North Pacific slope drainage basins: B, Snake River basin; N. C. Grover, chief hydraulic engineer; G. C. Baldwin, G. L. Parker, C. G. Paulsen. A. B. Purton, and F. F. Henshaw, district engineers. 1928. vi, 259, li pp.

Contains discharge measurements of four unnamed springs about 4 wiles north of Kimberly, Idaho (p. 252).

574. Surface water supply of the United States, 1923, Part XII, Nort' T Pacific slope drainage basins: C, Lower Columbia River basin and Pac:fic slope drainage basins in Oregon; N. C. Grover, chief hydraulic engineer; F. F. Henshaw and G. L. Parker, district engineers. 1927. v, 194, li pp., 3 pls.

Contains discharge measurements of Boundary Springs, Oreg. (p. 188), and Big Butte Spring, Oreg. (p. 189).

575. Surface water supply of Hawaii, July 1, 1922, to June $30,192 ?$; N. C. Grover, chief hydraulic engineer; E. D. Burchard, district $€$ ngineer. 1927. iv, $173 \mathrm{pp}$.

Contains discharge measurement of Spring No. 7, Waianae Valley (p. 67).

576. The ground-water resources of Mississippi, by L. W. Stephenson, W. N. Logan, and G. A. Waring, with discussions of the chemical character of the waters by C. S. Howard. 1928. vii, 515 pp., 12 pls.

Describes the physiography and surface water briefly. Discusses occirrence of ground water, both artesian and nonartesian, and the water-bearing properties of each geologic formation. A separate section describes the quality of groind water. Describes each county separately as to ground-water conditions, analyses of ground water, representative well records, and public supplies. Includes a geclogic map and map showing areas of artesian flow.

577. Plants as indicators of ground water, by O. E. Meinzer. 1927. v, 95 pp., 12 pls.

Lists species of plants that grow principally over shallow ground water and those that do not. Discusses the relation of these two groups and describes th? value of plants as indicators of the depth to water and its quality and quantity.

578. The Mohave Desert region, Calif., a geographic, geologic, and hJdrologic reconnaissance, by D. G. Thompson. 1929. xi, 759 pp., 34 pls.

1 Contains information on the geology, physiography, mineral resources, water supplies, and other features of a region covering about 25,000 square miles in seuthern California. Gives data on about 1,200 wells and 100 springs ir about 60 
578. The Mohave Desert region, Calif.-Continued.

separate valleys, with information on the geologic conditions, underground reservoirs, water level, recovery and use of water, and plants as indicators of ground water. Contains analyses of water from about 150 wells and springs. Gives special attention to playas and their relation to ground-water conditions.

580. Contributions to the hydrology of the United States, 1926; N. C. Grover, chief hydraulic engineer. 1927 . ii, 116 pp., 3 pls.

(a) Geology of No. 3 reservoir site of the Carlsbad irrigation project, N. Mex., with respect to water-tightness, by 0 . E. Meinzer, B. C. Renick, and Kirk Bryan, pp. 1-39, pls. f-2. Describes the geology and structure of the reservoir site, which covers about 8 square miles along Pecos River 1 to 10 miles below the dam of MeMillan Reservoir. The authors conclude that the risk due to rrobable leakage is too great to warrant the construction of a dam to impound water to the height - contemplated.

586. Surface water supply of the United States, 1924, Part VI, Missouri River basin; N. C. Grover, chief hydraulic engineer; W. A. Lamb, Robert Follansbee, C. G. Paulsen, J. B. Spiegel, H. C. Beckman, and H. B.

- Kinnison, district engineers. 1928. viii, 343 pp.

Contains discharge measurements of Waynesville Spring and Paydown Spring, Mo. (p. 388).

587. Surface water supply of the United States, 1924, Part VII, Lower Mississippi River basin; N. C. Grover, chief hydraulic engineer; H. C. Beckman, Robert Follansbee, H. B. Kinnison, and C. E. Ellsworth, district engineers. 1928 . iv, $123 \mathrm{pp}$.

Contains discharge measurements of 9 springs in Missouri and B iffalo and Tacovas Springs in Tex. (p. 120).

588. Surface water supply of the United States, 1924, Part VII], Western Gulf of Mexico basins; N. C. Grover, chief hydraulic enginear; C. E. Ellsworth district engineer. 1928. vi, $229 \mathrm{pp}$.

Contains 15 discharge measurements of Mill Spring, near Austin, Tex. (p. 221), and discharge measurements of 11 other springs in Texas (pp. 222, 223).

590. Surface water supply of the United States, 1924, Part X, T] 9 Great Basin; N. C. Grover, chief hydraulic engineer; A. B. Purton, H. D. McGlashan, F. F. Henshaw, C. G. Paulsen, and Robert Follansbee, district engineers. 1928. v, $131 \mathrm{pp}$.

Contains 5 discharge measurements of Formation Springs, Idaho (p. 126).

591. Surface water supply of the United States, 1924, Part XI, Pacific slope basins in California; N. C. Grover, chief hydraulic engineer; H. D. MoGlashan and F. F. Henshaw, district engineers. 192? viii, 448 pp.

Contains discharge measurement of Warner Hot Springs (p. 434).

593. Surface water supply of the United States, 1924, Part XIJ, North Pacific slope drainage basins: B, Snake River basin; N. C. Grover, chief hydraulic engineer; G. C. Baldwin, G. L. Parker, C. G. Paulsen, A. B. Purton, and F. F. Henshaw, district engineers. 1929. iv; 264 pp.

Contains discharge measurements of 14 springs in Idaho (pp. 255, 256).

594. Surface water supply of the United States, 1924, Part XIJ, North Pacific slope drainage basins: C, Lower Columbia River basin and Pacific slope drainage basins in Oregon; N. C. Grover, chief hydraulic engineer; F. F. Henshaw and G. L. Parker, district engineers. 19:9. vi, 215 pp.

Contains several discharge measurements on 4 springs 6 miles east of Butte Falls, Oreg. (p. 208). 
595. Surface water supply of Hawaii, July 1, 1923, to June $30,19^{\wedge} 4 ;$ N. C. Grover, chief hydraulic engineer; E. D. Burchard and M. F. Carson, district engineers. 1929. iv, $157 \mathrm{pp}$.

Contains discharge measurements on 7 springs near Kailua, T. H. (p. 62).

596. Contributions to the hydrology of the United States, 1927; N. C. Grover, chief hydraulic engineer. 1928. v, $266 \mathrm{pp} ., 14 \mathrm{pls}$.

(a) Methods of exploring and repairing leaky artesian wells: Preface, by 0 . $E$. Meinzer, pp. 1-3; Methods of exploring and repairing leaky artesian vells on the island of Oahu, Hawaii, by John McCombs, pp. 4-24, pls. 1-3, $A$; The A u deep-well current meter and its use in the Roswell artesian basin, N. Mex., by A. G. Fiedler, pp. 24-32, pls. 3, $B-5$. Describes the use of current meters in detecting leaky artesian wells in Hawaii and New Mexico and the methods used in plugging or repairing leaky wells.

(c) Ground water in the Ordovician rocks near Woodstock, Va., by G. M. Hall, pp. 45-66, pls. 7-8. Discusses the ground-water conditions in Shenandoah County, Va., and describes the geology and water-bearing properties of the Cambrian and Ordovician rocks. Describes the chemical character of the water and problems of pollution. Includes analyses of water and a geologic map.

(f) Laboratory tests on physical properties of water-bearing materials, by $\mathbf{N}$. D. Stearns, pp. 121-176, pls. 11-13. Describes the laboratory determination of specific gravity, mechanical composition, porosity, moisture equivalent, and rermeability, with illustrations of equipment used.

(g) Chemical character of waters of Florida, by W. D. Collins and C. S. Howard, pp. 177-233. Discusses quality of surface water and ground water in Florida and methods of treatment before utilization.

(h) Notes on practical water analysis, by W. D. Collins, pp. 235-266, pl. 14. Describes methods used in making water analyses in the United Stater Geological Survey and the graphical representation of analyses.

597. Contributions to the hydrology of the United States, 1928; N. C. Grover, chief hydraulic engineer. $1929 . \quad \mathrm{v}, 250 \mathrm{pp} ., 23 \mathrm{pls}$.

(a) Geology of reservoir and dam sites, with a report on the Owyhee irrigation project, Oreg., by Kirk Bryan, pp. 1-72, pls. 1-10. Describes ground.water considerations in the selection of reservoir and dam sites and gives a bibliography of engineering geology. Also published as Geologia de los sitios devasos dis almacenamiento $y$ cortinas: Irrigacion en Mexico, vol. 23, No. 5, September-October 1942, pp. 60-88.

(b) A study of ground water in the Pomperaug Basin, Conn., with special reference to intake and discharge, by $O$. E. Meinzer and N. D. Stearns, pp. 73-146 pls. 11-19. Describes the geography and geology of the Pomperaug Basin and the gund-water resources of the towns of Bethlehem, Southbury, and Woodbury, Conn. Discusses the methods of making a ground-water inventory with regard to p"ecipitation, evaporation, and surface-water and ground-water runoff; gives a monthly inventory 1913-16. Includes a discussion of relation of water table fiuctuations to g "ound-water storage. Contains geologic map.

(c) Problems of the soft-water supply of the Dakota sandstone, vith special reference to the conditions at Canton, S. Dak., by O. E. Meinzer, pp. 147-170, pl. 20. Describes the geology of water-bearing formations at Canton, S. Dak., with speclal reference to quality of water obtained from horizons in the Dakota sandstone. Includes water analyses and well records.

(d) Geology and water resources of the upper McKenzie Valley, Oreg., by H. T. Stearns, pp. 171-188, pls. 21-23. Describes the geology and ground-water resources of the Upper McKenzie Valley in western Oregon. Includes measurements of spring discharge and a geologic map.

598. Geology and ground-water resources of North Dakota, by H. E. Simpson, with a discussion of the chemical character of the water, by JF. B. Riffenburg. 1929 . v, 312 pp., 3 pls.

Discusses the physiography, climate, and occurrence of ground water in the various seologic formations of North Dakota. Describes the ground-water provinces of the 
598. Geology and ground-water resources of North Dakota-Continued. Stite and artesian water, with special reference to the Dakota sanistone. Includes county reports, a map showing areas of artesian flow, and a chapter on quality of the ground water.

599. Ground water in Yellowstone and Treasure Counties, Mont., by G. M. Hall and C. S. Howard. 1929. vi, 118 pp., 7 pls.

Describes the physiography and geology of part of south-central Montana and gives the water-bearing properties of each geologic formation. Discrasses the relation. of structure to ground water, gives methods of obtaining water. and describes public water supplies and their quality. Includes a geologic map, analyses of water, and a discussion of ground-water conditions by townships.

600. Geology and ground-water resources of central and southern Rosebud County, Mont., by B. C. Renick, with chemical analyses of the waters, by H. B. Riffenburg. 1929. x, 170 pp., 12 pls.

Describes the stratigraphy, structure, occurrence and movement of ground water, artesian conditions, surface-water supplies, and water-bearing properties of the various formations. Includes sections on quality of ground water, with water analyses. Discusses ground-water conditions by townships.

606. Surface water supply of the United States, 1925, Part VI, MTissouri River Basin; N. C. Grover, chief hydraulic engineer; W. A. Lamb, C. G. Paulsen, Robert Follansbee, J. B. Spiegel, H. B. Kinnis`n, and H. C. Beckman, district engineers. 1930. vi, $252 \mathrm{pp}$.

Contains discharge measurements of 12 springs in Missouri (p. 247).

607. Surface water supply of the United States, 1925, Part VII, Lower Mississippi River Basin; N. C. Grover, chief hydraulic engineer; H. C. Beckman, Robert Follansbee, H. B. Kinnison, and C. E. Ellsworth, district engineers. 1929. iv, $113 \mathrm{pp}$.

Contains discharge measurements of 22 springs in Missouri, and Nammoth Spring, Ark. (p. 109).

608. Surface water supply of the United States, 1925, Part V'III, Western Gulf of Mexico basins; N. C. Grover, chief hydraulic er gineer; C. E. Ellsworth and Robert Follansbee, district engineers. 192?. vi, 268 pp. Contains discharge measurements of 8 springs in Texas (pp. 262-263).

610. Surface water supply of the United States, 1925, Part $Y$, The Great Basin; N. C. Grover, chief hydraulic engineer; A. B. Jurton, H. D. McGlashan, F. F. Henshaw, C. G. Paulsen, and Robert Follansbee, district engineers. 1929. v, $141 \mathrm{pp}$.

Contains several discharge measurements of Formation Springs, Itaho (p. 135).

614. Surface water supply of the United States, 1925, Part XII, North Pacific slope drainage basins: C, Pacific slope drainage basins in Oregon and lower Columbia River Basin; N. C. Grover, chief hydraulic engineer; F. F. Henshaw and G. L. Parker, district engineers, 192؟, vi, 198 pp. Contains 9 discharge measurements of 4 springs 6 miles east of Butte Falls, Oreg. (p. 192).

615. Surface water supply of Hawaii, July 1, 1924, to June 30,$1925 ;$ N. C. Grover, chief hydraulic engineer; M. H. Carson, district engineer. 1930. iv, $155 \mathrm{pp}$.

Contains numerous discharge measurements of small springs at an' near Waianae, T. H. (pp. 55-57).

616. Geology and water resources of the Kau district, Hawaii (ir cluding parts of Kilauea and Mauna Loa Volcanoes), by H. T. Stearns and W. 0 . Clark, with a chapter on ground water in the Hawaiian Isländs, by 0 . E. Meinzer. 1930. ix, 194 pp., 33 pls.

Discusses principles of occurrence of ground water in the Hawaitian Islands and basal and perched ground water and their structural control. Describes the Kav 
616. Geology and water resources of the Kau district, Hawaii-Continued.

district of the island of Hawaii in particular, in two separate parts. The first part describes the geography and geology in detail, and the second describes the water resources, including occurrence of ground water in the main water table and as perched or high-level water. Includes a geologic map and charts showing quantities of water developed.

619. Geology and water resources of the Mokelumme area, Calif., ly H. T. Stearns, T. W. Robinson, and G. H. Taylor. 1980. xii, 402 pp . 21 pls. Gives description of the physiography, geology, and available records of surface water in parts of San Joaquin, Sacramento, and Amador Counties. Discusses in detail ground-water levels, specific yield of water-bearing materials, an water recharge and discharge. Contains well logs and records of al out 2,000 irrigation wells. Includes maps showing geology, water-table contours, and depth to water.

620. Geology and ground-water resources of western Sandoval Connty, N. Mex., by B. C. Renick. 1931. vi, 117 pp., 10 pls.

Describes the geology and artesian and other ground waters in the western part of Sandoval County, N. Mex. Discusses in detail the water-bearing pronerties of each geologic formation, geologic structure, quality of water, artesian conditions, and mineralized and thermal springs. Includes a geologic map and structure cross sections of the area.

626. Surface water supply of the United States, 1926, Part VI, Missorri River Basin; N. C. Grover, chief hydraulic engineer; W. A. Lamb. Robert Follansbee, C. G. Paulsen, J. B. Spiegel, and H. C. Beckman, district engineers. 1930. vi, $228 \mathrm{pp}$.

Contains discharge measurements of 6 springs in Mo. (p. 224).

627. Surface water supply of the United States, 1926, Part VII, Lorrer Mississippi River Basin; N. C. Grover, chief hydraulic enginee"; H. C. Beckman, Robert Follansbee, J. B. Spiegel, and C. E. Ellswcrth, district engineers. 1930 . iv, $98 \mathrm{pp}$.

Contains discharge measurements of 9 springs in Missouri, and Mammoth Spring, Ark. (p. 96).

628. Surface water supply of the United States, 1926, Part VIII, Western Gulf of Mexico basins; N. C. Grover, chief hydraulic engineer; C. E. Ellsworth and Robert Follansbee, district engineers. 1930. v, 207 pp.

Contains discharge measurements of 6 springs in Texas (p. 202).

630. Surface water supply of the United States, 1926, Part X, TI \& Great Basin; N. C. Grover, chief hydraulic engineer; A. B. Purton, H. D. McGlashan, F. F. Henshaw, C. G. Paulsen, and Robert Follansbee, district engineers. 1930. $v, 145$ pp.

Contains discharge measurement of Formation Springs, Idaho (p. 140).

632. Surface water supply of the United States, 1926, Part XII, North Pacific slope drainage basins: A, Pacific slope basins in Washington and upper Columbia River Basin; N. C. Grover, chief hydraulic engineer; G. L. Parker and W. A. Lamb, district engineers. 1930. 154 pp.

Contains diseharge measurements of east and west branches of Mapleword Springs, Wash. (p. 149).

633. Surface water supply of the United States, 1926, Part XII, North Pacific slope drainage basins: B, Snake River Basin; N. C. Grover, chief hydraulic engineer; G. C. Baldwin, G. L. Parker, C. G. Paulsen, A. B. Purton, and F. F. Henshaw, district engineers. 1931. vi, 263 pp.

Contains 11 discharge measurements of Market Lake Springs, near Robarts, Idaho (p. 256), and 1. measurement of Lidy Hot Springs, 15 miles southwest of Dubois, Idaho, 0.7 sec,-ft. (p. 257). 
634. Surface water supply of the United States, 1926, Part XII, North Pacific slope basins; C, Pacific slope basins in Oregon and lower Columbia River Basin; N. C. Grover, chief hydraulic engineer; F. F. Henshaw and G. L. Parker, district engineers. 1930. vi, 236 pp.

Contains discharge measurements of 10 springs in Oregon and of 2 springs at outlet of Merrill Lake, Wash. (pp. 230, 231).

635. Surface water supply of Hawaii, July 1, 1925, to June $3 C_{\text {, } 1926 ;}$ N. C. Grover, chief hydraulic engineer; M. H. Carson, district engineer. 1930. v, $145 \mathrm{pp}$.

Contains discharge measurements of several small springs near Waianae, $\mathbf{T}$. H. (pp. 52-54).

637. Contributions to the hydrology of the United States, 1930; N. C. Grover, chief hydraulic engineer. 1981. iv, 220 pp., 18 pls.

(b) Preliminary report on the ground-water supply of Mimbres Valley, N. Mex., by W. N. White, pp. 69-90, pl. 1. A preliminary study of Luna County, in southwestern New Mexico. Discusses the source of ground water, the facilities for intake and the quantity of ground-water intake, the movement of ground water, shape and fluctuations of the water table, and fluctuations in storage of greind water. Includes a map showing observation wells established and gives reconmendations for further study in the area.

(d) Geology and water resources of the middle Deschutes River Basin, Oreg., by H. T. Stearns, pp. 125-220, pls. 10-18. Describes briefly the grounc-water resources of a portion of Deschutes and Jefferson Counties, Oreg. Includes discussion of the geologic formations and their water-bearing properties and a measurement of ground-water discharge into Crooked and Deschutes Rivers. Contains a map showing contours of the water table.

638. Contributions to the hydrology of the United States, 1931; N. C. Grover, chief hydraulic engineer. 1932 . v, 162 pp., 25 pls.

(a) A preliminary report on the artesian water supply of Mernhis, Tenn., by F. G. Wells, pp. 1-34, pls. 1-2. Describes the geology and the source of ground water at Memphis, Tenn. Gives pumpage for the area, with its effect on water levels, and discusses the possibility of increased development. Includes analyses of water. See also Water-Supply Paper 656 and Cooperative report 372

(c) Outline of methods for estimating ground-water supplies, by $\mathbf{O}$. E. Meinzer, pp. 99-144. Discusses ground-water supplies existing under reservoir and conduit conditions. Includes the estimation of intake from streams and precipitation and estimations of discharge from data on overflow, evaporation, trenspiration, and fluctuation of the water table, with notes on safe yield. Describes fleld measuremenits of ground-water velocity and determination of permeability by laboratory methods, by the Thiem pumping method, and by the method based on area of influence of wells.

639. Geology and ground-water resources of the Roswell artesian basin, N. Mex., by A. G. Fiedler and S. S. Nye. 1933. xii, 372 pp., 46 pls.

Most. of the artesian water of the basin is obtained from the Picacho limestone, of Permian age. The original area of artesian flow comprised 663 square miles. About 60,000 acres are irrigated by water derived directly or indire tly from wells. It is concluded that no new land should be placed under irrigation with artesian water, but the development of shallow ground water should be encouraged.

640. Ground water in north-central Tennessee, by A. M. Piper. 1932. viii, 238 pp., 9 pls.

Describes the geography, stratigraphy, and geologic structure of the area. Discusses the occurrence of ground water in limestone formations and springs and artesianwater conditions. Gives data on the quality of the water, includirg 101 analyses of representative samples of well and spring waters. Concludes - with descriptions of the general features and ground-water conditions in each of the 12 counties that constitute the area studied. 
642. Surface water supply of the United States, 1927, Part II, South Atlantic slope and eastern Gulf of Mexico basins; N. C. Grover, chief hydraulic engineer; J. J. Dirzulaitis, E. D. Burchard, and W. R. King, district engineers. 1931. v, $103 \mathrm{pp}$.

Contains discharge measurements of 22 springs in Florida (p. 99).

643. Surface water supply of the United States, 1927, Part III, Ohjo River Basin; N. C. Grover, chief hydraulic engineer; A. W. Harringtcn, A. H. Horton, Lasley Lee, J. J. Dirzulaitis, H. E. Grosbach, W. R. King, and E. D. Burchard, district engineers. 1931. vii, $216 \mathrm{pp}$.

Contains 2 discharge measurements of Boiling Spring near Max Mealows, Va. (p. 211).

646. Surface water supply of the United States, 1927, Part VI, Missouri River Basin; N. C. Grover, chief hydraulic engineer; W. A. Lamb. Robert Follansbee, C. G. Paulsen, J. B. Spiegel, and H. C. Beckman, district engineers. 1930. vi, $216 \mathrm{pp}$.

Contains discharge measurements of Boyler's Mill, Hahatonka, and Wilkins Springs, 似. (p. 212).

647. Surface water supply of the United States, 1927, Part VII, Lower Mississippi River Basin; N. C. Grover, chief hydraulic engineer; H. C. Beckman, Robert Follansbee, J. B. Spiegel, and C. E. Ellsworth, district engineers. 1930. iv, $98 \mathrm{pp}$.

Contains records of discharge of Meramec, Big, and Greer Springs (pp. 15, 40, 43) and discharge measurements of Cold, Big, Blue at McCabe, Blue 7 miles northeast of Mountain View, and McCubben Springs, all in Missouri (p. 95).

648. Surface water supply of the United States, 1927, Part VIII, Western Gulf of Mexico basins; N. C. Grover, chief hydraulic engineer; C. E. Ellsworth, district engineer. 1930. v, $117 \mathrm{pp}$.

Contains several discharge measurements of Barton and Comal Spring: (p. 112) and of Bennetts artesian well and Goodenough and San Felipe Springs (p. 113), all in Texas.

653. Surface water supply of the United States, 1927, Part XII, North Pacific slope drainage basins: B, Snake River Basin; N. C. Grover, chief hydraulic engineer; G. C. Baldwin, C. G. Paulsen, F. F. Hensha Canfield, A. B. Purton, and G. L. Parker, district engineers 1931, vi, 230 pp.

Contains 5 elischarge measurements of Market Lake Springs near Roberta, Idaho (p. 224), and of Big Springs, Idaho (p. 224).

654. Surface water supply of the United States, 1927, Part XII, North Pacific slope drainage basins: C, Pacific slope basins in Oregon and lower Columbia River Basin; N. C. Grover, chief hydraulic engineer; F. F. Henshaw, G. H. Canfield, and G. L. Parker, district engineers. 1931. v, 142 pp.

Contains 3 discharge measurements of Big Butte Springs, Oreg. (p. 137).

655. Surface water supply of Hawaii, July 1, 1926, to June 30, 1927; N. C. Grover, chief hydraulic engineer; M. H. Carson, district engineer. 1930. $\mathrm{v}, 151 \mathrm{pp}$.

Contains discharge measurements of several small springs in Oahu (pp. 61-62) and of Keanae Spring on Maui, 3.63 sec. ft. (p. 145).

656. Ground-water resource of western Tennessee, by F. G. Wells, with a discussion of the chemical character of the water by F. G. Wells and M. D. Foster. 1933. vii, 319 pp., 16 pls.

Gives a summary of the geology and data on the occurrence, quality, and utllization of ground water. Discusses the water-bearing formations and th ground- 
656. Ground-water resource of western Tennessee-Continued.

water resources by counties, with special description of the water supply of Memphis. Contains 176 water analyses and a map showing locations of wells.

658. The industrial utility of public water supplies in the United States, 1932, by W. D. Collins, W. L. Lamar, and E. W. Lohr. 1934. iv, 135 pp., 1 pl.

Contains statements on ground-water supplies (p. 21) and many analyses of public water supplies obtained from wells.

659. Contributions to the hydrology of the United States, 1932; N. C. Grover, chief hydraulic engineer. 1932 . v, 209 pp., 19 pls.

(a) A method of estimating ground-water supplies based on diseharge by plants and evaporation from soil-results of investigations in Escalante Valley, Utah, by W. N. White, pp. 1-105, pls. 1-10. Gives the results of a detailed study of groundwater discharge in Escalante Valley, Utah.

(b) Geology' and ground-water resources of The Dallas region, Oreg., by A. M. Piper, pp. 107-189, pls. 11-19. Describes the basalts of the area and discusses the possibilities of developing ground water for irrigation from the upper and lower water-bearing sones of the Yakima basalt. Gives 5 analyses of-v'ell water and 1 analyses of spring water, tabulated records and logs of wells, and riacords of springs.

(c) Index of analyses of natural waters in the United States, 1926 to 1931, by W. D. Collins and C. S. Howard, pp. 191-209. Lists, by states, publications containing collections of mineral analyses of waters.

660. Artesian water in Somervell County, Tex., by A. G. Fiedler. 1934 (1935). iv, 86 pp., 7 pls.

Artesian water in Somervell County is derived largely from two aquifers of the "basal sands" of the Trinity group occurring at Glen Rose at depths of 100 to 135 feet and 275 to 300 feet, respectively. The draft from the artesian reservoir during the summer is estimated at 1,000,000 gallons a day, which includes 360,000 gallons a day of waste but not underground waste. Artesian head has declined generally throughout the county and continues at a slow rate. The report racommends adoption of a policy of conservation and further investigation of und erground leakage from wells.

661. Surface water supply of the United States, 1928, Part I, North Atlantic slope drainage basins; N. C. Grover, chief hydraulic en rineer; M. R. Stackpole, H. B. Kinnison, A. W. Harrington, O. W. Hartwell, A. H. Horton, and J. J. Dirzulaitis, district engineers. 1931. vii, 235 pp.

Contains discharge measurements of Koiner, Baker, and Loth Springs near Waynesboro, Va. (p. 229).

663. Surface water supply of the United States, 1928, Part III, Ohio River Basin; N. C. Grover, chief hydraulic engineer; A. W. Harrington, A. H. Horton, Lasley Lee, J. J. Dirzulaitis, H. E. Grasbach, W. R. King, and E. D. Buchard, district engineers. 1931. viii, 245 pp.

Contains discharge measurements of Umbarger. Town, and Kill'nger Springs at Marion, Va., and Gave, Blowing, Tanyard, Mllis, Francis, and Big Springs, Tenn. (p. 240).

667. Surface water supply of the United States, 1928, Part VII, Lower Mississippi River Basin; N. C. Grover, chief hydraulic engineem; H. C. Beckman, Robert Follansbee, J. B. Spiegel, and C. E. Ellsvrorth, district engineers. 1931. iv, $80 \mathrm{pp}$.

Contains discharge records of Meramec, Big, and Greếr Springs, Mo. (pp. 14, 37, 39), and discharge measurements of Midco Spring at Midco, Mo., (p. 78).

668. Surface water supply of the United States, 1928, Part VIH, Western Gulf of Mexico basins; N. C. Grover, chief hydraulic engineer; C. E. Ellsworth, district engineer. 1931. v, $123 \mathrm{pp}$.

Contains several discharge measurements of Barton, Comal, and Goodenough Springs, Tex. (p. 119); of springs and artesian well at San Antonio, Tex., and 
668. Surface water supply of the United States, 1928-Continued.

Dr. Graham's artesian well at La Pryor Tex. (p. 119) ; and of San Felipe Springs, near Del Rio, Tex., and Las Moras Springs, Brackettville, Tex. (p. 120).

673. Surface water supply of the United States, 1928, Part XII, North Pacific slope drainage basins: B, Snake River Basin; N. C. Grover, chief hydraulic engineer; G. C. Baldwin, G. L. Parker, C. G. Paulsen. A. B. Purton, and G. H. Canfield, district engineers. 1931. vi, 172 pj.

Contains 2 discharge measurements of Big Springs, at Big Springs, Idaho (p. 167).

675. Surface water supply of Hawaii, July 1, 1927, to June 30, 1928: N. C. Grover, chief hydraulic engineer; M. H. Carson, district ergineer. 1932. v, $105 \mathrm{pp}$.

Contains discharge measurement of Kumalae Springs near Honoluiu (p. 40).

676. Geology and ground-water resources of Atascosa and Frio Counties. Tex., by J. T. Lonsdale. 1935 . v, 90 pp., 8 pls.

Describes a portion of the Winter Garden district of southwest Texas. The exposed rock formations are of Quaternary and Tertiary ages. The chie waterbearing formations are the Carrizo sand, Mount Selman formation, and Cook Mountain formation. The Carrizo formation yields water of good quality, which is used extensively for irrigation. The other two formations are important sources of water for domestic use and to some extent for irrigation.

677. Ground water in south-central Tennessee, by C. V. Thies. $1936 . \quad$ v, 182 pp., 7 pls.

Describes the physiography of the region and the source of the ground water and discusses the water-bearing properties of the various formations, which range in age from lower Ordovician to Quaternary. Gives data on the water supply in descriptions of the area by counties.

678. Geology and ground-water resources of Uvalde and Medina Counties, Tex., by A. N. Sayre. 1936 . v, 146 pp., 11 pls.

Describes an area that is crossed by the Balcones escarpment. Discusses the general geology and the chemical character of the ground water in connection with the description of the several water-bearing formations. Presents information on ground-water intake, movement, discharge, and utilization. Includes tables of wells, well-measurements, and well logs. Contains a geologic and hydrologic mro showing heights to which water in the Edwards limestone would rise in 1930.

679. Contributions to the hydrology of the United States, 1935; N. C. Grover, chief hydraulic engineer.

(a) The Thiem method for determining permeability of water-bearing materials and its application to the determination of specific yield, results of invertigations in the Platte River Valley, Nebr., by L. K. Wenzel. 1936. pp. i-iv, 1-57, pls. 1-6. Describes pumping tests in Platte River Valley, Nebr., and the comparison of the results with the theoretical data of Thiem's formula.

(b) Thermal springs in the United States, by N. D. Stearns, H. T. Ster rns, and G. A. Waring. 1937. pp. i-iv, 59-206, i-iv, pls. 7-16. Discusses the geologic problems relating to thermal springs, and their occurrence by physiographic divisions. Includes annotated bibliography and tabulated lists by States of 1,059 spring localities. Contains State index maps showing location of the thermal springs and a map of the United States showing their distribution.

680. Droughts of $1930-34$, by J. C. Hoyt. 1936. vii, 106 pp., 1 pl.

Discusses the effects of the droughts of 1930, 1931, and 1934 on surface-water and ground-water supplies. Contains diagrams showing fuctuation of ground-water level (figs. 9, 10).

682. Surface water supply of the United States, 1929, Part II, South A tlantic slope and eastern Gulf of Mexico basins; N. C. Grover, chief hydraulic engineer; J. J. Drizulaitis, E. D. Burchard, and W. R. King, district engineers. 1932. vi, $178 \mathrm{pp}$.

Contains discharge measurements of 4 springs in Virginia and 10 sfrings in Florida (pp. 172, 173). 
683. Surface water supply of the United States, 1929, Part III, Ohio River Basin; N. C. Grover, chief hydraulic engineer; A. W. Harrington, William Kessler, Lasley Lee, E. D. Burchard, J. J. Dirzulaitis, H. E. Grosbach, and W. R. King, district engineers. 1932. viii, 272 pp.

Contains discharge measurements of Miles, Wallace, Cave, and Clifford Fryar Springs, Tenn. (p. 266).

686. Surface water supply of the United States, 1929, Part VI, Missouri River Basin; N. C. Grover, chief hydraulic engineer; W. A.. Lamb, Robert Follansbee, C. G. Paulsen, J. B. Spiegel, and H. C. Bockman, district engineers. 1932. ix, $290 \mathrm{pp}$.

Contains discharge record of Bennett Spring at Brice, Mo. (F. 276).

687. Surface water supply of the United States, 1929, Part VI:. Lower Mississippi River Basin; N. C. Grover, chief hydraulic engineer; H. C. Beckman, W. S. Frame, J. H. Gardiner, J. B. Spiegel, C. E. McCashin, and C. E. Ellsworth, district engineers. 1931. iv, $88 \mathrm{pp}$.

Contains discharge records of Meramec, Big, and Greer Springs, Mo. (pp. 14, 40, 42), and discharge measurement of Blue Spring, 3 miles soutl ast of Battlefield, Mo., 3.3 sec.-ft. (p. 85).

688. Surface water supply of the United States, 1929, Part VIJI, Western Gulf of Mexico basins; N. C. Gnover, chief hydraulic engireer; C. E. Ellsworth, district engineer. 1932. v, $131 \mathrm{pp}$.

Contains discharge records of Goodenough Spring, Tex. (p. 109), and discharge measurements of Barton, T-5, Righland, and Wolf Springs, and Comal River (springa) and San Felipe Creek (springs), Tex. (pp. 126, 127).

691. Surface water supply of the United States, 1929, Part $I I$, Pacific slope basins in California; N. C. Grover, chief hydraulic engineer; H. D. MeGlashan and G. H. Canfield, district engineers. 1931. ix, 294 pp.

Contains discharge measurement of Agency Spring at Klamath Agency, Oreg. (p. 287).

696. Surface water supply of the United States, 1930, Part I, North Atlantic slope drainage basins; N. C. Grover, chief hydraulic engineer; M. R. Stackpole, H. B. Kinnison, B. L. Bigwood, A. W. Harrington, O. W. Hartwell, A. H. Horton, and J. J. Dirzulaitis, district engineers. 1932. viii, 280 pp.

Contains discharge measurements of Hite's, Yager's, Harnst orger, and Price's Springs, Va. (p. 273).

697. Surface water supply of the United States, 1930, Part 2, South Atlantic slope and eastern Gulf of Mexico basins; N. C. Grover, chief hydraulic engineer; J. J. Dirzulaitis, E. D. Burchard, A. E. Johnson, W. R. King, D. S. Wallace, and C. E. McCashin, district engineers. 1932. vii, $248 \mathrm{pp}$.

Contains discharge measurements of Hall's Spring, near Buena Vista, Va., 1.0 sec.-ft. (p. 243), and discharge measurements of 7 springs in Florida (p. 244).

698. Surface water supply of the United States 1930, Part 3, Ohio River Basin; N. C. Grover, chief hydraulic engineer; A. W. Harrington, William Kessler, Lasley Lee, E. D. Burchard, J. J. Dirzulaitis, H. E. Grosbach, J. H. Morgan, and W. R. King, district engineers. 1922. viii, 292 pp.

Contains discharge records of Huntsville Spring, Tenn., and Tuscumbia Spring, Ala. (pp. 266, 272), and discharge measurements of Blue Spring at Jasper, Tenn., and Blowing Spring at Sequatchie, Tenn. (p. 285). 
701. Surface water supply of the United States, 1930, Part 6, Missonri River Basin; N. C. Grover, chief hydraulic engineer; W. A. Lamb. Robert Follansbee, C. G. Paulsen, J. B. Spiegel, and H. C. Beckman; district engineers. 1932. ix, $302 \mathrm{pp}$.

Contains discharge record of Bennett Spring at Brice, Mo. (p. 289), and discharge measurement of Hahatonka Spring, Hahatonka, Mo., 61 sec.-ft. (p. 296).

702. Surface water supply of the United States, 1930, Part 7, Lower Mississippi River Basin; N. C. Grover, chief hydraulic engineer; H. C. Beckman, W. R. King, J. H. Gardiner, Robert Follansbee, J. B. Sriegel, C. E. McCashin, and C. E. Ellsworth district engineers. 1932. v, 115 pp.

Contains discharge records of Round, Big, and Greer Springs, Mo. (pp. 57, 59, 62), and discharge measurements of Meramec Spring, Mo., 99 sec.-ft., and Evans Spring, 11/2 mi. southeast of Steelville, Mo., 2.6 sec.-ft. (p. 111),

703. Surface water supply of the United States, 1930, Part 8, Western Gulf of Mexico basins; N. C. Grover, chief hydraulic engineer; C. E. Ellsworth, district engineer. 1932. v, $131 \mathrm{pp}$.

Contains discharge record of Goodenough Springs (p. 116), and discharge measurements of Barton, Costley, and Coconut Springs, spring near Pipe Creek, Comal River (springs), and San Felipe Creek (springs), all in Texas (pp. 126, 197).

706. Surface water supply of the United States, 1930, Part 11, Pacific slope basins in California; N. C. Grover, chief hydraulic engineer; H. D. McGlashan and G. H. Canfield, district engineers. 1932. ix, 317 pp.

Contains discharge measurement of Agency Spring at Klamath Agency, Oreg. (p. 309).

710. Surface water supply of Hawaii, July 1, 1929, to June $30,19 \varepsilon$ ?; N. C. Grover, chief hydraulic engineer; M. H. Carson, district engineer. 1933. v, 101 pp.

Contains discharge measurements of Keolewa and Illiillka Springs on Molokai, (p. 49), and 27 discharge measurements of Waiakea Springs on Hawaii (p 98).

712. Surface water supply of the United States, 1931, part 2, South Atlantic coast and eastern Gulf of Mexico basins; N. C. Grover, chief hydraulic engineer; E. D. Burchard, J. J. Dirzulaitis, A. E. Johnson, W. R. King, C. E. McCashin, and D. S. Wallace, district engineers. 1933. vii, 233 pp.

Contains discharge records of Warm Spring, at Warm Springs, Va. (p. 20) : Sulphur, Weekiwachee, Blue (near Dunnellon), Ichatucknee, and Wakulla Springs, Fla. (pp. 148, 153, 163, 164); and discharge measurements of Rock, Seminole, Alexander, Silver Glen, Salt, Kissengen, Homosassa, Blue (at Juliette', Wekiva, and Fannin Springs, Fla. (pp. 227, 228).

713. Surface water supply of the United States, 1931, part 3, Ohio Riv?r Basin; N. C. Grover, chief hydraulic engineer; E. D. Burchard, J. J. Dirzulaitis, H. E. Grosbach, A. W. Harrington, William Kessler, W. R. King, Lasley Lee, and J. H. Morgan, district engineers. 1933. v, 346 pp.

Contains discharge record of Huntsville Spring, at Huntsville, Ala. (p. 316) ; discharge measurements of 108 large springs in east Tennessee (pp. 33i-339); and discharge measurement of Tide Spring, near Marion, Va., 0.3 sec.-ft. (p. 340),

716. Surface water supply of the United States, 1931, part 6, Missonri River Basin; N. C. Grover, chief hydraulic engineer; H. C. Beckman, Robert Follansbee, W. A. Lamb, T. R. Newell, C. G. Paulsen, and J. B. Spiegel, district engineers. 1933. $x, 347 \mathrm{pp}$.

Contains discharge record of Bennett Spring, at Brice, Mo. (p. 332), and discharge measurements of Hahatonka, Rolufs, and Gollahon Springs, Mo. (p. 840). 
717. Surtace water supply of the United States, 1931, part 7, Lo"rer Mississippi River Basin; N. C. Grover, chief hydraulic engineer; $\mathbf{F}$. C. Beckman, C. E. Ellsworth, J. H. Gardiner, W. R. King, C. E. McCrshin, and J. B. Spiegel, district engineers. 1932. $\mathrm{v}, 108 \mathrm{pp}$.

Contains discharge records of Round, Alley, Big, and Greer Springs (pp. 52, 53, 55; 58) and discharge measurements of Brown and Boze Mill Springs (p. 106), all in Missouri.

718. Surface water supply of the United States, 1931, part 8, $\nabla^{\top}$ estern Gulf of Mexico basins; N. C. Grover, chief hydraulic engineer; C. E. Ellsworth, district engineer. 1933. v, 135 pp.

Contains discharge record of Goodenough Springs (p. 122) and discharge measurements of Rock Spring, Swimming Pool Spring, springs on Maxwell ranch, and Kickapoo, Silver Lake, and San Felipe Springs (pp. 130-131), all in Texas.

720. Surface water supply of the United States, 1931, part 10, The Great Basin; N. C. Grover, chief hydraulic engineer; G. H. C`nfield, Robert Follansbee, H. D. McGlashan, and A. B. Purton, district engineers. 1932. $\mathrm{v}, 99 \mathrm{pp}$.

Contains discharge measurements of 8 springs in Malheur and Harney Lake Basins, Oreg. (p. 96).

721. Surface water supply of the United States, 1931, part 11, Pacific slope basins in California; N. C. Grover, chief hydraulic er oineer; H. D. McGlashan, and G. H. Canfield, district engineers. 1932 . xi, $497 \mathrm{pp}$.

Contains discharge measurement of Dripping Spring near Tenvecula. Calif. (p. 469), and 25 discharge measurements of Hamner Springs near Norco, Calif. (p. 471).

723. Surface water supply of the United States, 1931, Part 12, North Pacific slope basin; B, Snake River Basin; N. C. Grover, chief hydraulic engineer; G. H. Canfield, Lynn Crandall, T. R. Newell, G. I. Parker, and A. B. Purton, district engineers. 1933. vii, $205 \mathrm{pp}$.

Contains discharge measurement of Big Springs, Idaho (p. 197).

726. Surface water supply of the United States, 1932, part 1, I'orth Atlantic slope basins; N. C. Grover, chief hydraulic engineer; F. L. Bigwood, J. J. Dirzulaitis, A. W. Harrington, O. W. Hartwell, A. H. Horton, H. B. Kinnison, J. W. Mangan, and M. R. Stackpole, district engineers. 1934. $\mathrm{x}, 378 \mathrm{pp}$.

Contains discharge measurement of Ebbing and Flowing Spring, Va. (p. 369).

727. Surface water supply of the United States, 1932, part 2, S'outh Atlantic slope and eastern Gulf of Mexico basins; N. C. Grover, chief hydraulic engineer; E. D. Burchard, J. J. Dirzulaitis, A. E. Johnson, C. E. McCashin, and D. S. Wallace, district engineers. 1934. vii, 221 pp.

Contains discharge records of Warm Springs, Va. (p. 19), and Blue (near 'Orange City), Kissengen, Sulphur, Weekiwachee, Blue (near Dunnellon), Iohatucknee, and Wakulla Springs, Fla. (pp. 139, 152, 156, 169), and discharpe measurements of 29 other springs in Florida (pp. 215-216).

728. Surface water supply of the United States, 1932, part $\therefore$. Ohio River Basin; N. C. Grover, chief hydraulic engineer; E. D. B rrchard, J. J. Dirzulaitis, H. E. Grosbach, A. W. Harrington, A. H. Hcrton, William Kessler, W. R. King, Lasley Lee, J. W. Mangan, C. E. MtcCashin, and J. H. Morgan, district engineers. 1934. x, 370 pp.

Contains discharge record of Huntsville Spring, at Huntsville, Ala. (p. 333), and discharge measurements of 19 springs in Tennessee (pp. 359, 361, 362). 
731. Surface water supply of the United States, 1932, part 6, Missouri River Basin; N. C. Grover, chief hydraulic engineer; H. C. Beckman, Robert Follansbee, W. A. Lamb, T. R. Newell, and J. B. Spiegel, dist"ict engineers. 1933. $\mathrm{x}, 349 \mathrm{pp}$.

Contains discharge record of Bennett Spring at Brice, Mo. (p. 332), and discharge measurements of Conn, Roubidoux, Shanghai, and Gaines Ford Springs, M?. (p. 342).

732. Surface water supply of the United States, 1932, part 7, Lower Mississippi River Basin; N. C. Grover, chief hydraulic engineer; H. C. Beckman, C. E. Ellsworth, J. H. Gardiner, Berkeley Johnson, W. R. King, C. E. McCashin, and J. B. Spiegel, district engineers. 1933. $\quad$, 132 pp.

Contains discharge records of Round, Alley, Big, and Greer Springs (pp. 64, 69, 70. 73) and discharge measurements of Westover, Leeper, Mill, and Boze Mill Springs (p. 129), all in Missouri.

733. Surface water supply of the United States, 1932, part 8, Westerm Gulf of Mexico basins; N. C. Grover, chief hydraulic engineer; C. E. Elsworth, Robert Follansbee, and Berkeley Johnson, district engineer. 1933. vi, 197 p.p.

Contains 8 discharge measurements of Comanche Springs near Fort Stockton, Tex. (p. 190).

738. Surface water supply of the United States, 1932, part 12, North Pacific slope basins: B, Snake River Basin; N. C. Grover, chief hydraulic engineer; G. H. Canfield, Lynn Crandall, Robert Follansbee, T. R. Newell, G. L. Parker and A. B. Purton, district engineers. 1934. vii, 197 pp.

Contains discharge measurements of 12 springs in Idaho (pp. 190, 19?).

740. Surface water supply of Hawaii, July 1, 1931, to June 30, 1932; N. C. Grover, chief hydraulic engineer; M. H. Carson, district engineer. 1934. $\nabla, 121$ pp.

- Contains discharge records of Pearl Harbor Springs (pp. 48-56), and discharge measurements of Pearl Harbor and Waialae Springs (p. 66) on the island of Oahu.

741. Surface water supply of the United States, 1933, part 1, North Atlantic slope basins; N. C. Grover, chief hydraulic engineer; B. L. Bigwood, J. J. Dirzulaitis, A. W. Harrington, O. W. Hartwell, A. H. Horton, H. B. Kinnson, J. W. Mangan, and M. R. Stackpole, dstrict engineers. 1935. ix, 390 pp.

Contains 3 discharge measurements of Price's Spring, Pa. (p. 38).

742. Surface water supply of the United States, 1933, part 2, South Atlantic and eastern Gulf of Mexico basins; N. C. Grover, chief hydraulic engineer; E. D. Burchard, J. J. Dirzulaitis, A. E. Johnson, C. E. MtcCashin, and D. S. Wallace, district engineers. 1935. vii, $206 \mathrm{pp}$.

Contains discharge records of Warm Spring, Va. (p. 19), and Blue (noar Orange City), Kissengen, Sulphur, Weekiwachee, Blue (near Dunellon), and Ichatucknee Springs in Florida (pp. 132, 145, 146, 150, 163), and discharge measimements of 13 other springs in Florida (pp. 201-202).

743. Surface water supply of the United States, 1933, part 3, Ohio River Basin; N. C. Grover, chief hydraulic engineer; E. D. Burchard, J. J. Dirzulaitis, H. E. Grosbach, A. W. Harrington, A. H. Horton, Willian Kessler, W. R. King, Lasley Lee, J. W. Mangan, and J. H. Morgar district engineers. 1935 . ix, $357 \mathrm{pp}$.

Contains discharge measurements of 24 springs in Tennessee and 6 springs in Georgia (pp. 348-350). 
746. Surface water supply of the United States, 1933, part 6, Missouri River Basin; N. C. Grover, chief hydraulic engineer; H. C. Benkman, Robert Follansbee, W. A. Lamb, T. R. Newell, and J. B. Sniegel, district engineers. 1935 . viii, $276 \mathrm{pp}$.

Contains discharge record of Bennett Spring at Brice, Mo. (p. 259), and discharge measurements of 26 other springs in Missouri (p. 269).

747. Surface water supply of the United States, 1933, part 7, Lower Mississippi River Basin; N. C. Grover, chief hydraulic engineer; H. C. Beckman, C. E. Ellsworth, J. H. Gardiner, Berkeley Johnson, W. R. King, C. E. McCashin, and J. B. Spiegel, district engineers. 1935. v, 121 pp.

Contains discharge records of Round, Alley, Big, and Greer Springs, Mo. (pp. 59, 61, 62, 65), and discharge measurements of 32 other springs in Missouri (pp. 116-117).

748. Surface water supply of the United States, 1933, part 8, Western Gulf of Mexico basins; N. C. Grover, chief hydraulic engineer; C. E. Ellsworth, Robert Follansbee, and Berkeley Johnson, district engineers. 1935. vi, $180 \mathrm{pp}$.

Contains discharge records of Phantom Lake, Giffen, San Solomon, West Sandia, and East Sandia Springs, Tex. (pp. 145-158), and discharge measurements on these and 8 other springs in Texas (pp. 167-174).

750. Surface water supply of the United States, 1933, part 10, T : Great Basin; N. C. Grover, chief hydraulic engineer; G. H. Canfield, Robert Follansbee, H. D. McGlashan, T. R. Newell, and A. B. Purton, district engineers. 1935. v, $107 \mathrm{pp}$.

Contains discharge measurements of Snyder, Alpine, and Denver and Rio Grande Springs, Utah (p. 102), and unnamed springs in Salt Lake City, JJtah (p. 103).

753. Surface water supply of the United States, 1933, part 12, North Pacific slope basins: B, Snake River Basin; N. C. Grover, chief hydraulic engineer; G. H. Canfield, Lynn Crandall, Robert Follansbee, T. R. Newell, G. L. Parker, and A. B. Purton, district engineers. 1935. vii, 197 pp.

Contains discharge measurement of spring near Melba, Idaho (p. 192).

755. Surface water supply of Hawaii, July 1, 1932, to June 30, 1933; N. C. Grover, chief hydraulic engineer; M. H. Carson, district engineer. 1935. v, 125 pp.

Contains discharge records of Pearl Harbor Springs at 6 plices on the island of Oahu (pp. 38-43) and 20 discharge measurements on the same springs (p. 53).

757. Surface water supply of the United States, 1934, part 2, South Atlantic slope and eastern Gulf of Mexico basins; N. C. Grover, chief hydraulic engineer; D. H. Barber, E. D. Burchard, J. J. Dirzulaitis: A. E. Johnson, C. E. McCashin, and D. S. Wallace, district engineers. 1936. vii, 216 pp.

Contains discharge records of Warm Spring, Va. (p. 18), Blue (near Orange City), Kissengen, Sulphur, Weekiwachee, Blue (near Dunellon), and Ichatucknee Springs in Flórida (pp. 140, 155, 157, 160, 170), and North Springs, at Warm Springs, Ga. (p. 180), and dtscharge measurements of Lithia Spring and Crystal Springs in Florida and Blue Spring, near Hamilton, Ga. (p. 212).

758. Surface water supply of the United States, 1934, part 3, Ohio River Basin; N. C. Grover, chief hydraulic engineer; E. D. Burchard, J. J. Dirzulaitis, H. E. Grosbach, A. W. Harrington, A. H. Horton, William Kessler, Lasley Lee, J. W. Mangan, C. E. McCashin, and J. H. Morgan, district engineers. 1936. $\mathrm{x}, 387 \mathrm{pp}$.

Contains discharge measurements of 83 springs in Tennesses and 1 spring in Alabama (pp. 378-379). 
761. Surface water supply of the United States, 1934, part 6, Missorri River Basin; N. C. Grover, chief hydraulic engineer; H. C. Beckman, Robert Follansbee, R. G. Kasel, W. A. Lamb, T. R. Newell, and J. B. Spiegel, district engineers. 1935 (1936). ix, $340 \mathrm{pp}$.

Contains discharge record of Bennett Spring at Brice, Mo. (p. 323), and discharge measurements of 11 other springs in Missouri (pp. 332-333).

762. Surface water supply of the United States, 1934, part 7, Lowe" Mississippi River Basin; N. C. Grover, chief hydraulic engineer; D. H. Barber, H. C. Beckman, C. E. Ellsworth, Robert Follansbee, J. I. Gardiner, Berkeley Johnson, W. R. King, C. E. McCashin, and J. B. Spiegel, district engineers. $1936 . \mathrm{v}, 129 \mathrm{pp}$.

Contains discharge records of Round, Alley, Big, and Greer Springs, Mo. (pp. 67. $59,60,62$ ), and discharge measurements of 19 other springs in Missour: (p. 125).

763. Surface water supply of the United States 1934, part 8, Westers Gulf of Mexico basins; N. C. Grover, chief hydraulic engineer; C. E. Ellsworth, Robert Follansbee, and Berkeley Johnson, district engineers. 1936. vi, 188 pp.

Contains discharge measurements of Barton, Phantom Lake, San Solomon, and Comanche Springs, Tex. (pp. 181-183).

765. Surface water supply of the United States, 1934, part 10, Trie Great Basin; N. C. Grover, chief hydraulic engineer; G. H. Canfield, Robert Follansbee, H. D. McGlashan, T. R. Newell, and A. B. Purtor, district engineers: 1935. $\mathrm{v}, 95 \mathrm{pp}$.

Contains discharge measurement of Crystal Hot Springs, Utah (p. 91).

766. Surface water supply of the United States, 1934, part 11, Pacific slope basins in California; N. C. Grover, chief hydraulic enginenr; H. D. McGlashan and G. H. Canfield, district engineers. 1936. xi, 364 pp.

Contains discharge measurement of Hamner Springs (p. 351).

768. Surface water supply of the United States, 1934, part 12, North Pacific slope basins: B, Snake River Basin; N. C. Grover, chief hydraulic engineer; G. H. Canfield, Lynn Crandall, Robert Follansbee, T. P.. Newell, G. L. Parker, and A. B. Purton, district engineers. 1936. vii, 202 pp. Contains discharge measurement of Big Springs near Heise, Idaho (p. 196).

770. Surface water supply of Hawaii, July 1, 1933, to June 30, 19?4; N. C. Grover, chief hydraulic engineer; M. H. Carson, district engin rer. 1936. $120 \mathrm{pp}$.

Contains discharge record of Hanalei Tunnel, Kauai (p. 20), and Pearl Harbor Springs, Oahu (pp. 41-46), and discharge measurements of Pearl Harbor Springs (p. 55).

772. Studies of relations of rainfall and runoff in the United States, by W. G. Hoyt and others. 1936. $301 \mathrm{pp}$.

Contains data on ground-water runoff (pp. 245-247) and on ground-water levels in Platte River Valley, Nebr. (pp. 269-273). Contains list of 193 references to relations between rainfall and runoff, and related subjects, including several publications dealing with ground water.

773. Contributions to the hydrology of the United States, 1936; N. C. Grover, chief hydraulic engineer.

(a) Geology and ground-water resources of the Elizabeth City area. N. C., by S. W. Lohman. 1936. pp. i-iv, 1-57, pls. 1-4. Discusses the contamination by salt water of the surface-water supply during the drought of 1930-33 and the testing of deep, intermediate, and shallow sources of ground water as a nev source of public water supply. Gives attention to the problem of contamination by salt water. As a part of the investigation many small wells tapping the shrllow sands were constructed over a large area. These now furnish the entire elty supply. 
773. Contributions to the hydrology of the United States, 1936 -Continued.

(b) Water resources of the Edwards limestone in the San Antonio area, Tex., by Penn Livingston, A. N. Sayre, and W. N. White. 1936. pp. i-ii, 59-113, pl. 5. Discusses the Edwards limestone as a ground-water reservoir and the recharge to it and the discharge by springs and from wells. Gives data on the fluctuations in artesian pressure and the safe yield of the reservoir. Contains tabulated data on water levels in observation wells and a map showing lines of equal artesian pressure.

(c) Artesian water in the Florida peninsula, by V. T. Stringfilld. 1936. pp. i-iv, 115-195, pls. 6-16. The principal artesian formations are limeston's of Eocene and Miocene age, which yield copious amounts of water to wells and are the source of some of the largest springs in the United States. Artesian cond'ions are present nearly everywhere in the peninsula, but the areas in which wells flow are chiefly along the coasts and in the southern part of the State. Includes maps showing artesian flow of highly mineralized water and the piezometric surface of artesian water. Contains a table of wells and large springs and a map showing location of the large springs.

(d) Ground-water resources of Kleberg County, Tex., by Penn Livingston and T. W. Bridges. 1936. pp. i-ii, 197-232, pls. 17-21. Gives the history of ground-water development in the county and describes the water-bearing formations, the fluctuations in artesian pressure, movement of the ground water, and the chemical character of ground water, with comments on the waste of water and wel"-drilling methods. Contains records of 434 wells, with figures of chloride content and hardness. A map shows well locations and the height to which water would rise in the winter of 1932-33.

774. Geology and ground-water resources of the Snake River Plain in southeastern Idaho, by H. T. Stearns, Lynn Crandall, and W. G. Steward. 1938 (1939). ix, 268 pp., 31 pls.

Describes the geography and geology of the Snake River Plain above King Hill, Idaho, and gives data on the source, movement, and disposal of the ground-water supply of the Snake River basin, which is estimated at 4,000,000 acre-feet. Only a small part of this is utilized for irrigation. Recommends that future irrigation development be confined as far as practicable to the southeast side of Snake River above Milner, so that seepage water may return to a stretch of the river where it will be available for reuse. Contains a contour map of the water table.

775. Records of wells on the Snake River Plain, southeastern Idaho, by H. T. Stearns, Lynn Crandall, and W. G. Steward. 1936. i, 139 pp.

A supplement to Water-Supply Paper 774. Contains a tabulation of several hundred well records.

776. Geology and ground-water resources of Duval County, rex., by A. N. Sayre. 1937. vi, 116 pp., 8 pls.

The county is in the Coastal Plain, which for the most part is low and featureless. Between the Nueces River and the Rio Grande the plain is interrupted by an erosion remnant, the Reynosa Plateau, which reaches a maximum altitude of nearly 1,000 feet. The streams that cross the area flow only during and immediately after periods of heavy rainfall. The report describes the stratigraphy and structure of the area, with particular regard to ground water, and presents detailed data on water supplies from wells.

777. Water levels and artesian pressure in observation wells in the United States in 1935, with statements concerning previous work and results, prepared under the direction of $O$. E. Meinzer and L. K. Wenzel. 1936. iii, 268 pp.

A group of papers prepared by members of the United States Geological Survey. This is the first of a series of annual reports on the fluctuations of the groundwater levels and artesian pressure in the United States.

Introduction, by 0 . Meinzer.

Arkansas, by D. G. Thompson.

California, by F. C. Ebert and A. M. Piper.

Connecticut, by W. H. Brothwell.

Florida, by V. T. Stringfield. 
777. Water levels and artesian pressure in observation wells in tl $\cdot$ United States in 1935-Continued.

Hawail, by H. T. Stearns.

Idaho.

Indiana, by R. C. Cady.

Iowa and Missouri, by V. C. Fishel.

Kansas.

Michigan, by V. T. Stringfield.

Montana, by W. A. Lamb.

Nebraska, by L. K. Wenzel.

New Jersey, by H. C. Barksdale.

New Mexico, by C. V. Theis and A. G. Fiedler.

New York, by D. G. Thompson and A. W. Harrington:

North Carolina, by E. D. Burchard.

Oklahoma.

Oregon, by A. M. Piper.

Pennsylvania, by S. W. Lohman.

South Carolina.

Texas, by W. N. White and A. N. Sayre.

Utah, by G. H. Taylor and H. E. Thomas.

Virginia, by O. E. Meinzer, R. C. Cady, and V. C. Fishel.

Washington.

Wisconsin.

778. Geology and ground-water resources of Webb County, Tex., by J. T. Lonsdale and J. R. Day. 1937. v, 104 pp., 12 pls.

The exposed rock formations are of Tertiary and Quaternary ages. The Carrizo sand in the northwest yields potable water. The Cook Mountain formation supplies water for domestic use and some irrigation and yields flowing wells in parts of northeastern Webb County, but that water is too highly mineralized to use for irrigation. The Catahoula tuff yields water for domestic and industrinl use and some irrigation but is in general highly mineralized. The Goliad sand yiglds water for domestic and stock uses in the southeast part of the county but is variable in quantity and quality.

779. Geology and ground-water resources of south-central Nebraska, with special reference to the Platte River Valley between Chapman and Gothenburg, by A. L. Lugn and L. K. Wenzel. 1938. vii, 242 pp., 16 pls.

Describes water conditions in Quaternary deposits in an area covering 10,000 square miles and gives the results of a detailed study of part of the $P^{\prime}$ itte River Valley, where 800 wells supply water for irrigation. Discusses losses by percolation and from plant use. There was a great loss of stored water during 1931-34, but with return of normal precipitation the ground-water reserve will be restored.

780. Geology and ground-water hydrology of the Mokelumne area, Calif., by A. M. Piper, H. S. Gale, H. E. Thomas, and T. W. Robinson, 1939. vii, 230 pp., 22 pls.

Describes the geography, geology, and ground-water hydrology of the Mokelumne drainage basin and gives results of studies to determine the extent to which the ground-water supply depends upon water from Mokelumne River and the exfent to which the supply may be influenced by regulation of the stream. Con iludes that the Pardee Dam affords a means of regulating the discharge so as to effect a maximum ground-water replenishment. Contains numerous maps, hydrographs, ard profiles

782. Surface water supply of the United States, 1935, part 2, South Atlantic slope and eastern Gulf of Mexico basins; N. C. Grover, chief 1 vdraulic engineer; D. H. Barber, E. D. Burchard, J. J. Dirzulaitis, A. E. Johnson, C. E. McCashin, and D. S. Wallace, district engineers. 1937. 233 pp., $1 \mathrm{pl}$.

Contains discharge records of Warm Springs, Va. (p. 22), and Blue (near Orange City), Kissengèn, Crystal, Weekiwachee, Blue (near Dunnellon), and Iohatucknee Springs, Fla. (pp. 148, 162, 165, 168, 179), and discharge measurements of -9 other 
782. Surface water supply of the United States, 1935-Continved.

springs in Florida and numerous measurements of Blue Spring. near Hamilton, Ga. (p. 229).

783. Surface water supply of the United States, 1935, part 3, Ohio River Basin; N. C. Grover, chief hydraulic engineer; E. D. Burchard, J. J. Dirzulaitis, H. E. Grosbach, A. W. Harrington, A. H. Forton, William Kessler, Lasley Lee, J. W. Mangan, C. E. McCashin, and J. H. Morgan, district engineers. 1937. 400 pp., 1 pl.

Contains discharge measurement of Citico Spring at Chattanooga, Tenn. (p. 395).

786. Surface water supply of the United States, 1935, part 6, Missouri River Basin; N. C. Grover, chief hydraulic engineer; H. C. Beckman, Robert Follansbee, R. G. Kasel, W. A. Lamb, T. R. Newell, ant J. B. Spiegel, district engineers. 1936 (1937). 352 pp., 1 pl.

Contains discharge record of Bennett Spring at Brice, Mo. (p. 338), and discharg: measurement of Shanghai Spring, 7 miles east of Waynesville, Mo., 11.8 sec.-ft. (p. 347).

787. Surface $\backslash$ water supply of the United States, 1935, part 7, Lower Mississippi River Basin; N. C. Grover, chief hydraulic engineer; D. H. Barber, H. C. Beckman, C. E. Ellsworth, Robert Follansbee, J. H. Gardiner, Berkeley Johnson, C. E. McCashin, and J. B. Spiegel, district engineers. 1936. 150 pp., 1 pl.

Contains discharge records of Round, Alley, Big, and Greer Springs, Mo. (pp. 62, 65, 66, 68), and discharge measurements of 10 other springs in Missouri (p. 147).

788. Surface water supply of the United States, 1935, part 8, Western Gulf of Mexico basins; N. C. Grover, chief hydraulic engineer; C. F. Ellsworth, Robert Follansbee, and Berkeley Johnson, district engineers. 1937. 197 pp., 1 pl.

Contains several discharge measurements of Barton Springs (p. 191) and San Solomon and Comanche Springs, Tex. (pp. 193).

794. Surface water supply of the United States, 1935, part 14, Pacific slope basins in Oregon and lower Columbia River Basin; N. C. Grover, chief hydraulic engineer; G. H. Canfield and G. L. Parker, district engineers. 1936. 167 pp., 1 pl.

Contains discharge measurements of Big Spring and Crystal Springs, Oreg. (p. 162).

795. Surface water supply of Hawaii, July 1, 1934, to June 30, 1935; N. C. Grover, chief hydraulic engineer; M. H. Carson, district engineer. 1937. $138 \mathrm{pp}$.

Contains discharge records of Hanalei Tunnel, Kauai (p. 23), and Pearl Harbor Springs, Oahu (pp. 41-45), and discharge measurements of Pearl Harbor Springs (p. 54) and West Makapipi Spring, Maui (p. 63).

796. Contributions to the hydrology of the United States, 193\%; N. C. Grover, chief hydraulic engineer.

(a) Methods of locating salt-water leaks in water wells, by Penn Livingston and Walter Lynch. 1937. pp. i-ii, 1-20, pls. 1-9. Discusses four gereral methods: The pumping method, the velocity method, the sampler method, and the electric conductivity method.

(d) Geology and ground-water resources of Ogden Valley, Utah, by R. M. Leggette and G. H. Taylor. 1937. pp. i-iv, 99-161, pls. 35-40. Ogden Valley is a trough, bounded on the east and west by fauls and containing more than 600 feet of stream and lake deposits, including 70 feet of varved clay. Shallow wells encounter watertable conditions; those which pass through the clay encounter wrter under artesian pressure. The water level fluctuates 2 to 30 feet during the year. The city of Ogden is supplied by 48 artesian wells, whose discharge in 1933-34 ranged from 12.9 to 20.5 second-feet. See also Cooperative report 424 . 
796. Contributions to the hydrology of the United States, 1937-Con+inued.

(e) Ground water in Avra-Altar Valley, Ariz., by D. A. Andrews. 1937. pp. i-ii, 163-180, pls. 41-44. Avra-Altar Valley is in southeastern Arizona, about 30 miles west of Tucson. Water for domestic and stock use is obtained in the lower alluvial lands at 150 to 350 feet. A few wells on the higher alluvial slopes reach water at 550 to 800 feet. In most places the water is of good quality, but in a few places where rocks of Cretaceous age are penetrated the water is highly mineralized. Gives analyses of 26 samples of well water.

( $f$ ) Geology and ground-water resources of the valley of Gila River and San Simon Creek, Graham County, Ariz., by M. M. Knechtel, with a section on th? chemical character of the ground water, by $\mathrm{w}$. W. Lohr. 1938. pp. i-iv, 181-222, pls. 45-53. Shallow water is obtained in the valley alluvium. Lake beds in the central part of the valley trough yield water at various depths, usually under artesian head. A few small flowing wells have been obtained. Contains logs of seven wells. Describes several springs including Indian Hot Springs. The section on chemical cl aracter of the ground water includes 49 analyses of samples of water.

802. Surface water supply of the United States, 1936, part 2, South Atlantic slope and eastern Gulf of Mexico basins; N. C. Grover, chief 1 ydraulic engineer; D. H. Barber, E. D. Burchard, J. J. Dirzulaitis, A. E. Johnson, and D. S. Wallace, district engineers. 1938 . vi, $228 \mathrm{pp} ., 1 \mathrm{pl}$.

Contains discharge records of Warm Springs, Va. (p. 16), and Blue (near Orange City), Kissengen, Crystal, Weekawachee, Blue (near Dunnellon), and Ishatucknee Springs, Fla. (pp. 140, 154, 157, 160, 171), and discharge measurements of 10 other springs in Florida (p. 222).

803. Surface water supply of the United States, 1936, part 3, Ohin River Basin; N. C. Grover, chief hydraulic engineer; H. C. Beckman, E. D. Burchard, J. J. Dirzulaitis, H. E. Grosbach, A. W. Harringtcn, A. H. Horton, William Kessler, Lasley Lee, J. W. Mangan, C. E. McCashin, and J. H. Morgan, district engineers. 1938. vii, $453 \mathrm{pp} ., 1 \mathrm{pl}$.

Contains discharge measurement of Frazier Spring near Pikeville, Ténn. (p. 447).

806. Surface water supply of the United States, 1936, part 6, Missouri River Basin; N. C. Grover, chief hydraulic engineer; H. C. Beckman, Robert Follansbee, R. G. Kasel, W. A. Lamb, T. R. Newell, and J. B. Spiegel, district engineers. 1938.370 pp., 1 pl.

Contains discharge record of Bennett Spring at Brice, Mo. (p. 354), and discharge measurements of 14 other springs in Missouri (p. 363).

807. Surface water supply of the United States, 1936, part 7, Lower: Mississippi River Basin; N. C. Grover, chief hydraulic engineer; D. H. Barber, H. C. Beckman, C. E. Ellsworth, Robert Follansbee, J. F. Gardiner, Berkeley Johnson, C. E .McCashin and J. B. Spiegel district engineers. 1937. 149 pp., 1 pl.

Contains discharge records of Round, Alley, Big, and Greer Springs, Mo. (pp. $62,64,65,67$ ), and discharge measurements of 54 other springs in Mirsouri (pp. 144-145).

808. Surface water supply of the United States, 1936, part 8, Westerr Gulf of Mexico basins; N. C. Grover, chief hydraulic engineer; C. E. E'lsworth, Robert Follansbee, and Berkeley Johnson, district engineers. 1937. 262 pp., 1 pl.

Contains several discharge measurements of Barton, San Solomon, and Comanche Springs, Tex. (pp. 256-257).

815. Surface water supply of Hawaii, July 1,1935 , to June $30,193^{\circ} ;$ N. C. Grover, chief hydraulic engineer; M. H. Carson, district engineer. 1938, iv. $108 \mathrm{pp}$.

Contains discharge records of Hanalei Tunnel, Kauai (p. 17), Pearl Harbcr Springs, Oahu (pp. 35-39), and West Makapipi Spring, Maui (p. 57), and discharge measurements of Pearl Harbor Springs (p. 50). 
817. Water levels and artesian pressure in observation wells in the United States in 1936, with statement-concerning previous wcrk and results, prepared under the direction of O. E. Meinzer and L. K. Wenzel. 1937. iii, 511 pp.

Includes nearly all the periodic measurements made by the United States Geological Survey and cooperating agencies in Nebraska, Pennsylvania, and Utah and in eight areas of the Soil Conservation Service and complete records for selected wells in other States.

Introduction, by $\mathbf{O}$. E. Meinzer.

Arkansas, by D. G. Thompson.

California, by F. C. Ebert and A. M. Piper.

Colorado, by T. W. Robinson.

Florida, by V. T. Stringfield.

Hawail, by H. T. Stearns.

Indiana, by V. T. Stringfield.

lowa and Missouri, by V. C. Fishel and G. A. LaRocque.

Kansas, by V. C. Fishel and L. C. Crawford.

Maryland, by M. T. Thompson.

Michigan, by V. T. Stringfield.

Montana, by W. A. Lamb.

Nebraska, by L. K. Wenzel.

New Jersey, by H. C. Barksdale.

New Mexico, by C. V. Theis.

New York: Central New York, by A. W. Harrington; Long Island by R. M.

Leggette; Croton Valley, by C. E. Jacob.

North Carolina, by E. D. Burchard, V. C. Fishel, F. C. Ames, H. W. Palm, and

S. W. Lohman.

North Dakota, by A. N. Sayre.

Oklahoma, by V. C. Fishel and J. A. Allis.

Oregon, by A. M. Piper.

Pennsylvania, by S. W. Lohman.

South Carolina, by V. C. Fishel and J. M. Terry.

South Dakota, by A. N. Sayre.-

Tennessee, by D. G. Thompson.

Texas, by W. N. White, A. N. Sayre, Penn Livingston, V. C. Fishel, and V. L. Austin.

Utah, by G. H. Taylor and H. E. Thomas.

Virginia, by 0 . E. Meinzer, R. C. Cady, and V. C. Fishel.

Washington, by V. C. Fishel and J. P. Bonner.

Wisconsin, by G. T. Owen, V. C. Fishel, and C. C. Yonker.

818. Geology and water resources of the Mud Lake region, Idaho, including the Island Park area, by H. T. Stearns, L. L. Bryan, and Lynn Crandall. 1939.' v, 125 pp., 13 pls.

Describes the geography, geology, and hydrology of the northeastern part of the Snake River Plain. From 1900 to 1921 Mud Lake increased in size from a few hundred acres to 17.520 acres (including a group of smaller lak as), and tracts of swampy land developed, aggregating 10,000 acres. The large increase in water supply resulted from percolation of water used in irrigation on the Egin Bench, about 30 miles east of Mud Lake.

819. The warm springs of Georgia, their geologic relations and origin, a summary report, by D. F. Hewett and G. W. Crickmay. 1937. iv, 40 pp., 8 pls.

Seven groups of warm springs are known in Georgia, but popular interest centers in Warm Springs, in the west-central part of the State, which is improved for use by the Georgia Warm Springs Foundation. The several warm sp-ings are confined to a belt of pre-Cambrian metamorphic rocks, and all of them issie from the Hollis quartzite. The data collected show that the water of Warm Springs is that which falls on the erest of Pine Mountain and is carried in the Hollis quartzite to a depth of about 3,000 feet so that it absorbs heat from the rocks and is delivered at the surface with a temperature of $88^{\circ} \mathrm{F}$. 
820. Drought of 1936, with discussion on the significance of drought in relation to climate, by J.' C. Hoyt. 1938 . iv, 62 pp., 2 pls.

Diseusses the effects of the drought on ground-water supplies (pp. 11-13) and gives data on the fluctuation of the water level in an observation well in Hall County, Neb., and one in Arlington, Va.

822. Surface water supply of the United States, 1937, part 2, South Atlantic slope and eastern Gulf of Mexico basins; N. C. Grover, chief hrrdraulic engineer; D. H. Barber, F. M. Bell, E. D. Burchard, J. J. Dirzulaitis, A. E. Johnson, and D. S. Wallace, district engineers. 1938 (1939). vi, 266 pp., 1 pl.

Contains discharge records of Warm Spring, Va. (p. 18), and Blue (near Orange City), Kissengen, Crystal, Weekiwachee, Blue (near Dunnellon), and Ichatucknee Springs, Fla. (pp. 159, 174, 179, 182, 197), and discharge measurements of Juniper Spring and Fern Hammock Springs, Fla., and Blue Springs, and Radium Springs, Ga. (p. 260).

826. Surface water supply of the United States, 1937, part 6, Missouj River Basin; N. C. Grover, chief hydraulic engineer; H. C. Beckman, Robert Follansbee, R. G. Kasel, W. A. Lamb, T. R. Newell, and J. B. Spiegel, district engineers. 1938 (1939). vii, 376 pp., 1 pl.

Contains discharge record of Bennett Spring at Brice, Mo. (p. 361), and discharge measurements of Santa Fe Spring at Arrow Rock, Mo., 0.09 sec.-ft., and Paxton Spring at Humansville, Mo., 0.69 sec.-ft. (p. 369).

827. Surface water supply of the United States, 1937, part 7, Lower Mississippi River Basin; N. C. Grover, chief hydraulic engineer; D. H. Barber, H. C. Beckman, C. E. Ellsworth, Robert Follansbee, J. H. Gardiner, Berkeley Johnson, C. E. McCashin, and J. B. Spiegel, distrint engineers. 1938 (1939). iv, 173 pp., 1 pl.

Contains discharge records of Round, Alley, Big, and Greer Springs, Mo. (pp. 59, 61, 62, 65), and discharge measurements of 9 other springs in Missouri (p. 169).

828. Surface water suply of the United States, 1937, part 8, Westewn Gulf of Mexico basins; N. C. Grover, chief hydraulic engineer; C. E. Ellsworth, Robert Follansbee, and Berkeley Johnson, district en $:$ ineers. 1939. vii, 437 pp., 1 pl.

Contains discharge measurement of Buffalo Spring, Tex., 3.34 sec.-ft. (p. 423), numerous discharge measurements of Barton Springs, Tex. (p. 424), and 5 discharge measurements of Comanche Springs, Tex. (p. 430).

831. Surface water supply of the United States, 1937, part 11, Pacife slope basins in California; N. C. Grover, chief hydraulic engineer; H. D. McGlashan and G. H. Canfield, district engineers. 1938. vii, 358 pp., $1 \mathrm{pl}$.

Contains 6 discharge measurements of Hot Springs, near Santa Barbara, Calif., 0.24 to 0.95 sec.-ft. (p. 350). (Probably include surface water.)

834. Surface water supply of the United States, 1937, part 14, Pacife- slope basins in Oregon and lower Columbia River Basin; N. C. Grover, chief hydraulic engineer; G. H. Canfield and G. L. Parker, district en rineers. 1938. 188 pp., 1 pl.

Contains discharge records of 18 springs in the Walla Walla River Basin. OregonWashington, 1932-37 (pp. 166-170).

835. Surface water supply of Hawaii, July 1, 1936, to June 30, 1987; N. C. Grover, chief hydraulic engineer; M. H. Carson, district engineer. 1939. iv, $112 \mathrm{pp}$.

Contains discharge records of Hanalei Tunnel, Kaui (p. 17), Pear' Harbor Springs, Oahu (pp. 41-45), and West Makapipi Spring, Maui (p. 63), and discharge measurements of Pearl Harbor Springs and Kalihi Springs, Oahu (p. 56). 
836. Contributions to the hydrology of the United States, 1938-39; G. L. Parker, chief hydraulic engineer.

Issued only in separate chapters, as indicated below. Elach chapter contains its own index.

(b) Ground-water resources of the Holbrook region, Ariz., by M. A. Harrell and E. B. Eckel. 1939. pp. i-iv, 19-105, pls. 2-11. Describes the geography, geology, and ground-water resources of a portion of the Colorado Plateau in northeastern Arizona. The exposed sedimentary rocks range in age from Permian to Recent. Extrusive lavas and Tertiary or Quaternary cinder beds cover large areas. The principal water-bearing formations are the Coconino sandstone of Permian age, the lava flows, and the sand and gravel deposits of Recent aze along the major streams. Describes public water supplies briefly. Includes maps and tables giving data on most of the wells and springs of the region, including analyses of 118 samples of water.

(c) Artesian-water levels and interference between artesian vells in the vicinity of Lehi, Utah, by G. H. Taylor and H. E. Thomas. 1939. pp. i-iii, 137-156, pls. 12-14. Artesian woter is obtained in Pleistocene deposits at 75 to 750 feet, most wells being 130 to 200 feet deep. The supply was depleted by the drought period culminating in 1934, but during 1936 there was a general rise of 5 to 10 feet in the water level. Describes tests to determine the interferenc? of wells.

(d) Ground water in the United States, a summary of ground-water conditions and resources, utilization of water from wells and springs, methods of scientific investigation, and literature relating to the subject, by O. E. Meirzer. 1939. pp. i-v, 157-232, pl. 15. Describes the character and geographic distrikution of the major water-bearing formations and calls attention to the differences between formations in which water occurs under artesian conditions. Discusses the discharge of ground water through springs and by evaporation and transpiration. Gives data on the utilization of ground water for public and domestic supplies, industrial purposes, irrigation, and health and recreation purposes. Describes the mothods used in both areal and intensive ground-water investigations and gives a $k$ rief account of the ground-water work that has been done by the Geological Survey and cooperating parties. Contains a list of 104 representative publications in the United States relating to ground water.

(e) Local overdevelopment of ground-water supplies, with special reference to conditions at Grand Island, Nebr., by L. K. Wenzel. 1940. pr i-iii, 233-281, pls. 16-21. Declines in water levels in many parts of the United States have been local and due to overdevelopment. Over large areas declines have be?n caused chiefly or wholly by deficient rainfall. Water levels will probably recover in years of normal precipitation. At Grand Island, Nebr., local overdevelopment has taken place. The solution to the difficulty lies in redistributing the wells in such $a^{2}$ manner that less water will be pumped within the city and more will be pumpec from wells outside the city limits.

837. Inventory of unpublished hydrologic data, by W. T. Holland and C. S. Jarvis. 1938. ii, 77 pp.

Contains list of stations in 20 States where data on grourd-water observation wells have been recorded (pp. 51-53) and a section on literature relating to ground water (pp. 72-78).

839. Quality of water of the Rio Grande Basin above Fort Quitman, Tex., analytical data, by C. S. Scofield. 1938. ii, $296 \mathrm{pp}$.

Contains numerous analyses of samples of ground water from San Luis Valley, Colo., middle Rio Grande Valley, N. Mex., and Elephant Butte Project, New Mexico and Texas.

840. Water levels and artesian pressure in observation wells in the United States in 1937, prepared under the direction of $\mathrm{O}$. E. Meinzer and L. K. Wenzel. 1938 (1939). iv, $657 \mathrm{pp}$.

Water levels in the eastern and western parts of the Uni+od States generally showed net rises during 1937 ; in the middle part of the United States they generally showed net declines. Annual changes in water level correspon 7 in ceneral to departures from normal annual precipitation.

Introduction, by 0 . E. Meinzer. 
840. Water levels and artesian pressure in observation wells in the United States in 1937-Continued.

Arkansas, Grand Prairie region, by D. G. Thompson.

California: General summary, by F. C. Ebert; Mokelumne area, by A. M. Piper.

Connecticut, by W. H. Brothwell and R. M. Logie.

Florida, by V. T. Stringfield.

Hawaii, by H. T. Stearns.

Indiana, by V. T. Stringfield and M. M. Fidlar.

lowa and Missouri, Tarkio Creek area, by V. C. Fishel, G. A. Le Rocque, and G. N. Mesnier.

Kansas: south-central Kansas, by S. W. Lohman; Limestorie Creek area, by V. C.

Fishel and C. H. Hardison.

Maryland, by M. T. Thomson.

Michigan, by V. T. Stringfield, A. W. Bergquist, and O. F. Poindext?r.

Montana, Flathead Valley, by R. C. Cady.

Nebraska, by L. K. Wenzel.

New Jersey, by H. C. Barksdale.

New Mexico, by A. M. Morgan.

New York: Central New York, by A. W. Harrington; Long Islard by R. M. Leggette; Croton Valley, by C. E. Jacob.

North Carolina: State-wide project, by E. D. Burchard; Deep Rirer area, by

V. C. Fischel and H. W. Palm; Elizabeth Gity area, by A. G. Fiedler.

North Dakota, by L. K. Wenzel and F. W. Voedisch.

Oklahoma: Texas County, by S. L. Schoff; Stillwater Creek area, by V. C. Fishel and Verne Alexander.

Oregon, Walla Walla Basin, by A. M. Piper.

Pennsylvania, by R. W. Sundstrom.

South Carolina, Tiger Creek area, by V. C. Fighel and J. M. Tersy.

South Dakota, City of Huron, by A. N. Sayre.

Tennessee, Memphis, by D. G. Thompson.

Texas: State-wide project, by S. F. Turner; Fl Paso County. by A. N. Sayre; Howard County, by Penn Livingston; Elm Creek and Deer Creek areas, by V. C. Fishel and V. L. Austin.

Utah, by G. H. Taylor and H. E. Thomas.

Virginia, by F. H. Klaer, Jr.

Washington, Palouse River area, by V. C. Fishel, J. P. Bonner, and J. E. Anderson.

Wisconsin: Central and northern Wisconsin, by G. T. Owen; Coor Creek area by v. C. Fishel and C. C. Yonker.

841. Geology and ground-water resources of the Harney Basin, Oreg., by A. M. Piper, T. W. Robinson, and C. F. Park, Jr., with a stetement on precipitation and tree growth, by L. T. Jessup. 1939 (1940). vi, 189 pp., 20 pls.

The principal ground-water supplies are in the low central part of the basin, which comprises alluvial plains, playas and lake beds, cinder cones, and lava,fields. Both shallow water and deep artesian water occur in the Quaternary valley fill. Water also is present in pervious parts of the bedrock in three temperature ranges -slightly thermal, intermediate, and hot. The slightly thermal water occurs in wells In the north part of the basin; water of intermediate temperature issues from springs and flowing wells in the west haif of the basin; and hot wate issues from several widely scattered springs. The report contains climatic and surface-water data ; records of several hundred wells, including logs of about 20 wells and records of -water-level measurements in more than 100 wells during 1928-32; dita on about 40 springs; and analyses of about 115 water samples from wells, springs, and streams. Contains a statement on precipitation and tree growth by J. T. Jessup.

845. Water levels and artesian pressure in observation wells in the United States in 1938, prepared under the direction of 0 . E. Meinzer and $L$. K. Wenzel. 1939. iv, 724 pp.

Contains introduction and records of water levels or artesian pressura in observation wells during 1938 and earlier records of wells in some areas, as follows:

Introduction, by 0 . E. Meinzer. 


\section{Water levels and artesian pressure in observation wells the United States in 1938-Continued.}

Arkansas, Grand Prairie region, by D. G. Thompson.

California: General summary, by F. C. Ebert; Mokelumne area, by A. M. Piper. Connecticut.

Florida, by V. T. Stringfield and H. H. Cooper, Jr.

Ceorgia, by V. T. Stringfield, M. A. Warren, and A. C. Munyar.

Hawaii, by $H$. 'T. Stearns.

Indiana, by C. L. McGuinness.

Iowa and Missouri, Tarkio Creek area, by V. C. Fishel, G. N. Mesnier, and W. T. Wilson.

Kansas: Ford County, by H. A. Waite; Limestone Creek area, by H. A. Waite and C. W. Stewart ; South-central Kansas, by S. W. Lohman.

Louisiana, by J. C. Maher.

Maryland, by A. H. Horton.

Michigan, by A. W. Bergquist and O. F. Poindexter.

Mississippi, by G. F. Brown.

Montana, Flathead Valley, by R. C. Cady.

Nebraska, by L. K. Wenzel.

New Jersey, by H. C. Barksdale.

New Mexico: Mimbres Valley, by G. C. Taylor, Jr.; Portales Valley, by C. S.

Conover; Roswell artesian basin, by A. M. Morgan.

New York: Central New York, by A. W. Harrington; Long Island, by E. J. Shaefer; Croton Valley, by C. E. Jacob.

North Carolina: State-wide project, by E. D. Burchard; Deep-River area, by

V. C. Fishel and J. W. Gambrell; Elizabeth City area, by A. G. Fiedler.

North Dakota, by L. K. Wenzel and F. W. Voedisch.

Ohio; Butler and Hamilton Counties, by F. H. Klaer, Jr.

Oklahoma: Panhandle counties, by F. H. Klaer, Jr.; Stillwate* Creek área, by

v. C. Fishel.

Oregon, by G. A. LaRocque, Jr., and A. M. Piper.

Pennsylvania, by R. W. Sundstrom.

South Carolina, Tiger Creek area, by V. C. Fishel.

South Dakota, City of Huron, by A. N. Sayre.

Tennessee, Memphis, by D. G. Thompson.

Texas: State-wide project, by S. F. Turner; El Paso County, by A. N. Sayre;

Elm Creek and Deer Creek areas.

Utah, by G. H. Taylor and H. E. Thomas.

Virginia, by V. C. Fishel.

Washington, Palouse River area, by G. A. LaRocque, Jr., and A. M. Piper.

Wisconsin: Gentral and northern Wisconsin, by G. T. Owen; Coon Creek area, by V. C. Fishel and C. C. Yonker.

848. Ground water in Keith County, Nebr., by L. K. Wenzel an* H. A. Waite, with sections on Platte Valley Public Power and Irrigrtion District, Sutherland project, by E. E. Halmos, and Central Nebraska Public

- Power and Irrigation District, Tri-County project, by G. E. Johnson. 1941. iv, 68 pp., 8 plș.

Describes the water-bearing formations of the county, whicl are chiefly the Quaternary deposits and the Ogallala formation, of Tertiary are. Gives data on the depth to water, the fluctuations of ground-water level, recharpe and discharge, and utilization for domestic, stock, municipal, and irrigation supplies. Discusses the chemical character and gives analyses of 29 samples of well water. Describes well construction and includes the records of 349 wells. Contring map showing contours on the water table.

849. Contributions to the hydrology of the United States, 1940 papers by W. N. White, R. C. Cady, Penn Livingson and others.

(a) Geology and ground-water resources of the Lufkin area, Tex., by W. N. White, A. N. Sayre, and J. F. Heuser. 1941. pp. i-iv, 1-58, pls. 1-2. The area is underlain by deposits of Eocene age, of which three formations appear likely to yield large supplies of water to wells under artesian head. The Yegua formation yields water that is moderately mineralized, the Sparta sand yirtds large supplies 
849. Contributions to the hydrology of the United States, $1940-$ Continued.

of water that is moderately to highly mineralized, and the Carrizo sand yields large quantites of water of low mineralization.

(b) Effect upon ground-water levels of proposed surface-water storage in Flathead

if Lake, Mont., by R. C. Cady. 1941. pp. i-iii, 59-81, pls. 3-10. Treats of an alluivial plain at the north end of Flathead Lake, where Flathead River entrs it. The ground-water level rises and falls in response to the annual change of stage of the river and lake. It has been proposed to regulate the level of the lake so that a higher stage may be maintained for a longer time. If this is done a rise of the water table will probably take place. Some land will thereby be rendered unfit for agriculture, but most of the land will be unaffected by the rise.

(c) Geology and ground-water resources of the Balmorhea area, western Texas, by W. N. White, H. S. Gale, and S. P. Nye. 1941. pp. i-iii, 83-146, r'. 11. Discusses the geologic formations and the structure and its relation to ground water. Describes springs, shallow ground water, and the intake and cischarge of ground water. Contains well records and stream and spring discharçe measurements used to determine seepage losses. See also Cooperative report 390

(d) Underground leakage from artesian wells in the Las Vegas area, Nev., by Penn Livingston. 1941. pp. i-iii, 147-173, pls. 12-17. Describes the genemal geologic and hydrologic features of the artesian basin, the methods of well construction, and methods of testing for underground leakage. Discusses the waste of artesian water. The aggregate leakage is not great enough to be responsible for more than a small part of the serious decline in water levels and artesian pressum that has taken place in the basin.

850. Summary of records of surface waters of Texas, 1898-1937, by C. E. Ellsworth. 1939. vi, 154 pp.

Contains discharge measurements of Barton Springs and Mill Spring at Austin, Tex. (pp. 113-115), and Phantom Lake, Giffin, and San Solomon Springs at Toyahvale, Tex., and West Sandia, and East Sandia Springs at Balmorhea, Tex. (p. 141).

B52. Surface water supply of the United States, 1938, part 2, South Atlantic slope and easern Gulf of Mexico basins; N. C. Grover, chief hydraulic engineer; D. H. Barber, F. M. Bell, E. D. Burchard, J. J. D: wulaitis, A. E. Johnson, and D. S. Wallace, district engineers. 1940. vi, 293 pp., 1 pl.

Contains discharge records of Warm Spring, Va. (p. 21), and Blue (naar Orange City), Kissengen, Crystal, Weekiwachee, Blue (near Dunnellon); and rchatucknee Springs, Fla. (pp. 175, 189, 193, 196, 212), and discharge measuremerts of Luke Spring, Va., 2.55 sec.-ft., Iris Garden Spring, Fla., 3.9 to 7.5 sec.-ft.. and Cave Spring, Ga., 3.61 sec.-ft. (p. 286).

853. Surface water supply of the United States, 1938, part 3, Otio River Basin; N. C. Grover, chief hydraulic engineer; E. D. Burchard, J. J. Dirzulaitis, H. E. Grosbach, A. W. Harrington, A. H. Horton, William Kessler, J. W. Mangan, C. E. McCashin, J. H. Morgan, F. M. Veatch, and.C. V. Youngquist, district engineers. 1940. vii, 418 pp., 1 pl.

Contains discharge measurements of Blue Spring, Blowing Spring, and unnamed spring near Lenoir City, all in Tenn. (p. 412).

855. Surface water supply of the United States, 1938, part 5, Hudson Bay and upper Mississippi River Basins; N. C. Grover, chief hydranlic engineer; C. L. Batchelder, H. C. Beckman, F. C. Christopherson, H. E. Grosbach, R. G. Kasel, W. A. Lamb, J, H. Morgan; S. B. Soule, and A. H. Tuttle, district engineers. 1940. ix, 350 pp., 1 pl.

Contains discharge measurements of Stevert, Twin, and Big Springs, Iowa (p. 341).

856. Surface water supply of the United States, 1938, part 6, Missouri River Basin; N. C. Grover, chief hydraulic engineer; H. C. Beckman, Robert Follansbee, R. G. Kasel, W. A. Lamb, T. R. Newell, J. B. Spiegel, and A. H. Tuttle, district engineers. 1940 . vii, 419 pp., 1 pl. 
856. Surface water supply of the United States, 1938-Continvad.

Contains discharge record of Bennett Spring, Mo. (p. 410), and discharge measurements of Beaver Spring, S. Dak. (p. 410), and Wet Glaize and Land Springs, Mo. (p. 412).

857. Surface water supply of the United States, 1938, part 7, Lower Mississippi River Basin; N. C. Grover, chief hydraulic enginear; D. H. Barber, H. C. Beckman, C. E. Ellsworh, Robert Follansbee, J. H. Gardiner, Berkeley Johnson, J. L. Saunders, C. E. McCashin, J. P. Spiegel, and F. M. Veatch, district engineers. 1939. v, $197 \mathrm{pp} ., 1 \mathrm{pl}$.

Contains discharge records of Round, Alley, Big, and Greer Springs, Mo. (pp. 66, 68, 69, 73), and discharge measurements of Blue Spring ard Roaring River Springs, Mo. (p. 193).

858. Surface watex supply of the United States, 1938, part 8, Western Gulf of Mexico basins; N. C. Grover, chief hydraulic engineer; C. E. Ellsworth, Robert Follansbee, and Berkeley Johnson, district engineers. 1940. vii, 355 pp., 1 pl.

Contains discharge measurements of 8 springs in Texas (pp. 344, 345, 348).

860. Surface water supply of the United States, 1938, part 10, The Great Basin; N. C. Grover, chief hydraulic engineer; G. H. Canfield, Robert Follansbee, H. D. McGlashan, T. R. Newell, and A. B. Purton, district engineers. 1939. iv, 103 pp., 1 pl.

Contains discharge measurement of Abraham Hot Springs, Utah (p. 98).

861. Surface water supply of the United States, 1938, part 11, Pacific slope basins in California; N. C. Grover, chief hydraulic er rineer; H. D. McGlashan and G. H. Canfield, district engineers. 1939. vii, 374 pp., $1 \mathrm{pl}$.

Contains 4 discharge measurements of Hot Springs, near Sante Barbara, Calif., 0.33 to 0.61 sec.-ft. (p. 367). (Probably include surface water.)

864. Surface water supply of the United States, 1938, part 14, Pacific slope basins in Oregon and lower Columbia River Basin; N. C. Grover, chief hydraulic engineer; G. H. Canfield and G. L. Parker, district engineers. 1939. v, 184 pp., 1 pl.

Contaíns discharge records of 18 springs in the Walla Walla Rirer Basin, Oregon and Washington (pp. 176-178).

865. Surface water supply of Hawaii, July 1, 1937, to June 31, 1938; N. C. Grover, chief hydraulic engineer; M. H. Carson, district engineer. 1940. iv, $122 \mathrm{pp}$.

Contains discharge records of Hanalei Tunnel, Kauai (p. 17), Pearl Harbor Springs, Oahu (pp. 40-44), and West Makapipi Spring, Maui (p. 68), and $d^{*}$ 'charge measurements of Pearl Harbor Springs (p. 55).

872. Surface water supply of the United States, 1939, part'2, South Atlantic slope and eastern Gulf of Mexico basins; C. G. Paulsen, acting chief hydraulic engineer; D. H. Barber, F. M. Bell, E. D. F “rchard, J. J. Dirzulaitis, A. E. Johnson, and D. S. Wallace, distriet engineers. 1941. ix, 388 pp., 1 pl.

Contains discharge records of Warm Spring, Va. (p. 19), and $B^{\prime}$ 'se (near Orange City), Kissengen, Crystal, Weekiwachee, Blue (near Dunnellon); and Ichatucknee Springs, Fla. (pp. 184, 201, 207, 210, 224), and discharge measurerrents of Magnolia Spring, Ga., and Iris Garden Spring, Fla. (p. 349), and Cave Sprir', Ga. (p. 350).

876. Surface water supply of the United States, 1939, part 6, Irissouri River Basin; C. G. Paulsen, acting chief hydraulic engineer; F. C. Beckman, Robert Follansbee, R. G. Kasel, T. R. Newell, P. R. Spéer, J. B. Spiegel, and A. H. Tuttle, district engineers. 1941. xi, $502 \mathrm{pp} ., 1 \mathrm{pl}$.

Contalns discharge record of Bennett Spring at Brice, Mo. (p. 497). 
877. Surface water supply of the United States, 1939, part 7, Lower Mississippi River Basin; C. G. Paulsen, acting chief hydraulic engineer; D. H. Barber, H. C. Beckman, C. E. Ellsworth, Robert Follansbee, Borkeley Johnson, J. L. Saunders, C. E. McCashin, J. B. Spiegel, and F. M. Veatch, district engineers. 1940 (1941). vii, 379 pp., 1 pl.

Contains discharge records of Round, Alley, Big, and Greer Springs, Mo. (pp. $82,84,85,96)$.

878. Surface water supply of the United States, 1939, part 8, Western Gulf of Mexico basins; C. G. Paulsen, acting chief hydraulic engineer; D. H. Barber, C. E. Ellsworth, Robert Follansbee, and Berkeley Johnson, district engineers. 1941. ix, 393 pp., 1 pl.

Contains 8 discharge measurements of Las Moras Springs, Tex. (p. 333), and of 28 other springs in Texas (pp. 341-345).

879. Surface water supply of the United States 1939, part 9, Colorado River Basin; C. G. Paulsen, acting chief hydraulic'engineer; Robert Follansbee, J. H. Gardiner, Berkeley Johnson, and A. B. Purton, district engineers. 1940 (1941). vii, 309 pp., 1 pl.

Contains 10 discharge measurements of Warn Springs, 1,700 feet dovnstream from Coolidge Dam, Ariz., made from November 11, 1938, to August 1, 1939, 0.32 to 0.97 sec.-ft. (p. 261).

881. Surface water supply of the United States, 1939, part 11, Pacifi- slope basins in California; C. G. Paulsen, acting chief hydraulic en rineer; H. D. McGlashan and G. H. Canfield, district engineers. 1940 (1941). xii, 446 pp., 2 pls.

Contains 8 discharge measurements of Hot Springs, near Santa Barbar, Callf., 0.18 to 0.72 sec.-ft. (p. 348). (Probably include surface water.)

882. Surface water supply of the United States, 1939, part 12, Pacifi? slope basins in Washington and upper Columbia River Basin; C. G. F ulsen, acting chief hydraulic engineer; T. R. Newell, G. L. Parker, and A. H. Tuttle, district engineers. 1940 (1941), vii, 246 pp., 1 pl.

Contains 11 discharge measurements of Maplewood Springs at Puyallup Wash., 26.4 to 39.2 sec.-ft. (p. 188).

884. Surface water supply of the United States, 1939, part 14, Pacifin slope basins in Oregon and lower Columbia River Basin; C. G. Paulsen, acting chief hydraulic engineer; G. H. Canfield and G. L. Parker, district. engineers. 1940 (1941). vii, 220 pp., 1 pl.

Contains discharge records of 18 springs in the Walla Walla River Basin. Oregon and Washington (pp. 181-183).

885. Surface water supply of Hawaii, July 1, 1938, to June 30, 1939; C. G. Paulsen, acting chief hydraulic engineer; $M$ H. Carson, district engineer. 1941. v, $142 \mathrm{pp}$.

Contains discharge records of Hanalei water tunnel on Kaual (p. 16), Pearl Harbor Springs, Oahu (pp. 39-43), and West Makapipi Spring, Maui (p. 68), and Kalae Spring, Hawaii (p. 124).

886. Water levels and artesian pressure in observation wells in the United States in 1939, by O. E. Meinzer, L. K. Wenzel, and others. 1940 (1941). v, 933 pp.

Contains records of water levels or artesian pressure in about 5,500 obrervation wells. Alsa gives complete records of water levels in some wells not hiretofore published. The several reports are as follows:

Introduction, by $\mathbf{O}$. E. Meinzer and L. K. Wenzel.

Arizona, by S. F. Turner. 
886. Water levels and artesian pressure in observation wells in the United States in 1939-Continued.

Arkansas, Grand Prairie region, by D. G. Thompson.

Californią: General summary, by F. C. Ebert; San Joaquin Count.v, by A. M. Piper.

Connecticut, New Haven County, by J. G. Ferris.

Florida, by W. P. Cross and H. H. Cooper, Jr.

Georgia, by M. A. Warren and A. C. Munyan.

Hawaii, by $\mathrm{H}$ T. Stearns.

Idaho, by A. M. Piper.

Indiana, by C. L. McGuinness.

Towa, State-wide project, by T. W. Robinson.

Iowa and Missouri, Tarkio Creek area, by V. C. Fishel, G. N. Mesnier, and W. T. Wilson.

Kansas: Finney, Gray, and Stanton Counties, by B. F. Latta: Meade County, by J. C. Frye; Hamilton, Kearny, and Morton Counties, by 'T. G. McLaughlin ; Ford and Scott Counties, by H. A. Waite; Limestone Creek are 2, by H. A. Waite and C. W. Stewart; South-central Kansas, by S. W. Lohman an't G. H. von Hein.

Louisiana, by J. C. Maher and T. B. Stanley, Jr.

Maryland, by A. H. Horton.

Massachusetts, by M. L. Brashears, Jr.

- Michigan, by C. L. McGuinness, O. F. Poindexter, and Norman Billings.

Mississippi, by G. F. Brown and V. M. Foster.

Montana, Flathead Valley, by R. C. Cady.

Nebraska, by L. K. Wenzel.

New Jersey, by H. C. Barksdale and E. J. Schaefer.

New Mexico: Chaves and Eddy Counties, by A. M. Morgan and O. J. Loeltz; Luna and Roosevelt Counties, by C. S. Conover.

New York: Central New York, by A. W. Harrington: Long Island, by R. M. Leggette.

North Garolina: State-wide project, by E. D. Burchard; Desp River area, by

V. C. Fishel and J. W. Gambrell; Elizabeth City area, by A. G. Fiedler.

North Dakota, by L. K. Wenzel and F. W. Voedisch. Ohio: Butler and Hamilton

Counties, by F. H. Klaer, Jr.; City of Canton, by A. N. Sayre.

Oklahoma: Panhandle counties, Stillwater Creek area, and Cleveland County, by

S. L. Schoff.

Oregon, by A. M. Piper.

Pennsylvania, by R. C. Baker.

South Carolina, Tiger River area, by V. C. Fishel.

South Dakota; City of Huron, by A. N. Sayre: Southeastern part, by T. W.

Robinson.

Tennessee. Memphis.

Texas: State-wide project, by R. W. Sundstrom; El Paso County, by A. N.

Sayre: Elm Creek and Deer Creek areas, by R. W. Sundstrom

Utah, by G, H. Taylor, H. E. Thomas, and W. K. Bach.

Virginia: Northern Virginia, by $\vee$. C. Fishel ; Southeastern Virginia, by D. J. Cedérstrom.

Washington, by A. M. Piper.

Wisconsin, Coon Creek area, by V. C. Fishel and C. C. Yonker.

887. Methods for determining permeability of water-bearing materials, with special reference to discharging-well methods, by L. $Y$. Wenzel, with a section on direct laboratory methods and bibliogranhy on permeability and laminar flow, by V. C. Fishel. 1942. vi, 192 pp., 6 pls.

The permeability of a water-bearing material may be determ'ned by laboratory tests or by pumping tests. Describes the principal methods and procedure employed. Gives data on four pumping tests in Platte River Valley. Nebr., and one pumping test in Arkansas River Valley, Kans., with computation of the permeability of the water-bearing materials by several formulas.

889. Contributions to the hydrology of the United States, 1941-43.

(a) Water supply of the Dakota sandstone, by L. K. Wenzel and H. H. Sand. 1942. pp. i-iv, 1-81, pls. 1-3. Describes the development of floving artesian wells in the area and the decline in head caused by the great draft on the supply. This decline has been partly controlled since 1921 by legislation restricting the flow of 
889. Contributions to the hydrology of the United States, 1941-48-Continued. wells to benefieial use, but the original area of flowing wells has continued to grow smaller, until a balance is being reached between the withdrawal of wat $\rightarrow$ from the basin and recharge to it. The report gives tabulated data on 375 wells and 33 analyses of water samples, which show that the water is in general of posr quality. Contains map showing fluoride content of the ground water and map showing location of artesian wells and the original western limit of artesian flow and the limit in 1915, 1923, and 1938.

(b) Water-table fluctuations in the Spokane Valley and contiguous area , Washington-Idaho, by A. M. Piper and G. A. LaRocque, Jr., 1944. pp. l-iii, 83-189, pls. 4-7. Prepared in cooperation with the Washington State Department of Cunservation and Development. Deseribes ground-water features of the valley plairs along the Spokane and Little Spokane Rivers in Washington and of Rathdrum Prairie and contiguous extensive plains. Includes and interprets about 12,000 measurements of levels in wells in the period ending with 1938 .

(c) Ground-water resources of the Houston district, Texas, by W. N. Whitis, N. A. Rose, and W. F. Guyton. 1944. pp. i-iii, 141-290, pls, 8-11. Prepared in cooperation with the Texas Board of Water Engineers and the city of Houston. Covers the current phase of an investigation of the supply of ground water available for the Houston district, and adjacent region that has been in progress during the past 10 years.

(d) Exploratory water-well drilling in the Houston district, Texas, by N. A. Rose, W. N. White, and Penn Livingston. 1944. pp. i-iii, 291-315, pls, 12-16. Prepared in cooperation with the Texas Board of Water Engineers and the city of Houston. Describes 13 test wells 360 to 2,000 feet deep drilled by the city of Houston and présents information obtained from them on available water supplies.

(f) Ground water in the High Plains of Texas, by W. N. White, W. L. Broadhurst, and J. W. Lang. 1946. pp. i-iv, 381-420, pls. 17-21. Prepared in eooperation with the Texas Board of Water Engineers. Discussea the results of recent studies and gives data. on the principal water-bearing formations.

890. Ground-water resources of the Willamette Valley; Oregon, by A. M. Piper. 1942. v, 194 pp., 10 pls.

Describes the area and the bedrock formations, of which only the Yakima basalt yields water copiously over an extensive area. The unconsolidated deposits also yield much water. Contains analyses of 35 samples of well water, many well records, and a geologic map showing ground-water levels.

892. Surface water supply of the United States, 1940, Part 2, South Atlantic slope and eastern Gulf of Mexico basins; G. L. Parker, chief hyc'raulic engineer, D. H. Barber, F. M. Bell, E. D. Buchard, J. J. Dirzulaitis, A. E. Johnson, and D. S. Wallace, district engineers. 1942. vili, 441 pp:, 1 pl.

- Uuntains discharge records of Warm Spring at Warm Spring, Va. (p. 20), Blue (near Orange City), Kissengen, Crystal, Weekiwachee, Blue (near Dunnellon), and Ichatucknee Springs, all in Florida (pp. 228, 265, 272, 275, 289), and discharge measurements of De Soto and Cave Springs, Ga. (p. 434).

893. Surface water supply of the United States, 1940, Part 3, Ohio River. basin; G. L. Parker, chief hydraulic engineer; E. D. Burchard. J. J. Dirzulaitis, H. E. Grosbach, A. W. Harrington, A. H. Horton, William Kessler, J. W. Mangan, C. E. McCashin, J. H. Morgan, D. S. Wallace, J. V. B. Wells, and C. V. Youngquist, district engineers. 1942. ix, 662 pp., 1 pl.

Contains 2 discharge measurements of Bubbling Springs, S. C. (p. 652).

896. Surface water supply of the United States; 1940, part 6, Missouri River Basin; G. L. Parker, chief hydraulic engineer; H. C. Beckman, L. C. Crawford, Robert Follansbee, R. G. Kasel T. R. Newell, P. R. Speer, J. B. Spiegel, and A. H. Tuttle, district engineers. 1942. viii, 457 pp., 1 pl.

Contains 8 discharge measurements of Bennett Spring at Beninett Springs, Mo. (p. 449). 
897. Surface water supply of the United States, 1940, part 7, Lower Mississippi River Basin; G. L. Parker, chief hydraulic engi neer; D. H. Barber, H. C. Beckman, C. E. Ellsworth, Robert Follanshee, J. H. Gardiner, Berkeley Johnson, J. L. Saunders, C. E. McCashin, J. B. Spiegel, F. M. Veatch, and J. V. B. Wells, district engineers. 1941 (1942). vi, 349 pp., 1 pl.

Contains discharge records of Big Springs and Greer Springฯ. Mo. (pp. 83, 88), and discharge measurements of Meramec, Keener, Cave, and Kirr Bee Springs, Mo., and Roman Nose Spring, Okla. (p. 343).

898. Surface water supply of the United States, 1940, part 8, western Gulf of Mexico basins; G. L. Parker, chief hydraulic engineer; D. H. Barber, C. E. Ellsworth, Robert Follansbee, and Berkeley Johnson, district engineers. 1942 . viii, 426 pp., 1 pl.

Contains discharge measurements of Las Moras Springs (p. 406), Barton Springs (p. 414), Schwandners Spring (p. 415), and Comanche, Mud and Pinto Springa (p. 417), all in Texas.

899. Surface water supply of the United States, 1940, part ?, Colorado River Basin; G. L. Parker, chief hydraulic engineer; Robert Follansbee, J. H. Gardiner, Berkeley Johnson, and A. B. Purton, district engineers. 1941. vi, 294 pp., 1 pl.

Contans 3 arsenarge measurements of Warm Springs near Coolidge Dam, Ariz. - (p. 289).

900. Surface water supply of the United States, 1940, part 10, The Great Basin; G. L. Parker, chief hydraulic engineer; G. H. Canfield, Robert Follansbee, H. D. McGlashan, T. R. Newell, and A. F. Purton, district engineers. 1941. iv, 125 pp., 1 pl.

Contains discharge measurement of Sodhouse Spring near Vo'tage, Oreg. (b. 122).

901. Surface water supply of the United States, 1940, part 11, Pacific slope basins in California; G. L. Parker, chief hydraulic engineer; H. D. McGlashan and G. H. Canfield; district engineers. 1941. viii, 377 pp., 2 pls.

Contains 8 discharge measurements of Hot Springs near S inta Barbara, Calif., 0.17 to 1.10 sec.-ft. (b. 367). (Probably include surface water.)

902. Surface water supply of the United States, 1940, part 12, Pacific slope basins in Washington and upper Columbia River Basin; G. L. Parker, chief hydraulic engineer; T. R. Newell, A. H. Tuttle, and F. M. Veatch, district engineers. 1941. $\mathrm{v}, 210 \mathrm{pp} ., 1 \mathrm{pl}$.

Contains 9 discharge measurements of Maplewood Springs (Creek) at Puyallup Wash. (p. 203).

904. Surface water supply of the United States, 1940, part 14, Pacific slope basins in Oregon and lower Columbia River Basin; G. L. Parker, chief hydraulic engineer; G. H. Canfield and F. M. Veatch, district engineers. 1941. v, 208 pp., 1 pl.

Coniains discharge records of 18 springs in the Walla Walla River Basin, Oregon and Washington (pp. 199-201), and discharge measurements of Rock Springs, near Lupine, Oreg., 20.4 sec.-ft. (b. 202).

905. Surface water supply of Hawaii, July. 1, 1989, to Jure 30, 1940; G. L. Parker, chief hydraulic engineer; M. H. Carson, distrint engineer, 1942. iv, 136 pp.

Contains discharge record of Hanalei water tunnel on Kauai (b. 18), Pearl Harbor Springs on Oahu (pp. 43-46), and West Makapipi Spring on Maui (p. 75) and discharge measurements of Papapaholahola Spring on Kaui (D. 88), Pearl Harbor Springs (p. 58), and Waialala Springs on Molokai (b. 65). 
906. Water levels and artesian pressure in observation wells in the Thited States in 1940, part 1, Northeastern States, by O. E. Meinzer, L. K. Wenzel, and others. 1942. iii, 226 pp.

Contains the following:

Introduction, by $O$. E. Meinzer and $L$. K. Wenzel.

Connecticut, New Haven County, by J. G. Ferris.

Indiana, by C. L. McGuinness.

Massachusetts, by M. L. Brashears, Jr.

Michigan, by C. L. McGuinness, Norman Billings, and O. F. Poindexter.

New Jersey, by E. J. Schaefer.

New York: Central New York, by G. D. Freeman; Long Island, by R. M. Leggette.

Ohio: Butler and Hamilton Counties, by F. H. Klaer, Jr.; City of Carton, 'by

A. N. Sayre.

Pennsylvania, by R. C. Baker.

907. Water levels and artesian pressure in observiation wells in the United States in 1940, part 2, Southeastern Státes, by O. E. Meinzer, L. K. Wenzel, and others. 1942. iv, 120 pp.

Contains the following:

Introduction, by $\mathbf{O}$. E. Meinzer and L. K. Wenzel.

Alabama, by C. W. Carlston.

District of Columbia, by V. C. Fishel.

Florida: Northeaștern, West, and Central Florida, by H. H. Cooper, Jr.; Southeastern Florida, by W. P. Cross.

Georgia, by M. A. Warren and A. C. Munyan.

Maryland: Montgomery County, by A. H. Horton; Prince Georges Cornty, by

v. C. Fishel.

Mississippi, by V. M. Foster and G. F. Brown.

North Carolina: State-wide project, by E. D. Burchard; Forsyth, Guilferd, and

Randolph Counties, by V. C. Fishel ; Elizabeth City area, by A. G. Fiedler.

South Carolina, Greenville and Spartanburg Counties, by V. C. Fishel.

Tennessee, Memphis, by F. H. Klaer, Jr.

Virginia; Northern Virginia, by V. C. Fishel; Southeastern Virginia, by D. J. Cederstrom.

908. Water levels and artesian pressure in observation wells in the United States in 1940, part 3, North-central States, by O. E. Meinzer, L. K. Wenzel, and others. 1942 . iv, $288 \mathrm{pp}$.

Contains the following:

Introduction, by $\mathbf{O}$. E. Meinzer and L. K. Wenzel.

North Dakota, by W. C. Rasmussen.

South Dakota, by T. W. Robinson.

Nebraska, by L. K. Wenzel.

Kansas, by S. W. Lohman, J. C. Frye, B. F. Latta, H. A. Waite, T. G. Mo

Laughlin, and Frank Byrne.

Minnesota, by A C. Byers.

Iowa: State-wide project, by T. W. Robinson; Page and Montgomery Counties

(Tarkio Creek area), by V. C. Fishel.

Missouri, by V. C. Fishel.

Kansas, by v. C. Fishel.

909. Water levels and artesian pressure in observation wells in the United

States in 1940, part 4, South-central States, by O. E. Meinzer, L. K.

Wenzel, and others. 1941 (1942). iii, 208 pp.

Contains the following:

Introduction, by 0 . E. Meinzer and L. K. Wenzel.

Arkansas, Grand Prairie region, by D. G. Thompson and R. G. Kazmann.

Louisiana, by J. C. Maher and T. B. Stanley, Jr.

Oklahoma, by S. L. Schoff.

Texas: State-wide project, by R. W. Sundstrom; El Paso County, by A. A. Sayre. 
910. Water levels and artesian pressure in observation wells in the United States in 1940, part 5, Northwestern :States, by : O. F. Meinzer, L. K.

Wenzel, and others. 1941. iii, 184 pp.

Contains the following:

Introduction, by $\mathbf{O}$. $\mathbf{E}$. Meinzer and L. K. Wenzel.

Idaho, by J. W. Robinson and G. C. Taylor, Jr.

Montana, Flathead Valley, by R. C. Cady.

Oregon, by J. E. Upson.

Utah, by H. E. Thomas and W. K. Bach.

Washington, by G. C. Taylor, Jr., and J. W. Robinson.

Wyoming, by T. W. Robinson.

911. Water levels and artesian pressure in observation wells in the United

States in 1940, part 6, Southwestern States and Terriory of Hawaii,

by O. E. Meinzer, L. K. Wenzel, and others. 1941 (1942). iv, 240 pp.

Contains the following:

Introduction, by $\mathbf{O}$. E. Meinzer and L. K. Wenzel.

Arizona, by S. F. Turner, H. M. Babcock, D.-H. Bratton, E. M. Cushing, L. C.

Halpenny, und H. R. McDonald.

California, by A. M. Piper and F. C. Ebert.

New Mexico, by C. S. Conover, C. R. Murray, O. J. Loeltz, and S. F. Turner.

Hawaii, by H. T. Stearns.

912. Industrial quality of public water supplies in Georgia. 1940, by W. L.

Lamar. 1942. iii, 83 pp.

Describes 66 public water supplies serving 35.2 percent of the population of the State. About half of these supplies are obtained from wells in the Coastal Plain. Shows the quality of the supplies by 157 water analyses. Discinses various mineral substances in solution.

913. Geology and ground-water resources of the Big Spring area, Tex., by Penn Livingston and R. R. Bennett. 1944. v, 113 pp. 18 pls.

Well water supplies are obtained largely from sinks in the Triassic and Cretaceous rocks, caused by removal of salt from underlying Permian formations. Wells of smaller yield are obtained in less disturbed areas and from Tertiary deposits in certain valleys or basins. The report contains many well logs and records, a table of 82 analyses of ground water, and a map showing the water table.

919. Ground-water resources of the El Paso area, Texas, by A. N. Sayre and P. P. Livingston. 1945. vi, 190 pp., 16 pls:

Prepared in cooperation with the El Paso Water Board and the Texas State Board of Water Engineers. Gives a detailed description of the geology and the occurrence of ground water, with a discussion of the quality of water, by M. D. Foster. Treats of the ground-water levels, recharge, and quantity of water available. Presents an extensive discussion of mineral contamination of the city wells. Includes maps showing contours on the water table and many records and logs of wells.

922. Surface water supply of the United States, 1941, part 2, South Atlantic slope and eastern Gulf of Mexico basins: G. L. Parker, chief hydraulic engineer; D. H. Barber, F. M. Bell, H. C. Bolon, E. D. Burchard, G. E. Ferguson, A. E. Johnson, E. B. Rice, F. F. Schrader, M. T. Thomson,

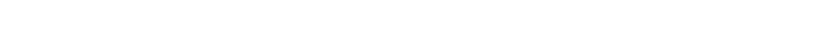

Contains discharge record of Warm Spring at Warm Springs, Va. (p. 20), and Kissengen, Crystal, Weekiwachee, Rainbow, and Ichatucknee Springs, Fla. (pp. 259. 266, 270, 284), and discharge measurements of De Soto Spring, Ga., and Coddwater, Blue, Nottingham Windmill, and Ledbetter Springs, Ala. (p. 426).

927. Surface water supply of the United States, 1941, part 7, lower Mississippi River basin: G. L. Parker, chief hydraulic engineer; D. H. Barber, H. C. Beckman, F. M. Bell, H. C. Bolon, C. E. Fllsworth, Robert Follansbee, J. H. Gardiner, Berkeley Johnson, C. E. McCashin, E. B. Rice, J. L. Saunders, J. B. Spiegel, and J. V. B. Wells, district engineers. 1942. vi, 355 pp. 
927. Surface.water supply of the United States, 1941-Continued.

Contains discharge records of Big and Greex Springs, Mo. (pp. 78, 83), and cischarge measurements of Racing, Montague, Alley, Powder Mill, Blue, rolly, and Camp Beaver Springs, Mo. (pp. 347-348).

929. Surface water supply of the United States, 1941, part 9, Colorac' River basin: G. L. Parker, chief hydraulic engineer; Robert Follan bee, J. H. Gardiner, Berkeley Johnson, and A. B. Purton, district en rineers. 1942. v1, 311 pp.

wntans $\dot{3}$ discharge measurements of Warm Springs on Gila River 1,700 feet be.uw Colidge Dam, 0.97 to 2.12 sec.-ft. (p. 306).

931. Surface water supply of the United States, 1941, part 11, Pacific slope basins in California; G. L. Parker, chief hydraulic engineer; H. D. McGlashan and G. H. Canfield, district engineers. 1942. viii, 417 pp.

Contains 14 discilarge measurements of Hot Spring near Santa Barbara, Calif., 0.08 to 12.3 sec.-ft. (p. 409). (Probably include surface water.)

933.-Surface water supply of the United States, 1941, part 13, Snale River basin; G. L. Parker, chief hydraulic engineer; G. H. Canfield, Lynn Crandall, Robert Follansbee, T. R. Newell, A. B. Purton, and F. M. Veatch, district engineers. 1942. vi, $246 \mathrm{pp}$.

Cuntains 2 discharge measurements of Box Canyon Springs, Idaho, 307 and 496 sec.-ft. (p. 240).

934. Surface water supply of the United States, 1941, part 14, Pacific slope basins in Oregon, and lower Columbia River basin; G. L. Parbor, chief hydraulic engineer; G. H. Canfield and F. M. Veach, district engineers. 1941. v, $229 \mathrm{pp}$.

Cuntains discharge records of springs in the Walla Walla River Basin, Oregon and Washingion (pp. 219-220).

935. Surface water supply of Hawaii, July 1, 1940, to June 30, 1941, G. L. Parker, chief hydraulic engineer; M. H. Carson, district engineer. 1943. iv, $140 \mathrm{pp}$.

.. .. . Contains' records of discharge of Pearl Harbor Springs (pp. 42-44, 47, 61), Waialala Springs (p. 69), and West Makapipi Spring (p. 82).

936. Water levels and artesian pressure in observation wells in th: United States in 1941, part 1, Northeastern States, by O. E. Meinz $x$, L. K. Wenzel, and others. 1943. iv, $251 \mathrm{pp}$.

Contains the following:

Introduction, by O. E. Meinzer and L. K. Wenzel.

Connecticut, by J. G. Ferris.

Indiana. by C. L. MeGuinness.

: Massachissetts, by M. L. Brashears, Jr.

4. Michigan, by C. L. McGuinness.

New Jersey, by. H. C. Barksdale and E. J. Schaefer.

Nëw" York: Central New York; by A. W. Harrington; Long Island by R. M. Leggette.

Ohio, by A. N. Sayre and F. H. Klaer, Jr.

Pennsylvania, by R. C. Baker.

937. Water levels and artesian pressure in observation wells in th ? United States in 1941, part 2, Southeastern States, by O. E. Meinzer, L. K.

Wenzel, and others. 1943. iv, $119 \mathrm{pp}$.

Contains the following:

Introduction, by $O$. E. Meinzer and L. K. Wenżel.

Alabama, by C. W. Cariston.

District of : Cohumbia, by Bernard Fisher. 
937. Water levels and artesian pressure in observation well in the United States in 1941-Continued.

Florida, by W. P. Cross and H. H. Cooper, Jr.

Georgia, by M. A. Warren.

Maryland, by A. H. Horton and Bernard Fisher.-

Mississippi, by G. F. Brown.

North Carolina, by A. G. Fiedler, E. D. Burchard, and Bernerd Fiaher.

South Carolina, by L. K. Wenzel.

Tennessee, by R. G. Kazmann, and F. H. Klaer, Jr.

Virginia, by Bernard Fisher and D. J. Cederstrom.

West Virginia, by R. L. Nace.

938. Water levels and artesian pressure in abservation well in the United States in 1941, part 3, North-central States, by O. E. Meinzer, L. K. Wenzel, and others. 1943. iv, $232 \mathrm{pp}$.

Contain the following:

Introduction, by $\mathbf{O}$. k. Meinzer and $L$. K. Wenzel.

North Dakota, by W. C. Rasmussen.

South Dakota, by T. W. Robinson.

Nebraska, by H. A. Waite.

Kansas, by S. W. Lohman, C. C. Williams, J. C. Frye, T. G. McLaughlin, H. A.

Waite, V. C. Fishel, G. H. von Hein, and B. F. Latta.

Minnesota, by A. C. Byers.

Iowa, by T. W. Robinson.

Missouri, by T. W. Robinson.

Wisconsin, by L. K. Wenzel.

939. Water levels and artesian pressure in observation wells in the United States in 1941, part 4, South-central States, by O. E. Meinzer, L. K.

Wenzel, and others. 1943. iii, 178 pp.

Contains the following:

Introduction, by $O$. E. Meinzer and L. K. Wenzel.

Arkansas, by R. G. Kazmann.

Louisiana, by J. C. Maher.

Oklahoma, by S. L. Schoff.

Texas, by R. W. Sundstrom and A. N. Sayre.

940. Water levels and artesian pressure in observation wells in the United States in 1941, part 5, Northwestern States, by O. E. Meinzer, L. K.

Wenzel, and others. 1942. iii, $172 \mathrm{pp}$.

Contains the following:

Introduction, by $O$. E. Meinzer and L. K. Wenzel.

Idaho, by G. C. Taylor, Jr.

- Montana, by Bernard Fisher.

Oregon, by J. E. Upson.

Utah, by H. E. Thomas.

Washington, by G. C. Taylor, Jr., and L. C. Huff.

Wyoming, by F. C. Foley.

941. Water levels and artesian pressure in observation wells in the United

States in 1941, part 6, Southwestern States and Territory of Hawaii, by O. E. Meinzer, L. K. Wenzel, and others. 1943. iv, 282 pp.

Contains the following:

Introduction, by $\mathbf{O}$. E. Meinzer and $\mathrm{L}$. $\mathrm{K}$. Wenzel.

Arizona, by S. F. Turner, H. M. Babcock, E. M. Cushing, and H. R. MeDonald.

California, by A. M. Piper, F. C. Fbert, and J. F. Poland.

New Mexico, by C. V. Theis, O. J. Loeltz, H. M. Babcock, P. D. Akin, and

C. R. Murray.

Hawali, by H. T. Stearns.

943. Geology and ground-water resources of Scott's Bluff Connty; Nebr., by

L. K. Wenzel, R. C. Cady and H. A. Waite. 1946. vi, 150 pp., 12 pls. Gives a detailed description of the several geologic formations and their waten-

bearine character. Includea data on wells and on quality of the water. 
944. Water levels and artesian pressure in observation wells in the United States in 1942, part 1, Northeastern States, by O. E. Meirzer, L. K. Wenzel, and others. 1944. iv, 242 pp.

cuncalus the following:

Introduction, by O. E. Meinzer and L. K. Wenzel.

Connecticut, by J. G. Ferris.

Indiana, by C. L. McGuinness.

Massachusetts, by M. L.' Brashears, Jr.

Michigan, by C, L. McGuinness, Norman Billings, and O. F. Poindexter.

New Jersey, by E. J. Schaefer and G. D. DeBuchananne.

New York: Central New York, by G. R. Ayer; Long Island, by M. L. Brashears, Jr. Ohio, by F. H. Klaer, Jr. (Stark County, by A. N. Sayre and F. H. Flaer, Jr.).

Pennsylvania, by G. D. DeBuchananne.

945. Water levels and artesian pressure in observation wells in the United States in 1942, part 2, Southeastern States, by O. E. Meirzer, L. K. Wenzel, and others. 1944. iv, 162 pp.

cuacuns the following:

Introduction, by O. E. Meinzer and L. K. Wenzel.

Alabama, by C. W. Cariston.

Florida: Northeastern, western, and central Florida, by H. H. Cooper, Jr. ; southeastern Florida by R. H. Brown.

Georgia, by M. A. Warren.

Maryland, Montgomery County, by A. H. Horton.

Mississippi, by R. W. Adams.

North Carolina, by M. J. Mundorff.

South Carolina: Beaufort and Jasper Counties, by M. A. Warren; Grenville and

Spartanburg Counties, by D. M. Ireland.

Tennessee, Memphis area, by R. G. Kazmann.

Virginia; Northern Virginia, by L. K. Wenzel and D. M. Ireland; southeastern

Virginia, by D. J. Cederstrom.

West Virginia, by R. M. Jeffords.

946. Water levels and artesian pressure in observation wells in the United States in 1942, part 3, North-central States, by O. E. Meirzer, L. K.

Wenzel and others. 1944. v, 278 pp.

Contains the following:

Introduction, by $\mathbf{O}$. E. Meinzer and L. K. Wenzel.

Illinois, by T. W. Robinson.

Iowa, by T. W. Robinson and W. E. Hale.

Kansas, by S. W. Lohman and others.

Minnesota, by A. L. Greenlee and T. W. Robinson.

Missouri, by T. W. Robinson, W. E. Hale, and S. W. Lohman.

Nebraska, by H. A. Waite and G. D. Jones.

North Dakota, by A. L. Greenlee.

South Dakota, by T. W. Robinson and W. E. Hale.

Wisconsin, by L. K. Wenzel and D. M. Ireland.

947. Water levels and artesian pressure in observation wells in the United States in 1942, part 3, North-central States, by O. E. Meirzer, L. K.

Wenzel, and others. 1944. iv, 181 pp.

Contains the following:

Introduction, by 0 . E. Meinzer and L. K. Wenzel.

Arkansas, Grand Prairie region, by R. G. Kazmann.

Louisiana, by J. C. Maher and P. H. Jones.

Oklahoma, by E. W, Reed.

Texas, by R. W. Sundstrom.

948. Water levels and artesian pressure in observation wells in the United Statè in 1942, part 5, Northwestern States, by O. E. Meir zer, L. K.

Wenzel, and others. 1944. iv, $194 \mathrm{pp}$.

Contains the following :

Introduction, by $\mathbf{O}$. F. Meinzer and L. K. Wenzel. 
948. Water levels and artesian pressure in ebservation wells in the United States in $1942-$ Continued.

Co.orauo, by S. W. Lohman.

Idaho, by L. C. Huff and G. C. Taylor, Jr.

Oregon, by L. C. Huff.

Utah, by P. E. Dennis, G. B. Maxey, and H. R. MeDonald.

Washington, by L. C. Huff, J. W. Robinson, and G. C. Taylor, Jr.

Wyoming, by A. M. Morgan and J. B. Graham.

949. Water levels and artesian pressure in observation wells in the United States in 1942, part 6, Southwestern States and Territory of Hawaii, by O. E. Meinzer, L. K. Wenzel, and others. 1944. v, 344 pp.

con a.ns we folo.wing:

Introduction, by $\mathbf{O}$. E. Meinzer and L. K. Wenzel.

Arizona: Introduction, by S. F.-Turner; Graham County (Safird Valley) -by W. T. Stuart and R. L. Cushman; Greenlee County (Duncan Valey), by H. M. Babcock and R. L. Cushman; Maricopa County (Queen Creek area), by E. M. Cushing; Pima County, by H. R. MeDonald and M. J. Scott; P rial County, by L. M. Cushing ; Santa Cruz County, by H. R. MeDonald and M. J. Scott.

California: River basins in southern California, by F. C. Ebert; Los Angeles and Orange Counties (Long Beach-Santa Ana area), by J. F. Poiand and A. A. Garrett ; San Joaquin County (Mokelumne area), by J. W. Robinson; Santa Barbara Cunty, by G. A. LaRoque, Jr., G. F. Worts, Jr., and J. E. Upsor.

Hawaii, by $\mathbf{H}$. T. Stearns.

New Mexico: Introduction, by C. V. Theis; Chaves and Eddy Crunties (Roswell ariesian basin), by P. D. Akin ; Hidalgo County (Virden Valley), by H. M. Babcock and R. L. Cushman; Lea County, by C. R. Murray and P. D. Akin; Luna County (Mimbres Valley), by C. R. Murray; Quay County (House area), by C. R. Murray and P. D. Akin; Roosevelt County (Portales Valley), by C. R. Murray and P. D. Akin; Socorro County (Hot Springs area), by C. R. Murray ; Torrance County (Estancia Valley), by C. R. Murray.

952. Surface water supply of the United States, 1942, part 2, Sith Atlantic slope and eastern Gulf of Mexico basins; G. L. Parker, cl ief hydraulic engineer; D. H. Barber, E. D. Burchard, G. E. Ferguson; A. E. Johnson, R. E. Marsh, E. B. Rice (acting), M. T. Thomson, and D. S. Wallace, district engineers: 1944. viii, $477 \mathrm{pp} ., 1 \mathrm{pl}$.

Contains discharge measurements of Warm Springs, Va. (p. 25), and Blue, Kissingen, Crystal,' Weekiwachee, Rainbow, Ichatucknee, and Wakulla Springs, Fla. (pp. 246, 286, 293, 297, 311).

957. Surface water supply of the United States, 1942, part 7, Iower Mississippi River Basin; G. L. Parker, chief hydraulic engineer;-D. H. Barber, H. C. Beckman, F. M. Bell, C. E. Ellsworth; Rokert Follansbee, Berkeley Johnson, R. E. Marsh E. B. lice (acting), J. L. Saunders, and J. V. B. Wells, district engineers. 1943. vii, 406 pr, 1 pl.

Contains discharge reeords, of Big Springs and Greer Spring, $M$ r. (pp. 82, 87), an $\mathrm{i}$ discharge measurements of 9 springs in Missouri and Mammoth Spring, Ark. (pp. 395, 396).

958. Surface water supply of the United States, 1942, part 8, Wrstern Gulf of Mexicó basins; G. L. Parker, chief hydraulic engineer; D. H. Barber, C. E. Ellsworth, Robert Follansbee, Berkeley Johnson, R. E. Marsh, and E. B. Rice (acting), district engineers. 1943. vi, $285 \mathrm{pp} ., 1 \mathrm{pl}$.

- Contains discharge records of Barton, San Solomon, Comanche, and Las Moras Springs, Tex. (pp. 128, 269, 270, 271).

959. Surface water supply of the United States, 1942, part 9, C-lorado River Basin; G. L. Parker, chief hydraulic engineer; Robert Follansbee, J: H. Gardiner, Berkeley Johnson, A. B. Purton, and M. T. Wilson (acting), district engineers. 1943. vii, 347 pp., 1 pl.

Contains discharge measurement of spring near Rio Blanco, Coho. (p. 340), and of Warm Springs near Coolidge Dam, Ariz. (p. 341). 
964. Surface water supply of the United States; 1942, part 14, Pacific slope basins in Oregon and lower Columbia River Basin; G. L. Parker, chief hydraulic engineer; G. H. Canfield and F. M. Veatch, district ergineers. 1943. vi, 231 pp., 1 pl.

Contains discharge measurements of 18 springs in the Walla Walla River Basin, Oregon and Washington (pp. 221, 222).

965. Surface ater supply of Hawaii, July 1, 1941, to June-30, 1942; G. L. Parker, chief hydraulic engineer; M. H. Carson, diștrict engineer. 1945. iv, $134 \mathrm{pp}$.

Contains discharge records of Pearl Harbor Springs (pp. 40-52, 44, 56) Waialaia Springs (p. 64), and West Makapipi Spring (p. 77).

968. Contributions to the hydrology of the United States, 1944-45.

(c) Ground-water exploration in the Nachitoches area, La., by J. C. Maher and P. H. Jones. (In preparation.) Describes the structural geology of the area and discusses salt-water conditions in sands beneath most of the city. Consludes that abundant supplies of soft water are present in the Sparta sand and Wilsox formation southwest of the city.

969. Geology and ground-water resources of Box Butte County, Nekr., by R.

C. Cady and O. J. Scherer. 1946. v, 102 pp., 9 pls.

Gives a detailed description of the geologic formations and their water-bearing character. Includes data on wells and on quality of the water.

972. Surface water supply of the United States, 1943, part 2, South Atlantic slope and eastern Gulf of Mexico basins; G. L. Parker, chief hydraulic engineer; E. D. Burchard, G. E. Ferguson, A. E. Johnson, R. E. Marsh, E. B. Rice (acting), M. T. Thomson, and D. S. Wallace, district engineers. 1945. viii, 503 pp.

Contains discharge measurements of Warm Springs, Va. (p. 24), and Blue, Kissingen, Crystal, Weekiwachee, Rainbow, Ichatucknee, and Wakulla Srrings, Fla. (pp. 290, 329, 335, 338, 352).

977. Surface water supply of the United States, 1943, part 7, Lower Mississippi River Basin; G. L. Parker, chief hydraulic engineer; H. C. Beckman, F. M. Bell, C. E. Ellsworth, Robert Follansbee, Berkeley Johnson, R. E. Marsh, E. B. Rice (acting) J. L. Saunders, and J. V. B. Wells, district engineers. 1945 . vii, $388 \mathrm{pp}$.

Contains discharge records of Big and Greer Springs, Mo. '(pp. 82, 87), and discharge measurements of Cotter Spring. Ark.' several : springs' in 'Mi isouri, and Roaring Spring, Tex. (pp. 374, 375, 378, 380).

978. Surface water supply of the United States, 1943, part 8, Western Gulf of Mexico basins; G. L. Parker, chief hydraulic engineer; C. E. Fllsworth, Robert Follansbee, Berkeley Johnson, and R. E. Marsh, district engineers. 1944. vi, $289 \mathrm{pp}$.

Contains discharge records of Barton, San Solomon, Comanche, and Las Moras Springs, Tex. (pp. 131, 271, 272, 273).

979. Surface water supply of the United States, 1943, part 9, Colorado River Basin; G. L. Parker, chief hydraulic engineer; Robert Follansbee, J. H. Gardiner, Berkeley Johnson, and M. T. Wilson; district engineers. 1944. vii, 355 pp., 1 pl.

Contains discharge measurement of warm springs near Coolidge Dam, Ariz. (p. 349 ).

984. Surface water supply of the United States, 1943, part 14, Pacific slope basins in Oregon and lower Columbia River Basin; G. L. Parker, chief hydraulic engineer; G. H. Canfield and F. M. Veatch, dist 'ict engineers. 1945. iv, $235 \mathrm{pp}$.

Contains discharge measurements of 18 springs in the Walla Walla Jiver Basin, Oregon and Washington (pp. 226, 227). 
985. Surface water supply of Hawaii, July 1, 1942, to. June 3ก. 1943; G. L. Parker, chief hydraulic engineer; M. H. Carson, district engineer. 1946. iv, 134 pp.

Contains discharge records of Pearl Harbor Springs (pp. 40-45), Waialala Springs (p. 65), and West Makapipi Spring (p. 78).

986. Water levels and artesian pressure in observation wells in the United States in 1943, part 1,. Northeastern States, by O. E. J rinzer, L. K. Wenzel, and other. 1946. iv, $291 \mathrm{pp}$.

Contains the following:

Introduction, by $\mathbf{O}$. E. Meinzer and L. K. Wenzel.

Connecticut, by M. L. Brashears, Jr.

Indiana, by F. H. Klaer, Jr., and J. G. Ferris.

Maine, by M. L. Brashears, Jr.

Massachusetts, by M. L. Brashears, Jr.

Michigan, by W. T. Stuart.

New Hampshire, by M. L. Brashears, Jr.

New Jersey, by G. D. DeBuchananne and J. M. Ludlow.

New York: Central New York, by G. R. Ayer, Long Island, by M. L. Brashears, J̦r. Ohio, by E. J. Schaefer.

Pennsylvania, by J. B. Graham.

Vermont, by M. L. Brashears, Jr.

987. Water levels and artesian pressure in observation wells in the United States in 1943, part 2, Southeastern States, by O. E. I'einzer, L. K.

Wenzel, and others. 1945. iv, $191 \mathrm{pp}$.

Contains the following:

Introduction, by $\mathbf{O}$. E. Meinzer and L. K. Wenzel.

Alabama, by C. W. Carlston.

Florida, by H. H. Cooper, Jr., and G. G. Parker.

Georgia, by M. A. Warren and S. M. Herrick.

Maryland, by R. R. Bennett, R. R. Meyer, and A. H. Horton.

Mississilppi, by R. W. Adams.

North Carolina, by M. J. Mundorff.

South Carolina, by M. A. Warren.

Tennessee, by R. G. Kazmann.

Virginia, by D. J. Cederstrom and J. M. Berdan.

Weat Virginia, by R. M. Jeffords.

988. Water levels and artesian pressure in observation wells in the United States in 1943, part 3, North-central States, by O. E. N'einzer, L. K.

Wenzel, and others. 1946. iv, $352 \mathrm{pp}$.

Contains the following:

Introduction, by $\mathbf{O}$. E. Meinzer and $\mathbf{L}$. K. Wenzel.

Illinois, by $\mathbf{H}$. G. Hershey.

Iowa, by W. E. Hale and D. A. Barton.

Kansas, by $\mathrm{S}$. W. Lohman and others.

Minnesota, by A. L. Greenlee.

Missouri, by W. E. Hale, S. W. Lohman, and D. A. Barton.

Nebraska, by H. A. Waite.

North Dakota, by A. L. Greenlee.

South Dakota, by W. E. Hale.

Wisconsin, by A. L. Greenlee and F. C. Christopherson.

989. Water levels and artesian pressure in observation wells in the United States in 1943 , part 4 , South-central States, by O. E. Irinzer, L. K.

Wenzel, and others. 1946. iv, 194 pp.

Contains the following:

Introduction, by $\mathbf{O}$. E. Meinzer and L. K. Wenzel.

Arkansas, by R. G. Kazmann.

Louisiana, by P. H. Jones, W. J. Drescher, and M. C. Pole.

Oklahoma, by E. W. Reed and C. L. Jacobsen.

Texas, by R. W. Sundstrom. 
990. Water levels and artesian pressure in observation wells in the United States in 1943, part 5, Northwestern States, by O. E. Meinzer, L. K. Wenzel, and others. 1946. iv, 279 pp.

Contains the following:

Introduction, by $O$. E. Meinzer and L. K. Wenzel.

Colorado, by S. W. Lohman.

Idaho, by P. E. Dennis and A. M. Piper.

Montana, by C. D. Bue and A. L. Greenlee.

Oregon, by J. W. Robinson.

Utah, by P. E. Dennis and H. R. McDonald.

Washington, by T. E. Eakin, A. M. Piper, and J. W. Robinson.

Wyoming, by A. M. Morgan.

991. Water levels and artesian pressure in observation wells in the United States in 1943, part 6, Southwestern States and Territory of Hawaii, by O. E. Meinzer, L. K. Wenzel, and others. 1945. $\quad$, 305 pp.

Contains the following:

Introduction, by $O$. E. Meinzer and L. K. Wenzel.

Arizona: Program of work, by S. F. Turner; Graham County (Safford Valley).

by R. L. Cuishman; Greenlee County (Duncan Valley), by R. L. Cushman; Maricopa County (Queen Creek area), by E. M. Cushing and J. M. Hostetter; Pime County. by E. M. Cushing and M. J. Scott; Pinal County, by E. M. Cushing and J. F. Hostetter; Santa Cruz County, by E. M. Cushing and M. J. Scott.

California, by J. F. Poland, J. W. Robinson, H. M. Stafford, J. E. UI aon, and others.

Hawaii, by H. T. Stearns.

New Mexico: Introduction, by C. R. Murray; Chaves and Eddy Countien (Roawell artesian basin), by P. D. Akin; Grant County, by C. R. Murray; Hidalg $>$ County (Virden Valley), by R. L. Cushman; Lea County, by C. R. Murray ard P. D. Akin; Luna County (Mimbres Valley), by C. R. Murray; Quay Count (House area), by C. R. Murray and P. D. Akin; Roosevelt County (Portales Vrlley), by C. R. Murray and P. D. Akin; Sierra County (Hot Springs area), by C. R. Murray; Torrance County (Estancia Valley), by C. R. Murray.

999. Geology and ground-water resources of Cedar City and Parowan Valleys, Iron County, Utah, by H. E. Thomas and G. H. Taylor. 1946 (1947), vii, 210 pp., 27 pls.

Gives detailed data on ground-water conditions in the two valleys, with records of water levels and of water pumped for irrigation.

\section{ANNUAL REPORTS}

Fifth Annual Report (1883-84). 1885. 469 pp., 58 pls.

The following paper relates to ground water:

(A 5 c) The requisite and qualifying conditions of artesian wells, by $\mathbf{T}$. $\mathbf{C}$. Chamberlin, pp. 125-173, pl. 21. This is the first paper published by the United States Geological Survey on the subject of ground water. It is a clear, accurate, and comprehensive statement of the conditions that produce artesian basins and give rise to flowing wells and is regarded as authoritative on the subject.

Ninth Annual Report (1887-88), 1889. 717 pp., 88 pls.

The following paper relates to ground water:

(A 9 d) Formation of travertine and siliceous sinter by the vegetation of hot springs, by W. H. Weed, pp. 613-676, pls. 78-87. Describes the Mammoth Hot Springs and other hot springs and geysers of Yellowstone National Park, also hot springs in New Zealand; gives analyses and discusses the chemical charactor of the waters from these spring and the deposits which they form.

Eleventh Annual Report (1889-90), Part II, Irrigation. 1891. 395 pp., 30 pls, and maps.

(A $11 \mathrm{~m}$ c) -Includes a section on artesian irrigation on the Great Plins (pp. 260-278) in which the limitations imposed by quantity, head, and cost are discussed. and irrigation by means of artesian wells in various countries is described. Records are given of wells in Kansas, Minnesota, Montana, Nebraska, North Dakcta, South Dakota, and Texas. 
Thirteenth Annual Report (1891-92), Part III, Irrigation. I 998.486 pp., 77 pls.

The following papers relate in part to ground water:

(A 13 II a) Water supply for irrigation, by F. H. Newell, pp. 7-99, pls. 108-110. Includes a brief discussion on "subsurface waters" (pp. 28-30), giving statistics on artesian wells and irrigation with well water in the United St-tes in 1890, and commenting accurately on quantity, occurrence, and discharge of water in desert valleys.

(A $13 \mathrm{II}$ b) American irrigation engineering, by H. M. Wilson, pp. 100-349, pls. 111-146. Includes a chapter on subsurface or ground waters with special reference to irrigation (pp. 326-346), in which are discussed artesian and pumped wells, underflow dams, infiltration galleries, and subirrigation.

Fourteenth Annual Report (1892-93), Part II, Accompanying papers. 1893. 597 pp., 73 pls.

The following papers relate to ground water:

(A 14 II a) Potable waters of the eastern United States, by W. J. McGee, pp. 1-47. Discusses cistern water, stream waters, and ground waters, including mineral springs and artesian wells.

(A 14 II b) Natural mineral waters of the United States, by A. C. Peale, pp. 49-88, pls. 3-4. Diseusses the history, origin, flow, classification, and grographic distribution of mineral and thermal springs, the ehemical composition and analysis of spring waters, and the utilization of mineral waters. Gives a list of American mineral spring resorts.

Sixteenth Annual Report (1894-95), Part II, Papers of an ecoromic character. 1895. 598 pp., 43 pls.

The following papers relate in part to ground water:

(A $16 \mathrm{II}$ e) The public lands and their water supply, by F. H. F'ewell, pp. 457-533, pls. 35-39. Describes the public lands and the streams, wells, and reservoirs as aources of water supply ; contains a brief but comprehensive and farsighted discussion of the ground-water iesources of the West (pp. 499-502); includes brief notes on ground water in Arizona, California, Colorado, Idaho, Kans zs, Nebraska, New Mexico; North Dakota, Oklahoma, Oregon, South Dakota, Texas Utah, and Washington (pp. 504-533).

(A 16 II $\mathrm{f}$ ) Water resources of a portion of the Great Plairs, by Robert Hay, pp. 535-588, pls. 40-42. Describes an indefinite area that lies or both sides of the east boundary of Colorado and extends from the vicinity of Smoky Hill River northward to the North Platte, thus comprising parts of Colorado, Nebraska, and Kansas. Discusses the lakes, streams, and springs of the ares, the underflow of the river bottoms, and the water-bearing strata beneath the higher lands, the source, quantity, and rate of percolation of, ground water, the rvells in the valleys and on the uplands, the unsuccessful wells, artesian conditions, "blowing" wells and the temperatures of the well waters. Describes briefly the topography and geology of the region and the utilization of the water supply.

Seventeenth Annual Report (1895-96), Part II, Economic geology and hydrography. 1896. 864 pp., 113 pls.

The following papers relate to ground water:

(A 17 II f) The underground water of the Arkansas Valley in eastern Colorado; by G. K. Gilbert, pp. 551-601, pls. 56-68. Relates to an indefirite region adjacent to Arkansas River, in southeastern Colorado. Deseribes the topography, geology. artesian conditions, and intake areas of the region, the water in the Dakota sandstone, in the upland sands, beneath the terraces, and in the dume sands, and the underfow of rivers and creeks. Includes a sketch map shoving the depths to artesian water. See algo Professional Paper 52.

(A $17 . \mathrm{Ir}$ g) Preliminary report on artesian waters of a portion of the Pakotas, by N. H. Darton, pp. 603-694, pls. 69-107. Covers the part of South Dakota lying east of the 101st meridian and the part of North Dakota lyin east of the 101st meridian and south of the 47 th parallel. Gives an outline of th: geologic relations, describes the water horizons and the extent of the artesian wieters, gives detailed information by counties concerning wells and prospects for obtaning wells, discusses the origin, quantity, head, and quality of the artesian waters and their use for developing power, gives data by counties regarding irrigation with artesian wafer 
Seventeenth Annual Report (1895-96), Part II-Continued.

and directions as to the construction and management of ariesian wells. Includes maps suowing the areas of ar.esian flow suppited from the Dakota sandstone and from glacial dxift, respectively, the height to which the artesian water vill rise, the depths to principal artesian horizon of the Dakota sandstone, and cortours of the surface of the bedrock.

(A $17 \mathrm{il} \mathrm{h)} \mathrm{The} \mathrm{water} \mathrm{resources} \mathrm{of} \mathrm{Illinois,} \mathrm{by} \mathrm{Frank} \mathrm{Leverett,} \mathrm{pp.} \mathrm{695} \mathrm{849,} \mathrm{pls.}$ 108-113. Describes the topography, drainage, precipitation, run-off, navigable rivers, water powers, wells supplying water for cities, villages, and rural districts, wells in alluvium, glacial drift, and Tertiary and Paleozoic formations, and flowing wells. Contains tabulated well data and water analyses, and includes maps of Illinois and eastern Indiana showing the distribution of Pleistocene deposits, the re'ation of giacial drift to ground-water supplies, the elevation of the St. Peter sandsione, and areas in which there are flowing wells supplied by glacial drift. Also contains a map of Wisconsin and northern Illinois showing the main intake area of the "Potsdam" and St. Peter sandstones.

\section{Eighteenth Annual Report (1896-97), Part II, Papers chiefly of a tl soretic} nature. 1897. 653 pp., 105 pls.

The following paper relates to ground water:

(A 18 II b) Geology of portions of the Edwards Plateau and Rio Grande Plain adjacent to Austin and San Antonio, Tex., with special reference to the oscurrence of artesian and other underground waters, by R. T. Hill and T. W. Vauchan, pp. 193-322, pls. 21-64. Describes the geography, geology, water-bearing formations, springs, and flowing and nonflowing wells. Discusses the artesian conditions, the probable identity of source of artesian and fissure-spring waters, and th: quality of the artesian water. Contains water analyses and includes a map of the vicinity of Auștin showing the relations of the springs and artesian wells to the g:ology.

Eighteenth Annual Report (1896-97), Part IV, Hydrography. 1897. 756 pp., 102 pls.

The following papers relate to ground water:

(A $18 \mathrm{w} \mathrm{b}$ ) The water resources of Indiana and Ohio, by Frank Leverett, pp. 419-560, pls. 33-37. Describes the drainage systems, the ground-water emditions, the flowing and nonflowing wells in glacial drift and rock formations, and the mineral springs. Contains numerous well records and water analyses. Gives data regarding water supplies for cities and villages derived from surface ard underground sources. Includes maps of Indiana and Ohio showing the Pleistocene deposits, the older geologic formations, and the relation of ground-water supplips to the depth of the glacial drift.

(A 18 iv c) New development in well boring and irrigation in eastern South Dakota, by N. H. Darton, pp. 561-616, pls. 38-47. Describes the progress that was made in 1896 in drilling wells and in irrigating with artesian waters ir Aurora, Beadle, Bonhomme, Brule, Buffalo. Charles Mix, Davison, Douglas, Hanson, Hutchinson, Jerauld, Sanborn, Spink, and Yankton Counties, and in areas west of Missouri River. Discusses the temperature, pressure, and flow of the artesian waters, the extent of the artesian basin, and the position of the bedrock. Gives aralyses of waters from Missouri River and from artesian wells in the Sanborn basin. Includes maps showing the rate of increase of temperature in wells with depth, ccntours of the bedrock surface; and flow of wells.

Nineteenth Annual Report (1897-98), Part II, Papers chiefly of a theoretic nature. $1899.958 \mathrm{pp} ., 172$ pls.

The following papers relate to ground water:

(A $19 \mathrm{Ir}$ b) Principles and conditions of the movements of ground raters, by F. H. King, pp. 59-294, pls. 6-17. Discusses the quantity of water stored in soil, in sandstone, and in other rocks, the'depth to which ground water penetrates, the gravitational, thermal, and capillary movements of ground water, and the configuration of the water table. Gives the results of tests made by the arthor and by earlier investigators of the flow of air and water through rigid, porsus media through sands, sandstones, and silts. Summarizes these results and draws conclusions regarding the relation of velocity to pressure. Discusses also the influence of form, diameter, and arrangement of sand grains on velocity; the rrathods of determining diameters of sand grains, the growth of rivers, the rate of seepage into flitration ditches, the interference of wells, and related subjects. 


\section{Nineteenth Annual Report (1897-98), Part II-Continued.}

(A 19 II c) Theoretical investigation of the motion of grourd waters, by C. S. Slichter, pp. 295-384, pl. 17. A mathematical discussion of the laws governing the movements of ground water, the discharge of flowing wells, and the mutual interference of węlls. Includes a bibliography on the motion of ground waters and related topics.

Nineteenth Annual Report (1897-98), Part IV, Hydrography. 1898. 814 pp., 118 pls.

The following paper's relate to ground water:

(A $19 \mathrm{iv} \mathrm{b)} \mathrm{The} \mathrm{rock} \mathrm{waters} \mathrm{of} \mathrm{Ohio,} \mathrm{by} \mathrm{Edward} \mathrm{Orton,} \mathrm{pp.} \mathrm{633-717,} \mathrm{pls.} \mathrm{71-73.}$ Describes the principal geologic formations of Ohio and the waters which they yield; gives detailed information regarding the water supplies of many cities and villages; discusses the flowing wells in various localities, including those in the preglacial channels of Allen, Auglaize, and Mercer Counties; and includes a number of water analyses.

(A 19 IV c) Preliminary report on the geology and water resources of Nebraska west of the 103d meridian, by N. H. Darton, pp. 727-785, pls. 74-118. Describes the general geology of Nebraska, and the topography, geology, and water horizons of the area covered by the reports. Gives information on springs, streams, irrigation, climate, and timber, and of elevations of various points. Includes a general geologic map of Nebraska and more detailed maps of the portior of the State west of the 103d meridian, showing the geology and the ground-water conditions. Reprinted as Professional Paper 17.

Twenty-first Annual Report (1899-1900), Part IV, Hydrogranhy. 1901. 768 pp., 156 pls.

The following papers relate in part to ground water:

(A $21 \mathrm{IV}$ a) Report of progress of stream measurements for the calendar year 1899, by F. H. Newell, pp. 9-488, pls. 1-57. Includes brief notes on ground-water supplies at Kearney, Nebr. (pp. 216-217), Alamosa, Colo. (p. 265, pl. 4, A), San Pedro Valley, Ariz. (pp. 352-353, pl. 31, A), Mohave Valley, Cal:f. (p. 472, pl, 52), Los Angeles River Valley, Calif. (p. 474), Lytle Creek Valley, Calìf. (pp. 481-482), and Mission Valley, Calif. (p. 486). The plates referred to are photographs of flowing wells or other ground-water features.

(A 21 IV b) Preliminary description of the geology and water resources of the southern half of the Black Hills and adjoining regions in South Dakiota and Wyoming, by N. H.- Darton, pp. 489-599, pls. 58-112. Covers an area comprising about 5,500 square miles in southwestern South Dakota and the adjoining pcrtion of Wyoming. Describes the topography, geology, water horizons, wells, surface waters, irrigation, soil, mineral resources, climate, and timber of "the area. Includes maps showing the geology, the depths to the Dakota sandstone, and other ground-water conditions.

(A $21 \mathrm{Iv}$ c) The High Plains and their utilization, by W. D. Johnson, pp. 601-741, pls. 113-156. Describes the area lying in an irregular belt about midway across the long eastward slope of the Great Plains and including parts of Wyoming, Nebraska, Colorado, Kansas, New Mexico, and Texas. Gives a comprehensive description of the physiographic features and Tertiary deposits of the region and a critical discussion of their interpretation. Discusses precipitation, climate, and the use of streams and storm waters for irrigation. Describes the artesian conditions, with special reference to the Meade artesian basin, and explains the principles of artesian and other ground waters. Concluded in the Twenty-second Annupl Report, Pt. IV:

Twenty-first Annual Report (1899-1900), Part VII, Geography and geology of the Black and Grand prairies, Tex., with detailed descriptions of the Cretaceous formations and special reference to artesian waters, by $R$. T. Hill. 1901. 666 pp., 71 pls.

Gives a general description of the geography of a region including Texas, Oklahoma, and New Mexico east of the Rio Grande and describes in more detail the geography and geology of the Black and Grand prairies. Discurses the principles governing artesian and other ground waters, the artesian systems of Texas, and the quality of the waters of these systems. Describes the arterian conditions by counties and gives analyses. Includes maps showing the geolog:, the locations of artesian wells, and the outcrop of, depths to, and areas of arterian flow from the Trinity, Paluxy, and Woodbine formations. 
Twenty-second Annual Report (1900-1901), Part ,IV, Hydrograrhy. 1902. 690 pp., 65 pls.

The following paper relates to ground water:

(A 22 IV c) The High Plains and their utilization, by W. D. Johnsor, pp. 631-669, pls. 51-65. This is the concluding part of the paper on the High Plains and their utilization begun in the Twenty-first Annual Report, Part IV. It discusses the occurrence of water, consolidated and unconsolidated formations, tha origin and level of the ground water of the High Plains, the utilization of ground water tor stock raising and irrigation, and methods of constructing wells.

\section{MONOGRAPHS}

11. Geological history of Lake Lahontan, a Quaternary lake of northwestern Nevada, by I. C. Russell. 1885 . xiv, 288 pp., 46 pls.

Contains data on thermal and other springs in the area (pp. 47-54), with 3 analyses of hot-spring waters, and map (pl. 8) showing springs of tho region.

13. Geology of the quicksilver deposits of the Pacific slope, with an atlas, by G. F. Becker, 1888. xix, 486, pp., 7 pls.

Contains data on Steambcat Hot Springs, Nev. (p. 338), analysis of the water (b. 347), and mention of other thermal springs (pp. 381, 382, 402).

25. The glacial Lake Agassiz, by Warren Upham. 1896. 658 pp. 38 pls.

Contains a chapter (pp. 523-582) on "Artesian and.common wellix of the Red River Valley," which discusses the sources of artesian water, the fresh waters in the drift sheets, the saline and alkaline waters in the Dakota sandstnne, and the use of artesian water for irrigation; contains analyses of waters from wells, streams, and lakes in Red River Valley and the adjoining region; and gives notes on wells in Clay, Kittson, Marshall, Norman, Polk, Traverse, and Wilkin Courties, in Minnesota ; in Cass, Grand Forks, Pembina, Richland. Traill, and Walsh Counties, in North Dakota; and in a part of the area covered by Lake Agassiz, in Manitoba. The monograph-includes numerous maps relating to the Pleistocene giology of the region and a map (pl, 37) showing the distribution and depths of gxtesian wells in glacial drift and bedrock.

27. Geology of the Denver Basin in Colorado, by S. F. Emmons Whitman Cross, and G. H. Eldridge. 1896.556 pp., 31 pls.

Contains a discussion of the water in the Pleistocene deposits (pp. 272, 273) and a section on artesian wells (pp. 401-465). Discusses the history of a rtesian-water developments in Colorado, the water-bearing horizons, the artesian structure, the quantity of artesian water, and the yield and decrease in yield of fowing wells. Includes three analyses of well waters and maps showing the geology of the region and the original area of artesian flow.

38. The Illinois glacial lobe, by Frank Leverett. 1899.817 pp., 24 pls.

Includes a chapter (pp. 550-788) on "Wells of Illinois,". which contains a general discussion of artesian and other wells, a table of municipal water supnlies derived from underground sources, and a detailed description of wells and ground-water conditions in nearly every county in the State. The monograph includes maps showing the geology, the distribution of wells, the intake areas of "Potscam" and St. Peter sandstones, and the relation of glacial drift to ground-water supplies.

43. The Mesabi iron-bearing district of Minnesota, by C. K. Leith. 1903.316 pp., 33 pls.

Contains several references to ground water in relation to the ore deposits (pp. 234, 235, 237, 238, 265-272, 274, 277-279).

45. The Vermillion iron-bearing district of Minnesota, by J. M. Clements. 1903. 463 pp., 13 pls.

Contains data on ground water in relation to the ore deposits (?p. 227-234).

47. A treatise on metamorphism, by C. R. Van Hise. 1904 . $1286 \mathrm{pr}, 13 \mathrm{pls}$.

This comprehensive treatise deals in much detail with the chemical and phyaical laws governing ground water, especially in the following sections: "Chemical and physical principles controlling the action of ground water" (pp. 65-123), "Circulation and work of ground water" (pp. 123-158), "The belt of weatherir R" (pp. 411429), "The belt of cementation" (pp. 566-594), and "Work of aqueous solutions in segregating ores" (pp. 1072-1198). 
52. The geology of the Idake Superior region, by C. R. Van Hise and C. K. Leith. 1911. 641 pp., 49 pls.

kixplains the secondary concentration of Mesabi iron ore by porcolating water (p. 186), gives the reaction of water and ferrous iton to form magnetite, a reversible reaction (p. 527), describes conditions favoring the solution of silica (pp. 538-539). gives analyses of mine waters and diseusses chloride waters (pp. 543-544, 579), and describes the deposition of copper by hot solutions (p. 582). States that the present work of meteoric solutions is slight (pp. 585-586).

53. The Pleistocene of Indiana and Michigan and the history of the Great Lakes, by Frank Leverett and F. B. Taylor. 1915. 529 pp., 32 pls.

Con ains data on depth to. ground water in the Huron-Erie lobe of glacial drift in Indiana (pp. 171-173). States that "underground waters from the glacial formations are generally abundant and are drawn upon not only for farm use but also for public supplies" (p. 522). Gives list of 14 Federal and State publications on

- the ground-water supplies.

\section{. PRofessional papers}

17. Preliminary report on the geology and water resources of Nebraska west of the $103 \mathrm{~d}$ meridian, by N. H. Darton. 1903 . $69 \mathrm{pp} ., 43 \mathrm{pls}$.

l.eprint of a paper in the Nineteenth Annual Report, Part IV, with slight changes.

25. The copper deposits of the Encampment district, Wyo., by A. C. Spencer. 1904. 107 pp., 2 pls.

Liscusses ground water on pages 44-45. A lower as well as urner limit of the wacer seems to be present.

32. Preliminary report on the geology and underground-water resources of the central Great Plains, by N. H. Darton. 1905. 433 pp., 72 pls.

- Covers South Dakota, Nebraska, central and western Kansas, eastern Colorado, and eastern Wyoming. Describes the geography, geology, and wate* horizons; gives chep-well data and well prospects by counties; also describes other mineral resources. Includes maps showing the geology, locations of deep wells, structure of the Dakota sandstone, depths to this standstone, head of artesian water, and areas of artesian flow.

38. Economic geology of the Bingham mining district, Utah, by J. M. Boutwell, with a section on areal geology, by Arthur Keith, and an introduction on general geology, by S. F. Emmons. 1905. 413 pp., 49 pls.

Discusses the character of the mine waters and their relation to oxidation of the ores (pp. 218-215).

42. Geology of the Tonopah mining district, Nev., by J. E. Spư`r. 1905. 295 pp., 24 pls.

Discusses present subterranean water (pp. 105-108) and the water in its relation to rock alteration and mineralization (pp. 206-262). Describes several thermal springs and discusses the nature of solfataric action (pp. 256-261).

43. The copper deposits of the Clifton-Morenci district, Ariz., by Waldemar Lindgren. 1905. 375 pp., 25 pls.

Describes ground-water conditions in the mines (pp. 22-24, 212, 213, 219-223, 232, 317-318), discusses oxidation by ground water (pp. 98, 197), disfines hydrometamorphism (pp. 124-125), and discusses hydrothermal metamorphism (pp. 164-177). Treats of water in magmas (p. 163) and mentions sulfate waters ( $\mathrm{fp} .180,181,198$ ).

44. Underground-water resources of Long Island, N. Y., by A. C. Veatch, C. S. Slichter, Isaiah Bowman, W. O. Crosby, and R. E. Horton. 1906. 394 pp., 34 pls.

Describes the geologic formations, the source and occurrence of ground water, and the conditions necessary to obtain flowing wells; gives data in regard to the springs, streams, ponds, lakes, artesian and other deep welis, -the water table and its fluctuations, blowing wells, and waterworks; contains record of the rate of movement of the ground water and resultis of sizing. and filtratior tests; and gives 


\section{Underground-water resources of Long Island, N. Y.-Continu-d.}

well records and notes concerning representative wells. Includes wate* analyses and maps showing the geology, contours of the water table, and location of wells and waterworks.

46. Geology and underground-water resources of northern Lorisiana and southern Arkansas, by A. C. Veatch. 1906. 422 pp., 51 pls.

Covers Louisiana north of the 31st parallel, about the southern hal of Arkansas, and adjacent areas in Texas, Oklahoma, and Mississippi. Describes the physiography and geology of the region, the principles governing ground waters and their application to this region, the water-bearing formations with refenence to springs and to the artesian pressure, quality and availability of the water, the occurrence of mineral waters, the hygienic value of deep-well waters, and method" and costs of constructing wells. Contains a description of the ground-water conditions in each county and tables of well data arranged by counties, with notes givin well sections and water analyses. Contains also a dictionary of altitudes, arranged by counties. Includes maps showing the geology of the region, the structure contours of the Nacatoch and Bingen formations, areas of artesian flow supplied br these formations, depths to the Sabine and Cockfleld sands, and areas of artesian flow supplied by these sands.

51. Geology of the Bighorn Mountains, by N. H. Darton. 1906. 129 pp., 47 pls.

Describes the geology of the region in detail and contains a brief discussion (po. $119,120)$ of the probable depths and water-bearing conditions of the principal sandstones. Includes a geologic map.

52. Geology and underground waters of the Arkansas Valley in erstern Colorado, by N. H. Darton. 1906.90 pp., 28 pls.

Describes the geology of the greater part of the drainage basir of Arkansas River in Colorado; the source, depths, head, areas of artesian flow, quantity and quality of the water in the Dakota sandstone; and the occurrence and quality of the waters in the Red Beds, Morrison formation, Laramie and associated formatiens, later Tertiary deposits, and dune sands. Includes numerous well sections, several water analyses, and maps showing the geology, depths to Dakota sandstone. areas of artesian flow, and areas not underlain by Dakota sandstone. A prel ninary report on the same region, by $G$. K. Gilbert, was published in the Seventeenth Annual Report, part II, 1896, pp. 1-51.

53. Geology and water resources of the Bighorn Basin, Wyo., by C. A. Fisher. 1907. 72 pp., 16 pls.

Describes the geography, geology, water-bearing formations, irrigation developments, mineral waters, and other mineral resources of the basin. Includes a geologic map.

54. Geology and gold deposits of the Cripple Creek district, Colo., by Waldemar Lindgren and F. L. Ransome. 1906. 516 pp., 29 pls.

Describes the original water level in the district and its relation to oxidation (p. 197). Discusses sulfide enrichment (p. 204) and the composition and source of the vein-forming waters with relation to the ores (pp. 217-231). Chapter 12, Underground water (pp. 233-251), deals with the original water.surface, tunnel drainage, and source of the water.

56. Geography and geology of a portion of southwestern Wyaming, with special reference to coal and oil, by A. C. Veatch. 1907.: 178 pp., 26 pls.

Covers the southwest corner of Wyoming and a small adjacent pcrtion of Utah. Gives a detailed description of the geology and a brief discussion of the waterbearing formations. Includes a geologic map with structure contours

62. The geology and ore deposits of the Coeur d'Alene district, Ide ho, by F. L. Ransome and F. C. Calkins. 1908. 203 pp., 29 pls.

Discusses ground water in the mines (p. 131): 
63. Economic geology of the Georgetown quadrangle (together with the Empire district), Colo., by J. E. Spurr and G. H. Garrey, with general geology, by S. H. Ball. 1908. 422 pp., 87 pls.

Discusses the hot springs at Idaho Springs and Glenwood (pp. 27, 163-168) and gives analyses of 6 spring waters at Idaho Springs (p. 164).

65. Geology and water resources of the northern portion of the Black Hills and adjoining regions in South Dakota and Wyoming, by N. H. Darton. 1909.105 pp., 24 pls.

Describes the geology of the sedimentary rocks and discusses their mineral resources, including their water supplies. Contains information conce"ning the timber, climate, and surface waters available for irrigation and stock raising. Includes maps showing the geology, outcrops of and depths to principal water-bearing formations, and areas of artesian flow.

66. The geology and ore deposits of Goldfield, Nev., by F. L. Rrnsome, assisted in the field by W. H. Emmons and G. H. Garrey. 1909. 258 pp., 35 pls.

Describes water supplies from wells and springs (pp. 142-143) and discusses the ore-depositing solutions (pp. 185-186). Chapter 15 (pp. 187-188) treats of underground water and depth of oxidation. Discusses magmatic water (p. 190).

68. The ore deposits of New Mexico, by Waldemar Lindgren, L. C. Graton, and C. H. Gordon. 1910. 361 pp., 22 pls.

Discusses the water level in several mines and its relation to oxtdation, to copper deposits, and to leached zones (pp. 59-61). Mentions the origin of certain hot springs (p. 71), describes the hot springs at Oja Caliente and their deposits, and glves an analysis of the water (pp. 72-74).

73. The Tertiary gravels of the Sierra Nevada of California, by Waldemar Lindgren. 1911. $226 \mathrm{pp}$., $28 \mathrm{pls}$.

Includes contributions by G. K. Gilbert and F. H. Knowlton. Describes faulting at Walley's Hot Springs, Nev., and gives data on the springs, including analysis of the water (p. 189).

74. Geology and ore deposits of the Butte district, Mont., by W. H. Weed. 1912. 262 pp., 41 pls.

Discusses the action of underground water in the formation $n$ the copper ores (pp. 97-104) and gives analyses of 7 mine waters.

75. Geology and ore deposits of the Breckenridge district, Colo., by F. L. Ransome. 1911. 187 pp., 33 pls.

Discusses the relation of the ground-water level to oxidation and enrichment of the lead-zinc ores (pp. 167-168).

77. Geology and ore deposits of the Park City district, Utah, by J. M. Boutwell, with contribuions by L. H. Woolsey. 1912. 231 pn., 44 pls.

Describes the immense amount of water encountered in the mines (pp. 24-26) and discusses the hydrothermal metamorphism and the level of ground vrater (pp. 101-102).

78. Geology and ore deposits of the Philipsburg quadrangle, Mront, by W. H. Emmons and F. C. Calkins. 1913. 271 pp., 17 pls.

Mentions large springs issuing from limestone (p. 22).

80. Geology and ore deposits of the San Francisco and adjacent districts, Utah, by B. S. Butler. 1913. 212 pp., 41 pls.

Describes water supplies from wells and springs (pp. 20-21). Discusses metasomatic alteration of the rocks by hot solutions (pp. 74-90), the origin of the ore-bearing solutions (pp. 135-136), and alteration of the ores with relation to the water level (pp. 137-138).

82. The geology of Long Island, N. Y., by M. L. Fuller. 1914. 231 pp., 27 pls.

Describes the action of springs in producing landstides (pp. 65-56) and gives records of wells (pp. 84, 90, 91, 102, 103, 119, 131, 182, 148, 149, 157, 158). 
90. Shorter contributions to general geology, 1914; David White, ch ief geologist. 1915. 199 pp., 21 pls.

(h) A deep well at Charleston, S. C., by L. W. Stephenson, with a mort on the mineralogy of the water, by Chase Palmer. pp. 69-94. Gives a detailed log of the well and data on fossils from the drillings. Discusses the character ard origin of the artesian water at Charleston.

94. Economic geology of Gilpin County and adjacent parts of Clear Creek and Boulder Counties, Colo., by E. S. Bastin and J. M. Hill. 1917. 379 pp., 23 pls.

Discusses the relation of ground water to ore deposits, especially the relation of the water table to the downward enrichment of gold, silver, and copper ores (pp. 134-152). Contains, however, almost no data regarding ground weter.

95. Shorter contributions to general geology, 1915; David White, chief geologist. $1916.120 \mathrm{pp}$, $7 \mathrm{pls}$.

(a) The composition of muds from Columbus Marsh, Nev., by W. B Hicks, pp. 1-11. Gives data in regard to shallow wells on Columbus Marsh.

96. The geology and ore deposits of Ely, Nev., by A. C. Spencer. 1917. 189 pp., 15 pls.

The climate is dry and the few perennial streams end in sinks, I nt probably there is considerable water beneath Steptoe and other large valleys, which it may prove feasible to develop by wells (pp. 16-17). "The action of the herted aqueous solutions is regarded as the cause of deep-seated metamorphism within the Fly district" (p. 60). Under the temperature of metamorphosing solutions the density curve of water from $0^{\circ}$ to $365^{\circ} \mathrm{C}$. is shown graphically (p. 63). Discusse the action of penetrating surface water in aiding weathering (pp. 72-76) and the relations of the water table to deposition of chalcocite (p. 90) and to porphyry ore (pp. 114-115).

97. Geology and ore deposits of the Mackay region, Idaho, by J. B. Umpleby. 1917. 129 pp., 21 pls.

States that "oxidation extends several hundred feet below ground-water level" and gives other data on the water table (p. 67). Reports that "Ground-water level in well below the present lowest mine workings" (p. 117).

98. Shorter contributions to general geology, 1916; David White, cl ief geologist. 1917. vi, $395 \mathrm{pp} ., 102 \mathrm{pls}$.

(a) Evaporation of brine from Searles Lake, Calif., by W. B. Hicks, pp. 1-8. Lists 22 wells from which brine samples were collected and gives an average analysis of the brine (p. 2).

104. The genesis of the ores of Tonopah, Nev,, by E. S. Bastin and F. B. Laney. 1918. 50 pp., 16 pls.

In the Tonopah mines the active ground-water circulation is practically confined to zones of fracturing. Hot ascending waters are encountered in a number of deep workings. Discusses deep mine waters (pp. 26-30), ground water (p. 33), the acidity of mine waters (pp. 43-44), and deposition.by hot ascending water (p. 47),

107. Geology and ore deposits of the Tintic mining district, Utah, by Waldemar Lindgren and G. F. Loughlin, with a historical review, by V. C. Heikes. 1919.282 pp., 39 pls.

Describes wells and springs in the distriet and ground water in the mines (pp. 18-19) and alteration due to downward circulating waters (p. 99). Discusses the water table in the mines and gives analyses of one well water and one mine water (pp. 122-125).

111. The ore deposits of Utah, by B. S. Butler, G. F. Loughlin, V. C. Heikes, and others. 1920. 672 pp., 57 pls.

Discusses concentration by atmospheric waters (pp. 156-158) and ground-water level (pp. 203-204).

113. Iron-depositing bacteria and their geologic relations, by E. C. Harder. 1919. 80 pp., 12 pls.

This is a study of the deposition of iron hydroxide in the waters of s?rings, bogs, 


\section{Iron-depositing bacteria and their geologic relations-Continued.}

mines, and streams by the action of iron-depositing bacteria. Describes several kinds of bacteria and their occurrence in iron-bearing spring, mine, and well waters. Gives an analysis of eity well water from Madison, Wis. (p. 14) and of water from a spring west of Lake Kegonsa (p. 16).

115. The copper deposits of Ray and Miami, Ariz., by F. L. Ransome. 1919. 192 pp., 54 pls.

"Small springs of potable water are distributed rather evenly cver the mountainous portions of the area, there being probably between 40 and 50 perennial springs in the Globe and Ray quadrangles combined" (p. 28). Gives the analvsis of a mine water that deposits hydrous copper silicate (p. 141) and discusses relations of the ground water to the surface and to the ore bodies (pp. 147-148) and the relation of enrichment to ground-water surface. (p. 176).

116. The Sunset-Midway oil field, Calif., Part I, Geology and oil resources, by R. W. Pack. 1920. 179 pp., 45 pls.

Describes water supplies from springs and wells (pp. 67, 68). Much of the well water is highly mineralized and charged with sulfur compounds. Discusses the effect of mineralized waters on the oil (pp. 87, 88).

117. The Sunset-Midway oil field, Calif., Part II, Geochemical relations of the oil, gas, and water, by G. S. Rogers, 1919.103 pp. 2 pls.

The major part of this paper is devoted to the oil-field waters of the area, their occurrence in relation to the oil-bearing strata and their types, with diseussion of the distribution and significance of the substances in solution. Gives analyses of 52 waters in groups showing the different types and their gradation in eharacter.

122. Copper deposits of the Tyrone district, N. Mex., by Sidney Paige. 1922. iv, 53 pp., 10 pls.

Water for domestic use at Tyrone is pumped from prospect drill holes in Quaternary gravel. Water for the concentrator is pumped from the No. 2 Chemung shaft (p. 4): Discusses the composition of solutions, alteration by ground water, and changes in level of ground water (pp. 27-29, 32, 33). Diagrams show the relstion of ground water to chalcoeite enrichment (pp. 30, 31). Describes leaching of the copper ore (pp. 39, 40).

127. The composition of the earth's crust, by F. W. Clarke and H. S. Wash ington. 1924. v, $117 \mathrm{pp}$.

A broad discussion of geochemistry, with a description of the role of water in igneous rocks (Dp. 2, 5, and 18-16). Gives the average amounts of water in sedimentary rocks (p. 29) and in the lithosphere (pp. 32, 33). "Hydrogen oxide (water) oceurs as liquid inclusions in the minerals of deep-seated igneous rocks and is an abundant component of volcanic emanations. It is a constituent cf rocks in the deeper parts of the earth's crust" (p. 78).

128. Shorter contributions to general geology, 1920; David White, chief geologist. 1921. iii, 146 pp., 22 pls.

(d) The use of geology on the western front, by A. H. Brooks, pp. 85-124, pls. 15-17. Explains the desirability of using geologists to locate wells (pp. 87, 115-117), discusses the importance of ground water as a controlling factor in the construction of trenches and "dugouts" and in military mining (pp. 102-109). and notes the use of water witehing by German troops (p. 87).

139. Geology and ore deposits of the Ducktown mining district, Tenn., by W. H. Emmons and F. B. Laney, with the active collaboration of Arthur Keith. 1926 . vi, 114 pp., 43 pls.

Discusses the permeability of the area, present circulation of water, the water table, composition of the ground water as related to the water table, and composition of the mine waters (pp. 66-71).

144. The copper deposits of Michigan, by B. S. Butler and W. S. Burbank, in , collaboration with T. M. Broderick, L. C. Craton, C. D. ITohl, Charles Palache, M. J. Scholz, Alfred Wandke, and R. C. Wells. 1929: xii; 238 pp., 75 pls.

States that there is no evidence of leaching of copper near the grrace and, that 
144. The copper deposits of Michigan-Continued.

though the deep salt waters contain copper, "no evidence of enrichment at the zone of change from fresh to salt water or to calcium chloride water has been found in any of the mines" (pp. 113, 114). Discusses deposition by descending solutions and by ascending solutions (pp. 120-141). Gives analyses of five nine waters (p. 122).

145. Geology and oil and coal resources of the Oregon Basin, Meetertse, and Grass Creek Basin quadrangles, Wyo., by D. F. Hewett. 1926. iv, 107 pp., 32 pls.

Describes springs and wells in the area (pp. 9, 10) and discusses relations of water to gas and oil (pp. 81, 82).

147. Shorter contributions to general geology, 1926; W. C. Mendent all, chief geologist. 1927. ii, 48 pp., 17 pls.

(b) The Montana earthquake of June 27,1925 , by J. T. Paradee, pr. $7-28$, pls. 3-13. Describes the changes in springs and wells caused by the 10, 11).

148. Geology and ore deposits of the Leadville mining district, $\mathrm{Co}^{\top} \mathrm{o}$,, by $\mathrm{S}$. F. Emmons, J. D. Irving, and G. F. Loughlin. 1927. xvi. 368 pp., 70 pls.

Discusses the occurrence of ground water in fault blocks (p. 65), the relation of the dẻpth of oxidation of the zine ores to the ground-water level (p.) 245, 246, 256-258), the composition of descending waters (p. 260), and the alteration of ores by descending waters (pp. 261-271).

152. Geography, geology, and mineral resources of part of southeastern Idaho, by G. R. Mansfield, with descriptions of Carboniferous and Triassic fossils, by G. H. Girty. 1927. xiii, $453 \mathrm{pp}$., $70 \mathrm{pls}$.

Describes the distribution and availability of ground-water supplies, vith records of 18 wells (pp. 313-315). Discusses normal, mineralized, and thermal springs and gives analyses of their waters (pp. 316-322) and the utilization of springs and wells for domestic supplies (p. 322).

153. Studies of Basin Range structure, by G. K. Gilbert. 1928. v: 92 pp., 40 pls.

Mentions the association of thermal springs with the frontal fault of the Wasateh Range and with four fault-block spurs (pp. 32, 33) and discusses the temperature of the spring waters and the effect on the temperature of dilution with coor ground water.

154. Shortèr contributions to general geology, 1928; W. C. Mendenl sll, chief geologist. 1929. iv, 299 pp., 76 pls.

(a) Moraines and shore lines of the Lake Superior Basin, by Frank Leverett, pip. 1-72, pls. 1-8. Briefly describes large springs on the west side of Indiar Lake (pp. $16,18)$.

157. The Mother Lode system of California, by Adolph Knopf. 1929. vii, 88 pp., 12 pls.

"The quantity of water yielded by the mines decreases markedly with depth. Some mines have become completely $\mathrm{dry}$; in others water in small quanti ies persists to the deepest levels attained. . . . The experience in deep mining on the : Mother Lode coincides with experience elsewhere, namely, that mines become drier in depth" (p. 24).

162. Geology. and ore deposits of the Goodsprings quadrangle, Nev., by D. F. Hewett. 1981. ix, 172 pp., 40 pls.

Describes springs and wells in the quadrangle and gives a list of 35 wells and an analysis of water from Cottonwood Spring (pp. 5-7). Discusses the occurrence of wa'er in some of the mines (p. 8).

163. The significance of geologic conditions in Naval Petroleum Reserve No. 3, Wyo., by W. T. Thom, Jr., and E. M. Spieker, with a section on the 
163. The significance of geologic conditions in Naval Petroleum Reserve No. 3, Wyo.-Continued.

waters of the Salt Creek-Teapot Dome uplift, by Herman Stabler. 1931. v, 64 pp., 30 pls.

Describes the character and distribution of waters in Teapot and Salt Creek ofl fields (pp. 21-23). Discusses the quality of the ground waters $f$-om the several formations and shows analyses graphically (pp. 39-54).

164. The Kaiparowits region, a geographic and geologic recornaissance of parts of Utah and Arizona, by H. E. Gregory and R. C. Moore. 1931. vii, 161 pp., 31 pls.

Enumerates the geologic horizons from which most of the seeps and springs issue (p. 127). Shows the principal springs on the topographic and geologic maps (pls. 1, 2). No springs are shown in the Arizona portion of these maps.

169. Geology and ore deposits of the Bonanza mining district, Colo., by W. S. Burbank, with a section on history and production by C. W. Henderson. 1932 . ix, 166 pp., 35 pls.

States that "the ground water in the southern part of the district is relatively deep and the ore-bearing veins show a much more pronounoed and deeper oxidation than in the northern part" (p. 3). Discusses hydrothermal metamorphism of the wall rocks (pp. 71-80) and the nature of the mineralizing solutions (pp. 80-85).

170. Shorter contributions to general geology, 1981; T. W. .S'anton, chief geologist. 1932. ii, 69 pp., 23 pls.

(e) The geologic importance of the lime-secreting algae, with a description of a new travertine-forming organism, by M. A. Howe, pp. 57-69, pls. 19-23. "The agency of microscopic algae, especially blue-green algae, in depositing line in calcareous hot springs and calcareous streams has long been recognized" (p 57). "The existence of several kinds of blue-green algae in hot springs shows their adaptation to the higher temperatures that doubtless prevailed in the earlie" stages of the development of life on the earth" (p. 59). The paper cites examples chiefly of marine reef-forming "nullipores," and of both marine and fresh-water limestones deposited by algae.

171. Geology and ore deposits of the Pioche district,-Nev., by L. G. Westgate and Adolph Knopf. 1932 . viii, 79 pp., 8 pls.

Describes several springs (p. 4) and discusses the relation of oxidation to the ground-water level (p. 46).

176. Geology and ore deposits of the Breckenridge mining district, Colo., by T. S. Lovering. 1934. vi, 64 pp., 15 pls.

Under "Supergene enrichment" discusses the leaching of rine and lead ores by ground water and the redeposition at lower levels (pp. 28-32).

177 The Gold Hill mining district, Utah, by T. B. Nolan. 1935 vii, 172 pp,. 15 pls.

Discusses relation of the water table to superficial alteration (p. 10).

178. Geology and ore deposits of the Montezuma quadrangle, Colo., by T. S. Lovering. 1935. ix, 119 pp., 40 pls.

Under "Hypogene alteration" discusses the action of watery sclutions at high temperatures (pp. 42, 43).

187. Geology of the Marathon region, Tex., by P. B. King. $19^{` 7 .} 148$ pp., 24 pls.

Describes the water supply of the Marathon Basin (p. 142).

188. The San Juan country, a geographic and geologic reconnaissance of southeastern Utah, by H. E. Gregory, with contributions by M. R. Thorpe. 1938. 123 pp., 26 pls.

Mentions ground water as an agent in producing rock shelters ani other recesses (p. 96) and as a factor in causing landslides (p. 103). Describes concitions favorable to springs and some of the principal springs (p. 116) and fowing artesian wells near Bluff and othes wells (pp. 116, 117). 
194. The gold quartz veins of Grass Valley, California, by W. D. Johnston, Jr., 1940. 101 pp., 39 pls.

Discusses the quantity and quality of mine waters and gives analyee of four mine waters (pp. 23-25).

202. Geology and ore deposits of the Metaline quadrangle, Wash., 1: C. F. Park, Jr., and R. S. Cannon, Jr., - 1943. v, 81 pp., 34 pls.

Describes caves in carbonate rocks and their relation to the ground-water level (pp. 38, 39).

\section{BULLETINS}

32. Lists and analyses of the mineral springs of the United States (a preliminary study) by A. C. Peale. 1886. 235 pp.

Defines mineral waters, gives lists of springs by States, and containa $819 \mathrm{sn}$ alyses of spring waters.

47. Analyses of waters of the Yellowstone National Park, with an ac :ount of the methods of analysis employed, by F. A. Gooch and J. I. Whitfield. 1888. $84 \mathrm{pp}$.

Describes methods used in analyzing natural waters and contains analyses of 48 geyser, spring, and surface waters in Yellowstone National Park.

108. A geological reconnaissance in central Washington, by I. C. Russell. 1893. 108 pp., 12 pls.

Describes the main geologic features of a region lying approximatel' between the 119th and 121st meridians and between the 46th and 48th parallels. Gives conclusions regarding prospects for artesian wells and includes a sketch geo'ogic map. This bulletin is largely superseded by Water-Supply Papers 55, 118, and 316.

131. Report of progress of the division of hydrography for the calend $x$ years 1893 and 1894, by F. H. Newell. 1895 . $126 \mathrm{pp}$.

Gives the discharge of Barton Spring, near Austin, Tex., as 17 secord-feet on November 13, 1894 (p. 92). Contains records of wells collected by Robert Hay in Nebraska, Colorado, and Kansas (pp, 92-126).

138. Artesian-well prospects in the Atlantic Coastal Plain region, by N. H. Darton. 1896. 232 pp., 19 pls.

Describes briefly the geologic structure and the ground-water conditions in the Atlantic Coastal Plain. Covers the Coastal Plain areas of New York, Nrw Jersey. Delaware, Maryland, District of Columbia, Virginia, North Carolina, South Carolina, and eastern Georgia, giving for each of these States a discussion of this geologic relations and well prospects, tabulated data regarding deep wells, and notes giving well sections, water analyses, and other detailed information not found in the tables. Includes maps and sections showing ground-water conditions.

140. Report of progress of the division of hydrography for 1895 , by $\mathbf{F}$. $H$. Newell. 1896. 356 pp.

: $\because$ Gives descriptions and discharge, records for the following springs in Texas: San Marcos Spring. 'San Antonio and San Pedro springs, Las Moras Spring, San Felipe Springs, and Barton Springs (pp. 83-86). Contains data on seepage and evaporation in Nebraska and Kansas (pp. 347-350).

164. Reconnaissance in the Rio Grande coal fields of Texas, by T. W. Vaughan. 1900. 100 pp., 11 pls.

Contains brief notes on artesian wells in the vicinities of Eagle Pass ard Carrizo springs. See especially pp. 25, 50-52.

199. Geology and water resources of the Snake River Plains of Idal $\%$, by $I$. C. Russell. 1902. 192 pp., 25 pls.

Gives a general sketch of the geography and geology of an indefinite region in Idaho adjacent to Snake River. Discusses artesian and other ground-water conditions and includes a meager amount of well data. 
227. The United States Geological Survey, its origin; development, organization, and operations. 1904 . 205 pp., 9 pls.

Includes a brief account (pp. 84-88) of the Division of Hydrolory (ground water) and of the investigations relating to ground water made by the United States Geological Survey prior. to 1904.

238. Economic geology of the Iola quadrangle, Kans., by G. I. Adams, Erasmus Haworth, and W. R. Crane. 1904. 83 pp. 11 pls.

Describes the geology and contains a geologic map of the quedrangle. Discusses briefly the water-bearing formations and the quality of their waters (p. 77).

252. Preliminary report on the geology and water resources of central Oregon, by I. C. Russell. 1905. 138 pp., 24 pls.

Covers an indefinite region that lies partly in the Great Basin and partly in the basin of Deschutes River, and includes portions of Malheur, Farney, and Crook Counties. Describes the geography and geology of the region, gives meager data regarding the surface and ground waters, discusses briefly the artesian conditions in the Deschutes Basin, and makes suggestion concerning records of artesian wells.

264. Record of deep-well drilling for 1904, by M. L. Fuller, E. F. Lines, and A. C. Veatch. $1905.106 \mathrm{pp}$.

Discusses the importance of accurate well records to drillers, to owners of oil, gas, and water wells, and to geologists. Deseribes methods of work. Gives tabulated records of wells in 39 States and Territories, and detailed record: of wells in California, Colorado, Illinois, Iowa, Kansas, Mississippi, Missouri, New Jersey, New York, Ohio, Pennsylvania, Texas, and West Virginia.

265. Geology of the Boulder district, Colo., by N. M. Fenneman. 1905. 101 pp., 5 pls.

Describes the geology of a rectangular area 16 miles north and south by 9 miles east and west, in the southwestern part of which is situated ths city of Boulder. Discusses briefly (pp. 67-69) the fiowing wells and water-bearirg formations, including the Dakota sandstone. Contains a geologic map of the arca.

282. Oil fields of the Texas-Louisiana Gulf Coastal Plain, by N. M. Fenneman. 1906. 146 pp., 11 pls.

Includes well records and discussions of phenomena reiated to wells, drilling methods, and movements, temperatures, and salinity of ground waters.

285. Contributions to economic geology, 1905; S. F. Emmons and E. C. Eckel, geologists in charge. 1906. 506 pp., 13 pls.

The following paper contains information on ground water:

( $f$ ) Coal and oil in southern Uinta County, Wyo., by A. C. Veatch, pp. 331-353, pls. 10-12. Describes the geology of an area that occupies Tps. 12 to. 23 N., Rs. 115 to 121 W., inclusive, in Uinta County. Wyo. Contains a geslogic map and a brief statement in regard to artesian conditions and prospects (p. 353). This ditéa is covered more fully in Professional Paper 56.

294. Zinc and lead deposits of the upper Mississippi Valley, by H. F. Bain. 1906. 155 pp., 16 pls.

Discusses relation of the ores to the water table (pp. 69-70, 144) and concentration of ore by descending water (pp. 138-141).

298. Record of deep-well drilling for 1905, by M. L. Fuller ard Samuel Sanford. 1906. $299 \mathrm{pp}$.

Gives an account of progress in the collection of well records and samples. Contains tabulated records of wells in 48 States and Territories and detailed recards of wells in Alabama, Arizona, Arkansas, California, Colorado, Delaware, Flórida, Georgia, Illinois, Indiana, Indian Territory, Iowa, Kansas, Kentưky, Maine, Maryland, Massachusetts, Minnesota, Mississippi. Missouri, Montana, New Jersey, New Mexico, New York, North Carolina, Ohio, Oklahama, Pennsylvani, . South Carolina, South Dakota, Texas, Utah, Waghington, West Virginia, and Wireomin. 
300. Economic geology of the Amity quadrangle, eastern Washington County, Pa., by F. G. Clapp. 1907 . 145 pp., 8 pls.

Contains a description of the geology of the quadrangle and a map shoring outcrops and structure. Includes brief statements on water supplies and wate-bearing formations (pp. 130-134). The quadrangle is covered more fully in Geoloric Folio 144. which also contsins information on ground water.

303. Preliminary account of Goldfield, Bullfrog, and other mining dist "icts in southern Nevada, by F. L. Ransome, with notes on the Manhat an district, by G. H. Garrey and W. H. Emmons. $1907.98 \mathrm{pp} ., 5 \mathrm{pls}$.

Gives data on the water supply of Goldfield (p. 24) and of Searchlight (p. 75).

308. A geologic reconnaissance in southwestern Nevada and eastern California, by S. H. Ball. 1907.218 pp., 3 pls.

Contains a brief section on "Hydrology," which discusses streams; springs, tanks, wells, and signs of water (pp. 18-23). Contains descriptions of specific arras which give detailed information regarding springs, wells, and other watering p'aces. Includes a geologic map that also showg watering places and connecting roads.

319. Summary of the controlling factors of artesian flows, by Myron L. Fuller. 1908. 44 pp., 7 pls.

Describes underground reservoirs, the sources of ground water, the confining agents, the primary and modifying factors of artesian circulation, the essential and modifying factors of artesian flow, and typical artesian systems.

330. The data of geochemistry (first edition), by F. W. Clarke. 1908. $716 \mathrm{pp}$. Superseded by Bulletin 770 .

350. Geology of the Rangely oil district, Rio Blanco County, Colo., with a section on the water supply, by H. S. Gale. $1908.61 \mathrm{pp}$., $4 \mathrm{pls}$.

Deseribes the geology and contains a geologic map of an area incliding approximately Tps. 1, 2, and 3 N., Rs. 101, 102, and 103 W., 6th principal meridian. Discusses the water supplies in this area, including artesian wells (p. 58).

352. Geologic reconnaissance of a part of western Arizona, by W. T. Lee, with notes on the igneous rocks of western Arizona, by Albert Johansen. 1908.99 pp., 11 pls.

Describes the geography and geology and contains a geologic sketch map of western Arizona north of longitude $33^{\circ} 30^{\prime}$, including the valley of Colorido River and Hualpai, Big Sandy. Detrital-Sacramento, Williams, and MeMullen Valleys. Contains a section on water supplies, which includes well data and discussion of ground-water prospects.

364. Geology and mineral resources of the Laramie Basin, Wyo. (a preliminary report), by N. H. Darton and C. E. Siebenthal. 1909. 81 pp., 8 pls.

Describes the gealogy and contains a geologic map. Includes a seetion on. grogad water (pp. 67-78), in which are given well data and 6 water analyses. A part of the area is covered by Geologic Folio 173 , which also containg information on ground water.

395. Radioactivity of the thermal waters of Yellowstone National Park, by Herman Schlundt and R. B. Moore. 1909.35 pp., 4 pls.

Deseribes the apparatus and methods used and presents and diseusse the sults of the experiments.

435. A reconnaissance of parts of northwestern New Mexico and north 9 m Arizona, by N. H. Darton. 1910. 88 pp., 17 pls.

Describes the geology and contains a geologic map of the region. Includes data in regard to wells at 24 stations on the Atchison, Topeka \& Santa Fe F.. R. (pp. 75-81).

438. Geology and mineral resources of the St. Louis quadrangle, Mo-Ill., by N. M. Fenneman. 1911. 73 pp., 6 pls.

Dewcribes the geology and contains a geologic map of a-rectangular aren 31 miles 
438. Geology and mineral resources of the St. Louis quadrgngle, Mo.-Ill-Continued.

east and west by 17 miles north and south, including the city of St. Louis. Discusses the water resources, including springs, flowing wells, and deep wells ending in Carboniferous and Ordovician formations (pp. 65-69). The part of this area that lies in Illinois is also covered by Bulketin 5 of the Illinois Geographical Survey.

447. Mineral resqurces of Johnstown, Pa., and vicinity, by W. C. Phalen and Lawrence Martin. 1911. 142 pp., 7 pls.

Describes the geology and contains a map of the Johnstown quadrangle showing structure contours. Includes a very brief description of water sinplies and groundwater conditions (pp. 136-137), which is reprinted in Geologic Folio 174, covering the same quadrangle.

471. Contributions to economic geology, 1910, Part II, Mineral fuels; M. R. Campbell, geologist in charge. $1912.663 \mathrm{pp} ., 62 \mathrm{pls}$.

Issued also in separate chapters. The following paper contains information on ground water:

(a) The Powder River oil field, Wyo., by C. H. Wegemann, pp. 56-75. Describen the geology and contains a geologic map of a quadrangular srea which includes Tps. 40-42 N., R. 81 W., and portions of adjoining townships. Contains brief notes on water supplies, including water-bearing formations (pp. 68, 59).

479. The geochemical interpretation of water analyses, by Chase Palmer. 1911. $31 \mathrm{pp}$.

Discusses the expression of chemical analyses and the chemical character and properties of natural waters. Gives a classification of waters, based on property values and reacting values, and discusses the character of the waters of certain rivers as interpreted from the analyses. Discusses also the relation of the properties of water to geologic formations, silica in river water, and the character of the water of Mississippi River, the Great Lakes, and St. Lawrence River as indicated by chemical analyses.

491. The data of geochemistry (second edition), by F. W. Clarke. 1911. 782 pp.

Superseded by Bulletin 770 .

506. Geology and mineral resources of the Peoria quadrangle, Ill., by J. A. Udden. 1912. 103 pp., 9 pls.

Describes the physiography and geology of a 15-minute quadrangle that includes the cities of Peoria and Pekin. Contains detailed well records and a section on water resources, in which are discussed the water-bearing formations, and the quality, quantity, head, temperature, and use of the artesian waters (pp. '90-97). Includes 8 chemical analyses and maps showing the geology and locations of artesian wells.

629. The enrichment of sulphide ores, by W. H. Emmons. $1913.260 \mathrm{pp}$.

Contains a section on underground circulation (pp. 26-31), in which are discussed the "vadose" and deeper circulation and the region of nearly stagnant waters. Contains also 87 analyses of mine waters with discussion (pp. 60-74) and a discussion of chemical changes in descending sulfate waters (pp. 89-91) and related subjects. See also Bulletin 625 .

580. Contributions to economic geology, 1911, Part I, Metals and nonmetals except fuels; Waldemar Lindgren, chief geologist. 1913.400 pp., 7 pls.

The following papers relate in part to ground water:

(b) The occurrence of potagh salts in the bitterns of the eastern United States, by W. C. Phalen, pp. 313-329. Includes brief statements in regard to the stratigraphic occurence and origin of salt water in New York, Michigan, O'io, West Virginia, Kansas, and Louisiana; also contains analyses.

(r) Salines in Silver Peak Marsh, Nev., by R. B. Dole, p3. 830-846. Includes records of 14 borings, 8 to 55 feet deep, a description of methods used in boring, and analyses of water from these holes and from wells and springs is the vicinity. 
531. Contributions to economic geology, 1911, Part II, Mineral fue's; M. R. Campbell, geologist in charge. $1913.361 \mathrm{pp} ., 24 \mathrm{pls}$.

The following papers contain information on ground water:

(c) Geology and petroleum resources of the De Beque oil field, Colo, by E. G. Woodruff, pp. 54-68, pl. 6. Contains a description of the geology and a gologic map of a square area covering Tps. 7 and 8 S., Rs. 97 and 98 W., in the vicinity of De Beque, in Mesa and Garfield Counties. Includes a brief statement on artesian water in the area (p. 61).

(d) Geologic structure of the Punxsutawney, Curwensville, Houtzdale, Barnesboro, and Patton quadrangles, central Pennsylvania, by G. H. Ashley and M. F. Campbell, pp. 69-89, pls. 7-8. Discusses the geologic structure of the five quadran and includes a map showing structure contours. It contains a brief statement in regard to shallow and deep wells and artesian prospects (pp. 88-89). The ground water in the Barnesboro and Patton quadrangles is also briefly described in Geologic Folio 189, and the ground water in these two quadrangles and in the Cirwensville quadrangle is briefly described in Water Supply Paper 110.

540. Contributions to economic geology, 1912, Part I, Metals and ronmetals except fuels; David White, chief geologist. 1914. 563 pp., 11 pls.

The following papers contain information on ground water:

(n) Prospecting for potash in Death Valley, Calif., by H. S. Gale, pp. 407-415. Includes detailed sections of five wells, 30 to 70 feet deep, with data iv regard to their waters, practically all of which are salty, as is shown by the ana'vses given.

Potash tests at Columbus Marsh, Nev., by H. S. Gale, pp. 422-427. Includes detalled sections of two wells, 32 and 82 feet deep. respectively, with data ir regard to their waters, some of which are not salty.

(p) Potash in western saline deposits, by J. H. Hance, pp. 457-469. Gives total solids in waters from various wells and springs in the drainage basins of Railroad Valley, Fourmile Flat, and Dixie Salt Marsh, in Nevada, and the record of a 305-foot well at Adamana, Ariz.

541. Contributions to economic geology, 1912, Part II, Mineral fuels; M. R. Campbell, geologist in charge. 1914. 532 pp., 29 pls.

The following paper contains information on ground water:

(d) Oil and gas near Green River, Grand County, Utah, by C. T. Lupton, pp. 115-133, pl. 6. Describes the geology and contains a geologic map of an area of about 300 square miles southeast of the town of Green River. Contains meager data in regard to wells, water supplies, and artesian conditions (pp. 117-123).

543. Geology and geography of a portion of Lincoln County, Wyo., by A. R. Schultz. 1914. 141 pp., 11 pls.

Descrives the geology and contains a geologic map of an area in the central part of Lincoln County, between Green River and the Salt River Finge (Tas. 22-39 N., Rs. 113-117 W.). Includes a brief discussion of ground water end artesian prospects (pp. 134, 135).

575. Geology of the Standing Rock and Cheyenne River Indian Res srvations, North and South Dakota, by W. R. Calvert, A. L. Beekly, V. H. Barnett, and M. A. Pishel. 1914. 49 pp., 8 pls.

Covers an area lying west of Missouri River, north of Cheyenne River, and south of Cannonball River, and extending westward to $102 \mathrm{~d}$ meridian. D sscribes the geology and contains a geologic map of the area. Includes a brief discussion of the water in the Dakota and Fox Hills sandstones and in other formations (pp. 24-25).

582. Mineral deposits of the Santa Rita and Patagonia Mountains, Ariz., by F. C. Schrader, with contributions by J. M. Hill. 1915.373 rn., 25 pls.

Includes a brief statement in regard to water supplies from both surface and underground sources (pp. 364-367).

606. Origin of the zinc and lead deposits of the Joplin region, Missouri, Kansas, and Oklahoma, by C. E. Siebenthal. 1915. 283 pp., 11 pls.

A theorelical treatise which relates to underground circulation in the Ozark region. Discusses artesian circulation and flowing wells (pp. 33-37), geochemical interpretation of water analyses, and acidity, neutrality, and alkalinity of natural water 
606. Origin of the zinc and lead deposits of the Joplin region, Missouri, Kansas, and Oklahoma-Continued.

(pp. 81-88). Reviews, discusses, and classifies analyses of zinc-benring and related waters from various parts of the United States and from foreign countries (pp. 88-155).

616. The data of geochemistry (third edition), by F. W. Clarke. 1915. 821 pp.

\author{
Superseded by Bulletin 770 .
}

618. Geology and underground water of Luna County, N. Mex., by N. H. Darton. 1916.188 pp., 13 pls.

Describes the geography and geology, the mineral resources, th a water supplies from streams, springs; and wells, and the irrigation development from surface and ground waters. Discusses the source, quantity, and quality of the ground waters and the extent of the water-bearing strata and gives well data by townships. Includes maps showing the geology, the contours of the water table, and the depths to ground water.

621. Contributions to economic geology, 1915, Part II, Mineral fuels; M. R. Campbell and David White, geologists in charge. 1916. 375 pp., 25 pls.

The following chapters contain information on ground water:

(e) A reconnaissance in Palo Pinto County, Tex., with special reference to oil and gas, by C. H. Wegemann, pp. 51-59. Gives a brief description of the geology of the county with a note on the prospects of obtaining water of good quality from deep sources.

(l) Oil and gas near Basin, Big Horn County, Wyo., by C. T. Lupton, pp. 157190, pl. 17. Describes the geology and contains a geologic map of parts of Tps. 60-52 N., Rs. 92 and $93 \mathrm{~W}$. Includes a brief description of the woter supplies and of the water-bearing sand with a table giving percentages of oil and gas wells that obtained water in each of these sand strata (pp. 164-166). It also includes well records that contain some data in regard to water (pp. 186-189).

625. The enrichment of ore deposits, by W. H. Emmons. 1917.530 pp., 7 pls. This paper is a revision of Bulletin 529 with a somewhat enlarg ?d scope.

627. The lignite field of northwestern South Dakota, by D. E. Winchester, C. J. Hares, E. R. Lloyd, and E. M. Parks. 1916. 169 pp., 11 pls.

Describes the geology and contains maps of Harding and Perkins Counties. Describes the drainage and water supply and contains a small amount of data on deep wells not given in Water-Supply Paper 227.

628. Geology and coal resources of Castle Valley, in Carbor. Emery, and Sevier Couṇties, Utah, by C. T. Lupton. 1916. 88 pp., 12 pls.

Describes the geology and contains a geologic map of an area lying betwoen the Wasatch Plateau and the San Rafael Swell, in east-central Utah, and extending from the vicinity of Mounds, on the Denver \& Riq Grande Rrilroad, southwest about 80 miles. Describes the drainage and water resources, inclucing the prospects of finding water in the Dakota sandstone and underlying McElmc formation. *

641. Contributions to economic geology, 1916, Part II, Mineral fuels; David White, G. H. Ashley, and M. R. Campbell, geologists in charge. 1917. viii, 333 pp., 25 pls.

The following chapters contain information on ground water:

(b) The oil and gas geology of the Foraker quadrangle, Osage County, Okla., by K. C. Heald, pp. 17-48, pls. 2-3. Contains, on page 20, a brlef statement in regard to ground-water conditions.

(i) Anticlines in central Wyoming, by C. J. Hares, pp. 223-280, pl. 23. Covers nearly 5,000 square miles in Natrona and Fremont Counties, weet of Casper and southeast of Lander. Contains (pp. 235-236) a brief discussion of the water supply, including statements regarding various hot springs, springs of large size, sulfur springs, and other mineral springs, also a statement regarding water-bearing formations and artesian prospects. Includes a geologic map. 
647. The Bull Moüntain coal fields, Musselshell and Yellowstone Counties, Mont., by L. H. Woolsey, R. W. Richards, and C. T. Lupton. 1917. 218 pp., 36 pls.

Gives detailed data regarding water supplies, including ground wat re, for the following townships: Tps. 5-8 N., R. 24 E.; Tps. 5-8 N., R. 25 B. ; Tps. 5.8 N., R. 26 E. ; Tps. $5-9$ N., R. 27 E. ; Tps. 5-9 N., R 28 E.; Tps, 5-9 N., R. 29 E.; Tps. 5-9 N., R. 30 E.; Tps, 5-9 N., R. 31 E.; T. 8 N., R. 32 E. See prres 16, 17 , 65-214.

653. Chemical relations of the oilfield waters in San Joaquin Valley, Calif., by G. S. Rogers. 1917. 119 pp.

Discusses water-bearing sands and dry sands in oil fields, the origin of galt water, and the relation of salt water to the occurrence of oil and to geologic structure in oil fields. Classifies the oil-field waters and gives the distribution of their principal constituents. Discusses the chemical relation between water and the hydrocarbons and the significance of water analyses in prospecting for oil. Gives 80 analyses of ground waters in the Coalinga, Kern River, Lost Hills, McKittrick, Midway, and Sunset oil fields, Calif.

656. Anticlines in the southern part of the Big Horn Basin, Wyo., a preliminary report on the occurrence of oil, by D, F. Hewett and C. T. Lupton. 1917. 192 pp., 32 pls.

Covers a large region in northwestern Wyoming, west of the Big Horn Mountains. Gives detailed data regarding surface waters, springs, wells, and ground-water prospects in the numerous anticlinal areas described in the report. See pages 15 , 16, 56-188. Includes a geologic map and section.

658. Geologic structure in the Cushing oil and gas field, Okla., and it? relation to the oil, gas, and water, by C. H. Beal. 1917. 64 pp., 11 fls.

Discusses (pp. 39, 44-61) the relation of ground water to bodies of $\mathrm{Nl}$ and gas and to oil-bearing and gas-bearing structures. Distinguishes "top water," "bottom water," and "edge water." Discusses, the surfaces that form the contacts between bodies of ground water and bodies of oil or gas and differentiates these from ordinary water tables. Includes diagram showing movement of water into oil wells. Incidentally gives ground-water data of local value.

661. Contributions to economic geology (short papers and preliminary reports), 1917, Part II, Mineral fuels; David White, G, H. Ashley, and M. R. Campbell, geologists in charge. 1918 . viii 328 pp., 2 \& pls.

(a) The Cleveland gas field, Cuyahoga County, Ohio, with a study of rook pressure, by G. S. Rogers, pp. 1-68, pls. 1-2. Some well logs show the occurrence of water (pp. 6-8). Briefiy describes occurrence of salt water in the Niagara formation (p. 10). Discusses apparent absence of water in the Clinton sand (p. 19). Includes map showing structure on top of Clinton sand.

(b) Structure of the northern part of the Bristow quadrangle, Creek Cornty, Okla., with reference to petroleum and natural gas, by A. E. Fath, pp. 69-9? pla. 3-4. Some well logs show the occurrence of water (pp. 93-99). Includes topographic map showing structure at base of the Tiger Creek sandstone.

(d) The Irvine oil field, Estill County, Ky., by E. W. Shaw, pp. 141-191, pls. 11-15. Discusses on pp. 176-179 the relation of ground water to the oil in th? field, the character of so-called "dry sands," the mineral composition of the waters, and the relation of mineral composition to the origin of the water and oil. In ?ludes four analyses of water from the Estill Springs.

(f) The Corsicana oil and gas field, Tex., by G. C. Matson and $O$. $\Gamma$ Hopkins, pp. 211-252, pls. 17-21. Describes occurrence of water in some of the different formations (pp. 216-236) and water conditions in the field (pp. 241-243, 251, 252). Gives analyses of water from the Corsicana and Woodbine sands (p. 242). Includes man showing structure of parts of the field.

(g) The Palestine salt dome, Anderson County, Tex., pp. 258-270, pls. 22-23 ; and. The Brenham salt dome, Washington and Austin Counties, Tex., rn. 271-280, pls. 24-25, by O. B. Hopkins. Mentions occurrence of water in an oil well in the Wells Creek district and describes sulfur springs in the Posey saline district (p. 270). Some of the well records mention occurrence of water (pp. 274-277, pl. 25). 


\section{Contributions to economic geology, 1917, Part II-Continued}

(h) Oil and gas possibilities of the Hatchetigbee anticline, Ala., by O. B. Hopkins, pp. 281-313, pls. 26-29. Some of the well records mention occurrince of water (p. 310). Describes salt water in the area (pp. 310, 311). Includes geologic map and structure sections and graphic well logs.

662. Mineral resources of Alaska, report on progress of investigations in 1916 , by A. H. Brooks and others. 1918, iv, 469, xi pp., 18 pls.

(f) Gold placers of the Anvik-Andreafski region, by G. L. Harrington, pp. 333349, pl. 16. Describes carbonated springs near Willow Creek landirc (pp. 347, 348). See also Bulletin 683 .

669. Salt resources of the United States, by W. C. Phalen. 1919. 284 pp., 17 pls.

$\mathrm{D}_{\mathrm{s}}$ seusses the geology and occurrence of salt deposits in the United States, by States. Contains numerous logs of test wells and other wells drilled into salt-bearing formations. Includes several geologic maps.

670. The Salt Creek oil field, Wyo., by C. H. Wegemann. 1917.52 pp., 7 pls.

Describes briefly the water supply of the area (pp. 11, 12), water sands in the Steele shale (pp. 20, 33, 34), and water in the oil sands with analyses of 9 water samples (pp. 42-45). Includes map showing structure on top of Wall Creek and Shannon sands.

677. Geology and mineral deposits of the Colville Indian Reserration, Wash., by J. T. Pardee. 1918. 186 pp., 12 pls.

Describes the relation of ground water to oxidation and enrichment of the ores in the Nespelem district, in which the permanent ground-water level is 15 to 40 feet below the surface (pp. 69, 70). In the Covada district the ground-water level is in most places at a depth of 10 to 30 feet. Some of the descriptions of individual mines and prospects in the Nespelem, Park City, Sanpoil and Covada districts contain references to depth to water level or quantities of rround water encountered in mining. Includes a reconnaissance map of the reservation and geologic maps of several of the mining districts.

680. A geologic reconnaissance for phosphate and coal in southeastern Idaho and western Wyoming, by A. R. Schultz. 1918. 84 pp., 2 pls.

Discusses the occurrence of hot springs in the area covered by the report, notably along Snake River and Fall Creek (pp. 31-33).

681. The oxidized zinc ores of Leadville, Colo., by G. F. Lougl lin. 1918. 91 pp., 8 pls.

Contains reference to unwatering of certain sections of the district to permit mining operations (pp. 15, 16). Discusses vertical distribution of the ores and relation to depths of oxidation and ground-water level (pp. 64-66) and genesis of the ores, especially as reiated to the influence of descending ground water and the position of the water table (pp. 68-85).

683. The Anvik-Andreafski region, Alaska (including the Marshall district), by G. L. Harrington. 1918.70 pp., 7 pls.

Contains descriptions of mineral springs near Willow Creek landing and an analysis of the water from Soda Springs (pp. 66-67). Includes reconnaissance topographic and geologic maps of the region.

686. Structure and oil and gas resources of the Osage Reservation, Okla., by David White and others. 1922. xvi, 427 pp., 60 pls.

A series of 26 papers on the stratigraphy and structure of specific townships in the county. The following papers contain references to ground watar.

(i) T. 26 N., Rs. 9, 10, and 11 E., by F. R. Clark, pp. 91-118, pls. 13-17. Shows water sands in logs of wells (pl. 17).

(l) Tps. 24, 25, and 26 N., Rs. 6 and 7 E.; Tps. 25 and 26 Y., R., 5 E.: T. 26 N., R. 4 E., by C. F. Bowen, pp. 137-148, pls. 21-23. Shows water sands in logs of wells (pl. 21).

(m) Tps. 24 and 25 N., R. 8 E., by K. C. Heald and K. F. Mather, pp. 149-170, plg. 24-26. Mentions water and salt water in upper sands (p. 154).

(s) T. 24 N., Rs. 11 and 12 E., by O. B. Hopkins and Sidney Powers, pp. 287- 
686. Structure and oil and gas resources of the Osage Reservation, Okla.Continued.

253. pls. 37-40. Shows water and salt water in logs of wells (pl. 39).

(t) T. 27 N., R. 11 E., by H. M. Robinson and R. V. A. Mills, pp. e55-277, pls. 41-42. Shows water and salt water in logs of wells (pl. 42).

(u) Tps. 21-23 N., Rs. 6-7 E., and Tps. 23-25 N., Rs. 3-5 E., by C. I. Bowen; P. V. Roundy, C. S. Ross, and Frank Reeves, pp. 279-301, pls. 43-45. Shows water in logs of wells (pl. 45) .

(v) T. 27 N., R. 10 E., by F. M. Robinson and R. V. A. Mills, pp 303-327, pls. 46-48. Shows water and salt water in logs of wells (pl. 47).

(w) T. 29 N., Rs. 11 and 12 E., by M. I. Goldman, pp. 329-352, pl. 49. Lists several water sands (pp. 333-334).

(y) T. 28 N., Rs. 11 and 12 E., by M. I. Goldman and H. M. Robinson pp. 359394, pls. 51-55. Mentions water sands (pp 370, 371) and shows water and salt water in logs of wells (pls. 51, 53).

(z) Tps. 26 and 27 N., R. 12 E., by P. V. Roundy, K. O. Heald, and G. B. Richardson, pp. 395-420, pls. 55-60. Mentions ground water available for drilling operations (p. 395).

688. The oil fields of Allen County, Ky., with notes on the oil geology of adjoining counties, by E. W. Shaw and K. F. Mather. 1919. J26 pp., 10 pls.

Describes the occurrence of salt water in certain parts of the oll-bearine formations in Allen County and gives analyses of 3 samples of salt water from wells in the area and discusses the properties of these samples (pp. 77-82). Gives a reference to gas and salt water encountered in wells drilled for water. Discusses replacement of oil by water (p. 94). Gives numerous logs and other records of wells, some of which are tabulated (pp. 94-111). The report also contains notes and well records for counties adjoining Allen County. Includes geologic and structur-contour maps, structure sections, and graphic well logs.

690. Contributions to economic geology (short papers and preliminary reports), 1918, Part I, Metals and nonmetals except fuels; F. I. Ransome, E. F. Burchard, and H. S. Gale, geologists in charge. 1919. vi, 147 pp., 5 pls.

(d) Quicksilver deposits of the Phoenix Mountains, Ariz., by F. C. Schrader, pp. 95-110. "Paradise Valley contains excellent underground water. In th Montgomery well, which ends in valiey fill at a depth of 225 feet, water was encountered at 196 feet" (p. 97).

691. Contributions to economic geology (short papers and preliminc.ry reports), 1918, Part II, Mineral fuels; David White, G. H. Ashley, and M. R. Campbell, geologists in charge. 1919. viii, 355 pp., 44 p's.

(a) The structure of parts of the central Great Plains, by N. H. Darton, pp. 1-26, pls. 1-4. Contains a number of well records, most of which show the occurrence of water, including deep borings in Colorado, Kansas, Nebraska, South Daknta, and Wyoming. Includes a preliminary map of the central Great Plains showing structure of the Dakota sandstone, several structure maps of small areas, and a number of well sections and generalized structure areas.

(c) Geologic structure of the northwestern part of the Pawhuska quadrangle, Okla., by K. C. Heald, pp. 57-100, pls. 13-15. Discusses briefly the ground-water conditions and the prospects of obtaining potable supplies in the sandston 78 penetrated in the oil wells (p. 60). Contains a general statement regarding the quality of the ground water. Includes a topographic structure-contour map of the area and several graphic well logs.

(d) Geology and oll and gas prospects of the Lake Basln .field, Mont., by E. T. Hancock, pp. 101-147, pls. 16-23. Briefiy describes streams and springs in this area (p. 105). Well logs and other records mention occurrence of water (pp. 143-145). Includes map showing structure on base of Eagle sandstone.

(e) Oil and gas geology of the Birch Creek-Sun River area, northweste'n Montana, by Eugene Stebinger, pp. 149-184, pl. 24. Contains a brief general sfatement concerning the effect of the presence of water on accumulation of ofl and gas 


\section{Contributions 'to economic geology, 1918, Part 11-Continned.}

(pp. 167, 168). Well log shows presence of water in glacial drift (p. 183). In. cludes geologic map and structure sections.

(g) The Nesson anticline, Williams County, N. Dak., by A. J. G.lier, pp. 211-217, pl. 26. Notes on two wells mention artesian water in the Dakot sandstone (pp. 216. 217). Includes structure contour map and structure section.

(h) Geology and oil prospects of the Salinas Valley-Parkfield area, Calif., by W. A. English, pp. 219-250, pls. 27-28. A well in the Pleyto district struck flowing water, and another encountered salt water (pp. 242, 243). A well in the Parkfleld district struck flowing sulfur water (p. 249). Includes geologic meps and structure section.

(j) Asphalt deposits and oil conditions in southwestern Arkansar, by H. D. Miser and A. H. Purdue, pp. 271-292, pl. 33. Well logs show water-beax'ing horizons (pp. 282-292). Includes geologic map.

(m) Structure and oil resources of the Simi Valley, southern Cal'ornia, by W. S. W. Kew, pp. 323-355, pls. 41-44. "Few springs occur in the Simi Hills, but springs are rather numerous on the Santa Susana Mountains, especially along the Santa Susana fault. Many of them are alkaline and charged with h-drogen sulphide. Water can easily be obtained for drilling, either from springs or by pumping from shallow wells" (p. 325). Includes geologic map, structure sections, and six plotted well logs showing fresh water in the surficial sands and sulfur wa ${ }^{+} e r$ in deeper strata.

692. Mineral resources of Alaska, report on progress of investigations in 1917, by G. C. Martin and others. 1919. iv, 408, xiv pp., $10 \mathrm{pls.}$

(b) Water-power investigations in southeastern Alaska, by G. H. Canfield, pp. 43-83, pl. 1; Mining developments in the Ketchikan district, by Theodore Chapin, pp. 85 89; Geology and mineral resources of the west coast of Chichagof Island, by R. M. Overbeck, pp. 91-136, pl. 2. Describes hot springs on the north arm of Peril Strait and White Sulphur Springs (Hooniah Warm Spring) (pp. 131-136) and quotes descriptions of them from Water-Supply Paper 418. Includes geologi? sketch map.

(e) Sulphur on Unalaska and Akun islands and near Stepovak Bay, by A. G. Maddren, pp. 283-298, pl. 7 ; The beach placers of the west coast of Kodiak Island, by A. G. Maddren, pp. 299-319, pl. 8. Describes (pp. 283-298) the areas of solfataras on Unalaska and Akun Islands, which give off sulfurous vapors and hot water and have formed surficial deposits of sulfur. The oxidizing action on the rocks by the hot acid vapors is a notable feature.

(g) Tin mining in Seward Peninsula, by G. L. Harrington, pp. 353-361; Graphlte mining in Seward Peninsula, by G. L. Harrington, pn. 363-367; The old and platinum placers of the Kiwalik-Koyuk region, by G. L. Harrington, pp. 369-400, pl. 10. Describes hot springs near Spring Creek (pp. 399, 400). These are the same as "Warm Springs near Inmachuk, River" of Water-Supply Paper 418. Includes geologic sketch map.

693. The evaporation and concentration of waters associated with petroleum and natural gas, by R. V. A. Mills and R. C. Wells. 1919. 104 pp., 4 pls.

Discusses the saline oil-field water that occurs with petroleum and natural gas in the Appalachian fields with regard to its origin and the development of its present chemical characteristics. Proposes that such water is not original connate water or connate water concenirated with no changes in the proportions of dissolved constituents, but that it has been concentrated by evaporation into moving and expanding gas, with changes in the proportions of dissolved ccnstituents as the result of selective deposition and addition of constituents from outside sources. Suggests that the process of concentration by evaporation, with deposition of sodium chloride and related salts, is at least partly responsible for the fomation of many salt domes. Discusses the causes of "salting up" of oil wells. Contains numerous chemical analyses of oil-field water and of deposits formed from it and several analyses of shallow ground water.

695. The data of geochemistry (fourth edition), by F. W. Clarke. 1920. 832 pp. 
697. Gypsum deposits of the United States, by R. W. Stone and others. 1920. 326 pp., 37 pls.

Discusses deposition of gypsum from ground water (pp. 23, 24). Mentions Harris' theory that certain Louisiana salt domes capped with gypsum resulted from deposition of the salts from hot solutions ascending from great depths along fault intersections, the expansive force of erystallization causing the doming. Describes the formation of gypsum by alteration of calcium carbonate by ground water containing sulfuric acid (p. 25). Includes maps showing distribution of gyps"m deposits and numerous stratigraphic and structure sections.

- 701. Geothermal data of the United States, including many original determinations of underground temperature, by N. H. Darton. 1920. 97 pp., 1 pl.

Gives all available published data bearing on the rate of increase of rnderground temperature with increasing depth. Includes several hundred original observations of temperature, most of them being made in water wells but some in springs and deep mines. Gives figures on depth to water, and yield of wells and cites all sources of information. Includes map showing structure of bedrock and relation to rates of increase of temperature in eastern South Dakota and southeastern North Dakota.

702: Oil possibilities in and around Baxter Basin, in the Rock Springs, uplift, Sweetwater County, Wyo., by A. R. Schultz. 1920. 107 pp., 17 pls.

Describes the water supply of the region (pp. 17-20). Within Baxter Fasin a few springs near Aspen Mountain furnish the only ground-water supply. Deep drilling in the center of the basin might obtain water from sandstones of the Colcrado group or from the Beckwith formation. In the area surrounding the basin surface and shallow ground water, as well as water from many of the springs, is highly mineralized. Underlying sandstones of Tertiary and Mesaverde formations yield flowing wells in some places. Bishop conglomerate in the southern part of the fie'd furnishes many springs with water of satisfactory quality. Contains a number of well logs and other well records, some of which mention occurrence of water. Includes geologic map showing structure on highest sandstone of the Baxter formation and stratigraphic and structure sections and plotted well logs.

710. Contributions to economic geology (short papers and preliminary reports), 1919, Part I, Metals and nonmetals except fuels; F. L. Ransome and E. F. Burchard, geologists in charge. 1920. ix, 248 pp., 10 pls.

(a) A reconnaissance of the Pine Creek district, Idaho, by E. L. Jon ₹8, Jr., pp. 1-36, pl. 1. Discusses briefly the position of the ground-water level as related to depth of axidation of the ore deposits (p. 13). Includes geologic sket th map of the district.

(b) Deposits of manganese ore in New Mexico, by E. L. Jones, Jr., pp. 37-60. Deseribes manganese prospects and mines scattered over the State. Mentions whether or not existing mine workings reached water level.

(d) Deposits of manganese ore in Arizona, by E. L. Jones, Jr., and F. L. Ransome, pp. 93-184, 3-8. Discusses the supergene origin of the deposits and their probable concentration by ground water (pp. 117, 118). Mentions whether or not the mine workings reached water level. Includes geologic sketch maps of several d'rtricts.

(e) Deposits of manganese ore in southeastern California, by E. L. Jones, Jr., pp. 185-208, pl. 9. Mentions water supplies from small springs (p. 191) and from shallow wells (pp. 202 and 208). Discusses oxidation of the original manganesebearing minerals by "surface water" (p. 204).

711. Contributions to economic geology (short papers and preliminary reports), 1919, Part II, Mineral fuels; David White and G. H. Ashley, geologists in charge. 1920. viii, 171 pp., 21 pls.

(a) The Farnham anticline, Carbon County, Utah, by F. R. Clark, pr, 1-3, pls, 1-2. Reports salt water at $1, \overline{840}$ feet in a well near Green River and fresh water at several horizons below 310 feet in the Navajo and Wingate sandstones in a well on San Rafael Swell (p. 11). Includes geologic map and structure secticns.

(d) Oil in the Warm Springs and Hamilton domes, near Thermopolis, Wyo., by A. J. Collier, pp. 61-73, pls. 7-10. Mentions travertine deposited from bat springs 
711. Contributions to economic geology, 1919-Continued.

(p. 62). Two wells near arest of Hamilton dome showed no wgter, oil, or gas (p. 63). Reports hot water in wells on anticline near Thermopolis in vicinity of hot springs (p. 73). Includes structure-contour maps, structure se-tions, and graphic well logs.

(e) Gas in the Big Sand Draw anticline, Fremont County, Wyo., by A. J. Collier, pp. 75-83, pl. 11. Gives $\log$ of well showing brackish water $a^{+}, 200$ and 315 feet (D. 78). Includes geologic map and structure section.

(o) Geology and ofl and gas prospects of the Huntley field, Mont., by E. T. Hancock, pp. 105-148, pls. 14-18. Logs of four wells give depths at wh ich water was encountered (pp. 142-143). Mentions several wells yielding water and traces of oil (p. 144). Includes geologic map showing structure on base of the Eagle sandstone.

(h) Anticlines near Maverick Springs, Fremont County, Wyc., by A. J. Collier. pp. 149-171, pls. 19-21. Reports mineral springs on west side of the Big Dome (p. 163). Nearly all deep wells obtain water, which usually fiows $a^{t}$ the surface; there are several water-bearing strata in some wells. In most wells the water is mineralized, but in some it is reported to be fresh. Describes several wells that yield water. Includes topographic map showing structure on top of the Fark City formation and structure sections.

713. Geography, geology, and mineral resources of the Fort Hall Indian Reservation, Idaho, by G. R. Mansfield, with a chaptior on water resources by W. R. Heroy. 1920. 152 pp., 13 pls.

Describes ground-water resources of the mountainous areas (p. 133) and ground water in Snake River Valley, the large springs of the valley being discussed with various hypotheses of their origin (pD. 133-140). Discusses utilization of ground water and surface water (pp. 140-148). Includes geologic map with st-ucture sections, detailed geologic maps and gections of certain townships, and a map illustrating the water resources.

715. Contributions to economic geology (short papers and preliminary reports), 1920, Part I, Metals and nonmetals except $f$ 'els; F. L. Ransome, H. S. Gales, and E. F. Burchard, geologists in charge. 1921. viii 230 pp., 20 pls.

(i) Potash resources of Nebraska, by W. B. Hicks, pp. 125-13؟. States that .freshwater lakes are often underlain by impervious beds beneath which is brine and that frcsh-water beds are generally encountered below potash derosits (pp. 126, 127). Mentions underlying Dakota sandstone, which contains fresh water; and lake deposits which contain fresh water wherever they are water-bearing. Most waters bolow a depth of 30 feet are fresh. Discusses origin of the potash brines and deposits as related to surface water and ground-water movement (pp. 1i 1-139).

(l) The Mogollon district, N. Mex., by H. G. Ferguson, pp. 171-204, pls, 15-20. Discusses the relation of the ground-water level to veins, fanlting, and renewed erosion (p. 192). Includes geologic map and structure sectiona.

(m) Permian salt deposits of the south-central United Statex by N. H. Darton, pp. 205-230, pls. 21-24. Gives records of numerous borings in Kansin, Oklahoma, Texas, and New Mexico, in a few of which salt-water horizons are mentioned. Includes structure sections and graphic well logs.

716. Contributions to economic geology (short papers and preliminary reports), 1920, Part II, Mineral fuels; David White and M. R. Campbell, geologists in charge. 1921. viii, 248 pp., 34 pl-.

(a) Geology of Alamosa Greek val'ey, Socorro County, N. Mex., with special reference to the occurrence of oil and gas, by D. E. Winchester. pp. 1-15, pls. 1-5. Gives location of principal springs in the area and reports that smaller springs are numerous (p. 3). States that bed of Alamosa Creek is saturated with water in most places. Includes geologic man and strueture sections.

(b) The Upton-Thornton oil fie!d, by E. T. Hancock, pp. 17-34, pl. 6. Gives log of a well at Cambria, water in the Pahasapa limestone being reported at 1,9472,345 feet (p. 20). Includes geologic structure-contour map and structure sections. (c) The Mule Creek oil field, Wyo., by E. T. Hancock, pp. 35-53, pl. 7. Log of a well shows water in the Dakota sandstone at 1,160-1,269 ft. (p. 52).

(d) Natural-gas resources available to Dallas and other citis of central north 
716. Contributions to economic geology, 1920-Continued.

Texas, by E. W. Shaw and P. L. Ports, pp. 58-89, pls. 8-9. Discusses rater encroachment in the gas field (pp. 67-68). Gives $\log$ of a typical well in Jox field, Oklahoma, which shows fresh-water horizons (p. 72). Includes topogranhic and structure-contour map showing water encroachment.

(e) The Lance Creek oil and gas field, Niobrara County, Wyo., by E. T. Hancock, pp. 91-122, pls. 10-13. States that water may be obtained in most of the stream beds of the region by shallow drilling, although streams themselves are dry most of the year (p. 94). Includes geologic structure-contour map.

(g) Coal in the middle and eastern parts of San Juan County, N. Mex., by C. M. Bauer and J. B. Reeside, Jr., pp. 155-237, pls. 16-34. States that shallor ground water, usually rather salty, can generally be obtained in arroyo bottoms (p. 158) and that coal is usually weathered for some distance from the outerop because of the low position of the water table (p. 179). Includes a geologic map of part of the area.

717. Sodium sulphate, its sources and uses, by R. C. Wells. 1923 . iv, 43 pp.

Mentions springs and wells in Nevada which yield saline water containin sodium sulfate (p. 23) and notes fresh-water springs occurring near sodium sulfate deposits in Wyoming (p. 29).

718. Geology and ore deposits of the Creede district, Colo., by W. H. Em-: mons and E. S. Larsen. 1923. ix, 198 pp., 12 pls.

Discusses in detail the chapter on ore deposits (pp. 98-141), the role $\circ$ ground water in deposition and alteration of mineral deposits. Includes topographic and geologic maps and structure sections.

719. Preliminary report on petroleum in Alaska, by G. C. Martin. 19?1. 88 pp., 11 pls.

Reports a strong flow of salt water in a well at Oil Bay and a strong flow of fresh water in a well near Cold Bay (pp. 62, 65). Includes geologic mars of the Controller Bay and Cook Inlet flelds with structure sections, a geologic reconnaissance map of the Alaska Peninsula, and topographic map and structure sections of the Yagataga field.

720. Economic geology of the Summerfield and Woodsfield quadrangles, Ohio, with descriptions of coal and other mineral resources, except oil and gas, by D. D. Condit. 1923.156 pp., 12 pls.

Describes briefly the water resources of the quadrangles (pp. 54, 65). Streams are small and not reliable. Springs are numerous. Ground water usually eccurs at shallow depths. Water in valleys at depths of more than 75 feet is usualy highly mineralized. Wells less than 75 feet deep on ridges usually obtain sufficient water for domestic use from sandstone, limestone, or coal. Contains geologic map showing structure on base of the Pittsburgh coal.

721. Geology and petroleum resources of northwestern Kern County, Calif., by W. A. English. 1921. 48 pp., 2 pls.

Mentions "edge water" in the Lost Hills field, a water sand in the North Belridge field, and interbedded water sands and oil sands in the Belridge fleld (pr. 37-38). Includes geologic map and structure sections.

723. Geology and ore deposits of the Manhattan district, Nev., by H. G. Ferguson. 1924. ix, 162 pp., 18 pls.

Reports that there are numerous small springs in the Toquima Range (r. 3) and that there is a considerable underground flow of water in gravel of som: of the dry canyons, estimated as 50,000 gallons a day in Manhattan Gulch. Gives analyses of ground water in Manhattan Gulch and a discussion of changes in its chemical character (pp. 129-132). Includes geologic maps and structure sections.

724. Nitrate deposits in the Amargosa region, southeastern California, by $L$. F. Noble, G. R. Mansfield, and others. 1922 . vii, $99 \mathrm{pp}$., $35 \mathrm{pls}$

Describes Saratoga Springs and several other sources of water supply (pp 24, 25). Wells on the lower slopes of large alluvial fans would probably yield sufficient water for commercial use in extracting nitrates. Describes water supplies in th: middle Amargosa region from several springs and mine tunnels (pp. 5960 ). 
725. Contributions to economic geology (short papers and preliminary reports), 1921, Part I, Metals and nonmetals except frels; F. L. Ransome and E. F. Burchard, geologists in charge. $19 \AA 2 . \mathrm{xi}, 440 \mathrm{pp}$. 19 pls.

(c) Deposits of manganese ore in Montana, Utah, Oregon, and Washington, by J. T. Pardee, pp. 141-243, pls. 7-10. A number of the descriptions of individual mines and prospects in the Philipsburg district, Mont., mention occurrence of water or depth to water level (pp. 146-174). The water supply for the C. F. \& I. mine is hauled from a spring in White Wash Valley (p. 193). In a mine in Pleasant Valley, Oreg., water stood 45 feet below the surface (p. 226).

(d) Contact-metamorphic tungsten deposits of the United States, by F. L. Hess and E. S. Larsen, pp. 245-309, pls. 11-14. Mentions water supplies from small springs in the Victorville and Benton areas, Calif. (pp. 262, 277), from springs or shallow wells near several prospects in Nevada (pp. 278, 283, 286, 288, 293, 294, 300), and from shallow wells in Willow Wash, Utah (p. 308).

(g) The Taylor Creek tin deposits, New Mexico, by J. M. Hill, pp. 347-359. "Water can be had in shallow wells in most of the canyons, and at a few places in Railroad, Kennedy, upper Corduroy, and upper Taylor Canyons watrr rises to the surface" (p. 249). Includes a geologic sketch map.

726. Contributions to economic geology (short papers and preliminary reports), 1921, Part II, Mineral fuels; David White ard M. R. Campbell, geologists in charge. $1922 . \mathrm{x}, 322 \mathrm{pp} ., 54 \mathrm{pls}$.

(b) Geology of the Cement oil field, Caddo County, Okla., by Frank Reeves, pp. 41-85, pls. 6-12. Explains change in color of Whitehorse sandstone in the Cement anticlinal area as being due to cementation by ground water ascending through fissures (pp. 55, 56). Gives several logs of wells, some showing water. Includes maps showing structure on top of Whitehorse sandstone in Cement on fields and Klowa areas, stratigraphic sections, and graphic .well logs.

(d) Lignite in the western part of the Fort Berthold Indian Reservation south of Missouri River, N. Dak., by C. M. Bauer and F. A. Herald, pp. 109-172, pls. 13-19. Gives brief descriptions of springs along streams and of the.quality of water from springs.

(e) Geologic structure of parts of New Mexico, by N. H. Dartcn, pp. 173-275, pls. 30-50. Contains logs of numerous wells, most of which were dri"ed for water, and notes the water-bearing strata.

(f) Geologic structure and oil and gas prospects of a part of Jefferson County, Okla., by H. M. Robinson, pp. 277-302, pls. 51-52. States that water for drilling may be obtained from shallow wells (p. 277). Contains seven well logs, six of which report water. Includes a structure contour map.

727. Potash in the greensands of New Jersey, by G. R. Mansfinld. 1922. viii, 146 pp., 10 pls.

Contains numerous well logs and test-hole records in which the occurrence of water is mentioned (pp. 14-103). The water table is close to the surface throughout most of the greensand areas. Includes geologic map and structrre sections.

733. Geology of the York tin deposits, Alaska, by Edward Steidtmann and S. H. Cathcart. 1922 . vii, 130 pp., 12 pls.

Discusses rock weathering due to solution by ground wate- carrying carbon dioxide and the effect of frozen ground on the circulation of ground water. Vigor of circulation is a vital factor in thawing (pp. 5, 6). Contains topographic-geologic map of the York tin region and seven topographic and geologic sketch maps of tin areas.

735. Contributions to economic geology (short papers and preliminary reports), 1922, Part I, Metals and nonmeals except fuels; F. L. Ransome, G. R. Mansfield, and E. F. Burchard, geologists in charge. 1923. $\mathrm{x}, 336$ pp., 15 pls.

(c) Bonanza ores of the Comstock lode, Virginia City, Nev.r by E. S. Bastin, pp. 41-63. Gives description, analyses, and discussion of the rine water of the Comstock lode (pp. 57-63). 
735. Contributions to economic geology, 1922, Part I-Continued.

(d) Silver enrichment in the San Juan Mountains, Colo., by E. S. Bastin, pp. 65-129. Gives description and four analyses of water from hot springs near Ouray (pp. 67-69), analysis of water from a "soda spring" (p. 119), and analyses of four samples of mine water (pp. 108, 119). Mentions enrichment by descendin water in a number of the mine descriptions. Many samples of mine water were tested for acidity or alkalinity. Notes springs that deposit sulfur and calcium carbonate (p. 126).

(e) Primary native-silver ores near Wickenburg, Ariz., and their bearing on the genesis of the silver ores of Cobalt. Ontario, by E. S. Bastin, pp. 131-155. Refers to comparative dryness of the mine wokks, depth to original ground-water level, and lack of oxidation of ore deposits (pp. 145, 146).

(f) General features of the brown hematite ores of western North Carolina, by W. S. Bayley, pp. 157-208, pls. 4-6. Notes the shallowness of the water tiable in low lands along Nottely and Valley Rivers (p. 194) and on many pages mentions springs in the area. Includes topographic and geologic maps, and structure sections of several of the districts.

736. Contributions to economic geology (short papers and preliminary reports), 1922, Part II, Mineral fuels; K. C. Heald, geologist in charge. 1923. vi, 254 pp., 24 pls.

(a) The structure of the Madill-Denison area, Oklahoma and Texas, with notes on oil and gas devetopment, by O. B. Hopkins, Sidney Powers, and H. M. Robinson, pp. 1-33, pIs. 1-6. Contains numerous $\log s$ and other records of wells, mort of which mention the occurrence of water. Includes a geologic map, a map showine strueture on top of the Goodiand limestone, and graphic well logs.

(b) Oil and gas prospects in and near the Crow Indian Reservation, Mont., by W. T. Thom, Jr., pp. 35-53, pl. 7. States that wells penetrating the Sundance formation will probably encounter two or three water-bearing sandstones (p. 40). Mentions water supply available for drilling in the different areas and notes that both surface water and shallow ground water are scarce. Reports weter in the Cloverly and Tensleep formations in Black Gulch dome area (p. 51). In ?ludes map of part of the area showing structure on the top of the Cloverly formation.

(d) The Osage oil field, Weston County, Wyo., by A. J. Collier, pp. 71-110, pls. 10-14. Mentions several wells drilled for water supply (p. 74). Gives numerous references to occurrence of water in wells drilled for oil. Contains a paragraph dealing with artesian wells in the Dakota and Lakota sandstones (p. 96). Tak ulated well records give data on the water-bearing sands (pp. 107-110). Includes a structure contour map and structure sections.

(e) Geology of the Ranger oil field, Tex., by Frank Reeves, pp. 111-170, pls. 15-19. Describes the occurrence of saline water in the oil sands (pp. 141, 142). Well tables (pp. 144-151) contain a few references to salt water, as do well logs (pp. 152-170). Includes structure contour maps and graphic well logs.

(g) The Brooks, Steen, and Grand Saline salt domes, Smith and Van Zandt Counties, Tex., by Sidney Powers and O. B. Hopkins, pp. 179-239, pls. 20-23. Disersses briefly the origin of springs in the Brooks saline region (p. 193). Reports that shallow wells in the Steen dome region obtain bad water (p. 213). Well records contain references to water (pp. 199-208, 216-237). Includes topographic maps of the domes and graphic well logs.

739. Mineral resources of Alaska, report on progress of investigrtions in 1921 , by A. H. Brooks and others. 1923. vi, 169, xiv pp., 3 pls.

(c) Recent investigations of petroleum in Alaska (Cold Bay, Iniskin Bøy, Anchorage, Nenana coal field), papers by S. R. Capps, F. H. Moffit, A. H. Erooks, and G. C. Martin, pp. 77-147, pls. 2-3. Mentions several springs yielding oil and gas along with water and describes a test well that struck a strong flow of salt water (pp. 127-129). Includes a geologic map and structure sections.

748. The Twentymile.Park district of the Yampa coal field, Routt County, Colo., by M. R. Campbell. 1923. iv, 82 pp., 13 pls.

Reports a well drilled for oil in the village of Milner, which yielded a small flow of artesian water, and mentions that other water wells have been drilled in Milner, some more than 400 feet deep (pp. 29, 30). Includes map showing outerop of coal and sandstone beds and geologic structure, and stratigraphic sections. 
749. Geology of the Tullock Creek coal field, Rosebud and Big Horn Counties, Mont., by G. S. Rogers and Wallace Lee. 1923. vi, 181 pp., 16 pls.

Describes the occurrence of springs in the region and states that water is probably obtainable from shallow wells in most of the coulees (p. 8). Includes geologic and structure contour map and stratigraphic and structure sections.

750. Contributions to economic geology (short papers and preliminary reports), 1923-24, Part I, Metals and nonmetals except fuels; F. L. Ransome, G. F. Loughlin, G. R. Mansfield, and E. F. Burchard, geologists in charge. $1925 . \mathrm{v}, 148 \mathrm{pp} ., 12 \mathrm{pls}$.

(b) Origin of certain rich silver ores near Chloride and Kingroan, Ariz., by $\mathbf{E}$. $\mathbf{S}$. Bastin, pp. 17-39. States that the water level was 220 feet below collar of Distaff shaft, 50 feet below collar of Rural shaft, 60 feet below surface in Queen Bee shaft, 25 feet below collar of Kay shaft, and about 100 feet in mines near Stockton Hill (pp. 19, 24, 25, 30, 33). Notes that oxidation of ores above the water level is incomplete and that downward enrichment of ores is slight (pp. 35, 36).

(c) Observations on the rich silver ores of Aspen. Colo., by E. S. Bastin, pp. 41-62, pl. 3. Describes secondary ores deposited from descending ground water and the occurrence and quality of the mine water, with analyses of two water samples (pp. 49-62).

751. Contributions to economic geology (short papers and preliminary reports), 1923-24, Part II, Mineral fuels; K. C. Heald and W. T. Thom, Jr., geologists in charge. 1925 . vi, 326 pp., 37 pls.

(b) Progress report on a subsurface study of the Pershing oil. and gas field, Osage County, Okla., by W. W. Rubey, pp. 23-70, pls. 7-9. Briefly disc'ssses the quality of oil-field water (p. 68). Includes structure contour map and graphi? well logs.

(c) Geology and possible oil and gas resources of the faulted area south of the Bearpaw Mountains, Mont., by Frank Reeves, pp. 71-114, pls. 10-14. Gives record of the four wells that were drilled for oil in the area, with data on the water-bearing strata (pp. 103-106). Discusses the role of ground water in oil accumulation and gives two analyse of water from one of the wells (pp. 107-111), Describes the water resources of the area, stating that there are many springs along fault planes but little shallow ground water except in gravel terraces (p. 113). Includes a geologic map.

(d) Geologic structure of San Juan Canyon and adjacent country, Utah, by H. D. Miser, pp. 115-155, pls. 15 20. Gives rec Jrds and logs of wells, three of which feport artesian water (pp. 150-155). Includes a geologic map.

(e) The Scobey lignite field, Valley, Daniels, and Sheridan Counties, Mont., by A. J. Collier, pp. 157-230, pls. 21-29. Some springs issue at the contact of glacial drift and bedrock. Shallow wells obtain water in gravel. Wells in underlying rock yield water that often carries sulfur and iron (pp. 161, 162). Includes geologic map and structure and columnar section.

( $f$ ) The Ekalaka lignite field, southeastern Montana, by C. M. Bauer, pp. 231-267, pls. 30-34. States that the Dakota and Lakota sandstones are potential sources of artesian water and that the Fox Hills sandstone carries water in that part of the area which it underlies (p. 248). Includes geologic maps and columnar sections.

(g) Geology and oil and gas prospects of part of Moffat County, Colo,, and southern Sweetwater County, Wyo., by J. D. Sears, pp. 269-319, pls. 35-37. Mentions flows of hot sulfur water and salt water from the Frontier (?) sandstone (pp. 307, 308, 315, 316). Describes oil and gas shows in springs (pp. 309, 310). Mentions water in the Dakota sandstone (pp. 311, 319). States that Marshall's Spring furnishes hardly enough for camp use (p. 318). Includes a geologic structure contour map.

753. Geology and oil resources of a part of Los Angeles and Ventura Counties, Calif., by W. S. W. Kew. 1924. viii, 202 pp., 17 pls.

Contains data on numerous wells, some of which mention occurrence of water (pp. 121-196). Includes a geologic map and structure sections.

756. Oil and gas fields of the Lost Soldier-Ferris district, Wyo., by A. E. Fath and G. F. Moulton. 1924 . iv, 57 pp., 8 pls.

Gives K. C. Heald's opinion on relation of oll to edge water (b. 31). One of the graphic well logs of plate 8 records water at one horizon. Mentions water in the 
756. Oil and gas field osf the Lost Soldier-Ferris district, Wyo.-Continued.

riall Creek sand (p. 34) and in the Frontier sand (pp. 35, 52). Inclutes geologic maps showing structure on top of the Wall Creek sand, and graphic well logs.

759. Geology of the Bristow quadrangle, Creek County, Okla., with reference to petroleum and ratural gas, by A. E. Fath. 1925. iv, 63 fn., 13 pls.

Describes drainage and water supply of the area (p. 4). Most farms cbtain water from wells 15 to 35 feet deep. Water for some farms and municipalities and for well-drilling is obtained from deeper wells in sandstone, some as much as 300 feet deep. Data on oil wells at various places in the report mention the occurrence of water. Includes topographic and geologic map, stratigraphic sections, graphic well logs, correlated well sections, and structure contour maps.

760. Contributions to the geography of the United States, 1923-24; M. R. Campbell, geologist in charge. 1925. iv, 130 pp., 32 pls.

(c) Erosion by solution and fill, by W. T. Lee, pp. 107-121, pls. 23-39. Describes the formation of sinkholes in sputheastern New Mexico by solution and the development of underground drainage. Gives data on several wells and describes Carisbad Cavern.

762. Geology and ore deposis of the Rochester district, Nev., by Adolnh Knopf. 1924. ix, 78 pp., 4 pls.

Some of the descriptions of individual mines and prospects state whether or not the workings reached water level (pp. 59-76). Includes geologic map and structure sections.

763. Geology and ore deposits of the Aravaipa and Stanley mining districts, Graham County, Ariz., by C. P. Ross. 1925. vi, 120 pp., 18 pls.

Discusses oxidation and enrichment of ore deposits as related to the position of the water table (pp. 72-76). States that water was encountered in the shaft of the Arizona mine at a depth of 500 feet (p. 97). Describes a spring at the Cold Spring prospect (p. 108). Includes a geologic map and structure sections.

767. Geology and coal resources of the Gallup-Zuni Basin, N. Mex.. by J. D. Sears. 1925. v, 53 pp., 17 pls.

States that the Gallup city water supply comes from 7 wells 1,000 to 1,600 feet deep in Dakota sandstone (pp. 6, 7). Wells as much as several hundred feet deep furnish water to villages and settlers in the district (p. 51). Mentions a 1,155-foot well drilled for oil near Defiance Switch on the Santa Fe Ry., which obtained an artesian flow from the Navajo sandsione at 1,030 feet (p. 51). Includes geologic map of Gallup coal district showing structure on top of upper Oters coal bed, geologic map of Gallup-Zuni Basin, geologic map of Zuni Indian Reservation showing coal outcrops, map of - part of New Mexico showing structure on top of Chupadera formation, and columnar sections and graphic well logs.

770. The data of geochemistry (fifth edition), by F. W. Clarke. 1924. 841 pp. Larlier editions were published as Bulletins $330,491,616$, and 695 . Gives estimates of the total quantity of underground water in the earth's crust (p. 35). Contains a uiscussion of the statement and interpretaion of water analyses (pp. 64-68) and a short discussion of springs (pp. 68-69). A chapter on mineral wells and springs (pp. 181-217), the deflnition and classification of mineral waters (incluiling typical alluyses), changes in composition of water and reactions with adjacent material, chemical deposits from water, vadose and juvenile waters, and the relatior of thermal springs to volcanism.

774. The copper deposits near Salmon, Idaho, by C. P. Ross. 192? iv, 44 pp., 5 pls.

Gives a brief description of Salmon Hot Springs (p. 10). Includes a geclogic sketch map of part of the area.

775. Geology and lignite resources of the Marmarth field, southwestern North Dakota, by C. J. Hares. 15.28. vi, 110 pp., 14 pls.

'I here are numerous springs i $\iota_{L}$ the area, but their water is mostly of roor quality Wells also furnish water of poi * quality. A few flowing artesian wells in the area probably obtain water from the Fox Hills sandstone (pp. 10-11). Some of the township descriptions contain mentior. of the water supply (pp. 58-104). Inclutes geologic map showing outcrops of lignite beds, and columnar sections. 
780. Contributions to economic geology (short papers and Freliminary reports), 1925, Part I, Metals and nonmetals except fuels: G. F. Loughlin and G. R. Mansfield, geologists in charge. 1926. iv, 167 pp., 19 pls.

(0) Geslogy of a part of western Texas and southeastern l'Tew Mexico, with special reference to malt and potash, by H. W. Hoots, pp. 33-126, pls. 3-17. Contains numerous logs and other records of wells. Mentions occurrence of fresh water in the upper part of the Dockum group (Triassic) near Midland, Tex., and describes character and water supply of the Trinity sands (pp. 96, 98). Includes geologic map, maps showing thickness of salt beds and structure on top of salt beds, and graphic well logs.

781. Contributions to economic geology (short papers and preliminary reports), 1925, Part II, Mineral fuels; W. T. Thom, Jr., geologist in charge. 1926 . iii, 29 pp., 6 pls.

(i) Geology of the Baxter Basin gas field, Sweetwater County, Wyo., by J. D. Sears, pp. 13-29, pls. 2-6. Reports that many springs "issue alor' fault lines and along the contact of the Bishop conglomerate with older formaticns" (p. 15). Well tables mention occurrence of water in some wells (pp. 24, 25). Includes geologic and structure contour map, stratigraphic sections, and graphic we'l logs.

782. Ore deposits of the Jerome and Bradshaw Mountains quadrangles, Ariz., by Waldemar Lindgren, with statistical notes by V. C. Heikes. 1926. ix, 192 pp., 23 pls.

Describes relation of ground water to depth of oxidation, givin? depths to water level in certain mines (pp. 49-53). Some of the descriptions of individual mines and prospects also contain comments on water level in relation to oxidation, or depth to water level, or quantity of water pumped from the mines. Includis a geologic map.

783. Mineral resources of Alaska, report on progress of investigations in 1924, by P. S. Smith and others. 1926. ii, 168, xvii pp. 7 pls.

(a) usneral industry of Alaska in 1924 and Administrative report, by P. S. Smith, pp. 1-39; Selected list of Survey publications on Alaska, pp. i-x rii. States that a well drilled on the Pearl Creek dome in the Cold Bay district cbtained some gas and a strong flow of water at 3,017 feet (p. 29).

(b) Mineral investigations in southeastern Alaska, by A. F. Buddington, pp. 41-62, pls. 1-3. Describes Dalton Hot Springs and gives analysis of the water (pp. 56-58).

785. Contributions to economic geology (short papers and preliminary reports), 1926, Part I, Metals and nonmetals except fuels; G. F. Loughlin and G. R. Mansfield, geologists in charge. 1926. iii, 75 pp., 2 pls.

(a) Recent developments in the Aspen district, Colo., by Adolpt Knopf, pp. 1-28, p. 1. Suctes that large volumes of ground water issue from limestine into the Hope tunnel near Aspen (p. 25). Includes a geologic map.

(b) Potash investigations in 1924, by W. B. Lang, pp. 29-4r, pl. 2. Brine is recorded in 2 wells in Texas (p. 30) and in 1 flowing well in Utah (p. 39).

786. Contributions to economic geology (short papers and preliminary reports), 1926, Part II, Mineral fuels; W. T. Thom, Jr., geologist in charge. 1927. ii, 98 pp. 5 pls.

(a) The geology of the Ingomar anticline, Treasure and Rosebuc Counties, Mont., by K. C. Heald, pp. 1-37, pls. 1-2. States that springs and wells furnish the only permanent supply of water, the best being in the Judith River and Claggett formations at depths down to 1,500 feet (pp. 5, 6). The Dakota (b) sanc'stone in the anticline commonly carries water but is dry in some places (p. 22). I-cludes a geologic map showing structure on top of the Judith River formation.

(b) Geology of the Cat Creek and Devils Basin oil fields and adjacent areas in Montana, by Frank Reeves, pp. i-iv, 39-98, pls. 3-5. Discusses eff -et of circulating ground water containing sulfate on oil with which it comes in contact (p. 70). Describes occurrence of water in the sands of the Cat Creek field, including partial analyses of 11 water samples (pp. 71-80). Discusses role of groind water in accumulation of oil (pp. 81-86). Tabulated well data and logs of rells mention occurrences of water (pp. 87-95). Includes geologic map and structurs sections of part of the area, structure-contour map of central Montana, and granhic well logs. 
787. Geology and ore deposits of the Mogollon mining district, N. Mex., by H. G. Ferguson. 1927. vi, 100 pp., 25 pls.

States that permanent water level in the productive part of the district had had not been reached 800 feet below stream level, owing to damming sction of the Queen fault and vein (pp. 47, 48). A diagram shows probable relations of water level to oxidation and enrichment of the ore bodies (p. 49). Includes resonnaissance and detailed geologic maps and structure sections.

789. The Iniskin-Chinitna Peninsula and the Snug Harbor district, Alaska, by F. H. Moffit. 1927. iv, 71 pp., 11 pls.

Gives data on 6 test wells, mentioning salt water in 4 of them (pp. 49, 50). Includes topographic and geologic maps and structure sections.

794. "Red Beds" and associated formations in New Mexico, with an outline of the geology of the State, by N. H. Darton. 1928. xvi, 3־5 pp., 62 pls. (Published in April 1929.)

Contains numerous logs and other records of wells, many of which report occurrence of water. Includes a shaded topographic map of the State, rezonnaissance geologic maps of parts of the State, and a large number of stratigraphic and structure sections and graphic well logs.

795. Contributions to economic geology (short papers and prelininary reports), 1927, Part I, Metals and nonmetals except fuels; G. F. Loughlin and G. R. Mansfield, geologists in charge. 1928. iv, 221 r?., 12 pls.

(b) Potash brines in the Great Salt Lake Desert, Utah, by T. B. Nolan, pp. 25-44, pl. 3. Briefly describes saline springs occurring at the edge of the desert that yield water of much lower salinity than the brines of the desert flat (p. 32). Includes a map showing salinity of the brine underlying Great Salt Lake Desert.

796. Contributions to economic geology (short papers and prelininary reports), 1927, -Part II, Mineral fuels; W. T. Thom, Jr., geologist in charge. 1928. v, 201 pp., 27 pls.

(a) The Gillette coal fleld, northeastern Wyoming, by C. E. Dobbir and V. $\mathbf{H}$. Barnett, pp. 1-50, pls. 1-10: The Minturn district and the northwestern part of the Gillette field, by W. T. Thom, Jr., pp. 50-64, pls. 11-13. States that most domestic water supplies of the area are from dug and drilled wells and from springs issuing from coal beds. Water under artesian pressure is probably obtainable from the Fox Hills sandstone or lower part of the Lance formation (p. 5). Includes giologic maps of parts of the area.

(b) Geology and oil and gas prospects of northeastern Colorado, by K. F. Mather, James Gilluly, and R. G. Lusk, pp. 65-124, pls. 14-18. Well logs show th? occurrence of water (pp. 118-124, pl. 18). Includes geologic map and section of part of northeast Colorado, strueture-contour map of Fort Collins-Wellington oil fleld, and graphic well logs.

(c) Geology and coal resources of the Salina Canyon district, Se-rier County, Utah, by E. M. Spieker and A. A. Baker, pp: 125-170, pls. 19-22. Stetes that the Wasatch formation may carry water under artesian pressure near Saline Creek south of Taylor Flat (p. 170). Includes geologic map and structure section and columnar section.

(d) Geology and oil and gas possibilities of the Bell Springs district, Carbon County, Wyo., by C. E. Dobbin, H. W. Hoots, and C. H. Dane, pp. 171-202, pls. 23-27. States that numerous springs occur in the bluffs east of Separation Flats, especially near Bell Springs (pp. 172, 173). Well records mention orcurrence of water in some wells drilled for oil (pp. 193-195). Includes geologic nop showing structure on top of Cloverly formation in surrounding area and graph:s well logs.

797. Mineral resources of Alaska, report on progress of investigations in 1926, by P. S. Smith and others. 1929. ii, 227 , xii pp., 6 pls.

(f) Geology and mineral resources of the Aniakchak district, by R. S. Knappen, pp. 161-227, pl. 6. Briefly describes mineral springs in the area (p. 1EA). Includes a geologic map.

798. Geology of the Muddy Mountains, Nev., with a section through the Virgin Range to the Grand Wash Cliffs, Ariz., by C. R. Longwell. 1928. vi, 152 pp., 17 pls. 


\section{Geology of the Muddy Mountains, Nev.-Continued.}

A section on water resources describes springs in the area (pp. 16-18). Includes a geologic map and structure sections.

801. Geology and water resources of the Edgeley and La Moure quadrangles, N. Dak., by H. A. Hard. 1929. v, 90 pp., 5 pls.

Discusses springs of the area (p. 12), and a section on water rexources describes the occurrence of ground water in the glacial drift. Pierre and Berton formations, and especially in the Dakota sandstone (pp. 44-56). A section on artesian conditions and prospects, as shown by a survey in 1923 by $O$. E. Meinzer, gives the history of well drilling and describes original head and area of artesian flow, decline in head, shrinkage in area of artesian flow, increase in hydraulic gradient, and decline in yield of flowing wells from 1886 to 1923 (pp. 57-74). Gives data on specific capacities and total discharge of artesian wells, rate of recharge of Dakota sandstone, withdrawal of water from storage, compression of the sandstcne, and quality, temperature, and occurrence of natural gas in water of the Dakota sandstone (pp. 74-78). Tabulated well data give location, depth, and other infcrmation on the principal artesian wells in and near Edgeley quadrangle, including date on original head and flow and head and flow in 1923 (pp. 79-87). Includes geologic maps and maps showing thickness of glacial drift and artesian water conditions.

803. Geography, geology, and mineral resources of the Portneuf quadrangle, Idaho, by G. R. Mansfield. 1929. vi, 110 pp., 8 pls.

Describes the ground-water conditions and mentions springs anf travertine deposits (pp. 102-104). Includes a geologic map showing structure on the phosphate shale member of the Phosphoria formation, and structure sections.

804. Geology and coal and oil resources of the Hanna and Ce.rbon Basins, Carbon County, Wyo., by C. E. Dobbin, C. F. Bowen, and H. W. Hoots. 1929. vi, 88 pp. 27 pls.

Mentions the presence of water in several wells penetrating the unper part of the Cloverly formation (pp. 85, 86). Includes geologic map showing cutcrops of coal hers, structure sections, columnar sections, and graphic well logs.

806. Contributions to economic geology (short papers and preliminary reports) 1928, Part II, Mineral fuels; H. D. Miser, geologist in charge. 1929. v, 195 pp., 44 pls.

(a) The Pumpkin Buttes coal field, Wyo., by C. H. Wegemann, R. W. Howell, and C. E. Dobbin, pp. 1-14, pls. 1-5. States that "springs issuing from sandstone and coal beds occur at many places in the field; the largest are th? perennial Hot Springs" (p. 3).

(b) The northward extension of the Sheridan coal fleld, Big Hown and Rosebud Counties, Mont., by A. A. Baker, pp. 15-67, pls. 6-29. Describes s'reams, springs, and general ground-water conditions in the area (pp. 20-22). Log of a well gives depths to water-bearing beds (p. 64).

(c) Geology and oil and 'gas prospects of part of the San Rafael Swell, Utah, by James Gilluly, pp. 69-130, pls. 30-35. States that springs are few and that their water is of poor quality (p. 76). Log of a well in Emery County mentions occurrence of water at 2,943 feet (p. 129). Includes geologic map showing stucture on base of Shinarump conglomerate and structure and columnar sections.

(d) Geology of the Rock Creek oil fleld and adjacent areas, Carbon and Albany Counties, Wyo., by C. E. Dobbin, H. W. Hoots, C. H. Dane, and E. T. Hancock, pp. 131-153, pls. 36-43. Data on test wells mention water in the Clcverly formation (p. 49) and in the Wall Creek (?) sand (pp. 150-151).

(e) Thrust faulting and oil possibilities in the plains adjacent to the Highwood Mountains, Mont., by Frank Reeves, pp. 155-195, pl. \$4. Mentions "water in several sands" (p. 181) and various water-bearing sands in $\operatorname{logs}$ of 6 wells (pp. 186-190). Includes geologic map showing structure on top of Kootenai formation and structure sections.

808. Geology of the De Queen and Caddo Gap quadrangles, Ark., by H. D. Miser and A. H. Purdue. 1929. xi, 195 pp., 18 pls.

Describes water resources of the quadrangles (pp. 182-189). Statis that springs are numerous, especially in the mountainous parts of the area. Describes the hot 
808. Geology of the De Queen and Caddo Gap quadrangles-Continund.

springs and gives two analyses of their water. Says that water under artesian pressure may be obtained throughout most of the Coastal Plain portion cf the area. Maps show areas where flowing wells may be expected in the Trinity, Woodbine, and Tokio formations, and contours show the maximum depths to which artesian wells should be drilled (pp. 184, 185). Most of the older formations north of the Coastal Plain also yleld some water to wells. Includes geologic maps an th structure sections.

811. Contributions to economic geology (short papers and preliminary reports), 1929, Part I, Metals and nonmetals except fuels; G. F. Loughlin, G. R. Mansfield, and E. F. Burchard, geologists in charg?. 1930. vi, 252 pp., 53 pls.

(c) Indiana oolitic limestone, relation of its natural features to Its commercial grading, by G. F. Loughlin, pp. 113-202, pls. 27-45. Discusses relation of groundwater level to development of certain features of the limestone (pp. 138-143).

812. Contributions to economic geology (short papers and preliminary reports), 1929, Part II, Mineral fuels; H. D. Miser, geologist ir charge. 1930. vi, 338 pp., 48 pls.

(a) The Forsyth coal field, Rosebud, Treasure, and Big Horn Count'ing, Mont. by C. E. Dobbin, pp. 1-55, pls. 1-10. Describes springs from the Lanee and Fort Union formations (pp. 5, 6). States that domestic water supplies ar? obtained chiefly from dug wells or from drilled wells penetrating sandstone overlying the Rosebud coal bed.

(b) The Kevin-Sunburst oil field and other possibilities of oil and gas in the Sweetgrass arch, Mont., by A. J. Collier, pp. 57-189, pls. 11-18. Mention w well and spring water from the Virgelle sandstone (Cretaceous) (p. 61). States that large areas covered by Colorado shale have no potable water supply. Some of the well data (pp. 88-92) and tabulated well records (pp. 94-168) mention occurrence of water. Many of the "dry holes" yield salt water or sulfur water. Describes water associated with the oil (pp. 179, 180). Gives analyses of six water samplen (pl. 18). Includes maps of Sweetgrass arch and the Kevin-Sunburst field showing structure on the Madison limestone, and graphic well logs.

(c) Geology and coal resources of the Meeker quadrangle, Moffat and Rio Blanco Counties, Colo., by E. T. Hancock and J. B. Elby, pp. 191-242, pls. 19-30. Mentions occurrence of flowing salt water in two wells drilled for oil on the Meekir dom (p. 213). Includes geologic map showing structure on top of Trout Creek sandstone, and structure and columnar section.

814. Geology and ore deposits of the Wood River region, Idaho, by J. B. Umpleby, L. G. Westgate, and C. P. Ross, with a description of the Minnie More and nearby mines, by D. F. Hewett. 1930. ri, 250 pp., 33 pls.

Describes hot springs of the Wood River region and gives 3 analyser of water from Hailey Hot Springs (pp. 115-117). Discusses briefly the occurrence and quantity of ground water (pp. 117-120). Some of the descriptions of indivinual mines and prospects mention the presence of water.

816. Geology of the Eagle-Circle district, Alaska, by J. B. Mertie, J."., 1930. v, 168., 12 pls:

Describes a cold sulfur spring near Yukon River north of Calico Bluff and gives an analysis of the water (pp. 64, 65). Includes geologic reconnaissance map and structure sections.

818. Geology and mineral resources of the Cleveland district, Ohio, $I \geq \mathbf{H}$. P. Cushing, Frank Leverett, and F. R. Van Horn. 1931. vii, 128 np., 23 pls.

Mentions the presence of water in Devonian or late Silurian limestone -in the logs of two wells (pp. 117, 121). States that the Big Lime (Silurian) and Brea sandstone (Carboniferous) are aquifers (pp. 130-131). Describes briefly commercial springs and mineralized spring waters. Includes a topographic map showing the areal geology, a map showing the Pleistocene deposits, and one showing structure on top of the Clinton sand, and structure sections. 
819. The Wasatch Plateau coal field, Utah, by E. M. Spieker. 1931. vi, 210 pp., 33 pls.

Mentions springs from the Emery sandstone and Mancos shale and briefly comments on the quality of the water (p. 12). Includes geologic structure-contour maps and structure sections, a topographic map of the southern extersion of the fleld, and columnar sections.

821. Contributions to economic geology (short paper's and preliminary reports), 1930, Part I, Metals and nonmetals except fuels; G. F. Loughlin and E. F. Burchard, geologists in charge. 1931. iv, 77 pp., 18 pls.

(b) A geologic study of the Madden Dam project, Alhajuela, Canal Zone, by Frank Reeves and C. P. Ross, pp. 11-49, pls. 4-13. Presents the results of an investigation to determine the feasibility of constructing a dam to store water. mainly for dry-season use, in the Panama Canal. Gives data on vater-level in test holes and describes permeability and solution tests on samples f-om core drilling (pp. 20-24). Describes pressure tests in which water was pumper into test wells in an attempt to determine the amount and direction of leakrge and discusses location of the dam with respect to possible leakage (pp. 26-34). Gives logs of 24 test wells (pp. 43-49). Includes general topographic and geologic map of the reservoir and detailed geologic map and sections of the area in vicinity of dam.

822. Contributions to economic geology (short papers and preliminary reports), 1930, Part II, Mineral fuels; H. I). Miser, geolorist in charge. 1931. ii, 100 pp., 9 pls.

(a) Geology and mineral resources of parts of Carbon, Big Horn, Yellowstone, and Stillwater Counties, Mont., by R: S. Knappen and G. F. N'sulton, pp. 1-70, pls. 1-5. Describes briefly the water supplies of the area (p. 7). Both alluvial materials and sandstone below stream level yield water to wells; some wells flow. Describes circulation of ground water and notes that data on some wells report the occurrence of water (pp. 57-63). A section on ground water contains description of several wells and springs and two analyses of water from deep wells (pp. 67-70). Includes geologic map showing structure on top of the Greybull sandstone member of the Cloverly formation.

828. Geology and mineral resources of the Quakertown-Doylestown district, Pennsylvania and New Jersey, by F. Bascom, E. T. T'herry, G. W. Stose, and A. I. Jonas. 1931. iv, 62 pp., 4 pls.

A section on water resources describes surface-water and ground-water resources of the area, including occurrence of ground water in the different formations, descriptions of public supplies, and analyses of two samples, of vrater from public supplies (pp. 56-59). Includes geologic map and structure sections.

829. Geology and coal, oil, and gas resources of the New Kersington quadrangle, Pa., by G. B. Richardson. 1932. viii, 102 pp., 9 r.ls.

Logs and other records of wells report water in various sands in the oil-producing areas (pp. 55-56). Some of the well logs in an appendix (pp. 74-97) mention the occurrence of water. Includes geologic map, topographic map showing structure on top of Upper Freeport coal, sketch geologic and contour maps of surrounding areas, columnar sections, and graphic well logs.

831. Contributions to economic geology (short napers and preliminary reports), 1931-32, Part II, Mineral fuels; H. D. Miser, geologist in charge. 1932. iv, 108 pp., 37 pls.

(b) The Ashland coal field, Rosebud, Powder River, and Custer Counties, Mont., by N. W. Bass, pp. 19-105, pls. 3-37. Briefly describes ground-water resources of the area (p. 26). Many springs of potable water come from coal keds. Potable well water is obtainable in most parts of the area, and flowing artesian water is found in the Tongue River and Otter Creek Valleys. Where springs yield alkaline water from the Lebo shale, potable water may he obtained by drilling to the Lance formation. Contains geologic map showing outcrops of coal beds, and columnar sections.

835. Geology and oil resources of the Elk Hills, Calif., includ"ng Naval Petroleum Reservo No. 1, by W. P. Woodring, P. V. Rourdy, and H. R. Farnsworth. 1932. v, 82 pp., 22 pls. 
835. Geology and oil resources of the Elk Hills, Calif-Continued

Some of the well records mention occurrence of water (pp. 47-58). Describes the water of the eastern field, including occurrence, chemical characteristics, and direction and rate of movement (pp. 58-80). Shows location and migration of edge water in the different horizons (pls. 16, 17). Includes geologic map showing structure on limestone "A" of Tulare formation, map showing structure on top of the Scalez bed, and many graphic well logs.

837. Tertiary and Quaternary geology of the low Rio Grande regicn, Tex., by A. C. Trowbridge. 1932: viii, 260 pp., 45 pis.

Contains numerous well logs, some of which mention the occurrence of water. "Water is obtainable in wells at moderate depths in most parts of th ? region, but the water varies widely in quality" (p. 256). Includes geologic map of the region and structure contour maps of several of the oil and gas fields.

839. Geology of the Boston area, Massachusetts, by Laurence LaForge. 1932. v, 105 pp., 15 pls.

Describes briefly the ground-water and surface-water resources of the area (pp. 91, 92). Includes a geologic map and structure sections and map showing the surficial geology.

840. Geology and mineral resources of the Middletown quadrangle, $\mathrm{Pa}$., by G. W. Stose and A. I. Jonas. $1933 . \quad$ v, 86 pp., 15 pls.

Describes briefly springs of the area, with comments on the quality of spring water, occurrence of ground water in the different formations, and the larger springs in the area (pp. 76-82). Includes geologic map and structure sections.

841. Geology and oil possibilities of the Moab district, Grand and San Juan Counties, Utah, by A. A. Baker. 1933. v, 95 pp., 11 pls.

ve.eriwes brieny springs of the area, with comments on the quality of spring water from the different formations (pp. 7,8 ). Record of a well on the Shafer dome reports fresh water at a depth of 5,860 feet in beds separated by shale from overlying salt beds (p. 17). Logs of 8 wells report occurrence of water in the Hermosa, Paradox, and Molas (?) formations (pp. 85-92). Includes a geoloric map and structure sections and a geologic structure contour map.

842. Metalliferous deposits of the greater Helena mining region, Mont., by J. T. Pardee and F. C. Schrader. 1933, xi, 318 pp., 47 pls.

A few of the descriptions of individual mines contain references to depth to water level, or volume of water pumped from mines. Includes a geologi: map of the region and detailed geologic maps of a number of the mining districts.

843. A brief review of the geology of the San Juan region of sonthwestern Colorado, by Whitman Cross and E. S. Larsen. 1935. vi, 138 pp., 16 pls.

Briefly describes water supplies of the region (pp. 132, 133). Incl ades geologic map, drainage map showing distribution of hot springs, and columner sections.

844. Mineral resources of Alaska, report on progress of investirations in 1931, by P. S. Smith and others.

(c) The Suslota Pass district, upper Copper River region, Alaska, by F. H. Moffit. 1933. pp. i-ii, 137, 162, pl. 2. Briefly describes springs and undergrormd drainage of the area (p. 140). Includes geologic reconnaissance map.

(d) Mineral deposits of the Rampart and Hot Springs districts, Alaska, by J. B. Mertie, Jr. ; Placer concentrates of the Rampart and Fot Springs distrints, by A. E. Waters, Jr., 1934, pp. i-iv, 163-246, pls. 3-5 Describes Manley Hot Springs and Hutlinana Hot Springs, with analysis of a sample of water from each (pp. 224-226).

846. Contributions to economic geology (short papers and prelininary reports), 1933; G. F. Loughlin, geologist in charge.

(a) Some mining districts of eastern Oregon, by James Gilluly, J. C. Reed, and C. F. Park, Jr. 1933. pp. i-viii, 1-140, pls. 1-8. Many of the deseriptions of individual mines and prospects contain references to water levels in the mines. Includes geologic maps of the Morman Basin and Virtue districts and of Gold Fill and vieinity in the Ochoco Creek area. 
847. Contributions to economic geology (short papers and preliminary reports), 1934-36; G. F. Loughlin, geologist in charge.

(a) The Contact mining district, Nev., by F. C. Schrader. 1935. pp. i-iv, 1-41, pls. 1-4. States that oxidation of the ores extends 150 to 250 feet below the surface, although water level is reached at shallower depths in most mir.ss (p. 17). A few of the descriptions of individual mines contain comments on cuantities of water encountered in mining. Includes geologic reconnaissance map.

(b) The Rosebud coal field, Rosebud and Custer Counties, Mont., by W. G. Pierce. 1936. pp. i-iv, 43-120, pls. 5-21. Discusses surface-water and ground-water supplies and gives data on springs and flowing artesian wells in the area (pp. 45-51). Includes a geologic map showing outcrops of coal beds, a generalized structure-contour map, and structure and columnar sections.

(c) The Richey-Lambert coal field, Richland and Dawson Counties, Mont., by F. S. Parker. 1936. pp. i-iy, 121-174, pls. 22-27. Briefly describes surface-water and ground-water supplies of the area in a section on drainage and water supply, including comments on the quality of water from different formations (pp. 126, 127). Includes a geologic map showing outcrop of coal beds, a generalized structure coal map, and columnar sections.

(e) Geology and mineral resources of the western part of the Arkansas coal field, by T. A. Hendricks and Bryan Parks. 1937. pp. i-iv, 189-224, pl. 35. Describes occurrence of salt water in gas-bearing sands in the area (pp. 215, 216).

(f) Geology and mineral resources of north-central Chouteau, western Hill, and eastern Liberty Counties, Mont., by W. G. Pierce and C. B. Hunt. 1937. pp. i-iv, 225-270, pls. 36-43. Describes briefly water resources of the area. "The two formations that yield the greatest amount of water are the Judith River formation and the Eagle sandsone" (p. 264). Includes geologic map showing structu"e on top of Eagle sandstone, columnar sections, and graphic well logs.

849. Investigations in Alaska Railroad belt, 1931, by P. S. S̈mith and pthers.

(g) The Girdwood district, Alaska, by C. F. Parks, Jr. 1933 [1934]. pp. i-viii, $381-424$, pl. 33. Discusses the relation of oxidation of the ores to position of the water table (pp. 409, 410). Briefly describes water supplies of the area (p. 413). Includes geologic map and structure sections.

851. The Book Cliffs coal field in Garfield and Mesa Counties, Colo., by C. E. Erdmann. 1934 (1935.) vi, 150 pp., 21 pls.

Briefly describes drainage and water supply of the area (pp. 16-19). States that springs are few and their water is poor. Says that salt water ras encountered at 265 feet in a well drilled for oil. One mine was flooded, probakly by water from coal beds. Mentions the presence of salt water in the Mancos shale and water in the Entrada and Wingate sandstones (pp. 70-72). Includes geologic map showing outcrop of coal beds, map showing structure on top of the Sego sandstone, and structure and columnar sections.

852. The Book Cliffs coal field in Emery and Grand Counties, Utah, by D. J. Fisher. 1936. iv, 104 pp., 15 pls.

Data on a test well for oil show water in the Navajo-Wingate sandstone (p. 42). Reports water in six wells near Cisco in the Dakota (?) sandston? (p. 44). Includes geologic structure contour maps and structure sections.

853. Zinc and lead deposits of northern Arkansas, by E. T. McKnight. 1935. vi, $311 \mathrm{pp} ., 11 \mathrm{pls}$.

States that springs are abundant throughout the area and that they supply the fair-weather flow of streams (pp. 13-15). Discusses the origin of the ores; the theory of deposition by artesian circulation is believed not to apvly (pp. 138-150). Also briefly discusses relation of oxidation of the ores to the position of the water table (p. 151). Some of the descriptions of individual mines mention occurrence of water and depth to water level (pp. 153-303). Includes geoloxic maps showing structure on base of St. Joe limestone and on St. Peter sandstone and structure sections.

854. Geology and ore deposits of the Casto quadrangle, Idaho, by C. P. Ross. 1934 (1935). vi, 135 pp., 8 pls.

Describes the hot springs of the area and_gives analyses of water samples from three of them (pp. 105, 106). Includes geologic map and structur? sections. 
855. Geology and mineral resources of the Bellefonte quadrangle, Pa., by Charles Butts and E. S. Moore. 1936. vi, 111 pp., 12 pls.

Briefly describes underground drainage of the area (p. 12). Sinkho'es are common. Discusses the water resources, gives the records of several drillet wells, and describes the municipal supplies of the larger towns (pp. 105-107). Incl ides geologic map and structure sections.

856. Geology of Big Horn Ćounty and the Crow Indian Reservation, Mont., with special reference to the water, coal, oil, and gas res ources, by W. T. Thom, Jr., G. M. Hall, C. H. Wegemann, and G. F. Moulton. 1935. vii, 200 pp., 15 pls.

Describes briefly the ground-water investigations made in Montana from 1915 to 1921 (pp. 8, 9). Treats of drainage and surface-water irrigation (pp. 19-24). Logs of gas and oil wells mention occurrences of water (pp. 104-124). Hiscusses the water resources of the county under the following heading: Water-bearing properties of the rock formation, Relation of rock structure to water supply, Artesian conditions, Water supplies, Methods of obtaining ground-water supplies, Storage of surface water, Storage of ice, and Quality of water. The last includes analyses of 36 water samples. Gives detailed descriptions of water supplies by townships (pp. 156-196). Includes geologic map showing structure on top of Cloverly formation, structure section, detailed structure-contour maps of parts of the area, and colum nar sections and graphic well logs.

860. Geology and fuel resources of the southern part of the San Jran Basin, N. Mex.

(b) Part 2, The Mount Taylor coal field, by C. B. Hunt. 1936. i-vi, 31-80, pls. 18-38. Data on several wells record water in the Dakota sandstone, and water in the Mesaverde formation is mentioned (pp. 79, 80). Includes geolog c structurecontour map and columnar section.

(c) Part 3, The La Ventana-Chacra Mesa coal field, by C. H. Dane. 1936 [1937] pp. i-v, 81-166, pls. 39-55. Describes drainage and water supply of the area and mentions several springs (pp. 85, 86). Includes geologic map showing structure on base of Hasta sandstone, and columnar sections.

861. Geology of the Anthracite Ridge coal district, Alaska, by G. A. Waring, 1936 (1937). iv, 57 pp., 14 pls.

The occurrence of flowing artesian water in 4 of the 8 test holes drilled is mentioned (pp. 46-48). The drilling equipment and method of drilling are described (pp. 49-54). Includes topographic and geologic maps; structure sections, and graphic well logs.

863. Geology of the Salt Valley anticline and adjacent areas, Grant County, Utah, by C. H. Dane. 1935 (1936). v, 184 p.j., 21 pls.

Describes the topography, drainage, and water supply of the area (pp. 5-11). "The springs of the area provide the most satisfactory source of drinking water." Well logs and well records mention occurrences of salt water and sulfur water in several formations (pp. 158-171). Includes geologic map, a map showing structure on base of the Wingate sandstone, and structure sections.

865. Geology of the Monument Valley-Navajo Mountain region, San Juan County, Utah, by A. A. Baker. 1936. vi, 106 pp., 17 pls.

A section on drainage and water supply mentions the underflow in Oljeto Wash and states that the principal domestic water supplies are from springs, the location of which are shown on the geologic map (pp. 10-12). Refers to the apparent lack of water in the sediments penetrated by wells drilled for oil and gas (p. 97). Includes geologic structure-contour map. structure sections, reconnaissance topographic map, and columnar sections.

867. Geology of the Coastal Plain of South Carolina, by C. W. Coo're. 1936. v, 196 pp., 18 pls.

Contains numerous descriptions of wells, springs, and sinkholes and $\varepsilon$ number of well logs (pp. 21-152). Describes ground-water resources of the region, insluding data on the water-bearing characteristics of the different formations, the quality of the water, and county descriptions (pp. 161-188). Includes records of abort 250 wells 


\section{Geology of the Coastal Plain of South Carolina-Contirned.}

and about 100 water analyses. Contains geologic map of the Cretaceous and Tertiary formations and a map showing distribution of the Quaternary formations and terraces.

870. Geology and ore deposits of the Bayard area, Central mining district, N. Mex., by S. G. Lasky. 1936. vi, 144 pp., 17 pls.

Briefiy describes water supply of the area. Streams are internittent except for short stretches fed by springs, most of which occur along faults. Water is generally obtained from wells, which must be drilled to depths of several hundred feet. The water table stands at about stream level in the area. Describes several wells in the area and occurrence of water in the Ground Hog mine (pp. 9-11). Discusses the relation of water level to depth of supergene alteration (p. 1c0). Some of the descriptions of individual mines and prospects mentions depth th water level or quantities of water encountered (pp. 105-138). Shows the approximate position of permanent water level in part of the area (p. 15). Includes geologic map and structure sections.

871. Mineral resources of the region around Boulder Dam, by D. F. Hewett, Eugene Callaghan, B. N. Moore, T. B. Nolan, W. W. Pubey, and W. T. Schaller. 1936 . vi, 197 pp., 14 pls.

Describes the artesian basin in the vicinity of Las Vegas, Clark County, Nev. Measurements of discharge from about 50 wells show a $3 \overline{5}$ to 50 percent decline "during the last 15 years" (p. 183).

873. Geology and mineral resources of the Butler and Zelienople quadrangles, Pa., by G. B. Richardson. 1936. v, 93 pp., 8 pls.

Logs and other records of wells drilled for oil mentions occurrence of water, and description of oil and gas resources gives some data on presense or absence of water in the various oil sands and on quality of the water (pp. 10, 11, 46-64). A section on water describes briefly the surface-water and grounc-water resources, mentioning the principal water-bearing formations (pp. 69-72). Includes analyses of four. samples of water from deep wells and one sample from a shallow well. Gives result of thermal gradient determination in a deep well. Some of the well logs mention occurrence of water (pp. 76-88). Includes a geologic map of each quadrangle and a topographic map of each that also shows structire on top of the Vanport limestone.

874. Geology and fuel resources of the southern part of the Oklahoma coal field.

(a) Part 1, The McAlester district, Pittsburg, Atoka, and Latimer Counties, by T. A. Hendricks. 1937. pp. i-iv, 1-90, pls. 1-10. Describes very briefly the water supply of the district (p. 8). Also describes the water-bearing properties of the Gerty sand (Quaternary) (p. 93). Includes geologic map showing cistribution of the Gerty sand, and structure sections.

(b) Part 2, The Lehigh district, Coal, Atoka, and Pittsburg Ccunties, by $\mathbf{M} . \mathbf{M}$. Knechtel. 1937. pp. i-iv, 91-149, pl. 11. One of the records of we'ls drilled for oil and gas mentious the occurrence of salt water (p. 142). Includes a geologic map showing structure on the Lehigh coal bed.

(c) Part 3, The Quinton-Scipio district, Pittsburg, Haskell, and Latimer Counties, by C. H. Dane, H. E. Rothróck, and J. S. Williams. 1938. pp. i-v, 151-253, pls. 12-26. One of the records of wells drilled for oil and gat mentions orcurrence of salt water (p. 207). The lower beds of the middle part of the McAlester shale almost invariably carry "a hole full of water" (p. 210). States that the Hartshorne sandstone is the chief gas-producing formation in the area but is barren of liquids at atmospheric pressures and that a well penetrating the Morrow formation obtained water near the base (pp. 212, 213). Describes the use of casing to shut off water in gas wells in the area (p. 222). Includes geologic map showing distribution of Gerty sand, structure contour maps, and graphic well logs showing occrrrence of water.

877. Geology and ore deposits of the Bayhorse region, Custer County, Idaho, by C. P. Ross. 1938 . vii, 161 pp., 18 pls.

Describes briefly a spring-fed stream, Warm Springs Creek (p. 7). Mentions deposits of travertine, some of which are believed to be spring depositi, and describes 
877. Geology and ore deposits of the Bayhorse region-Continued.

the hot springs of the area, with analyses of water from three of the springs (pp. 62-65). Notes the high permeability of the Germer tuffaceous beds. In certain parts of the area these absorb much of the rainfall and diminish surface run-off (p. 98). $A$ few of the descriptions of individual mines and prospects mention cceurrence of water, or depth to water level in the mines (pp. 116-157). Includes geolc gic map and structure sections.

879. Geology and mineral resources of the Baker quadrangle, Oreg., by James Gilluly. 1937. vi., 119 pp., 3 pls.

A section on development of drainage discusses the part played by ground water in the undermining and recession of permeable lava beds where such beds overlie relatively impermeable unconsolidated sediments (pp. 79-83). Several of the descriptions of individual mines and prospects mention occurrence of ground weter or depth to water level (pp. 93-114). Includes a geologic map and structure sect'ons.

884. Geology and mineral deposits of the Snowmass Mountain area, Gunnison County, Colo., by J. W. Vanderwilt. 1938. viii, 184 pp., 24 p's.

Some of the descriptions of individual mines and prospects mention oncurrence of water or position of the water level (pp. 114-152). Includes a geoloric map and structure sections.

885. Geology and ore deposits of the Lordsburg mining district, Hidalgo County, N. Mex., by S. G. Lasky. 1938. v, 62 pp., 25 pls.

A section on surface and ground water states that springs and strears are absent from the district (pp. 8, 9). Gives average depths to the water table in the hill and valley portions of the district. Gives data on quantities of water en countered in mines, including rates of pumping at several mines and effect on the water table in the vicinity. Includes analyses of two samples of mine waters. Briefly discusses position of the water table as related to oxidation and enrichment of the area (p. 41). Several of the descriptions of individual mines and prospects mention occurrence of water or denth to water level. Includes geologic maps and structure sections.

886. Contributions to economic geology (short papers and prelininary reports), 1937; H. D. Miser, E. F. Burchard, D. F. Hewett, and G. R. Mansfield, geologists in charge.

(c) Geology and ore deposits of the southwestern Arkansas quick-si' rer district, by J. C. Reed and F. G. Wells. 1938. pp. i-vi, 15-90, pls. 2-17. Several of the descriptions of individual mines and prospects mention occurrence of quantities of water in the mines. Includes geologic map and structure sections.

891. Geology and mineral resources of the Honeybrook and Pl senixville quadrangles, Pa., by F. Bascom and G. W. Stose. 1938. v, 145 pp., 11 pls.

Describes ground-water resources of the quadrangles, including dereriptions of the water-bearing characteristics of the three major classes of rock present (unmetamophosed, and igneous), the principal water-bearing formations, and public and privat water supplies. Includes analyses of samples of water from three springs (pp. 135-140), a geologic map, and structure sections.

893. Metalliferous mineral deposits of the Cascade Range in $O$ "egon, by Eugene Callaghan and A. F. Buddington. 1938. viii, 141 pp., 22 pls.

A few of the individual descriptions of mines and prospects mention the occurrence of water. Describes the hydrothermal alteration of wall rock (p. 49). Contains reconnaissance geologic map of the Cascade Range in Oregon south of Mount Hood and a topographic and geologic map of the Bohemia district.

899. Geologic structure and occurrence of gas in part of southwestern New York.

(a) Part 1, Structure and gas possibilities of the Oriskany sandstone in Steuben, Yates, and parts of the adjacent counties, by W. H. Bradley and J. F. Tepper. 1938. pp. i-iv, 1-68, pls. 1-4. Briefly describes the permeability and occurrence of salt water in the Oriskany sandstone (p. 46). Many of the records of wells in the quadrangle descriptions and in the well tables mention occurrence of salt weter or fresh water (pp. 46-65). Includeg geologic structure contour map. 
902. The brown iron ores of eastern Texas, by E. B. Eckel. 1938. vi, 157 pp., 20 pls.

Shallow wells in the Sparta sand (Eocene) give abundant supplies of good water (p. 32). "As a general rule two of the chief horizons for shallow water wells on the uplands of eastern Texas occur near the top and base of the Weches greensand. Where the Sparta sand is more than about 12 to 15 feet thick the wells encounter water at the top of the Weches member, but where the Weches occurs at the surface water is ordinarily found at or near the base of the greensard" (p. 44). Discusses the relation of the ground-water table to the iron deposits and gives an analysis of water from Hughes Springs (pp. 44, 45).

903. The Nushagak district, Alaska, by J. B. Mertie, Jr. 1938 iv, 96 pp., 12 pls.

Gives data on several wells drilled in glaciofluviatile deposits of the Nushagak Bay area (pp. 70, 71).

905. The coal resources of McCone County, Mont., by A. J. Colling and M. M. Knechtel. 1939. vii, 80 pp., 16 pls.

"Most of the water for domestic use is obtained from shallow dug wells near the creeks, from drilled wells a few teet to 200 or 300 feet deep, and from springs near the outcrops of coal beds. The towns of Circle, Brockway, and vida obtain practically their entire water supplies from a single well each. A well 270 feet deep at Circle supplies water for use in the locomotives of the Northern Pacific Railway" (p. 7).

906. Contributions to economic geology, 1938-39, short papers an preliminary reports, by N. H. Darton, D. A. Andrews, W. S. Burbank, and others.

(b) Geology and coal resources of the Minot region, N. Dak., by D. A. Andrews. 1939. pp. i-iv, 43-84, pls. 11-15. Discusses artesian water in the Des Lacs area (p. 80, 81). Shows the approximate extent of the flowing-well area and the location of many other water wells, in which the approximate depth to water is indicated by the altitude of the coal beds (p. 11). See also Water-Supply Paper 598, pages 250-262.

(c) The Mizpah coal field, Custer County, Mont., by F. S. Prxker and D. A. Andrews. 1939 [1940]. pp. i-iv, 85-133, pls. 16-40. "Water for dcmestic supply is obtained from wells and springs. Along the Powder River flowing wells 100 to 300 feet in depth penetrate sandy layers of the sandstone member of the Lance formation and furnish plentiful supplies of potable water. Along Mizpal Creek wells of equal depth do not flow, but the water rises within a short distance of the surface" (p. 91).

908. Geology of area between Green and Colorado Rivers, Grnnd and San Juan Counties, Utah, by E. T. McKnight. 1944. (1941). v, 147 pp., - 13 pls.

Describes and gives the location of the principal springs of the area (pp. 15, 16, pl. 1).

921. Contributions to economic geology, 1940, short papers by H. D. Miser, W. G. Pierce, and D. A. Andrews.

(a) Manganese carbonate in the Batesville district, Ark., by H. D. Miser, with a chapter on minerals of the ores, by D. F. Hewett and H. D. Miser. 1941. pí. i-v, 1-97. pls. 1-10. Mentiops the action of ground water on the character and concentration of the ore bodies (pp. 31, 38-40).

(b) Geology and oil and coal resources of the region south of Codv, Park County. Wyo., by W. G. Pierce and D. A. Andrews. 1941. pp. i-v, 99-180, i-iv, pls. 11-24. Describes hot-spring deposits of sulfur (p. 177).

922. Strategic minerals invéstigations, 1940, short papers and preliminary reports.

(b) Quicksilver deposits of the Battle Creek district, Humboldt County, Nev., a preliminary report; by $R$. J. Roberts. 1940 . pp. i-iii, 1-29. pls. 1-5. "The lodes of the Mount Diablo district appear to have been deposited from hot waters that derived their metallic constituents from distant magmatic sources" (p. 49). "The warm springs near the Mount Diablo mine and those near many other quilcksilver 
922. Strategic minerals investigations, 1940-Continued.

mines may represent dying stages of the hot-spring activity that rroduced the mineral deposits" (p. 50). "It seems clear that nearly all of the sulphide minerals are products of the original mineralization, deposited from ascending water. . . . In the Mount Diablo district, as in many others, the effects produced on quicksilver ores by descending waters appear to be trivial economically" (p. 51).

g) ifanganese aeposits at Philipsburg, Granite County, Mont., a preliminary report, by E. N. Goddard. 1940. pp. i-iv, 157-204, pls. 26-34. "There seems littl ? doubt that the primary ore of the Philipsburg district was deposited from: hydrothermal solutions that rose from depths along vein fissures. . . . The early ore-bearing solutions introduced quartz and the sulphides. . . . The later solutions, whicl carried the bulk of the manganese, deposited manganese carbonate. . . . It is possible that in the course of weathering and oxidation some of the manganese has bien dissolved by circulating ground water and redeposited at lower levels" (p. 177). Discusses the irregularity of the water table and its relation to the depth of oridation (pp. 178. 179).

(b) Antimony deposits of the Wildrose Canyon area, Inyo Count,', Calif., by D. E. White. 1940. pp. i-iii, 307-325, pls. 45-46. Mentions hot-spring deposits of alluium cemented by travertine and their relation to antimony minerals (p. 314). "The ore bodies probably were deposited at relatively low temperature and pressure by aqueous solutions ascending from deep-seated igneous sources" (p. 319).

(l) Quicksilver deposits of the Mayacmas and Sulphur Bank districts, Calif., a preliminary report, by C. P. Ross. 1940 (1941) pp. i-iii, 327-353, pls. 47-53. Discusses the origin of the deposits through the agency of "hot solutions fror some deep magmatic source" (pp. 345, 346).

$(r)$ Quicksilver deposits in San Luis Obispo County and southwestern Monterey Gounty, Calif., by E. B. Eckel, R. G. Yates, and A. E. Granger. 1941. pp. i-v, 515-580, pls. 78-87. Discusses the origin of the deposits by solutions rising from considerable depth along faults and deposition due to "the chemical nature of the rocks or of the ground waters within them" (pp. 543-544).

923. Geology and mineral resources of the Randolph quadrangle, Utah-Wyo., by G. B. Richardson. 1941. v, 54 pp., 8 pls.

Describes water supplies from springs and wells. Swan Creek Spring, Utah, issues from the Blacksmith limestone, the discharge being 30 to 35 second-feet in winter and more than 200 second-feet in May (pp. 49-51).

934. Phosphate resources of Florida, by G. R. Mansfield. 1942. iv, 82 pp., 8 pls.

Gives logs of five deep wells (pp. 52-56).

936. Strategic minerals investigations, 1942, short papers and preliminary reports.

(q) The Coso quicksilver district in Inyo County, Calif., by C. P. Ross and R. G. Yates. 1943. pp. 395-416. Describes deposits of siliceous sinter and ca'eareous tufa near Coso Hot Springs (pp. 402-403, 412-416).

I

\section{MINERAL RESOURCES}

The report on mineral resources for the calendar years 1883 and 1884 and the reports for each subsequent year contain sections on mineral waters, which give statistics, by calendar years, of production, importation, and exportation, lists of mineral springs, and other information in regard t? the trade in. the waters of the United States that are sold for medicinal or table use. The statistics are given largely by States.

The reports on mineral waters for successive years were prepared by the following authors:

1883-1900, inclusive, by A. C. Peale.

1901-1904, inclusive, anonymous.

1905, by M. L. Fuller.

1906-1909, inclusive, by Samuel Sanford. 
Reports on mineral waters-Continued.

1910-1912, inclusive, by G. C. Matson.

1913-1915, inclusive, by R. B. Dole.

1916-1919, inclusive, by A. J. Ellis.

1920-1923, inclusive, by W. D. Collins.

In addition to the annual statistics, these reports contain the following papers relating to mineral water:

Mineral Resources of the United States, 1882. 1883.

The divining rod, by R. W. Raymond, pp. 610-626. Gives a vivid historical review and discussion of the so-ealled "divining rod," which has been s'pposed to have virtue for finding ground water and other minerals, as well as for detecting criminals, ete.

Mineral Resources of the United States; 1905. 1906.

Bibliography of mineral waters, by A. C. Peale, pp. 1308-1312. Ir cludes a general bibliography and a bibliography for the United States, 1903-1905.

Mineral Resources of the United States, 1911, Part II, Nonmetal - 1912.

The concentration of mineral water in relation to therapeutic antivity, by $R$. $B$. Dole, pp. 1175-1192. Discusses mineral constituents in relation to physiological reactions, minimum doses of inorganic substances, the therapeutic action of certain inorganic radicles, and tolerance for mineral matter in drinking we.ter.

Mineral Resources of the United States, 1913, Pairt II, Nonmetals. 1914.

Published analyses of American mineral waters, by R. B. Dole, pp. 433-434. An incomplete bibliography of papers containing analyses of mineral waters.

Radioactivity of mineral waters, by R. B. Dole, pp. 435-440. Gives the radioactivity of 52 well-known waters from springs in Europe and the United States, compares their strength with that of radioactive compounds used in medical practice, and discusses therapeutic uses of radioactive waters. Includes an incomplete bibliography of publications on radium, radioactivity, and radiotherapy.

Mineral Resources of the United States, 1914, Part II, Nonmetals. 1916.

A historical sketch of the mineral-water trade, by R. B. Dole, pp. 215-219. Tabulates and discusses the domestic prodaction and importation from 1883 to 1914 and includes diagrams showing the annual production and the p-ice during this period.

Mineral Resources of the United States 1916, Part II, Nonmetals. 1919.

Comparison of American and European mineral waters, by A. A. Chambers, pp. 500-510. Compares the analyses of certain chalybeate, carbonate, sulfide, chloride, and sulfate spring waters in the United States with the analyser of well-known mineral waters of Europe of similar types. Concludes that the counterparts of European waters can in general be found in this country. Contains a brief bibliography of mineral waters, chiefly those from American springs.

Mineral Resources of the United States, 1918, Part II, Nonmetals. 1921.

Mineral waters, by A. J. Ellis, pp. 495-531, pl. 5. States that the three groups of waters included are natural carbonated waters that have lost part of their carbon dioxide, natural waters that have been artificially carbonated, and waters from which iron has been removed. Three uses of mineral water are racognized-table use, medicinal use, and use, in the manufacture of soft drinks. TI map showing distribution of sources of mineral waters indicates concentration of the industry in California, Minnesota, Wisconsin, Illinois, and the North Atlantic Cinst States.

Mineral Resources of the United States, 1921, Part II, Nonmetals. 1924.

Mineral waters, by W. D. Collins [with list of published analyses of mineral waters], pp. 229-236. In addition to statistics of sales of mineral waters in 1920 and 1921, gives statements and figures on the condition of trade. Also discusses - the value of analyses of mineral waters and lists 16 publications containing "large numbers of analyses of springs waters, analyses of water from sp-ings of special importance, or analyses of other waters with which spring waters ma" be compared."

Mineral Resources of the United States, 1923, Part II, Nonmetals. 1927.

Mineral waters, by W. D. Collins, pp. 109-124. In addition to the statistics on sales in the United States in 1922 and 1923, gives statistics on soft drinks and on imports and exports, with a discussion of the condition of trade and a review of the mineral-water trade, 1883-1923. Tabulates by states the source of mineral waters sold in 1923, giving the name and location of each spring or well. 
GEOLOGIC FOLIOS

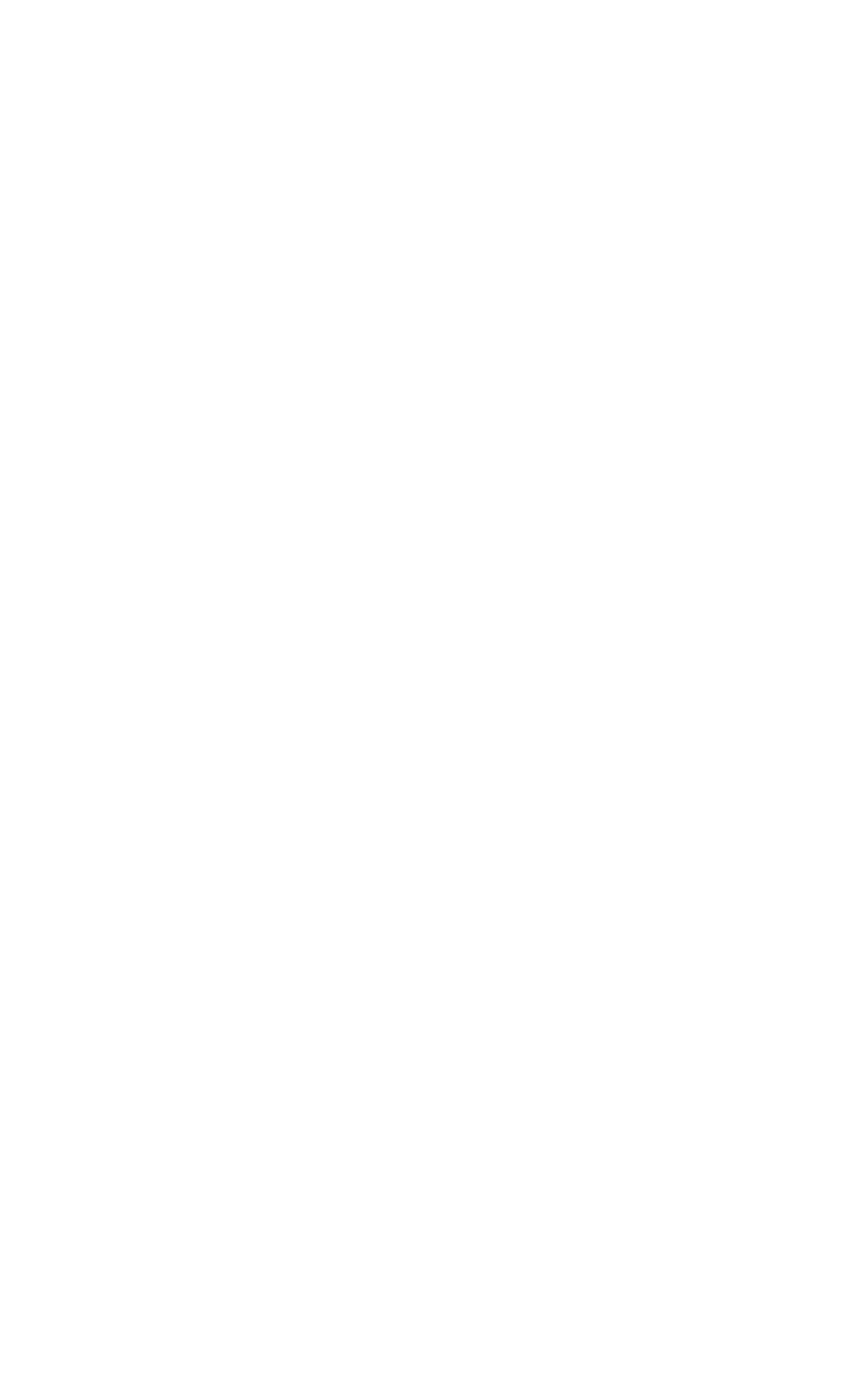


- Geologic foliog-Continued

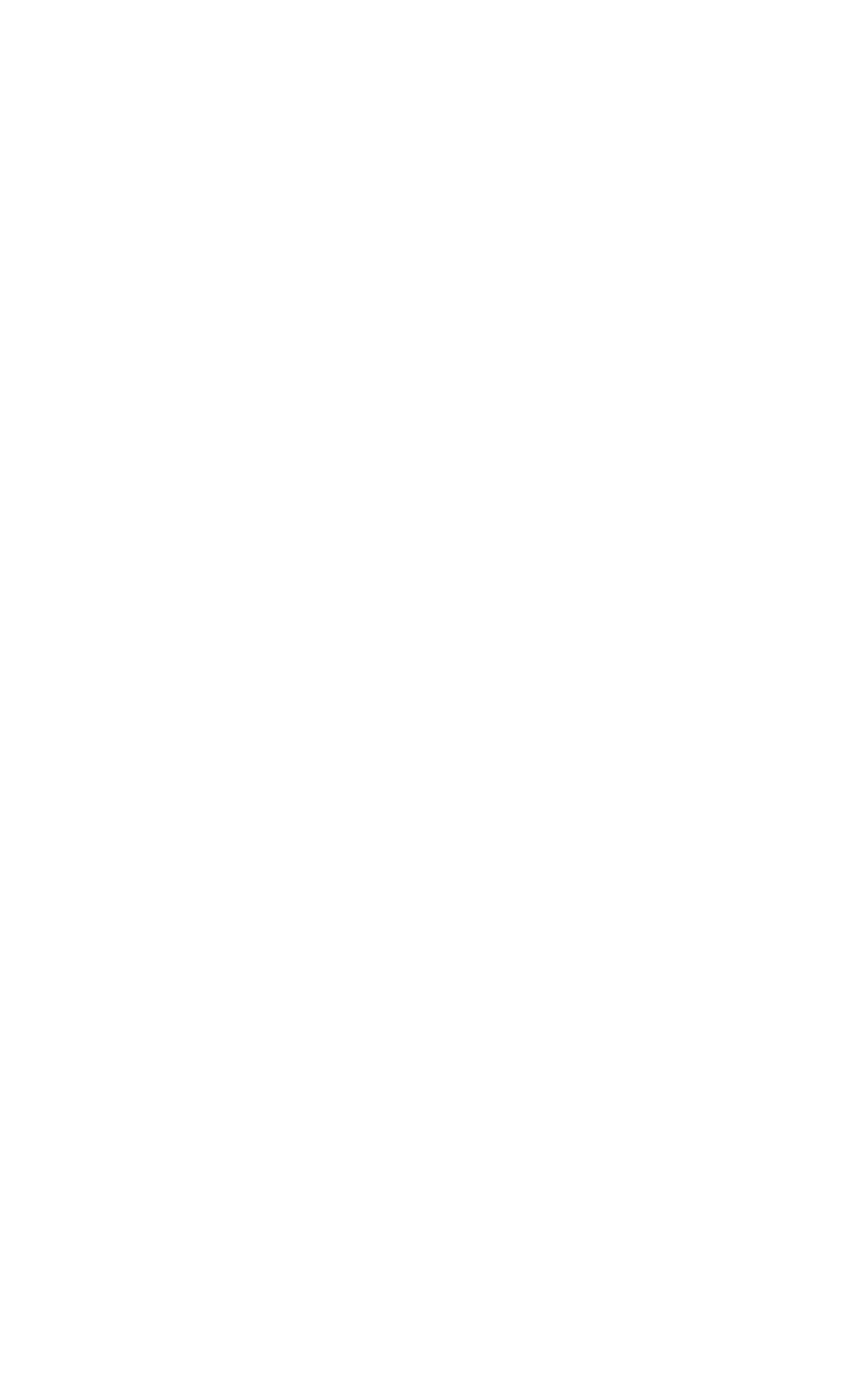


Geologic folios-Continued

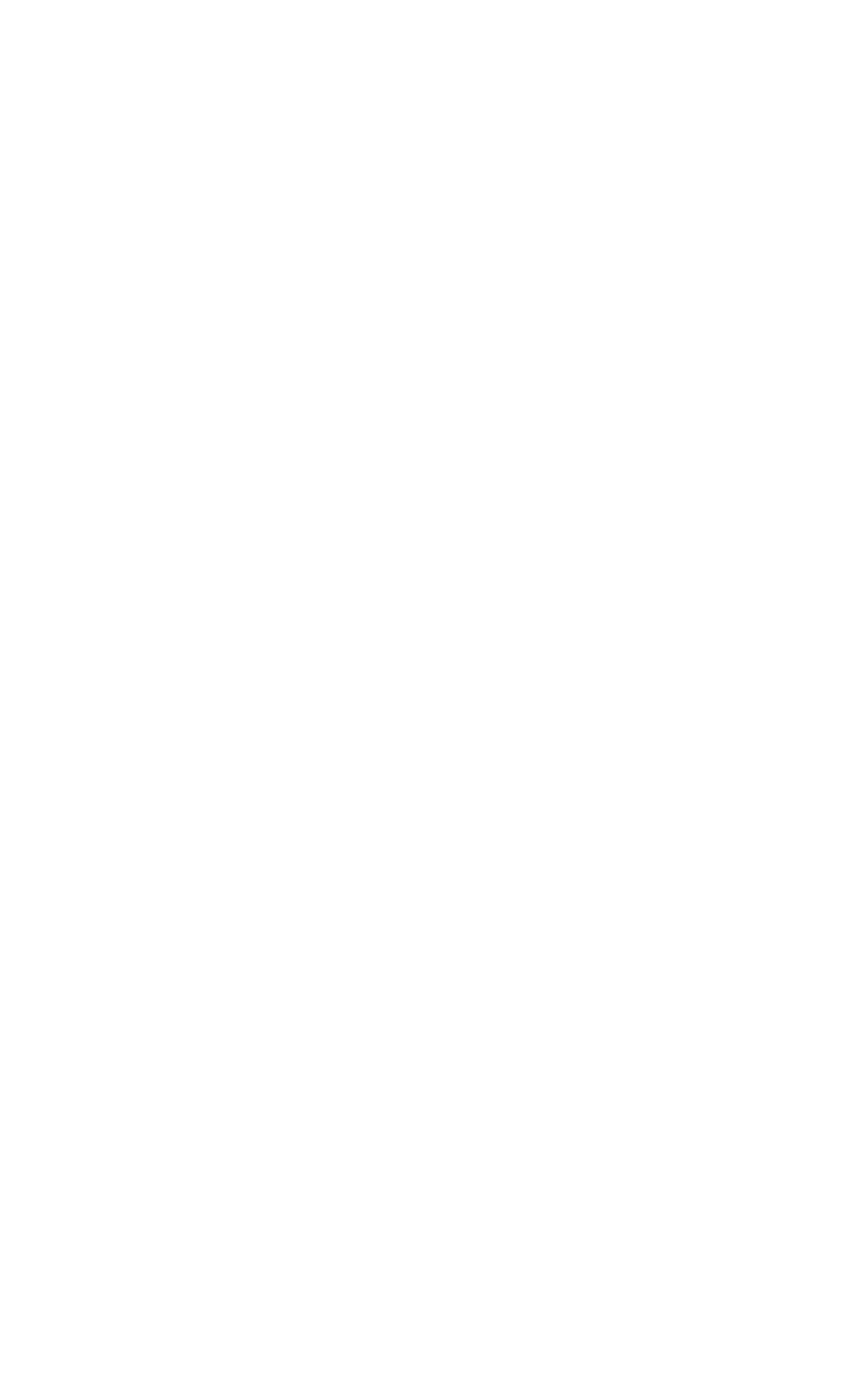




\section{Geologic folios-Continued}

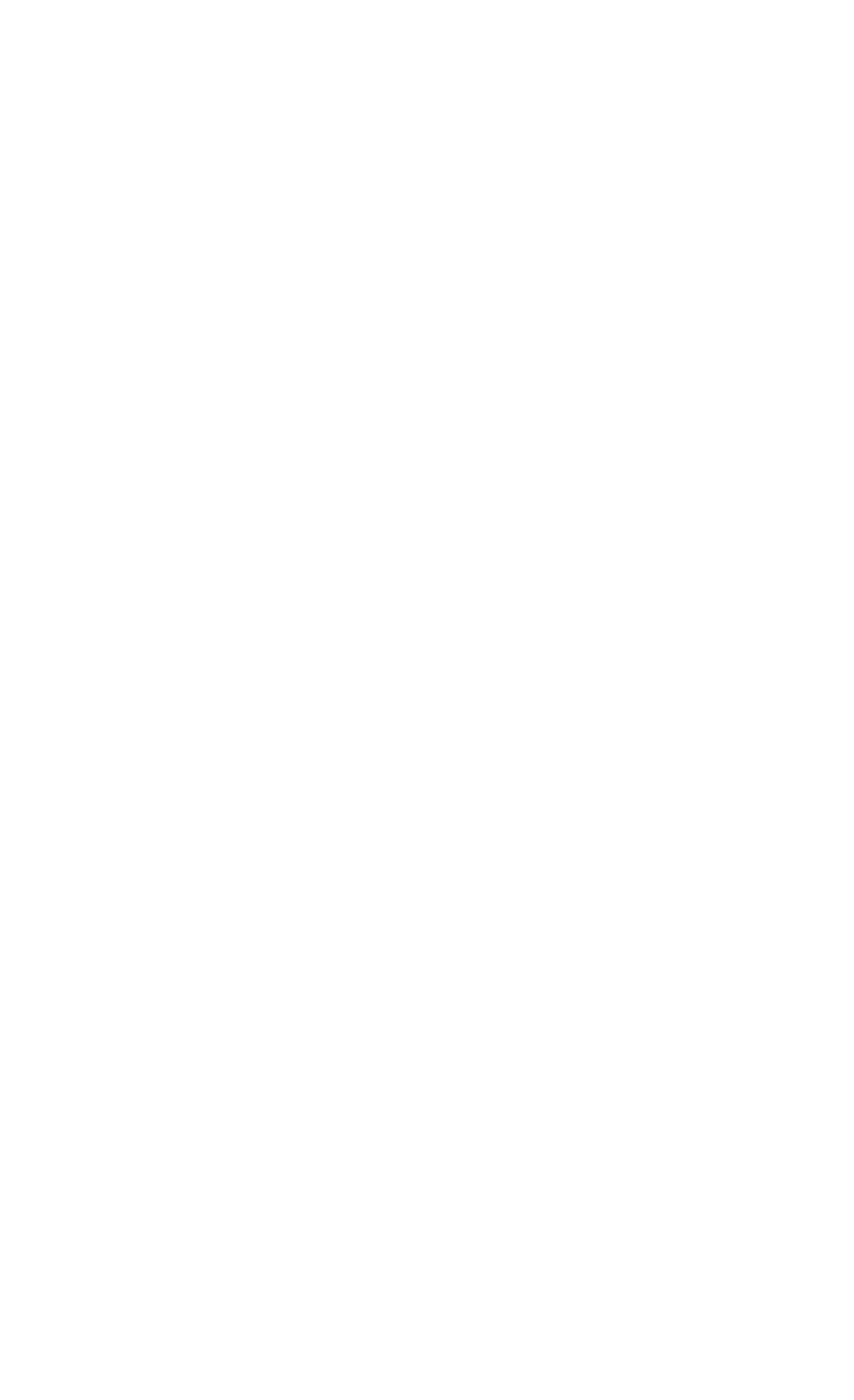


Geologic folios-Continued

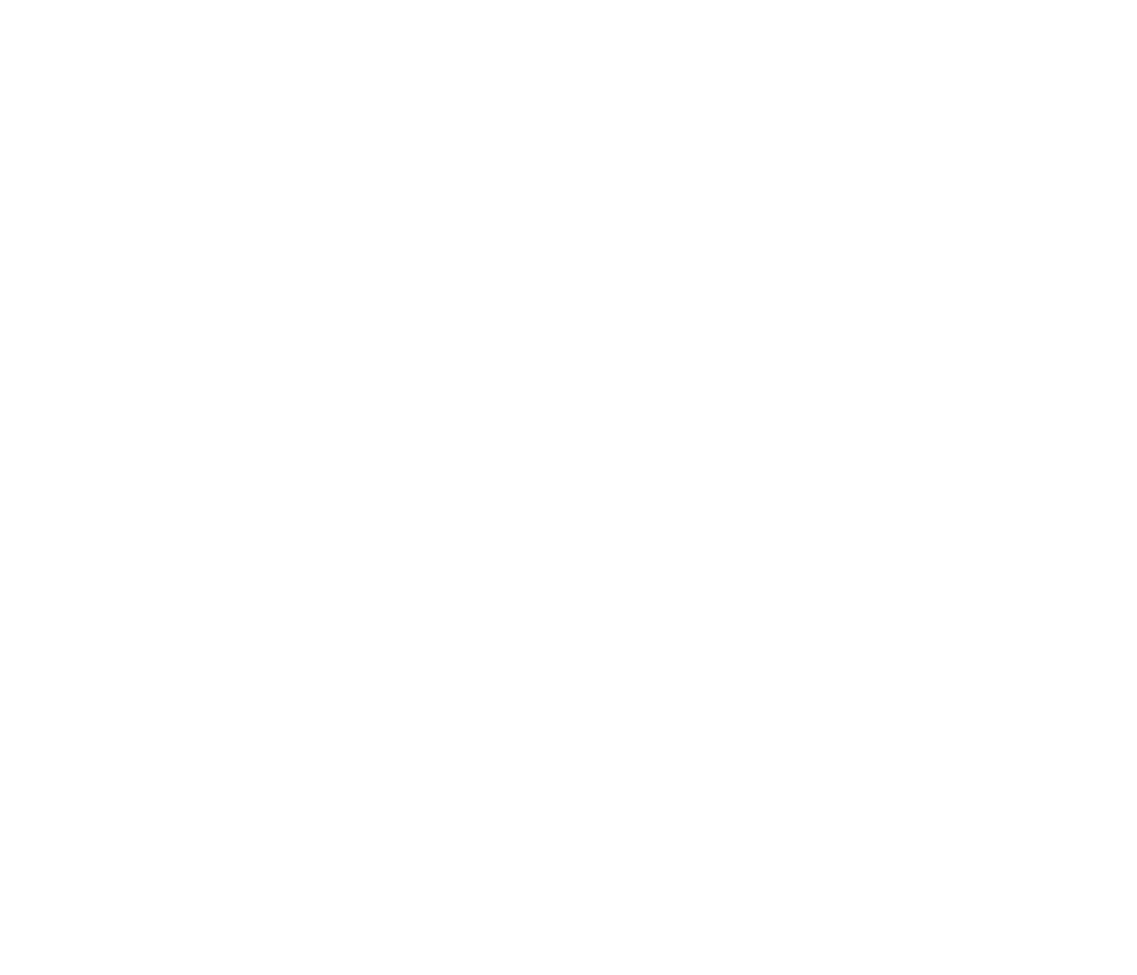

1. Includes map showing artesian or other ground-water conditions.

2. Information on mineral water only.

3. International boundaxy.

4. Discusses mineral waters associated with the ore deposits and ground water in relation to the zone of oxidized ore and in relation to mine drainage.

5. Contains no discussion of ground water but a section and data regarding oil and gas wells, which give information as to depth at which salt water is found.

6. Gives 6 analyses of ground water.

7 . The geologic maps show ground-water contours.

8. Gives $\log$ of well at Fort Dupont and data on several other wells.

9. Gives well logs, water analyses, and maps of ground-water conditions.

10. Gives $\log$ of 1 deep well and 2 analyses of ground water.

11. Describes the hot springs and gives average analysis of their water and the analyses of several cold springs.

12. Gives several well records and maps of artesian water-bearing formations.

13. Gives 38 analyses of well, spring, and stream waters.

14. Gives 2 analyses of well water.

15. Gives analysis of spring water.

16. Gives analyses of 9 well waters and 3 spring waters.

\section{REPORTS PUBLISHED BY COOPERATING AGENCITS} ALABAMA

1. The underground water resources of Alabama, by E. A. Smith. Alabama Geol. Survey Monograph 6, Montgomery, Ala., 1907. 388 pp., 30 pls.

Describes the geography, geology, and climate of the State. Contains a general discussion in regard to the occurrence, circulation, and recovery of ground water and in regard to artesian wells. Gives detailed description of wells, miners 1 waters, and ground-water conditions, with discussions of artesian prospects by provin res, counties, and vicinities. Discusses the chemistry and classification of the waters from the various horizons and gives water analyses. Includes maps showing ths geology and the areas of artesian flow. 
2. Ground water in the Paleozoic rocks of northern Alabama, by W. D. Johnston, Jr., with analyses by M. D. Foster and C. S. Howard. Alabama Geol. Survey Special Rept. No. 16, University, Ala., 1933. 414 pp., 23 pls.

Gives a brief discussion of the climate, an outline of the geol igy, and a description of the physiography. Discusses ground water in the several kinds of rocks and describes in detail the limestone caves in the several counties and the various waterbearing formations. Discusses the relation of ground water tc structure, ground water in mines, and the chemical character of natural waters. A description by counties occupies the latter part of the report (pp. 135-345) ant is followed by 23 photographs, chiefly of caves and springs.

3. Fluoride in the ground water of the Cretaceous area of Als.bama, by C. W. Carlston. Alabama Geol. Survey Bull. 52, University, Ala., 1942. 67 pp., 1 pl.

States that most of the water containing harmful amounts of fluoride is derived from the Eutaw formation and that this water is generally very low in total hardness and high in bicarbonate content. Says that it is generally possi"le to obtain water of low fluoride content by drilling to an underlying formation, or, in some places, by the use of water from shallow wells.

4. Ground-water resources of the Cretaceous area of Alabama, by C. W. Carlston. Alabama Geol. Survey Special Rept. 18, University, Ala., 1944. 203 pp., 6 pls.

Describes ground-water conditions in a belt about 50 miles wide, extending northwest-southeast across the State. Discusses the several water-bearing formations, quality of the water, and the several methods of well construction that are used and contains description of the ground-water supplies for 20 countieq.

\section{ARIZONA}

11. Ground-water investigations by the U. S. Geological Survey in cooperation with the State of Arizona, by S. F. Turner. Arizona State Water Commissioner 11th Bienn. Rept., Phoenix, Ariz., 1941- pp. 66-71.

A summary of investigations made in the Big Sandy Valley, the Queen Creek area, and Safford and Duncan Valleys.

12. Ground-water resources of the Big Sandy Valley, Mohave County, Ariz., by R. B. Morrison. Arizona State Water Commissioner, Tucson, Ariz., Dec. 30, 1940. 6 pp., 1 map. (Mimeographed.)

- Describes the geology, with special attention to the older val'ay fill and younger alluvium. Most of the wells obtain water from the latter. Discusses the probability of obtaining artesian water. Contains map showing location of wells, springs, and generalized geology.

13. Records of wells and springs in Big Sandy Valley, Mohare County, Ariz., by R. B. Morrison, with water analyses, by D. Hem. Arizona State Water Commissioner, Tucson, Ariz., July 21, 1941. 20 pp. (Mimeographed.)

Contains data on 73 wells and 20 springs with partial analysizs of the water and logs of 7 wells. Contains 3 maps showing location of the wells and springs.

14. Ground-water levels and pumpage in Arizona in 1939-40: Safford Valley, by S. F. Turner, L. C. Halpenny, H. R. McDonald, and D. H. Bratton; Duncan and Virden Valleys, by H. M. Babcock. Arizona State Water Commissioner, Tucson, Ariz., August 1941. 85 pp. (Mimeographed.)

Contains brief descriptions of the valleys and records of wat? $r$ levels in observation wells.

15. Water resources of Safford and Duncan-Virden Valleys, Ariz., and $\mathbf{N}$. Mex., by S. F. Turner and others, with analyses by J. D. Hem. Arizona State Water Commissioner, Tucson, Ariz., August 15, 1941. 58 pp., 28 tables. (Mimeograṕhed. 2 pls., 15 figs., bound separately.)

Prepared in cooperation with the Corps of Engineers, United States Army. Gives 
15. Water resources of Safford and Duncan-Virden Valleys, Ariz., and N. Mex.-Continued.

brief description of the geology, with inventory of water entering and leaving each valley. Concludes that river floods did not contribute much water to the grounds water reservoir, except in the form of temporary bank storage, most of which was returned to the river during receding stages. Discusses the effects of floods pumping, evapo-transpiration, and irrigation. Gives data on the fluctuation of ground-water levels and on the quantity and quality of the ground water. Includes map of each valley showing contours of the ground-water table.

16. Safford Valley, Graham County, Ariz., records of wells and springs, well logs, water analyses, and map showing location of wells and springs, by R. B. Morrisgn, H. R. McDonald, and W. T. Stuart, with introduction by S. F. Turner and water analyses by J. D. Hem. Arlzcna State Water Commissioner, Tucson, Ariz., July 10, 1942. 102 pp. (Mimeographed.)

Contains records of 610 wells and 126 springs, 199 well logs, and 390 water analyses and map showing location of the wells and springs.

17. Duncan-Virden Valley, Greenlee County, Ariz., and Hidalgo County, N. Mex., by R. B. Morrison and H. M. Babcock, with introduction by S. F. Turner and water analyses by J. D. Hem. Arizona State Water Commissioner, Tucson, Ariz., Sept. 1, 1942. 29 pp., 1 map. (Mimeographed.)

Prepared in cooperation with the Corps of Engineers, United Strtes Army. Presents records of nearly 200 wells and springs, 24 well logs, and 59 water analyses and map showing locations of wells and springs.

18. Queen Creek area, Maricopa and Pinal Counties, Ariz., records of wells, well logs, water analyses, and map showing location of wells, by $\mathrm{H}$. M. Babcock and L. C. Halpenny, with introduction by S. F. Turner and water analyses by J. D. Hem., Arizona State Water Commissioner, Tucson, Ariz., Sept. 25, 1942. 51 pp., 1 map. (Mimeog*aphed.)

Prepared in cooperation with the Corps of Engineers, United States Army. Gives records of 251 wells, drillers logs of 54 wells, the logs of 16 test holes, 84 analyses of samples of well water, and two analyses of samples of water from Qwen Creek. Lists 18 previous reports or releases on water supply in southern Arizona.

19. Report on cooperative ground-water investigations, by S. F. Turner. Arizona State Water Commissioner 12th Bienn. Rept., Phoenix, Ariz., 1943. pp. 64-66.

Lists the publications that have been released and describes the ground-water projects that are under investigation.

20. Ground-water resources of the Santa Cruz Basin, Ariz., by S. F. Turner and others, Tucson, Ariz., May 14, 1943. 84 pp., 3 pls. 4 figs. (Mimeographed.)

Prepared in cooperation with the Corps of Engineers, United States Army. Contains sections on the History of the Santa Cruz Valley and Development of irrigation, by M. J. Scott; Geology and its relation to ground-water supplies, by G. A. Waring; and Quality of water, by J. D. Hem. Presents a detailed study of the ground-water supplies in the irrigated areas and gives estimates of the amounts of ground-water inflow from the several tributary areas. Contains many data on ground-water recharge from flood flows.

20 a. Geology and ground-water resources of the Verde River Valley roar Fort McDowell, Ariz., by H. R. McDonald and H. D. Padgett, Jr., Tucson, Ariz., Nov. 1 1945. 99 pp., 5 pls., 11 tables, 14 figs. (Mimeographed.)

Prepared in cooperation with the city of Phoenix, Ariz. Gives genervi data on the geology and discusses the recharge and discharge of ground water, ground-water storage, and quality of the water with chemical analyses. Includes recrds of 114 wells. 


\section{ARKANSAS}

20 e. Ground-water supplies for rice irrigation in the Grand Prairie region, Ark., by Kyle Engler, D. G. Thompson, and R. G. Kazm`nn. Ark. Agr. Exper Sta. Bull. 457, Fayetteville, Ark., June 1945. 55 pp., 1 pl.

Describes geologic conditions affecting the occurrence of grounc water. Gives data on water levels in 1929, 1938, and 1944. Discusses determinaticn of permeability, transmissibility, and storage coefficients, the yield from Pleistorene water-bearing beds, and conservation of the supply. The plate shows contours of the piezometric surface of the Grand Prairie rice region in the spring of 1944 .

\section{CALIFORNIA}

21. Subtersanean storage of flood waters by artificial methods in San Bernardino Valley, Calif., by C. H. Lee. Conservation Commission of California Rept. for 1912, Sacramento, Calif., 1912. pp. 3£5-400, 3 pls.

Gives history and methods of water spreading and amount of water spread along Santa Ana River and other streams. Gives data in regard to procipitation, run-off, and stream percolation in the San Bernardino Basin. Describer the ground-water reservoir in this basin, giving data on fluctuations of the water table and the artesian head. Discusses ground-water fluctuations in other basins in soutl orn California and draws conclusions as to the effect of water spreading. Includes a map showing the original area of artesian flow in the San Bernardino Basin and the areas in 1904 and 1912, also locations of wells and of lands used for spreading water.

22. Ground-water resources of Indian Wells Valley, Calif., by C. H. Lee. Conservation Commission of California Rept. for 1912, Sacramento, Calif., 1912. pp. $401-429,5$ pls.

A brief report covering an arid valley, known as Salt Wells Valley, whieh lles mostly in northeastern Kern County but extends into Inyo and San Bernardino Counties and comprises a part of the area included in Tps. 25-27 S., Rs. 38-40 E. Gives information in regard to precipitation, stream flow, evaporation of ground water, and water supply available by pumping from wells.

23. Ground-water supply and natural losses in the valley of Santa Ana River between Riverside Narrows and the Orange County line, by H. C. Troxell. Calif. Dept. Pub. Works, Div. Water Resources Bull. 44, pt. 2, Sacramento, Calif., 1934. pp. 141-172, 11 pls.

"The purpose of this investigation was to determine the total quantity of ground water that reaches the valley or flood channel of the river in this area." The date presented are based on discharge records at five gaging stations on the river and on records of the ground-water level in several wells. Concludes that there is a large supply of ground water now unused, which could be recovered by pumping from wells. "The storage in this underground reservoir, as well as the summer inflow, could be drawn upon to meet the fluctuating demands of irrigation."

24. Index of factual data from water wells on a part of the coastal plain in Los Angeles and Orange Counties, Calif., by A. M. Piper, J. F. Poland, and others. Los Angeles, Calif., June 1942. 298 pp. 2 pls. (Dittoed.)

Prepared in cooperation with the Orange County Water D'strict, the Orange County Flood Control District, the Los Angeles County Flood Control District, and the Board of Water Commissioners of the city of Long Beach. Embodies a cross reference to numbers that have been ascribed by various ager eies to about 4,000 wells in the area. Describes each of the three principal systems of numbers for the wells, based on "serial" numbers, "location" numbers, and numbers applied by the United States Geological Survey. Gives sources and scope of th a date and indexes of the wells under the three numbering systems.

25. Descriptions of water wells in the coastal zone of the Lcng Beach-Santa Ana area, Calif., by J. F. Poland and others. Los Angeles, Calif., December 1942. vii, $152 \mathrm{pp.}$ (Mimeographed.) 
25. Descriptions of water wells in the coastal'zone of the Long Beach ${ }_{7}$ Santa Ana area, Calif--Continued.

Prepared in cooperation with the Orange County Water District, the Orange County Flood Control District, the Los Angeles County Flood Control District, and the Board of Water Commissioners of the city of Long Beach. A collectior of data on 1,939 wells in the Long Beach-Santa Ana area compiled in the course of an investigation of salt-water contamination of the ground water in that area.

26. Partial chemical analyses of waters from wells, streams, ponds, and sumps in the coastal zone of the Long Beach-Santa Ana area, Calif., 1940-43, by A. A. Garrett and others. Los Angeles, Calif., July 1943. xxi, 89 pp., 3 pls. (Dittoed.)

Prepared in cooperation with the Orange County Water District, the Orange Caunty Flood Control District, the Los Angeles County Flood Control District, and the Board of Water Commissioners of the city of Long Beach.

Presents analytical data from 2,090 partial analyses of water samples taken from 943 wells, 41 points on streams, and 29 ponds and sumps. Draws conclusions as to significant changes in quality of the waters.

27. Water resources of Santa Barbara County, Calif., a report of progress in the cooperative inventory, by J. E. Upson, A. M. Piper, and others. Los Angeles, Calif., August 1943. 32 pp. (Mimeographed.)

Prepared in cooperation with Santa Barbara County. Describes the mathods of investigation, including geologic mapping, establishment of observation vrells, and chemical analyses of water samples. Discusses the general features of tha groundwater basins of Santa Ynez Valley, Goleta Basin, and Carpenteria Basin.

28. Water levels in observation wells in Santa Barbara County, Calif., in 1942, by G. A. La Rocque, Jr., G. F. Worts, Jr., and J. E. Upson. Los Angeles, Calif., August 1943. 239 pp. (Mimeographed.)

Prepared in cooperation with Santa Barbara County. Gives a summary of the hydrologic features and describes 195 observation wells, with records of the water levels.

29. Progress report on the cooperative ground-water investigation in the Long Beach-Santa Ana area, Calif., by A. M. Piper, J. F. Poland, and others. Los Angeles, Calif., August 1943. 45 pp.; 8 pls. (Mimeographed.)

Prepared in cooperation with the Orange County Water District, th: Orange County Flood Control District, the Los Angeles County Flood Control District, and the Board of Water Commissioners of the city of Long Beach. Discusses secpe of the investigation and gives data on observation wells, chemical analyses of ground waters, inventory of ground-water withdrawal, and water-level measurements. Describes the geologic features of the coastal zone and the extent of salt-water encroachment.

30 a. Description of water wells and water levels in observation wells in 1930-41 in the Carpenteria, Goleta, and Santa Yriez Valley areas of Santa Barbara County, Calif., by G. A. LaRocque, Jr., G. F. Worts, Jr., and J. E. Upson. Los Angeles, Calif., May 1944. 359 pp. (Mimeographed.)

Prepared in cooperation with Santa Barbara County. Gives deseriptions of many observation wells and records of the water levels. To be published also as Water Supply Paper.

30 b. Description of water wells and water levels in observation wells in 1920-41 in the San Antonio, Santa Maria, and Cuyama Vølleys of Santa Barbara County, Calif., by G. A. LaRocque, Jr., J. E. Unson, G. F. Worts, Jr., and L. Porter, Jr. Los Angeles, Calif., Augrist 1944. 168 pp. (Mimeographed.)

Prepared in cooperation with Santa Barbara County. Gives description of many observation wells and records of the water levels. To be published also as Water Supply Paper. 
80 c. Progress report on the cooperative ground-water investigation in the Torrance-Santa Monica area, Calif., by J. F. Poland, A. A. Garrett, and Allen Sinnott. Los Angeles, Calif. September 1944. 53 pp., 6 pls. (Dittoed.)

Prepared in cooperation with the Los Angeles County Flood C-ntrol District and other agencies. States that during the past 20 years there hav been progressive salt-water contamination of the shallow water-bearing gravel wost of Long Beach and of the main water-bearing zone extending northward from Redondo Beach. Discusses the sources of contamination and the absence of natural barriers to prevent more extensive contamination.

30 d. Geologic features in the coastal zone of the Long Beach-Santa Ana area, Calif., with particular respect to the ground-water conditions, by J. F. Poland, A. M. Piper, and others. Los Angeles, Calif., May 1945. 327 pp. (Mimeographed.)

Prepared in cooperation with the Orange Oounty Water D'strict, the Orange County Flood Control District, the Los Angeles County Flood Control District, and the Board of Water Commissioners of the city of Long Beach. Discusses the geology and gives detailed information on the ground-water conditions of the area. To be published also as Water Supply Paper of the United States Geological Survey.

30 e. Withdrawals of ground water from the Long Beach-S?nta Ana area, Calif., by J. F. Poland, Allen Sinnott, and others. Los Angeles, Calif., November 1945. 112 pp. (Mimeographed.)

Prepared in cooperation with the Orange County Water District, the Orange County Flood Control District, the Los Angeles County Flood C'ntrol District, and the Board of Water Commissioners of the city of Iong Beach. Presents detailed information on the amounte of ground water developed in the area.

30 f. Chemical character of native and contaminated waters in the Long Beach-Santa Ana area, Calif., Appendix, by A. M. Piper, A. A. Garrett, J. F. Poland, and others. Los Angeles, Calif., November 1945. 111 pp. (Dittoed.)

Prepared in cooperation with the Orange County Water District, the Orange County Flood Control District, the Los Angeles County Flood Control District, and the Board of Water Commissioners of the city of Long Beach. Discusses the character of the contamination and presents analyses of the ground waters.

\section{COLORADO}

31. Geology and ground-water conditions of the Rio Grands depression inColorado and New Mexics, by Kirk Bryan. Nat. Rerources Comm., Regional Planning, part 6, Upper Rio Grande, vol. 1, part 2, Groundwater resources, Washington, D. C., February 1938.

Discusses the ground-water conditions in the area, the movemants of the ground water, and water supply in the Santa Fe formation. Issued in mirneographed form in 1987 by the U. S. Geological Survey with the title Outline of the geology and groundwater conditione of the Rio Grande depression in Colorado and New Mexico (64 pp.).

32. Ground water in the San Luis Valley, Colo., by T. W. Robinson and H. A. Waite. Nat. Resources Comm., Regional Planning, part 6, Upper Rio Grande, vol. 1, part 2, Ground-water resources, Washington, D. C., February 1938. pp. 226-267.

Discusses ground water in the shallow valley fll-its source, recharge, and use for irrigation. Describes the artesian water from late Tertiary deposits and gives data on the quantity discharged and the fluctuations in head. Issued in mimeographed form in 1987 by the U. S. Ceological Survey (119 pp.).

\section{CONNECTICUT}

41. Record of wells, springs, and ground-water levels in the towns of Bridge port, Easton, Fairfield, Stratford, and Trumbull, Conn., by R. M. Leg- 
41. Record of wells, springs, and ground-water levels in the towns of Bridgeport, Easton, Fairfield, Stratford, and Trumbull, Conn.-Cortinued. gette and others. Connecticut Ground-Water Survey Bull. GW-1, Hartford, Conn., November 1988. 242 pp. (Mimeographed.)

Gives the owners, elevations above sea level, types, depths, diameters, dopths to bedrock, water levels, chloride determinations, and maps showing the lmotions of 1,878 wells in 5 towns in southwestern Connecticut.

42. Record of wells, springs, and ground-water levels in the towns of $F$-anford, Chester, Clinton, E'ssex, Guilford, Haddon, Killingsworth, I"adison; North Branford, Old Saybrook, Saybrook, and Westbrook, Conn., by R. M. Leggette and others. Connecticut Ground-Water Surroy Bull. GW-2, Hartford, Conn., 1938. 340 pp. (Mimeographed.)

Gives tabulated data on 2,624 wells in the 12 towns. Includes maps sl owing the location of wells and springs.

43. Record of wel's, springs, and ground-water levels in the towns of Bethany, East Haven, Hamden, Milford, North Haven, Orange, West Haven, and Woodbridge, Conn., by R. M. Leggette and others. Connecticut GroundWater Survey Bull. GW-3, Hartford, Conn., 1988. 247 pp. (Mimeographed.)

Gives tabulated data on 1,847 wells in the 8 towns named. Includes mazs showing the location of wells and springs.

44. Record of wells, springs, and ground-water levels in the towns of Berlin, Cromwell, Durham, Meriden, Middlefield, Middletown, Portland, and Wallingford, Conn., by R. M. Leggette and others. Connecticut GroundWater Survey Bull. GW-4, Hartford, Conn., 1938. 170 pp. (Mimeographed.)

Gives tabulated data on 1,158 wells in the 8 towns named. Includes mans showing the location of wells and springs.

45. Record of wells, springs, and ground-water levels in the towns of Colchester, East Haddon, East Hampton, East Lyme, Lyme, Now London, Old Lyme, and Waterford, Conn., by R. M. Leggette an others. Connecticut Ground-Water Survey Bull. GW-5, Hartford, Corn., 1938. 314 pp. (Mimeographed.)

Gives tabulated data on 3,042 wells in the 8 towns named. Includes mavs showing location of wells and springs.

46. Ground-water levels in north-central Connecticut, Oct. 1, 1934, to Dec. 31, 1937, by R. M. Leggette and others. Connecticut Ground-Water Survey Bull. GW-6, Hartford, Conn., 1938. 212 pp. (Mimeographed.)

Gives measurements of water levels made in 1934-37 in 218 wells in 27 towns in north-central Connecticut.

47. Ground-water Survey, U. S. Geological Survey-State of Connecticut, report of cooperative program covering current biennium, $1, \mathrm{~J}$. G. Ferris. Connecticut State Water Comm. 9th Bienn. Rept., 1940-42, Pub. Doc. 78, Hartford, Conn., 1942. pp. 75-77.

Contains a description of the ground-water investigation being conducted in the New Haven area, one of the most critical in the State with respect to grind-water supply.

48. Ground-water Survey, U. S. Geological Survey-State of Connecticut, report on cooperative program covering current biennium, by E. J. Lowry. Connectiçut State Water Comm. 10th Bienn. Rept., 1942-44, Pub. Doc. 78, Hartford, Conn., 1944. pp. 46-47.

Summarizes the progress of ground-water studies in Connecticut during 1942-44.

\section{FLORIDA}

51. A preliminary report on the underground-water supply of central Florida, 
51. A preliminary report on the underground-water supply of central Florida-Continued.

by E. H. Sellards. Florida Geol. Survey Bull. 1, Tallahassee, Fla., 1908. 103 pp.

A general discussion of ground water and of the shallow and deep water-bearing formations in the central part of the State. Contains analyses of well and spring waters and water-supply tables giving the principal sources of water in towns in each county.

52. The artesian water supply of eastern Florida, by E. H. Sellards and Herman Gunter. Florida Geol. Survey 3d Ann. Rept., Tallahassee, Fla., 1910. pp. $86-195$.

Gives a-general discussion of ground water and of artesian water and a deseription, by counties, of ground-water supplies in 9 counties in eastern Florida, with local details, including well logs and water analyses. Contrins maps showing areas of artesian flow in Florida and in the several counties. See also Fifth Annual Report, 1913.

53. The underground water supply of west-central and west Florida, by $\mathrm{E}$. H. Sellards and Herman Gunter. Florida Geol. Survey 4th Ann. Rept., Tallahassee, Fla., 1912. pp. 81-155.

Consists of county reports on the location and surface features, elevation, drainage, area of artesien flow, and local details, including well logs and water analyses in 16 counties in the western part of the State. Includes maps showing the areas of artesian flow.

54. The artesian water supply of eastern and southern Florida, by E. H. Sellards and Herman Gunter. Florida Geol. Survey 5th A nn. Rept., Tallahassee, Fla., 1913. pp. 103-290.

Gives a preliminary discussion of ground water and of artesian conditions in Florida and a description by counties of the water-bearing formations and areas of artesian flow in 19 counties in the eastern and southern parts of the State, in part reprinted from the Third Annual Report. Contains water analrses and well logs and maps showing areas of artesian flow.

55. Geology of Florida by C. W. Cooke and Stuart Mossom. Florida Geol. Survey 20th Ann. Rept., Tallahassee, Fla., 1929. pp. 29-228, 29 pls. (Also issued as a separate publication.)

A comprehensive summary of the geology of the State. De icribes the several formations and gives details for each county in which they are exposed. Mentions the solution of Ocala limestone by free circulation of ground water (p. 48), springs and sinks in the Ocala and Tampa limestones and in the Hawtho'n formation, sinks in the Choctawatchee formation (p. 145), and natural wells and pot holes in the Key Largo limestone (p. 209).

56. Ground-water resources of Florida, by D. G. Thompson and V. T. Stringfield. Florida Geol. Survey Press Bull. 13, Tallahassee. Fla., Apr. 4, 1931. $18 \mathrm{pp}$.

Describes ground-water studies in Florida by the United Stater Geological Survey in cooperation with the Florida State Geological Survey, with 1 rief statements on principal water-bearing formations, contamination by salt water, and other problems relating to the occurrence of ground water.

57. Ground water in the Lake Okeechobee area; Fla., by V. T. Stringfield. Florida State Board Cons. Rept. Investig. No. 2, Tellahassee, Fla., 1933. 31 pp. (Mimeographed.)

Describes the several water-bearing formations of Recent $t \tau$ Eocene age and the artesian conditions, with well records and data on the quality of the water.

58. Ground-water resources of Sarasota County, Fla., by V. T. Stringfield. Florida Geol. Survey 23d-24th Ann. Rept., Tallahassee, Fla., 1933. pp. 121-194.

Describes the Tertiary formations of the area and their water-hearing properties, the present water supplies from wells and springs, truck-farm iristition from wells, 


\section{Ground-water resources of Sarasota County, Fla.-Continued.}

the artesian area, and the quality of ground water and its relation to rea water, with discussion of the Ghyben-Herzberg theory. Gives data on the consumption of water, and the State law for conserving the artesian water. Includes a hydrologic map, table of analyses of ground water, and table of well records.

59. Exploration of artesian wells in Sarasota County, Fla., by V. T. Stringfield. Florida Geol. Survey 23d-24th Ann. Rept., Tallahassee, Fla., 1933. pp. 195-227.

Summarizes the data obtained concerning the source of the artesian water by use of the deep-well current meter, discusses the quality of the water, and gives analyses of 27 well waters.

60. Ground-water investigations in Florida, by V. T. Stringfield. Flori ${ }^{\text {fa Geol. }}$ Survey Bull. 11, Tallahassee, Fla., 1933. 33 pp.

This is in part a progress report on studies of ground-water supplies and consumption in Manatee, Pinellas, northwestern Hillsborough, Orange, Seminole, and Duval Counties. Contains notes on the quality of water, artesian conditions, and contamination by salt water.

61. Ground water in Seminole County, Fla., by V. T. Stringfield. Florida State Board Cons. Rept. Investig. No 1, Tallahassee, Fla., 1934. 14 pp. (Mimeographed.)

A summary of investigations on the quantity and quality of shallow water and artesian supplies.

62. Progress report on the investigation of water resources in soutieastern Florida, by W. P. Cross, S. K. Love, G. G. Parker, and D. S. Wallace. Washington, D. C., December 1940. 116 pp., 4 pls. (Mimeographed.)

Prepared in cooperation with Dade County and the cities of Miami, Mirmi Beach. and Coral Gables. A detailed discussion of the area under the headings Surface water, Geology and test wells, Ground water, and Quality of water.

63. Interim report on investigation of water resources in southeastern Florida, with special reference to the Miami area, in Dade County, $1 ; \mathrm{G}$. G. Parker, G. E. Ferguson, and S. K. Love. Florida Geol. Surv ?y Rept. Investig. No. 4, Tallahassee, Fla., June 30, 1944.39 pp. 9 pls. (Mimeographed.)

Discusses the nonartesian ground-water supplies and their protection from saltwater contamination. Gives information on the surface-water supplies. Includes maps showing salt-water encroachment and contours of the water table.

64. Ground-water conditions in Orlando and vicinity, Fla., by A. G. Unklesbay. Tallahassee, Fla., 1944. 61 pp., 11 figs. (Mimeographed.)

Prepared in coeperation with the. Florida Geological Survey and the Corps of Engineers, United States Army. Gives a short discussion of the geolory and of ground-water conditions.. Presents about 250 well records and tabulated water-level measurements on about 145 observation wells.

65. Late Cenozoic geology of southern Florida, with a discussion of the ground water, by G. G. Parker and C. W. Cooke. Florida Geol. Survey Bull. 27, Tallahassee, Fla., 1944. 119 pp., 26 pls., 4 figs.

Prepared in cooperation with the Florida Geological Survey, Dade GNnty, and the cities of Miami, Miami Beach, and Coral Gables. Describes the Sandy Flatlands, the Big Cypress Swamp, and the Everglades. Diseusses in detail the Pl'scene and Pleistocene rocks. States that test wells in the Miami area indicate that the Tamiami formation is among the most productive water-bearing formations ever investigated by the United States Geological Survey. Considers large areas of salty ground water in the northern : part of the Everglades to be remnants of sea water altered by dilution with fresh water and by chemical reactions mainly of the basa-exchange type. 


\section{FOREIGN}

71. Memorandum on the geology of the ground waters of the Jsland of Antigua, B. W. I., by T. W. Vaughan. Imperial Dept. Agr. for the West Indies, West Indian Bull., vol. 14, No. 4, Georgetown, Parbados, 1915. pp. 276-280.

Outlines the physiography and geology of Antigua and their bearing on groundwater conditions. Discusses the prospects of obtaining artesian and other ground water and the quality of the ground water, especially with reference to salt. Includes a sketch map of the island showing the geology. Refers to work of H. A. Tempany, chemist and superintendent of agriculture for the Leeward Islands, who published two papers on the same subject contrining some detailed spring and well data and a number of analyses of ground water. The papers by Tempany are The water supply of Antigua (West Indian Bull., vol. 12, No. 4) and The ground waters of Antigua (West Indian Bull., vol. 14, No. 4.)

72. Geology of the Republic of Haiti, by W. P. Woodring, J. S. Brown, and W. S. Burbank. Dept. Public Works, Geol. Survey, Rerrablic of Haiti, Port-au-Prince, Haiti, 1924. 631 pp., 40 pls.

Parts I-IV (pp. 28-512) form a comprehensive report on the giagraphy, geology, geomorphology, and mineral resources. Part $V$ discusses the surface and groundwater supplies by topographic sreas (pp. 513-542), the quality of water (pp. 542550), springs (pp. 550-566), and public water supplies (pp. 566-5:3). Under quality of water gives analyses of about 15 water samples in tabulated and in graphic form. Describes several types of springs and includes 6 analyses of sprire water. Includes a bibliography and two appendixes on fossils (pp. 596-613), fcur geologic maps (pls. 1, 2, and 86 and fig. 29), and four sketch maps showing springs and water supplies (figs. 34-37). French edition also published.

\section{GEORGIA}

81. A preliminary report on the underground waters of Georgia, by $\mathbf{S}$. W. McCallie. Georgia Geol. Survey Bull. 15, Atlanta, Ga., 1908. 370 pp., 30 pls.

Describes the physiography and geology of the State and discusses briefly precipitation, evaporation, and absorption by the soil. Describes in gereral the water of the various geologic formations, and in more detail the ground-water conditions in each county in the Coastal Plain, Crystalline area, and Paleozioic area. Contains numerous analyses of ground water and discussions of the qrality. Includes a chapter entitled "Experiment relating to problems of well contamination at Quitman" and one entitled "Blowing springs and wells of Georgia." Imeludes a table of data regarding public water supplies, a table of miscellaneous sining records, and a geologic map of Georgia.

82. Reports on condition of water supply at Savannah, Ga. Mayor of Savannah Ann. Rept., Savannah, Ga., 1915.

Contains the following papers submitted by the United States Geological Survey: Preliminary report on Savannah water supply, by L: W. Sterhenson and R. B. Dole, pp. 1-14.

The water supply of Savannah, Ga., by R. B. Dole, pp. 15-89. These papers discuss the yield and head of the artesian wells of Savannah, the consumption of water, the sanitary and chemical quality of the water, and the cost of operation. They give the results of fluorescein tests and several analyses of surface and ground water. They conclude with recommendations for future developments.

83. Artesian water in southeastern Georgia, with special reference to the coastal area, by M. A. Warren. Georgia Div. Cons...Dept. Mines, Mining and Geol. Bull. 49, Atlanta, Ga., September 1944. 140 pp., 34 figs.

States that the principal artesian aquifers are the Ocala limestone (Docene) and Suwanee limestone (Oligocene) and discusses their distribution and direction of dip. Says that excessive discharge from wells has greatly lowered the original piezometric surface and gives specific data. Considers the possibility of contamination by Inflow of salt water in the Savannah area to be remote. 
84. Artesian water in southeastern Georgia with special referenc? to the coastal area, well records, by M. A. Warren. Georgia Div. Cons., Dept. Mines, Mining and Geol. Bull. 49-A, Atlanta, Ga., 1945. 83 pp. (Offset.)

Presents tabulated records of wells in 12 counties in southeastern Georria.

\section{HAWAII}

91. Report of the Water Commission of the Territory of Hawaii to the Governor of Hawaii, by G. K. Larrison, A. G. Smith, and T. F. Sedgwick. Honolulu, T. H., 1917. 53 pp., maps, diagrams and tables.

Discusses and gives data regarding artesian water on the Island of Oahu, the relation of precipitation to artesian head, the discharge of flowing and pumped wells, the interference of wells, the progress of artesian well boring, ard waste of water from artesian wells. Includes a proposed law relating. to the us? of water from artesian wells. The data were collected by R. C. Rice and R. D. Klise, of the United States Geological Survey, under the direction of T. F. Sedgwick.

92. Geology and ground-water resources of the island of Oahu, Hawaii, by $H$. T. Stearns and K. N. Vaksvik. Hawaii Dept. Public Lands, Div. Hydrography Bull. 1, Honolulu, T. H., 1935. 479 pp., 33 pls.

Part 1 (pp. 1-198) describes the geography, geomorphology, and genlogy, with mention of the water-bearing properties of the several volcanic series. Part 2 (pp. 199-467) describes ground-water resources in detail. Basal ground wate* (pp. 215378) treats of the water in the several lava formations, the artesian conditions being discussed in several subdivisions. Perched ground water (pp. 378.467) treats of water-supply tunnels and springs. Gives a numbering system for d*illed wells. shown on the map in Bulletin 2. Includes small map of ground-water arees on Oahu.

93. Annotated bibliography and index of geology and water supp'v of the island of Oahu, Hawaii, by N. D. Stearns. Hawaii Dept. Pubic Lands, Div. Hydrography Bull. 3, Honolulu, T. H., 1935. 74 pp.

An annotated list of 436 titles, arranged alphabetically by authors. About 170 of the articles are listed in the index under ground water and subjects relating to it.

94. Records of the drilled wells on the island of Oahu, Hawaii, by H. T. Stearns and K. N. Vaksvik. Hawaii Dept. Public Lands. Di". Hydrography Bull. 4, Honolulu, T. H., 1938. 213 pp.

By March 1938 a total of 186 wells had been drilled within the district of Honolulu and 549 on Oahu outside the district of Honolulu. In the tabulated rists 409 of these 735 wells have been given numbers, 1 to 409 inclusive, the other 326 wells being designated by subletters or numbers. The data include location, well logs, ownership, and use.

96. Geologic map and guide of the island of Oahu, Hawaii (with a chapter on mineral resources), by H. T. Stearns. Hawaii Dept. Public Lands, Div. Hydrography Bull. 2, Honolulu, T. H., 1939. 75 pp., 6 pls.

The text contains no data on ground water, but the map (pl. 2, scale 1:62,500) shows the location of drilled wells, dug wells and shafts, water tunnels, and springs, numbered with reference to lists given in Bulletin 1.

97. Supplement to the Geology and ground-water resources of the Island of Oahu, Hawaii, by H. T. Stearns, with chapters on resistivity survey of Schofield Plateau, by J. H. Swartz, and petrography of the Waianae Range, by G. A. Macdonald. Hawaii Dept. Public Lands, Div. Hydrography Bull. 5, Honolulu, T. H., 1940. 164 pp., 6 pls.

This report brings up to date the progress in ground-water development on Oahu since Bulletin 1 was issued in 1935. Describes ten shafts constructed sin?e 1935 that are capable of delivering $100,000,000$ gallons of water a day. A graph shows the striking rise of ground-water levels as a result of the wet years of 1936.39. Includes the results of an electrical resistivity survey of the depth to water undor the Schofield Plateau. Lists public water supplies and their geologic source, the discharge of the Waia hole water-development tunnels, and the monthly pumpage of Honolulu and the sugar plantations from 1934 to 1939 . Gives tunnels developing ground water 


\section{Supplement to the Geology and ground-water resources of the Island of} Oahu, Hawaii-Continued.

that were not described in Bulletin $\Lambda$ and records of wells drilled since Bulletin 4 was published. Includes the records of transpiration and evaparation at Luakaha and Raukonahua stations since 1934. Contains a map showing shafts and tunnels and a map of Oahu showing ground-water areas.

98. Geology and ground-water resources of the islands of Lanai and Kahoolawe, Hawaii, by H. T. Stearns, with chapters on the prography of Lanai and Kahoolawe, by G. A. Macdonald, and geophysical investigations on Lanai, by J. H. Swartz, Hawaii Dept. Public Lends, Div. Hydrography Bull. 6, Honolulu, T. H., 1940. 177 pp., 18 pls

The report is divided into Part 1, Geology and ground-water resources of the island of Lanai (pp. 1-115), and Part 2, Geology and ground-water resources of the island of Kahoolawe (pp. 117-173). After introductory statements on the geography and history of Lanai, the report discusses the geomorphology and this geology of the island, with statements on the water-bearing properties of the several formations of volcanic and sedimentary rocks. Presents a 3-page discussion of the petrography of the volcanic rocks, followed by discussion of ground water (pp. 63-95). This includes basal ground water (pp. 75-85) and high-level ground water-(pp. 85-95). Explains under the former heading the application of the Ghyben-Herzberg principle to conditions on the island. Under the latter heading gives data on the construction and discharge of the several water tunnels. The geophysical investigations by Swartz (pp. 97-115) were made to determine the depth to the water table koneath a part of the island. The discussion of Kahoolawe is similar to that of Lanai $i_{r}$ with description of the water-bearing properties of the several series of volcanic rack. Treats fully of the petrogaphy of the volcanic rocks (pp. 140-173). The roport includes a geologic and topographic map of Lanai and a small geologic map of Kahoolawe showing wells.

99. Geology and ground-water resources of the Island of Maui, Hawaii, by $\mathrm{H}$. T. Stearns and G. A. Macdonald. Hawaii Dept. Publi? Lands, Div. Hydrography Bull. 7, Honolulu, T. H., 1942. 344 pps., 44 pls.

The report is divided into Part 1, General geology and ground-nater resources of Maui (pp. 1-222) ; Part 2, Geology and ground-water resources of the Nahiku area, east Maui (pp. 22-274); and Part 3. Petrography of Maui (pp. 275-335). Maul is composed of two eroded volcanoes and covers 728 square miles. The lava rocks in east Maui are divided into the Honomanu, Kula, and Hana vol ranic series, and in west Maul into the Wailuku and Lahaina volcanic series. The sadimentary rocks consist of alluvium, calcareous dunes, and a mud flow. The Fonmmanu, Wailuku, and Kula lavas are the chief aquifers. They supply 28 irrigation wells, which yield an average of 170 million gallons a day of basal water. These wells are minelike shafts with infiltration tunnels and are called Maui-type wells. Well 16 yields $40,000,000$ gallons daily with a $2 \frac{1}{2}$-foot drawdown, which is the largest amount yielded by any well in the Hawaiian Islands. The largest spring (No. 26) on the island is artesian. It yields $10,400,000$ gallons daily and i ssues from Kula lavas near Nahiku. West Maui has numerous perennial strerms supplied by springs from a dike complex. Twenty-three tunnels in west $M$ rui recover 20.5 million gallons a day of high-level water, mostly from this dike complex. East Maui has few perennial streams in proportion to its size, and they are chiefly small, owing to the water sheds being underlain with permeable lavas. Forty tunnels recover a million gallons a day of high-level water in east $M$ zui and all from structures other than dikes.

It is estimated that about 100 million gallons a day of basal water wastes into the sea from west Maui and about 700 million gallons a day from east Maui. Describes a number of sites where wells could be sunk to recover this water. Also describes sites where tunnels could be driven to recover high-level supplies. The hydrology of east and west Maui is conspicuously different in many respects, mainly because of the difference in the stage of dissection, the extensive veneer of very permeable Hana lavas on east Maui, and the comparatively small area of the Lahaina lavas of similar age on west Maui. The only thernal water known in the Hawaiian Islands, except on the active volcano of Kilauch, is in a well in west Maui.

The report includes a geologic and topographic map of Maui (scale 1:62,500) showing wells, tunnels, springs, irrigation ditches, and reservoirs. 


\section{IDAHO}

111. Preliminary report on the water resources of the Mud Lake Basin, Idaho, by L. L. Bryan and H. T. Stearns, Moscow, Idaho, June 1922. 44 pp., 41 pls. (Mimeographed.)

Prepared in cooperation with the U. S. General Land Office, the Idaho Department of Reclamation, and the IdahQ Bureau of Mines and Geology. Discusses the geology, climate, streams, and water table and gives data on the water supply in lakes, the ground-water supply, and artesian conditions. Includes numerov's diagrams showing stream discharge and ground-water levels. Contains map showing groundwater contours and table of 17 analyses of well, spring, and lake waters. See also Water-Supply Paper 818.

112. Geology and water resources of the Goose Creek Basin, Cassic. County, Idaho, by A. M. Piper. Idaho Bur. Mines and Geology Bull. 6, Moscow, Idaho, 1923. 78 pp., 6 pls.

The area studied also includes small parts of the basin in Utah and Nevada. Describes the surface-water resources and gives runoff, precipitation, and other records. Describes the water in the Quaternary alluvium and, in the Tertiary volcanic rocks (pp. 49-74). Discusses the artesian area, describes therwal springs, and gives well records and analyses of water samples.

113. Ground-water supply at Moscow, Idaho, by F. B. Laney, V. R. D. Kirkham, and A. M. Piper. Idaho Bur. Mines and Geology Pamrh. No. 8, Moscow, Idaho, 1923. 13 pp., 3 pls. (Mimeographed.)

Describes the geology of the Moscow basin, ground-water conditions in the valley fill, and the decline in head of artesian wells. Gives the total annual consumption of water in Moscow as 230,000,000 gallons. Estimates the annual ir crement to the basin to be $550,000,000$ gallons. Makes recommendations for improving the city water system. Includes a map showing geology of the basin, location of wells, and artesian head.

114. Ground water in Pahsimeroi Valley, Idaho, by O. E. Meinzer. Idaho Bur. Mines and Geology Pamph. No. 9, Moscow, Idaho, February 1924. 35 pp., 3 pls. (Mimeographed.)

Describes the land forms, rock formations, and geologic development of the basin. Gives data on the precipitation and streams. Discusses the water table and the discharge, quality, and temperature of ground water. Concludes that flowing artesian water is not to be expected from the consolidated roeks but that snill flowing wells may be developed in the valley fill. Contains 22 well records and .4 analyses of ground water. Includes map showing geology and well locations.

115. Geology and water resources of the Bruneau River Basin, Owyhe: County, Idaho, by A. M. Piper. Idaho Bur. Mines and Geology Pamph. No. 11, Moscow, Idaho, 1924. 56 pp., 2 pls. (Mimeographed.)

Describes the structure of the several geologic formations of the area and the Lewis artesian basin. After brief discussion of the surface-water reso"rces, gives details of the Bruneau artesian slope, with records of 104 artesian wells.- Discusses the quality of the water and presents analyses of 20 well waters ard 3 spring waters. Makes recommendations for further development of the artisian water supply.

116. Ground water for irrigation on Camas Prairie, Camas and Elmore Counties, Idaho, by A. M. Piper. Idaho Bur. Mines and Geolog.' Pamph. 15, Moscow, Idaho, 1926. 46 pp., 1 pl. ( Mimeographed.)

Describes the geology and ground-water conditions in the lava and tla alluvium. Discusses the artesian conditions and area, with statements of the amount, permanence, and quality of the water and gives numerous well records and analyses of 4 well waters and 3 spring waters. Treats briefly of irrigation problems and well construction. Includes a map showing the geology and the wator table by contours.

117. Ground water for municipal supply at Idaho Falls, Idaho, by A. M. Piper and V. R. D. Kirkham. Idaho Bur. Mines and Geology Pamph. No. 16, Moscow, Idaho, 1926. 13 pp. (Mimeographed.) 
117. Ground water for municipal supply at Idaho Falls, Idaho-Continued.

Gives the results of a short field examination in March and April 1926. Concludes that the most favorable chances for an uncontaminated vrater supply will be obtained by drilling to porous layers of basalt or to sand ant gravel beneath the basalt.

118. Craters of the Moon National Monument, Idaho, by H. T. Stearns. Idaho Bur. Mines and Geology Bull. 13, Moscow, Idaho, 1928. 57 pp., 21 pls.

Describes the area and the types of lava. Water or ice is present in three kinds of localities-large water holes in broken lava, where snow collects in winter; crevices into which water may drip during thawing periods in autum or opring and be refrozen by cold circulating air; and lava caves or tubes, where drafts of cold air freeze water that has percolated into them. Lists the names and locations of 15 places where perennial water or ice is present. Plate 1 is a sketch map showing the location of the area. The other plates are photographs of the area and of volcanic phenomena.

\section{ILLINOIS}

131. Water resources of the East St. Louis district, by Isaiah Bowman and C. A. Roeds. Illinois State Geol. Survey Bull. 5, Urbrna, Ill., 1907. 128 pp., 4 pls.

Discusses the economic features of the district as a manufanturing site and describes the topography and geology and the water supplies from springs, eisterns, streams, lakes, reservoirs, and wells. Discusses undergrourd drainage, fluctuations of the water table, water resources of the karst, contarnination of karst water, unusual phenomena associated with springs and wells, and artesian conditions. Contains well sections and mineral and sanitary analyses of water.

\section{INDLANA}

134. Ground-water resources of the Indianapolis area, Marion County, Ind., by C. L. McGuinness. Indiana Dept. Cons., Div. Geol. Indianapolis, Ind., Jan. 1, 1943. 49 pp. (Mimeographed.)

Describes the geology of the area and the principal water-berring formations. Gives data on the development of wells.

135. Preliminary report on ground-water conditions in the vicinity of Scottsburg, Scott County, Ind., by F. H. Klaer, Jr., Indiana Dept. Cons., Div. Water Res., Indianapolis, Ind., April 1945. 8 pp., 1 pl. (Mimeographed.)

The total public water supply from shallow wells in glacial deposits was about 130,000 gallons a day in December 1944. This amount was not sufficient for all needs, and nearly 60 test wells were drilled to determine other favorable areas for constructing wells. Further testing is recommended south of the local drainage basin of a small lake that has supplied water for industrial use.

136. Memorandum concerning a pumping test at Gas City, Ind., with a detailed discussion of the methods used in the quantitative analysis of water-well interference problems, by J. G. Ferris. Indian - Dept., Cons., Div. Water Resources, Indianapolis, Ind, April 1945. 23 pp., 8 figs. 7 tables. (Mimeographed.)

The municipally-owned water supply of Gas City is obtained from a sroup of four wells serving a population of 3,400 . The daily consumptior in 1943 ranged from 171,000 gallons in January to 297,000 gallons in August. The report gives data on test drilling and pumping tests to develop a larger supply and presents a mathematical analysis of the pumping tests.

\section{IOWA}

137. Underground water resources of Iowa, by W. H. Norton, V'. S. Hendrixson, H. E. Simpson, O. E. Meinzer, and others. Iowa Geol. Survey, vol. 21, Des Moines, Iowa, 1912. pp. 29-1214, 16 pls. 
137. Underground water resources of Iowa-Continued.

An exhaustive study of the ground-water resources of the State, dividec into 15 chapters as follows:

1. Topography and climate, by H. E. Simpson.

2. Geology, by W. H. Norton and H. E. Simpson.

3. Geologic occurrence of ground water, by W. H. Norton, H. F. Simgron, and W. S. Hendrixson.

4. Artesian phenomena, by W. H. Norton.

5. Chemical composition of underground waters, by W. S. Hendrixson.

6. Munieipal, domestic, and industrial water supplies, by W. S. Hendxixs nn.

J. Mineral waters, by W. S. Hendrixson.

8-15. Detailed descriptions by counties, chiefly by O. E. Meinzer, W. H. Norton, and H. E. Simpson, with several county descriptions by M. F. Arey, W. J. Miller, A. O. Thomas, and J. L. Tilton.

Includes a map of Iowa showing artesian conditions and elevation of the St. Peter sandstone and map showing glacial drift sheets. This report is essentially the same as Water-Supply Paper 293.

\section{KANSAS}

141. Water supplies from wells available for irrigation in the uplands of Ford County, Kans., by S. W. Lohman. Kansas Geol. Survey Min. Res. Circ. 9 (Univ. Bull. vol. 39, No. 6), Lawrence, Kans., Mar. 1F. 1938. $10 \mathrm{pp}$.

Hollowing 7 years of deficient precipitation, a few apparently successf 1 irrigation wells have been drilled, in some of which the water stands more than 150 feet below the surface. Before irrigation from wells becomes more widespread, it is recommended that detailed ground-water studies be started with a view to determining the probable effect that increased withdrawal may have on the underground reservoirs.

142. Ground-water resources of Kansas. Kansas Geol. Survey Bull. 27, Lawrence, Kans., June 25, 1904. 112 pp., 34 pls.

The main part of the report treats of the geologic conditions affecting the occurrence of ground water and describes the several -water-bearing formations of the State. A small map (fig. 19) shows the ground-water provinces of the State. Contains the following papers:

Ground water in the McPherson district, by S. W, Lohman, pp. 63-66.

Occurrence of ground water in Ford County, by H. A. Waite, pp. 67-68.

Ground water in the Meade artesian basin, by J. C. Frye, pp. 69-71.

Ground water in the Scott district, by H. A. Waite, pp. 73-74.

Ground-water investigations in the Stanton district, by T. G. McLaughlin and Bruce Latta, pp. 75-76.

Gaging the ground-water reservoirs of Kansas, by S. W. Lohman, pp. 77-79.

143. Prospecting for a softer water supply for the Kansas State Penitentiary, Lansing, Kans., by S. W. Lohman and Alexander Mitchell. Kansas State Board of Health, Lawrence, Kans., July 1940. 17 pp., 1 map. (Mimeographed.)

Describes present supply from four wells of large diameter in alluvium and the pumping equipment. Gives data on nine test wells. Recommends eitl ar more complete treatment of present supply to reduce hardness or the use of water from Missouri River.

144. A preliminary report on the water supply of the Meade Artesian Basin, Meade County, Kans., by J. C. Frye. Kansas Geol. Survey B $\times 1$. 35, Lawrence, Kans., 1940. 39 pp., 7 pls.

Describes the geologic formations and their water-bearing characteristics and discusses artesian water, the amount developed from springs, flowing vells and nonflowing wells. Treats of the quality of the water, present utilization, ard future development of the basin. Contains a short diseussion of the shallow ground water. Includes maps showing ground-water levels and areas of artesian flow and a contour map of the piezometric surface near Meade County State Rarl. 
145. Geology and ground-water resources of Stanton County, Kans., by B. F. Latta, with analyses by R. H. Hess. Kansas Geol. S'xrvey Bull. 37, Lawrence, Kans., November 1941. 119 pp., 9 pls.

Gives a summary of the geography and geology of the county and a general discussion of the occurrence of ground water, its recharge, discharge, recovery, utilization, and quality. Describes the several water-bearing formations. Includes 38 analyses of water samples from wells, 22 well logs, and tabulated data on 147 wells. Contains maps showing geology, water-table contours, and depths to water.

146. Ground-water conditions in the vicinity of Lawrence, Kans., by $\mathbf{S}$. W. Lohman. Kansas Geol. Survey Bull. 38, pt. 2, Lawreree, Kans., June 23, 1941. pp. 17-64, 2 pls.

"This report presents the results of a detailed investigation of the groundwater conditions in and near Lawrence, with particular reference to the possibility of replacing the present municipal surface-water supply with a suitable supply of ground water. - . The alluvium in the Kansas River Valley is by far the most productive source of ground water in the vicinity of Lawrence." Estimates that an adequate supply for the city can be obtained from the alluvium in the Kansas River Valley. Includes a map showing water-table contours and gives analyses of $\mathbf{3 4}$ water samples from wells and test borings and records and logs of wells and borings.

147. Ground-water resources of Mississippian and older rocks in Bourbon, Crawford, Cherokee, and Labette Counties, southeastarn Kansas, by G. E. Abernathy. Kansas Geol. Survey Bull. 38, $\mathrm{F}^{+} .8$, Lawrence, Kans., Sept. 5, 1941. pp. 221-236.

Describes the geographic features and the water-bearing characteristics of the Lamotte sandstone, Roubidoux sandstone, Jefferson City-Cotter dolomite, and Boone limestone. Includes several water analyses.

148. Reconnaissance of ground-water resources in Atchison County, Kans., by J. C. Frye. Kansas Geol. Survey Bull. 38, pt. 9, Lawrence, Kans., Sept. 10,1941 . pp. $237-260,3$ pls.

A short discussion of the character of the Pennsylvanian, Tertiary (?), and Quaternary rocks, and water supplies in them.

149. Geology and ground-water resources of Morton County, Kans., by T. G. McLaughlin, with analyses by R. H. Hess. Kansas Geol. Survey Bull. 40, Lawrence, Kans., March 1942.126 pp.

Describes the general geology and the several water-bearing formations and gives data on the recovery, utilization, and quality of water. Contains well records, well logs, data on water levels, and 38. analyses of water from typical wells. Includes maps showing geology, water-table contours, and depths to water.

150. Ground-water supplies available for national defense industries in southcentral Kansas, by S. W. Lohman. Kansas Geol. Survey Bull: 41, pt. 1, Lawrence, Kans., Feb. 28, 1942. pp. 1-20.

Describes the available ground-water supplies in McPherson Valley, in Arkansas River Valley between Hutchinson and the Oklahoma State line, and in areas where only small supplies are available.

151. Ground-water supplies in Kansas available for national defense industries, by S .W. Lohman, J. C. Frye, H. A. Waite, V. C. Fishel, T. G. McLaughlin, B. F. Latta, and G. E. Abernathy. Kanses Geol. Survey Bull. 41, pt. 2, Lawrence, Kans., Apr. 14, 1942. pp. 21-68.

"This report calls timely attention to the availability in maro parts of Kansas of large supplies of water from wells or from streams for use by national defense agencies. It also summarizes the quality of water from wells ir different parts of the State with reference to suitability for industrial use." Contains list of references to publications on geology and water resources in Kansas.

152. Kansas mineral resources for wartime industries; Water resources, by J. C. Frye, J. M. Jewett, and others. Kansas Geol. Surrey Bull. 41, pt. 3, Lawrence, Kans., May 9, 1942 . pp. 177-179. 
152. Kansas mineral resources for wartime industries-Continued.

"Industrial ground-water supplies in excess of 5 million gallons a day can be obtained at many places in Kansas, and at certain selected localities supplies in excess of "20 million gallons a day are available."

153. Geology and ground-water resources of Ford County, Kans., I H. A. Waite, with analyses by R. H. Hess. Kansas Geol. Survey Bull. 43, Lawrence, Kans., December 1942. 250 pp., 16 pls., 22 figs.

Describes the source, occurrence, availability, and quality of ground water. The Ogallala formation (Pliocene) and Dakota sandstone (Cretaceous) are the chief water-bearing formations in the uplands. Large supplies of hard water are obtained from alluvium in the Arkansas River Valley. Discusses recharge and d"rcharge of ground water and describes the various types of wells used. Tables give well records, well logs, and chemical analyses.

154. Geology and ground-water resources of Meade County, Kans., by J. C. Frye, with analyses by R. H. Hess and E. O. Holmes. Kansas. Geol. Survey Bull. 45, Lawrence, Kans., December 1942. 152 pp., 12 pls., 10 tables.

Summarizes the geology, geography, and ground-water resources and gives data on well logs and test holes. States that much artesian water is obtained from the Ogallala formation (Pliocene). Includes chemical analyses of 48 samples of ground water and tabulated records of 354 wells and 24 test holes.

155. Geoolgy and ground-water resources of Hamilton and Kearny Counties, Kans., by T. G. McLaughlin, with analyses by E. O. Holmes. Kansas Geol. Survey Bull. 49, Lawrence, Kans., December 1943. 22^ pp., 17 pls. 21 tables.

A detailed report on the area, with preliminary description of the geosraphy and general geology. Discusses fluctuation of the water table, ground-water resharge and discharge, and recovery, utilization, and quality of water, with analyses. Snmmarizes the principal geologic formations and their water-bearing properties. Includes well records and logs, map showing geology and water-table contours, and map showing depths to water.

156. Ground water in the oil-field areas of Ellis and Russell Countier, Kans., by J. C. Frye and J. J. Brazil. Kansas Geol. Survey Bull. 50, Lawrence, Kans., December 1943. 104 pp., 2 pls.

Describes the geology of the area, which is covered by deposits of Cretaceous, Tertiary, and Quaternary age. States that water in some of the Cretaceous sandstones is highly mineralized but in some of the Dakota sandstone (Cretareous) and in younger formations is satisfactory for most uses. The depth to water ranges from about 5 feet in the main stream valieys to more than 150 feet in some upland wells that obtain water from Dakota sandstone.

157. Ground-water conditions in the Neosho River Valley in the virinity of Parsons, Kans., by C. C. Williams. Kansas Geol. Survey Bull. 52, pt. 2, Lawrence, Kans., Mar. 15, 1944.80 pp. 9 pls.

Gives the results of an investigation for water supply for the Kansas Ordnance Plant. Test drilling showed a thickness of about 35 feet of alluvium. A pumping test showed that about 200,000 gallons of water a day could be developed from several wells distributed in an area of about one square mile, with a punping rate not greater than 50 gallons a minute from each well.

158. Geology and ground-water resources of Finney and Gray Counties, Kans., by B. F. Latta, with analyses by E. O. Holmes. Kansas Geol: Survey Bull. 55, Lawrence, Kans., August 1944. 272 pp., 12 pls., 21 figs.

Describes the geologic formations and states that the main water-bearing beds are in the Ogallala formation (Pliocene) and in Pleistocene deposits and stream alluvium in the valleys of the Arkansas and Pawnee Rivers. States that the ground water is generally hard but suitable for most purposes. Discusses recharge to the aquifers and presents maps showing contours on the water table and depth to water.

159, Geology and ground-water resources of Thomas County, Kans., by J. C. Frye, with analyses ,by E. O. Holmes, Kansas Geol. Survey Bull. 59, Lawrence, Kans., December 1945. 111 pp., 6 pls., 13 figs. 
159. Geology and ground-water resources of Thomas County, Kans-Continued.

A detailed report on Thomas County, with discussion of the sereral water-bearing formation, data on quantity of water, and well records.

\section{KENTUCKY}

160. Progress report on the ground-water resources of the Louisville area, Ky., by W. F. Guyton, W. T. Stuart, and G. B. Maxey. Kentucky Dept. Mines and Minerals, Geol. Div., Lexington, Ky., March 1944. 20 pp., 10 figs. (Mimeographed.)

Pleintocene deposits of gravel in the Ohio River Valley near Louisville have a maximum thickness of about 130 feet. Heavy pumpage for industrial plants in 1941 42 seriously lowered the ground-water supply, which is recharged chiefly by infiltration from the river. The report recommends reduction of punnage until it does not exceed the recharge and guggests the development of adcitional supplies by induced filtration from the river, recharge through wells and bisins, and the construction of well in outwash deposits southwest of Louisville. Contains maps showing contours on the bedrock, contours on the water table, and lines of equal thickness of saturated aquifer.

160 a. Conservation of ground water, including artificial recharge, by two companies in the Louisville area, Ky., by W. T. Strart. Kentucky Dept. Mines and Minerals, Geol. Div., Lexington, Ky., July 1944. 10 pp., 5 figs. (Mimeographed.)

Describes the need for cool water by two large alcohol distille-ies and the serious lowering of the ground-water table by continuous pumping of the $e^{i r}$ own wells. States that the difficulty was solved by pumping the private wells only in the summer and using water from the municipal wells in the winter.

$160 \mathrm{~b}$. Ground water in the bedrock beneath the glacial outwash in the Louisville area, Ky., by D. K. Hamilton. Kentucky Drpt. Mines and Minerals, Geol. Div., Lexington, Ky., August 1944. 13 pp., 4 figs. (Mimeographed.)

Describes the formation of shale and jointed and cavernous limestone of Ordovician to Mississippian age. States that about 50 deep wells have been drilled. About one-third of these yield water of good quality at rates of morn than 20 gallons a minute; the rest encountered highly mineralized water. Estimater the total pumpage in 1943 as being 5 to 8 million gallons a day.

160 c. Chemical analyses of water from wells in the Louisvi"e area, Ky., by H. E. Sublett. Kentucky Dept. Mines and Minerals, Geol. Div., Lexington, Ky., August 1944. 6 tables. (Mimeographed.)

Presents 92 tabulated analyses of water from wells in or near Louisville.

$160 \mathrm{~d}$. Conservation of ground water in the Louisville area. $\mathrm{Ky}$., by W. F. Guyton and H. E. Sublett. Kentucky Dept. Mines anc' Minerals, Geol. Div., Lexington, $\mathrm{Ky}$., October 1944. 4 pp. (Mimeographed.)

Gives the results of a cooperative investigation on the decline of the ground-water level, which indicate that pumpage exceeded the probable recharge by 20 to 30 million gallons a day. Recommends that pumping be reduced to less than 40 million gallons a day.

160 e. Chemical analyses of water from wells in the Louisvile area, Ky., by H. E. Sublett. Kentucky Dept. Mines and Minerals, Geol. Div., Lexington, Ky., November 1944. 2 pp., 4 tables. (Mimergraphed.)

Supplements list of analyses issued August 1944 and includes second analyses of water from 48 of the wells in the previous group. Also includes analyses of water from 10 wells that were not previously sampled. Map shows location of all the wells included in both tabulations.

$160 \mathrm{f}$. Drillers' logs of wells and test borings in the Louisville area, Ky., by D. K. Hamilton. Kentucky Dept. Mines and Minerals, Geol. Div., Lexington, Ky., January 1945.70 pp. (Mimeographeł.)

A tabulated list of 175 logs of wells and test borings in Kentucky. 


\section{LOUISIANA}

161. Geology and underground water resources of northern Louisiana, with notes on adjoining districts, by A. C. Veatch. Louisiana Genl. Survey Bull. 4, Baton Rouge, La., 1906. 209 pp.

Discusses the subject under the chapter headings of Geology, General underground water conditions, Methods and cost of well making, and Underground wat $\mathrm{x}$ prospects by counties. Contains table of wells and springs and maps of artesian areas. A preliminary report entitled, "The underground waters of northern Louisiana and southern Arkansas," by A. C. Veatch, but not specifically a joint report of the State and Federal surveys, was issued in 1905 as Louisiana Geol. Survey B ll. 1, pt. 2.

162. Investigations of ground-water supplies in Louisiana, by V. T. S'ringfield and J. C. Maher. Louisiana Cons. Rev., vol. 8, No. 1, New Orleans, La., Spring 1939. pp. 35-38.

A general discussion of ground-water resources of the State and their development for municipal supplies and irrigation. In 1937 nearly 214,000 acres ware irrigated from wells, chiefly rice land in the southwest part of the State. Mentions studies of water levels in Rapides Parish, with notes on the post-Miocene and Miocene water-bearing beds. Notes the presence of objectionable amounts of fluoride in some waters,

163. Fluoride in the ground water of Avoyelles and Rapides Parithes, La, by J. C. Maher. Louisiana Dept. Cons. Geol. Pamph; Nis 1, New Orleans, La., 1939. 23 pp., 2 pls.

Discusses the chemical character of water from the Miocene forrations and from sediments overlying the Miocene deposits. States that most of the water from Miocene formations contains some fluoride, the water from the younger Miocene sands in and near Bunkie having the highest fluoride content. Mentions that the coarser sediments overlying the Mibcene deposits yield soft water that contains no fluoride: Incitides a häp showing loéation of welis.

164. Progręss of ground-water investigations in Louisiana, by J. C. Maher and T. B. Stanley, Jr. Louisiana Cons. Rev., vol. 8, No. 4, New Orleans, La., Winter 1939-40. pp. 35-88, 44-45-

Gives general statements concerning the water-bearing formations in Rapides, Grant, LaSalle, Jefferson Davis, Acadia, Avoyelles, Tangipahoa, St. Tammany, and East Baton Rouge-Parishes. Contains map of Rapides Parish showing piezometric surface of water in Miocene sands.

165. Ground water in Grand and LaSalle Parishes, La., by J. C. Maher. Louisiana Cons. Rev., vol. 9, No. 1, New Orleans, La., Spring 1940. pp. $86=41$.

A description of the séveral geologic formations, with summary stitementis of their water-bearing properties and the quality of the water.

166. Preliminary report on ground-water conditions at Alexandric. La., by J. C. Maher. Louisiana Dept. Cons. Geol. Pamph. No. 2, Now Orleans, La., 1940. 54 pp., 1 pl.

Describes the three principal water-bearing sands in the Miocene series and the water-bearing beds of the Pleistocene and Recent deposits. Discusses the fluctuation of water levels and decline of artesian head and presents records of the water level and of pumpage. Gives analyses of waters from 4 wells. 'A map showin? the piezometric surface is reproduced from Louisiana Geol. Survey Bull. 17.

167. Ground-water resources of Rapides Parish, La., by J. C. Mahe". Louisiana Geol. Survey Bull. 17, New Orleans, La., 1940. 100 pp., 10 pls.

Describes the several water-bearing formations, which range from Miocene to Recent in age. Discusses the public water supplies, consumption of water, quality of water, and artesian conditions. Gives 61 analyses of well waters, measurements of water level or artesian pressure in 55 wells, and logs of 46 wells. Includes maps showing quality of water and piezometric surface.

168. Records of wells and water analyses for Caddo and Bossier Parishes, La., by L. O. Wiringa. New Orleans, La., 1943. 71 pp., 1 map. (Mimeographed.) 
168. Records of wells and water analyses for Caddo and Bossier Parishes, La. -Continued.

Prepared in cooperation with the Police Juries of Caddo and B-ssier Parishes, the Louisiana Department of Conservation, and the Louisiana Depariment of Public Works. Contains a short summary of the investigation and tabulated records of 327 wells in Bossier Parish. Gives the results of preliminary chemical examination of 82 well waters in Caddo Parish and 29 in Bossier Parish and ehemical analyses of four well waters from each parish.

169. Ground-water geology at Natchitoches, La., by J. C. Maher and P. H. Jones. New Orleans, La., May 1, 1944. 23 pp. 3 pls., 1 table. (Mimeographed.)

Prepared in cooperation with the Louisiana Geological Survey and the city of Natchitoches. Data obtained by test drilling indicate that the city is on a downthrown fault block. Salt water is present in the-sands underlying rost of the city. but to the southwest abundant supplies of soft water are present in the Sparta sand and in sands of the Wilcox formation. A supply of at least one million gallons a day may be obtained for the city from three to five properly constructed wells in that area. See also Water Supply Paper $968 \mathrm{c}$.

170. Ground-water resources of Jefferson Davis and Acadia Parishes, La., by T. B. Stanley, Jr., and J. C. Maher. Louisiana Dept. Pub. Works, , Baton Rouge, La., 1944. 93 pp., 10 pls., 10 figs.

Prepared in cooperation with the Louisiana Department of Conservation and the Louisiana Department of Public Works. Outlines the geology and discusses source and movement of the ground water. Describes water-level fluctuations, decline of water levels, safe yield, and water utilization. Plates 6-10 show contours on the piezometric water surface at different dates. Includes tabulated records of 221 wells in Acadia Parish and 220 wells in Jefferson Davis Parish.

170 a. Ground-water conditions of the Baton Rouge area, Lovisiana, with special reference to the shallow artesian sands of the industrial district, a progress report, by.E. M. Cushing and P. H. Jones. Louisiana State Dept. Public Works, Baton Rouge, La., 1945. 33 pp., 7 figs. (Mimeographed.)

Prepared in cooperation with the Louisiana Department of Consirvation and the Louisiana Department of Public Works. Describes the geology, with special regard to the Tertiary and Quaternary deposits and ground-water condition 7 in the shallow sands. Summarizes the quality of ground water, yield of wells, purypage, recharge, and conservation of the ground-waier supplies.

\section{MARYLAND}

171. The surface and underground water resources of Maryland, including Delaware and the District of Columbia, by W. B. Clark, E. B. Mathews, and E. W. Berry. Maryland Geol. Survey Special Pub., vol. 10, pt. 2, Baltimore, Md., March 1918. pp. 153-549.

Discusses the ground-water table, artesian wells, springs, dug wells, and the several water-bearing formations in Maryland (pp. 231-262). Descrik es surface-water and ground-water conditions in the several counties of Maryland, the District of Columbia, and Delaware and gives well records (pp. 263-491). Discurses public water supplies and sanitary conditions and chemical character of the waters and gives many water analyses (pp. 492-542).

\section{MICHIGAN}

181. Failure of wells along the lower Huron River, Mich., in 1904, by M. L. Fuller. Michigan Geol. Survey Rept. for 1904, Lansing, Mich., 1904. 31 pp.

Diseusses the geology and water supplies by regions. The Grosse Irle well, of great flow, locally thought to have caused decline of wells in the lower Huron River region, is not a factor. Removal of timber and ditching have been factors, but the chief cause was the severe drought of 1903-4. Return to normal rainfall will result in increase of the water supply. Recommends deeper wells as simplest solution of the shortage. Discusses desirability of lawF regulating deep or anţrian.welis. 


\section{MISSISSIPPI}

191. Artesian water resources in Mississippi, by V. M. Foster and G. F. Brown. Mississippi State Plann. Comm., University, Miss., March 1939.16 pp., 6 tables. (Mimeographed.)

A report of progress of investigations during the preceding year, with discussion of the decline of artesian pressure, or static water levels. Gives 6 pages of tabulated well data showing the decline in various wells.

192. Geology and ground-water supply at Camp McCain, by G. F. Brown and R. W. Adams. Mississippi Geol. Survey Bull. 55, University, Miss., 1943. 116 pp., 11 pls.

States that the prineipal water-bearing beds are the Meridian sand in the base of the Claiborne group and sands near the middle of the Wilcox formation, and that the former is capable of yielding enough water to supply all needs of the camp down to about 280 feet. Says that the water is of good quality but contains appreciable amounts of iron and carbon dioxide and therefore needs treatment.

193. Geology and ground-water supply at Camp Van Dorn, by G. F. Brown and W. F. Guyton. Mississippi Geol. Survey Bull. 56, University, Miss., 1943. 68 pp., 13 pls.

Describes the geologic formations that underlie the area and their water-bearing properties. States that the water supply of the camp is obtained from nine wells, which draw from three different formations.

194. Geology and ground-water resources of the Camp Shelby are ${ }_{\text {, }}$ by G. F. Brown. Mississippi Geol. Survey Bull. 58, University, Miss $、 1944.72$ pp., 7 pls. 8 figs.

States that large supplies of fresh water are contained in the Catahoula sandstone, Hattiesburg formation, and Pascagoula formation, all of Miocere age. Water for the camp is obtained chiefly from the Hattiesburg formation, the p"mpage being about four million gallons a day, from depths mainly of less than 100 feet. Also describes Pleistocene deposits and their water-bearing possibilities.

195. Teology and ground-water resources of the coastal area of Mississippi, by G. F. Brown, V. M. Foster, R. W. Adams, E. W. Reed. and H. D. Padgett, Jr. Mississippi Geol. Survey Bull. 60, University, Miss., 1944. 232 pp., 14 pls., 18 tables, 23 figs.

Gives a detailed description of the geology and water-bearing proverties of the several formations. Discusses the ground-water resources in George, Jfancock, Harrison, Jackson, Pearl River, and Stone Coynties. Describes the waste of ground water, encroachment, and conservation of ground water. Includes geologic map, cross sect.uns, hydrographs, and logs and records of many wells.

\section{MISSOURI}

200. The larire springs of Missouri, by H. C. Beckman and N. S: Hinchey. Missouri Geol. Survey and Water Res., vol. 29, $2 d$ ser., Rolla. Mo., 1944. 141 pp., 18 pls.

Gives general information on the springs in Missouri and descriptions and discharge of 159 springs. Includes outline map of Missouri showing location and relative size of the large springs.

\section{NEBRASKA}

201. Ground-water level survey in Nebraska, by H. A. Waite. Nel raska Geol. Survey Paper No. 7, Lincoln, Nebr., 1935. 14 pp.

Describes the selection of observation wells and methods of recorling the data. Gives summary of water-level records in Platte River Valley, October 1730 to October 1934. Includes map showing location of observation wells.

202. Ground water in the Republican River Basin in Nebraska, part.1, Nuckolls, Webster, Franklin, and Harlan Counties, by H. A. Waite, E. C. Reed, and D. S. Jones, Jr. Nebraska Water Res. Survey Water Supply Paper 1, Lincoln, Nebr., October 1944. 43 pp., 8 figs. (Offset.) 
202. Ground water in the Republican River Basin in Nebraska, part 1-Continued.

rrepared in cooperation with Nebraska Department of Roads and Irrigation. Gives short discussions of the geology and ground-water conditions in each county and the logs of 243 test holes. Includes maps showing location of test holes and data on the water-bearing formations.

203. Ground water in the Republican River Basin in Nebraska, part 2, Furnas County, by H. A. Waite, E. C. Reed, and D. S. Jones Jr. Nebraska Water Res. Survey Water Supply Paper 1, Linooln, Nel v., February 1945. 32 pp., 2 figs. (Offset.)

Prepared in cooperation with Nebraska Department of Roads and Irrigation. Gives a brief description of the geology of Furnas County and its relation to the occurrence of ground water. Contains map showing location of test holes, contours on top of the Cretaceous bedrock, and the approximate thickness of the waterbearing sand and gravel in the valley of the Republican River and its principal tributaries. Presents the logs of about 130 test holes.

204. Ground water in the Republican River Basin in Nebraska. part 3, Red Willow and Frontier Counties, by H. A. Waite, E. C. Re`d, and D. S. Jones, Jr. Nebraska Water Res. Survey Water Supply Paper 1, Lincoln, Nebr., August 1945. 35 pp., 2 pls. (Offset.)

rrepared in cooperation with the Nebraska Department of Roads and Irrigation. Describes the geology and ground-water conditions in each county. Fresents the logs of 151 test holes in Red Willow County and 15 in Frontier County. Includes maps showing location of test holes and data on the water-bearing beds.

205. Ground-water survey of area north of O'Neill, Holt Coun'y, Nebr., by E. C. Reed. Nebraska Water Res. Survey Water Supply Paper 2, Lincoln, Nebr., December 1944. 26 pp., 12 figs.

rrepared in cooperation with Nebraska Conservation and Survey Division Gives results of a study of the possibilities of pump irrigation in an area of about 70 square miles situated north and northwest of $O^{\prime} N$ eill. Includes re?ords of 13 test holes 39 to 84 feet deep and descriptions of the geology, topography, drainage, soils, and ground water. Concludes that pump irrigation may be economically feasible on a small scale in a limited part of the area.

\section{NEVADA}

208. Progress report on the ground-water resources of the Las Vegas artesian baisin, Nev., by G. B. Maxey and C. H. Jamesson. Carson City, Nev., March 1945. 36 pp., 10 figs. (Mimeographed.)

Prepared in cooperation with the Nevada State Engineer's Offire. Discusses the valley fill and the occurrence of shallow water and artesian wate". Gives data on the quality of the water. Eimphasizes the need for improved well construction and for conservation of the ground water. Includes map of the basin showing location of wells and depths to water.

\section{NEW JERSEY}

211. Memorandum on investigation of quantities of ground $w$ ter available for public and industrial supplies in New Jersey, by D. G. Thompson. New Jersey Water Policy Comm. Rept., pt. 2, appendix 3, Trenton, N. J., Feb. 27, 1926. pp. 91-102.

Describes the ground-water conditions in various jarts of the State and in several metropolitan areas. Gives the problems involved in a closer contro' by the State of the development of the ground-water resources.

212. Ground-water supplies of the Atlantic City region, by D. G. Thompson, New Jersey Dept. Cons. and Devel. Bull. 30, Trentor. N. J., 1928. 138 pp., 7 pls.

Describes the present water supplies, their quality (with four analyses of well water), and the consumption, and discusses the possible sources of future supply. 
212. Ground-water supplies of the Atlantic City region-Continued.

Contains a detailed study of the 800-foot sand of the Kirkwood formation (Tertiary) with discussion of the danger of salt-water contamination. Gives a short dracription of the shallow ground-water horizons on the mainland.

213. Ground-water supplies in the viciinty of Asbury Park, N. J., b D. G. Thompson. New Jersey Dept. Cons. and Devel. Bull. 35, Trenton, N. J., 1930. $50 \mathrm{pp}$.

Describes the water supplies and ground-water horizons and the consumption and quality of water, with 8 water analyses. Gives a detailed description of the waterbearing capacity of the three principal sands in the Cretaceous deposits and discusses the possibility of contamination by salt water.

214. Ground-water supplies of the Passaic River Valley near Chathan, N. J., by D. G. Thompson. New Jersey Dept. Cons. and Devel. Pull. 38, Trenton, N. J., 1932. 51 pp., 1 pl.

Gives a short description of the water supplies of the area and the amount of water consumed. Discusses the geologic conditions aftecting the occurrence of ground water. Presents data on the amount of water available and gives the results of three pumping tests. A short discussion of quality of water includes 5 analyses of well water. Includes a map showing the location of well fields and contours on the surface of the bedrock.

215. Ground-water supplies of the Camden area, $N$ J., by D. G. Thrmpson. New Jersey Dept. Cons- and Devel. Bull. 39, Trenton, N. J., 1932. 80 pp., 2 pls.

Describes the water supplies of the area from wells in Tertiary and Cretaceous sands, discusses the geologic conditions, and gives graphic logs of 13 well v Gives a detailed study of wells and data on the consumption of water. A discussion of quality of water includes 5 analyses from city wells and 3 other samples of the Camden water supply. Contains a map showing the principal water-bearing formations in the area.

216. Supplementary report on the ground-water supplies of the Atlartic City region, N. J., by H. C. Barksdale, R. W. Sundstrom, and M. S. Brunstein. New Jersey State Water Policy Comm. Special Rept. 6, Trenton, N. J., 1936. 139 pp.

This is primarily a study of the three principal producing sands of the Atlantıc City waterworks and a discussion of contamination by salt water. Cintains 8 analyses of the ground water and numerous tests of chloride content of the water. Includes maps showing location of wells and maps of the city well field showing by contours the piezometric surface.

217. Water supplies in the No. 1 sand in the vicinity of Parlin, N. J., by $\mathbf{H}$. C. Barksdale. New Jersey State Water Policy Comm. Special Rept. 7, Trenton, N. J., 1937. 33 pp.

A study of the lowest water-bearing sand in the Raritan formation (Cretaceous), especially with regard to marked lowering of head of the water due to extensive pumping. Contains a short discussion of the quality of the water (with 3 analyses of deep well water) and of the danger of salt-water contamination. Includes a mas showing intake area of the No. 1 sand and location of principal wells.

218. The ground-water supplies of Middlesex County, N. J., by H. C. B?rksdale and others. New Jersey Water Policy Comm. Special Rept. 8, Trenton, N. J., 1943. 160 pp., 13 pls.

Describes the geology of the area and the main water-bearing formaticns. State that the Old Bridge sand of the Raritan formation is the most important aquifer and supplies more than half of the total amount of water used for rmblic and industrial purposes. Also discusses the yield from the Farrington sand of the Raritan formation and from strata of the Newark group. Concludes that no more large ground-water developments can be made in the county and that additional large supplies must come from surface water sources. 


\section{NEW MEXICO}

231. Report on investigations of the Roswell artesian basin, Craves and Eddy Counties, N. Mex., by A. G. Fiedler. New Mexico State Eng. 7th Bienn. Rept. 1925-26, Santa Fe, N. Mex., 1926. pp. 21-60, 10 pls.

A $\cdot$ study of the head of artesian water and the quantity of water discharged from wells. Describes the area of artesian flow and includes map (pl. 2) showing the original and later flowing-well areas. Discusses recharge and methods of repairing and plugging wells and makes recommendations as to future water development and its control by legislation. See also Cooperative reports 236, 2.40, 242.

232. The geology and artesian water prospects in the San Jose-Rio Puerco Valley in Sandoval County, N. Mex., by B. C. Renick. New Mexico State Eng. 7th Bienn. Rept. 1925-26, Santa Fe, N. I^ex., 1926. pp. 61-75.

Discusses the stratigraphy, structure, and artesian-water conditions and the prospecive areas of ar.esian flow. Gives recommendations for drillirg three test wells.

233. Ground-water reconnaissance in Socorro County, N. Mex., by Kirk Bryan. New Mexico State Eng. 7th Bienn. Rept. 1925-26, Santa Fe, N. Mex., 1926. pp. 77-87.

A short discussion of the geography of the area and of the alluvial water-bearing deposits in the plains areas.

234. Ground-water reconnaissance in DeBaca County, N. Mex., by Kirk Bryan. New Mexico State Eng. 7th Bienn. Rept. 1925-26, Sante Fe, N. Mex., 1926, pp. 88-91.

A summary statement concerning the water-bearing formations, with discussion of possible artesian water in the Chupadera formation, of Permian age, and shallow ground water in the alluvial flood plains and terraces of the Peros River.

235. Geology and ground-water resources of the drainage brsin of the Rio Penasco above Hope, N. Mex., by B. C. Renick. New Mexico State Eng. 7th Bienn. Rept. 1925-26, Santa Fe, N. Mex., 1926. pp. 103-138, 1 pl.

A study of the possible development of additional water supplies for irrigation at Hope community, especially from bodies of perched ground water. Study was made of flve areas, but recommendation is made for testing only the middle Penasco. Describes the stratigraphy and structure. Gives special attention to perched water and springs and to shallow ground-water conditions. A short discussion of quality of water includes analyses of the river water and of three samples of spring water.

236. Ground-water investigation of the Roswell artesian bas: $n, N$. Mex., by A. G. Fiedler and S. S. Nye. New Mexico State Eng. $\mathcal{E}^{\text {th }}$ Bienn. Rept. 1926-28, Santa Fe., N. Mex., 1928. pp. 81-107, 5 pls.

A general discussion of the stratigraphy and structure, with a brief description of ground-water conditions, and a detailed study of artesian-water development and the decline'in artesian head. Treats briefly of the area of flowing wells, quantity of water discharged, and recharge. Includes a.map showing area of artesían flow and area of economic pumping lift.

237. Report on a reconnaissance of the gropnd-water area of the Mimbres Valley, Luna County, N. Mex., by A. G. Fiedler. New Mexico State Eng. 8th Bienn. Rept. 1926-28, Santa Fe, N. Mex. $192 £$ pp. 159-171.

The examination was made in order to study the quantity and annual replenishment of the ground-water supply. Since early irrigation develorment in 1910, the ground-water level appears to have declined 5 or 6 feet throurhout most of the region. Discusses the development of the water in the alluvial deposits, the water level, and available quantity of ground water, with recommendations for detailed study. See also Cooperative reports $238,242,246,251$.

238. Preliminary report on the ground-water supply of Mimbres Valley, N. Mex., by W. N. White. New Mexico State Eng. 9th Bienn. Rept. 1928-30, Santa -Fe, N. Mex., 1930. pp. 131-152. 
238. Preliminary report on the ground-water supply of Mimbres Valley, N. Mex.-Continued.

Discusses the source of ground water and gives records of stream discharge, underflow, and ground-water intake. Gives observations on the changes in groundwater level and recommendations for legal control of further develomment. See also Cooperative reports $243,246,251$.

239. Shallow ground-water supplies in northern Lea County, N. Mex., by S. S. Nve. New Mexico State Eng. 9th Bienn. Rept. 1928-30, Santa Fe. N. Mex., 1930. pp. 363-387, 1 pl. Also published as Dept. State Eng. Bull. 2, June 1930.

Gives a short description of the exposed geologic formations. Preserits detailed study of water in the Tertiary deposits and its development for irrigatior Discusses briefly quality of water and gives 15 analyses of well waters. Conclud that the ground-water supply is relatively undeveloped but recommends the beginning of observations of the water level. Reproduces the State law regulating use of ground water. See also Cooperative reports 244, 247, 250.

240. Recommendations for a more efficient utilization of the water resources of the Roswell artesian basin, N Mex., by A. G. Fiedler and $\mathrm{S}$. S. Nye. New Mexico State Eng. 9th Bienn. Rept. 1928-30, Santa Fe, N. Mex., 1930. pp. 389-423, 2 pls. Also published as Dept. State Enr. Bull. 1, 1930.

After brief description of the geology and the artesian water develonment, discusses the ground-water recharge, the amount of water in the valley fill, and the construetion of wells. Gives a short discussion of the water table in the Felix shallow-water district. Includes a map showing flowing-well and pumpinr-well area and maps showing depths to water table.

241. Report on the ground water in Curry and Roosevelt Counties, N. Mex., by C. V. Theis. New Mexico State Eng. 10th Bienn. Rept 1930-32, Santa Fe, N. Mex., 1932. pp. 98-160.

Gives a summary of the geology of the area and detailed discussion of ground water in the valley fill and the development of irrigation. Gives logs of 5 wells and records of depth, water level, and yield of about 450 wells. In the diseussion of quality of water gives several anaiyses. Includes map showing hrdrographic and geologic data and maps showing hydrologic features, slope of water table, and lowering of the water table. See also Cooperative report 245 .

242. Progress report of the Roswell artesian basin investigation, by A. G. Fiedler and S. S. Nye. New Mexico State Eng. 10th Bienn. Rept. 1930-32, Santa Fe, N. Mex., 1932. pp. 162-182.

Gives a summary of the artesian conditions and irrigation development and describes the local artesian conditions by townships. Discusses the chan res in head of artesian water from 1925 to 1932 . Includes a short description of water level in the Felix shallow-water district.

243. Progress report on the ground-water supply of the Mimbres Valley, N. Mex., by W. H. White. New Mexico State Eng. 10th Bienn. Rept. 1930-32. Santa Fe, N. Mex., 1932. pp. 183-228.

A report on investigations made to determine the safe pumping yield of the ground-water reservoir. Gives a summary of the amount of water pumped and the water-table fluctuations, with short discussions of the form of the wate- table and quality of the water. Gives tabulated data on pumping plants and depth to water in observation wells. Contains a map showing location of observatior wells and contours of the water table.

244. Progress report on the ground-water supply of northern Lea Cunty, $N$. Mex., by S. S. Nye. New Mexico State Eng. 10th Bienn. Rept. 1930-32, Santa Fe, N. Mex., 1932. pp. 229-251.

Gives observations on the geologic formations, with discussion of ground water in the Tertiary deposits and data on quality of the water. Presents records of water level in observation wells and data on the water table. Gives results of pumping tests on five wells. Ineludes a map showing contours of the water tabli. 
245. Progress report on the ground-water supply of the-Portales Valley, N. Mex., by C. V. Theis. New Mexico State Eng. 11th Biern. Rept. 193234, Santa Fe, N. Mex., 1934. pp. 87-108.

Gives summary of a previous report (See Cooperative report 241) and data on additional pumping tests. Presents data on the quantity of ground water pumped for irrigation and records of water levels in observation wells. Inclutes maps showing changes in ground-water level.

246 Progress report on the ground-water supply of the Mimbres Valley, $N$. Mex., by W. N. White. New Mexico State Eng. 11tl Bienn. Rept. 1932-34, Santa Fe, N.Mex., 1934. pp. 109-125.

Gives data on pumping plants and the amount of water pumped from wells. Records the changes in ground-water level as noted in observation wells.

247. Progress report on the ground-water supply of Lea Count.7, N. Mex., by C. V. Theis. New Mexico State Engineer. 11th Bienn. Rept. 1932-34, Santa Fe., N. Mex., 1934. pp. 127-153.

Discusses the character of the water-bearing material. Gives details on the pumpage of water and the changes in water level. Describes the recharge area, with computations on the ground-water recharge based on the fretuations of the water table.

248. Geology and ground-water conditions of the Pecos River Valley in the vicinity of Laguna Grande de la Sal, N. Mex., with special reference to the salt content of the river water, by T. W. Robinson ard W. B. Lang. New Mexico State Eng. 12th-13th Bienn. Repts. 1934-38, Santa Fe., N. Mex., 1938. pp. 77-100, 5 pls.

Discusses the geology of the area and ius general relation to the occurrence of brine. Describes the occurrence of ground water in the several forrations, including artesian water in Laguna Grande de la Sal. Includes maps shcring location of wells and springs and map showing area underlain by brine.

249. Progress report on the ground-water supply of the Portales Valley, N. Mex., by C. V. Theis. New Mexico State Eng. 12th-13tr. Bienn. Repts. 1934-38, Santa Fe, N. Mex., 1938. pp. 101-119.

Gives data on precipitation, evaporation, and amount of pumping, and changes in water levels, 1934-37, based on the records from 136 observation wells. Includes maps showing changes in the ground-water level.

250. Progress report on the ground-water supply of Lea County, N. Mex., by C. V. Theis. New Mexico State Eng. 12th-13th Bienn. Pepts. 1934-38, Santa Fe, N. Mex., 1938. pp. 121-134.

Gives a summary of hydrologic conditions, data on the amount of pumping from 1934 to 1937, and the fluctuations of water levels in 24 observation wells.

251. Progress report on the grounc.water supply of the Mimbres Valley, $N$. Mex., by C. V. Theis. New Mexico State Eng. 12th-13tl Bienn. Repts. 1934-38, Santa Fe, N. Mex., 1938. pp. 135-154.

Gives data on the water pumped from wells, 1934-37. Presents the changes in water level and an in interpretation of the data. Includes map showing areas irrigated by wells and maps showing decline in the water table.

252. Geology and shallow-water resources of the Roswell artecian basin, $\mathrm{N}$. Mex., by A. M. Morgan. New Mexico State Eng. 12:h-13th Bienn. Rept. 1934-38, Santa Fe, N. Mex., 1938. pp. 155-249, 5 pls.

Discusses the several geologic formations and the presence of water in the Quaternary and Permian strata. Gives data on depth to shallow ground water, its development for irrigation, and the quantity available. Includes map showing contour of the water table and map showing depths to the water table. Gives records of 495 wells drawing water from the valley fill and records of change in water level in a number of observation wells. 
253. Origin of water in Major Johnson Springs, near Carlsbad, N. Mex., by C. V. Theis. New Mexico State Eng. 12th-13th. Bienn. Rept. 1934-38, Santa Fe, N. Mex., 1938. pp. 251-252.

The flow of the springs changes with the stage of water in Lake MicMillian, a few miles to the northeast, varying from 272 second-feet when the reservoir is full to about 40 second-feet when it is empty. The springs are probably fed by river water through shallow underground channels, but the water is derived from leakage from the Roswell artesian basin. All the leakage from Lake MacMillian reappears in the springs.

254. Ground-water conditions in the middle Rio Grande Valley, N. Mex., by C. V. Theis and G. C. Taylor, Jr. New Mexico State Eng. 12th-13th Bienn. Repts. 1934-38, Santa Fe, N. Mex., 1938. pp. 263-271.

Describes the position of the water table as measured in about 1,100 shallow wells. "These measurements have shown that over most of the flood'plain area of the middle Rio Grande Valley the water table lies within 8 feet of the surface and that the movement of ground water is considerably influenced by spepage from irrigation and irrigation canals and by ground-water discharge by tranqpiration in areas of natural vegetation." Gives tabulated data on depth to water, by acreage, in the several districts. Discusses source and movement of the ground water.

255. Ground water in the middle Rio Grande Valley, N. Mex., by C. V. Theis. Nat. Resources Comm. Regional Planning, Part 6, Upper Rio Grande, vol. 1, part 2, Ground-water resources, Washington, D. C., February 1938. pp. 268-291. Also published by the U. S. Geol. Survey as Ground water in the middle Rio Grande Valley, N. Mex., 19£7. 63 pp. (Mimeographed.)

Describes the method of investigation. Discusses the water table and movement and source of the ground water. Gives a real description of rechargs, movement and discharge of the ground water, and description of ground-water cond tions before drains were constructed. Includes map showing contours of the water table.

256. Geology and ground water [Pecos River Basin, N. Mex. and T $x$ xas], by A. N. Sayre, C. V. Theis, A. M. Morgan, W. E. Hale, J. W. Lang, and P. E. Dennis. Nat. Resources Plann. Bd., Pecos River joint investigation in the Pecos River Basin in New Mexico and Texas, pt. 3, vol. 3, Rept. B, Washngton, D. C., March 1941. 93 pp. (Mimeographed.)

An intensive survey of the area, with discussion of the geology, gecmorphology, and ground-water hydrology of the several areas in the Pecos Valley in New Mexico and the Pecos River Basin in Texas. Contains maps showing the water table and location of wells and hydrographs showing fluctuation of the ground-water level.

257. Ground-water hydrology of areas in the Pecos Valley, N. Mex., by C. V. Theis and others. Nat. Resources Plann. Bd., Pecos River joint investigation reports, Washington, D. C., June 1942. pp. 38-7\%.

Discusses the relation of the ground water and geology to the regimen of the river. Describes several large springs from cavernous limestone and sinall springs of salt water from the Rustler formation.

\section{NEW YORK}

271. Statement concerning the investigation of the ground-water resources of Long Island, N. Y., by D. G. Thompson and A. G. Fiedler. J'ew York State Legislative Doc. (1932) No. 104, Albany, N. Y., 1932. pp. 17-23.

Describes the area, the development of ground water, the population and present consumption of water, and the scope of the investigation.

272. Statement concerning the investigation of ground-water res wurces of Long Island, N. Y., by D. G. Thompson. New York State Lregislative Doc. (1933) No. 103, Albany, N. Y., 1933. pp. 17-34. Also published by U. S. Geol. Survey, Mar. 20, 1933. 13 pp. (Mimeographed.)

Describes some of the problems in an investigation of the ground-water supplies of Long Island. About $250,000,000$ gallons a day is pumped from wells in the boroughs of Brooklyn and Queens. Salt water is being drawn into some wells in Brooklya. 
273. Ground waters of Monroe County, N. Y., by R. M. Leggette. L. O: Gould, and B. H. Dollen. Monroe County Regional Plann. Bd., Rochester, N. Y., August 1935. $141 \mathrm{pp.}$ (Mimeographed.)

Briefly describes the geology. Ancient sedimentary rocks are overlain by glacial drift to a maximum depth of 300 feet. The preglacial valley of the Genesee River and its main tributaries is the most promising source for large quantities of ground water. Gives partial analyses of 1,913 samples of water and more detailed analyses of 179 samples. Contains table of 116 springs and tabvlated records of more than 4,000 wells. Includes map of the bedrock surface-and maps showing well locations.

274. Withdrawal of ground water on Long Island, N. Y., by D. G. Thompson and R. M. Leggette. New York Dept. Cons., Water Power and Control Comm. Bull. GW-1, Albany, N. Y., 1936. 28 pp. (Mimeographed).

Briefly discusses the water-bearing formations and the use of grcund water in the area. Presents extensive data on the amounts of water withdrawn during 1904-34.

275. Record of wells in Kings County, N. Y., by R. M. Leggette and others. New York Dept. Cons. Water Power and Control Comm. Bull. GW-3, Albany, N. Y., 1937. 175 pp. (Mimeographed.)

Prepared in cooperation with the Kings County Water Board. This is the first of a series of four reports containing records of wells on Long Islend not contained in U. S. Geological Survey Professional Paper 44. Published to accompany Bulletin GW-2, Engineering report on the water supplies of Long Island. Gives tabulated data on about 700 wells. Includes logs and other information for many of the wells and a map showing location of wells. See also Cooperative report 279.

276. Record of wells in Suffolk County, N. Y., by R. M. Leggette and others. New York Dept. Cons., Water Power and Control Comm. Bull. GW-4, Albany, N. Y., 1938. 19 pp. (Mimeographed.)

Prepared in cooperation with the Suffolk County Water Autho-ity. This is the second of a series of four reports containing records of wells on Long Island. Gives tabulated data on about 200 wells and many well logs. Includes mas showing location of wells. See also Cooperative report 281.

277. Record of wells in Nassau County, N. Y., by R. M. Leggette and others. New York Dept. Cons., Water Power and Control Comm. Bull. GW-5, Albany, N. Y., 1938. 140 pp. (Mimeographed.)

Prepared in cooperation with the Nassau County Water Board. This is the third of a series of four reports containing records of wells on Long Island. Includes data on about 200 wells in Nassau County, many well logs, and map showing location of wells.

278. Record of wells in Queens County, N. Y., by R. M. Leggette and others. New York Dept. Cons., Water Power and Control Comn. Bull. GW-6, Albany, N. Y., 1938. 240 pp. (Mimeographed.)

Prepared in cooperation with the Queens County Water Board. This is the last of a series of four reports containing records of wells on Lnng Island. Gives records of numerous wells and tabulated data on 604 wells. Incl des map showing beation of wells.

279. Record of 'wells in Kings County, N. Y., by R. M. Legg?tte and M. L. Brashears, Jr. New York Dept. Cons., Water Powe.r and Control Comm. Bull. GW-8, Albany, N. Y., 1944. 134 pp., 1 pl. (Dittoed.)

These records are in addition to those published in U. S. Geolcgical Survey Professional Paper 44 and New York Water Power and Control Ccmmission Bulletin GW-3. It was prepared in cooperation with the Kings County $W$ rter Board. Presents logs and descriptive notes on about 250 wells. Includes mar showing location of wells. See also Cooperative report 275.

280. The water table in the western and central parts of Long Island, N. Y., by C. E. Jacob. New York Dept. Cons., Water Pow sir and Control Comm. Bull. GW-12, Albany, N. Y., 1945. 24 pp., 2 pls (Offset.) 
280. The water table in the western and central parts of Long Islard, N. Y. -Continued.

Summarizes the geology and early ground-water records. Gives tabclated data on shallow observation wells (p. 289). Plates show contour of the watir table in May 1943 and profiles of the water table in 1903 and 1943.

281. Record of wells in Suffolk County, N. Y., Supplement 1, by C. M. Roberts and M. L. Brashears, Jr. New York Dept. Cons., Water Pcwer and Control Comm. Bull. GW-9, Albany, N,Y., 1945. 155 pp. (Tittoed.)

Prepared in cooperation with the New York State Water Power and Control Commission, the Suffolk County Board of Supervisors, and the Suffolk Cornty Water Authority. Contains records of about 400 wells in Suffolk County in addition to those published in U. S. Geological Survey Professional Paper 44 and the New York State Water Power and Control Commission Bulletin GW-4. Includes map showing location of wells. See also Cooperative report 276.

282. Record of wells in Nassau County, N. Y., Supplement, by C. M. Roberts and M. L. Brashears, Jr. New York Dept. Cons., Water Power and Control Comm., Bull. GW-10, Albany, N. Y., 1946. 191 pp. (Mimeographed.)

Prepared in cooperation with the New York State Water Power and Ccntrol Commission, the Nassau County Board of Supervisors, and the Nassau Cornty Water Board. Contains records of many wells in the county in addition to thos? published in U. S. Geological Survey Professional Paper 44 and New York State Water Power and Control Commission Bulletin GW-5, with data on the ground-water levels. Includes map showing location of wells. See also Cooperative report 277.

\section{NORTH CAROLINA}

291. The Coastal Plain of North Carolina, by W. B. Clark, B. L. Mill sr, L. W. Stephenson, B. L. Johnson, and H. N. Parker, North Carol'na Geol. and Econ. Survey, vol. 3, Raleigh, N. C., 1912. 552 pp., 42 p's.

Consists of two paris bound in one volume. Part $I$ describes the physiography and geology; Part II describes the water resources, both surface and underground. Part II opens with a bibliography and a general discussion of the ground-water conditions but consists chiefly of detailed descriptions, by counties, of the topography, geology, ground-water conditions, and artesian prospects, with tables giving well data. These county descriptions are followed by a discussion of the quality of the water, by counties, and tables of analyses. The volume contains maps of the Crastal Plain of North Carolina showing the distribution of the surficial deposits and the unferlying formations, the position of the basement rocks, and the areas in which potable water can be obtained from the various formations.

292. The geology and ground-water hydrology of the experimental area of the United States Public Health Service at Fort Caswell, N. C., by N. D. Stearns, U. S. Pub. Health Service, Hygienic Lab. Bull. 147, Washington, D. C., 1927 . pp. 137-168.

Discusses the area under the headings of Physiography, Geology, Climatic data, Percolation, Temperature of water in wells, Soil moisture, Porosity, Mechanical analyses, Water levels, and Calculated velocity.

293. Selected well logs in the Coastal Plain of North Carolina, by M. J. Mundorff. North Carolina Dept. Cons. and Devel., Div. Min. Res. Inf. Circ. 3, Raleigh, N. C., 1944. 40 pp., 1 map. (Mimeographed.)

Contains the logs of 52 wells and a map showing their location. Incl tdes a brief description of the principal water-bearing formations.

\section{NORTH DAKOTA}

301. A preliminary report on water conservation and utilization: V'ater Resources Committee report to Federal consultant, by A. N. Sayre. North Dakota State Plann. Bd., Bismarck, N. Dak., April 10, 1935. $131 \mathrm{pp}$.

A report on the surface and ground-water resources of North Dakot?, including water analyses. Serious depletion of stream flow and ground-water levels has taken 
301. A preliminary report on water conservation and utilization-Continued. place in many parts of the State. Discusses geology with relatirn to ground-water supplies. Wells are divided into those drawing from "mantle d?posits", including glacial drift, and those drawing from artesian aquifers.

302. Investigation of ground-water supplies and dam sites in the James and Sheyenne River Basns, N. Dak. and S. Dak., by A. N. Sayre, in War Department, Corps of Engineers, Water Supply and $S:$ wage Disposal 1935, Fort Humphreys, D. C., 1936. pp. 90-104. (Off $\mathrm{se}^{\dagger}$. )

Prepared for the Federal Emergency Administration of Public Works. Discusses the geology with relation to ground-water supplies and supplie of 15 cities and towns and gives data on 7 dam sites. Describes rural supplies from the Dakota sandstone, Niobrara and Benton formations, and glacial deposits. Contains a record of water levels, logs of wells, and analyses of surface water and ground water.

303. Status of information on ground waters in North Dakota. South Dakota, and Minnesota, by E. P. Rothrock and others. Nat. Resources Plann. Bd., Report of subcommittee on underground waters, Omaha, Nebr., March 1940. 69 pp., 9 pls. (Mimeographed.)

Contains summaries and other data on State reports for North Dakota and South Dakota, with recommendations for future studies. Includes appen fix I, Bibliography of reports and papers, and appendix II. Bibliography of Stati laws relating to ground water.

304. A reconnaissance of possible well irrigation areas (in N. Dak.), by W. C. Rasmussen. North Dakota Geol. Survey Bull. 20, G and Forks, N. Dak., 1945. 6 pp.

Describes potential areas in North Dakota where ground wate- may be adequate to permit well irrigation and recommends the Oakes area for immediate investigation. Contains outline map of North Dakota showing the Pleistocene grology.

\section{OHIO}

311. Abstract of the progress report on the ground-water investigation in Butler and Hamilton Counties, Ohio, by D. G. Thom nson and F. H. Klaer, Jr. Mill Creek Valley Cons. Assoc., Cincinrati, Ohio, Feb. 19, 1940. 12 pp., 2 pls. (Mimeographed.)

Discusses the water-bearing beds, pumpage and water-level data, and specific data on the several areas studied. Includes graphs showing water-level records and pumpage.

312. A quantitative study of the well fields of the Mill Creek Valley watersupply project, Butler County, Ohio, by F. H. Klaer, Jr., and R. G. Kazmann. Cincinnati, Ohio, July 1943. 54 pp., 8 pls., 2 appendixes of 42 pp. containing well data and logs. (Dittoed.)

Prepared in cooperation with the Federal Works Agency. Fresents the results of a study of a project to supply water for Wright Aeronautical Corp. at Lockland, Ohio. Concludes that the pumpage of 12 million to 15 million gallons a day will cause litte permanent regional lowering of ground-water levels in the area.

\section{OKLAHOMA}

321. Geology and ground-water resources of Texas County, Okla., by S. L. Schoff. Oklahoma Geol. Survey Bull. 59, Norman, C'rla., 1939. 248 pp., 5 pls.

Describes the exposed formations, which range from Permian to Recent in age, and their water-bearing properties. About three-quarters of the area is covered by Tertiary beds, and the Ogallala formation (Pliocene) contains the principal waterbearing sands. Recharge is chiefly from local precipitation. Svallow water is obtained in valley alluvium. Discusses the present development and the chemical character of the water, 72 analyses of well water being given, nearly all of them 
321. Geology and ground-water resources of Texas County, Okla.-Continued. from the Ogallala formation. Briefly describes the present and possible future supplies for irrigation. Gives, data on observation wells and 21 well logs. The records of about 560 dug and drilled wells are tabulated. Includes a map showing the geology and depths to water.

322. Geology and ground-water resources of Cimarron County, Okla., by $\mathbf{S}$. L. Schoff, with a section on Mesozoic stratigraphy, by J. W. Stovall. Oklahoma Geol. Survey Bull. 64, Norman, Okla., 1943. 317 p?., 23 pls.

Describes the geology and the principal water-bearing beds. States that the Dakota sandstone is an unimporant water-bearing formation, but that the Ogallala formation, which underlies more than half of the county, contains the principal water-bearing strata and that the water, though somewhat hard, is satisfacory for most domestic, industrial, and irrigation uses.

323. Oklahoma water, quantity, occurrence, and quality of surface ard ground water. Data on ground water by E. W. Reed, G. L. Oakland, and C. L. Jacobsen. Oklahoma City, Okla., Mar. 1, 1945.145 pp., $3^{\Re}$ pls., 29 figs. 11 tables. (Offset.)

Prepared for Oklahoma Planning and Resources Board by the Wate- Resources Branch of the Geological Survey. A comprehengive summary of the wat?r resources of Oklahoma. The discussion of ground water resources includes dercription of the principal water-bearing formations and of the alluvium of the main river valleys. Contains bibliography of 27 reports dealing with ground water in Oklah ma.

\section{OREGON}

331. Ground-water resources of the Willamette Valley, Oreg., by A. M. Piper. Oregon Agr. Exper. Sta., Portland, Oreg., Aug. 6, 1935. 3 pp (Mimeographed.)

Describes the occurrence of ground water in the alluvium of the flood plains and in detrital materials of the central valley plain. Briefly discusses ir-igation, by small pumping units. See also Water-Supply Paper 890.

332. Water resources and watershed protection problems of Oregon municipalities, by A. M. Piper and others. Oregon State Plann. Bd., Portland, Oreg., Feb. 15, 1937. 26 pp.

Principally a report on municipal watersheds; ground-water supplies are briefly mentioned. About 70 towns and villages use water from wells exelusively. Other municipalities use ground water as auxiliary supplies. Many obtain their water from springs. Includes maps showing the types of municipal water supplies throughout the State.

333. The ground-water problem in Oregon, by A. M. Piper. Oregon Agr. Exper. Sta. Circ. 124, Corvallis, Oreg., June 1937. 20 pp.

Outlines ground-water conditions in the Willamette Valley, the Drlles region, Harney Basin, the Milton-Fillwater district, and the Butter Creek bas'n. Recommends a reconnaissance of the entire State to determine, evaluate, and classify the numerous ground-water problems, with a series of observation wel's and comprehensive investigations to study the ground-water resources and det irmine safe yields.

\section{PENNSYLVANIA}

341. Ground water in southwestern Pennsylvania, by A. M. Piner, with analyses by M. D. Foster and C. S. Howard. Pennsylvania Topog. and Geol. Survey, 4th ser., Bull. W1, Harrisburg, Pa., 1933. 406 pp., 1 pl.

This is the first of a series of six reports issued 1933-39, which cover the groundwater resources of the entire State. Gives a summary of the geologic and physiographic history, and the structure. Describes the water-bearing materials, methods of well construction, and pumping equipment. Briefly describes artesian conditions in two areas. The data on chemical character of the water include 91 analyses of well water. Mentions salt water at numerous places in the text. Discusaes in dotail 
341. Ground water in southwestern Pennsylvania-Continued.

the sequence and water-bearing properties of the rocks (pp. 91-205) and gives summary descriptions of the six counties that comprise the area (pr, 205-398), with extensive tabulated lists of wells and springs, and drillers' logs. Contains a map showing the geology, with structure contours, chiefly from preriously published data, and notes on the water-bearing properties of each formation. Includes six county maps showing location of wells and springs.

342. Ground water in southeastern Pennsylvania, by G. M. Hall, with analyses by M. D. Foster and C. S. Howard. Pennsylvania Toryg, and Geol. Survey, 4th ser., Bull. W2, Harrisburg, Pa., 1934. 255 pp., 7 pls.

Describes the rock formations and their water-bearing propertier from pre-Cambrian igneous and metamorphic rocks to Quaternary glacial deposins Gives a summary of wells by groups of formations, followed by a discussion of the dissolved mineral matter, and summaries of analyses of 144 samples of water from wells and springs tabulated at the end of the report. Briefly discusses the utilization and recovery. of ground water and describes ground-water conditions. including some flowing wells, in the 15 counties that comprise the area. Containa a geologic map compiled from previously published data, with notes on the water-l aring properties of the several formations.

343. Ground water in northwestern Pennsylvania, by R. M. I eggette, with analyses by M. D. Foster, W. L. Lamar, and S. K. Love. Pennsylvania Topog. and Geol. Survey, 4th ser., Bull. W3, Harrisbirg, Pa., 1936. 215 pp., 9 pls.

Gives a brief summary of the geology, followed by a general discussion of the oceurrence of ground water in glacial drift, sandstone, shale, and coal. The rocks consist of Quaternary, carboniferous, and older formations. Discusses quality of water and gives a tabulated summary of analyses of water from glacial drift, sandstone, and shale (pp. 54-63). Descriptions of ground-water contitions, with well records, in each of the 12 counties that comprise the area form the latter part of the report (pp. 64-211). Contains a geological map prepared from previously published data, with notes on the water-bearing properties of the s?veral formations.

344. Grouñd water in northeastern Pennsylvania, by S. W. Lohman, with analyses by M. D. Foster, L. A. Shinn, and K. T. Williems. Pennsylvania Topog. and Geol. Survey, 4th ser., Bull. W4, Harrisburg, Pa., 1987. 312 pp., 7 pls.

After a general description of the geology and ground-water conditions, discusses the various water-bearing formations of Quaternary, Carboniferous, and earlier geologic ages. The detailed description of ground-water development in the 14 counties that comprise the area includes data on the formations, artesian conditions, well records, and quality of water, with tabulated analyses. Includea a geologic map prepared from previously published data, with notes on the water-bearing properties of the several formations.

345. Ground water in south-central Pennsylvania, by S. W. Lohman, with analyses by E. W. Lohr. Pennsylvania Topog. and Geol. Survey, 4th ser., Bull. W5, Harrisburg, Pa., 1938. 315 pp., 17 pls.

Gives a summary of the geography and geology of the area and of the occurrence of ground water in the different kinds of rocks. Describes recoviry and utilization of ground water and discusses the quality of water and its various chemical constituents in regard to use. Gives tabulated stmmary of the analyses of 92 water samples, arranged according to the 13 geologic formations or groups in which they are present. Describes these water-bearing formations in detail and the ground-water conditions in the 14 counties that comprise the area. Includes a geologic map prepared from previously published data, with notes on the water-bearing properties of the several formations.

346. Ground water in north-central Pennsylvania, by S. W. Lohman, with analyses by E. W. Lohr. Pennsylvania Topog. and Geol. Survey, 4th ser., Bull. W6, Harrisburg, Pa., 1939. 219 pp., 11 pls.

After a summary of the geography, geologic history, and gepmorphology, gives general statements on the ground water and its recovery and atilization. Under 
346. Ground water in north-central Pennsylvania-Continued.

Quality of water discusses the chemical constituents in regard to use and gives a tabulated summary of 41 analyses of ground water, grouped according to the geologic formations in which they are present. Discusses the several water-bearing formations and describes ground-water conditions and development in the 8 counties that comprise the area, with data on wells, springs, public water surnlies, and quality of water.

347. Geology and mineral resources of York County, Pa., by G. W. S'ose and A. I. Jonas. Pennsylvania Topog. and Geol. Survey, 4th ser., Bull. C67, Harrisburg, Pa., 1939. 199 pp., 38 pls.

Contains a short discussion of public water supplies from creeks, springs, and wells (pp. 187-188), condensed from Ground water in southeastern-Pennsylvania, by G. M. Hall, Pennsylvania Topog. and Geol. Survey, 4th ser., Bull. W2, 1934. Contains topogrāphic and geologic map, with geologic sections.

348. Report of cooperative hydrologic investigations, Pennsylvania Water and Power Resources Board, foreword by J. W. Mangan. U. S. Geol. Survey, Harrisburg, Pa., 1940. 168 pp., 3 pls., 1 map, 6C graphs. (Mimeographed.)

Prepared in cooperation with Pennsylvania Department of Forests and Waters and the Weather Bureau, U. S. Department of Agriculture. Relates chieff to surfacewater discharge but contains discussion of normal ground-water depletion and storage (pp. 59-64). Appendix A is Major floods in Pennsylvania (pp. 154-167). Seven of the graphs relate to ground-water depletion (figs. 3, 4, 7, 17, 22, 36, 51), and one (fig. 11) relates to ground-water recharge.

349. Ground-water resources of Pennsylvania, by S. W. Lohman. Pennsylvania Topog. and Geol. Survey, 4th ser., Bull. W7, Harrisburg, Pa., 1941. $32 \mathrm{pp}$.

A short description of the geology of the State and of water in the several rock formations, with data on the quality and quantity of the ground water, methods of recovery, and public water supplies.

351. Industrial ground-water supplies, by J. B. Graham. Pennsylvania Dept. Internal Affairs, Harrisburg, Pa., 1944. pp. 112-115.

A brief discussion of the water-bearing formations of Pennsylvania grouped according to their yield. The most productive are the glacial lake and stremm deposits and the Cretaceous formations; the least productive are the pre-Cambian, lower Cambrian, upper Pennsylvanian, and Permian rocks.

352. Chemical analyses of surface waters of Pennsylvania, July-Oetiober 1944 and March-May 1945, by W. F. White, Jr. Harrisburg, Pa., August 1945. $31 \mathrm{pp.}$ (Offset.)

Prepared in cooperation with the Pennsylvania State Planning Board, the Pennsylvania Department of Commerce, and the Pennsylvania Department of Forests and Waters. Analyses of seven of the larger springs in the State are given for com, parison with analyses of samples of water from the streams. See also Cooperative report 447.

\section{RHODE ISLAND}

355. Progress report on the ground-water resources of Providence, R. I., by C. M. Roberts and M. L. Brashears, Jr. Rhode Island In $\mathrm{l}$. Comm. Geol. Bull. 1, Providence, R. I., 1945. 35 pp., 2 figs., 3 tables: 2 maps.

Summarizes earlier studies of the area and gives information on the geography and geology. Includes data on the ogcurrence and yield of ground water, with analyses of samples of water from nine industrial wells, and logs anc records of 67 wells and test holes. Maps show location of wells and depth to bedrock.

356. Well and test hole records for Providence, R. I., by C. M. Roberts and $H$. N. Halberg. Rhode Island Ind. Comm., Geol. Bull. 2, Providence, R. I., 1945. 52 pp., 2 maps.

Contains tabulated data on 168 wells and the logs and records of 155 wells and - test holes. Maps show location of wells and depth to bedrock. 


\section{SOUTH DAKOTA}

361. Artesian conditions in west-central South Dakota, by E P. Rathrock and T. W. Robinson. South Dakota Geol. Survey Fopt. Investig. No. 26, Vermillion, S. Dak., 1936. 93 pp. (Mimeographed.)

Treats of the geology (pp. 1-34) and the hydrology (pp. 35-93), with a discussion of the areas by counties. Contains map showing contours on top of the Dakota sandstone and map showing head of artesian water in the Dakota sandstone. Contains analyses of 17 samples of well water. See also Cooperative report 302 .

\section{TENNESSEE}

371. Mineral resources of the Waynesboro quadrangle, Tenn., br H. D. Miser. Tennessee Geol. Survey Bull. 26, Nashville, Tenn., 1؟21. 171 pp., 16 pls.

Contains a discussion of the water resources, including ground water, and town supplies from wells and springs, with five analyses of spring and well waters. Mentions the possible use of springs for irrigating small tracts.

372. Preliminary report on the artesian water supply of Memphis, Tenn., by F. G. Wells. Tennessee Dept. Education, Div. Geology Pull. 42, Nashville, Tenn., 1931. 34 pp., 2 pls., 7 figs.

Gives history of artesian-weil development in Memphis and describes the several geologic formations and their water-bearing properties. Presents dita on pumpage, seasonal fluctuations of head in wells, and chemical character of the water. Includes map of Memphis showing location of wells. Also published as Water-Supply Paper 638 a.

373. The water supply of the Memphis area, Tenn., by R. G. Karmann. Memphis, Tenn., September 1944. 66 pp., 12 figs. (Dittoed.)

Prepared in cooperation with the Memphis Light, Gas, and Water Division. Ground water is obtained at Memphis from terrace sand and gravel at depths of 40 to 130 feet, from sands of the Claiborne group at 250 to 600 feet, and from the Wilcox formation at 1,200 to 1,500 feet. Most of the municipal and industrial pumpage is from depths of about 500 feet. Pumpage has greatly increased in recent years, being about 115 million gallons a day in 1944 . Studies are being made to determine the source of recharge and the safe yield of water.

\section{TEXAS}

381. Report of a reconnaissance in Trans-Pecos Texas north of the Texas \& Pacific Railway, by G. B. Richardson. Texas Univ. Min Survey Bull. 9; Texas Univ. Bull. 23, Austin, Tex., 1904. 119 pp., 11 pls.

Describes the topography, geology, mineral resources, and ground water of Toyah, Salt, and Hueco basins, Gypsum Plain, Guadalupe-Delaware Mountrins, Diablo Plateau, and Rio Grande Valley. Contains a table of well data, well sections, and water analyses, and includes a map showing the geology and the 1-ations, of wells and springw.

382. Summary report on the survey of the underground water of Texas, by W. N. White. Texas State Bd. Water Eng. and Eng. Exp?r. Sta. of A. \& M. College of Texas, Austin, Tex., March 1935. 28 pp. 2 maps. (Mimeographed.)

Summarizes the ground-water studies that have been made in southern Texas, in the east Texas oil-field area, in Somervell County, in the High Plains, and in western Texas, and gives data on the reports that have been issued or aire in preparation. Gives brief discussion of the water-bearing formations ard data on areas irrigated and comments on salt-water contamination.

383. Progress report on the Works Progress Administration ground-water projects [Texas)], by S. F. Turner. Texas State Bd Water Eng., Austin, Tex., Aug. 1, 1936. 7 pp. (Mimeographed.)

A summary of the work being done; with map of the State showing counties covered. 
384. County reports on ground-water surveys in Texas by the Works Progress Administration, under the general supervision of W. N. White, S. F. Turner, W. O. George, and others. Texas State Bd. Water Eng., Austin, Tex. (Mimeographed.)

These reports contain records of wells and springs, drillers' logs, logs of Works Progress Administration test wells, partial analyses of water, and maps showing location of all wells and springs described. The following reports have been issued:

1934

Nueces County, by W. A. Lynch, 28 pp.

1986

Cheroke County, by G. H. Cromack, 104 pp.

Hansford County, by W. L. Broadhurst, 60 pp.

Hardeman County, by F. E. Russell and L. P. Huggins, 85 pp.

Henderson County, by W. M. Lyle, 113 pp.

Lavaca County, by W. O. George, 66 pp.

Martin County, by J. W. Lang, 82 pp.

Refugio County (part), R. A. Muenster, 46 pp.

1937

Andrews County (south half), by J. W. Lang, 33 pp.

Bailey County, by W. L. Broadhurst, 53 pp.

Brazoria County (west of Brazos River). by J. F. Heuser, 45 pp.

Burleson County, by W. I. Clark, 46 pp.

Comal County, by E. J. Michal, 41 pp.

Dallam County, by C. R. Follett, 48 pp.

Eastland County, by J. H. Samuell, 58 pp.

Ector County, by D. A. Davis, 34 pp.

Foard County, by L. P. Huggins, 60 pp.

Fort Bend County (west of Brazos River), by G. A. Elledge, 52 pp.

Freestone County, by H. L. Chenault, 86 pp.

Gillespie County, by Elgean Shields, 51 pp.

Glasscock County, by J. W. Lang, 49 pp.

Gregg County, by G. H. Shafer and H. M. Lyle, 92 pp.

Guadalupe County, by E. S. Altgelt and E. J. Michal, 66 pp.

Howard County, by J. H. Samuell, 96 pp.

Karnes County, by G. H. Shafer, 73 pp.

Knox County, by L. P. Huggins, 59 pp.

Lee County, by W. I. Clark, 27 pp.

Leon County, by G. H. Shafer, $74 \mathrm{pp}$.

Lubbock County, by M. G. Hughett and B. G. Brigance, 49 pp.

Milam County, by W. I. Clark, 57 pp.

Nacogdoches County, by G. H. Cromack, 53 pp.

Rusk County, by W. M. Lyle, 86 pp.

Smith County, by W. M. Lyle, 67 pp.

Stephens County, by G. H. Samuell, $36 \mathrm{pp}$.

Wilson County, by E. L. Marek, 72 pp.

1088

Austin County, by R. E. May, 36 pp.

Brown County, by D. A. Davis, 25 pp.

Coleman County, by J. H. Samuell and D. A.' Davis, 64 pp.

Colorado County, by R. E. May, 24 pp.

De Witt County, by H. M. Mapp, 43 np.

- Floyd County, by W. L. Broadhurst, J. W. Lang, and G. H. Shafer, 49 pp.

Goliad (part), and Refrigio Counties, by R. A. Muenster and E. J. Michrl, 91 pp.

Hale County, by W. L. Broadhurst, C. R. Follett, J. W. Lang, B. G. Brigance, and

G. H. Shafer, 72 pp.

Hartley County, by C. R. Follett and J. H. Harrison, 42 pp.

Lamb County, by W. L. Broadhurst, 33 pp.

Midland County, by D. A. Davis, 42 pp.

Panola County, by W. M. Lyle, 45 pp.

Parmer County, by C. R. Follett and E. L. Bradshaw, 45 pp.

Potter County, by L. C. Snyers, 52 pp.

Randall County, by W. G. Christian and L. C. Smyers, 32 pp.

Shelby County, by W. M. Lyle, 82 pp. . 
384. County reports on ground-water surveys in Texas by the Works Prog ress Administration-Continued.

1989

Carson County, by S. W. Adair, 50 pp.

Collingsworth County, by C. R. Follett and Bruce Wilson, $6 \dot{2} \mathrm{pp}$.

Crosby County, by C. B. Mueller, 55 pp.

Edwards County, by J. M. Frazier, Jr., 29 pp.

Gonzales County, by J. M. Frazier, Jr., 58 pp.

Ochiltree County, by L. G. Davis, 44 pp.

San Patricio County, by C. E. Johnson, 62 pp.

San Saba County, by G. H. Shafer, 49 pp.

\section{0}

Andrews County, by J. W. Lang and L. G. Davis, 54 pp.

Aransas County, by C. E. Johnson, 45 pp.

Armstrong County, by J. C. Dalgarn, 46 pp.

Callahan County, by C. B. Mueller, 42 pp.

Kendall County, by J. M. Frazier, Jr., 48 pp.

Live Oak County, by W. A. Lynch, 15 pp.

Mason County, by W. M. Lyle, 48 pp.

Roberts County, by C. R. Follett and C. V. Foster, 63 pp.

Taylor County, by H. A. Smith, 37 pp.

Val Verde County, by J. M. Frazier, Jr., 50 pp.

1941

Calhoun County, by C. E. Johnson, 69 pp.

Irion County, by J. M. Frazier, Jr, 39 pp.

Winkler County, by H. M. Forbes, J. F. Lance, and J. F. Lang; 85 pp.

\section{2}

Childress County, by C. V. Foster, 38 pp.

Robertson County, by L. G. Davis, 61 pp.

Sterling County, by W. O. George and J. C. Dalgarn, 58 pp.

385. State-wide inventory of ground-water resources (in Texe.s) making good progress, by S. F. Turner. Texas State Bd. Water Eng., Austin, Tex., Oct. 12, 1936. 7 pp. (Mimeographed.)

A summary of the work being done, with map of the State showing counties covered.

386. Inventory of wells and springs (in Texas) making good progress, by $\mathbf{S}$. F. Turner. Texas State Bd. Water Eng., Austin, Tex., Feb. 11, 1937. 7 pp. (Mimeographed.)

A summary of the work that is being carried on.

387. Distribution of Texas ground-water publications, a propress report, by S. F. Turner. Texas State Bd. Water Eng., Austir. Tex., June 1, 1937. 9 pp. (Mimeographed.)

A summary of water-level studies being made, with tabular dita, and map of the State showing counties covered.

388. Progress report on the ground-water resources of the ITouston district, Tex., by W. N. White, S. F. Turner, and Penn Livingston. Texas State Bd. Water Eng., Austin, Tex., June 10, 1937. 57 pp., 2 maps. (Mimeographed.)

Describes the studies on water levels. Contains map showing location of observation wells and water level in wells.

389. A progress report (on cooperative water-level surveys in Texas), by $\mathbf{S}$. F. Turner. Texas State Bd. Water Eng., Austin, Tex., Dec. 15, 1937. 5 pp. (Mimeographed.)

A summary of cooperative water-level surveys under the headings: Use of ground water in Texas; Progress of water well and spring inventory; and Distribution of Texas ground-water publications. Includes two maps of the Stat showing localities and counties being covered. 
390. Ground-water resources of the Balmorhea area in western Texas, $k, y$. N. White, H. S. Gale, and S. S. Nye. Texas State Bd. Water Eng., Austin, Tex., February 1938. 83 pp., 2 maps. (Mimeographed.)

Presents a brief discussion of the geology, describes the large springs of the area, with discharge measurements, and gives data on other springs and the shallow ground water, with well records and water analyses. Discusses the source of ground water from streams and its discharge. Includes a map showing ralation of the large springs to the geologic structure and a map showing contour of the water table. Published also as Water-Supply Paper $489 \mathrm{c}$.

391. Ground water in the High Plains in Texas, by W. N. White, W. L. E "oadhurst, and J. W. Lang. Texas State Bd. Water Eng., Austin, Tex., July 26, 1938. 10 pp., 1 map. (Mimeographed.)

A summary of the importance of ground water in the area, the developnent of irrigation, previous investigations, source and discharge of the ground water, and amount of water pumped in 1937. About 1,150 wells were used for the irrigation of 160,000 acres.

392. A few facts regarding ground water in Texas and the principles gcwerning the occurrence of ground water, by W. N. White. Texas "rater Resources Comm., State Plann. Bd., Austin, Tex., July 29, 1938. 6 pp. (Mimeographed.)

A short summary of the occurrence and movement of ground water and of rroundwater supplies in Texas, with comment on the waste of water from flowing artesian wells.

393. County reports on ground-water surveys in Texas, under the general supervision of W. N. White, S. F. Turner, W. O. George, and others. Texas State Bd. Water Eng., Austin, Tex. (Mimeographed.)

Contain records of wells and springs, driller's logs, partial analyses of watir, and maps showing location of all wells and springs described. The following reports have been issued:

Dawson County, by J. C. Cumley, 40 pp.

Deaf Smith County, by J. W. Lang and C. R. Follett, 52 pp:

Hays County, by B. A. Barnes, 30 pp.

Hidalgo County, by J. T. Lonsdale and S. S. Nye, $70 \mathrm{pp}$.

Oldham County, by C. R. Follett and G. H. Shafer, $50 \mathrm{pp}$.

Swisher County, by C. R, Follett, 35 pp.

1939

Brazoria County (east of Brazos River), by S.' F. Turner and P. P. Livingston, 11 pp.

Castro County, by L. J. Ryan, J. W. Lang, and W. L. Broadhurst, 60 pp.

Fort Bend County (east of Brazos River), by P. P. Livingston and S. F. Turner, 11 pp.

Galveston County, by P. P. Livingston and S. F: Turner, 27 pp.

Grimes County, by S. F. Turner, 5 pp.

Harris County, by P. P. Livingston and S. F. Turner, 97 pp.

Montgomery County, by S. F. Turner and P. P. Livingston, $20 \mathrm{pp}$.

Waller County, by S. F. Turner and P. P. Livingston. 20 pp.

1940

Bee County, by W. A. Lynch and J. M. Frazier, Jr., 30 pp. Brooks County, by S. F. Turner and J. C. Cumley, 63 pp. Dimmit, Zavala, and Maverick (part) Counties, by W. N. White, S. F. Turner, T. W. Robinson, P. P. Livingston, and G. H. Cromack, 141 pp.

Hockley County, by C. B. Mueller, J. W. Lang, and W. L. Broadhurst, 72 pp. Jim Hogg County (northern part), by J. C. Cumley, 15 pp. Jim Wells County, by S. F. Turner, W. A. Lynch, and J. C. Cumley, 55 pp. Kenedy County, by S. F. Turner and J. C. Gumley, 56 pp. Kinney County, by R. R. Bennett and G. H. Cromack, 37 pp. Victoria County, by J. C. Cumley, 29 pp. 
393. County reports on ground-water surveys in Texas-Continued.

1941

Galveston County, by B. A. Barnes, 155 pp.

Hidalgo County, by J. T. Lonsdale, 102 pp.

Loving, Ward, Reeves, and northern Pecos Counties, by P. F. Dennis and J. W. Lang, 173 pp.

Tom Green County, by B. A. Barnes and J. C. Dalgarn, 80 p?.

Travis County, by J. C. Cumley and C. R. Follett, 101 pp.

Wharton_County, by G. H. Cromack and T. W. Bridges, 52 pp.

1942

Blanco County, by B. A. Barnes and J. C. Cumley, 55 pp.

Cass County, by W. L. Broadhurst, 39 pp.

Chambers County, by L. G. Davis, 94 pp.

Donley County, by W. G. Christian and W. H. Alexander, 44 p?.

Hardin County, by G. H. Cromack, 35 pp.

Farrison County, by W. L. Broadhurst, 40 pp.

Houston district, Harris County, and adjoining parts of Fo-t Bend and Waller Counties, by W. N. White, N. A. Rose, and W. F. Guyton, 178 pp.

Jackson County, by C. R. Follett and J. C. Cumley, $47 \mathrm{pp}$.

Jasper and Newton Counties, by G. H. Cromack, 49 pp.

Jefferson County, by P. P. Livingston and G. H. Cromack, 64 pp.

Morris County, by W. L. Broadhurst, 19 pp.

Orange County, by P. P. Livingston and G. H. Cromack, 42 p .

Upshur County, by W. L. Broadhurst, 15 pp.

Williamson County, by J. C. Cumley, G. H. Cromack, and C. R. Follett, 93 pp

Wood County, by C. R. Follett, 42 pp.

1943

Camp, Franklin, and Titus Counties, by W. L. Broadhurst, 40 pp.

Dallas County, by J. C. Cumley, 104 pp.

Fayette County, by G. H. Cromack, 50 pp.

Gregg County, by W. L. Broadhurst, 34 pp.

Grimes County, by G. H. Cromack, 37 pp.

Hopkins County, by W. L. Broadhurst, 17 pp.

Marion County, by W. L. Broadhurst, 16 pp.

Montgomery County, by N. A. Rose, 28 pp.

Rains County, by W. L. Broadhurst, 13 pp.

Rusk County, by C. R. Follett, 56 pp.

Sabine and San Augustine Counties, by C. R. Follett, 39 pp.

Washington County, by C. R. Follett. $45 \mathrm{pp}$.

1944

Matagorda County, by G. H. Gromack and T. W. Bridges, 30 pp.

Terry County, by G. H. Cromack, 28 pp. 1945

Atascosa County, by R. W. Sundstrom and C. R. Follett, 53 pr

Deaf Smith County, by W. H. Alexander, Jr., 83 pp.

Floyd County, by C. R. Follett and J. H. Dante, 101 pp.

Hale County, by R. B. Merritt and C. R. Follett, 177 pp.

Liberty County, by W. H. Alexander, Jr., 51 pp.

Lubbock County, by J. W. Lang, 126 pp.

Swisher County, by J. H. Dante, 91 pp.

Yoakum County, by G. H. Cromack, 28 pp.

1946

Floyd Gounty, by C. R. Follett and J. H. Dante, 101 pp.

Gaines County, by G. H. Cromack, 26 pp.

394. Progress report on the ground-water resources of the Houston district,

Tex., by W. N. White. Texas State Bd. Water Eng., Austin, Tex., Mar. 1, 1939. 12 pp., 5 pis. (Mimeographed.)

Gives data on water levels in 21 observation wells during 1937-39. See also WaterSupply Papers 840, 845, 886.

395. Ground water in the High Plains in Texas, by W. N. White. Texas State

Bd. Water Eng., Austin, Tex., Apr. 12, 1939. 2 pp. (Mimeographed.)

A summary of studies being made. Discusses decline of water table, natural ground-water discharge, and ground-water reports. 
396. Progress report on the ground-water resources of the Houston district, Tex., by W. N. White, N. A. Rose, and W. F. Guyton. Teras State Bd. Water Eng., Austin, Tex., November 1940. 44 pp. (Mimeographed.)

Gives a summary of the geology of the water-bearing formations and discusses the pumpage and the decline of water levels in 1937-40. Treats briefly of the chemical character of the water and gives notes on the results of exploratory well drilling for additional supplies, for Houston. Describes the transmissibility and storage capacity of the water-bearing beds and summarizes the ground-water developments.

397. Ground water in the High Plains in Texas, by W. N. White, W. T. Broadhurst, and J. S. Lang. Texas State Bd. W.ater Eng., Austin, Tex., December 1940. 56 pp. (Mimeographed.)

Discusses recharge and discharge of ground water in the region, the development of irrigation, and the use of ground water for irrigation in 1937-39. Presents data on the changes in water levels in some areas to the middle of November 1940. Comments on the effect of pumping on the ground-water supply. Inc'rides maps showing location of wells and springs.

398. Quality of water (Pecos River Basin in Texas), by C. S. Howard, W. F. White, Jr., and W. W. Hastings. Pecos River Joint Investig., pt. 3, Rept. C., Austin, Tex., February 1941. 62 .pp. (Mimeograpl ed.)

Prepared in cooperation with the New Mexico State Engineers and the Texas State Board of Water Engineers. Describes the chemical character of tl a water in the several portions of the upper, middle, and lower basins. Discusses ground water of only the lower basin, giving analyses of 34 samples of water. States that many sources of ground water in the Pecos River Basin of Texas are highly mineralized, and inflow from those sources causes an increase in the concentration of the river water.

399. Water supply in the Sandflat area and adjacent territory in Rusl; Nacogdoches, and Shelby Counties, Tex.; Ground water, by W. I. Broadhurst; Surface water by Trigg Twichell. Texas State Bd. Water Eng., Austin, Tex., April 1942. 25 pp., 1 map. (Mimeographed.)

Discusses an area in east. Texas on the southwest flank of the Sabine uplift and briefly describes the geology and the principal water-bearing formation' (Carrizo sand and Wilcox formation). Gives data on 28 wells and springs, tabrlated well records, well logs, and analyses of water samples from 13 wells and 1 spring. Cintains map showing the surface geology and location of the wells.

400. The ground-water resources of Texas-their conservation and development, by $\mathbf{S}$. F. Turner. Texas State Bd. Water Eng., Austin, Tex., June 1939. 7 pp. (Mimeographed.)

A resumé of an illustrated lecture given at a number of colleges in Texas, de scribing the ground-water resources of the State and the waste that is taking place, with recommendations for conservation and development. -

401. A few interesting facts regarding the natural flow from artesic $n$ well 4, owned by the San Antonio Public Service Co., San Antonio, Tex., by P. P. Livingston. Texas State Bd. Water Eng., Austin, T^x., June 17, 1942. 7 pp. (Mimeographed.)

The well is 1,032 feet deep and is supplied from the Edwards lim 3 stone. The natural flow is 37 cubic feet per second ( 16.000 gallons a minute), which is believed to be the largest natural flow of any well in the United States.

402. Ground water in the Pecos River Basin in Texas, by A. N. Sayre, J. W. Lang, and P. E. Dennis. Natural Resources Plann. Bd * Pecos River Joint Investig., Repts. of participating agencies, Washington, D. C., 1942. pp. 76-101.

- Describes the principal water-bearing formations and the area of fowing wells. Discusses the high water table and the chemical character of the ground water.

403. Published reports on Texas ground-water resources, by W. N. White and R. W. Sundstrom. Texas State Bd. Water Eng., Austin, Trx., 1942. 6 pp. (Mimeographed.)

A list of 145 titles consisting of 21 water-supply papers, 1 circular, 18 mimeographed reports, and 105 mimeographed publications on specific counties containing records of wells and springs, drillers logs, and water analyses. 
404. Ground-water supply of Big Spring, Tex., by P. P. Livingston. Texas State Bd. Water Eng., Austin, Tex., Sept. 29, 1942.5 pp., 2 figs. (Mimeographed.)

Gives conclusions reached concerning water supplies available for the city of Big Spring. See also Water-Supply Paper 813.

105. Progress report on ground water in the High Plains in Texas; by W. $H$. Alexander, Jr., W. L. Broadhurst, and W. N: White. Teras State Bd. Water Eng., Austin, Tex., April 1943. 17 pp. (Mimeographed.)

Summarizes data on the mean annual precipitation and discusser the intake and natural discharge of ground water, the depth to ground water, and its use for irrigation in the High Plains. Gives data on the fluctuations of ground-water levels in the Plainview, Hereford, Muleshoe, Lubbock-Littlefield, and T'xline districts. Summarizes the net loss or gain of storage in the districts in 1؟38-43 and gives figures on the total pumpage.

406. Exploratory water well drilling in the Houston district Tis., by N. A. Rose, W. N. White, and P. P. Livingston. Texas State Bd. Water Eng., Austin, Tex., June 1943. 41 pp. (Mimeographed.)

Prepared in cooperation with the city of Houston, Tex. Describer equipment and methods used in drilling wells and making the tests, laboratory determinations, and comnarisons and correlations. Illustrations include electrical logs of test wells. Also published as Water-Supply Paper $889 \mathrm{~d}$.

407. Water resources of Harrison County, Tex., by W. L. Broadhurst and S. D. Breeding. Texas State Bd. Water Eng., Austin, Ter., September 1943. 62 pp. (Mimeographed.)

Discusses the several geologic formations and their water-bearing properties and the present development of water supplies from wells.

408. Progress report on the ground-water resources of the Tex?s City area, Tex., by N. A. Rose. Texas State Bd. Water Eng., Austin, Tex., Nov. 15, 1943. 45 pp., 4 figs. (Mimeographed.)

The area is underlain by formations of sand and clay of Pleistorene age. Water is obtained chiefly from the "Alta Loma" sand. Because pumpage due to industrial expansion was about ten times as great in 1943 as it was in 1930, artesian pressure has declined until it is considerably below sea level, and the chlcride content of the water has increased materially.

409. Ground-water resources in the vicinity of Vernon, Tex., by C. R. Follett, R. W. Sundstrom, and W. N. White. Texas State Bd. Water Eng., Austin, Tex., February 1944. 43 pp., 1 pl. (Mimeographed.)

States that the area is underlain chiefly by Permian and Pennरvlvanian rocks, which contain only small supplies of highly mineralized water, $k$ ut that terrace deposits of gravel and sand yield water of good quality. The report describes the present water supply of Vernon and recommends the testing of terrace deposits south and southwest of the city for additional supplies.

410. Ground water in Texas; list of published and unpublishet reports on ground water prepared in cooperation with the U. S. D ppartment of the Interior, Geological Survey, by R. W. Sundstrom and W. N. White. Texas State Bd. Water Eng., Austin, Tex., April 1944. 12 pp. (Mimeographed.)

A list of 276 titles, arranged chronologically under the fallowing 1 eadings: Water supply papers (25), Mimeographed reports and teprints (31), Mimeographed reports containing results of water-well surveys (134), and Unpublished reports (86).

411. Progress report on ground water in the High Plains in Tex?s, by W. $H$. Alexander, Jr., W. L. Broadhurst, and W. N. White. Terasistąte Bd. Water Eng., Austin, Tex., May 1944. 12 pp., 7 figs. (Mireographed.)

The fourth of a series of mimeographed progness reports on the Irigh Plains, the others being issued in July 1938, December 1940, and April 1943 (Gocperative reports $391,397,405$ ). The present report is concerned primarily with pumpage during the irrigation season of 1943 and changes in water levels. Summatizes the development of irrigation and the fluctuation of water levels in several districts. 
412. Results of pumping tests of municipal wells at Tyler, Tex., by W. L. Broadhurst. Texas State Bd. Water Eng., Austin, Tex.; October 1944. 28 pp., 3 figs. (Mimeographed.)

States that the city wells obtain waters from sands of the Wilcox formation. Concludes that a total of 10 million gallons a day could be obtained from the city well fields and two other well fields that could be developed a few miles away.

413. Progress report on the ground-water resources of the Houston district, Tex., by N. A. Rose and W. H. Alexander, Jr. Texas State Bd. Water Eng., Austin, Tex., November 1944. 37 pp., 12 figs. (Mimeographed.) Frepared in cooperation with the city of Houston. Gives data on hiscory of tue investigation and previous reports, and developments of ground wate" in 1942-44. Describes the Houston and Pasadena pumping areas and the "Katy rice-growing area. Presents data on fluctuation of the shallow water level and on the chemical character and temperature of the ground water. Maps (figs. 6-9) show altitude of water levels in wells in the Houston district in January of each year from 1941-44 inclusive.

414. Ground water (in certain parts of Texas), by W. N. White. Trixas State Bd. Water Eng. Rept. for Sept. 1, 1942-Aug. 31, 1944, Awstin, Tex., Dec. 1944. pp. 32-58.

Summarizes ground-water conditions in the High Plains region, El Paso area, Pecos River Basin, Winter Garden district, Houston district, Galvestor-Texas CityBaytown district, Lufkin-Nacogdoches area, Balcones fault zone, Big Spring area, and East Texas. Includes a list of the published reports on the ground-water resources of Texas.

415. Public water supplies in eastern Texas, by R. W. Sundstrom, W. W. Hastings, and W. L. Broadhurst. Texas State Bd. Water Fng., vol. 1 (pp. 1-237); vol. 2 (pp. 238-459), Austin, Tex., February 1945. (Mimeographed.)

A summary of public water supplies in 77 counties of eastern Teras. Gives in condensed form the available data for each municipality, including water consumption, storage facilities, number of customers, chemical and sanitary treatment of the water, and chemical analyses of the water. Where ground water is used, gives weli records and logs, character of pumping equipment, yield of wells and waterlevel records. States that ground water is used at 273 localities, surf 7 ce water at 46, and a combination of the two sources at 4 localities.

416. Ground water in the High Plains in Texas, progress report Nc. 5, by W. H. Alexander, Jr., and J. W. Lang. Texas State Bd. Water Eng., Austin, Tex., May 1945. 29 pp., 11 figs. (Mimeographed.)

Discusses development of irrigation from wells since 1934, the depth to ground water, and the fluctuations of water level in 10 counties. Summarizes the net changes in water levels 1938-44 and presents tabulated data on representative wells, Maps (figs. 1 and L-A) show location of observation wells and depth to water: Graphs (figs. 2-10) show changes in water level in typical wells, 1936-44.

417. Water resources of Gregg County, Tex., by W. L. Broadhurst and S. D. Breeding. Texas State Bd. Water Eng., Austin, Tex., September. 1945. 60 pp., 2 figs. (Mimeographed.)

Presents data on the geologic formations and their water-bearing properties and the development of water supplies from wells. Includes data on surface water supplies, tables of well records, well logs, and analyses of ground water. Maps (figs. 1, 2) show areal geology and location of wells.

418. Ground-water resources of Liberty County, Tex., by W. H. Alexander, Jr., with a section on surface water runoff by S. D. Breedinm. Texas State Bd. Water Eng., Austin, Tex., October 1945. 79 pr., 1 pl., 4 figs. (Mimeographed.)

Describes the geologic formations and their water-bearing properties and gives data on development of water supplies from wells. Presents a summary of withdrawals of ground water, and its temperature. Contains a section on surface water supplies and tabulated well records, well logs, and water analyses. Includes map showing location of wells and springs. 


\section{UTAH}

421. Ground-water investigations in Utah to June 30, 1936, by G. H. Taylor and H. E. Thomas. Utah State Eng. 20th Bienn. Rert., Salt Lake City, Utah, 1936. pp. 91-106.

A résumé of past and current ground-water work. Several hurdred observation wells have been established in about 25 distinct ground-water areas during the past year. Detailed investigations were made in parts of Davis, Sanpete, Utah, Boxelder, and Salt Lake Counties.

422. Underground-water investigation in Utah, by P. E. Dennis. Utah State Eng. 23d Bienn. Rept., July 1, 1940-June 30, 1942. Salt Lake City, Utah, 1942. pp. 36-37.

Describes the work being done by the Geological Survey in cooreration with the State Engineer of Utah and mentions recent manuscript reports prepared on various areas in the State, which have been released to the public.

423. Underground leakage from artesian wells in the Flowell axea, near Fillmore, Utah, by P. P. Livingston and G. B. Maxey. Utah State Eng. Tech. Pub. No. 1, Salt Lake City, Utah, February 1945. 31 pp., 6 pls.

About 100 artesian wells in the area obtain water from alluvig, outwash. Tesis on 48 wells showed leakage from one aquifer to another, the total in the area probably being less than 3,000 gallons a minute, only about one-fifth of which is lost in shallow sand and gravel. During the nonirrigation season of 1943-44 most of the total flow was wasted from uncapped wells. The report recommends tha control of flowing wells and gives instructions for the repair of leakg wells.

424. The Ogden Valley artesian reservoir, Weber County, Utah, by H. E. Thomas. Utah State Eng. Tech. Pub. No. 2, Salt Lalie City, Utah, 1945. 37 pp., 5 figs.

Describes the source, movement, and disposal of water in the artesian reservoir. Gives records of water level in three observation wells and summarizes data on the capacity of the artesian reservoir and the rate of recharge.

\section{VIRGINIA}

431. The underground water resources of the Coastal Plain privince of Virginia, by Samuel Sanford. Virginia Geol. Survey Bull. 5, Charlottesville, Va., 1913. $361 \mathrm{pp} ., 1 \mathrm{pl}$.

- Describes and discusses the topography, geology, origin, occurrence, and emergence of ground water, types of springs and their pollution, artesian conditions, cisterns, collecting tunnels, types of wells, magnetic wells, and freshenin $x$ of deep water. Gives detailed information on wells and ground-water conditions by counties and contains tables of well data and of analyses of spring and well water. Includes a map showing the areas of artesian flow and the quality of the ground water.

432. Springs of Virginia, by W. D. Collins, M. D. Foster, Frank Reeves, and R. P. Meacham. Virginia Div. Water Resources and Power Bull. 1, University, Va. 1930. 55 pp.

Presents the results of investigations on springs in the southern part of the Great Valley of Virginia, being the first of a proposed series cf reports on the springs of Virginia. Gives the name and location. geologic occurrene, discharge, and temperature of 566 springs, with partial analyses of the waters of more than 400 of them. "Numerous cold springs issue at the outcrops of the Oriskany sandstone, the Helderberg limestone, and the limestone formations of Ordovician and Cambrian age. The springs found at the outcrop of the other formations ar? generally small. most of those in shale formations being conflned to slight seepages of waters relatively high in sulphates. Practically all of the warm springs issus at the outerops of the Oriskany sandstone (Lower Devonian), Lowville limestone (M: Adle Ordovician). and Copper Ridge dolomite (Ordovician or Cambrian)." Contains a map showing the location of springs that discharge 100 gallons a minute or more.

433. Thermal springs of Virginia, by Frank Reeves. Virginia Geol. Survey Bull. 36, University, Va., 1932. 56 pp., 8 pls.

"In the northwest part of Virginia and adjacent parts of West Virginia ther are 90 or more springs that have temperatures ranging from those slightly in excess 


\section{Thermal springs of Virginia-Continued.}

of the mean annual temperature to a temperature of $105^{\circ} \mathrm{F}$. Nearly al the warm springs issue from the Oriskany sandstone, the Lowville limestone, and the Elbrook limestone, where these formations rise to the surface from considerable depth a a result of anticlinal folding." The report gives a preliminary discussion of distribution, temperature, discharge, and chemical character of the springs, followed by a discussion of "Geology of the thermal springs." It then discusses "Source of the heat and water supply of the warm springs," with special regard to the geological structure. A summary (pp. 35-52) gives a tabulated list of 325 springs, with name and location, discharge, temperature, and geologic occurrence. Contains a geologic map of the thermal springs region of Virginia and West Virginia, showing location of the springs.

434. Preliminary report on ground water in northern Virginia, by R. C. Cady. Virginia Geol. Survey Bull. 41, University, Va., 1933. 48 pn., 1 pl.

After a preliminary discussion of the geology of the area and the occurrence of ground water, describes the water-bearing properties of the various rock formam tions of the region. Contains a small geologic map of northern Virginia. with notes on the water-bearing properties of each formation or group. Gives a summary (table 17) of data on the rock fornation, depth, and yield of 1,320 wells examined. See also Cooperative report $\mathbf{4 3 6}$.

435. Ground-water resources of the Shenandoah Valley, Va., by R. C. Cady, with analyses by E. W. Lohr. Virginia Geol. Survey Bull. 45, University, Va., 1936. $137 \mathrm{pp} ., 5$ pls.

Presenty a summary of the occurrence of ground water in relation to geologic structure and the principal types of rocks and discusses the water-bearin - properties of the several formations of the area. A short description of springs is followed by details on ground-water conditions in each of the 6 counties of the area, with data on the municipal supplies, 458 well records, and 40 analyses of ground water. Includes a map showing location of wells and springs.

436. Ground-water resources of northern Virginia, by R. C. Cady. Virginia Geol. Survey Bull. 50, University, Va., 1938. 200 pp., 7 pls.

Gives a preliminary description of the geology and the relation of ground water to the geologic structure and principal types of rocks. Describes the water-bearing pronerties of the various rock formations of the area. Describes ground-water conditions in each of six counties and parts of three other counties thit comprise the area, with data on the water bearing formations, municipal supplies, well records, well logs, and analyses of ground water. Includes a small goologic map of northern Virginia, with notes on the water-bearing properties of each formation (reproducer from Virginia Geol. Survey Bull. 41).

437. Geology and artesian water resources of a part of the souther Virginia Coastal Plain, by D. J. Cederstrom. Virginia Geol. Survey Pull. 51-E, University, Va., 1939. pp. 119-136.

A summary of the stratigraphy of the Cretaceous and later deposits and their geologic structure. Contains a brief description of the occurrence and quality of the artesian water, based on the analyses of about 55 samples. Gives special attention to the fluoride content. Includes map showing the structure on the base of the Eocene, the flowing-well areas, the piezometric surface of water in the Potomac group, and the distribution of fluoride in well water.

438. Ground-water resources of the southeastern Virginia Coastal Plain, by D. J. Cederstrom. Virginia Geol. Survey Circ. 1, Univeraity, Va., 1941. 11 pp., 2 pls. 4 figs.

A preliminary report accompanying release of,well records, anialyses, and logs of wells. Summarizes geology and occurrence of ground water. The area is subdivided into Fall Zone, area east of Fall Zone to Norfolk, and the Norfolk area. Discusses yield of wells and quality of water in these three areas. Gives data showine heights above sea level to which water will rise in wells in the Potoma? group and the distribution of fluoride in southeastern Virginia.

139. Deep wells in the Virginia Coastal Plain, by D. J. Cederstrom. Virginia Geol. Survey Reprint ser. No. 6, University, Va., 1943. 14 pp.

States that large supplles of water are obtainable from wells more than 500 feet deep throughout most of the Virginia Cosstal Plain. Says that the weter at these 
439. Deep wells in the Virginia Coastal Plain-Continued.

4

depths is brackish in an area bordering Chesapeake Bay, incluting the Fastern Shore, and only about 200 to 300 gallons a minute can be obtained along the Fall Zone. Between these two areas the presence of a favorable thickn oss of. sands that yield fresh water has been demonstrated at almost every. place where deep wells have been drilled. Also states that supplies of at least one million gallons a day may be obtained from properly constructed wells throughout most of the area. The report ineludes a table of well records. Also published in The Commonwealth (Va. Chamber of Commerce), vol. 10, No. 4, April 1943, pp. 20-22, 56.

440. Chloride in ground water in the Coastal Plain of Virginia, $k, D$. J. Cederstrom. Virginia Geol. Survey Bull. 58, University, Va., 1943. 36 pp., 4 pls.

A detailed discussion of the chloride content in artesian water ard also in shallow ground water, with summary of chloride content in deep well waters, by counties.

441. Selected well logs in the Virginia Coastal Plain north of James River, by D. J. Cederstrom. Virginia Geol. Survey Circ. 3, Uriversity, Va., 1945. 82 pp. (Offiset.)

Summarizes the geology, structure, and principal water-bearing formations in the Coastal Plain. Gives columnar section of sedimentary rocks in the area and logs of 81 wells.

442. Geology and ground-water resources of the Coastal Plain ir southeastern Virginia, by D. J. Cederstrom. Virginia Geol. Survey Bull. 63, University, Va., 1946. 385 pp., 38 pls., 31 figs. 50 tables.

Presents a detailed description of the geology and ground-water conditions in the area. Contains many well records and logs and information or the quality and quantity of ground water.

\section{WASHINGTON}

446. Factual data pertaining to wells and springs in the Columl : Basin project area, Wash., by G. C. Taylor, Jr. Portland, Oreg., January 1944. 85 pp., 1 pl. (Dittoed.)

Prepared in cooperation with the Washington Department of Conservation and Development. Explains the principal features of the well records ard gives three tables as follows: 'Records of wells in the Columbia Basin project area. Records of the principal springs in the area, and Chemical analyses of representative waters in the area.

\section{WEST VIRGINIA}

447. Apparatus for the measurement of temperatures in deep wells, and temperature determinations in some deep wells in Pennsylvania and West Virginia, by C. E. VanOrstrand. pp. lxvi-ciii frcm West Virginia Geol. Survey Rept. for 1918, Wheeling, W. Va., 19:8.

Describes and illustrates the several types of thermometers used and gives tabutated data on measurements in 12 wells in West Virginia and 1 well in Pennsylvania.

448. Ground-water investigations in West Virginia, by P. H. Price and R. L. Nace. West Virginia Univ. Bull. ser. 44, No. 2. Morgantown, W. Va., August 1943. pp. 37-41. (West Virginia Eng. Exper. S Tech Bull. No. 23.)

Discusses the need for ground-water studies in West Virginia and outlines the projected plan of study by the United States Geological Survey in cooperation with the West Virginia Geological and Economic Survey. Gives a general discussion of the occurrence of ground water in the State.

449. Ground-water conditions along the Ohio Valley at Parkersl rrg, W. Va., by R. M. Jeffords. West Virginia Geol. Survey Bull. 10, Morgantown, W. Va., 1945. 57 pp., 19 figs., 11 tables.

Describes the Parkersburg well field and the geology in relation to the well water. Discusses quality of the water, with analyses, and gives conclusions regarding the source of recharge, limitation of yield, and additional supplies. Conel -des that a considerable part of the water is derived by percolation from the Ohio Fiver, with effective filtration of impurities. 


\section{WISCONSIN}

tu. The underground and surface water supplies of. Wisconsin, by Samuel Weidman and A. R. Schultz. Wisconsin Geol. and Nat. Hist. Survey Bull. 35, Madison, Wis., 1915. 664 pp., 5 pls.

Describes the geography and geology of the State and the conditions controlling local ground waters and artesian waters, the following wells and artesian prospects, the springs and mineral waters, the uses of water supplies, and the quality of water from various geologic sources and from the rivers and lakes of the State. Gives detailed description by counties, with well sections and water analyses. Includes maps showing the geology, the surface of the pre-Cambrian rocks, the head of artesian water, and the areas of soft and hard water.

\section{WYOMING}

455. Cooperative ground-water investigations in Wyoming, by F. C. Foley; T. W. Robinson, A. M. Morgan, and J. B. Graham. Wyoming State Eng. 26th Bienn. Rept., 1941-42, Cheyenne, Wyo., 1942. pp. 41-49.

A preliminary report on investigations in the Egoert-pine Bluffs area, the Cheyenne area, and the Laramie area. Each investigation includes a study of the geology, the recharge and discharge of ground water and the gradient and direction of its flow, estimates of the quantity of ground water in storage, the limits of saie development of areas that are yielding water to wells, and a discussion of areas favorable for new production of ground water.

456. Cooperative ground-water investigations in Wyoming, by A. M. Morgan. Wyoming State Eng. 27th Bienn. Rept., 1943-44, Cheyerne, Wyo., October 1944. pp. 43-49.

Contains brief description of the principal aquifers and data on ground-water levels in the Egbert-Pine Bluff area, Carpenter area, Cheyenne area, and Laramie area.

\section{MIMEOGRAPHED AND OTHER DUPLICATED REPTRTS}

These brief reports are on file in the Washington office of the Gro'nd Water Division of the Geological Survey. Copies of most of them can b? obtained on application to the Geological Survey. Many of them have been superseded by more detailed reports.

1. Fluorescein an aid in tracing waters underground, by Herman Stabler. 1910. 2 pp.

Describes tests made by the method in tracing the underground courses of water from streams and sinkholes.

2. Ground water in the Missouri Valley near Townsend, Broadwater County, Mont., by J. T. Pardee. Jan. 25, 1922, 6 pp.

Gives the results of an investigation made in 1921. Ground.water is abundant in the valley bottoms at about 20 feet and on the bench lands at depths of 100 to 300 feet. Conditions are in general unfavorable for artesian water. Describis local conditions in the several parts of the area, with notes on quality of water. See also Water-Supply Paper 539.

3. Ground water in Piute Valley, Nev., by D. F. Hewett. Aug. 28, 1922. 2 . pp., 1 pl.

The results of investigation offer no encouragement to prospect for artesian water nor water in the valley alluvium. Four shafts failed to reach water at depths of 67 to 250 feet. Springs are few and small. Many mining shafts of the Searchlight district, however, encountered some water.

4. Ground water in Quinn River and Paradise Valleys, Nev., by Kirk Bryan. Jan. 29, 1923. 3 pp.

Small artesian flows are obtained for watering stock, but large arterian supplies for irrigation cannot be developed. Shallew ground water is present but is not profitable for irrigation. In a few places artesian water might be developed in the lavas bordering the valleys. 
5. Ground water in Sandoval County, N. Mex., by B. C. Reniek. Dec. 26, 1924. 2 pp.

Shallow ground water is obtained in the alluvium of the flood plain of the Rio Grande and in the alluvium and underlying Santa Fe formation along Jemez Creek. Wells on the Indian reservations obtain water in the Santa Fe fo"mation. Recommends a test well for artesian water west of San Ysidro. Discusses probability of artesian water in the Dakota sandstone and other formations. See also WaterSuppls Paper 620.

6. Glossary of terms pertaining to ground water and related srhjects, by 0 . E. Meinzer. Mar. 1918. 37 pp.

Gives definitions of 520 terms used in ground-water studies. See also WaterSupply Paper 494.

7. Water supply for Arlington County, Va., by C. P. Ross. Jan. 2, 1926. 3 pp. A study of water supply for the Arlington and Washington districts, beyond the limits of the Alexandria municipal supply. Shallow wells will not be advisable because of liability of contamination and of depletion during droughts. Wells drilled to depths of 100 to 150 feet and getting water from crystalline rocks may be feasible, but the yield of each well will be small. Surface-water from Pirmit Run or the Potomac River might furnish an adequate supply.

8. Note in regard to the investigation in the Escalante Desert, Utah, on the discharge method of estimating water supplies, by W. N. White. Mar. 10, 1927. $8 \mathrm{pp}$.

A summary of observations on the daily fluctuation of the ground-water level caused by alfalfa and native vegetation. See also Water-Supply Paper 659 a.

9. The Roswell artesian basin, New Mexico, by A. G. Fiedler and S. S. Nye. July 14, 1928. 4 pp., 1 map.

Summarizes the results of studies and describes the artesian conditions. Gives a eummary of the geology, consisting of Quaternary valley fll overlyin? Permian rocks of the Chupadera formation. Most of the artesian water comes from cavernous limestone in the Chupadera. Discusses source of the artesian water. Includes a map showing area of flowing wells and of pumped wells. See alin Water-Supply Paper 639.

10. Ground water for irrigation in Raft River Valley, Idaho, by IJ. T. Stearns. Apr. 25, 1929.1 p.

A summary statement that the ground-water supply is adequate to irrigate an additional area of 10,000 acres.

11. Soft water in the Dakota sandstone, by O. E. Meinzer. May 25, 1929. 3 pp.

Gives data on the quality of water from the Dakota sandstone, ir different wells. See also Water-Supply Paper $597 \mathrm{c}$.

12. What becomes of the rain water, by O. E. Meinzer and N. D. Stearns. May 28, 1929. 3 pp.

Announces publication of Water-Supply Paper 597 b. Summarizes studies carried on in Pomperaug Basin, Conn., under the headings: Natural storage for tie wacer supply; Estimates of runoff, evaporation, and underground percolition; Recharge and discharge of the subterranean reservoir.

13. Ground water in the vicinity of Lodi, Calif., by H. T. Stearns, T. W. Robinson, and G. H. Taylor. Sept. 20, 1929. 2 pp.

Summary of a cooperative investigation begun in 1926. The vineyards and orchards of the area are supplied by water pumped from wells. There are 2,000 pumps on wells used for irrigation, and more than half of them are in an area of less than 72 square miles. A total of 45,800 acres is irrigated by well water. About 70,800 acre-feet of water is pumped annually for irrigation and domestic and stock use. See also Water-Supply Paper 619.

14. Artesian water supply of Memphis, Tenn., by F. G. Wells. Sept. 24, 1929.

2 pp.

Gives a summary of the ground-water conditions, the Holly Sprinms and Grenada formations being the most productive water-bearing horizons. The ripley formation

- is a deeper water-bearing zone. Gives data on the pumpage of water. See also WatorSupply Papers 688 and 656. 
15. Ground water in Mimbres Valley, N. Mex., by W. N. White. Dee. 14. 1929. 2 pp.

See also Wäter-Supply Paper 637 b.

16. Ground water in Little Lost River Valley, Idaho, by Lynn Crandall and H. T. Stearns. May 24, 1930. 1 p.

A summary of ground-water and artesian conditions in the area, with data on test wells.

17. Ground water in Big Last River Valley, Idaho, by Lynn Crancall and H. T. Stearns. June 23, 1930. 1 p.

A summary of conditions with surface waver used for irrigation and of the possibility of extending irrigation by pumping shallow ground water.

18. Ground-water supplies for rice irrigation in the Grand Prairie regicn, Ark. by D. G. Thompson. Jan. 26, 1931. 21 pp., 2 pls.

A report on an area where about 200,000 acre-1eet of water is being pumped yearly from Pleistocene deposits for irrigation. The hydrostatic head has dropped notably, and the safe yield has been exceeded for several years. Includes a mas showing contours of artesian head. See also Cooperative report 20 e and Journal article 196.

19. Survey of the underground waters of Texas, by O. E. Meinzer an ${ }^{\lambda}$ W. N. White. Feb. 16, 1981. 31 pp., 3 maps.

Describes the geology and the water-bearing formations and gives data on the extent of irrigation with water from the several formations. Discusses un ferground leakage and the waste of water.

20. Geology and ground-water resources of the Dalles region, Oreg., $\mathrm{ry}$ A. M. Piper. Apr. 7, 1981. 5 pp.

A summary of the geology and structure. Water supplies for irrigation may be obtained from the upper and lower zones of the Yakima basalt. See al'? Water. Supply Paper 659 b.

21. Ground water for irrigation in Yamhill County, Oreg., by A. M. Piror. Apr. 7, 1981. 2 pp.

A summary based on an investigation in cooperation with the Oregon State Agricultural Experiment Station. Discusses the water available for irrigation from wells in the valley plain of the Willamette River and its tributaries. See al n WaterSupply Paper 890 and Cooperative report 331.

22. Recent replenishment of ground-water supply recorded by observation well near Washington, D. C., by R. C. Cady. Apr. 28, 1931. 1.p.

A summary of recent changes of water level in an observation well. See also Water-Supply Paper 777.

23. Ground-water levels in Grand Prairie region, Ark., by D. G. Thompson. June 13, 1931. 1 p.

Measurements in $99^{\circ}$ observation wells show lower water levels in the spring of 1931 than on corresponding dates in 1930. The average lowering was $1 \%$ feet. See also. Water-Supply Paper 777.

24. Ground water for irrigation in the Harney Basin, Oreg., by A. M. Piper and T. W. Robinson. Aug. 11, 1931. 21 pp.

A preliminary account of the geology and ground-water resources of Harney Basin. Oreg. Two promising sources of water exist, the deeper part of the valley fill and the uppermost water-bearing strata of the bedrock. Thermal sjorings are numerous. The geologic structure is a shallow saucer-shaped basin, modified by faulting. Artesian conditions probably are present. The methods of well construction heretofore used are inadequate. See also Water-Supply Paper 8ג1.

25. Artesian water supply of Memphis and other parts of western Tennessee, by F. G. Wells. Aug. 17, 1931. 5 pp.

Gives data on development of the Memphis water supply and a summory of the geology of the area. See also Water-Supply Papers 638 a and 656.

36. Ground-water resources of northeastern Pennsylvania, by R. M. Leggette and S. W. Lohman. Sept. 21, 1931. 8 pp.

A summary of studies in 12 counties and part of another in connention with which the records of about 1,000 wells were collected and 89 analyser of well and 


\section{Ground-water resources of northeastern Pennsylvania-Continued:}

spring water were made. Describes geology and the water-bearing properties of the different types of rock. See also Cooperative report 344 .

27. Inter-relationship of underground and surface water invertigations, by 0 . E. Meinzer. Proc. Conf. District Eng. of U. S. Geol. Survey, Oct. 10, 1981. pp. 36-48.

Discusses relation of ground water to stream flow and methchs of investigation. Regards noot zone and zone of saturation as reservoirs that regulate surface flow of water. Effects of droughts on wells are comparable to their effects on springs. Wells that extend for considerable depths below the water table are not easily affected by drought, and wells that extend into large art?sian reservoirs are independent of seasonal variations in precipitation.

28. Water supply of the Roswell artesian basin, N. Mex., by A. G. Fiedler and S. S. Nye. Jan. 26, 1932.3 pp.

Summary of data on the artesian water supply and State lerislation for control of its development. See also Water-Supply Paper 639.

29. Replenishment of ground water recorded by observation well near Washington, D. C., by R. C. Cady. Fẹb. 15, 1932. 2 pp., 2 pls.

A summary of the changes in water level in an observatior well in Arlington County, Va., during 1928-31. See also Water-Supply Paper 777.

30. Inventory of the water supply on the Snake River Plains in southeastern Idaho, by H. T. Stearns, Lynn Crandall, and W. G. Stisward. Feb. 25, 1932. 8 pp.

A summary of the quantitative results of an extensive investigation during 1920-27. The average annual contribution of water to the Snake River Plains about King Hill, Idaho, from all tributary valleys, both surface and underground flow, was computed to have been $9,079,500$ acre-feet. The average annual disposal of water was computed to have been $9,971,000$ acre-feet, includire the discharge of Snake River, transpiration of crops, evaporation, and incridased storage in surface reservoirs and underground. The difference of 891,500 acre-feet. is equal to about 12 percent of the average annual precipitation in the region and represents to some extent the ground-water recharge from precipitation. See also Tater-Supply Papers 774 and 775 .

31. Ground-water resources of Webb County, Tex., by J. T. Lonisdale and J. R. Day. Feb. 9, 1933. 9 pp., 1 pl.

The most promising water-bearing formations are the Carrize sandstone and the Cook Mountain formation, which yield large quantities of wator, some of which is suitable for irrigation. Water suitable for domestic and stoo use occurs in the Catahoula and Reynosa formations, and some wells in these, fcrmations, may yield water suitable for irrigation under proper conditions of soil drainage. See also Water-Supply Paper 778.

32. Soil pipe test plug and mercury manometer, by G. H. T'ylor. Mar. 10, 1932. 2 pp.

Describes a device made and used in Utah for measuring the shut-in pressure of flowing artesian wells.

33. Venturi fiume, by G. H. Taylor. Mar. 10, 1932. 2 pp.

Describes a s-inch Venturi flume designed by H. C. Troxell ard C. A. Taylor and used in southern California to measure the discharge of water frnm irrigation wells.

34. Replenishment of ground water recorded by observation wells in Pennsylvania, by S. W. Lohman. Apr. 27, 1932. 2 pp.

Summarizes the changes in water levels in observation wells in 1931-32. See also Water-Supply Paper 777.

35. Ground-water resources of southeastern Pennsylvania, by G. M. Hall. Apr. 30, 1932. 6 pp., 1 map.

Gives the results of studies in 13 counties and parts of 2 others. Inclndes a summary of data obtained from 1,300 wells and partial analyses of 144 samples of well and spring waters. Includes a map showing ground-water conditiona. See also Cooperative report 342 . 
B6. Ground-water supplies in the vicinity of Salt Lake City, Utah, by R. M. Leggette and G. H. Taylor. July 23, 1932. 9 pp.

Describes geology and ground-water conditions of Jordan Valley, Utah. The area of artesian flow in 1931 was about the same as in 1904, and therefore the safe yield of the ground-water reservoir has not been exceeded. Considerable wavte takes place from the uncontrolled flow of wells. Construction of existing we"s is inefficient. Includes maps showing artesian head and chloride content.

37. Water levels in wells in northern Virginia, by R. C. Cady. Sept. 6, 1932. $1 \mathrm{p}$.

A summary of recent changes in water level in observation wells. See alro WaterSupply Paper 777.

38. Underground water resources of Atascosa and Frio Counties, Tex., by J. T. Lonsdale. Oct. 13, 1932. 9 pp.

The Carrizo sandstone and Mount Selman formation yield considerable water to both flowing and pumped wells. Gives data on the amount of land irrigated and the waste of water. Describes water-level measurements to determine the amount of water that can be withdrawn without seriously depleting the supply. Sen WaterSupply Paper 676.

89. Ground-water resources of the Houston-Galveston area, Tex., by W. N. White, Penn Livingston, and S. F. Turner. Oct. 17, 1932. $14 \mathrm{pp}$.

Describes the chief water-bearing formations and the studies on pumrage and water levels. The underground reservoir is capable of supplying more water than has heretofore been withdrawn from it. See also Water-Supply Papers $889 \mathrm{~d}$ and $\mathrm{f}$ and Cooperative reports 388,394 , and 396 .

40. Ground-water resources of Duval County, Tex., by A. N. Sayre." Teb. 12, 1933. $14 \mathrm{pp}$.

The chief water-bearing formations are the Catahoula tuff and the Reynosa formation. Most of the water is rather highly mineralized, but in the southeast part of the area water suitable for irrigation is obtained. Irrigation with ground water is there feasible, but development should proceed slowly until the adequary of the supply has been determined. See also Water-Supply Paper 776.

41. Statement concerning the investigation of ground-water resources of Long Island, N. Y., by D. G. Thompson and F. G. Wells. Mar. 2), 1933. $13 \mathrm{pp}$.

Describes some of the problems to be eonsidered in a current investiration of ground-water supplies of Long Island. It is estimated that 250,000,000 gallons a

- day is pumped from wells in the boroughs of Brooklyn and Queens and in Nassau County, Salt water is being drawn into wells in certain parts of Brool yn. See also Cooperative reports $271,272,274$.

42. The upward trend of the ground-water level in northern Virginia, by $R$. C. Cady. June 20, 1933. 2 pp.

A summary of the changes of water-level in five observation wells during 1928-33. See also Water-Supply Paper 777.

43. The construction and protection of drilled wells, by A. G. Fiedler. Sept. 9, 1933. $8 \mathrm{pp}$.

Describes the methods of drilling wells by the cable-tool percussion and the hydraulic rotary methods. Discusses the contamination of wells, methods of protection of castings, and the chlorination of completed wells.

44. Ground water in the Walla Walla basin, Oreg.-Wash., by A. M. P'per, T. W. Robinson, and H. E. Thomas. Oct. 25, 1933. 3 pp.

Summary of a study of the alluvial basin of the Walla Walla River, with data on fluctuation of the ground-water level in response to irrigation and to rainfall:

45. Mercury manometer pressure gage, by G. H. Taylor, Dec. 10, 1933. $1 \mathrm{p.}, 1 \mathrm{pl}$.

Describes the construction and operation of a gage for measuring the shut-in pressure of flowing artesian wells as used in Utah. 
46. Ground-water resources in the Houston district, Tex., by W. N. White and Penn Livingston. Dec. 29, 1933. 6 pp.

Gives figures on the amount of water pumped for the city of Houston in 1928-33, the fluctuations in artesian pressure, and flve analyses showing the quality of the water. See also Cooperative reports 388, 394, 396.

47. Water resources of the Mud Lake region, Idaho, by H. T. Stearns, L. L. Bryan, and Lynn Crandall. Jan. 8, 1934. 7 pp.

A review of the data collected since 1921 and interpretations of all data on the Mud Lake region, Idaho, including inventory of the ground-water supply and methods for obtaining maximum conservation and utilization. See also Vrater-Supply Paper 818.

48. Ground-water supply for the Kula and Makawao districts, Maui (Hawaii), by H. A. Powers. Jan. 12, 1934. 5 pp.

Preliminary report on the possibilities of developing additional ground-water supplies for the Kula and Makawao districts. The drought of 1932-33 seriously affected the public water supply, and new sources of ground water we"e desired. A material increase in the water supply can probably be obtained by the development of ground water from buried drainage surfaces.

49. Investigation of ground-water levels in Platte River Valloy, Nebr., by L. K. Wenzel and A. L. Lugn. Feb. 28, 1934. 2 pp.

A summary of the studies that have been made, including test. drilling, pumping tests, measurements of water level, and collection of well data. See also WaterSupply Paper 779.

50. Future ground-water supplies for Honolulu, Hawaii, by H. T. Stearns. Mar. 21, 1934. 20 pp., 1 map.

Gives data on additional ground-water supplies available to Honolulu from the dike complex of the Koolau range, from six minor high-level sources, and from the artesian reservoirs. Contains map showing boundary of dike complex and most favorable location for a water tunnel.

51. Ground water in Dimmit and Zavala Counties, Tex., by W. N. White, S. F. Turner, and W. A. Lynch. Apr. 11, 1934. 4 pp.

The outcrop area of the Carrizo sand, which supplies water to the irrigation wells of the area, covers about 175,000 acres, and most of the recharge occurs from precipitation on the outcrop area during years of heavy rainfall. Prior to 1929 there was a decline of water levels. From 1929 to 1933 there was decrease in withdrawal, and the water level was about the same in the latter as in the former year. The yield of wells amounted to 20,000 acre-feet, sufficient to irrigate 27,000 acres. Additional development of ground water is not justifial 'e in view of the facts brought out by the investigation. See also Cooperative raport 393, Dimmit and Zavala Counties and part of Maverick County.

52. Seepage loss and gain of the Mokelumne River, Calif., by H. C. Pritchett, C. D. Bue, and A. M. Piper. June 5, 1934. 4 pp.

To determine the extent to which the ground-water .supply is dependent on the water flowing in Mokelumne River, a monthly water inventory was made for the years 1926 to 1933 , based on detailed investigation. A table gives the net loss or gain by seepage. See also Water-Supply Paper 619.

53. Geology and ground-water resources of the Snake River Plain in southern Idaho, by H. T. Stearns, Lynn Crandall, and Wr. G. Steward. July 17, 1934. $3 \mathrm{pp}$.

Reviews the cooperative examination of the area and lists eight previous releases giving information on the progress of the work. See also Water-Supply Papers 774 and 775.

54. Relation of ground-water to stream flow, by O. E. Meinzer. July 10, 1934. $8 \mathrm{pp}$.

A condensed discussion of the subject, under the headings: Direct discharge ; Zone of saturation; Belt of soil moisture; Intermediate belt and capillary fringe; Ground-water recharge; Gronnd-water discharge; and Types of springs and their relation to stream flow. 
55. Mineral water supply of the Mineral Wells area, Tex., by S. F. Turner. U. S. Geol. Survey Circ. 6, 1934. 9 pp.

Prepared in cooperation with Texas State Bd. Water Eng. and Texas State Dept. Health. An area of about 150 square miles surrounding the city of Mineral Wells was examined. In* 1931 there were about 150 commercial wells, all in the city, averaging 200 feet in depth and obtaining water from the Brazos River conglomerate, of Pennsylvanian age. The water is especially high in sodium sulfate. Results of pumping tests show mutual interference of some wells. Gives the results of field chemical tests on 59 water samples and analyses of 12 samples, the location of the wells sampled being shown on an index map.

56. Well water supplies, by O. E. Meinzer. Feb. 1, 1935. 7 pp.

A paper prepared for the News Memorandum of the Bureau of Yards and Docks, United States Navy, with special regard to ground-water supplies at naval stations. Discusses the common water-bearing formations, safe yield of wells, and salt-water and drilling problems, with references to published reports of the United States Geological Sturvey.

57. Preliminary report on the water resources work of State genlogical surveys, by O. E. Meinzer. Mar. 29, 1935. 8 pp.

A report to the chairman of the State Geological Surveys Committre of the Division of Geology and Geography, National Research Council. Discuss sy the relation of Federal to State geological surveys and the best bases of cooperation. "The water resources investigations of an ideal State geological survey or comrarable organization may be classed as (1) research in the principles and methods of hydrology; (2) systematic investigation of the natural waters of the State with respect to occurrence, quantity, head, quality, and methods of recovery; and (3) dissemination and application of the results of the research and investigation."

58. Four-year decline of the ground-water level in the Platte Piver Valley in central Nebraska caused by subnormal precipitatior, by $\mathbf{L}$. $\mathbf{K}$. Wenzel. Apr. 1, 1935.2 pp., 2 pls.

The water level declined 1 to 8 feet from October 1930 to October 1934, the decline being greatest where the water table lies deepest. During the period the deficlency of precipation amounted to about $1,400.000$ acre-feet, and the net loss of ground water was about 400,000 acre-feet. The records indicate that recharge in normal years will restore the water levels to their normal position. See alsc Water-Supply Paper 779.

59. A Nation-wide program of water-level measurements, by O. E. Meinzer. April.10, 1935. $3 \mathrm{pp}$.

Describes the development of water-level measurements on observation wells, and their value in connection with studies of drought conditions.

60. Report of the Committee on Observation Wells, a preliminar manual of methods, by R. M. Leggette, L. K. Wenzel, R. C. Cady, S. W. Lohman, V. T. Stringfield, R. W.Sundstrom, and S. F. Turner; introduction by O. E. Meinzer. May 1935.58 pp., 8 figs.

Gives instructions on types of observation wells, their equipment and protection, the methods and frequency of measurements, installation and operation of automatic recorders, and collection of field data.

61. The relation of ground-water levels to temperatures and prexipitation at Harvey, N. Dak., by A. N. Sayre. June 10, 1935. 2 pp.

Gives data on water level in a well of the city water supply syster in which the level is low in the spring season and rises to maximum height in early summer. The water-level fluctuations also show a marked relation to the season 1 l temperature. Includes diagram showing fluctuation in water level in the well from January 1927 to May 1935.

62. Geology and ground-water resources of the Harney Basin, Oreg., by A. M. Piper, T. W. Robinson, and C. F. Park, Jr. June 25, 1935. 5 pp.

The alluvial deposits contain clean water-bearing sands, which are thick and abundant near the apex of alluvial cones and thin and less nurierous beneath 
62. Geology and ground-water resources of the Harvey Barin, Oreg.Continued.

the central plain. The deeper wells yield water under artesian pressure. Thermal springs, from known or inferred faults, discharge water as much as $154^{\circ} \mathrm{F}$. in temperature. Along the borders of the plain the ground.water is moderately mineralized, chiefly with sodium bicarbonate. In the central part of the plain some wells yield saline or sulfate water. See also Water-Supply Paper 841.

63. An ebb and flow spring near Greenbrier Cove, Tenn., by G. M. Hall. Aug. 10, 1935. $2 \mathrm{pp}$.

Describes the varying discharge of a small spring. See also Journal article 142.

64. Ground-water resources of south-central Nebraska, with special reference to the Platte River Valley between Chapman and Gothenburg, by L. K. Wenzel and A. L. Lugn. Sept. 16, 1935. 2 pp.

Nearly all water supplies of the area are from wells. It is estinated that the pumpage for municipal, irrigation, and other uses is about $30,000 \approx$ cre-feet a year and that about 56,000 acre-feet a year percolates southward under the upland and reappears in the tributaries of Republican and Blue Rivers. With the return of normal years of precipitation there will be restoration of the ground-water supply. See also Water-Supply Paper 779.

65. The artesian water supply of Ogden, Utah, by R. M. Leggette and G. H. Taylor. Sept. 17, 1935. 5 pp.

A summary of ground-water conditions in Ogden Valley, Utah, with data on fluctuations in ground-water level and discussion of artesian conditions. See also Water-Supply Paper 796 d.

66. Ground water in the southern High Plains, by C. V. Theis, H. P. Burleigh, and H. A. Waite. Oct. 30, 1935. 4 pp., 1 map.

Most of the ground water is in the Ogallala formation, which overlies Cretaceous and Triassic rocks that contain small amounts of highly mineralized water. About half an inch of precipitation reaches the water table yearly. The ground water moves east or southeast and discharges by evaporation from lakes or as springs along the esearpment that bounds the plains on the south and east.

67. Ground water in Avra Valley, Ariz., by D. A. Andrews. Nov. 7, 1935: 1 p.

In the pediment zone of Avra Valley the bedrock lies near the surface, and water supplies may be found in some places in shallow wells in the disintegrated rocks. In the parts of the valley underlain by alluvium large quantities of vater are available to wells at depths ranging from 150 to 800 feet. See also Water-Supply Paper 796 e.

68. Ground-water resources of northwestern New Mexico, by G. A. Waring and D. A. Andrews. Nov. 8, 1935. 2 pp., 1 map.

The principal water-bearing formations are sandstones of Upper Cretaceous to Jurassic age. Most of the northern part of the region from a synclinal basin. in which flowing wells have been obtained in the Dakota sandstone. Includes a map showing the geology of the area.

69. Ground water in the Butter Creek area, Umatilla County, Orer., by A. M. Piper. Jan. 4, 1936. 1 p.

The supply of shallow ground water is in thin discontinuous layens of sand and gravel. These are recharged periodically when the creek is in freshet, but their storage capacity is small, and many shallow wells failed in 1934-35. Water-bearing beds at depths of several hundred feet yield reliable supplies for domsstic and stock use but are at too great pumping depths to be feasible for irrigation.

70. Demand for water for air conditioning, by H. C. Barksdale. Feb. 10, 1936. 2 pp.

A summary account of an.address by Thornton Lewis of the Carriar Engineering Corp. Discusses the several methods of air conditioning and the use of well water for the purpose. Gives data on the amount of water required and ecots of installations.

71. Water supplies from wells in southeastern Utah and southwastern Colorado, by G. A. Waring and M. M. Knechtel. Apr. 7, 19364 pp.

Gives a summary of the water-bearing formations and possible artesian conditions in several parts of the region, with notes on water horizons in several test wells drilled for oil. 
72. Mercury manometer pressure gage, by G. H. Taylor. Apr. 10, 1936. 4 pp., 1 pl.

Describes and illustrates the equipment used for measuring the shut-in pressure of artesian wells in Utah, with explanation of operation of the gage. Gives itemized cost of construction of the instrument.

73. Symposium on ground-water levels, by D. G. Thompson and others. June 10, 1936. $1 \mathrm{p}$.

Gives summary of meeting and titles of 10 papers presented in the symposium, with statement as to extent of the studies of ground-water levels in 25 States and the Territory of Hawaii.

74. Ground-water levels in observation wells on eight experimental areas of the Soil Conservation Service, by R. M. Leggette and $0^{+}$hers. July 10, 1936. $8 \mathrm{pp}$.

Gives data on water levels in wells in experimental areas near Mankato, Kans.; Tarkio, Mo.; High Point, N. C. ; Stillwater, Okla.; Spartanburg, S. C. ; Temple, Tex.; Pullman, Wash.; and La Crosse, Wis.

Prepared in cooperation with the Soil Conservation Service, United States Department of Agriculture.

75. Some characteristics of a satisfactory observation well, by A, M. Piper. Aug. 10, 1936. 2 pp.

Describes conditions desirable in an observation well.

76. A Nation-wide system for designating wells, by O. E. Meinze:. Aug. 10, 1936. $2 \mathrm{pp}$.

Describes the systems adopted for wells in Oregon and Utah, with comments on other suggested plans for designating the map location of individual wells.

77. Storage, surface and underground, by W. N. White. Oct. 10, 1936. 7 pp.

Discussion of a paper of the same title by R. E. Horton. Treat; especially of the annual rate of replenishment of underground reservoirs as affected by rainfall and stream discharge. Discusses increase of ground-water supply b- artificial recharge and storage in upstream areas. Includes a list of 12 papers or ground-water levels and storage.

78. The value of "geophysical" methods in hydrologic work, by O. E. Meinzer. Dec. 10, 1936. 3 pp.

Treats of the electric-resistivity method and its use in locating vater horizons near $\mathrm{Fl}$ Paso, Tex., and in Hawaii ; in dam-site investigations in the West; and in salt-water studies in New Jersey.

79. Hydrology in Europe, by O. E. Meinzer. Dec. 10, 1986. 4 pp.

A short account of a meeting of the International Union of Geolesy and Geophysics at Edinburgh, Scotland, and notes on hydrologists who were visitẹd in Germany, Holland, and France.

80. State-wide numbering system for designating wells, by A. M. Piper. Dec. 10, 1936. $1 \mathrm{p}$.

Describes the system used in the Division of Geology, Washington State Department of Conservation and Development, for filing well logs, accordin $r$ to a symbol that designates the location to the nearest tenth mile with reference to the land-net system.

81. A Nation-wide system for designating wells, by A. M. Piper. Dec. 10, 1936. 3 pp., 1 pl.

Comments on a previous paper by 0 . E. Meinzer and describes the system used by the author in designating wells in Oregon, based on the township and range lines as coordinates.

82. Ground water in Gila and San Simon Valleys, Graham County, Ariz., by M. M. Knechtel and E. W. Lohr. Dec. 14, 1936. 2 pp.

The valley area is an intermontane trough 10 to 20 miles wide extending southward from the San Carios Indian Reservation. Along Gila River is an alluvial plain 1 to 3 miles wide. The higher land is terraced. The lower lands are underlain by numerous strata of sand and gravel containing water under little or no artesian 
82. Ground water in Gila and San Simon Valleys, Graham Cornty, Ariz.Continued.

pressure. The terrace gravel yields little water. The deeper valley deposits yield artesian water under sufficient pressure to flow in some places. Analyses of 49 water samples show them to be mainly of sodium chloride, sodium carbonate, and sodium sulfate types. About one-third of the waters analyzed are too highly mineralized to be fit to use for irrigation. See also Water-Supply Parar $796 \mathrm{f}$.

83. Artesian water in the vicinity of Woods Cross, Davis County, Utah, by G. H. Taylor and H. E. Thomas. Jan. 27, 1937.1 p.

Describes tests of the interference between artesian wells in an area of about 5 square miles.

84. Apparatus for testing the permeability of samples of unconsolidated sediments in the field, by V. C. Fishel and V. T. Stringfield. Jeb. 10, 1937. 3 pp., 2 pls.

Describes the apparatus and gives a chart for determining the permeability from the rate of decline of the water level in the manometer tube.

85. Ground-water resources of the Holbrook area in east-central Arizona, by M. A. Harrell and E. B. Eckel. Mar. 7, 1937. 2 pp.

The Holbrook area covers about 10,000 square miles on the Colorado Plateau in parts of Coconino, Navajo, and Apache Counties, Ariz. The principql water-bearing formations are the Coconino sandstone, the lava flows, and recent sand and gravel along the major streams. The best supplies are obtained from the Coconino sandstone. Small structures such as the Holbrook dome aid in causing artesian conditions in small areas. See also Water-Supply Paper $836 \mathrm{~b}$.

86. Ground-water levels in Utah, by G. H. Taylor and H. E. Thomas. Mar. 11, 1937. 1 p.

The general rise in ground-water levels in Utah in 1936 indicatis that recharge to ground-water basins, most of which are artesian, has been greater than the discharge. This has been caused in part by increased precipitation and in part by the adoption of conservation measures that limit the amount of water wasted from artesian wells. See aiso Water-Supply Paper 817.

87. Ground-water supplies of Mill Creek Valley and the Norrood Trough, Ohio, by D. G. Thompson. April 5, 1937. 23 pp.

Gives an introductory discussion of the geology and glaciation ard then describes ground-water recharge, the present water supply, which is chiefly from the Ohio River, and the quality of water. Gives data on consumption and the decline of the water table. Possible sources of additional supply from reservoirs are considered.

88. Ground-water supplies of Mill Creek Valley and the Norwood Trough near Cincinnati, Ohio, by D. G. Thompson. Apr. 29, 1937. 2 pp.

Ground water is obtained generally from wells in alluvial deposits that fill ancient river valleys cut in the bedrock. Recent studies show a great decline in groundwater levels due in large part to heavy and increasing pumpage. Recommends other sources.

89. Sundry hydrologic observations, especially concerning the ground-water supply of London, by O. E. Meinzer. May 18, 1937. 4 pp.

Gives a summary of the water-supply system for a population of about 7,500,000, the average daily consumption of water being about $280,000,000$ gall :ns.' About twothirds is from the Thames River, one-sixth from the Lee River, and one-sixth from wells that obtain most of their water from the Cretaceous chall formation. In the central part of London the ground-water level has declined greatly in recent years, owing to the great draft by wells.

90. Artesian-water levels and interference between artesian wells in the vicinity of Lehi, Utah, by G. H. Taylor and H. E. Thomas. July 22, 1937. 2 pp.

In the vicinity of Lehi, Utah, artesian water is obtained from two harizons, at depths of 130 to 200 feet and at 200 to 400 feet. During 1936, becruse of decreased irrigation due to a rainy growing season and closer control of flowing wells to prevent waste of water, the ground-water level rose 5 to 10 feet. A series of tests show that wells in the same horizon cause interference with each other but do not affect wells of a different horizon. See also Water-Supply Paper 836 a. 
91. Ground water and ground-water hydrologists in Germany, by O. E. Meinzer. Nov. 10, 1937. $11 \mathrm{pp}$.

A summary of observations concerning the water supplies of Hamburg, Berlin, Leipzig. Frankfurt, Baden-Baden, Heidelberg, Neureut, Gelsenkirchen, and the Ruhr district.

92. Ground water and ground-water hydrology in Holland, by O. E. Meinzer. Feb. 10, 1938. 5 pp.

An account of a visit to The Hague and examination of its water-surply system and of the supply to Amsterdam from the dune area, where the balance of fresh- waier and salt-water depends on the principles discovered by Badon Ghyben and Alexander Herziverg.

93. Ground-water levels in Utah during 1937, by G. H. Taylor and H. E. Thomas. Feb. 11, 1938. 2 pp.

Summarizes the changes in water level in about 400 observation wells distributed throughout the State. See also Water-Supply Paper 840 .

94. Ground-water resources of south-central Pennsylvania, by S. W. Lohman. Mar. 14, 1938. 2 pp.

Summarizes the results of cooperative study of the area. See also Cooperative ( report 345.

95. Ground water in the United States, by O. E. Meinzer. May 10, 1938. 5 pp. A summary of the ground-water conditions and resources of the exuntry, the utilization of the ground water, and the seientific investigation and literature relating to the subject. See also Water-Supply Paper 489.

96. Water-level recovery curve form, by S. F. Turner. May 10, 1938. 4 pp. Presents two examples of use of the form as employed in Texas, with comments on it.

97. Artesian water resources of Southampton, Sussex, and Isle of Wight Counties, Va., by D. J. Cederstrom. May 14, 1938. " 3 pp.

Discusses briefly the geology and artesian water resources of the area and emphasizes the loss of artesian head and the quality of the water, particularly the fluoride content.

98. Ground water in north-central Pennsylvania, by S. W. Lohman. July 2, 1938. $2 \mathrm{pp}$.

A summary of a cooperative study of the area. See also Cooperative report 346 .

99. General summary of water levels and artesian pressure in tho United States in 1937, by O. E. Meinzer and L. K. Wenzel. July 16, 1938.

$4 \mathrm{pp}$.

Gives a summary of ehanges in water level in various States durine the year. See also Water-Supply Paper 840 .

100. Report on the public water supply of Shelter Island Heights, N. Y., by M. L. Brashears, Jr. July 23, 1938. 1 p.

The water supply is from four shallow wells, in two of which there has been salt-water encroachment. The situation is not serious, but pumping from these wells should be done only when additional water supply is necessary.

101. A summary of artesian conditions in the United States, by O. E. Meinzer. Aug. 10, 1938 . $6 \mathrm{pp}$.

A discussion of artesian conditions in general and in the Paleozoic formations of the east-central region, in the Roswell basin of New Mexico, the Atlantic and Gulf Coastal Plain, the Cretaceous formations of the Great Plains region, in glacial drift, and in valley fill of the western mountain region. See also Water-Supply Paper $836 \mathrm{~d}$.

102. Wells used for public-water supply at Spokane, Wash., by A. M. Piper and G. A. LaRocque, Jr. Nov. 10, 1938. 2 pp., 2 tables.

The supply from the Spokane River was discontinued in 1908, whon a large supply was developed from shallow wells in coarse glacial outwash near the river. See also Water-Supply Paper 889 b. 
103. Source of salt in ground water in the vicinity of Lagun? Grande de la Sal, N. Mex., by T. W. Robinson and W: B. Lang. Nov. 18, 1938. 1 p

$A$ body of brine at the base of the Rustler formation extends from north of the Laguna to near Malaga Bend of the Pecos.River. Artesian pressume forces the brine into the river at and near the Bend. The salt is derived from the Salado halite. The brine from the Laguna does not reach Malaga Bend.

104. Georgia public water supplies, by W. D. Collins. Jan. 6, 1939. 6 pp

Suriace water supplies are used in the Appalachian Highlands and artesian well water in the Coastal Plain. Gives data on the dissolved solic's and hardness of the water supplies of 65 eities. See also Water-Supply Paper 912.

105. Shallow-water resources of the Roswell artesian basin, I'ew Mexico, by A. M. Morgan. Jan. 18, 1939. 1 p.

A summary of shallow ground-water conditions in the area. See also Water-Supply Paper 639.

106. Geology and ground-water resources of Texas County, Okla., by S. L. Schoff. Jan. 25, 1939. 3 pp.

A summary of the results of a cooperative study begun in 1937. S 'e also Cooperative report 321.

107. Water levels in wells rise from low stages in northern Virginia, by $R$. C. Cady. Jan. 25, 1939. 1 p.

A summary of recent changes in water levels in observation wel $\cdots$, See also WaterSupply Paper 845.

108. Ground-water supply of Mimbres Valley, N. Mex., by C. V. Theis and G. C. Taylor, Jr. Jan. 27, 1939. 1 p.

Notice of release of two reports on ground-water supply and ground-water levels in the valley. "These reports show that since 1914, when the first records were obtained, there has been a consistent fall in water levels in th a heavily pumped areas." See also - Water-Supply Paper 637 b.

109. Ground-water levels declined slightly in North Dakota in 1938, by L. $\mathrm{K}$. Wenzel. Feb. 7, 1939.6 pp., 2 pls.

Gives a summary of the changes of water level in $\mathbf{7 7}$ observation wells throughout the State and data on the observation-well program in cooperation with the North Dakota Geological Survey. Includes map showing location of wells. See also WaterSupply Paper 845.

110. The work of the Division of Ground Water in Utah, by G. H. Taylor. Feb. 10, 1939. 7 pp.

Gives a summary of ground-water studies in Utah, the importance of ground water in the State and the laws regulating its development. Emphasizes the value of studies of the ground-water level in connection with conservation of the supply.

111. Ground-water resources of the Arkansas Valley in Ford County, Kans., by H. A. Waite. Mar. 13, 1939. 2 pp.

Gives a summary of the studies made on the ground-water: level, wells, and pumping plants for irrigation with water from the valley allurium. See also Cooperative reports $141,142,153$.

112. Ground-water levels in Utah during 1938, by G. H. Taylor and H. E. Thomas, Mar. 10, 1939. 2 pp., 1 map.

Summarizes data on the changes in water level in various ports of the State, which are based on records from about 680 observation wells. Includes map showing avsrage changes in the ground-water level. See also Water-Suppl? Paper 845.

113. Changes in water level in shallow wells near Roswell, N. Mex., in 1938, by A. M. Morgan. Mar. 27, 1939. 2 pp.

A summary of data on changes in water level in 407 shallow wells in the area. See also Water-Supply Paper 845.

114. A method to pxotect a pressure-recording installation on flowing wells during freezing weather, by W. K. Bach. May 10, 1\&39.' 1 p., 1 pl.

Describes and illustrates a system of valves in which an antifrisezd traid is used. Fuel oil has been found to be the most satisfactory liquid for the parpose. 
115. Ground water in Cimarron County, Okla., by S. L. Schoff and J. W. Stovall. May 29, 1939. 9 pp., 1 map.

A summary of the geology and an outline of the ground-water hydrology. Includes a map showing the several ground-water areas or provinces and the depth to water by contour lines.

116. Releases by the Division of Ground Water during the fiscal year ended June 30, 1989, by O. E. Meinzer and Jane Daniel. Aug. 10, 1939. 7 pp.

$A$ list of reports, papers, and memoranda released during the fiscal year. Contains the titles of 105 reports and papers published or transmitted for publication.

117. The role of hydraulic laboratories in geophysical research: Gro 'und Water; permeability, specific yield, etc., by O. E. Meinzer. Sept. 13, 1939. 10 pp. (Mimeographed by U. S. Bureau of Standards.)

"The present paper relates only to studies that have been or can be performed in the laboratory on the movement and storage of ground water." Discusses experimental work that has been done on the law of flow through weter-bearing materials; investigations relating to dense materials; rate of flow com ruted from velocity; rate of flow computed from permeability; storage coefficient of artesian aquifers; and specific yield. Contains list of 22 papers cited.

118. Water-table fluctuations in and adjacent to the Spokane Valler, Wash.Idaho, by A. M. Piper. Oct. 9, 1939. 1 p.

A summary of data collected on ground-water levels and ground-water flow. See also Water-Supply Paper 889 b.

119. Cable-tool test drilling in unconsolidated deposits near Wichit. Kans., by J. C. Frye, Jr. Aug. 10, 1939, 6 pp.; Nov. 10, 1939, 6 pp.

Describes conditions encountered and equipment and procedures used in driling test wells for public-water supply in the "Equus beds." See also Journal article 214.

120. Municipal and industrial supplies from wells in Butler and Hamilton Counties, Ohio, by D. G. Thompson and F. H. Klaer, Jr. Feb. 19, 1940.

2 pp.

Summarizes the amount of water pumped, with notes on the precipitation. See also Cooperative report 311 .

121. Water levels in wells are at'low stages in northern Virginia and vicinity of Washington, D. C., by V. C. Fishel. Feb. 23, 1940. 1 p.

A summary of changes recorded in four observation wells in Virgini 3. See also Water-Supply Paper 906.

122. Ground-water levels in Utah in 1939 , by G. H. Taylor, H. E. Thomas, and W. K. Bach. Apr. 6, 1940. 5 pp.

Gives a summary of changes in ground-water levels in the several parts of the State during 1936-39. See also Water-Supply Paper 886.

123. Ground-water levels in Oklahoma in 1939, by S. L. Schoff. Apr. 10, 1940. 1 p.

A summary of water-level changes during 1939. See also Water-Supply Paper 886.

124. Records of wells in Mississippi, by G. F. Brown. Apr. 11, 1940. 1 p.

Cooperative study has been in progress since 1938, and records of shout 1,300 wells have been obtained. See also Water-Supply Papers 845 and 886 .

125. Decline of water level in Portales Valley, N. Mex., 1932-39, by C. V. Theis. May 2, 1940. 2 pp., 1 map.

Gives summary of observation of ground-water level during 1932-39 and notes the area of decline or rise in the water table. Includes a map showing by contour lines the change in water levels. See also Water-Supply Papers 817, 845, 886.

126. Test drilling with hand tools as developed by the Soil Conservation Service, by S. L. Schoff. May 10, 1940. 2 pp.

Describes equipment and method of rapidly drilling wells in adluvial material to about 50 feet maximum depth. 
127. High-low float gage, by R. M. Leggette. May 10, 1940. $\varepsilon$ pp., 1 pl.

Describes a simple and inexpensive float gage "for indicating $r$ ighest and lowes. stages of water level reached in an observation well or at a stremm-gaging station during the interval between visits by an observer." Illustrated by diagrams and photograph.

128. Ground-water resources of the Pensacola area, Fla., by C E. Jacob, H. H. Cooper, Jr., and S. A. Stubbs. May 11, 1940. 2 pp.

Summarizes ground-water conditions in sand and gravel in Escambia County, gives data on amount of water pumped by the Pensacola waterworks, and comments on salt-water encroachment at Bayou Chico.

129. Artesian water in the coastal area of Georgia, by M. A. Warren. May 11, 1940. $1 \mathrm{p}$.

Announces preliminary results of a cooperative investigation begun in November 1938. About $115,000,000$ gallons of artesian water is withdrawn deily from wells in the six coastal counties of Georgia, of which about $40,000,000$ gal ons is withdrawn in Chatham County, in which Savannah is located, and about an equal amount in Glynn County, in which Brunswick is located. Most of the artesian water is derived from the Ocala limestone.

130. Water levels in wells rise from low stages in northern Virginia, by $V$. C. Fishel. May 15, 1940. 1 p.

A summary of recent changes noted in observation wells. See also Water-Supply Paper 906.

131. Ground-water levels in Pennsylvania make notable recorery from extreme low stages, by R. C. Baker. May 24, 1940. 1 p.

A summsry of recent changes in ground-water levels, as noted in observation wells. See also Water-Supply Paper 906.

132. Meade artesian basin, Meade County, Kans., by J. C. Fryє.. Aug. 3, 1940. 1 p.

A summary of a cooperative report recently prepared. The annual yield from the artesian water-bearing beds that can be maintained without decreasing the head is about 7,100 acre-feet. Under conditions of general pumping sufficient to lower the head enough to stop all surface flows and underground leakage an annual yield of 10,000 acre-feet could probably be obtained. See also Cooperative remorts 144,154 .

133. Bibliography of technical reports, articles, and memoranda published or otherwise released (by the Ground Water Division) during the fiscal year ended June 30, 1940, by O. E. Meinzer and Jane Daniel. Aug. 10, 1940. $11 \mathrm{pp}$.

Contains titles of 133 reports_and papers relating to ground wirter.

134. Artesian water in the coastal area of Georgia, by M. A. Warren. Aug. 16, 1940. $4 \mathrm{pp}$.

Describes the progress of cooperative studies in 11 counties, where records of 1.100 wells have been collected. Summarizes information on the water-bearing formations, artesian head, areas of flowing wells, and consumption.

135. Kah-ne-ta Spring and adjacent hot springs in Wasco County, Oreg., by A. M. Piper. Aug. 19, 1940. 1 p.

Describes a group of thermal springs in north-central Oregon ranging in temperature from $122^{\circ}$ to $182^{\circ}$ F. States that the discharge of Kah-ne-ta Spring is 380 gallons a minute and that of 5 other springs nearby is 1 to 30 gallons a minute each.

136. Water supplies from wells in the Indianapolis area, Ind., by C. L. McGuinness. Aug. 21, 1940. 3 pp.

Gives data on pumpage and a summary of observations of changes in water level.

137. Ground-water levels in Utah, September 1, 1940, by G. H. Taylor. - Sept. 21, 1940. 1 p.

A summary of recent changes in ground-water levels in Utah. See also Water Supply Paper 910. 
138. Ground-water levels in five wells in Utah, October 1,1940 , by G. H. Taylor. Oct. 19, 1940. 1 p.

Gives data on the change of water level in five observation wells. See also WaterSupply Paper 910.

139. Water-stage recorder, self-starting, by S. F. Turner, L. C. Halperny, and H. M. Babcock. Nov. 10, 1940. 4 pp., 2 pls.

Describes and illustrates an instrument developed and used on intermittert sıreams in Arizona. Description of a collapsible shelter for waler-stage recorders $I^{\prime}$ ' Turner accompanies the article ( $1 / 2 \mathrm{p} ., 1 \mathrm{pl}$.$) .$

140. Ground-water resources of the Big Sandy Valley, Mohave Count,', Ariz., by R. B. Morrison. Dec. 30, 1940. 2 pp.

A brief description of the geology and shallow well water in the valley alluvium. Suggests possibilities of artesian water in a small area. Comments on the contents of chloride, alkaline salts, and fluoride in some of the waters. See also Cioperative report 12 .

141. Artesian water conservation in North Dakota has beneficial effects, by L. K. Wenzel. Feb. 5, 1941. 2 pp.

A summary of artesian water development in the State from the Dakota sandstone.

142. Equipment for measuring depth to water, by Penn Livingston ard A. M.

Pipex. Feb. 10, 1941. 4 pp., 2 pls.

Describes and illustrates equipment using electric means of indicating the groundwater level. Includes a discussion and description by Piper of a float-actuated device for elosing the electric circuit.

143. Water resources of southeastern Florida, by W. P. Cross and athers. Mar. 29, 1941. 3 pp.

Cavernous limestone is the source of most private and public water s'pplies in Dade County. Fla. Contamination by salt water has taken place only near the sea coast and near the lower part of some canals. See also Cooperative report 62.

144. Ground-water resources of Stanton County, Kans., by B. F. Latt ${ }^{\prime . .}$ Apr. 7, 1941. 1 p.

A summary of the ground-water conditions in the county. See also Cooperative report 145 .

145. Ground-water levels in Utah in 1940 , by H. E. Thomas and W. K. Bach. Aptr. 8, 1941. 3 pp.

A summary of the changes in ground-water level in the principal vall эys of the State, based on observation of nearly 1,100 wells. See also Water-Supply Paper 910.

146. Ground-water levels in Arizona in 1939-40, by S. F. Turner. Apr. 28, 1941. 2 pp.

Summarizes water-level measurements in the Queen Creek area, the Santa Cruz River Valley, and Safford and Duncan Valleys. There was a general decline in the first area, fluctuation conforming to the irrigation-pumping season in the second, and a slight net rise in the third. See also Water-Supply Papers 886 and 911.

147. Ground-water levels in Kansas in 1940, by S. W. Lohman. Apr. 28, 1941. 1 p.

A summary of the changes in water level in 486 observation wells in the State. See also Water-Supply Paper 908.

148. Decline of ground-water levels in New Mexico, 1930-41, by C. V. Theis. May 5, 1941. 2 pp.

Gives summary of change in ground-water levels. See also Water-Supply Paper 911.

149. Decline of ground-water level in Portales Valley, N. Mex., 19£?-41, by C. V. Theis. May 5, 1941. 2 pp.

A summary of changes in ground-water levels in the valley. See also WaterSupply Paper 911.

150. Changes in water level in shallow wells in the Roswell artesian area, Chaves and Eddy Counties, N. Mex., by A. M. Morgan. May 13, 1941.

2 pp.

Summarizes the changes in water level that took place from January 1938 to January 1941. See also Water-Supply Paper 011. 
151. Salt-water problems and methods of investigation. May $1 \$ 41, \ldots, \ldots, \div$ Contains the 30 short papers listed below, which were presented at a conference of the geologists and engineers of the Ground Water Division of the Geological Survey, in Washington, on April 30, 1941.

Salt-water intrusion in the No. 1 sand near Parlin, N.'J., by J, C. Baker, 3 pp. General statement on salt-water problems in Maryland, by $H$. C. Barksdale, 3 pp. Ground-water investigations in the vicinity of Galveston, Tex., with special reference to salt-water intrusion, by B. A. Barnes, 7 pp., 4 figs.

Summary of ground-water conditions in New York with respect to salt-water encroachment, by M. L. Brashears, Jr., 3 pp.

General statement concerning salt-water encroachment in Mascachusetts, by M.

L. Brashears, Jr., 1 p.

The results of electric resistivity prospecting for salt-water contacts in the Hawaiian Islands, by A. C. Byers, 5 pp.

Salt water in the Coastal Plain of Alabama, by C. W. Carlstor. 3 pp.

Chlorides in the Virginia Coastal Plain, by D. J. Cederstrom, 4 pp., 1 fig.

The possibility of salt-water intrusion in northeast Florida, by H. H. Cooper,

Jr., 5 pp.

Salt-water intrusion in the vicinity of Pensacola, Fla., by H. H. Cooper, Jr., 4 pp. Summary of salt-water encroachment studies in southeast Florida, by W. P. Cross, 8 pp.

Summary on salt-water intrusion in New Haven, Conn., by J. G. Ferris, 2 pp. The salt-water problem in Coastal Plain of Mississippi; by V. A", Foster, 3 pp. Salt-water problems in the East Texas oil field, by P. P. Livingston, 3 pp., 1 fig. Salt-water problems in the Winter Garden area, Tex., by P. P. Livingston, 8 pp. Equipment for exploring wells, by P. P. Livingston, 5 pp., 1 fig.

Summary of salt-water intrusion in Kansas, by S. W. Lohman, $10 \mathrm{pp}$.

Salt-water problems in Louisiana, with special reference to th: Colfax area, by

J. G. Maher, 8 pp.

Ground-water conditions along the Pacific coast with respect to salt-water intrusion, by A. M. Piper, 3 pp.

Salt-water problems in Iowa and South Dakota, by T. W, Robi:7sou, 2 pp,

Occurrence of salt water in the Houston district, Tex., by N. A. Y 3 pp., 2 figs. Salt-water problems in the EI Paso, Tex., area by A. N. Sayre, 3 pp.:

Conditions affecting salt-water intrusion in the Atlantic City region, N. J., by E. J. Schaefer, 3 pp.

Salt-water intrusion in Oklahoma, by S. L. Schoff, $5 \mathrm{pp}$.

Salt-water invasion in Hawaii, by H. T. Stearns, 8 pp.

General survey of problems of salt-water contamination of grornd water in the Coastal Plain of the southeastern States, by V. T. Stringfield, 2 pp.

Saline ground-water conditions in Utah, by H. E. Thomas, 4 p.

Salt-water problems in Arizona, by S. F. Turner, 1 p.

Artesian water in the coastal area of Georgia, with special reference to the possibility of salt-water encroachment in the Savannah area, br M. A. Warreri. 8 pp.

Notes on salt-water problems, by L. K. Wenzel, 3 pp.

152. Water levels in wells are at low stages in northern Virginia and vicinity of Washington, D. C., by V. C. Fishel. June 18, 1941. 1 p.

A summary of records on two observation wells in the area. See also Water-Supply Paper 987.

153. Bibliography on electrical well logging, by N. A. Rose. Jrne 1941. 2 pp. A list of 24 papers containing data on the electrical logging of wells, published during 1934-40.

154. Geology and ground-water resources of Morton County, Fans., by T. G. MeLaughlin. July 30, 1941. 1 p.

A summary of ground-water conditions in the county and notice of release of the report. See also Cooperative report 149.

155. Design and use of maximum-minimum water-level gage, by S. F. Turner, with comments by H. R. McDonald, E. M. Cushing, and D. H. Brattón. Aug. 10, 1941. 4 pp., 3 pls.

Describes the use of metal strips coated with slaked lime, whit'ng;" or other material to show the water mark in wells. Ineludes three form sheets showing method of recording observations. 
156. Ground water in the Cincinnati area reaches the lowest levels in three years, by F. H. Klaer, Jr. Sept. 2, 1941. 3 pp.

A summary of the changes in ground-water levels near Cincinnati, Ohio, during 1938-40. See also Water-Supply Papers 845, 886, and 906.

157. Geophysical studies in the Hanawi area, Nahiku, Island of Mawi, Territory of Hawaii, by J. H. Swartz and others. Sept. 10, 1941. 1 p.

Summarizes the results of electric resistivity surveys to trace inland a spring that yields 10 million gallons of water a day from lava.

158. Geophysical studies on the island of Molokai, Territory of Hawaii, by G. R. MacCarthy. Oct. 3, 1941. 1 p., 1 map.

Summarizes the results of electric resistivity measurements to determine the thickness of the basal fresh-water lens overlying salt water. From data obtained, the altitude of the basal fresh-water table was computed to range from 1.3 to 13.8 feet above sea level. Includes a map showing by contour lines the altitude of the basal fresh-water table in the west half of the island.

159. Completion of test well for irrigation near Deming, N. Mex., by C. R. Murray. Oct. 11, 1941. 1 p.

Gives data on a test well driven 1,000 feet deep to determine whether there are additional water-bearing formations below those drawn upon by present irrigation wells. Additional water-bearing strata were found between 300 and 450 feet, but at greater depths clay was encountered underlain by igneous rock. Wells tapping the lower beds will have less drawdown than the present wel $\kappa^{\prime}$, but the conditions found do n8t indicate that any greater quantity of ground water will be available than has previously been estimated.

160. Water resources of Safford and Duncan-Virden Valleys, Arizona and New Mexico, by S. F. Turner, R. B. Morrison, and others. Oct. 13, 1941 2 pp.

Summary of an investigation in progress since October 1, 1939, on the source, amount, and disposal of all water entering each valley. The river-bottom growth in Safford Valley used about 70,000 acre-feet of water dnring the water year October 1, 1939 to September 30, 1940. The consumption by crops was about 100,010 acre-feet. during the same period. The principal sources of ground-water supply are canal seepage, irrigation seepage, infiltration from the Gila River, underflow from tributary washes, artesian leakage, and rainfall.

161. Bibliography of technical reports, articles, and memoranda published or otherwise released (by the Ground Water Division) during the fiscal year ended June 30, 1941, by O. E. Meinzer and Jane Daniel. Nov. 10, 1941. $14 \mathrm{pp}$.

Contains titles of 169 reports and papers relating to ground water.

162. Ground-water resources of Box Butte County; Nebr., by R. C. Cady and O. J. Scherer. Jan. 6, 1942. 1 p.

Most of the ground water pumped comes from formations of Miocene ard Pliocene age. Although these formations consist of fine-grained sand and sandstone, they yield large quantities of water to wells. Their productiveness is due to the great thickness of the saturated beds and to the fact that their sands are well assorted and contain very little silt and clay. See also Water-Supply Paper 969.

163. Ground-water resources of Scotts Bluff County, Nebr., by L. K. Wenzel, 'R. C. Cady, and H. A. Waite. Jan. 6, 1942. 1 p.

The estimated annual discharge of ground water by wells is about 8,000 acre-feet: the loss due to evaporation and to transpiration by plants in the lowlands is about 100,000 acre-feet; and about 325,000 acre-feet of ground water percolates to streams that carry it out of the county. See also Water-Supply Paper 943.

164. Ground-water levels rise in North Dakota, by W. C. Rasmussen. Jan. 29, 1942. $1 \mathrm{p}$.

A summary of changes in the water level in 22 observation wells from September 1937 to November 1941. See alsọ Water-Supply Papers 845, 886, 908, 938. 
165. Artificial recharge of ground water, by D. G. Thompson. Feb. 10, 1942. 8 pp.

Briefly discusses recharge by water spreading and by means of wells. Gives examples of each method and references to several articles on the subject, with extracts from U. S. Dept. Agr. Tech. Bull. 578 and data on the water-supply system of Des Moines, Iowa.

166. Ground-water levels in Kansas during the period October to December 1941, by S. W. Lohman. Feb. 11, 1942. 1 p.

A summary of changes in water level in observation wells during the period. See also Water-Supply Paper 938.

167. Ground-water levels in Utah in 1941, by H. E. Thomas. Feb. 25, 1942. 2 pp.

A summary of changes in ground-water level in 18 principal areas of groundwater development in the State. See also Water-Supply Paper 910.

168. Ground-water table in Oklahoma rises to high levels, by S. L. Schoff. Mar. 3, 1942. 2 pp.

A summary of the changes of water level in observation well d during 1941. Includes graph showing average water level 1938-41 and cumulative departure from normal precipitation. See also Water-Supply Paper 939.

169. Ground-water conditions in the Territory of Hawaii in 1941, by H. $T$. Stearns. Apr. 21, 1942. 2 pp.

A summary of the changes in water levels in observation wellir. See also WaterSupply Paper 941.

170. Ogden Valley artesian reservoir, by H. E. Thomas. Apr. 27, 1942. 1 p. An additional supply of water is believed to be available from the Ogden Valley artesian reservoir by means of wells. See also Cooperative report 424.

171. Ground-water conditions in Arizona in 1941, by S. F. Turner. May 28, 1942. 2 pp.

A summary of pumpage and average ground-water levels ir several parts of Santa Cruz Basin, and in Safford and Duncan-Virden Valleys in the Gila River Basin. See also Water-Supply Paper 941.

172. Bibliography of technical reports, articles, and memoranda published or otherwise released (by the Ground Water Division) d'ring the fiscal year ended June 30, 1942, by O. E. Meinzer and Jane Daniel. Nov. 10, 1942. 9 pp.

Contains titles of 111 reports and papers relating to ground water.

173. Ground-water investigations in Oklahoma Panhandle cortinued in 1939, by S. L. Schoff. Dec. 15, 1939. 3 pp. (Released by the Oklahoma Geological Sprvey.)

Gives purpose and methods of investigation of ground water in the Panhandle, including well inventory, observation-well program, water analyses, permeability tests of water-bearing materials, and plans for future work.

174. Ground-water levels in Oklahoma rise slightly in 1940, i y S. L. Schoff. March 1941. 2 pp. (Released by the Oklahoma Geological Survey.)

Summarizes the annual trend in water levels in observation wells.

175. Geological Survey investigates ground water in North $\mathrm{C}^{-n}$ nadian Valley, by S. L. Schoff. August 1941. 1 p. (Released by. the Oklahoma Geological Survey.)

Outlines work to be done in North Canadian Valley, Okla., including well inventory, observation-well program, test drilling, and pumping tests to determine extent and quality of the water resources.

176. Water in wells in New Mexico rose to unprecedented high levels during 1941, by C. V. Theis. June 6, 1942. 2 pp. State.

Gives a summary of the change in ground-water levels in several parts of the 
177. Water goes to war, abstract, by R. R. Bennett. Aug. 10, 1942. 1 p.

An abstract of an article by Dewey Jchnson in Cast Iron News [Chicago, III.]. April 1942. Gives data on the amount of water used in producing we $r$ equipment. States that 100 galTons are required to produce one pound of powder and 66 gallons for every pound of steel. Also gives the amounts used in some other onerations and at army camps.

178. Geology and ground-water resources of Beaver County, Okla,, by S. L. Schoff. Oct. 3, 1942. 4 pp., 1 map. (Released by the Oklahoma Geological Survey.).

Announces release of tables of well records for Beaver County, O'la., pending final report on the ground-water resources of the county, and gives shomt description of the water-bearing formations, present water supplies, and prospects for future supplies.

179. Ground-water resources of Cedar City and Parowan Valleys, Utah, by H. E. Thomas and G. H. Taylor. Nov. 7, 1942. 3 pp.

Summarizes data on the water levels and amounts of water pumped for irrigation. See also Water-Supply Paper 993.

180. Test-well drilling in the Florida Everglades, by R. H. Brown. Nov. 10, 1942. 4 pp., 4 photographs, map.

Describes the method of drilling 8 small test wells with hand-operated equipment.

181. Ground-water conditions in the United States, monthly reports on, by

L. K. Wenzel. Feb. 10, 1943. 2 pp.

Summarizes early results obtained from monthly records on 130 obs:rvation wells in 40 States.

182. Predictions of drawdowns in a well field, compared with acturl measurements, by R. G. Kazmann. Feb. 10, 1943. 2 pp.

Following a test on the operation of a well field, correlations were made of the level of a nearby river, ground-water levels, temperatures, pumping rates of the wells, and well interferences. Graphs are presented showing the ralationship of pumping rate, ground-water temperature and drawdown, and the variation of interference effects with ground-water temperature.

183. Ground-water resources of Salt Lake City, Utah, by H. E. Thomas. Feb. 12, 1943. 2 pp.

Summarizes the developed and avaikable supplies of ground water in Jordan Valley, near the city, and gives data on yield of some of the flowing wells.

184. Ground-water levels remain high in most areas of Oklahoma, by $\mathbf{E}$. W. Reed. Mar. 9, 1943. 2 pp. (Released by Oklahoma Geological Survey.)

Says that water levels were the highest on record in several parts of the State but declined in the Norman area, owing to heavy pumpage.

185. Water resources of the Santa Cruz Basin, Ariz., by S. F. Turner. May 14, 1943. 2 pp.

Deseribes source of the ground-water supplies and gives the safe annual yields for several subdivisions of the basin. Calls special attention to the recharge from flood flows. See also Cooperative report 15.

186. Geology and water resources of Tooele Valley, Tooele County, Utah, by H. E. Thomas. May 28, 1943. 2 pp.

States that more than 1,000 wells obtain artesian water chiefly from a zone of sand and gravel 60 to 125 feet thick encountered at depths of 90 to 300 feet. Says that the annual discharge from springs is about 20,000 acre-feet, and that about 6,000 acre-feet is withdrawn from wells.

187. Bibliography of technical reports, articles, and memoranda riblished or otherwise released (by the Ground Water Division) durirg the fiscal year ended June 30, 1943, by J. M. Berdan and Jane DE niel. Aug. 10, $1943.9 \mathrm{pp}$.

Contains titles of 118 reports and papers relating to ground water. 
188. An inexpensive monthly recorder, redesign of Lietz 8-day water-stage recorder for monthly operation, by J. G. Ferris. Nov. 10, 1943. 4 pp., 4 figs.

Describes the instrument and gives two diagrams showing gear trains and two graphs showing character of record produced.

189. Results of detailed field work on the geology and ground-water resources of Cimarron County, Okla., by E. W. Reed and S. L. Schof. January 1944. 4 pp. (Released by the Oklahoma Geological Survey.)

Gives a summary of the field work done and conclusions as to ground-water conditions.

190. Water levels in tidewater Virginia in 1943, by Arthur Bevan. Feb. 9, 1944. 2 pp.

Gives a summary of data obtained from observation wells during 1943 showing declines due to abnormally low rainfall.

191. Ground-water exploration •at Alexandria, La., by J. C. Maher. Feb. 10, 1944. 7 pp.

Summarizes previous work and describes the present exploratory program, using data on test drilling, sampling, drillers' logs, and electric logs. Concl ides that it is advisable to do test drilling separately from water-supply development, so as to allow preparation of exact specifications for the latter.

192. Report of ground-water pumpage on Long Island, N. Y., by M. L. Brashears, Jr. Feb. 24, 1944. 2 pp.

States that the pumping of ground water for public supplies in the three western counties of Long Island averaged 168 million gallons a day in 1942, which was about 11 percent more than in 1941, and that in Suffolk County, which comprises the eastern part of the island, the net pumpage for public water suppl'as, irrigation, and industrial uses was 35 million gallons a day.

193. Well records for the Aberjona Valley area, Mass., by M. L. Brashears, Jr. Mar. 26, $1944.1 \mathrm{p}$.

- States that some of the wells yield as much as 1,800 gallons a minute and that the average ground-water withdrawal in the area is about six million gallons a day, about two-thirds of which is used for industrial purposes and the remainder for public water supply.

194. Water levels, determination under, adverse conditions, by R. M. Jeffords. May 10, 1944. 2 pp.

Describes an indicator paste for use on measuring tapes. The material changes color when wet, adheres firmly to tapes, and is not affected by oll. Three brands of the material are listed.

195. Measurement of discharge from wells with vertical pipes by the coordinate method, by H. R. McDonald and G. B. Maxey. Aug. 10, 1944. 5 pp., 2 tables, 1 graphic chart.

Describes experiments in which inserts of standard sizes of pipe into rough and jagged casing were used. Presents discharge curves showing gallons a minute for various sizes of pipe, plotted against height of jet.

196. Ground-water conditions and pumpage in Arizona in 1943, by S. F. Turner. Sept. 6, 1944. 2 pp.

States that an average of $\mathbf{7 4 5}$ million gallons a day was pumped from wells in 1943, chiefly for irrigation, in the basin of Gila River above its confluence with Salt River, including the Santa Cruz River Basin. Gives table showing the pumpage from five areas in southern Arizona in 1940-43.

198. Bibliography of technical reports, articles, and memoranda published or otherwise released (by the Ground Water Division) during the fiscal year ended June 30, 1944, by J. M. Berdan and Jane Daniel. Nov. 10, 1944. $8 \mathrm{pp}$.

Contains titles of 100 reports and papers relating to ground water. 
199. Report of ground-water pumpage on Long Island, N. Y., by Mr. L. Brashears, Jr. Jan. 6, 1945. 2 pp.

States that the pumpage of ground water for public supplies in the three western counties of Long Island averaged 117 million gallons a day in 1943, which was 30 percent less than in 1942, the decrease being due chieflyito decrease in the average rate of pumping by New York City from its Long Island ground-water sources. States also that in Suffolk County, which constitutes the eastern portion of the island, the net pumpage for public water supplies, irrigation, and industrial purposes, was estimated at 40 million gallons a day.

200. Forms for pumpage inventory, electrically operated pumps, using trajectory method for measuring discharges, by J. F. Hostetter. Feb. 10, 1945. 3 pp., 3 tables.

Describes the trajectory method of measuring a stream of water that falls freely from the discharge pipe of a pump, where the pipe is either horizonta' or inclined to the horizontal. States that the method is more rapid than measurement by weir or current meter and requires only a carpenter's square and level.

201. Partial penetration of pumping well, adjustments for, by C. E. Jacob. Aug. 10, 1945. 7 pp., 4 graphic figs.

Gives mathematical discussion of discharge from a well that penetrates only a part of the thickness of a water-producing bed.

202. Report of ground-water pumpage on Long Island, N. Y., by Iđ. L. Brashears, Jr. . Aug. 21, 1945. 2 pp.

States that the pumpage of water for public supplies in the three western counties of Long 'Island averaged 153 million gallons a day in 1944, which was about 30 percent greater than in 1943, and that in Suffolk County, which constitutes the eastern portion of the island, the net pumpage for public water supplies. irrigation, and industrial purposes was estimated at 45 million gallons a day.

203. Pumpage from wells in southern Arizona in 1944 greatly exieeds safe yield, by S. F. Turner. Sept. $27,1945.3 \mathrm{pp}$.

States that the pumpage in 1944 from wells in the Santa Cruz and Gila River Basins in Santa Cruz, Pima, and Pinal Counties exceeded the estimated safe annual yieid by more than 400,000 acre-feet, about 873,800 acre-feet being pumped, chiefly for irrigation. Gives pumpage from flve areas in southern Arizona for 1*40-44.

204. Pumpage from wells, and water levels in the Memphis area, Tenn., during August 1945, by R. G. Kazmann. Oct. 23, 1945. 2 pp.

States that the water levels rose somewhat, owing to decrease in water consumption in Memphis and vicinity, and that the pumpage in August 1945 from the 500-foot sand was about 93 million gallons a day.

205. Recovery method of determining permeability, empirical adjus'ment for, by C. E. Jacob. Nov. 10, 1945. 5 pp., 3 figs.

The recovery method developed by Theis is applicable for determining permeability or transmissibility when the storage coefficient (S) remains constant. Fiailure of the data to plot on a straight line through the origin is shown to be due to variation in $\mathbf{S}$.

206. Coefficient of storage of a water-bearing formation, by R. G. Kazmann. Nov. 10, 1945. $4 \mathrm{pp}$.

A general discussion of the difficulties involved in laboratory methods of determination and in pumping-test determinations.

207. Ground-water observation wells, criteria for determining theis optimum locations, by J. G. Ferris. Nov. 10, 1945. 4 pp.

States that the selection of the optimum well site requires knowledge not only of geology and hydrology but also of other allied sciences.

209. Bibliography of technical reports, articles, and memoranda published or otherwise released (by the Ground Water Division) during the fiscal year ended June 30, 1945, by J. M. Berdan and Jane Daniel: Feb. 10, 1946. 15 pp.

Contains titles of 85 published reports and papers relating to groun 1 water and 105 titles of papers otherwise released 


\section{JOURNAL ARTICLES}

The following abbreviations are used for the publications most frequently cited:

A. A. P. G. Bull., Bulletin of the American Association of Petroleum Geologists, Tulsa, Okla.

A. G. U. Trans., Transactions of the American Geophysical Union, Washington, D. C.

A. W. W. Assoc. Jour. (or Proc.), Journal (or Proceedings) of the American

Water Works Association, New York, N. Y.

Civil Eng., Civil Engineering, New York, N. Y.

Econ. Geol., Economic Geology, Lancaster, Pa.

Eng. News-Record, Engineering Netws-Record, New York, N. Y.

G. S. A. Bull., Bulletin of the Geological Society of America, New York, N. Y. Jour. Geol., Journal of Geology, Chicago, Ill.

Wash. Acad. Sci. Jour., Journal of the Washington Academy of Science, Washington, D. C.

Water Works Eng., Water Works Engineering, New York, N. Y.

1. Artesian well prospects in eastern Virginia, Maryland,.and Delaware, by

N. H. Darton. Inst. Min. Eng. Trans., vol. 24, New York, 1894. pp. 372-397.

Describes the geology of the middle Atlantic Coastal Plain and the artesian water conditions, with records of 5 wells in Virginia and 4 in Maryland. Gives conclusions as to presence of artesian water in various parts of the area.

2. Geothermal data from deep artesian wells in the Dakotas, by N. H. Darton. Am. Jour. Sci., 4th ser., vol. 5, No. 27, New Haven, Conn., March 1898. pp. 161-168.

Gives data on temperature of the water from 46 wells, a map showing rate of increase of temperature with depth, and a contour map of the bed ock aurface.

3. Some peculiar artesian conditions on Long Island, N. Y., by A. C. Veatch. Science, new ser., vol. 19, No. 490, Lancaster, Pa., May 20, 1904. pp. 795-796.

The deep zone of flow and the surface zone are essentially continuous. The head depends not on dip of the strata but on the curved nature of the ground-water table. The dip of the strata is therefore immaterial, and flows in many cases are produced against'or up the dip. The slope of the ground-water table is so precipitous at the heads of many of the deep reentrant bays on the north shore th at a slight difference in permeability is sufficient to determine an artesian horizon.

4. Artesian water in crystalline rocks, by G. O. Smith. Science, new ser., vol. 21, No. 528, Lancaster, Pa., Feb. 10, 1905. pp. 224-225.

Describes the conditions under which artesian water is present in an area of crystalline rocks in the vicinity of York, Maine. In three cases cited the water overflows at the surface. These data are also given in Water-Supply Paper 145. pp 120-128.

5. Hydrologic work of the United States Geological Survey ir the eastern United States, by M. L. Fuller. Internat. Geol. Cong., vol. 8, Washington, D. C., 1905 . pp. 509-514.

Discusses the work of the Division of Hydrology in its general scope (bibliographic, statistical, technical, legal, scientific, and economic) and the work related to geography (form of water table and movement of ground-water body, catchment areas, geologic structure, depth of water, artesian head, artesian areas, and cartographir representation).

6. The hot springs at Thermopolis, Wyo., by N. H. Darton. Jour. Geol., vol. 14, No. 3, Apr.-May 1906. pp. 194-200.

Several large hot springs issue from the "red beds" of the Chugwater formation on the crest of a small anticline. The total discharge is more thar 1,000 gallons a 
6. The hot springis at Thermopolis, Wyo:-Ciontinued.

minute and the maximum temperature $135^{\circ} \mathrm{F}$. The analysis given shown total dis:solved solids of 129.82 grains per gallon. Describes the extensive hot-spring deposits and discusses the source of the water. The heat may be due to the depth from which the water rises, or it may be due to deep-seated igneous rocks in the vicinity, which have not yet cooled.

7. Underground water investigations in the United States, by M. I. Fuller. Econ. Geol, vol. 1, No. 6, June 1906. pp. 554-569.

Summarizes the development of hydrologic investigations and the charanter of hydrologic problems. Discusses special investigations requiring the collectinn of well samples and measurements of underflow. Describes the principles of ocrurrence of ground water and mentions methods of sinking wells and drainage and pollution problems. States the problems for future investigation, including source, depth of penetration, saturation, circulation, mineralization, and rate of underflor.

8. Symposium on water supplies in Michigan, by Frank Leverett, V. C. Vaughan, G. S. Williams, M. O. Leighton, and I. C. Russell. Michigan Acad.. Sci., 8th Ann. Rept., Lansing, Mich., 1906. pp. 99-136,

Consists of five short papers, three of which deal with ground water as follows: Geological conditions of municipal and institutional water supplies in Michigan, by Leverett, which contains data on wells; Michigan water supplies, by Vaughan, which discusses bacteriological quality of surface water and ground-watex supplies; and Ideals concerning municipal water supplies, by Russell, which-discus res shallow and deep wells.

9. A phase of ground-water problems in the West, by W. C. Mendenhall. Econ. Geol., vol. 4, No. 1, Jan.-Feb. 1909. pp. 35-45.

A summary of ground-water conditions in the coastal plain of southern California. Contains map of the artesian basins in the valley of southern California.

10. Conservation of our artesian water supply, by F. G. Clapp. Eng. News, vol. 62, No. 3, New York, July 15, 1909. pp. 68-71.

Discusses the amount, uses, and decline of ground water, the causes of decline, the waste of artesian water, remedies for decline, and the ground-water legislation of several States.

11. The interference of wells, by F. G. Clapp. Eng. News, vol. 62, No. 19, Nov. 4, 1909. pp. 483-485.

Describes the mode of occurrence of ground water and the interferense of wells in sand and gravel, limestone, slate, and crystalline rocks, and discusses the pollution of water-bearing strata by oil-well waste and sewage.

12. Underground water in crystalline rocks, by F. G. Clapp. Eng. News, vol. 60 , No. 19 , Nov. 6,1909 . pp. 525-527.

Gives a summary of investigations chiefly in Maine, New Hampshire, Massachusetts, and Maryland, the results of which were published in Water-Supply Paper 223, "Underground waters of southern Maine." Describes the character of crystalline rocks and the mode of occurrence of water in them in joint cracks or fisxures. Diecusses uncertainty of and the proportion of successful wells and mentions the limiting depth of abundant water and the composition of water in crystalline rocks.

13. Geologic basis for artesian prediction, by N. H. Darton. A. W. WN. Assoc. Proc. 28th Ann. Conv. (1908), 1909. pp. 280-291.

A general discussion of the requisite conditions for artesian water, with diagrams showing synclinal structure and hydrostatic grade.

14. Artesian waters of the Atlantic Coastal Plain, by M. L. Fuller. A. W. W. Assoc. Proc. 28th Ann. Conv. (1908), 1909. pp. 294-322.

Discusses the subject under the following heads: Geologic developn'ont of the Coastal Plain; Artesian waters; Principal geologic and artesian water groups of the Atlantic Coastal Plain; Quality of artesian waters; and Utilization of Coestal Plain supplies.

15. Chlorides in oil-field waters, by C. W. Washburne. Am. Inst. 1 $1_{\text {in. Eng. }}$ Trans., vol. 48, New York, 1914. pp. 687-693.

The volcanic theory is advanced to explain the excess of chloride in some deep subsurface water. 
16. The interpretation of, water analyses by the geologist, by G. S. Rogers. Econ. Geol., vol. 12, No. 1, January 1917. pp. 56-88.

Palmer's method of stating and interpreting water analyses is shown to be based on the principle that natural waters are balanced chemieal systems having definite properties. These properties are shown to summarize composition, to furnish a convenient basis for preliminary comparison and study, and to afford a measure of the potency of the water as a geologic agent. Contains anslyser of various types of natural water.

17. The evaporation of water at depth by natural gases, by $F$. van A. Mills and R. C. Wells. Abstr. in Washington Acad. Sci. Jonr., vol. 7, No. 10, May 19, 1917. pp. 309-310.

Water associated with petroleum-and natural gas is subject to concentration of the dissolved constituents incident to the extraction of the hyd-rcarbons through wells. This concentration is brought about by evaporation of the water in the - expanding gas incident to its withdrawal. Also, during geoloric time, connate water has been evaporated by escaping gases, thus contributing toward the formation of highly concentrated oil-field and gas-field brines. See also Bulletin 693.

18. The absence of water in certain sandstones of the Appalachian oil fields, by Frank Reeves. Econ. Geol., vol. 12, No. 4, June 1917. pp. 354-378.

Presents evidence that indicates that the sandstones were dried out soon after deposition. The facts do not show that there is a disappearance of water with depth. The brines of deep-seated sedimentary strata are thought to be connate.

19. Origin of the natural brines of oil fields, by Frank Reeves. Johns Hopkins Univ. Circ., vol. 36, No. 293, Baltimore, Md., 1917. pp. 57-68.

Submits evidence based on a study of brines in southwest Penn vvlvania and West Virginia to show their probable connate origin. Their presence prevented lateral and vertical entrance of other-water, and their chemical analys's not only shows greater similarity to ocean water than to surface water, but also the distribution of chemical constituents is more accurately explained by connate origin.

20. Some instances of flowing wells on anticlines, by F. G. C'op. Science, new ser., vol. 32, No. 814, Aug. 5, 1910, pp. 189-190; ab *tr. in G. S. A. Bull., vol. 21, No. 12, Dec. 31, 1910 . p. 770.

Describes fiows from several unproductive oil wells on two anticlines in the northern Appalachian region. In Pleasants County, W. Va., the flowing wells are on a saddle of an anticlinal crest, the pressure being transmitted f*om water-bearing formations in the domes. On a fiank of the Frederickstown anticline in Beaver County, Pa., the water comes from depths of less than 100 feet, and the head is due to pressure transmitted from more superficial formations in nearby hills.

21. Classification of springs, by Kirk Bryan. Jour. Geol., vol. 27, No. 7, Oct.Nov. 1919. pp. 522-561.

Gives characteristics of springs and spring water. Proposes a elassification based on deep-seated and shallow sources and issuance from porous o- from impervious rocks. Gives sketch maps and diagrams showing the several typer of springs.

22. The springs of Snake River Canyon, by Lynn Crandall. Idaho Irr. Eng. and Agr. Soc. Joint Conf. Proc. (1918-19), Boise, Idaho, 1919. pp. 146-150.

Numerous springs along Snake River Canyon between Milner and King Fill discharge more than 5,000 second-feet of water. The springs issue 80 to 150 feet above the river. Gives discharge measurements on the springs in 1902 and 1917-18. "The flow is usually minimum during March and April and maximum during September and October." Discusses probable source of the wate" and its potential use for irrigation.

23. Some oil-field waters of the Gulf Coast, by G. S. Rogers: A. A. P. G. Bull., vol. 3, 1919. pp. 310-331.

Differences in character and concentration of waters occurring in various horizons with regard to salt domes are believed to be sufficiently mark ad and regular to permit the use of analyses in estimating the position of a water and probably also in locating deeply buried salt domes. 
24. Quantitative methods of estimating ground-water supplies, by O. E- Meinzer. G. S. A. Bull., vol. 31, No. 2, June 1920. pp. 329-338.

Discusses the estimation of safe yield of ground water by intake methods, discharge methods, water-table methods, and underflow methods.

25. Geysers of Yellowstone National Park, by N. H. Darton. Geolıgische Charakterbilder, Heft 23 (quarto), Berlin, 1920. 8 pp., 6 pls.

"It has been estimated that there are more than 4,000 hot springs in the park, not counting many steaming fissures, and about 100 geysers. It is dificult to make distinction between a hot spring and a geyser, for many of the springs boil for long periods and erupt occasionally or even only once. . . It has been suggested that radioactivity might cause some of the hydrothermal action in the Yellowstone Park, but special investigations have shown that the emanations were too weak to be a material factor." Describes Hells Half Acre, Castle Geyser, Excelsior Geyser, Lone Star Geyser, Old Faithful Geyser, and Foundatior Geyser.

26. Hidrologia subterranea, by 0 . E. Meinzer. Ingenieria Internacional, New York, t. 5, No. 4, April 1921. pp. 195-202; Bol. Minero (Dept. Mines, Mexico), t. 11, No. 6, June 1921. pp. 837-849.

A general article, in Spanish, treating of the subject under the following headings: Fundamental principles; Forces which control water in rocks; Properties of the rocks with respect to water; Capacity to retain and to give up water; Zones of the rocks (saturation, aeration, and discharge); Hydraulic properties of sone rocks: Influence of structure of the rocks; Absorption of water; Springs of the zone of saturation; Artesian wells; and Quantities of water.

27. Ground-water problems in the Hawaiian Islands, by O. E. Meinzer. Abstr. in Washington Acad. Sci. Jour., vol. 11, No. 17, October 19, 1921. pp. 424-425.

The rocks consist chiefly of very permeable lavas. This permeability rasults in heavy absorption of rain, flatness of the water table, scarcity of springs and streams, large yields of aquifers, and large yields and specific capacities of we'ls. The ground water can be divided into two kinds: high-level water, and low-levil water. Describes the occurrence of the two kinds.

28. The hot water supply of the Hot Springs, Arkansas, by Kirk Bryan. Jour. Geol., vol. 30, No. 6, Aug.-Sept. 1922. pp. 425-449.

Describes the character of the water and the geology of the area. Cites evidence indicating meteoric origin of the water and other evidence indicating juveni e origin. Concludes that both hypotheses rest on insecure foundations.

29. Map of the Pleistocene lakes of the Basin and Range province and its significance, by O. E. Meinzer. G. S. A. Bull., vol. 33, No. 9, Sept.'1, 1922. pp. 541-552.

Discusses the physiography of the region and the areas of ground-water cischarge. Contains maps of the present and Pleistocene lakes in the Basin and Range province. Discusses extent to which ancient lakes would be restored by lowered temperatures.

30. Relation of sea water to ground water along coasts, by J. S. Brown. Am. Jour. Sci., 5th ser., vol. 4, No. 22, New Haven, Conn., October 1922. pp. 274-294.

Describes contamination of wells near the Connecticut coast by sea water, and the relation of topography and geology to the wells. Explains the law of eruilibrum of salt and fresh water, as developed by Ghyben and later by Herzberg. Discusses the effects of pumping, the season, and the tides, on the saline contamination.

31. Graphic representation of water analyses, by W. D. Collins. Ind. and Eng. Chemistry, vol. 15, No. 4, Easton, Pa., Apr. 1, 1923. pp. 394.

Describes and illustrates the graphic method employed in the United Strtes Geological Survey, using patterns or colors to show the six prineipal dissolvod solids, calcium, magnesium, sodium, chloride, sulfate, and bicarbonate, with prorision for showing also silica and suspended matter.

32. Source of ground-water supply for Atlantic City, by D. G. Thempson. Official Pub. Atlantic City, N. J., Chamber of Commerce, April 1924. pp. 6-9.

A summary of ground-water studies which have been carried on since July 1923, with data on the water supplies. 
33. A course of lectures on ground water, by 0 . E. Meinzer. JTowell Drillers' News, vol. 3, Nos. 4-11, Minneapolis, Minn., Apr.-Nov. 1924.

These lectures were delivered before the Minnesota Well Drillers Association February 6-8, 1924. They were published in eight issues of the journal under the following headings: How water occurs in the rocks (Apr. 1924, pp. 1, 3, 5, 8) ; Kind of rocks and their value for yielding water to wells (May 19?4, pp. 1, 3, 8, 11, 12); Structure of the rocks and its meaning to drillers (June 1924, pp. 1, 2, 6) ; Rock formations-Geological history of Minnesota (July 1924, pp. 1, 3, 9); The origin and circulation of the ground water (Aug. 1924, pp. 1, 3, 8, 9); The water table and the pollution of water wells (Sept. 1924, pp. 1, 7, 11); The quantity and conservation of ground water (Oct. 1924, pp. 1, 7); and Estimating the quantity of ground-water supplies (Nov. 1924, pp. 1, 6, 7).

34. Origin of the thermal springs of Nevada, Utah, and southern Idaho, by 0 . E. Meinzer. Jour. Geol., vol. 32, No. 4, May-June 1924. pp. 295-303.

Summarizes the occurrence of thermal springs with relation to volcanic rocks, artesian structure, and faults, with conclusions as to source of tharmal water. Contains map of southeastern Idaho showing relation of thermal springs and large cold springs to the Snake River basalt plain; also map of no"thwestern Nevada showing relation of springs, mainly thermal, to pre-Quaternary faults (after WaterSupply Paper 489, fig. 69).

35. Craters of the Moon National Monument, by H. T. Stearr . Geog. Rev., vol. 14, No. 3, New York, July 1924. pp. 362-372.

A short popular description of the area, with mention of the unusual sources of water-ice wells, springs, and lava tunnels.

36. The hot springs of the Republic of Haiti, by J. S. Brown. Jour. Geol., vol. 32, No. 5, July-Aug. 1924. pp. 384-399.

Describes four groups of warm springs-those of Terre-Neuve or Eaux Boynes, of Los Pozos, and of the southern peninsula and the sulfur springs or "sources puantes." Gives analysis of water from each group and discusses the source of the water. Also published in Cooperative report 72.

37. The hot springs of Arkansas, by Kirk Bryan. Jour. Geol.. vol. 32, No. 6, Aug.-Sept. 1924. pp. 449-459.

Describes the springs at Hot Springs, Ark., with data on the'r temperature and flow. "The spring openings at Hot Springs are numerous, but all are found within an area of about 20 acres. The total flow has been estimated at 165 gallons a minute and the temperature range from $35^{\circ}$ to $64^{\circ} \mathrm{C}$. Analysir of the somewhat random measurements made in the past 120 years gives no tristworthy evidence of a permanent increase or decrease in fiow or temperature."

38. California oil-field waters, by Chase Palmer. Econ. Geol., vol. 19, No. 7. November 1924. pp. 623-635.

"The oil fields on the west side of San Joaquin Valley yield three types of water: 1. Saline waters containing sulphates as their principal salts; 2 , saline waters containing large amounts of chlorides; 3, alkaline carbonate waters having notable amounts of alkall carbonates." Describes the types and gives eramples. Discusses the hypothesis of $\mathrm{H}$. Von Hoefer as to change of sulfate water into carbonate water mixed with sulfide water. Treats of the origin of oil-field sulfur waters and alkaline carbonate waters. The alkaline sulfide waters are alkaline carbonate waters altered by absorption of a volatile sulfur compound emanating from the oil. The geochemical relation of alkaline water to granite rock minerals applies to the alkaline carbonate waters in the California oil fields.

39. Some geochemical relations of ground water and associated natural gas in the Lance formation, Montana, by B. C. Renick. Jour. Geol., vol. 32, No. 8, Nov.-Dec. 1924 . pp. 668-684.

Describes the geology of the artesian basin along the valley of Yellowstone River below Forsyth. Gives analyses of artesian water from 10 gag-bearing wells. 'Discusses the chemical character of the waters and of the gases that they contain. These gases contain more than 30 percent of nitrogen and un'mportant amounts of bellum. Methane reduces sulfate in the water to hydrogen srifide, forming carbonate and bicarbonate. 
40. Investigations of ground water in the western part of the United States, by O. E. Meinzer. Pan-Pacific Sci. Cong., Australia (1923), vol. 2, Melbourne, 1924. pp. 1284-1290.

Describes briefly several of the most important lines af investigation under the headings: Survey of desert watering places; Water in the basalt of the Northwest and in the Hawaiian Islands; Quantitative investigations ; Hydrologi^ laboratory ; and The Dakota artesian basins.

41. Artesian water supply of Dakota sandstone, by 0 . E. Meinzer and $\mathbf{H}$. A. Hard. Abstr. in Pan-Am. Geologist, vol. 43, No. 5, Des Moines, Iowa, -June 1925. pp. 377-378.

Abstract of a paper presented at the annual meeting of the American Associar tion for the Advancement of Science, December 1924. The Dakota san istone forms the most remarkable artesian basin in the United States with respect to its great extent, the long distance through which the water must percolate from the outcrops of the formation, and especially the tremendous pressure under which the water in the sandstone was originally held by its thick and continuous cover of impermeable shales. The decline in pressure and flow, after the drilling of more than 16,000 wells, has been great. See also Water-Supply Paper 520 e.

42. Laboratory tests of water-bearing materials, by N. D. Stearns. Abstr. in Pan-Am. Geologist, vol. 44, No. 1, Des Moines, Iowa, Aumust 1925. pp. 77-78.

Abstract of a paper presented at the annual meeting of the American Association for the Advancement of Science, December 1924. The systematic hydrologic tests include those of mechanical composition, porosity, moisture equivalent, and permeability. Calls special attention to a new method of taking volumetric samples and to a new piece of apparatus for making permeability determinations based on Darcy's law that the flow of ground water through a given material viries directly as the bydraulle gradient.

43. California oil-field waters, by Chase Palmer; discussion by B. C. Renick. Econ. Geol., vol. 20, No. 7, November 1925. pp. 697-698.

Discussion of a paper by Palmer in the November 1924 issue of the same journal. Cites Palmer's statement that the alkaline sulfide waters are alkaline carbonate waters that have been altered by volatile sulfur compounds, specificall carbonoxysulfide. Asks whether this substance has been found in the California waters.

44. Ground-water problems on the barrier beaches of New Jersey, by D. G. Thompson. G. S. A. Bull., vol. 37, No. 9, Sept. 30, 1926, pp. 463-474; Abstr. in Pan-Am. Geologist, vol. 45, No. 2, March 1926, p. 162.

The water supply for Atlantic City and nearby resorts is obtained largely from Miocene sand below 300 feet of clay. The sand is reached at about 800 feet at Atlantic City and somewhat deeper southward. During the past 30 years, owing to heavy pumping, the static head has dropped more than 80 feet. The head will drop farther as the draft becomes greater until the limit of economic pumping is reached. The danger of drawing salt water into the wells is a factor to be considered.

45. Geology of large springs, by O. E. Meinzer. Abstr. in G. S. A. Bull., vol. 38, No. 3, Mar. 30, 1927. pp. 213-216.

A summary of data later published as Water-Supply Paper 557.

46. Locating leakage in artesian wells, by A. G. Fiedler. Eng. and Contract., vol. 66, N.o. 7, New York, April 1927. pp. 290-294.

Announces publication of Water-Supply Paper 596 a, and incluces notes on locating leaks in wells.

47. Natural sodium bicarbonate waters in the United States, by W. D. Collins and C. S. Howard. Ind. and Eng. Chemistry, vol. 19, No. 5, Easton, Pa., May 1, 1927. pp. 623-624.

The type of natural water most generally used in the United States is characterized by its content of alkaline earth bicarbonates. Presents diagram showing composition of three surface waters and seven well waters for city supplies. Gives summary of examination of about 8,800 analysea of water, many of the waters 
47. Natural sodium bicarbonate waters in the United States-Continued. : being distinctly sodium bicarbonate waters. The Atlantic Cosstal Plein is perhaps the best defined area in which such water is found. It is common also in southern California, Nevada, southern Arizona, North Dakota, and Montana and is also present in other specified areas.

48. Recent work ${ }^{*}$ on the discharge method of estimating ground-water supplies, by W. N. White. Abstr. in Washington Acad. Sci. Jcrur., vol. 17, No. 9, May 4, 1927. pp. 238-240.

Describes investigations begun in 1925 in Escalante Valley. Utah.

49. Exploring and repairing leaky artesian wells, by A. G. Fiedler and John McCombs. Water Works, vol. 64, No. 6, Chicago, Ill., June 1927. p. 254.

Announces publication of Water-Supply Paper 596 a, with a fer remarks on leaky wells.

50. The Au deep-well current meter for locating leaks, by A. G. Fiedler. Eng. News-Record, vol. 99 , No. 10, Sept. 8, 1927. pp. 382-383.

Describes a type of current meter designed and constructed by C. H. Au of the United States Geological Survey. It is essentially a turbine wheel rounted within a cylindrical brass case that is suspended in a 3-inch pipe and lowered and removed from a well by means of a cable and reel.

51. Ground water in New Mexico now subject to appropriation, by A. G. FiedPer. Eng. News-Record, vol. 99, No. 10, Sept. 8, 1927. p. 395.

Gives the provisions of the new State law, which is the outeome of a. study of the Roswell artesian basin made by Mr. Fiedler.

52. The "Craters of the Moon" in Idaho, by H. T. Stearns. Geog. Jour., vol. 71, No. 1, London, January 1928, pp. 43-49; Smithsonian Inst. Ann. Rept. 1928 (Pub. No. 2990), 1929. pp. 307-313.

A note prepared in cooperation with the Idaho Bureau of Mines and Geology. It is a popular description of the area, with mention of the oceurjence of water and ice in caves and tunnels in the lava.

53. Record of earthquake made by automatic recorders on wells in California, by H. T. Stearns. Seismol. Soc. America Bull., vol. 18, No. 1, Stanford Univ., Calif., March 1928. pp. 9-15.

Describes and presents graphs made by automatic recorder, showing slight fluctuation of water level in well during earthquake as contrasted with fuctuations due to pumping of nearby wells and to the weight of passing trains.

54. Compressibility and elasticity of antesian aquifers, by O. E. Meinzer. Econ. Geol., vol. 23, No. 3, May 1928. pp. 263-291.

The pore space in an artesian aquifer is filled with water that exerts a hydrostatic force against the weight of the overlying rocks. When wells are drilled this force is reduced. The artesian water supports a part of the load of the overlying rocks, and the aquifers contract when the artesian pressure is decreased and expand when it is increased.

55. Note on an ebb and flow spring near Rogersville, Tenn., by G. M. Hall. Tennessee Acad. Sci. Jour., vol. 3, No. 3, Nashville, Tenn., July 1928. pp. 3-9.

A spring 3.8 miles northeast of Rogersville forms part of the water supply of a dairy. During periods of about 1 hour the flow changes from a rinimum of 10 gallons a minute to a maximum of 50 gallons a minute. The period between maximum discharges is locally said to be 2 hours 40 minutes. Describs the geology of the area. A cross section showing hypothetical caverns in limestone. illustrates the probable cause of variation in flow, which is siphon action.

56. The origin of artesian pressure, by A. M. Piper. Econ. Geol., vol. 23, No. 6, Sept.-Oct. 1928. pp. 683-696.

The Dakota-Lakota beds are stream and coastal plain deposits in which it is likely that many lenses of sandstone are interconnected parts of to-tuous pipes of coarse sediments. The notably salt water in northwestern south B.kata is in the 
56. The orgin of artesian pressure-Continued.

deepest part of the geosyncline and may' be connate water that has not been flushed out of the beds by meteoric water. The lines of equal artesien head, as drawn by Darton, are essentially parallel to the structure contours. Adequate interpretation of the hydraulic profile is impossible, because the effeets of unequal draft and the rate of decline in head have not been fully evaluated.

57. Change in plant associations by change in ground-water level, by Kirk Bryan. Ecology, vol. 9, No. 4, Brooklyn, N. Y., October 1928. pp. 474-478.

Examples are given where rapid deepening of stream beds has occurred, partly as the result of loss of vegetation by overgrazing but probably also ix part as a result of change to drier climate. With deepening of the stream beds the groundwater level has been lowered, and areas formerly covered with phreatorhytes, such as sacaton, willow, and cottonwood, are now inhabited only by plants that do not depend upon ground water or by mesquite, which can send its roots to considerable depth to reach water.

58. Methods of estimating ground-water supplies, Part I, Outline of available methods, by O. E. Meinzer. Soc. Econ. Geologists, Tech. sesr. (1928), Lancaster, Pa., 1928. 25 pps. (Multigraphed.)

Discusses rock formations as reservoirs and describes methods of estimating discharge by overflow, by transpiration and evaporation, from fluctuations of water table, and from ground-water rating curve. Considering rock formations as conduits, describes methods based on field tests of velocity, laboratory determinations of permeability, pumping tests, area of influence of wells, and the movements of water levels in relation to rates of withdrawal. See also Water-Supply Finer $638 \mathrm{c}$.

59. Importance of well specifications, by A. G. Fiedler. Howell Drille.ns' News, vol. 8, No. 1, Minneapolis, Minn., January 1929. p. 6.

Gives a summary of the specifications for well drilling.

60. Submergence of a pump, by D. G. Thompson. Water Works Enǧ., vol. 82, Apr. 10, 1929. p. 485.

Discusses the proper method of measuring drawdown.

61. Use of cement in well construction, by A. G. Fiedler. Water Wc rks Eng., vol. 82 , May 8,1929 . pp. 587-588, 620,623 .

Describes cementing by the dump-bailer method, the tubing method, and the casing method. Also mentions plugging by asphalt and the plugging of bottorn water by cement or by lead wool.

62. Relation of ground-water conditions to leakage of reservoirs, by $\mathbf{O}$. $\mathbf{E}$. Meinzer. Am. Inst. Min. Eng. Tech. Pub. 215, New York, July 1929. pp. 19-30.

Discusses permeability of rocks and relation of reservoir sites to water table and outlines methods of investigation. Emphasizes application of general groundwater studies within the reservoir area. Appended discussion by $\mathbf{L}$. Crandall gives data on leakage of the Mackay, Idaho, reservoir.

63. Problem of soft water in the Dakota sandstone, by O. E. Meinzer. Howell Drillers' Néws, Minneapolis, Minn., vol. 8, No. 8, August 1927, pp.' 1-3; No. 9; September 1929, pp. 1, 3, 5, 8; No. 10, October 19?9; pp. 1, $6,7-9$.

Deseribes the extent and water-bearing characteristics of the Dakote sandstone. In general the upper strata contain soft water and the lower strata cintain hard water. Soft water is obtained near Canton. S. Dak., in wells 300 to 500 feet deep sunk to upper strata of the sandstone. The water rises under artesian, pressure. 200 feet or more above the depth at which it is struck. The city of Canton obtains its supply of 150,000 gallons a day from several wells in the sandstone. Discusses the chemical character of the water and also the physical character of the waterbearing sandstone, which is fine-grained and has slight coherence.

64. The sanitation of farm water supplies, by A. G. Fiedler. Howel Drillers' News, vol. 8, No. 9; Minneapolis, Minn., September 1929. pr: 1, 2, 10.

Diseusses the responsibility of the driller to keep the well free from pollution. 
64. The sanitation of farm water supplies-Continued.

gives examples of surface pollution of farm wells, explains methods of protecting wells by casing, and recommends the sterilization of new wells with chloride of lime.

65. Artesian water supply. of Memphis Tenn., by F. G. Wells. Water Works and Sewerage, vol. 76, No. 9, Chicago, Ill., October 1929. p. 415.

Gives the history of the Memphis water supply and a brief summary of the geologic conditions. Discusses the total pumpage, drawdown, and character of the water. See also Water-Supply Paper 656.

66. The origin of artesian pressure (a discussion), by D. G. Th?mpson. Econ. Geol., vol. 24, No. 7, November 1929. pp. 758-771.

The data on artesian head in the Dakota sandstone, presented $k$ " N. H. Darton, were collected in different years and have different degrees of reliability. The duscharge of large quantities of water from the Dakota sandstone has caused loss of head over large areas. Darton's map of the piezometric surface probably does not represent the condition before the formation was tapped. Facts advanced by W. L. Russell to support his theory that the artesian pressure is due primarily to weight of the overlying rocks may be explained in other ways.

67. The well driller and the water-works field, by A. G. Fiedler. Water Works and Sewerage, Chicago, Ill., April 1930, pp. 120-122; (abbreviated) Water Works Eng., Apr. 23, 1930, pp. 586, 589; Howell Drillers' News, vol. 9, No. 5, May 1930, pp. 1, 2, 3, 5; A. W. W. Assoc. Jour., vol. 22, No. 7, July 1930 , pp. 919-925.

About half the people of the United States use water supplies from wells, and three-fourths of the cities and villages that have waterworks draw upon underground supplies. "The driller's task is to construct the well in such a manner that it will not only make a sufficient quantity of water of suitable qual ty available but also yield the greatest quantity of water at least expense." Defines yield, drawdown. and capacity of a well. Emphasizes the desirability of obtaining water supplies of low mineral content and describes methods of protecting wells from surface pollution and contamination underground from highly mineralized watrr.

68. Chemical character of the hot springs of Arkansas and Virrinia, by M. D. Foster. Ind. and Eng. Chemistry, vol. 22, No. 6, Eas'on, Pa., June 1930. pp. 632-635.

Gives analyses of water from three springs at Hot Springs, Ark., made by Haywood in 1907 and by Miss Foster 1925-26, which show nearly conttant composition of some springs and changes in others. Analyses of water from five springs in Warm Springs Valley, Va., show them to be of sitnilar compositicn. Discusses the differences in mineral content of the several springs:

69. New Mexico law on artesian water only unconstitutional on technicality, by A. G. Fiedler. Water Works Eng., vol. 83, No. 26, Dec. 17, 1930. p. 1844.

A reply to discussion of ownership rights of artesian water in same journal, Nov. 19,1930, p. 1746.

70. Fundamental principles of well construction, by A. G. Fiedler. Water Works and Sewerage, vol. 78, Chicago, Ill., March 1931, pp. 94-96; abstr. in A. W. W. Assoc. Jour., vol. 24, No. 4, April 19??, p. 611.

Discusses selection of location and the features of sanitary significance. Con tamination should be prevented by properly casing the well. Chlorination of wells is now extensively practiced to eliminate and prevent contamination.

71. Choosing the site and constructing the well, by A. G. Fidler. Water Works Eng., vol. 84, Apr. 8, 1931, pp. 444-446; also published as proper methods of well construction, in Howell Drillers' New', vol. 10, No. 4, April 1931, pp. 1, 7, 9, 10; and vol. 10, No. 5, May 1931, pp. 1, 2, 8.

Discusses the importance of location and types of wells and their protection from pollution and contamination. Recommends the chlorination of newly completed wells and describes methods. Gives methods of plugging abandoned wells. 
72. Air in well supply, by A. G. Fiedler. Water Works Eng., vol. 84, May 20, 1931. pp. $726,778$.

Dissolved gases sufficient in quantity to cause pumping troubles are not uncommon in ground water. With the release of pressure caused by pumping, the dissolved gases pass out of solution and give rise to bubbles, which, wher of minute size, give a chalky appearance to the water."

73. Investigations relating to the absorption of precipitation and its penetra-

- ion to the zone of saturation, by G H. Taylor. A. G. U. Trans., June 1931. pp. 206-211.

Describes methods and results obtained by measuring downward movement of ground water. Presents 'sketches showing the position of interceptin pans and collecting basins. Gives tables showing moisture equivalent and moisture content of soil as obtained by soil-sampling tubes from experimental plats ir California. States that it is difficult if not impossible to determine the amount of downward movement of water with certain types of intercepting pans.

74. Investigations in progress in hydrologic laboratories, by A. M. Piper. A, G. U. Trans., June 1931. pp. 219-220.

Mentions research problems relating to movement of ground water thrt are being investigated in hydrologic laboratories in the United States.

75. Ground-water hydrology and Pleistocene geology of the Plotte River Valley and adjacent areas in Nebraska, by A. L. Lugn. A. G. U. Trans., June 1931. pp. 224-226.

A preliminary report on the occurrence and quantity of ground water in the area. See also Water-Supply Paper $\mathbf{7 7 9}$.

76. Formation of the Section of Hydrology of the American Goophysical Union, by O. E. Meinzer. A. G. U. Trans., June 1931. pp. 2?7-229.

Gives the reasons for formation of the section and the make-up of the several committees. Lists 26 suggested fields of hydrology to be covered by permanent committees.

77. Fishing jobs and the use of fishing tools, by A. G. Fiedler. Jor nson Nat. Drillers' Jour., St. Paul, Minn., vol. 3, No. 7, July 1931, pp. 1, 2; No. 8; August 1931, pp. 1, 2; No. 9, September 1931, pp. 1-3.

Describes in three short articles the various kinds of fishing tools and their uses in cable-tool drilling of wells.

78. Proper well construction, by A. G. Fiedler. 9th Ann. Water Works School Proc., Kansas Water Works Assoc., Univ. Kansas, Lawrence, Feb. 1931, pp. 13-20; abstr. in A. W. W. Assoc. Jour. vol. 23, No. 8, August 1931 , p. 1256.

Discussion of factors of location, type of well, protection at surface and underground, chlorination of completed wells, and abandonment and pluggirg of unused wells.

79. National aspects of the drought, by J. C. Hoyt. Civil Eng., vol. 1, No. 13, October 1931. pp. 1167-1171.

The basic causes of the drought of 1930 are unknown; the 1930 rairfall was deficient in 40 States. "Low stream flow and low ground-water levels serimsly affected water suppiies dependent upon natural stream flow or shallow wells. Most of the water sources supplied from adequate storage or from deep wells tapring waterbearing formations were ample for usual activities." Discusses runoff records, drought damage, effect on water power and navigation, and the factors of evaporation and trauspiration.

80. Problems of ground-water supply in Florida, by D. G. Thompson. A. W. W. Assoc. Jour., vol. 23, No. 12, December 1931. pp. 2085-2100.

Large supplies of ground water occur in solution channels in the Tampa and Ocala limestones. In the Orlando area all surface drainage and sewago is disposed of down "drainage wells" which reach solution channels. There is danger of bacterial pollution and also of contamination by salt water near the ser coast. 
81. Some ground-water problems in the southeastern States, by . R. G. Thompson. A. W. W. Assoc. Jour., Proc. 3d Ann. Meeting (Southeastern Section), 1931. pp. 58-65.

The greater number of public water supply systems in South Carolina, Georgia, Alabama, and Mississippi use ground water, but the greater conscmption is from systems using surface water. Discusses the relation of ground-water supplies to the geologic conditions, the danger of contamination by salt water elong sea coasts, and the problems of safe yield from water-bearing formations.

82. Report of the Committee on Underground Waters for 1931-32, by D. G. Thompson. A. G. U. Trans., June 1932. pp. 298-305.

Outlines scope of field covered by newly formed Committee on Underground Waters, reviews recent and current investigations in the field, and discusser suggested lines of activity for the committee.

83. Hydrological investigative work by petroleum companies, by P. D. Trask.

A. G. U. Trans., June 1932. pp. 306-307.

Enumerates nine phases of ground-water occurrence in oil-field development. Comments especially on the encroachment of edge water.

84. Investigations of underground water problems in Arizona, California, New Mexico, and Oregon, by A. M. Piper. A. G. U. Trans., June 1932. pp. 308-310.

A summary of investigations in progress.

85. Recent investigation of Thiem's method for determining permeability of water-bearing materials, by L. K. Wenzel. A. G. U. Trans., June 1932. pp. 313-317.

Deseribes pumping tests in Nebraska and measurements made of the depths to water in 81 observation wells spaced radially from the pumped well. Gives Thiem's formula, modified for convenient use, drawdowns in certain observation wells, and computed coefficients of permeability.

86. Equation for lines of flow in vicinity of discharging artesian well, by $O$. V. Theis. A. G. U. Trans., June 1932. pp. 317-320.

A mathematical discussion of the effect of artesian flow of a well on the piezometric surface in the viclnity of the well.

87. Investigations of the fluctuations of water levels in observition wells in Virginia, by R. C. Cady. A. G. U. Trans., June 1932. pp. 370-373.

Discusses the record of an observation well in Arlington County and the relation of the fluctuation in water level to the barometric changes.

88. Investigations of fluctuations of the ground-water table in Pennsylvania, by S. W. Lohman. A. G. U. Trans., June 1932. pp. 373-375.

Thirty-six shallow wells scattered over Pennsylvania are being measured weekly in an attempt to correlate the ground-water levels with the ground-water runoff in the streams at low stages and to forecast low stream-flow conditions.

89. Methods for estimating ground-water supplies, by O. E. Meinzer. Water and Water Eng., London, vol. 34, No. 411, Dec. 20, 1932, pp. 603-606; vol. 35, No. 413, Jan. 20, 1933, pp. 25-28.

A summary of information published as Water-Supply Paper 638-c. . Describes methods for estimating the rale at which rock formations will supply water, the hydrologic principles on which the methods are based and their historical development and applicability. With quantitative methods, rock formaticns may be considered as reservoirs, or as conduits of water. Reservoir methods are based on measurement of intake, discharge, or changes in storage. Includ 's evaluation of extraneous influences on water levels, such as barometric and tidal effects.

90. Studies of ground water in New Jersey, by D. G. Thompson. Civil Eng., vol. 3, No. 2, February 1933. p. 94.

Although the majority of public water supply systems use griound water, the larger cities depend chiefly on surface-water supplies; hence the total ofmanmption of surface water is much greater than that of ground water. Ir 1923 the State of New Jersey began investigation of the ground-water supplies in cooperation with the United States Geological Survey, and there is need for similar infensive investiga tion in other eastern areas. 
91. A remarkable intermittent spring (Wyo.), by N. D. Stearns. Mid-Pacific Mag., vol. 45, No. 3, Honolulu, T. H., March 1933 . pp. 217-218.

Describes "The Geyser" spring, on the bank of Swift Creek, 7 miles riortheast of Afton, Wyo. The spring issues from a fissure high on the side of a limestone cliff and intermittently flows and ceases to flow in intervals of about 20 minutes. Cites stories of the discovery and early history of the spring.

92. The mud scow method of drilling, by A. G. Fiedler. Johnson L'at. Drillers' Jour., vol. 5, No. 2, St. Paul, Minn., Apr.-May 1.933. pp. 5, 6.

Describes the mud scow (California or stovepipe) method of drilling, the kind of casing used, drilling rig, tools, and hydraulic jacks, and the operaticns of drilling. perforating the casing, and developing the well.

93. Notable improvements in ground-water development, by 0 . E. Meinmar. Eng. News-Record, vol. 110, No. 23, June 8, 1933 . pp. $75 \mathrm{C} .752$.

Gives data on the extensive use of ground water for public supplies. Discusses better methods of well construction, better pumping machinery, and the value of groundwater investigations.

94. Some relations between ground-water hydrology and oceanography, by $D$.

G. Thompson. A. G. U. Trans., June 1933. pp. 30-33.

Contrasts the fresh-water and salt-water conditions, contamination of the former by the latter, and the occurrence of fresh water overlying salt water.

95. Geophysical interpretation of ground-water levels, by O. E. I einzer. A. G. U. Trans., June 1933. pp. 36-37.

Discusses effect of rock pressure on artesian head and an flucturtions in water levels and describes the effect of drawdown and cone of depression on the water table.

96. Report of the Committee on Underground Waters for 1932-33, by D. G.

Thompson. A. G. U. Trans., June 1933. pp. 366-374.

Specifies the organizations studying problems of ground-water hydrology and reviews current ground-water investigations.

97. Investigations of underground-water pnoblems in California, New Mexico, and Otegon, by A. M. Piper. A. G. U. Trans., June 1933. pp. 374-377.

Forms Appendix $B$ of the Report of the Committee on Undergro'nd Waters for 1932-33. Describes the studies made during the year and gives short statements of the results.

98. List of papers relating to ground-water hydrology, by A. N. Sayre. A. G. U. Trans., June 1933. pp. 377-379.

Forms Appendix $\mathrm{C}$ of the Report of the Committee on Undergro'nd Waters for 1932-33. Gives titles of 26 papers relating to ground water published during 1931-33.

99. A 10-year record of water-table fluctuations near Runyon, N. J., by H. C. Barksdale. A. G. U. Trans., June 1933. pp. 466-471.

Gives data on the changes in water level, with graphs showing dsily fluctuations.

100. Fluctuations of water surface in observation wells and at st "eam-gaging stations in the Mokelumne area, Calif., during the earthruake of December 20, 1932, by A. M. Piper. A. G. U. Trans., Juie 1933. pp. 471-475.

Describes and presents graphs showing the effect of the trencrs on the water level in four observation wells and mentions the mechanical effect on eight watefstage recorders on streamis in the area.

101. Specific yield determined from a Thiem's pumping test, by J, K. Wenzel. A. G. U. Trans., June 1933. pp. 475-477.

Gives data on a pumping test in the Platte River Valley, Nebr., with diagram showing profiles of the cone of depression, and table of specifie yield for several distances from the pumped well and for several periods after pumping began.

102. Deep-well salinity exploration, by A. G. Fiedler. A. G. U. Trans., June 1933. pp. 478-480:

s Describes method of locating entry of contaminating salt water into a well by means of electrical conductivity measurements and cites the use of the method in salinity exploration work in Sarasota County. Fla. 
103. Notes on the relation between the moisture equivalent and the specific retention of water-bearing materials, by A. M. Piper. A. G. U. Trans., June 1933. pp. 481-487.

Defines the terms used and describes experiments with alluvial matorials from the Mokelumne area, Calif. Summarizes the results of others in similar work connected with soil and irrigation studies.

104. Salt water in sea coast and island wells, by D. G. Thompsor. Civil Eng., vol. 3, No. 10, October 1933. pp. 579-580.

Comments on J. O. Riddel's article, "Excluding salt water from island wells," in Civil Engineering for July 1933. Recommends water-stage recorders for further study in Nassau.

105. The construction and protection of drilled wells, by A. G. Fimler. Pennsylvania Water Works Operators' Assoc. Jour., vol. 5, Harrisburg, Pa., 1933. pp. 72-80.

Describes the cable-tool percussion and the hydraulic rotary methods of well drilling and the protection of drilled wells by proper casing against pollvtion from the surface and contamination from highly mineralized ground water. Discusses prolection of the casing by cement and describes the methods of placing the cement by dump-bailer, by pumping through tubing, and by pouring dov'n the casing. Hecommends chlorination of newly completed wells to overcome any pollution which has taken place during the drilling.

106. The history and development of ground-water hydrology, by 0 . E. Meinzer. Washington Acad. Sci. Jour., vol. 24, No. 1, Jan. 15, 1934. pp. 6-32.

Uutlines the hypotheses of the origin of ground water from the Greak philosophers to modern times and the rise of geology and its application to grourd water. Discusses interrelation of geology and hydrology as a course in the funcamental training of graduate students in geology.

107. The geyser area near Beowawe, Eureka County, Nev., by T. $P$ Nolan and G. H. Anderson. Am. Jour. Sci., 5th ser., vol. 27, Nc. 159, New Haven, Conn., March 1934. pp. 215-219.

Gives a detailed description of the geology and of the geysers, fumaroles, hot springs, and mud pots, which cover an area of less than a quarter of a square mile about 6 miles southwest of Beowawe railroad station. Discusses origin of the thermal activity and presents analyses of three samples of the water.

108. Investigation of ground water in the Elizabeth City area, Nor $h$ Carolina, by S. W. Lohman. A. W. W. Assoc. Jour., vol. 26, No. 2, February 1934. pp. 201-216.

Results of a study of the possibility of developing a suitable prblic supply of ground-water to replace the surface-water supply, which has become contaminated by salt water. Extensive test drilling and pumping indicate that watis deeper than 300 feet is too salty and an abundant supply at 75 feet is also of porr quality, but that the required amount of water of good quality can be obtained from shallow beds of sand by many wells distributed over a large area. See also Water-Supply Paper 778 a.

109. The building of Oahu, by H. T. Stearns. Mid-Pacific Mag., vol, 67, No. 3, Honolulu, T. H., March 1934. pp. 202-210.

Describes geologic and water conditions under the following heatings: Koolau and Waianae volcanoes dominate the geology of the island: Fluctrations of a level and late eruptions complete the geologic structure; Water resour ses are studied by means of geology; Dike systems exert major control over high-level water; Ground-water barrier is indicated between Koolau and Waianae lav?s:- Additional water supplies can be obtained from some of the artesian reservoirs; Recent lavas will yield additional water supplies: Limestone reefs contain reserve supply of water; Inventory shows the geologic source of the water; Methods ame outlined for developing water supplies from the dike system: Tunnels are recrmmended for the artesian reservoirs; and Summary of undeveloped water supplies 
110. Report of the Committee on Underground Waters for 1933-34, by D. G. Thompson. A. G. U. Trans., June 1934. pp. 312-316.

Reviews eurrent ground-water investigations.

111. Permeability, by O. E. Meinzer. A. G. U. Trans., June 1934. pp. 316-317. Forms appendix $A$ of the Report of the Committee on Underground Waters for 1933-34. Discusses units to express coefficient of permeability and citer objections to the Wyckoff and the Nutting expressions.

112. Lake and ground-water levels, by O. E. Meinzer. A. G. U. Trras., June 1934. pp. 317-318.

Forms appendix $B$ of the Report of the Committee on Underground Waters for 1933-34. Calls attention to work done in assembling records of advance and retreat of glaciers and states that "the fluctuation of lake levels is a elosely related subject that is equally fundamental in the study of hydrology." Recommends a survey of the records available with a view to considering the feasibility of more detailed studies of changes in lake levels. Also recommends survey of existing records of fluctuations in groundwater levels with a view to making plans for firther work and for the standardization of methods.

113. A selected list of papers relating to ground-water hydrology, by A. $N$. Sayre. A. G. U. Trans., June 1934. pp. 318-320.

Forms appendix $\mathbf{C}$ of the Report of the Committee on Underground Waters for 1933-34. Lists 43 papers relating to ground water published during 1932-33 and gives brief statements on some of them, calling attention to phases of ground-water problems that are not apparent from the titles.

114. Tests of permeability with low hydraulic gradients, by O. E. Meinzer and V. C. Fishel. A. G. U. Trans., June 1934. pp. 405-409.

Describes apparatus and results of tests. The flow varies approximatrly with the hydraulic gradient. The tests strengthen the presumption that Darey's law holds precisely for flow through permeable material under indefinitely low gradinnts.

115. The transmission of pressure in artesian aquifers, by R. M. Leggette and G. H. Taylor. A. G. U. Trans., June 1934. pp. 409-413.

Describes field tests in Utah to determine the rate at which changes in pressure are transmitted in artesian aquifers and the distance to which such charces extend. The transmission of pressure is not always rapid; the rate appears in be determined largely by the distance traversed and the magnitude of the changes of pressure.

116. Relation of stream flow to ground-water levels, by L. L. Harrold. A. G. U. Trans., June 1934. pp. 414-416.

Describes the relation of stream flow to ground-water levels near Colesville, Md. A study of their relations permits predietions regarding ground-water levels, groundwater discharge, and stream discharge.

117. A study of salt-water encreachment in the Galveston area, Tex., by $\mathbf{S}$. F. Turner and M. D. Foster. A. G. U. Trans., June 1934. pp, 432-435,

The chloride content of ground water in the region of Houston and Galveston is shown by isochlors drawn on a generalized geologic section. The chloride content of the water in each of the sands of the Beaumont, Lissie, and Goliad formations shows a continuous increase from the outerop to the Gulf. Some salt-water encroachment is indicated.

118. Progress in control of artesian-water supplies, by O. E. Meinzer. Eng. News-Record, vol. 113, No. 6, Aug. 9, 1934. pp. 167-169.

Describes successful efforts to conserve artesian water supplies in tha Honolulu, Hawaii, and Roswell, N. Mex., artesian basins. Effective programs of conservation must include hydrologic study and investigation of mechanical difficulties, a program of education, and a legislative plan with provision for enforcement. Legal control relates to proper construction and operation of wells and equitable distribution of the water. Recommends the doctrine of prior appropriation for benefeial use as against the doctrines of unrestricted use and correlative rights. 
119. Water-supply conditions in the drought-stricken regions, by 0 . $\mathrm{E}$. Meinzer. Public Works, vol. 65, No. 9, Washington, D. C., September 1934. pp. 19-20.

Discusses water-supply conditions in the drought region of the north-central part of the country, prospects of replenishment, and relief measures. Many surfacewater supplies and shallow wells failed, but the recognized water-kearing formations in general supplied the demands made upon them without serious depletion.

120. Ground water in the Midwest drought area, by O. E. Ifeinzer. Eng. News-Record, vol. 113, No. 16, Oct. 18, 1934. pp. 495-498.

An interpretation of the influence of geology on the water resources of the north interior States with reference to the drought. Next to the weather, the geologic conditions are the most important controls of both surface-wrater and groundwater supplies in times of drought. The region is largely underlair by water-bearing formations, which constitute great hold-over reservoirs. The critical areas were those where the main water-bearing formations are absent, or contain salt water, or are thin or impervious.

121. Methods of exploring artesian wells in Florida, by V. T. Stringfield. A. W. W. Assoc., 9th Ann. Conv. Proc., vol. 26, 1934. pp. 54-59. (Mimeographed.)

A summary of studies made in Sarasota County and tests on wells in the county with deep-well current meters in September and October 1932. See also Cooperative report 59.

122. Ground water as a source of public water supplies, by L. K. Wenzel. Public Works, vol. 66, No. 3, Washington, D. C., March 1935, pp. 12-14; Johnson Nat. Drillers' Jour., May-June 1937, pp. 5-7.

Discusses extent of use of ground water for public water surplies and relation of stream flow to ground-water level. Gives a graph of fluctuations of artesian head in the Atlantic City 800-foot sand showing that the head changes with pumpage rather than with precipitation.

123. Well drilling in relation to water-supply problems, by A. G. Fiedler. Johnson Nat. Drillers' Jour., vol. 7, No. 2, St. Paul, Minn., MarchApril 1935. pp. 4, 5, 11.

Discusses principles of ground-water occurrence, ground-vater conditions in the north-interior region, and ground-water levels. "The present low ground-water levels in the north-interior region are largely due to the severe drought conditions of the last few years, and there will be recovery of the ground'-water levels with recurring wet years."

124. Earthquakes instrumentally recorded in artesian wells, by R. M, beggette and G. H. Taylor. Seismol. Soc. America Bull., vol. 25, No, 2, Stanford Univ., Calif., April 1935. pp. 169-175.

During the earthquakes of March 12 and April 14, 1934, the fluctuation of pressure in a recording gage on an artesian well. in Ogden Valley, Utah, was, respectively, 5.5 and 3.8 pounds per square inch.

125. Ground-water problems of the Coastal Plain, by O. E. Meirzer. A. W. W. Assoc. Jour., vol. 27, No. 4, April 1935. pp. 479-484.

The Coastal Plain is underlain by seaward-dipping sediments from which water is pumped extensively. Overpumping causes not only lowering of ground-water level but in some places allows the encroachment of salt water. Highly mineraliged water is found in some places in deep wells, and shallow water is therefore used for large and also small supplies.

126: Ohio Valley well supplies subject to slow reduction of car qcity, by $\mathbf{O}$. $\mathbf{E}$. Meinzer. Eng. News-Record, vol. 114, No. 18, May 2, 19?5. pp. 621-622.

The largest, water supplies are from glacial drift, especially outwash sand and gravel north of the Ohio River and in the river valley. 'Discusses problems of quantity and quality of water.

127. Report of the Committee on Underground Waters for $19^{\wedge} 4-35$, by $\bar{D}$. $G$. Thompson. A. G. U. Trans., August 1935. pp. 433-437.

Summarizes developments of the past year and investigations in progress. "The outstanding feature of the past year has been the focusing of vublic attention on 
127. Report of the Committee on Underground Waters 1934-35-Continued. problems of underground water as a result of the drought conditions, tha activities of the national and State resource and planning surveys, and the creation of emergency relief projects."

128. Active ground-water projects in' California, Oregon, and Washiupton, by A. M. Piper. A. G. U. Trans., August 1935. pp. 441-443.

A summary of work in progress.

129. A Statewide program of periodic measurements of ground-water level in Nebraska, by L. K. Wenzel. A. G. U. Trans., August 1935. pp : 495498.

Describes the program for ground-water level measurements in about. 350 wells in Nebraska. Gives correlation of water-level fluctuations, with precipitation in the Platte River Valley in central Nebraska.

130. The need for a Nation-wide program of observation wells, by O. E. Meinzer. Abstr. in A. G. U. Trans., August 1935. pp. 498-499.

The severe droughts of recent years have developed great interest in the groundwater resources of the country. The records of water levels in wells and their interpretation have long formed an important part of ground-water work. On January 1, 1933, about 3,000 observation wells in the country were being measured periodically by the Ground Water Division of the United States Geol. Su'vey or by cooperating parties. The immediate problem is to round out this work into a comprehensive and coordinated national program.

131. Further tests of permeability with low hydraulic gradients, by V. C. Fishel. A. G. U. Trans., August 1935. pp. 499-503.

Tests were made to determine the validity of Darcy's law, for very low hydraulic gradients. The results indicate that rate of flow varies directly as the hydraulic gradient down to indefinitely low gradients.

132. Ground-water studies in the humid and semiarid parts of the Texas Coastal Plain, by S. F. Turner and Penn Livingston. A. G, U. Trans., August 1935. pp. 503-507. .

A summary of information on the three principal water-bearing formations: the Carrizo sand (Bocene), the Goliad sand (Pliocene), and the Lissie formation (Pleistocene). Discusses the recharge areas of outcrop of the formations, the decline in artesian head, and the amount of pumpage.

133. The relation between the lowering of the piezometric surface and the rate and duration of discharge of a well using ground-water storage, by C. V. Theis. A. G. U. Trans., August 1935. pp. 519-524.

A mathematical discussion' of the lowering of ground-water level, dereloping a nonequilibrium type of formula for the effects of pumping, involving time as an independent variable and a "coefficient of storage."

134. The piezometric surface of artesian water in the Florida Penirsula, by V. T. Stringfield. A. G. U. Trans., August 1935. pp. 524-529.

The principal artesian formations consist of limestones of Eocene an 7 Miocene age. The princtpal recharge areas are in the central, north-central, a nd northwestern parts of the peninsula and one area in Georgia. The principa' areas of natural discharge include the north-central and northwestern portions, thrivgh large springs, some of which are submarine. Contains maps showing area of artesian flow, area of highly mineralized water, and piezometric surface of th? artesian water.

135. Ground-water relieves 1934 drought emergency in Salt Lake Citv, Utah, by G. H. Taylor and R. M. Leggette. Eng. News-Record, vol. 115, No. 11, Sept. 12, 1935 . pp. 359-361.

Salt Lake City depends chiefly on mountain streams for water supply. I 1931 the low precipitation of the preceding winter was not enough to provide adequate supply. On benches east of Jordan River 17 wells were sunk, which $y^{i}$ alded 29,700,000 galions a day. 
136. Indian Hot Springs, Graham County, Ariz., by M. M. Knechtel. Washington Acad. Sci. Jour., vol. 25, No. 9, Sept. 15, 1935. pp. 4^9-413.

Gives data on the discharge and temperature $\left(82^{\circ}\right.$ to $\left.119^{\circ} \mathrm{F}.\right)$ of water from 4 springs and a flowing artesian well and another flowing well 7 miles to the southeast. From temperature observations on other wells in the region concludes that the spring water rises from a depth of about 2,500 feet. Analyses show the water to be rather highly mineralized, sodium and chloride being the chief constituents.

137. Artesian water in the Florida Peninsula, by V. T. Stringf old and F. C. Westendick. A. W. W. Assoc. Proc., 1935 (Florida Section). pp. 5-16. (Mimeographed.)

Describes the several water-bearing formations of the State ard presents maps showing area of artesian flow, piezometric surface of the artesian water, and the area of highly mineralized water.

188. Limited effect on water supplies expected from Florida canal, by V. T. Stringfield. Eng. News-Record, vol. 116, No. 2, Jan. 9, 1936. pp. 59-61.

Abstract of a report by a board of engineers and geologists to the War Department relating to the geology and hydrology of a sea-level canal under construction across the northern part of the Florida Peninsula. The board finds that the water level in the Ocala limestone will be lowered about 40 feet along part of the canal route, and the effects of this lowering will extend 10 or 15 miles from the canal. Also the lowering of the water table along the canal will affect the artesian head in the artesian basin east of Silver Spring. Includes map showing piezometric surface.

139. Florida's water supply and canal, by V. T. Stringfield. Eng. NewsRecord, vol. 116, No. 2, Jan. 9, 1936. p. 63.

Calls attention to study and preliminary report for the War Department on ground-water conditions in connection with the construction of the ship canal across Florida. Points out that construction of the canal ought not to proceed to any large commitments, nor should the excavation penetrate far into the limestone layer until these investigations are completed and much more precise quantitative knowledge of supply, pressure, transmission of the water through the rocks, and the effect on springs is available.

140. Quantitative investigations of New Jersey ground waters, by $H$. C. Barksdale. Water Works Eng., vol. 89, No. 3, Feb. 5, 1936. pp. 150-153.

Intensive studies of the Atlantic City, Camden, Asbury Park, Runyon, Canoe Brook, and Last Paterson areas were made to determine ground-water conditions and safe yields. Continued overdevelopment will seriously menace the 800 -foot Atlantic City sand with salt-water invasion.

141. Rock temperatures and depths to normal boiling point cf water in the United States, by H. C. Spicer. A. A. P. G. Bull., vol. 20, No. 3, March 1936. pp. 270-279.

Presents a table showing the highest and lowest extrapolate temperatures in the earth at two given depths for a number of localities. Comprted maximum and minimum depths to $212^{\circ}$ F. are also given for each locality.

142. The "fittifying" spring near Greenbrier Cove, Tenn., by G. M. Hall and H. C. Amick. Tennessee Acad. Sci. Jour., vol. 9, No. 2, Nashville, Tenn., April 1936. pp. 89-92.

Describes a small spring whose discharge has varied periodically since an earthquake of February 21, 1916. The water issues from talus but may flow from cavernous reservoirs in limestone, which give it the ebb-and-flow character.

143. Origin of large springs and their alcoves along the Snake River in southern Idaho, by H. T. Stearns. Jour. Geol., vol. 44, No. 4, May-Junë 1936. pp. 429-450.

A group of large springs discharge 5,000 cubic feet per second from the north side of Snake River Canyon between Bliss and Twin Falls, Idaho, issuing from pillow lava at the base of basalt flows. Some of the springs issue from box canyons or alcoves, which have been made by the springs, probably by the selution of the basalt. It is believed that these springs are older than the others. 
144. Movements of ground water, by O. E. Meinzer. A. A. P. G. Jiuil., vol. 20, No. 6, June 1936. pp. 704-725.

Water tends to move from a position of high pressure to one of low pressure. Pressure changes are transmitted with much lag under water-table confitions and with less lag under artesian conditions. Static conditions are present ir reservoirs completely sealed or sealed at one end or which contain fluids differing in specific gravity, such as water and oil or fresh and salt water.

145. Geologic features in New England ground-water supply, by Kirk Bryan. New England Water Works Assoc. Jour., vol. 50, N.o. 2, Boston, Mass., June 1936. pp. 222-228.

The two general sources of ground-water supply in New England are the bedrock, -which is suitable for small individual supplies, arid the glacial sand and gravel, which are adaptable to large supplies. Outlines the theory of formation of sand and gravel bodies by glaciation. By means of correlation between iron content of well water and the areas of older drift refutes the belief that the 1 rat or late Wisconsin ice covered all New England. Contains maps showing the position and extent of the Wisconsin ice according to two theories.

146. Recent geologic studies on Long Island with respect to ground-water supplies, by D. G. Thompson, F. G. Wells, and H. R. Blank. Abstr. in G. S. A. Proc. for 1935, June 1936. pp. 110-111.

Of the more than $200,000,000$ gallons of water a day pumped from wells, about 65 percent comes from the surficial deposits of Illinoian or Wisconsin age, about 15 percent from the Jameco gravel of early Pleistocene age, and about 20 bercent from the Cretaceots strati.

147. Two thermal springs in Idaho and Oregon, by G. A. Waring. Abstr. in G. S. A. Proc. for 1935, June 1936. pp. 115-116.

Thermal springs issue from rhyolite in the canyon of West Fork of Bruneau River, Idaho, and the canyon of South Fork of Owyhee River, Oreg. The Idaho springs are scalding, the Oregon springs merely warm, but the waters of the tro localities are similar in chemical character and seem to be similar in geologic crigin. They contain unusually large amounts of silica and fluoride in solution ant may rise from comparatively shallow depths through siliceous and fluoride-bearing roeks that have abnormally high temperatures.

148. Report of the Committee on Underground Waters for 1935-36, by D. G. Thompson. A. G. U. Trans., July 1936. pp. 326-329.

Refers to resistivity work in the search for water-bearing gravels by the Illinois, Missouri, and South Dakota Geological Surveys, by the Colorado School of Mines. Columbia University, the United States Geological Survey, and United States Bureau of Mines.

149. Some problems relating to fluctuations of ground-water level, by $D$. $G$. Thompson. A. G. U. Trans., July 1936. pp. 337-341.

A discussion of the several factors involved in changes of ground-wat? $r$ level.

150. Long-time records of ground-water levels on Long Island, N. Y., by $R$. M. Leggette. A. G. U. Trans., July 1936. pp. 341-344.

A summary of studies that have been carried on intermittently since 1851 .

151. A long-term 2 record of water-level fluctuations at Plainfield, N. J., by $\mathbf{H}$. T. Critchlow and H. C. Barksdale. A. G .U. Trans., July J936. pp. 361-363.

The Plainfleld-Union Water Co. has made daily measurements of the water level in a test well at the plant during most of the period 1891-1936. The fluctuations of water level are shown in a figure, together with records of the total pumpage and the precipitation.

152. Decline of artesian head in west-central South Dakota, by T. 'N. Robinson. A. G. U. Trans., July 1936. pp. 363-366.

The Dakota sandstone is the principal source of artesian water supply in westcentral South Dakota. Since the early developments there has been pronounced decline of the static water level. The greatest decline has taken placs along the Missouri River and averaged 15 feet a year at Chamberlain dnring 1891-1911. There was a decline in head of about 100 feet from 1900 to 1915 . The paper inclndes a map showing the artesian water head. 
153. The relation of the drought of 1934 to ground-water supmlies in the James and Sheyenne River Basins in North and South Dikota, by A. N. Sayre. A. G. U. Trans., July 1936. pp. 366-370.

The ohlef sources of ground water in the area are the Dakota sandstone and vlacial sand and gravel. The drought bad no effect on water sup-lies from the sandstone and only minor ffect on the supplies of large engla ial reservoirs, except where excessive water was pumped. The smaller ground-water reservoirs were seriously depleted but have recovered.

154. The recovery of ground-water levels in Nebraska in 1935, by L. K. Wenzel. A. G. U. Trans., July 1936. pp. 370-371.

Gives average fiuctuations and net changes in water level in groups of wells segregated according to different depths of water level below the land surface.

155. An interpretation of water-table fluctuation at four wells in southern Callfornia, by F. C. Ebert. A. G. U. Trans., July 1936. pn. 371-378.

Gives hydrographs for four wells in the south coastal basin showing the relation of the fluctuations of the water levels in the wells to precipitation and stream flow.

156. Fluctuations of ground-water levels in Utah, by G. H. Taylcr. A. G. U. Trans., July 1936. pp. 378-382.

Gives hydrographs showing the relation of the fluctuation of the water level's to stream flow and precipitation for six wells looated near Huntsville, Holladay. West Jordan, Great Salt Lake, Willard, and Fillmore.

157. Review of the work of WJ M̂CGee on ground-water leve's, by O. E. Meinzer. A. Q. U. Trans., July 1936. pp. 386-390.

The paper points out several incorrect assumptions that underlie McGee's quantitative conclusions, which were based on a questionnaire answered by crop reporters. who gave the depths of water in each well at the time the well was constructed and at the time of the questionnaire-the fall of 1910, which was a dry year. Presents data to show that the seasonal and cyclic fluctuations of the water table could account for all the average decrease in depth of water report od by McGee.

158. Several methods of studying fluctuations of ground-water lerels, by $\mathbf{L}$. $\mathbf{K}$. Wenizel. A. G. U. Trans., July 1936. pp. 400-405.

Describes and illustrates the following three methods of studying changes of ground-water level when records over a considerable period of tim? are available: the seasonal water-level method, the long-time trend method, and estimating the amount of precipitationon required to increase ground-water storage.

159. The channel-storage method of determining effluent seepage, by 0 . $E$. Meinzer, R. C. Cady, R. M. Leggette, and V. C. Fishel. A. G. U. Trans., July 1936. pp. 415-418.

The channel-storage method is based on the law that in any period when there is no overland runoff the quantity of water derived by effluent seepage into a stream system equals the quantity discharged from the stream system minus the decrease or plus the increase in channel storage. The paper presonts the results of investigation on a small drainage basin in Virginia.

160. The diurnal fluctuation in the ground water and flow of $t$ $\rightarrow$ Santa Ana River (Calif.) and its meaning, by H. C. Troxell. A. G. U. Trans., July 1936. pp. 496-504.

Points out some erroneous conceptions about transpiration. $\mathrm{T}$; diurnal cycle in the ground-water table and in the stream represents an accrmulation curve showing the difference between additions to and extractions from storage. The maximum rate of ground-water discharge occurs at the time wl in the groundwater level is at the minimum stage and vice versa.

161. The occurrence of ground water with reference to contamination, by $A$. G. Fiedler. A. W. W. Assoc. Jour., vol. 28, No. 12, Drember 1936. pp. 1954-1962.

Classifies rocks with respect to their origin and discusses the relationship of their interstices to the transmission of contamination. The mode of occurrence of ground-water supplies, whether under water-table or artesian cond tions, is a vital factor in the protection of the supply from contamination. Contrmination moves in the same direction as the ground water, but normal direction o movement may be reversed by heavy pumping, 
162. Droughts and floods, by J. C. Hoyt. Eng. News-Record, vol. 118, No. 5, Feb. 4, 1937. pp. 196-197.

Discusses the floods of 1936 in northeastern United States and drought conditions in some of the western States. Ground-water levels in many p'aces declined below those of 1935. "The rather general recharge of the ground-water reservoirs in 1935 was suffeient to create a hold-over storage that was in many areas ample to supply demands in 1936."

163. Our water supply, by O. E. Meinzer. Washington Acad. Sci. Jour., vol. 22, No. 3, Mar. 15, 1937, pp. 85-101; Smithsonian Inst. Anr. Rept. for 1937, Washington, D. C., 1938 . pp. 291-305.

A survey of the function of water in the physical and biological evolution of the earth and its relation to human activities. The hydrologic cycle has two phases: One includes evaporation, atmospheric movement of the water vapir, and precipitation; the other includes the movement and temporary storage of precipitated water. Considers climatic changes in geologic and historic time and nstural storage in rock formation. Calls attention to the emergence of hydrology as a recognized science and the need for the adequate development.

164. The New England ground-water supply, by Kirk Bryan. Harverd Alumni Bull., vol. 39, No. 22, Cambridge, Mass., Mar. 22, 1937. pp. 676-681.

Discusses the origin and nature of glacial deposits in New Englard in relation to ground-water supplies and the relation of degree of weathering of the deposits to the iron content of the water.

165. Wells for the water of Hawaii, by N. D. Stearns. Eng. News-] Pecord, vol. 118, No. 12, Mar. 25, 1937. pp. 450, 452.

To prevent contamination by salt water, the "Maul" type of we" is used. It consists of a vertical or inclined shaft at the bottom of which is a pumning chamber and sump fed by one or more infiltration tunnels. These are so constructed as to skim the fresh water from the surface of the heavier salt water.

166. Contamination of ground water, by A. G. Fiedler. The Driller, vol. 11, No. 4, South Milwaukee, Wis., April 1937. pp. 7-10, 26-28.

The chief factors that influence contamination are the character of water-bearing rocks (size, shape, and arrangement of interstices) and the mode cf occurrence, whether under water-table or artesian conditions. Discusses rate and direction of movement and the effect of pumping.

167. Surface run-off control, by R. E. Horton; discussion by W. N. White. Upstream Eng. Conf., Headwaters control and use. U. S. Forest Service, Washington, D. C., April 1937. pp. 41-47.

Ground water plays a large part in stream discharge. To decrease surface runoff and increase ground-water supplies, artificial methods of recharge, such as water spreading, have been used under favorable conditions with success. $T 7$ importance of not upsetting the natural balance of the stream is stressed.

168. Land subsidence caused by pumping, by 0 . E. Meinzer. Fing. NewsRecord, vol. 118, No. 19, May 13, 1937. p. 715.

Subsidence in the Santa Clara Valley, Calif., was cauged by vithdrawal of ground water and resulting compression of the aquifers. Similar srabsidence has probably taken place in other areas. Compressibility and elasticity of artesian aquifers may be of great importance in connection with water supplies.

169. Recent geologic studies on Long Island with respect to ground-water supplies, by D. G. Thompsion, F. G. Wells, and R. H. Blank. Ticon. Geol., vol. 32, No. 4, June-July 1937. pp. 451-470.

Clay beds are widespread on Long Island, but erosion channels through them permit some recharge to underlying sandy strata. About 65 percent of the pumped water Bupply of more than $200,000,000$ gallons a day comes from surficial beds of Illinoian or Wisconsin age. Because of restricted recharge to the Io rer beds and the desirability of saving them for use in localities where the upper be $\lambda_{s}$ may easily become contaminated by salt water, any future large developments stould be from the surficial beds. 
170. Investigating ground-water resources, by S. F. Turner. C'ril Eng., vol. 7, No. 7, July 1937 . pp. 487-490.

A summary of the types of ground-water investigations made in Texas by the United States Geological Survey. Methods of determining the safe yield are the recharge method, the transmission method, and the discharge method. Mentions special problems of salt-water encroachment and salt-water leaks in water wells.

171. Report of the Committee on Underground Waters for 1936-37, by D. G. Thompson. A. G. U. Trans., July 1937. pp. 318-325.

A summary of investigations by various organizations and individuals.

172. A selected list of papers relating to ground-water hydrolc Sayre. A. G. U. Trans., July 1937. pp. 325-328.

Forms Appendix $A$ of the Report of the Committee on Underground Waters for 1936-37. Lists 76 papers and makes brief statements on some of them, calling attention to phases of ground-water problems that are not apparent from the titles.

173. Report of the Committee on the Chemistry of Natural Waters, by C. S. Howard. A. G. U. Trans., July 1937. pp. 342-343.

Summarizes work relating to quality of ground water done in Pennsylvania, New Mexico, and Florida.

174. The value of geophysical methods in ground-water studies, by $\mathbf{0}$. $\mathbf{E}$. Meinzer. A. G. U. Trans., July 1937. pp. 385-387.

Introduces a series of five other papers on the subject. Geophysisal methods will prove valuable in the study of ground - water, especially the elsctrical-resistivity method, which depends on the conductivity of the water. It is promising for distinguishing salt water from fresh water and coarse water-bearing materials from sediments that are too fine to yield much water.

175. Resistivity studies of some salt-water boundaries in Hawaii $\times n$ Islands, by J. H. Swartz. A. G. U. Trans., July 1937. pp. 387-393.

The basal fresh water floats on salt water in accordance with the Ghyben-Herzberg principle. The top of the salt water was located by resistivity methods in several places, three examples being given. Mentions possible carses of errors in the determinations but states that in general it is feasible to determine the depths to salt water by resistivity measurements made with the partitioning method.

176. The use of resistivity methods in the location of salt-water bodies in the El Paso, Tex., area, by A. N. Sayre and E. L. Stephenson. A. G. U. Trans., July 1937. pp. 393-398.

The location of areas near El Paso in which salt water occurs was attempted by electrical resistivity methods. The northern boundary of on: such area was defined. In another area water of better quality beneath the salt water was suggested by the resistivity curves and was encountered in a test well.

177. The mutual interference of artesian wells on Long Island, N. Y., by R. M. Leggette. A .G. U. Trans., July 1937. pp. 490-494.

Interference tests on several artesian wells pumping from the Lloyd sand show that the beginning or cessation of pumping in one group of wells has a measurable effect on artesian head in wells as much as 7 miles distant.

178. Ground-water levels in Pennsylvania in 1936, by S. W. Lohman. A. G. U. Trans., July 1937. pp. 494-498.

Conditions that produced record-breaking floods in March 193: raised groundwater levels to the highest average stage of the past 5-1/3 years, but they declined to low stages in September. Ground-water discharge to the Susquehanna River during the period seems to have been sufficient to account for the strerm flow, exclusive of storm runoff.

179. Ground water in Utah, by G. H. Taylor. A. G. U. Trans., July 1937. pp. 536-541.

Discusses the ground-water areas and ground-water level in Ut $\mathrm{W}$ and the regulation and conservation of ground water by legislation. Includes map showing ground-water provinces and areas. 
180. Amount of ground-water recharge in the southern High Plains, by C. V. Theis. A. G. U. Trans., July 1937 . pp. 564-568.

Nearly all the rainfall either evaporates locally or percolates underground. The average annual rainfall is 14 to 22 inches. A thick mantle of silt overlies the water-bearing Ogallala formation. Several methods of estimating the reharge indicate an average of less than half an inch of water a year.

181. The Florida ship canal, by J. S. Brown. Econ. Geol., vol. 3\%. No. 5, August 1937. pp. 589-599.

Discussion of a paper by Sidney Paige in Econ. Geol., Sept.-Oct., 193: pp. 687570. Concludes that construction of the canal will cause substantial lowering of the water table over a wide area, substantial decrease in flow of certain large streams, and intrusion of sea water into the lower portion of the Ocala formation.

182. Administrative control of underground water, physical and legal aspects, by Harold Conkling; discussion, by D. G. Thompson. Am. S'sc. Civil Eng. Proc., vol. 63, p. 2 (Trans., vol. 102), New York, Octol \$r 1937. pp. 798-819.

"Much of the classification of ground waters adopted in many court derisions and by writers of legal textbooks is not consistent with scientific principles of groundwater hydrology." Discusses the subject under the heads: Attempts at, or lack of, control in eastern States (gives also examples of legislation in the West) ; Doctrines of correlative rights and appropriation; Examples of lack of appreciation of fundamental hydrologic problems.

183. The chemical character of the ground waters of the south Atlantic Coastal Plain, by M. D. Foster. Washington Acad. Sci. Jour., vol. 27, No. 10, Oct. 15, 1937 . pp. 405-412.

The chemical character is due chiefly to the amount of dissolved carbon dioxide and the materials through which the waters percolate. Wells of shallow and moderate depth in the Coastal Plain of Virginia, North Carolina, and South Car Jina yield calcium bicarbonate waters. Deep wells yield sodium bicarbonate waters, due to base exchange. In Florida and Georgia there is no evidence of base exchange, and both shallow and deep wells yield calcium bicarbonate waters. Along the coast the normal ground-water relationships may be upset by admixture of salt water.

184. Ground-water supplies, by A. G. Fiedler and others. Public Health Service Repts., Supp. 124, Washington, D. C., 1937. 24 pp.

Discusses the procurement of water from wells and describes location, protection, and treatment necessary to make it suitable for use. Chief factors of sanitixy quality are mode of occurrence, nature of the formation, slope of land surface and water level, rate of pumping, height above any nearby surface water body, and distance from sources of pollution. Shows approved types of pumping equipment and details of installation by 20 text figures.

185. Effect of a sea-level canal on the ground-water level of Florida, by D. G. Thompson, O. E. Meinzer, and V. T. Stringfield. Econ. Geol.. vol. 33, No. 1, January-February 1938. pp. 87-107.

Discusses a paper by Sidney Paige in Econ. Geol., Sept.-Oct. 1936, pp. 537-570. Treats of the permeability of the Ocala limestone, artesian conditions effect on ground-water levels, salt-water conditions, and the effect on the water-supply of the Sanford district.

186. The value of long-time records of ground water, by S. F. Turner. Texas Water Works 20th Short School Proc., College Station, Tex., Feb. 14-18, 1938. pp. 48-56.

Describes methods of studying the ground-water resources of the Stat ?. Fmphasizes the value of long-time records of water levels and pumpage. Giver types of observation wells and methods of measuring water levels in them.

187. The chemical character of natural waters, by W. L. Lamar. A. W. W. Assoc. Jour., vol. 30, No. 3, March 1938. pp. 495-497.

The actual amounts and relative amounts of the dissolved mineral ornstituents usually determine the chemical character and general usefulness of a wrter. Some ground water, especially shallow water, varies in composition from tim to time. A single analysis of iron and manganese content may be misleading. The treatmont of a water sample during the time between collection and analysis is imrortant. 
188. Progress report, Geological survey of Texas ground v"aters, by S. F. Turner. Southwest Water Works Jour., Austin, Tex., June 1988. pp. $21,30$.

Describes the progress of the water-well and spring inventory of the State and the distribution of well records to libraries throughout the State.

189. Ground-water supplies in Florida, by V. T. Stringfield. Civil Eng. vol. 8, No. 7, July 1938 . pp. 457-458.

An abridgment of a paper presented before the 1938 meetire of the American Society of Civil Engineers. Florida depends upon ground water for municipal and private requirements. Emphasizes the need for careful planning in ground-water exploitation.' Describes the water-bearing formations of the State and diseusses the factors that should be taken into account in their development.

190. Some problems relating to legal control of use of ground waters, by D. G. Thompson and A. G. Fiedler. A. W. W. Assoc. Jour., vol. 30, No. 7, July 1938, pp. 1049-1091; Alastr. in Water Works Eng., vol. 91, No. 16, Aug. 3, 1938, pp. 1040-1041, 1053.

Briefly reviews the occurrence of ground water and cites ground-water developments to illustrate legal control problems arising as a result of i'e of ground water. Discusses general principles of law and rights relating to surface waters in relation to their bearing upon legal control of ground water. The doctrive of reasonable use and correlative rights does not appear to bring about desired ground-water control. The doctrine of appropriation, properly applied, offers a mears of control, which is being used successfully in several areas.

191. Importance of ground-water supply, by 'O. E. Meinzer. Water Works Eng., vol. 91, Nos. 17-18, August 1938. pp. 1086-1088, 1139-1143, 1157.

Development of pure water supplies in recent years has been a large factor in increasing longevity. The great ground-water reservoirs in the United States are the valley fill in the Western States, the Great Plains sand and gravel, lava in the Northwest and in Hawaii, glacial drift in the Northern S'rtes, the Gulf and Atlantic Cosstal Plains, the Dakota sandstone, and Paleozoic roiks. Emphasizes the increasing development and use of ground water.

192. Report of the Committee on Underground Waters for 1937-38, by D. G. Thompson. A. G. U. Trans., August 1938. pp. 342-345.

Summarizes the more important papers and developments in the field of ground water during the year in appendixes as follows: A, Ground-water investigations in California, by H. F. Blaney; B, Ground-water problems rilated to production of oil, by F. H. Lahee: C, Notes on the hydrology of limestone terranes, by A. C. Swinnerton.

193. Ground water for air conditioning on Long Island, N. Y., by R. M. Leggette and M. L. Brashears, Jr., A. G. U. Trans., Augr st 1938, pp, 412418.

Use of ground water for air conditioning has resulted in considerable increase in pumpage on the western end of Long Island, where the draft on the groundwater reservoir was already excessive. In order to conserve the ground water, the State Water Power and Control Commission requires that water from new wells used for air conditioning shall be returned to the ground. This is usually done through a recharge well. The temperature of the ground water has been increased $10^{\circ}$ to $15^{\circ}$ by the return of the used water.

194. Ground-water underflow in Croton Valley, N. Y., a corpparison of field and laboratory methods, by .C. E. Jacob. A. -G. U. Trans., August 1938. pp. 419-430.

Gives data on test wells in the valley, water-level measuremints, and determinations of the underflow by the Slichter method, the Thiem method, and the Theis method. The values of the underflow, determined by these mithods, ranged, from $\mathbf{8 6 , 0 0 0}$ to 99,000 gallons a day. In his summary and conclusions the author discusses the weaknesses and the advantages of each method used.

195. Estimating safe yield as illustrated by the El Paso, Tex., ground-water investigation by A. N. Sayre. Econ. Geol., vol. 33, I'0, 7, November 1938. pp. 697-708.

The ground water is in a closed basin, and except for Rio Grande there is no 
195. Estimating safe yield as illustrated by the El Paso, Tex., Grovnd-water investigation-Continued.

outflow and very little inflow. Pumpage is concentrated near EA Paso. Volumes of cones of depression were computed, and average specific yield was calc' rlated. The volume of water released from storage is only a fraction of the total prmpage.

196. Ten years of ground-water records in the Grand Prairie region, Ark., by D. G. Thompson. Abstr. in G. S. A. Bull., vol. 49, No. 12, December 1938. pp. 1903-1904.

Records for 1928-38 show water-level dęcline each year. During the irrigation season 150,000 to 250,000 acre-feet of water is pumped from Pleistocen? sand and gravel. Artesian herd has declined in the area between the Ozark I'ateau and Crowley's Ridge, though only a small withdrawal of ground water has taken place, which shows that the recharge is small, owing to a nearly impervious cover of silt and clay.

197. Geology and artesian-water resources of a portion of the Virginin Coastal Plain, by D. J. Cederstrom. Abstr. in G. S. A. Bull., vol. 4ף, No. 12, Dec. 1, 1938. p. 1947.

Describes ground-water conditions in Southampton, Sussex, and Isle of Wight 'Counties. Artesian water is obtained from Cretaceous beds. The original head has lowered, and a cone of depression has formed in the area-including the cities of Franklin and Courtland. Hard water moving eastward becomes soft in base exchange. The fluoride content is high in some areas. No appreciable sa't-water intrusion has developed.

198 Geochemical relations of ground waters in the Houston-Galveston area, Tex., by $\dot{M}$. D. Foster. Abstr. in G. S. A. Bull., vol. 49, No. 12, Dec. 1, 1938. p. 1949.

Ground-water supplies in the area are chiefty from the Willis ( ?), Lissie, and Beaumont formations. Shallow waters in the different formations differ in content of calcium bicarbonate and total mineral content. Waters in all the formatlons change from calcium bicarbonate to sodium bicarbonate type as they pass downward, presumably as a result of reaction between the waters and bare-exchange minerals in the sands.

199. The significance and nature of the cone of depression in groind-water bodies, by C. V. Theis. Econ. Geol., vol. 33, No. 8, December 1938 . pp. 889-902.

Discusses the hydraulic character of an aquifer, its equilibrium, the piezometric surface, and cones of depression.

200. Wells on the public range, by G. A. Waring. Eng. News-Record, vol. 121; No. 24, Dec. 15, 1938 . pp. 757-758.

Gives notes on the drilling of wells for water for cattle and sheep under the Taylor Grazing Act, with figures on the costs of wells. To the end of July 1937 the Division of Grazing, United States Department of the Interior, had drilled 109 successful wells.

201. Salt-water intrusion, a coastal ground-water problem, by H. C. Parksdale. Abstr. in Econ. Geol., vol. 34, No. 1, January-February 1939. . p.: 129. .

Salt-water intrusion is upward movement of salt-water caused by artiaccial lowering of fresh-water head in beds containing both fresh and, salt wate-". Discusses the principle of Ghyben and Herzberg and gives examples. Fffective control of ground-water pumpage will be necessary to prevent salt-water intrusion in many important water-bearing formations of the Atlantic Coastal Plain.

202. Ground waters of the Houston-Galveston area, by M. D. Faster. Ind. and Eng. Chemistry, vol. 31, Easton, Pa., August 1939, pp. 1028-1034; Abstr. in A. W. W. Assoc. Jour., vol. 32, No. 5, May 1940, pp. 889-890.

Describes occurrence and quality of ground water in the area, which forms part of the Gulf Coastal Plain. The principal sources of ground water are the Willis, Lissie, and Beaumont sands (Tertiary and Pleistocene). Shallow waters are characterized by calcium bicarbonate. With increasing depth, in some formations sodium is exchanged for calcium and magnesium, owing to base exchange min rrals in the beds. The area is one in which heavy numping tends to produce intrution of salt 
202. Ground waters of the Houston-Galveston area-Continued.

water into some of the important water-bearing beds. About 100 million gallons a: day of ground water is used for industrial purposes in the area. T'a ground-water conditions, chemical character of the water, change of character with depth, artesiam head, and possibility of salt-water contamination with overpumpin are typical of the general conditions throughout the Gulf Coastal Plain. The pxper includes 13: analyses of ground water and a graphic presentation of the chenical composition of typical waters.

203. Ground-water problems in the southern High Plains, by W. N. White.

A. G. U. Trans., August 1939. pp. 32-35.

Discusses surface and ground-water supplies for irrigation and also the effect of pumping on the ground-water level. Describes studies to determine the rate of natural discharge of ground water at the edge of the High Plains. Artificial methods of increasing the recharge to ground-water supplies do not seem $t$, be feasible.

204. Geophysical investigations in the Hawaiian Islands, by J. F. Swartz. A. G. U. Trans., August 1939. pp. 292-298.

Ground water occurs both as perched water and as basal grourd water floating on salt water in accordance with the Ghyben-Herzberg principle. Magnetic and electrical resistivity surveys were made on Oahu, Molokai, and $M \varepsilon$ ui. Several wells were located which had been covered over, and the height of the water table was determined in several places.

205. Report of the Committee on Underground Watens for $193 \varepsilon-39$, by D. G. Thompson. A. G. U. Trans., August 1939. pp. 545-555.

In large parts of the area affected by the drought of 1934 water levels have risen. although there has been no excessive precipitation. In some areas where precipitation has continued deficient or where there has been heavy pumring water levels have declined. Large rises have taken place on Long Island, N. Y., and in parts of California, owing to heavy precipitation. Evidence on the compressibility of water-bearing formations has accumulated. Studies of contamination by salt water are being made.

206. Earth tides shown by fluctuations of water levels in wells in New Mexico and Iowa, by T. W. Robinson. A. G. U. Trans., Augtast 1939 . pp. 656-666.

Analyses of the fluctuations of the water levels in two wells, ore near Carlsbad, N. M., and the other near Iowa City, Iowa. show that after corrections are made for barometric fluctuations there are semidiurnal fluctuations thet can be closely correlated with the earth tides caused by the moon and the sun.

207. Fluctuations in artesian pressure produced by passing rail \%oad trains as shown in a well on Long Island, N. Y., by C. E. Jac?b. A. G. U. Trans., August 1989. pp. 666-674.

A study of the fluctuation of water level in a well 54 feet from a railroad track. The author shows that the weight of a passing train compresses the aquifer and causes water to rise in the well. The magnitude of fluctuation $0^{*}$ the water level varies with the speed and weight of the train.

208. Discussion of question No. 2 of the International Commission on Subterranean Water, Definitions of the different kinds of subterranean water, by O. E. Meinzer. A. G. U. Trans., August 1939. Fn. 674-677.

Subterranean water is classified on the basis of its occurrence, and international terms are proposed to designate different kinds of water in the zones of aeration and of saturation.

209. Earth tides expressed in fluctuations of the water level in artesian wells in New Mexico, by C. V. Theis. Internat. Union Geodesy and Geophysics, Washington, D. C. September 1939. 11 pp. (Mimeographed.)

Gives data on fluctuations in water level in artesian wells nisar Carlsbad and Conchas Dam, N. Mex., in phase with the moon's rotation. Ascribes the fluctuations to elastic dilation and compression of water contained in the aquif $\rightarrow r$ due to bulging and recession of earth's crust by earth tides. Derives tentative formula relating these fuctuations to eapth tides. 
210. The value of "geophysical" methods in hydrologic work, by O. E. Meinzer. Johnson Nat. Drillers' Jour., vol. 11, No. 5, St. Paul, Minn. September-October 1939 . pp. 3-5.

Defines geophysics and describes several geophysical methods useful in groundwater studies, particularly the electrical resistivity method.

211. Manganese in a thermal spring in west-central Utah, by Eugere Callaghan and H. E. Thomas. Econ. Geol., vol. 34, No. 8, Decemher 1939. pp. 905-920.

Describes a deposit at Abraham Hot Spring, 19 miles north of Delta, Utah, from which 715 tons of manganese ore was shipped in 1929-30. Gives 4 analvees of the thermal water, which show very small content of manganese.

212. Ground-water conditions of the Dakota sandstone in northwest 3 rn Iowa, by T. W. Robinson. Abstr. in Econ. Geol., vol. 34, No. 8, December. 1939. p. 940 .

Water in the Dakota sandstone in northwestern Iowa occurs uncer artesian conditions, but the head is nowhere sufficient to produce natural flow from wells at the land surface. A contour map of the piezometric surface of the rater in the formation shows the general direction of movement to be southward, 1 int a prominent ground-water divide begins about 60 miles east of the Iowa-South $\Gamma$ izkota State line and extends about 100 miles southward from the Minnesota-Iowa State line. Some decline of artesian head has occurred locally in heavily pumped areas.

213. Ground water in the Oklahoma Panhandle, by S. L. Schoff. Abstr. in Econ. Geol., vol. 34, No. 8, December 1939. p. 942.

Gives data on depth to water and thickness of zone of saturation in different areas. The Ogallala formation furnishes most of the ground water. Alluvium and the Dakota and Cheyenne sandstones are also important sources of ground water. Jurassic and Triassic rocks supply a few wells. Permian red beds yield arall suppliea of highly mineralized water in the eastern part of the area.

214. Geology and ground-water resources of the "Equus beds" area in southcentral Kansas, by S. W. Lohman and J. C. Frye. Econ. Geo', vol. 35, No. 7, Nov. 1940, pp. 839-866; abstr. in Econ. Geol., vol. §4, No. 8, December 1939 , pp. 942-943.

Describes the location and testing of a new water supply for Wichita, and the remapping of the "Equus beds." Hydrologic studies included drilling 1c0 test wells and driving 60 others, collection of water samples for analysis, mapning of the water table, and measurements of ground-water recharge. Includes map showing the geology and contours of the water table.

215. Ground-water problems in Ohio, with special reference to $B$ tler and Hamilton Counties, by F. H. Klaer, Jr. A. G. U. Trans., Søpt. 1940, pp. 1126-1131; abstr. in G. S. A. Bull., vol. 50, No. 12, December 1939, p. 1983.

Ground water is used by three-fourths of the public water-supply systems in Ohio, which supply $11 / 4$ million people. Large quantities are used for cooling and other industrial uses. Water levels have declined throughout the State. Investigation was begun in the Cincinnati area in 1938, where $65,000,000$ gallons was pumped daily from alluvial valleys. Declines in the water level of as much as 90 feet have taken place in the past 50 years in the industrial centers.

216. A brief review of ground-water conditions in Michigan, by C. L. McGuinness. A. G. U. Trans., Sept. 1940, pp. 1122-1126; abstr. in G. S. A. Bull., vol. 50, No. 12, December 1939, p. 1985.

Describes geology and water-bearing characteristics of the rock fornations and glacial drift and methods of well construction in the forested areas developed by the Michigan Forest Fire Experiment Station. Gives ground-water corditions, use for public supplies, and mentions the program of water-level meas'rements in observation wells.

217. Occurrence of ground water in the Hawaiian Islands, by H. T. Stearns. B. P. Bishop Mus. Special Pub. 35, Honolulu, T. H., Apr. 12, 1`40. p. 24.

A general statement concerning water in the lavas of the islands. 
218. Fluctuations in ground-water levels, by H. E. Thomas. Seismol. Doc. America Bull., vol. 30, No. 2, Stanford Univ., Calif., April 1940. pp. 93-97.

Describes and illustrates fluctuations in water levels in wells in Utah, California, and New Mexico caused by earthquakes in Alaska on November 10, 1938, and in Chile on January 24, 1939. Compares these fluctuations with previously reported seismic fluctuations in wells.

219. The source of water derived from wells, by C. V. Theis. Civil Eng., vol. 10, No. 5, May 1940. pp. 277-280.

Essential factors controlling the establishment of a new hydraulic equilibrium when water is discharged from an aquifer by a well are distance from and character of recharge, distance to natural discharge, and shape of the cons of depression as determined largely by the physical characteristics of the aquifer. Water discharged from wells must be balanced by a loss of storage in the aquifer, a decrease in the natural discharge, or an increase in the recharge, the last of which is possible only when the available recharge exceeds the capacity of the aquifer to transmit water under natural conditions.

220. Analysis of legal concepts of subfiow and percolating waters, by C. F. Tolman and A. C. Stipp; discussion by 0. E. Meinzer. Am. Soc. Civil Eng. Proc., vol. 66, No. 5, May 1940. pp. 1022-1024.

States that erroneous legal concepts have been perpetuated because of the re luctance of courts to depart radically from precedents established in previous cases. Asks if a person pumping subflow should not be given priority over a subsequent appropriation of surface flow.

221. Ground water in the southeastern States, by V. T. Stringfield. A. W. W. Assoc. Jour., vol. 9, No. 1, May 1940. pp. 58-69.

Briefly reviews the ground-water provinces and water-bearing formations, with a discussion of artesian conditions. Includes maps showing the inajor physical divisions, geologic formations, the area of artesian flow in Georgia, Florida, and Mississippi, and a map of the piezometric surface of artesian wat $r$ in Florida and part of Georgia.

222. The physics of the divining rod, by J. C. Maby and T. B. Franklin; review by A. C. Byers and R. G. Kazmann. Eng. and Min. Jour., vol. 141 , No. 6, New York, June 1940, p. 87.

A review of "The physies of the divining rod," by J. C. Maby and T. B. Franklin, G. Bell \& Sons, Ltd., London, 1939. $452 \mathrm{pp}$. The reviewers say that the authors "attempt to demonstrate that the diviners' art is based on muscular reaction to physical radiations."

223. Ground water in the Oklahoma Panhandle, by S. L. Schoff. Eeon. Geol, vol. 35, No. 4, June-July 1940 . pp. 534-545.

Depth to the water table ranges from less than 25 feet to a hout 300 feet. The Ogallala formation supplies most of the ground water, being 100 to 500 feet thick. Alluvium and the Dakota and Cheyenne sandstones are also imnortant sources of water. Includes maps showing hydrology of the Oklahoma Panhandle and a map of the water table in northeastern Texas County, Okla.

224. Status of legal control of ground water, by A. G. Fiedler. Assoc. Am. State Geologists Jour., vol. 11, No. 3, Morgantown, W. Va., July 1 1940. pp. 30-33. (Mimeographed.)

Discusses doctrines of English law, reasonable use, correlative rights, and appropriation. In the East the tendency is towards "reasonable use :" in the West toward "appropriation," as in the New Mexico law of 1927.

225. Ground water, salt-water infiltration, and ground-surface recession in Santa Clara Valley, Santa Clara County, Calif., by C. F. Tolman and J. F. Poland. A. G. U. Trans., July 1940. pp. 23-35,

Describes the several geologic formations of the area and gives cross sections of the alluvial deposits. Discusses salt-water contamination and grind-surface movement, with explanation of sinking. 
226. An electrical resistivity apparatus for testing well waters, by I. F. Poland and R. B. Morrison. A. G. U. Trans., July 1940 . pp. $35-46$.

Describes an instrument for testing natural waters for the presence of dissolved electrolytes by the electrical-resistivity method. Gives typical field testio for chloride.

227. Report of the Committee on Underground Waters for $1939-40$, by D. G.

Thompson. A. G. U. Trans., July 1940. pp. 433-439.

Mentions the number of reports received from foreign countries or questions relating to ground water. Gives subjects approved for discussion at the 1942 meeting. Summarizes developments in ground-water studies during the past year. Includes appendix $A$ on determination of ground-water level by seismic methods, by E. B. Burwell, Jr., and appendix B on hydrology and physiography $o^{*}$ limestone terranes, by A. C. Swinnerton.

228. The contamination of ground water by salt water near Parlin, N. J., by H. C. Barksdale. A. G. U. Trans., July 1940. pp. 471-474.

A summary of studies on the intrusion of salt water into fresh-wate" horizons. The safe yield of aquifers may be limited by the danger of salt-water intrusion rather than by their capacity to absorb and transmit water.

229. Ground-water recharge in areas of deep water table in the Great Plains, by R. C. Cady. A. G. U. Trans., July 1940. pp. 570-574.

A summary of. studies in western Nebraska, based chiefly on observations of water levels in wells. Includes water-table contour map of Keith County and wap of Box Butte County showing contours and gradients of the water table.

230. On the flow of water in an elastic artesian aquifer, by C. E. Jac b. A. G. U. Trans., July 1940. pp. 574-586.

A rigorous mathematical derivation of equations relating to fluctuations of pressure in an idealized elastic artesian aquifer due to atmospheric or other loading and to discharge by wells.

231. Typical quantitative analysis as applied to Lake Superior, by C. P. Pettis; discussion, by O. E. Meinzer. Am. Soc. Civil Eng. Trans., vol. 66, October 1940. p. 834.

The geology and ground-water conditions of the drainage basin were not discussed by Mr. Pettis. Calls attention to the probable water-table conditions and th o fact that it is not clear how the losses of water from land and lake areas were computed.

232. Watch well supplies, by D. G. Thompson. Eng. News-Record, vol. 125, No. 15 , Oct. 10,1940 . pp. 454-455; also Johnson National Drillers, Jour., vol. 15, No. 2, March-April 1943, p. 15.

- Gives examples of the need to guard against sabotage of ground-water simplies. The protection should cover the manufacture and installation of vital equipm 9 nt. Public officials should check on the availability of ground-water supplies for an emergency and should look into the adequacy of their public supplies.

233. Hydrology of the Wichita area (Kans.), by S. W. Lohman. Civil Eng., vol. 10, No. 11, November 1940. p. 725.

Discusses the specifications for testing and accepting wells. States that vells should be rated on the yield per foot of drawdown. Describes the use of a watei-table map in determining ground-water movement and in computing ambunt of watên withdrawn from storage.

234. Ground water for public -supply in western Pennsylvania, by $\mathbf{R}$ M. Leggette. A. W. W. Assoc. Jour., vol. 32, No. 11, November 1940. pp. 1857-1864.

Mentions six reports issued by the Pennsylvania Topographic and Geologic Survey in cooperation with the United States Geologieal Survey and gives summary of the data in Bulls. W1 and W3. Briefiy describes the several water-bearing formations and the source of the ground water and discusses well casing, screens, and drilling.

235. Problems of Coastal Plain geology and hydrology, by D. J. Cederstrom. Abstr. in Virginia Jour. Sci. (Proc. Virginia Acad. Sci.), vol. 1, No. 7, Charlottesville, Va., November 1940. pp. 242-243. Also abstr. in G. S. A. Bull., vol. 51, No. 12, pt. 2, December 1940, p. 1992.

Outerops, well logs, and geophysical data give information on the bedreck surface and on folding in the overlying deposits. Hydrologic problems thelude the manner of 
235. Problems of Coastal Plain geology and hydrology-Continued.

recharge to Cretaceous beds, the chemistry of softening by base erchange, the origin of bicarbonate and fluoride contents, the relation of fresh water to salt water, and safe yield.

236. Present status of our knowledge regarding the hydraulics of ground water, by O. E. Meinzer and L. K. Wenzel. Econ. Geol., vol. 35,, No. 8, December 1940, pp. 915-941; abstr. in A. G. U. Trans., July 1940, pp. 648-649.

On the basis of Darcy's law a number of fleld and laboratory methods have been developed for determining the permeability of water-bearing materials. The methods may be placed in four groups: Direct laboratory methods, indirect laboratory methods, field velocity methods, and field discharge methods. Methods of the first and fourth groups are most widely used. The paper also discusses the range in permeability of natural materials, the relation of storage to movement of ground water, and the compressibility and elasticity of artesian aquifers.

237. Fluctuations of water level in wells in the Los Angeles besin, Calif., during five strong earthquakes, 1933-1940, by G. A. LaRocque, Jr. A. G. U. Trans., August 1941. pp. 374-386.

Describes the character of the basin and presents graphs and tabulated data on fluctuation of the water level in observation wells.

238. The effect of a well on the flow of a nearby stream, by C. V. Theis. Ap G. U. Trans., August 1941. pp. 734-737.

Assuming a homogeneous aquifer and free interchange betweer ground water and a surface stream, the decrease in flow of the stream due to a nearby well varies with its distance, the duration of discharge, and the physical character of the aquifer. Gives an equation expressing the effect under ideal conditioning.

239. The effect of a well on the flow of a nearby stream, by C. V. Theis; discussion, by L. K. Wenzel. A. G. U. Trans., August 19:41: p. 737.

Discussion of a mathematical paper by $C$. $V$. Theis in the same publication. "The results obtained by the use of the mathematical approach to groind-water problems. although definitely remunerative, have clearly demonstrated that formulas involving ground-water flow can be applied to fleld conditions with assurance only when considerable caution and judgment are exercised."

240. Ground-water inventory in the upper Gila River Valley, l'ew Mexico and Arizona: Scope of investigation and methods used, ly S. F. Turner and L. C. Halpenny. A. G. U. Trans., August 1941. p]. 738-744.

- Discusses the studies that are being carried on under the headings: Surface flow and underflow, Ground water, Bank storage, Transpiration, and Rainfall and evaporation. Gives hydrographs of two wells and of Gila River at two stations.

241. Coefficients of storage and transmissibility obtained fron pumping tests in the Houston district, Tex., by C. E. Jacob. A. G. U. Trans., August 1941. pp. 744-756.

Describes technique used to determine physical characteristics of water-bearing sands, from observations at well flefds under transient conditions of operation.

242. Application of coefficients of transmissibility and storage to regional problems in the Houston district, Tex., by W. F. Gu ton. A. G. U. Trans., August 1941. pp. 756-770.

A discussion of decline of water levels in the district, with mathematical treatment of the subject. Contains map showing altitude of water levels in February 1940 and hydrographs of seven wells.

243. Factors producing a 9-year decline in ground-water levels in Scott County, Kans., by H. A. Waite. A. G. U. Trans., August 1941. pp. 772-775.

Gives data on the ground-water level in an area where there $w \$ 8$ a notable dectine during 1932-40. Discusses the relation of pumping and of precipitstion to this decline. Contains map showing contours of water table. 
244. Ground-water dams created by faulting of alluvial sedimerts in the Hurricane fault zone, Utah, by H. E. Thomas. A. G. U. Trars., August 1941. pp. 775-778.

Describes the fault zone. Gives evidences of faulting of the alluvial ondiments and of the effects on the ground-water table.

245. Depth of active solution by ground waters in the Pecos Valley, N. Mex., by A. M. Morgan. A. G. U. Trans., August 1941. pp. 779-783.

Describes the rock formations underlying the valley. Discusses the rater-bearing cavernous limestones of the San Andres and Chalk Bluff formations, which constitute the important artesian aquifer.

246. Notes on the elasticity of the Lloyd sand on Long Island, N. Y., by C. E. Jacob. A. G. U. Trans., August 1941. pp. 783-787.

Describes the character of the water-bearing Lloyd sand and gives a mathematical discussion of its high apparent compressibility.

247. Report of Committee on Underground Waters for 1940-41, by D. G. Thompson. A. G. U. Trans., August 1941. pp. 948-950.

A report of ground-water studies that have been carried on during the past year by the United States Geological Survey and by State and other organizations.

248. Artesian water in the coastal area of Georgia and northeasteln Florida, by V. T. Stringfield, M. A. Warren, and H. H. Cooper, Jr. Econ. Geol., vol. 36, No. 7, November 1941. pp. 698-711.

The area is one of the most productive artesian basins in the United States, yielding at least $180,000,000$ gallons a day, nearly half of which is used by six large industrial plants. The water comes from the Ocala limestone from depths of 200 to 500 feet. Most of the wells flow, except near Savannah, where the head has been reduced by heavy withdrawal, but encroachment of salt water has not yet taken place. The total dissolved solids in the artesian water range from about 175 to 500 parts per million. Contains maps showing the artesian area and contours of the piezometric surface.

249. Groundwater temperature on Long Island, N. Y., as affected b!r recharge of warm water, by M. L. Brashears, Jr. Econ. Geol., vol. 36, No. 8, December 1941. pp. 811-828.

Ground water generally is more economical than surface water for cool' $1 \mathrm{~g}$ purposes because of its lower temperature. The New York State Water Power and Control Commission requires that ground water pumped for cooling purposes must: be returned to the ground. The amount of recharge during the cooling season has in reased from about $1 / 2$ million gallons a day in 1933 to 30 million gallons a day in 1940 . The temperature of the water returned to the ground ranges from $2^{\circ}$ to $20^{\circ}$ higher than the temperature of the water pumped from the ground.

250. Industrial ground water at Franklin (Va:), by D. J. Cederstom. The Commonwealth (published by Virginia State Chamber of Commerce), vol. 9, No. 1, Richmond, Va., 1942. p. 22.

A yield of 2,600 gallons a minute is reported from a well at a kraft raper mill at Franklin, Other coastal plain wells at West Point, Fort Eustis, and Hopewell yleld about 1,000 gallons a minute each. The water comes from sand of the Pctomac group (Lower Cretaceous) at depths of 368 to 603 feet.

251. Ground-water investigations in West Virginia, by P. H. Price and R. L. Nace. West Virginia Engineer, vol. 4, No. 3, Morgantowr. W. Va., March 1942. pp. 8, 9, 23, 24.

Gives a summary of the development and possibilities of ground-water supplies, with tables showing the sources of public water supplies in the State.

252. Ground water in southeastern Florida, by W. P. Cross and S. K. Love. A. W. W. Assoc. Jour., vol. 35, No. 4, April 1942. pp. 490-504.

Discusses the subject under the headings Topography and drainage, Water-bearing formations, Methods of investigation, Shallow ground water, Quality of water, Saltwater intrusion, and Ground water as a future source of supply. Contain * three mape showing water-table contours in the Miami area. 
253. Chemical character of the larger public water supplies in Genrgia, by W. L. Lamar. A. W. W. Assoc. Jour., vol. 35, No. 4, April 1942. pp. 505-512.

Discusses the public water supplies of 66 cities having a populatior of more than 2,500 each and constituting 35 percent of the total population of the State. Surfacewater supplies serve 33 cities having a total population of 759,784 , and ground-water supplies serve the other 33 cities having a total population of 339,035 . Discusses the chemical character of the surface-water and ground-water supplies ant gives a table showing hardness of each. See also Water-Supply Paper 912.

254. Base exchange and sulphate reduction in salty ground water along Atlantic and Gulf coasts, by M. D. Foster. A. A. P. G. Bull., vol. 26, No. 5, May 1942. pp. 838-851.

Salty water from wells along the Atlantic and Gulf coasts are 1 nw in calcium, magnesium, and sulfate in comparison with theoretical mixtures of sea water and fresh ground water from about the same depths in the same formations. This indicates that base exchange and sulfate reduction have taken place. From the indicated occurrence of these phenomena conclusions are drawn about the oricin of the contaminating salt water, whether it is present-day sea water or connate rater. Contains tables and diagrams giving analyses of representative samples of ground water.

255. Hydrology (Physics of the earth, IX), edited by O. E. Meinzer. McGraw-Hill Book Co., New York, June 1942. pp. 712.

The ninth volume of a series of reports on physics of the earth is rued under the auspices of the Division of Physical Sciences of the National Researcl Council. The present volume includes the following chapters dealing with ground watrars by members of the United States Geological Survey: 1, Introduction (on the hydro'ogic cycle and the historical development of hydrology), by 0 . E. Meinzer, pp. 1-31; 10, Ground water, by O. F. Meinzer and L. K. Wenzel, pp. 385-417; 13 E, Chemirtry of ground water, by M. D. Foster, pp. 646-655; and 15, Hydrology of lava-rock terranes, by H. T. Stearns, pp. 678-703. Ground water is also discussed in chapter 9 Soil moisture. by K. v. Terzaghi and L. T. Baver, and chapter 14, Hydrology of limestone terranes, by A. $\mathbf{O}$. Swinnerton. Other chapters discuss various phases of surface water, including precipitation, snow and ice, glaciers, lakes, runoff, and droughts.

256. Ground-water investigations in West Virginia, by $P . H$. Price and R. L. Nace. West Virginia Eng. Exper. Sta. Tech. Bull. 23, Morrantown, W. Va., August 1943. pp. 37-41.

A summary of the investigation being carried on by the United St-tes Geological Survey in cooperation with the State.

257. Water for industrial purposes, by W. D. Collins. The Amorican City, New York, vol. 52, 1937, July, pp. 57-59; August, pp. 55-57; September, pp. 75, 76.

Discusses the main constituents that make up practically all the difolved mineral matter in most natural waters and the effects of hardness, alkalinity, and corrosiveness. Specifies the desirable features of water for various industrial uses. Presents information on the general character of public water supplies in different parts of the United States.

258. Notes on the geology and ground water of the Everglades in southern Florida, by G. G. Parker, Soil Science Society of Floride. Proc., vol. 4A, Gainesville, Fla., April 21, 1942. pp. 47-76.

Gives a summary of the geology and principal water-bearing formaticns in southern Florida.

259. Ground-water studies in the Southwest, by O. E. Meinzer. A. G. U. Trans., pt. 1, August 1942. pp. 6-9.

Describes the extent of ground-water investigations in the Southwest by the United States Geological Survey and cooperating agencies and outlines the prrhlems of some of the principal ground-water provinces.

260. Solution phenomena in the Pecos Basin in New Mexico, by A. M. Morgan. A. G. U. Trans., pt. 1, August 1942. pp. 27-35.

Describes the solution phenomena associated with the gypsum and $g$.psiferous beds of the San Andres formation and the halite, polyhalite, and anhydrite of the Salado formation. 
262. Repart of the Committee on Underground Waters for 1941-42, by D. G.

Thompson. A. G. U. Trans., pt. 2, November 1942. pp. 467-468.

"Since about September 1940 the Division of Ground Water of the United States Geological Survey . . . has reported on ground-water conditions at about 750 localities in the United States and foreign countries where military establishments, industrial plants for the production of war materials, or housing projects were being contemplated."

263. Deep-well pumping in Idaho, by H. T. Stearns. Howell Drillers' News, vol. 4, No. 9, Minneapolis, Minn. September 1925. p. 3.

In the laval plaing in the vicinity of Dubois, Idaho, water in dril ad wells is obtained from depths of 300 to 400 feet by lift pumps, chiefly for wat 3 ring sheep. Most of the wells are operated by windmills. Some deeper wells are operated by steam or gasoline engines. From one well in which the depth to static water level is 680 feet, a 10-horsepower engine pumped 32,000 gallons in 65 hours wi hout appreciably lowering the water level. Gives data on the cost of pumping.

264. Lava Beds National Monument, Calif., by H. T. Stearns. Geog. Soc. Philadelphia Bull., vol. 26, No. 4, Philadelphia, Pa., October 1928. pp. 239-253.

Contains a short discussion of the sources of spring water in the area

265. Preliminary report on the ground-water resources of the Harmaiian Islands, by H. T. Stearns. Hawaii Div. Hydrography Contr. 22, Terr. Plann. Bd. 1st Rept., Honolulu, T. H., April 1939. pp. 142-1E2.

A general report on ground-water conditions in the islands, with 6 m 7 ns showing ground-water areas and chief ground-water developments. Includes data on the fuctuation of water levels in wells.

266. Ground-water control through legislation, by N. B. Bennett, Jr.; discussion, by F. C. Foley. Wyoming Eng. S.oc. 23d Ann. Conv. Proc., Cheyenne, Wyo., January 23-24, 1942. pp. 28-31. (Mimeographed.)

Emphasizes the need for legislation because of the rapid development of ground water for irrigation in the State. Summarizes the ground-water stud' os that are being carried on in Wyoming.

267. Ground water, by O. E. Meinzer. Nebraska State Soil Cons. 3d Conf. District Supervisors Proc., Lincoln, Nebr., Jan. 8, 1942. pp. 39-42. (Mimeographed.)

A discussion of gxound water as a storage supply and its development $f$ irrigation and for municipal and industrial supplies. Also describes development of ground-water supplies for defense industries. Mentions cooperative studies by the United States Geological Survey and State organizations and also legislation for the cornervation of the ground-water supplies.

268. Some aspects of subsurface water in research on agricultural weter sheds, by H. S. Riesbol; discussion by D: G. Thompson and L. K. Wenzel. Hydrology Conference, State College, Pa., Proc., June 30-July 2, 1941. Tech. Bull. 27, School Eng., February 1942. pp. 108-110.

Difference in types of fluctuation of the ground-water level may denend on the topographic position of wells, their distance from streams, and the depth to water. The formula used for determining flow of ground water into a ditch may be applicable to flow of ground water into a stream. Although the rate of movement is slow, the large area of discharge along stream banks may produce conditions so ti at contributions of ground water to streams may in some areas be much greater, at least for short periods, than is customarily thought.

269. Instructions for the use of the well schedule in the collection of records of water wells, by O. E. Meinzer. Nat. Resources Comm., Washington, D. C., July 1, 1935. i, 13 pp. (Mimeographed.)

Describes the well schedule (form 9-185, March 1935) used in the Graund Water Diviaion of the United States Geological Survey and apecifies the inforration to be abtained for each of 14 headings on the form. 
270. The importance of snow in relation to ground-water rechnrge by C. $L$. McGuinness. Central States Snow Conf., Michigan State Coll. Proc., vol. 1, Lansing, Mich., December 1941, pp. 166-172. (Offset.)

Ground-water recharge in cold climates takes place chiefy during the spring melt-ing of snow, the amount of recharge being dependent on the disarpearance of frost from the soil. Detailed observations of water level in the Lower Peninsula of Michigan show the rapid effects of freezing and thawing weather, rapid local recharge from melting snow and from heavy rains, and minor fluctuations due to transpiration and to changes in barometric pressure.

271. Ground water in the United States of America, by 0. E. Meinzer. Water and Water Engineering, vol. 43 (No. 543), London, Au६zust 1941. pp. 257, 259.

- Slightly condensed and changed from the abstract of Water-Suppl - Paper 836 d.

272. Cooperative ground-water investigation in Massachusetts, by M. L. Brashears, Jr. New England Water Works Asso. Jour., vol. 56, No. 2, Boston, Mass., June 1942. pp. 152-156.

Describes the work, consisting of an inventory of wells and the collection of related information pertaining to ground-work conditions. Gives data on th? weekly measurement of ground-water level, with graphs for three groups of wells during 1939-41.

273. Cooperative ground-water investigation in Connecticut, by J. G. Ferris. New England Water Works Assoc. Jour., vol. 56, No. 2, Boston, Mass., June 1942. pp. 157-165.

Gives data on a study of ground-water conditions in the New Haven area, with graphs showing the relation between ground-water level, pumpage, and precipitation. Most of the ground water is from glacial drift. Increased pump ige for industrial uses has caused some increase in the infiltration of salt water.

274. Oil-field waters of W.yoming and their relation to geological formations, by J. G. Crawford. A. A. P. G. Bull., vol. 24, No. 7, July 1940. pp. 1214-1329.

A comprehensive paper containing a large number of representative water analyses. These show that the water that may have been present originally in the sediments has been washed out and circulation of surface-derived water is generally active. Discusses the general characteristics of water in the several imrortant oil-ibearing formations.

275. Oil-field waters of Montana plains, by J. G. Crawford. A. A. P. G. Bull.; vol. 26, No. 8, August 1942. pp. 1317-1374.

Presents and discusses tabular and graphic analyses of waters from the oil-producing and gas-producing zones of Montana. The analyses indicate that all these waters have been considerably modified by the infiltration of meteoric water.

276. Equipment for exploring wells, by P. P. Livingston. John $\approx o n$ Nat. Drillers' Jour., vol. 14, No. 4, St. Paul, Minn., July-August J942, pp. 10-13.

Describes the Au current meter, which is used for detecting leaks in artesian water wolls, and a power-driven winch designed for running tho instrument into and out of wells. Describes the pipe and valve assembly for testing flowing wells.

277. Recharge and discharge of the ground-water reservoirs on the High Plains in Texas, by W. L. Broadhurst. A. G. U. Trans., pt. 1, August 1942. pp. 9-15.

The principal ground-water reservoir is the Ogallala formation. which lies at or near the surface over most of the area. Recharge takes place through depression ponds, influent streams, and sandhill and upland areas. Discharge by pumping wells for irrigation has increased greatly since 1934 and has resulted in a general lowering of the water table of about 3 feet.

278. Recharge, movement, and discharge in the Edwards limestone reservoir, Texas, by A. N. Sayre and R. R. Bennett. A. G. U. Trans., pt. 1, August 1942. pp. 19-27.

"The Edwards limestone of Lower Cretaceous age is the princ"nal water-bearing formation in a belt 5 to 25 miles wide that extends from Austin southwest to San 
278. Recharge, movement, and discharge in the Edwards limestone reservoir, Texas-Continued.

Antonio and thence west through Uvalde and Del Rio to Comstock, a distance of about 250 miles." Briefly describes the geology, recharge, discharge, and movement of the ground water.

279. Recharge to ground water from floods in a typical desert wash, Pinal County, Ariz., by H. M. Babcock and E. M. Cușing. A. G. C. Trans., pt. 1, August 1942. pp. 49-56.

A discussion of recharge in the flood channel of Queen Creek, Pinal Ccunty, Ariz. The flow is almost entirely storm water, the stream bed usually being dry.

281. Modified Wheatstone bridge assembly for laboratory use and water-well exploration, by J. F. Poland and A. M. Piper. A. G. U. Trans., pt. 1, August 1942. pp. 87-94.

Gives description of the instrument and its use in ground-water studies.

282. Irrigation in northeastern Brazil, by G. A. Waring. Western Fngineering, vol. 1, No. 2, San Francisco, Calif., May 1912, pp. 97-1C5; vol. 1 No. 3, June 1912, pp. 185-194.

Describes various storage reservoirs projected and contains incidental reference to ground-water supplies.

283. Supprimento d'agua no nordeste do Brasil (water supply in northeastern Brazil), por G. A. Waring. Inspectoria Federal de Obras Contra as Seccas, Pub. No. 23, Rio de Janeiro, December 1912. 78 pp., 10 figs. (Second edition, February 1923.)

Chiefly a description of projects for storage reservoirs but also discusses subterranean water (pp. 60-65). Includes outline map and a graph of rainfall and stream discharge.

284. Reef formations of the northeast coast of Brazil, by G. A. Waring. Am. Jour. Sci., 4th ser., vol. 37 (whole No. 221), New Haven, Conn., May 1914. pp. $367-390,1$ pl.

Describes various reefs and lithified beaches and assigns the origin of some of them to ground water percolating seaward at about tide level. Mentions fresh-water springs along shore at about half-tide level.

285. Some features of the geology of northeastern Brazil, by G. A. Waring. Carnegie Mus. Annals, vol. 13, Pittsburgh, Pa. October 1920. pp. $183-223,7$ pls.

Contains information on springs (pp. 221-223).

286. The geology of the island of Trinidad, B. W. I., by G. A. Warin , with a chapter on the paleontology by G. D. Harris. Johns Hopkins Studies in Geology, No. 7, Baltimore, Md., 1926. 180 pp., 20 pls.

Contains incidental references to ground water. Geologic map shows the swamps and other lowland areas of shallow ground water, alluvial outwash slopes of abundant ground water, and limestone areas of the Northern Range, from which several large springs issue.

287. Geologic reconnaissance of a region adjacent to Guantanamo Bay, Cuba, by 0 . E. Meinzer. Wash. Acad. Sci. Jour., vol. 23, No. 5, May 15, 1933. pp. 246-263.

Describes the several geologic formations and the physical character of the strata. Geologic map (fig. 1) shows six formations. These include extensive lowlend deposits of marine and delta clay, sand, and gravel and also valley alluvial grevel. These unconsolidated deposits are of Recent age and contain much shallow ground water.

288. Durchflussmenge und physikalische Erscheinungen in naturlichen und kunstlichen Bodenschichten, von L. K. Wenzel (original title, Determination of run-off and physical conditions of the flow of und?rground water in natural or in altered ground, the flow being natural or induced; translated into German by G. Thiem). Gas- und Wasserfacl . vol. 83, Berlin, 1940. pp. 150-153. 
288. Durchfiussmenge und physikalische Erscheinungen in naturlichen und kunstlichen Bodenschichten-Continued.

Publication in German of a paper presented at the meeting of the International Association of Scientific Hydrology, September 1939. The paper summarizes reports relating to the movements of ground water submitted for presentation at the Washingon meeting of the Internaional Union of Geodesy and Geophryics, September 1939, by authors from Belgium, Denmark, France, Germany, the Netherlands, Poland, Tunisia, and the United States.

289. Notes on the geology and hydrology of St. Croix, Virgin Islands, by D. J. Cederstrom. Am. Jour. Sci., vol. 239, No. 8, New Faven, Conn., August 1941. pp. 553-576; abstr. in G. S. A. Bull., vol. 51, No, 12, pt, 2, December 1940, p. 1992.

A summary of the results of field work, and information obtained by test drilling. The island is composed largely of volcanic and sedimentary rocks of Cretaceous age, strongly folded, intruded by dioritic magmas, and overlain by clay and marl of Oligocene and Mlocene age. The Tertiary rocks have been gently fclded along westward-southwestward trending axes. Oscillations in sea level producrd alluvium-filled valleys, alluvial terraces, raised beaches, and coral reefs. Groun ${ }^{\prime}$ water can be obtained in moderate quantities from the old rocks, the Tertiary marls, and the alluvium. The alluvium is the most promising source for additiona' water supplies. The cause of well failures and the source of mineralization of the water are discussed.

290. A review of the States' cooperation and need for further croperation in ground-water observation and investigation, by S. F. Trwner. Assoc. Western State Eng. Proc., 14th Ann. Conv., Phoenix, Ariz., October 14, 1941. pp. $78-86$.

Describes the various types of investigations made by the Division of Ground Water, United States Geological Survey, and the investigations that are under way in Arizona. Briefly discusses the projects in other western States, with special reference to the needs for expansion.

291. Ground-water studies in the Southwest, by O. E. Meinzer. A. G. U. Trans., pt. 1, August 1942. pp. 6-9.

Contains a brief discussion af each of the ground-water provine?s in the Southwest and states that investigations are in progress in all of them. Fmphasizes that the outstanding feature of the ground water is the great amo'nt of hold-over storage, which is drawn upon when pumping exceeds recharge, and that depletion is manifested in the lowering of water levels and by salt-water encroachment.

293. Deep-seated solution in the Meade Basin and vicinity, Kansas and Oklahoma, by J. C. Frye and S. L. Schoff. A. G. U. Trans,, pt, 1, August 1942. pp. 35-39.

Describes the abundant depressions resembling sinkholes. Concludes that they are formed chiefly by solution of beds of salt and anhydrite at depths of 500 to 1,000 feet or more below the surface and by deep-seated circulation of water from the artesian basin and that this circulation was made possible by late Pliocene faults.

294. Results of pumping tests of the Carrizo sand in the Lufkin area, Texas, by W. F. Guyton. A. G. U. Trans., pt. 1, August 1942. pp. 40-48.

The coefficients of transmissibility and storage determined from rumping tests by means of Thiem's formula and Theis' nonequilibrium formula were in close agreement and may be used to estimate future drawdowns of water levels in the area.

295. Progressive down-dip changes in composition in artesian waters from the Cretaceous rocks of Virginia, by D. J. Cederstrom. Wash. Acad. Sci. Jour., vol. 32, No. 9, Sept. 15, 1942 . pp. 280-281.

There is progressive increase of mineralization east of the Fall Zone and softening by base exchange. Carbon dioxide that is liberated in the sediments causes excessively high bicarbonate content. Some of the carbon dioxide may result from the breakdown of sulfate. The origin of fluoride in the waters is also discussed.

296. Chemical composition of salty ground waters along the Atlantic and Gulf coasts, by M. D. Foster. Wash. Acad. Sci. Jour., vol. 32. No. 9, Sept. 15, 1942. pp. 282-283.

The waters do not seem to be simple mixtures of gxound water vith sea waters. 
296. Chemical composition of salty ground waters along the Atlantic and Gulf coasts-Continued.

They are lower in calcium, magnesium, and sulfate and higher in sodium, suggesting that the waters have undergone base exchange and reduction of sulfate. The indicated replacement of magnesium and calcium by sodium suggests that these base minerals are not in equilibrium with present-day sea water or with salty waters formed by its admixture with fresh ground water in which sodium carbcnate is the predominant constituent.

297. Differential density of ground water in ore deposition, by D. J. Cederstrom. Econ. Geol., vol. 37, No. 6, September-October 1942. p. 524.

Comments on a paper by J. S. Brown on the same subject (Econ. Genl., vol. 37, No. 4, July 1942, pp. 310-317) and suggests tests of his theory of the enrichment of ore deposits below the water table.

298. Remarks on hydrologic terminology (discussion), by O. E. Meiาzer. A. G. U. Trans., pt. 2, November 1942. pp. 479-482.

Concerns the important concept that is expressed by different authors br the terms loss, evaporative loss, evaporation, evaporation and transpiration, evapo-transpiration, consumptive use, or fly-off. Considers that it might be well to adopt the lastnamed term, as it is a short, simple term correlative to runoff.

299. An experiment on flow through a capillary tube (discussion), by C. E. Jacob and O. E. Meinzer. A. G. U. Trans., pt. 2, November 1942. pp. 534-538.

Discussion of a paper by R. E. Horton, who deseribes the experiment and coneludes that net or effective capillary head should be used in applying Darcy's law. Discussion by Jacob and Meinzer show that in the experiment the water moved in accordance with Darcy's law.

300. Ground water-a vital national resource, by 0 . E. Meinzer. A.W.W. Assoc. Jour., vol. 34, No. 11, November 1942. pp. 1595-1605.

The fundamental fact about ground water is that it occurs in great widespread subterranean reservoirs, many of which have large storage capacities. Though irregular and intricate in their construction, they can be accurately mapped, and their structure can be determined. Their hydraulics are also intricate with respect to the intake, head, movement, storage, and discharge of their waters, and involve prineiples of physics which have little or no significance in the hydraulics of surface water. The waters of these reservoirs, however, obey rigorously the laws of fluid mechanics. and within limitations imposed by the irregularities of the rock formations and of the weather it is possible to determine their annual recharge, perennial yield, and storage capacities. Moreover, the efficient and beneficial operation of this reservoirs can be accomplished by the practical application of the knowledge developed by these scientific methods of investigation.

301. Chemical character of public water supplies in southeastern Flıida, by S. K. Love and H. A. Swenson. A. W. W. Assoc. Jour., vol. 34, No. 11, November 1942. pp. 1624-1628.

Gives analyses of water samples from 25 public supplies in six countier. Fighteen of these supplies are pumped from wells in limestone. The hardness of each supply is shown graphically on an outline map.

302. Ground water and its relation to Louisiana's war effort, by J. C. Maher. Louisiana Conservationist, vol. 1, No. 3, New Orleans, J Ja., February 1943. pp. 7, 8.

Describes the uses of ground water in Louisiana and lists the work in progress and the work accomplished by the Louisiana State Geological Survey in cooperation with the United States Geological Survey.

303. Water supplies and Louisiana's war effort, by J. C. Maher. J.ouisiana Municipal Review, vol. 6, No. 1, New Orleans, La., January-February 1943. pp. 8, 9 .

Presents a short discussion of the water supplies developed at 16 miltary establishments and war industry plants in the State. 
304. Substantial replenishment creates generally favorable outlonk for groundwater supplies, by L. K. Wenzel. The Illinois Well Driller, vol. 13, No. 1, Urbana, Ill., February 1943. p. 8.

Describes the network of observation wells measured by the United States Geological Survey and states that water levels have risen generally during 1942 . Points out that the rate of recharge varies greatly with the character of the water-bearing formations.

305. Summary and review of ground-water levels in Louisians during 1942, by J. C. Maher. Louisiana Conservationist, vol. 1, No. 4, New Orleans, La., March 1943. pp. 1, 5.

Describes the coopexative program of ground-water observations and discusses water levels and artesian pressure in various parts of the State. Presents maps showing location of observation wells, and the observation wells and chloride content of waters in New Orleans.

306. Notes on the early history of water-well drilling in the United States, by C. W. Carlston. Econ. Geol., vol. 38, No. 2, March-April 1943. pp. 119-136.

Describes developments in methods, from the successful complation of the first well drilled for brine near Charleston, West Virginia, in 1808 to the invention of the process of jetting wells in 1884 .

307. Report of the Committee on Ground Water, 1942-1943, by ऽ. W. Lohman. A. G. U. Trans., pt. 2, January 1944. pp. 409-417.

Gives a summary of the work of the committee of 16 persons and of important papers issued during the year.

308. The work of the International Commission on Subterranear Water in the Western Hemisphere: Appendix A, Report of the Committee on Ground Water, by O. E. Meinzer. A. G. U. Trans., pt. 2, January 1944. p. 418.

A summary of the work of the commission during the year, including appointment of representatives to Central and South America under the Coordinator of InterAmerican Affairs.

309. The work of the Geological Survey and cooperating State agencies on ground water for war purposes: Appendix B, Report of the Committee on Ground Water, by O. E. Meinzer. A. G. U. Trans., pt. 2, January 1944. pp. 418-420.

A summary of the work of members of the United States Geolcgical Survey and other agencies in aiding the development of ground-water supplies for war plants and other industries and establishments connected with the war eff $n$ rt.

310. Report on research in the field of ground water being conducted by oil companies: Appendix C, Report of the Committee on Ground Water, by N. A. Rose. A. G. U. Trans., pt. 2, January 1944. Fn. 420, 421.

Calls attention to the similarity of some problems of the petroleum engineer and of the ground-water hydrologist and gives specific examples.

311. A method for determining transmissibility and storage coefficients by tests of multiple well systems, by L. K. Wenzel and A . L. Greenlee. A. G. U. Trans., pt. 2, January 1944. pp. 547-560.

A mathematical consideration of quantitative methods and the use of the nonequilibrium formula, with discussion by M. K. Hubbert, C. V. Theis, and the authors (pp. 560-564).

312. Correlation of ground-water levels and precipitation on Long Island, N. Y., part 1, Theory, by C. E. Jacob. A. G. U. Trans., pt. 2, January 1944. pp. 564-573.

A mathematical discussion of the theory of movement of gro'ind water and a short discussion of correlation of data. (For part 2 see Journal article 341.) Also reprinted with same paging in New York Dept. Conserv., Water Power and Control Comm., Bull. G-14, Albany, N. Y., 1945. 
313. A frequency method af evaluating ground-water levels, by L. O. Huff. A. G. U. Trans., pt. 2, January 1944. pp. 573-580.

Suggests a statistical method of evaluating ground-water levels, by which the levels are treated in terms of the frequency of their occurrence. Presents three graphs' illustrating the method.

314. The work of geologists on water supplies for war purposes, by $\mathbf{0}$. E. Meinzer. Econ. Geol., vol. 38, No. 4, June-July 1943 . pp. $32^{n}-324$,

A summary of work being done in the prosecution of the war by geologists trained in hydrology.

315. Natural waters available for industrial use, by W. D. Collins. C'em. and Eng. News, vol. 21, No. 13, Easton, Pa., July 10, 1943. pp. 10?2-1065.

Discusses the three general classes of natural waters-soft, hard, and saltand their distribution in the United States. Gives typical analyses of surface and ground waters.

316. Summary of ground-water conditions in Jeff Davis and Acadia Parishes, La., by J. C. Maher. Louisiana Conservationist, vol. 1, No. 8, New Orleans, La., August 1943. pp. 4, 7.

Gives a general discussion of ground-water supplies, the amounts pumped for irrigation, and the encroachment of salt water in some areas.

317. Ground water and the relation of geology to its occurrence in the Houston district, Texas, by N. A. Rose. A. A. P. G. Bull., vol. 27, No. 8, August 1943. pp. 1081-1101.

The geologic formations from which the Houston district obtains its water supply consist of interbedded clay, sand, and gravel of Miocene, Pliocene, and Pleistocene ages. The pumpage increased greatly during 1937-41 and caused marked decline in water levels. The quality of ground water compares favorably with oth $э$ r supplies in the United States. Exploratory drilling shows that additional supplies are available west and northwest of Houston and that salt-water encroachment from down the dip is not likely to occur for many years.

318. Saline contamination of coastal ground water in southern California, by J. F. Poland. Western City, vol. 19, No. 10, Los Angeles, Cal`f., October 1943. pp. $46,48,50$.

Describes the character of the unconsolidated water-bearing deposits ${ }^{f}$ the area and discusses the contamination in certain places by encroachment of salt water from the ocean.

319. Additional notes on the geology and ground water of southern Florida, by G. G. Parker and N. D. Hoy. Soil Science Society of Florida Proc., vol. 5-A, Gainesville, Fla., March 1943. pp. 33-55.

Discusses the geologic history of the area and the characteristics of the several formations, based on 15 test wells 20 to 97 feet deep in the Everglades. Includes a small map showing direction of surficial drainage in southern Florida.

320. Replenishment of underground reservoirs, by L. K. Wenzel. Th? nlinois Well Driller, vol. 14, No. 2, Urbana, Ill., February 1944. p. 7.

A brief discussion of the principles of ground-water recharge with reference to water-table conditions.

321. Ground-water investigations in Florida (with special reference to Duval and Nassau Counties) by H. H. Cooper, Jr. A. W. W. Assoc. Jour., vol. 36, No. 2, February 1944. pp. 169-185.

States that the principal source of water is a thickness of 800 feet $\mathrm{cr}$ more of permeable limestone of Eocene age, consisting of the Ocala limestone and deeper beds. Describes the geologic formations and discusses the quality of wrter, areas of recharge and discharge, storage and transmissibility, cones of depression, waterlevel records, and salt-water encroachment.

322. Municipal and industrial ground-water supplies in Tidewater Vir rinia, by D. J. Cederstrom. Virginia Municipal Rev., vol. 21, No. 4, R:shmond, Va., April 1944. pp. 65-66.

A short summary of the ground-water supplies available for municipql and industrial uses. 
323. The ground-water supply at Louisville, Kentucky, by-W. T. Stuart The Kentucky Eng., vol. 6, No. 3, Louisville, Ky. May 1944. $I^{\text {n. 18-2z. }}$

States that ground-water supplies are obtained from glacial ortwash gravel in the valley of the Ohio River and that recharge takes place of infil -ation from this river. Concludes that some areas are pumped too heavily. Contairs maps showing contours on the bedrock and on the ground-water table and hydrographs showing pumpage and drawdown in wells.

324. Ground-water geologist warns against water diviners, by 0 . E. Meinzer. Water Works Eng., vol. 97, N.o. 11, May 31, 1944. p. 5 r1.

Comments on an article by Eric Hardy entitled "Water diviners officially recognized by British Army" (Water Works Eng., vol. 97, No. 7, A pr. 5, 1944. pp. 340, 361). Mentions correspondence with A. Beeby Thompson and others indicating that diviners were not used, or used only in a few instances.

325. Variations in chemical composition of Los Angeles Basin ground waters (discussion), by J. F. Poland. Econ. Geol., vol. 39, No. 4, June-July 1944. pp. 315-318.

Discusses a paper entitled "The nature and significance of certain variations in composition of Los Angeles Basin ground waters," by R. B. Morse (Econ. Geol., vol. 38, No. 6, September-October 1943, pp. 475-511). Attention is called to the fact that carbonaceous deposits, which are locally abundant, are a probable cause of base exchange in the Long Beach area and that the naturally softened waters are almost universally darkened by organic matter.

326. Some field applications of water transmissibility and storare coefficients, by R. G. Kazmann. Agr. Eng., vol. 25, No. 8, Dallas, Tex., August 1944.. pp. 299-300, 304.

Gives definitions and a brief history of determinations of transmissibility and storage coefficients and discusses tests made in three localities. States that the storage coefficients obtained were used to determine source of water supply, quantity available, and minimum yield to be expected from a well field unde" certain assumed conditions of operation.

327. Protection of ground-water supplies-conservation of gro'nd water, by O. E. Meinzer. Johnson Nat. Drillers' Jour., vol. 16, Nค. 5, St. Paul, Minn., September-October 1944. pp. 10-14.

Discusses the large amount of ground water used for municipal supplies and the great development of irrigation in the Western States. Says that the increase is due to several causes, including improved methods of constructing wells, improved pumping equipment, and improved methods of removing iron, manganese, and the hardening constituents. Emphasizes the need for careful development to avoid contamination by salt water in some areas and to avoid serious depletion in .others.

328. North Dakota's ground-water problem, by A. L. Greenlee. North Dakota Water and Sewage Works Conference Bull., vol. 12, Nc. 6, Bismarck, 'N. Dak., December 1944. pp. 3, 4.

Briefly discusses the principal geologic and hydrologic divisions of North Dakota and describes the necessity for State-wide investigation of ground-water resources.

329. Ground-water studies in northeastern Massachusetts, by M. L. Brashears, Jr. New England W. W. Assoc. Jour., vol. 58, No. 4, Boston, Mass., December 1944. pp. 307-316.

Discusses the cooperative studies being made. States that wat prevels declined during 1940-44 due to deficient precipitation but are expected to recover when the precipitation increases.

330. Depleted wells at Louisville (Ky.) recharged with city waters, by W. F. Guyton, with foreword by 0. E. Meinzer. Water Work Eng., vol. 98, No. 1, Jan. 10, 1945. pp. 18-20.

Describes the geologic conditions at Louisville, which make, artificial recharge of the ground-water reservoir practicable, and discusses, the resul' of recharge as practiced at three industrial plants. Suggests recharge of groun-water reservoirs with cold eity water during winter as a practicable means of en ruiring cold water throughout the year for industrial uses. 
331. Ground water and geologic structure of Natchitoches area; La., by J. C. Maher and' P. H. Jones. A. A. P. G. Bull, vol, 29, No, 1, Janvary 1945, pp. 23-44.

The municipal water supply of the city of Natchitoches has been obtained from shallow wells in the Wilcox formation, but the supply has been gradualiy depleted, Nine exploratory test. wells have shown. that abundant supplies; of soft water can be obtained 'from the Sparta sand and sands of the Wilcox formation źnutheast of the city.

332. Structural geology of southeastern Virginia, by D. J. Cederstrom. A. A. P. G. Bull., vol. 29, No. 1, January 1945. pp. 71-95.

Upper, Cretaceous deposits are widely distributed south of the James River but seem to be absent immediately north of the river. This condition is ascribed to pre-Hocerte channeling. There are Eocene deposits some distance north of the river, where the land is believed to have subsided throughout Eocene time.'Snbsidence is accounted for by faulting of the basement rock, the maximum displacement along the postuiated fault being 800 to 600 feet in the Hampton Roads area.

333. Recharge to water-bearing formations along the Ohio Valley, by R. M. Jeffords. A. W. W. Assoc. Jour., vol. 37, No. 2, February 1945. pp. 144-154.

The alluvial deposits in the valley furnish large supplies to many public water systems and industrial plants. Recharge is in part by infiltration from the river and is indicated by the temperature and chemical character of well vater. This recharge is of great importance in some localities.

334. Ground-water problems in North Carolina, by M. J. Mundorff. A. W. W. Assoc. Jour., vol. 37, No. 2, February 1945. pp. 155-160.

Discusses the character of water-bearing rocks in the mountain ant piedmont areas as contrasted with those in the Coastal Plain. Describes the quality of the water in the different formations.

335. Ground-water investigations in Pennsylvania, by G. H. Ashley and J. B. Graham. A. W. W. Assoc: Jour.; vol. 37, No. 2, February 1945. pp. 161-164.

- A general discussion of the occurrence of ground water in Pennsylvania and an account of reconnaissance investigations in 1925-35. States that in 1943 money was made available for beginning a detailed study of the ground-wate $x$ resources of the State. See also cooperative reports 341-346, 349 .

336. Water for the invasion of Saipan, by H. T. Stearns. Military Eng., vol. 37, No. 233, Washington, D. C., March 1945. pp. 96-98...

Briefly describes the sources of water used for the invasion of Sainan. States that a number of the Japanese wells were taken over and repaired and additional wells were put down. Says that drive points were used on the beaches in the early stages of the ipvasion and that later springs and irrigation wells were cleaned out and used.

337. Relation of phenomenal rise of water levels to a defective gas well, Harris County, Tex., by N. A. Rose and W. H. Alexander, Jr. A. A. P. G. Bull., vol. 29, No. 3, March 1945. pp. 253-279.

Water levels in wells throughout the Houston district have declined since 1987. owing to increased pumping. In an area about 25 miles long and 10 miles wide north and northeast of Houston the water level has risen since Decembar 1, 1942. This condition is ascribed to leakage of several million cubic feet of gas a day from a gas well into the water-bearing sands.

338. Ground-water supplies not in danger of exhaustion except in certain areas of heavy pumping, by V. T. Stringfield. Cast Iron Pive News, vol. 9, No. 2, Chicago, Ill., April 1945. pp. 16-21.

Summarizes the conditions that produce artesian wells. Discusses with frawal and recharge of water, waste of artesian water, and the need for detailed irvestigation of ground-water supplies. Concludes that in areas where ground-water levels are not affected by artificial withdrawal the water table normally fluctuates through an annual range and also in longer cycles that correlate with cycles of wet and dry years. 
339. Legal control of use of ground water, by C. L. McGuinness. Water Works Eng., vol. 98, No. 9, May 2, 1945. pp. 475, 508-512.

States that the principle of prior appropriation will promote to the greatest extent the orderly and effective development of the ground-water supplies. Reviews the water-right doctrines as applied to the Western States and the laws to control waste from artesian wells.

340. Report of the Committee on Ground Water, 1943-44, by S. W. Lohman. A. G. U. Trans., pt. 5, May 1945. pp. 712-721.

Summarizes the activities of the committee of 16 members and gives short statoments concerning important ground-water studies being carried on in various parts of the United States.

341. Correlation of ground-water levels and precipitation on Long Island, N. Y., part 2, Correlation of data, by C. E. Jacob. A. G. U. Trans., pt. 6, May 1945. pp. 929-939.

Gives data on 14 shallow test wells and presents a map of Long Island showing configuration of main ground-water table. Gives graphic well records of the fluctuation of the water level. (For part 1 see Journal article 312.) Also reprinted with same paging in New York Dept. Conserv., Water Power and Control Comm., Bull. G-14, Albany, N. Y., 1945.

342. Well discharge, a method of computing the quantity of water derived from storage within a given radius of a discharging well, by $L$. $K$. Wenzel and R. G. Kazmann. A. G. U. Trans., pt. 6, May 1945 . pp. 940-944.

A mathematical consideration of the formulas that are used to determine the coefficients of storage and transmissibility of water-bearing meterials and to determine the drawdown of the ground-water level caused by the discharge of a well or group of wells, with a discussion (pp. 944-951) by C. E. Jacob, W. F. Guyton, and R. G. Kazmann.

343. Cation exchange in ground water contaminated with sea water near Miami, Fla., by S. K. Love. A. G. U. Trans., pt. 6, May 1945. pp. 951-955.

The composition of the ground water contaminated by sea water differs considerably from the composition of simple mixtures of ground water and sea water. The differences can be explained as being due to cation exchange. The concentration of calcium is larger and of magnesium and sodium smaller than is required by computed analysis of mixture of the waters. Analyses of samples of the contaminated ground water that are presented suggest that soil colloids may be involved in the chemical changes.

344. Problems of the perennial yield of artesian aquifers, by O. E. Meinzer. Econ. Geol., vol. 40, No. 3, May 1945. pp. 159-163.

Calls attention to the sharp distinction between typical phreatic, or water-table conditions, and typical piestic, 'or artesian conditions. Reviews early studies of the hydraulic of wells and describes experimental work of recent years. States that the present view is that water delivered from an artesian aquifer $l$ as come first from the aquifer itself and later in larger volume from the associated clay and silt beds. Therefore there has been relatively little compression of the aquifor and hence little reduction in its permeability.

345. Ground-water exploration at Alexandria, La., by J. C. $\Lambda^{\top}$ aher and P. H. Jones.' Econ. Geol., vol. 40, No. 3, May 1945. pp. 164-182.

Serious overdevelopment of the ground-water supply in Alexindria and vicinity necessitated the development of additional supplies in the Brvou Rapides area, about 6 miles northwest of Alexandria. Exploratory work was $f$ st done. including the drilling of 6 test holes. The principal fresh-water sands are at depths of 150 to 970 feet, in Miocene deposits. Brackish or salt water is found at a minimum depth of 1,100 feet.

346. Geologic factors affecting the perennial yield of artesian aquifers in three areas in Mississippi, by G. F. Brown. Econ. Geol., vol. 40, No. 3. May 1945. pp. 183-192.

The water supply for Camp McCain comes from a basal sand of the Claiborne group and a deeper sand of the Wilcox formation; that for Carn Van Dorn comes 
346. Geologic factors affecting the perennial yield of artesian aquifers in three areas in Mississippi-Continued.

from four aquifers within Miocene deltaic deposits; and that for Camp Shelby comes from wells in sand lenses of the Hattiesburg formation. See also Cooperatixe reports 192,193 , and 194.

347. Quantitative studies of some artesian aquifers in Texas, by W. F. Guyton and N. A. Rose. Econ. Geol., vol. 40, No. 3, May 1945. pp. 193-226.

The most reliable index of the quantity of water a formation will yield has heretofore been considered to be the correlation of pumpage with water levels in wells. Under new methods, pumping tests establish the equation of a water-level drawdown curve for a short period of time; by means of the equation the curve can then be extended over a longer period. Pumping tests made for this purpose at six places in Texas are briefly described.

348. Salt-water encroachment in southern Florida, by G. G. Parker. A. W. W. Assoc. Jour., vol. 37, No. 6, June 1945. pp. 526-542.

Briefly describes the geology and ground-water conditions and discusse in detail the encroachment of salt water at Miami, Miami Beach, and Coral Gables. See also Cooperative report 63 .

349. Conservation of ground water in the Louisville area, Ky., by W. F. Guyton. A. W. W. Assoc. Jour., vol. 37, No. 6, June 1945. pp. 543-562.

Deseribes the filled valley of the Ohio River. Gives data on water punpage and yield of wells and discusses emergency recharge during 1944. Outlines plans for future conservation of ground water. Includes map of the Louisville are? showing contours on the water table. See also Cooperative reports $160 \mathrm{~d}$ and $160 \mathrm{e}$.

350. Ground-water problems in New Jersey, by H. C. Barksdale. A. W. W. Assoc. Jour., vol. 37, No. 6, June 1945. pp. 563-568.

A short discussion of the safe yield from wells, salt-water intrusion and the need for legal regulation of pumping.

351. Effect of air-conditioning demand on the well water availability, by V. T. Stringfield. Heating and Ventilating, vol. 42, No. 6, New Yor', N. Y, June 1945. pp. 61-66.

A summary of the temperature and chemical composition of ground water in the United States and discussion of the occurrence, available quantity of ground water, the effects of overdraft, and possible additional supplies in some areas.

352. Salt-water encroachment in limestone at Silver Bluff, Miami, Fla., by R. H. Brown and G. G. Parker. Econ. Geol., vol. 40, No. 4, June-July 1945. pp. 235-262.

Silver Bluff is part of a coastal ridge that has an average height of about 8 feet above sea level. It is composed of oolitic limestone underlain by erral limestone and calcareous sandstone. Drainage canals have lowered the originel grouniwater level and allowed salt water to eneroach inland 8,000 to 9,000 feet. A balance between fresh and salt water seems to be established for a zone between the shore and about 2,500 feet inland. Farther inland the balance has not yet been attained.

353. The perennial yield of artesian water in the coastal area of Georgia and northeastern Florida, by H. H. Cooper, Jr., and M. A. Warren. Econ. Geol., vol. 40, No. 4, June-July 1945. pp. 263-282.

Heavy withdrawat of artesian water has created large cones of depiession at Savannah and Fernandina and smaller cones at Jacksonville and Brunswick. However, large additional supplies can be developed in most parts of the area if the new well flelds are located at sufficient distances from existing ones and the lcwer parts of the water-bearing limestones are not developed too extensively.

354. Ground-water geology of Camp Polk and North Camp Polk, La., by J. C. Maher. A. A. P. G. Bull., vol. 29, No. 8, August 1945. pp. 1169-1188.

The area is underlain by poorly consolidated, fluviatile, and brackish-xater sediments of Miocene age. The four most important water-bearing sands are at depths of 600 to 1,450 feet. The combined pumpage of the two camps is several million gallons a day. 


\section{Ground water in the Baltimore area (Md.), by R. R. Bennett. Baltimore} Engineer, vol. 20, No. 3, September 1945. pp. 1-7.

Gives a review of ground-water development in the area and deroribes the several water-bearing formations. Diseusses inerease of pumpage, decline of the water levels, and intrusion of salt-water. States that the determination of safe yield of the waterbearing formations is complicated by several factors and must arvait the collection of detailed information by test drilling and by pumping tests.

356. Ground-water-levels in West Virginia, by R. M. Jeffords. West Virginia Engineer, vol. 7, No. 9, Morgantown, W. Va., September 1945. pp. 6-11.

Describes the growth of the observation-well program in West Virginia, gives table showing net changes in water level in 32 typical wells in 1944, an presents graphs of water-table fluctuations at three localities from January 1943 to June 1945, inclusive. Summarizes the highest and lowest recorded ground-water levels and waterlevel conditions during 1944.

357. Water for secondary recovery of petroleum in West Virrinia by $\mathbf{R}$. $M$. Jeffords. Producers' Monthly, vol. .9, No. 10, Bradford, Pa., October 1945. pp. 14-18.

Describes the available surface-water and ground-water supplies and discusses their chemical quality. Concludes that large supplies of water are available but that careful consideration should be given to the chemical character of water used for injection to prevent reaction with the natural brine to form insoluble compounds that would seal off the injection wells.

358. Ground-water report for Philadelphia area (Pa.), by T. B. Graham. Commonwealth of Pennsylvania, Dept. of Internal Affairs, Monthly Bull., vol. 13, No. 11, Harrisburg, Pa., October 1945. pp. 15-17.

States that during the war period the summer production from wells in the southern part of the city was about 30 million gallons a day. Fiscusses the local recharge and possibilities of new developments.

359. General principles of artificial ground-water recharge, by 0 . E. Meinzer. Econ. Geol., vol. 41, No. 3, May 1946. pp. 191-201; : Estr. in Econ, Geol., vol. 40, No. 1, January-February 1945. pp. 90.91.

This is the flrst of a series of five papers on artificial recharge prepared as a symposium on the subject. The full utilization of natural subterranean reservoirs of water requires systematic development based on geology and hydrology and the principles of hydraulics. In an artesian aquifer geologic study with test drilling is needed to determine the intake area and its structural relations to the pumped wells. Artiflcial recharge requires an effective process for-getting surface watex into the saturated part of the aquifer.

is il

360. Artificial recharge of productive ground-water aquifers in New: Jersey, by H. C. Barksdale and G. D. DeBuchananne. Al otr. in Econ. Geol., vol. 40, No. 1, January-February 1945. p. 78.

Artiflcial recharge by water spreading is practiced in several places in New Jérsey. At the Perth Amboy Water Works such recharge has be?n carried on for more than 30 years. The eity of East Orange spreads the water $f$ "om several small streams over the area supplying its wells. In some places well sites are chosen to take advantage of potential recharge from bodies of surface watex.

361. Artificial recharge of ground water on Long Island, $\mathbf{N}$. Y., by $\cdot \mathbf{M}$. L. Brashears, Jr. Econ. Geol., vol. 41; No. 5, August :1946. pp. 503-516; abstr. in Econ. Geol., vol. 40, No. 1, January-February 1945. p. 79,

During the summer of 1944 more than 200 recharge wells and several recharge pits on Long Island returned water to underground storage at the rate of 60 million gallons a day. The water is returned to glacial deposits of sand and gravel from which most of it was pumped. In many places the water table is far below sea level, and sea water continues to move inland in areas of heavy pumping, , ,

362. Artificial recharge of glacial sand and gravel with cold filtered river water at Louisville, Ky., by W. F. Guyton. Abstr. in Econ. Geol., vol. 40, No. 1, January-February 1945. pp. 85-86.

Industrial plants at Louisville pumped about 62 million gallons of water a day from wells in 1943, which resulted in the serious decline of wat we lotels. The res. 
362. Artificial recharge of glacial sand and gravel with cold filtered river water at Louisville, Ky.-Continued.

charge has been increased about 2 million gallons a day by introducing city water into the aquifer through wells in winter. This makes an ample supply of cool water available from the wells during the summer when the city water becomes too warm to be used in certain' plants.

363. Artificial recharge of artesian limestone at Orlando, Fla., by A. G. Unklesbay and H. H. Cooper, Jr. Abstr. in Econ. Geol., vol. 40, No. 1, January-February 1945, p. 95.

The principal aquifer at Orlando consists of about 900 feet of permeable limestone of Eocene age overlain by relatively impervious beds. Owing to the lack of adequate surface drainage, more than 175 wells have been drilled into $t+a$ limestone to drain streets, control lake levels, and dispose of sewage.

364. Work of the United States Geological Survey on ground-water supplies for war purposes in the United States, by C. L. McGuinness. Abstr. in Econ. Geol., vol. 40, No. 1, January-February 1945. p. 90.

Pumpage of ground water for public supply in the United States was greatly accelerated after the beginning of the war in Europe. Large ground-water supplies were aiso developed for military and haval establishments. The techniral staff of the Geological Survey engaged in ground-water investigations has mad: many examinations and prepared more than 3,000 reports on ground water for war purposes.

365. The effect of the Pleistocene epoch on the geology and ground water of southern Florida, by G: G. Parker. Florida Academy of Science Quart. Jour., vol. 8, No. 2, Miami, Fla., 1945. pp. 119-143.

Staies that southern Florida emerged from the sea in late Pliocens time. Describes the geologic history during the several -glacial and interglacial ages. Says that the Tamiami formation is the most important aquifer but that the Pamlico sand, Anastasia formation, and Miami colite are drawn upon for shallow well supplies. Includes map of the Everglades drainage district showing contours on top of the Pliocene rocks.

366. Military water supply, by A. N. Sayre. Abstr. in G. S. A. Bul ., vol. 56, No. 12, pt. 2, December 1945. p. 1193 .

The trained ground-water geologist can render important service to the armed forces by providing water-supply intelligence for planning on the operational and on the strategic levels and by acting as field adviser to the engineer trops charged with supplying water. He can also be helpful as a consultant to the construction engineers during the operations by locating well sites, evaluating springs and stream supplies, and advising or instructing troops on methods of well construction, development, and pumping.

367. Hydrology in relation to economic geology, by O. E. Meinzer. Econ. Geol., vol. 41, No. 1, January-February 1946 . pp. 1-12.

Address of president of the Society of Economic Geologists deliver?d at Pittsburgh, Pa., December 27, 1945. Discusses the broad aspects of the science of hydrology, the geologic controls in hydrology, and the hydrologic controls in geology. Describes the scope and prospects of economic geology and its relation to engineering. States that hydrology is involved in economic geology in thre? important respects-as an agency in the genesis of most important mineral and rock products of economic value; as a factor in most of the geologic problems of earth construction: and as dealing with a uniquely important mineral produc.. Concludes with a discussion of water considered as a mineral.

368. Military water supplies in the southwest Pacific area, by A. N. Sayre. Am. Soc. Civil Eng. Proc., in press.

Presented at annual meeting of the American Society of Civil Engin sers in New' York, N. Y., January 17, 1946. States that combat supplies for each soldier were one-half to 1 gallon a day, bivouac supplies 1 to 5 gallons a day, an temporary camp supplies 5 to 15 gallons a day. In humid regions supplies were obtained from streams and shallow wells, but in arid regions pipe lines were often extended many miles from available supplies. Describes distillation units used on same of the small Pacific islands where no fresh water was available. Discusses chlorination 
368. Military water supplies in the southwest Pacific area-Continued.

and other means used for purifying water supplies. Emphasizes the need for advance information on water supplies in the strategic planning of military operations. Summarizes the work of geologists and engineers in developing water supplies in various areas of military activity.

369. Pumping tests conducted at Kansas City, Kans., by. the Corps of Engineers, U. S. Army, by V.. C. Fishel. A. G. U. Trans. 1944, pt. 5, appen$\operatorname{dix}$ E, Report of the Committee on Ground Water, April 1945. p. 724.

Summarizes pumping tests that were made on a well near tha Missouri River. the water level being checked by readings on 38 nearby observation wells.

370. Ground-water studies in Central America, by A. N. Sayre. A. G. U. Trans. 1944, pt. 5, appendix F, Report of the Commit'ee on Ground Water, April 1945. pp. 724-725.

Summarizes studies that were carried on during 1943 to obtain satisfactory water supplies for 35 eities in El Salvador.

371. List of current publications concerning ground water, by J. M. Berdan. A. G. U. Trans. 1944, pt. 5, appendix H, Report of the Committee on Ground Water, April 1945. pp. 728-734.

A list of 172 titles of articles relating to ground water published during 1939-44.

372. A graphic procedure in the geochemical interpretation of vater analyses, by A. M. Piper. A. G. U. Trans. 1944, pt. 6, May 1945. pp. 914-923.

“This paper outlines certain fundamental principles in a graphic procedure which appears to be an effective tool in segregating analytical data for critical study with rezpect to sources of the dissolved constituents in waters, modifications in the character of a water as it passes through an area, and related geochemical problems." A discussion by the author is given on pages 927-928.

373. Ground water in Louisana, by P. H. Jones. Louisiana Stcte Univ. Eng. Exper. Sta. News, vol. 2, No. 1, Baton Rouge, La., January 1946. pp. 10-21.

States that the largest single use of ground water in Louisiana is for irrigation. Perhaps two-thirds of the annual withdrawal, or about $120,000,000,000$ gallons, is used for this purpose, chiefly for rice growing in the southwes'ern part of the State and in the strawberry farming area in the southeastern part. Gives a summary of ground-water conditions and records of wells in which water-level measuremenis were made during 1944. 


\section{INDEX}

The following abbreviations are used in the index:

W, Water-supply paper.

A, Annual report.

M, Monograph.

P, Professional paper.

$B$, Bulletin.

MR, Mineral resources.
GF, Geologic folio.

C, Report published by conperating agency.

D, Mimeographed or other duplicated report.

J, Journal article.

Names of formations and geologic ages are entered as used in the reports, indexed without revision to bring them into accord with current usage.

A

Abernathy, G. E., Ground-water resources in southeastern Kansas..... . C 147

Ground-water supplies in Kansas available for national defense...C 151

Absorption areas for artesian water ................. 5 c; C 16

Absorption of water, apparatus for measuring ..............W 155

by sinkholes ......................... 233; A 16 II $f$

by specific materials ..............W 258, 294, 343, 423; C 81

drainage wells in relation to $\ldots \ldots \ldots \ldots \ldots \ldots W$ 258, 774, 818; C 92 estimates of ..........W 219, 294, 423, 520 e, $597 \mathrm{~b}, 638 \mathrm{c} ; \mathrm{C} \mathrm{15,16}$ from floods .............W 294, 380; C 15, 16, 21; D 173; J 240, 279 from irrigation .....................W 294; C 15, 16; D 173 from precipitation .. W 153, 155, 294, 380, 400 e, 597 b, 638 c; C 15, 16;

D 173; J 73 from streams ....W 153, 158, 199, 294, 345, $375 \mathrm{~d}, 380,400$ e, 432, 519, $597 \mathrm{~b}, 637 \mathrm{~b}, 628 \mathrm{c} ; \mathrm{C} 21$

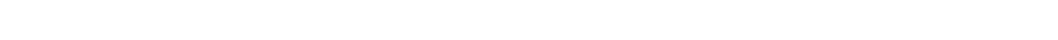

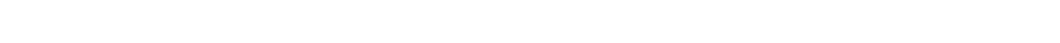
measurement of ..W 155, 294, 400 e, 423, 519, 597 b, 637 b, 63 ₹ c; C 15, $16 ; \mathrm{J} \mathrm{240,279}$

principles of .......W 114, 159, 219, 257, 494; A 14 II a, 19 II b; C 1, 431 spreading flood waters in relation to................ 21; J 279 See also Quantity of ground water; Recharge of ground water.

Acidity of ground water. See Analyses; Quality.

Adams, G. I., Economic geology of Iola quadrangle, Kans........... B 238

Patrick and Goshen Hole quadrangles, Wyo. and Nebr.........W 70

Water supply of Ozark region in northern Arkansas .........W 110

Adams, R. W., Geology and ground-water resources of the coastal

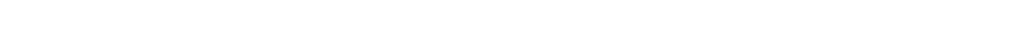

Geology and ground-water supply at Camp McCain (Miss.) ........ 192

Water levels and artesian pressure in the United States...... $W^{\top} \mathbf{9 4 5}, 987$ Adaville formation, water in, in Wyoming ................ 53 Africa, deep wells in . . . . . . . . . . . . . . . . . . . 257 Air conditioning, water for .....C 97, 160, 160 a; D 70; J 193, 24؟. 351, 361 
Air in soils, flow of $\ldots \ldots \ldots \ldots \ldots \ldots \ldots \ldots \ldots \ldots \ldots \ldots \ldots \ldots \ldots$. 19 in b ground water in relation to $\ldots \ldots \ldots \ldots \ldots \ldots \ldots \ldots \ldots \ldots$ W 4${ }^{n} 4 ;$ A 19 II b

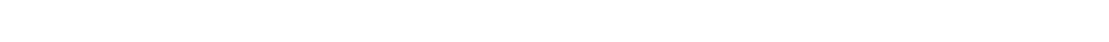
Akin, P. D., Water levels and artesian pressure in the United States W 949, 991 Alabama, areas, all of State $\ldots \ldots \ldots \ldots \ldots \ldots \ldots \ldots \ldots \ldots . \ldots \ldots$ 102, 114; C 1 areas, Bessemer quadrangle ........................FF 221 Birmingham quadrangle ....................... 175 Columbiana quadrangle $\ldots \ldots \ldots \ldots \ldots \ldots \ldots \ldots \ldots \ldots \ldots \ldots$ GF 226 Hatchetigbee anticline ..................... $661 \mathrm{~h}$ Marengo County ............................. 298

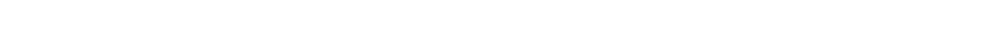
Montevallo quadrangle ........................GF 226

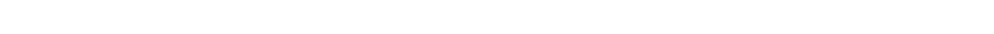

Vandiver quadrangle $\ldots \ldots \ldots \ldots \ldots \ldots \ldots \ldots \ldots \ldots \ldots \ldots$. 2 . 221 artesian water in $\ldots \ldots \ldots \ldots \ldots \ldots \ldots \ldots \ldots \ldots \ldots \ldots \ldots \ldots$ 114; C 1 bibliography of ground water in $\ldots \ldots \ldots \ldots \ldots \ldots \ldots$ 114, 120, 149, 163 mineral waters in ..........W 114; B 32; MR 1883-1923; GF 175; C 1 quality of ground water in ........W 102, 114; B 32; GF 175; C 1, 23 salt water in ....................W 114; B 661 1; C 1; D 151 spring discharge measurements in $\ldots \ldots \ldots \ldots \ldots W$ 98, 698, 713, 728, 758 springs in ..........W 114, 557; A $14 \mathrm{n} \mathrm{b;} \mathrm{B} \mathrm{32;} \mathrm{GF} \mathrm{175,} \mathrm{221,} \mathrm{226,} \mathrm{C} 1$ temperature of ground water in .................... 1 water levels in ...................... 907, 937, 945, 987 well records for $\ldots \ldots \ldots \ldots \ldots \ldots \ldots \ldots \ldots \ldots$ 57, 102, 149; B 264, 298; C 1 Alachua clay, water in, in Florida ....................W 319 Alaska, artesian water in $\ldots \ldots \ldots \ldots \ldots \ldots \ldots . . . \ldots 19,739$ c, $7 \varepsilon 3$ a, 861, 903 bibliography of ground water in................W 120, 163 mineral waters in ..................W 418; B 32; 1TR 1883-1884

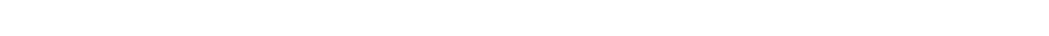
salt water in $\ldots \ldots \ldots \ldots \ldots \ldots \ldots \ldots \ldots \ldots \ldots \ldots \ldots \ldots$. 719,739 c, 789 spring discharge measurements in .................W 134 springs in .....W 418; B 32, $662 \mathrm{f}, 683,692 \mathrm{~b}, \mathrm{e}, \mathrm{g}, 739 \mathrm{c}, 783 \mathrm{~b}, 797 \mathrm{f}$, $816,855 \mathrm{c}, \mathrm{d}$ Springs, thermal, in .........W 418; B 692 b, e, g, 783 l. 797 f, 844 d temperature of ground water in $\ldots \ldots \ldots \ldots \ldots \ldots \ldots \ldots \ldots$ 418; B 32

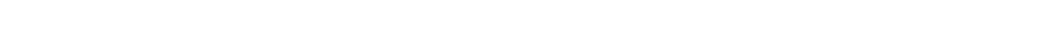

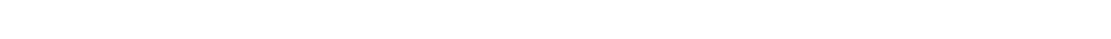
Gaines folio, Pa.-N. Y. .........................GF 92 Milwaukee special folio, Wis. ......................FF 140 Alexander, Verne, Water levels and artesian pressure in the Trited States,

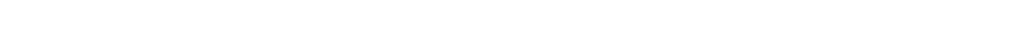
Alexander, W. H., Jr., Ground water in the High Plains in Tixas..C 405,

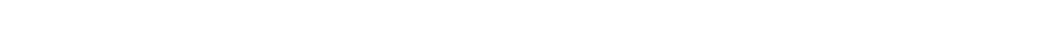
Ground-water resources of Liberty County, Tex. ............. 418 Ground-water resources of the Houston district, Tex. .......... 413 Relation of phenomenal rise of water levels to a defective g's well,

Harris County, Tex. ........................... 337 Algae in ground water ..................W 315, 338, 345 g; A 9 d Algeria, artesian water in ....................... 11 n c bibliography of ground water in $\ldots \ldots \ldots \ldots \ldots \ldots \ldots \ldots \ldots \ldots$ W 163 irrigation with ground water in $\ldots \ldots \ldots \ldots \ldots \ldots \ldots \ldots$ W $136 ;$ A 11 II $\mathrm{c}$ 
Algonkian formations. See Pre-Cambrian.

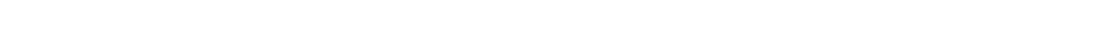

Alkali coefficient of water for irrigation $\ldots \ldots \ldots \ldots \ldots \ldots \ldots . W$ W 274, 335, 398

Alkali flats, water in ........................ W 42?; B 530 r Alkali in ground water. See Analyses; Quality.

Alkali in soil, water table in relation to $\ldots \ldots \ldots \ldots \ldots W$ W20, 343, 422. 423, 495 Alkalinity of ground water. See Analyses; Quality.

Allis, J. A., Water levels and artesian pressure in the United Strtes, 1946

Alluvial fans. See Valley fill; Debris-filled basins.

W 817

Alluvium, interbedded with lava, artesian water in ............... 199 interbedded with lava, perched water in ..........W 616; C 92, 99 water in-

Alabama $\ldots \ldots \ldots \ldots \ldots \ldots \ldots \ldots \ldots \ldots \ldots \ldots \ldots$, GF $226 ;$ C 4

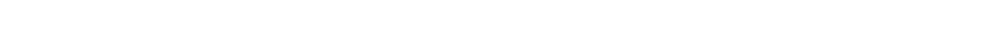

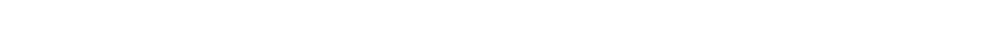

Arizona ......W 450 a, 498, 499, 796 e; B 690 d; GF 217; C 1.2, 15, 20;

D $67,82,140,173 ;$ I 240,279

Arkansas ....................... ...........W 399

California .....W 112, 140, 142, 219, 294, 345 h, 375 a, 400 e, 446, 450 c, 495, 497, 519, 619; C 23; J 318

Connecticut ......................W 374, 397, 466. 470, 540

Cuba ....................................... J 287

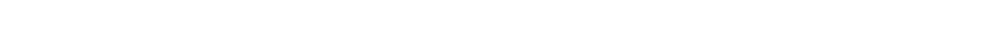

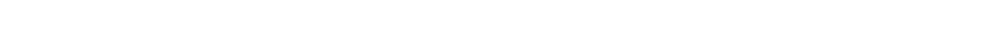

Idaho $\ldots \ldots \ldots \ldots \ldots \ldots$ W $774,818,889$ b; C 111, 112, 113. 114, 117

Illinois ..........................A 17 II; GF 195; C 131

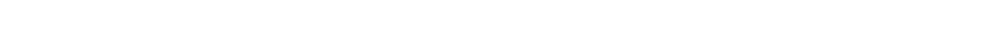

Kansas .......W 153, 258, 273; GF 206, 212; C 142, 143 146, 150 $153,154,155,156,157,158,159$; D 111, 119; J 214

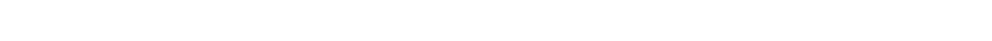

Michigan ..............................GF 2C5; C 182

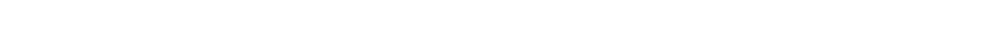

Mississippi $\ldots \ldots \ldots \ldots \ldots \ldots \ldots \ldots \ldots \ldots \ldots \ldots \ldots \ldots \ldots$ W 159, $\mathbf{5 7 6}$

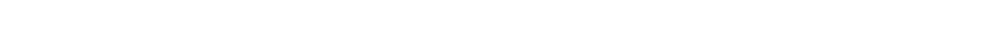

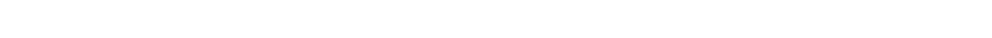

Nebraska..$\ldots \ldots \ldots \ldots \ldots$ W 12, 184, 425 b, 848; GF 89; C 202, 204

Nevada .....................W 450 c, 467; C 20; D 3, 4

New Mexico ...W 140, 141, 158, 188, 422, 620, 637 b; B 725 g; C 233, $234,237,238,241,248,256$; D 5, 68

North Dakota $\ldots \ldots \ldots \ldots \ldots \ldots \ldots \ldots \ldots \ldots \ldots \ldots \ldots . .59 \varepsilon$, GF 181

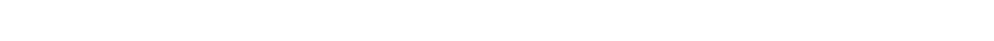

Oklahoma ................W 500 b; C 321, 323; D 106. 115, 178

Oregon $\ldots \ldots \ldots \ldots \ldots \ldots$ W 220, 231, 637 d, 890; C 331; D 21, 44, 69

Pennsylvania ...................W 114; C 341, 345. 346, 351

St. Croix, Virgin Islands ......................... 289

Texas ....................... 187; C 256, 402, 409, 418

Trinidad, British West Indies .....................J 286

Utah ...........................W 157, 217; P 1§9; D 186

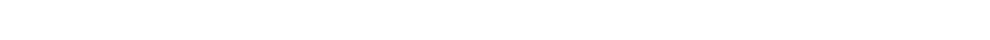

Washington $\ldots \ldots \ldots \ldots \ldots \ldots \ldots \ldots \ldots \ldots \ldots \ldots . \ldots \ldots$ W $88 \varepsilon$ b; D 44

West Virginia $\ldots \ldots \ldots \ldots \ldots \ldots \ldots \ldots \ldots \ldots \ldots \ldots . C$ 448; 449; J 333 
Alluvium, water in, Wisconsin C 451

Wyoming W 425 b; B 716 a

See also Valley fill; Gravel; Sand.

Alum Bluff formation, water in, in Florida

water in, in Georgia

Aluminum in ground water ...........W 273, 338; R 47; MR 1911

Ames, F. C., Water levels and artesian pressure in the United States, 1936

W 817

Amick, H. C., The "fittifying" spring near Greenbrier Cove, Tenn. ...J 142 Ammon, G., on flow of air through soils ............... 19 II b Ammonia in ground water ...............W 240, 256; MR 1911 II $\mathrm{n}$ Amsden formation, water in, in Montana ................. 856

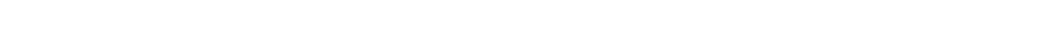
Anacacho formation, water in, in Texas ............. $18 \mathrm{~m} \mathrm{~b}$; GF 64 Analyses, mechanical, of water-bearing material..W 67, 104, 136, 489, $596 \mathrm{f}$;

Analyses of ground water-

A $19 \mathrm{II} \mathrm{b;} \mathrm{P} 44$

Alabama W 102; B 32; GF 175, 221; C 1, 2

Alaska W $418 ;$ B 662 f, 683,783 b, 816

Antigua .C 71

Arizona .W 104, 136, 320, 364, 375 b, 450 a, $498,499,796$ e, f, 836 b;

B 32; GF 129; C 13, 15, 16, 17, 18, 19; J 136

Arkansas ...W 102, 145, 364, 399; P 45; B 32, 330, 491, 606, 616, 808; GF 215; J 28

Asia .] $330,491,616$

Atlantic Coastal Plain ....................... 183, 254 Australia ......................... 330, 491, 616 Austria-Hungary $\ldots \ldots \ldots \ldots \ldots \ldots \ldots \ldots \ldots$ B 330, 491, 616; MR 1916 British Columbia ..................... 330, 491, 616 California ...W 58, 59, 116, 142, 255, 278, 338, 364, 398, 429, 446, 450 b, 495, 497, 578; P 98 a, 117; B 32, 330, 491, 529, 540 n, 606, 616, 653; C 26 Canada ......................... $330,491,616$ Colombia ........................... 330, 491, 616 Colorado..W 240, 364, 839; A 17 II f; M 27; P 32, 52, 63; B 32, 330, 491, $529,606,616,735 \mathrm{~d}$; MR 1916; GF 135, 153, 203 Connècticut ...W 102, 110, 232, 374, 397, 449, 466, 470, 537, 540, 597 b; P $44 ;$ B 32

Delaware C 171

District of Columbia .................W 364; B 32, 138; C 171

England $\ldots \ldots \ldots \ldots \ldots \ldots \ldots \ldots \ldots \ldots \ldots$ 330, 491, 616; MR 1916 Fiji Islands ......................... $330,491,616$ Florida ....W 102, 319, 364, $596 \mathrm{~g}$; B 32; C 51, 52, 53, 54, 57, 58, 59, 62;

France

B $330,491,616 ;$ MR 1916

Georgia W $102,160,341,912 ;$ B $32.138 ;$ C 81,82

Germany ................B 330, 491, 529, 606, 616; MR 1916

Gulf Coastal Plain ........................J 23, 254

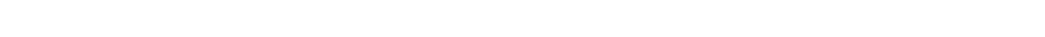

Hawaii C 92, 97, 98

Iceland .) $330,491,616$

Idaho .W 560 d, 818; P 152; B 32, 877; C 111, 112, 114, 115, 116 
Analyses of ground water, Illinois W 164, 364; A 17 II h; B 32, 330, 438, 491, 506,616 ; GF $81,188,195,200,208,213$; C 131 Indiana .................W 254; A 18 Iv b; B 32, 330, 491, 616 Iowa W 293, 364; B 32; GF 145, 200

Italy B $330,491,616$

Java B $330,491,616$

Kansas W $145,153,258,273,345 ;$ P $32 ;$ B $32,330,491$, € 96,616 ; C $143,145,146,147,149$ Kentucky .....W 102, 164, 233, 364; B 22, 330, 491, 606, 616, 661 d, 688 Louisiana ...........W 101; P 46; B 330, 491, 616; C 163, 166, 167 Maine .....W 102, 114, 144, 223, 258, 364; B 32, 330, 491, 616; GF 149

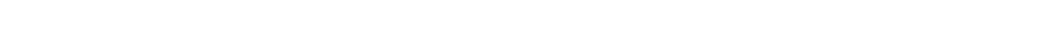

Maryland B 32, 138; GF 13i; C 171

Massachusetts W $102,110,144 ;$ B 32

Mexico .B 529

Michigan W $31,102,145,182,183,364 ;$ B $32,330,491,606,616$, 625; GF 155, 205; C 181

Minnesota .......W 102, 256; M 25; B 32, 330, 491, 616, 625; GF 201 Mississippi ...................W 159, 364; 576; P 46; B 32 Missouri ......W 102 145, 195, 364; B 32, 330, 438, 491, 606, 616, 625 Montana ......W 221, 345, 364, 400 b, 518, 520 d, 539, 560 b, 6c?; B 32, $330,491,529,606,616,751$ c, 822 a, 856; GF 56; . 39,275

Nebraska W $184,215,848$

Nevada W 364, 365, 423, 425 d, 467; P 73, 95 a; B 32, 330, 491, $529,530 \mathrm{r}, 540 \mathrm{n}, \mathrm{p}, 606,616,72$ ? $\mathrm{C} 112$

New Hampshire .....................W 102, 144; B 32

New Jersey ......B 32, 138, 727; GF 191; C 212, 213, 214, 215, 216, 217

New Mexico ......W 123, 158, 188, 275, 343, 364, 422, 425 a, (200, 639, 839 ; P 68; B 32, 330, 491, 616, 618; GF 207; C 15, 235, 239, 241, 243, 244 New South Wales ....................... 330, 491, 616 New York ....W 102, 108, 110, 144, 145, 364; P 44; B 32, 330, 491, 616; MR 1916; GF 190; C 273, 276

New Zealand .B $330,491,616$ North Carolina ........W 160, 258, 364; B 32, 138, 330, 491, 616; C 291 North Dakota ..W 420 e, 560 b; A 17 II g; M 25; B 32; GF 168; C 301, 302 Ohio .......W 259; A 18 Iv b, 19 Iv b; B 32, 330, 491, 616, 693; GF 197 Oklahoma .............W 148, 345, 364, 500 b, 520 b; B 606; C 321 Oregon .........................W 220, 659 b, 841; B 32 Pennsylvania .W 108, 110, 364; B 32, 330, 491, 616, 693, 828, 873, 891; GF 223,225 ; C $341,342,343,344,345,346,352$

Philippine Islands ....................... 330, 491, 616 Rhode Island $\ldots \ldots \ldots \ldots \ldots \ldots \ldots \ldots \ldots \ldots \ldots \ldots \ldots \ldots$ 102, 144; B 32 South Carolina ..............W 258, 364; P 90 h; B 32, 138, 867 South Dakota ...W 227, 597 c; A 17 II g, 21 rv b; P 32: B 32: GF 1.07, 108. 164, 165: C 302, 361 $165 ; \mathrm{C} 302,361$ Switzerland $\ldots \ldots \ldots \ldots \ldots \ldots \ldots \ldots \ldots \ldots \ldots \ldots \ldots \ldots$ B 330, 491, 616 Tennessee ...W 164, 364; B 32, 330, 491. 529, 616, 638 a, 640, 656,677 ;

C 371

Texas ...W 66, 141, 190, 276, 317, 335, 343, 364, $375 \mathrm{~g}, 660,83 \mathrm{C}, 849$ a; 913; A 18 II b, 21 vIr; P 46; B 32, 661 f, 902; GF 166. 194: C 381, 388, 390, 398, 399; D 46, 55; J 202 
Analyses of ground water, United States...........W 496, 658, $659 \mathrm{c}$ Utah .....W 157, 199, 217, 277, 333, 364; P 107; B 32, 330, 491, 616 Vermont ........................W 102, 114, 144; B 32

Virginia ...W 258, 364, 596 c; B 32, 330, 491, 616; GF 80; C 431, 432, 433, 435,436

Washington $\ldots \ldots \ldots \ldots \ldots \ldots \ldots \ldots \ldots \ldots \ldots \ldots \ldots \ldots \ldots$. 111; B 32

West Indies $\ldots \ldots \ldots \ldots \ldots \ldots \ldots \ldots \ldots \ldots \ldots \ldots \ldots \ldots \ldots \ldots \ldots$ C 71

West Virginia ..................W 145, 364; B 32.693; GF 179

Wisconsin ......................... 113; B 32; GF 140

Wyoming ....W 364, 425 b; A 9 d, 21 Iv b; P 32, 152, 163; B 32, 47, 330,

$364,491,616,670 ;$ GF 107, 173; J 274

Analyses of ground water, bacteriologic ..........W 193, 256, 259; C 82

bibliography of $\ldots \ldots$. W 559 ; . B 330, 491, 606, 616; MR 1913 II h, 1916

interpretation of $\ldots \ldots \ldots \ldots \ldots \ldots \ldots \ldots \ldots \ldots \ldots \ldots \ldots \ldots \ldots . \ldots \ldots, 372$

sanitary $\ldots \ldots \ldots \ldots \ldots \ldots \ldots \ldots \ldots \ldots \ldots \ldots$ 31, 144, 193, 195, 256; C 131 Analyses of mine waters-

Arizona .................................W 364; P 115

California ............................W 364; P 194; B 529

Colorado ....................W 364; B 529, 718. 735 d, 750 c

Germany ................................... 529

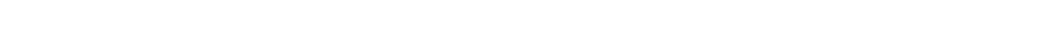

Mexico ...................................... 529

Michigan ......................W 364; M 52; P 144; B 625

Minnesota .............................. 52 ; В 625

Missouri .............................. 364; B 625

Montana ...........................W 345 g, 364; B 529

Nevada ........................W 364; B 529, 735 c

New Mexico .................................. 885

Oklahoma ....................................W 364

Tennessee .........................W 364; P 139; B 529

Utah ................................ 364; P 107

Analyses of mineral waters, bibliography of .........MR 1913 II h, 1916 Analyses of oil-field waters-

California ........................ 117, 163; B 835

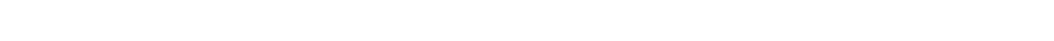

Montana .......................... 751 c, 786 b

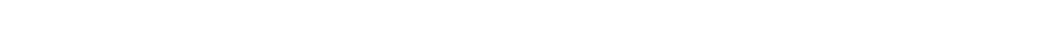

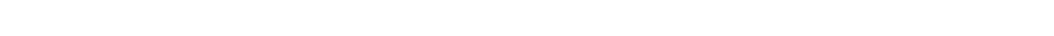

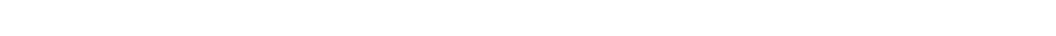

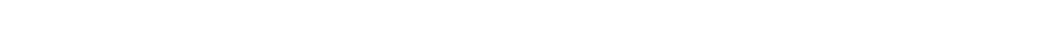

Analyses of soil, methods of mechanical $\ldots \ldots \ldots \ldots W 67,104,136,489,596 \mathrm{f}$;

A 19 II b; P 44

Analyses of spring waters-

Alaska $\ldots \ldots \ldots \ldots \ldots \ldots \ldots \ldots \ldots \ldots \ldots \ldots \ldots \ldots \ldots . \ldots \ldots$ 418; B 816, 844 d

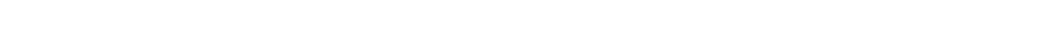

California ............................W 338; M 13

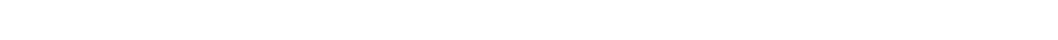

Idaho $\ldots \ldots \ldots \ldots \ldots \ldots \ldots \ldots \ldots \ldots \ldots \ldots \ldots \ldots \ldots \ldots$ B 814, 8`4, 877; J 147

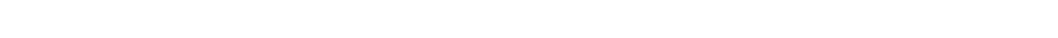

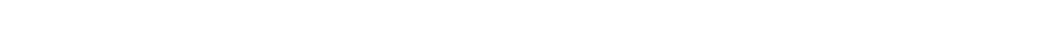

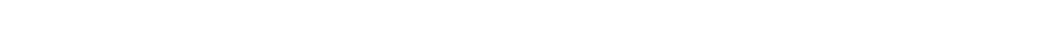

Wyoming $\ldots \ldots \ldots \ldots \ldots \ldots \ldots \ldots \ldots \ldots \ldots \ldots \ldots \ldots \ldots \ldots \ldots \ldots \ldots$ J 6 
Analyses of tufa formed by hot springs W 145; A 9 d; P 152

Analyses of water, accuracy of W 236, 274, $596 \mathrm{~h}$

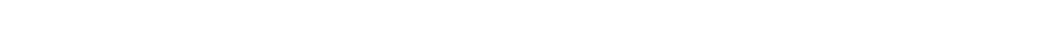
computation of $\ldots \ldots \ldots \ldots \ldots \ldots \ldots \ldots \ldots \ldots \ldots$ 151, 236, 398, $596 \mathrm{~h}$

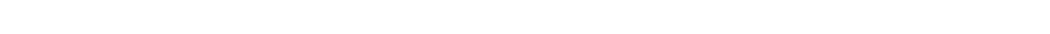

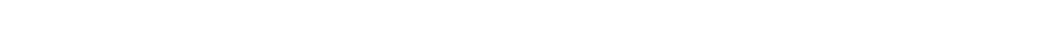
equivalents for ................................... 1911 II $n$ expression of $\ldots \ldots$ W $236,274,559 ;$ A 14 II b; B 47, 330, 479, 491, 889 e in field $\ldots \ldots \ldots \ldots \ldots \ldots \ldots \ldots \ldots \ldots \ldots \ldots \ldots \ldots$ W $151,193,537$; $B \ldots 7$

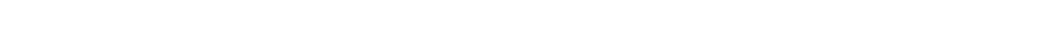
interpretation of $\ldots \ldots \ldots \ldots \ldots \ldots W$ W 274, 398, 559; B 479, 606, 616; J 16

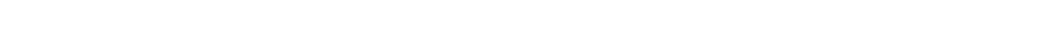
methods of $\ldots \ldots \ldots \ldots \ldots \ldots \ldots \ldots \ldots \ldots \ldots \ldots$ W 193, 236, 254,320; B 47

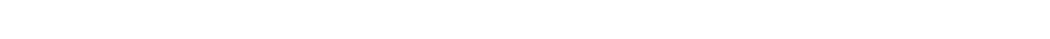

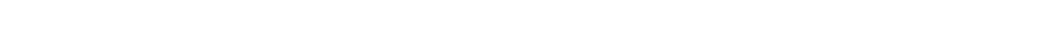
Analyses of water for-

acidity .................................... 236 alkalinity ........................... 151, 596 h

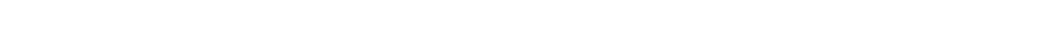

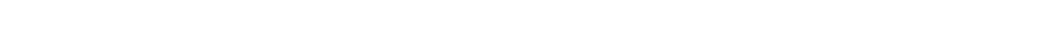
carbonate $\ldots \ldots \ldots \ldots \ldots \ldots \ldots \ldots \ldots \ldots \ldots \ldots$ W 151, 236, 596 h; B 47 chloride $\ldots \ldots \ldots \ldots \ldots \ldots \ldots \ldots \ldots \ldots$ W 144, 151, 236, 596 h; F 47; J 15 color .............................. 151, $596 \mathrm{~h}$ hardness $\ldots \ldots \ldots \ldots \ldots \ldots \ldots \ldots \ldots \ldots \ldots \ldots \ldots \ldots$ 151, $520 \mathrm{~d}, 596 \mathrm{~h}$

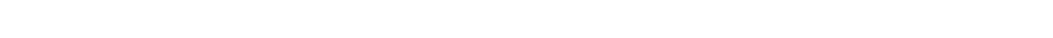
potassium ...................W 236, $596 \mathrm{~h} ;$ P 98 a; B 47 radioactivity ....................... 395; MR 1913 II $h$ silica $\ldots \ldots \ldots \ldots \ldots \ldots \ldots \ldots \ldots \ldots \ldots \ldots \ldots \ldots \ldots \ldots \ldots$ W 236, 596 h; B 47 specific substances $\ldots \ldots \ldots \ldots \ldots \ldots \ldots \ldots \ldots \ldots \ldots \ldots \ldots$ W 236; B 47 See also Assays of ground water.

Anamorphism, zone of, ground water in relation to $\ldots \ldots \ldots \ldots \ldots . . \ldots 7$ Anastasia formation, water in, in Florida ............ 258, 365 Anderson, G. H., Geyser area near Beowawe, Eureka County, Nev . . . .J 107 Anderson, J. E., Water levels and artesian water in the United States, 1937

Andrews, D. A., Geology and coal resources of the Minot region, N. Dak B 906 b

Geology and oil and coal resources of the region south of Cody, Wyo B $921 \mathrm{f}$

Ground water in Avra-Altar Valley, Ariz ............W 796 e Ground water in Avra Valley, Ariz ................. 67 Ground-water resources of northwestern New Mexico ......... 68

Mizpah coal field, Mont ...................... 906 c Annual recharge of ground water. See Quantity of ground water.

Antigua, ground water in $\ldots \ldots \ldots \ldots \ldots \ldots \ldots \ldots \ldots \ldots \ldots \ldots \ldots \ldots \ldots \ldots \ldots$

Antimony in ground water $\ldots \ldots \ldots \ldots \ldots \ldots \ldots \ldots \ldots \ldots \ldots \ldots \ldots \ldots \ldots \ldots \ldots$

Antrim shale, water in, in Michigan ................. 114

Apparatus for-

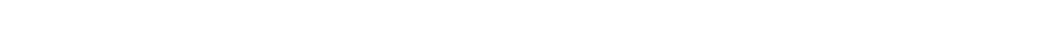

making mechanical analysis of soil . .............W 67, $596 \mathrm{f}$ recording water levels in wells ....W 155; A 19 II b; D 127, 139, 155, 188 separating the emanation of uraninite in water ............ 395 


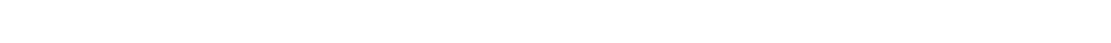

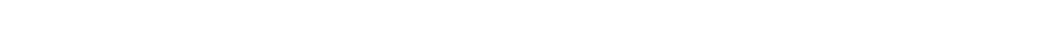

testing solids in water $\ldots \ldots \ldots \ldots \ldots \ldots \ldots \ldots \ldots \ldots \ldots$ W 137, 138, 139

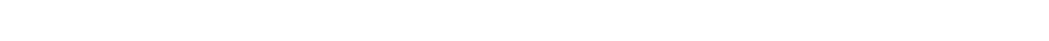

testing windmills $\ldots \ldots \ldots \ldots \ldots \ldots \ldots \ldots \ldots \ldots \ldots \ldots \ldots \ldots$ 20,41, 42

Apparatus for measuring, artesian pressure .....W 145; C 92; D 32, 45, 72

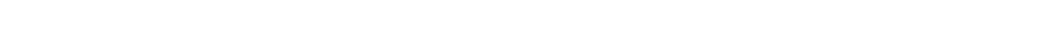

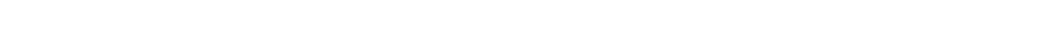
discharge of wells and springs .........W 150, 200, 596 a; D 33, 195 evaporation of water from sand .............W 291; A 19 II b flow of ground water.... W 67, 110, 112, 140, 141, 637 b; 887; P 44; J 194 flow of water and air through various media ............. 19 II b

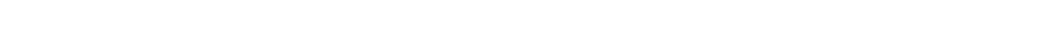
permeability of water-bearing material ....W $596 \mathrm{f}, 887$; A 19 II b; D 84 radioactivity in water ................ 395; MR 1913 II $h$ rate of rise of water in wells ..................... 140 water retained by soils $\ldots \ldots \ldots \ldots \ldots \ldots \ldots \ldots \ldots \ldots \ldots \ldots$ A 19 II b

Apparatus showing, flow of water due to settling of sediments...A 19 II b loss in head by friction in sands ................... 258 loss in head of artesian water ...W 12, 54; A 17 II g, 19 IV c: P 17, 32, 52 Aquifers, compression of artesian .. W 887, 889 a, d; J 54, 133, 168, 199, 207, $219,230,236,241,242,246,280,344$ use of term $\ldots \ldots \ldots \ldots \ldots \ldots \ldots \ldots \ldots \ldots \ldots \ldots \ldots \ldots \ldots \ldots$ 293, 494 See also specific formations.

Arapahoe formation, water in, in Colorado .............. 27; P 32 Archean formations. See Pre-Cambrian; specific formations.

Archimedes limestone, water in, in Arkansas .............W 114, 145 Areas of ground-water discharge, methods of determining .....W 423, $597 \mathrm{~b}$ Arey, M. F., Underground water resources of Iowa ..........W 293 Arikaree formation, water in, in Colorado ................ 32 water in, in Nebraska ........W 425 b; A 19 Iv c; P 17, 32; GF 87, 88 in South Dakota .....................W 227; P 32

in Wyoming .....................W $425 \mathrm{~b} ; \mathrm{P} 32 ; \mathrm{C} 456$ Aristotle, on origin of ground water ............. 14 II B; J 106, 255 Arizona, absorption of water in ......W 104; C 15, 20; D 17\%; J 240, 279 areas, Apache County ....................... 836 b Avra-Altar Valley ...............W 796 e; C 20; D 67, 173

Big Sandy Valley .................... 11, 12, 13; D 140

Bisbee quadrangle ..........................FF 112

Clifton quadrangle $\ldots \ldots \ldots \ldots \ldots \ldots \ldots \ldots \ldots \ldots \ldots \ldots$ GF 129

Coconino County ....................... 836 b

Duncan Valley .........W 886, 911, 941; C 11, 14, \.5, 17; D 160 Gila River Valley .......W 104, 450 a, 498, 796 f; C 11, 14, 15, 17;

D $82,146,160,171,203 ; \mathrm{J} 240$

Globe quadrangle ........................FF 111

Graham County .....W 450 a, 796 f, 886, 911, 941; C 11, 14; 15, 16;

D $146,16^{n}, 171 ; \mathrm{J} 240$

Greenlee County .....W 886, 911, 941 ; C 11, 14, 15, 17; D 19, 160,

$171 ; \mathrm{J} 240$

Holbrook region .................... W 836 b; D 85

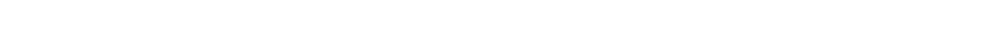

Maricopa County .....W 2, 136, 375 b, 886, 911, 941; B 298; C 11, 18 


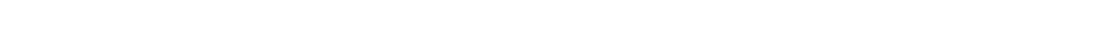

Mohave County ................... 12, 13, 15; D 140

Navajo County ......................... 380,836 b

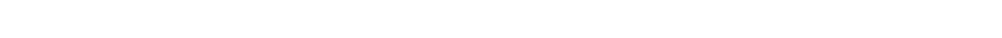

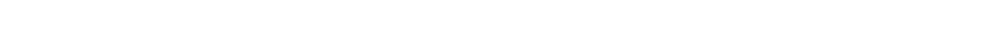

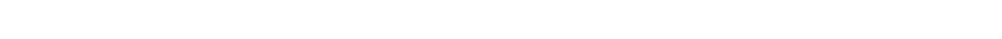

Papago region ..........W 490 d, 499; C 14, 20; D 146, 171; 173

Paradise Valley ........................W $375 \mathrm{k}:$ B $690 \mathrm{~d}$

Patagonia Mountains ......................... 582

Phoenix and vicinity $\ldots \ldots \ldots \ldots \ldots \ldots \ldots \ldots \ldots \ldots \ldots \ldots \ldots \ldots, 136,375 \mathrm{~b}$

Pima County .....W 490 d, 499, 796 e, 886, 911, 941; C 11, 20; D 173

Pima Indian Reservation .........W 104; C 20; D 146; 171, 173

Pinal County .........W 104, 886, 911, 941; C 11, 20, 18; D 173

Queen Creek area ...............C 11, 18; W 146, 1.71; J 279

Ray area ......................... 115; GF 217

Safford Valley .........W $796 \mathrm{f}, 886,911,941 ; \mathrm{C} 11, \mathrm{~J} 4,15,16$;

D $146,160,171 ; \mathrm{J} 240$

Salt River Valley ........................W 136

San Bernardino Valley ........................ W 320

San Carlos Indian Reservation ......W 450 a, 886, 911, 941; C 11 $14,15,16 ; \mathrm{D} 146,160,171,173 ; \mathrm{J} 240$

San Pedro Valley .....................W 320; A 21 IV a San Simon Valley ..................W 425 a, $795 \mathrm{f} ; \mathrm{D} 82$ Santa Cruz River Basin .......W 104, 490 d, 499, 796 є, 886, 911 941 ; C 11, 20; D 146, 171, 173, 185, 203

Santa Rita Mountains ...................... 582; C 20 southeasterñ $\ldots \ldots \ldots \ldots \ldots \ldots \ldots \ldots \ldots \ldots \ldots \ldots$ W 320, 425 a; C 19 southwestern $\ldots \ldots \ldots \ldots \ldots \ldots \ldots \ldots \ldots \ldots \ldots \ldots \ldots \ldots W \quad 4^{\circ} 0$ d, 499

Sulphur Spring Valley ....................... 320

Verde River Valley $\ldots \ldots \ldots \ldots \ldots \ldots \ldots \ldots \ldots \ldots \ldots \ldots \ldots$ C 20 a

Virden Valley $\ldots \ldots \ldots \ldots \ldots \ldots \ldots \ldots \ldots \ldots \ldots \ldots \ldots \ldots \ldots \ldots \ldots$

west-central ............................... 352

artesian water in..W $320,380,425$ a, 450 a, 498,796 f; A 21 Iv a; B 435 ; GF 112; C 15, 16, 19, 20; D 82 bibliography of ground water in ............W 149, 163; C 18, 19 evaporation of ground water in .....W 2; C 15, 20; D 160; J 240, 279

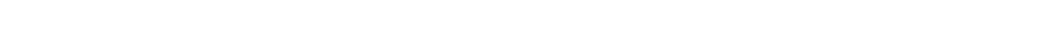
irrigation with artesian water in ...W 425 a, 450 a, 796 f; A 21 Iv a;

B 435 ; C 15, 16

irrigation with other ground water in ..W 2, 104, 136, 320, $375 \mathrm{~b}, 395$, 425 a, 450 a, 498, 796 f, 886, 911, 941; A 16 II e; C 12, 13, 14, 15, 16, 17, 18,$20 ; \mathrm{D} 146,160,171,173,185,196,203 ; \mathrm{J} 240$ mine waters in ...................W 364; B 582; GF 112 mineral waters in ... B 32; MR 1883-1916; GF 129; C 13, 15, 16, 17, 18, 20 ;

D 151

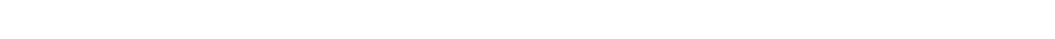
pumping in .......W 104, 136, 320, $375 \mathrm{~b}, 425$ a; D 171, 18E: 196, 203 quality of ground water in ....W 104, 136, 320, 364, $375 \mathrm{~b}, 42 \mathrm{~F}$ a, $450 \mathrm{a}$, $496,498,499,796$ e, f, 836 b; B 32; GF 129; C 13, 14, 15, 16, 17, 18, 20,20 a; D 52, 151; J 136 quantity of ground water in ...W 104, 136; C 14, 15, 20, 20 a; D 146, $160,171,173,185,196,203 ; J 24$ C. 279, 300 
Arizona, salt water in....W 104, 136, 320, 375 b, 796 e, f; GF 12؟; C'13, 15, 16, $17,18,20 ; \mathrm{D} 151$ spring discharge measurements in ...W 879, 899, 959, 979; C 13, 15, 16, 17 springs in .....W 320, 380, $490 \mathrm{c}$, d, 498, 499, 557, 679 b: $796 \mathrm{f}, 836 \mathrm{~b}$; A 14 II b; B 32, 582, 763, 808; GF 111, 129; C 13, 15, 16, 17, 20;

D $85 ; \mathrm{J} 136$ springs, thermal, in .W 679 b, 796 f; B 32, 582; GF 129; C 1£, 16, 20; J 136 temperature of ground water in .....W $320,796 \mathrm{f} ; \mathrm{B} \mathrm{32,} ₹ 52,582 ; \mathrm{C} \mathrm{13}$, $15,16,17,18,20$ underflow in ..................W 104; C 12, 15, 20; D 160; J.240 water levels in $\ldots \ldots \ldots \ldots \ldots \ldots \ldots \ldots \ldots \ldots \ldots$ 886, 911, 941, 949, 991 water table in .....W 104, 136, 320, 375 b, 425 a, 498; GF 129; C 13, 14,

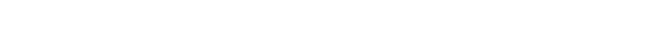
watering places in ..............W 380, $490 \mathrm{c}, \mathrm{d}, 499,499$; B 352 well records for....W $57,104,136,149,320,375 \mathrm{~b}, 380,4 \mathrm{C}^{\mathrm{R}}, 499,796 \mathrm{f}$, 836 b; B 298, 352, 435, 540 p; GF 111, 112; C 13, 15, 16, 17, 18, 20, 20 a

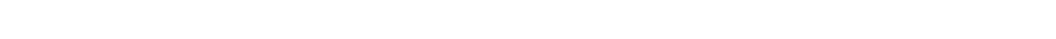

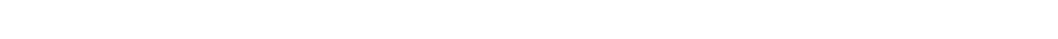

Arkansas, areas, all of State $\ldots \ldots \ldots \ldots \ldots \ldots \ldots \ldots \ldots \ldots \ldots \ldots \ldots$ W 102

areas, Batesville district $\ldots \ldots \ldots \ldots \ldots \ldots \ldots \ldots \ldots \ldots \ldots \ldots$ B 921 a

Eureka quadrangle ...........................FF 202

Grand Prairie region ............... 18, 23; J 196; C 20 e Hempstead County ......................... 298 Hot Springs and vicinity .................W 145; J 28 Hot Springs quadrangle $\ldots \ldots \ldots \ldots \ldots \ldots \ldots \ldots \ldots \ldots \ldots \ldots$ GF 215 northeastern ...............................W 399 northern $\ldots \ldots \ldots \ldots \ldots \ldots \ldots \ldots \ldots \ldots \ldots \ldots \ldots \ldots \ldots \ldots \ldots$ W 114, 145

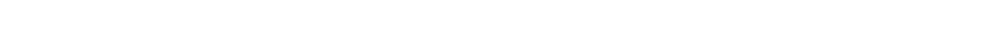
southern $\ldots \ldots \ldots \ldots \ldots \ldots \ldots \ldots \ldots \ldots \ldots \ldots \ldots \ldots \ldots \ldots \ldots .6$ 114;,$P 46$

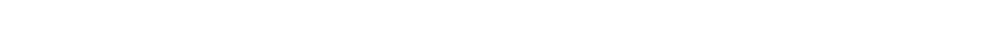
Tahlequah quadrangle $\ldots \ldots \ldots \ldots \ldots \ldots \ldots \ldots \ldots \ldots \ldots \ldots$. . . . 122 Winslow quadrangle ..................... 145; GF 154 artesian water in ..............W 114, 145, 399; P 46; B 808; D 18 bıblography of ground water in $\ldots \ldots \ldots \ldots \ldots \ldots$ W 114, 120, 149, 163 irrigation with ground water in ................W 399; D 18 mineral waters in .....W 114, 145; P 46; B 32; MR 1883-1923; GF 154 public water supplies in $\ldots \ldots \ldots \ldots \ldots \ldots \ldots \ldots \ldots \ldots \ldots \ldots . \ldots$ 399; P 46 pumping in .............................W 399; D 18 quality of ground water in ....W 102, 145, 364, 399; P 46; B 32, 330, 491, 606,616 ; GF $154 ; \mathrm{J} 28,68$ radioactive waters in $\ldots \ldots \ldots \ldots \ldots \ldots \ldots \ldots \ldots \ldots \ldots \ldots \ldots . \ldots R$. $1913 \mathrm{~m} \mathrm{~h}$ rice irrigation in $\ldots \ldots \ldots \ldots \ldots \ldots \ldots \ldots \ldots \ldots \ldots \ldots \ldots \ldots \ldots \ldots \ldots$ W 399 salt water in $\ldots \ldots \ldots \ldots \ldots \ldots \ldots \ldots \ldots \ldots \ldots \ldots \ldots \ldots \ldots$ B 691 j, 847 e spring discharge measurements in $\ldots \ldots \ldots \ldots \ldots \ldots \ldots \ldots K^{r} 84,957,977$ springs in .....W 102, 110, 114, 145, 364, 557, 627, 679 b; A 14 In b; P 36; B 32, 808; GF 122, 154, 215; D 85; J 37, 68, 136 springs, thermal, in .........W 145, 679 b; B 808; GF 215; J 37, 68 water levels in .........W 777, 817, 840, 845, 886, 909, 939, 947, 989 water table in ........W 399; P 46; B 886 c, 921 a; D.93; J 196; C 20 e well records for ......W 57, 102, 145, 149, 399; P 46; B โ\$4, 298, 691 j 
Arkansas, wells in, construction of $\ldots \ldots \ldots \ldots \ldots \ldots \ldots \ldots \ldots \ldots$ W 145; P 46 cost of $\ldots \ldots \ldots \ldots \ldots \ldots \ldots \ldots \ldots \ldots \ldots \ldots \ldots \ldots \ldots \ldots \ldots$ W $399 ;$ P 46

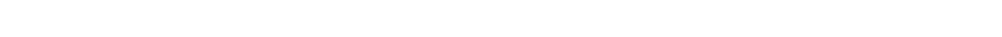

Arnold, Ralph, Santa Cruz folio, Calif .................GF 163 Arsenic in ground water .................W 338; B 47; MR 1911 II n Artesian aquifers, compression of.....W 887, 889 a, d; J 54, 13 $, 168,199$, $207,219,230,236,241,242 ; 246,280,344$

Artesian basins produced by settling of strata ............... 21 Iv c Artesian pressure, factors influencing ................ 5 c; B 319 in the United States ...W 777, 817, 840, 845, 886, 906, 907, 90? 909, 910, 911, 936, 937, 938, 939, 940, 941, 944, 945, 946, 947 $948,949,986,987,988,989,990,991$ methods of measuring $\ldots \ldots \ldots \ldots \ldots \ldots \ldots \ldots . W 118,145 ;] 32,45,72$ Artesian springs '.............W 90, 255, 278, 388, 796 f; A 2. Iv c; C 16 Artesian water, absorption areas for ........... 5 c; C 16; D 95, 101 apparatus showing loss of head in ...W 12, 54, 227; A 17 II $\mathrm{g}$, 19 IV c;

barometric pressure in relation to ............. 319; GF 156; C 92

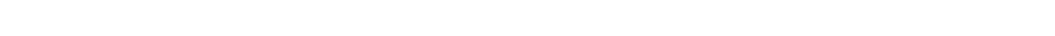

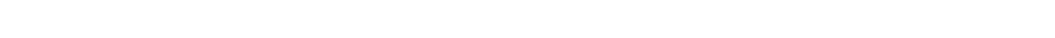
confining beds for ................. 5 c, 21 iv c; B 3r9; C 92,99 conservation of $\ldots \ldots W$ W 142, 145, 158, 219, 225, 234, 256, 278, 293, 400 b, 423, 425 a, 520 e; C 91, 92, 431; J 338 cost of recovering, in California $\ldots \ldots \ldots \ldots \ldots \ldots \ldots \ldots \ldots \ldots 22,398$ in Montana ................................... $400 \mathrm{~b}$ in Nevada $\ldots \ldots \ldots \ldots \ldots \ldots \ldots \ldots \ldots \ldots \ldots \ldots \ldots \ldots$. $375 \mathrm{~d}, 423$ criteria useful in prospecting for .............. 5 c; C 431; J 13 definition of $\ldots \ldots \ldots \ldots \ldots \ldots \ldots \ldots \ldots \ldots \ldots W 160,341,494,8{ }^{\wedge} 6 \mathrm{~d}$; $\mathrm{C} 451$ deformation in relation to ...............W 518; B 606; J 54 depth in relation to $\ldots \ldots \ldots \ldots \ldots \ldots \ldots \ldots \ldots \ldots \ldots \ldots \ldots \ldots \ldots \ldots \ldots \ldots$ dip of strata in relation to ..................... 5 c; J 3 discharge of $\ldots \ldots \ldots \ldots \ldots \ldots \ldots \ldots \ldots \ldots \ldots \ldots \ldots \ldots \ldots \ldots \ldots \ldots$ early investigations of $\ldots \ldots \ldots \ldots \ldots \ldots \ldots \ldots \ldots \ldots \ldots \ldots \ldots \ldots \ldots \ldots$ II 11 c escape of, in wells $\ldots \ldots \ldots \ldots \ldots \ldots \ldots \ldots \ldots$ W 118, 257, 520 e; A 5 e fallacies regarding $\ldots \ldots \ldots \ldots \ldots \ldots \ldots \ldots \ldots \ldots \ldots \ldots W$ 278, 380; B 319 faults in relation to ....................... 18 II b; J 294

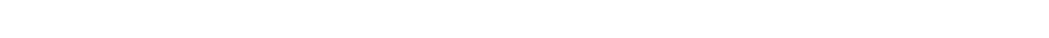
head of, atmospheric effects on $\ldots \ldots \ldots \ldots \ldots \ldots \ldots \ldots \ldots$ B $₹ 19$; GF 156 climate in relation to $\ldots \ldots \ldots \ldots \ldots \ldots \ldots \ldots \ldots \ldots \ldots \ldots, 21,91$ density in relation to $\ldots \ldots \ldots \ldots \ldots \ldots \ldots \ldots \ldots \ldots \ldots \ldots$ B 319 depth in relation to $\ldots \ldots \ldots \ldots \ldots \ldots \ldots \ldots \ldots \ldots$ A 5 c; GF 168 fluctuations in ...W 34, 101, 240, 256, 319, 638 a; GF 15f; C 21, 91, $92,94,97,242,43:$; 56,66 gage for measuring $\ldots \ldots \ldots \ldots \ldots \ldots \ldots \ldots \ldots \ldots \ldots \nabla^{\top} 145 ; C$ C 92 loss in ....WW 59, 60, 90,137, 138, 139, 142, 145, 219, 24^.255, 256, 293, 425 a, 520 e, 596 a; A 17 II g; GF 96, 97, 99, 100, 113, 114

156; C 91, 231, 431; J 152, 177 measurement of $\ldots \ldots \ldots \ldots \ldots \ldots . W 118,145 ; \mathrm{C} 58,94,144 ; \mathrm{J} 149,230$ Salton Sink in relation to ...................... 225 temperature in relation to ..................... 319 water table in relation to $\ldots \ldots \ldots \ldots \ldots \ldots W$ 256, 293; A 5 c; C 451 high-level flows of $, \ldots, \ldots \ldots \ldots \ldots \ldots \ldots \ldots \ldots \ldots \ldots \ldots \ldots \ldots$ W 320 
Artesian water, hot, in Idaho $\ldots \ldots \ldots \ldots \ldots \ldots \ldots \ldots \ldots \ldots \ldots . . \ldots \ldots$ G 45

in Montana ................................... $400 \mathrm{~b}$

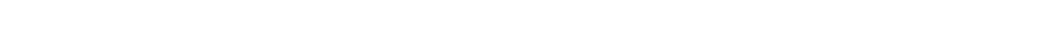

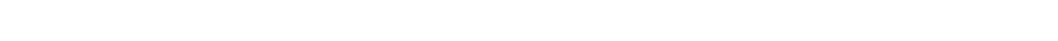

law relating to $\ldots \ldots \ldots \ldots \ldots \ldots$ W $55,78,122,520$ e, 596 a; C 91, 131

leakage of $\ldots \ldots \ldots \ldots \ldots \ldots \ldots \ldots \ldots W 118,257,638$ c; A 5 c; C 92

methods for detecting $\ldots \ldots \ldots \ldots \ldots \ldots \ldots$ W 118, 596 a; A 5 c; C 92 maps showing See Maps.

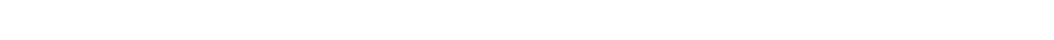
movements of $\ldots \ldots \ldots \ldots \ldots \ldots \ldots \ldots \ldots \ldots \ldots . . W$ 494; B 606; J 86

See also Movements of ground water.

origin of ..W 101, 158, 494, 520 e, 889 a; A 5 c; M 27; B 319; GF 97, 117; J 344, 347; 353 perched bodies of $\ldots \ldots \ldots \ldots \ldots \ldots \ldots \ldots \ldots \ldots \ldots \ldots$ W 32k $494 ;$ C 99

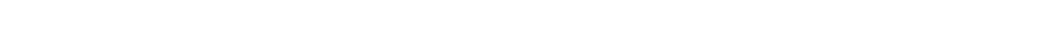
power developed from ...........W 67, 494; A 17 II g; GF 168; C 81 principles of ...W 114, 118, 195, 254, 257, 341, 365, 399, 494 598, 520 e, 889 a; A 5 c, 14 II a, 21 IV c, 21 vII; M 27; P 44, 46; B 319, 856;

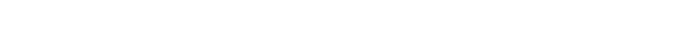
significance of term ............................... 160 temperature of. See Temperature of artesian water, unusual conditions of $\ldots \ldots \ldots \ldots \ldots \ldots \ldots \ldots \ldots \ldots W$ W 145, B $319 ; \mathbf{J} 3$ Artesian water in-

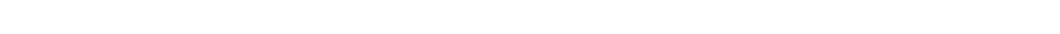

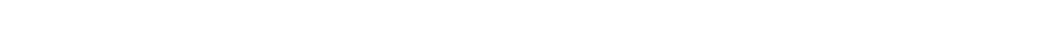

Benton formation ..................GF 96, 99, 100, 113, 114, 165

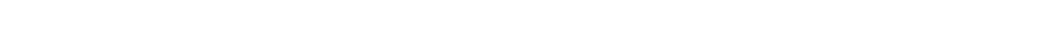

Calvert formation $\ldots \ldots \ldots \ldots \ldots \ldots \ldots \ldots \ldots \ldots \ldots$ GF $136,137,152$

crystalline rocks ..W 106, 145, 160, 232, 374, 397; A 5 c; GF 149, 157, $158 ; \mathrm{C} 451 ; \mathrm{J} 4$

Dakota sandstone ..W 6, 12, 34, 215, 216, 227, 256, 520 e, 597 c, 598, 889 a; A 16 II $f, 17$ II f, g, 18 Iv c, 19 Iv c, 21 IV c; $M 25,27 ; P 17,32$, 52, 65; B 350, $691 \mathrm{~g}, 736 \mathrm{~d}$; GF $68,71,85,87,88,96,97,100,107$, $108,113,114,127,128,135,156,164,165,168 ;$ C 361; J $41,56,66$ Deadwood sandstone .................W 227; P 32; GF 164; C 361 debris-filled basins ..W 142, 181, 219, 225, 240, 277, 278, 320, 333, 343 $375 \mathrm{~d}, 423$

Denver formation ............................... 27 Ellensburg formation $\ldots \ldots \ldots \ldots \ldots \ldots \ldots \ldots \ldots \ldots \ldots \ldots$ 5 55,118 ; GF 86 faults ..................................... B 319 fissured rocks $\ldots \ldots \ldots \ldots \ldots \ldots \ldots \ldots \ldots \ldots$ W 160, 232, 374, 397; A 5 c

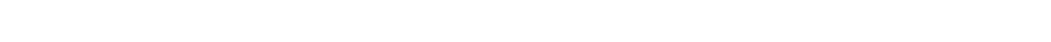
Fredericksburg group ........................ 21 vir glacial drift .. W 182, 183, 254, 256, 293; A 17 II g, h, 18 Iv b, 19 IV b; M 38

P 44; GF 96, 97, 99, 100, 113, 114, 117, 140, 155, 157, 165, 16ร. 210; C 451 Glen Rose formation ........................... 21 vir

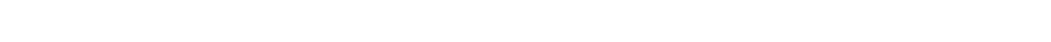
Grand Falls chert $\ldots \ldots \ldots \ldots \ldots \ldots \ldots \ldots \ldots \ldots \ldots \ldots \ldots \ldots \ldots \ldots$, GF 148 joints $\ldots \ldots \ldots \ldots \ldots \ldots \ldots \ldots \ldots \ldots \ldots \ldots \ldots \ldots$ W 160, 232, 256; B 319 Jurassic formations $\ldots \ldots \ldots \ldots \ldots \ldots \ldots \ldots \ldots \ldots \ldots \ldots \ldots \ldots \ldots \ldots$ lacustrine deposits $\ldots \ldots \ldots \ldots \ldots \ldots \ldots \ldots, \ldots, W$ 217, 220; 277, 333, 425 a 
Artesian water in, Lakota sandstone ..P 65; B 736 d; GF 107, 108 127, 128, 150,$164 ; \mathrm{C} 361$ Laramie formation . ..............W 599, 600; M 27; GF 87 lava .................W 4, 55, 616; B 252; C 91, 92, 9r, 99; J 255 lava and interbedded alluvium .................W 4, 54; B 199 Lloyd sand $\ldots \ldots \ldots \ldots \ldots \ldots \ldots \ldots \ldots \ldots \ldots \ldots \ldots \ldots \ldots \ldots \ldots$ Magothy formation ............................ 152 Minnelusa formation $\ldots \ldots \ldots \ldots \ldots \ldots \ldots \ldots \ldots \ldots$ GF 128, 150, 164; C 361 Monmouth formation ............................ 137

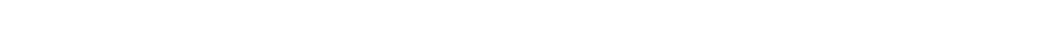

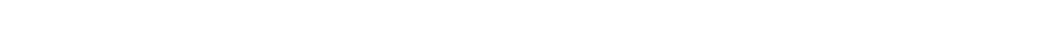
Newark sandstone $\ldots \ldots \ldots \ldots \ldots \ldots \ldots \ldots \ldots \ldots \ldots \ldots \ldots$ W $2 £ 2$; GF 157 Niagara limestone .................. 19 Iv b; GF 145; C 451 Ocala limestone .. W 319, 773 c; C 51, 52, 53, 54, 55, 56, 57, 58, 59, 60, 61, $62,63,64,65 ; \mathrm{J} \mathrm{134,} \mathrm{137,} \mathrm{138,} \mathrm{139,} \mathrm{189,} \mathrm{221,} \mathrm{248,} \mathrm{252,} 258$

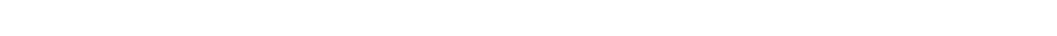
Permian formations ......................... $500 \mathrm{~b}$ Pierre shale $\ldots \ldots \ldots \ldots \ldots \ldots \ldots \ldots \ldots \ldots \ldots \ldots \ldots \ldots \ldots \ldots \ldots$ GF 165 Plattesville limestone $\ldots \ldots \ldots \ldots \ldots \ldots \ldots \ldots \ldots \ldots \ldots \ldots$ GF 145; C 451 Pleistocene coastal clays $\ldots \ldots \ldots \ldots \ldots \ldots \ldots \ldots \ldots \ldots \ldots \ldots$ A 21 VII Potomac group .................. 138; GF 137, 152; C 437 Potsdam sandstone ..W 256, 293; A 17 II h; M 38; GF 81, 140, 145; C 451 preglacial channels ......................... 19 Iv b

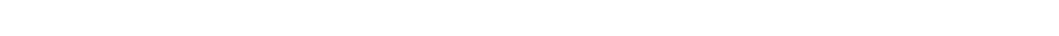

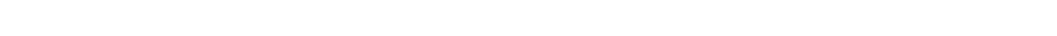
rocks overlain by glacial drift .................W 145, 256 St. Peter sandstone .. W 233, 256, 293; A 17 II h; M 38; B 438; GF 81, $140,145,148 ;$ C 451

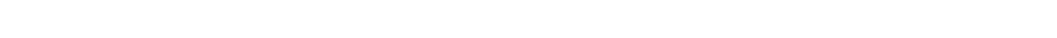
solution passages $\ldots \ldots \ldots \ldots \ldots \ldots \ldots \ldots \ldots \ldots \ldots \ldots \ldots \ldots \ldots$. 319 Tertiary formations .................... 906 b, c; C 58

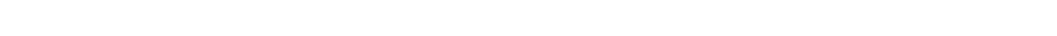
Triassic formations .............W 232, 470, 540; M 27; GF 157

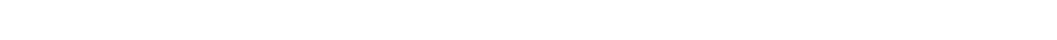
unconfined horizontal beds $\ldots \ldots \ldots \ldots \ldots \ldots \ldots \ldots$ W 145; P 44; B 319 valley fill $. . W 89,137,138,142,181,199,219,220,222,225,240,277,278$, $320,333,375$ d, 519; GF 163; C 32, 113, 116; D 18

Wasatch formation ........................ 53 ; B 796 c weathered rocks beneath clay $\ldots \ldots \ldots \ldots \ldots \ldots \ldots \ldots \ldots \ldots \ldots$ B 319

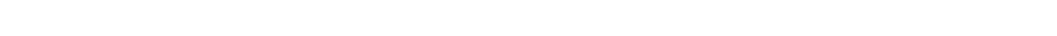
See also specific States.

"Artesian wedges," nature of . ......................... 119

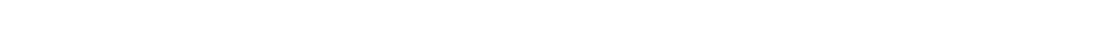
closing of $\ldots \ldots \ldots \ldots \ldots \ldots \ldots \ldots \ldots \ldots \ldots \ldots \ldots \ldots$ W 90, 227; A 17 II $\mathrm{g}$ detecting flows in $\ldots \ldots \ldots \ldots \ldots \ldots \ldots \ldots \ldots \ldots$ 118; J 46. 49, 50, 276

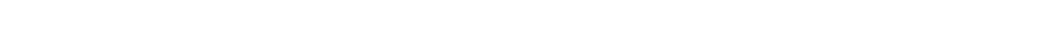
gases in relation to yield of $\ldots \ldots \ldots \ldots \ldots \ldots \ldots \ldots \ldots \ldots \ldots \ldots \ldots$ c in United States prior to $1890 \ldots \ldots \ldots \ldots \ldots \ldots \ldots \ldots \ldots \ldots$ A 13 III a interference of $\ldots \ldots \ldots \ldots \ldots \ldots \ldots \ldots \ldots \ldots \ldots \ldots \ldots \ldots \ldots \ldots \ldots \ldots$ II $\mathrm{c}$ large yields of $\ldots \ldots \ldots \ldots \ldots \ldots \ldots \ldots \ldots \ldots \ldots$ 67, 158; GF 205; C 91 laws of flow in $\ldots \ldots \ldots \ldots \ldots \ldots \ldots \ldots \ldots \ldots \ldots \ldots \ldots \ldots \ldots \ldots \ldots \ldots \ldots$ II $\mathrm{c}$ leaks in $\ldots \ldots \ldots \ldots \ldots \ldots \ldots \ldots \ldots W$ 118, 257, 596 a, 638 c; A 5 c ; C 92 
Artesian wells, management of $\ldots \ldots \ldots \ldots \ldots \ldots \ldots \ldots \ldots \ldots \ldots \ldots \ldots \ldots$ W 227 methods of controlling $\ldots \ldots \ldots \ldots \ldots \ldots \ldots \ldots \ldots \ldots \ldots \ldots W^{*} 118$; A 5 c temperature of water in relation to yield of $\ldots \ldots \ldots \ldots \ldots \ldots \ldots \ldots$ A 5 c yield of, diameters in relation to ................W 293, 887

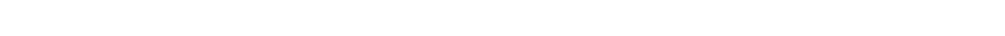
effect of gases on ........................... 5 c effect of temperature on ..................... 5 c; B 319

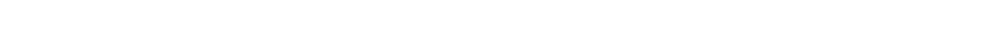
methods of measuring ..W 110, 219, 240, 257; W 33, 45, 72, 114, 195 principles of $\ldots \ldots \ldots \ldots \ldots \ldots \ldots \ldots \ldots \ldots \ldots \ldots \ldots \ldots \ldots \ldots \ldots$ 293, 887 seasonal variations in $\ldots \ldots \ldots \ldots \ldots \ldots \ldots \ldots \ldots \ldots \ldots$ w $210 ; \mathrm{C} \mathrm{91,92}$ See also Artesian water; Well construction.

Ash beds, perched water on $\ldots \ldots \ldots \ldots \ldots \ldots \ldots \ldots \ldots \ldots \ldots \ldots$ 616; C 92,99 Ashley, G. H., Ditney folio, Ind. ........................ 84

Geologic structure of Punxsutawney, Curwensville, Houtzdale, Barnes-

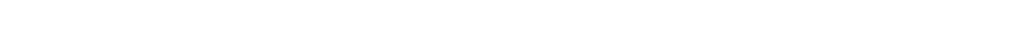
Ground-water investigations in Pennsylvania .............. J 335 Nicholas quadrangle, W. Va. ...................... 145 Water resources of the Middlesboro-Harlan region of southenstern Ken-

tucky ..................................... 110

Asia, irrigation with ground water in $\ldots \ldots \ldots \ldots \ldots \ldots \ldots \ldots \ldots \ldots \ldots \ldots$ W 1

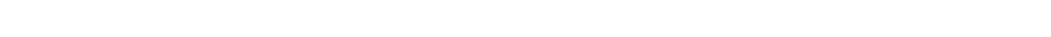

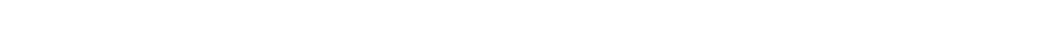

See also China; India; Japan; Persia; Russia; Turkestan

Aspirator for mechanical analysis of soil $\ldots \ldots \ldots \ldots \ldots \ldots \ldots \ldots \ldots \ldots$ W 67

Assays of ground water-

Arkansas ..................................W 399

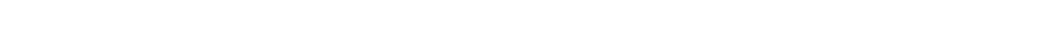

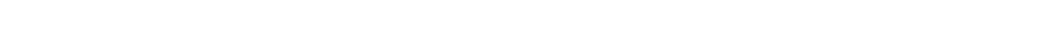

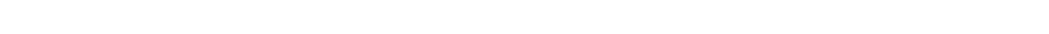

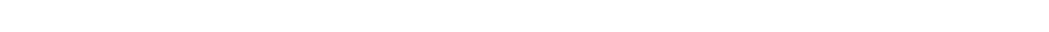

Kentucky ..................................... W 233

New Mexico ................................. 275

North Carolina .............................C 291

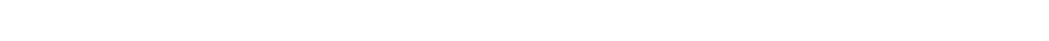

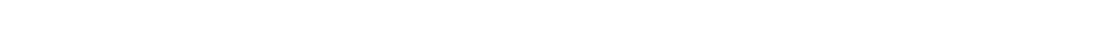

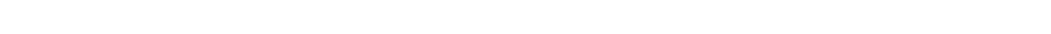

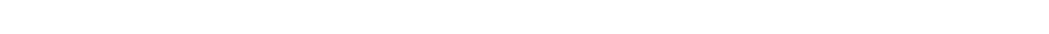

computation of $\ldots \ldots \ldots \ldots \ldots \ldots \ldots \ldots \ldots \ldots \ldots \ldots \ldots \ldots \ldots$ W 151, 398

methods of making, for specific substances $\ldots \ldots \ldots \ldots \ldots W 151,193,398$

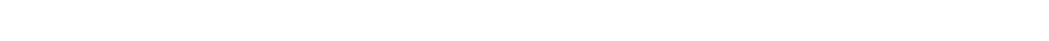

Atlantic Coastal Plain. See specific States.

Atmospheric effects on wells. See Wells.

Auriferous gravel, water in, in California ...................GF 66

Austin, V. L., Water levels and artesian pressure in the United States

Austin formation, water in, in Texas ........... 276; A 12 II b; GF 64

Australia, bibliography of ground water in ................ 163

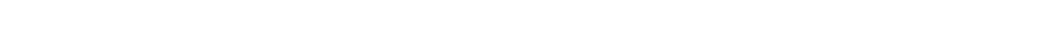

Austria-Hungary, bibliography of ground water in ............W 163 mineral waters in $\ldots \ldots \ldots \ldots \ldots \ldots \ldots \ldots \ldots \ldots \ldots \ldots \ldots$. . . . . 1916 
Austria-Hungary, quality of ground water in..... B 330, 491, 616; MR 1916 radioactive waters in ..........................MR 1913 II $\mathrm{h}$ Ayer, G. R., Water levels and artesian pressure in the United States:

W 944, 986

\section{B}

Babb, C. C., Progress of stream measurements, $1904 \ldots \ldots \ldots \ldots \ldots$. W 130 Babcock, H. M., Duncan-Virden Valley, Greenlee County, Ariz., and

Hidalgo County, N. Mex. ........................... 17

Ground-water levels and pumpage in Arizona in 1939-40.......... 14

Ground-water resources of the Santa Cruz Basin, Ariz. ........... 20

Queen Creek area, Maricopa and Pinal Counties, Ariz. ............ 18

Recharge to ground watęr from floods in a typical desert wash ......J 279

Water levels and artesian pressure in the United States..W 911, 941, 949

Water resources of Safford and Duncan-Virden Valleys, Ariz.-N. Mex. C 15

Water-stage recorder, self-starting ..................... 139

Bach, W. K., Ground water levels in Utah ................. 122, 145

Method to protect a pressure-recorder .................. 114

Water levels and artesian pressure in the United States......W 886, 910 Bacteria in ground water-.. W 193, 256, 259, 335, 341, 398, 399; P 113; C 82 Bacteriological analysis of water ..................... W 193, 315 Bailey, E. H. S., Stream pollution by mine waters in southeast Kansa“.. W 273 Bain, H. F., Zinc and lead deposits of the upper Mississippi Valley...... B 294 Baker, A. A., Geology and coal resources of the Salina Canyon district,

Utah .......................................... 796 c

Geology and oil possibilities of the Moab district, Utah ......... 841 Geology of the Monument Valley-Navajo Mountain region, Utah..B 865 Northward extension of the Sheridan coal field, Mont. ......... B 806 b Baker, R. C., Ground-water levels in Pennsylvania ............... 131

Salt-water intrusion in the No. 1 sand near Parlin, N. J..........D 151

Water levels and artesian pressure in the United States....W 88C 906, 936

Baldwin, G. C., Surface water supply of the United States, W 393, 463, 483, $513,553,613,633,653,673$

Ball, S. H., Geologic reconnaissance in southwestern Nevada and erstern

California .................................... 308

Baluchistan, ground water in, bibliography of $\ldots \ldots \ldots \ldots \ldots \ldots \ldots \ldots$ W 163

Barber, D. H., Surface water supply of the United States, 1935 ......W 782

Barbour, E. H., Wells and windmills in Nebraska.............W 29

Barium in ground water ...........W 254, 338, 399; B 47; MR 1911 II $n$

Barker, F. C., Irrigation in Mesilla Valley, N. Mex. ............W 10

Barksdale, H. C., Artificial recharge of productive ground-water aqrifers in

New Jersey ...................................... 360

Contamination of ground water by salt water near Parlin, N. J. ....J 228

Demand for water for air conditioning $\ldots \ldots \ldots \ldots \ldots \ldots \ldots \ldots \ldots$. 70

Ground-water problems in New Jersey ..................J 350

Ground-water supplies of Middlesex County, N. J. ............. 218

Ground-water supplies of the Atlantic City region, N. J.........C 216

Quantitative investigation of New Jersèy ground waters .........J 140

Salt-water intrusion, a coastal ground-water problem...........J 201

Salt-water problems in Maryland ........................ 151

Water-level fluctuations at Plainfield, N. J. ................J 151 
Barksdale, H. C., Water levels and artesian pressure in the United States

W 777, 817, 840.845, 886, 936

Water supplies, Parlin, N. J. . . . . . . . . . . . . . . . . C 217

Water-table fluctuations near Runyon, N. J. ...............J 99

Barnes, B. A., Ground water, Galveston, Tex., with special reference to

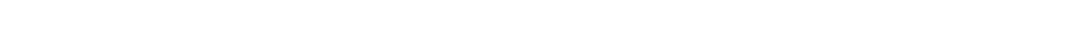

Barnett, V. H., Gillette coal field, northeastern Wyoming........ B 796 a

Standing Rock and Cheyenne River Indian Reservations, N. Dak.-

S. Dak ................................... 575

Barometric effects on wells. See Wells.

Barriers to ground water. See Dams.

Barton, D. A., Water levels and artesian pressure in the Unitec States,

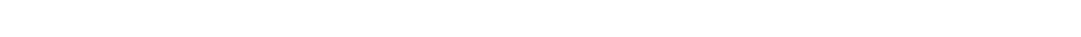

Basalt. See Lava.

Bascom, Florence, Coatesville-West Chester folio, Pa.-Del..........GF 223

Elkton-Wilmington folio, Md.-Del.-N. J.-Pa. ..............GF 211

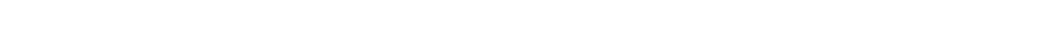

Geology and mineral resources of the Honeybrook and Phnenixville quadrangles, $\mathrm{Pa} . \ldots \ldots \ldots \ldots \ldots \ldots \ldots \ldots \ldots \ldots \ldots \ldots \ldots \ldots$ B 891

Geology and mineral resources of the Quakertown-Doylestorn

district, Pennsylvania and New Jersey ................. 828

Philadelphia folio, Pa.-N. J.-Del. ..................GF 161

Trenton folio, N. J.-Pa. ......................GF 167

Water resources of Philadelphia district, Pa.-N. J.-Del ........W 106

Base exchange in ground water, caused by carbonaceous matter......J 325

in Atlantic and Gulf States ......................... 296

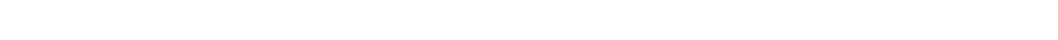

Basins. See Debris-filled basins.

Bass, N. W., Ashland coal field, Mont. ................ 831 b

Bastin, E. S., Bonanza ores of the Comstock lode, Nev. ........... 735 c

Eastport folio, Maine ...........................GF 192

Economic geology of Gilpin County and adjacent parts, Colo. . . . . . P 94

Genesis of the ores at Tonopah, Nev .................... 104

Origin of silver ores near Chloride and Kingman, Ariz. ....... $750 \mathrm{~b}$

Penobscot Bay folio, Maine ........................FF 149

Primary natives-silver ores near Wickenburg, Ariz. ........ 735 e

Rockland folio, Maine ............................FF 158

Silver enrichment in the San Juan mountains, Colo. ......... $735 \mathrm{~d}$

Silver ores of Aspen, Colo. ....................... $750 \mathrm{c}$

Batesville santstone, water in, in Arkansas .............W 114, 115

Bauer, C. M., Coal in San Juan County, N. Mex. .............. 716 g

Ekalaka lignite field, southeastern Montana............. $751 \mathrm{f}$

Lignite in Fort Berthold Indian Reservation, N. Dak. ........ 726 d

Bayley, W. S., General features of hematite ores of North Carclina. . B $735 f$

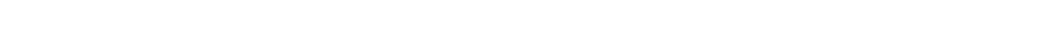

Raritan folio, N. J ..........................GF 191

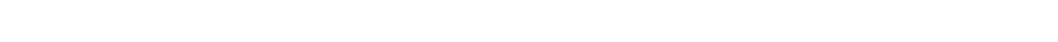

Underground waters of southern Maine ..............W 223

Wells and springs in Maine ......................W 102

Beal, C. H., Geologic structure in Cushing oil and gas field, Okl \%, and its

relation to oil, gas, and water $\ldots \ldots \ldots \ldots \ldots \ldots \ldots \ldots \ldots \ldots \ldots \ldots \ldots$ 
Beaumont clay, water in, in Texas ...................W 335 Becker, G. F., Geology of the quicksilver deposits of the Pacific slone..M 13 Beckman, H. G., Large springs of Missouri ............... 200 . Surface water supply of the United States, Part 6..W 586, 606, 626, 646, $686,701,716,731,746,761,786,806,826,856.876,896$

Surface water supply of the United States, Part 7. .W 607, 627, 647, 667, $687,702,717,732,747,762,787,807,827,857,877,897,957,977$

Beckwith formation, water in, in Wyoming ................ 56 Bedding planes, water in ................W 114, 254, 4 489; B 319 Beekley, A. L., Geology of Standing Rock and Cheyenne River Indian

Reservations, N. Dak.-S. Dak. ........................... 575

Belgium, ground water in, bibliography of $\ldots \ldots \ldots \ldots \ldots \ldots \ldots \ldots$ W 163

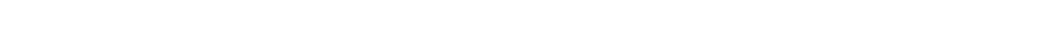

Bell, F. M., Surface water supply of the United States ......... $\mathrm{W}^{r} 852,872$

Bennett, R. R., Geology and ground-water resources of the Big Spring

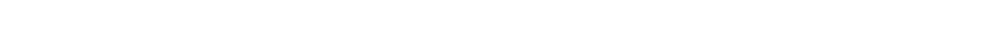

Ground water in the Baltimore area (Md.) ..............J 355

Recharge, movement, and discharge in the Edwards limestone

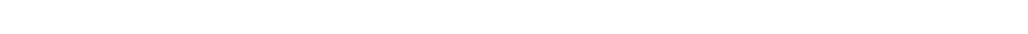

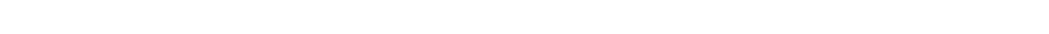

Water levels and artesian pressure in the United States, 1943...W 987

Benton formation, water in-

Kansas ............................ 273; P 32

Nebraska ...........................W 216; P 32

North Dakota ......................W 587; B 801; C 302

South Dakota ..W 90, 227; P 32; GF 96, 97, 99, 100, 113, 114, 165; C 302

Wyoming ........................ 32; B 364; GF 173

Berea grit, water in, in Michigan ................W 30, 31, 114

water in, in Ohio ........................ 114; B 818

Berdan, J. M., Bibliography of technical reports, articles, and momoranda published or otherwise released (by the Ground Water Divisicn, United State Geological Survey) ................... 187, 198, 209 List of current publications concerning ground water.........J 371 Water levels and artesian pressure in the United States, 1943 . . . . W 987 Bergquist, A. W., Water levels and artesian pressure in the

United States ........................... 840,845

Bermuda Islands, bibliography of ground water in ...........W 163

Berry, E. W., Surface and underground water resources of Maryland... C 171

Bevan, Arthur, Water levels in tidewater Virginia in 1943 ......... 190

Bibbins, Arthur, Patuxent folio, Md.-D. C. ................... 152

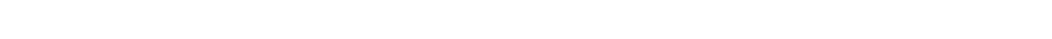

Bibliography, absorption of water $\ldots \ldots \ldots \ldots \ldots \ldots \ldots \ldots \ldots \ldots \ldots \ldots \ldots \ldots$ W 294

analyses of American mineral water ...........MR $1913 \mathrm{II} \mathrm{h,} 1916$ analyses of water ....W $659 \mathrm{c}$; B 330, 491, 606, 616; MR $1913 \mathrm{II} h$; 1916

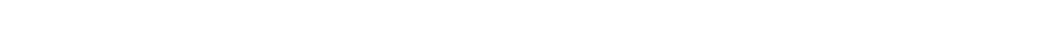

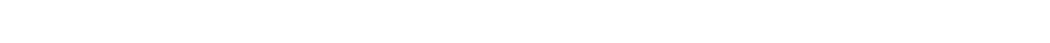

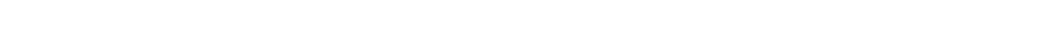

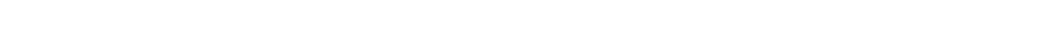

electrical well logging .......................... 153

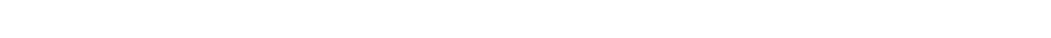

fluctuations of water table $\ldots \ldots \ldots \ldots \ldots \ldots \ldots \ldots \ldots \ldots \ldots \ldots$ W 155 
Bibliography, ground water. See specific States.

ground-water literature. . W 163, 836 d; D 116, 133, 161; J 98, 113, 172, 371 mineral waters, general ..............W 120, 163; MrR 1905, 1916 mineral waters in United States ......W 120, 163; MR 19n5, 1916, 1921 movements of ground water ..................... 19 In c percolation ...................................W 294 permeability $\ldots \ldots \ldots \ldots \ldots \ldots \ldots \ldots \ldots \ldots \ldots \ldots \ldots \ldots \ldots \ldots \ldots$ W 887

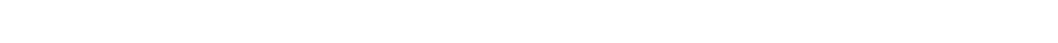
radioactivity of ground water ...................... $1913 \mathrm{~d}$ United States Geological Survey publications on ground water

W $120,340,427$

water in crystalline rocks $\ldots \ldots \ldots \ldots \ldots \ldots \ldots \ldots \ldots \ldots \ldots \ldots \ldots$ W 232

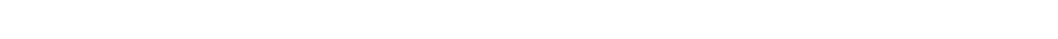

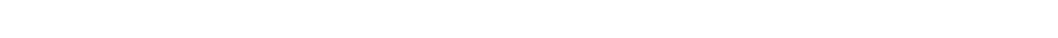

Bicarbonate in ground water. W 254, 259, 273, 338, 341, 398; P 117; MR 1911

Bighorn limestone, water in, in South Dakota .............. 32

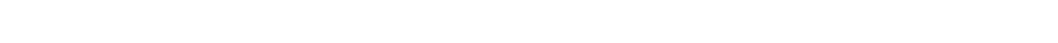

Billings, Norman, Water levels and artesian pressure in the United States

W 886, 906, 944

Bingen formation, water in, in Arkansas .........W 114; P 46; B $691 \mathrm{j}$

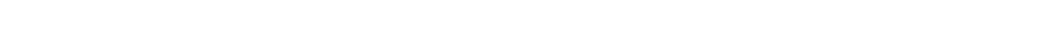

Birdseye limestone, water in, in Ohio .................W 259

Black alkali in ground water ....................W 320, 343

Black creek formation, water in, in North Carolina........... 291; J 334

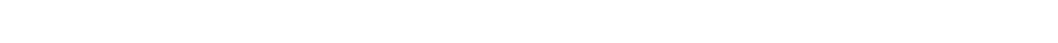

Blackwelder, Eliot, Laramie-Sherman folio, Wyo. .............GF 173

Blank, H. R., Geologic studies on Long Island with respect to ground-water

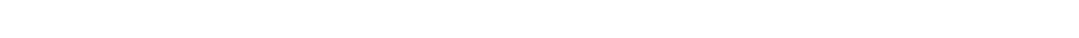

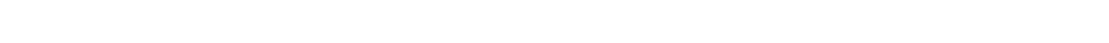

Blowing springs $\ldots \ldots \ldots \ldots \ldots \ldots \ldots \ldots \ldots \ldots \ldots \ldots \ldots \ldots \ldots \ldots \ldots$

Blowing wells. See Wells, blowing.

Boiler compounds . W 398

Boiler use of ground water. See Quality; Analyses.

Bolsons. See Debris-filled basins; Valley fill.

Bone Valley gravel, water in, in Florida .................W 319 Bonner, J. P. Water levels and artesian pressure in the United States

Boone formation, water in, in Arkansas ...........W 145; GF 122, 154

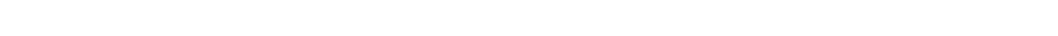

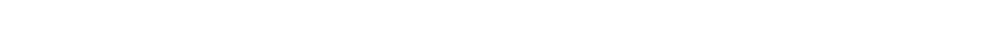
in Oklahoma $\ldots \ldots \ldots \ldots \ldots \ldots \ldots \ldots \ldots \ldots \ldots \ldots$ GF 122, 132, 154 Borate in ground water .......W 338; B 47, 330, 491, 616; MR 1911 in $\mathrm{n}$ Boring of wells. See Well construction.

Boston formation, water in, in Arkansas ................ 145

Bottom water, relation of, to oil $\ldots \ldots \ldots \ldots \ldots \ldots \ldots \ldots \ldots \ldots \ldots$ B 658

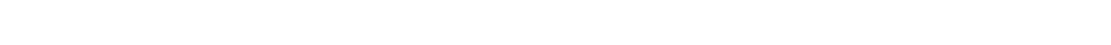

Boutwell, J. M., Econome geology of the Bingham mining distriet, Utah.P 38 Geology and ore deposits of the Park City district, Utah........P 77

Records of wells and springs in New Hampshire ...........W 102

Bowen, C. F., Structure and oil and gas resources of the Osage Reservation,

Okla. .B $6861, u$ 
Bowman, Isaiah, East St. Louis district, Ill. ................. 131 .

Flowing wells and municipal water supplies in southern peninsula of Michigan .................................W 182

Problems of water contamination .....................W 160

Well-drilling methods .........................W 257

Well records on Long Island, N. Y. ................... 44

Bownocker, J. A., Columbus folio, Ohio ...................GF 197

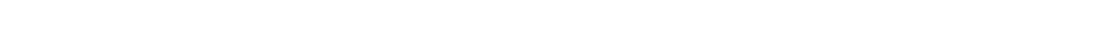

Boyd, David, Irrigation near Greeley, Colo. ..................W 9

Bradley, W. H., Structure and gas possibilities of the Oriskany sand rtone,

N. Y. ....................................... 899 a

Branner, J. C., Santa Cruz folio, Calif. .....................GF 163

Brashears, M. L., Jr., Artificial recharge of ground water on Long Island,

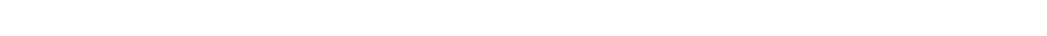

Cooperative ground-water investigation in Massachusetts :.......J 272

Ground-water conditions in New York with respect to salt-water encroachment ................................ 151

Ground water for air conditioning on Long Island, N. Y ........J 193

Ground-water studies in northeastern Massachusetts ..........J 329

Ground-water temperature on Long Island, N. Y ...........J 249

Progress report on the ground-water resources of Providence, R. I. . C 355

Public water supply of Shelter Island Heights, N. Y ......... D 100

Record of wells in Kings County, N. Y ................C 279

Record of wells in Nassau County, N.Y .................. 282

Record of wells in Suffolk County,-N. Y., Supplement 1 .........C 281

Report of ground-water pumpage on Long Island, N. Y . .D 192, 199, 202

Salt-water encroachment in Massachusetts .............. 151

Water levels and artesian pressure in the United States ....W 886, 906, 936944,986

Well records for the Aberjona Valley area, Mass. ............D 193

Bratton, D. H., Design and use of maximum-minimum water-lerel gage

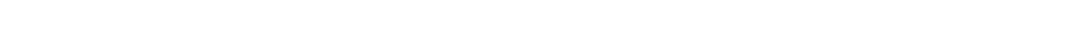

Ground-water levels and pumpage in Safford Valley, Ariz. ....... 14

Water levels and artesian pressure in the United States, 1940 ...W 911

Brazil, J. J., Ground water in the oil-field areas of Ellis and Russell Counties,

Kans. .................................. 156

Brazil, ground water in, ................. 282, 283, 284, 285

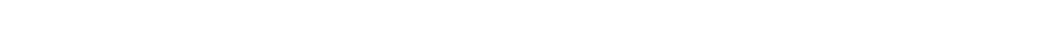

springs in ............................. 284, 285

Breathing wells. See Wells.

Breccia, as ground-water dam in Hawaii .............. 92, 98, 99

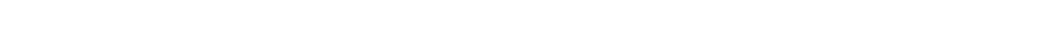

Breeding, S. D., Ground-water resources of Liberty County, Tex ....C 418

Water resources of Gregg County, Tex ................. 417

Water resources of Harrison County, Tex ............... 407

Brewing. See Quality.

Bridges, T. W., Ground-water resources of Kleberg County, Tex .....W 773 d

Brine. See Quality; Salt water.

British Columbia, ground water in, bibliography of ...........W 163

Broadhurst, W. L., Ground water in the High Plains in Texas ...W 889 c;

C 391, 397, 405, 411

Public water supplies in eastern Texas ................ 415 
Broadhurst, W. L., Recharge and discharge of ground-water reservoirs on

the High Plains in Texas ......................... 277

Results of pumping tests of municipal wells at Tyler, Tex . . . . C 412

Water resources of Gregg County, Tex ................. 417

Water resources of Harrison County, Tex ................ 407

Water supply in the Sandflat area, Tex ............... 399

Bromide in ground water ...W 31, 233, 338, 398; P 117; B 47; MR 1911 II n Brooks, A. H., Use of geology on the western front ........... $128 \mathrm{~d}$ Brothwell, W. H., Water levels and artesian pressure in the United States W 777, 840

Brown, C. W., Penobscot Bay folio, Maine ................... 149

Brown, G. F., Artesian water resources in Mississippi ........... 191

Geologic factors affecting the perennial yield of artesian aquifers in

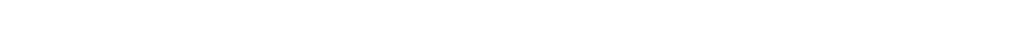

Geology and ground-water resources at Camp McCain (Miss.) . . C 192

Geology and ground-water resources of the Camp Shelby area (Miss.)

C 194

Geology and ground-water resources of the coastal are? of Mississippi

Geology and ground-water supply at Camp Van Dorn (Miss.) . . . . C 193

Records of wells in Mississippi ....................... 124

Water levels and artesian pressure in the United States ...W 845, 886, 907,937

Brown, J. S., Coastal ground water, with special reference to Connecticut

Florida ship canal

Geology of the Republic of Haiti ..................... 72

Ground water in the New Haven area, Conn .............W 540

Hot springs of the Republic of Haiti ................. 36

Relation of sea water to ground water along coasts ..........J 30

Routes to desert watering places in the Salton Sea region, Calif . . W 490 a

Salton Sea region, Calif ......................W 497

Brown, R. H., Salt-water encroachment in limestone at Silvar Bluff, Miami,

Fla ...................................... 352

Test-well drilling in the Florida Everglades ............. 180

Water levels and artesian pressure in the United States, 1942 . . .W 945

Brownstown formation, water in, in Arkansas . . . . . . . . . . . P 46

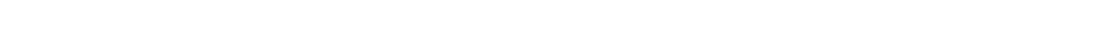

water in, in Nebraska .............W 425 b; A 19 Iv c; P 17, 32

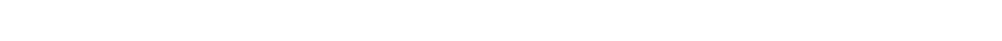

in Wyoming ....................W $425 \mathrm{~b} ; \mathrm{P} 32 ; \mathrm{C} 456$

Brunstein, M. S., Ground-water supplies of the Atlantic City region ...C 216 Bryan, Kirk, Change in plant associations by change in ground-water level

Classification of springs $\ldots \ldots \ldots \ldots \ldots \ldots \ldots \ldots \ldots \ldots \ldots \ldots \ldots \ldots \ldots$

Geologic features in New England ground-water supply .......J 145

Geology and ground-water conditions of the Rio Grande depression in

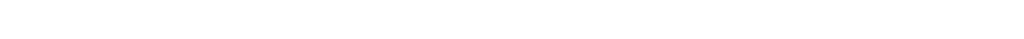

Geology and ground-water resources of Sacramento Valley, Calif . . W 495

Geology of No. 3 reservoir site, Carlsbad irrigation project, N. Mex 
Bryan, Kirk, Geology of reservoir and dam sites, with report on Ovryhee project, Oreg. .............................W 597 a

Ground water for irrigation in Sacramento Valley, Calif ......W 375 a

Ground water in Quinn River and Paradise Valleys, Nev ......... 4

Ground-water reconnaissance in De Baca County, N. Mex .......C 234

Ground-water reconnaissance in Socorro County, N. Mex ........ 233

Hot springs of Arkansas ........................... 37

Hot water supply of the Hot Springs, Ark ..............J 28

New England ground-water supply ................... 164

Papago country, Ariz., with guide to desert watering places .......W 499

Routes to desert watering places in the Papago country, Ariz. .. W 490 d Bryan, L. L., Geology and water resources of the Mud Lake basin, Idaho

Geology and water resources of the Mud Lake region, Idaho .....W 818

Water resources of the Mud Lake region, Idaho ........ 111; D 47

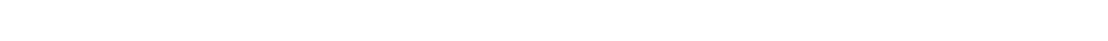

Buddington, A. F., Metalliferous mineral deposits of the Cascade Range,

Oreg ............................................ 893

Mineral investigations in southeastern Alaska ............. $783 \mathrm{~b}$

Bue, C. D., Seepage loss and gain of Mokelumne River, Calif .......D 52

Water levels and artesian pressure in the United States, 1943 ....W 990

Burbank, W. S., Copper deposits of Michigan ................ 144

Geology and ore deposits of the Bonanza mining district, Colo ...P 169

Burchard, E. D., Surface water supply of Hawaii, 1922-23 . . . . . . . W 575

Surface water supply of the United States, $1940 \ldots \ldots \ldots \ldots \ldots \ldots$. . . 893

Water levels and artesian pressure in the United States .....W 777, 817,

$840,845,886.907,937$

Burgoon sandstone, water in, in Pennsylvania ............FF 133; C 343

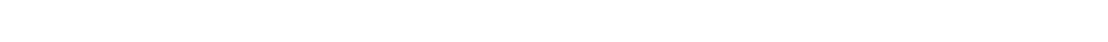

Burleigh, H. P., Ground water in the southern High Plains ........D 66

Burlington limestone, water in, in Illinois ......... 438, 506: GF 208

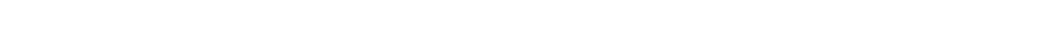

in Missouri ...........................W 195; B 438

Butler, B. S., Copper deposits of Michigan ................ 144

Geology and ore deposits of the San Francisco and adjacent

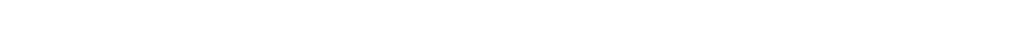

Ore deposits of Utah $\ldots \ldots \ldots \ldots \ldots \ldots \ldots \ldots \ldots \ldots \ldots \ldots \ldots$

Butts, Charles, Barnesboro-Patton folio, Pa .................F 189

Bessemer-Vandiver folio, Ala ...................GR 221

Birmingham folio, Ala .......................... 175

Ebensburg folio, $\mathrm{Pa} \ldots \ldots \ldots \ldots \ldots \ldots \ldots \ldots \ldots \ldots \ldots \ldots$. 133

Geology and mineral resources of the Bellefonts quadrangle, Pa . . B 855

Montevallo, Columbiana folio, Ala ...................FF 226

Warren folio, Pa.-N. Y ........................FF 172

Byers, A. C., Electric resistivity prospecting for salt water contacts

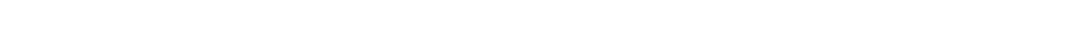

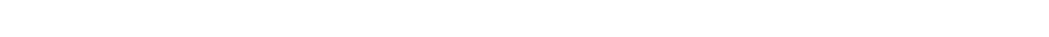

Water levels and artesian pressure in the United States ....W 908, 938

Byrne, Frank, Water levels and artesian pressure in the United

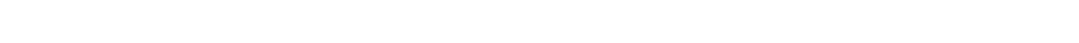


C

Cady, R. C., Channel storage method of determining effluent seepage ...J 169

Effect on ground-water levels of storage in Flathead Lake, Mont. . W $489 \mathrm{~b}$

Geology and ground-water resources of Box Butte County, l'ebr .. W 969

Geology and ground-water resources of Scotts Bluff Country, Nebr. . W 943

Ground water in northern Virginia .................. 434

Ground-water level in northern Virginia ............... 42

Ground-water recharge of deep water table in the Great Plains ...J 229

Ground-water resources of Box Butte County, Nebr .......... D 162

Ground-water resources of northern Virginia ............. 436

Ground-water resources of Scotts Bluff County, Nebr .......... 163

Ground-water resources of Shenandoah Valley, Va ........... 435

Observation wells, manual of methods .................. 60

Replenishment of ground water near Washington, D. C. . . . . . D 22, 29

Water levels and artesian pressure in the United States....W 777, 817, $840,845,886,907,910$

Water levels in observation wells in Virginia .............J 87

Water levels in wells in northern Virginia ........... 37, 107

Caesium in ground water ..................... 520 d; B 47

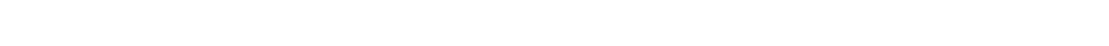

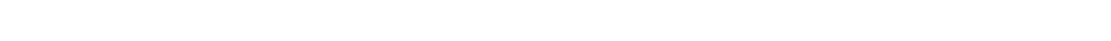

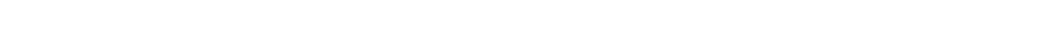

Amador County .....................W 619, 780; D 52

Antelope Valley $\ldots \ldots \ldots \ldots \ldots \ldots \ldots \ldots \ldots \ldots \ldots \ldots \ldots \ldots \ldots$

Bakersfield and vicinity ........................... 17

Cache Creek ...............................W 45

Carpinteria Valley $\ldots \ldots \ldots \ldots \ldots \ldots \ldots \ldots \ldots \ldots \ldots \ldots$ C 27, 30 a

Coachella Valley .......................... 225

coastal plain of southern California ........W 137, 138, 139; J 9

Colfax quadrangle ........................F 66

Colorado Desert ..........................W 225

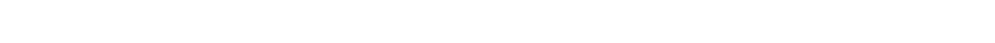

Concord quadrangle $\ldots \ldots \ldots \ldots \ldots \ldots \ldots \ldots \ldots \ldots \ldots \ldots \ldots \ldots$ GF 193

Cuyama Valley ........................... 30 b

Death Valley ................................ $540 \mathrm{n}$

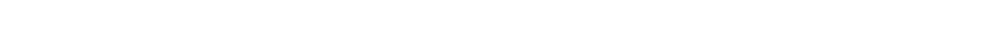

Elk Hills $\ldots \ldots \ldots \ldots \ldots \ldots \ldots \ldots \ldots \ldots \ldots \ldots \ldots \ldots \ldots \ldots \ldots$. 835

foothill belt east of Los Angeles ...............W 219

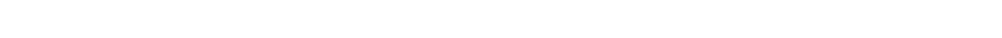

Goleta Valley $\ldots \ldots \ldots \ldots \ldots \ldots \ldots \ldots \ldots \ldots \ldots \ldots \ldots \ldots$ 27, 30 a

Haywards quadrangle $\ldots \ldots \ldots \ldots \ldots \ldots \ldots \ldots \ldots \ldots \ldots \ldots \ldots$ GF 193

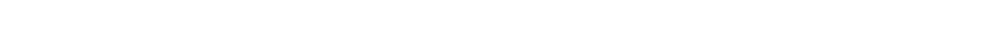

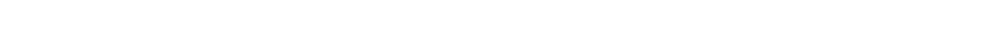

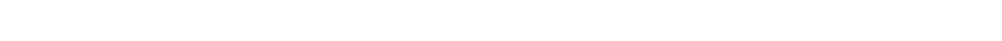

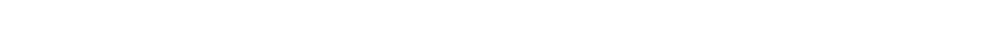

Kings River Delta ......................... 58

Lanfair Valley ....................... 450 b

Lodi vicinity ....................... 619; D 13

Long Beach-Santa Ana area $\ldots \ldots \ldots \ldots \ldots \ldots C$ 25, 2?, 29, $30 \mathrm{~d}$, e, f

Los Angeles County ....................... 24

Los Angeles River Valley .............W 112; A 21 rv a; J 325

Lytle Creek Valley ........................ 21 Iv a 
California, areas, Marysville quadrangle ...............GF 17

Mesquite Valley ..........................W 450 c

Mission Valley $\ldots \ldots \ldots \ldots \ldots \ldots \ldots \ldots \ldots \ldots \ldots \ldots \ldots$. 21 Iv a

Mohave Desert .......................W $49 \mathrm{nq}$ b, 578

Mohave Valley $\ldots \ldots \ldots \ldots \ldots \ldots \ldots \ldots \ldots \ldots \ldots \ldots \ldots$ 21 Iv a

Mokelumne area ....................W 619, 780; D 52

Monterèy County .......................... 264

Morgan Hill district ...................... 400 e

Mother Lode .............................. 157

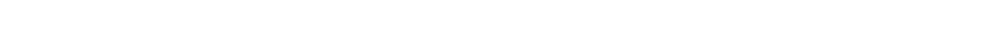

Orange County ......................... 278; C 24

Owens Valley $\ldots \ldots \ldots \ldots \ldots \ldots \ldots \ldots \ldots \ldots \ldots \ldots \ldots \ldots \ldots$ W 181, 294

Pahrump Valley ..........................W 450 c

Redding quadrangle ........................GF 138

Riverside County ............................W 490

Sacramento County ..................W 619, 780; D 52

Sacramento Valley ...............W 375 a, 495, 619, 780; D 52

Salinas Valley ........................... 89

Salt Wells Valley $\ldots \ldots \ldots \ldots \ldots \ldots \ldots \ldots \ldots \ldots \ldots \ldots \ldots \ldots$ C 22

Salton Sea region $\ldots \ldots \ldots \ldots \ldots \ldots \ldots \ldots \ldots \ldots \ldots \ldots \ldots \ldots$ W 490 a, 497

San Antonio Valley ...................... 30 b

San Bernardino Valley $\ldots \ldots \ldots \ldots \ldots \ldots \ldots \ldots \ldots$ 59, 60, 142; C 21

San Diego County ...................W 52, 416; B 264

San Franciseo quadrangle .....................GF 193

San Jacinto basin ..........................W 429

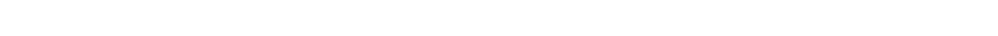

San Joaquin Valley ..................W 222, 378; B 653

San Luis Obispo County ....................... 298

San Luis quardangle .......................FF 101

San Mateo quadrangle .........................FF 193

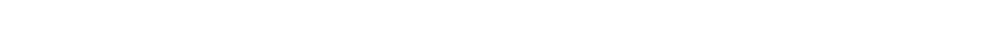

Santa Barbara and vicinity ................... 116

Santa Barbara County ................ 27, 2q 30 a, b

Santa Clara County ................W 519; B 298; J 225

Santa Clara Valley .............W 345 h, 400 e, 519; T 168, 225

Santa Cruz quadrangle .......................FF 163

Santa Maria Valley .......................... 30 b

Santa Ynez Valley ...................... 27, 30 a

southeastern ......................W 224, 490 a, 497

southern ............W 146, 213, 219, 331, 468; B 753; J 9, 318

Sunset-Midway oil field ..................... 116

Tamalpais quadrangle $\ldots \ldots \ldots \ldots \ldots \ldots \ldots \ldots \ldots \ldots \ldots \ldots \ldots$ GF 193

Temecula basin ...........................W 429

Torrance-Santa Monica area ................... 30 c

Truckee quadrangle ........................6F 39

Tulare County .............................. 298

Ventura County ......................... 298

artesian water in ...W 45, 59, 60, 89, 137, 138, 139, 142, 146, 181, 213, 219, $222,224,225,278,398,429,450$ c, $468,495,497,519$; B 691 h; GF 138, 163, 193; C 21; J 9

auriferous gravels of, water in GF 66 bibliography of ground water in W 57, 120, 142. 149, 163 
California, desert watering places in........W 224, 490 a, b, 497; B 308 evaporation in $\ldots \ldots \ldots \ldots \ldots \ldots \ldots \ldots \ldots \ldots \ldots$ W 18, 58, 181, 294, $345 \mathrm{~h}$ infiltration tunnels in ................W 116, A 19 II b; GF 193 irrigation, with artesian water in ....W 137, 138, 139, 142, 219, 222, 225,

$278,398,429$

with other ground water in ...W 17, 45, 58, 59, 60, 89, 116, 137, 138, $139,142,146,181,219,222,225,278,345 \mathrm{~h}, 375$ a, 395, 398, 400 e, 429, 446, 450 c, 495, 497, 519, 619; A 16 II e; C 23; D 13 mineral waters in .........W 338; B 32; MR 1883-192£; GF 39, 101 public water supplies in ........W 59, 60, 116, 345 h, 495. 519; GF 193 pumping in .W 116, 137, 138, 139, 219, 222, 375 a, 398, 429, 446; 619; C 30 e quality of ground water in ...W 58, 59, 116, 137, 138, 139, 142, 224, 225, $278,338,364,398,429,446,450$ b, c, 495, 497, 519, 578; B 32, 529,540 n, 606, 653; GF 17, 39; C 29, 30 c, f; J 38, 43, 325 quantity of ground water in ...W 58, 112, 137, 138, 139, 140, 142, 219, 222, 278,345 h, 375 a, 398, 400 e, 519; C 21, 22, 2?, 26, 27, 30 a salt water in ...W 58; P 98 a; B $540 \mathrm{n} ; 653,669,691 \mathrm{~h} ; \mathrm{C} 25,29,30$ c, f; J 225, 318 seepage water in $\ldots \ldots \ldots \ldots \ldots \ldots \ldots \ldots \ldots \ldots \ldots$ W 18, 58; A 19 II b spring discharge measurements in ...W 177, 251, 298, 300, 338, 370, 441, $460,591,721,766,831,861,881,901$ springs in ..W 142, 181, 219, 224, 278, 338, 429, 450 b, 490 c. b, 497, 557; 578, 679 b; A 14 II b; M 11, 13; B 32, 308, 691 m, 710 e, 725 d, 922 b;

k; GF 39, 65, 101; J 264 thermal ......W 142, 181, 338, 364, 429, 679 b; M 13; B.308, 922 b; GF 3?, 101; J 264 temperature of ground water in ........... 142; B 32; GF 39 underflow, of Los Angeles River in ..................W 112 of Mohave River, Rio Hondo, and San Gabriel River in .....W 140 water levels in .......W 619, 777, 817, 840, 845, 886, .911, 941, 949, 991 water table in ...W 58, 137, $138,139142,146,213,219,222,225,251,294$, 331,345 h, 375 a, 398, 400 e, 429, 446, 468, 495, 497, 519, 619, 780; GF 193; C 21, 22, 24, 28, 29, 30 a, b, d, e; J 9, 53, 100, 155, 160 well records for ...W $45,57,58,60,89,137,138,139,142,149,181,213$, $219,222,225,251,278,294,331,345$ h, 398, 42?, 446, 450 b, c, $468,495,497,519,619,780$; B 264, 298, 540 r, $691 \mathrm{~m}, 753$, 835 ; GF 193; C 21, 22, 24, 25 wells in, construction of $\ldots \ldots \ldots \ldots \ldots W 52,110,140,257,375$ a, 495 cost of $\ldots \ldots \ldots \ldots \ldots$ W 137, 138, 139, 142, 219, 222, 225, 278, 375 a, 398 Calkins, F. C., Geology and water resources of east-central Washington.W 118 Callaghan, Eugene, Manganese in a thermal spring in west-central Utah.J 211 Metalliferous mineral deposits of the Cascade Range in Origon . . B 893 Caloosahatchee marl, water in, in Florida ................W 319 Calvert, W. R., Geology of Standing Rock and Cheyenne River Indian

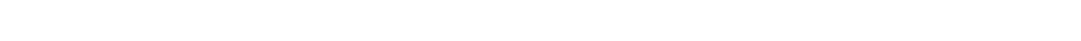

Calvert formation, water in, in Delaware ................. 137 water in, in Maryland .................GF 136. 137, 152, 204 Cambrian formations, water in-

Alabama W 114; GF 175, 221: C 1, 2

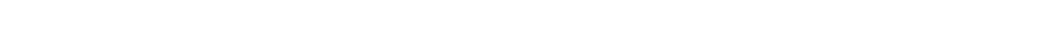

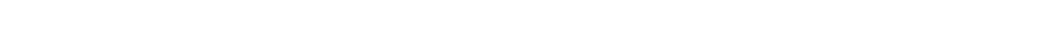

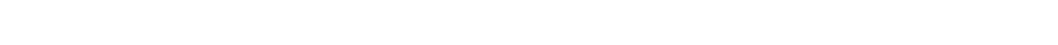


Cambrian formations, water in, Georgia .............W 114; C 81 Illinois ...............W 114; A 17 II h; M 38; GF 81, 145, 200 Iowa $\ldots \ldots \ldots \ldots \ldots \ldots \ldots \ldots \ldots \ldots \ldots \ldots$ W 114, 145, 293; GF 145, 200 Kansas .............................GF 148; C 142 Maine ................................ 149, 158 Maryland $\ldots \ldots \ldots \ldots \ldots \ldots \ldots \ldots \ldots \ldots \ldots \ldots \ldots \ldots \ldots \ldots \ldots$ GF 179, 204

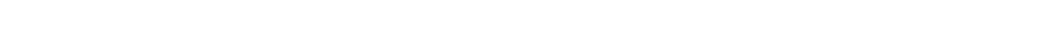
Missouri .......................W 114, 145, 195; GF 148 Nebraska $\ldots \ldots \ldots \ldots \ldots \ldots \ldots \ldots \ldots \ldots \ldots \ldots \ldots \ldots \ldots \ldots \ldots$

New Mexico ................................GF 199

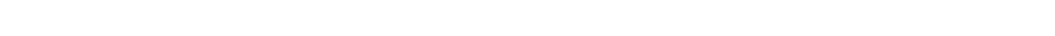

North Carolina .......................GF 124, 147, 151

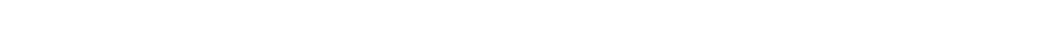

Oklahoma ................................... 323

Pennsylvania ......W 106, 110, 114; B 840, 855, 891; GF 162, 179, 225;

C 342, 345. 347, 349

South Carolina $\ldots \ldots \ldots \ldots \ldots \ldots \ldots \ldots \ldots \ldots \ldots \ldots \ldots$ GF 147

South Dakota ...W 227, 428; A 21 Iv b; P 32, 65; GF 107, 127, 128, 164

Tennessee .............................GF 124, 151

Virginia ................W 114, 596 c; C 432, 433, 434, 435, 436

West Virginia $\ldots \ldots \ldots \ldots \ldots \ldots \ldots \ldots \ldots \ldots \ldots \ldots \ldots \ldots \ldots \ldots$. 114, 179

Wisconsin $\ldots \ldots \ldots \ldots \ldots \ldots \ldots \ldots \ldots \ldots$ W 114, 145; GF 140, 145; C 451

Wyoming ............A 21 rv b; P 32, 51, 65; GF 107, 127, 128, 150

See also specific formations.

Campbell, M. R., Marnesboro-Patton Folio, Pa ..............GF 189

Danville folio, Ill.-Ind .......................... 67

Geologic structure of Punxsutawney, Curwensville, Houtzdale, Barnes-

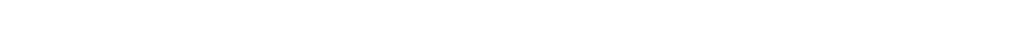

Canada, ground water in, bibliography of $\ldots \ldots \ldots \ldots \ldots \ldots \ldots \ldots$ W 163

Canal Zone, water table in . ............................. $821 \mathrm{~b}$

well records for $\ldots \ldots \ldots \ldots \ldots \ldots \ldots \ldots \ldots \ldots \ldots \ldots \ldots \ldots \ldots$

Canfield, G. H., Surface water supply of the United States, part $10 \mathrm{~W} 720,900$

Surface water supply of the United States, part $11 \ldots \ldots$ 691, 706

Surface water supply of the United States, part $12 \ldots \ldots \ldots \ldots$ W 753

Surface water supply of the United States, part $14 \ldots W 794,834,864$,

884,$904964 ; 984$

Cannon, R. S. Jr., Geology and ore deposits of the Metaline quadrangle,

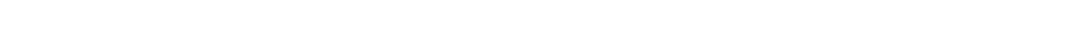

Canyon formation, water in, in Texas ................. 317

Capacity of rocks for water. See Quantity; Porosity.

Capacity of wells. See Wells.

Cape Fear formation, water in, in North Carolina

Capillarity, fluctuation of water table in relation to

ground water in relation to $\ldots \ldots \ldots \ldots \ldots \ldots \ldots W 489,494,63 \varepsilon$ c; $M 47$

water retained by $\ldots \ldots \ldots \ldots \ldots \ldots \ldots \ldots \ldots \ldots$ W 489, 638 c; $A$ 19 II b

Capillary movements of ground water ... W 153, 294, 343, 489, 494; A 19 II b

Capps, S. R., Underground waters of north-central Indiana .......W 254

Carbonaceous matter, action of, on ground water ...........J 325

Carbonate in ground water ...W 254, 259, 273, 338, 341, 398; P 117; B 330, 491, 616; MR 1911, 1916

Carbonation produced by ground water 
Carboniferous formations, water in-

Alabama ........................W 114; GN 175; C 1, 2

Arizona ..........................W 380, 836 b; B 435

Arkansas ......................W 110, 114, 145; GF 122, 154

Colorado $\ldots \ldots \ldots \ldots \ldots \ldots \ldots \ldots \ldots \ldots \ldots \ldots \ldots \ldots \ldots . . \ldots$ 32, 52; B 785 a

Georgia .............................W 114; C 81

Illinois .. W 114; A 17 In h; M 38; B 438, 506; GF 105, 185, 188, 195; C 131

Indiana ...............W 26, 114, 254; A 18 rv b; GF 105; C 134

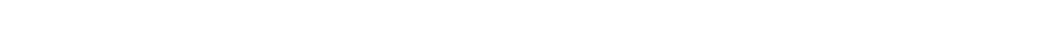

Kansas ....W 273; P 32; B 238; GF 148, 159, 206; C 142, 144, 147, 148

Kentucky ...................W 114; GF 184, 233; C 160 b

Maryland .......................W 110; 114; GF 160, 179

Massachusetts ............................... 839

Michigan $\ldots \ldots \ldots \ldots \ldots \ldots \ldots \ldots \ldots \ldots \ldots \ldots \ldots$ 30, 31, 114, 182, 183

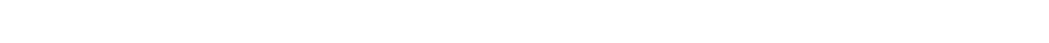

Missouri ...................W 114, 195; B 438; GF 148, 206

Montana ....................W 221; B 822 a, 856 ; J 275

Nebraska ......................W 12; A 19 Iv c; P 17, 32

New Mexico ...W 123, 158, 343, 620; B 435; C 234, 235, 236, 248, 252; D 9

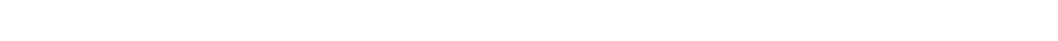

Ohio .............W 91, 114; A 18 Iv b; 19 Iv b; B 818; GF 184

Oklahoma ..W 148, 500 b, 520 b; B 641 b, 661 b, 686, 691 c, 759; GF 122.

132, 154; C 23

Pennsylvania ..W 110, 114; B 300, 531 d, 829, 873; GF 102, 121, 123, 132. $144,146,160,172,174,189$; C 341, 343.345, 346, 349

South Dakota ....W 227, 428; A 21 Iv b; P 32, 65; GF 107, 127, 128, 164

Tennessee $\ldots \ldots \ldots \ldots \ldots \ldots \ldots \ldots \ldots \ldots \ldots \ldots \ldots \ldots \ldots \ldots$ W 114, 677

Texas ................W 154, 191, 276, 317; A 18 II b; GF 194

Utah ........................W 380; B 896 c, 841, 863

Virginia ................................. 114

West Virginia ..................W 110, 114; GF 160, 179, 184

Wyoming ...A 21 iv b; P 32, 51, 53, 65; B 364; GF 107, 127, 128, 141, 150, 173; J 274

See also specific formations.

Carlston, C. W., Early history of water-well drilling in the United States

J 306

Fluoride in the ground water of the Cretaceous area of Alabama....C 3 Ground-water resources of the Cretaceous area in Alabama .......C 4 Salt water in the Coastal Plain of Alabama .............. 151 Water levels and artesian pressure in the United States...W 907, 937, 945,987

Carpenter, Everett, Ground water in Boxelder and Tooele Counties, Utah

Ground water in southeastern Nevada ..............W 365 Carrizo sand, water in, in Texas ...........W 849 a; C 4.07; J 132, 294 Carson, M. H., Surface water supply of Hawaii ...W 595, 615, 635, 655, 675, $710,740,755,770,795,815,835,865,885,905.935,965,985$ Casings in wells. See Well casings.

Casper formation, water in, in Wyoming .......... 364; GF 173; C 456 Castle Hayne formation, water in, in North Carolina ............. 291 
Catahoula formation, water in, in Arkansas P 46

water in, in Louisiana W 114; P 46; C 164, 166, 167

in Mississippi ....................... 193, 194, 195

in Texas ........................W 335, 778; D 40

Catchment areas. See Origin of ground water; Absorption of water.

Cathcart, S. H., Geology of the York tin deposits, Alaska .......... 733

Cation exchange of substances in ground water ..............J 343

Caverns, deposits made by ground water in ......W 233, 258; A 18 il b

formed by ground water, in Florida ...................W 319

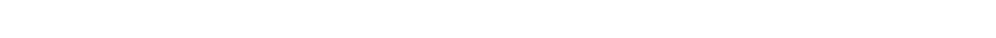

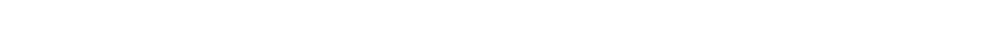

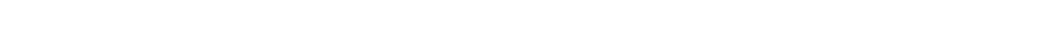

water in .. W114, 233, 255, 258, 319, 489, A 18 Iv b, 21 Iv c; C 2, 92, 131

pollution of $\ldots \ldots \ldots \ldots \ldots \ldots \ldots \ldots \ldots \ldots \ldots \ldots \ldots \ldots \ldots \ldots \ldots \ldots \ldots, 233,258$

See also Pollution of ground water; Sinkholes.

Caves. See Caverns; Sinkholes; Lava tubes.

Cederstrom, D. J., Artesian water resources of Southampton, S1rssex, and Isle of Wight Counties, Va ..................... 97

Chloride in ground water in the Coastal Plain of Virginia .......C 440

Chloride in the Virginia Coastal Plain ................ 151

Deep wells in the Virginia Coastal Plain ................ 439

Differential density of ground water in ore deposition ........J 297

Geology and artesian water resources of a part of the southern

Virginia Coastal Plain ......................... 437

Geology and artesian-water resources of a portion of the Virginia

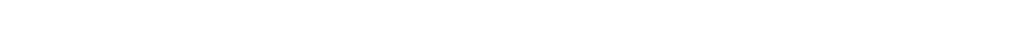

Geology and ground-water resources of the Coastal Plain in south-

eastern Virginia $\ldots \ldots \ldots \ldots \ldots \ldots \ldots \ldots \ldots \ldots \ldots \ldots \ldots \ldots \ldots$ C 442

Geology and hydrology of St. Croix, Virgin Islands ...........J 289

Ground-water resources of the southeastern Virginia Coastal Plain.C 438

Industrial ground water at Franklin, Va ...............J 250

Municipal and industrial ground-water supplies in tidewater

Virginia ...................................J 322

Problems of Coastal-Plain geology and hydrology ..........J 235

Progressive down-dip changes in composition in artesian water.

from the Cretaceous rocks of Virginia ................J 295

Selected well logs in the Virginia Coastal Plain north of

James River .............................C 441

Structural geology of southeastern Virginia .............J 332

Water levels and artesian pressure in the United States ...W 886, 907, $937,945,987$

Cellars, drainage of, into wells $\ldots \ldots \ldots \ldots \ldots \ldots \ldots \ldots \ldots \ldots \ldots \ldots \ldots \ldots \ldots$ W 258

Cementation produced by ground water ............... 4\%; B 726 b

Central America, public water supplies in $\ldots \ldots \ldots \ldots \ldots \ldots \ldots \ldots \ldots . \ldots \ldots$

Chadron sandstone, water in, in Colorado .................. 32

water in, in Nebraska ............... 19 Iv; $P$ 17, 32 ; GF 156

in South Dakota..$\ldots \ldots \ldots \ldots \ldots \ldots \ldots \ldots \ldots \ldots .6$ W 2?7; P 32

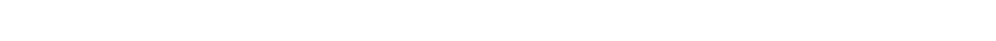

Chalk, water in, in South Dakota ...............FF 100, 119, 114, 156 Chalybeate waters. See Quality of ground water regarding iron.

Chamberlin, T. C., Requisite and qualifying conditions of artesian wells .A 5 c 
Chambers, A. A., Comparison of American and European mineral

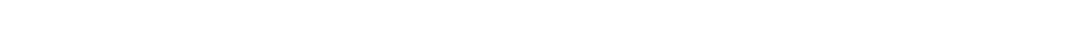

Chandler, A. E., Water storage on Cache Creek, Calif ............W 45

Chanute shale, water in, in Kansas ....................... 238

Character of ground water. See Analyses; Pollution; Quality.

Chattahoochee formation, water in, in Florida ...............W 319

water in, in Georgia ............................ $\mathbf{3 4 1}$

Chemistry of ground water. See Analyses; Pollution; Purification: Quality.

Cherokee shale, water in, in Missouri ...................... 195

Chesapeake group, water in, in Atlantic Coastal Plain ............ 138 water in, in Maryland ............................ 23, 204

in North Carolina ............................... 291

in Virginia $\ldots \ldots \ldots \ldots \ldots \ldots \ldots \ldots$ W 114; GF 23; C 431, 437, 441, 442

Chester group, water in, in Illinois .................. $\mathrm{V}^{\mathrm{r}} 114$; B 438

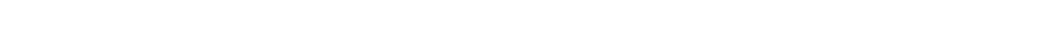

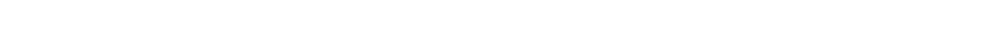

Chester Valley limestone, water in, in Delaware ...............W 106

water in, in New Jersey ........................... 106

in Pennsylvania ................................ 106

Chickamauga limestone in Georgia $\ldots \ldots \ldots \ldots \ldots \ldots \ldots \ldots \ldots \ldots, \mathrm{c} 81$

Chickies quartzite, water in, in Delaware .................. 106

water in, in New Jersey ........................... 106

in Pennsylvania $\ldots \ldots \ldots \ldots \ldots \ldots \ldots \ldots \ldots \ldots \ldots \ldots$. 106; GF 162

China, ground water in, bibliography of $\ldots \ldots \ldots \ldots \ldots \ldots \ldots \ldots$ W 163

well drilling in ................................... 257

Chinle formation, water in, in Arizona $\ldots \ldots \ldots \ldots \ldots \ldots \ldots \ldots \ldots \ldots \ldots \ldots$ W 836 b

Chloride in ground water-

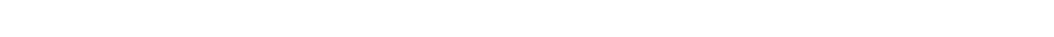

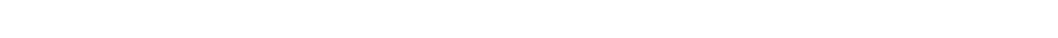

Hawaii $\ldots \ldots \ldots \ldots \ldots \ldots \ldots \ldots \ldots \ldots \ldots \ldots \ldots \ldots . \ldots$ ? $?$, 94, 97, 99

Louisiana ...................................... 305

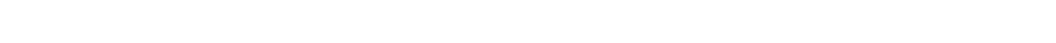

Massachusetts ..............................W 114, 144

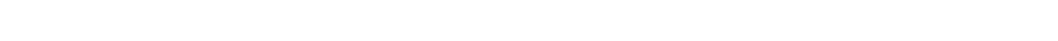

New Hampshire ..................................W 144

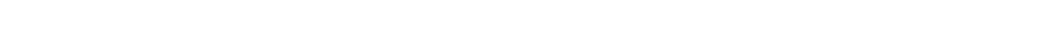

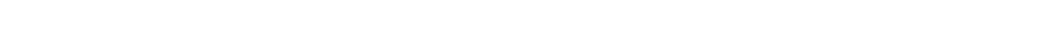

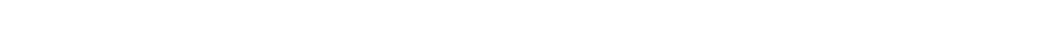

Rhode Island $\ldots \ldots \ldots \ldots \ldots \ldots \ldots \ldots \ldots \ldots \ldots \ldots \ldots \ldots$ W 114, 144

Texas ....................................... 408, J 117

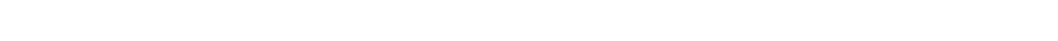

Virginia .......................... 431, 439, 440; J 197

Choctawatchee marl, water in, in Florida .................W 319

Chouteau limestone, water in, in Missouri ................W 195

Christopherson, F. C., Water levels and artesian pressure in th: United

States, 1943 .................................... 988

Chugwater formation, water in, in Montana ...........W 599; B 822 a

water in, in Wyoming ................. 364, 656, $711 \mathrm{~h}$; GF 173

Chupadera formation, water in, in New Mexico ................ 9

Cincinnati shale, ground water in relation to, in Wisconsin .......... 451

Cincinnatian formations, water in, in Indiana ................W 254

Circulation of ground water. Sée Movements of ground water. 
Gisco formation, water in, in Texas

W 317

Cisterns, catchment areas for

A 14 II a

combined with wells $\ldots \ldots \ldots \ldots \ldots \ldots \ldots \ldots \ldots \ldots \ldots \ldots \ldots \ldots$ W 255

construction of $\ldots \ldots \ldots \ldots \ldots \ldots \ldots \ldots \ldots \ldots \ldots$ W 255, 499, 518; A 14 II a

effect of "creep" on $\ldots \ldots \ldots \ldots \ldots \ldots \ldots \ldots \ldots \ldots \ldots \ldots$. 14 In a

in arid regions $\ldots \ldots \ldots \ldots \ldots \ldots \ldots \ldots \ldots \ldots \ldots \ldots W$ 380, 49 , $59.6,600$

pollution of $\ldots \ldots \ldots \ldots \ldots \ldots \ldots \ldots \ldots \ldots \ldots \ldots \ldots$ 255, 599, 600; C 431

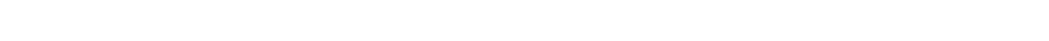

Citronelle formation, water in, Mississippi ................ 195

Claiborne formation, water in-

Arkansas $\ldots \ldots \ldots \ldots \ldots \ldots \ldots \ldots \ldots \ldots \ldots \ldots \ldots \ldots \ldots \ldots$ W 399; P 46

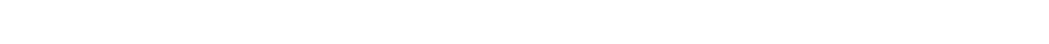

Louisiana ................................ 46

Mississippi $\ldots \ldots \ldots \ldots \ldots \ldots \ldots \ldots \ldots \ldots \ldots \ldots \ldots W$ 159, 576; C 192; J 846

Tennessee $\ldots \ldots \ldots \ldots \ldots \ldots \ldots \ldots \ldots \ldots \ldots \ldots \ldots \ldots \ldots \ldots \ldots \ldots$. 373

Texas ............................... 407, 417

Clapp, F G., Amity folio, Pa. ...................... 144

Barnesboro-Patton folio, Pa. ..................... 189

Bibliography of ground-water literature in $1905 \ldots \ldots \ldots \ldots \ldots$ W 163

Composition of mineral springs in Maine $\ldots \ldots \ldots \ldots \ldots \ldots \ldots W$ W 258

Conservation of our artesian water supply $\ldots \ldots \ldots \ldots \ldots \ldots \ldots . \ldots . \ldots$

Economic geology of the Amity quadrangle, Pa. ............ 300

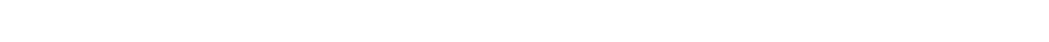

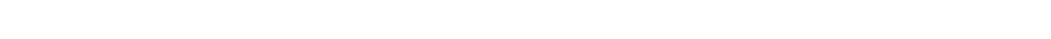

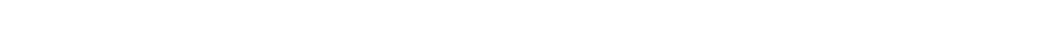

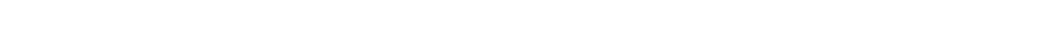

Underground water in crystalline rocks $\ldots \ldots \ldots \ldots \ldots \ldots \ldots \ldots \ldots$ J 12

Underground waters near Manassas, Va. ..............W 258

Underground waters of southern Maine $\ldots \ldots \ldots \ldots \ldots \ldots \ldots \ldots$ W 223

Underground waters of southwestern Ohio .............W 259

Water resources of the Curwensville, Patton, Ebensburg, and Barnesboro

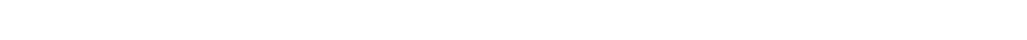

Well waters in the slates of Maine $\ldots \ldots \ldots \ldots \ldots \ldots \ldots \ldots \ldots$ W 258

Clapp, W. B., Progress of stream measurements for $1905 \ldots \ldots \ldots \ldots \ldots$ W 177

Clark, F. R., Farnham anticline, Carbon County, Utah .......... 711 a

Structure and oil and gas resources of the Osage Reservation, Okla. B $686 \mathrm{i}$

Clark, W. B., Coastal plain of North Carolina ................ 291

Philadelphia folio, Pa.-N. J.-Del. ....................FF 161

Surface and underground water resources of Maryland..........C 171

Trenton folio, N. J.-Pa .........................GF 167

Clark, W. O., Exploratory drilling for water in Steptoe Valley, Ner... W 467

Geology and water resources of the Kau district, Hawaii .........W 616

Ground water for irrigation in the Morgan Hill area, Calif.....W 400 e

Ground water in Santa Clara Valley, Calif ..............W 519

Ground water resources of the Niles cone, Calif..$\ldots \ldots \ldots W 345 \mathrm{~h}$

Clarke, F. W., Composition of the earth's crust .............. 127

Data of geochemistry ................ 330, 491, 6.6, 695, 770

Water analyses from the laboratory of the United States Geological

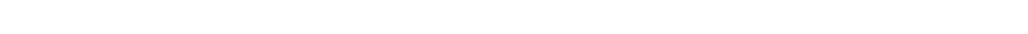


Classification of ground water, chemical. . W 254, 273, 274, 341, 3?2. 399, 559; B 330, 479, 491, 606, 616; J 208; C 1 of ground water, for boiler use W 254, 259, 274, 293, 335, 341, 398, 399, 576 for domestic use .............W 335, 341, 343, 398, 399, 576 for irrigation $\ldots \ldots \ldots \ldots \ldots \ldots \ldots \ldots \ldots \ldots W$ 274, 333, 335, 398, 399

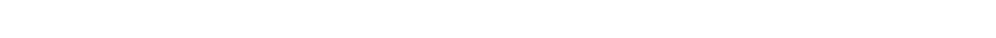
numerical standards for $\ldots \ldots \ldots \ldots \ldots \ldots \ldots \ldots \ldots \ldots \ldots$ W 274, 398

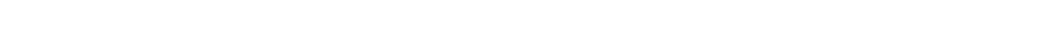
of oil-field waters $\ldots \ldots \ldots \ldots \ldots \ldots \ldots \ldots \ldots \ldots \ldots \ldots \ldots \ldots \ldots \ldots$ of springs $\ldots \ldots \ldots \ldots \ldots \ldots \ldots \ldots \ldots \ldots$ W 255, 338, 494, 5r7; A $14 \mathrm{n} \mathrm{b}$ of well-drilling methods $\ldots \ldots \ldots \ldots \ldots \ldots \ldots \ldots \ldots \ldots \ldots \ldots$ 257, 494 of wells $\ldots \ldots \ldots \ldots \ldots \ldots \ldots \ldots \ldots \ldots \ldots \ldots \ldots \ldots \ldots \ldots \ldots$ W 255, 494

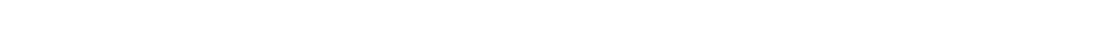
water in ..........W 114, 223, 255, 257, 319, 425 b, 4ra; A 21 vIII Cleaning of wells. See Well construction.

Clear Fork formation, water in, in Texas ................W 317 Cleavage in relation to ground water ................. 223, 489 Cleavage planes, water in $\ldots \ldots \ldots \ldots \ldots \ldots \ldots \ldots \ldots$ W 114, 22£, 489; B 319 Clements, J. M., Vermillion iron-bearing district of Minnesota ........M 45 Climate. See Evaporation; Precipitation.

Clinton limestone, water in, in Indiana ................... 114 water in, in Michigan ......................... 114 in Ohio ........................W 114, 259; A 19 rv b

Clinton sandstone, water in, in Michigan .................. 30

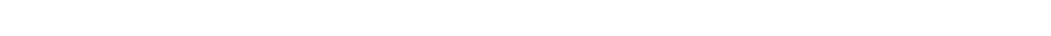

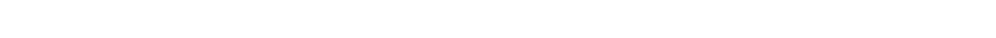

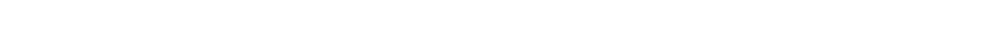

Cloverly sandstone, water in, in Montana ................. 736 b water in, in Wyoming........P 51, 53; B 364, 804, 806 d; GF 141, 142, 173 See also Dakota sandstone.

Coal beds, water in-

Montana ............................. 847 c, 856

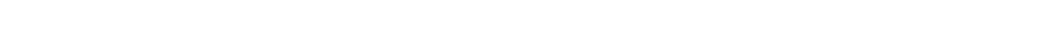

Pennsylvania .............B 300, 447; GF 174; C 343, 344, 345; J 173

South Dakota ...................................... 627

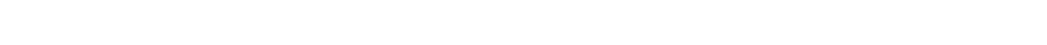

Coal mine waters, sulfuric acid in $\ldots \ldots \ldots \ldots \ldots \ldots \ldots \ldots \ldots \ldots$ W 273

Coastal Plain. See specific States.

Cockfield formation, water in, in Arkansas ............W 114; P 46 water in, in Louisiana ...................W 114; P 46; C 164

Coconino sandstone, water in, in Arizona ..............W 836 b

Coldwater shale, water in, in Michigan ..............W 30, 114

Coli bacillus in ground water ..................W 193, 256, 315

Collecting areas. See Absorption; Origin.

Collecting galleries. See Infiltration ditches and tunnels.

Collier, A. J., Anticlines near Maverick Springs, Wyo. .......... $711 \mathrm{~h}$

Coal resources of MoCone County, Mont .................... 905

Gas in the Big Sand Draw anticline, Wyo .............. 711 e

Kevin-Sunburst oil field and oil and gas in Sweetgrass arch, Mont. B 812 b

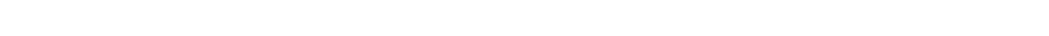

Oil in Warm Springs and Hamilton domes, Wyo .............. $711 \mathrm{~d}$ 
Collier, A. J., Osage oil field, Wyo. ............................. 736 d Scobey lignite field, Mont ........................ 751 e Collins, W. D., Chemical characters of waters of Florida .......W $596 \mathrm{~g}$ Geology and ground-water resources of Sacramento Valley, Crlif. . W 495 Georgia public water supplies ....................... 104 Graphic representation of water analyses .................J 31 Index of analyses of natural waters in the United States.. W 560 c, 659 c Industrial utility of public water supplies in the United States. . W 496, 658 Mineral waters ............................ 19 ? $\mathbf{b}, 1923 \mathbf{f}$ Natural sodium bicarbonate water in the United States ..........J 47 Natural waters available for industrial use ................. 315 Practical water analysis ........................ $596 \mathrm{~h}$ Quality of water and industrial development in the United States .. W 559 Springs of Virginia ............................. 432 Temperature of water available for industrial use in the United

States ................................... $520 \mathrm{f}$

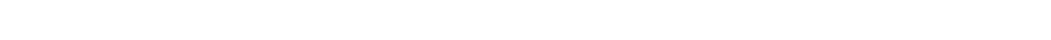
Color in ground water ................W 240, 254, 259, §38, 341, 398

Colorado, areas, Apishapa quadrangle ......................F 186 areas, Arkansas Valley ..................... 17 II $\mathrm{f}, \mathrm{P} 52$

Bonanza mining district $\ldots \ldots \ldots \ldots \ldots \ldots \ldots \ldots \ldots \ldots \ldots \ldots$ P 169

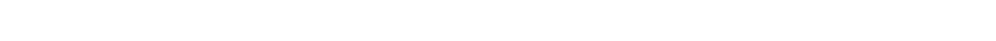

Brilliant quadrangle $\ldots \ldots \ldots \ldots \ldots \ldots \ldots \ldots \ldots \ldots \ldots \ldots$ GF 214

Castle Rock quadrangle ........................FF 198

Colorado Springs quadrangle ....................GF 203

De Beque quadrangle ......................... 531 c

Denver Basin ............................. 27 ; P 32 eastern ................A 17 II f, 21 Iv c, 22 Iv c; $P$ 32, 52 Elmoro quadrangle .......................... 58

Fremont County ........................... 298

Garfield County .............................. 531 c

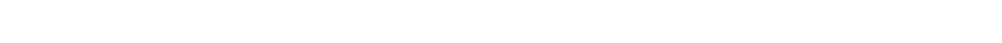

Mesa County ............................ 531 c

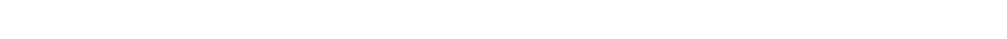

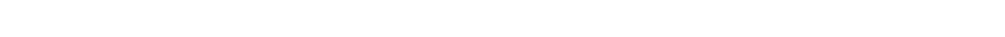

northeastern ............................ 16 in $f$

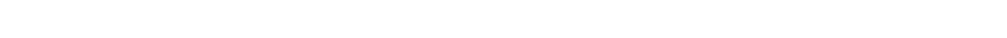

Ouray quadrangle ...........................FF 153

Pueblo County .............................. 298

Pueblo quadrangle $\ldots \ldots \ldots \ldots \ldots \ldots \ldots \ldots \ldots \ldots \ldots \ldots \ldots \ldots$ GF 36

Rangely oil district $\ldots \ldots \ldots \ldots \ldots \ldots \ldots \ldots \ldots \ldots \ldots \ldots \ldots$. 350

Raton quadrangle ..........................FF 214

Rio Blanco County ............................ 350

Rio Grande Basin $\ldots \ldots \ldots \ldots \ldots \ldots \ldots \ldots \ldots \ldots \ldots \ldots \ldots \ldots$. 31

San Luis Valley ........................W 240; C 32

Silverton quadrangle $\ldots \ldots \ldots \ldots \ldots \ldots \ldots \ldots \ldots \ldots \ldots \ldots$ GF 120

South Platte Valley .......................W 184

southeastern $\ldots \ldots \ldots \ldots \ldots \ldots \ldots \ldots \ldots \ldots \ldots \ldots \ldots \ldots \ldots \ldots$. 52

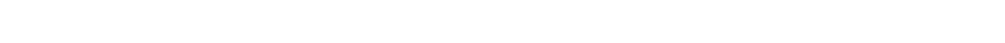

Spanish Peaks quadrangle $\ldots \ldots \ldots \ldots \ldots \ldots \ldots \ldots \ldots \ldots \ldots$ GF 71

Trinidad and vicinity $\ldots \ldots \ldots \ldots \ldots \ldots \ldots \ldots \ldots \ldots \ldots \ldots \ldots \ldots \ldots$ 
Colorado, areas, Walsenburg quadrangle .................FF 68 artesian water in ......W 9, 240; $A 16$ II f, 17 II f, 21 IV a; M 27; P 32, 52 ; B 265, 350, 531 c, 748; GF 36, 58, 68, 71, 135, 198, 203; l; 32 bibliography of ground water in .............W 57, 120, 149, 163

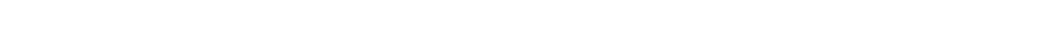
irrigation with artesian water in .................... 240 with other ground water in..W 5, 9, 240, A 16 II e, f, 21 IV c, 22 IV c; C 32 law relating to ground water in $\ldots \ldots \ldots \ldots \ldots \ldots \ldots \ldots \ldots \ldots$. 9,122 mine waters in ...................W 364; B 7En c; GF 120 mineral waters in ............... 32; MR 1883-1923; GF 153, 203 public water supplies in $\ldots \ldots \ldots \ldots \ldots \ldots \ldots \ldots \ldots \ldots$ W 240; P 32; GF 198

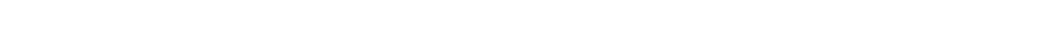
quality of ground water in. W 9, 240, 364, 839; A 17 II f; M 27; P 32, 52;

B 32, 529, 606; GF 135, 153, 203 salt water in $\ldots \ldots \ldots \ldots \ldots \ldots \ldots \ldots \ldots \ldots \ldots \ldots \ldots \ldots$ B 531 c, 812 c, 851

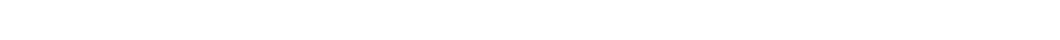
sheet water in $\ldots \ldots \ldots \ldots \ldots \ldots \ldots \ldots \ldots \ldots \ldots \ldots \ldots \ldots \ldots \ldots \ldots \ldots \ldots \ldots$ II $\mathbf{f}$

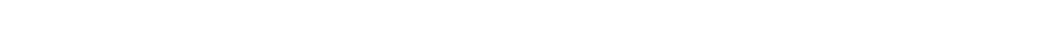
springs in-W 240, 364, 679 b; A 14 II b, 16 II f, 17 II f; P 63; B 32, 350, $735 \mathrm{~d}, 843,851$; GF 135, 153, 203 thermal ................W 364, 679 b; P 63; B 735 d, 843; GF 153 temperature of ground water in .................... 153

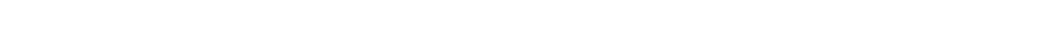
water table in ...................W 9; P 94; B 265; GF 120 well records for .. W 57, 149, 240, 264; A 16 II f, 17 II f; M 27; P 32, 52; B 131, 264, 298, 691 a, 796 b; GF 135, 186 wells in, construction of $\ldots \ldots \ldots \ldots \ldots \ldots \ldots \ldots \ldots \ldots$ W 240; GF 68 cost of .......................W 9, 240; B 131; GF 68 Colorado group. See specific formations.

Colorado River Basin, bibliography of ground water in .........W 340 Columbia clay, water in, in Missouri ................. 195 Columbia formation, water in-

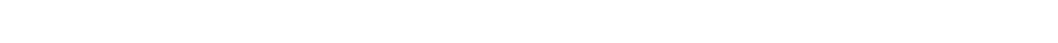

Georgia $\ldots \ldots \ldots \ldots \ldots \ldots \ldots \ldots \ldots \ldots \ldots \ldots \ldots \ldots \ldots \ldots \ldots \ldots \ldots \ldots$

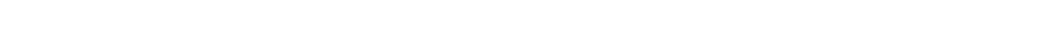

Maryland .................................. 13, 23

North Carolina ...............................C 293

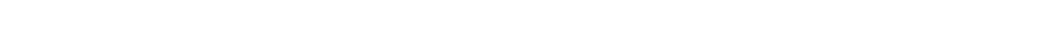

Virginia ......................GF 13, 23; C 431, 441

Columbia River lava. See Lava.

Comanche series, water in, in Texas ..................W 317

Composition of ground water. See Analyses; Quality.

Condit, D. D., Economic geology of the Summerfield and Woodsfield

quadrangles, Ohio ............................... 720

Condra, G.' E., Geology and water resources of Missouri River Valley in

Nebraska ................................. 215

Geology and water resources of Republican River Valley, Nek r...W 216

Confining beds for artesian water .............. 319; A 5 c; C 92, 99

Conglomerate, drainage into wells in .................. 258

water in $\ldots \ldots \ldots \ldots \ldots \ldots \ldots \ldots \ldots$ W 110, 232, 255, 257, 45f a, 489, 499 
Connate water .....W 160, 398, 494; P 90 h; B 319, 330, 491, 530 b, 616, 653, $661 \mathrm{~d} ; \mathrm{C} 291$

Connecticut, areas, all of State $\ldots \ldots \ldots \ldots \ldots \ldots W$ 210, 1:4, 160, 2^?; C $\overline{4} 8$ areas, Bradford Point ....................... 232 central ...........................W 110; C 44

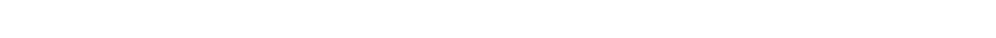

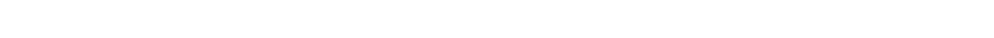
Meriden area .............................W 449 near New York ............................ 44 New Haven area .................W 537, 540; C 47; J 273 north-central .......................... 46

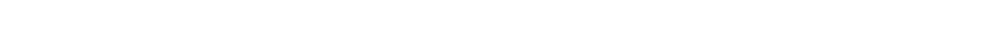

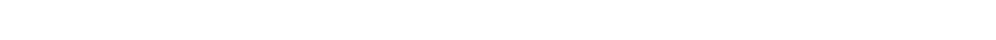

Pomperaug basin ...................W 597 b; D 12

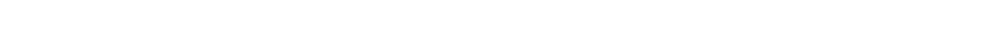

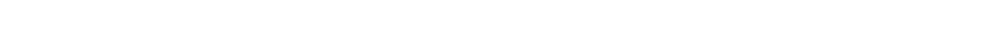

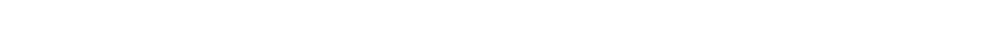

southern $\ldots \ldots \ldots \ldots \ldots \ldots \ldots \ldots \ldots \ldots \ldots \ldots \ldots \ldots \ldots$ C 43

Southington-Granby area $\ldots \ldots \ldots \ldots \ldots \ldots \ldots \ldots \ldots \ldots \ldots \ldots 6$

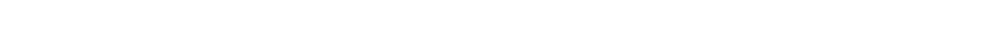

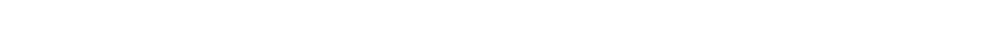

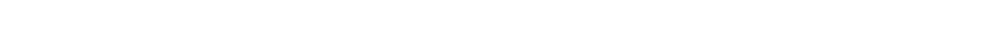

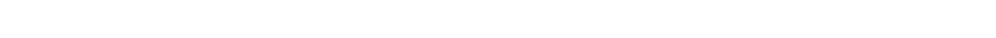

Waterbury district .......................... 397

Willimantic district ........................W 374

artesian water in $\ldots \ldots \ldots \ldots \ldots \ldots \ldots \ldots \ldots$ W 232, 374, 397, 466, 470, 540 bibliography of ground water in $\ldots \ldots \ldots \ldots \ldots \ldots W$ 114, 120, 163, 537

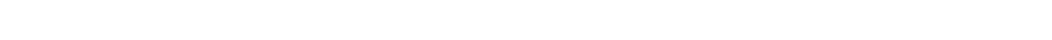
mineral waters in ..............W 114, 232; B 32; MR 1883-1923 public water supplies in ..W 232, 374, 397, 449, 466, 470, 537, 540, 597 b; C $41,42,43,44,45$ quality of ground water in. W 102, 110, 144, 232, 374, 397, 449, 466, 470, $537,540,597$ b; P 44; B 32; C 41, 42, 43, 44, 45 quantity of ground water in .............W 160, 232, $597 \mathrm{~b} ; \mathrm{D} 12$ salt water in .......................W $537 ;$ D 151; J 30 springs in ....WW $102,114,232,374,397,449,466,470,537,549,597$ b; A $14 \mathrm{II} \mathrm{b} ; \mathrm{B} 32 ; \mathrm{C} 41,42,43,44,45$ temperature of water in $\ldots \ldots \ldots \ldots \ldots \ldots \ldots \ldots \ldots \ldots . \ldots \ldots$ 2 2 ; $B$ B 32 water levels in $\ldots \ldots \ldots \ldots \ldots \ldots \ldots$ 777, 840, 845, 886, 906, 936, 944, 986 water table in ...W 160, 232, 374, 397, 540, 597 b; C 41, 42, 43, 44, 45, 4 ; J 273 well records for....W 57, 102, 110, 149, 232, 274, 374, 397, 449, 466, 470, 537, 540, 597 b; B 264, 298; C 41, 42, 43, 44, 45, 46; J 273 wells in, construction of $\ldots \ldots \ldots \ldots \ldots \ldots \ldots \ldots$ 232, 374, 397, 449, 540

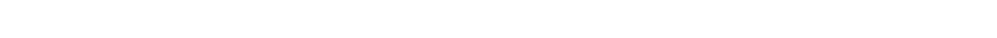

Conover, C. S., Water levels and artesian pressure in the United States

W 845, 886, 911

Conservation of artesian water ..W 142, 145, 158, 219, 225, 234, 256, 978,293 , $400 \mathrm{~b}, 423,425$ a, 520 e; C 92, 1 ; J 10

Conservation of dike-complex in Hawaii $\ldots \ldots \ldots \ldots \ldots \ldots \ldots$. 92, 97, 98, 99

Conservation of ground water in Texas .................. 400

Conservation of ground water in the United States $\ldots \ldots \ldots \ldots \ldots \ldots$ W 234 
Construction of wells. See Well construction.

Contact planes, artesian water in ..................... 319

Contamination. See Analyses; Pollution; Purification; Quality.

Contours of water table. See Maps.

Cook Mountain formation, water in, in Texas. W $375 \mathrm{~g}, 676,77^{\circ}, 849$ a; D 19

Cooke, C. W., Geology of Florida ..................... 55

Geology of the Coastal Plain of South Carolina .............. 867

Late Cenozoic geology of southern Florida ...............C 65

Cooper, H. H. Jr., Artesian water in the coastal area of Georgin and

northeastern Florida ........................... 248

Artificial recharge of artesian limestone at Orlando, Fla........J 363

Ground-water investigations in Florida, with special refemence to the

Jacksonville area ...........................J 321

Ground-water resources of the Pensacola area, Fla............ 128

Perennial yield of artesian water in coastal area of Georgia and

northeastern Florida ......................... 353

Possibility of salt-water intrusion in northeast Florida ....... 151

Salt-water intrusion in the vicinity of Pensacola, Fla..........D 151

Water levels and artesian pressure in the United States......W 845,

886, 906, 907, 937, 945, 987

Cooper, W. F., Well and spring records in lower Michigan.........W 102

Copper in ground water ..................W $399 ;$ M $52 ;$ B 47

Coral reefs, water in $\ldots \ldots \ldots \ldots \ldots \ldots \ldots \ldots \ldots \ldots \ldots \ldots \ldots \ldots$ C2, 97

Corniferous limestone, water in, in Ohio ............. 114; A 19 Iv b

Corrosion by water, in boilers, methods of calculating...........W 274

See also Quality; Well screens.

Cotton manufacturing, quality of water for.............W 254, 298

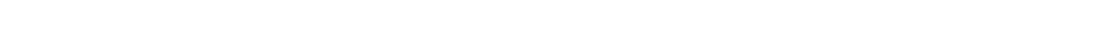

Cowgill, E. B., Irrigation on the Great Plains............... 5

Crandall, Lynn, Geology and ground-water resources of the Shake River

Plain, Idaho .......................... 774, D 53

Geology and water resources of the Mud Lake region, Idaho.....W 818

Ground water in Big Lost River Valley, Idaho ............. 17

Ground water in Little Lost River Valley, Idaho............... 16

Records of wells on Snake River Plain, Idaho ...........W 775

Springs of Snake River Canyon, Idaho ................... 22

Surface water supply of the United States ..........W 738, 768

Water resources of the Mud Lake Region, Idaho ............ 47

Water supply on the Snake River Plains, Idaho ............. 30

Crane, W. R., Economic geology of the Iola quadrangle, Kans . . . . B 328

Crawford, J. G., Oilfield waters of Montana plains .............J 275

Oilfield waters of $\mathrm{W}$ yoming and their relation to geologic formations.J 274

Crawford, L. C., Water levels and artesian pressure in the United States, 1936

W 817

Crenothrix in ground water $\ldots \ldots \ldots \ldots \ldots \ldots \ldots \ldots \ldots$ 254, 259, 338; P 113

Cretaceous formations, water in-

Alabama $\ldots \ldots \ldots \ldots \ldots \ldots \ldots \ldots \ldots \ldots \ldots \ldots$ W 114; GF 226; C 1, 2, 3, 4,

Arizona $\ldots \ldots \ldots \ldots \ldots \ldots \ldots \ldots \ldots \ldots \ldots \ldots \ldots \ldots \ldots$ W $39 n, 836$ b; B 435

Arkansas . . . . . . . . . . . . . . . . . . . . $114,35 ?$; 46 ; B 691 j

Colorado .............A 17 II f; M 27; P 32, 52; B 265, 350; GF 36,

$58,68,71,1\lceil 5,153,186,203$ 
Cretaceous formations, water in, Delaware ..W 106, 114; B 138; GF 137, 162,

2`1; C 171

- District of Columbia ............W 114; B 138; GF 70, 152; C 171

Georgia ................W 67, 114, 341; B 138, 164; C 81

Iowa $\ldots \ldots \ldots \ldots \ldots \ldots \ldots \ldots \ldots \ldots \ldots \ldots \ldots \ldots$ 114, 293; GF 156

Kansas ........W 6, 273; P 32; C 142, 144, 145, 153, 155, 156, 1.59; J 261

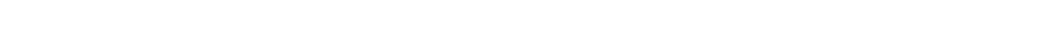

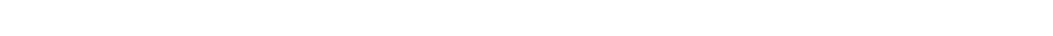

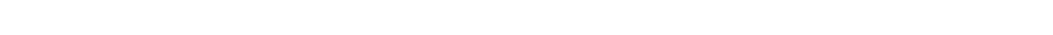

Maryland .....W 114; B 138; GF 13, 137, 152, 182, 204, 211; C 171; J 355

Minnesota .....................W 114, 256; M 2E; GF 117

Mississippi .....................W 114, 159, 5ra; C 192

Montana .. W 518, 520 d, 539, 600; B 691 d, 711 g, 751 c, 768 a, 812 a, b, 822 a, 847 c, f, 856 ; GF 55, 128; J 275

Nebraska .. W 12, 70, 215, 425 b; A 19 IV c; P 17, 32; GF 85, 87, 88, 108,

156; C 202, 208, 204

New Jersey .W 106, 114; B 138, 727; GF 137, 157, 162, 167; C 219, 215, 217

New Mexico .......W 123, 343, 380, 620; B 435; GF 199; C 232; D 5, 68

New York .............W 114; P 44; B 138; GF 157; C 274; J 146

North Carolina .........W 114, 773 a; B 138; GF 80; C 291, 2^3; J 334

North Dakota ...........W 520 e, 598; M 25; B 575; GF 117; 168, 181

Oklahoma ....................W 148; C 323; D 115; J 223, 261

Pennsylvania .................W 106; B 138; GF 162, 167; C 351

South Carolina ..................W 114; P 90 h; E 138, 867

South Dakota .. W 34, 90, 227, 428, 597 c; A 17 II g, 21 Iv b; P 32, 65;

B 575, 627; GF 85, 96, 97, 100, 107, 108, 113, 114, 127,

$128,156,164,165 ; \mathrm{D} 11$

Tennessee ..........W 114, 164, 638 a, 656, 677; C 371, 372; D 14, 25

Texas ....W 190, 191, 276, 317, 335, $375 \mathrm{~g}, 678,913$; A 18 II b, 21 vir; B $661 \mathrm{f}$; GF $42,64,76,183$; C 402,417 ; D 19, 66

Utah ....................... 56; B 541 d; 628.819, 863

Virginia ......W 114; B 138; GF 13, 80; C 431, 434, 436, 437; J 295, 332

Wyoming ..W 70, 425 b; A 21 Iv b; P 32, 51, 53, 56, 65; B 364, 471, 543,

$6211,641,656,670,711$ e; GF 107, 127, 128, 141, 142, 150, 173; J 274

See also specific formations.

Crickmay, G. W., The warm springs of Georgia .............W 819

Crider, A .F., Drainage by wells in Arkansas . . . . . . . . . . . . W 160

Geology and ground waters of northeastern Arkansas.........W 399

Underground-water resources of Mississippi .............W 159

Critchlow, H. T., A long-term record of water level at Plainfield, N. J..J 151

Criteria for locating ground water $\ldots \ldots \ldots \ldots \ldots \ldots \ldots \ldots$ W 224, 423; B 308

Crooked wells $\ldots \ldots \ldots \ldots \ldots \ldots \ldots \ldots \ldots \ldots \ldots \ldots \ldots \ldots \ldots \ldots \ldots \ldots$ W 257

Crosby, W. O., Sizing and filtration tests on Long Island, N. Y......P 44

Water from delta type of sand plain .................. 145

Water resources of Massachusetts and Rhode Island .........W 114

Well and spring records in Massachusetts and Rhode. Island ......W 102

Cross, W. P., Ground water in southeastern Florida . . . . . . . . . . J 252

Salt water encroachment studies in southeast Florida .......... 151

Water levels and artesian pressure in the United States. . W 886 907, 937

Water resources in southeastern Florida ........... 6 ?; D 143

Cross, Whitman, Geology of the Denver Basin, Colo ............M 27

Geology of the San Juan region, Colo ................ 843 
Cross, Whitman, Ouray folio, Colo. ..................... 153

Silverton folio, Colo ............................. 120

Crystalline rocks, artesian water in.......W 160, 232, 374, 3؟7; B 391; $\mathbf{J} 4$

deep wells in $\ldots \ldots \ldots \ldots \ldots \ldots \ldots \ldots \ldots \ldots \ldots \ldots \ldots \ldots \ldots$ 232; C 431

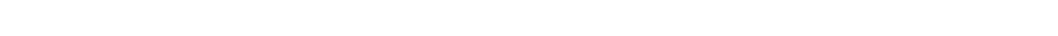

water in-

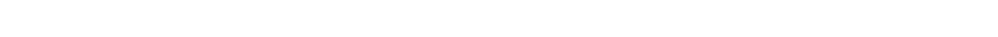

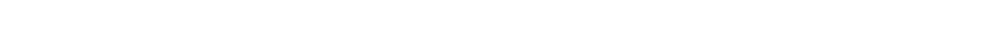

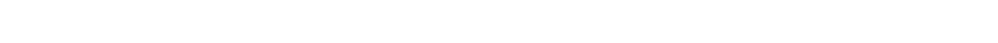

California ....................... 219, 338

Connecticut .........W 232, 374, 397, 449, 466, 470, 540, 597 b

Delaware .......................GF 211, 223; C 171

District of Columbia .....................W 114; C 171

general .. W 160, 232, 489; A 5 c, 19 II b; P 127; B 319; J 12, 145, 255

Georgia ............................ 81

Maine ................W 145, 223; GF 14?, 158; J 4, 12

Maryland ..............GF 152, 204, 211; C I.71; J 12, 355

Massachusetts .......................... 12

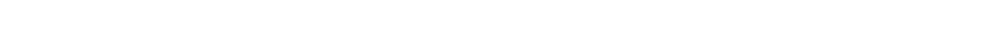

Montana ..................................W $345 \mathrm{~g}$

Nevada .............................W 365; D 3

New Hampshire ........................... 12

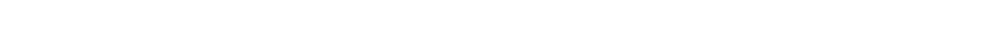

New Mexico ......................... 343, 620

New York ......................W 114; GF 157

North Carolina ...............GF 124, 147, 151, 222; C 291

Pennsylvania .........W 106, 114, 167; B 891; GF 211, 223, 225

South Carolina .......................GF 147, 222

Tennessee ............................F 124, 151

Utah .................................. 277

Virginia $\ldots \ldots \ldots \ldots \ldots \ldots \ldots \ldots \ldots \ldots \ldots \ldots \ldots \ldots$ W 114; C 431 ; D 7

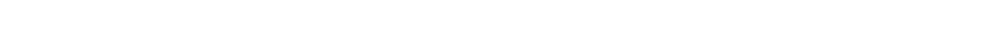

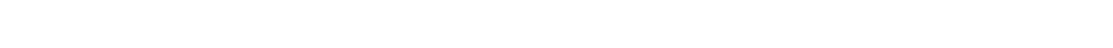

ground water in, bibliography of $\ldots \ldots \ldots \ldots \ldots \ldots \ldots \ldots \ldots$ W 163

Cummings, E. R., Columbus folio, Ohio ................... 197

Curbs. See Wells; Well casings.

Cushing, E. M., Design and use of maximum-minimum water level gage

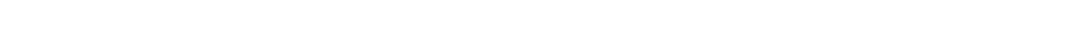

Ground-water conditions of the Baton Rouge area, La ......C 170 a

Ground-water resources of the Santa Cruz Basin, Ariz.......... 20

Recharge to ground water from floods in a typical desert wash....J 279

Water levels and artesian pressure in the United States ...W 911, 941,

949,991

Cushing, H. P., Geology and mineral resources of the Cleveland district,

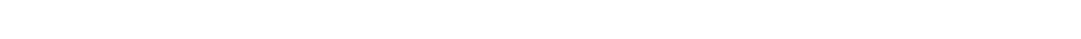

Cushman, R. L., Water levels and artesian pressure in the United States

W 949, 991

D

Dakota sandstone, water in-

Arizona.$\ldots \ldots \ldots \ldots \ldots \ldots \ldots \ldots \ldots \ldots \ldots \ldots \ldots \ldots \ldots \ldots \ldots \ldots$ w 380 
Dakota sandstone, water in, Colorado. .W 9; A 16 II f, 17 II f; M 27; P 32, 52; B 265, 691 a; GF $36,58,68,71,135,186$; D 71 general $\ldots \ldots \ldots \ldots \ldots \ldots \ldots \ldots \ldots \ldots \ldots \ldots \ldots \ldots \ldots$. W $67 ; \mathrm{J} 41,56,66$ Iowa ...........................W 215, 293; J 212 Kansas W 6, 273; A 16 II f, 21 IV c; P 32; B 691 a; GF 212; C 153, 155, 156 Montana ....................... 751 f, g, 786 a; GF 128 Nebraska .. W 12, 215, 216, 425 b; A 16 II f, 21 IV c; P 32; B 691 a, 715 i; GF 85, 87, 88, 108; C 202, 204 New Mexico .............W 380, 620; B 767, 860 b; GF 214; D 5, 68 North Dakota ..W 520 e, 598, 889 a; A 17 II g; M 25; B 575, 691 g, 801; GF 168, 181; C 301, 302, 3^3; D 141 Oklahoma .........................A 21 rv c; C 322; J 213 South Dakota ..W 34, 90, 215, 227, 428, 597 c, 889 a; A 17 II $\mathrm{g}$, 21 Iv b; P 32,65 ; B 575, 691 a; GF 85, 96, 97, 99, 100, 107, 108, 113. 114, 128, $164,165,209,219$; C 302, 303, 361; D 11; J 63, 152

Texas W 191

Utah W $380 ;$ P $188 ;$ B 541, 628, 852; D 71

Wyoming .. W 425 b; A 21 Iv b, 21 IV c; P 32, 51, 53, 65; B ร 64, 471 a, 691 a, 716 c, 781 b; GF 107, 127, 128, $141,142,173$ Dale, T., Fort Ticonderoga quadrangle, Vt.- N. Y. ...........W 110 Dams, fluctuation of water table in relation to....W 155, $597 \mathrm{a}, 849 \mathrm{~b} ; \mathrm{P} 44$ for ground water, artificial $\ldots \ldots \ldots \ldots \ldots \ldots \ldots$ W $39,67,199 ;$ A 13 III b

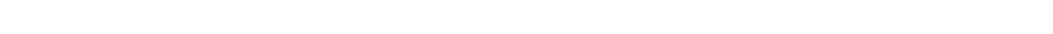
natural ........................W 320, 343, 42^,489, 494

Dane, C. H., Geology and fuel resources of the Quinton-Scipio district

Okla B $874 \mathrm{c}$

Geology and oil and gas possibilities of the Bell Springs district,

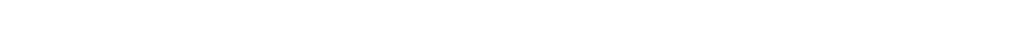

Geology of the Rock Creek oil field, Wyo ................ 806 d

Geology of the Salt Valley anticline, Utah ................ 863

La Ventana-Chacra Mesa coal field, N. Mex ................ 860 c

Daniel, Jane, Bibliography of technical reports, articles, and memoranda published or otherwise released (by Ground Water Division, United States Geological Survey) ..........D 116, 133, 161, 172, 187, 198, 209 Darcy, Henri, on áow of water through soils...WW 67, 887; A 19 II b; J 255 Darcy's law, experimental verification of ...............J 299 Darton, N. H., Aladdin folio, Wyo.-S. Dak.-Mont .............GF 128 Artesian water in the vicinity of the Black Hills, S. Dak .......W 428 Artesian water of a portion of the Dakotas ............ 17 II $\mathrm{g}$ Artesian well prospects in Virginia, Maryland, and Delaware ......J 1 Artesian wells on the Atlantic Coastal Plain ................ 138 Bald Mountain-Dayton folio, Wyo .................... 141 Belle Fourche folio, S. Dak .......................F 164 Camp Clark folio, Nebr .............................. 87 Central Black Hills folio. S. Dak .....................GF 219 Cloud Peak-Fort McKinney folio, Wyo .................... 142 Deep borings in the United States .............. 57, 61, 149

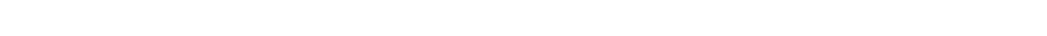

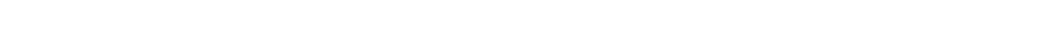
Edgemont folio, S. Dak.-Nebr ....................... 108 Fredericksburg folio, Va.-Md ....................... 13 Geologic basis for artesian prediction $\ldots \ldots \ldots \ldots \ldots \ldots \ldots \ldots . . \ldots$ J 13 
Darton, N. H., Geologic structure of parts of New Mexico ......... 726 e Geology and mineral resources of the Laramie Basin, Wyo .....B 364 Geology and underground waters of Arkansas Valley in eastern Colorado .................................. 52

Geology and underground waters of Luna County, N.Mex. W 345 c; B 618

Geology and underground waters of Nebraska west of tl $: 103 d$ meridian .............................. 19 rv c; P 17

Geology and underground waters of South Dakota ........W 227 Geology and underground waters of the central Great Plairs .....P 32 Geology and water resources of the Black Hills and adjoinino regions,

S. Dak ................................. 21 Iv b; P 65

Geology of the Bighorn Mountains, Wyo ............... 51

Geothermal data from deep artesian wells $\ldots \ldots \ldots \ldots \ldots \ldots \ldots$ J 2

Geothermal data of the United States ................. 701

Geysers of Yellowstone National Park .................. 25

Hot springs at Thermopolis, Wyo .................. 6

Laramie-Sherman folio, Wyo ....................... 173

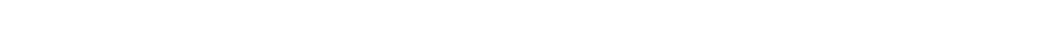

Newell folio, S. Dak ............................ 209

New York City folio, N. Y.-N. $J \ldots \ldots \ldots \ldots \ldots \ldots \ldots \ldots \ldots \ldots \ldots \ldots$

Nomini folio, Md.-Va ........................GF 23

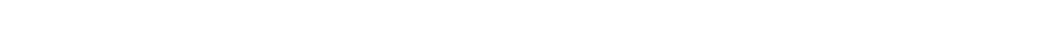

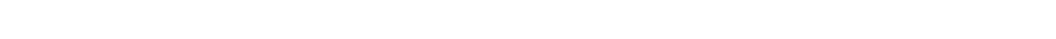

Passaic folio, N. J.-N. Y . . . . . . . . . . . . . . . . . GF 157

Parmian salt deposits of south-central United States ........ $175 \mathrm{~m}$

Philadelphia folio, Pa.-N. J.- Del . . . . . . . . . . . . . . GंF 162

Reconnaissance of northwestern New Mexico and northern Arizona.B 435

"Redbeds" and associated formations in New Mexico .......... 794

Scotts Bluff folio, Nebr ........................GF 88

Silver City folio, N. Mex .......................GF 199

Structure of parts of the central Great Plains ............. 691 a

Sundance folio, Wyo.-S. Dak ........................ 127

Syracuse-Lakin folio, Kans .......................FF 212

Trenton folio, N. J.-Pa .......................FF 167

Underground waters of Delaware, District of Columbia, Maryland,

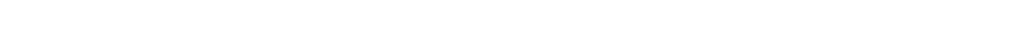

Underground waters of southeastern Nebraska ...........W 12

Washington folio, D. C.-Md.-Va ..................... 70

Well boring and irrigation in eastern South Dakota in $1896 \ldots$ A 18 rv c

Davis, A. P., Irrigation near Phoenix, Ariz .............. 2

Davis, C. A., Wells and municipal water supplies in the southarn

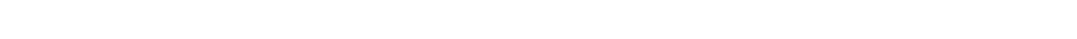

Dawson arkose, water in, in Colorado .................FF 198

Day, J. R., Geology and ground-water resources of Webb County, Tex. .W 778

Ground-water resources of Webb County, Tex ........... 31

Deadwood sandstone, water in, in South Dakota ...W 227, 428; A 21 Iv b:

P 32, 65; GF 107, 128, 164, 209, 219

water in, in Wyoming ... A $21 \mathrm{Iv} \mathrm{b}$; P 32, 51, 65; GF 107, 12?, 141, 142, 150

Dean, H. J., Surface water supply of Oregon, 1878-1910 ........W 370

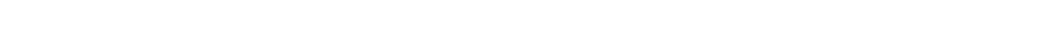

Debris-filled basins, fluctuations of water table in ...W 142, 219, 343, $345 \mathrm{~g}$, 345 h, 375 a, 400 e, 423,637 b, 886, 911, 941; G 14; 15, 16, 21 
Debris-filled basins, ground water in-

Arizona ............W 104, 136, 320, 375 b, 425 a, 49?, 796 e, f;

B $352 ;$ C 15,$16 ; \mathrm{J} 240$

California .........W 89, 142, 219, 222, 225, 278, 294, 375 a, 398,

$345 \mathrm{~h}, 400 ;$ GF 163

Colorado .............................. 240

discharge of $\ldots \ldots \ldots \ldots \ldots \ldots \ldots W 142,219,294,423,637$ b; C 21, 22

Montana .......................W $345 \mathrm{~g}, 400 \mathrm{~b}$

Nevada .................W 365, 375 d, 423; B 350 r

New Mexico ...W 123, 260, 275, 343, 345 c, 620, 637 b; B 618; GF 207

Oregon ........................... 220, 231

quantity of $\ldots \ldots \ldots \ldots \ldots \ldots \ldots \ldots W$ W 142, 219, 294, 423; C 21, 22

Texas $\ldots \ldots \ldots \ldots \ldots \ldots \ldots \ldots \ldots \ldots \ldots \ldots \ldots \ldots$ GF 166, 194; C 381

Utah ................... 157, 199, 217, 277, 333

See also Valley fill.

DeBuchananne, G. D., Artificial recharge of productive ground-water

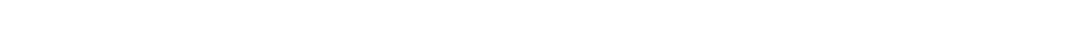

Water levels and artesian pressure in the United States ...W 944, 986

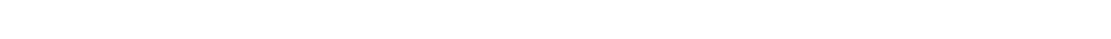

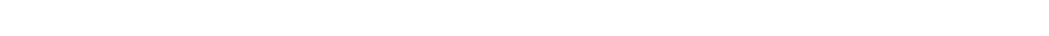

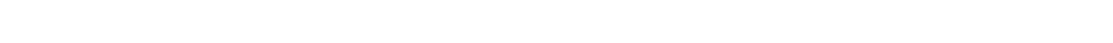

Deforestation, fluctuation of water table in relation to $\ldots \ldots \ldots \ldots$ W 155

Delaware, areas, all of State ...............W 114; C 171; J 1

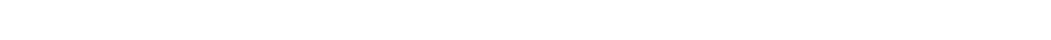

Coatesville quadrangle $\ldots \ldots \ldots \ldots \ldots \ldots \ldots \ldots \ldots \ldots \ldots$ GF 223

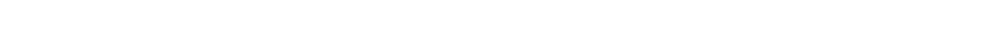

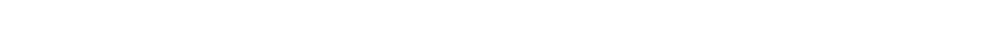

New Castle County .......................... 298

northeastern ........................W 106; GF 162

West Chester quadrangle .......................FF 223

Wilmington quadrangle $\ldots \ldots \ldots \ldots \ldots \ldots \ldots \ldots \ldots \ldots \ldots$ GF 211

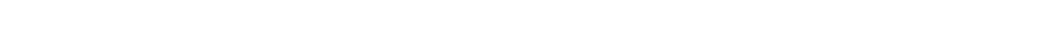

bibliography of ground water in $\ldots \ldots \ldots \ldots \ldots \ldots$ W 114, 15), 149, 163

mineral waters in $\ldots \ldots \ldots \ldots \ldots \ldots \ldots \ldots \ldots \ldots$ B 32; MP. 1883-1918

public water supplies in $\ldots \ldots \ldots \ldots \ldots \ldots \ldots \ldots \ldots \ldots \ldots$ B 138; C 171

quality of ground water in $\ldots \ldots \ldots \ldots \ldots \ldots \ldots \ldots \ldots \ldots$ W 258; C 171

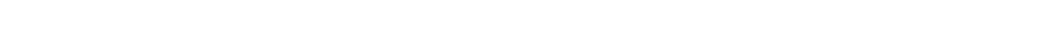

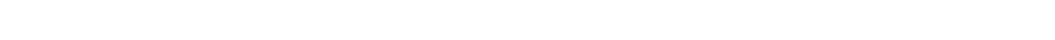

well records for .......W 57, 114, 149; B 138, 298; GF 137, 162; C 171

Delta deposits, water in, in California ..............W 225, 619

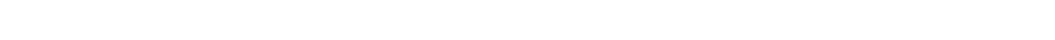

Denmark, bibliography of ground water in ..............W 163

Dennis, P. E., Geology and ground water of the Pecos River Basir.

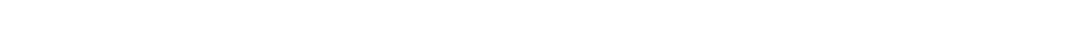

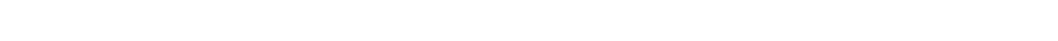

Underground water investigation in Utah .............. 422

Water levels and artesian pressure in the United States ....W 948, 990

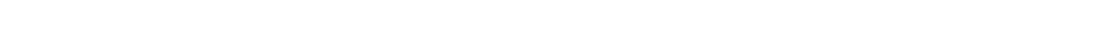

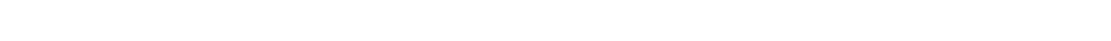

Deoxidation produced by ground water $\ldots \ldots \ldots \ldots \ldots \ldots \ldots \ldots \ldots$ M 47

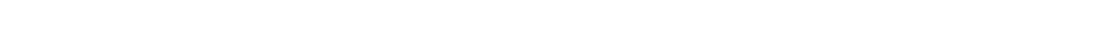

Depth to ground water, methods of estimating $\ldots \ldots \ldots \ldots \ldots \ldots$ 423, 577 
Depth to which ground water penetrates ...W 67, 160, 494; A 19 II b; M 47 Descartes on origin of ground water ................. 14 II b Desert basins. See Debris-filled basins; Valley fill.

Desert flats, ground water under .................. 277; B 530 k Desert springs. See Watering places; Springs.

Desert watering places. See Watering places.

Desert wells. See Watering places; Wells.

De Smet formation, water in, in Wyoming .......... 51; GF 141, 142

Des Moines group, water in, in Iowa .................... 293

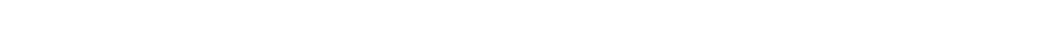

Deussen, Alexander, Geology and underground waters of the Texas Coastal

Plain ......................................... 335

Ground water in Lasalle and McMullen Counties, Tex .......W 375 g

Development of wells, by gravel screens .....W 255, 256, 293, 343, 345 a, g

by pumping $\ldots \ldots \ldots \ldots \ldots \ldots \ldots \ldots \ldots \ldots$ W 255, 256, 293, 343, 345 a, g

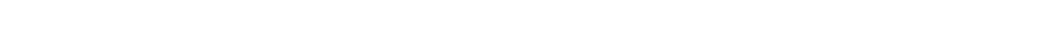

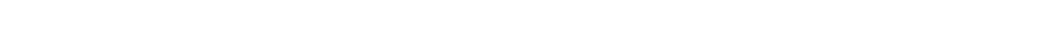

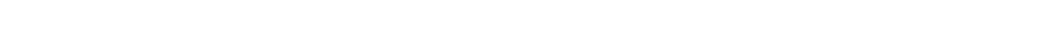

See also Well construction.

Devonian formations, water in-

Alabama ............................ 114; C 1, 2

Arkansas ............................. 114; B 808

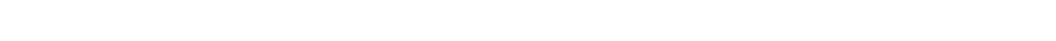

Indiana $\ldots \ldots \ldots \ldots \ldots \ldots \ldots \ldots \ldots \ldots \ldots \ldots$. 26, 114, 25ג; A 18 Iv b

lowa $\ldots \ldots \ldots \ldots \ldots \ldots \ldots \ldots \ldots \ldots \ldots \ldots \ldots \ldots \ldots \ldots \ldots$ 114, 145, 293

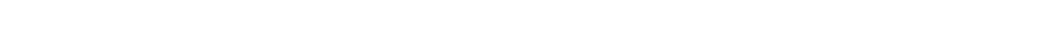

Maryland ........................W 110, 114; GF 179

Michigan ...............W 30, 31, 114, 182, 183; GF 205; C 181

Minnesota ...................................W 256

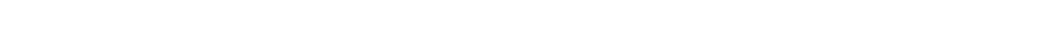

New York ............................ W 114; C 273

Ohio ..................W 91, 114; A 18 Iv b, 19 Iv b; GF 197

Pennsylvania .............W 110, 114; GF 179; C 344, ¿ $45,346,349$

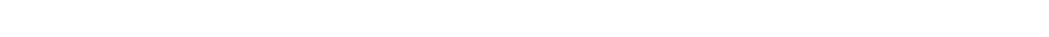

Virginia ....................W 114; C 432, 433, 434, 435, 436

West Virginia ..................W 110, 114; GF 179; C 433

See also specific formations.

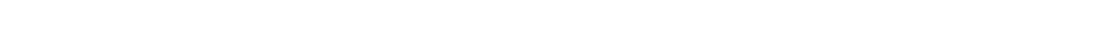

Diameter of soil grains, methods of measuring ............. 19 II b

Diesem, H. C., Cost of pumping for irrigation in western Nebrask 7 . W $425 \mathrm{~b}$

Diffusion of gases and solids in ground water ............... 47

Dikes, water confined by $\ldots \ldots \ldots \ldots \ldots \ldots \ldots \ldots \ldots \ldots \ldots \ldots$. 92, 97, 98, 99

Diller, J. S., Redding folio, Calif ..................... 138

Dils, N. S., Progress of stream measurements, $1902 \ldots \ldots \ldots \ldots \ldots \ldots$ W 85

Dip of strata, artesian conditions in relation to $\ldots \ldots \ldots \ldots \ldots \ldots \ldots$. 5 c

Dirzulaitis, J. J., Surface water supply of the United States, part 1

W 661,696, 726

Surface water supply of the United States, part 2 ..W $682,6: 7,712,727$,

$742,757,782,802,822, \varepsilon 52,872,892$

Surface water supply of the United States part $3 \ldots \ldots \ldots W(13,663,713$ 
Discharge of flowing wells, dome method of measuring.....W 67, 110, 157,

vertical pipe method of measuring .................. 195

Discharge of ground water, by capillarity W 275, 294, $345 \mathrm{~h}, 423,4 \mathrm{4}, 438 \mathrm{c}$;

A $13 \mathrm{III}$ a, 19 I b; C 15, 16, 22; D 54, 160; J 240; 255, 279

by evaporation ...W $7,153,275,294,343,345 \mathrm{~h}, 380,423,494,597 \mathrm{~b}, 638$

c, 659 a; A 13 III a, 19 II b; C 15, 16, 22; D 54, 160; J 240, 255, 279

by transpiration ...W $7,153,294,320,343,375 \mathrm{~d}, 423,494,560 \mathrm{~d}, 577$, 638 c, 659 a, 744, 818; C 15, 16, 22; D 54, 160; J 240, 255

water table in relation to $\ldots$ W $153,294,343,423,495,597 \mathrm{~b} ; \mathrm{C} 15,16$;

D 160; J 240, 255

See also Capillarity; Evaporation; Quantity of ground water; Trans-

piration; Springs; Water table.

Discharge of wells, dome method of measuring ...W 67, 110, 157, 219, 240

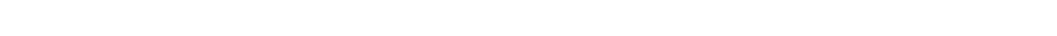

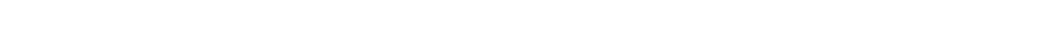

See also Wells; Artesian wells.

Disposal of ground water. See Discharge; Evaporation; Quantity; Springs;

Transpiration.

Dissociation of solids dissolved in ground water, theory of .........M 47

Dissolved solids in ground water. See Analyses; Quality.

Distilling, quality of water for ................ 233, 254, 398

District of Columbia, artisian water in ......... 138; GF 70, 15?; C 171

bibliography of ground water in $\ldots \ldots \ldots \ldots \ldots \ldots \ldots \ldots \ldots$ W 114, 120, 163

mineral waters in .................W 114; B 32; MR 1896-1920

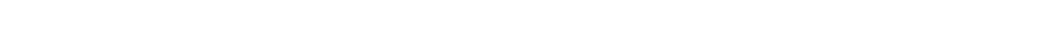

quality of ground water in .............W 364; B $32,13^{\urcorner}$; C 171

springs in $\ldots \ldots \ldots \ldots \ldots \ldots \ldots \ldots \ldots \ldots \ldots \ldots \ldots \ldots$ W 114; B $32 ; C$ C 171

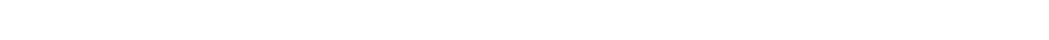

well records for ..........W 57, 114, 149; B 138; GF 70, 15:; C 171

Divining rod. See Water witching.

Dobbin, C. E., Forsyth coal field, Mont .................. 796 a

Geology and coal and oil resources of the Hanna and Carbon

Basins, Wyo .................................. 804

Geology and oil and gas possibilities of the Bell Springs

district, Wyo .................................... 796 d

Geology of the Rock Creek oil field, Wyo ................ 806 d

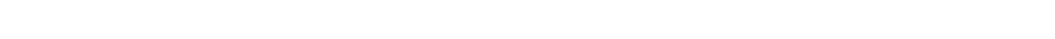

Pumpkin Buttes coal field, Wyo ................... 806 a

Dodge, R. E., New York City folio, N. Y.-N. J ..............GF 83

Dole, R. B., Chemical character of the waters in north-central Indiana. .W 254

Chemical character of the waters in northeastern Arkansas ......W 399

Chemical characer of the waters in southwestern Ohio .......W 259

Concentration of mineral water in relation to therapeautic activity

MR 1911 II n

Fluorescein in the study of ground water ..............W 160

Ground water in Lasalle and McMullen Counties, Tex ........ Tr $375 \mathrm{~g}$

Ground water in San Joaquin Valley, Calif ..............W 398

Historical sketch of the mineral-water trade .............. 1914

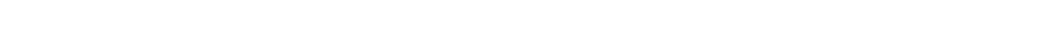

Published analyses of American mineral waters ........MR 1913 II $\mathrm{h}$

Quality of surface waters east of the one hundredth meridian .... W 236 
Dole, R. B., Quality of surface waters in Minnesota ............W 193 Quality of the underground waters in the Coastal Plain of Georgia.. W 341 Radioactivity of mineral waters ................... 1913 II $\mathrm{h}$

Salines in Silver Peak Marsh, Nev .................. 530 r

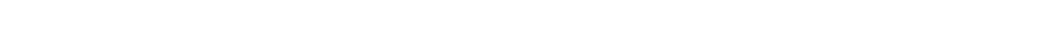

Dollen, B. H., Ground waters of Monroe County, N. Y .......... 273

Domes in relation to salt water ....................... 335

Double-acting pumps ............................ 14

Double Mountain formation, water in, in Texas ............W 317

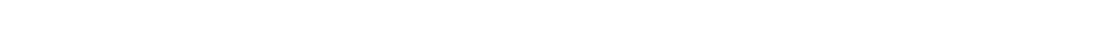

water in, in Missouri ........................... 206

Dowsing. See Water witching.

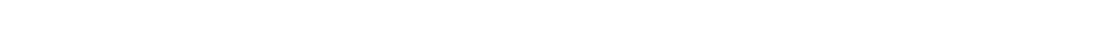
into wells-

Arkansas ................................ 160

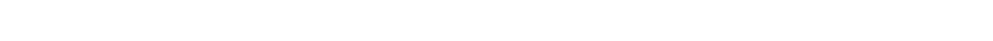

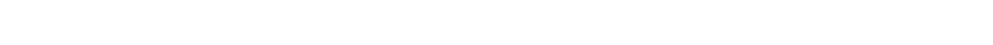

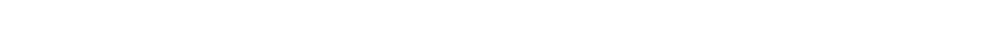

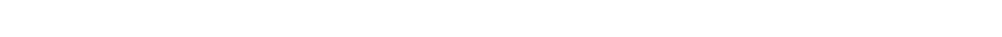

Michigan $\ldots \ldots \ldots \ldots \ldots \ldots \ldots \ldots \ldots \ldots \ldots \ldots \ldots \ldots \ldots \ldots$ W 145, 160

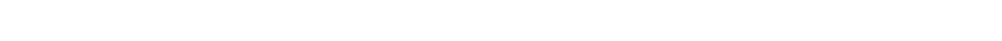

of sewage and industrial wastes into wells $\ldots \ldots \ldots \ldots \ldots \ldots \ldots$ W 258

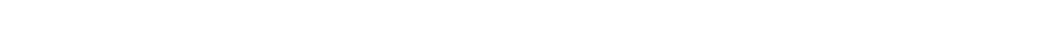

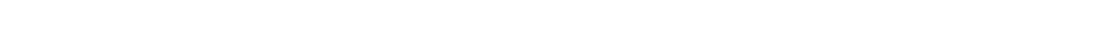

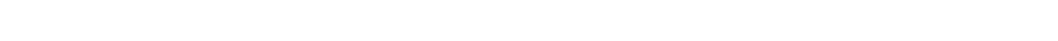

Drake, N. F., Nampa folio, Idaho-Oreg .................FF 103

Silver City folio, Idaho .......................FF 104

Dresbach sandstone, water in, in Iowa .................. 293

water in, in Minnesota ..................... 256; GF 201

See also Cambrian formations; Potsdam sandstone.

Drescher, W. J., Water levels and artesian pressure in the United States,

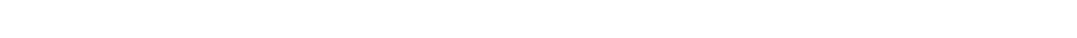

Drift. See Glacial drift.

Drilling. See Well construction.

Drillings from wells. See Well drillings.

Drought, effect of, on water levels .......W 680; J 79, 119, 120, 123, 162

Dry farming, ground water in relation to $\ldots \ldots \ldots W 275,277,320,425$ a

Dry sands at deep horizons $\ldots \ldots \ldots \ldots \ldots \ldots \ldots \ldots \ldots \ldots \ldots . \ldots \ldots 65,661 \mathrm{~d}$

Dundee limestone, water in, in Michigan ..........W 30, 114; GF 205

Dune sand, water in-

Arkansas .................................. 145

Colorado ............................ 17 II f; P 52

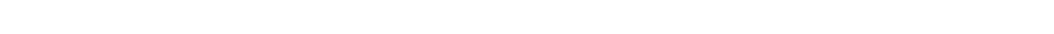

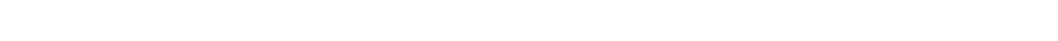

Kansas ............................ 273; C 155

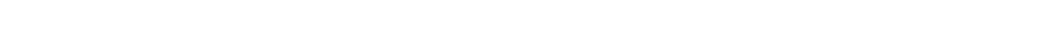

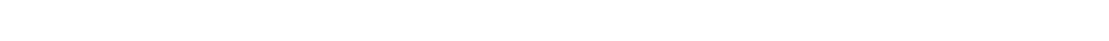

Dynamite, methods of using, in wells.............W 223, 255, 257

Dynamometer diagrams of reciprocating pumps $\ldots \ldots \ldots \ldots \ldots \ldots$ W 14

Dynamometers for testing windmills $\ldots \ldots \ldots \ldots \ldots \ldots \ldots \ldots \ldots \ldots, 20$ 
E

Eagle Pass formation, water in, in Texas ................. 18 II b Eagleford clay, water in, in Texas ....................... 276 Eakin, T. E., Water levels and artesian pressure in the United States,

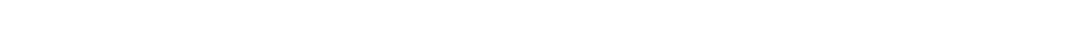

Earthquakes, effect of, on ground water ..........P 147 b; J 124, 218

Ebert, F. C., Water levels and artesian pressure in the United States

W 777, 817, 840, 845, 886, 911, 941, 949

Water levels in wells in southern California ...............W 468

Water-table fluctuations in southern California ............. 155

Eckel, E. B., Brown iron ores of east Texas ................ B 902

Ground-water resources of the Holbrook region, Ariz ....W 836 b; D 85

Quicksilver deposits in San Luis Obispo County and southwestern

Monterey County, Calif ......................... B $922 \mathbf{r}$

Eckel, E. C., Wells and springs in Mississippi ................W 102

Eden shale, water in, in Kentucky $\ldots \ldots \ldots \ldots \ldots \ldots \ldots \ldots \ldots \ldots \ldots$ W 233

water in, in Ohio .............................. 259

"Edge water" related to oil $\ldots \ldots \ldots \ldots \ldots \ldots \ldots \ldots \ldots \ldots \ldots \ldots \ldots \ldots \ldots \ldots$

Edwards limestone, water in, in Texas ...W 678, 773 b; A 18 II b; GF 42, f4; C 401

Effluent seepage. See Runoff, ground-water

Egypt, ground water in, bibliography of $\ldots \ldots \ldots \ldots \ldots \ldots \ldots \ldots \ldots \ldots \ldots \ldots \ldots$

ground water in, irrigation with $\ldots \ldots \ldots \ldots \ldots \ldots \ldots \ldots \ldots \ldots \ldots \ldots \ldots \ldots, 1,136$

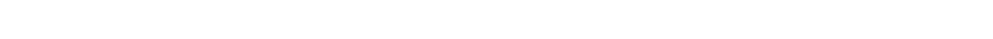

El Salvador, Central America, public water supplies in ..........J 370

Eldridge, G. H., Geology of the Denver Basin, Colo. .............. 27

Electric currents in ground water .......................W 258

Electric resistivity logging of wells, by oil companies......... 153; J 310

in Louisiana ...................................... 191

in Texas ........................................ 406

Electrolytic bridge to determine total solids in water. .W 137, 138, 139; J 226

Elevators for lifting water ............................ 1,14

Ellensburg formation, water in, in Washington ....W 55, 118, 316; GF 86, 106

Ellis, A. J.; Geology and ground waters in western part of

San Diego County, Calif. .......................W 446

Ground water in Hartford, Stamford, Salisbury, Willimantic,

and Saybrook areas, Conn. ......................W 374

Ground water in Musselshell and Golden Valley Counties, Mont. .. W 518

Ground water in Paradise Valley, Ariz. ...............W 375 b

Ground water in the Waterbury area, Conn ............W 397

Mineral waters.$\ldots \ldots \ldots \ldots \ldots \ldots \ldots \ldots \ldots$ MR 1916, 1917, 1918, 1919

The divining rod, a history of water witching $\ldots \ldots \ldots \ldots \ldots \ldots W 416$

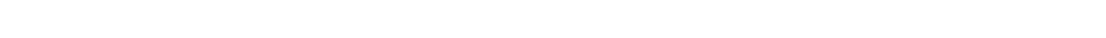

Water in crystalline rocks in Connecticut ................W 232

Ellsworth, C. E., Summary of surface water supply in Texas .....W 850

Surface water supply of the United States ...W 508, 528, 548, 568, 587, $588,608,628,648,668,688,703,718,733,748,763$.

$788,808,828,858,878,898,958,977,978$

Emmons, S. F., Geology and ore deposits of the Leadville mining

district, Colo ................................... 148

Geology of the Denver Basin, Colo .................. 27

Emmons, W. H., Enrichment of ore deposits ................ 625 
Emmons, W. H., Enrichment of sulphide ores ................ 529

Geology and ore deposits of the Creede district, Colo .......... 718

Geology and ore deposits of the Ducktown mining district, Tenn ..B 139

Geology and ore deposits of the Philipsburg quadrangle, Mont ....P 78

England, bibliography of ground water in $\ldots \ldots \ldots \ldots \ldots \ldots \ldots \ldots \ldots \ldots$

ground water in London $\ldots \ldots \ldots \ldots \ldots \ldots \ldots \ldots \ldots \ldots \ldots \ldots$

mineral waters in $\ldots \ldots \ldots \ldots \ldots \ldots \ldots \ldots \ldots \ldots \ldots \ldots \ldots \ldots$. 1916

public water supplies in ............................ 89

quality of ground water in .............. 330, 491, 616; MR 1916

Engler, Kyle, Ground-water supplies for rice irrigation in the

Grand Prairie region, Ark ............................ 20 e

English, V. A., Geology and oil prospects of Salinas Valley-Parkfield

area, Calif ................................... $691 \mathrm{~h}$

Geology and petroleum resources of northwestern Kern County,

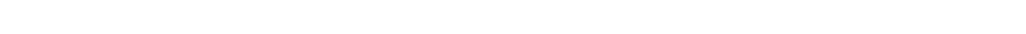

Eocene formations. See Tertiary; specific formations.

Equus beds, water in, in Kansas ..................W 273; J 214

Erdmann, C. E., Book Cliffs coal field, Colo .................. 851

Escondido formation, water in, in Texas .................. $375 \mathrm{~g}$

Europe, well drilling in ............................... 257

See also specific counties.

Eutaw formation, water in, in Alabama $\ldots \ldots \ldots \ldots \ldots \ldots \ldots . \ldots \ldots \ldots$ 1, 3, 4 water in, in Georgia ........................ $341 ;$ C 81 in Tennessee $\ldots \ldots \ldots \ldots \ldots \ldots \ldots \ldots \ldots \ldots \ldots \ldots W$ W 164, 638 a; C 372

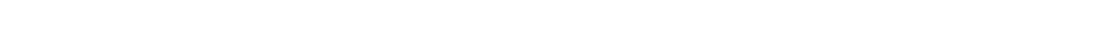
controlling factors in ...........W 294, 489, 494, $836 \mathrm{~d}$; J 163, 231

fluctuations of water table in relation to $\ldots \ldots \ldots \ldots \ldots \ldots \mathrm{W}^{\mathrm{w}} 155,294,423$

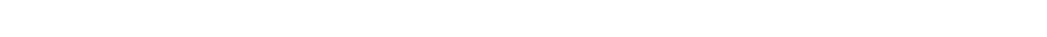
of ground water-

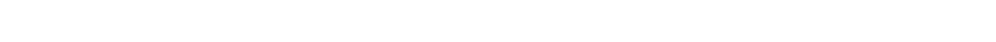

California $\ldots \ldots \ldots \ldots \ldots \ldots \ldots \ldots \ldots . . W 18,58,181,2^{24}, 345 \mathrm{~h} ; \mathrm{C} 22$

Colorado $\ldots \ldots \ldots \ldots \ldots \ldots \ldots \ldots \ldots \ldots \ldots \ldots \ldots$ W 358; M 27

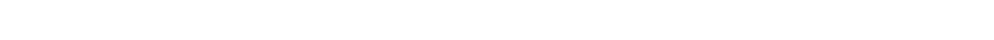

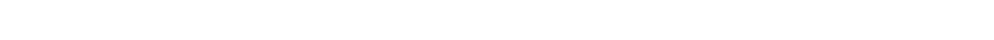

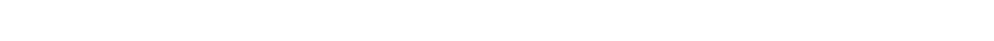

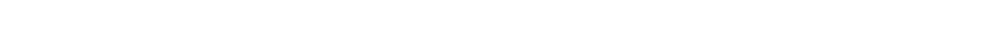

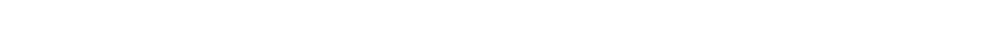

Kansas ................................W 153; B 140

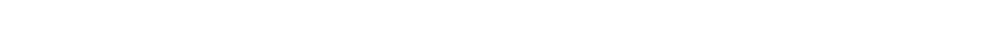

Nevada ................................W 375 d, 423

New Mexico ......................... 275, 358; C 249

Texas $\ldots \ldots \ldots \ldots \ldots \ldots \ldots \ldots \ldots \ldots \ldots \ldots \ldots \ldots \ldots$ W 358; GF 166

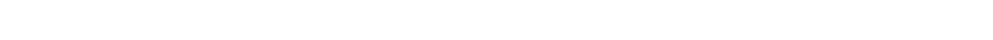

Washington .............................. 425 e

Everglades, ground water in, in southern Florida ....... 57, 62; J 252, 258

Explosives, methods of using, in wells .............W 223, 255, 257

Exports of mineral waters. See Mineral waters.

\section{$\mathbf{F}$}

Fairbanks, H. W., San Luis folio, Calif.................GF 101

Farm supplies of ground water ....................... 255

Farnsworth, H. R., Geology and oil resources of the Elk Hills, Calif....B 835 
Fath, E. A., Geology of the Bristow quadrangle, Okla ........... 759 Oil and gas fields of the Lost Soldier-Ferris district ,W yo ....... 756

Structure of the northern part of the Bristow quadrangle, Okla..B 661 b Fault planes, water in .................... 114, 232; B 319 Faults:

ground water in relation to-

Arizona ....................W 380, $796 \mathrm{f}$; C 15, 16

California ................W 142, 294, 338, 345 h, 519

Colorado ............................ 148

Connecticut ........................W 2£2, 597 b

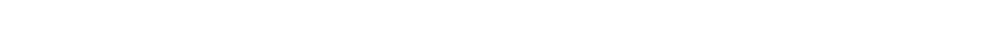

Kansas. ................................... 6

Montana .................................W 599

Nevada ............................W 365, 423

New Jersey .............................GF 167

New Mexico ...................................FF 199

Pennsylvania ............................FF 167

Texas .........................W 375 g; A 18 In b

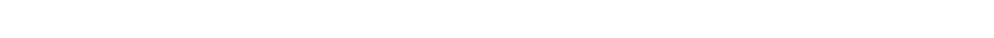

springs in relation to-

Arizona .................W 380, $796 \mathrm{f}$; C 15, 16; J 13 b

California .................W 142, 294, 338, 345 h, 519

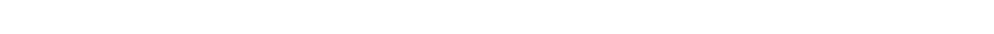

Montana ................................W 599

Nevada ..............................W 365, 423

New Mexico .................................FF 199

Texas $\ldots \ldots \ldots \ldots \ldots \ldots \ldots \ldots \ldots \ldots \ldots \ldots \ldots \ldots \ldots$ A 18 in b

Utah $\ldots \ldots \ldots \ldots \ldots \ldots \ldots \ldots \ldots \ldots \ldots \ldots \ldots \ldots$ W 199, 277; P 153

thermal springs in relation to $\ldots \ldots \ldots W$ W $142,227,338,365,48$ ?, $796 \mathrm{f}$;

A 14 II b; GF 199; C 15, 16

water table in relation to $\ldots \ldots \ldots \ldots \ldots \ldots \ldots \ldots$ W 294, $345 \mathrm{~h}, 423,489$

Fayette sandstone, water in, in Texas .................W $375 \mathbf{g}$

Fenneman, N. M., Geology and mineral resources of the St. Louis

quadrangle, Mo..-Ill ............................. 438

Geology of the Boulder district, Colo .................. 265

Oil fields of the Texas-Louisiana Gulf Coastal Plain ........... 282

Ferguson, G. E., Investigation of water resources in southeastern

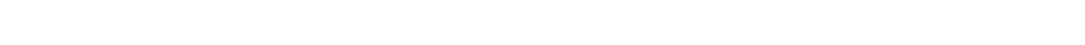

Surface water supply of the United States ...........W 952, 972

Ferguson, H. G., Geology and ore deposits of the Manhattan..

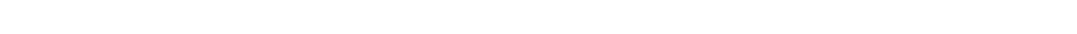

Geology and ore deposits of the Mogollon mining district, N. Mex ..B 787

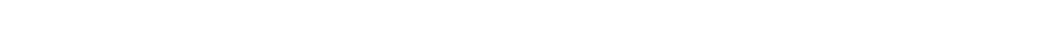

Ferris, J. G., Ground-water investigation in Connecticut ........J 273

Ground-water observation wells .................... 207

Ground-water survey, United States Geological Survey-

State of Connecticut ...................... 47

Inexpensive monthly water-stage recordex $\ldots \ldots \ldots \ldots \ldots \ldots \ldots$ D 188

Memorandum concerning a pumping test at Gas City, Ind ....... 136

Summary on salt-water intrusion in New Haven, Conn ........D 151

Water levels and artesian pressure in the United States....W 886, 906, 
Fidlar, M. M., Water levels and artesian pressure in the United States, 1937 .W 840

Fiedler, A. G., Air in well supply $\ldots \ldots \ldots \ldots \ldots \ldots \ldots \ldots \ldots \ldots \ldots \ldots \ldots$

Artesian awater in Somervell County, Tex ...............W 660

$\mathrm{Au}$ deep-well current meter .....................W 596 a

$\mathrm{Au}$ deep-well current meter for locating leaks ............J 50

Cement in well construction $\ldots \ldots \ldots \ldots \ldots \ldots \ldots \ldots \ldots \ldots \ldots \ldots$ J 61

Choosing the site and constructing the well $\ldots \ldots \ldots \ldots \ldots \ldots \ldots$ J 71

Construction and protection of drilled wells ........... 43; J 105

Contamination of ground water .................... 166

Deep-well salinity exploration ........................ 102

Exploring and repairing leaky artesian wells .............J 49

Fishing jobs and use of fishing tools ..................J 77

Geology and ground-water resources of Roswell artesian basin,

N. Mex ................................. 639

Ground-water area of the Mimbres Valley, N. Mex ...........C 237

Ground water in New Mexico now subject to appropriation .......J 51

Ground-water resources of Long Island, N. Y . . . . . . . . . C 271

Ground-water supplies . ......................... 184

Importance of well specifications $\ldots \ldots \ldots \ldots \ldots \ldots \ldots \ldots \ldots \ldots$ J 59

Legal control of use of ground waters $\ldots \ldots \ldots \ldots \ldots \ldots \ldots \ldots . \ldots \ldots$ 190, 224

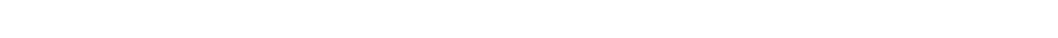

Mud scow method of drilling .......................... 92

New Mexico law on artesian water ..................J 69

Occurrence of ground water with reference to contamination .....J 161

Principles of well construction ...................... 70

Roswell artesian basin, N. Mex .............. 231, 236, 242; D 9

Sanitation of farm water supplies ................... 64

Utilization of the water resources of Roswell artesian basin, N. Mex.C 240

Water levels and artesian pressure in the United States....W 777, 817, $840,845,886,907,937$

Water supply of Roswell artesian basin, N. Mex ............ 28

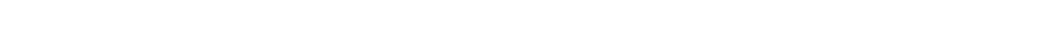

Well driller and the water works field ................ 67

Well drilling in relation to water supply $\ldots \ldots \ldots \ldots \ldots \ldots \ldots \ldots . \ldots . \ldots . \ldots 123$

Field assays of water, methods of making .............W 151, 398

See also Analyses; Assays.

Fiji Islands, analyses of water in ................ 330, 491, 616

Filter galleries. See Infiltration ditches and tunnels.

Filtration of water. See Purification.

Filtration tests, methods of making .................. 44

Finding water in $\operatorname{deserts} \ldots \ldots \ldots \ldots \ldots \ldots \ldots \ldots \ldots \ldots \ldots$ 224, 423; B 308

See also Watering places on routes of travel.

Finishing wells in sand $\ldots \ldots \ldots \ldots \ldots \ldots \ldots \ldots \ldots \ldots \ldots \ldots$ W 256, 293, 343

See also Well construction.

Finkle, F. C., Pumping underground water in southern California ...W 146

Finlay, G. I., Colorado Springs folio, Colo ..............GF 203

Firing wells, methods of $\ldots \ldots \ldots \ldots \ldots \ldots \ldots \ldots \ldots \ldots \ldots$ 223, 255, 257

Fishel, V. C., Apparataus for testing permeability of unconsolidated

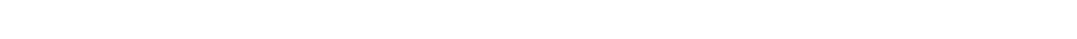

Channel storage method of determining effluent seepage .......J 159

Ground-water supplies in Kansas available for national defense ... C 152 
Fishel, V. C., Methods for determning permeability ............W 887

Pumping tests conducted at Kansas City, Kans .............J 369

Tests of permeability with low hydraulic gradients ........J 114, 131

Water levels and artesian pressure in the United States ...W 777, 817, $840,845,886,906,907,908,938$

Water levels in wells in northern Virginia ......... 121, 130, 151 Fisher, Bernard, Water levels and artesian pressure in the United $S^{\text {'ates }}$

W 937,940

Fisher, C. A., Geology and underground waters of the Roswell artesian

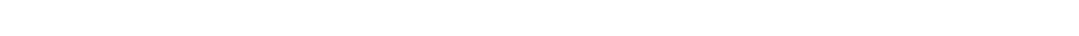

Geology and water resources of the Bighorn Basin, Wyo ........P 53

Geology and water resources of the Great Falls region, Mont ...W 221

Nepesta folio, Colo ............................ 135

Fisher, D. J., Book Cliffs coal field in Emery and Grand Counties, Utah. . B 852

Fissility, ground water in relation to .............W 223, 232

Fissures, movement of water through..W 489, 774, 818; A 19 II b; C 92, 98, 99

springs in relation to .............W 114; A 18 II b; B 199; C 451

Fleck, H., on flow of air through soils .................. 19 II b

Flood control by feeding into underground reservoirs $\ldots \ldots \ldots \ldots \ldots$ C 21

Flood-plain deposits. See Alluvium.

Flooding of oil wells $\ldots \ldots \ldots \ldots \ldots \ldots \ldots \ldots \ldots \ldots \ldots \ldots \ldots \ldots$ W 91,257

Floods in relation to ground water ...W 153, 258, 345 a, 425 b; C 15, 20, 21;

D $160 ; \mathrm{J} \mathrm{240,279}$

Florida, areas, all of State $\ldots \ldots \ldots \ldots \ldots \ldots$ W 114, 319; C 56, 60; I 134, 189

areas, Broward County ........................ 62

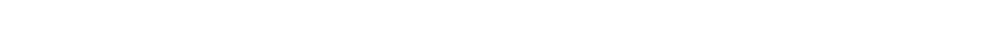

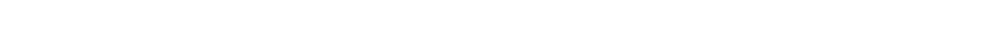

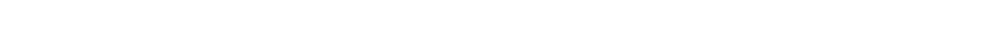

Duval County ....................... 298; J 321

eastern ........................ 52, 54, 65

Everglades ...............C 57, 62; D 180; J 252. 258, 319

Jacksonville ........................... 298

Lake Okeechobee ........................... 57

Miami area ................. 6 63, 65; J 343. 348, 352

Nassau County ......................... 321

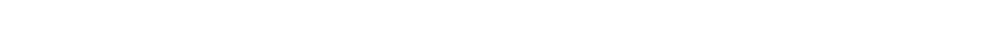

northern $\ldots \ldots \ldots \ldots \ldots \ldots \ldots \ldots \ldots \ldots \ldots \ldots \ldots$ J 138, 139, 181, 185

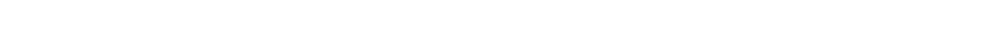

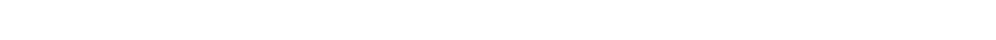

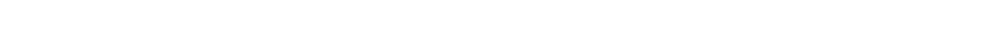

Sarasota County $\ldots \ldots \ldots \ldots \ldots \ldots \ldots \ldots \ldots \ldots$ C 58, 59; I 102, 121

Seminole County ....................... 61

southeastern .............C 63; D 143; J 252, 258, 301, 319

southern ......................... 54, 65; J 365

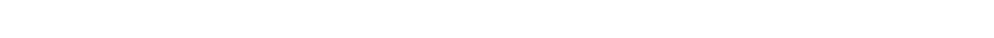

Volusia County ........................... 298

west-central and western $\ldots \ldots \ldots \ldots \ldots \ldots \ldots \ldots \ldots \ldots \ldots$

artesian water in ...W 319, $773 \mathrm{c}$; C 51, 52, 53, 54, 55, 56, 57, 58, 59, 60, $61,62,63,64,65 ; \mathrm{J} 121,134,137,138,139,189,221$,

$248,25 \AA, 258,353$

bibliography of ground water in $\ldots \ldots \ldots \ldots \ldots \ldots \ldots W 114,120,163$

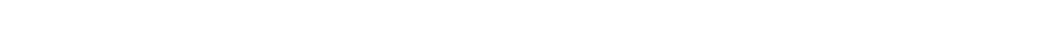


Florida, irrigation with ground water in $\ldots \ldots \ldots \ldots \ldots \ldots \ldots \ldots \ldots \ldots \ldots \ldots \ldots$ mineral waters in .................W 114; B 32; MR 1883-1923

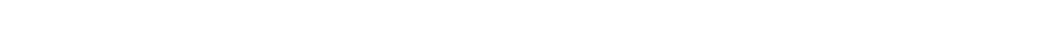
quality of ground water in ...W 102, 319, 364, $596 \mathrm{~g}$; B 3?; C 51, 57, 58, $59,60,61 ; \mathrm{J} 137,173,248,252,301,343$ quantity of ground water in ..............W $319 ; \mathrm{C} 62,63 ; \mathrm{J} 252$ salt water in ..C 56, 58, 62; D 128, 143, 151, 180; J 80, 102, 134, 137, 181, $252,258,321,343,348,352$ spring discharge measurements in ...W 712, 727, 742, 757, 782, 802, 822, $852,872,892,952,972$ springs in $\ldots W 102,114,204,242,319,452,557,642,6 ? 2,697,773 \mathrm{c}$; A 14 II b; B 32 ; C $51,53,55$; J 80 water levels in $\ldots \ldots \ldots \ldots \ldots w$ 777, 817, 840, 845, 886, 907, 937, 945, 987 water table in ...........W 319; C 62,$64 ; \mathrm{J} 80,138,139,181,185$ well records for ...W $57,102,149,319$; B 264, 298, 934; C 52, 53, 54, 57, $58,59,62.64 ; \mathrm{J} 252,258$

Flow of air and water through porous media, methods of measuring. . A 19 II b Flow of ground water. See Movements of ground water.

Flow of wells. See Wells; Artesian wells.

Flowage, zone of, ground water in relation to $\ldots \ldots \ldots \ldots \ldots \ldots$ W 489; M 47

Flowing wells. See Artesian water; Artesian wells.

Fluctuations of water table. See Water table; specific States.

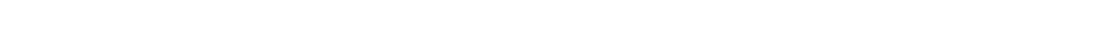

for determining movements of ground water ....W 160, $638 \mathrm{c}$; D 1 Fluoride in ground water-

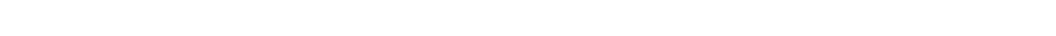

general ............................MR 1911 II n; J 173

-Louisiana $\ldots \ldots \ldots \ldots \ldots \ldots \ldots \ldots \ldots \ldots \ldots \ldots \ldots \ldots \ldots \ldots$ C 162, 163

Oklahoma ......................................... 322

Virginia $\ldots \ldots \ldots \ldots \ldots \ldots \ldots \ldots \ldots \ldots$ C 437, 438; D 97; J 197, 295

Wyoming ...................................... 47

Flushing of wells. See Well construction.

Flynn, B. H., The Sandusky, Maumee, Muskingum, and Miami drainage

areas, Ohio ....................................... 91

Flynn, M. S., The Sandusky, Maumee, Muskingum, and Miarri

drainage areas, Ohio ................................. 91

Fly-off, proposed term for evaporation and transpiration ..........J 298

Foaming and priming constituents of water, methods of calculating

W 274, 398

Foaming of water in boilers, quality in relation to ...W 254, 256, 259, 274, $341, ? 98,399 ;$ C 451

Foley, F. C., Cooperative ground-water investigations in Wyoming .... 455 Ground-water control througth legislation (discussion) $\ldots \ldots \ldots \ldots \mathrm{J} 266$

Water levels and artesian pressure in the United States, $1941 \ldots$ W 940

Foliation planes, water in ......................W 489; B 319

Follansbee, Robert, Surface water supply of the United States $, . . W 456,959$

Follett, C. R., Ground-water resources in the vicinity of Vernon, Tex ...C 409 Forbes, R. H., Agriculture in San Simon Valley, Ariz.-N. Mex ......W 425 a

Agriculture in Sulphur Springs Valley, Ariz $\ldots \ldots \ldots \ldots \ldots \ldots \ldots$ w 320

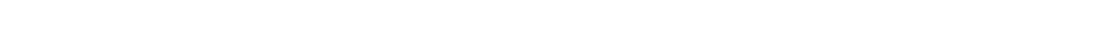

Forests, water table in relation to ....................... 155

Fort Thompson formation, water in, in Florida ............ 57; J 258 
Fortier, Samuel, Seepage in northern Utah

Fossil sea water. See Connate water.

Fossils in drillings from wells ...............W 293; P $9^{n} \mathbf{h} ;$ C 99

Foster, M. D., Base exchange and sulphate reduction in salty ground

waters along Atlantic and Gulf coasts .................J 254

Chemical character of the ground waters of the South Atlantic

Coastal Plain ................................... 183

Chemical character of the hot springs of Arkansas and Virginia ...J 68

Chemical composition of salty waters along the Atlantic and

Gulf coasts ................................ 296

Chemistry of ground water, in Hydrology (Physics of the Earth, IX)

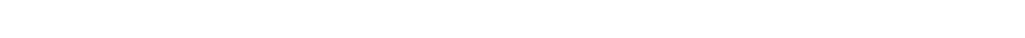

Geochemical relations of ground waters in the Houston-

Galveston area, Tex ............................ 198

Ground-water resources of western Tennessee .............W 656

Ground waters of the Houston-Galveston area, Tex............J 202

Quality of water in Ground-water resources of the El Paso area, Tex

Salt-water encroachment in the Galveston area, Tex..........J 117

Springs of Virginia ........................... 432

Water analyses, in Ground water in southeastern Pennsylvania... . C 342

Water analyses, in Ground water in southwestern Pennsylvania....C 341

Foster, V. M., Artesian water resources of Mississippi ............C 191

Geology and ground-water resources of the coastal area of Mirsissippi

C 195

Salt-water problem in Coastal Plain of Mississippi ........... 151

Water levels and artesian pressure in the United States $\ldots \ldots V^{\top} 886,907$

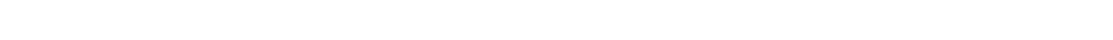

Fox Hills formation, water in-

Colorado ..........................W 9; M 27; P 32

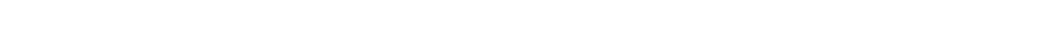

Montana .................................... 751 f

Nebraska ................................ 32

North Dakota ..................W 598; B 575, 775; GF 181

South Dakota ..................W 227; P 32; B 575; GF 209

Wyoming ...................... P 32; B 796 a; GF 173

Fracture, zone of, ground water in relations to ....W 489; M 47; GF 149

France, bibliography of ground water in $\ldots \ldots \ldots \ldots \ldots \ldots \ldots \ldots$ W 163

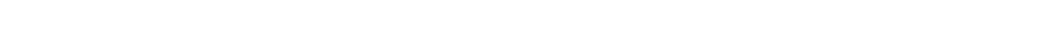

quality of mineral water in ......................... 1916

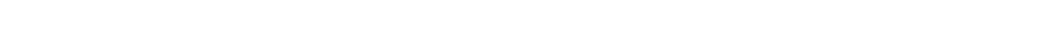

springs in, yield of $\ldots \ldots \ldots \ldots \ldots \ldots \ldots \ldots \ldots \ldots \ldots \ldots \ldots \ldots \ldots$ Ir b

Franconia sandstone, water in, in Minnesota .................. 201

Frederickburg group, water in, in Texas ............... 21 vI

Freeman, G. D., Water levels and artesian pressure in the United S'ates,

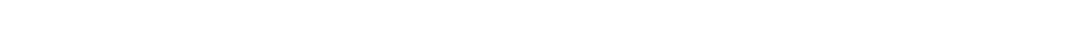

Freeman, W. B., Surface water supply of the United States... WW 247288

Freezing of wells $\ldots \ldots \ldots \ldots \ldots \ldots \ldots \ldots \ldots \ldots \ldots \ldots \ldots \ldots W$ 29, 256, 258

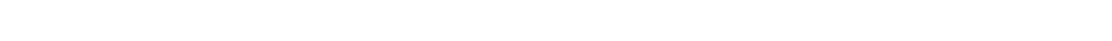

Friction of ground water $\ldots \ldots \ldots \ldots \ldots \ldots \ldots \ldots \ldots \ldots \ldots \ldots$ M 47

Frontier formation, water in, in Montana ................. 751 g

water in, in Wyoming ................ 53; B 656, $756,781 \mathrm{~b}$ 
Frost, confining beds for artesian water produced by ............ 319 effect of, on ground-water supply ....................W 145

Frye, J. C., Cable-tool test drilling near Wichita, Kans............ 119

Deep-seated solution in the Meade basin, Kans.-Okla. ..........J 293

Geology and ground-water resources of Meade County, Kans.......C 154

Geology and ground-water resources of the "Equus beds" Kans ....J 214

Geology and ground-water resources of Thomas County, Kens.....C 159

Ground water in the Meade artesian basin, Kans ............. 142

Ground water in the oil-field areas of Ellis and Russell Counties, Kans

C 156

Ground-water resources in Atchison County, Kans............ 148

Ground-water supplies in Kansas available for national defense....C 151

Kansas mineral resources for wartime industries.............. 152

Meade artesian basin, Kans ....................... 132

Water levels and artesian pressure in the United States .....W 908, 938

Water supply of the Meade artesian basin, Kans.............. 144

Fry-pan deposits, water in, in Texas .................... 18 II b

Fuller, M. L., Artesian waters of the Atlantic Coastal Plain ...........J 14

Bibliography of ground-water literature in $1905 \ldots \ldots \ldots \ldots \ldots \ldots$ W 163.

Bibliography of United States Geological Survey papers on underground

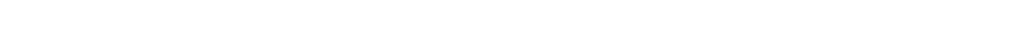

Contributions to hydrology $\ldots \ldots \ldots \ldots \ldots \ldots \ldots \ldots \ldots W$ 102, 110, 145

Controlling factors of artesian flows $\ldots \ldots \ldots \ldots \ldots \ldots \ldots \ldots \ldots \ldots \ldots \ldots$

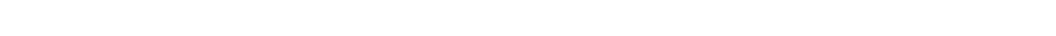

Drainage by wells ................................. 258

Failure of wells along lower Huron River, Mich ............. 181

Flowing wells and municipal supplies in the southern peninsula of

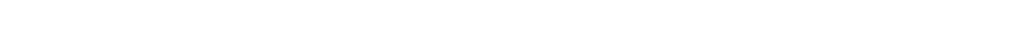

Freezing of wells and related phenomena $\ldots \ldots \ldots \ldots \ldots \ldots \ldots W$ W 258

Gaines folio, Pa.-N. Y. ........................... GF 92

Geology and underground waters of southern Minnesota........W 256

Geology of Long Island, N. Y.......................P 82

Ground-water problem in southeastern Michigan ............W 145

Hydrologic work of the United States Geological Survey ir the eastern United States ............................... 5

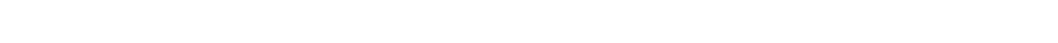

Large springs of Ozark region, Mo.-Ark $\ldots \ldots \ldots \ldots \ldots \ldots \ldots \ldots$ W 145

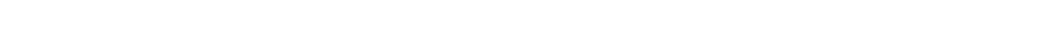

Patoka folio, Ind.-Ill ............................ 105

Peculiar mineral waters from crystalline rocks $\ldots \ldots \ldots \ldots \ldots \ldots$ W 160

Production of mineral waters ........................ 1905

Protection of shallow wells in sandy deposits .............W 258

Records of deep wells .......................... 264, 298

Representation of wells and springs on maps ..............W 160

Significance of the term "artesian" .....................W 160

Total amount of free water in the earth's crust $\ldots \ldots \ldots \ldots \ldots \ldots W \mathbf{W} \mathbf{1 6 0}$

Triassic rocks of the Connecticut Valley .................W 110

Underground-water investigations in the United States............J 7

Underground-water papers, $1906 \ldots \ldots \ldots \ldots \ldots \ldots \ldots \ldots \ldots \ldots$ W 160

Underground waters for farm use $\ldots \ldots \ldots \ldots \ldots \ldots \ldots \ldots \ldots \ldots$ W 255

Underground waters of eastern United States .............W 114 
Fuller, M. L., Underground waters of southwestern Ohio . . . . . . W 259 Uses of underground waters of southern Louisiana .........W 101

\section{G}

Gages for determining vacuum in pumps ...............W 141 for recording water levels in wells ........W 155; D 127, 139, 155, 188 Gale, H. S., Geology and ground-water hydrology of the Mokelumne area,

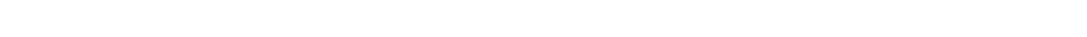
Geology and ground-water resources of the Balmorhea area, wertern Texas .................................W 849 c Ground-water resources of the Balmorhea area, Tex........... 390

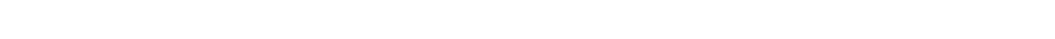
Potash tests at Columbus Marsh, Nev ................. $540 \mathrm{n}$ Water resources of the Cowee and Pisgah quadrangles, N. C .....W 110 Water supply of Rangely oil district, Colo ................ 350

Galena limestone, water in, in Illinois ........W 114; B 506; GF 81, 200 water in, in Iowa ..................... 293; GF 145, 200

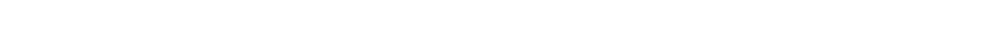

in Wisconsin ............................ 114; GF 145

Gambrell, J. W., Water levels and artesian pressure in the United States

Gardiner, J. H., Surface water supply of the United States. .

W 845,886

W $879,899,959,979$

Garrett, A. A., Chemical character of native and contaminated water in the

Long Beach-Santa Ana area, Calif ........................ $30 \mathrm{f}$

Cooperative ground-water investigation in the Torrance-Santa Monica

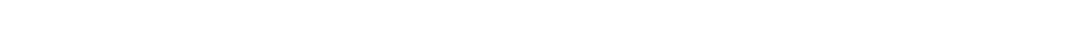

Partial chemical analyses of waters from coastal zone of Long Beach-

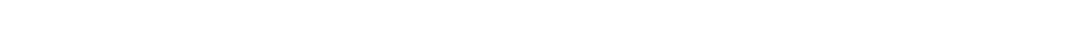

Water levels and artesian pressure in the United States, $1942 \ldots \ldots \ldots$. W 949

Garrey, G. H., Economic geology of the Georgetown quadrangle, Colo....P 63

Gases in ground water.........W 494; M 47; P 145; B 395, 658; J 39, 72

Geochemistry of ground water.....B 330, 491, 616, 695, 770; J 117, 198, 372

Geologic causes of fluctuations of ground-water levels ...........W 155

Geologic work of ground water ................ 47; F 529, 606

Geology in relation to hydrology . . . . . . . . . . . . . . . J 367

Geophysical surveys for ground water ........D 78; J 95, 174, 210, 310

in Hawaii .................. 97, 98; D 157, 158; . 175, 204

in Texas ......................................... 176

George, W. O., County reports on ground-water surveys in Texas by

Works Progress Administration ..................... 384

County reports on ground-water surveys in Texas in cooperation with

Texas State Board of Water Engineers . ............... 393

Georgia, areas, all of State $\ldots \ldots \ldots \ldots \ldots \ldots \ldots \ldots \ldots \ldots \ldots$ 102, 114; C 81

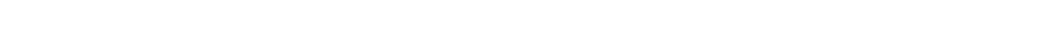

Coastal Plain ..............W 341; B 138; D 129, 134; J 353

Decatur County ........................... 298

Ellijay quadrangle .......................... 187

Fulton County .............................. 298

Pierce County .................................. 298

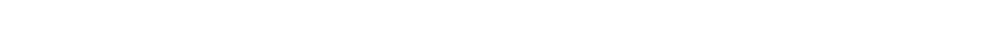


Georgia, areas, Savannah and vicinity .........W 67; B 298; C 82, 83

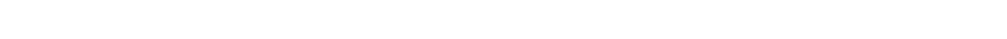
Tattnall County ............................ 298 artesian water in ..W 67, 341; B 138; C 81, 82, 83, 84; D 104, 129,

134; J 221, 248, 353 bibliography of ground water in $\ldots \ldots \ldots \ldots W 57,114,120,149,163 ; C 81$ cones of depression in $\ldots \ldots \ldots \ldots \ldots \ldots \ldots \ldots \ldots \ldots \ldots \ldots \ldots \ldots \ldots \ldots$ drainage into wells in $\ldots \ldots \ldots \ldots \ldots \ldots \ldots \ldots \ldots \ldots \ldots \ldots \ldots$ W 160 irrigation with ground water in ................W 341; C 81 mineral waters in ..........W 114, 160; B 32; MR 1883-1923; GF 187 power from artesian wells in ...................... 81 public water supplies in $\ldots \ldots \ldots \ldots \ldots$ W 67, 102, 341, 912; B 138; C 81, 82

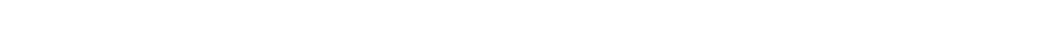
quality of ground water in. W 102, 160, 341, 912; B32, 138; C81, 82,

$83 ; \mathrm{D} 104 ; \mathrm{J} 253$

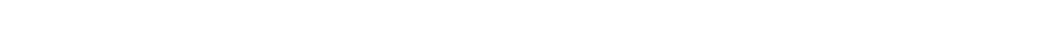
spring discharge measurements in..W $36,127,168,743,757,782,822$, $852,872,892$ springs in ....W 102, 114, 145, 197, 341, 557, 679 b, 819; A 14 II b, B 32; GF $187 ; \mathrm{C} 81$

thermal W $679 \mathrm{~b}, 819$ water levels in $\ldots \ldots \ldots \ldots \ldots \ldots \ldots \ldots \ldots$ W 845, 886, 907, 937, 945, 987

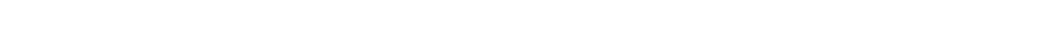
well records for .......W 57, 67, 102, 149, 341; B 138, 264, 298; C 81, 84 Gering formation, water in, in Nebraska .............. 19 Iv c; P 17 Germany, bibliography of ground water in $\ldots \ldots \ldots \ldots \ldots \ldots \ldots \ldots$ W 163 deep wells in ................................. 257

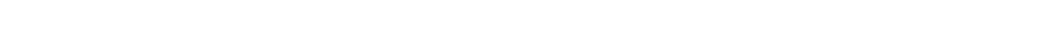
mineral waters in $\ldots \ldots \ldots \ldots \ldots \ldots \ldots \ldots \ldots \ldots \ldots \ldots$ B 606; MR 1916 quality of water in $\ldots \ldots \ldots \ldots \ldots \ldots \ldots \ldots \ldots \ldots$ B 330,491, 529, 606, 616

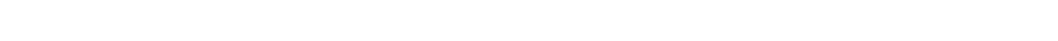

Geyser springs ............................... 114

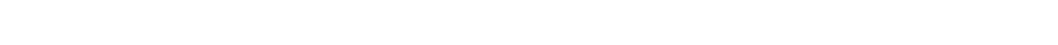

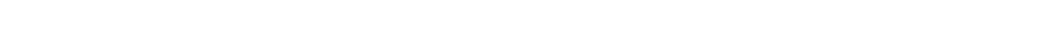

Geysers, analyses of water from $\ldots \ldots \ldots \ldots$ W 364; A 9 d; B 47, 330, 491, 616

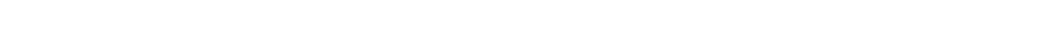
in Yellowstone National Park ..........W 364; A 9 d, 14 II b; 47, 395 radioactivity of water from ............... 395; MR 1913 II $h$ water yielded by ............................ 14 In b Gila conglomerate, water in, in Arizona ....W 320, 425 a, 796 f; GF 111; C 16 Gilbert, G. K., Pueblo folio, Colo ....................GF 36 Underground water of Arkansas Valley, Colo ........... 17 Ir $f$ Giles, J. M., progress of stream measurements for $1905 \ldots \ldots \ldots \ldots \ldots$ W 173 Surface water supply of the United States, $1906 \ldots \ldots \ldots \ldots \ldots \ldots$ W 209 Gilluly, James, Geology and mineral resources of the Baker quadrangle, Oreg . ............................ B 897

Geology and oil and gas prospects of northeastern Colo ..... 796 b Geology and oil and gas prospects of part of the San Rafael

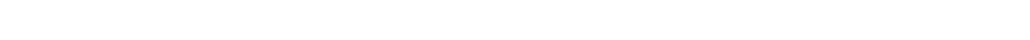

Some mining districts of eastern Oregon .............. 846 a

Glacial deltas, water in $\ldots \ldots \ldots \ldots \ldots \ldots \ldots \ldots \ldots \ldots \ldots \ldots \ldots$ W 145, 489

Glacial drift, water in-

Arkansas W 145; GF 140 
Glacial dxift, water in, Connecticut ....W 114, 232, 374, 397, 449, 466, 470, $540,597 \mathrm{~b} ; \mathrm{C} 41,42,43,44,45$

Idaho .W 818

Illinois ..W 114; A 17 II h;M 38; GF 67, 105, 185, 188, 195, 208, 220; C 131

Indiana .. W 21, 26, 115, 114, 254; A 18 iv b; M 53; GF 167, 105; C 134, 135

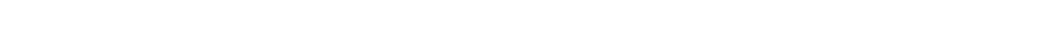
Kansas .........................W 273; GF 206; C 142 Kentucky ............................ C 160; J 323 Maine ........................... 145, 223; GF 149

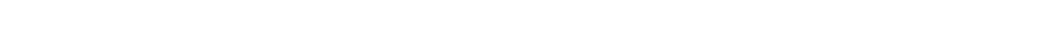
Massachusetts ..................W 145; B 839; D 193; J 145

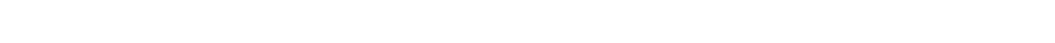
Minneosota ...................W 256; M 25; GF 117, 201, 210 Missouri .........................W 195; GF 206 Montana ...................W 221, 400 b; B 691 e, 751 e Nebraska ........................W 12; GF 156; J 75

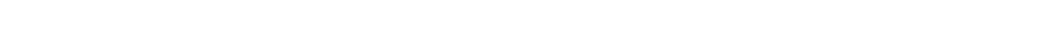
New York ........W 110, 114, 145; GF 157, 169, 190; C 273, 274; J 146 North Dakota ........W 598; A 17 II g; M 25; B 801; GF 117, 168; C 301, $302,304,328$

Ohio ....W 114, 259; A 18 Iv b, 19 IV b; GF 197; C 311, 312; D 1.20; J 126 Pennsylvania ......W 114; C 341, 342, 343, 344, 345, 346, 349, 351; D 26 South Dakota ......W 34, 90, 227; A 17 II g; GF 96, 97, 99, 100, 113, 114, 156,$165 ; \mathrm{C} 302$ Washington $\ldots \ldots \ldots \ldots \ldots \ldots \ldots \ldots \ldots \ldots \ldots \ldots \ldots \ldots \ldots$ W 425 e; D 102

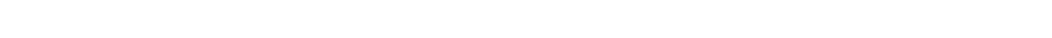
See also Till.

Glen Rose formation, water in, in Texas .............. 2i vIl GF 64 Glenn, L. C., Underground waters of South Carolina ............W 114

Underground waters of Tennessee and Kentucky west of Tennessee River and of an adjacent area in Illinois ................. 164

Water resources of Kentucky and Tennessee ........... $\mathrm{V}^{r}$ 102, 144 Glossary of ground-water terms ..................... 6 Gneiss, water in .....W 106, 114, 160, 223, 232, 255, 257, 489, 54C; GF 147,

See also Crystalline rocks.

$157,162,191$

Gold in ground water ........................ 94; B 529, 625 Goldman, M. I., Structure and oil and gas resources of the Osage

Reservation, Okla ........................ 686 w, y

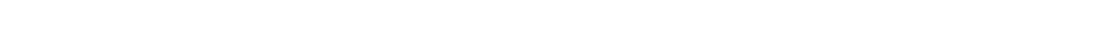
Gooch, F. A., Analyses of waters of Yellowstone National Park........B 47 Goodell, E. B., Laws forbidding pollution of inland waters ......W 152 Gordon, C. H., Geology and underground waters of northeastern Texas. . W 276

Geology and underground waters of the Wichita region, north-central

Texas .................................. W 317

Ore deposits of New Mexico ...................... 68

Gould, C. N., Geology and water resources of Oklahoma..........W 148

Geology and water resources of the eastern portion of the Penhandle

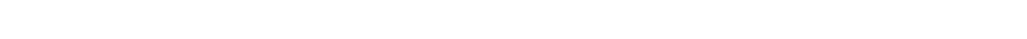

Geology and water resources of the western portion of the Panhandlé of Texas 
Gould, L. O., Ground waters of Monroe County, N. Y.............C 273

Graham, J. B., Cooperative ground-water investigations in Wyoming . . . C 455

Ground-water investigations in Pennsylvania ..............J 335

Ground-water report for Philadelphia area (Pa.) ...........J 358

Industrial ground-water supplies ...................... 351

Water levels and artesian pressure in the United States..... W 948, 986

Grand Falls chert, water in, in Kansas ................... 148

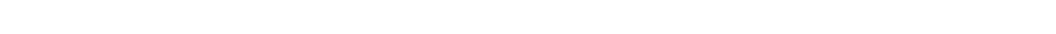

Grand Gulf formation, water in, in Alabama $\ldots \ldots \ldots \ldots \ldots \ldots \ldots \ldots$. 1

water in, in Mississippi .......................... 159

Granger, A. E., Quicksilver deposits in San Luis Obispo Count and

southwestern Monterey Couney, Calif .................... 922 r

Granite, water in ......W 114, 16, 223, 232, 255, 256, 257, 258, 277, $345 \mathrm{~g}$,

See also Crystalline rocks.

374, 397, 489; A 18 in b; GF 45, 147, 149, 151, 158

Grant, U. S., Lancaster-Mineral Point folio, Wis.-Iowa-Ill .......... GF 145

Water resources of the Mineral Point quadrangle, Wis .........W 145

Graton, L. C., The ore deposits of New Mexico ..............P 68

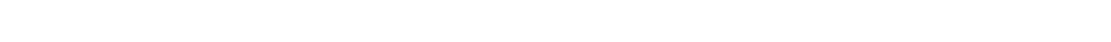

flow of water in; experiments with. W 112, 136, 140, 141, 153, 184, 258; P 44

in buried channels, water in $\ldots \ldots \ldots \ldots \ldots \ldots \ldots \ldots W 273,2 n$; $A 19$ Iv b

interbedded with lava, water in .................. 4; B 199

porosity of $\ldots \ldots \ldots \ldots \ldots \ldots \ldots \ldots \ldots \ldots \ldots \ldots \ldots \ldots . W 10 . \ldots \ldots, 136,140 ; C 16$

spreading flood water over ..................... 21; J 279

walls of wells formed of .........W 256, 293, 343, 345 a, d, g, 375 a

wáter in $\ldots \ldots \ldots \ldots \ldots W$ 6, 112, 114, 136, 153, 184, 223, 233, 255, 257, 258, $273,319,374,397,399,425$ b, 638 a, 796 f, 836 b;

P 44; C 13, 15, 16; J 279

See also Alluvium; Glacial drift; Porosity; Valley fill.

Gravel screens in wells ..........W 256, 293, 343, 345 a, d, g. 375 a, 597 c

Graydon sandstone, water in, in Missouri ................W 195

Great plains. See High Plains; specific States

Greece, ancient, mineral water used in ................ 14 II b

Greene, F. C., Leavenworth-Smithville folio, Mo.-Kans ...........GF 206

Greenhorn limestone, water in, in Nebraska ................ 156

water in, in South Dakota ....................... 156

See also Benton formation.

Greenlee, A. L., Method for determining transmissibility and storage coeffi-

cients by tests of multiple well systems .................... 311

North Dakota's ground-water problems ..................J 328

Water levels and artesian pressure in the United States. . W 946, 988, 990

Gregory, H. E., Ground watex in Hartford, Stanford, Salisbury, Willimantic,

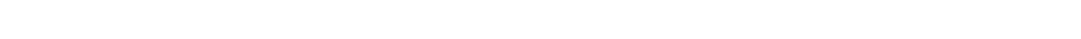

The Kaiparowits region, Utah and Arizona ...............P 164

The Navajo country-a geographic and hydrographic reconnaissance

W 380

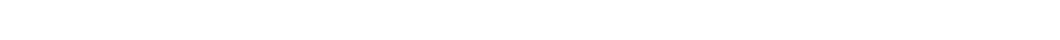

Underground water resources of Connecticut ............W 232

Underground waters of Connecticut ...............W 102, 114

Gregory, W. M., Flowing wells and municipal water supplies in the southern

peninsula of Michigan $\ldots \ldots \ldots \ldots \ldots \ldots \ldots \ldots \ldots \ldots \ldots \ldots \ldots \ldots$ W 183

Grenada formation, water in, in Tennessee $\ldots \ldots \ldots \ldots \ldots \ldots \ldots \ldots$ D 14 
Greybull sand, water in, in Montana $\ldots \ldots \ldots \ldots \ldots \ldots \ldots \ldots \ldots \ldots \ldots$ B 822 a water in, in Wyoming .............................. $621 \mathrm{l}$

Ground-water level. See Water table.

Grunsky, C. E., Irrigation near Bakersfield, Calif ..............W 17 Irrigation near Fresno, Calif ........................ 18

Guides to desert watering places. See Watering places.

Gulf Coastal Plain. See specific States.

Gunter, Herman, Artesian water supply of eastern and southern Florida. .C 54 Artesian water supply of eastern Florida $\ldots \ldots \ldots \ldots \ldots \ldots \ldots \ldots$. C 52 Underground water supply of west-central and west Florida ....... 53 Guyton, W. F., Artificial recharge of glacial sand and gravel at

Louisville, $\mathrm{Ky}$................................... 362 Coefficients of transmissibility and storage, Houston district, Te-..J 242 Conservation of ground water in the Louisville area, $\mathrm{Ky} \ldots \ldots \ldots \ldots . . J \mathrm{~J} 349$ Depleted wells at Louisville (Ky.) recharged with city water ......J 330 Geology and ground-water supply at Camp Van Dorn (Miss.) ...... 193 Ground-water resources of the Houston district, Tex ....W 889 d; C 396 Ground-water resources of the Louisville area, Ky ............ 160 Pumping tests of the Carrizo sand in the Lufkin area, Tex.........J 294 Quantitative studies of some artesian aquifers in Texas ..........J 347 Well discharge; a method of computing the quantity of water de:ived

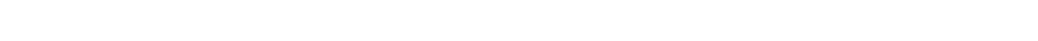

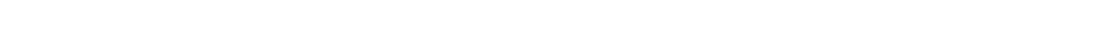
500 b; B 6ะ7; C 381

Gypseous water ....W 148 154, 273, 275, 276, 317, 320, 343, $375 \mathrm{~g}, 398,489$, water in ................W 148, 154, 343, 489, 500 b, 580 a; C 381

\section{H}

Hagen, G., on flow of water through soils ................ 19 in b

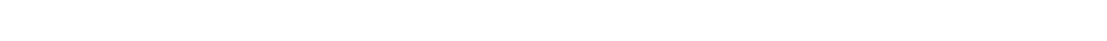

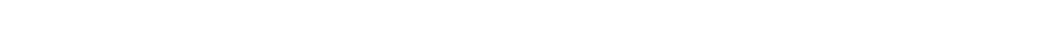

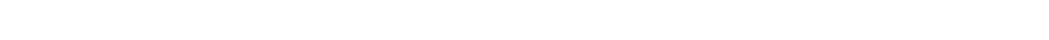
well records for $\ldots \ldots \ldots \ldots \ldots \ldots \ldots \ldots \ldots \ldots \ldots \ldots \ldots \ldots \ldots \ldots \ldots$. 72

Halberg, H. N., Well and test hole records for Providence, R. I........C 356 Hale, W. E., Geology and ground water (Pecos River Basin, N. Mex.) ..C 256

Water levels and artesian pressure in the United States.....W 946, 988

Hale formation, water in, in Arkansas .....................GF 154

water in, in Oklahoma ........................... GF 154

Hall, B. M., Operations at river stations $\ldots \ldots \ldots \ldots \ldots \ldots \ldots{ }^{\times r} 27,36$

Water resources of Georgia .........................W 197

Hall, C. M., Alexandria folio, S. Dak .....................GF 100

Castleton-Fargo folio, N. Dak.-Minn..................GF 117

De Smet folio, S. Dak..........................GF 114

Geology and water resources of James River Valley, S. Dak.......W 90

Hall, C. W., Geology and underground waters of southern Minnesota...W 256

Underground waters of Minnesota ..................W 102, 114

Hall, G. M., Ebb and flow spring near Greenbrier Cove, Tenn........D 63

Ebb and flow spring near Rogersville, Tenn.................J 55

"Fittifying" spring near Greenbrier Cove, Tenn..............J 142

Geology of Bighorn County and the Crow Indian Réservation, Mont.. B 856

Ground water in Ordovician rocks near Woodstock, Va. .......W $596 \mathrm{c}$ 
Hall, G. M., Ground water in southeastern Pennsylvania ..........C 342

Ground water in Yellowstone and Treasure Counties, Mont.......W 599

Ground water resources of southeastern Pennsylvania ......... 35

Hall, M. R., Progress of stream measurements.........w 98, 127, 168

Surface water supply of southern Atlantic and eastern Gulf States,

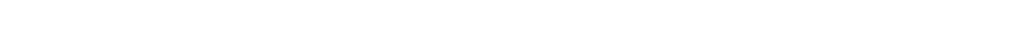

Water resources of Georgia ..................... 197

Hall, W. E., Surface water supply of the United States, 1917 ......W 452

Halpenny, L. C., Ground-water inventory in upper Gila River Valley, N.

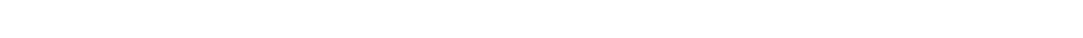

Ground-water levels and pumpage in Arizona, 1939-40 .........C 14

Queen Creek area, Maricopa and Pinal Counties, Ariz........... 18

Water levels and artesian pressure in the United States, $1940 \ldots$. W 911

Water resources of Safford and Duncan-Virden Valleys, Ariz.-N. Mex.C 15

Water-stage recorder, self-starting ................ 139

Hamilton, D. K., Drillers' logs of wells and test borings in the

Louisville area, $\mathrm{Ky}$................................... $160 \mathrm{f}$

Ground water in the Louisville area, Ky .............. $160 \mathrm{~b}$

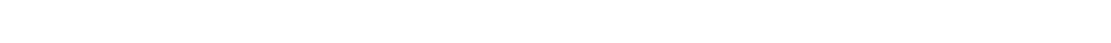

Hamlin, Homer, Underflow tests along Los Angeles River, Calif ....W 112

Water resources of the Salinas Valley, Calif. .............W 89

Hammond, G. A.. Diamond-drill methods ................W 146

Hance, J. H., Potash in western saline deposits ............... 540 p

Hancock, E. T., Geology and coal resources of the Meeker quadrangle, Colo

B 812 c

Geology and oil and gas prospects of the Huntley field, Mont...B $711 \mathrm{~g}$

Geology and oil and gas prospects of the Lake Basin field, Mont. . B $691 \mathrm{~d}$

Geology of the Rock Creek oil field, Wyo ................. $806 \mathrm{~d}$

Lance Creek bil and gas field, Wyo .................. 716 e

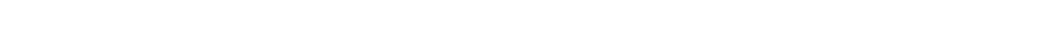

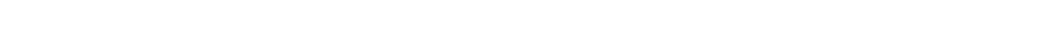

Hanna, F. W., Progress of stream measurements, $1905 \ldots \ldots \ldots \ldots \ldots$. W 170

Hannibal formation, water in, in Missouri ...............W 195

Hard, H. A., Artesian water supply of Dakota sandstone ...........J 41

Artesian water supply of the Dakota sandstone in North Dakota. . W 520 e

Geology and water resources of the Edgeley and La Moure quadrangles,

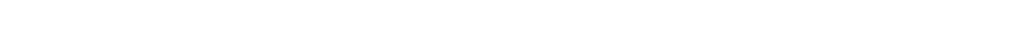

Harder, E. C.. Iron-depositing bacteria and their geologic relations....P 113

Hardison, C. H., Water levels and artesian pressure in the Un'ted States,

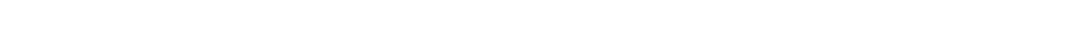

Hardness of ground water W 232, 254, 259, 273, 320, 338, 341, 343, 398, 399, 559

Hare, R. F., Geology and water resources of Tularosa Basin, N. Mex....W 343

Hares, C. J., Anticlines in Wyoming ................W 641 I

Geology and lignite resources of the Marmarth field, N. Da.k. . . . B 775

Harrell, M. A., Ground-water resources of the Holbrook region, Ariz

W 836 b; D 85

Harrington, A. W., Water levels and artesian pressure in the United States

$777,817,840,845,886,936$

Harrington, G. L., Anvik-Andreafski region, Alaska ............ 683

Gold placers of the Anvik-Andreafski region, Alaska ........ $662 \mathrm{f}$

Tin mining in Seward Peninsula, Alaska ............... $692 \mathrm{~g}$ 
Harris, G. D., Underground waters of southern Louisiana.........W 101

Harrold, L. L., Relation of stream flow to ground-water levels........J 116

Hastings, W. W., Public water supplies in eastern Texas........... 415

Quality of water, Pecos River basin, N. Mex ............... 398

Hatchetigbee formation, water in, in Alabama ............... 1

Hawaii, areas, all of Territory .................... 27, 265

areas, Hawaii Island $\ldots \ldots \ldots \ldots \ldots \ldots \ldots \ldots \ldots \ldots \ldots \ldots \ldots \ldots, 318,36,616$

Kahoolawe Island $\ldots \ldots \ldots \ldots \ldots \ldots \ldots \ldots \ldots \ldots \ldots \ldots \ldots \ldots$

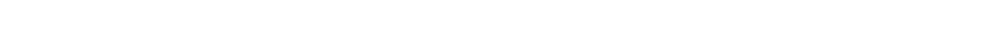

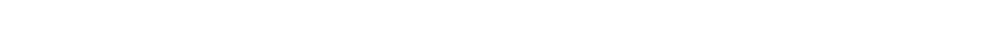

Lanai Island $\ldots \ldots \ldots \ldots \ldots \ldots \ldots \ldots \ldots \ldots \ldots \ldots \ldots \ldots \ldots \ldots$

Maui Island .............W $318,336,373,445$; C 99 ; I 48,157

Molokai Island .......................W 77 ; D 158

Oahu Island . . . . . . .W 318, 336, 373, 430, 445; C 91, 92, 94, 97;

D E $;$ J 109

artesian water in $\ldots \ldots \ldots \ldots W W 318,336,373,430,596$ a, 616; C 91, 92, $94,95,97,99 ;$ D $50 ; \mathrm{J} 109,217,265$

bibliography of ground water in ............W 163, 616; C 93 infiltration tunnels in ........W 318, 445, 616; C 92, 97, 98, 凡9; J 165 irrigation with ground water in. .W 77, 318, 336, 616; C 91, 92, 94, 97, 99;

J 109,265

law relating to ground water in................ 596 a public water supplies in $\ldots \ldots \ldots \ldots \ldots \ldots \ldots \ldots \ldots \ldots \ldots \ldots \ldots \ldots \ldots$ pumping in .............................. 99 quality of ground water in $\ldots \ldots \ldots \ldots \ldots W 77,616 ; C$ 92, 94, \7, 98, 99 quantity of ground water in ......W 77, 616; C 91, 92, 97, 98, 99; J 265 salt water in .......W 77, 616; C 92, 94, 97, 98, 99; D 151; J 175, 204 spring discharge measurements in. W 318, 336, 373, 430, 445, 535, 575, $595,615,635,655,675,710,740,755,770,795,815$, $835,865,885,905,935,965,985 ; \mathrm{C} 92,98,99$

springs in $\ldots \ldots \ldots \ldots \ldots \ldots \ldots \ldots \ldots$ W 77, 616; C 92, 96, 98, 99; D 157

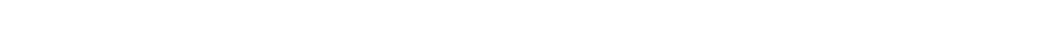
water levels in $\ldots \ldots \ldots \ldots W$ W77, 817, 840, 845, 886, 911, 941, 949, 991; C $92,-94,97,98,99$ water table in .....W 616; C 92, 95, 97, 98, 99; D 158, 169; J 27, 204, 265 well records for .....W $318,336,373,430,616 ;$ C 91, 92, 94, 97, 98, 99 wells in, construction of .............W 596 a; C 92, 97; J 165 yield of $\ldots \ldots \ldots \ldots \ldots W 77,318,336,373,616$; C $91,92,97,98,99$ Hawkins, R., Water supply of Livingston County, Mo ........W 102 Haworth, Erasmus, Economic geology of Iola quadrangle, Kans ..... B 238

Underground waters of southwestern Kansas ............W 6 Hawthorn formation, water in, in Florida ......W 319; C 57, 58, cn, 61, 62; $\mathrm{J} 134,137,258$

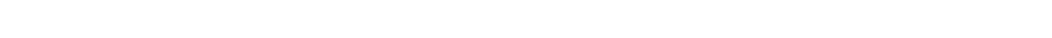

Hay, Robert, Water resources of a portion of the Great Plains ...A 16 II $f$

Well records in Nebraska, Colorado, and Kansas ........... 131

Head of ground water. See Artesian water; Water table.

Heald, K. C., Geologic structure of northwestern Pawhuska

Geology of the Ingomar anticline, Mont ............. 786 a quadrangle, Okla $\ldots \ldots \ldots \ldots \ldots \ldots \ldots \ldots \ldots \ldots \ldots \ldots \ldots \ldots \ldots$ B 619 c 
Heald, K. C., Oil and gas geology of the Foraker quadrangle, Okla . . B 641 b Structure and oil and gas resources of the Osage Reservition,"

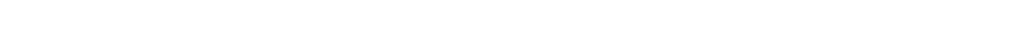

Hem, J. D. Quality of water, in Ground-water resources of the Santa Cruz

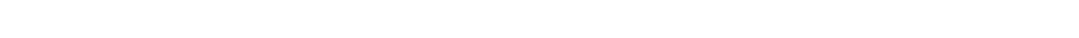

Water analyses, in Duncan-Virden Valley, Ariz., and New Mexico ...C 17

Water analyses, in Queen Creek area, Ariz ................... 18

Water analyses, in Records of wells and springs in Big Sandy Valley,

Ariz ..................................... 13

Water analyses in Safford Valley, Graham County, Ariz .......... 16

Water analyses, in Water resources of Safford and Duncrn-Virden

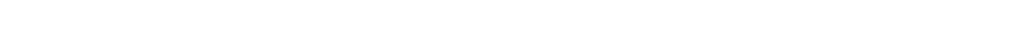

Hendricks, T. A., Geology and fuel resources of McAlester di-trict,

Okla ............................................ 874 a

Geology and mineral resources of western part of Arkansas

coal field $\ldots \ldots \ldots \ldots \ldots \ldots \ldots \ldots \ldots \ldots \ldots \ldots \ldots \ldots \ldots \ldots \ldots$ B 847 e

Hendrixson, W. S., Underground water resources of Iowa .....W 293; C 137

Henrietta limestone, water in, in Missouri ..............W 195

Henshaw., F. F., Surface water supply of Seward Peninsula, Alaska ... W 314

Surface water supply of the United States, part $10 \ldots W \quad 310,360,440$, $46^{\top}, 480,510,530$

Surface water supply of the United States, part $11 \ldots \ldots \ldots$ 271, 391

Surface water supply of the United States, part $12 \ldots V^{r} 332,394,514$,

$574,594,614,634,654$

Herald, F. A., Lignite in Fort Berthold Indian Reservation, N. Dak...B 726 d

Heroy, W. B., Geography, geology, and mineral resources of Firt Hall

Indian Reservation, Idaho ........................... 713

Herrick, S. M., Water levels and artesian pressure in the United States,

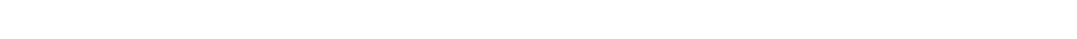

Hershey, H. G., Water levels and artesian pressure in the United States,

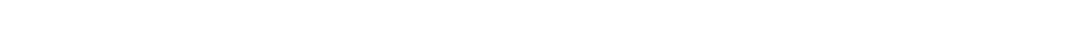

Hess, F. L., Contact-metamorphic tungsten deposits of the United States

B $725 \mathrm{~d}$

Hess, R. H., Water analyses, in Geology and ground-water resources of

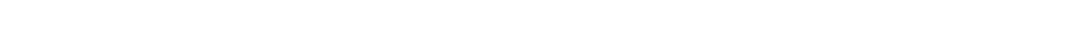

Water analyses, in Geology and ground-water resources of Meade

County, Kans ................................ 154

Water analyses, in Geology and ground-water resources nf Morton

County, Kans

Water analyses, in Geology and ground-water resources of Stanton

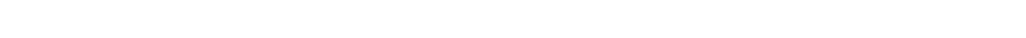

Heuser, J. F., Geology and ground-water resources of the Lu?kin area,

Tex ......................................... 849 a

Hewett, D. F., Anticlines in southern part of Big Horn Basin, Wyo .... B 656

Geology and oil and coal resources of the Oregon Basin, Yryo .....P 145

Geology and ore deposits of the Goodsprings quadrangle, Nev ... . .P 162

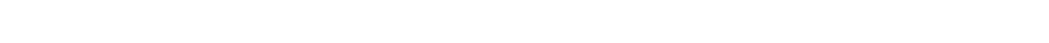

Mineral resources of the region around Boulder Dam .......... 871

Warm springs of Georgia ........................W 819

Hicks, W. B., Composition of muds from Columbus Marsh, Nov .....P 95 a

Evaporation of brine from Searles Lake, Calif ............. 98 a

Potash resources of Nebraska $\ldots \ldots \ldots \ldots \ldots \ldots \ldots \ldots \ldots \ldots \ldots \ldots \ldots \ldots$ 
High-level water W 616; C 92, 97, 98, 99

High Plains, ground water in W 489; A 21 IV e, 22 IV e See also specific States.

Highbridge limestone, water in, in Kentucky .................W 233 Hill, J. M., Economic geology of Gilpin County and adjacent parts

of Clear Creek County, Colo .............................P 94

Mineral deposits of Santa Rita and Patagonia Mountains, Ariz ...B 575

Hill, R. T. Austin folio, Tex ........................GF 76

Geography and geology of Black and Grand Prairies, Tex ......A 21 vII Geology of the Edwards Plateau and Rio Grande Plain, Tex ..A 18 In b Nueces folio, Tex ..................................GF 42

Hills, R. C., Elmoro folio, Colo ........................GF 58

Spanish Peaks folio, Colo ...........................GF 71

Walsenburg folio, Colo ............................GF' 68

Hinchey, N. S., Large springs of Missouri .................. 200

Hinderlider, M. C., Progress of stream measurements for 1904 ...W 131, 133

Progress of stream measurements for $1905 \ldots \ldots \ldots \ldots \ldots \ldots \ldots$. W 173

Hinds, Henry, Colchester-Macomb folio, Ill ..................GF 208

Leavenworth-Smithville folio, Mo.-Kans ................GF 206

History of ground-water hydrology $\ldots \ldots \ldots \ldots \ldots \ldots \ldots \ldots \ldots . . . . . . .106,255$

History of ground-water investigations, United States Geological

Survey, prior to $1904 \ldots \ldots \ldots \ldots \ldots \ldots \ldots \ldots \ldots \ldots \ldots \ldots$ W 10?; B 227

Holland, W. T., Inventory of unpublished hydrologic data .........W 837

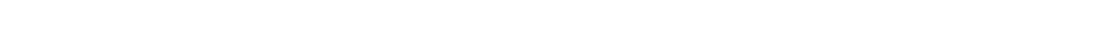

ground water in, bibliography of $\ldots \ldots \ldots \ldots \ldots \ldots \ldots \ldots \ldots \ldots \ldots$ W 163

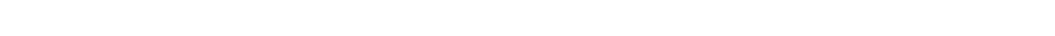

Hollick, Arthur, New York City folio, N. Y.-N. J ..............GF 83

Hollister, G. B., Water of a gravel-filled valley near Tully, N. Y .....W 145

Holly Springs formation, water in, in Tennessee ............... 14

Holmes, E. O., Water analyses, in Geology and ground-water resources of

Finney and Gray Counties, Kans. ..................... 158

Water analyses, in Geology and ground-water resources of

Hamilton and Kearny Counties, Kans ................... 155

Water analyses, in Geology and ground-water resources of

Meade County, Kans ........................... 154

Water analyses, in Geology and ground-water resources of

Thomas County, Kans .............................. 159

Hood, O. P., Tests of pumps and water lifts .................W 14

Hoots, H. W., Geology and oil and gas possibilities of the Bell Spriros

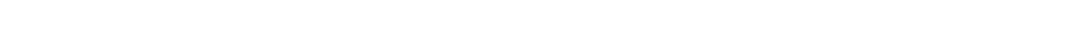

Geology of the Rock Creek oil field, Wyo ................ $806 \mathrm{~d}$

Geology of western Texas and southeastern New Mexico ........ $780 \mathrm{~b}$

Hopkins, O. B., Brenham salt dome, Tex .................. B $661 \mathrm{~g}$

Brooks, Steen, and Grand Saline salt domes, Tex ........... $736 \mathrm{~g}$

Corsicana oil and gas field, Tex ..................... $661 \mathrm{f}$

Oil and gas possibilities of the Hatchetigbee anticline, Ala .....B $661 \mathrm{~h}$

Palestine salt dome, Tex ......................... B $661 \mathrm{~g}$

Structure and oil and gas resources of the Osage Reservation,

Okla ....................................... $686 \mathrm{~s}$

Structure of the Madill-Denison area, Okla. and Tex ........B $736 \mathrm{~g}$

Horton, A. H., Water levels and artesian pressure in the United States 
Horton, R. E., Drainage into wells ....................W 145

Progress of stream measurements for $1905 \ldots \ldots \ldots \ldots \ldots \ldots \ldots . W$ W 170

Surface streams of Long Island, N. Y ...................... 44

Weir experiments, coefficients, and formulas ...........W 150, 200

Hostetter, J. F., Forms for pumpage inventory ............... 200

Water levels and artesian pressure in the United States, $1943 \ldots$ W 991

Hot springs. See Springs, thermal.

Howard, C. S., Chemical character of water of Florida ..........W $596 \mathbf{g}$

Ground water in Yellowstone and Treasure Counties, Mont .......W 599

Index of analyses of natural waters in the United States ..W $560 \mathrm{c}, 659 \mathrm{c}$

Natural sodium bicarbonate waters in the United States ..........J 47

Quality of water, Pecos River Basin, N. Mex ................ 398

Report of committee on the chemistry of natural waters ........J 173

Water analyses, in Ground water in southeastern Pennsylvania .....C 342

Water analyses, in Ground water in southwestern Pennsylrania ...C 341

Howe, Ernest, Ouray folio, Colo ....................... 153

Silverton folio, Colo ............................GF 120

Howe, M. A., Geologic importance of the lime-secreting algan ....P $170 \mathrm{e}$ Howell, R. W., Pumpkin Buttes coal field, Wyo ............. B 806 a Hoy, N. D., Geology and ground water of southern Florida ........J 319 Hoyt, J. C., Droughts and floods ........................... 162

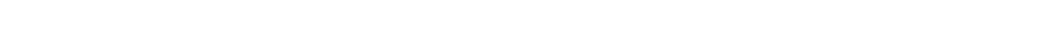

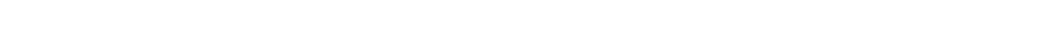

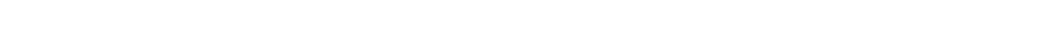

Progress of stream measurements .....W 99, 131, 132. 170, 173, 174

Hoyt, W. G., Relations of rainfall and run-off in the United States ...W 772 Hubbard, G. D., Columbus folio, Ohio ...................GF 197 Hudson shale, water in, in Mịchigan .....................W 114 Hueco limestone, water in, in Texas ....................... 194 Huff, L. C., Frequency method of evaluating ground-water levels .....J 313

Water levels and artesian pressure in the United States .....W 940, 948

Hunt, C. B., Geology and mineral resources of Chouteau, Hill, and Liberty

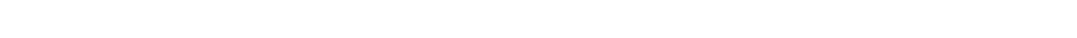

Mount Taylor coal field (N. Mex.) .................... 860 b

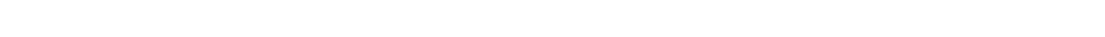

Hutson, W. F., Irrigation systems in Texas ................W 13

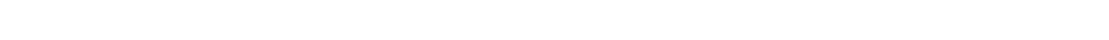

Hydraulic rams for lifting water ............W 1, 254, 256, 540; C 431 Hydrographic contours. See Maps showing contours of water table.

Hydrology-

Arizona $\ldots \ldots \ldots \ldots \ldots \ldots \ldots \ldots \ldots . . .6$ 11, 15, 16; D 160; J 84, 240, 300

California $\ldots \ldots \ldots \ldots \ldots \ldots \ldots \ldots \ldots \ldots \ldots \ldots \ldots \ldots . \ldots \ldots$ 84, 97, 128

hydrology, division of, early work of $\ldots \ldots \ldots \ldots . W$ 1n2; B 227; J 5 general $\ldots \ldots \ldots \ldots . . J$ 26, 33, 76, 93, 94, 106, 144, 163, 191, 255, 271, 367

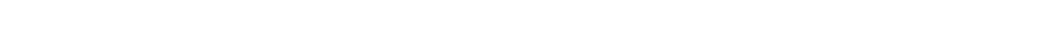

New Mexico $\ldots \ldots \ldots \ldots \ldots \ldots \ldots \ldots \ldots \ldots \ldots \ldots \ldots \ldots \ldots \ldots . . . . \ldots$ J 84, 97

Oregon $\ldots \ldots \ldots \ldots \ldots \ldots \ldots \ldots \ldots \ldots \ldots \ldots \ldots \ldots \ldots \ldots$. J 84, 97, 128

United States ......J 82, 96, 110, 127, 148, 171, 192, 205, 227, 247, 262

Washington ...................................... 128

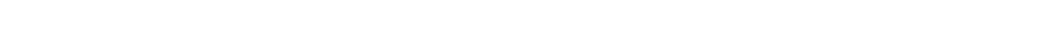

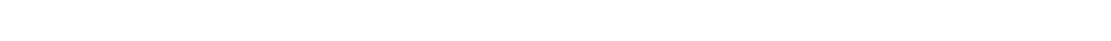

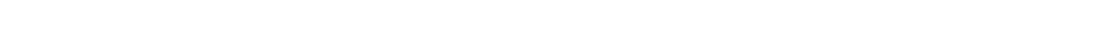


Ice for domestic water supplies $\ldots \ldots \ldots \ldots \ldots \ldots \ldots \ldots \ldots \ldots \ldots$ B 350

Ice manufacturing, quality of water for $\ldots . \ldots \ldots \ldots \ldots \ldots \ldots \ldots$ W 233

Ice-perched water holes $\ldots \ldots \ldots \ldots \ldots \ldots \ldots \ldots \ldots \ldots \ldots \ldots \ldots \ldots \ldots$

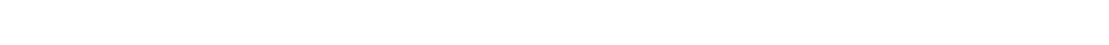
quality of ground water in $\ldots \ldots \ldots \ldots \ldots \ldots \ldots \ldots \ldots \ldots, 430 \ldots \ldots$

Idaho, areas, Big Lost River Valley .................. 17

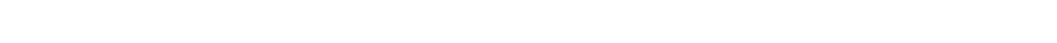

Bruneãu River Basin $\ldots \ldots \ldots \ldots \ldots \ldots \ldots \ldots \ldots \ldots \ldots \ldots$ C 115

Camas County ........................... 116

Craters of the Moon ................... 118; J 35, 52

Curlew Valley .......................... 333

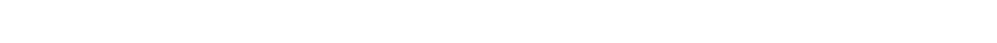

Elmore County $\ldots \ldots \ldots \ldots \ldots \ldots \ldots \ldots \ldots \ldots \ldots \ldots \ldots \ldots \ldots \ldots$

Fort Hall Indian Reservation $\ldots \ldots \ldots \ldots \ldots \ldots \ldots \ldots \ldots \ldots$. 713

Goose Creek Basin ........................... 112

Idaho Falls ............................ 117

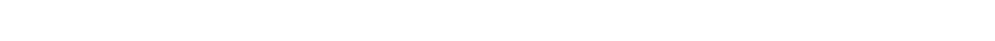

Little Lost River Valley $\ldots \ldots \ldots \ldots \ldots \ldots \ldots \ldots \ldots \ldots \ldots \ldots$ D 16

Mackay region $\ldots \ldots \ldots \ldots \ldots \ldots \ldots \ldots \ldots \ldots \ldots \ldots \ldots \ldots$ P 97

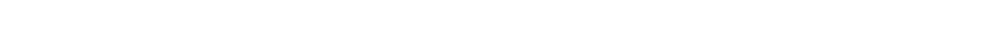

Mud Lake Basin ...............W 560 d, 818; C 1.11; D 47

Nampa quadrangle ..........................FF 103

Nez Perce County ..................... TW 53, 54

Pahsimeroi Valley ........................... 114

Pocatello Valley .........................W 333

Port Neuf quadrangle $\ldots \ldots \ldots \ldots \ldots \ldots \ldots \ldots \ldots \ldots \ldots$ B 803

Raft River Valley ........................ 10

Silver City quadrangle .....................GF 104

Snake River Plains .......W.774, 775, 818; B 199, 713;. D 30, 53 southeastern ......................W $774 ;$ P 152

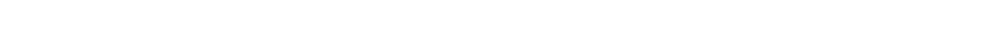

Spokane Valley .....................W 889 b; D 118 artesian water in ...W 54, 78, $560 \mathrm{~d}, 774,818$; B 199; GF 45, 103, 104; C111, 113, 115, 116; D 16, 47 bibliography of ground water in $\ldots \ldots \ldots \ldots \ldots \ldots \ldots \ldots \ldots W$ 120, 163

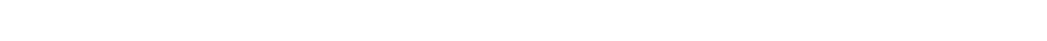
irrigation with artesian water in $\ldots \ldots \ldots \ldots \ldots \ldots \ldots W \quad 560 \mathrm{~d}, 774,818$ with other ground water in ...W $560 \mathrm{~d}, 774,818$; A 16 II e; P 152; GF 103,$104 ;$ C 116; D 10, 17, 47, 53 mineral waters in .................... 32; MR 1883-1916

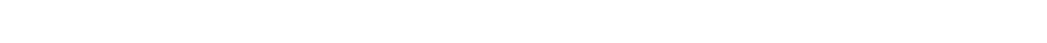
quality of ground water in ...WW $560 \mathrm{~d}, 774,818$; B 32; GF 45; C 111, $112,114 \cdot 115,116$ quantity of ground water in $\ldots \ldots \ldots \ldots \ldots \ldots \ldots \ldots \ldots$ W $560 \mathrm{~d}, 774,818$ salt water in $\ldots \ldots \ldots \ldots \ldots \ldots \ldots \ldots \ldots \ldots \ldots \ldots \ldots \ldots \ldots \ldots$ spring measurements in ...W 85, 135, 393, 463, 483, 513, 533, 553, 570, $573,590,593,610,613,630,633,653,673,723,738 ; 768 ; 774$ 
Idaho, springs in. . W 54, 78, 557, 679 b, 774, 818; A 14 II b; P 152; B 32, 199, $680,713,774,803,814,854,877$; GF 45, 103, 104; C 112, $114,115,116 ; \mathrm{J} 22,34,35,52,143,147$ thermal ...W 78, 679 b, 818; P 152; B 199, 680, 774, 803, 814, 854, 877; GF 45, 104; C 112, J15; J 34, 35, 147 temperature of ground water in ...........W 78; B 32, 199; GF 104 water levels in $\ldots \ldots \ldots \ldots \ldots \ldots \ldots \ldots$ 775, 777, 886, 9丁0, 940, 948, 990 water table in ...W 774, 775, 818, 889 b; GF 103; C 111, 114; D 30, 53, 118 well records for ....W 57, 149, 775, 818; P 152; B 199, 264, 298, 713;

GF 45, 104; C 112, 114, 115, 116

wells in, construction of $\ldots \ldots \ldots \ldots \ldots \ldots \ldots \ldots \ldots \ldots \ldots$. 78 ; C 116

Igneous contacts, water in $\ldots \ldots \ldots \ldots \ldots \ldots \ldots \ldots \ldots \ldots \ldots$ W 489; B 319

Igneous rocks, sodium caronate water in relation to $\ldots \ldots \ldots \ldots \ldots$ W 320 See also Crystalline rocks; Lava.

nlinois, areas, all of State .................. 114; A 17 II h; M 38 areas, Belleville quadrangle ......................FF 195

Boone County ................................ 264

Breese quadrangle ..........................GF 195

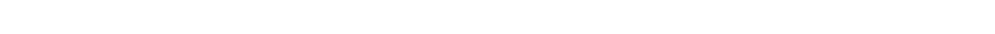

Carlyle quadrangle ............................FF 216

Centralia quadrangle ........................GF 216

Chicago quadrangle $\ldots \ldots \ldots \ldots \ldots \ldots \ldots \ldots \ldots \ldots \ldots \ldots \ldots$ GF 81

Colchester-Macomb quadrangle ..................GF 208

Cook County ................................ 298

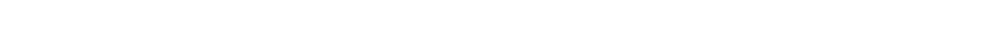

Danville quadrangle $\ldots \ldots \ldots \ldots \ldots \ldots \ldots \ldots \ldots \ldots \ldots \ldots \ldots \ldots$ GF 67

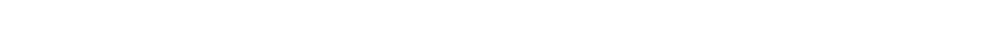

East St. Louis district . . . . . . . . . . . . . . . . . . . C 131

Galena quadrangle ...........................FF 200

Gillespie quadrangle ..........................FF 220

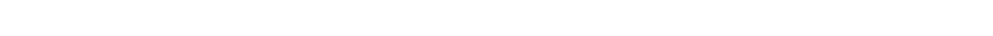

Henry County $\ldots \ldots \ldots \ldots \ldots \ldots \ldots \ldots \ldots \ldots \ldots \ldots \ldots \ldots \ldots$. 264

Herrin quadrangle ...........................GF 185

Lancaster quadrangle $\ldots \ldots \ldots \ldots \ldots \ldots \ldots \ldots \ldots \ldots \ldots$ GF 145

La Salle County ........................... 264, 298

Mineral Point quadrangle $\ldots \ldots \ldots \ldots \ldots \ldots \ldots \ldots \ldots \ldots \ldots$ GF 145

Mount Olive quadrangle ........................FF 220

Murphysboro quadrangle ......................GF 185

New Athens quadrangle .......................... 213

Okawville quadrangle $\ldots \ldots \ldots \ldots \ldots \ldots \ldots \ldots \ldots \ldots \ldots \ldots$. . . 213

Patokà quadrangle ............................... 105

Peoria quadrangle $\ldots \ldots \ldots \ldots \ldots \ldots \ldots \ldots \ldots \ldots \ldots \ldots \ldots$. 506

Rockford area $\ldots \ldots \ldots \ldots \ldots \ldots \ldots \ldots \ldots \ldots \ldots \ldots \ldots \ldots$ W 67

St. Louis quadrangle $\ldots \ldots \ldots \ldots \ldots \ldots \ldots \ldots \ldots \ldots \ldots \ldots \ldots$ B 438

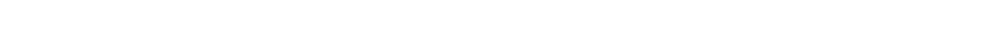

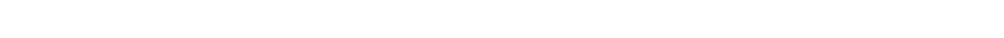

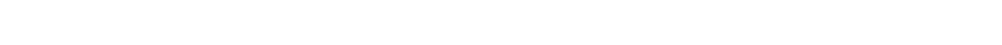

Tallula quadrangle ...........................GF. 188

artesian water in.W 67; A 17 II h; M 38; B 438, 506; GF 67, 81, 195; C 131

bibliography of ground water in .........W 57, 114, 12n, 149, 163, 164

mineral waters in ................W 114; B 32; MR 1883-1923

public water supplies in .........A $17 \mathrm{~m} \mathrm{~h}$; M 38; B 506; GF 195; C 131 
Illinois, quality of ground water in...W 164, 364; A 17 II h; B 32, 438, 506; GF $81,188,195,20$ ?; C 131 springs in .....W 114, 164, 363; A 14 II b; B 32, 438; GF 105, 20?; C 131 temperature of ground water in ................... 32, 506 water levels in W 946, 988 water table in B 506; GF 67; C 131 well records for .... W57, 149, 164; A 17 II h; M 38, 506; GF 67, 81, 105; B 264, 298, 438; GF 67, 81, 105; C 311

wells in, construction and cost of $\ldots \ldots \ldots \ldots \ldots \ldots \ldots \ldots \ldots \ldots$ W 164 Illustrations: apparatus for -

determining color in water

W 151

determining thorium in ground water ............... 395

making underflow measurements ............W 11n, 140; P 44

measuring artesian wells $\ldots \ldots \ldots \ldots \ldots \ldots \ldots \ldots \ldots \ldots \ldots \ldots$ C 92

measuring leaks in artesian wells $\ldots \ldots \ldots \ldots \ldots \ldots \ldots \ldots$ m 596 a

area having ground-water discharge .................. 294

artesian reservoir, section of $\ldots \ldots \ldots \ldots \ldots \ldots \ldots \ldots \ldots \ldots \ldots \ldots \ldots$

artesian springs $\ldots \ldots \ldots \ldots \ldots \ldots \ldots \ldots \ldots \ldots \ldots \ldots \ldots$ W 34, 90; A 21 Iv c

artesian water power $\ldots \ldots \ldots \ldots \ldots \ldots \ldots \ldots \ldots \ldots \ldots \ldots \ldots \ldots$ W 598 ; C 81

augers for boring wells $\ldots \ldots \ldots \ldots \ldots \ldots \ldots \ldots \ldots \ldots \ldots \ldots$ 257, 495

bedding planes in limestone with water oozing therefrom .....W 254 blowing spring $\ldots \ldots \ldots \ldots \ldots \ldots \ldots \ldots \ldots \ldots \ldots \ldots \ldots \ldots \ldots \ldots \ldots$ C 81 caves containing water $\ldots \ldots \ldots \ldots \ldots \ldots \ldots \ldots \ldots \ldots \ldots$ W 114; A 21 Iv c dams, subsurface $\ldots \ldots \ldots \ldots \ldots \ldots \ldots \ldots \ldots \ldots \ldots \ldots \ldots \ldots \ldots$ W 67 deposits made by hot springs ..................W $3 \AA$; ; P 53 devices for lifting water $\ldots \ldots \ldots \ldots \ldots \ldots \ldots \ldots \ldots \ldots \ldots \ldots \ldots \ldots$ diamond drills .................................. 257

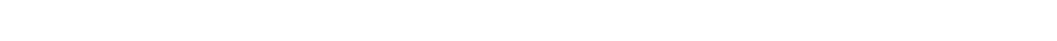
drainage wells $\ldots \ldots \ldots \ldots \ldots \ldots \ldots \ldots \ldots \ldots \ldots \ldots \ldots \ldots \ldots$ W 145 drilling rigs-

deep-well $\ldots \ldots \ldots \ldots \ldots \ldots \ldots \ldots \ldots \ldots \ldots \ldots \ldots \ldots \ldots \ldots \ldots$. 32

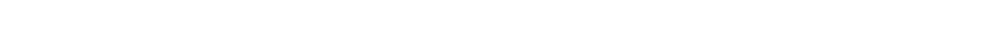

jetting process $\ldots \ldots \ldots \ldots \ldots \ldots \ldots \ldots \ldots \ldots \ldots \ldots \ldots \ldots$ W 30, 140, 257

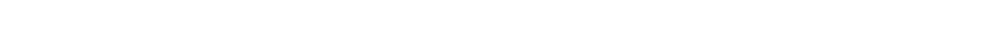

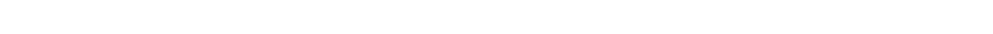

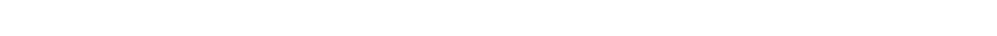

used in-

Arkansas $\ldots \ldots \ldots \ldots \ldots \ldots \ldots \ldots \ldots \ldots \ldots \ldots \ldots \ldots \ldots$

California $\ldots \ldots \ldots \ldots \ldots \ldots \ldots \ldots \ldots \ldots \ldots \ldots \ldots$ W 110, 140, 495

Georgia ............................. 81

Great Plains .......................... 21 Iv c

Indiana .................................. 254

Louisiana $\ldots \ldots \ldots \ldots \ldots \ldots \ldots \ldots \ldots \ldots \ldots \ldots \ldots \ldots \ldots$ P 46

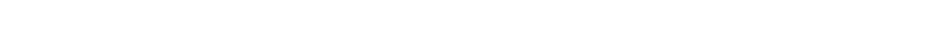

South Dakota ......................... 18 rv c

Texas ................................ W 141

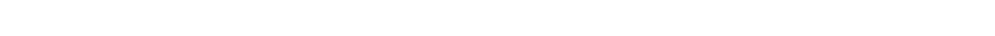

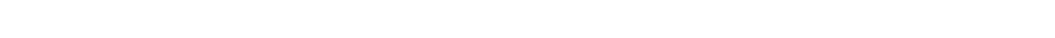

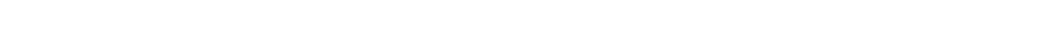

driving outfit for tubular wells $\ldots \ldots \ldots \ldots \ldots \ldots \ldots \ldots \ldots \ldots \ldots$ W 159

dynamometers ................................... 20 
Illustrations: electric resistivity $\operatorname{logs}$ of test wells $\ldots \ldots \ldots \ldots \ldots \ldots$ C 406 evaporation pans $\ldots \ldots \ldots \ldots \ldots \ldots \ldots \ldots \ldots \ldots \ldots \ldots \ldots \ldots$ 294, 818

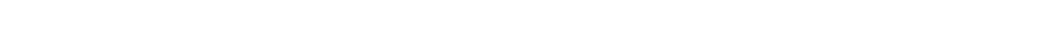

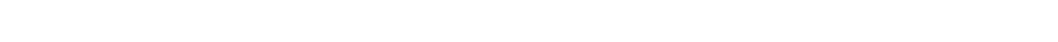

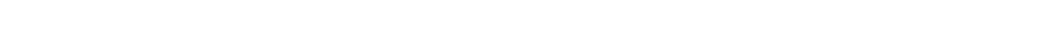

fissure springs $\ldots \ldots \ldots \ldots \ldots \ldots \ldots \ldots \ldots \ldots \ldots \ldots \ldots \ldots \ldots$ W 489; A 21 vII flowing wells-

Alabama $\ldots \ldots \ldots \ldots \ldots \ldots \ldots \ldots \ldots \ldots \ldots \ldots \ldots \ldots \ldots \ldots \ldots \ldots$

Arizona .............................. 21 Iv a

California $\ldots \ldots \ldots \ldots \ldots \ldots \ldots \ldots \ldots \ldots \ldots \ldots \ldots \ldots \ldots$ 140, 294

Colorado ....................W 240; A 21 rv a; P 32, 52

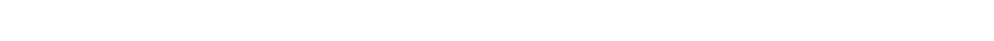

Georgia ..........................W 341; C 81

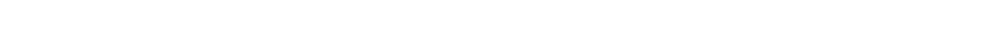

Kansas ..........................W 6; A 21 Iv c

Kentucky ...............................W 164

Michigan $\ldots \ldots \ldots \ldots \ldots \ldots \ldots \ldots \ldots \ldots \ldots \ldots \ldots \ldots \ldots \ldots$ W 145, 182

Mississippi ............................. 576

Nebraska $\ldots \ldots \ldots \ldots \ldots \ldots \ldots \ldots \ldots \ldots \ldots \ldots \ldots \ldots \ldots$ W 29, 215, 216

Nevada ...............................W 365

New Mexico ....................... 158, 343, 596 a

New York $\ldots \ldots \ldots \ldots \ldots \ldots \ldots \ldots \ldots \ldots \ldots \ldots \ldots \ldots \ldots \ldots$

North Carolina ........................... 291

North Dakota .......................... 520 e, 598

Ohio ................................. 19 Iv b

Oklahoma ............................... $500 \mathrm{~b}$

South Dakota .................W 90; A 17 II g, 21 Iv b; P 32

Tennessee $\ldots \ldots \ldots \ldots \ldots \ldots \ldots \ldots \ldots \ldots \ldots \ldots \ldots \ldots \ldots$ W 164

Texas ......................W 13, 190; \& 18 II b; B 164

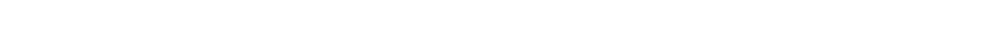

geysers in Yellowstone National Park .................. 396

infiltration ditches in California $\ldots \ldots \ldots \ldots \ldots \ldots \ldots \ldots \ldots$. 21 Iv a

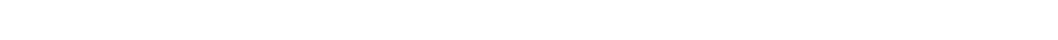

Jackson candle turbidimeter ......................W 151

lakes produced by artesian water $\ldots \ldots \ldots \ldots \ldots \ldots \ldots \ldots \ldots$. 18 Iv c

mud volcanoes in California ...................... 225

perforators for well casings $\ldots \ldots \ldots \ldots \ldots \ldots \ldots \ldots \ldots \ldots$ W 110, 140

pumping plants-

Arizona .............................. 135, 320

California $\ldots \ldots \ldots \ldots \ldots \ldots \ldots \ldots \ldots \ldots \ldots \ldots \ldots \ldots \ldots$ W 45, 495; $C 22$

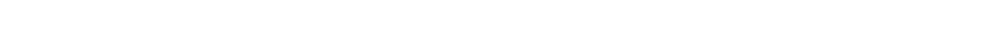

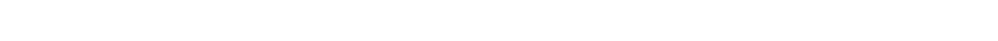

New Mexico ............................. 158

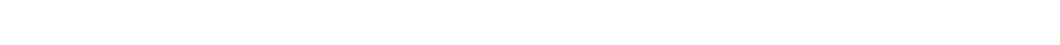
reservoirs for well water $\ldots \ldots \ldots \ldots \ldots \ldots \ldots \ldots \ldots$. 10, 1£. 20, 154; B 319 sinkholes, Florida ............................ 319 general ...........W 67, 114, 343, 489; A 21 iv b, c; P 53, 65 Great Plains $\ldots \ldots \ldots \ldots \ldots \ldots \ldots \ldots \ldots \ldots \ldots \ldots \ldots \ldots \ldots \ldots \ldots \ldots \ldots$

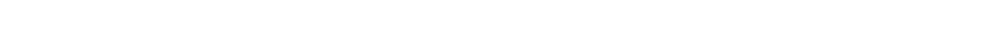

Wyoming $\ldots \ldots \ldots \ldots \ldots \ldots \ldots \ldots \ldots \ldots \ldots \ldots A$ 21 iv b; $P$ 53, 65 siphon elevators $\ldots \ldots \ldots \ldots \ldots \ldots \ldots \ldots \ldots \ldots \ldots \ldots \ldots \ldots \ldots \ldots \ldots$ 
Illustrations: soil evaporation tanks $\ldots \ldots \ldots \ldots \ldots \ldots \ldots \ldots \ldots \ldots$ W 294, 659 a solution channel on fault line ....................... 319 solution channels in limestone $\ldots \ldots \ldots \ldots \ldots \ldots \ldots \ldots \ldots$ 254, 259, 374 spring mounds in Nex Mexico ......................W 343 springs, $\operatorname{artesian} \ldots \ldots \ldots \ldots \ldots \ldots \ldots \ldots \ldots \ldots \ldots$ 34, 90; A 21 Iv c

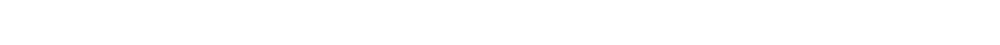

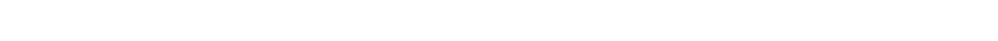
hot $\ldots \ldots \ldots \ldots \ldots \ldots \ldots \ldots \ldots \ldots \ldots \ldots \ldots \ldots \ldots \ldots \ldots \ldots \ldots$ 338, 418; A 9 d large .......................W 221, 341 ; A 18 II b produced by faults .........................W 199 produced by fissures $\ldots \ldots \ldots \ldots \ldots \ldots \ldots \ldots \ldots \ldots \ldots \ldots \ldots \ldots$. 21 vII

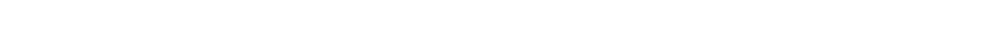

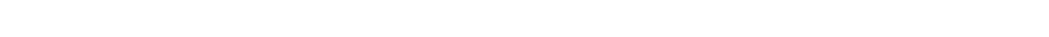

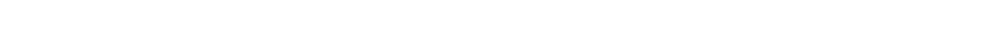

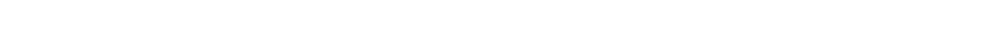

Arkansas ............................... 557

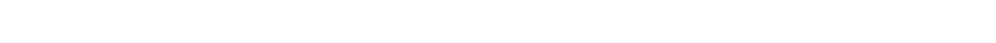

Connecticut ........................W 540, 597 b

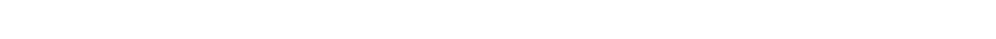

Georgia .........................W 341; C 81

Idaho .................................. 557

limestone ........................W 317; A 21 iv b

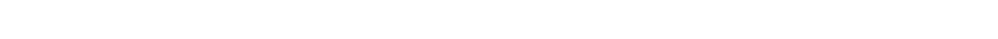

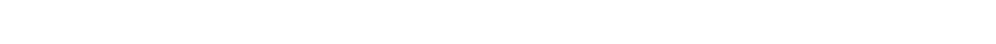

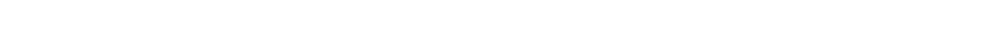

Montana ......................... 221, 557

Nebraska .............................. 12

New Mexico ......................W 158, 343, 620

Oregon ..........................W 557, $597 \mathrm{~d}$

Texas .......................W 557; A 18 II b, 21 vI

Yellowstone National Park .................... 9 d

stalactites deposited by ground water in Texas $\ldots \ldots \ldots \ldots \ldots$........ 18 II b

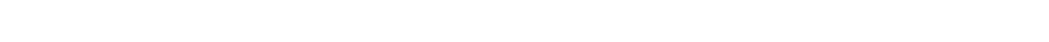

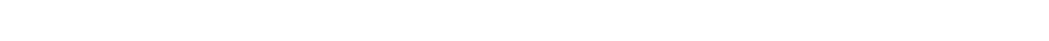

tablet case used in making assays of water ..............W 151

tank filled by artesian pressure ...................... 32

"tanks" for watering livestock .................W 154; A 22 IV c

terraces formed by hot springs $\ldots \ldots \ldots \ldots \ldots \ldots \ldots \ldots \ldots \ldots \ldots \ldots \ldots \ldots \ldots$

transpiration tank .......................W 659 a; J 240

travertine deposited by hot springs in California $\ldots \ldots \ldots \ldots \ldots \ldots$ W 338

deposited by springs in New Mexico...............W 343

tufa deposited by ground water in Texas ............. 18 II b

deposited by hot springs $\ldots \ldots \ldots \ldots \ldots \ldots \ldots \ldots \ldots \ldots \ldots \ldots \ldots \ldots$

underflow measurements ................W 110, 140; P 44; C 81 underground streams $\ldots \ldots \ldots \ldots \ldots \ldots \ldots$ W 67, 114, 255; A 21 Iv c; C 81

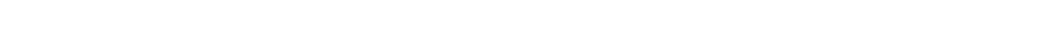
water holes in Colorado ........................... 52

water power from artesian wells $\ldots \ldots \ldots \ldots \ldots \ldots \ldots \ldots \ldots \ldots \ldots$ C 81

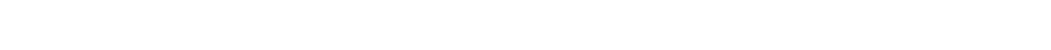

water wheels for lifting water $\ldots \ldots \ldots \ldots \ldots \ldots \ldots \ldots \ldots$ W 1, 4, 13, 319

well curbs $\ldots \ldots \ldots \ldots \ldots \ldots \ldots \ldots \ldots \ldots \ldots \ldots \ldots \ldots \ldots \ldots \ldots \ldots \ldots$ C 291

well derricks $\ldots \ldots \ldots \ldots \ldots \ldots \ldots \ldots \ldots \ldots \ldots \ldots \ldots \ldots \ldots \ldots \ldots$ P 53 
Illustrations: well screens $\ldots \ldots \ldots \ldots \ldots \ldots \ldots \ldots \ldots \ldots \ldots \ldots$ W 101, 141

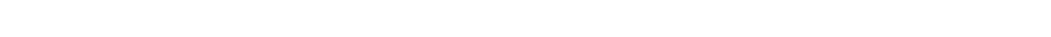

wells, combination dug and drilled $\ldots \ldots \ldots \ldots \ldots \ldots \ldots \ldots$. 22 IV $\mathrm{c}$

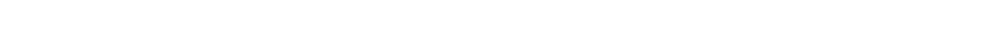

natural $\ldots . \ldots \ldots \ldots \ldots \ldots \ldots \ldots \ldots \ldots \ldots \ldots \ldots$ W $6 ;$ A 21 IV $\mathrm{c}$

polluted $\ldots \ldots \ldots \ldots \ldots \ldots \ldots \ldots \ldots \ldots \ldots \ldots \ldots$ 159, 255; C 291

windlass and well curb ............................. 29

windmills ..........W 1, 6, 8, 20, 29, 41, 42, 154, 191; A 21 iv c, 22 Iv c

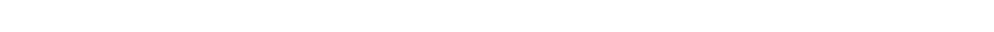

for watering livestock ..............W 191; A 2: IV c, 22 IV c

See also Maps.

Improvement of water in wells $\ldots \ldots \ldots \ldots \ldots \ldots \ldots \ldots \ldots \ldots$ w $160 ; \mathrm{C} 92$

Inclusions of water in rocks $\ldots \ldots \ldots \ldots \ldots \ldots \ldots \ldots \ldots \ldots \ldots \ldots \ldots, \ldots \ldots$

Incrustations on well screens ........................W 256, 293

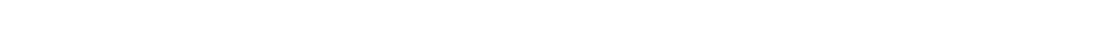

irrigation with ground water in $\ldots \ldots \ldots \ldots \ldots \ldots \ldots$ W 1,$87 ; A$ il 11 il

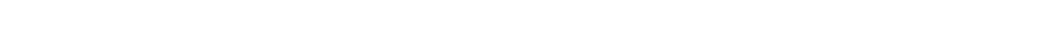

pumps and other water lifts used in $\ldots \ldots \ldots \ldots \ldots \ldots$ W 1, 14; A 12 II $\mathrm{c}$

Indian Territory. See Oklahoma.

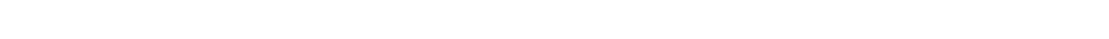

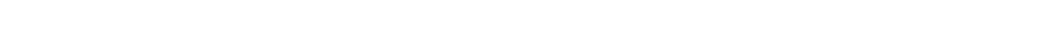

Delaware County .............................. 298

Ditney quadrangle $\ldots \ldots \ldots \ldots \ldots \ldots \ldots \ldots \ldots \ldots \ldots \ldots$, GF 84

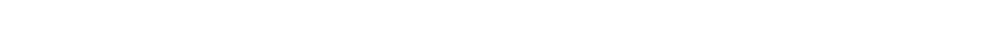

glaciated portion $\ldots \ldots \ldots \ldots \ldots \ldots \ldots \ldots \ldots \ldots \ldots \ldots \ldots \ldots, \ldots \ldots \ldots$

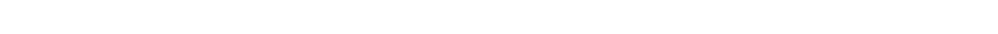

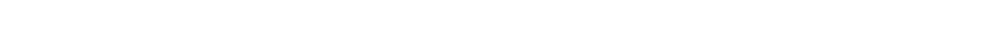

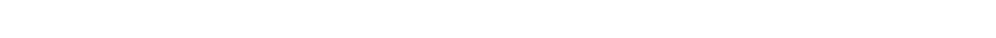

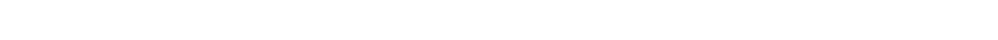

north-central .................................. 254

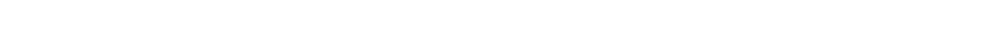

Patoka quadrangle $\ldots \ldots \ldots \ldots \ldots \ldots \ldots \ldots \ldots \ldots \ldots \ldots$ GF 105

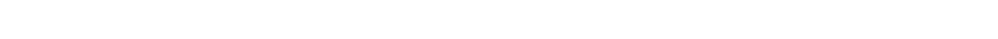

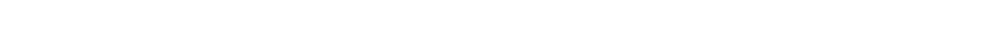

Vanderburg County ............................ 298

artesian water in ..............W 21, 26, 114, 254; A 1₹ Iv b; GF 67

bibliography of ground water in ............W 57, 114, 120, 149, 163

mineral waters in.......W 114; A 18 IV b; B 32; MS 1883-1923; GF 84 public water supplies in ..............W 254; A $18 \mathrm{rv} \mathrm{b;} \mathrm{C} 135$

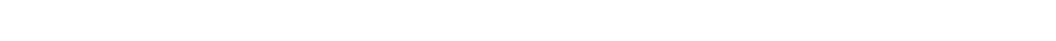
quality of ground water in ...........W 254; A $18 \mathrm{Iv} \mathrm{b;} \mathrm{B-32;} \mathrm{GF} 84$

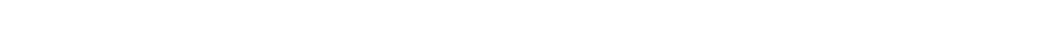

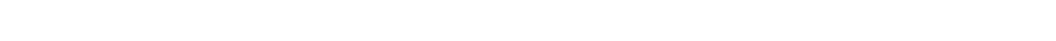
springs in .............W 114, 254; A $14 \mathrm{II} \mathrm{b,} 18 \mathrm{~m} \mathrm{b;} \mathrm{F} \mathrm{32;} \mathrm{GF} 105$ water levels in $\ldots \ldots \ldots \ldots \ldots . W$ W 777, 817, 840, 845, 886, 906, 936, 944, 986 water table in .......................W 254; GF 67; D 136 well records for .......W 21, 26, 57, 113, 149; 254; A 18 Iv b; B 264, 298;

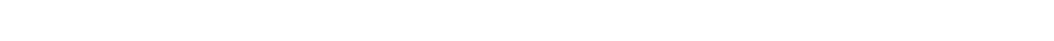

Indications of ground water ..........W 224, 423, 497, 499, 57\%, 578; B 308

Industrial use of ground water, importance of ..............J 300, 305

See also Quality of ground water. 
Industrial wastes, drainage of, into wells

W 258

Infiltration. See Absorption.

Infiltration ditches and tunnels, construction of .......W 67, 11f 380,494 cost of $\ldots \ldots \ldots \ldots \ldots \ldots \ldots \ldots \ldots \ldots \ldots \ldots \ldots \ldots \ldots \ldots$ W 116, 184; C 92

Infiltration ditches and tunnels in-

Arizona ..................W 104, 380; C 15, 20; D 160; J 240, 279

California ....................W 116; A 19 In b, 21 Iv a; GF 193

Colorado .....................................W 240

Connecticut $\ldots \ldots \ldots \ldots \ldots \ldots \ldots \ldots \ldots \ldots \ldots \ldots \ldots \ldots \ldots \ldots$ 374, 397

Hawaii ..........W 318, 445, 616; C 92, 97, 98, 99; D 48, 50; J 109, 165

Idaho ............................ 54,774

Nebraska ....................................W 184

New Mexico .......................W 188, 275. 343, 380

Ohio ...................................... 259

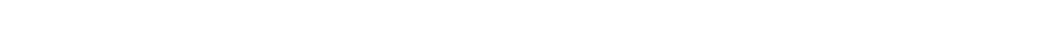

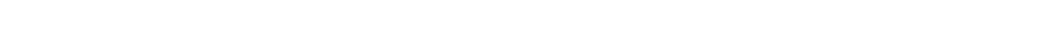

Virginia $\ldots \ldots \ldots \ldots \ldots \ldots \ldots \ldots \ldots \ldots \ldots \ldots \ldots \ldots \ldots \ldots \ldots \ldots \ldots$

Influent seepage. See Absorption of water, from streams.

Instruments. See Apparatus.

Intake of ground water. See Aborption of water; Origin of grounc' water; Quantity of ground water.

Interference of wells....W 67, 122, 137, 184, 223, 494, 836 c; A 19 r b; M 27;

GF 97; C 91, 136, 431, 451; D 55, 83; J 11, 241

Interference with springs and streams, law relating to..........W 122

Iodide in ground water ..........W 233, 338; P 117; B 47; MF 1911 II n Ione formation, water in, in California ..........W 375 a, 619; GF 138 Iowa, areas, all of State $\ldots \ldots \ldots \ldots \ldots \ldots \ldots \ldots \ldots \ldots \ldots$ W 114, 293; C 137

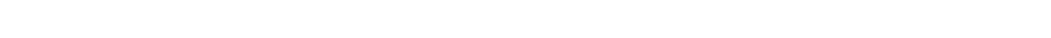

Cherokee County ............................. 264

Council Bluffs and vicinity ..................... 32

Des Moines County .............................. 264

Elk Point quadrangle .........................GF 156

Floyd County .................................. 298

Galena quadrangle ......................... 200

Lancaster quadrangle $\ldots \ldots \ldots \ldots \ldots \ldots \ldots \ldots \ldots \ldots \ldots \ldots$ GF 145

Louisa County ............................ 298

Mahaska County .......................... 298

northwestern $\ldots \ldots \ldots \ldots \ldots \ldots \ldots \ldots \ldots \ldots \ldots \ldots \ldots \ldots$ W $215 ; \mathrm{J} 212$

Scott County $\ldots \ldots \ldots \ldots \ldots \ldots \ldots \ldots \ldots \ldots \ldots \ldots \ldots \ldots \ldots$ 264, 298

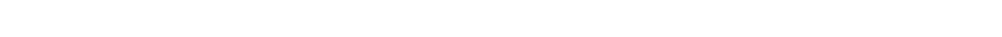

Waterloo ..................................W 145

artesian water in ............W 145, 293; P 32; GF 145, 156; C 137

bibliography of ground water in...........W 57. 114, 12c. 149, 163

mineral waters in .............W 293; B 32; MR 1883-1:23; C 137

pollution of ground water in.....................W 293

public water supplies in ...................W 293; C 137

quality of ground water in......W 293, 364; B 32; GF 145, 290; C 137

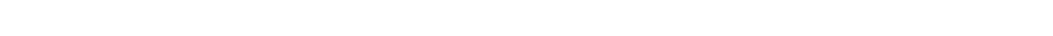

spring discharge measurements in ..................W 855

springs in ............W 145, 293; A 14 II b; B 32; GF 145, 156, 200

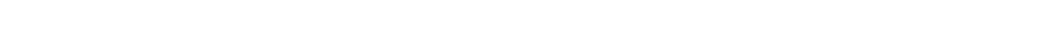

water levels in $\ldots \ldots \ldots \ldots \ldots \ldots W 777,817,840,845,886,908,93 ?, 946,988$ 
Iowa, water table in $\ldots \ldots \ldots \ldots \ldots \ldots \ldots \ldots \ldots \ldots \ldots \ldots \ldots \ldots \ldots \ldots \ldots \ldots$ J 206 well records for ..............W 57, 149, 293; B 264, 298; GF 156 wells in, construction of ......................... 293

Ireland, D. M., Water levels and artesian pressure in the Unite States

W 945, 946

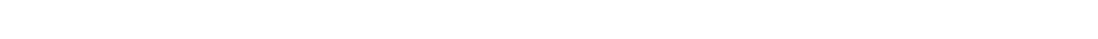
in ground water...WW 254, 256, 259, 273, 338, 341, 398, 399; P 113; B 902; MR 1911 II d, 1916; C 1, 341, 342; J 145, 164

Irrigation, artesian water for. See specific States.

effect of, on quality of ground water................W 9, 58, 774 on water table W 18, 58, 142, 155, 219, 345 h, 375 a, $560 \mathrm{~d}, 774,818$; C 15 flood water in connection with ground water for...........W 320,343 ground water for. See specific States.

hot springs for $\ldots \ldots \ldots \ldots \ldots \ldots \ldots \ldots \ldots \ldots \ldots$ W 774, 818; GF 104 measurement of ground water for $\ldots \ldots \ldots \ldots \ldots \ldots \ldots \ldots \ldots \ldots \ldots \ldots$ quality of ground water for.W $260,274,320,333,335,343,375 \mathrm{~g}, 398,836 \mathrm{~d}$ subsurface $\ldots \ldots \ldots \ldots \ldots \ldots \ldots \ldots \ldots \ldots \ldots \ldots$. $81.8 ;$ A 13 m b.

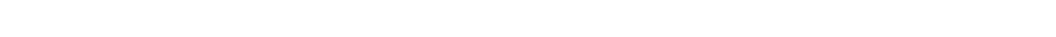
temperature of ground water for $\ldots \ldots \ldots \ldots \ldots \ldots \ldots \ldots \ldots \ldots \ldots \ldots \ldots \ldots$

Irving, J .D., Geology and ore deposits of the Leadville district, Colo....P 148

Isochlors, in New England States ....................... 144

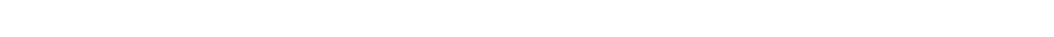

in Texas ............................................ 117

in Virginia ...................................... 431

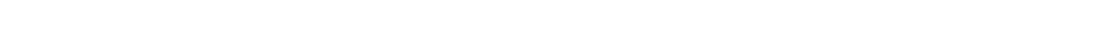
quality of ground water in $\ldots \ldots \ldots \ldots \ldots \ldots \ldots \ldots \ldots \ldots$. 330,$491 ; 616$

Jackson, D. D., Normal chlorine in New York and New England.......W 144 Jackson coal measures, water in, in Michigan .................W 30 Jackson formation, water in-

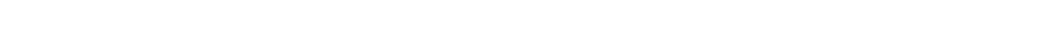

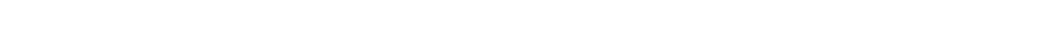

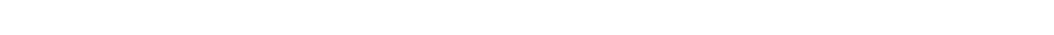

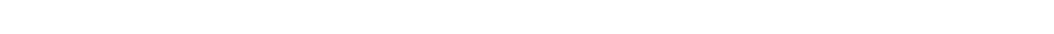

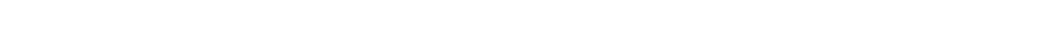

Tennessee ............................W 638 a; C 372

Jacob, C. C., Surface water supply of the United States ....... $\mathbf{V}^{r} 440,460,479$

Jacob, C. E., Coefficients of storage and transmissibility ...........J 241

Correlation of ground-water levels and precipitation on Long Island,

N. Y. ................................. J 312, 341

Elasticity of the Lloyd sand, Long Island, N. Y ............J 246

Experiment on flow through a capillary tube (discussion) …....J 299

Flow of water in an elastic artesian aquifer $\ldots \ldots \ldots \ldots \ldots \ldots \ldots . . . J 230$

Fluctuations in artesian pressure produced by passing trains......J 207

Ground-water resources of the Pensacola area, Fla. ........... 128

Ground-water underflow in Croton Valley, N. Y. ..............J 194

Partial penetration of pumping well .................. 201

Recovery method of determining permeability ............. 205

Water levels and artesian pressure in the United States ..V 817, 840, 845

Water table in the western and central parts of Long Island . N. Y . .C 280 
Jacob, C. E., Well discharge; a method of computing the quantity of water derived from storage (discussion)

Jacobsen, C. L., Oklahoma water, quantity, occurrence, and quality of surface

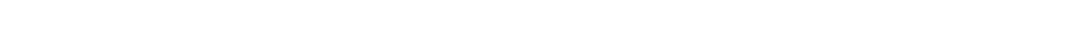

Water levels and artesian pressure in the United States, $1943 \ldots$. . W 989 Jameco gravel, water in, in New York................ 44; C 274 Jameson, C. H., Ground-water resources of the Las Vegas artesian basin,

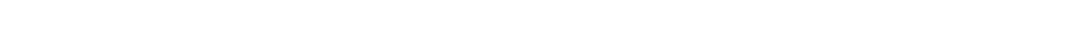

Japan, bibliography of ground water in $\ldots \ldots \ldots \ldots \ldots \ldots \ldots \ldots \ldots \ldots$ W 163

Jarvis, C. S., Inventory of unpublished hydrologic data .........W 837 Java, quality of ground water in ................ 33C, 491, 616

Jefferson City limestone, water in, in Missouri ..............W 195

Jeffords, R. M., Ground-water conditions along the Ohio Valley at

Parkersburg, W. Va ............................ 449

Ground-water levels in West Virginia ................. 356

Recharge to water-bearing formations along the Ohio Valley ......J 333

Water for secondary recovery of petroleum in West Virginia ......J 357

Water levels and artesian pressure in the United States ...W 945, 987

Water levels determination under adverse conditions .......... D 194

Johnson, B. L., Bibliography of ground-water literature in $1905 \ldots \ldots$. W 163

Coastal Plain of North Carolina ...................... 291

Johnson, D. W., Law relating to ground water .............W 122

Johnson, G. A., Purification of public water supplies ............W 315

Johnson, H. R., Water resources of Antelope Valley, Calif .........W 278

Johnson, L. C., Underground water resources of Mississippi ........W 159

Underground waters of Mississippi ............... 102, 114

Johnson, W. D., The High Plains and their utilization ...A 21 Iv c, 22 Iv c

Johnston, W. D. Jr., Gold quartz veins of Grass Valley, Calif .......P 194 Ground water in the Paleozoic rocks of northern Alabama ........ 2

Joints, artesian water in $\ldots \ldots \ldots \ldots \ldots \ldots \ldots \ldots \ldots \ldots \ldots$ W 160, 232; B 319

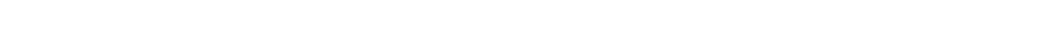

drilling in relation to $\ldots \ldots \ldots \ldots \ldots \ldots \ldots \ldots \ldots \ldots \ldots \ldots \ldots$ V 223.256

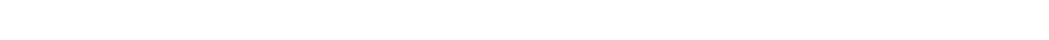

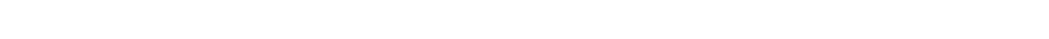

springs in relation to $\ldots \ldots \ldots \ldots \ldots \ldots \ldots \ldots \ldots \ldots \ldots \ldots$ 221, 232

water in. W 114, 145, 160, 221, 223, 232, 254, 258, 489, 578 b; B 319; GF 149

crystalline rocks $\ldots \ldots \ldots \ldots \ldots \ldots \ldots \ldots \ldots \ldots \ldots \ldots \ldots$ 160, 232, 489

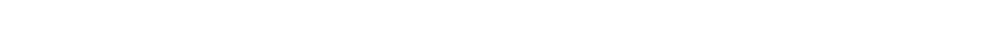

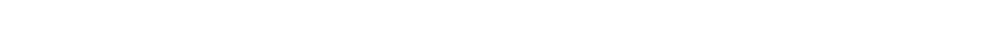

lava ...................W $560 \mathrm{~d}, 637 \mathrm{~d}, 774,818 ; \mathrm{J} 255$

schist ............................ 223,489

slate $\ldots \ldots \ldots \ldots \ldots \ldots \ldots \ldots \ldots \ldots \ldots \ldots \ldots \ldots \ldots \ldots$ V 223,489

Jonas, A. I., Geology and mineral resources of the Middletown quadrangle,

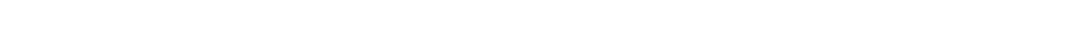

Geology and mineral resources of York County, $\mathrm{Pa} \ldots \ldots \ldots \ldots$. C 347

Jones, D. S., Jr., Ground water in the Republican River Basin in Nabraska

C 20?, 203, 204

Jones, E. L., Jr., Manganese ore in Arizona ............... $710 \mathrm{~d}$.

Manganese ore in New Mexico ..................... 710 b

Manganese ore in southeastern California ................ 710 e

Pine Creek district, Idaho ..................... 710 a 
Jones, G. D., Water levels and artesian pressure in the Unite- States, 1942 ..........................................W 946 Jones, P. H., Ground water and geologic structure of Natchitoches area,

La ...........................................J 331

Ground-water conditions of the Baton Rouge area, La .......C 170 a

Ground-water exploration at Alexandria, La ............J 345

Ground-water exploration in the Natchitoches area, .......W 968 c

Ground-water geology at Natchitoches, La .............. 169

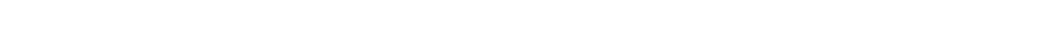

Water levels and artesian pressure in the United States .....W 947, 989

Jordan sandstone, water in, in Iowa ....................W 293 water in, in Minnesota ......................W 256; GF 201

See also Potsdam sandstone; Cambrian formations.

Jurassic formation, water in-

Arizona

Colorado .B 851; D 71

Kansas A 1.6 II $\mathrm{f} ; \mathrm{C} 145$

Montana B 822 a, 856

Nebraska A 16 II f; GF 108

New Mexico W 380, 620; B 767; D 68

Oklahoma .J 213

South Dakota ..................... 32; GF 107, 127, 164 Utah ...............W 380; P 56, 188; B 628, 711 a, \&52, 863; D 71 Wyoming ............P 32, 56, 65; B 471, 543; GF 107, 108, 127, 150 See also specific formations.

Juvenile water .W 160; B 319, 330, 491, 494, 616

\section{$\mathbf{K}$}

Kaibab limestone, water in, in Arizona ................W 836 b Kansas, areas, all of State ..............W 273; A 11 In c; C 142, 151

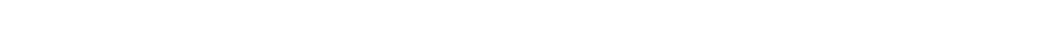

Arkansas River Valley ..............W 153, §45 a; C 153

Atohison County .......................... 148

central .......................A 21 Iv c, 22 Iv c; P 32

Ellis County $\ldots \ldots \ldots \ldots \ldots \ldots \ldots \ldots \ldots \ldots \ldots \ldots \ldots \ldots \ldots \ldots \ldots$

Finney County .......................... 158

Ford County ...................C 141, 14?, 153; D 11

Garden City and vicinity $\ldots \ldots \ldots \ldots \ldots \ldots \ldots \ldots \ldots \ldots$ 140, 153

Gray County ............................. 158

Greeley County ........................... 264

Hamilton County .......................... 155

Independence quadrangle $\ldots \ldots \ldots \ldots \ldots \ldots \ldots \ldots \ldots \ldots \ldots$ GF 159

Iola quadrangle $\ldots \ldots \ldots \ldots \ldots \ldots \ldots \ldots \ldots \ldots \ldots \ldots \ldots \ldots$ B 238

Joplin district $\ldots \ldots \ldots \ldots \ldots \ldots \ldots \ldots \ldots \ldots \ldots \ldots$ W 145; GF 148

Kansas City ............................... 369

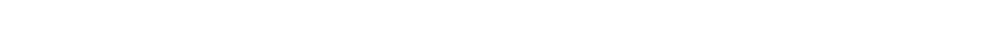

Lakin quadrangle $\ldots \ldots \ldots \ldots \ldots \ldots \ldots \ldots \ldots \ldots \ldots \ldots \ldots$ GF 212

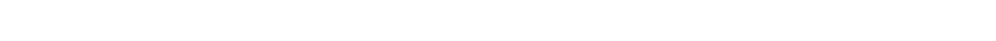

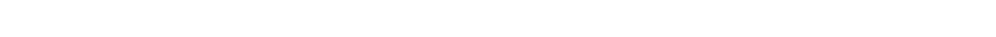

Leavenworth quadrangle .....................GF 206

McPherson district ........................... 142

Meade artesian basin ......W 6; A 21 IV c; C 42, 144; D 132; J 293 
Kansas, areas, Meade County .......................... 154

Morton County ............................. 149; D 154

Neosho River Valley ............................. 157

northwestern $\ldots \ldots \ldots \ldots \ldots \ldots \ldots \ldots \ldots \ldots \ldots \ldots \ldots$ A 16 in $\mathrm{f}$

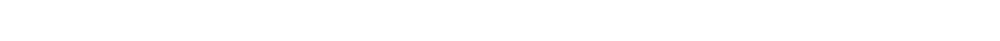

Russell County .................................. 156

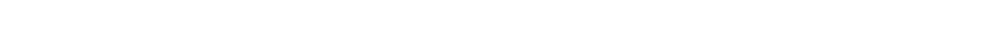

Scott district $\ldots \ldots \ldots \ldots \ldots \ldots \ldots \ldots \ldots \ldots \ldots \ldots$. C 142; J 243

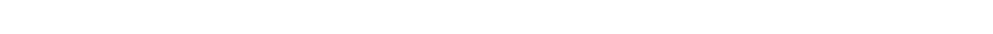

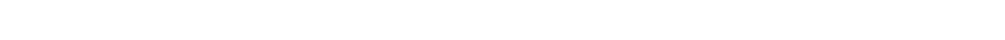

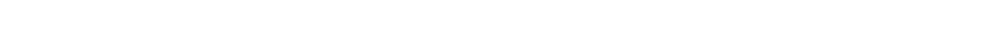

Stanton County ....................... 142, 145; D 144

Syracuse quadrangle $\ldots \ldots \ldots \ldots \ldots \ldots \ldots \ldots \ldots \ldots \ldots$. GF 212

Thomas County ................................. 159

western $\ldots \ldots \ldots \ldots \ldots \ldots \ldots \ldots \ldots \ldots \ldots$ A 21 Iv c, 22 IV c; $\mathbf{P} 32$

Wichita and vicinity $\ldots \ldots \ldots \ldots \ldots \ldots \ldots . W 345$ a; D 119; P 214, 233 artesian water in ...W 6, 273; A 11 II c, 16 II f, 21 IV c; P 32; GF 148; C 144,$148 ; \mathrm{D} 132$. bibliography of ground water in $\ldots \ldots \ldots \ldots \ldots \ldots \ldots$ W 57, 120, 149, 163 irrigation with artesian water in ...................... 144 with other ground water in ......W 5, 6, 8, 153, 258, $345 \mathrm{a}, \mathrm{b}$; A 11 II c, 16 II e, f, 21 IV c, 22 IV c; C 141, 144, 149; D 111, 132 mineral waters in .......P 32; B 32; MR 1883-1923; GF 148, 159, 206 public water supplies in $\ldots \ldots \ldots \ldots \ldots \ldots \ldots$ W 273; P 32; GF 148; J 214 pumping in $\ldots \ldots \ldots \ldots \ldots \ldots \ldots \ldots \ldots \ldots \ldots \ldots \ldots \ldots \ldots \ldots \ldots \ldots \ldots, 140,153,258,345$ a pumping tests in ................................... 369 quality of ground water in ...W 6, 145, 153, 273, 345 a; P 32; B 32, 238, $330,491,530$ b, 606, 616; GF 206; C 143, 145, 146, 149, 151, 153, 154, 155;

$156,157,158,159$ quantity of ground water in ..........W 6, 153, 258, 345 a; C 152 salt water in .......W 273; B 238, 530 b, 669, 715 m; GF 206; D 151 springs in ...W 6, 145; A 14 II b, 16 II f, 21 Iv c; B 32, 238; GF 148, $159,2(7 ;$ C 144

underflow measurements in $\ldots \ldots \ldots \ldots \ldots \ldots \ldots \ldots \ldots \ldots W$ W 153, 258 water levels in ............W 777, 817, 840, 845, 886, 908, 938, 946, 988 water table in ...W 6, 153, 258; C 144, 149; D 74, 111, 147, 166; J 214, 243 well records for ...W 57, 149, 153, 258, 273, 345 a; A 16 II f; P ₹2; B 131, $264,298,669,691$ a; C 141, 143, 145, 146, 149, 153, 154, 155, 159 wells in, construction of $\ldots \ldots \ldots \ldots \ldots \ldots \ldots \ldots \ldots . W 258,345$ a cost of ...........................W 345 a; A 11 Ir c; B 131 windmills in ................................... 8,41

Karst water. See Limestone, water in.

Kasel, R. G., Surface water supply of the United States, $1938 \ldots \ldots \ldots$ W 855 Katamorphism, zone of, ground water in relation to ............M 47 Kazmann, R. G., Coefficient of storage of a water-bearing formation....D 206 Field applications of water transmissibility and storage coefficients.J 326 Ground water supplies for rice irrigation in the Grand Prairie region, Ark .................................. 20 e

Physies of the divining rod (review) $\ldots \ldots \ldots \ldots \ldots \ldots \ldots \ldots \ldots . . . .222$

Predictions of drawdown in a well field ................ 182

Pumpage from wells, and water levels in the Memphis area ....D 204 
Kazmann, R. G., Quantitative study of the well fields of the MTill Creek

Valley water supply project, Ohio .................... 312

Water levels and artesian pressure in the United States.....W 909, 937, $939,945,947,987,989$

Water supply of the Memphis area, Tenn .............. 373

Well discharge; a method of computing the quantity of water derived

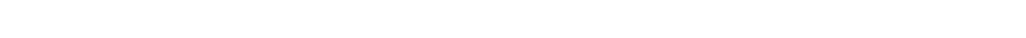

Keith, Arthur, Gacney-Kings Mountain folio, S. C.-N. C . . . . . . . GF 222

Mount Mitchell folio, N. C.-Tenn ......................FF 124

Pisgah folio, N. C.-S. C ........................FF 147

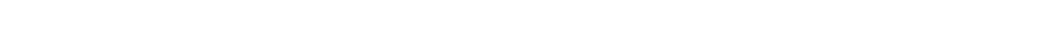

Washington quadrangle, D. C.-Md.-Va $\ldots \ldots \ldots \ldots \ldots \ldots \ldots$ GF 70

Kelton, F. C., Geology and water resources of Sulphur Spring Valley,

Ariz ..........................................W 320

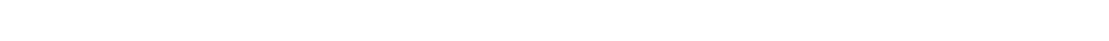

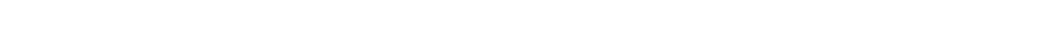

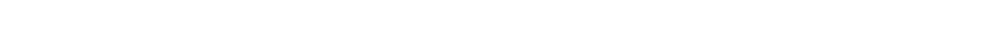

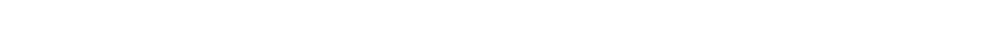

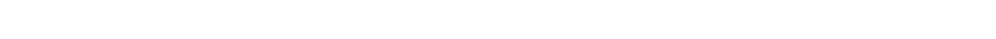

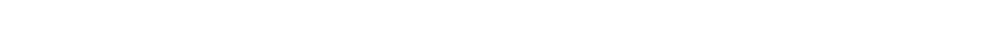

Kenova quadrangle ........................... 184

Louisville .............C 160, 160 a, b, c, d, e; . 3 323, 330, 349

Metcalfe County ............................ 298

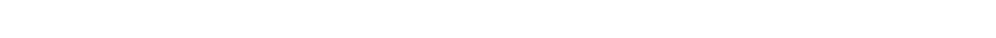

north-central ............................ 233

west of Tennessee River $\ldots \ldots \ldots \ldots \ldots \ldots \ldots \ldots \ldots \ldots \ldots$ W 164

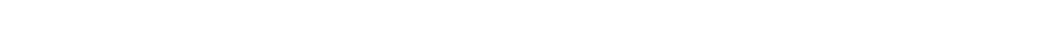

bibliography of ground water in ......W 57, 114, 120, 149, 163, 164, 233

conservation of ground water in .................... $160 \mathrm{~d}$

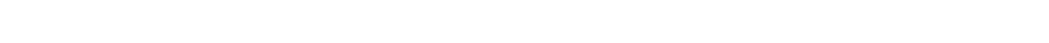

industrial use of ground water in ........ 160, $160 \mathrm{a}, \mathrm{b}, \mathrm{d} ; \mathrm{J} 330,349$

mineral waters in ..............W 164, 233; B 32; MR 1883-1923

public water supplies in $\ldots \ldots \ldots \ldots \ldots \ldots \ldots \ldots \ldots \ldots \ldots$ W 233; J 349

pumping in .............................. 323, 349

quality of ground water in ...W 102, 164, 233, 364; B 32.330, 491, 606,

$616,661 \mathrm{~d}$; GF 184; C $160 \mathrm{c}, \mathrm{e}$

quantity of ground water in ................. $233 ;$ C $160 \mathrm{~d}$ salt water in ........................ $661 \mathrm{~d}, 688$; GF 184 springs in ..............W 114, 233; A 14 II $k$; B 32, $661 \mathrm{~d}$

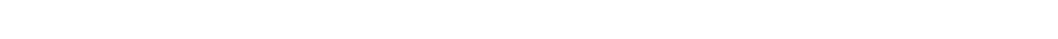
well records for. W 57, 102, 149, 164, 233; B 264, 298, 688; GF 184; C 160 f wells in, construction of ........................ 164

cost of ............................. 164; B 131

Keokuk limestone, water in, in Illinois .............. 438; GF 208

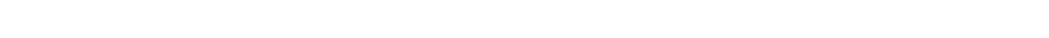

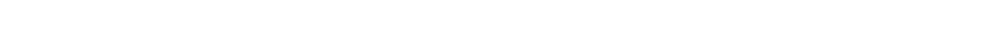

Kew, W. S. W., Geology and oil resources, Los Angeles and

Ventura Counties, Calif .......................... 753

Structure and oil resources of Simi Valley, southern Califormia ... B $691 \mathrm{~m}$

Keweenawan formations, water in, in Wisconsin ............. 451

Keyes, C. R., Geology and underground water conditions of the

Jornada del Muerto, N. Mex ......................W 123 
Kinderhook formation, water in, in Illinois $\ldots \ldots \ldots \ldots \ldots \ldots \ldots$ B 438

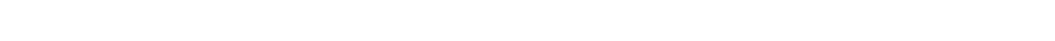

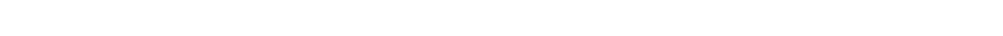

Kindle, E. M., Niagara folio, N. Y ..................... 190

Water resources of the Catatonk area, N. Y ...........W 145

Watkins Glen-Catatonk folio, N. Y . . . . . . . . . . . . . . GF 169

King, F. H., Movements of ground water ................ 19 In b

King, P. B., Geology of the Marathon region, Tex .............. 187

King, W. R., Surface water supply of the United States, part 2 . .W 642, 682,

697,712

Surface water supply of the United States, part $3 \ldots$ W $66 \AA, 683,698$, $713,728,743,758$

Klaer, F. H., Jr., Ground-water conditions in the vicinity of Scottsburg,

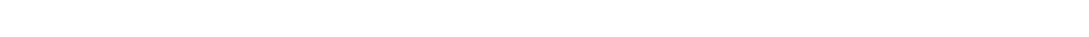

Ground water in the Cincinnati area, Ohio .............. 156

Ground-water investigation in Butler and Hamilton Counties, Ohio C 311

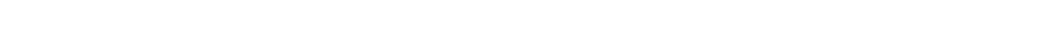

Municipal and industrial water supplies from wells in Butler and

Hamilton Counties, Ohio .................... 120, 156

Quantitative study of the well fields of the Mill Creek Valley water-

supply project, Ohio ....................... 312

Water levels and artesian pressure in the United States ... ${ }^{w} .840,845$, $886,906,907,936,937,944,986$

Knapp, G. N., Philadelphia folio, Pa.-N. J.-Del ...............GF 162

Underground waters in New Jersey ..................W 114

Knappen, R. S., Geology and mineral resources of parts of Carbon,

Big Horn, Yellowstone, and Stillwater Counties, Mont ........ 822 a

Geology and mineral resources of the Aniakchak district, Alasla. . B $797 \mathrm{f}$

Knechtel, M. M., Coal resources of McCone County, Mont .......... 905

Geology and fuel resources, Lehigh district, Okla .......... 874 b

Geology and ground-water resources of the valley of Gila River and

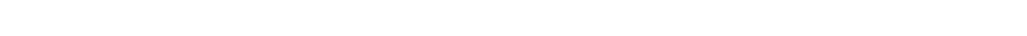

Ground water in Gila and San Simon Valleys, Ariz ........... 82

Indian Hot Springs, Ariz ...................... 136

Water supplies from wells in southeastern Utah and southwestern

Colorado ................................ 71

Knobstone formation, water in, in Indiana ................ 114

Knopf; Adolph, Developments in the Aspen district, Colo .......... 785 a

Geology and ore deposits of the Pioche district, Nev .........P 171

Geology and ore deposits of the Rochester district, Nev ......... 762

Mother Lode system of California ................. 157

Kokomo limestone, water in, in Indiana ................W 254

Kümmel, H. B., Franklin Furnace folio, N. J . ..............GF 161

Passaic folio, N. J.-N. Y .....................GF 157

Philadelphia folio, Pa.-N. J.-Del ...................GF 161

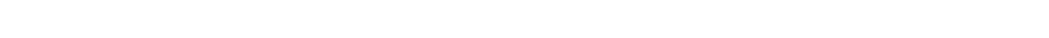

Trenton folio, N. J.-Pa .......................FF 167

Lacustrine deposits, water in-

Arizona ................W 425 a, 796 f; C 12, 15, 16; D 160; J 240

Idaho $\ldots \ldots \ldots \ldots \ldots \ldots \ldots \ldots \ldots \ldots \ldots \ldots \ldots \ldots \ldots \ldots \ldots \ldots \ldots$ 
Lacustrine deposits, water in, Illinois $\ldots \ldots \ldots \ldots \ldots \ldots \ldots \ldots \ldots$ GF 105

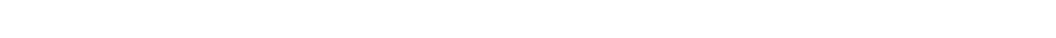

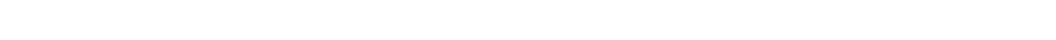

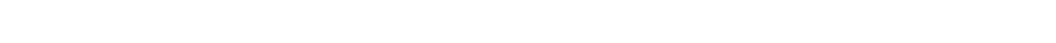

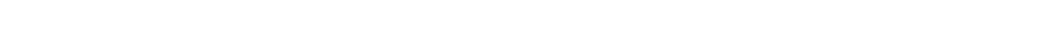

Montana .......................... 221, 400 b

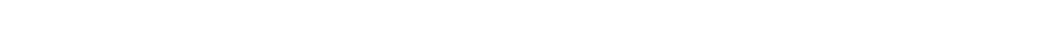

Oregon ..........................W 22?, 231, 637 d

Utah $\ldots \ldots \ldots \ldots \ldots \ldots \ldots \ldots \ldots \ldots \ldots \ldots \ldots \ldots \ldots \ldots \ldots$ W 217, 277, 333

Washington $\ldots \ldots \ldots \ldots \ldots \ldots \ldots \ldots \ldots \ldots \ldots \ldots \ldots \ldots \ldots \ldots \ldots$ w 425 e

Wisconsin $\ldots \ldots \ldots \ldots \ldots \ldots \ldots \ldots \ldots \ldots \ldots \ldots \ldots \ldots \ldots \ldots V^{\top} 114 ;$ C 451

Lafayette formation, water in-

Arkansas ............................W 399; P 46

Atlantic Coastal Plain .......................... 138

Florida ...................................W 319

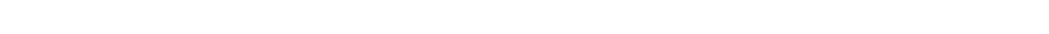

Kentucky .....................................W 164

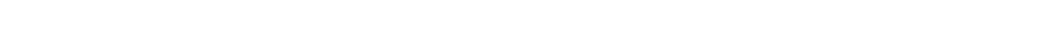

Maryland $\ldots \ldots \ldots \ldots \ldots \ldots \ldots \ldots \ldots \ldots \ldots \ldots \ldots \ldots \ldots$ GF 13, 23, 152

Mississippi ............................... 159

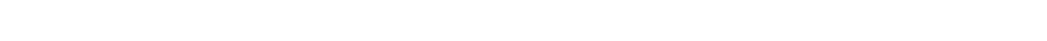

North Carolina .............................. 291

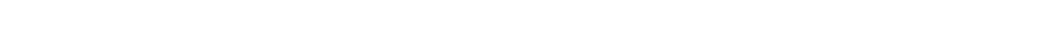

Virginia ............................GF 13, 23; C 431

LaForge, Laurence, Ellijay folio, Ga.-N. C.-Tenn ...............GF 187

Geology of the Boston area, Mass ..................... 839

Water resources of the central and southwestern highlands of

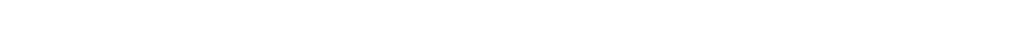

Well and spring records for Massachusetts $\ldots \ldots \ldots \ldots \ldots \ldots \ldots W$ W 102

Lagrange formation, water in, in Kentucky ..............W 164

water in, in Missouri ............................... 195

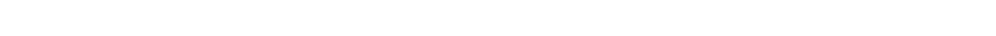

Lake beds. See Lacustrine deposits.

Lakes, underground ............................ 431

Lakota sandstone, water in, in Montana ........... 7f 1 ; GF 138

water in, in Nebraska ...................GF 85, 1n8; C 202, 204

in South Dakota.A 21 Iv b; P 32, 65; GF 85, 107, 108, 128, 164, 209, 219

in Wyoming ..........A 21 IV b; P 32, 65; GF 107, 127, 128, 150

Lamar, W. L., Chemical character of natural waters ............J 187

Chemical character of public water supplies of Georgia .......J 253

Industrial quality of public water supplies in Georgia, 1940 . . . W 912

Industrial utility of public water supplies in the United States 1932 .W 658

Lamb, W. A., Surface water supply of the United States, 1912 ......W 326

Water levels and artesian pressure in the United States ....W 777, 817

Lamination planes, water in $\ldots \ldots \ldots \ldots \ldots \ldots \ldots \ldots \ldots \ldots \ldots \ldots$ 819, 489

LaMotte sandstone, water in, in Missouri ..............W 195

Lance formation, water in, in Montana. .W 520 d, 599, 600; B 812 a, 831 b, 856

water in, in North Dakota ...............W 598; B 575; GF 181

in South Dakota .......................... 575

in Wyoming ........................ 656, 796 a

Landes, Henry, Underground waters of Washington $\ldots \ldots \ldots \ldots \ldots$ W 111 
Lane, A. C., Flowing wells and municipal water supplies in the gnuthern peninsula of Michigan $\ldots \ldots \ldots \ldots \ldots \ldots \ldots \ldots \ldots \ldots \ldots \ldots T^{\top} 182,183$ Lower Michigan mineral waters $\ldots \ldots \ldots \ldots \ldots \ldots \ldots \ldots \ldots \ldots$ W 31 Water resources of the lower peninsula of Michigan ..........W 30

Laney, F. B., Genesis of the ores at Tonopah, Nev ...........P 104 Geology and ore deposits of the Ducktown mining district, Tenn ...P 139 Ground-water supply at Moscow, Idaho ................ 113

Lang, J. W., Geology and ground water, Pecos River Basin, N. Mnx ...C 256 Ground water in the High Plains in Texas .....W 889 c; C 3?1, 397, 416 Ground water in the Pecos River Basin in Texas ............. 402 Lang, W. B., Geology and ground-water conditions of the Pecos Rivor Valley in the vicinity of Laguna Grande de la Sal, N. Mex ............ 248 Potash investigations in $1924 \ldots \ldots \ldots \ldots \ldots \ldots \ldots \ldots \ldots \ldots \ldots \ldots \ldots$ b $78 \ldots \ldots \ldots \ldots \ldots$ Source of salt in ground water in the vicinity of Laguna Grande de la Sal, N. Mex ............................. 103

Lansing formation, water in, in Kansas .................. 206 water in, in Missouri .........................FF 206

Laramie formation, water in

Colorado .........................M 27; P $32.52 ;$ GF 71

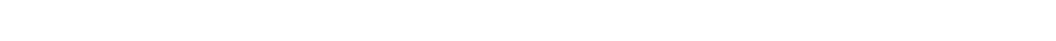

Nebraska $\ldots \ldots \ldots \ldots \ldots \ldots \ldots \ldots \ldots \ldots \ldots \ldots \ldots \ldots \ldots \ldots$. P 32; GF 87

South Dakota $\ldots \ldots \ldots \ldots \ldots \ldots \ldots \ldots \ldots \ldots \ldots \ldots \ldots \ldots \ldots$ W 227; P 32

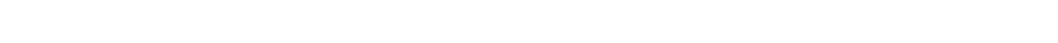

LaRocque, G. A. Jr., Fluctuation of water level in Los Angeles Basin, Calif: during earthquakes ............................J 237

Water levels and artesian pressure in the United States ...W 817, 840, 845,949

Water levels in observation wells in Santa Barbara County, Calif....C 28 Water-table fluctuation in Spokane Valley, Wash.-Idaho .......W 889 b Water wells and water levels in Carpinteria, Goleta, and Santa Ynez

Valley areas, Calif .......................... 30 a

Water wells and water levels in San Antonio, Santa Maria, and

Cuyama Valleys, Calif ........................ 30 b

Wells used for public supply at Spokane, Wash ............. 102

Larrison, G. K., Report of Water Commission of Hawaii .......... 91

Surface water supply of Hawaii $\ldots \ldots \ldots \ldots \ldots \ldots \ldots \ldots \ldots$ 430, 445

Water resources of Hawaii, $1912 \ldots \ldots \ldots \ldots \ldots \ldots \ldots \ldots \ldots \ldots$ W 336

Larsen, E. S., Contact-metamorphic tungsten deposits of the Unit `d States

B $725 \mathrm{~d}$

Geology and ore deposits of the Creede district, Colo ......... 718

Geology of the San Juan region of southwestern Colorado ........ 843

LaRue, E. C., Surface water supply of the United States ..... 21/ 212, 289

Lasky, S. G., Geology and ore deposits of the Bayard area, N. Mex ...B 870

Geology and ore deposits of the Lordsburg mining district, N. N'ex. . B 885

Latta, B. F., Geology and ground-water resources of Finney and Gray

Counties, Kans ................................ 158

Geology and ground-water resources of Stanton County, Kan . . C 145

Ground-water investigations in the Stanton district, Kans .....C 142

Ground-water resources of Stanton County, Kans ............ 144

Ground-water supplies in Kansas available for national defens * ...C 151

Water levels and artesian pressure in the United States ...W 886, 908, 938 
Lava, artesian water in.W 4, 560 d, 818; B 199, 616; C 91, 92, 94, 97, 99; J 255 water in $\ldots \ldots \ldots \ldots \ldots \ldots \ldots \ldots \ldots \ldots W$ 110, 160, 489, 557; P 319; J 255

Arizona ...................W 499, 836 b; C 13; D 85

California ...................W 219, 375 a; GF 138

Connecticut ..................W 232, 374, 597 b

Hawaii.W 77, 616; C 91, 92, 94, 97, 98, 99; D 48, 50, 157; J 27, 109, 217

Idaho ...W 54, 560 d, 774; B 199, 818; C 111, 112, 117, 118; J 22, 143

Maine ................................. 223

Nevada ................................W 365

New Mexico ............................ 620

Oregon .............W 220, 231, 637 d, 659 b; B 2; ; D 20, 24

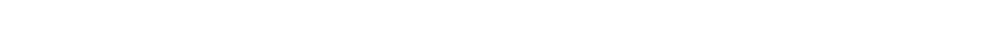

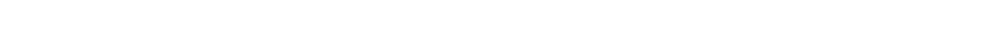

Virginia ............................... 436

Washington .............W 4, 55, 118, 316, 42.5 e; GF 106

Lava tubes, water in $\ldots \ldots \ldots \ldots \ldots \ldots \ldots \ldots . W$ 774, 818; C 92, ؟P, 99; J 255

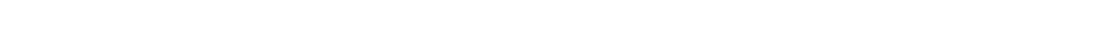

relating to ground water-

Florida ........................... 152; C 58

general ..........W 122, 152; J 10, 182, 190, 220, 224, 267; 339

Hawaii .................................. 118

Michigan .......................W 122, 152, 182, 183

New Mexico ...........W 152; C 231, 238, 239; J 10, 51, 69, 118

New York .............................. 190

South Dakota ....................... 122; C 361

Weshington $\ldots \ldots \ldots \ldots \ldots \ldots \ldots \ldots \ldots \ldots \ldots \ldots \ldots$ W 55, 78, 122,152

Wyoming $\ldots \ldots \ldots \ldots \ldots \ldots \ldots \ldots \ldots \ldots \ldots \ldots \ldots$ W 122., 152; J 266

relating to pollution of ground water $\ldots \ldots \ldots \ldots \ldots \ldots \ldots \ldots$ W 122,152

Lawson, A. C., San Francisco folio, Calif .................. 193

Lead in ground water ................... 254, 39?; B 47, 606

Leaks in artesian wells, methods of detecting ...W 118, 596 a, 796 a; A 5 c;

C.92. 423

Lee, C. H., Geology and ground waters, western part of San Diego County,

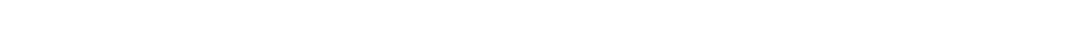

Ground-water resources of Indian Wells Valley, Calif ..........C 22

Subterranean storage in San Bernardino Valley, Calif ......... 21

Water resources of part of Owens Valley, Calif ............W 294

Lee, W. T., Erosion by solution and fill ................ 760 c

Geologic reconnaissance of part of western Arizona ........... 352

Geology and water resources of Owens Valley, Calif ..........W 181

Raton-Brilliant-Koehler folio, N. Mex ................FF 214

Underground waters of Gila Valley, Ariz ...............W 104

Underground waters of Salt River Valley, Ariz ...........W 136

Water resources of Beaver Valley, Utah ...............W 217

Water resources of Rio Grande Valley in New Mexico and their

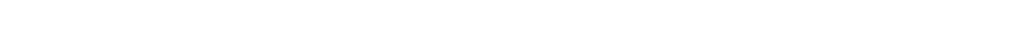

Lee, Wallace, Geology of the Tullock Creek coal field, Mont ....... B 749

Gillesnie-Mount Olive folio, IIl .................GF 220

Leggette, R. M., Artesian water supply of Ogden, Utah .........D 65

Channel-storage method of determining effluent seepage ..........J 159

Earthquakes instrumentally recorded in artesian wells ........J 124

Geology and ground-water resources of Ogden Valley, Utah .....W $796 \mathbf{d}$ 
Leggette; R. M., Ground water for air conditioning on Long Island, N. Y. J 193

Ground water for public supply in western Pennsylvania .......J 234

Ground water in northwestern Pennsylvania .............. 343

Ground-water levels in observation wells, Soil Conservation Service.D 74

Ground water relieves 1934 drought emergency in Salt Lake City,

Utah ....................................... 135

Ground-water resources of northeastern Pennsylvania .........D 26

Ground-water supplies in the vicinity of Salt Lake City, Utah . ....D 36

Ground waters of Monroe County, N. Y ............. 273

High-low float gage $\ldots \ldots \ldots \ldots \ldots \ldots \ldots \ldots \ldots \ldots \ldots \ldots \ldots \ldots$ D 127

Interference of artesian wells on Long Island, N. Y ..........J 177

Long-time records of ground-water levels on Long Island, N. Y...J 150

Observation wells, manual of methods ............... 60

Record of wells in Kings County, N. Y ........... 275, 279

Record of wells in Nassau County, N. Y ............... 277

Record of wells in Queen County, N. Y .............. 278

Record of wells in Suffolk County, N. Y ................ 276

Record of wells, springs, and ground-water levels, Conn ...C 41, 42, 43

$44,45,46$

Transmission of pressure in artesian aquifers .............J 115

Water levels and artesian pressure in the United States ... $\mathrm{V}^{\top} 817,840$, $886,906,936$

Withdrawal of ground water on Long Island, N. Y ......... 274 Legislation. See Law.

Leighton, M. O., Field assay of water .................W 151

Quality of water in Susquehanna River Basin ............W 108

Leith, C. K., Geology of the Lake Superior region .............. 52

Mesabi iron-bearing distrct of Minnesota ................M 43

Leona formation, water in, in Texas .............. 18 It b; GF 64

Leonard, A. G., Bismarck folio, N. Dak ................GF 181

Leverett, Frank, Ann Arbor folio, Mich .................. 155

Danville folio, Ill.-Ind ......................... 67

Flowing wells and municipal water supplies in the southern peninsula

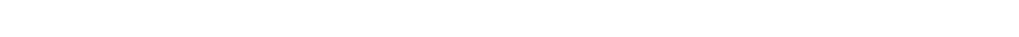

Flowing wells in northern Michigan ................W 160

Geological conditions of municipal and institutional

water supplies in Michigan $\ldots \ldots \ldots \ldots \ldots \ldots \ldots \ldots \ldots \ldots \ldots \ldots$

Geology and mineral resources of the Cleveland district, Ohio ...B 818

Illinois glacial lobe $\ldots \ldots \ldots \ldots \ldots \ldots \ldots \ldots \ldots \ldots \ldots \ldots \ldots \ldots$

Moraines and shore lines of the Lake Superior basin .......P 154 a

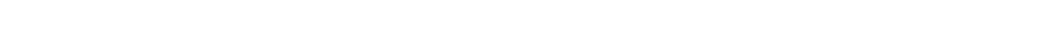

Underground waters, of Illinois, Indiana, and Ohio ........WW 114

Water resources of Illinois $\ldots \ldots \ldots \ldots \ldots \ldots \ldots \ldots \ldots \ldots . \ldots \ldots$ II $h$

Water resources of Indiana and Ohio ............... 18 Iv b

Wells of northern Indiana .......................W 21

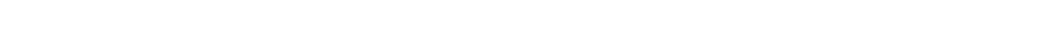

Lexington limestone, water in, in Kentucky ..............W 235

Limestone, caverns formed by ground water in .....W 233, 255, 259, 489;

B $760 \mathrm{c} ; \mathrm{C} 81$

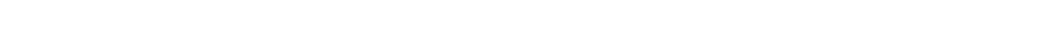

pollution of water in $\ldots \ldots \ldots \ldots \ldots \ldots \ldots \ldots \ldots W$ 233, 255, 258; C 131

solution channels in $\ldots \ldots \ldots \ldots \ldots \ldots \ldots \ldots \ldots . \ldots$ 233, 25 $, 259,489$ 


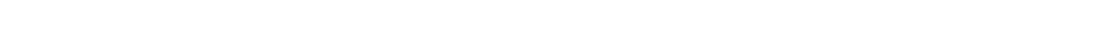
water in $\ldots \ldots \ldots \ldots \ldots \ldots \ldots \ldots \ldots \ldots \ldots$ W 110, 114, 255, 257; A 5 c See also specific formations.

Lindgren, Waldemar, Boise folio, Idaho ..................GF 45

Clifton folio, Ariz ...............................GF 129

Colfax folio, Calif ............................... 66

Copper deposits of the Clifton-Morenci district, Ariz .........P 43

Geology and gold deposits of the Cripple Creek district, Colo .....P 54

Geology and ore deposits of the Tintic mining distrct, Utal .....P 107

Nampa folio, Idaho-Oreg ...........................GF 103

Ore deposits of New Mexico ......................... 68

Ore deposits of the Jerome and Bradshaw Mountains quad-angles,

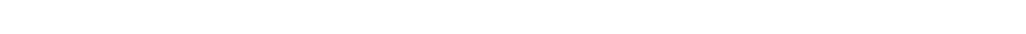

Silver City folio, Idaho ............................. 104

Tertiary gravels of the Sierra Nevada of California ...........P 73

Truckee folio, Calif ..............................GF 39

Water resources of Molokai, Hawaiian Islands .............W 77

Lines, E. F., Records of deep wells, $1904 \ldots \ldots \ldots \ldots \ldots \ldots \ldots \ldots$. B 264

Lippincott, J. B., Development and application of water near San

Bernardino, Colton, and Riverside, Calif .................W 59, 60

Storage of water on Kings River, Calif ...................W 58

Water problems of Santa Barbara, Calif ................W 116

Lissie gravel, water in, in Texas .................. 335; J 132

Lithium in ground water ...........W 160, 259, 338; B 47; MR 1911 ir n

Little, H. P., Colchester folio, Md ........................GF 204

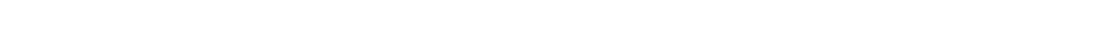

Livingston, P. P., Equipment for exploring wells .......... 151; J 276

Equipment for measuring depth to water ............... D 142

Exploratory water-well drilling in the Houston district, Tex....W 889 e;

Ground water in parts of the Texas Coastal Plain ............J 132 Ground-water resources in the Houston distriet, Tex ....... 338; D 46 Ground-water resources of El Paso, Tex ...............W 919 Ground-water resources of Kleberg County, Tex ..........W $773 \mathrm{~d}$ Ground-water resources of the Big Spring area, Tex .........W 913 Ground-water resources of the Houston-Galveston area, Tex .....D 39 Ground-water supply of Big Spring, Tex .............. 404 Locating salt-water leaks in water wells .................W 796 a Natural flow from artesian well, San Antonio, Tex ............. 401

Salt-water problems in the East Texas oil fields ............. 151

Salt-water problems in the Winter Garden area, Tex .......... 151 Underground leakage from artesian wells in the Flowell area, Utah.C 423 Underground leakage from artesian wells in the Las Vegas. area,

Nev ...........................................W $849 d$

Water levels and artesian pressure in the United States .....W 817, 840

Water resources of the Edwards limestone in San Antonio

area, Tex ...................................W $7 \mathbf{7 7 3}_{\mathbf{b}}$

Lloyd, E. R., Lignite field of northwestern South Dakota ........B 627

Lloyd sand, water in, in New York .................? 44; C 274

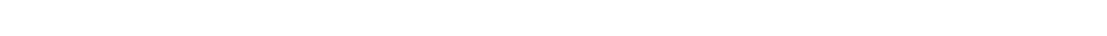

Locating water in deserts .......W 224, 423, 497, 498, 499, 577; B 308 
Loeltz, O. J., Water levels and artesian pressure in the

United States $\ldots \ldots \ldots \ldots \ldots \ldots \ldots \ldots \ldots \ldots \ldots \ldots \ldots \ldots \ldots \ldots$ 886, 911, 941

Loess, turbidity of ground water due to $\ldots \ldots \ldots \ldots \ldots \ldots \ldots \ldots \ldots$ C 131 water in-

Illinois $\ldots \ldots \ldots \ldots \ldots \ldots \ldots$ W 164; GF 105, 188, 195, 213, 216; C 131

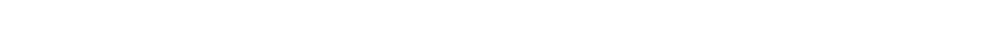

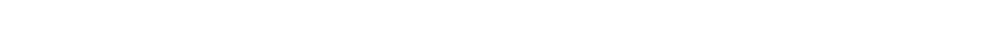

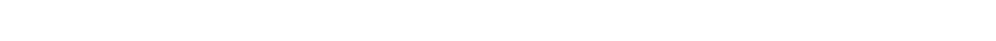

Kentucky .................................W 164

Minnesota ................................W 256

Mississippi $\ldots \ldots \ldots \ldots \ldots \ldots \ldots \ldots \ldots \ldots \ldots \ldots \ldots \ldots \ldots$ w 159, 576

Nebraska ................W 848; GF 156; C 20? 204; J 75

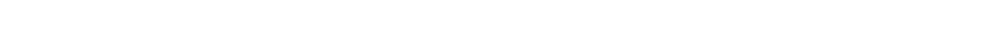

South Dakota ............................. 156

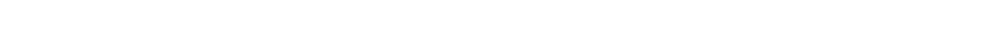

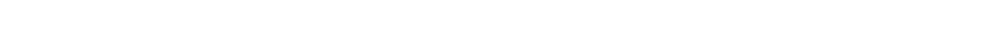

Logan, W. N., Ground-water resources of Mississippi ..........W 576

Logan sandstone, water in, in Ohio .................W 114

Logarithms for recomputing water analyses $\ldots \ldots \ldots \ldots \ldots \ldots \ldots W$ W 293

Logie, R. M., Water levels and artesian pressure in the

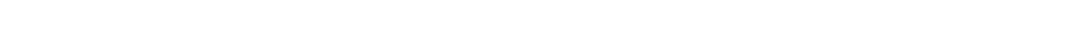

Lohman, S. W., Fluctuations of the ground-water table in

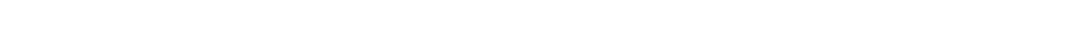

Gaging the ground-water reservoirs of Kansas ............. 142

Geology and ground-water resources of the Elizabeth City area, N. C . ................................ 773 a

Geology and ground-water resources of the "Equus beds"

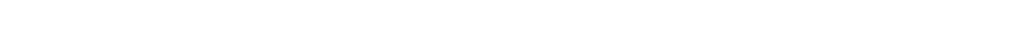

Ground-water conditions in the vicinity of Lawrence, Kans .....C 146

Ground-water in north-central Pennsylvania ........... 346; D 98

Ground-water in northeastern Pennsylvania ........... 344; D 26

Ground-water in south-central Pennsylvania ........... 345; D 94

Ground-water in the Elizabeth City area, N. C .............J 108

Ground-water in the McPherson district, Kans ........... 142

Ground-water levels in Kansas ................. 147, 166

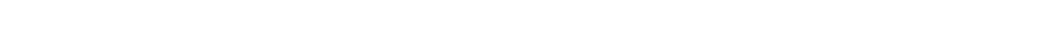

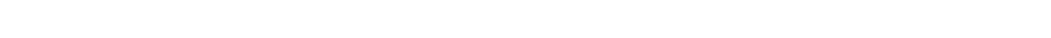

Ground-water supplies for national defense in south-central

Kansas ....................................C 150

Hydrology of the Wichita area, Kans ................. 233

Observation wells, manual of methods $\ldots \ldots \ldots \ldots \ldots \ldots \ldots \ldots$. 60

Replenishment of ground-water in Pennsylvania ...........D 34

Report of Committee on Ground Water ............J 307, 340

Summary of salt-water intrusion in Kansas ................ 151

Water levels and artesian pressure in the United States ...W 777, 817,

$840,845,886,908,938,946, \mathrm{~s} 48,988,990$

Water supplies from wells for irrigation, Ford County, Kan . ...C 141

Water supply for the State Penitentiary, Lansing, Kans ........ 143

Lohr, E. W., Geology and ground-water resources of the valley cf

Gila River and San Simon Creek, Ariz ...............W 796 f

Ground-water in Gila and San Simon Valleys, Ariz .........D 82 
Lohr, E. W., Industrial utility of public water supplies in the

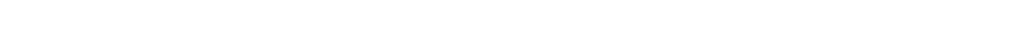

Longwell, C. R., Geology of the Muddy Mountains, Nev ........... 798

Lonsdale, J. T., Geology and ground-water resources of Atacosa and

Frio Counties, Tex .............................W 676

Geology and ground-water resources of Webb County, Tex .....W 778

Ground-water resources of Webb County, Tex ............. 31

Underground water resources of Atacosa and Frio Counties, Tex....D 38

Lost rivers . ..................W 774, 818; A 18 Iv b, 21 Iv c; J 279

Loughlin, G. F., Geology and ore deposits of the Leadville mining district,

Colo .......................................... 148

Geology and ore deposits of the Tintic mining district, Utah .....P 107

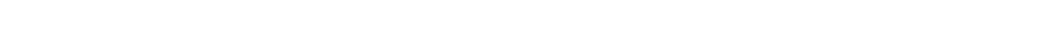

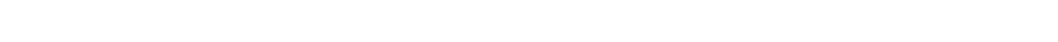

Oxidized zinc ores of Leadville, Colo .................... 681

Louisiana, areas, Acadia Parish ................... $170 ; \mathbf{J} 316$

areas, Alexandria ..................... C 166; D 191; J 345

all of State $\ldots \ldots \ldots \ldots \ldots \ldots \ldots \ldots \ldots \ldots \ldots \ldots \ldots \ldots \ldots$ W 114; C 162

Avoyelles Parish ................................ 163

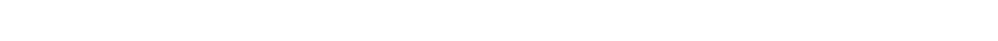

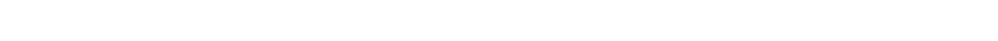

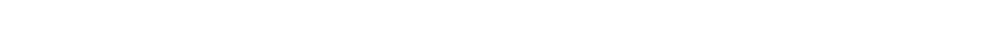

Caddo Parish .................................. 168

Camp Polk .................................... 354

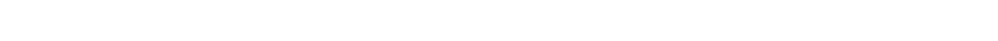

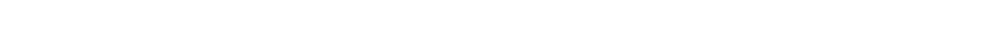

Grant Parish .................................. 165

Jefferson Davis Parish ....................... 170; J 316

La Salle Parish $\ldots \ldots \ldots \ldots \ldots \ldots \ldots \ldots \ldots \ldots \ldots \ldots \ldots \ldots$ C 165

Natchitoches area $\ldots \ldots \ldots \ldots \ldots \ldots \ldots \ldots \ldots$ W $968 \mathrm{c} ; \mathrm{C} 169 ; \mathrm{J} 331$

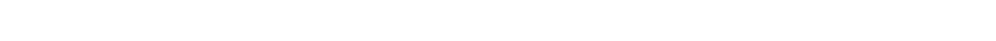

North Camp Polk ............................J 354

northern $\ldots \ldots \ldots \ldots \ldots \ldots \ldots \ldots \ldots \ldots \ldots \ldots \ldots . . .146 ; C$ C 161

Rapides Parish $\ldots \ldots \ldots \ldots \ldots \ldots \ldots \ldots \ldots \ldots \ldots \ldots \ldots$. 163, 167

southern ................................W 101

artesian water in ..........W 101; P 46; C 161, 164, 166, 167; J 305

bibliography of ground water in .............W 114, 120, 149, 163

industrial use of ground water in $\ldots \ldots \ldots \ldots \ldots \ldots \ldots \ldots . . . .302,303$

mineral waters in ............W 114; P 46; B 32; MR 1883-1923

public water supplies in $\ldots \ldots \ldots \ldots \ldots \ldots \ldots \ldots \ldots$ W 101; P 46; J 331

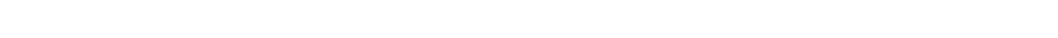

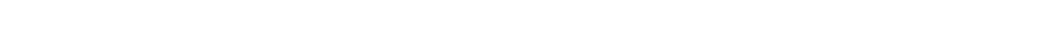

quality of ground water in $\ldots \ldots \ldots W$ W 101; P 46; B 330, 4£ 1, $530 \mathrm{~b}, 616$;

C $163,165,166,167,168,170$ a

quantity of ground water in $\ldots \ldots \ldots \ldots \ldots \ldots \ldots \ldots \ldots \ldots \ldots \ldots$ rice irrigation with ground water in ....W 101; C 162, 164; J 316, 373 salt water in ............... 282,530 b, 669; D 151; J 305, 316 salt water in oil fields in ......................... 282 springs in ................W 114; A $14 \mathrm{II}$ b; P 46; B 32; C 161

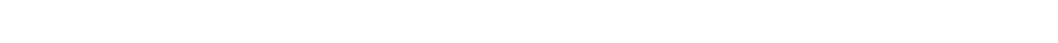
water levels in $\ldots \ldots \ldots \ldots \ldots \ldots \ldots \ldots \ldots$ W 845, 886, 909, 939, 947, 989 
Louisiana, water table in..........P 46; C 162, 166, 167, 170; I 305, 373 well records for ..W 101, 149; P 46; B 264, 298, 669; C 161, 163, 167,

168,170

wells in, construction of $: \ldots \ldots \ldots \ldots \ldots \ldots \ldots \ldots \ldots \ldots \ldots$

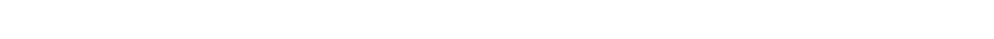

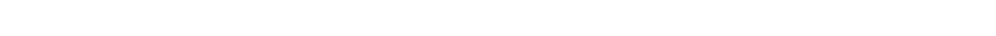

Louisiana limestone, water in, in Missouri ...............W 195

Love, S. K., Cation exchange in ground water contaminated with se.? water near Miami, Fla ...............................J 343

Chemical character of public water supplies in southeastern Florida.J 301 Ground water in southeastern Florida ..................J 252 Investigation of water resources in southeastern Florida ........C 63 Water resources in southeastern Florida ................ 62

Lovering, T. S., Geology and ore deposits of the Breckenridge rining

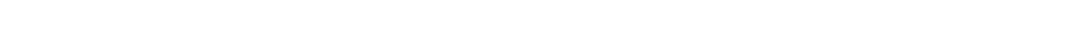

Geology and ore deposits of the Montezuma quadrangle, Colo ...P 178

Lower Magnesian limestone, water in, in Illinois ........ 17 II h; GF 81 water in, in Wisconsin ...................W 14; C 451

See also New Richmond sandstone; Oneota limestone; Prairie du

Chien group; Shakopee dolomite.

Lowry, E. J., Ground-water survey, United States Geological Survey-

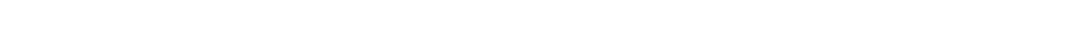

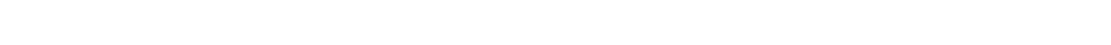

Ludlow, J. M., Water levels and artesian pressure in the United Str.tes,

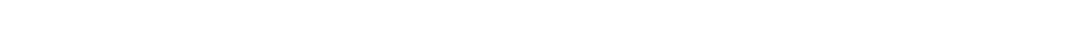

Lugn, A. L., Geology and ground-water resources of south-central

Nebraska ...................................W 779

Ground-water hydrology and Pletstocene geolgy of Platte Valley,

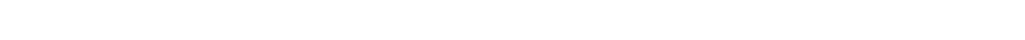

Ground-water levels in Platte Valley, Nebr .............. 49

Ground-water levels in Platte River Valley, Nebr ............. 49

Ground-water resources of south-central Nebraska ............D 64

Lupton, C. T., Anticlines in southern part of Big Horn, Basin, Wyo . . B 656

Bull Mountain coal field, Mont ...................... 646

Geology and coal resources of Castle valley in Carbon, Emery, and

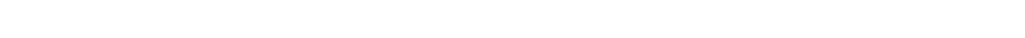

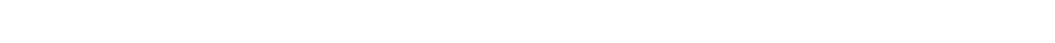

Oil and gas near Green River, Utah .................... $541 \mathrm{~d}$

Lusk, R. G., Geology and oil and gas prospects of northeastern

Colorado .................................. 796 b

Lynch, W. A., Ground water in Dimmit and Zavalla Counties, Tex ....D 51

Methods of locating salt-water leaks in water wells ........W 796 a

Lysimeters for measuring absorption of water $\ldots \ldots \ldots \ldots . W 155,619 ; \mathrm{J} 73$

\section{$\mathbf{M}$}

McCallie, S. W., Underground waters of Georgia ..........W 114; C 81

Well and spring records for Georgia ................W 102

Well contamination at Quitman, Ga $\ldots \ldots \ldots \ldots \ldots \ldots \ldots \ldots$ W 110

MacCarthy, G. R., Geophysical studies on Molokai, Hawaii ........D 158

McCashin, C. E., Surface water supply of the United States. .W 727, 728, 742, 
McCombs, John, Methods of exploxing and repairing leaky artesian wells on Oahu, Hawaii ............................W 596 a

MacDonald, G. A., Geology and ground-water resources of Mrui,

Hawaii ........................................ 99

McDonald, H. R., Design and use of maximum-minimum water-Javel gage (comments) ............................. 155

Geology and ground-water resources of the Verde River Valley,

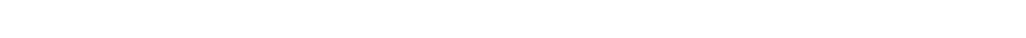

Ground-water levels and pumpage in Ariz., $1939-40 \ldots \ldots \ldots \ldots \ldots$. 14

Ground-water resources of the Santa Cruz Basin, Ariz .......... 20

Measurements of discharge from wells with vertical pipes ....... 195 .

Safford Valley, Graham County, Ariz., records of wells and springs...C 16

Water levels and artesian pressure in the United States...W 911, 941, 948, 949,990

Water resources of Safford and Duncan-Virden Valleys, Ariz.

and N. Mex ..................................... 15

McGee, W J, Potable waters of eastern United States ........... 14 II a

McGlashan, H. D., Surface water supply of the United Seates...W 331, 441, $460,591,721,766,831,861,881,901$

Water resources of California ....................W 298, 300

McGuinness, C. L., Ground-water conditions in Michigan ..........J 216

Ground-water resources of the Indianapolis area, Ind ........... 134

Importance of snow in relation to ground-water recharge ........J 270

Legal control of use of ground water ................... 339

Water levels and artesian pressure in the United States ...W 845, 886, 906, 936, 944

Water supplies from wells in the Indianapolis area, Ind .......D 136

Work of the United States Geological Survey on ground-water supplies

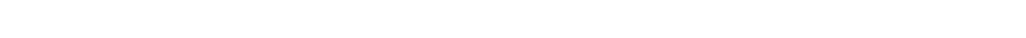

McKnight, E. T., Geology of area between Green and Colorado Rivers,

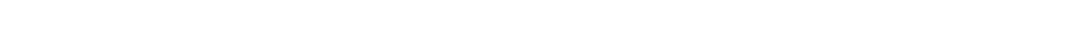

Zinc and lead deposits of northern Arkansas .............. 853

McLaughlin, T. G., Geology and ground-water resources of Hanilton and

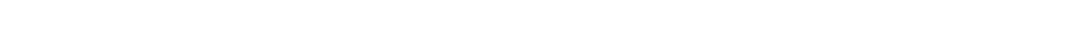

Geology and ground-water.resources of Morton County, Kans.C 149; D 154

Ground water in the Stanton district, Kans ............... 142

Ground-water supplies in Kansas available for national defense ...C 151

Water levels and artesian pressure in the United States.W 886, 908, 938

McLeansboro formation, water in, in Illinois ............GF 213, 216, 220

McLouth, C. D., Flowing wells and municipal water supplies of

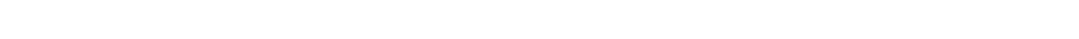

Maddren, A. G., Sulphur on Unalaska and Akun Islands and ner.r Stepo-

vak Bay, Alaska ............................ 692 e

Magmatic water ...W 160, 489, 494; P 66, 178; B 319, 330, 4?1, 616, 9221

Magnesium in ground water ....W 254, 259, 273, 338, 341, 343, 398, $520 \mathrm{~d}$;

P 117; MR 1911 II n

Magnetism in ground water $\ldots \ldots \ldots \ldots \ldots \ldots \ldots \ldots \ldots \ldots \mathrm{V}^{\mathrm{r}} 258 ; \mathrm{C} 431$

Magothy formation, water in, in Maryland .............GF 152, 182, 204

water in, in New Jersey .......................... 215

Maher, J. C., Fluoride in ground water of Avoyelles and Rapides

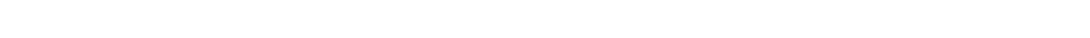

Ground water and geologic structure of Natchitoches, La .......J 331 
Maher, J. C., Ground water and its relation to Louisiana's war effort ....J 302 Ground-water conditions at Alexandria, La .............. 166 Ground-water conditions in Jeff Davis and Acadia Parishes, LE. ...J 316 Ground-water exploration at Alexandria, La .......... 191; J 345 Ground-water exploration in the Natchitoches area, La .....WW 968 c Ground-water geology at Natchitoches, La ................ 169 Ground-water geology of Camp Polk and North Camp Polk, Le ...J 354 Ground water in Grant and La Salle Parishes, La ............. 165 Ground-water investigations in Louisiana .................... 164

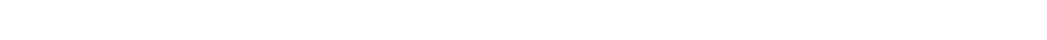
Ground-water resources of Jefferson Davis and Acadia Parishes, La.C 170 Ground-water resourêes of Rapides Parish, La ............. 167 Ground-water supplies in Louisiana .................. 162 Salt-water problems in Louisiana, with special reference to

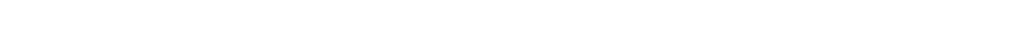
Water levels and artesian pressure in the United States.. W845, 886, 909, 937,947

Water supplies and Louisiana's war effort ..............J 308 Mahoning sandstone, water in, in Pennsylvania ...........GF 123, 224 Maine, areas, all of State $\ldots \ldots \ldots \ldots \ldots \ldots \ldots \ldots \ldots \ldots \ldots$ 102, 114, 258

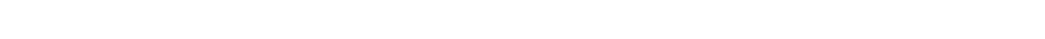

Cumberland County ........................... 298

Eastport quadrangle ........................FF 192

Penobscot Bay quadrangle ......................GF 149

Portsmouth-York region ...................W 145; J 4

Rockland quadrangle $\ldots \ldots \ldots \ldots \ldots \ldots \ldots \ldots \ldots \ldots \ldots \ldots$ GF 158

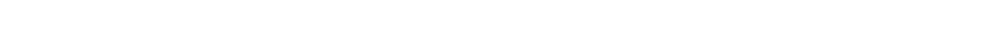
artesian water in $\ldots \ldots \ldots \ldots \ldots \ldots \ldots W$ 145, 228, 258; GF 149. 158; J 4 bibliography of ground water in $\ldots \ldots \ldots \ldots \ldots \ldots \ldots \ldots W$ 114, 120, 163 mineral waters in ............W 258; B 32; MR 1883-192?; GF 149

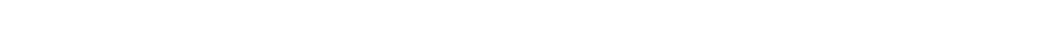
public water supplies in .................W 114, 223; GF 149 quality of ground water in ...W 102, 114, 144, 223, 258, 364; B 32. 330, 491,

616 ; GF 149 quantity of ground water in $\ldots \ldots \ldots \ldots \ldots \ldots \ldots \ldots \ldots \ldots \ldots \ldots \ldots$ W 258 springs in ... W 102, 114, 223, 258, 364; A 14 rI b; B 32; GF 14?. 158, 192 water levels in ................................. 986 well records for ..............W 57, 102, 145, 149, 223; P 264, 298 wells in, construction of $\ldots \ldots \ldots \ldots \ldots \ldots \ldots \ldots \ldots \ldots \ldots \ldots$ W 223

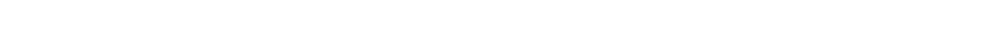
Malt making, quality of water for $\ldots \ldots \ldots \ldots \ldots \ldots \ldots$ 233, 254. 341, 398 Mangan, J. W., Hydrologic investigations, Pennsylvania ........C 348 Manganese in ground water ..........W 338; B 47; MR 1911 Ir $n$; J 211

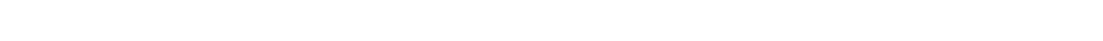
Mansfield, G. R., Geography, geology, and mineral resources of pirt of southeastern Idaho ............................. 152

Geography, geology, and mineral resources of the Fort Hall

Indian Reservation, Idaho ..................... 713

Geography, geology, and mineral resources of the Portneuf

quadrangle, Idaho .............................. 803

Nitrate deposits in the Amargosa region, southeastern California. .B 724

Phosphate resources of Florida .................... 934 
Mansfield, G. R., Potash in the greensands of New Jersey .......... 727 Maps:

absorption areas-

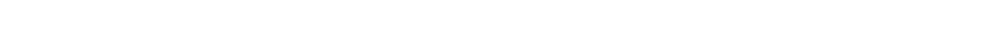

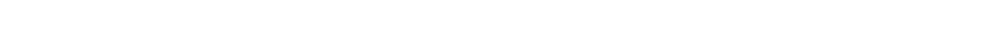

New Mexico ......................... 158, 637 b

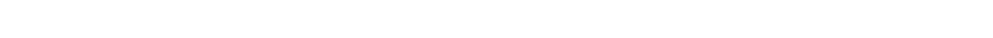

South Dakota ......................... 21 Iv b

Texas ............................W 375 g; A 21 vir

Wisconsin ........................ 17 II $\mathrm{h} ; \mathrm{M} 38$

Wyoming ........................... 21 Iv b

areas irrigated with ground water-

Arizona .......................... 425 a; C 20

California .............W 137, 138, 139, 142, 219, 225, 495

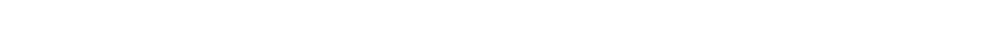

New Mexico .............................. 251

areas of artesian flow-

Alabama .......................... 114, 796 f

Arizona .................................. 425 a

Arkansas ..........................W 399; P 46

California .....W 89, 137, 138, 139, 142, 213, 219, 222, 225, 278, 398, 429,$519 ; \mathrm{C} 21 ; \mathrm{J} 9$

Colorado .............W 240; P 32, 52; GF 36, 58, 68, 71, 135

Florida .........................W 114; C 58; J 137

Georgia ............................W 114, 341; C 81

Hawaii $\ldots \ldots \ldots \ldots \ldots \ldots \ldots \ldots \ldots \ldots \ldots \ldots \ldots \ldots \ldots$ C 92, 97; J 265

Illinois ........................... 17 in $\mathrm{h}$; M 38

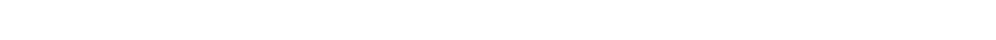

Iowa $\ldots \ldots \ldots \ldots \ldots \ldots \ldots \ldots \ldots \ldots \ldots \ldots \ldots . . . \ldots$ 215, 29£; P 32 ; C 137

Kansas ............................... 32; C 144

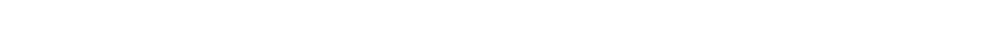

Michigan ....................W 182, 18§; GF 155, 205

Minnesota ........................ 256; GF 117

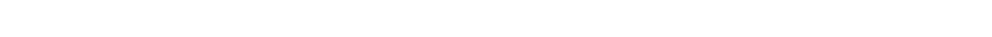

Montana ................................... 128

Nebraska ...............W 215; A 19 Iv c; P 17, 32; GF 85

Nevada ..............................W $425 \mathrm{~d}$

New Mexico ..................W 158; C 231, 236, 240; D 9

North Dakota ...........W 520 e, 598; A 17 II g; GF 117, 168 C 303

Ohio .................................W 259

South Dakota ...W 90, 215; A 17 II g; P 32, 65; GF 85, 96, 97, 99, 100, $107,108,113,114,128,164,165,209,219$

Texas ...................W 335, 375 g; A 21. vII; D 19, 38

Utah ........................W 157, 277, 333

Virginia ............................ 23 ; C 431

Wyoming ...........P 32, 63; GF 107, 127, 128, 150, 173 areas of black alkali water in Arizona ..............W 320 areas of colored ground water in Colorado ...............W 240 areas of ground-water discharge in Nevada .....W $375 \mathrm{~d}, 423,425 \mathrm{~d}$ contours of oil-water and gas-water surfaces in Oklahoms ...... 658 
Maps, contours of water table-

Arizona .........................W 320; C $15.20 ;. J 279$

California ...W 59, 137, 138, 139, 142, 219, 222, 294, 345 h, 398, 400 e, $446,495,519$

Florida .C $62.63 ; \mathrm{J} 252$

Georgia W 907

Hawaii .C 99

Idaho ...................W $560 \mathrm{~d}, 774,818 ;$ C 111, 116

Kansas .....................C 144, 145, 146; J 155, 214

Kentucky ...........................C 160; J 323

Louisiana ............................... 170

Montana ..........................W 345 g; 849 b

Nebraska ........................W 848; C 203; J 229

New Mexico ........W 343; GF 207; C 243, 244, 249, 251, 252; D 125

New York.........................P 44; C 280; J 341

Oklahoma ...............................J 223

Texas .................................... 390

Washington $\ldots \ldots \ldots \ldots \ldots \ldots \ldots \ldots \ldots \ldots \ldots \ldots \ldots \ldots \ldots$ W 425 e depth to water-bearing formations-

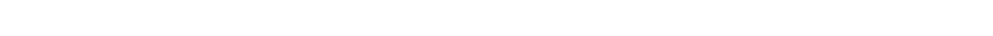

Colorado .................P 32, 52; GF 36, 58, 68, 71, 135

Iowa ............................W 215; GF 156

Kansas ............................... 32

Maryland .............................. 13 ${ }^{\circ}$ GF 136

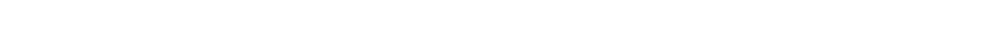

Montana .........................W 849 1; GF 128

Nebraska ....................W 12, 215; P 32; GF 85, 156

North Dakota ....................... 17 II $\mathfrak{k}$; GF 117

South Dakota ....W 34, 90, 215, 227, 428; A 17 II g, 21 I b; P 32; GF $85,97,99,100,107,108,113,114,127,128,15 € .164,165$

Texas ................................. 21 vII

Wyoming ...........A 21 IV b; P 32; GF 107, 127, 12? 150, 173 depth to water table-

Arizona .......................W 320, $375 \mathrm{~h}, 425$ a

California ..................W 375 a, 400 e, 429, 495; C 30

Connecticut .......................... 374,397

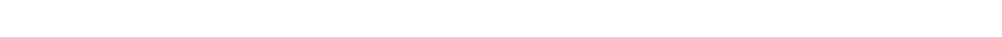

Kansas .......................W 6; C 155, 158; J 243

Nebraska .....................W 425 b; A 19 Iv c; P 17

Nevada .......................W $375 \mathrm{~d}, 423,467$

New Mexico ...W 275, 343, 345 c, 422, 425 a; B 618, 870; GF 207; C 236, 240, 241, 245, 252

Oklahoma ..C $3{ }^{\circ} 1 ;$ D 115

Oregon ............................W $637 \mathrm{~d}$

Texas .............................W 913; J 242

Utah ............................. 157,199

Wýming ............................... 425 b desert watering places-

Arizona $\ldots \ldots \ldots \ldots \ldots \ldots \ldots \ldots \ldots \ldots \ldots \ldots \ldots$ 380,490 c, d. 498,499 California ................W 224, 490 a, b, 497; B 308 Nevada ..........................W 244, 35; B 308 
Maps, desert watering places, New Mexico .............W 343, 380

Utah ..............................W 277, 833 faults in relation to

carbonated springs $\ldots \ldots \ldots \ldots \ldots \ldots \ldots \ldots \ldots \ldots \ldots \ldots \ldots \ldots \ldots \ldots$

flowing wells ............................ 18 In b

ground-water levels .....................W $345 \mathrm{~h}, 489$

hot springs $\ldots \ldots \ldots \ldots \ldots \ldots \ldots \ldots \ldots \ldots \ldots \ldots \ldots \ldots \ldots \ldots$ 338, 489

sprungs $\ldots \ldots \ldots \ldots \ldots \ldots \ldots \ldots \ldots \ldots \ldots \ldots \ldots \ldots$ W 338, 489, 557; A 18 II. b

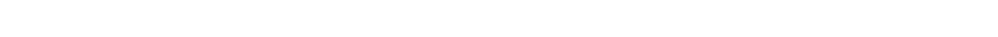

ground-water divide on Long Island, N. Y $\ldots \ldots \ldots \ldots \ldots \ldots . P 44$ head of artesian water-

Arkansas ............................. 46; D 18

Colorado ........................ 52; GF 135, 186

Florida $\ldots \ldots \ldots \ldots \ldots \ldots \ldots \ldots \ldots \ldots \ldots \ldots \ldots \ldots \ldots$ C $6^{\urcorner} ; \mathrm{J} 134,137$

Idaho ................................ 113

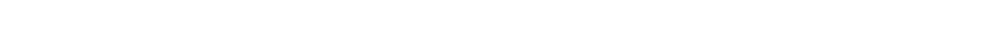

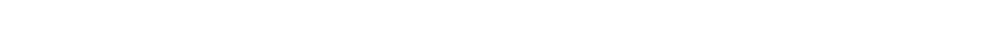

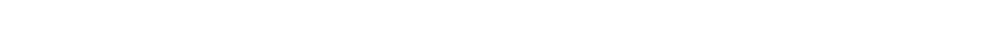

Louisiana ........................P 46: C 166, 167

Michigan $\ldots \ldots \ldots \ldots \ldots \ldots \ldots \ldots \ldots \ldots \ldots \ldots \ldots \ldots \ldots \ldots$ GF 205

Nebraska ..................................... 85

North Dakota ...............W 520 e; A 17 II g; GF 117

South Dakota ...W 90, 227; A 17 II g; GF 85, 96, 97, 99, 100, 108,

114,$165 ; \mathrm{C} 361 ; \mathrm{J} 152$

Tennessee $\ldots \ldots \ldots \ldots \ldots \ldots \ldots \ldots \ldots \ldots \ldots \ldots \ldots \ldots \ldots \ldots$. 164

Texas $\ldots \ldots \ldots \ldots \ldots \ldots \ldots \ldots \ldots \ldots \ldots \ldots \ldots \ldots \ldots \ldots \ldots \ldots \ldots \ldots \ldots$

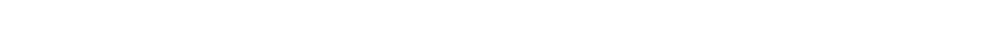

Wisconsin .............................. 451

localities where irrigation with artesian water is practicab's.. A $17 \mathrm{II} \mathrm{g}$ movement of ground water ..................W 67; A 19 II b piezometric surface-

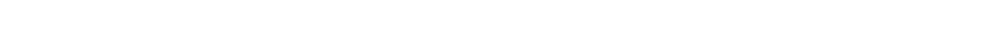

Florida $\ldots \ldots \ldots \ldots \ldots \ldots \ldots \ldots \ldots \ldots \ldots \ldots \ldots \ldots \ldots \ldots$. J 138, 221

Georgia $\ldots \ldots \ldots \ldots \ldots \ldots \ldots \ldots \ldots \ldots \ldots \ldots \ldots \ldots \ldots \ldots \ldots . \ldots \ldots$

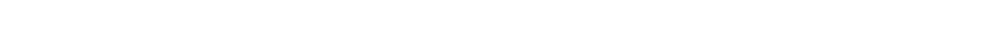

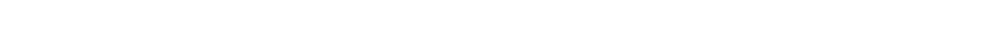

Pleistocene lakes . ............................. 29

precipitation and runoff $\ldots \ldots \ldots \ldots \ldots \ldots \ldots \ldots \ldots \ldots \ldots \ldots$ 301, 312 quality of ground water-

bicarbonate and carbonate in Arizona ...............W 320 chloride-

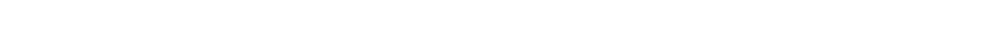

Connecticut $\ldots \ldots \ldots \ldots \ldots \ldots \ldots \ldots \ldots \ldots \ldots \ldots \ldots \ldots \ldots$ w 144, 232

Florida $\ldots \ldots \ldots \ldots \ldots \ldots \ldots \ldots \ldots \ldots \ldots \ldots \ldots \ldots$ C 62; J 252, 258, 301

Louisiana $\ldots \ldots \ldots \ldots \ldots \ldots \ldots \ldots \ldots \ldots \ldots \ldots \ldots \ldots \ldots \ldots$. 167

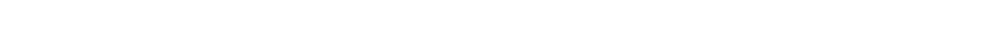

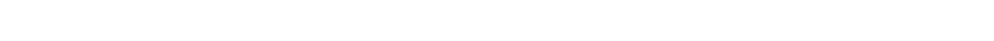

Virginia $\ldots \ldots \ldots \ldots \ldots \ldots \ldots \ldots \ldots \ldots \ldots \ldots \ldots \ldots \ldots \ldots \ldots$ C 431

fluoride in North Dakota ....................... 303 hardness in--

Arizona $\ldots \ldots \ldots \ldots \ldots \ldots \ldots \ldots \ldots \ldots \ldots \ldots \ldots \ldots \ldots \ldots$ W $320 ; C 20$

Florida $\ldots \ldots \ldots \ldots \ldots \ldots \ldots \ldots \ldots \ldots \ldots \ldots \ldots \ldots \ldots . \ldots \ldots$. 301 
Maps, hardness in, Iowa $\ldots \ldots \ldots \ldots \ldots \ldots \ldots \ldots \ldots \ldots \ldots \ldots \ldots$ w 293

Michigan .................................. 31

Minnesota ................................. 256

United States $\ldots \ldots \ldots \ldots \ldots \ldots \ldots \ldots \ldots \ldots \ldots \ldots \ldots \ldots \ldots \ldots$ W 559

Wisconsin $\ldots \ldots \ldots \ldots \ldots \ldots \ldots \ldots \ldots \ldots \ldots \ldots \ldots \ldots \ldots \ldots \ldots \ldots \ldots$

potability in North Carolina $\ldots \ldots \ldots \ldots \ldots \ldots \ldots \ldots \ldots \ldots \ldots \ldots \ldots \ldots$

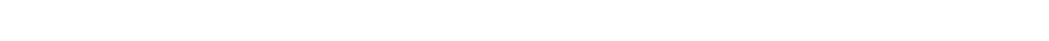

saline shallow water in Michigan $\ldots \ldots \ldots \ldots \ldots \ldots \ldots \ldots \ldots$ w 30,31

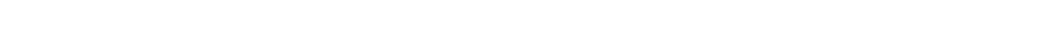

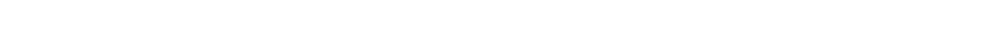

in New Mexico ............................W 275

total solids in Arizona $\ldots \ldots \ldots \ldots \ldots \ldots \ldots \ldots \ldots \ldots \ldots . \ldots$ 320; C 20

in California $\ldots \ldots \ldots \ldots \ldots \ldots \ldots \ldots \ldots \ldots \ldots \ldots \ldots$ W 137, 138, 139

relation of glacial drift to ground water .....W 21, 489; A 18 rv b; M 38 representation of wells and springs on $\ldots \ldots \ldots \ldots \ldots \ldots \ldots \ldots$ W 160 sinkholes $\ldots \ldots \ldots \ldots \ldots \ldots \ldots \ldots \ldots \ldots \ldots \ldots \ldots \ldots \ldots \ldots \ldots \ldots \ldots$ W 319 structure contours of water-bearing formations-

Colorado ............................ 32, 52

District of Columbia $\ldots \ldots \ldots \ldots \ldots \ldots \ldots \ldots \ldots \ldots \ldots \ldots$ GF 70, 152

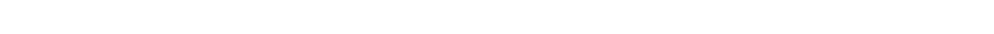

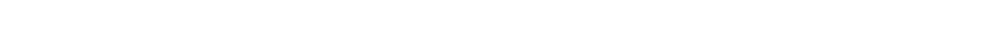

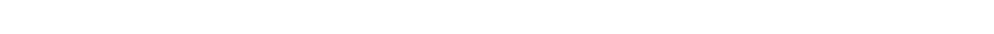

Maryland $\ldots \ldots \ldots \ldots \ldots \ldots \ldots \ldots \ldots \ldots \ldots \ldots$ GF 24, 71), 152, 182

Montana ............................... 847 , 856

Nebraska ........................... $\mathrm{V}^{\mathbf{r}} 12 ; \mathbf{P} 32$

North Dakota ............................ 168

South Dakota .......................... 32

Texas ..........................W 335; A 21 vII

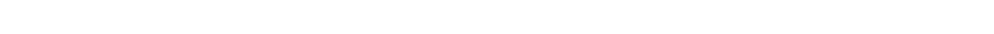

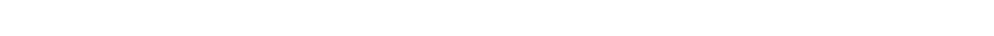

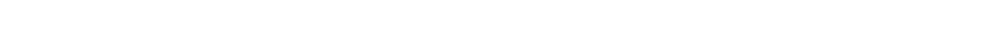

temperature in deep wells, rates of increase in $\ldots \ldots \ldots \ldots \ldots$. 18 iv c temperature of ground water in Michigan ..........W 182, 183 thickness of water-bearing deposits .....W 254, 256, 259, 4^9; GF 205 vegetation in relation to water supply-

Arizona $\ldots \ldots \ldots \ldots \ldots \ldots \ldots \ldots \ldots \ldots \ldots \ldots \ldots \ldots \ldots \ldots \ldots$ 17 320,577

Nevada ...........................W 423, 577

New Mexico ............................W 343, 577

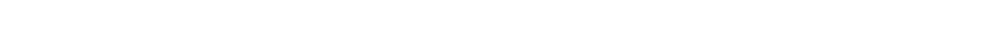
water table in California, fluctuations of $\ldots \ldots W 345 \mathrm{~h}, 400 \mathrm{e}, 446,619$ watering places on routes of travel-

Arizona .W 380, 499

California $\ldots \ldots \ldots \ldots \ldots \ldots \ldots \ldots \ldots \ldots \ldots \ldots \ldots \ldots$ W 2:4; B 308

Nevada ........................W 224, 365; B 308

New Mexico ......................... V 343, 380

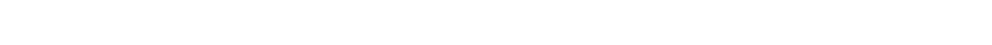

yields of flowing wells $\ldots \ldots \ldots \ldots \ldots \ldots \ldots \ldots \ldots \ldots \ldots \ldots \ldots$ IV c

Maquoketa shale, water in, in Iowa .................... 293

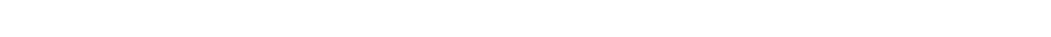

in Wisconsin ............................... 451

Marl, water in, in Great Plains ...................... 16 II $f$

water in, in New Jersey ......................... 727 
Marshall formation, water in, in Michigan ............ 30, 31, 114

Martin, G. C., Accident-Grantsville folio, Md.-Pa.-W. Va ..........GF 160

Preliminary report on petroleum in Alaska .................. 719

Water resources of the Accident and Grantsville quadrangl ss,

Md.-Pa.-W. Va ............................... 110

Water resources of the Frostburg and Flintstone quadrangl $1 \mathrm{~s}$,

Md.-W. Va .................................. 110

Water resources of the Pawpaw and Hancock quadrangles,

W. Va.-Md.-Pa ............................W 145

Martin, Lawrence, Mineral resources of Johnstown, Pa., and vicinity ...B 447 Martin, W. F., Water resources of Hawaii, 1909-11 ...........W 318 Maryland, areas, all of State ................W 114; C 171; J 1 areas, Accident quadrangle ..................W 110; GF 160

Anne Arundel County ....................... 298

Baltimore and vicinity ...............W 114; B 138; J 355

- Choptank quadrangle .......................GF 182

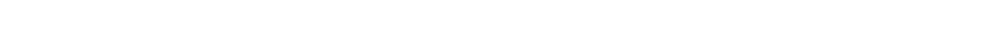

Dover. quadrangle $\ldots \ldots \ldots \ldots \ldots \ldots \ldots \ldots \ldots \ldots \ldots \ldots$ GF 137

Elkton quadrangle $\ldots \ldots \ldots \ldots \ldots \ldots \ldots \ldots \ldots \ldots \ldots \ldots \ldots$ GF 211

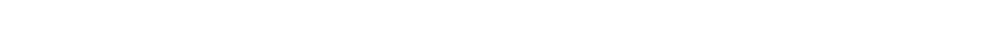

Fredericksburg quadrangle $\ldots \ldots \ldots \ldots \ldots \ldots \ldots \ldots \ldots \ldots$ GF 13

Frostburg quadrangle . . . . . . . . . . . . . . . . . W 110

Grantsville quadrangle $\ldots \ldots \ldots \ldots \ldots \ldots \ldots \ldots \ldots \ldots$ W 110; GF 160

Hancock quadrangle $\ldots \ldots \ldots \ldots \ldots \ldots \ldots \ldots \ldots \ldots$ W 145; GF 179

Nomini quadrangle $\ldots \ldots \ldots \ldots \ldots \ldots \ldots \ldots \ldots \ldots \ldots \ldots$ GF 23

Patuxent quadrangle $\ldots \ldots \ldots \ldots \ldots \ldots \ldots \ldots \ldots \ldots \ldots \ldots$ GF 152

Pawpaw quadrangle $\ldots \ldots \ldots \ldots \ldots \ldots \ldots \ldots \ldots \ldots \ldots \ldots$ W 145, 179

St. Marys County ......................... 298

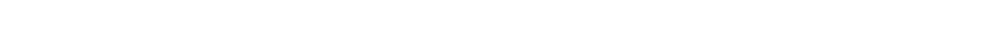

Talbot County ............................. 298

Tolchester quadrangle .......................GF 204

Washington quadrangle ......................FF 70

artesian water in ...B 138; GF 23, 70, 136, 137, 152, 160, 179, 182, 204;

C $171 ; \mathrm{J} 1$

bibliography of ground water in $\ldots \ldots \ldots \ldots \ldots \ldots W 114,120,149,163$ mineral waters in ................. 32; MR 1883-1923; GF 152 public water supplies in .................. 138; C 171 quality of ground water in. .W 258; B 32, 138; GF 136, 137, 179, 204; C 171

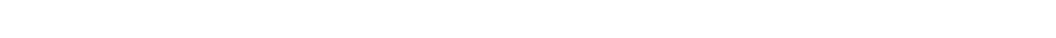
springs in. W 110, 114, 145; A 14 II b; B 32; GF 152, 160, 179, 204: C 171 water levels in $\ldots \ldots \ldots \ldots \ldots \ldots \ldots$ W 817, 840, 845, 886, 907, 937, 945, 987 water table in ................................ 116 well records for .....WW 57, 114, 149; B 138, 298; GF 70, 152; C 171: J 1

Massachusetts, areas, all of State ..............W 1C2, 114; J 329 areas, Aberjona Valley ....................... 193

Brookline ...........................W 374, 397

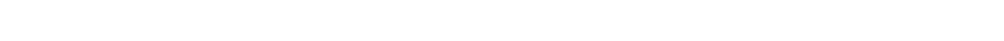

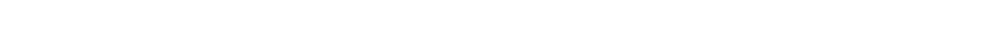

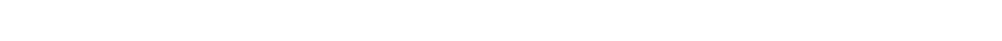
bibliography of ground water in $\ldots \ldots \ldots \ldots \ldots \ldots \ldots \ldots \ldots$ W 114, 120, 163 industrial use of ground water in .................. 193 mineral waters in .................W 114; B 32; MR 1883-1923 
Massachusetts, public water supplies in ...........W 373, 397; D 193 quality of ground water in $\ldots \ldots \ldots \ldots \ldots \ldots$ W 102, 110, 114, 144; B 32 quantity of ground water in $\ldots \ldots \ldots \ldots \ldots \ldots \ldots \ldots \ldots \ldots \ldots$ D 198 salt water in $\ldots \ldots \ldots \ldots \ldots \ldots \ldots \ldots \ldots \ldots \ldots \ldots \ldots \ldots \ldots$ 114; D 151 springs in ............W 102,114, 145, 679 b; A 14 Ir b; B 32, 839 thermal ................................ $679 \mathrm{~b}$ water levels in $\ldots \ldots \ldots \ldots \ldots \ldots \ldots \ldots \ldots \ldots \ldots$ 886, 906, 936 944, 986 water table in $\ldots \ldots \ldots \ldots \ldots \ldots \ldots \ldots \ldots \ldots \ldots \ldots \ldots \ldots$. 272, 329 well records for .....W 57, 102, 110, 149; B 264; 298; D 193; J 272

Matawan formation, water in, in Atlantic Coastal Plain ............ 138 water in, in Maryland ...........................F 182, 204

in New Jersey ......................W 106; GF 167

in Pennsylvania $\ldots \ldots \ldots \ldots \ldots \ldots \ldots \ldots \ldots \ldots \ldots \ldots \ldots$ W 106; GF 167

Mather, K. F., Geology and oil and gas prospects of northeastern

Colorado ................................. 796 b

Oil fields of Allen County, $\mathrm{Ky} \ldots \ldots \ldots \ldots \ldots \ldots \ldots \ldots \ldots \ldots$. $68 . \ldots \ldots$

Structure and oil and gas resources of the Osage Reservation,

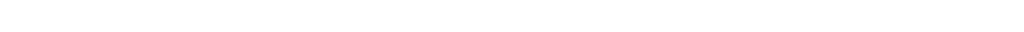

Mathews, E. B., Surface and underground water resources of Mary'and.C 171

Mathews, E. B., Tolchester folio, Md. ....................GF 204

Matson, G. C., Corsicana oil and gas field, Tex .............. $661 \mathrm{f}$

Geology and ground waters of Florida ................W 319

Pollution of water in limestone $\ldots \ldots \ldots \ldots \ldots \ldots \ldots \ldots \ldots \ldots \ldots$ W 258

Production of mineral waters in the United States ........MR 1910-1912

Water resources of the Blue Grass region, $\mathrm{Ky} \ldots \ldots \ldots \ldots \ldots \ldots$ W 233

Maxey, G. B., Ground-water resources of the Las Vegas artesian b7.sin,

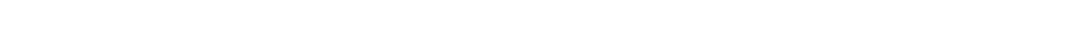

Ground-water resources of the Louisville area, $\mathrm{Ky} \ldots \ldots \ldots \ldots \ldots$. . 160

Measurement of discharge from wells with vertical pipes ....... 195

Underground leakage from artesian wells in the Flowell area, Utah.C 423

Water levels and artesian pressure in the United States, 1942 ... W 948

Maysville formation, water in, in Kentucky ..............W 233

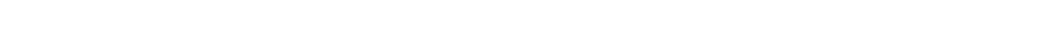

Meacham, R. P., Springs of Virginia ................ 432

Medicinal properties of water ...W 31, 164, 195, 233, 254, 259, 293.335, 338,

341; A $14 \mathrm{n} \mathrm{b}$; MR $1911 \mathrm{n} \mathrm{n,} 1913$ ii h

Medina formation, water in, in Indiana .................. 114 water in, in Ohio .................................. 19 iv b

Meeker, R. I., Surface water supply of the United States, 1906 . . . . W 209 Meeteetse sandstone, water in. in Wyoming ................ 656 Meinzer, O. E., Analysis of legal concepts of subflow and percolating

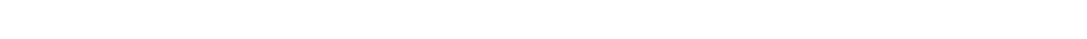

Artesian conditions in the United States ................ 101

Artesian water for irrigation in Little Bitterroot Valley, Mont... W $400 \mathrm{~b}$

Artesian water supply of the Dakota sandstone ...........J 41

Artesian water supply of the Dakota sandstone in North Dakota. . W 520 e

Bibliography and index of publications prepared by the United States

Geological Survey relating to ground water ............W 427

Bibliography of technical reports, articles, and memoranda, published

or otherwise released (by the Ground Water Division, United States

Geological Survey) .................... 116, 138, 161, 172

Channel storage method of determining effluent seepage .......J 159 
Meinzer, O. E., Coastal ground water, with speoial reference to Connectitcut

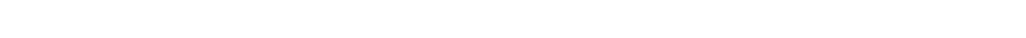

Compressibility and elasticity of artesian aquifers $\ldots \ldots \ldots \ldots \ldots . . . J 4$

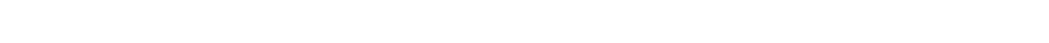

Definitions of the different kinds of subterranean water ........J 208

Depleted wells at Louisville, Ky., (foreword) .............J 330

Effect of a sea-level canal on the ground-water level of Florida ...J 185

Experiment on flow through a capillary tube (discussion) .......J 299

Exploratory drilling for water and use of ground water

for irrigation in Steptoe Valley, Nev ..............W 467

Formation of the Section of Hydrology of the American Gerphysical

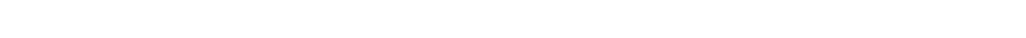

General principles of artificial ground-water recharge .........J 359

Geologic reconnaissance of a region adjacent to Guantánan? Bay,

Cuba .................................... 287

Geology and underground waters of southern Minnesota .....W 256

Geology and water resources of Big Smoky, Clayton, and Alkali

Spring Valleys, Nev ........................W 423

Geology and water resources of Estancia Valley, N. Mex .......W 275

Geology and water resources of Sulphur Spring Valley, Ariz ....W 320

Geology and water resources of the Kau district, Hawaii (chapter

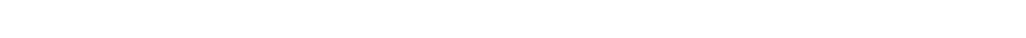

Geology and water resources of Tularosa Basin, N. Mex ......W 343

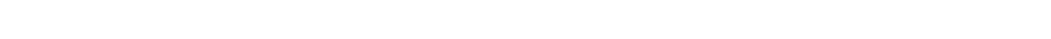

Geology of No. 3 reservoir site of the Carlsbad irrigation project,

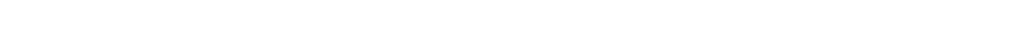

Geophysical interpretation of ground-water levels ...........J 95

Glossary of terms pertaining to ground water and related subjects. D 6

Ground water, a vital national resource $\ldots \ldots \ldots \ldots \ldots \ldots \ldots \ldots$ J 300

Ground water, in Hydrology (Physics of the Earth, IX) J 2.55 (chap. 10)

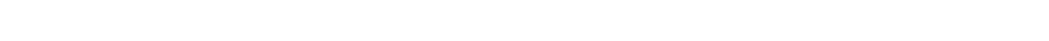

Ground water and ground-water hydrologists in Germany ...... 91

Ground water and ground-water hydrology in Holland ......... 92

Ground water for irrigation in Lodgepole Valley, Nebr.-Wyn ..W 425 b

Ground water for irrigation near Wichita, Kans ........W 345 a

Ground water for irrigation on the Great Plains .........W 345 b

Ground-water geologist warns against water diviners ........J 324

Ground water in Big Smoky Valley, Nev ............W $375 \mathrm{~d}$

Ground water in Juab, Millard, and Iron Counties, Utah ......W 277

Ground water in Musselshell and Golden Counties, Mont ......W 518

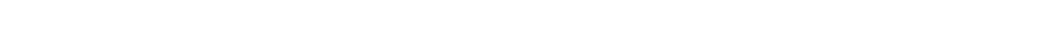

Ground water in Paradise Valley, Ariz .............W 375 b

Ground water in uincy Valley, Wash ...............W 425 e

Ground water in the Midwest drought area .............J 120

Ground water in the Pomeraug Basin, Conn., with special roference to

intake and discharge ......................... $597 \mathrm{~b}$

Ground water in the United States ..................... 95

Ground water in the United States, a summary ..........W $836 \mathrm{~d}$

Ground water in the United States of America .............J 271

Ground water in the western part of the United States. . . . . . . . . .J 40

Ground water in Yellowstone and Treasure Counties, Mont.' (preface) 
Meinzer, O. E., Ground-water problems in the Hawaiian Islands .......J 27

Ground-water problems of the Coastal Plain ..............J 125

Ground-water studies in the Southwest .................J 291

Ground waters of Estancia Valley, N. Mex. (preliminary report). .W 260

Hidrologia subterranea .............................J 26

History and development of ground-water hydrology ..........J 106

Hydrologic cycle and the historical development of hydrology, in

Hydrology (Physics of the Earth, IX) ............ 255 (chap. 1)

Hydrologic observations, especially concerning the ground-watev

supply of London $\ldots \ldots \ldots \ldots \ldots \ldots \ldots \ldots \ldots \ldots \ldots \ldots \ldots \ldots \ldots$

Hydrology in Europe .......................... 79

Hydrology in relation to economic geology ...............J 367

Importance of ground-water supply . . . . . . . . . . . . . . . 191

Improvements in ground-water development ..............J 93

Instructions for the use of the well schedule ...............J 269

Inter-relationship of underground and surface water investigations. . D 27

Lake and ground-water levels . .....................J 112

Land subsidence caused by pumping .................J 168

Large springs in the United States ..................W 557

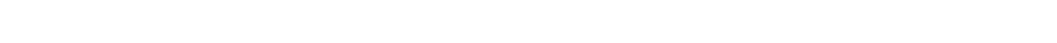

Lower Gila region, Ariz., (preface) $\ldots \ldots \ldots \ldots \ldots \ldots \ldots \ldots \ldots$ W 498

Map of the Pleistocene lakes of the Basin and Range province and

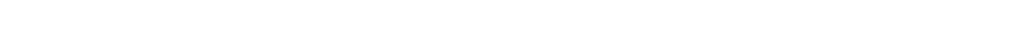

Methods for estimating ground-water supplies .............J 89

Methods of estimating ground-water supplies, part 1, Outline of

available methods ............................ 58

Methods of exploring and repairing leaky axtesian wells (preface) W 596 a

Mohave Desert region, Calif. (preface) ...............W 578

Movements of ground water ....................... 144

Nation-wide program of observation wells ..............J 130

Nation-wide program of water-level measurements ........... 59

Nation-wide system for designating wells $\ldots \ldots \ldots \ldots \ldots \ldots \ldots$ D 76

Observation wells, manual of methods (introduction) $\ldots \ldots \ldots \ldots \ldots$ D 60

Occurrence of ground water in the United States, with a discus:ion

of principles $\ldots \ldots \ldots \ldots \ldots \ldots \ldots \ldots \ldots \ldots \ldots \ldots \ldots \ldots \ldots \ldots$ W 489

Ohio Valley well supplies subject to slow reduction of capacity....J 126

Origin of the thermal springs of Nevada, Utah, and Southern Idaho ..J 34

Our water supply $\ldots \ldots \ldots \ldots \ldots \ldots \ldots \ldots \ldots \ldots \ldots \ldots \ldots \ldots \ldots \ldots$

Outline of ground-water hydrology, with definitions...........W 494 .

Papago country, Ariz., (preface) ....................W 499

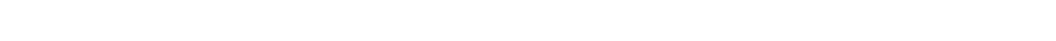

Plants as indicators of ground water $\ldots \ldots \ldots \ldots \ldots \ldots \ldots \ldots \ldots \ldots$ W 577

Problems of the perennial yield of artesian aquifers ..........J 344

Protection of ground-water supplies-conservation of ground water. .J 327

Quantitative methods of estimating ground-water supplies ........J 24

Relation of ground-water conditions to leakage of reservoirs.......J 62

Relation of ground water to stream flow ............... 54

Releases by the Division of Ground Water (United States Gerlogical

Survey) during the fiscal year ended June $30,1939 \ldots \ldots \ldots \ldots \ldots$ D 116

Remarks on hydrologic terminology (discussion) ...........J 298

Review of the work of W J McGee .................. 157 
Meinzer, O. E., Role of hydraulic laboratories in geophysical research:

Permeability, specific yield, etc ................... 117

Routes to desert watering places in California and Arizona

(preface) .............................. 490 a

Salton Sea region, Calif., (preface) .................W 497

Soft water in the Dakota sandstone ................. 11; J 63

Soft-water supply of the Dakota sandstone, with special reference to

Canton, S: Dak .......................... 597 c

Status of our knowledge regarding the hydraulics of ground water. .J 236

Survey of the underground waters of Texas .............. D 19

Tests of permeability with low hydraulic gradients ..........J 114

The divining rod, a history of water witching (introductory note). . W 416

Typical quantitative analysis as applied to Lake Superior (discussion)

Underground water resources of Iowa ........... 293; C 137

Value of geophysical methods in ground-water studies..........J 174

Value of "geophysical" methods in hydrologic work........ 78; J 210

Water levels and artesian pressure in the United States in 1937... 99

Water levels and artesian pressure in the United States (introduction)

W $777,817,840,845,886$

Water levels and artesian pressure in the United States, 1940 (introduction) $\ldots \ldots \ldots \ldots \ldots \ldots \ldots \ldots \ldots \ldots \ldots \ldots$ W 906, 907, 908, 909, 910, 911

Water levels and artesian pressure in the United States, 1941

(introduction) $\ldots \ldots \ldots \ldots \ldots \ldots \ldots \ldots \ldots W$ 936, 937, 938, 939, 940, 941

Water levels and artesian pressure in the United States, 1942 (introduc-

ion) $\ldots \ldots \ldots \ldots \ldots \ldots \ldots \ldots \ldots \ldots \ldots \ldots W$ 986, 987, 988, 999, 990, 991

Water resources of Butte, Mont ..................W $345 \mathrm{~g}$

Water resources work of the State geological surveys.........D 57

Water-supply conditions in the drought-stricken regions ........J 119

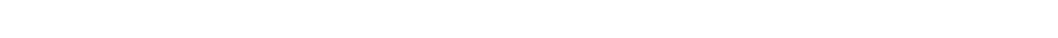

What becomes of the rain water .................... 12

Work of geologists on water supplies for war purposes.........J 314

Work of the International Commission on Subterranean Water in the

Western Hemisphere ............................J 308

Work of the (United States) Geological Survey and cooperating State

agencies on ground water for war purposes .............J 309

Mendenhall, W. C., Conservation of underground water .........W 234

Desert watering places in California and Nevada...........W 224

Development of underground waters in the central Coastal Plain of southern California ........................W 138

Development of underground waters in the eastern Coastal Plain of southern California .......................... 137

Development of underground waters in the western Coastal Plain of

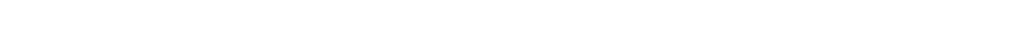

Fluctuations of ground water levels in southern California....W 251, 331 Ground water in San Joaquin Valley, Calif ..............W 398

Ground-water levels in southern California $\ldots \ldots \ldots \ldots \ldots \ldots \ldots$ W 213

Ground-water problems in the West ................... 9

Ground waters and irrigation enterprises in the foothill belt of southern California ..........................W 219 
Mendenhall, W. C., Ground water of San Joaquin Valley, Calif. (rrelimi-

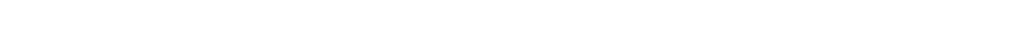
Ground waters of the Indio region, Calif., with a sketch of the Colorado Desert .............................. 225

Hydrology. of San Bernardino Valley, Calif .............W 142

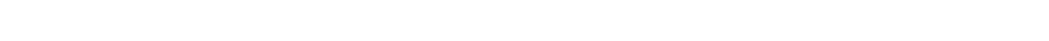

Underground waters of southern California..............W 146

Merrill, F. J. H., New York City folio, N. Y.-N. J. ............GF 83

Mertie, J. B., Jr., Geology of the Eagle-Circle district, Alaska......... 816 Mineral deposits of the Rampart and Hot Springs districts, Alaska B 844 d Nushagak district, Alaska ....................... 903

Mesaverde formation, water in, in Arizona $\ldots \ldots \ldots \ldots \ldots \ldots \ldots \ldots$ W 380 water in, in New Mexico ..................W 380, 620; B 86 b

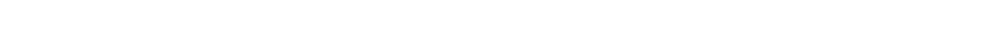

in Wyoming ...................... 656, 702; GF 173

Mesnier, G. N., Water levels and artesian pressure in the United States

W $₹ 40,845,886$

Mesozoic formations. See Cretaceous; Jurassic; Triassic; specific formations. Meters for measuring underflow ...................W 140, 141

Mexico, bibliography of ground water in.................. 163 quality of ground water in ................W 182, 183; B 529

Meyer, R. R., Water levels and artesian pressure in the United States. .W 987 Miami oolite, water in, in Florida ..........W 319; C 62; J 252, 258, 365

Michigan, areas, Albion and vicinity $\ldots \ldots \ldots \ldots \ldots \ldots \ldots \ldots \ldots \ldots \ldots \ldots \ldots$

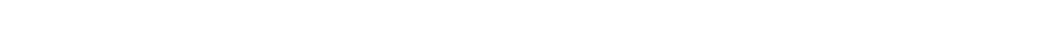

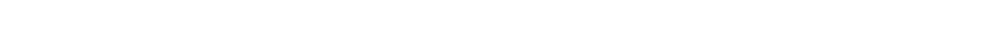

Detroit quadrangle .........................FF 205

Grosse Isle .............................. 145

Lake Superior region ...................... 52 ; J 231

northern peninsula $\ldots \ldots \ldots \ldots \ldots \ldots \ldots \ldots \ldots \ldots \ldots$ W 114,160

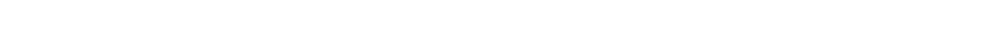

southern peninsula $\ldots \ldots \ldots \ldots \ldots \ldots W 30,31,102,114,145,182,183$

artesian water in .........W 30, 145, 160, 182, 183; GF 15`, 205; C 181 bibliography of ground water in $\ldots \ldots \ldots \ldots \ldots \ldots$ W 57,114, 120, 149, 163

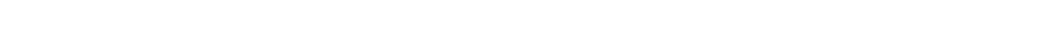
laws relating to ground water in $\ldots \ldots \ldots \ldots \ldots \ldots \ldots$ w 122, 152, 182, 183

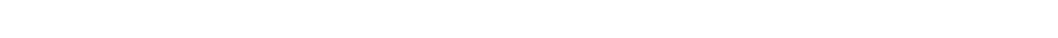
mineral waters in ........W 31, 114; B 32; MR 1883-1923; GF 155, 205 pollution of ground water in .................... 30,31 public water supplies in ..........W 30, 160, 182, 183; GF 155; J 8 quality of ground water in....W $30,31,102,145,160,182,183,364$; B 32, 530 b, 606, 625; GF 155, 205; C 181, J 8 quantity of ground water in .................... 205 salt water in ................W 30, 31; B 530 b, 669; GF 205 springs in .......W 31, 102, 114, 170, 182, 183; P 154 a; $\gg 32$; GF 205 temperature of ground water in............W 30, 182, 183; B 32 water levels in $\ldots \ldots \ldots \ldots \ldots W 777,817,840,845,886,906,936,944,986$ water table in $\ldots \ldots \ldots \ldots \ldots \ldots \ldots \ldots$ W 30, 182, 183; GF 155; J 216, 270 well records for $\ldots \ldots \ldots \ldots \ldots$ W $57,102,149,160,182,183 ;$ B 264, 298, 669;

wells in, construction of $\ldots \ldots \ldots \ldots \ldots \ldots \ldots \ldots \ldots \ldots \ldots W^{r} 30,182,183$

Michigan formation, water in, in Michigan .............W 30, 114 
Midway formation, water in, in Georgia ................. 341

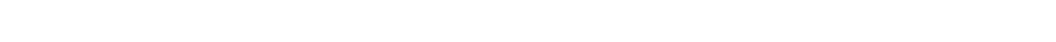

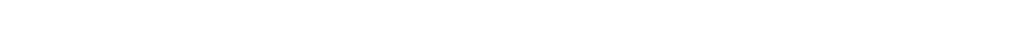

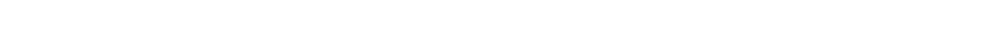

Military water supplies-

general $\ldots \ldots \ldots \ldots \ldots \ldots \ldots \ldots \ldots \ldots \ldots \ldots \ldots \ldots \ldots \ldots . . \ldots$ 309, 314, 366

Louisiana ............................... 202, 203

Mississippi $\ldots \ldots \ldots \ldots \ldots \ldots \ldots \ldots \ldots \ldots \ldots \ldots \ldots \ldots \ldots \ldots$ C 192, 193, 194

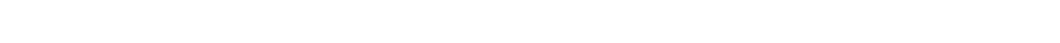

southwest Pacific ............................. J 368

United States .......................... 177; J 364

Miler, B. F., Elkton-Wilmington folio, Md.-Del.-N. J.-Pa ..........GF 211

Miller, B. L., Choptank folio, Md...................GF 182

Coastal Plain of North Carolina .................... 291

Dover folio, Del.-Md.-N. J. . . . . . . . . . . . . . . . . . GF 137

Patuxent folio, Md.-D. C . . ........................ 152

Philadelphia folio, Pa.-N. J.-Del ....................FF 161

St. Marys folio, Md.-Va ....................... 136

Tolchester folio, Md. ...........................FF 204

Trenton folio, N. J.-Pa .........................GF 167

Miller, W. J., Underground water resources of Iowa ...........W 293

Millican formation, water in, in Texas ..................... 194

Mills, R. V. A., Evaporation and concentration of waters associated with

petroleum and natural gas $\ldots \ldots \ldots \ldots \ldots \ldots \ldots \ldots \ldots \ldots \ldots \ldots \ldots \ldots$

Evaporation of water at depth by natural gases ............J 17

Structure and oil and gas resources of the Osage Reservation, Okla

Mineral springs-

B $686 \mathrm{t}, \mathrm{v}$

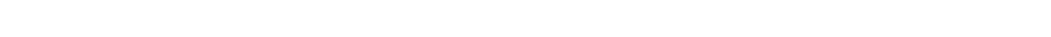

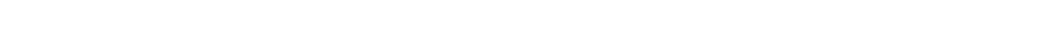

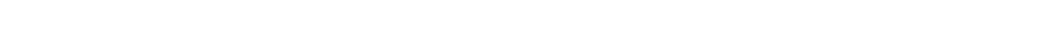

United States ............................W 679 b

Virginia .............................. 432, 433

Mineral waters, analyses of, biblingraphy of..MR $1913 \mathrm{II} h, 1916,1921$; D 55

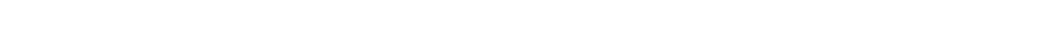

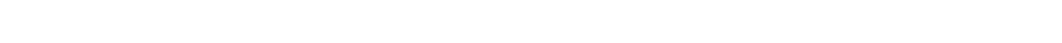

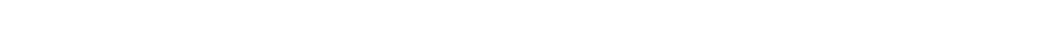

concentration of $\ldots \ldots \ldots \ldots \ldots \ldots \ldots \ldots \ldots \ldots \ldots$ W 341 ; MR 1911 II $\mathrm{n}$

definition of.$\ldots \ldots \ldots \ldots$ W 338; A 14 II b; B 330, 491, 616; MR 1883-1923

exports and imports of United States ..............MR 1883-1923

history of $\ldots \ldots \ldots \ldots \ldots \ldots \ldots \ldots \ldots \ldots \ldots \ldots$ A 14 II b; MR 1914

origin of $\ldots \ldots \ldots \ldots \ldots \ldots \ldots \ldots \ldots \ldots \ldots \ldots \ldots \ldots \ldots \ldots \ldots \ldots \ldots \ldots \ldots \ldots$ II $b$

Pliny on $\ldots \ldots \ldots \ldots \ldots \ldots \ldots \ldots \ldots \ldots \ldots \ldots \ldots \ldots \ldots \ldots \ldots \ldots$ In 14

production of, in the United States ................. 1883-1923

radioactivity in, bibliography of ................... 1913 if $h$

therapeutic value of $\ldots \ldots \ldots \ldots \ldots \ldots \ldots \ldots \ldots \ldots \ldots \ldots \ldots$ MR 1913 II $\mathrm{h}$

statistics of $\ldots \ldots \ldots \ldots \ldots \ldots \ldots \ldots \ldots \ldots \ldots \ldots$ B 32 ; MR 1883-1923

therapeutic properties of. W 195, 259, 338; A 14 II b; MR 1911 II n;

1913 II h, 1916

trade in and value of, in the United States ......A 14 II b; M R1883-1923

See also specific States. 
Minerals dissolved in ground water. See Analyses; Quality.

Mineş, water in....W 160, $345 \mathrm{~g} ;$.M 52; P 25, 43, 54, 62, 66, 77, 157, 162, 194; B $582,677,681,715$ l, 725 c, $782,842,846$ a, 847 a, 853,870 , $877,879,884,885,886,893$; GF 112, 12? 129; C 2 water in, quality of..W $273,345 \mathrm{~g}, 364$; P $38,42,43,62,74,104,107,115$, $122,139,144,148,194 ;$ B $330,491,529,606,616,625,718$ 735 c, 750 c; GF 191 Minnekahta limestone, water in, in South Dakota.......W 227; A 21 Iv b;

GF 107; C 361 water in, in Wyoming .......................... 107 Minnelusa sandstone, water in, in South Dakota. .W 227, 428; A 21 Iv b; P 32, $65 ;$ GF 107, 127, 128, 164, 209, 219 water in, in Wyoming........A 21 IV b; P 32, 65; GF 107, 127, 128, 150

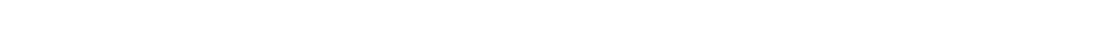
areas, Casselton-Fargo quadrangle ................GF 117

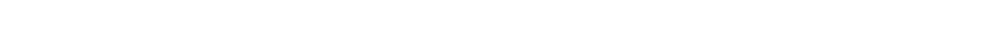

Herman-Morris quadrangle ...................... 210

Lake Superior region $\ldots \ldots \ldots \ldots \ldots \ldots \ldots \ldots \ldots \ldots \ldots \ldots \ldots$

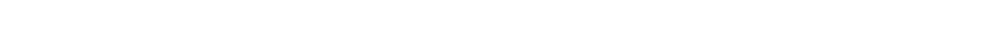

Minneapolis quadrangle $\ldots \ldots \ldots \ldots \ldots \ldots \ldots \ldots \ldots \ldots \ldots \ldots$ GF 201

northwestern $\ldots \ldots \ldots \ldots \ldots \ldots \ldots \ldots \ldots \ldots \ldots \ldots \ldots \ldots \ldots$

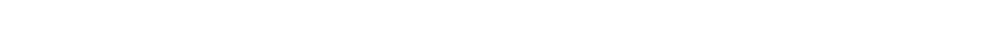

Pine County ............................ 298

Red River Valley ...................... 11 II c; M 25

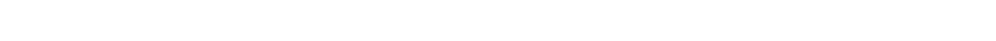

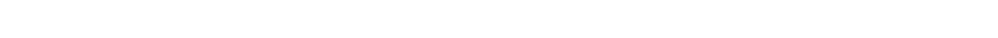

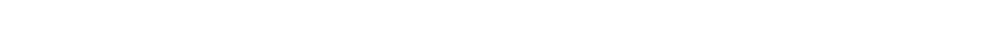

Vermillion district.$\ldots \ldots \ldots \ldots \ldots \ldots \ldots \ldots \ldots \ldots \ldots \ldots \ldots$ artesian water in ........W 114, 256; A 11 II c; M 25; GF 117, 201, 210 bibliography of ground water in.......W 57, 114, 120, 149.163; C 303

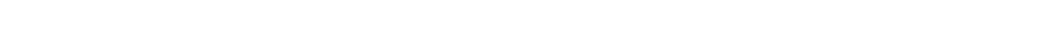

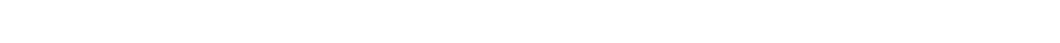
irrization with artesian water in ............... 11 II c; M 25 mineral waters in ..................... 32; MR 1883-1923 public water supplies in ..................... 193, 256 quality of ground water in..W 102, 193, 256; M 25; B 32, 38 n, 491, 616;

625; GF 201

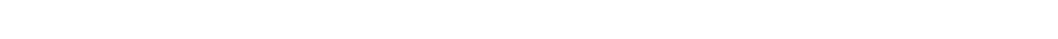
springs in $\ldots \ldots \ldots \ldots \ldots \ldots \ldots \ldots \ldots \ldots W 102,114,256$; B 32; GF 117, 201 water levels in $\ldots \ldots \ldots \ldots \ldots \ldots \ldots \ldots \ldots \ldots \ldots \ldots \ldots \ldots$ 908; $\$ 38,946,988$ water table in $\ldots \ldots \ldots \ldots \ldots \ldots \ldots \ldots \ldots \ldots \ldots \ldots \ldots \ldots \ldots .256 ; \mathbf{C} 303$ well records for $\ldots \ldots \ldots \ldots \ldots \ldots \ldots W 57,102,149,193,256 ; 1{ }^{\circ} 25 ;$ B 264, 298; GF 117, 201

wells in, construction of $\ldots \ldots \ldots \ldots \ldots \ldots \ldots \ldots \ldots \ldots \ldots$ W 256

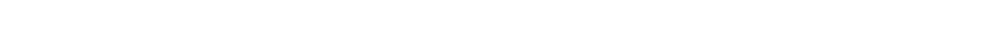
Miocene formations. See Tertiary; specific formations.

Miser, H. D., Asphalt deposits and oil conditions in southwestern

Arkansas $: \ldots \ldots \ldots \ldots \ldots \ldots \ldots \ldots \ldots \ldots \ldots \ldots \ldots \ldots \ldots \ldots \ldots \ldots \ldots$ b $69 \ldots$ Geologic structure of San Juan Canyon and adjacent country, Utah B 751 d Geology of the De Queen and Caddo Gap quadrangles, Ark ........B 808 Hot Spritigs folio, Ark ......................... 215 Manganese carbonate in the Batesville district, Ark .......... 921 a 
Miser, H D., Mineral resources of the Waynesboro quadrangle, Trnn. . . C 371 San Juan Canyon, southeastern Utah ................ W 538

Mississippi, areas, all of State $\ldots \ldots \ldots \ldots \ldots \ldots \ldots \ldots W$ 102, 114, 159, 576 areas, Camp McCain ........................ 192; J 346 Camp Shelby .......................... 194; J 346 Camp Van Dorn ........................ 193; J 346 George County ........................... 195 Hancock County ...................... 264. 298; C 195 Harrison County ...................... 298; C 195 Jackson County ....................... 264 298; C 195

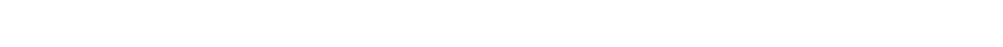

Marshall County ............................ 298

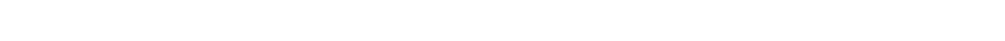

Panola County ............................. 298

Pearl River County .......................... 195

Stone County ........................... 195 western ................................. 46 artesian water in ..................W 159, 576; C 191; J 221 bibliography of ground water in...............W 114, 120, 163 mineral waters in $\ldots \ldots \ldots \ldots \ldots \ldots \ldots \ldots$ W 114, 576; B 32; MR 1883-1923 public water supplies in ...................... 576 quality of ground water in ........W 159, 364, 576; P 46; B 32; C 192 quantity of ground water in $\ldots \ldots \ldots \ldots \ldots \ldots \ldots \ldots \ldots \ldots$ C 192, 193, 194

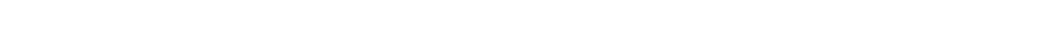
springs in $\ldots \ldots \ldots \ldots \ldots \ldots \ldots \ldots \ldots \ldots \ldots \ldots \ldots \ldots$ 114, 576; $B$ 32 temperature of ground water in ..................... 576 water levels in $\ldots \ldots \ldots \ldots \ldots \ldots \ldots \ldots \ldots \ldots$ 845, 886, 907, 937, 945, 987 water table in ....................... 159, 576; C 191; D 124 well records for .........W 102, 149, 159, 576; P 46; B 264, 298; C 195 Mississippian formations. See Carboniferous; specific formations.

Missouri, areas, all of State $\ldots \ldots \ldots \ldots \ldots \ldots \ldots \ldots \ldots \ldots \ldots$ 102, 114, 195 areas, Camden County .............................W 110

Joplin district $\ldots \ldots \ldots \ldots \ldots \ldots \ldots \ldots \ldots \ldots \ldots \ldots$ W 102, 145; GF 148

Leavenworth quadrangle $\ldots \ldots \ldots \ldots \ldots \ldots \ldots \ldots \ldots \ldots \ldots$ GF 206

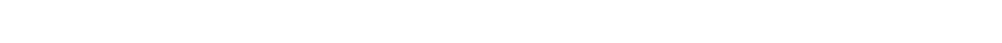

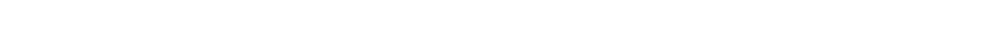

Randolph County ........................... 264

St. Louis quadrangle $\ldots \ldots \ldots \ldots \ldots \ldots \ldots \ldots \ldots \ldots \ldots \ldots \ldots \ldots$

Smithville quadrangle $\ldots \ldots \ldots \ldots \ldots \ldots \ldots \ldots \ldots \ldots \ldots$ GF 206 artesian water in ................... 195; B 438; GF 148 bibliography of ground water in..........W 57, 120, 149, 163, 340 mineral waters in .............W 195; B 32; MR 1883-1923; GF 206 public water supplies in ..................W 195; GF 148 quality of ground water in.....W 102, 145, 195, 364; B 32, 330, 438, 491, 606,616 ; GF 206 salt water in $\ldots \ldots \ldots \ldots \ldots \ldots \ldots \ldots \ldots \ldots \ldots \ldots \ldots \ldots \ldots \ldots \ldots$ GF 206 spring discharge measurements in...W 99, 131, 173, 209, 526, 547, 566, $567,586,587,606,607,626,627,646,647,667,686,687 ; 7\urcorner 1 ; 702,716$, $717,731,732,746,747,761,762,786,787,806,807,826,827,856$, $857,876,877,896,897,95$ T, 977; C 200 
Missouri, springs in...W 102, 110, 114, 145, 195, 364, 557; B 32, 438; GF 148, 206; C 200 water levels in $\ldots \ldots \ldots \ldots \ldots W 777,817,840,845,886,908,938,946,988$

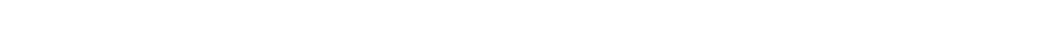
well records for ..............W 57, 102, 149, 195; B 214, 298, 438

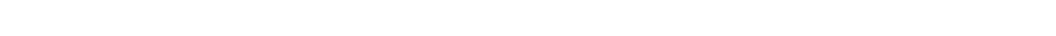

Missouri group, water in, in Iowa ..................... 293

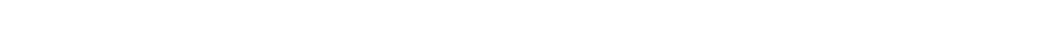

Mitchell, Alexander, Water supply for the State Penitentiary, Lansing, Kans. C 143

Moenkopi formation, water in, in Arizona $\ldots \ldots \ldots \ldots \ldots \ldots \ldots$ W $836 \mathrm{~b}$ Moffit, $F_{2} \cdot H .$, Iniskin Bay district, Alaska .................... 739 c Iniskin-Chinitna Peninsula and Snug Harbor district, Alaska . . . . . B 789

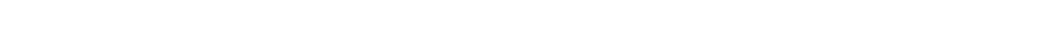
Molecular attraction in relation to ground water $\ldots \ldots \ldots \ldots \ldots V^{r} 489 ; M 47$ Monmouth formation, water in, in Delaware .................FF 137

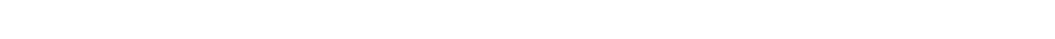

in New Jersey .......................... 106

in Pennsylvania ......................... 106

Monroe formation, water in, in Michigan ............ 30, 115

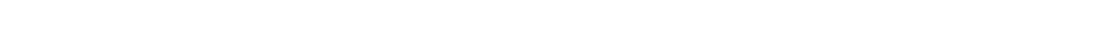
areas, Big Horn County .......................... 856

Butte and vicinity .......................... $345 \mathrm{~g}$

Cat Creek oil field ............................ 786 b

Crow Indian Reservation ..................... 736 b, 856

Devils Basin oil field ......................... 786 b

Ekalaka lignite field $\ldots \ldots \ldots \ldots \ldots \ldots \ldots \ldots \ldots \ldots \ldots \ldots$. 751 f

Flathead County .....................W 400 b; B 298

Flathead Lake $\ldots \ldots \ldots \ldots \ldots \ldots \ldots \ldots \ldots \ldots \ldots \ldots \ldots$ W 849 b

Fort Benton quadrangle ......................FF 55

Golden Valley County .....................W 518

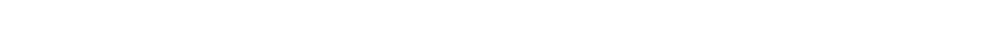

Ingomar anticline .......................... 786 a

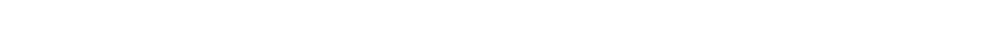

Little Belt Mountain quadrangle .................GF 56

Little Bitterroot Valley .....................W 400 b

McCone County ............................. 905

Missouri Valley $\ldots \ldots \ldots \ldots \ldots \ldots \ldots \ldots \ldots \ldots \ldots \ldots \ldots \ldots \ldots$

Mizpah coal field ......................... 906 c

Musselshell County ..................W 518; B 647

Rosebud coal field ....................... 847 b

Rosebud County .......................W 550 d; 600

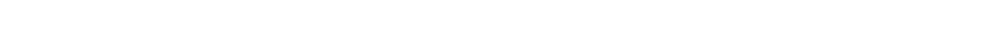

southeastern $\ldots \ldots \ldots \ldots \ldots \ldots \ldots \ldots \ldots \ldots \ldots \ldots \ldots \ldots \ldots \ldots$ P 32

Three Forks quadrangle $\ldots \ldots \ldots \ldots \ldots \ldots \ldots \ldots \ldots \ldots \ldots$ GF 24

Townsend Valley $\ldots \ldots \ldots \ldots \ldots \ldots \ldots \ldots \ldots \ldots \ldots \ldots \ldots \ldots \ldots$ W 539

Treasure County $\ldots \ldots \ldots \ldots \ldots \ldots \ldots \ldots \ldots \ldots \ldots \ldots \ldots \ldots$ W 599

Tullock Creek coal field ....................... 749

Yellowstone County ....................W 599; B 647

artesian water in ...W 149, 221, $345 \mathrm{~g}, 400 \mathrm{~b}, 518,539,599,600$; B 646, 647,751 g, 806 b, 822 a, 831 b, 847 b; GF E5, 128; J 39

bibliography of ground water in $\ldots \ldots \ldots \ldots \ldots \ldots \ldots \ldots \ldots$ 120, 163 
Montana, irrigation with artesian water in ........... $400 \mathrm{~b}, 599$ with other ground water in ............W $345 \mathrm{~g}, 400 \mathrm{~b}, \mathbf{- 5 9 9}$ mineral waters in ............... 32; MR 1883-192s: GF 24, 56 public water supplies in $\ldots \ldots \ldots \ldots \ldots \ldots \ldots \ldots \ldots$ W $345 \mathrm{~g}, 539,599,600$ quality of ground water in ...W 221, $345 \mathrm{~g}, 364,400 \mathrm{~b}, 518520 \mathrm{~d}, 539$, 560 b, 599, 600; B 32, 529, 606; GF 56; D 2; J 275 quantity of ground water in ....................W $345 \mathrm{~g}$ salt water in $\ldots \ldots \ldots \ldots \ldots \ldots \ldots \ldots \ldots \ldots$ B $691 \mathrm{~d}, 711 \mathrm{~g}, 751 \mathrm{c}, \mathrm{g}, 812 \mathrm{~b}$ spring discharge measurements in ...............W 130, 326 springs in ...W 221, 364, 400 b, 518, 539, 557, 599, 600, 679 b; P 78, 147 b; B 32, 749, 751 c, e, g, 786 a, 806 b, 812 a, 822 a, 831 b 847 b, 856;

GF 24, 56

thermal W $364,400 \mathrm{~b}, 679 \mathrm{l}$; GF 24,56 temperature of ground water in ..........W $400 \mathrm{~b}$; B 3 $3^{?}$; GF 24, 56 water levels in $\ldots \ldots \ldots \ldots \ldots \ldots \ldots$ W $777,817,840,845,886,910,940,990$ water table in .............W $345 \mathrm{~g}, 539,599,600,849$ b; D 2 well records for ...W 57, 149, 221, $345 \mathrm{~g}, 400 \mathrm{~b}, 518,539,599,600$; B 264, $298,691 \mathrm{~d}, 711 \mathrm{~g}, 751 \mathrm{c}, 786 \mathrm{~b}, 80$ f b, e, $812 \mathrm{~b}$

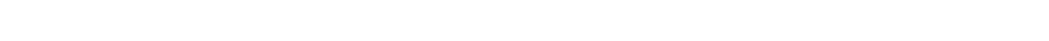

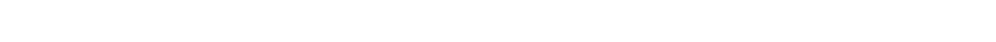

Moore, R. B., Radioactivity of thermal waters of Yellowstone National

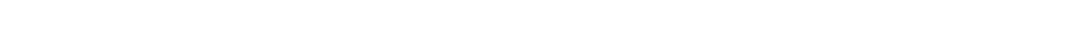

Moore, R. C., Ground-water resources of Kansas ............. 142

Kaiparowits region, Utah and Arizona ................P 164

Morgan, A. M., Changes in water levels in shallow wells in the

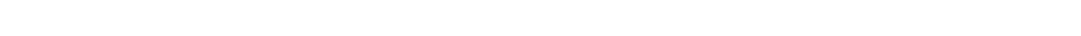
Changes in water levels in shallow wells near Roswell, N. Mex ...D 113 Cooperative ground-water investigations in Wyoming .....C 455, 456 Geology and ground water, Pecos River Basin, N. Mex ......... 256 Geology and shallow-water resources of the Roswell artesian basin,

N. Mex ............................... 252

Shallow-water resources of the Roswell artesian basin, N. Mex ....D 105 Solution by ground waters in Pecos Valley, N. Mex ...........J 245 Solution phenomena in the Pecos basin, N. Mex ............J 260 Water levels and artesian pressure in the United States ....W 840, 845, $886,948,990$

Morocco, ground water in, bibliography of $\ldots \ldots \ldots \ldots \ldots \ldots \ldots \ldots$ W 163

Morrison, R. B., Dunrin-Virden Valley, Greenlee County, Ariz., and

Hidalgo County, N. Mex ......................... 17

Electrical resistivity apparatus for testing well waters ........J 226 Ground-water resources of the Big Sandy Valley, Ariz ...... C 12; D 140 Records of wells and springs in Big Sandy Valley,

Mohave County, Ariz ........................ 13

Safford Valley, Graham County, Ariz., records of wells and springs. .C 16 Water resources of Safford and Duncan-Virden Valleys, Arjz. and

N. Mex .............................. 15; D 160

Morrison formation, water in-

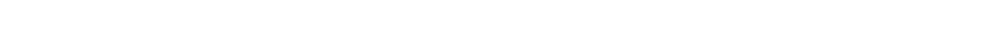

Colorado $\ldots \ldots \ldots \ldots \ldots \ldots \ldots \ldots \ldots \ldots \ldots \ldots \ldots \ldots \ldots \ldots \ldots$. 62

Montana .........................W 599; B 586

New Mexico ...............................W 620 
Morrison formation, water in, South Dakota GFi 107

Wyoming B $7111 ; \mathrm{GF} 107$

Morrow formation, water in, in Arkansas .............W 14F; GF 122 water in, in Oklahoma ............................ 122

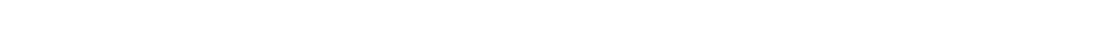

Mossom, Stuart, Geology of Florida .................... 55

Moulton, G. F., Geology and mineral resources of parts of Carbon,

Big Horn, Yellowstone, and Stillwater Counties, Mont .......... 822 a Geology of Big Horn County and the Crow Indian Reservation, Mont.B 856 Oil and gas fields of the Lost Soldier-Ferris district, Wyo ....... 756 Mounds produced by springs ................. 277, 320, 423 Mount Selman formation, water in, in Texas ...W 335, $375 \mathrm{~g} ; 6$ 6\% $849 \mathrm{a}$; C 407, 417; D 19

Movements of fluids through rigid media $\ldots \ldots \ldots \ldots \ldots \ldots \ldots \ldots$. 19 II b Movements of ground water-

Alaska $: \ldots \ldots \ldots \ldots \ldots \ldots \ldots \ldots \ldots \ldots \ldots \ldots \ldots \ldots \ldots \ldots$ B 733

Arizona .................W 104, 136, 320, 375; C 15, 20; J 279

belts of cementation and of weathering ................M 47

California .....................W 112; 140, 7en; B 835

capillary pores $\ldots \ldots \ldots \ldots \ldots \ldots \ldots \ldots \ldots$. W 489, 494; A 19 й b; M 47 Colorado ............................. 27; C 31 crystalline rocks $\ldots \ldots \ldots \ldots \ldots \ldots \ldots \ldots \ldots \ldots \ldots \ldots \ldots \ldots \ldots$ 160, 232 debris-filled valleys ......W 222, $277,320,345 \mathrm{~h}, 398,400$ e, 423, $637 \mathrm{~b}$ deep zones ..................W 67, 254; M 47; B 529; J 83 granite $\ldots \ldots \ldots \ldots \ldots \ldots \ldots \ldots \ldots \ldots \ldots \ldots \ldots \ldots$ 160, 232 : GF 158 Hawaii $\ldots \ldots \ldots \ldots \ldots \ldots \ldots \ldots \ldots \ldots \ldots \ldots \ldots \ldots \ldots \ldots$ W 616; C 92, 99

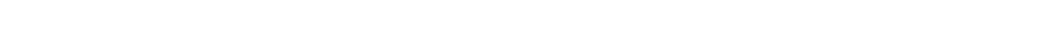

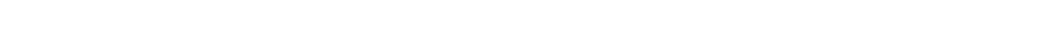

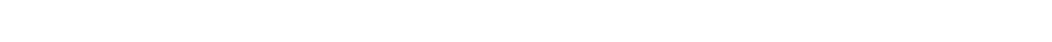

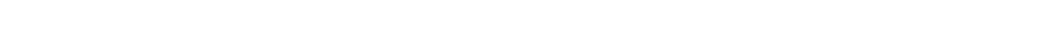

Montana ................................... 600

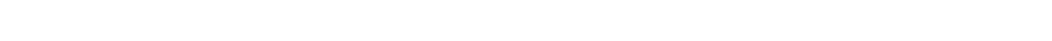

New Mexico ......W 141, 158, 275, 343; B 618, 637 b; C 31, 254, 255

New York .............................W 140; P 44

North Carolina ............................... 291

shallow zones .........................W 254; B 599; C 451

subcapillary pores $\ldots \ldots \ldots \ldots \ldots \ldots \ldots \ldots \ldots \ldots \ldots \ldots \ldots$ W 489,494; M 47

super-capillary openings $\ldots \ldots \ldots \ldots \ldots \ldots \ldots \ldots \ldots \ldots \ldots$ W 489,494; M 47

Texas ............................... 141; J 117

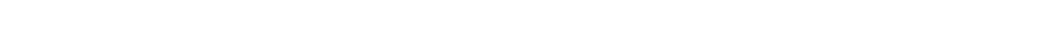

Virginia .............................. 431

Movements of ground water, absence of $\ldots \ldots \ldots \ldots \ldots \ldots \ldots$ B 529; C 431

artesian $\ldots \ldots \ldots \ldots \ldots \ldots \ldots \ldots \ldots \ldots \ldots \ldots \ldots \ldots \ldots \ldots$ (n6; J 86

ascending ....................... 47; J.133, 144; 159, 194

barometric conditions in relation to ................ 19 in b

bibliography of $\ldots \ldots \ldots \ldots \ldots \ldots \ldots \ldots \ldots \ldots \ldots \ldots \ldots \ldots \ldots$ Ir $\mathrm{c}$

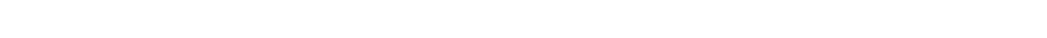

deformation of rocks in relation to ................ 19 II b descending $\ldots \ldots \ldots \ldots \ldots \ldots \ldots . . \ldots 47$; 73, 74, 114, 131, 133, 144, 159, 194 diagrams showing ................W 67, 232; M 47; B 606 direction of $\ldots \ldots \ldots \ldots \ldots \ldots \ldots \ldots W$ 67, 114, 140, 184, 345 $h$; $A$ ig II b dynamic changes in relation to .................. 19 II b 
Movements of ground water, faults in relation to...........W $345 \mathrm{~h}$ fissures in relation to ............... W 160, 232; A 19 II b fluorescein method of determining $\ldots \ldots \ldots \ldots \ldots \ldots \ldots W$ 160, 638 c; D 1 friction of rocks in relation to .............. 19 II b; M 47 general ...........J 133, 144, 159, 194, 219, 220, 230 236, 255, 268 law of $\ldots \ldots \ldots \ldots \ldots \ldots \ldots \ldots \ldots \ldots \ldots \ldots$ W 67,$140 ; A .19$ In c; M 47 measurements of $. . W 110,112,140,141,153,184,258,637 \mathrm{~b}, 638 \mathrm{c} ; \mathrm{P} 44$ chloride method ....................W 67, $637 \mathrm{~b}, 638$ c electrolytic methed $\ldots \ldots . W$ W 67, 110, 112, 140, 638 c, 887; P 44; J 194 fluorescein method $\ldots \ldots \ldots \ldots \ldots \ldots \ldots \ldots \ldots \ldots \ldots \ldots$ W 160, 638 c molecular attraction in relation to $\ldots \ldots \ldots \ldots \ldots \ldots \ldots \ldots . . .648 ; M 47$ precipitation in relation to $\ldots \ldots \ldots \ldots \ldots \ldots \ldots \ldots \ldots \ldots \ldots$ pressure in relation to .............W 67, 140; A 19 II b; M 47 principles of ..W 67, 114, 140, 232, 494; A 19 II c, 21 IV c; M 47; B 606 rate of $\ldots W 67,112,140,141,153,159,184,258,597$ b; A 16 n f, 19 In b; M 47; P 44; C 431

rock consolidation in relation to $\ldots \ldots \ldots \ldots \ldots \ldots \ldots \ldots \ldots . \ldots \ldots$ II $\mathrm{b}$ salines in Louisiana and Texas in relation to ............... 282 seepage from reservoirs in relation to $\ldots \ldots \ldots \ldots \ldots \ldots \ldots \ldots . . . \ldots 44$ settling of sediments in relation to $\ldots \ldots \ldots \ldots \ldots \ldots \ldots \ldots .19 \mathrm{n}$ b size of grain in relation to $\ldots \ldots \ldots \ldots \ldots \ldots \ldots W 67,104,136 ; A$ A 19 in b temperature in relation to $\ldots \ldots \ldots \ldots \ldots \ldots \ldots \ldots$. W 140; A 19 In b

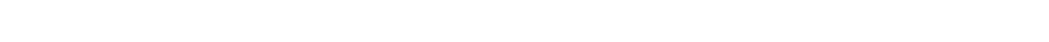

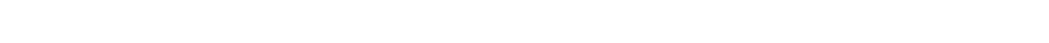

Mud flow, water perched by $\ldots \ldots \ldots \ldots \ldots \ldots \ldots \ldots \ldots \ldots \ldots \ldots \ldots \ldots$

Mundorff, M. J., Ground-water problems in North Carolina .........J 334

Selected well $\operatorname{logs}$ in the Coastal Plain of North Carolina ....... 293

Water levels and artesian pressure in the United States ...W 945, 987

Municipal water supplies. See Public water súpplies.

Munyan, A. C., Water levels and artesian pressure in the United

States ............................ 845, 907

Murphy, E. C., The windmill, its efficieney and economic use .....W 41, 42

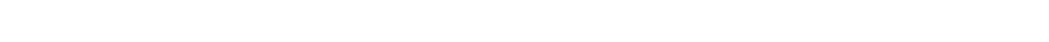

Murray, C. R., Test wells for irrigation near Deming, N. Mex . . . . . . D 159

Water levels and artesian pressure in the United States ...W 911, 941,

949,991

Myrick formation, water in, in Texas ............W 375 g; GF 64

$\mathbf{N}$

Nacatoch formation, water in, in Arkansas .........W 114; P 46; B 691 j

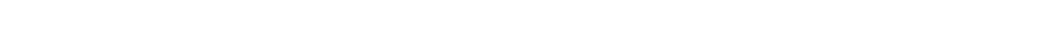

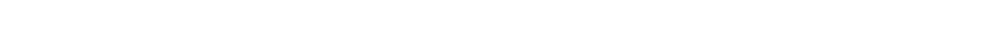

Nace, R. L., Ground-water investigations in West Virginia . . C 448, J 251, 256

Water levels and artesian pressure in the United States, 1.941 .WW 937

Nanafalia formation, water in, in Alabama ............... 1

Napoleon sandstone, water in, in Michigan $\ldots \ldots \ldots \ldots \ldots \ldots \ldots$ 30, 114

Nashua marl, water in, in Florida .................. 319

Natural gas in relation to ground water $\ldots \ldots \ldots \ldots \ldots \ldots \ldots \ldots \ldots$ B 658

Navarro formation, water in, in Texas $\ldots \ldots \ldots \ldots \ldots \ldots \ldots \ldots \ldots \ldots \ldots$ 
Nebraska, areas, all of State .......................P 32; C 201 areas, Box Butte County ......................W 969; D 162

Camp Clark quadrangle $\ldots \ldots \ldots \ldots, \ldots \ldots \ldots \ldots \ldots \ldots \ldots \ldots$ GF 87

Edgemont quadrangle $\ldots \ldots \ldots \ldots \ldots \ldots \ldots \ldots \ldots \ldots \ldots \ldots$ GF 108

Eilk Point quadrangle $\ldots \ldots, \ldots \ldots \ldots, \ldots, \ldots \ldots \ldots, \ldots \ldots \ldots \ldots$ GF 156

Franklin County $\ldots \ldots \ldots \ldots \ldots \ldots \ldots \ldots \ldots \ldots \ldots \ldots \ldots \ldots$ C 802

Frontier County ................................... 204

Furnas County $\ldots \ldots \ldots \ldots \ldots \ldots \ldots \ldots \ldots \ldots \ldots \ldots \ldots \ldots \ldots \ldots \ldots$

Goshen Hole quadrangle $\ldots \ldots \ldots \ldots \ldots \ldots \ldots \ldots \ldots \ldots \ldots$ W 70

Grand Island $\ldots \ldots \ldots \ldots \ldots \ldots \ldots \ldots \ldots \ldots \ldots \ldots \ldots \ldots \ldots \ldots$ W 836 e

Harlan County ............................... 202

Kearney and vicinity $\ldots \ldots \ldots \ldots \ldots \ldots \ldots \ldots \ldots \ldots$ A 21 iv a

Keith County ...............................W 848

Lincoln and vicinity $\ldots \ldots \ldots \ldots \ldots \ldots \ldots \ldots \ldots \ldots \ldots \ldots, \mathbf{P} 32$

Lodgepole Valley ............................. 425 b

Missouri River Valley ............................W 215

northeastern ..................................W 215

Nuckolls County ................................. 202

Oelrichs quadrangle $\ldots \ldots \ldots \ldots \ldots \ldots \ldots \ldots \ldots \ldots \ldots \ldots$ GF 85

Omaha and vicinity ..............W 293; A 19 Iv c; P 17, 32

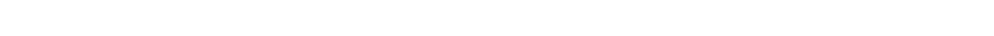

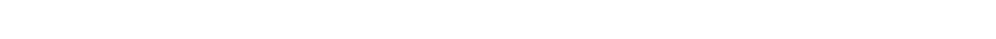

Platte River Valley ......W 679 a, 779, 848; A 21 tv a; D 49, 58; J 75

Red Willow County ............................. 204

Republican River Valley ................W 216; $\mathrm{C}$ 2n2, 203, 204

Scotts Bluff County .......................W 943; D 163

Scotts Bluff quadrangle $\ldots \ldots \ldots \ldots \ldots \ldots \ldots \ldots \ldots \ldots$ GF 88

South Platte Valley ...........................W 184

south-central $\ldots \ldots \ldots \ldots \ldots \ldots \ldots \ldots \ldots \ldots \ldots \ldots \ldots$ W $779 ;$ D 64

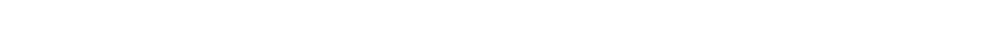

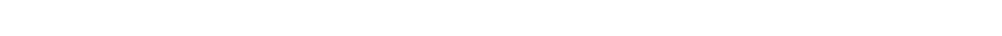

southwestern .....................A 16 II.f, 21 iv c, 22 Iv c

Webster County ............................... 202

west of $103 d$ meridian ..............A 19 Iv c; P 17; J 229

artesian water in ....W 12, 29, 184, 215, 216, 425 b; A 16 II $f, 19$ iv c;

P 17, 32; GF 85, 87, 88, 108, 156

bibliography of ground water in $\ldots \ldots \ldots \ldots \ldots \ldots$ W $61,120,149,163$

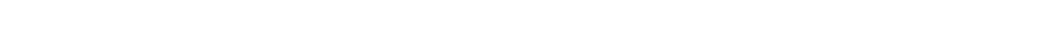
irrigation with ground water in ...W 5, 12, 29, 184, 216, 425 b; A 16 II e, f, 19 Iv c, 21 Iv c, 22 IV c; P 17; C 2^5; J 75, 267 mineral waters in ...................... 32; MR 1905-1923 public water supplies in ..................W 184, $425 \mathrm{~b}, 836$ e

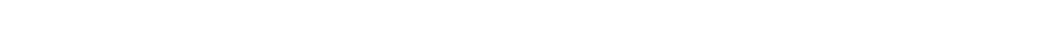
quality of ground water in ...W 12, 29, 184, 215, 216, $425 \mathrm{~b}, 818,943,969$;

P.32; GF 108 quantity of ground water in $\ldots \ldots \ldots \ldots \ldots \ldots \ldots W$ W 184, $679 \mathrm{a} ; \mathrm{D} 64,163$

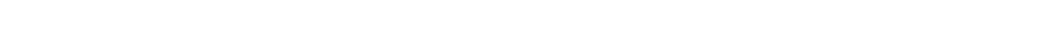

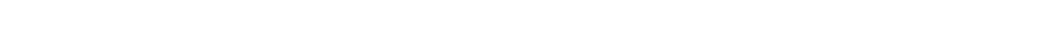
sheet water in $\ldots \ldots \ldots \ldots \ldots \ldots \ldots \ldots \ldots \ldots \ldots \ldots$ W 29; A 16 In $f$ springs in ...W 12, 39, 70, 184, 230; A 16 II f, $19 \mathrm{IV}$ c; P 17; B 32; GF

temperature of ground water in $\ldots \ldots, \ldots, \ldots, \ldots, \ldots, \ldots, 215 ;$ B 32 
Nebraska, underflow measurements in .....................W 184 water levels in $\ldots \ldots \ldots \ldots \ldots$ W 777, 817, 840, 845, 886, 908, 938, 946, 988 water table in ...W 12, 29, 184, 425 b, 772, 820; 848; A 21 IV a; C 201;

D 49, 58; J 101, 129, 154, 229 well records for. . W 12, 29, 61, 149, 215, 216, $425 \mathrm{~b}, 848,943$, 969; A 16 II $\mathrm{f}$; P 32; B 131, 264, 298, 691 a; GF 88, 108, 156; C 202, 203, 204, 205 wells in, construction of $\ldots \ldots \ldots \ldots \ldots \ldots \ldots \ldots$ W 184, 215. 258, 425 b

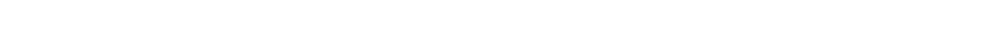

Nellist, J. F., Flowing wells and municipal water supplies in the southern portion of the southern peninsula of Michigan ...............W 182

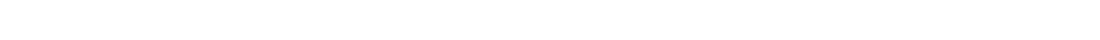
areas, Big Smoky Valley .....................W $375 \mathrm{~d}, 423$

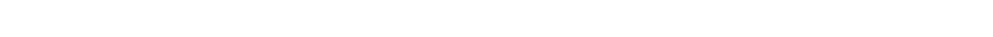
Columbus Marsh ...................... 95 a; B $540 \mathrm{n}$

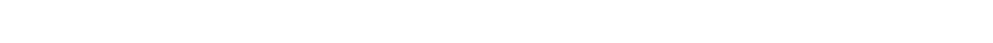

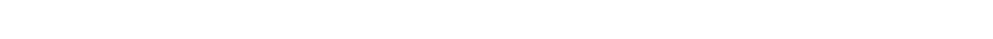

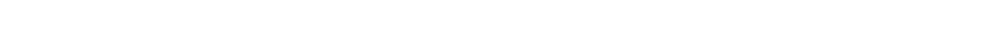

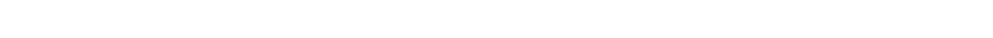
Goodsprings quadrangle $\ldots \ldots \ldots \ldots \ldots \ldots \ldots \ldots \ldots \ldots \ldots \ldots, \ldots \ldots \ldots$ Humboldt River Valley $\ldots \ldots \ldots \ldots \ldots \ldots \ldots \ldots \ldots \ldots \ldots \ldots$ W $425 \mathrm{~d}$

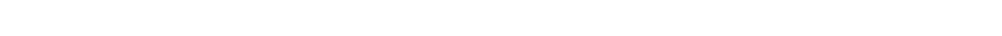
Las Vegas and vicinity ...........W 289, 365, $489 \mathrm{~d}$; P 871; C 208 Manhattan district .............................. $\mathbf{7 2 3}$ Mesquite Valley $\ldots \ldots \ldots \ldots \ldots \ldots \ldots \ldots \ldots \ldots \ldots \ldots \ldots$ W 450 c Pahrump Valley..$\ldots \ldots \ldots \ldots \ldots \ldots \ldots \ldots \ldots \ldots \ldots \ldots \ldots$ W 450 c

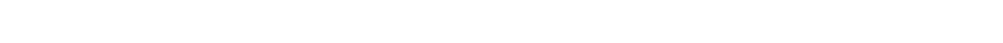

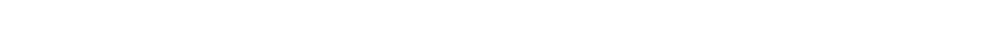

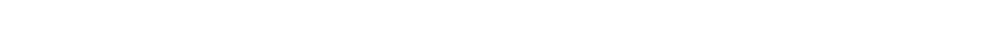
Quinn River Valley $\ldots \ldots \ldots \ldots \ldots \ldots \ldots \ldots \ldots \ldots \ldots \ldots \ldots \ldots \ldots \ldots$ Railroad Valley ........................W 365; B 540 p

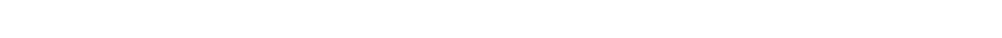
Rochester district $\ldots \ldots \ldots \ldots \ldots \ldots \ldots \ldots \ldots \ldots \ldots \ldots \ldots, \ldots \ldots \ldots$ Searchlight $\ldots \ldots \ldots \ldots \ldots \ldots \ldots \ldots \ldots \ldots \ldots \ldots \ldots \ldots \ldots \ldots \ldots, \ldots \ldots$

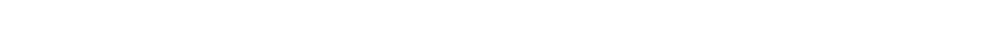
south-central $\ldots \ldots \ldots \ldots \ldots \ldots \ldots \ldots \ldots \ldots \ldots \ldots$ W 224, 423; B 308

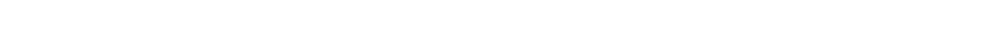
southern $\ldots \ldots \ldots \ldots \ldots \ldots \ldots \ldots \ldots \ldots \ldots \ldots \ldots$ W 224, 365; B 308

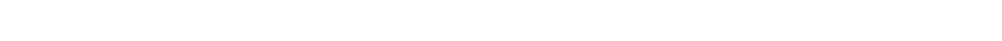
artesian water in ...W 289, 365, $375 \mathrm{~d}, 423,450 \mathrm{c}, 849 \mathrm{~d}$; B 871; C 208; D 4

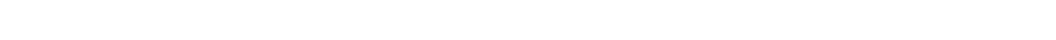
irrigation with artesian water in $\ldots \ldots \ldots \ldots \ldots \ldots \ldots$ W $375 \mathrm{~d}, \mathbf{4 2 3}, \mathbf{4 2 5} \mathrm{d}$ with other ground water in ..........W $365,375 \mathrm{~d}, 422,450 \mathrm{c}, 467$ mineral waters in ....................... 32; MR 1883-1923 public water supplies in $\ldots \ldots \ldots \ldots \ldots \ldots \ldots \ldots \ldots .6224,365,423,425 \mathrm{~d}$ pumping in ............................... $375 \mathrm{~d}, \mathbf{4 2 3}$ quality of ground water in ...W 224, 364, 365, $375 \mathrm{~d}, 423,425 \mathrm{~d}, 450 \mathrm{c}$, 467; P 95 a; B 32, 529, 530 r, 540 n, p, 606; C 208

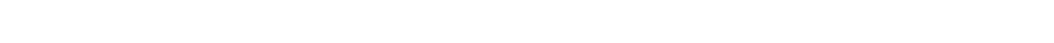
salt water in ...................W 423; B $530 \mathrm{r}, 54^{\wedge} \mathrm{n}, 669,717$ spring discharge measurements in....W 85, 133, 360, 389, 370, 440, 460; 
Nevada, springs in W 224, 364, 365, $375 \mathrm{~d}, 423,450 \mathrm{c}, 467,557,679 \mathrm{l} ; \mathrm{M} 11 ; \mathrm{P}$ $42,73,162,171$; B 32, 308, 723, 724, 725 d, 798; C 112; J 34, 107 thermal ...W 364, 365, 423, 467, 679 b; M 11; P 42, 73; F 308, 798; C 112; J 34, 107 temperature of ground water in .............W 365,$423 ; \mathrm{B} 32$ underground leakage from artesian wells in ..........W 844 d water table in ...............W 365, 423, 425 d, 467; P 162; C 208 well records for $\ldots \ldots \ldots \ldots W 61,149,224,365,423,450$ c, 467; P 95, 162;

B $530 \mathrm{r}, 540 \mathrm{n} ; \mathrm{C} 208$ wells in, construction of $\ldots \ldots \ldots \ldots \ldots \ldots \ldots \ldots \ldots \ldots$ W $375 \mathrm{~d}, 423$

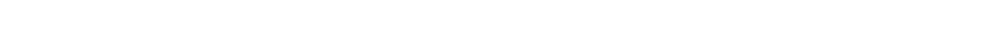

New Hampshire, areas, all of State ................W 102, 114 areas, Portsmouth-York region .................W 145 bibliography of ground water in $\ldots \ldots \ldots \ldots \ldots \ldots \ldots \ldots$ 114, 120, 163 mineral waters in ................... 32; MR 1883-1923 quality of ground water in $\ldots \ldots \ldots \ldots \ldots \ldots \ldots \ldots \ldots$ W 102; 144; B 32 springs in ........................W 102, 114; B 32

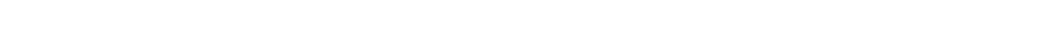
well records for $\ldots \ldots \ldots \ldots \ldots \ldots \ldots \ldots \ldots \ldots W 61,102,149 ;\urcorner 264,298$

New Jersey, areas, all of State ................... 114

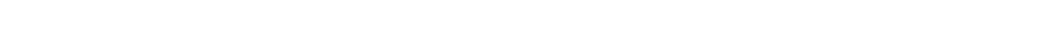

Atlantic City ...................... 212, 216; J 44

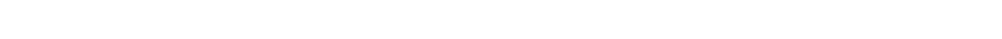

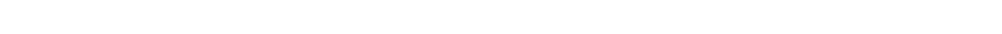

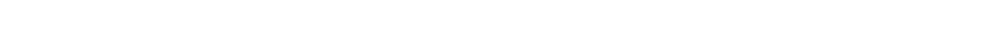

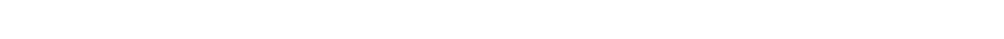

Franklin Furnace quadrangle ...................GF 161

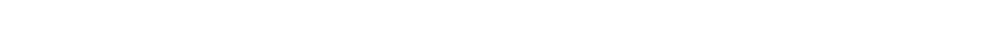

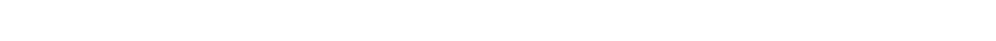

Monmouth County .....................F 264, 298

Parlin .......................... 217; J 228

Passaic quadrangle ........................FF 157

Passaic River Valley ........................ 214

Philadelphia district $\ldots \ldots \ldots \ldots \ldots \ldots \ldots \ldots \ldots \ldots$ W 106; GF 162

Raritan quadrangle $\ldots \ldots \ldots \ldots \ldots \ldots \ldots \ldots \ldots \ldots \ldots$ GF 191

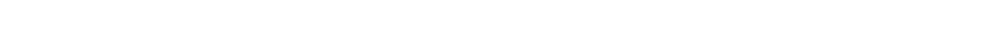

Trenton quadrangle $\ldots \ldots \ldots \ldots \ldots \ldots \ldots \ldots \ldots \ldots \ldots \ldots \ldots \ldots$ GF 167

Wilmington quadrangle ......................FF 211 artesian water in ..............W 106; B 138; GF 157, 162; J 44 bibliography of ground water in ..........W 61, 114, 120,149, 163

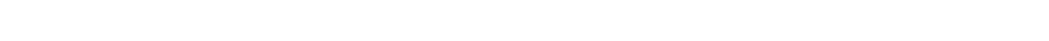
mineral waters in ...............W 114; B 32; MR 1883-1923 public water supplies in $\therefore W$ 106, 110, 374, 397; B 138; GF 162, 167; C 211, 212, 213, 214, 215, 216, 217, 218; J 32, 44 quality of ground water in ...W 258; B 32, 138; GF 191; C 211, 212, 213, $214,21 E .216,217$ quantity of ground water in ........... 211, 214, 215, 218; J 350 salt water in $\ldots \ldots \ldots \ldots \ldots \ldots \ldots \ldots \ldots W$ 258; D 151; J 140, 210, 228, 350 springs in $\ldots \ldots \ldots \ldots \ldots \ldots \ldots \ldots W$ 110, 114; $B$ 32; GF 161, 167, 191 water levels in $\ldots \ldots \ldots \ldots \ldots W$ 777, 817, 840, 845, 886, 906, 936.944, 986 water table in $\ldots \ldots \ldots \ldots \ldots \ldots \ldots \ldots \ldots \ldots \ldots \ldots \ldots . C$ 217; J 99, 151 
New Jersey, well records for.....W 61, 106, 114, 149; B 138, 294, 298, 727; GF $157,161,162 ; \mathrm{C} 214,215$

New Mexico, areas, Albuquerque district ..............W 188 areas, Animas Valley ...........................W 422

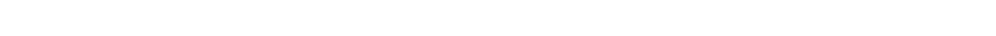

Brilliant quadrangle ...........................FF 214

Carlsbad irrigation project $\ldots \ldots \ldots \ldots \ldots \ldots \ldots \ldots \ldots \ldots$ W 580 a

central ............................... 260, 275

Curry County .............................. 241

De Baca County ............................ 234

Deming and vicinity ............W 345 c; B 618; GF 207; D 159

Duncan-Virden Valley ... W 911, 941; C 15, 17; D 146, 160, 171; J 240

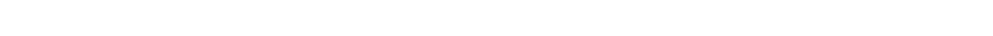

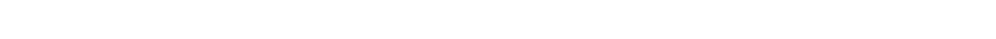

Encino Valley ............................. 275

Estancia Valley .........................W 260, 275

Gallup-Zuni basin ........................... 767

Grant County .............................. 422

Hachita Valley .............................W 422

Hidalgo County ......W 911, 941; C 14, 15, 17; D 146, 160, 171; J 240

Jornada del Muerto ...................... 123, 188

Koehler quadrangle ...........................FF 214

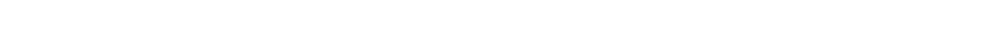

Lea County ..................... 239, 244, 247, 250

Lordsburg mining district ..................... 885

Luna County ...............W 345 c, 637 b; B 618; GF 207

Mesilla district $\ldots \ldots \ldots \ldots \ldots \ldots \ldots \ldots \ldots \ldots \ldots$ W 10, 140, 141, 188

Mimbres Valley ...W 345 c, 637 b; B 618; GF 207; C 237, 238, 243, 246,$251 ; \mathrm{D} 15,108$

Mount Taylor coal field ........................ 860 b

Navajo country ..........................W 380

northwestèn .....................W 380; B 435; D 68

Pecos River Valley ............W 158; C 248, 256, 2־7; J 245, 260

Pinos Wells Valley ........................W 275

Playas Valley ............................W 422

Portales Valley ................. 241, 245, 249; D 125, 149

Raton quadrangle ........................FF 214

Rio Grande Valley .......W 10, 140, 141, 188; C 31, 254, 255; J 173

Rio Penasco Basin ............................ 235

Roosevelt County ............................ 241

Roswell artesian basin ...W 158, 596 a, 639; C 231, 236, 240, 242, 252;

D $9,28,105,113,150$

San Jose-Rio Puerco Valley ................... 232

Can Juan County ........................ 716 g

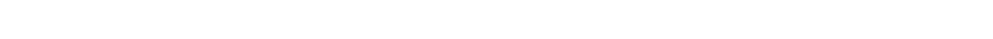

San Simon Valley .......................W 425 a

Sandoval County $\ldots \ldots \ldots \ldots \ldots \ldots \ldots \ldots \ldots \ldots \ldots \ldots \ldots$ W $620 ; \mathrm{D} 5$

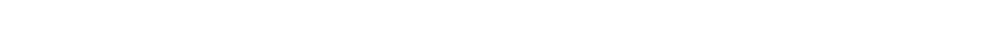

Silver City quadrangle ......................GF 199

Socorro County .......................... 233

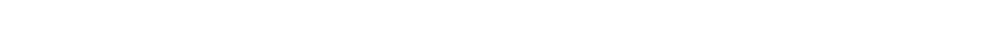

southeastern $\ldots \ldots \ldots \ldots \ldots \ldots \ldots \ldots \ldots \ldots \ldots \ldots \ldots \ldots \ldots \ldots \ldots$ B 760 , 780 
New Mexico, areas, southern $\ldots \ldots \ldots \ldots \ldots \ldots \ldots \ldots \ldots \ldots \ldots \ldots \ldots$ W 141 southwestern $\ldots \ldots \ldots \ldots \ldots \ldots \ldots \ldots \ldots \ldots \ldots \ldots \ldots$ W 422, 425 a

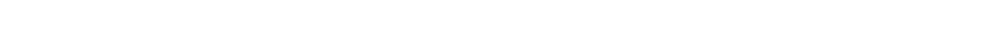
Torrance County .....................W 260, 275; B 298 Tularosa Basin ...............................W $\mathbf{3 4 3}$ Tyrone district $\ldots \ldots \ldots \ldots \ldots \ldots \ldots \ldots \ldots \ldots \ldots \ldots \ldots \ldots \ldots$ P 122 Vaughn and vicinity $\ldots \ldots \ldots \ldots \ldots \ldots \ldots \ldots \ldots \ldots \nabla^{\top} 275,343$ Virden Valley .......................... 15; D 160 artesian water in ...W 123, 158, 188, 343, 380, 422, 596 a, 620, 639; B 767; GF 199; C 231, 236, 240, 242, 248, 256; D 5, 9, 28; J 51 bibliography of ground water in $\ldots \ldots \ldots \ldots \ldots \ldots \ldots$ W $61,12 \uparrow .149,163$ infiltration ditches in $\ldots \ldots \ldots \ldots \ldots \ldots \ldots \ldots \ldots \ldots \ldots$ W $343 ;$ C 16 irrigation with artesan water ...W 158, 425 a, 620; C 231, 23f 240, 242 with other ground water in ...W 5, 10, 140,141,158, 188, 260, 275, 343,345 c, 380, 422, 425 a, 620, 637 b, 639, 911, 941; A $16 \mathrm{n} \mathrm{e,} 21$ IV c, 22 IV c; B 618 ; C 14, 15, 17, 235, 236, 237, 238, 239, 240, 241, $242,243,244,245,246,249,250,251,252,256$; D 146, 159, 160, $1.71 ; \mathrm{J} 240$ law relating to ground water in $\ldots \ldots \ldots \ldots \ldots \ldots \ldots \ldots W$ 152; J 69 mineral waters in ..................... 32; MR 1883-1.923; C 17 public water supplies in $\ldots \ldots \ldots \ldots \ldots \ldots \ldots \ldots \ldots \ldots$. 343, 422, 620 pumping in .......................... 10, 260, 275, 345 c pumping tests in ..............W 140, 141, 343, 345 c; B 618 ; C 15 quality of ground water in ...W 123, 158, 188, 260, 275, 343, 364. 422, 425 a, $620,639,839$; B 32, 330, 491, 616, 618, 620, 839; GF 207; C 14, 17, $235,239,240,241,243,244 ; \mathrm{J} 173$ quantity of ground water in ...W 141, 158, 188, 275, 343, $345 \mathrm{c}, 422,637 \mathrm{~b}$;

B 618; GF 207; C 231, 236, 237, 238, 239, 240, 241, 245, 246247,252 , $2 \div 6 ;$ D 160 salt water in .......W 275, 343, 620; B 669, $715 \mathrm{~m}$; C 248, 2־7; D 103 seepage in $\ldots \ldots \ldots \ldots \ldots \ldots \ldots \ldots \ldots \ldots \ldots \ldots \ldots \ldots W$ W $358 ; C$ C 15 springs in ......W 158, 188, 343, 364, 380, 557, 620, $637 \mathrm{~b}, 67 \mathrm{c}$ b; P 68; B $32,618,716$ a, 860 c; GF $199 ;$ C $235,253,257$ thermal ..............W 364, 620,679 b; P 68; B 32; GF 199 water levels in ......W 777, 817, 840, 845, 886, 911, 941, 949, 991; C 14 water table in ...W 10,188, 275, 343, $345 \mathrm{c}, 422,425$ a, $620,637 \mathrm{~b}$; B 618; GF 207; C 15, 237, 238, 240, 241, 242, 243, 244, 245, 246, 247, 249, 250, 251, 252, 254, 255, 256; D 105, 108, 113, 148, 149, 150, 176; J 206, 240 well records for ...W $61,149,158,188,275,343,345 \mathrm{c}, 380,620.637 \mathrm{~b}$; B $264,298,435,618,726$ e, 760 c, 780 b, 794; C 17, 235, 241, 24i, 252, 256 wells in, construction of $\ldots \ldots \ldots \ldots \ldots \ldots \ldots \ldots \ldots \ldots$. 343; C 240

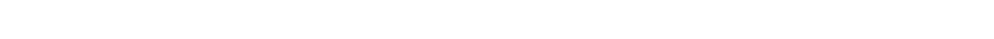

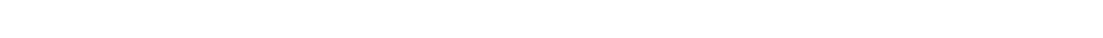
water in, in Minnesota ............................ 256 See also Lower Magnesian limestone.

New South Wales, bibliography of ground water in ............W 163 quality of ground water in $\ldots \ldots \ldots \ldots \ldots \ldots \ldots \ldots \ldots \ldots$ B 330, 491, 616

New York, areas, all of State ...................... areas, Catatonk quadrangle $\ldots \ldots \ldots \ldots \ldots \ldots \ldots \ldots \ldots$ W 145 ; GF 169

Coastal Plain ................................... 138

Croton Valley $\ldots \ldots \ldots \ldots \ldots \ldots \ldots \ldots \ldots \ldots \ldots \ldots \ldots \ldots \ldots \ldots$

Erio County $\ldots \ldots \ldots \ldots \ldots \ldots \ldots \ldots \ldots \ldots \ldots \ldots \ldots \ldots \ldots \ldots \ldots$ B 298 
New York areas, Gaines quadrangle $\ldots \ldots \ldots \ldots \ldots \ldots \ldots \ldots \ldots$, GF 92

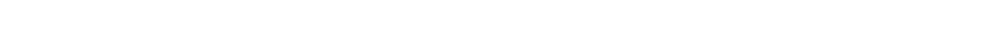

Kings County $\ldots \ldots \ldots \ldots \ldots \ldots \ldots \ldots \ldots \ldots \ldots \ldots \ldots \ldots \ldots \ldots \ldots \ldots \ldots \ldots, 275,279$ Long Island $\ldots W$ W 25, 110, 140, 155, 374, 397, 537; P 44; B 138; GF 138; C 271, 272, 274, 275, 276, 277, 278, 280; D 41, 92, 151, 199, $202 ; \mathrm{J} \mathrm{3}, 146,150,169,177,193,246,249,312,341$

Monroe County ............................... 273

Nassau County ............................. 277, 282

New York City .............................. 25; GF 83

Niagara quadrangle $\ldots \ldots \ldots \ldots \ldots \ldots \ldots \ldots \ldots \ldots \ldots \ldots$, GF 190

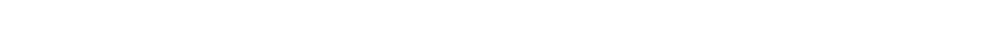

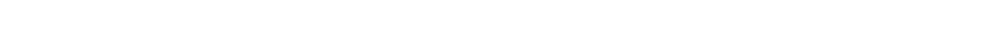

Shelter Island Heights ........................... 100

southwestern $\ldots \ldots \ldots \ldots \ldots \ldots \ldots \ldots \ldots \ldots \ldots \ldots \ldots \ldots \ldots \ldots$ B 899 b

Suffolk County $\ldots \ldots \ldots \ldots \ldots \ldots \ldots \ldots \ldots \ldots \ldots \ldots \ldots \ldots \ldots \ldots \ldots, 276,281$

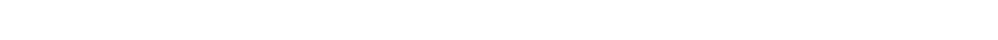

Ticonderoga quadrangle $\ldots \ldots \ldots \ldots \ldots \ldots \ldots \ldots \ldots \ldots \ldots$ W 110

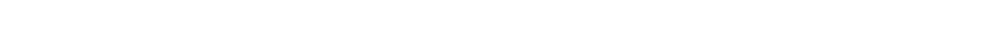

Watkins Glen quadrangle ...................W 110; GF 169 artesian water in ...W 110, 145; P 144; B 138; GF 169; C 273; J 3, 177 bibliogsaphy of ground water in $\ldots \ldots \ldots \ldots \ldots$ W 61,114, 120,149,163 industrial use of ground water in $\ldots \ldots \ldots \ldots \ldots \ldots \ldots \ldots$. 192, 202 laws relating to ground water in $\ldots \ldots \ldots \ldots \ldots \ldots \ldots \ldots$ W $152 ; \mathrm{J} 190$ artesian water in.....W 110, 145; P 44; B 138; GF 169; C 273; J 3, 177

GF $92,169,190$

public water supplies in....W 25, 110, 155, 374, 397; P 44; F 138; GF 83; 169,$190 ; \mathrm{C} 273,274 ; \mathrm{D} 41,100,192,202$

pumping in $\ldots \ldots \ldots \ldots \ldots \ldots \ldots \ldots \ldots \ldots \ldots \ldots \ldots \ldots$ D 192, 199, 202 quality of ground water in ...W 102, 108, 110, 144, 145, 364: P 44; B 32, $330,491,530$ b, 616; MR 1916; GF 190; C 273, 275, 276, 278 quantity of ground water in $\ldots \ldots \ldots \ldots . W$ W 25, 155; P 44; C 274; D 199 radioactive water in $\ldots \ldots \ldots \ldots \ldots \ldots \ldots \ldots \ldots \ldots$. 1913 II $\mathrm{h}$ salt water in ... B $^{\circ} 530$ b, 669, 899 a, b; C 271, 272; D 41, 100, 151; J 169 springs in ...W 102, 114, 145, 364, 679 b; P 44, 82; B 32; GF 169; C 273

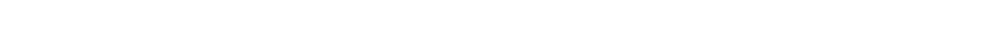
underflow on Long Island ................... 140, 155; P 44 water levels in $\ldots \ldots \ldots \ldots \ldots W$ W77, 817, 840, 845, 886, 906, 936, 944, 986 water table in ...W 155; P 44; C 273, 275, 276, 277, 278, 279, 280, 281, 282;

D 41; J 150, 177, 193, 194, 312, 341 well records for .. W 61, 102, 110, 149; P 44, 82; B 138, 264, 2rs, 669, 899 a; GF 157; C 273, 275, 276, 277, 278, 279, 280, 281, 282

New Zealand, bibliography of ground water in ......W. 163; B 330, 491, 616

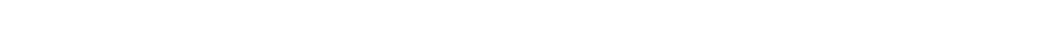
quality of ground water in $\ldots \ldots \ldots \ldots \ldots \ldots \ldots \ldots \ldots . .3330,491,616$

Newark horizon, water in, in Arkansas ...................W 145

Newark sandstone, water in, in Connecticut .........W 110, 114, 232, 374 water in, in New Jersey ............W 106; GF 167, 191; C 218

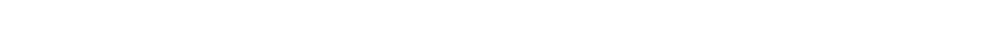

in Pennsylvania $\ldots \ldots \ldots \ldots$ W 106, 114; B 828, 891; GF 162, 167

Newell, F. H., Progress of stream measurements .......W 75, 84; A 21 Iv a Public lands and their water supply ..................A 16 II e Report of progress of the Division of Hydrography ......... 131, 140 
Newell, F. H., Water supply for irrigation $\ldots \ldots \ldots \ldots \ldots \ldots \ldots$ is in a Newell, T. R., Surface water supply of the United States, $1932 \ldots \ldots \ldots$ W 738 Newsom, J. F., Santa Cruz folio, Calif ....................F 163 Niagara limestone, water in-.

Illinois $\ldots \ldots \ldots \ldots \ldots \ldots \ldots \ldots \ldots \ldots \ldots$ W 114; B 506; GF 81, 200 Indiana $\ldots \ldots \ldots \ldots \ldots \ldots \ldots \ldots \ldots \ldots \ldots \ldots \ldots \ldots \ldots$ W $1113,114,254$ Iowa $\ldots \ldots \ldots \ldots \ldots \ldots \ldots \ldots \ldots \ldots \ldots \ldots \ldots$ W 293; GF 145, 200 Michigan ..................................... 30, 114 Ohio .........................W 114, 259; A 19 Iv b; B 661 a Wisconsin $\ldots \ldots \ldots \ldots \ldots \ldots \ldots \ldots \ldots \ldots \ldots \ldots$ W 114; GF 145; C 451

Nicaragua, bibliography of ground water in $\ldots \ldots \ldots \ldots \ldots \ldots \ldots \ldots$ W 163

Niobrara formation, water in, in Kansas ..................W 273 water in, in Nebraska ...................W 216; C 202, 204 in North Dakota ........................W 59?; C 302 in South Dakota ................W 227; GF 100, 1F6; C 302 Nitrate in ground water ......W 256, 338; B 47, 330, 491, 616; MR 1911 iI n

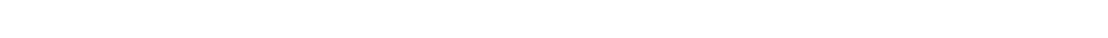
Noble, L. F., Nitrate deposits in the Amargosa region, southeastern

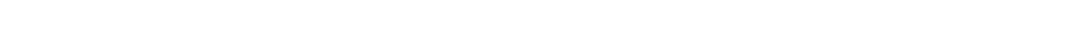

Nolan, T. B., Geyser area near Beowawe, Nev ................J 107

Good Hill mining district, Utah $\ldots \ldots \ldots \ldots \ldots \ldots \ldots \ldots \ldots \ldots \ldots \ldots \ldots \ldots$

Potash brines in Great Salt Lake Desert, Utah ............ 795 b

Normal carbonate in ground water ...W 254, 259, 273, 338, 341, 398; B 330,

Normal chloride. See Chloride; Isochlors. 491, 616; MR 1911 II, 1916

Norristown shale, water in, in New Jersey ................W 106 water in, in Pennsylvania ..........................W 106

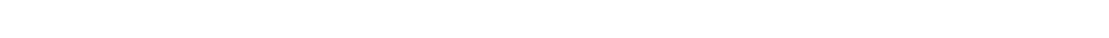
areas, Coastal Plain ...................... 138; C 291, 293

Cowee quadrangle $\ldots \ldots \ldots \ldots \ldots \ldots \ldots \ldots \ldots \ldots \ldots \ldots \ldots$ W 110

Elizabeth City $\ldots \ldots \ldots \ldots \ldots \ldots \ldots \ldots \ldots \ldots \ldots \ldots$ W 773 a; J 108

Fort Caswell .................................. 292

Gaffney quadrangle $\ldots \ldots \ldots \ldots \ldots \ldots \ldots \ldots \ldots \ldots \ldots$. GF 222

Kings Mountain quadrangle $\ldots \ldots \ldots \ldots \ldots \ldots \ldots \ldots \ldots$ GF 222

Lenoir County ............................... 298

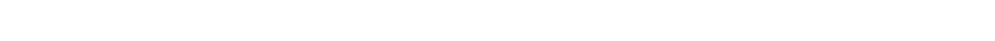

Mount Mitchell quadrangle .......................GF 124

New Hanover County $\ldots \ldots \ldots \ldots \ldots \ldots \ldots \ldots \ldots \ldots \ldots \ldots \ldots \ldots \ldots \ldots$

Norfolk quadrangle $\ldots \ldots \ldots \ldots \ldots \ldots \ldots \ldots \ldots \ldots \ldots \ldots$ GF 80

Nottely River Basin ........................... 735 f

Pisgah quadrangle $\ldots \ldots \ldots \ldots \ldots \ldots \ldots \ldots \ldots \ldots$ W 110; GF 147

Roan Mountain quadrangle $\ldots \ldots \ldots \ldots \ldots \ldots \ldots \ldots \ldots \ldots$ GF 151

Valley River Basin ........................... 735 f

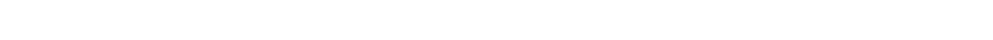
artesian water in $\ldots \ldots \ldots \ldots \ldots \ldots \ldots \ldots \ldots \ldots$. 138; GF 80; C 291 bibliography of ground water in .......W 61, 114, 120, 149, 163; C 291

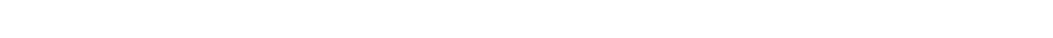
mineral waters in $\ldots \ldots \ldots \ldots \ldots \ldots \ldots \ldots \ldots$ W 114; B 32; MR 1883-1923 public water supplies in .................. 138; C 2؟1; J 108 quality of ground water in ...W 160, 258, 364; B 32, 138, 330, 491, 616; salt water in $\ldots \ldots \ldots \ldots \ldots \ldots \ldots \ldots \ldots \ldots \ldots . W 258,773$ a; J 108, 334 
North Carolina, spring discharge measurements in ............W 893 springs in ........W 114, 364, 679 b; B 32, 735 f; GF 124, 147, 151, 222 thermal .............................. 679 b water levels in $\ldots \ldots \ldots \ldots$ W $777,817,840,845,886,907,937,945,987$

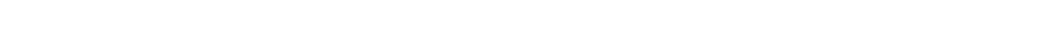
well records for ...W 61, 114, 149; B 138, 264, 298; GF 80, 124; C 291, 293

North Dakota, areas, all of State ......W 520 e, 598; A 11 II c; C 301; J 328 areas, Bismarck quadraingle $\ldots \ldots \ldots \ldots \ldots \ldots \ldots \ldots \ldots \ldots$ GF 181

Casselton-Fargo quadrangle ......................FF 117 eastern ......................... A 17 II g; M 25 Eckelson quadrangle ........................F 168 Edgeley quadrangle ...................W 520 e; B 801 Ellendale-Jamestown area ...................W 889 a Jàmes River Basin .......................... 302 Jamestown quadrangle $\ldots \ldots \ldots \ldots \ldots \ldots \ldots \ldots \ldots \ldots \ldots \ldots$ GF 168 La Moure quadrangle ........................... 801 Marmarth lignite field $\ldots \ldots \ldots \ldots \ldots \ldots \ldots \ldots \ldots \ldots \ldots \ldots \ldots \ldots$ Minot region ................................... $906 \mathrm{~b}$

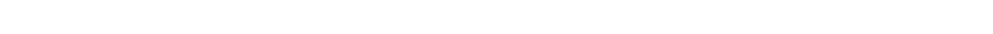

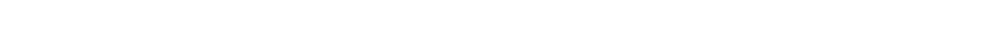

Red River Valley ...................... A 11 II c; M 25

Sheyenne River Basin ..................... 302 southeastern ......................... 17 II $\mathbf{g}$

Standing Rock Indian Reservation $\ldots \ldots \ldots \ldots \ldots \ldots \ldots \ldots$ B 575

Tower quadrangle .........................GF 168 artesian water in ..W 520 e, 598, 889 a; A 11 II c, 17 II g; M 25; B 575, $691 \mathrm{~g}, 775,801,960 \mathrm{~b}, \mathrm{c}$; GF 117, 168; C 301, 3C3; D 141; J 2 bibliography of ground water in ........W 61, 120, 149, 163; C 303 irrigation with artesian water in .........W 598; A 11 I c, 16 II e, 17

I $\mathrm{g} ; \mathrm{M} 25 ; \mathrm{C} 304$

with other ground water in $\ldots \ldots \ldots \ldots \ldots \ldots \ldots \ldots \ldots$ A 16 II e mineral waters ..................... 32; NR 1883-1923 public water supplies in . . . . . . . . . . . . . . . 598; C 302 quality of ground water in. W 520 e, 560 b, 598, 889 a; A 17 II g; M 25;

B 32; GF 168; C 301, 302

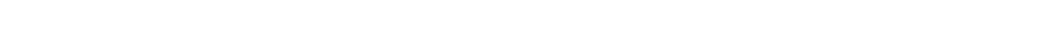
springs in .............W 598; B 32, 575, 726 d, 775. 801; GF 117 water levels in $\ldots \ldots \ldots \ldots \ldots \ldots \ldots$ W 817, 840, 845, 886, 908, 938, 946, 988 water table in ................ 302, 303; D 61, 109, 164; J 153 well records for....W 61, 149, $520 \mathrm{e}, 598$; A 17 II g; M 25; B 298, 801; GF $117,168,181 ; \mathrm{C} 302 ; \mathrm{J} 2$

wells in, construction of $\ldots \ldots \ldots \ldots \ldots \ldots \ldots \ldots \ldots \ldots \ldots \ldots \ldots \ldots$ W 598 cost of $\ldots \ldots \ldots \ldots \ldots \ldots \ldots \ldots \ldots \ldots \ldots \ldots \ldots \ldots \ldots \ldots \ldots$ II c

Norton, W. H., Underground water resources of Iowa.......W 293; C 137

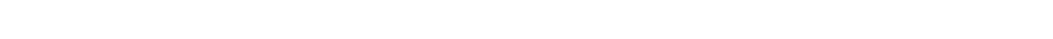

Water supplies at Waterloo, Iowa ................... 145

Nusbaum formation, water in, in Colorado ...................F 135

Nye, S. S., Geology and ground-water resources of Roswell artesian

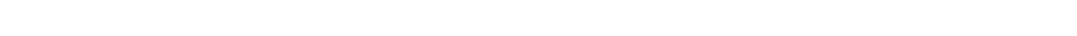

Geology and ground-water resources of the Balmorhea area, western

Texas ................................W 849 c

Ground-water resources of the Balmorhea area, Tex..........C 390 
Nye, S. S., Ground-water supply of northern Lea County, N. Mex . . . . . C 244 Roswell artesian basin, N. Mex .................. 236, 242

Shallow ground-water supplies in northern Lea County, N. Mex.... C 239 Utilization of the water resources of Roswell artesian basin, N. ITex.C 240

Water supply of the Roswell artesian basin, N. Mex...........D 28 Oakland, G. L., Oklahoma water, quantity, occurrence, and quality of

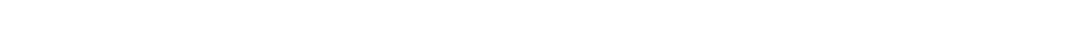
Oakville sandstone, water in, in Texas ..................W $375 \mathbf{g}$ Ocala limestone, water in, in Florida .... C.57, 58, 60, 61; D 143; J 80, 134, $137,181,185,248,25$ «. 319,321

water in, in Georgia ......................... 83; D 129 Occlusion of sea water. See Connate water.

Odor of ground water $\ldots \ldots \ldots \ldots \ldots \ldots \ldots \ldots \ldots \ldots \ldots \ldots \ldots \ldots \ldots$

Ogallala formation, water in-

Colorado .................................. 32

Kansas ................P 32; GF 212; C 141, 153, 154, 155, 158

Nebraska ........W 425 b, 848; A 19 IV e; P 17, 32; GF 87; C 202, 204

New Mexico ........................... 241, 256

Oklahoma .................C 321, 322; D 106, 115, 178; J 213

Texas ............................. 256; D 66; J 277

Wyoming ............................. 32 ; C 456

O'Harra, C. C., Aladdin folio, Wyo.-S. Dak.-Mont. ...............GF 128

Belle Fourche folio, S. Dak .......................... 164

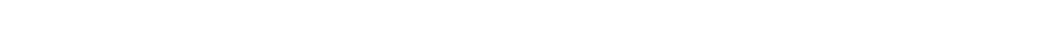

Ohio, areas, all of State .................W 114; A 18 IV b, 19 IV b

areas, Butler County ................... 311; D 120; J 215

Cincinnati area .............C 311; D 82, 88, 120, 156; J 215

Cleveland gas field ......................... 661 a

Columbus quadrangle ......................GF 197

Hamilton County .................. 311; D 120; J 215

Hocking County ........................... 298

Kenova quadrangle .........................FF 184

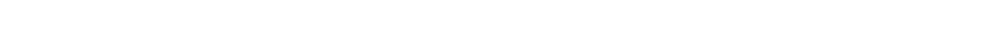

Miami drainage basin $\ldots \ldots \ldots \ldots \ldots \ldots \ldots \ldots \ldots \ldots \ldots$ W 91

Mill Creek Valley .............C 311, 312; D 87, 88, 120; J 215

Muskingum drainage basin $\ldots \ldots \ldots \ldots \ldots \ldots \ldots \ldots \ldots \ldots \ldots$ W 91

Norwood trough ................. 311; D 87,88, 120; J 215

Sandusky drainage basin ......................W 91

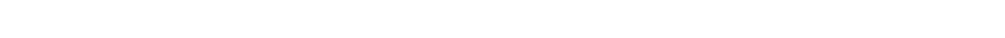

Summerfield quadrangle ........................ 720

Wayne County ............................. 298

Woodsfield quadrangle ........................ 720

artesian water in............W 114, 259; A 18 Iv b, 19 Iv b; GF 197 bibliography of ground water in...........W $61,114,12$ ? 149,163 mineral waters in..........W 114, 259; A 18 Iv b; B 32; MF. 1883-1923 public water supplies in. .W 91, 259; A 18 IV b, 19 IV b; C 311; D 87, 120;

J 215

quality of ground water in....W 114, 259; A 18 IV b, 19 IV b; B 32, 330,

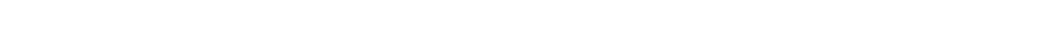

491,530 b, 616; GF 184, 197

salt water in.......W 259; A 18 Iv b; B 530 b, 661 a, 669, 673; GF 184 springs in ......W 91, 114; A 14 II b, 18 Iv b; B 32, 720, 818; GF 197 
Ohio, water levels in W $845,886,906,936,944,986$ water table in ........................ 311; D 87, 88, 156 well records for....W 61, 91, 149, 259; A 18 Iv b, 19 Iv b; B ‘ $\$ 4,298,669$; GF 184

Ohio shale, water in, in Kentucky .W 233 water in, in Ohio ............................ 19 Iv b Oil, ground water in relation to..P 145; B 653, 658, $661 \mathrm{~d}, 691 \mathrm{e}, 716 \mathrm{~d}, 721$, $751 \mathrm{~b}, 756,786 \mathrm{~b}, 812 \mathrm{~b}, 835$ quality of ground water in relation to ..... B $653,661 \mathrm{~d}, 693,786 \mathrm{~b}, 835$;

$\mathrm{J} 274,275$

Oil wells, pollution of ground water by .............. 113, 257 water in $\ldots \ldots \ldots \ldots \ldots \ldots \ldots \ldots \ldots \ldots \ldots$ P 116, 117; B 282, 6F 3, 658, $661 \mathrm{~d}$

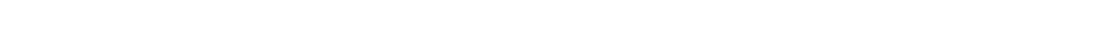

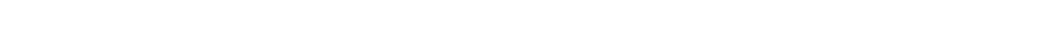

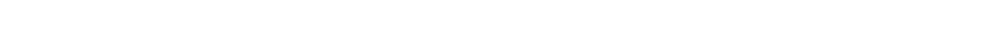
Bristow quadrangle ....................... 661 b, 759 central ......................W 148; A 21 Iv c, 22 Iv c Cherokee Nation $\ldots \ldots \ldots \ldots \ldots \ldots \ldots \ldots \ldots \ldots \ldots \ldots \ldots \ldots \ldots$. . . 298

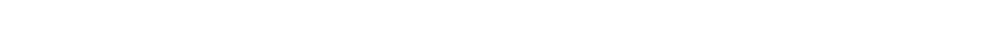
Cimarron County ...................... 32^; D 115, 189 Creek Nation ................................ 298 Cushing oil and gas field $\ldots \ldots \ldots \ldots \ldots \ldots \ldots \ldots \ldots \ldots \ldots \ldots$ B 658 Ellis County ............................... 500 b Enid and vicinity ...................... $345 \mathrm{~b}, 520 \mathrm{~b}$ Foraker quadrangle .......................... 641 b Grand Prairie ............................. 21 vir Jefferson County ........................... $726 f$ McAlester district ......................... 874 a

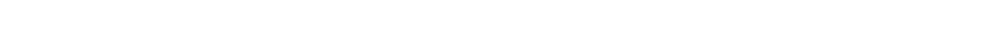

Muskogee quadrangle ........................GF 132 north-central ................................. 691 c Oklahoma City and vicinity $\ldots \ldots \ldots \ldots \ldots \ldots \ldots \ldots \ldots \ldots \ldots \ldots$ W 345 Osage County ...................... 641 b, 686, 751 b Panhandle .........................D 173; J 213, 223 Pawhuska quadrangle ......................... 691 c Quinlan-Scipio district .......................... 874 c

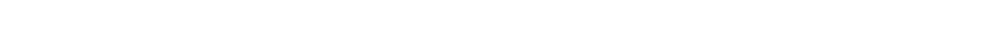

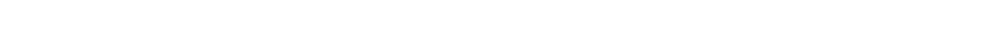
Texas County ........................ 321; D 106 western ........................W 148; A 21 Iv c, 22 Iv c Winslow quadrangle ...........................FF 154 artesian water in .......................... 148, 500 b bibliography of ground water in..............W 120, 163; C 323 irrigation with artesian water in $\ldots \ldots \ldots \ldots \ldots \ldots \ldots \ldots \ldots$ W $500 \mathrm{~b}$ wth other ground water in.....W 5, 148, $345 \mathrm{~b}, \mathrm{~d}, 500 \mathrm{~b}$; A 16 II e, 21 IV c, 22 IV c; C 231 mineral waters in ..................... 32; MR 1883-1923 public - water supplies in .................W 500 b, 520 b

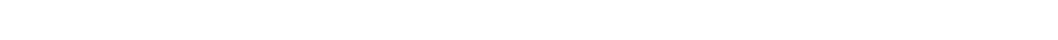
quality of ground water in.....W 148, $345 \mathrm{~b}, \mathrm{~d}, 364,500 \mathrm{~b}, 520 \mathrm{~b}, 606$; 
Oklahoma, salt water in. W 148, 500 b; B 669, 689, 715 m, 874 b, c; GF 122 ;

W 151

spring discharge measurements in ............W 99, 20?, 247, 897 springs in $\ldots \ldots \ldots \ldots \ldots \ldots \ldots \ldots \ldots \ldots \ldots$ W 148, 364; B 32; fF 122, 132 water levels in .........W $777,817,840,845,886,909,939,947,989$ water table in.........C 321; D 74, 115, 123, 168, 173, 174, 184; J 223 well records for. . W 57, 61, 148, 149, $345 \mathrm{~b}, \mathrm{~d}, 500 \mathrm{~b}, 520 \mathrm{~b} ; \mathrm{B} 2 \mathrm{f} 4,298,686$, $716 \mathrm{~d}, 726$ b, f, 736 a, 874 b, c; C 321; D 178

Oligocene formations. See Tertiary; specific formations.

Oneonta limestone, water in, in Iowa ...................W 293

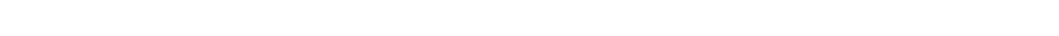

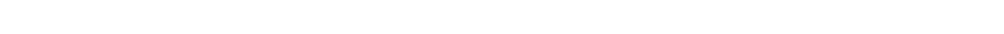

See also Lower Magnesian limestone.

Onion Creek marl, water in, in Texas

A $18 \mathrm{II} \mathrm{b}$

Onōndaga limestone, water in, in Ohio

W 114; A 19 IV b

water in, in Pennsylvania ................... 344, 345, 346

Opeche formation, water in, in South Dakota ................. 107

water in, in Wyoming ........................... 107

Ordovician formations, water in-

Alabama ........................W 114; GF 175; C 2

Arkansas ...............................W 114, 145

Colorado ................................... 32

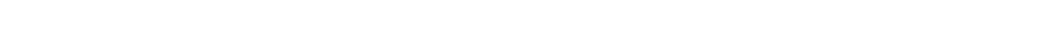

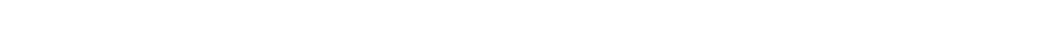

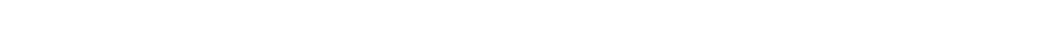

Illinois ....W 114; A $17 \mathrm{~m} \mathrm{h;} \mathrm{M} \mathrm{38;} \mathrm{B} \mathrm{438,} \mathrm{506;} \mathrm{GF} \mathrm{81,} \mathrm{145,} \mathrm{185,} \mathrm{188,} 200$

Indiana $\ldots \ldots \ldots \ldots \ldots \ldots \ldots \ldots \ldots \ldots \ldots$ W 113, 114, 254; A 18 Iv b

Iowa $\ldots \ldots \ldots \ldots \ldots \ldots \ldots \ldots \ldots \ldots \ldots \ldots W$ 114, 145, 293; GF 145, 200

Kansas .........................GF 148, 206; C 142, 147

Kentucky ...........................W 114, 2n3; C 160 b

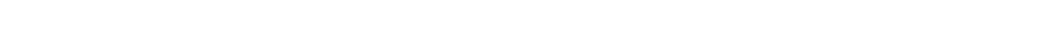

Maryland .................................FF 179

Michigan $\ldots \ldots \ldots \ldots \ldots \ldots \ldots \ldots \ldots \ldots \ldots \ldots \ldots \ldots \ldots \ldots \ldots$ 30, 114

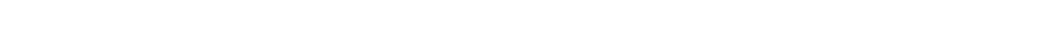

Missouri ..................W 114, 145, 195; B 438; GF 148

Nebraska ............................... 32

New York ................................... 114

North Garolina ................................GF 151

Ohio ......................W 114, 259; A 18 iv b, 19 iv b

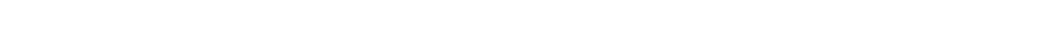

Pennsylvania ..W 106, 110, 114; GF 162, 170, 179; C 342, 345, 346, 347, 349

South Dakota ............................. 32

Tennessee $\ldots \ldots \ldots \ldots \ldots \ldots \ldots \ldots \ldots \ldots \ldots$ W 114, 677; GF 151; C 371

Virginia $\ldots \ldots \ldots \ldots \ldots \ldots \ldots \ldots \ldots$ W 114, 596 c; C $432,433,434,435,436$

West Virginia $\ldots \ldots \ldots \ldots \ldots \ldots \ldots \ldots \ldots \ldots \ldots$ W 110, 114; GF 179; C 433

Wisconsin ...................W 114, 145; GF 140, 145; C 451

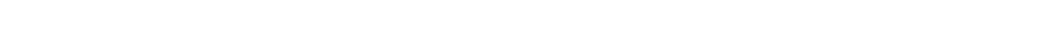

See also specific formations.

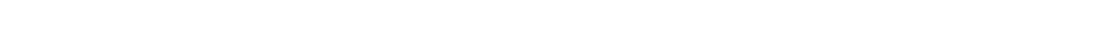
P $42,43,54,66,68,74,75,77,80,104 ; 111 ; 115,122 ; 144,148,169$; 176; B 294, 529, 582, 606, 710 b, d, 718, 735 d, 750 b, c; 769, 763, 902; 921 a, 922 b, g, k, l, r, 936 q; GF 112, 120. 129; J 297

See also Water table. 
Oregon, areas, Butter Creek Basin................. 333; D 69

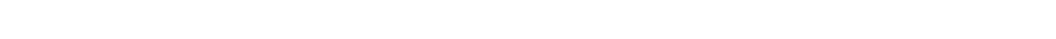

Deschutes River Basin ......................W 637 d

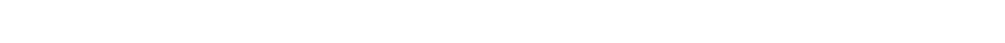

Harney Basin ................W 231, 841; C 333; D 24, 62 Milton-Fillwater district $\ldots \ldots \ldots \ldots \ldots \ldots \ldots \ldots \ldots \ldots \ldots \ldots \ldots$ Nampa quadrangle ..........................FF 103 south-central .............................. 220 southeastern $\ldots \ldots \ldots \ldots \ldots \ldots \ldots \ldots \ldots \ldots \ldots \ldots \ldots \ldots \ldots \ldots$ W 78,231 The Dalles region .................W $659 \mathrm{~b} ; \mathrm{C} 333$; D 20 upper Mackenzie Valley .....................W 597 d Walla Walla basin ........................... 44 western ..............................W $597 \mathrm{~d}$ Willamette Valley ...................W 890; C 331, 333 Yamhill County ......................... 21 artesian water in ............W 78, 220, 231, 841; F 252; GF 103 bibliography of ground water in ................W 120, 163 irrigation with ground water in......W 220, 231, $637 \mathrm{~d}, 659 \mathrm{~b}, 841,890$;

A 16 II e; GF 103; C 331; D 24, 62 mineral waters in ...................... 32; MR 1883-1923 public water supplies in ...................... 332 quality of ground water in.....W 220, 231, 364, $659 \mathrm{~b}, 841$; B 32; D 62 quantity of ground water in..........W 220, 231, $597 \mathrm{~d}, 637 \mathrm{~d}, 841$

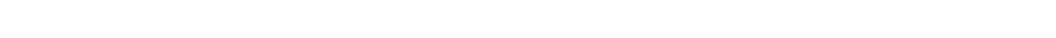
spring discharge measurements in. . W 214, 250, 251, 252, 271, 310, 360, 370, $390,391,394,440,460,480,510,514,530,574,594$, $614,634,654,691,706,720,794,834,864,884$, $900,904,934,964,984$ springs in ..W 78, 220, 231, 557, $597 \mathrm{~d}, 637 \mathrm{~d}, 659 \mathrm{~b}, 679 \mathrm{~b}, 841$; A $14 \mathrm{II} \mathrm{b}$; M 11; B 32, 252; GF 103; C 332; D 24, 62, 135; J 147 thermal ....W 220, 231, 597 d, 679 b, 841; B 252; D 24, 62, 135; J 147 temperature of ground water in........W 220, 231, $597 \mathrm{~d}$; B 32, 252 water levels in ........W $777,817,840,845,886,910,940,948,990$ water table in .........W 220, 231, $637 \mathrm{~d}$; B 893; GF 103; D 24, 44 well records for.......W 61, 149, 220, 231, $637 \mathrm{~d}, 659 \mathrm{~b} ; \mathrm{E} \mathrm{252,264,298}$ wells in, construction of ..................W 78, 231; D 24

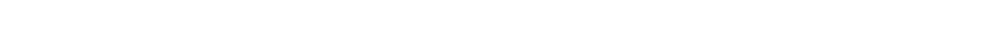
Organic matter in water.$\ldots \ldots \ldots \ldots \ldots \ldots \ldots \ldots \ldots \ldots \ldots \ldots \ldots \ldots \ldots$ W 889 e Origin of ground water....W 9, 67, 114, 142, 155, 158, 219, 222, 233, 254, 294, 343,345 h, 375 a, b, d, 398, 399, 400 e, 423, 489, 494; 597 b; 600; 637 b; 638 c, 678; A 14 II b, 16 II f, 17 II g, 22 Iv c; P 44, 90 h, 127; B 319, 529, $618 ; \mathrm{C} 15,16,22,92,98,99,273 ; \mathrm{D} 54,160,173 ; \mathrm{J} \mathrm{T} ; 34 ; 106 ; 255$

C 15, 16, 22, 92, 98, 99, 273; D 54, 160, 173; J 7, 34, 106, 255 Descartes and other ancient writers, on .............. $1 \overline{4}$ II b

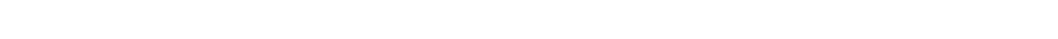
from deep fissures ............................ $400 \mathrm{~b}$ from interior of earth $\ldots \ldots \ldots \ldots \ldots \ldots \ldots \ldots \ldots \ldots \ldots$. 127; B 319

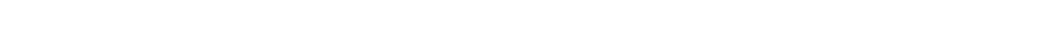
from oceans $\ldots \ldots \ldots \ldots \ldots \ldots \ldots \ldots \ldots \ldots \ldots \ldots \ldots \ldots$. 319

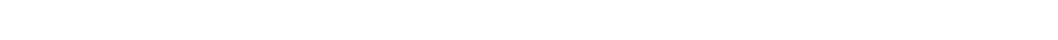
See also Absorption; Quantity.

Origin of mineral springs $\ldots \ldots \ldots \ldots \ldots \ldots \ldots \ldots \ldots \ldots \ldots . W$ 338; $\mathbf{R} 14$ In b 
Orinda formation, water in, in California ..................FF 193

Orton, Edward, Rock waters of Ohio ................. 19 iv b

Osage group, water in, in Illinois $\ldots \ldots \ldots \ldots \ldots \ldots \ldots \ldots \ldots \ldots \ldots \ldots \ldots \ldots \ldots \ldots$

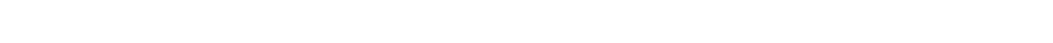

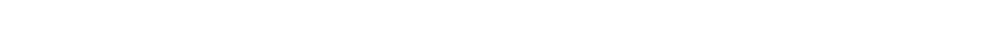

Otton, E. G., Ground-water supplies of the Ypsilanti Triangle area.

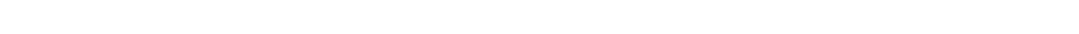

Overbeck, R. M., Geology and mineral resources of the west coast of

Chichagof Island, Alaska ........................ 692 b

Owen, G. T., Water levels and artesian pressure in the United Stctes

W $817,840,845$

Oxidation of ores, sulfates produced by ............W 273, $345 \mathrm{~g}$

Oxidation of rocks, ground-water levels in relation to..P 94, 97, $14 \varepsilon$ 169, 171, 177; B 529, 625, 677, 681, 710 a, $716 \mathrm{~g}, 718,735 \mathrm{~d}, \mathrm{e}, 750 \mathrm{~b}, 763$,

$782,787,811 \mathrm{c}, 814,847$ a, 853, 870, $922 \mathrm{~g}$

Oxidation produced by ground water.....M 47; P 38, 43, 66, 68, 75, 77, 148;

B 692 e, 710 e, $718,733,811 \mathrm{c}, 849 \mathrm{~g}, 893,922 \mathrm{l}$

\section{$\mathbf{P}$}

Pack, R. W., Sunset-Midway oil field, Calif ...............P 116

Packers for wells. See Well construction.

Padgett, H. D., Jr., Geology and ground-water resources of the coastal area

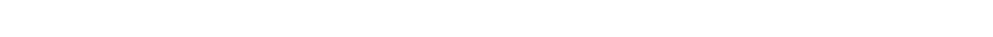

Geology and ground-water resources of the Verde River Vallay, Ariz

C 20 a

Pahasapa limestone, water in, in South Dakota W 227; P 32; GF 107, 128, 164 water in, in Wyoming .............P 32; B 716 b; GF 107, 128, 150

Paige, Sidney, Copper deposits of the Tyrone district, N. Mex ......P 122

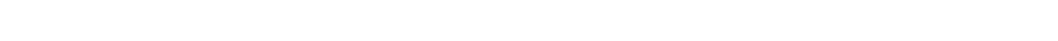

Silver City. folio, N. Mex . . . . . . . . . . . . . . . . . . GF 199

Palache, Charles, Franklin Furnace folio, N. J...............FF 161

Paleozoic formations. See specific formations.

Palm, H. W., Water levels and artesian pressure in the United Stc.tes

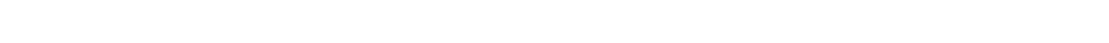

Deep well at Charleston, S. C.................... $90 \mathrm{~h}$

Geochemical interpretation of water analyses .............. 479

Quality of the waters in the Blue Grass region, $\mathrm{Ky} \ldots \ldots \ldots \ldots \ldots$ W 233

Palmer, H. S., Ground water in the Norwalk, Suffield, and Glastonb'rry

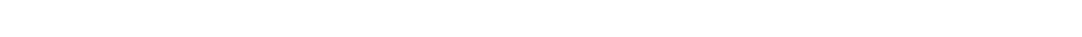

Ground water in the Southington-Granby area, Conn.........W 466

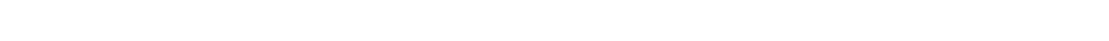

Pamlico sand, water in, in Florida ..................... 365

Pamunkey formation, water in, in Atlantic Coastal Plain .......... B 138

water in, in Maryland .................... 138; GF 13, 23, 204

in Virginia ...........W 114; B 138; GF 13, 23; C 431, 437, 441, 442

Panola formation, water in, in Kentucky .................W 233

Paper manufacturing, quality of water for $\ldots \ldots \ldots \ldots \ldots W$ 254, 341, 398

Pardee, J. T., Deposits of manganese ore in Montana, Utah, Oregion and

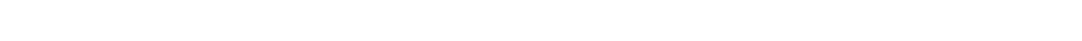

Geology and ground-water resources of Townsend Valley, Mont.... W 539 
Pardee, J. T., Geology and mineral deposits of the Oolville Indian

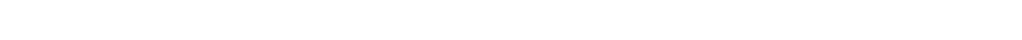

Ground water in the Missouri Valley near Townsend,-Mont.......D 2

Metalliferous deposits of the greater Helena mining region, Mont. . B 842

Montana earthquake of June 27, $1925 \ldots \ldots \ldots \ldots \ldots \ldots \ldots$. 147 b

Park, C. F., Jr., Geology and ground-water resources of the Harney

Basin Oreg ..............................W 841; D 62

Geology and ore deposits of the Metaline quadrangle, Wash......P 202

Girdwood district, Alaska ....................... 849 g

Mining districts of eastern Oregon $\ldots \ldots \ldots \ldots \ldots \ldots \ldots \ldots \ldots$ B 846 a

Parker, F. S., Mizpah coal field, Mont ................... 906 c

Richey-Lambert coal field, Mont ................... 847 c

Parker, G. G., Effect of the Pleistocene epoch on the geology and ground

water of southern Florida $\ldots \ldots \ldots \ldots \ldots \ldots \ldots \ldots \ldots \ldots \ldots \ldots \ldots \ldots$

Geology and ground water of southern Florida .............J 319

Geology and ground water of the Everglades in southern Florida....J 258

Investigation of water resources in southeastern Florida ......... 63

Late Cenozoic geology of southern Florida ............... 65

Salt-water encroachment in limestone at Silver Bluff, Miami, Fla. . J 352

Salt-water encroachment in southern Florida .............J 348

Water levels and artesian pressure in the United States, 1943... W 987

Water resources in southeastern Florida ................ 62

Parker, G. L., Surface water supply of the United States. ...W 362, 632, 834,

Parker, H. N., Quality of some waters of the Coastal Plain of 882,884

North Carolina ................................ 81

Quality of water in Kansas ........................ 273

Parkman sandstone, water in, in Montana ................. 856

water in, in Wyoming .................... 5]; GF 141, 142

Parks, Bryan, Geology and mineral resources of the western pr.rt of the

Arkansas coal field ............................... 847 e

Parks, E. M., Lignite field of northwestern South Dakota .......... 627

Parma sandstone, water in, in Michigan .............. 30, 114

Pascagoula formation, water in, in Mississippi.......W 159, 193, 194, 195

Patapsco formation, water in, in Maryland .................. 204

in Pennsylvania ............................... 342

Patuxent formation, water in, in Maryland .................... 204

water in, in North Carolina ...................... 291

Paulsen, C. G., Surface water supply of the United States, 1918, part 3 .W 473

Surface water supply of the United States, part 10..W 570, 590, 610, 630

Surface water supply of the United States, part $12 \ldots$ W 533, 573, 593, 613

Payette formation, water in, in Idaho ................... 45

Peale, A. C., Bibliography of mineral waters ................. 1905

Mineral springs of the United States .................. 32

Natural mineral waters of the United States ........... 14 II b

Producion of mineral waters ..................... 1883-1900

Three Forks folio, Mont .......................... 24

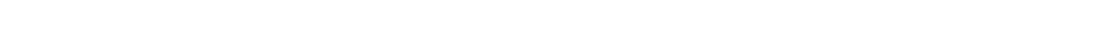

Peedee sand, water, in North Carolina .................. 291

water in, in South Carolina ......................... 867

Pendleton sandstone, water in, in Indiana $\ldots \ldots \ldots \ldots \ldots \ldots \ldots \ldots$ W 254 
Pennsylvania, areas, all of State ...............W 114; C 349; J 335 areas, Accident quadrangle $\ldots \ldots \ldots \ldots \ldots \ldots \ldots \ldots \ldots \ldots . . .6 F \quad 160$

Allegheny River Basin $\ldots \ldots \ldots \ldots \ldots \ldots \ldots \ldots \ldots \ldots \ldots, \mathrm{C} \quad 348$

Amity quadrangle $\ldots \ldots \ldots \ldots \ldots \ldots \ldots \ldots \ldots \ldots \ldots$ B 300; GF 144

Barnesboro quadrangle ................W 110; B 531 $\mathrm{c}$; GF 189

Bellefonte quadrangle $\ldots \ldots \ldots \ldots \ldots \ldots \ldots \ldots \ldots \ldots \ldots \ldots . ., 855$

Butler quadrangle $\ldots \ldots \ldots \ldots \ldots \ldots \ldots \ldots \ldots \ldots \ldots \ldots \ldots \ldots$ B 873

central ........................................ $581 \mathrm{~d}$

Chambersburg quadrangle $\ldots \ldots \ldots \ldots \ldots \ldots \ldots \ldots \ldots$ W 110; GF 170

Coatesville quadrangle $\ldots \ldots \ldots \ldots \ldots \ldots \ldots \ldots \ldots \ldots \ldots$ GF 223

Curwensville quadrangle ....................W 110; B 531 d

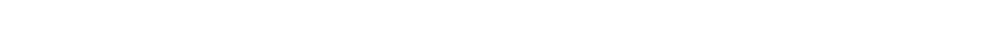

Doylestown district $\ldots \ldots \ldots \ldots \ldots \ldots \ldots \ldots \ldots \ldots \ldots \ldots \ldots \ldots \ldots \ldots$

Ebensburg quadrangle $\ldots \ldots \ldots \ldots \ldots \ldots \ldots \ldots \ldots \ldots \ldots$ W 11r; GF 133

Elders Ridge quadrangle $\ldots \ldots \ldots \ldots \ldots \ldots \ldots \ldots \ldots$ W 11c; GF 123

Elkton quadrangle $\ldots \ldots \ldots \ldots \ldots \ldots \ldots \ldots \ldots \ldots \ldots$, GF 211

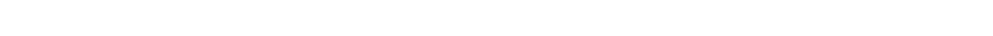

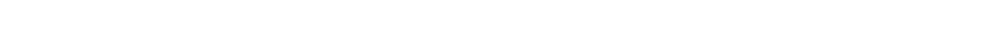

Gettysburg quadrangle $\ldots \ldots \ldots \ldots \ldots \ldots \ldots \ldots \ldots \ldots \ldots$ GF 225

Grantsville quadrangle $\ldots \ldots \ldots \ldots \ldots \ldots \ldots \ldots \ldots \ldots \ldots \ldots$ GF 160

Hancock quadrangle $\ldots \ldots \ldots \ldots \ldots \ldots \ldots \ldots \ldots \ldots$ W 145; GF 179

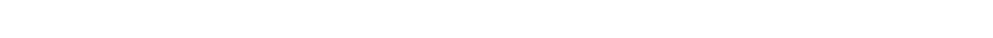

Houtzdale quadrangle $\ldots \ldots \ldots \ldots \ldots \ldots \ldots \ldots \ldots \ldots \ldots, \mathrm{B} 531 \mathrm{~d}$

Indiana quadrangle $\ldots \ldots \ldots \ldots \ldots \ldots \ldots \ldots \ldots \ldots \ldots$. GF 102

Johnstown and vicinity $\ldots \ldots \ldots \ldots \ldots \ldots \ldots \ldots \ldots \ldots \ldots, \ldots \ldots \ldots$

Johnstown quadrangle $\ldots \ldots \ldots \ldots \ldots \ldots \ldots \ldots \ldots \ldots \ldots$ GF 174

Mercersburg quadrangle...$\ldots \ldots \ldots \ldots \ldots \ldots \ldots$ W 110; GF 170

Middletown quadrangle $\ldots \ldots \ldots \ldots \ldots \ldots \ldots \ldots \ldots \ldots \ldots$ B 840

Monongahela River Basin ........................ 348

New Kensington quadrangle ...................... 829

north-central ............................... 314 ; D 98

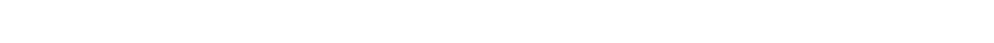

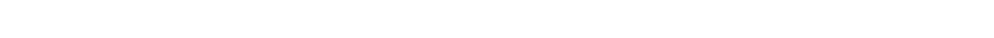

Patton quadrangle ..................W 110; B 531 d'; GF 189

Pawpaw quadrangle $\ldots \ldots \ldots \ldots \ldots \ldots \ldots \ldots \ldots \ldots$ W 145; GF 179

Philadelphia district $\ldots \ldots \ldots \ldots \ldots \ldots \ldots$ W 106; B 138; GF 162; J 358

Phoenixville quadrangle $\ldots \ldots \ldots \ldots \ldots \ldots \ldots \ldots \ldots \ldots \ldots$ B 891

Punxsutawney quadrangle $\ldots \ldots \ldots \ldots \ldots \ldots \ldots \ldots \ldots \ldots, \mathbf{B} 531 \mathrm{~d}$

Quakertown district $\ldots \ldots \ldots \ldots \ldots \ldots \ldots \ldots \ldots \ldots \ldots \ldots \ldots, \ldots \ldots \ldots$

Rogersville quadrangle $\ldots \ldots \ldots \ldots \ldots \ldots \ldots \ldots \ldots \ldots \ldots$ GF 146

Somerset quadrangle $\ldots \ldots \ldots \ldots \ldots \ldots \ldots \ldots \ldots \ldots \ldots$. GF 224

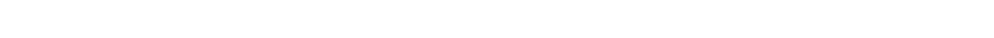

southeast $\ldots \ldots \ldots \ldots \ldots \ldots \ldots \ldots \ldots \ldots \ldots \ldots \ldots, C \mathbf{3}^{112} ; \mathrm{D} \mathbf{3 5}$

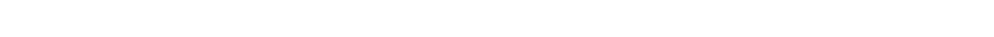

Susquehanna River Basin $\ldots \ldots \ldots \ldots \ldots \ldots \ldots \ldots \ldots \ldots \ldots \ldots \ldots$ C 348

Trenton quadrangle $\ldots \ldots \ldots \ldots \ldots \ldots \ldots \ldots \ldots \ldots \ldots \ldots$ GF 167

Warren County ................................. 298

Warren quadrangle ............................ 172

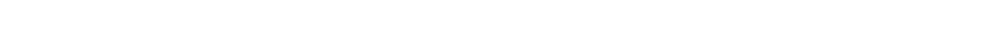

Waynesburg quadrangle $\ldots \ldots \ldots \ldots \ldots \ldots \ldots \ldots \ldots$ W 110; GF 121

West Chester quadrangle $\ldots \ldots \ldots \ldots \ldots \ldots \ldots \ldots \ldots \ldots$. GF 223

Windber quadrangle $\ldots \ldots \ldots \ldots \ldots \ldots \ldots \ldots \ldots \ldots \ldots$ GF 224 


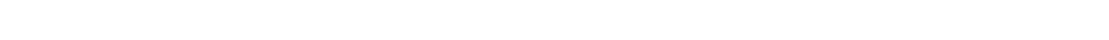

Zelienople quadrangle ......................... B 873 artesian water in ...W 106; B 138, $531 \mathrm{~d}$; GF 102, 121, 133, 160, 179, 189;

C $341,342,343,344,346 ;$ D 26; J 20

bibliography of ground water in $\ldots \ldots \ldots \ldots \ldots . W 61,114,120,149,163$ mineral waters in $\ldots \ldots \ldots \ldots \ldots \ldots \ldots$ W 114; B 32; MR 1883-1923; GF 92 public water supplies in ...W 106, 110; B 447; GF 121, 123, 162, 167, 170, 189; C 342, 343, 344, 345, 346, 347, 349; J 234, 358 quality of ground water in ...W 108, 110, 364; B 32, 300, 447; GF 144, 179 ; C $341,342,343,344,345,346,349$; D 26 ; J 173 quantity of ground water in $\ldots \ldots \ldots \ldots \ldots \ldots \ldots \ldots$ C $34 \varepsilon, 349 ; \mathrm{J} 358$ salt water in ............ 330, 669, 693, 829; GF 144; C 341, 343, 344 spring discharge measurements in ....................W 741 springs in ...W 106, 114, $679 \mathrm{~b}, 741$; A 14 II b; B 32, 300, 447, 828, 840, 891; GF 121, 123, 133, 160, 167, 170, 172, 174, 179, 189, 225;

C $341,342,343,345,346,352$

thermal ................................. 679 b temperature of ground water in ..................... 447 water levels in $\ldots \ldots \ldots \ldots \ldots$ W 777, 817, 840, 845, 886, 906, 936, 944, 986 water table in ......... 300; C 345, 346; D 34, 94, 98, 131; J 88, 178 well records for ...W 61, 106, 149; B 138, 264, 298, $531 \mathrm{~d}$, (699, 829, 855, 873 ; GF 121, 123, 162; C- 341 343, 344, 345, 346; D 35

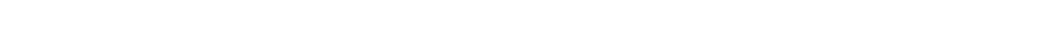

Pennsylvania formations; See Carboniferous; specific formations.

Pepper, J. F., Structure and gas possibilities of the Oriskany sandstone

in southwestern New York ........................ 899 a Perched ground water ...W 164, 233, 258, 320, 335, 489, 494, 56r d, 616, 818; P 44, 46; C 92, 98, 99, 235; 431; J 255 flowing wells from $\ldots \ldots \ldots \ldots \ldots \ldots \ldots \ldots \ldots \ldots \ldots$ W $3 \Sigma$, , $494 ;$ C 99 Percolation. See Movements of ground water.

Perforation of casings $\ldots \ldots \ldots \ldots \ldots \ldots \ldots \ldots \ldots \ldots \ldots$ W 1.10, 140, 257 Perkins, G. F., Underground waters of Vermont ..............W 114

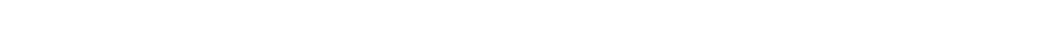
Permeability of rocks..W 67, 114, 489, 494, $596 \mathrm{f}, 638$ c, 679 a, $\varepsilon \vee 7$; B 821 b; D 84,$117 ;$ J $62,89,111,114,225$

effect of compression on ..........................J 344 method of determining ......W 679 a, 887; D 205; J 42, 85, 131, 230, 241 committee on, report of ........................... 307

Permian formations, water in

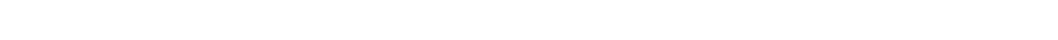

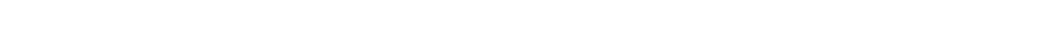

New Mexico .......................... 234, 2E6; J 245, 260

Oklahoma ......................W 500 b, 520 b; C 323; J 213

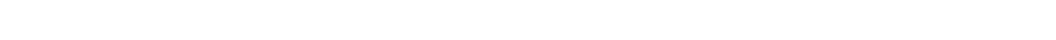

Perry, T. 0., Experiments with windmills $\ldots \ldots \ldots, \ldots \ldots \ldots \ldots \ldots \ldots$ W 20

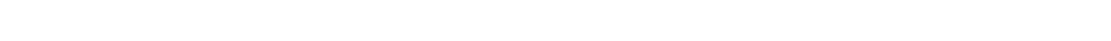

Persia, bibliography of ground water in $\ldots \ldots \ldots \ldots \ldots \ldots \ldots \ldots \ldots \ldots$ W 163

Persian wheels for lifting water $\ldots \ldots \ldots \ldots \ldots \ldots \ldots \ldots \ldots \ldots \ldots$ W 1

Peru, bibliography of ground water in $\ldots \ldots \ldots \ldots \ldots \ldots \ldots \ldots \ldots \ldots \ldots$ W 163

Petroleum. See Oil.

Phalen, W. C., Ellijay folio, Ga.-N. C.-Tenn ................GF 187

Johnstown folio, $\mathrm{Pa} \ldots \ldots \ldots \ldots \ldots \ldots \ldots \ldots \ldots \ldots \ldots \ldots \ldots$ GF 174

Kenova folio, Ky.-W. Va.-Ohio ......................GF 184 
Phalen, W. C., Mineral resources of Johnstown, Pa., and vicinity ...... B 447 Potash in bitterns of eastern United States ............. 530 b Salt resources of the United States .................... 669 Philippine Islands, bibliography of ground water in $\ldots \ldots \ldots \ldots \ldots W$ W 163 quality of ground water in ................... 330, 491, 616 Phosphate in ground, water.......W 338; B 47, 330, 491, 616; MR 1911 II n

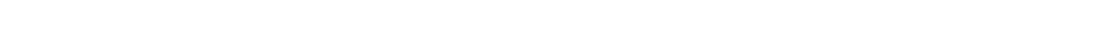
Phreatic water, definition of $\ldots \ldots \ldots \ldots \ldots \ldots \ldots \ldots$ W 494; A 14 In a; J 344 Phreatophytes. See Vegetation.

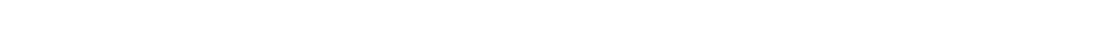
Pierce, C. H., Water resources of Hawaii ..............W 318, 336

Pierce, W. G., Geology and coal resources of the region south of Coty,

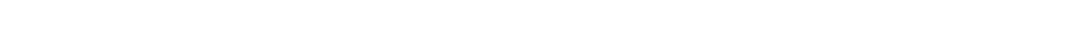

Geology and mineral resources of north-central Chouteau, western

Hill, and eastern Liberty Counties, Mont ............. 847 f

Rosebud coal field, Mont ........................ 847 b Pierre shale, water in-

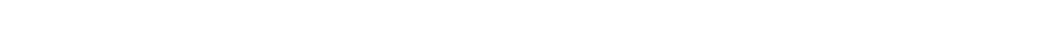

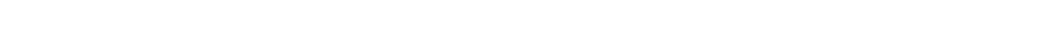

New Mexico ................................FF 214

North Dakota ..........................W 5gR; B 801

South Dakota ....................W 227; GF 113, 114, 165

Piestic or artesian water conditions ...................J 344

Piney sandstone, water in, in Wyoming ................... 51

Piper, A. M., Characteristics of a satisfactory observation well ....... 75

Chemical character of native and contaminated waters in the

Long Beach-Santa Ana area, California ............... 30 f

Cooperative ground-water investigation in the Long Beach-

Santa Ana area, California ....................... 29

Equipment for measuring depth to water ............. 142

Fluctuations in observation wells in the Mokelumne area, Calif ...J 100

Geologic features in the coastal zone of the Long Beach-

Santa Ana area, California ...................... 30 d

Geology and ground-water hydrology of the Mokelumne area, Calif. W 780

Geology and ground-water resources of the Bruneau River Basin,

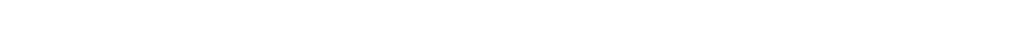

Geology and ground-water resources of The Dalles region, Oreg... W 659

b; D 20

Geology and ground-water resources of the Harney basin, Oreg.. W 841;

D 62

Geology and water resources of the Goose Creek basin, Idaho..... C 112

Graphic procedure in geochemical interpretation of water analyses.J 372

Ground-water conditions along the Pacific coast with respect

to salt-water intrusion ........................ 151

Ground water for irrigation in the Harney basin Oreg. .........D 24

Ground water for irrigation in Yamhill County, Oreg .........D 21

Ground water for irrigation on Camas Prairie, Idaho .......... 116

Ground water for municipal supply at Idaho Falls, Idaho ....... 117

Ground water in north-central Tennessee ................W 640

Ground water in southwestern Pennsylvania ............... 341

Ground water in the Butter Creek area, Oreg ............. 69

Ground water in the Walla Walla basin, Oreg.-Wash ..........D 44

Ground-water problem in Oregon .................. 333 
Piper, A. M., Ground-water projects in California, Oregon, and Washington

Ground-water resources of Willamette Valley, Oreg ......W 890; C 331 Ground-water supply at Moscow, Idaho ............... 113 Index of factual data from water wells in Los Angeles and Orange Counties, Calif ............................. 24

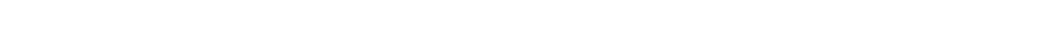

Kah-ne-ta Spring and adjacent hot springs in Oregon ........D 135

Modified Wheatstone bridge assembly for water-well exploration ...J 281 Nation-wide system for designating wells (comments) $\ldots \ldots \ldots \ldots$ D 81

Origin of artesian pressure $\ldots \ldots \ldots \ldots \ldots \ldots \ldots \ldots \ldots \ldots \ldots \ldots$ J 56

Partial chemical analyses of waters from coastal zone of

Long Beach-Santa Ana area, Calif., (foreword) ............ 26

Relation between moisture equivalent and specific retention of

water-bearing materials ........................ 103

Seepage loss and gain in the Mokelumne River, Calif ........... 52

State-wide numbering system for designating wells $\ldots \ldots \ldots \ldots \ldots$ D 80

Underground water in Arizona, California, New Mexico, and Oregon.J 97

Underground water problems in Arizona, California, New $I^{\pi}$ exico,

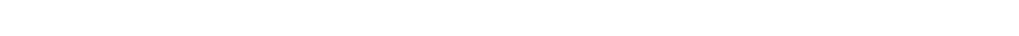

Water levels and artesian pressure in the United States ...W 777, 817, $840,845,886,911,941,990$

Water resources and watershed protection problems of Oregnn

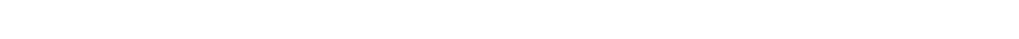

Water resources of Santa Barbara County, Calif .............. 27

Water-table fluctuations in Spokane Valley, Wash.-Idaho. . W 889 b; D 118

Water wells in the coastal zone of the Long Beach-Santa Ana area,

Calif ...................................... 25

Wells for public water supply at Spokane, Wash ............ 102

Pishel, M. A., Geology of the Standing Rock and Cheyenne River

Indian Reservations, N. Dak.-S. Dak .................. 575

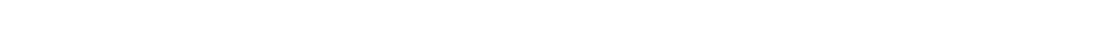

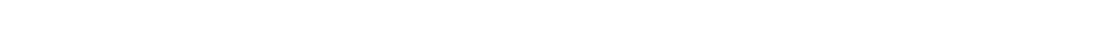

Pitkin limestone, water in, in Arkansas .............W 145; GF 154

water in, in Oklahoma ............................. 154

Pittsburgh sandstone, water in, in Pennsylvania ................ 123

Plains, marl, water in, in Colorado ................... 16 II $\mathrm{f}$

water in, in Kansas ............................ 16 If $f$

in Nebraska ............................. 16 II $f$

Platteville limestone, water in, in Iowa $\ldots \ldots \ldots \ldots \ldots \ldots \ldots$ W 293; GF 145

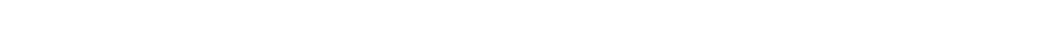

in Wisconsin ....................... GF 145; C 451

See also Trenton limestone.

Plattsburg limestone, water in, in Kansas .................. 206

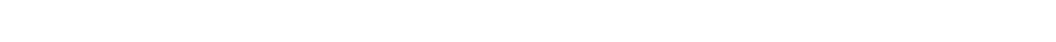

Pleasanton shale, water in, in Missouri ................... 195

Pleistocene deposits. See Glacial drift; Quaternary deposits; Valley fill.

Pliny, on mineral waters ......................... 14 in b

Pliocene formations. See Tertiary; specific formations.

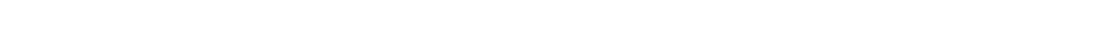

Plutonic water. See Juvenile water; Magnetic water.

Pocono formation, water in, in Pennsylvania ...B 300; GF 224; C 341, 343, 
Poindexter, O. F., Ground-water supplies of the Ypsilanti Triangle area,

Mich ........................................ 182

Water levels and artesian pressure in the United States ... 840,845

$886,906,944$

Poland, J. F., Chemical character of native and contaminated waters in the

Long Beach-Santa Ana area, Calif ................... 30 i

Cooperative ground-water investigation in the Long Beach-Santa Ana area, Calif $\ldots \ldots \ldots \ldots \ldots \ldots \ldots \ldots \ldots \ldots \ldots \ldots \ldots \ldots \ldots \ldots$ C 29

Cooperative ground-water investigation in the Torrance-Santa Monica area, Calif .............................. 30 e

Electrical resistivity apparatus for testing well waters .........J 226

Geologic features in the coastal zone of the Long Beach-Santa Ana

area, Calif ............................... 30 d

Ground water, salt water, and ground recession in Santa Clara Valley,

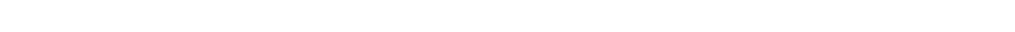

Index of factual data from water wells in Los Angeles and Orange

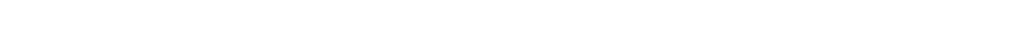

Modified Wheatstone bridge assembly for water-well exploration ..J 281

Partial chemical analyses of waters from coastal zone of

Long Beach-Santa Ana area, Calif., (foreword) .......... 26

Saline contamination of coastal ground water in southern Califcrnia.J 318

Variations in chemical composition of Los Angeles Basin ground

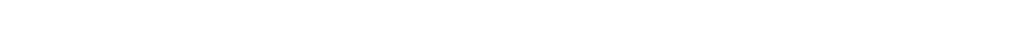

Water levels and artesian pressure in the United States . . W 941, 949, 991

Water wells in the coastal zone of the Long Beach-Santa Ana area,

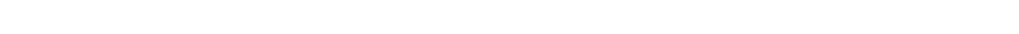

Withdrawals of ground water from the Long Beach-Santa An?. area,

Calif ..................................... 30 e

Pollution of artesian water $\ldots \ldots \ldots \ldots \ldots \ldots \ldots \ldots \ldots \ldots \ldots \ldots \ldots \ldots \ldots$ C 131

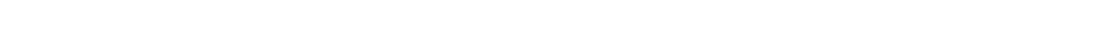

Pollution of ground water, chloride as an indicator of $\ldots W$ W 114, 144, 223, $232,256,398 ;$ C 81

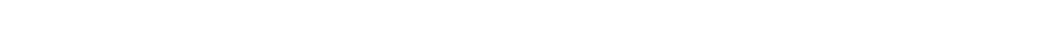

fluorescein as an indicator of $\ldots \ldots \ldots \ldots \ldots \ldots \ldots \ldots \ldots \ldots$ W 160; C 82

general W 110, 145, 160, 255, 293; A 14 II a; C 451; J 11, 161, 166, 184, 232

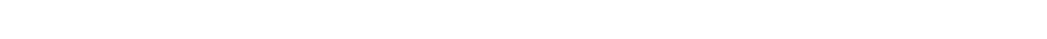

tests for $\ldots \ldots \ldots \ldots \ldots \ldots \ldots \ldots \ldots \ldots \ldots \ldots$ 144, 160, 193, 255; C 81, 82

Pollution of ground water by-

bacteria ..............W 193, 256, 259, 335, 341, 398, 39?; C 81, 82

drainage wells ........................... 258

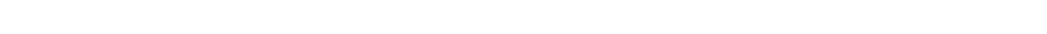

sea water .. W 232, 537, 596 a; C 83, 216, 440; D 151; J 117, 17 $, 193,201$, $202,225,228,249,296,318,321,348,352,355$

sewage $\ldots \ldots \ldots \ldots \ldots \ldots \ldots \ldots \ldots \ldots \ldots \ldots \ldots \ldots \ldots$ W 232, 255, 293; C 81, 82

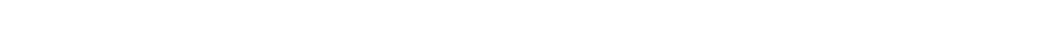

Pollution of ground water in-

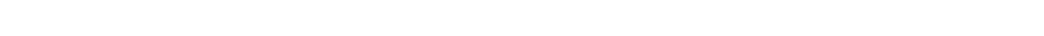

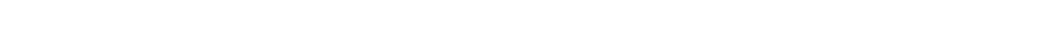

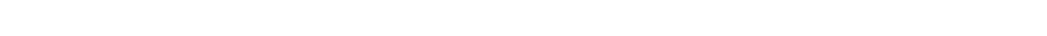

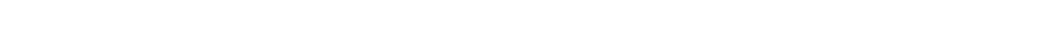

Georgia $\ldots \ldots \ldots \ldots \ldots \ldots \ldots \ldots \ldots \ldots \ldots \ldots \ldots \ldots \ldots \ldots \ldots \ldots$ C 81, 82

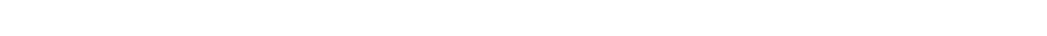


Pollution of ground water in, Hawaii $\ldots \ldots \ldots \ldots \ldots \ldots \ldots \ldots \ldots \ldots \ldots$. 97

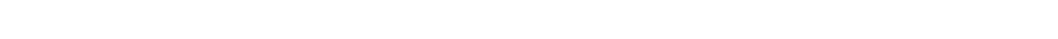

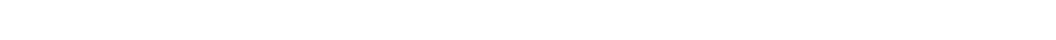

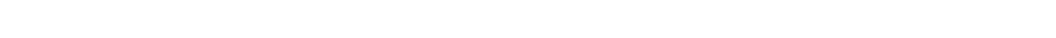

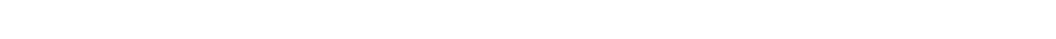

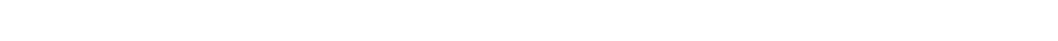

limestone $\ldots \ldots \ldots \ldots \ldots \ldots \ldots \ldots \ldots \ldots \ldots \ldots \ldots \ldots W$ W 255, 258; C 131

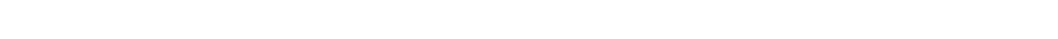

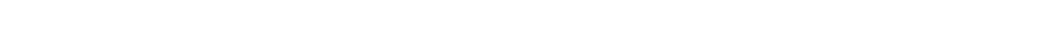

Michigan $\ldots \ldots \ldots \ldots \ldots \ldots \ldots \ldots \ldots \ldots \ldots \ldots \ldots \ldots \ldots \ldots \ldots \ldots \ldots \ldots \ldots, 30,31$

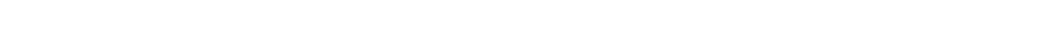

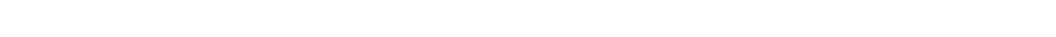

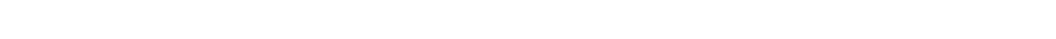

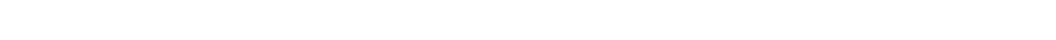

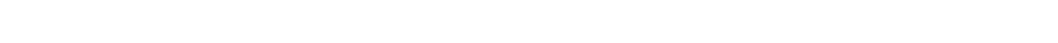

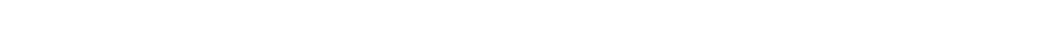

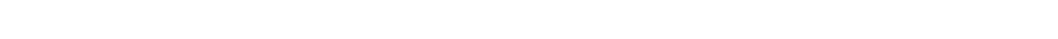

Virginia $\ldots \ldots \ldots \ldots \ldots \ldots \ldots \ldots \ldots \ldots \ldots \ldots \ldots \ldots$ W 596 c; C 431

See also Purification of ground water.

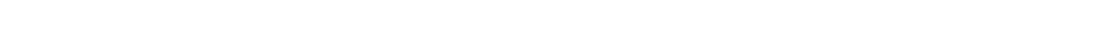

Pollution of water, definition of term ..................W 315

Pollution of wells ..W 110, 145, 160, 169, 223, 232, 255, 257, 293; C 81, 82;

J $61,64,71,105,161,166$

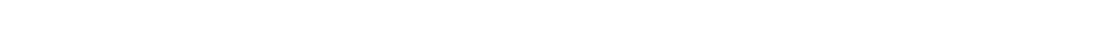

Pool springs ..........................W 221, 277, 365, 423

Porosity, methods of determining ...........W 400 e, 596 f; A 19 il b

Porosity of

crystalline rocks $\ldots \ldots \ldots \ldots \ldots \ldots \ldots \ldots \ldots \ldots \ldots \ldots \ldots$ W 160, 232

gravel $\ldots \ldots \ldots \ldots \ldots \ldots \ldots \ldots \ldots \ldots \ldots \ldots \ldots \ldots \ldots$ W 104, 136, 140

rocks $\ldots \ldots \ldots \ldots \ldots \ldots \ldots \ldots \ldots \ldots \ldots \ldots \ldots$ W $67,114,160 ; A$ A 19 in b

sand $\ldots \ldots \ldots \ldots \ldots \ldots \ldots \ldots \ldots \ldots \ldots \ldots W 6 \ldots \ldots, 140,294,40^{\wedge}$ e; $A 19$ II b

soil $\ldots \ldots \ldots \ldots \ldots \ldots \ldots \ldots \ldots \ldots \ldots \ldots$ W 67 ; A 19 II b; C 431

valley fill $\ldots \ldots \ldots \ldots \ldots \ldots \ldots \ldots \ldots \ldots$ W 222, 294, 345 h, 398, 400 e

water-bearing materials $\ldots \mathrm{W} 67,104,114,136,140,160,232,294,400$ e, 489,596 f, 638 c; A 17 II f, 19 II b; M 47; C 1

wet material above the water table $\ldots \ldots \ldots \ldots \ldots \ldots$. 17 II $f, 19$ II $b$

Port Hudson formation, water in, in Arkansas ................. 46

water in, in Louisiana ............................ 46

Porter, E. A., Surface water supply of the United States. .W 360, 389, 390, 440

Porter, L., Jr., Water wells and water levels in San Antonio, Santa

Maria, and Cuyama Valleys, Calif .................... $30 \mathrm{~b}$

Porto Rico. See Puerto Rico.

Ports, P. L., Natural gas resources available to Dallas, Texas ..... $716 \mathrm{~d}$

Potability of ground water, mineral content in relation to. W 341, 343, 398, 399

Potassium in ground water .....W 338, 343, $520 \mathrm{~d}$; P 98 a, 117; B 530 b, r, $540 \mathrm{n}, \mathrm{p}, 715 \mathrm{i}$; MR 1911 II $\mathrm{n}$

Potomac group, water in-

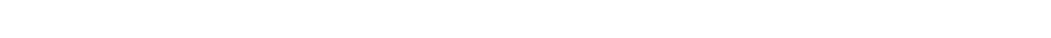

Delaware ................................ 138; GF 137

District of Columbia ........................ 138; GF 70

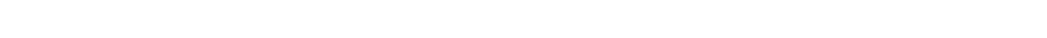

Maryland ........................ 138; GF 13, 70, 137, 182, 204

North Carolina ................................. 29 
Potomac group, water in, Virginia..W 114; B 138; GF 13, 70; C 431, 436, 437, 441,$442 ; \mathrm{J} 250$

Potsdam sandstone, water in, in Illinois ...W 144; A $17 \mathrm{JI} \mathrm{h}$; M 38; GF 81, 200 water in, in Iowa ....................W 293; GF 145, 200

in Wisconsin ...............W 114, 145; GF 140, 145; C 451 See also Cambrian formations; Dresbach sandstone; Jordan sandstone. Pottsville formation, water in, in Illinois ..............F 185, 220 water in, in Pennsylvania ............ 300; C 341, 343, 344, 345, 346

Powell, J. W., Artesian irrigation on Great Plains ...........A 11 II c Power for pumping, hydraulic rams ............W 256, 278; C 431 hydroelectric generators .................W 146, 375 a, 398 internal-combustion engines ...W 1, 146, 153, 320, $375 \mathrm{a}, \mathrm{d}, 398,423,425 \mathrm{~d}$

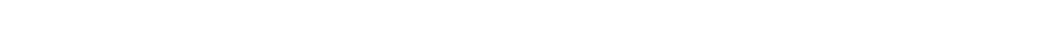

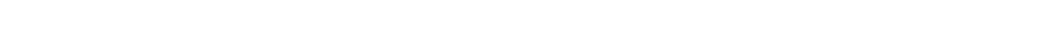
various means $\ldots \ldots \ldots \ldots \ldots \ldots \ldots \ldots \ldots \ldots \ldots \ldots \ldots \ldots \ldots$ W $1,14,29$ See also Windmills.

Power from artesian wells .............W 67, 494; A 17 II g; GF 168 Powers, H. A., Ground-water supply in the Kula and Makawao districts,

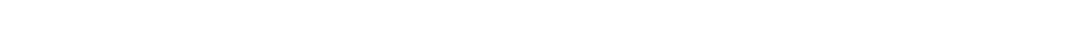

Powers, Sidney, The Brooks, Steen, and Grand Saline salt domes, Tex. B $736 \mathrm{~g}$ Structure and oil and gas resources of the Osage Reservation, Okla,

Structure of the Madill-Denison area, Okla. and Tex ......... 736 a

Prairie du Chien group, water in, in Iowa ..................W 293 See also Lower Magnesian limestone.

Pre-Cambrian formations, water in-

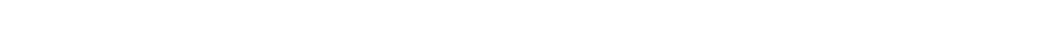

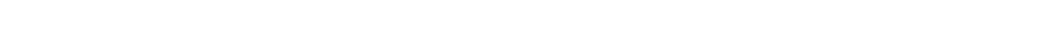

Connecticut $\ldots \ldots \ldots \ldots \ldots \ldots \ldots \ldots \ldots \ldots \ldots \ldots \ldots$ 114, 232. 374, 397

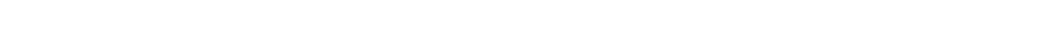

District of Columbia .....................W 114; GF 152

Georgia $: \ldots \ldots \ldots \ldots \ldots \ldots \ldots \ldots \ldots \ldots \ldots \ldots \ldots \ldots \ldots \ldots$ W 114, 160; C 81

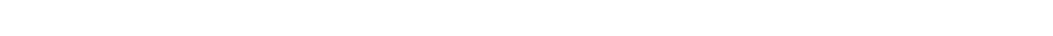

Maine $\ldots \ldots \ldots \ldots \ldots \ldots \ldots \ldots \ldots \ldots \ldots \ldots \ldots$ 114, 145, 223, 25E: GF 149

Maryland ........................ 114; G] 152, 204

Minnesota ......................W 114, 256; GF 117

Missouri .............................. 114, 195

Montana ...........................W $345 \mathrm{~g}, 400$. b

New Hampshire $\ldots \ldots \ldots \ldots \ldots \ldots \ldots \ldots \ldots \ldots \ldots \ldots \ldots \ldots \ldots \ldots \ldots \ldots \ldots$ 114, 145

New Jersey ......................W 114; GF 157, 191

New Mexico ............................. 343,620

New York ......................W 110, 114; GF 157

North Carolina ..................W 114; GF 124, 147, 151

North Dakota ............................ 117

Pennsylvania ................W 106, 114; GF 157, 162; C 342

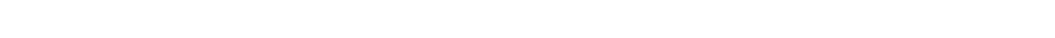

South Carolina ......................W 114; GF 147

Tennessee ...........................FF 124, 151

Texas ..............................FF 183, 194

Vermont .................................W 110

Virginia $\ldots \ldots \ldots \ldots \ldots \ldots \ldots \ldots \ldots \ldots \ldots \ldots \ldots \ldots \ldots$ 114; $C$ 434, 435, 436

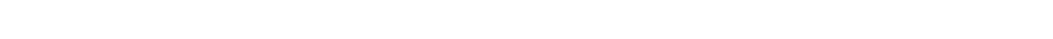

Wsconsin .............................. 114; C 451

See also Crystalline rocks; specific formations. 
Precipitation, absorption in relation to $\ldots \mathrm{W} 142,153,155,219,294,345 \mathrm{~h}$, 400 e, 638 c; P 44; C 11, 15, 20, 21; D 173; J 73, 240, 279 artesian flows in relation to $\ldots \ldots \ldots \ldots \ldots \ldots \ldots \ldots \ldots \ldots \ldots \ldots$ fluctuatons of water table in relation to ...W $142,153,155,219,345 \mathrm{~g}$, h, 375 a, d, 400 e, 423; A 19 II b; P 44; C 15, 20 movements of ground water in relation to $\ldots \ldots \ldots \ldots . \nabla 638 \mathrm{c} ; \mathrm{P} 44$ supplies of ground water in relation to ...W 137, 138, 139, 142, 153, 155, 219,345 h, 400 e, 423, 494, 638 c; P 44; C 21 yields of springs in relation to ............W 277,$489 ; A 19$ Iv b

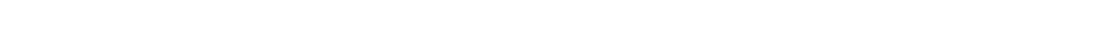
Pressey, H. A., New York City folio, N. Y.-N. J ...........GF 83 Pressure head. See Artesian water.

Pressure of ground water, dissolved gases and solids in relation to ...M 47 Price, P. H., Ground-water investigations in West Virginia. .J 251, 256; C 448 Primary alkalinity and primary salinity of water $\ldots \ldots \ldots \ldots$ W 338; B 479

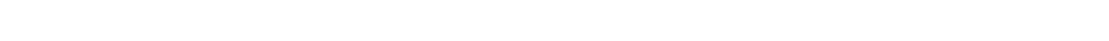
Pritchett, H. C., Seepage lass and gain of the Mokelumne River, Calif...D 52 Prosser, C. S., Columbus folio, Ohio ...................GF 197 Provinces of the Umited States in regard to ground water .....W 114, 489 Public water supplies, consumption of ...W 91, 195, 256, 315, 423; C 82; $\mathrm{J} 232,364$ cost of $\ldots \ldots \ldots \ldots \ldots \ldots \ldots \ldots \ldots \ldots \ldots \ldots \ldots \ldots \ldots \ldots \ldots \ldots, 423 ; C 2$ for large cities, ground water for $\ldots \ldots \ldots \ldots \ldots \ldots W 315,83^{\circ} \mathrm{d} ; \mathrm{J} 93,122$ history of, in the United States ..................W 315

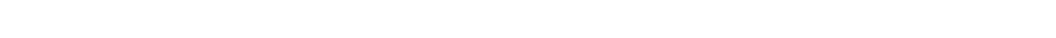

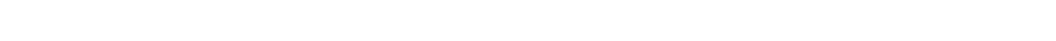
ownership of $\ldots \ldots \ldots \ldots \ldots \ldots \ldots \ldots \ldots \ldots \ldots \ldots \ldots$ W 91, 254; C 451

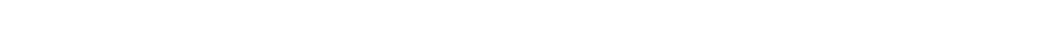

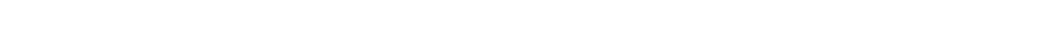
relative merits of surface and ground water for ...WW 193, 223, 254, 256, See also specific States.

$293 ;$ C 82

Puerto Rico, bibliography of ground water in ..............W 120 Pulliam formation, water in, in Texas .................... 64

Pumping, land subsidence due to $\ldots \ldots \ldots \ldots \ldots \ldots \ldots \ldots \ldots \ldots$ 168, 225 movement of ground water in relation to $\ldots \ldots \ldots \ldots W 638 \mathrm{c} ; \mathrm{P} 44 ; \mathrm{J} 86$ variation of water table in relation to ....WW 142,$155 ; 219,345 \mathrm{~h}, 638 \mathrm{c}$ 679 a, 887; P 44; C 92, 99

Pumping for irrigation. See specific States.

Pumping tests .........W 140, 141, 153, 258, 320, 333, $345 \mathrm{c}, 398,425 \mathrm{~b}$, $519,619,679$ a, 887; B 618; C 136, 214, 241, 244, 245, 343; D 55, $96,182,201,205 ; \mathrm{J} 85,101,133,194,199,230,236,241,246,294$, $311,326,369$

Pumps, centrifugal $\ldots \ldots \ldots \ldots \ldots \ldots \ldots \ldots \ldots \ldots \ldots$ W 1, 184, 3n, 375 a, 398

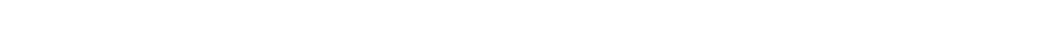
various types $\ldots \ldots \ldots \ldots \ldots \ldots \ldots \ldots \ldots \ldots \ldots \ldots \ldots \ldots \ldots \ldots \ldots \ldots \ldots \ldots, 14$

Pumps and other lifting devices-

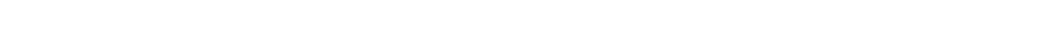

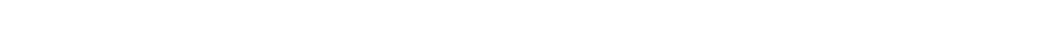
hydraulic rams $\ldots \ldots \ldots \ldots \ldots \ldots \ldots \ldots \ldots W$ 1, 254, 256, $2 \mp 8,540 ; C 431$ siphons $\ldots \ldots \ldots \ldots \ldots \ldots \ldots \ldots \ldots \ldots \ldots \ldots \ldots \ldots$ 254, 320, 374, 397, 540 water wheels $\ldots \ldots \ldots \ldots \ldots \ldots \ldots \ldots \ldots \ldots \ldots \ldots \ldots \ldots \ldots \ldots \ldots$ W 13, 29 
Pumps and other lifting devices, windlasses ...............W 254

Purdue, A. $\mathbf{H}_{\text {; }}$, Asphalt deposits and oil conditions in southwestern Arkansas

B $691 \mathrm{j}$

Geology of the DeQueen and Caddo Gap quadrangles, Ark .......B 808

Hot Springs folio, Ark ............................ 215

Underground waters of northern Arkansas ..............W 114

Water resources near contact between Paleozoic and Mississippi

embayments, northern Arkansas ..................W 145

Water resources of the Winslow quadrangle, Ark ...........W 145

Well and spring records for Arkansas .................W 102

Winslow folio, Ark.-Okla ......................... 154

Purgatoire formation, water in, in Colorado ................ 186

water in, in New Mexico .......................... 214

Purification of ground water-

cold-water softening $\ldots \ldots \ldots \ldots \ldots \ldots \ldots W$ 254, 259, 293, 341, 398, 399

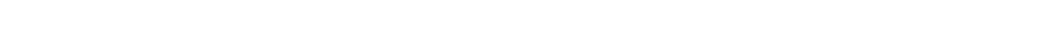

exchange silicate softening $\ldots \ldots \ldots \ldots \ldots \ldots \ldots \ldots \ldots \ldots \ldots$ W 559,600

feed-water heating $\ldots \ldots \ldots \ldots \ldots \ldots \ldots \ldots W$ 254, 259, 293,-341, 398, 399

filtration tests for .............................. 44

history of, in the United States .................... 315

lime and soda-ash softening $\ldots \ldots \ldots \ldots \ldots \ldots \ldots \ldots \ldots \ldots \ldots$ 315, 559

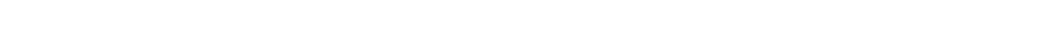

methods of $\ldots \ldots \ldots \ldots \ldots \ldots \ldots . W$ W 254, 259, 293, 315, 341, 398, 399; C 451

natural filtration $\ldots \ldots \ldots \ldots \ldots \ldots \ldots \ldots \ldots \ldots \ldots$ W 255, 258, $520 \mathrm{~d}, 600$

slow sand filtration $\ldots \ldots \ldots \ldots \ldots \ldots \ldots \ldots$ 254, 259, 315, 341, 398, 399

sterilization ......................... 254, 315, 518

Purton, A. B., Surface water supply of the United States. . W 510, 529, 549, $750,765,860$

Pynchon, W. H. C., Drilled wells of the Triassic area of the

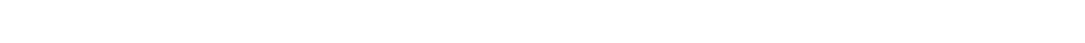

Q

Quality of ground water, artesian head in relation to............ 319 bacteriologic .........W 193, 254, 256, 259, 335, 341, 398, 399; C 81, 82 changes in $\ldots \ldots \ldots \ldots \ldots \ldots \ldots \ldots \ldots \ldots \ldots \ldots$ W 160, 258; B 330, 491, 616

due to replacement of connate water $\ldots \ldots \ldots \ldots \ldots \ldots \ldots \ldots$ W 160

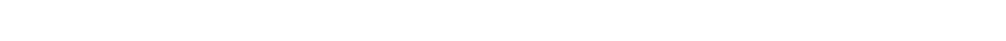

chloride as indicator of $\ldots \ldots \ldots \ldots \ldots \ldots \ldots W$ 144, 232, 256, 259; C 81 classification with regard to ..W $273,274,341,398,399 ;$ B 479, 606, 653 concentration processes in relation to ..........W 320,343, 453; B 653 -dissociation theory of $\ldots \ldots \ldots \ldots \ldots \ldots \ldots \ldots \ldots \ldots \ldots \ldots \ldots \ldots \ldots$

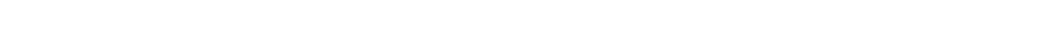

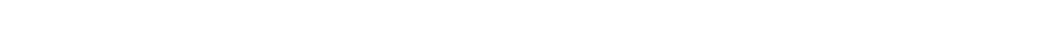

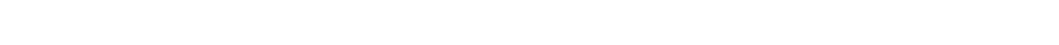
regarding -

acidity '....W. $254,259,273,274,293,341,345$ g, 398; B 47, 330, 479, $491,606,616 ; \mathrm{C} 1,451$ alkalinity .............W 151, 338; P $90 \mathrm{~h}, 117 ; \mathrm{B} \mathrm{47,479,606}$ aluminum $\ldots \ldots \ldots \ldots \ldots \ldots \ldots \ldots \ldots \ldots \ldots \ldots$ 273, 338; MR 1911 in $n$ ammonium $\ldots \ldots \ldots \ldots \ldots \ldots \ldots \ldots \ldots \ldots \ldots$ W 240, 256; MR 1911 in $n$ antimony $\ldots \ldots \ldots \ldots \ldots \ldots \ldots \ldots \ldots \ldots \ldots \ldots \ldots \ldots \ldots \ldots \ldots$ arsenic.$\ldots \ldots \ldots \ldots \ldots \ldots \ldots \ldots \ldots \ldots \ldots$ W 338; B 47; MR 1911 in $n$ 
Quality of ground water, regarding, barium. .W 254, 338, 399; B 47;

MR 1911 i $n$ bicäbonate ....W 254, 259, 273, 338, 341, 398; P 117; ItR 1911 II n; $\mathrm{J} 47,254,255$

bisulfate . ${ }^{*} \mathrm{R} 1911 \mathrm{II} \mathrm{n}$ borate W 338; B 47, 330, 491, 616; MR 1911 II n bromide .........W 31, 233, 338, 398; P 117; B 47; MR 1911 II $n$

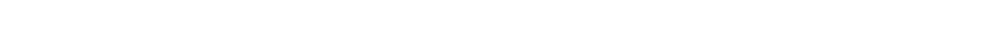
calcium ........W 254, 259, 273, 338, 341, 398; P 117; MR 1911 II n carbon dioxide $\ldots \ldots \ldots \ldots \ldots \ldots \ldots \ldots \ldots \ldots \ldots$ W 273, 338; GF 206 carbonate ........W 254, 259, 273, 320, 328, 341, 343, 398; P 117; B 330, 491, 616; MR 1911 II n, 1916 chloride ..........W 30, 58, 77, 114, 144, 223, 232, 254, 256, 259; $273,275,320,341,398,537$; P 117; B 330, 491, 616; MR 1911 II n, 1916; C 92, 94, 97, 98, 99; J 15, 197, 254, 255

color W 240, 254, 259, 338, 341, 398 copper W $399 ;$ B 47

fluoride .B 47; MR 19J.1 II n; J 197 gases in solution $\ldots \ldots \ldots \ldots \ldots \ldots \ldots \ldots \ldots \ldots \ldots \ldots \ldots \ldots \ldots \ldots \ldots$

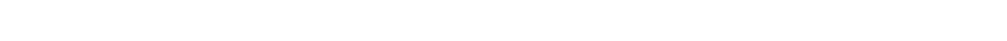
gypsum ................W 273, 317, 320, 313, 398; C 381 hardness ....W 151, 232, 254, 259, 273, 320, 338, 341, 343, 398, 399; 559 hydrogen sulfide ....W $254259,338,341,398,399$; B 282, 398, 447; MR 1911 II $\mathrm{n}$; GF 174; C 1 B 282, 398, 447; MR 1911 II n; GF 174; C 1

hydroxide MR 1911 II $\mathrm{n}$ iodide W 233, 338; P 117; B 47; MR 1911 in n iron .W 254, 256, 259, 273, 338, 341, 398, 399; MR 1911 II n, 1916; GF 206; C 1 iron and fixed nitrogen $\ldots \ldots \ldots \ldots \ldots \ldots \ldots \ldots \ldots \ldots \ldots \ldots$ lead $\ldots \ldots \ldots \ldots \ldots \ldots \ldots \ldots \ldots \ldots \ldots \ldots \ldots$ W 254, 399; B 47, 606 lithium ................W 160, 259, 338; B 47; MR 1911 II $\mathrm{n}$ magnesium .. W 254, 259, 273, 338, 341, 343, 398; P 117; MR 1911 II $n$ manganese ...................W 338; B 47, MR 1911 II $n$ neutrality $\ldots \ldots \ldots \ldots \ldots \ldots \ldots \ldots \ldots \ldots \ldots \ldots \ldots \ldots$. B 479,606 nitrate .......W 256, 338; B 47, 330, 491, 616; MR 1911 II n; J 255 odor ................................. 338 organic matter ...................W 193, 254, 259, 341, 398

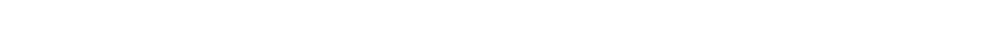
phosphate ...........W 338; B 47, 330, 491, 616; MR 1911 II $n$ potassium ....W 338, 343; P 117; B 530 b, r, 540 n, p; MR 1911 in $n$ radioactivity .................W 338; B 395; MR 1913 II $n$ rubidium $\ldots \ldots \ldots \ldots \ldots \ldots \ldots \ldots \ldots \ldots \ldots \ldots \ldots \ldots \ldots \ldots \ldots \ldots$ salinity W 320,537 ; B 479, 606

See also specific States, salt water in.

silica $\ldots \ldots \ldots \ldots \ldots \ldots \ldots \ldots \ldots \ldots \ldots$ W 240, 273, 338; F 330, 491, 616 silver $\ldots \ldots \ldots \ldots \ldots \ldots \ldots \ldots \ldots \ldots \ldots \ldots \ldots \ldots \ldots \ldots \ldots$. 94 sodium ....W 254, 259, 273, 338, 341, 398; P 117; MR 1911 n n; J 47 specific gravity .......................... 47 strontium $\ldots \ldots \ldots \ldots \ldots \ldots \ldots \ldots \ldots \ldots \ldots \ldots \ldots \ldots \ldots$ 338; B 47 sulfate .....W 254, 259, 273, 275, 338, 341, 343 g, 39尺; P 117; J 254 
Quality of ground water, regarding, sulfite $\ldots \ldots \ldots \ldots \ldots \ldots \ldots \ldots \ldots$

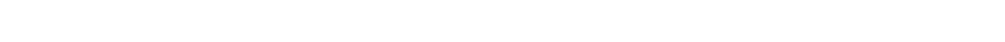
susperded matter .............W 254, 258, 259, 341, 398;.C 131

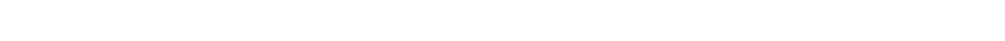
thiosulfites $\ldots \ldots \ldots \ldots \ldots \ldots \ldots \ldots \ldots \ldots \ldots \ldots \ldots \ldots \ldots$ r 1911 In $n$

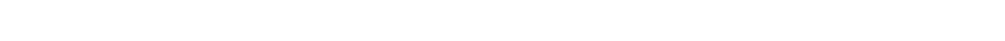

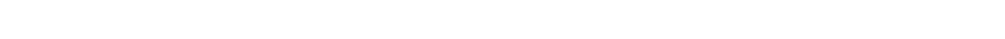

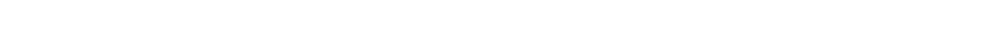
turbidity $\ldots \ldots \ldots \ldots \ldots \ldots \ldots \ldots \ldots \ldots \ldots \ldots \ldots \ldots \ldots$ W 341, 398; C 131 due to loess $\ldots \ldots \ldots \ldots \ldots \ldots \ldots \ldots \ldots \ldots \ldots \ldots \ldots \ldots \ldots$ C 131

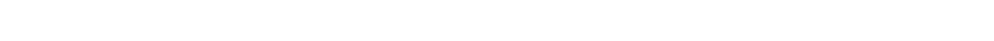
zinc $\ldots \ldots \ldots \ldots \ldots \ldots \ldots \ldots \ldots \ldots \ldots \ldots$ W 254, 273.399; B 606 relation of, to -

carbonate deposits $\ldots \ldots \ldots \ldots \ldots \ldots \ldots \ldots \ldots \ldots \ldots \ldots \ldots \ldots \ldots$ d

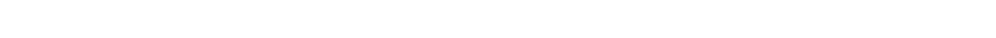
deposits of hot springs $\ldots \ldots \ldots \ldots \ldots \ldots \ldots \ldots \ldots \ldots \ldots \ldots \ldots$ d depth $\ldots \ldots \ldots \ldots$ W 256, 275, 320, 341, 343, 398, 399, 518, 520 d, 597 c

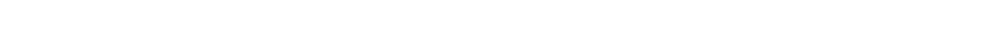
geologic formations W 254, 256, 259, 273, 275, 293, 320, 3r $5,338,341$; $343,345 \mathrm{~g}, 375 \mathrm{~d}, \mathrm{~g}, 398,399,423,518,576,597 \mathrm{c} ;$ A 14 Ir b; P 90 h; B 479, 653; C 451

gypsum beds W 275 health ...W 31, 164, 195, 233, 254, 259, 293, 335, 338, 341, 343; 398;

industries A 14 II b; P 46; MR $1911 \mathrm{n}, 1913 \mathrm{II} \mathrm{h}$

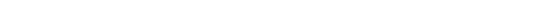
occluded sea water $\ldots \ldots \ldots \ldots \ldots \ldots \ldots \ldots \ldots \ldots \ldots \ldots \ldots$ W 398

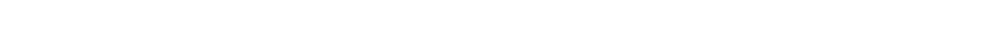

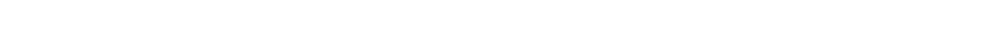
silica deposits $\ldots \ldots \ldots \ldots \ldots \ldots \ldots \ldots \ldots \ldots \ldots \ldots \ldots \ldots \ldots \ldots \ldots$. 9 sodium carbonate from igneous rocks $\ldots \ldots \ldots \ldots \ldots \ldots \ldots \ldots$ W 320

in Cretaceous formations .................W 256, 343 soil alkali $\ldots \ldots \ldots \ldots \ldots \ldots \ldots \ldots \ldots \ldots \ldots \ldots \ldots$ W $320,343,398,423$

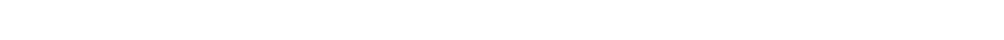
temperature $\ldots \ldots \ldots \ldots \ldots \ldots \ldots \ldots \ldots \ldots \ldots \ldots \ldots \ldots \ldots$ M 47 underground circulation $\ldots \ldots \ldots \ldots \ldots \ldots \ldots \ldots \ldots \ldots$ W $320 ;$ M 47 vegetation $\ldots \ldots \ldots \ldots \ldots \ldots \ldots \ldots \ldots \ldots \ldots \ldots \ldots . \ldots \ldots$ 34. 423, 577

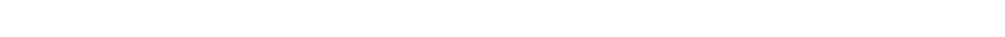
water table $\ldots \ldots \ldots \ldots \ldots \ldots \ldots \ldots \ldots \ldots \ldots \ldots \ldots \ldots \ldots \ldots$ W 320, 343 well casings $\ldots \ldots \ldots \ldots \ldots \ldots \ldots \ldots \ldots \ldots \ldots \ldots \ldots \ldots \ldots$ W 293 sanitary W 144, $193,232,254,255,256,259,335,341,398,39$; C $81 ; 82$ therapeutic ....WW 31, 164, 195, 233, 254, 259, 293, 335, 338, 341, 398; A $14 \mathrm{n} \mathrm{b}$; P 46; MR $1911 \mathrm{nI} \mathrm{N.} 1913$ il h See also Analyses; Maps; Pollution; Purification, and Quality of water; specific States.

Quality of mine water. .W 273, $345 \mathrm{~g}, 364$; P 94; B 330, 491, 529, 6C5, 616, 625 in regard to acidity $\ldots \ldots \ldots \ldots \ldots \ldots \ldots \ldots \ldots . W 273,345 \mathrm{~g} ; \mathrm{P} 104 ; \mathrm{B} 735 \mathrm{~d}$ relation of, to corrosion W 273

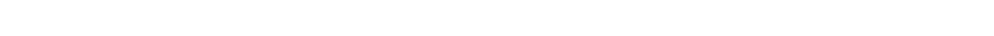

Quality of water for, boiler use W 30, 233, 254, 256, 259, 274, 293, 320, 335, 341; $375 \mathrm{~g}, 398,399,446,497,500 \mathrm{~b}, 518,520 \mathrm{~b}, 576,658$; C 451 


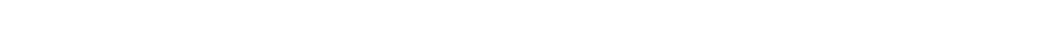
cotton mills $\ldots \ldots \ldots \ldots \ldots \ldots \ldots \ldots \ldots \ldots \ldots \ldots \ldots \ldots \ldots W, 254,398$ distilling $\ldots \ldots \ldots \ldots \ldots \ldots \ldots \ldots \ldots \ldots \ldots \ldots \ldots \ldots \ldots$ 233, 254, 398 domestic use $\ldots . \ldots \ldots . W$ W 30, 254, 320, 335, 341, 343, $375 \mathrm{~g}, 398,399,497$; $500 \mathrm{~b}, 518,576$; C 451; MR 1911 in $\mathrm{n}$ drinking, relation of concentration to......W 343, 398; I"R 1911 in $n$ dyeing $\ldots \ldots \ldots \ldots \ldots \ldots \ldots \ldots \ldots \ldots \ldots \ldots \ldots \ldots \ldots \ldots$ W 254, 341, 398

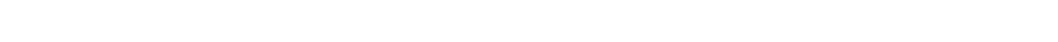
industrial uses $\ldots \ldots \ldots \ldots \ldots$. . 233, 254, 259, 274, 293, 341, 398, 559, 658 irrigation ............W 260, 274, 320, 333, 335, 343, $375 \mathrm{~g}, 398,399$, $429,497,590 \mathrm{~b}, 518,620$ livestock ................................. $335, \mathbf{3 4 3}$ medicinal use ......W 31, 164, 195, 233, 254, 259, 293, 335, 338, 341; 398 A 14 II b; P 46; MR 1911 II n, 1913 il h paper making $\ldots \ldots \ldots \ldots \ldots \ldots \ldots \ldots \ldots \ldots \ldots \ldots \ldots \ldots \ldots$ W 254, 341, 398

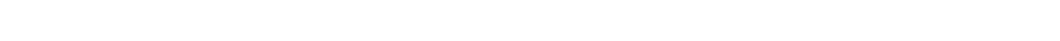

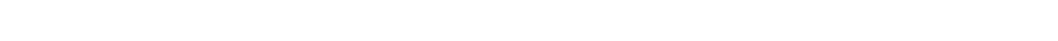

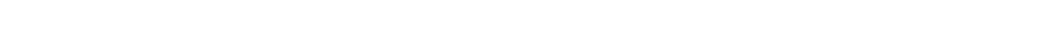
sugar making .............................. $30,341,398$ tanning ................................W 254, 341, 398

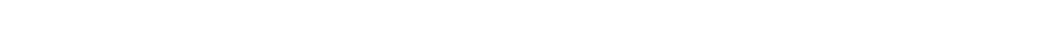

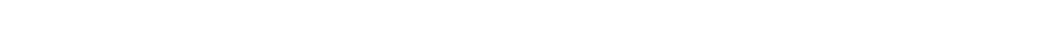
Quality of water for-

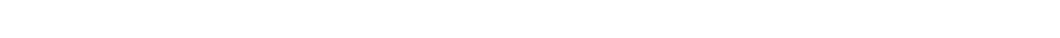
Quality of water, with relation to -

boiler compounds .....................W 254, 293, 398, 399, 658 corrosion of boilers $\ldots \ldots \ldots \ldots \ldots \ldots \ldots \ldots W 254,256,259,293,398,658$ foaming in boilers .......W 254, 256, 259, 274, 341, 398, 399, 658; C 451 priming in boilers ...........................W 274, 658 scale formed in boiler .....W 233, 254, 256, 259, 274, 293, 341, 398, 399, $658 ;$ C 451 soap consumption W 256, 274 softening $\ldots \ldots \ldots \ldots \ldots \ldots \ldots \ldots \ldots \ldots \ldots \ldots$ W 254, 274, 298,-315, 398 See also Analyses; Maps; Pollution; Purification; Quality of ground water. Quantity of ground water, absorption method of determining...W 155, 219, 294, 400 e, 423, 519, 579 b, 638 c; C 21; J 17C: 186, 279, 300 annual $\ldots \ldots \ldots \ldots \ldots$ W 137, 138, 139, 142, 219, 222, 234, 275, 294, $345 \mathrm{~g}$; h, 375 a, d, 400 e, 423,425 e, 597 b, 619, 637 b, 638 c, 774, 818; C 14, 15, 16, 21, 22, 92, 98, 99; D. 77, 146, 160171,$173 ;$ J $170,240,279$ discharge method of determining. W $294,423,597 \mathrm{~b}, 638 \mathrm{c}$; C 15, 16; D 8; J 132. 170, 186, 300

for air conditioning .J 351 for military supplies D 177 laid down with sediments ........................... 19 n b methods of measuring ..W 112, 136, 140,142, 155, 294, 34k h, 400 e, 423, $597 \mathrm{~b}, 638 \mathrm{c} ; \mathrm{C} 23$ total W $67,114,160,234 ; 638$ c; M 47 transmission method of determining ............J 132. 170, 186, 300

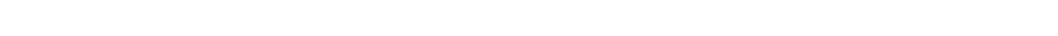

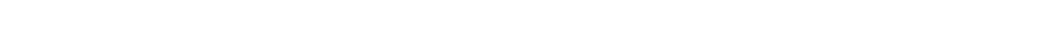
water-table method of determining ....W $142,345 \mathrm{~h}, 40 \mathrm{~N}$ e; $519 ; 638 \mathrm{c}$ 
Quantity of ground water-

alluvium W $104,112,136,140,153,184,188,258, \mathfrak{s} 45 \mathrm{~g}$, h; 374,375 a, 397, 399, 400 e crystalline rocks ..................W 160, 232, 345 g; A 19 In b Dakota sandstone ...........W 889 a; A 17 II g; P 52; B 265; J 191 debris-filled basins .....W 142, 219, 222, 275, 294, 343, $345 \mathrm{~g}, \mathrm{~J}, 375$, a, 398,400 e, 423; C 21, 22 earth's crust $\ldots \ldots \ldots \ldots \ldots \ldots \ldots \ldots \ldots \ldots \ldots \ldots W 67,114,160,2 \AA 4 ;$ M 47 gravel ...........W 112, 136, 140, 153, 258, 375 a, 399, 400 e; P 44 sand $\ldots \ldots \ldots \ldots \ldots \ldots \ldots \ldots \ldots$ W 25, 112, 114, 153, 255, 400 e; A 19 II b sandstone $\ldots \ldots \ldots \ldots \ldots \ldots \ldots \ldots \ldots \ldots \ldots \ldots \ldots \ldots \ldots$ W 232; A 19 II b

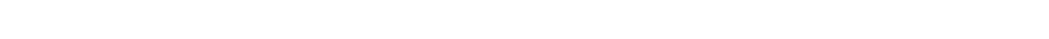
soil W 294; A 19 II b valley fill $\ldots \ldots \ldots \ldots \ldots . W$ W 104, 136, 137, 138, 139, 142, 219, 222, 225, 275 , $278,294,343,345 \mathrm{~g}, \mathrm{~h}, 375$ a, 398, 423, 425 a; B 618 ; C 21, 22; J 191

See also Absorption; Movements; Origin; specific States.

Quartzite, water in.....W 160, 232, 255, 256, 257, 293, 489; GF 162, 2245; C 342 Quaternary deposits, water in-

Alaska B 903

Arizona W $836 \mathrm{~b} ; \mathrm{C} 15,20 ; \mathrm{D} 85$

Arkansas W $399 ;$ C 20 e; D 18

Connecticut .........................W 537, 597 b

Delaware $\ldots \ldots \ldots \ldots \ldots \ldots \ldots \ldots \ldots \ldots \ldots \ldots \ldots \ldots \ldots$. . . . 137; C 171

District of Columbia ........................... 171

Florida ...................W 319; C 57, 60, 61, 62; J 258, 365

Georgia ...............................W 341; $\mathbf{c} 81$

Hawaii $\ldots \ldots \ldots \ldots \ldots \ldots \ldots \ldots \ldots \ldots \ldots \ldots \ldots \ldots \ldots \ldots \ldots$ C 92, 98, 99

Idaho W 774,$818 ; \mathrm{C} 112,144$

Kansas W 6,$273 ;$ C 142, 144, 145, 148, 155, 156, 158; J 214 Louisiana ..............W 101, 114; C 163, 164 165, 166, 167, 170 a Maryland ................GF 137, 152, 182, 204; C 171; J 355 Mississippi ......................W 159, 576; C 195; J 346

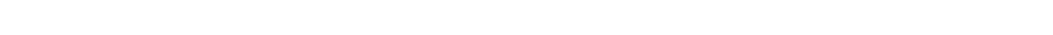

Montana ..............................W 518. 599, 600

Nebraska ...........................W 779, 848

New Jersey .................................. 214

New Mexico ................W 620; P 122; C 236, 241, 248, 252

New York ............................ 274; D 41

North Carolina ................................. 293

North Dakota .........................W 5E ${ }^{\text {; }}$ C 304

Oklahoma ......................... 874 a; C 321 ; J 223

Oregon ........................W 220, 231, 637 d, 841

Pennsylvania ...................C 341, 342, 343, 344 345, 346

South Carolina ............................... 867

Tennessee .........................W 638 a, 656, 677

Texas ....W 375 g, 678, 778, 849 a, 889 c, 919; A 21 vu; C 407, 408, 418;

D 19, 31; J 317

Utah W $836 \mathrm{c}$

Virginia C $434,435,436$

Washington W. 425 e

See also Alluvium; Glacial drift; Valley fill. 
Queensland, ground water in, bibliography of W 163 Quicksand, sinking wells through W 30, 257, $375 d, 423$

\section{$\mathbf{R}$}

Racine limestone, water in, in Wisconsin GF 140

Radioactivity of ground water-

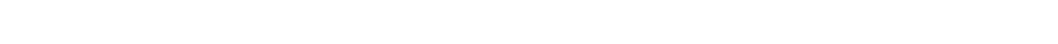

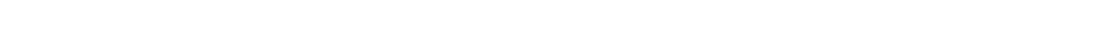

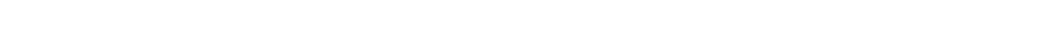

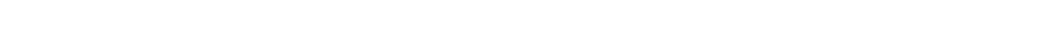

measurement ..................... 395; MR 1913 II h

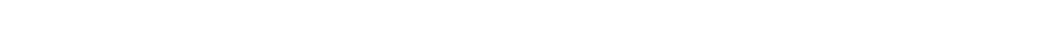

relation of, to temperature $\ldots \ldots \ldots \ldots \ldots \ldots \ldots \ldots \ldots \ldots \ldots \ldots$ B 395

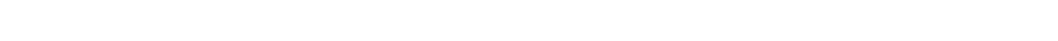

Yellowstone National Park ............... 395; MR 1913 II $\mathrm{h}$

Rafter, G. W., Water resources of the State of New York, part 2......W 25 Rainfall. See Precipitation.

Rams, hydraulic ...................W 1, 254, 256, 258, 540; C 431

Ransome, F. L., Bisbee folio, Ariz ....................GF 112

Copper deposits of Ray and Miami, Ariz ............... 115

Geology and gold deposits of Cripple Creek district, Colo........P 54

Geology and ore deposits of Breckenridge district, Colo $\ldots \ldots \ldots \ldots$ P 75

Geology and ore deposits of Coeur d' Alene district, Idahn ......P 62

Geology and ore deposits of Goldfield, Nev ...............P 66

Globe folio, Ariz .........................FF 111

Goldfield, Bullfrog, and other mining districts in southern Nevada . . B 303

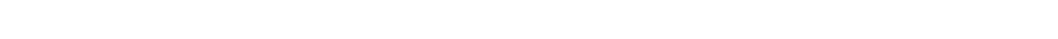

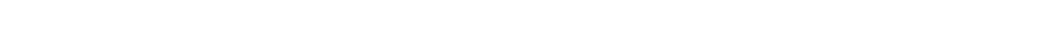

Silverton folio, Colo .........................GF 120

Raritan formation, water in-

Atlantic Coastal Plain ........................... 138

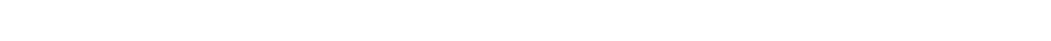

New Jersey ...........W 106; GF 157, 162, 167; C 213, 215, 217, 218

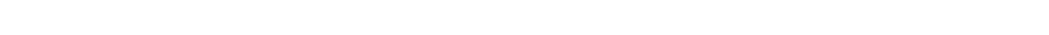

Pennsylvania ..........................W 106; GF 167

Rasmussen, W. C., Ground-water levels rise in North Dakota........D 164

Reconnaissance of possible well irrigation areas (in N. Drk.) . . . . C 304

Water levels and artesian pressure in the United States ...W 908, 938

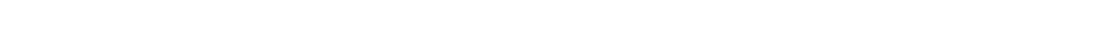
Reaction coefficients in water analyses $\ldots \ldots \ldots \ldots \ldots \ldots \ldots \ldots \ldots$ W 274 Recharge, artificial, of ground water-

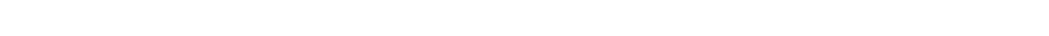

general ............................ 165; J 359

Kentucky .................................... J 362

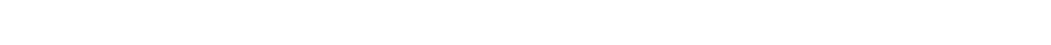

New York ..................................... 361

Recharge of ground water-

Arizona ................... 11, 15, 20, 20 a; D 160; J 240, 279

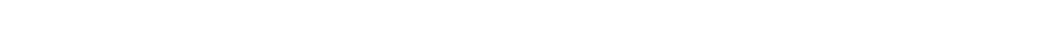

Colorado $\ldots \ldots \ldots \ldots \ldots \ldots \ldots \ldots \ldots \ldots \ldots \ldots \ldots \ldots \ldots \ldots \ldots \ldots \ldots$ C 32

Florida ............................. 5 59; J 321

general $\ldots \ldots \ldots \ldots \ldots \ldots$ D 77,$165 ;$ J 58, 89, 167, 170, 240, 267, 279, 320 
Recharge of ground water, Hawaii $\ldots \ldots \ldots \ldots \ldots \ldots \ldots \ldots \ldots$. 92, 98, 99

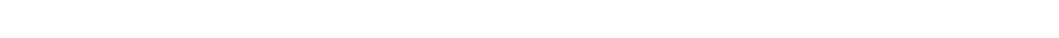

New Mexico ....................... 241, 248, 254, 255

New York ...............................J 193, 249

Pennsylvania .............................. 348

southern High Plains .......................... 180

southwestern States $\ldots \ldots \ldots \ldots \ldots \ldots \ldots \ldots \ldots \ldots \ldots \ldots \ldots \ldots$ J 291

Texas ......................... 51, 66; J 132, 203, 277

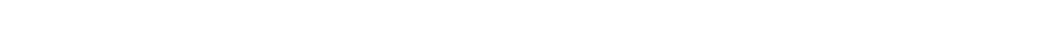

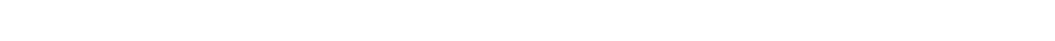

Reciprocating pumps $\ldots \ldots \ldots \ldots \ldots \ldots \ldots \ldots \ldots \ldots \ldots \ldots \ldots$ 14, 41, 398

Recovery of ground water. See Irrigation; Power for pumping; Public

water supplies; Pumps; Well construction; Wells.

Red beds, water in-

Colorado ............................. 21 Iv c; P 52

Kansas ......................... 6, 273; A 21 Iv c

Nebiaska .............................. 21 Iv c

New Mexico ........................W 123; A 21 Iv c

Oklahoma $\ldots \ldots \ldots \ldots \ldots \ldots \ldots \ldots \ldots \ldots \ldots \ldots \ldots \ldots$ W 148; A 21 Iv c

Texas $\ldots \ldots \ldots \ldots \ldots \ldots \ldots \ldots \ldots \ldots \ldots \ldots \ldots$ W 154, 191; A 21 Iv c

Wyoming .............................. 21 iv

See also specific formations.

Red clastic series, water in, in Minnesota ............W 256; GF 201

Redbank formation, water in, in Atlantic Coastal Plain ........... 138

Redwall limestone, water in, in Arizona ................. 836 b

Reed, E. C., Ground water in the Republican River Basin in Netraska

C 202, 203, 204

Reed, E. W., Geology and ground-water resources of the coastal area of

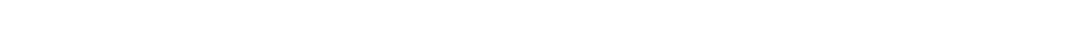

Ground-water survey of area north of O'Neill, Holt County, T'Tebr. .C 205

Ground-water levels remain high in most areas of Oklahoma...... 184

Oklahoma water, quantity, occurrence, and quality of surface and

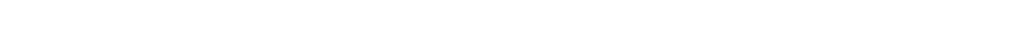

Results of detailed field work on the geology and ground-water resources of Cimarron County, Okla ................. 189

Water levels and artesian pressure in the United States..... 947, 989

Reed, J. C., Geology and ore deposits of the southwestern Arkansas

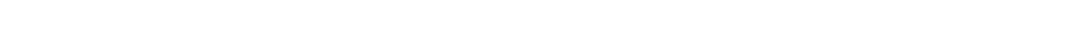

Mining districts of eastern Oregon .................. 846 a

Reeds, C. A., Water resources of the east St. Louis district, Ill... . . . . . : C 131

Reeside, J. B., Jr., Coal in San Juan County, N. Mex. ........... 716 g

Reeves, Frank, Absence of water in certain sandstones of the

Appalachian oil fields . ............................J 18

Geologic study of the Madden Dam project, Canal Zone ......... 821 b

Geology and possible oil and gas resources south of Bearpaw

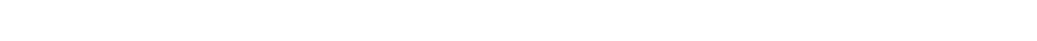

Geology of the Cat Creek and Devils Basin oil fields, Mont .... B 786 b

Geology of the Ranger oil field, Tex ............... 736 e

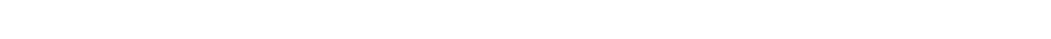

Springs of. Virginia .............................. 432

Structure and oil and gas resources of the Osage Reservation, Okla 
Reeves, Frank, Thermal springs of Virginia C 433

Thrust faulting and oil possibilities in the plains adjacent to Hghwood

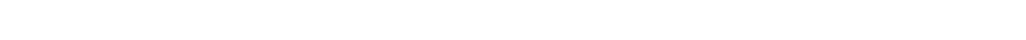

Renick, B. C., Additional ground-water supplies for the city of F nid,

Okla $\mathrm{W} 520 \mathrm{~b}$

Base exchange in ground water by silicates as illustrated in Montana ...................................W 520 d

California oil-field waters $\ldots \ldots \ldots \ldots \ldots \ldots \ldots \ldots \ldots \ldots \ldots \ldots . \ldots$ J 43

Geochemical relations of ground water and associated natur 1 gas

in the Lance formation, Mont ...................... 39

Geology and artesian water prospects in the San Jose-Rio Puercos

Valley, N. Mex ................................ 232

Geology and ground-water resources of central and southern Rosebud

County, Mont ............................. 600

Geology and ground-water resources of the drainage basin of Rio

Penasco above Hope, N. Mex .................... 235

Geology and ground-water resources of western Sandoval Co"nty,

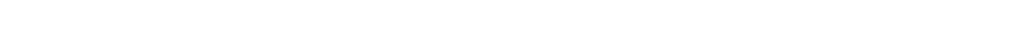

Geology of No. 3 reservoir site, Carlsbad irrigation project,

N. Mex .............................. 580 a

Ground water in Sandoval County, N. Mex ............... 5

Reservoirs, for well water $\ldots \ldots \ldots \ldots \ldots \ldots \ldots \ldots \ldots \ldots \ldots W 1,5,20,343$

underground $\ldots \ldots \ldots \ldots \ldots \ldots \ldots \ldots \ldots \ldots \ldots \ldots \ldots \ldots \ldots \ldots \ldots$

Residual soils, water in ............................. 124

Resistivity investigations. See Geophysical surveys.

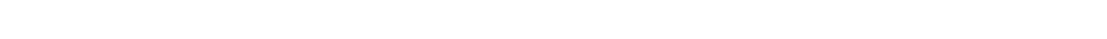

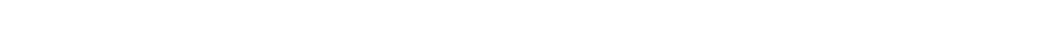
bibliography of ground water in $\ldots \ldots \ldots \ldots \ldots \ldots \ldots \ldots$ 114, 120, 163 mineral waters in $\ldots \ldots \ldots \ldots \ldots \ldots \ldots \ldots \ldots$ W 114; B 32; M] 1885-1923 quality of ground water in .......W 102, 114, 144; B 32; C 355, 356

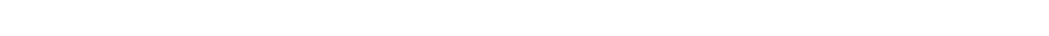
springs in .......................W 102; A 14 II b; B 32 well records for ..............W 61, 102, 149; B 264, 298; C 355, 356

Rice irrigation, with ground water, in Arkansas .......W 399; C 20 e; D 18 with ground water, in Louisiana .....W 101; C 162, 164; J 316, 373

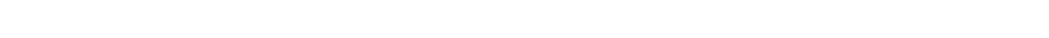

Richards, R. W., Bull Mountain coal field, Mont .............. 646

Richardson, G. B., Castle Rock folio, Colo ................GF 198

El Paso folio, Tex ............................... 166

Geology and coal, oii, and gas resources of New Kensington qradrange,

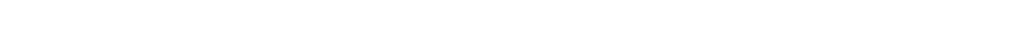

- Geology and mineral resources of the Butler and Zelienople quadrangles,

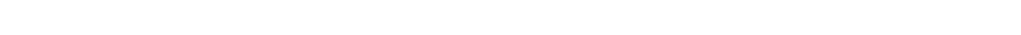

Geology and mineral resources of the Randolph quadrangle, Utah-

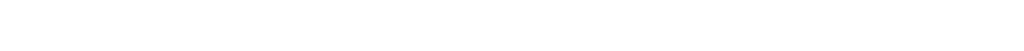

Indiana folio, $\mathrm{Pa} \ldots \ldots \ldots \ldots \ldots \ldots \ldots \ldots \ldots \ldots \ldots \ldots \ldots \ldots \ldots \ldots \ldots$ GF 102

Reconnaissance in trans-Pecos Texas ................. 381

Somerset-Windber folio, Pa. .....................FF 224

Structure and oil and gas resources of the Osage Reservation,

Okla .................................. 686 z

Subsurface structure in part of southwestern New York ...... B 899 b

Underground water in Sanpete and central Sevier Valleys, Utah ... W 199 
Richardson, G. B., Underground water in the valley of Utah Lake and Jordan River, Utah .........................W 157

Van Horn folio, Tex ............................. 194

Richmond formation, water in, in Kentucky ................. 233

water in, in Ohio ...........................W 259

Riddell, C. W., Exploratory drilling for water in Steptoe Valley, $N_{9 v}$. W 467

Riffenburg, H. B., Chemical character of ground waters of the northern

Great Plains ............................... 560 b

Geology and ground-water resources of North Dakota ........W 598

Ripley formation, water in

Alabama ................................... 4

Georgia ..............................W 341; C 81

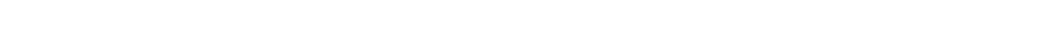

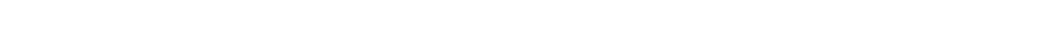

Mississippi ...............................W 159

Tennessee $\ldots \ldots \ldots \ldots \ldots \ldots \ldots \ldots \ldots \ldots \ldots \ldots$ W 164, 638 a; C 37?; D.14, 25

Roberts, C. M., Progress report on the water resources of Providerme,

R. I ...................................... 355

Record of wells in Nassau County, N. Y ............... 282

Record of wells in Suffolk County, N. Y., Supplement 1 ......C 281

Well and test hole records for Providence, $R . \mathbf{I} \ldots \ldots \ldots \ldots \ldots \ldots$. 356

Robinson, H. M., Geologic structure and oil and gas prospects of

part of Jefferson County, Okla ......................... 726 f

Structure and oil and gas resources of the Osage Reservation,

Okla ................................ 686 t, $v, y$

Structure of the Madill-Denison area, Okla. and Tex ........ 736 a

Robinson, J. W., Water levels and artesian pressure in the United States

W 910, 948, 949, 990, 991

Robinson, T. W., Cooperative ground-water investigations in Wyoming $\mathbf{C} 455$

Decline of artesian head in west-central South Dákota ...C 361; J 152

Earth tides shown by fluctuations of water levels in wells in

New Mexico and Iowa ........................... 206

Geology and ground-water conditions of the Pecos River Val'sy

in the vicinity of Laguna Grande de la Sal, N. Mex ......... 248

Geology and ground-water hydrology of the Mokelumne araa,

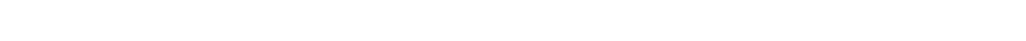

Geology and ground-water resources of the Harney Basin, Oeg..D 62

Geology and water resources of the Mokelumne area, Calif .....W 619

Ground-water conditions of the Dakota sandstone in northwe stern

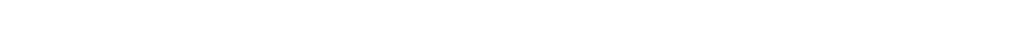

Ground water for irrigation in the Harney Basin, Oreg ........ 24

Ground water in the San Luis Valley, Colo ............. 32

Ground water in the vicinity of Lodi, Calif ................ 13

Ground water in the Walla Walla basin, Oreg.-Wash ........D 44

Salt-water problems in Iowa and South Dakota ............ 151

Source of salt in ground water in the vicinity of Laguna Grande

de la Sal, N. Mex ......................... 103

Water levels and artesian pressure in the United States... $W^{\top} 817,886$, 908, 910, 938, 946

Rogers, G. S., Chemical relations of oil-field waters in San Joaquin

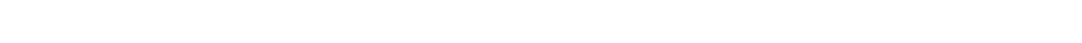

Cleveland gas field, Ohio ......................... 661 a 
Rogers, G. S., Geology of the Tullock Creek coal field, Mont. . . . . . . . B 749

Interpretation of water analyses by the geologist $\ldots \ldots \ldots \ldots \ldots . . . J 16$

Oil-field waters of the Gulf Coast ......................J 23

Sunset-Midway oil-field, Calif., part 2, geochemical

relations of the oil, gas, and water ............... 117

Rose, N. A., Bibliography on electrical well logging ............ 153

Exploratory water-well driling in the Houston district, Tex. $\mathrm{Tr}^{\mathrm{r}} 889$ e; C 406

Ground water and the relation of geology to its occurrenc?

in the Houston district, Tex ................... 317

Ground-water resources of the Houston district, Tex.W 889 d; C 396, 413

Ground-water resources of the Texas City area, Tex ........ 408

Occurrence of salt water in the Houston district, Tex ........ 151

Quantitative studies of some artesian aquifers in Texas .......J 347

Relation of phenomenal rise of water levels to a defectivis

gas well, Harris County, Tex ..................... 337

Research in the field of ground water being conducted by oil

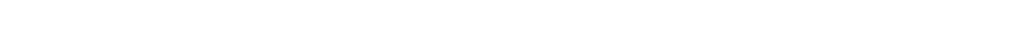

Ross, C. P., Copper deposits near Salmon, Idaho .............. 774

Coso quicksilver district in Inyo County, Calif ............. 936 q

Geologic study of the Madden Dam project, Canal Zone ........ $821 \mathrm{~b}$

Geology and ore deposits of the Aravaipa and Stanley mining districts,

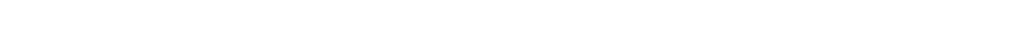

Geology and ore deposits of the Wood River region, Idaho .......B 814

Geology and ore deposits of the Casto quadrangle, Idaho ....... B 854

Geology and ore deposits of, the Wood region, Idaho ........... 814

Lower Gila region, Ariz ...................... 498

Quicksilver deposits of the Mayacmas and Sulphur Bank districts,

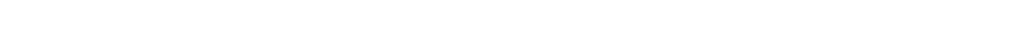

Quicksilver deposits of the Mount Diablo district, Calif ...... 922 b

Routes to desert watering places in the lower Gila region, Ariz ...W $490 \mathrm{c}$

Water supply for Arlington County, Va .............. 7

Ross, C. S., Structure and oil and gas resources of the Osage Peservation,

Okla .................................... 686 u

Ross, D. W., Progress of stream measurements for $1904 \ldots \ldots \ldots \ldots$. W 135

Rothrock, E. P., Artesian conditions in west-central South Dal'nta ... C 361

Ground waters in North Dakota, South Dakota, and Minnesota ... C 303

Rothrock, H. E., Geology and fuel resources of Quinton-Scipio district;

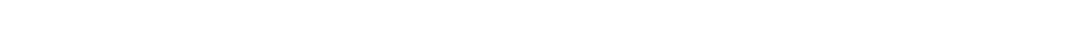

Roubidoux sandstone, water in, in Missouri ...............W 195

Roundy, P. V., Geology and oil resources of the Elk Hills, Calif. . ....B 835

Structure and oil and gas resources of the Osage Reservation,

Okla ............................... 686 u, z

Rubey, W. W., Subsurface study of the Pershing oil and gas fielt,

Okla ................................... 751 b

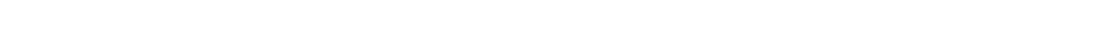

Runoff, ground-water ...............W 597 b; J 159, 255, 288

Russell, I. C., Ann Arbor folio, Mich .................GF 155

Artesian basins in Idaho and Oregon ................ 78

Geological history of Lake Lahontan, Nev ...............M 11

Geological reconnaissance in central Washington ............. 108

Geology and water resources of central Oregon ............. 252

Geology and water resources of Nez Perce County, Idaho .....W 53, 54 
Russell, I. C., Geology and water resources of the Snake River P'ains

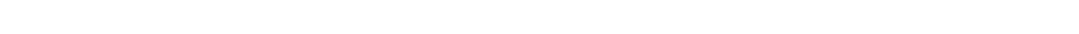

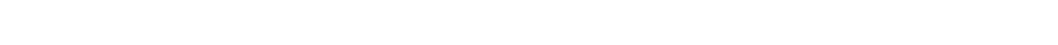

Reconnaissance in southeastern Washington $\ldots \ldots \ldots \ldots \ldots \ldots W$ W 4

Russia, bibliography of ground water in $\ldots \ldots \ldots \ldots \ldots \ldots \ldots \ldots \ldots$ W 163

Rustler dolomite, water in, in Texas .................... 402

$\mathbf{S}$

Sabine formation, water in, in Arkansas ............. 114; P 46 water in, in Louisiana ..................... W 114; P 46

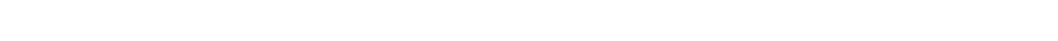
See also Wilcox formation.

Sackett, R. L., Disposal of strawboard and oil-well wastes .......W 113 Sahara Desert, bibliography of ground water in $\ldots \ldots \ldots \ldots \ldots \ldots W$ W 163

St. Clair black shale, water in, in Michigan $\ldots \ldots \ldots \ldots \ldots \ldots \ldots \ldots$ W 30

St. Lawrence formation, water in, in Iowa $\ldots \ldots \ldots \ldots \ldots \ldots \ldots$ W 293 water in, in Minnesota ........................W 256

St. Louis limestone, water in, in Illinois ................W 114

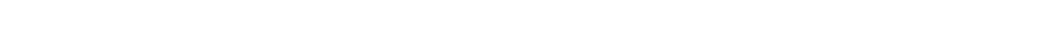

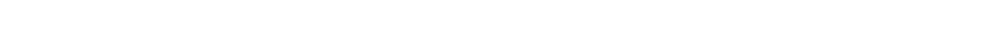

in Missouri .............................. 195

St. Marys formation, water in, in North Carolina ............. 291

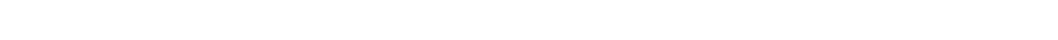
See also Chesapeake group.

St. Peter sandstone, water in-

Illinois.W 114; A 17 í h; M 38; B 438, 506; GF 81, 188, 200, 298, 213, 216

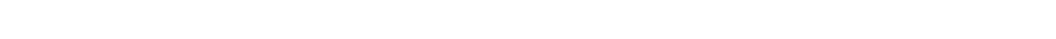
Iowa ......................W 293; GF 145, 200; C 137

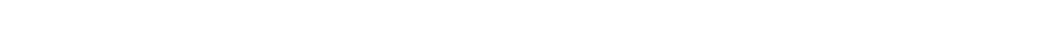

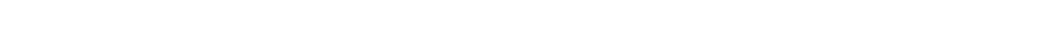
Minnesota ......................... 256; GF 201 Missouri ..................W 195; B 438; GF 148, 206 Nebraska .............................. 32

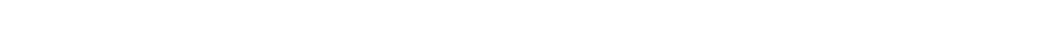
Wisconsin ................W 114, 145; GF 140, 145; C 451

Saipan, Marianas Islands, ground water in .............J 336

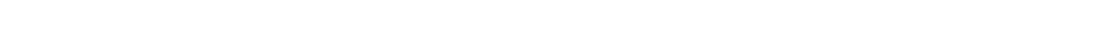

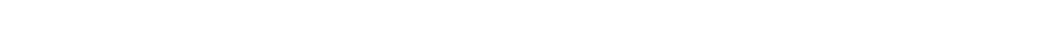

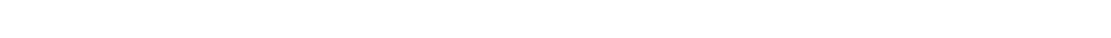

Salinity, of ground water $\ldots \ldots \ldots \ldots \ldots \ldots \ldots \ldots \ldots$ 338; B 473, 606, 693 primary, secondary, and tertiary ..............W 338; B 479

Salisbury, R. D., Franklin Furnace folio, N. J..............GF 161

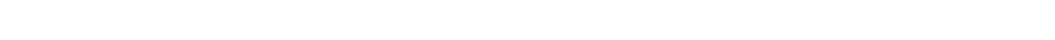

Passaic folio, N. J.-N. Y .......................... 157

Philadelphia folio, Pa.-N. J.-Del .................GF 161

Raritan folio, N. J . . .......................GF 191

Trenton folio, N. J.-Pa .......................GF 167

Salt water, along Atlantic and Gulf coasts ..........W 889 e; J 296

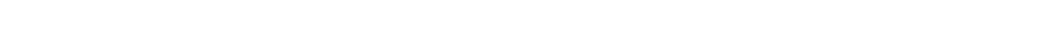

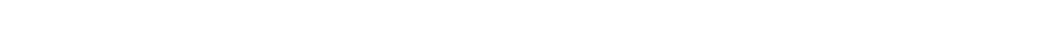
physiologic functions of $\ldots \ldots \ldots \ldots \ldots \ldots \ldots \ldots$ W 144; MP 1911 II $n$ relation of, to "domes" ..................W 355; J 257 See also specific States. 


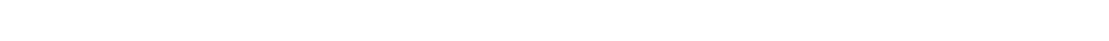

Saltsburg sandstone, water in, in Pennsylvania ............... GF 102

Samples of water, methods of collecting ...........W $596 \mathrm{~h}$; B 47 methods of collecting, for normal chloride determination ......W 144

Samples of well drillings, fossils in $\ldots \ldots \ldots \ldots \ldots \ldots \ldots \ldots \ldots W-293 ; \mathrm{P} 90 \mathrm{~h}$

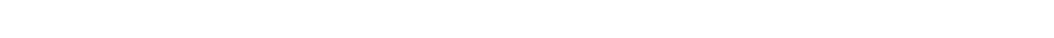
methods of examining ....................W 293; P $90 \mathrm{~h}$

Sand, H. H., Water supply of the Dakota sandstone ..........W 889 a

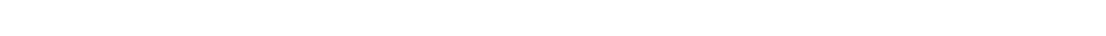
confining beds for artesian water produced by ......... 44; B 319

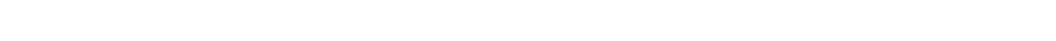
drilling through $\ldots \ldots \ldots \ldots \ldots \ldots \ldots \ldots \ldots \ldots \ldots \ldots$ 30, 25r; $375 \mathrm{~d}, 423$

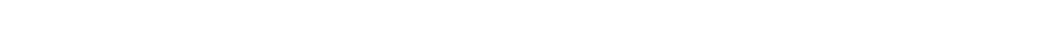
finishing wellsin $\ldots \ldots \ldots \ldots \ldots \ldots \ldots \ldots \ldots \ldots \ldots \ldots$ W 256, 293, 343 flow of water in, experiments with .............W 140; A 19 II b porosity of $\ldots \ldots \ldots \ldots \ldots \ldots \ldots \ldots \ldots \ldots \ldots$ W 140; A 19 í b; C 16 water in $\ldots \ldots \ldots \ldots \ldots \ldots \ldots \ldots W$ 25, 114, 140, 223, 233, 25 5, 257, 258, 319,489 ; A 19 í b; P 44; B $\varepsilon 19$; GF 105

Sand hills, water in $\ldots \ldots \ldots \ldots \ldots \ldots \ldots \ldots \ldots \ldots \ldots$ W 145, 273, 497

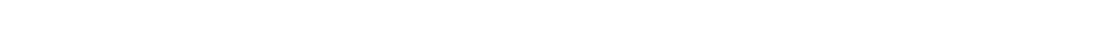

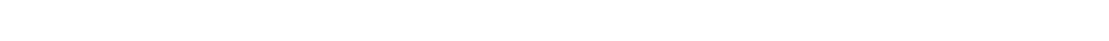

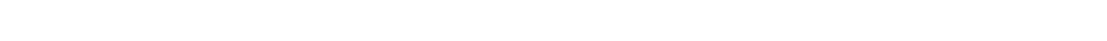
movement of water through ..................... 19 II b water in ...............W 110, 114, 255, 257, 489; A 5 c, 19 II b See also specific formations.

Sanford, Samuel, Geology and ground waters of Florida ........W 319 Production of mineral waters ..................... 1906-1909 Records of deep wells, $1905 \ldots \ldots \ldots \ldots \ldots \ldots \ldots \ldots \ldots \ldots \ldots \ldots$ Saline artesian waters of Atlantic Coastal Plain ............W 258 Underground water resources of the Coastal Plain of Virginia ...C 431 Sanitary inspection of water supplies $\ldots \ldots \ldots \ldots \ldots \ldots \ldots \ldots \ldots$ W 193, 255 Sanitation. See Analyses; Pollution; Purification; Quality.

Santa Fe formation, water in, in New Mexico ............. 31; D 5

Santa Rosa sandstone, water in, in Texas ................ 402

Sardeson, F. W., Herman-Morris folio, Minn ..............GF 210

Minneapolis-St. Paul folio, Minn ...................FF 201

Satanka formation, water in, in Wyoming ............... 456 Saunders, J. L., Surface water supply of the United States..W 897, 957, 977 Savage, T. E., Murphysboro-Herrin folio, Ill ..............GF 185

Tallula-Springfield folio, Ill ...................FF 188 Sayre, A. N., Estimating safe yield as illustrated by the EI Paso, Tex.,

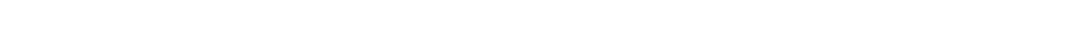

Geology and ground water, Pecos River Basin, N. Mex ........C 256

Geology and ground-water resources of Duval County, Tex .....W 776

Geology and ground-water resources of the Lufkin area, Tex ...W 849 a Geology and water resources of Uvalde and Medina Counties, Tex. . W 678 Ground water in the Pecos River Basin in Texas ............. 402 Ground-water resources of Duval County, Tex ............. 40

Ground-water resources of the El Paso area, Tex ...........W 919

Ground-water studies in Central America ...............J 370

Ground-water supplies and dam sites in the James, and Sheyenne

River Basins, N. Dak.. and S. Dak ............... 302 
Sayre, A. N., Investigation of ground-water supplies and dam siter. James and Sheyenne River Basins, N. Dak., and S. Dak ............J 153 Military water supplies in the southwest Pacific area ..........J 368

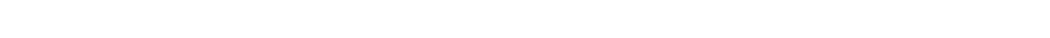
Papers relating to ground-water hydrology ...........J 9?, 113, 172 Recharge, movement, and discharge in the Edwards limestone reservoir, Tex ................................ 278

Relation of drought of 1934 to ground-water supplies in James $\varepsilon$ nd Sheyenne River Basins, N. Dak., and S. Dak ..............J 153

Relation of ground-water levels to temperature and precipitation at Harvey, N. Dak ............................... 61

Salt-water problems in the El Paso, Tex., area .............. 151 Use of resistivity methods in location of salt-water bodies in the

El Paso, Tex., area .............................. 176

Water conservation and utilization, N. Dak ................. 301 Water levels and artesian pressure in the United States ..W 777, 817, 840, $845,886,906,909,93^{?}, 939,944$

Scale formed in boilers by water ...W $233,254,256,259,274,293,341,398$,

Schaefer, E. J., Conditions affecting salt-water intrusion in the Atlantic 299; C 451

City region, N. J ................................ 151

Water levels and artesian pressure in the United States ..W 845, 886, 906 936. 944,986

Scherer, O. J., Ground-water resources of Box Butte County,

Nebr ...................................W $₫ 99 ; \mathrm{D} 162$

Schist, water in $\ldots \ldots \ldots \ldots \ldots$ W $114,160,223,232,255,257,48^{\natural}$; GF 147

Schistosity in relation to ground water $\ldots \ldots \ldots \ldots \ldots \ldots \ldots$ W 232, 489

Schlundt, Herman, Radioactivity of thermal waters of Yellowstone.

National Park .................................... 395

Schoff, S. L., Deep-seated solution in the Meade Basin, Kans. and

Okla.

Geological Survey investigates ground water in North Canadiar

Valley (Okla.) ................................ 175

Geology and ground-water resources of Beaver County, Okla ....D 178

Geology and ground-water resources of Cimarron County, Okla ...C 322

Geology and ground-water resources of Texas County, Okla..C ? 21 ; D 106

Ground water in Cimarron County, Okla ............... 115

Ground water investigations in Oklahoma Panhandle ...D 173; J 213, 223

Ground-water levels in Oklahoma .................... 123, 174

Ground-water table in Oklahoma ................... 168

Results of detailed field work on the geology and ground-water

resources of Cimarron County, Okla .................. 189

Salt-water intrusion in Oklahoma $\ldots \ldots \ldots \ldots \ldots \ldots \ldots \ldots \ldots \ldots$ D 151

Test drilling with hand tools $\ldots \ldots \ldots \ldots \ldots \ldots \ldots \ldots \ldots \ldots \ldots \ldots$ D 126

Water levels and artesian pressure in the United States.....W 840, 886,

909; 939

Schrader, F. C., Contact mining district, Nev .............. 847 a

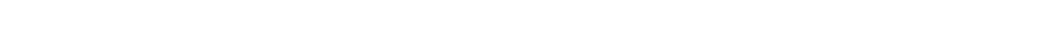

Metalliferous deposits of the greater Helena mining region, Mont..B 842

Mineral deposits of Santa Rita and Patagonia Mountains, Ariz .....B 582

Quicksilver deposits of the Phoenix Mountains, Ariz ........ $690 \mathrm{~d}$ 
Schultz, A. R., Geology and geography of Lincoln County, Wyo . . . . B 543 Oil possibilities in Baxter Basin, Wyo ...................... 702

Phosphate and coal in southeastern Idaho and western Wyoming ...B 680

Underground waters of the Wisconsin district ...........W 114

Water supplies of Wisconsin $\ldots \ldots \ldots \ldots \ldots \ldots \ldots \ldots \ldots \ldots \ldots$. 451

Schwennesen, A. T., Geology and water resources of the Gila ant

San Carlos Valleys, Ariz ........................W 450 a

Ground water for irrigation near Enid, Okla .........W 345 b

Ground water for irrigation near Oklahoma City, Okla .......W $345 \mathrm{~d}$ Ground water in Animas, Playas, Hachita, and San Luis basins,

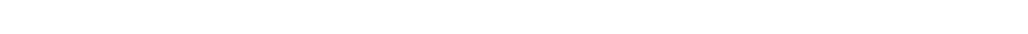

Ground water in Quincy Valley, Wash ...............W 425 e

Ground water in San Simon Valley, Ariz.-N. Mex .........W 425 a

Pumping tests in Luna County, N. Mex .........W ₹45 c; B 618

Scofield, C. S., Quality of water of the Rio Grande Basin, Tex .......W 839

Scott, M. J., Development of irrigation, in Ground-water resources of the

Santa Cruz Basin, Ariz .......................... 20

History of the Santa Cruz Valley in Ground-water resources of the

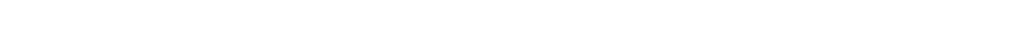

Water levels and artesian pressure in the United States ...W 949, 991 Screens in wells. See Well screens.

Sea water, confining beds for artesian water produced by ......... 319

effect of, on ground water near coast ...W 77, 144, 223, 34F h, 537, 616;

C $92,97,98,99$

encroachment of $\ldots \ldots \ldots W$ 77, 144, 223, 345 h, 537, 616; C 92, 97, 98, 99

Sea water in rocks. See Connate water.

Sears, J. D., Geology and coal resources of the Gallup-Zuni bas: $\eta$,

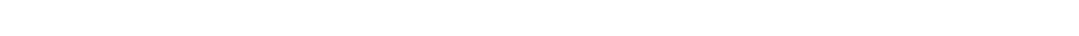

Geology and oil and gas prospects of part of Moffat County, Colo.,

and southern Sweetwater County, Wyo ................ $751 \mathrm{~g}$

Geology of the Baxter Basin gas field, Wyo .............. $781 \mathrm{~b}$

Secondary alkalinity of ground water $\ldots . . \ldots . W$. 338; P $90 \mathrm{r}$; B 479, 606 .

Secondary salinity of ground water. See Quality; Salinity; Sal ${ }^{\text {t }}$ Water.

Sections of wells. See Well records.

Sedgwick, T. F., Report of Water Commission of Hawaii ........... 91

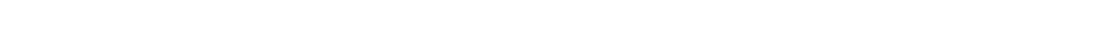

Sedimentary rocks, ground water in $\ldots \ldots \ldots \ldots \ldots \ldots \ldots \ldots \ldots \ldots \ldots \ldots \ldots \ldots \ldots$

Seed-bag packers for wells $\ldots \ldots \ldots \ldots \ldots \ldots \ldots \ldots \ldots \ldots$ W 54.118; A 5 c

Seelheim, F., on flow of water through soils ............... 19 II b

Seepage from reservoirs, relation of, to movements of ground water in

California ............................ 18, 58, 294

Colorado .......................... 9, 50, 358

general ............................. 597 a; P 44

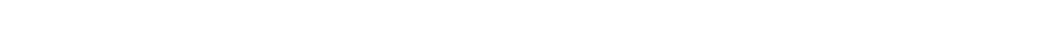

Nebraska ................................... 140

Nevada ..................................... 423

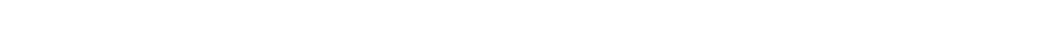

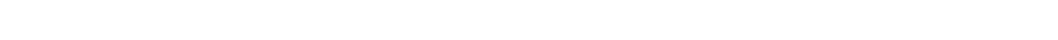

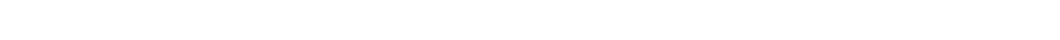

Sellards, E. H., Artesian water supply of eastern and southern Florida. . C 54

Artesian water supply of eastern Florida ............... 52

Underground water supply of central Floricla ............. 51

Underground water supply of west-central and west Florida ...... 53 
Sellersburg limestone, water in, in Indiana W 254

Selma chalk, water in, in Alabama $\ldots \ldots \ldots \ldots \ldots \ldots \ldots \ldots \ldots \ldots$ C 1

water in, in Tennessee ......................W 638 a; C 372

Serpentine, water in ..................... 489; GF 157

Settlement, fluctuation of water table in relation to ..........W 155

Seymour formation, water in, in Texas . . . . . . . . . . . . . .W 317

Shakopee dolomite, water in, in Minnesota $\ldots \ldots \ldots \ldots \ldots \ldots$ W 256

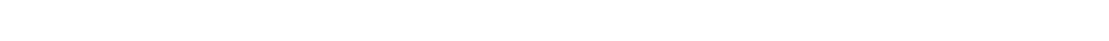

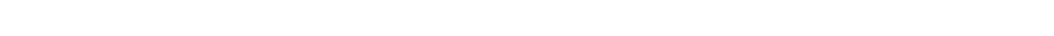

water in $\ldots \ldots \ldots \ldots \ldots \ldots$ W 110, 232, 233, 254, 257, 259, 425 b. 489, 596 c

Sharon conglomerate, water in, in Ohio ................. 19 Iv b

Shattuck, G. B., Patuxent folio, Md.-D. C. ................FF 152

St. Marys folio, Md.-Va. ........................... 136

Shaw, E. W., Belleville-Breese folio, Ill ................... 195

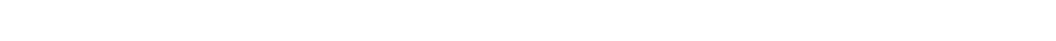

Galena-Elizabeth folio, Ill.-Iowa $\ldots \ldots \ldots \ldots \ldots \ldots \ldots \ldots \ldots$ GF 200

Irvine oil field, $\mathrm{Ky} \ldots \ldots \ldots \ldots \ldots \ldots \ldots \ldots \ldots \ldots \ldots \ldots \ldots \ldots$. 661 d

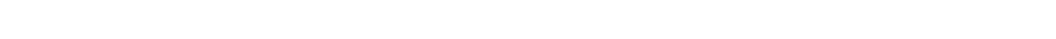

Natural-gas resources available to Dallas, Tex ........... $716 \mathrm{~d}$

New Athens-Okawville folio, Ill ...................... 213

Oil fields of Allen County, Ky ..................... 688

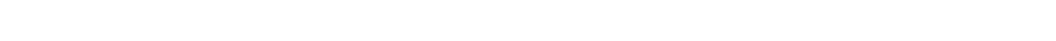

Sheet water .......................W 29, 154; A 16 In $\mathrm{f}$

Shell marl, water in ....................W 319, 489; C 62; J 258

Shenandoah limestone, water in, in Pennsylvania ...........GF 162

Shepard, E. M., Springs of Decaturville dome, Mo ...........W 110

Underground waters of Missouri ................. 114, 195

Well and spring records for Missouri $\ldots \ldots \ldots \ldots \ldots \ldots \ldots \ldots$ W 102

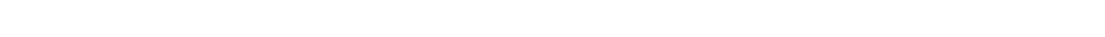

Shinarump conglomerate, water in, in Arizona $\ldots \ldots \ldots \ldots \ldots \ldots$ W 836 b

Shooting of wells ........................W 223, 255, 257

Siebenthal, C. E., Geology and water resources of the San Luis Valley,

Colo ...................................... 240

Geology of the Laramie Basin, Wyo ................. 364

Joplin district folio, Mo.-Kans ......................F 148

Laramie-Sherman folio, Wyo ...................... 173

Origin of the zinc and lead deposits of the Joplin region .......B 606

Silica in ground water ..........W 240, 273, 338; M 52; B 330; 491, 616

Sills, relation of, to springs ...................W 400 b, 489

Silurian formations, water in-

Alabama .........................W 114; GF 175; C 2

Arkansas ............................. 114; B 808

Georgia $\ldots \ldots \ldots \ldots \ldots \ldots \ldots \ldots \ldots \ldots \ldots \ldots \ldots \ldots \ldots \ldots$ 114; C 81

Illinois ...................W 114; A 17 II $\mathrm{h}$; M 38; B 506

Indiana $\ldots \ldots \ldots \ldots \ldots \ldots \ldots \ldots \ldots \ldots \ldots \ldots$ W $113,114,254 ; A 18$ iv b

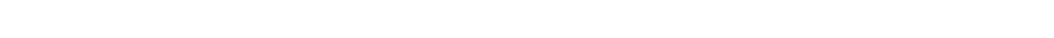

Kentucky ........................W 114, 233; B 688

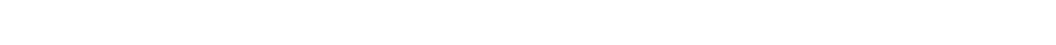

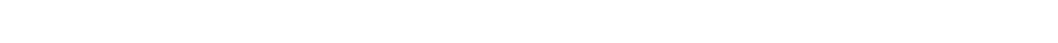

Michigan $\ldots \ldots \ldots \ldots \ldots \ldots \ldots \ldots \ldots \ldots \ldots$ W 30, 31, 114, 182, 183; GF 205

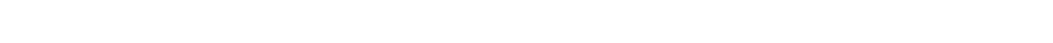

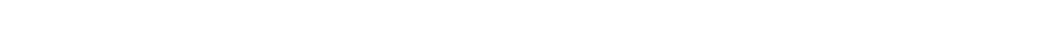


Silurian formations, water in, New York .............. 114; C 273 Ohio .............W 91, 114, 259; A 18 Iv b, 19 Iv n; B 818; GF 197 Pennsylvania ...........W 110, 114; GF 179; C 344, 345, 346, 349 Tennessee $\ldots \ldots \ldots \ldots \ldots \ldots \ldots \ldots \ldots \ldots \ldots \ldots \ldots \ldots . \ldots \ldots$ 114, 677; C 371 Virginia ......................W 114; C 433, 434, 436 West Virginia ......................W 114; GF 179; C 433 Wisconsin ......................W 114; GF 140; C 451 See also specific formations.

Silver in ground water ...................... 94; B 529, 625 Simpson, H. E., Geology and ground-water resources of North Dakota. . W 598

Underground water resources of Iowa ............W 293; C 137 Singing wells in Nebraska ........................W 29 Sinkholes, absorption of water by ...WW 319; A 16 II f; C 55, 81; J 260, 293 in gypseous deposits $\ldots \ldots \ldots \ldots \ldots \ldots \ldots \ldots \ldots \ldots \ldots \ldots$ 343; A 21 Iv c natural wells produced by $\ldots \ldots \ldots \ldots \ldots \ldots \ldots \ldots \ldots \ldots \ldots$. 21 Iv c pollution by $\ldots \ldots \ldots \ldots \ldots \ldots \ldots \ldots \ldots \ldots \ldots \ldots \ldots$ W 233, 255, 258; C 131 Sinking of wells. See Well construction.

Sinnott, Allen, Cooperative ground-water investigation in

Torrance-Santa Monica area, Calif .................... 30 c

Withdrawals of ground water from the Long Beach-Santa Ana area,

Calif ....................................... 30 e

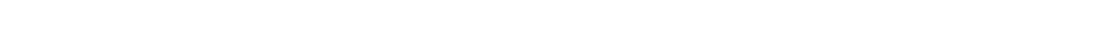

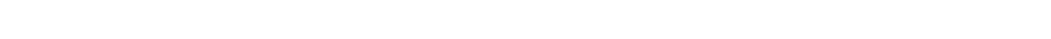

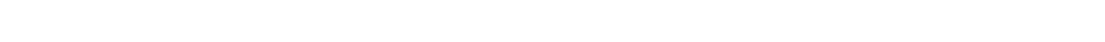

Siphons in wells .....................W 254, 320, 374, 397, 540

Sizing tests for water-bearing materials $\ldots \ldots \ldots \ldots \ldots \ldots \ldots \ldots \ldots$ P 44

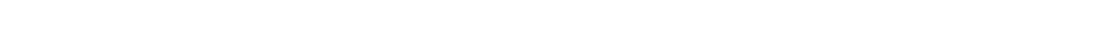

Slichter, C. S., Approximate method of measuring flow of wells .....W 110

California or "stovepipe" method of well construction ......WW 110

Description of underflow meter ....................W 110

Ground waters of Rio Grande Valley, Tex.-N. Mex ............W 141

Measurements of underflow .......................W 140

Motions of underground waters $\ldots \ldots \ldots \ldots \ldots \ldots \ldots \ldots \ldots \ldots$ W 67

Theoretical investigation of the motion of ground waters ...A 19 II $\mathrm{c}$

Underflow in Arkansas Valley in western Kansas ..........W 153

Underflow of the South Platte Valley (Colo. and Nebr.) .......W 184

Underground water resources of Long Island, N. Y ..........P 44

Smith, A. G., Report of water commission of Hawaii $\ldots \ldots \ldots \ldots \ldots$ C 91

Smith, E. A., Underground water in Alabama .............. 114

Underground water resources of Alabama $\ldots \ldots \ldots \ldots \ldots \ldots \ldots \ldots$ C. 1

Well and spring records for Alabama ................W 102

Smith, G. O., Artesian water in crystalline rocks ..............J 4

Ellensburg folio, Wash ......................... 86

Geology and water resources of a portion of Yakima County, $\mathrm{W}^{\mathrm{r}} \mathrm{ash} . \mathrm{W} 55$

Mount Stuart folio, Wash ......................... 106

Penobscot Bay folio, Maine . ......................GF 149

Water from glacial gravels near Augusta, Maine ...........W 145

Water resources of the Portsmouth-York region, N. H.-Maine ...W 145

Smith, P. S., Mineral industry of Alaska in $1924 \ldots \ldots \ldots \ldots \ldots \ldots$. 783 a

Smith, W. S. T., Edgemont folio, S. Dak.-Nebr ............GF 108

Joplin district folio, Mo.-Kan ...................GF 148

Water Resources of the Joplin district, Mo.-Kan ..........W 145

Well and spring records for Joplin and vicinity, Mo ..........W 102 
Soap consumption by water $\ldots \ldots \ldots \ldots \ldots \ldots \ldots \ldots \ldots \ldots \ldots$ 256, 274

Soap. making, quality of water in relation to ..............W 233

Sodium in ground water $\ldots \ldots \ldots \ldots \ldots \ldots \ldots \ldots W$ 236, 254, 259, 278, 338, 341;

398,520 d; P 117; B 47; 1 R 1911 II n

Softening of water $\ldots \ldots \ldots \ldots \ldots W 254,274,293,315,398,520 \mathrm{c}_{\mathrm{f}} 559,596 \mathrm{~g}$ Soil causing perched water $\ldots \ldots \ldots \ldots \ldots \ldots \ldots \ldots \ldots \ldots \ldots$ W $616 ; \mathrm{C} 92,99$ Solids in ground water. See Analyses; Quality.

Solution, depressions caused by, in Kansas and Oklahoma .........J 293 Solution caverns, water in ................W 114; B 319; J 260, 293 Solutions comprising ground water, theories and laws relating to.B 606 ; M 47 Solutions for water analysis $\ldots \ldots \ldots \ldots \ldots \ldots \ldots \ldots \ldots \ldots \ldots$ W 236 Source of ground water. See Absorption of water; Origin of grornd water.

South Australia, bibliography of ground water in $\ldots \ldots \ldots \ldots \ldots \ldots$ W 163

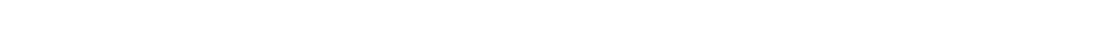

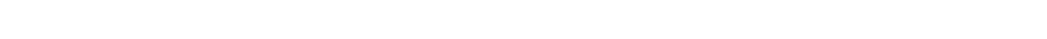

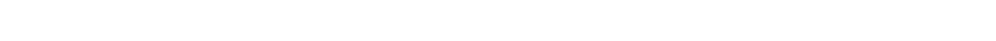

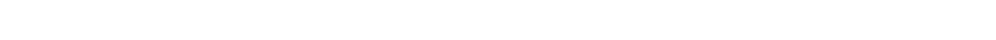

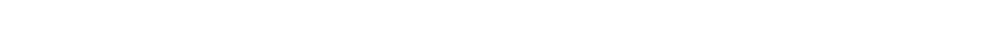

Gaffney quadrangle ........................GF 222

Hampton County ................................. 298

Kings Mountain quadrangle ...................GF 222

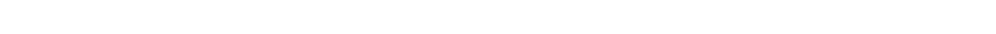

Orangeburg County $\ldots \ldots \ldots \ldots \ldots \ldots \ldots \ldots \ldots \ldots \ldots \ldots \ldots$ B 298

Pisgah quadrangle ........................FF 147

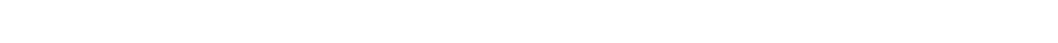

bibliography of ground water in $\ldots \ldots \ldots \ldots \ldots \ldots$ W 61, 114, 120, 149, 163

mineral waters in .................... 32; M] 1883-1923

public water supplies in ........................ 138

quality of ground water in ...........W 258, 364; P $90 \mathrm{~h}$; B 32, 138

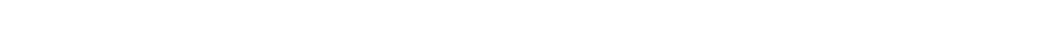
springs in ................W 114; A 14 In b; B 32; GF 147, 222 water levels in $\ldots \ldots \ldots \ldots \ldots$ W 777, 817, 840, 845, 886, 907, 937, 945, 987

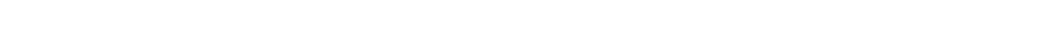

well records for ...........W 61, 114, 149; P 90 h; B 138, 298, 867

South Dakota, areas, Aberdeen quadrangle ..............GF 165

areas Aladdin quadrangle ........................ 128

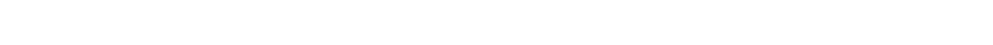

all of State $\ldots \ldots \ldots \ldots \ldots \ldots \ldots \ldots \ldots \ldots \ldots \ldots \ldots V^{r} 227$ P 32

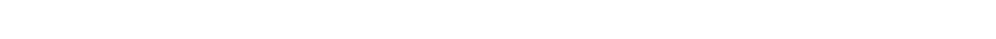

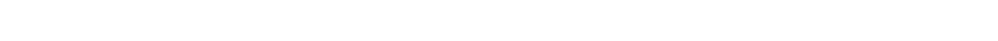

Belle Fourche quadrangle .....................FF 164

Black Hills region .................W 428; A 21 iv b; P 65

Byron quadrangle .........................GF 165

Canton ..........................W 597 c: D 11; J 63

Cheyenne River Indian Reservation ................ 575

Corson County ........................... 575

Deadwood quadrangle $\ldots \ldots \ldots \ldots \ldots \ldots \ldots \ldots \ldots \ldots \ldots \ldots \ldots$. 219

De Smet quadrangle ......................... 114

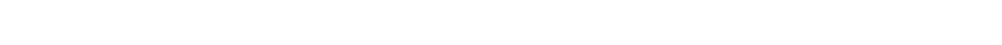

eastern ........................ 17 II g, 18 IV c

Edgemont quadrangle $\ldots \ldots \ldots \ldots \ldots \ldots \ldots \ldots \ldots \ldots \ldots \ldots$ GF 108

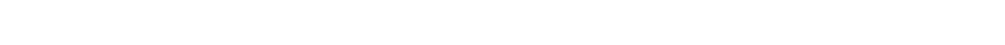

Harney quadrangle ........................GF 219 
South Dakota, areas, Hermosa quadrangle .................GF 219

Huron quadrangle $\ldots \ldots \ldots \ldots \ldots \ldots \ldots \ldots \ldots \ldots \ldots \ldots \ldots$ GF 113

James River Valley ........................W 90; C 302

Miner County .................................. 298

Mitchell quadrangle $\ldots \ldots \ldots \ldots \ldots \ldots \ldots \ldots \ldots \ldots \ldots$, GF 99

Newcastle quadrangle ...........................GF 107

Newell quadrangle $\ldots \ldots \ldots \ldots \ldots \ldots \ldots \ldots \ldots \ldots \ldots \ldots$. GF 209

Northville quadrangle $\ldots \ldots \ldots \ldots \ldots \ldots \ldots \ldots \ldots \ldots \ldots$, GF 165

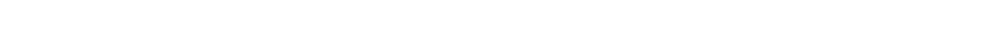

Oelrichs quadrangle $\ldots \ldots \ldots \ldots \ldots \ldots \ldots \ldots \ldots \ldots \ldots \ldots, \ldots \ldots \ldots$ GF 85

Olivet quadrangle $\ldots \ldots \ldots \ldots \ldots \ldots \ldots \ldots \ldots \ldots \ldots \ldots \ldots \ldots \ldots \ldots \ldots+$ GF 96

Parker quadrangle $\ldots \ldots \ldots \ldots \ldots \ldots \ldots \ldots \ldots \ldots \ldots \ldots \ldots \ldots \ldots \ldots \ldots$, GF 97

Rapid quadrangle $\ldots \ldots \ldots \ldots \ldots \ldots \ldots \ldots \ldots \ldots \ldots \ldots$ GF 219

Redfield quadrangle $\ldots \ldots \ldots \ldots \ldots \ldots \ldots \ldots \ldots \ldots \ldots \ldots$, GF 165

Sheyenne River Basin.$\ldots \ldots \ldots \ldots \ldots \ldots \ldots \ldots \ldots \ldots \ldots$ C 302

southeastern ............................W 34, 90, 215

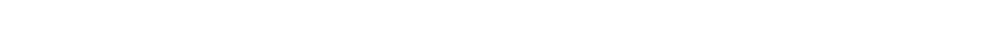

Standing Rock Indian Reservation $\ldots \ldots \ldots \ldots \ldots \ldots \ldots \ldots \ldots$. 575

Sundance quadrangle $\ldots \ldots \ldots \ldots \ldots \ldots \ldots \ldots \ldots \ldots \ldots$. GF 127

west-central ........................................... 361

Ziebach County ............................ 575

artesian water in ...W 34, 90, 227, 428, $597 \mathrm{c}, 889$ a; A $17 \mathrm{II} \mathrm{g,} 18 \mathrm{iv} \mathrm{c}$,

21 IV b; P 32, 65; B 575; GF 85, 96, 97, 100, 107, 108, 113, 114, 128, $156,164,165,209,219 ;$ C 303, 36 J; J 2, 63, 152

bibliography of ground water in $\ldots \ldots \ldots \ldots \ldots$ W 61, 120, 149, 163; C 303 irrigation with artesian and other ground water in.A $16 \mathrm{II} \mathrm{e,} 1.7 \mathrm{II} \mathrm{g}, 18 \mathrm{IV} \mathrm{c}$ law relating to ground water in $\ldots \ldots \ldots \ldots \ldots \ldots \ldots \ldots$ 122; C 131 mineral waters in $\ldots \ldots \ldots \ldots \ldots \ldots \ldots \ldots \ldots \ldots . . .632 ; I^{\pi} R$ 1883-1923 public water supplies in..............W $597 \mathrm{c}$; C 302; D 11; J 63 quality of ground water in ...W 227, $597 \mathrm{c}, 889 \mathrm{a}$; A $17 \mathrm{II} \mathrm{g,} 21 \mathrm{IV} \mathrm{b}$; P 32;

B 32; GF 97, 99, 100, 107, 108, 113, 164, 165; C 302, 361; D 11; J 63 salt water in ..................................... 151 springs in ..W 34, 90, 145, 679 b; A 14 II b, 21 IV b; B 32, 575 、627; GF 99, $100,108,113,114,156$

thermal .....................W 145, 679 b; A 21 Iv b; P 82 water levels in $\ldots \ldots \ldots \ldots \ldots \ldots \ldots$ W 817, 840, 845, 886, 908, 938, 946, 988 water table in $\ldots \ldots \ldots \ldots \ldots \ldots \ldots \ldots \ldots \ldots \ldots . C 302.303 ; \mathrm{J} 153$ well records for ...W 34, 61, 90, 149, 227, 597 c; A 17 II g, $1 \varepsilon$ Iv c, 21 Iv b; P 32, 65; B 264, 298, 691 a; GF 96, 99, 100, 107, 108, 113, 114; $156,164,165 ; \mathrm{C} 302,361 ; \mathrm{J} 2$ wells in, construction of ...........W 34, 227, 597 c; A 17 II g; GF 96 Southwest Pacific, ground water for military use in .............J 368 Spain, bibliography of ground water in.................... 163 Sparta sand, water in, in Tennessee $\ldots \ldots \ldots \ldots \ldots \ldots \ldots \ldots \ldots \ldots \ldots \ldots \ldots \ldots$ C 373 water in, in Texas ............................ 849 a; C 407

in Louisiana .....................W $968 \mathrm{c}$; C 169; J 331

Spearfish formation, water in, in South Dakota ...............GF 107

water in, in Wyoming ............................. 107

Specific capacity of wells ....W.W.140,141, 153, 320 e, $400 \mathrm{~b}, 495 \mathrm{~b}, 494,887$, A 19 II b; P 44; C 82; D 117 Specific gravity of ground water $\ldots \ldots \ldots \ldots \ldots \ldots \ldots \ldots \ldots \ldots \ldots \ldots \ldots \ldots, 319$ Specific yield $\ldots \ldots \ldots \ldots \ldots \ldots \ldots W$ 489, 494, $596 \mathrm{f}, 679$ a, 780, 887; J 101, 103 . 
Significance of geologic conditions in Naval Petroleum Reserve No. 3,

Wyo ....................................... 163

Wasatch Pleatau coal field, Utah ..................... 819

Spencer, A. C., Cooper deposits of the Encampment district, Wyo .....P 25

Franklin Furnace folio, N. J.........................GF 161

Geology and ore deposits of Ely, Nev ...................P 96

Spergen limestone, water in, in Missouri .................W 195

Spicer, H C., Rock temperatures, and depths to normal boiling pcint

of water in the United States ..........................J 141

Spieker, E. M., Geology and coal resources of the Salina Canyon

district, Utah .................................. $796 \mathrm{c}$

Spreading of flood waters in California $\ldots \ldots \ldots \ldots \ldots \ldots \ldots \ldots \ldots \ldots \ldots$ C 21

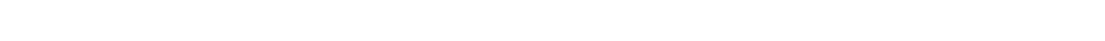

Spring discharge measurements. See specific States.

Spring-stream valleys in Great Plains $\ldots \ldots \ldots \ldots \ldots \ldots \ldots \ldots \ldots$ A 22 IV e

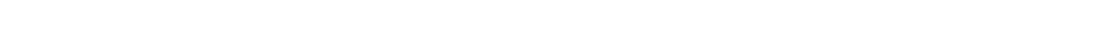

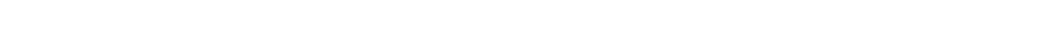

alluvium and bedrock contacts causing .................W 380

artesian.W 255, 278, 338, 494, 557, 796 f; A 21 IV c; C 13, 16, 72, 431; J 136

barriers causing ...........................W 320, 343,423,489

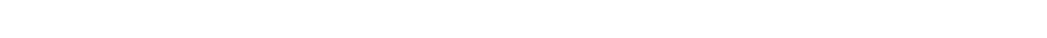

carbonated ................W 338; P 63, 152; B 662 f, 683, $797 \mathrm{f}$

changes in character of water from..........W 557; B $3 \AA$ ?, 491, 616 classification of .........W 114, 223, 255, 338, 365, 557; A $14 \mathrm{II} \mathrm{b;} \mathrm{J} 21$ coal beds causing ............................. 447,627 deposits of ......W 338; A 9 d; P 53, 68, 73, 152; B 330, 491, 616, 662 f, $669,680,683,692$ e, $717,7.5 \mathrm{~d}, 822$ a

faults in relation to ...W $142,199,232,277,338,365,380,423,489,557$, 599; A 14 II b, 18 II b; P 73, 187; B 751 c, 803; GF 199; C 13; J-136 fissure $\ldots \ldots \ldots \ldots \ldots \ldots \ldots$ W 114, 255, 494, 557; A 18 II b; B 199; C 451

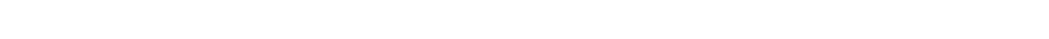

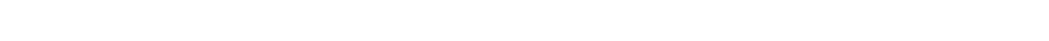
geyser $\ldots \ldots \ldots \ldots \ldots \ldots \ldots \ldots \ldots \ldots \ldots \ldots \ldots \ldots \ldots \ldots \ldots \ldots \ldots \ldots \ldots \ldots \ldots, 114,365,494$ gravity $\ldots \ldots \ldots \ldots \ldots \ldots \ldots \ldots \ldots \ldots \ldots \ldots \ldots \ldots V^{\mathrm{r}} 255,494$ impervious floors causing $\ldots \ldots \ldots \ldots \ldots \ldots \ldots W$ W 67, 380, 616; C 92, 98, 99 improvement of $\ldots \ldots \ldots \ldots \ldots \ldots \ldots \ldots \ldots \ldots W$ W 255, 380; B 252; C 431

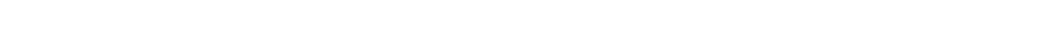
irrigation water from $\ldots \ldots \ldots \ldots \ldots \ldots . . W 277,365 ;$ GF $104 ; \mathrm{C}, 13,16,19$ joints in relation to ..........................W 221, 232, 494 joints in sandstone causing .......................... 221 large $\ldots . . W 27,28,36,37,85,98,99,127,130,131,145,15 \varepsilon, 168,173$, $177,209,214,221,251,271,277,288,300,319,326,332,33 \varepsilon, 360,362$, $365,370,391,394,557,597$ d, 616, 637 d, 774, 818; A 14 II b; 18 II b: P 78, 154 a; B 131, 140, 641 i, 713, 798, 822 a, 855, 923; C $55,99,253,390 ; \mathrm{J} \mathrm{22,} \mathrm{45,} \mathrm{80,} 143$

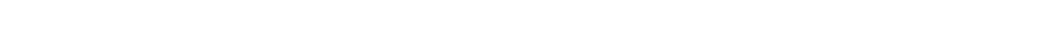
mineralization of water from ................W 418; C 13, 17, 19 mounds produced by $\ldots \ldots \ldots \ldots \ldots \ldots \ldots \ldots W$. 277, 320, 343, 3 35, 423, 494 ocherous deposits of $\ldots \ldots \ldots \ldots \ldots \ldots \ldots \ldots \ldots \ldots \ldots . . . \ldots \ldots 330,491,616$ origin of $\ldots \ldots \ldots \ldots \ldots \ldots \ldots \ldots \ldots \ldots W$ W $338,494,557,836 \mathrm{~d}$ : A 14 II b perched $\ldots \ldots \ldots \ldots \ldots \ldots \ldots \ldots \ldots \ldots \ldots$. 233,616 ; C 92, 98, 99, 431 periodic or ebbing and flowing......W 145, 365, 494, $836 \mathrm{~d}$; C 435; J 91 


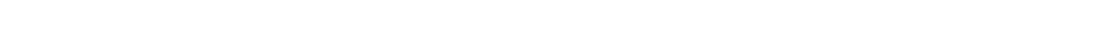
laws relating to $\ldots \ldots \ldots \ldots \ldots \ldots \ldots \ldots \ldots \ldots \ldots \ldots \ldots \ldots \ldots, 122,152$ pool $\ldots \ldots \ldots \ldots \ldots \ldots \ldots \ldots \ldots \ldots \ldots \ldots \ldots \ldots \ldots$ W $221,277,3^{2} 5,423 ; 494$

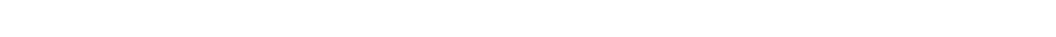
relation to stream flow ............................. 54 salt ...W 148, 154, 338, 343; M 25; P 152; B 669, 795 b; GF 12?, 129; C 72

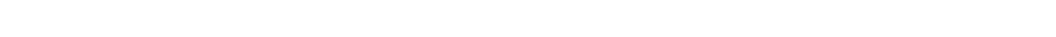
siliceous deposits of $\ldots \ldots \ldots \ldots \ldots \ldots \ldots \ldots$ W 338; A 9 d; B 370, 491, 616 sills in relation to ................................ $400 \mathrm{~b}$ streams in relation to ...................W 557; A 14 II a; D 54, 95

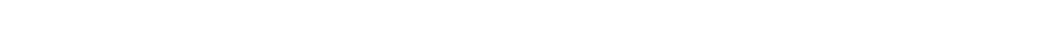
sulfur ....W 148, 217, 338; P 152; B $641 \mathrm{i}, 661 \mathrm{~g}, 692 \mathrm{e}, 711 \mathrm{~h}, 797 \mathrm{f}$, $816,818,921$ b; GF 101, 154; C 72 ; J 36

symbols for, on maps ............................W 160

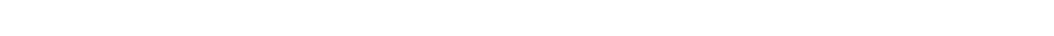
therapeutic value of waters from ........A 14 II b; MR 1911 II n, 1916 travertine deposited by. .W 338, 423; A 9 b; P 152; B 330, 491, 616, $662 \mathrm{f}$, $680,683,711 \mathrm{~d}, 803,822 \mathrm{a}, 844 \mathrm{c}, 877,922 \mathrm{k}$ tubular ........................................W 255494 vegetation of $\ldots \ldots \ldots \ldots \ldots \ldots \ldots \ldots \ldots \ldots \ldots \ldots W$ 277, 338; $A$ 9 d volcanoes in relation to $\ldots \ldots \ldots \ldots \ldots \ldots \ldots \ldots \ldots \ldots \ldots \ldots \ldots \ldots \ldots$ W 181 yield of, in United States ...................... 14 II b; B 32 See also specific States.

Springs, thermal, artesian wells in relation to $\ldots \ldots \ldots \ldots \ldots \ldots \ldots W$ W $400 \mathrm{~b}$ boiling points at various elevations in relation to...........W 338 definition of $\ldots \ldots \ldots \ldots \ldots \ldots \ldots \ldots \ldots \ldots \ldots \ldots$ W $494 ; A$ A 14 II b distribution of $\ldots \ldots \ldots \ldots \ldots \ldots \ldots \ldots \ldots \ldots \ldots$ W 145, 679 b; A 14 II b duration of ....................................... 145 faults in relation to $\ldots \ldots \ldots \ldots \ldots \ldots$ W $277,338,365,380,48$; A 14 II b origin of heat in .............W 338, 418,620,819; A 14 Ir b; C 433

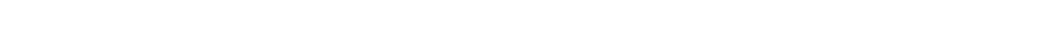
topography in relation to $\ldots \ldots \ldots \ldots \ldots \ldots \ldots \ldots \ldots \ldots \ldots \ldots \ldots \ldots$ A 14 II b variations in temperature of ..............W 489, 819; A 14 II b vilcanism in relation to $\ldots \ldots \ldots \ldots \ldots \ldots$ W $181,679 \mathrm{~b} ; \mathrm{B} 3\urcorner 0,491,616$ See also specific States.

Spurr, J. E., Economic geology of the Georgetown quadrangle, Colo....P 63

Geology of the Tonopah mining district, Nev ...............P 42

Stabler, Herman, Fluorescein an aid in tracing waters undergrourd......D 1 Ground water in San Joaquin Valley, Calif...............W 398

Pumping tests, in Ground water in the San Jacinto and Temecula Basins, Calif .................................W 429

Significance of geologic conditions in Naval Petroleum

Reserve No. 3, Wyo ............................. 163

Stream waters of western United States ................W 274

Stafford, H. M., Water levels and artesian pressure in the United S'ates W 991 Stanley, T. B., Jr., Ground-water investigations in Louisiana ......... 164

Ground-water resources of Jefferson Davis and Acadia Parisher. La .C 170

Water levels and artesian pressure in the United States.....W 886, 909 Starch making, quality of water for $\ldots \ldots \ldots \ldots \ldots \ldots \ldots \ldots \ldots W$ W 341,398 Stauffer, C. R., Columbus folio, Ohio ....................GF 197 Steam making. See Quality of water. 
Stearns, H. T., Building of Oahu (Hawaii) $\ldots \ldots \ldots \ldots \ldots \ldots \ldots \ldots$ J 109

"Craters of the Moon" in Idaho ....................J 52

Craters of the Moon National Monument, Idaho .......... 118; J 35

Deep-well pumping in Idaho ........................ 263

Future ground-water supplies for Honolulu, Hawaii .......... 50

Geologic map and guide of the island of Oahu, Hawaii .......... 96

Geology and ground-water resources of the island of Maui, Hrwaii. .C 99

Geology and ground-water resources of the island of Oahu, Hawaii. . C 92 Geology and ground-water resources of the island of Oahu, Hawaii

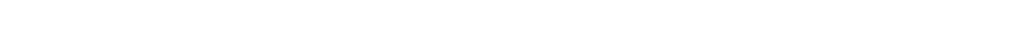

Geology and ground-water resources of the islands of Lanai and

Kahoolawe, Hawaii $\ldots \ldots \ldots \ldots \ldots \ldots \ldots \ldots \ldots \ldots \ldots \ldots \ldots$

Geology and ground-water resources of the Snake River Plain. Idaho

V $774 ;$ D 53

Geology and water resources of the Kau district, Hawaii .......W 616

Geology and water resources of the middle Deschutes River Basin, Oreg.

W $637 \mathrm{~d}$

Geology and water resources of the Mokelumne area, Calif .......W 619

Geology and water resources of the Mud Lake region, Idaho .....WW 818

Geology and water resources of the upper McKenzie Valley, Orèg W $597 \mathrm{~d}$

Ground-water conditions in the Territory of Hawiai in $1941 \ldots \ldots \ldots$. 169

Ground water for irrigation in Raft River Valley, Idaho ........D 10

Ground water in Big Lost River Valley, Idaho ............. 17

Ground water in Little Lost River Valley, Idaho ............ 16

Ground water in the vicinity of Lodi, Calif..............D 13

Ground-water resources of the Hawaiian Islands ............J 265

Hydrology of lava-rock terranes, in Hydrology (Physics of the.

Earth, IX) ......................... 255 (chap. 15)

Lava Beds National Monument, Calif. ..................J 264

Occurrence of ground water in the Hawaiian Islands .........J 217

Origin of large springs and their alcoves along Snake River in

southern Idaho $\ldots \ldots \ldots \ldots \ldots \ldots \ldots \ldots \ldots \ldots \ldots \ldots \ldots \ldots$ J 143

Record of earthquake made by automatic recorders of wells in

California $\ldots \ldots \ldots \ldots \ldots \ldots \ldots \ldots \ldots \ldots \ldots \ldots \ldots \ldots \ldots \ldots \ldots . \ldots \ldots$

Records of drilled wells on the island of Oahu, Hawaii.......... 94

Records of wells on Snake River Plain, Idaho ............W 775

Salt-water invasion in Hawaii ...................... 151

Thermal springs in the United States ................ 679 b

Water for the invasion of Saipan (Marianas Islands) ..........J 336

Water levels and artesian pressure in the United States.....W 777, 817, $840,845,886,911,941,949,991$

Water resources of the Mud Lake basin, Idaho .......... 111; D 47

Water supply on the Snake River Plains, Idaho ............. 30

Stearns, N. D., Bibliography and index of geology and water supnly of

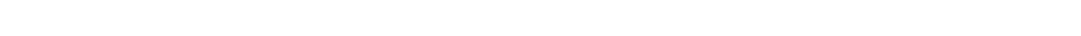

Geology and ground-water hydrology at Fort Caswell, N. C. . . . . C 292

Ground water in the Pomperaug Basin, Conn ............ 597 b

Laboratory tests of water-bearing materials ............J 42

Physical properties of water-bearing materials .........W $596 \mathbf{f}$

Remarkable intermittent spring (in Wyoming) .............J 91 
Stearns, N. D., Thermal springs in the United States ...........679

Wells for the water of Hawaii ....................... 165

Stebinger, Eugene, Oil and gas geology of the Birch Creek-Sun River

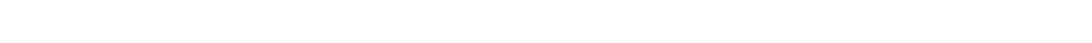

Sieidtmann, Edward, Geology of the York tin deposits, Alaska ....... B 733

Stephenson, E. L., Use of resistivity methods in location of salt-water

bodies in the El Paso, Tex., area ...................... 176

Stephenson, L. W., Coastal Plain of North Carolina .............. 291

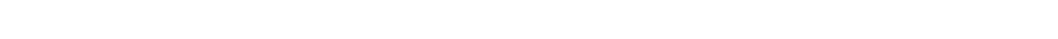

Geology and ground water of northeastern Arkansas .........W 399

Ground-water resources of Mississippi ................W 576

Underground waters of the Coastal Plain of Georgia ..........W 341

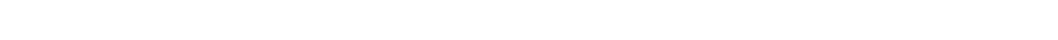

Sterrett, D. B., Gaffney-Kings Mountain folio, S. C.-N. C..........GF 222

Stevens, G. C., Surface water supply of the United States, 1912 ....W 331

Stevens, J. C., Surface water supply of Nebraska ..............W 230

Surface water supply of the North Pacific Coast drainage, 19n5... W 214

Surface water supply of the United States, 1907-08........W 250, 252

Steward, W. G., Geology and ground-water resources of the

Snake River Plain, Idaho .....................W 774; D 53

Records of wells on Snake River Plain, Idaho ............W 775

Water"supply on the Snake River Plains, Idaho ............ 30

Stewart, C. W., Water levels and artesian pressure in the United States

W 845,886

Stewart, J. E., Surface water supply of Hawaii, 1920-21 . . . . . . . W. 535

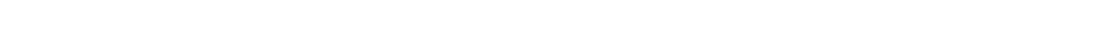

Stockton formation, water in, in New Jersey ...............FF 167

water in, in Pennsylvania .............. 828, 891; GF 167; C 342

Stone, R. W., Elders Ridge folio, $\mathrm{Pa} \ldots \ldots \ldots \ldots \ldots \ldots \ldots \ldots \ldots \ldots$ GF 123

Gypsum deposits of the United States ................. 697

Water resources of the Elders Ridge quadrangle, Pa.........W 110

Waynesburg folio, $\mathrm{Pa} \ldots \ldots \ldots \ldots \ldots \ldots \ldots \ldots \ldots \ldots \ldots \ldots \ldots$. 121

Storage, coefficient of $\ldots \ldots \ldots \ldots \ldots \ldots \ldots \ldots \ldots$ 206; J 294, \&11, 326, 342

Storage of well water $\ldots \ldots \ldots \ldots \ldots \ldots \ldots \ldots W$ 1, 5, 20, 184, 343, 599, 600

Storrs, H. A., Cost of power for pumping irrigation water .........W 146

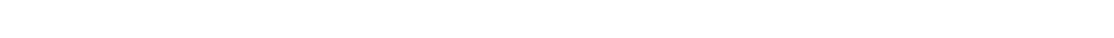

Coatsville-West Chester folio, Pa.-Del.................GF 223

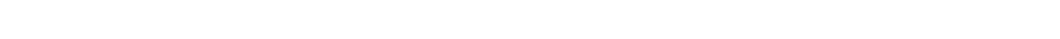

Geology and mineral resources of the Honeybrook and Phoerixville quadrangles, $\mathrm{Pa} \ldots \ldots \ldots \ldots \ldots \ldots \ldots \ldots \ldots \ldots \ldots \ldots \ldots$. $89 . \ldots$

Geology and mineral resources of the Middletown quadrangle $\mathrm{Pa}_{\mathrm{f}}$.. B 840

Geology and mineral resources of York County, $\mathrm{Pa} \ldots \ldots \ldots \ldots \ldots$. . 347

-Mercersburg-Chambersburg folio, Pa .................. 170

Pawpaw-Hancock folio, Md.-W. Va.-Pa .................. 179

Water resources of the Chambersburg and Mercersburg quadrangles,

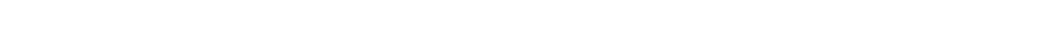

Water resources of the Pawpaw and Hancock quadrangles, W. Va.,

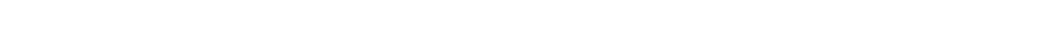

Stovall, J. W., Geology and ground-water resources of Cimarror County,

Okla

Ground water in Cimarron County, Okla ................ 115

Stovepipe well casings $\ldots \ldots \ldots \ldots \ldots \ldots \ldots \ldots \ldots$ W 110, 140, 255, 257, 495 
Strainers in wells. See Well screens.

Stratified drift, water in ...........................W 110 water in, in Connecticut ..................W 252, 374, 497

See also Glacial drift.

Stream deposits. See Alluvium; Valley fill.

Streams, artesian head in relation to ..................... 156 diversion of, by underground channels .............. 21 iv c ground water in relation to.....W 9, 10, 18, 58, 67, 199, 234, 294, $375 \mathrm{~d}$, $423,494,637$ b; A 14 II a, 19 II b; D 54, 77; J 159, 167, 238, 239 underground ..........W 233, 258, 494; A 18 Iv b, 21 Iv c; C 81, 431 water table in relation to ...................W 155, $637 \mathrm{~b}$ Stringfield, V. T., Apparatus for testing the permeability of unconsolidated sediments $\ldots \ldots \ldots \ldots \ldots \ldots \ldots \ldots \ldots \ldots \ldots$ D 84 Artesian water in the coastal area of Georgia and northeasters Florida

Artesian water in the Florida Peninsula ...........W 773c; J 137 Effect of a sea-level canal on the ground-water level of Florida . .....J 185 Effect of air-conditioning demand on well-water availability .....J 351 Exploration of artesian wells in Sarasota County, Fla. ......... 59 Florida's water supply and canal .................... 139 Ground water in Seminole County, Fla ................ 61 Ground water in the Lake Okeechobee area, Fla ............ 57 Ground water in the southeastern States ...............J 221 Ground-water investigations in Florida ................ 60 Giound-water resources in Florida ................. 56 Ground-water resources of Sarasota County, Fla ............. 58 Ground-water supplies in Florida ...................J 189 Ground-water supplies in Louisiana ................... 162 Ground-water supplies not in danger of exhaustion .........J 338 Limited effect on water supplies expected from Florida canal.....J 138 Methods of exploring artesian wells in Florida ............J 121 Observation wells, manual of methods ................. 60 Piezometric surface of artesian water in the Florida Peninsula......J 134 Salt-water contamination of ground water in the Coastal Plain of the

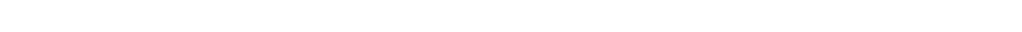

Water levels and artesian pressure in the United States

Structural valleys. See Debris-filled basins.

Stuart, W. T., Conservation of ground water in the Louisville area, Ky C 160 a Ground-water resources of the Louisville area, $\mathrm{Ky} \ldots \ldots \ldots \ldots \ldots$. . 160 Ground-water resources of the Santa Cruz Basin, Ariz ......... 20 Ground-water supply at Louisville, Ky ................J 323 Safford Valley, Graham County, Ariz., records of wells and springs..C 16 Water levels and artesian pressure in the United States ..... 949, 986 Water resources of Safford and Duncan-Virden Valleys, and

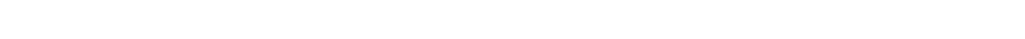

Stubbs, S. A., Ground-water resources of the Pensacola area, Fla .....D 128

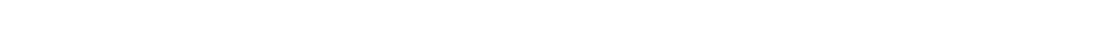
Subcapillary openings $\ldots \ldots \ldots \ldots \ldots \ldots \ldots \ldots \ldots \ldots \ldots \ldots$ W $494 ;$ M 47 Subirrigation $\ldots \ldots \ldots \ldots \ldots \ldots \ldots \ldots \ldots \ldots \ldots \ldots \ldots \ldots \ldots \ldots \ldots \ldots \ldots \ldots$ 13 IIr b 
Sublett, H. E., Chemical analyses of water from wells in the Lonisville

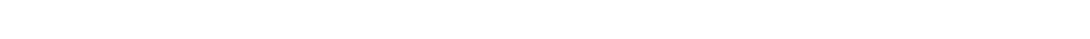
Conservation of ground water in the Louisville area, Ky ....... C $160 \mathrm{~d}$ Subsurface dams. See Dams.

Subterranean water, work of International Commission on.........J 308

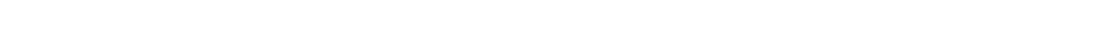

Sugar making, quality of water for $\ldots \ldots \ldots \ldots \ldots \ldots \ldots \ldots W^{r} 30,341,398$

Sulfate, field tests for . . . . . . . . . . . . . . . . . . . 151

in ground water ....W 254, 259, 273, 275, 338, 341, 343, $345 \mathrm{~g}, 398$; P 116, 117; B 330, 491, 616, 717, 786 b, 818; MR 1911 II n, 1916

Sulfide enrichment, ground water in relation to ........ 529,625 ; P 54 Sulfide, in ground water ...W 338, $345 \mathrm{~g}$; P 116, 117; B $812 \mathrm{~b}, 818,822$ a; MR 1911 II n, 1916; GF 206

in rocks, ground-water levels in relation to $\ldots \ldots \ldots \ldots \ldots \ldots .629,625$

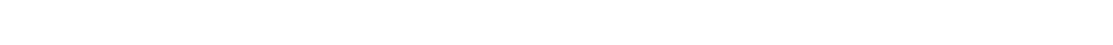

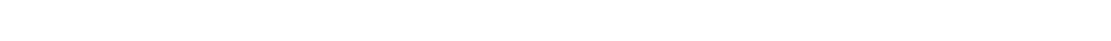

Sundance formation, water in, in Montana .....W 599; B 736 b, 822 a, 856 water in, in South Dakota ........................ 107

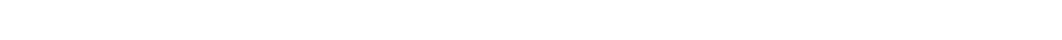
Sunderland formation, water in, in Maryland ...............FF 152 Sundstrom, R. W., Ground water in Texas, list of published an' un-

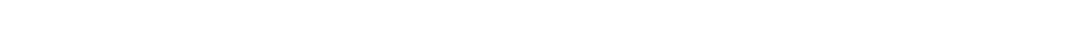

Ground-water resources in the vicinity of Vernon, Tex ......... 409 Ground-water supplies of the Atlantic City region, N. J.........C 216 Observation wells, manual of methods ................ 60

Public water supplies in eastern Texas ................. 415

Published reports on Texas, ground-water resources........... 403 Water levels and artesian pressure in the United States.....W 840, 845, $886,909,939,947,989$

Supai formation, water in, in Arizona .................... 836 b Supercapillary openings $\ldots \ldots \ldots \ldots \ldots \ldots \ldots \ldots \ldots \ldots \ldots$ 494; M 47

Suspended matter in ground water ......W 254, 258, 259, 341, 398; C 131

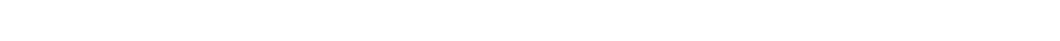

Suwanee formation, water in, in Florida $\ldots \ldots \ldots \ldots \ldots \ldots \ldots \ldots \ldots$ J 258

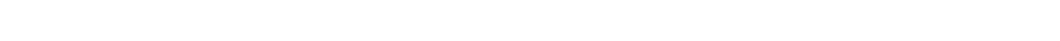

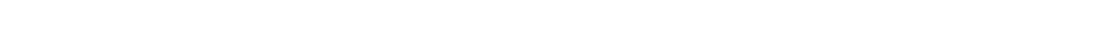

Swartz, C. K., Pawpaw-Hancock folio, Md.-W. Va.-Pa ...........GF 179

Swartz, J. H., Geophysical investigations in the Hawaiian Islands . . . . J 204 Geophysical investigations on Lanai, Hawaii .............. 98 Geophysical studies in the Hanawi area, Maui Hawaii.......... 157 Resistivity studies of salt-water boundaries in the Hawaiian Islands . $\mathbf{J} 175$ Resistivity survey of Schofield Plateau, Oahu, Hawaii .......... 97

Swenson, H. A., Chemical characer of public water supplies in

southeastern Florida ............................. 301

Switzerland, bibliography of ground water in $\ldots \ldots \ldots \ldots \ldots \ldots \ldots \ldots$ W 163

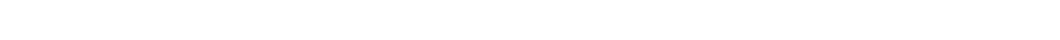

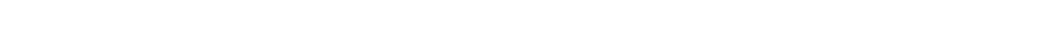

Sylvania-sandstone, water in, in Michigan ............ $\Gamma^{r}$ 30; GF 205 Symbols for wells and springs on maps $\ldots \ldots \ldots \ldots \ldots \ldots \ldots \ldots \ldots$ W 160 
Taff, J. A., Muskogee folio, Okla GF 132

Tahlequah folio, Okla-Ark

GF 122

Talbot, A. N., Corrections in determinations of flow from vertical well casings

W 110

Talbot formation, water in, in Delaware ................... 137

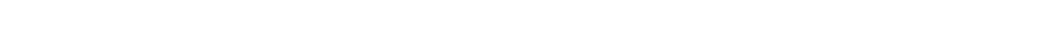

Tallahatta buhrstone, water in, in Mississippi ............... 159

Tamiami limestone, water in, in Florida ............ 65; J 258, 365

Tampa formation, water in, in Florida.......W 319, 773 c; C 57, 58, 60, 62;

J $80,134,137,252,258$

Tanning, quality of water for $\ldots \ldots \ldots \ldots \ldots \ldots \ldots \ldots \ldots$ 254, 341, 398

Tar springs in Alabama ............................ 1

Tarr, R. S., Water resources of the Watkins Glen quadrangle, N. Y . . W 110

Watkins Glen-Catatonk folio, N. Y..................GF 169

Tasmania, bibliography of ground water in ............... 163

Taylor, F. B., Niagara folio, N. Y....................GF 190

Pleistocene of Indiana and Michigan and the history of the

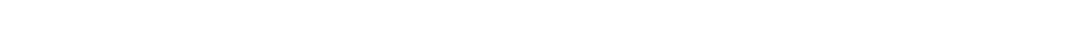

Water resources of the Taconic quadrangle, N. Y.-Mass.-Vt . . . . W 110

Taylor, G. C., Jr., Factual data pertaining to wells and springs in the

Columbia Basin project area, Wash .................. 446

Ground-water conditions in the middle Rio Grande Valley, N. Mex. .C 254

Ground-water supply of Mimbres Valley, N. Mex............. 108

Water levels and artesian pressure in the United States.....W 845, 910,

940,948

Taylor, G. H., Absorption of precipitation and its penetration to the

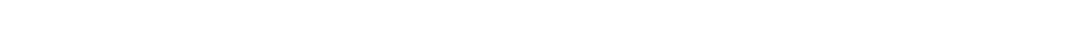

Artesian water in the vicinity of Woods Cross, Utah .......... 83

Artesian water levels in the vicinity of Lehi, Utah .....W 8 i $9 \mathrm{c}$; D 90

Artesian water supply of Ogden, Utah ................ 65

Earthquakes instrumentally recorded in artesian wells .........J 124

Fluctuations of ground-water levels in Utah .............J 156

Geology and ground-water resources of Cedar. City and

Parowan Valleys, Iron County, Utah ..............W 993; D 179

Geology and ground-water resources of Ogden Valley, Utah....W $796 \mathrm{~d}$

Geology and water resources of the Mokelumne area, Calif .....W 619

Ground water in the vicinity of Lodi, Calif ............. 13

Ground water in Utah ......................... 179

Ground-water investigations in Utah to June 30, $1936 \ldots \ldots \ldots \ldots \ldots$. 421

Ground-water levels in five wells in Utah .............. 138

Ground-water levels in Utah ...........D 86, 93, 112, 122, 137

Ground water relieves 1934 drought emergency in Salt Lake City,

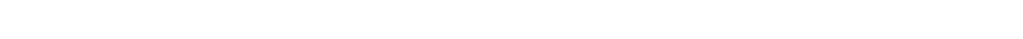

Ground-water supplies in the vicinity of Salt Lake City, Utah .....D 36

Mercury manometer pressure gage $\ldots \ldots \ldots \ldots \ldots \ldots \ldots \ldots$ D 45, 72

Soil pipe test plug and mercury manometer $\ldots \ldots \ldots \ldots \ldots \ldots \ldots$ D 32

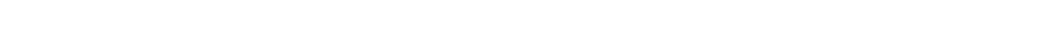

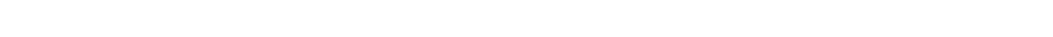

Water levels and artesian pressure in the United States .... 777,817 ,

84 C. 845,886

Work of the Division of Ground Water in Utah ........... 110 
Taylor, L. H., Progress of stream measurements for $1902 \ldots \ldots \ldots \ldots$ W 85

Taylor, T. U., Irrigation systems of Texas $\ldots \ldots \ldots \ldots \ldots \ldots \ldots \ldots \ldots \ldots$ W 71

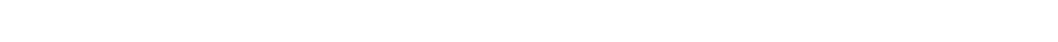

Progress of stream measurements $\ldots \ldots \ldots \ldots \ldots \ldots \ldots W$ 84, 132, 174

Underground waters of the Coastal Plain of Texas .........W 190

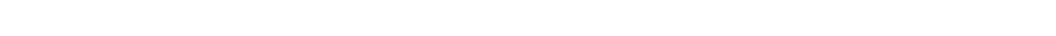

Temperature, artesian flows influenced by .......W 400 b; A. 5 c; B 319

changes of, fluctuations of water table in relation to . W 155; M 47; P 44 movements of ground water in relation to ........... 19 II b; B 319 of artesian water .....W 55, 78, 240, 400 i; A 18 Iv c; B 199, 319, 701, $711 \mathrm{~d}, 796 \mathrm{f}$; GF $45 ; \mathrm{C} 1,361$; J 2 of ground water W 55, 78, 114, 220, 225, 240, 400 b, 520 f, 576, 679 b 841; B 199, 319; GF 45; C 1, 115, 292, 341, 432, 433; J 2, 28, 136, 141, 193 affected by artificial recharge $\ldots \ldots \ldots \ldots \ldots \ldots \ldots \ldots \ldots . \ldots \ldots 3,249$ causes that raise ....................W $3 \boldsymbol{i}^{8} ;$ A 14 II b density in relation to $\ldots \ldots \ldots \ldots \ldots \ldots \ldots \ldots \ldots \ldots \ldots \ldots \ldots$ dissolved gases in relation to $\ldots \ldots \ldots \ldots \ldots \ldots \ldots \ldots \ldots \ldots \ldots \ldots$ dissolved solids in relation to $\ldots \ldots \ldots \ldots \ldots \ldots \ldots \ldots \ldots \ldots \ldots$

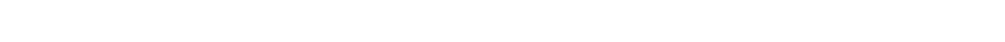

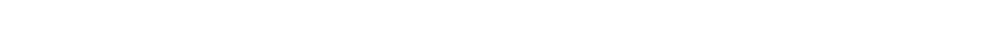

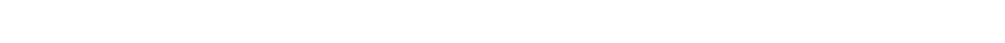

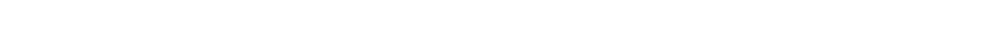
variations in ..................... $520 \mathrm{f}$; A 14 II b volcanism in relation to $\ldots \ldots \ldots \ldots \ldots \ldots \ldots \ldots$ B $330,491,616$ See also specific States.

Tennessee, areas, all of State $\ldots \ldots \ldots \ldots \ldots \ldots \ldots \ldots \ldots \ldots \ldots$ 102, 114 areas, Ducktown district ...................... 139 Memphis ............W 638 a; C 372, 373; D I.4, 204; J 651 Mount Mitchell quadrangle ....................GF 124 north-central ............................. 640 Roan Mountain quadrangle ..................... 151

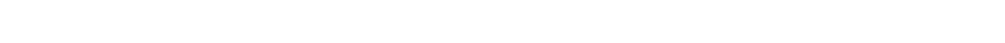

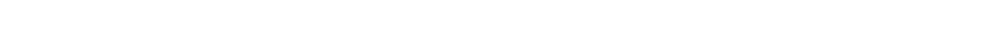
west of Tennessee River .....................W 164 western .........................W 656; D 25 artesian water in .............W 164, $638 \mathrm{a}, 640,656 ; \mathrm{C} 372 ; \mathrm{J} 65$ bibliography of ground water in $\ldots \ldots \ldots \ldots \ldots$ W 114, 120, 149, 163, 164 industrial use of ground water in ............. 373; D 204 mine waters in ........................ mineral waters in ...............W 164; B 32; MR 1883-1923 public water supplies in .........W 638 a; C 371; D 2.5, 204; J 65 pumping in ............................ 372, 373; D 204 quality of ground water in ...W 164, 364, 638 a, 640,656, 677; B 32, 330, 491, 529, 616; GF 124; C 371, 372, 373 quantity of ground water in ...............W 638 a; C 373 spring discharge measurements in ...W 473, 663, 698, 713, 728, 743, 758, $783,803,853$ springs in ...W 114, 164, 364, 638 a, 640; A 14 II b; B: 32; GF 124, 151; C $371 ; \mathrm{D} 63 ; \mathrm{J} 55,142$ water levels in $\ldots \ldots \ldots \ldots \ldots \ldots \ldots$ W 817, 840, 845, 886, 907, 937, 945, 987

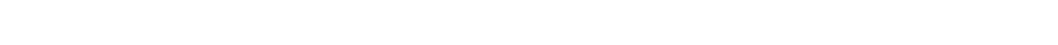


Tennessee, well records for ...W 61, 102, 149, 164, 638 a, 640, 677; B 264, 298;

wells in, construction and cost of

.W 164

Tensleep sandstone, water in, in Montana .....W 599; B 736 b, $\$ 22$ a, 856 water in, in Wyomirg ...........P 51, 53; B 656, 711 h; GF 141, 142

Terry, J. M., Water levels and artesian pressure in the United States .. W 817,

Tertiary alkalinity of ground water ..............W 338; B 479

Tertiary formations, water in-

Alabama ........................W 114; B 6i1 h; C 1

Alaska $\ldots \ldots \ldots \ldots \ldots \ldots \ldots \ldots \ldots \ldots \ldots \ldots \ldots \ldots \ldots \ldots \ldots \ldots \ldots$

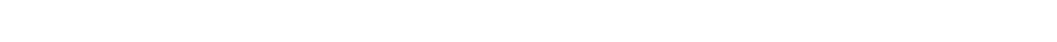

Arizona $\ldots \ldots \ldots \ldots \ldots \ldots \ldots \ldots \ldots \ldots \ldots \ldots \ldots \ldots$ 380, 499, 836 b

Arkansas ...................W 114, 145, 399; P 46; B 691 j

California ..............W 225, 375 a, 446, 519; B 721; GF 66, 138

Colorado .....A 16 II f, 17 II f, 21 Iv c,22 Iv c; M 27; P 32, 52; B 531 c;

GF 71, 135, 198, 214; C 32

Delaware .................W 114; B 138; GF 137, 162; C 171

District of Columbia ......................GF 152; C 171

Florida W 114, 319; C 51, 52, 53, 54, 55, 56, 57, 58,

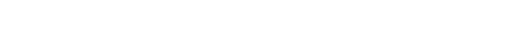

Georgia ..................W 114, 341; B 138; C 81; D 129, 134

Hawaii $\ldots \ldots \ldots \ldots \ldots \ldots \ldots \ldots \ldots \ldots \ldots \ldots \ldots \ldots$ 6 616; C 92, 98, 99

Idaho $\ldots \ldots \ldots W$ 53, 54, 78, 774, 818; B 199; GF 45 103, 104; C 112, 115

Illinois ......................W 114, 164; A 17 II $h$; M 38

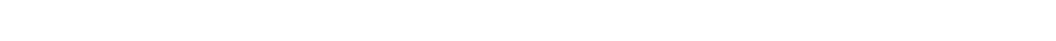

Kansas ...W 6, 273, 345 a; A 16 Ir f, 21 IV c, 22 IV c; P 32; C 141, 142, 144, $145,148,153,154,155,156,159 ; \mathrm{J} 214$

Kentucky .............................. 114, 164

Louisiana .....W 101, 114; P 46; C 163, 165, 166, 167, 170 a; J 345, 354 Maryland ........W 114; B 138; GF 13, 23, 136, 137, 152, 182, 204; C 171 Mississippi ...............W 114, 159, 576; C 193, 194, 195; J 346 Missouri ...............................W 114, 195 Montana ...............W 518, $520 \mathrm{~d}, 539,599,600$; B 856, 905 Nebraska .....W 12, 70, 215, 216, 425 b, 848, 943, 969; A 16 r f, 19 Iv c, 21 IV c, 22 IV c; P 17, 32; GF 87, 88; C 202, 204; D 162

Nevada ..W 423

New Jersey ............W 114; B 138; GF 137, 162; C 212, 215, 216

New Mexico ....W 380, 620; A 21 IV c, 22 IV c; GF 214; C 232.239, 241, 244. 247; D 68

New York ................................. 41

North Carolina ............W 114, 773 a; B 138; GF 80; C 291, 293 North Dakata .....................W 598; GF 181; J 328 Oklahoma ... W 148, 345 b, 500 b, 520 b; A 21 rv c, 22 Iv c; C 321, 323; D 106, 115, 178; J 223

Oregon $\ldots \ldots \ldots \ldots \ldots \ldots \ldots \ldots$ W 53, 54, 78, 220, 231, 637 d; B 252; GF 103

Pennsylvania ..........................W 144; GF 162

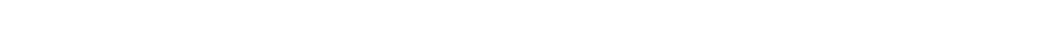

South Carolina .......................W 114; B 138, 867

South Dakota .......................W 227; P 32; B 627

Tennessee ................W 114, 164, 638 a, 656; C 37 ; D 14, 25 
Tertiary formations, water in Texas....W 154, 190, 191, 276, 335, $375 \mathrm{~g}, 678$, 778,849 a, 889 c, d, e, 913, 919; A 21 IV c; 21 vII, 22 IV c; F 661 g; GF 64; C 407, 417, 418; D 19, 31, 38, 40, 51, 66; J 292, 317

Utah B 56 ; B 285 f

Virginia ...W 114; B 138; GF 13, 23, 80, 136; C 431, 434, 436, 437; J 332 Washington ......W 53, 54, 55, 111, 118, 316, 425 e; B 1.08; GF 86, 106 Wyoming ...W 70; A 21 Iv c, 22 Iv c; P 32, 51, 56; B $2 \varepsilon 5 \mathrm{f}, 364,425 \mathrm{~b}$,

See also specific formations. 543, 702; GF 173; C 456

Tertiary salinity in ground water W $33 \varepsilon: B 479 ; J 258$

Texas, areas, all of State A 11 II c; C 400; D 19

areas, Andrews County ........................ 384

Arkansas County ......................... 384

Armstrong County .......................... 384

Atascosa County ...................W 676; C 393; D 38

Austin and vicinity ...............W 84, 132, 174; B 131

Austin County ............................. 384

Austin quadrangle ...........................FF 76

Bailey County ............................ 384

Balcones fault zone ....................... 414

Balmorhea area ...................W 849 c; C 390, 393

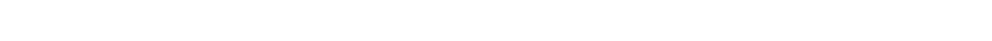

Bee County $\ldots \ldots \ldots \ldots \ldots \ldots \ldots \ldots \ldots \ldots \ldots \ldots \ldots \ldots \ldots \ldots \ldots \ldots$

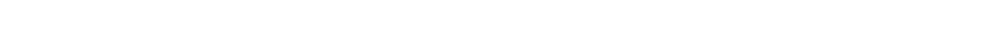

Big Spring ....................W 913; C 404; 414

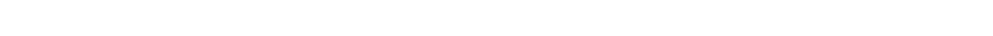

Blanco County ............................. 393

Brazoria County ........................ 384, 393

Brenham salt dome ...................... 661 g

Brooks County .......................... 393

Brown County .......................... 384

Burleson County ........................ 384

Barnet quadrangle $\ldots \ldots \ldots \ldots \ldots \ldots \ldots \ldots \ldots \ldots \ldots \ldots \ldots$ GF 183

Calhoun County .......................... 384

Callahan County ......................... 384

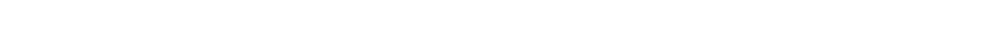

Camp County ............................... 393

Carrizo Springs and vicinity ..................W 66; B 164

Carson County .............................. 384

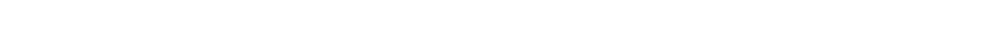

Castro County ........................... 393

Chambers County $\ldots \ldots \ldots \ldots \ldots \ldots \ldots \ldots \ldots \ldots \ldots \ldots \ldots \ldots$ C 393

Cherokee County ..........................C 384

Childress County ........................... 384

Coastal Plain ...................W 190, 3^5; B 282; J 132

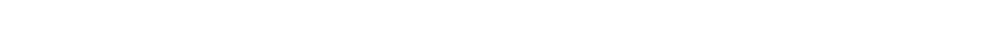

Collingsworth County ....................... 384

Colorado County ......................... 384

Comal County ........................... 384

Corsicana .............................. 661 f

Crosby County .......................... 384

Dallam County $\ldots \ldots \ldots \ldots \ldots \ldots \ldots \ldots \ldots \ldots \ldots \ldots \ldots$. 384 
Texas, areas, Dallas County ...................... 278 ; C 393

Dawson County ............................... 393

Deaf Smith County ............................. 393

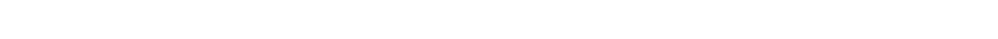

Dimmit County ...................... 298; C ₹73; D 51

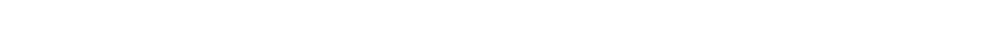

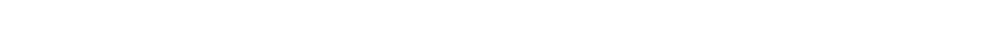

eastern ..................... 46; B 902; C 414, 415; D 40

Eastland County $\ldots \ldots \ldots \ldots \ldots \ldots \ldots \ldots \ldots \ldots \ldots \ldots \ldots \ldots$ C 384

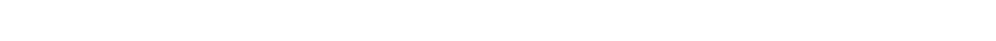

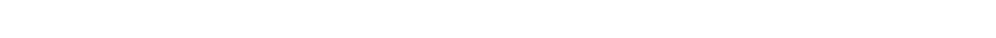

Edwards Plateau ........................... 18 II b

El Paso and vicinity .......W 140, 141, 343, 919; C 414; J 176, 195

El Paso quadrangle $\ldots \ldots \ldots \ldots \ldots \ldots \ldots \ldots \ldots \ldots \ldots \ldots \ldots$ GF 166

Fayette County . . . . . . . . . . . . . . . . . . . . . . 393

Floyd County $\ldots \ldots \ldots \ldots \ldots \ldots \ldots \ldots \ldots \ldots \ldots \ldots$. 384, 393

Foard County $\ldots \ldots \ldots \ldots \ldots \ldots \ldots \ldots \ldots \ldots \ldots \ldots \ldots \ldots \ldots \ldots \ldots$ C 384

Fort Bend County ..................... 298; C 384, 393

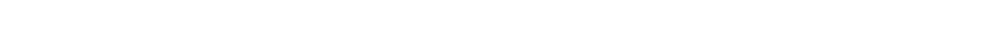

Franklin County ............................... 393

Freestone County $\ldots \ldots \ldots \ldots \ldots \ldots \ldots \ldots \ldots \ldots \ldots \ldots \ldots \ldots \ldots \ldots$ C 384

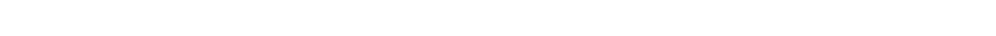

Gaines County ............................... 393

Galveston County $\ldots \ldots \ldots \ldots \ldots \ldots \ldots \ldots \ldots \ldots . .6$. 393, 414; J 117

Gillespie County .............................. 384

Glasscock County ........................W 913; C 384

Goliad County .................................. 384

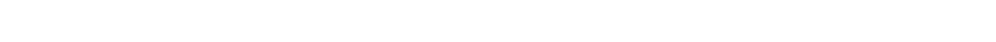

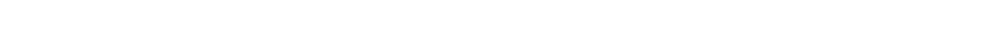

Gregg County $\ldots \ldots \ldots \ldots \ldots \ldots \ldots \ldots \ldots \ldots \ldots \ldots . C$ 384; 393,418

Grimes County .............................. 393

Guadelupe County $\ldots \ldots \ldots \ldots \ldots \ldots \ldots \ldots \ldots \ldots \ldots$ B 2?8; C 384

Hale County ............................. 384, 393

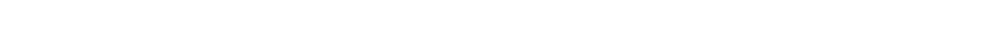

Hardeman County ............................. 384

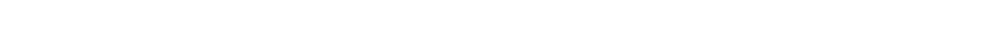

Harris County .......................... 254; C 393

Harrison County ........................... 393; 407

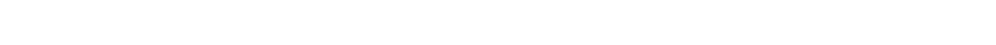

Hays County ........................... 2 2^8; C 393

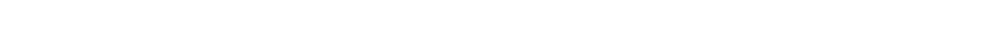

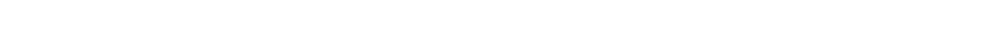

High Plains ...W 889 c; A 21 Iv c, 22 Iv c; C 391, 395, 397, 405, 411,

$414,41.6$; J 277

Hockley County $\ldots \ldots \ldots \ldots \ldots \ldots \ldots \ldots \ldots \ldots \ldots \ldots \ldots \ldots$. 393

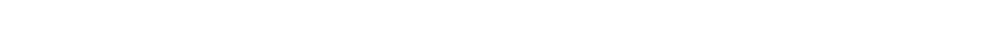

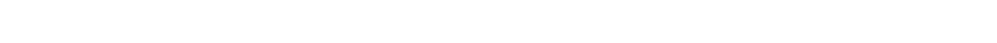

Houston district ...W 889 c, d, e; C 388, 393, 394, 396, 406, 413, 414;

D $46 ;$, T 242,317

Houston-Galveston area $\ldots . \ldots \ldots \ldots \ldots \ldots \ldots \ldots . . \mathrm{D} 39 ; \mathrm{J}$ 198, 202

Howard Countỳ ........................W 913; C 384 
Texas, areas, Irion County $\ldots \ldots \ldots \ldots \ldots \ldots \ldots \ldots \ldots \ldots \ldots \ldots \ldots$ C 384

Jackson County .......................... 393

Jasper County ............................ 393

Jeff Davis County ........................ 849 c

Jefferson County ........................... 393

Jim Hogg County $\ldots \ldots \ldots \ldots \ldots \ldots \ldots \ldots \ldots \ldots \ldots \ldots \ldots \ldots \ldots \ldots$

Jim Wells County .......................... 393

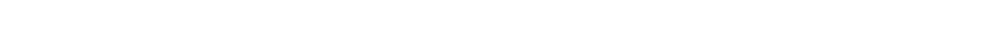

Karnes County .......................... 384

Kendall County ....................... 298; C 384

Kenedy County $\ldots \ldots \ldots \ldots \ldots \ldots \ldots \ldots \ldots \ldots \ldots \ldots \ldots \ldots \ldots$ C 393

Kinney County ........................... 393

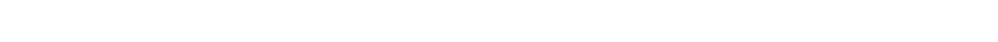

Knox County ............................ 384

Lamb County ............................. 384

Lampasas County .......................... 298

La Salle County ....................... 375 g

Lavaca County .......................... 384

Lee County ............................ 384

Leon County $\ldots \ldots \ldots \ldots \ldots \ldots \ldots \ldots \ldots \ldots \ldots \ldots \ldots \ldots \ldots \ldots \ldots$

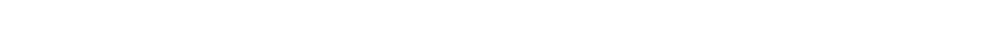

Live Oak County ....................... 384, 393

Llano quadrangle $\ldots \ldots \ldots \ldots \ldots \ldots \ldots \ldots \ldots \ldots \ldots \ldots \ldots \ldots$ GF 183

Loving County ........................... 393

lower Rio Grande region $\ldots \ldots \ldots \ldots \ldots \ldots \ldots \ldots \ldots \ldots \ldots$. 837

Lubbock County ....................... C 384, 393

Lufkin area .......................W 849 a; C 414; J 294

McMullen County ......................W 375 g

Marathon area ........................... 187

Marion County .......................... 393

Martin County ........................... 384

Mason County ........................... 384

Matagorda County ......................... 393

Maverick County ......................... 393

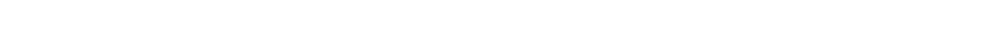

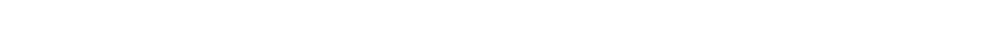

Milam County ........................... 384

Mineral Wells area .......................... 55

Montgomery County ...........................C 393

Morris County .......................... 393

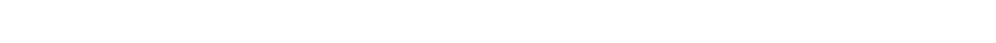

Newton County ......................... 393

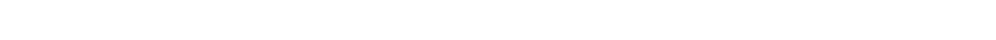

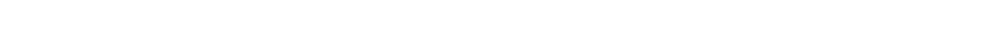

Nueces County ...................... 29? ; C 384, 393

Nueces quadrangle $\ldots \ldots \ldots \ldots \ldots \ldots \ldots \ldots \ldots \ldots \ldots \ldots \ldots$ GF 42

Ochiltree County .......................... 384

Oldham County $\ldots \ldots \ldots \ldots \ldots \ldots \ldots \ldots \ldots \ldots \ldots \ldots \ldots$ C 393

Orange County .......................... 393

Palo Pinto County .......................... 621 e

Panhandle, eastern part of $\ldots \ldots \ldots \ldots \ldots \ldots \ldots \ldots \ldots \ldots \ldots$ W 154

western part of $\ldots \ldots \ldots \ldots \ldots \ldots \ldots \ldots \ldots \ldots \ldots \ldots \ldots$ W 191 


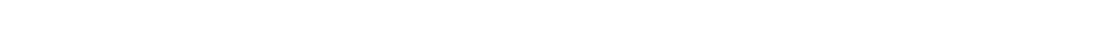

Parker County .................................... 298

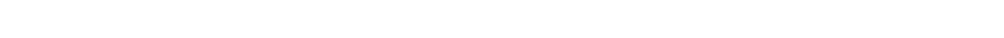

Pecos County ................................ 393

Pecos River Basin ....................... 256, 398, 402, 414

Potter County .................................. 384

Rains County ................................. 393

Randall County .................................. 384

Reeves County (Balmorhea area) ..............W 849 c; C 393

Refugio County ................................. 384

Rio Grande Plain ....................W 141, 839; A 18 in b

Roberts County .......................... 298; C 384

Robertson County ............................... 384

Rusk County ............................ 384, 393, 399

Sabine County ............................... 393

San Angelo and vicinity ........................W 132

San Antonio area .......................W 773 b; A 18 in b

San Augustine County ............................. 393

San Patricio County .............................. 384

San Saba County ............................... 384

Shelby County $\ldots \ldots \ldots \ldots \ldots \ldots \ldots \ldots \ldots \ldots \ldots \ldots \ldots \ldots$. 384, 399

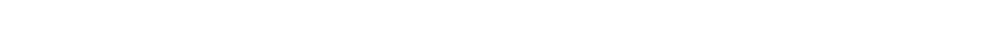

Somervell County ....................................... 660

southern $\ldots \ldots \ldots \ldots \ldots \ldots \ldots \ldots \ldots \ldots \ldots \ldots \ldots \ldots$ A 18 II b

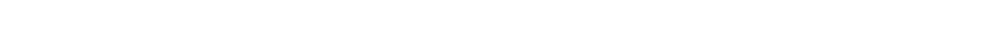

Sterling County $\ldots \ldots \ldots \ldots \ldots \ldots \ldots \ldots \ldots \ldots \ldots \ldots \ldots \ldots \ldots \ldots \ldots$ C 384

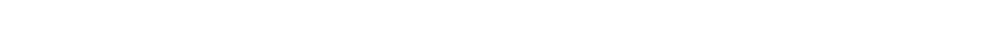

Swisher County .................................... 393

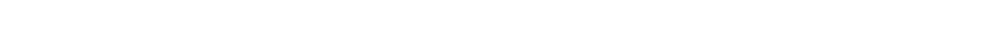

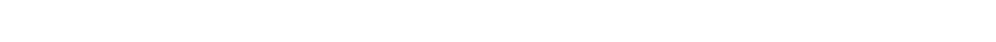

Texas City ................................. 408, 414

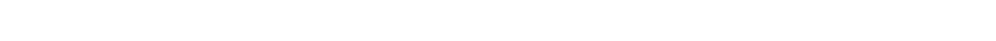

Tom Green County $\ldots \ldots \ldots \ldots \ldots \ldots \ldots \ldots \ldots \ldots \ldots \ldots \ldots$. 393

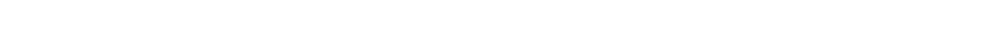

trans-Pecos region ..............W 140, 141, 143; GF 166; C 381

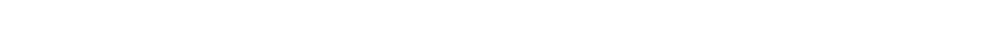

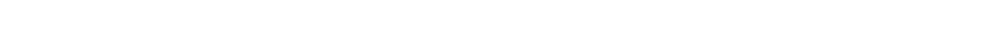

Upshur County ................................ 393

Uvalde County ....................................... 678

Uvalde quadrangle $\ldots \ldots \ldots \ldots \ldots \ldots \ldots \ldots \ldots \ldots \ldots \ldots$ GF 64

Val Verde County ................................. 384

Van Horn quadrangle $\ldots \ldots \ldots \ldots \ldots \ldots \ldots \ldots \ldots \ldots \ldots$, GF 194

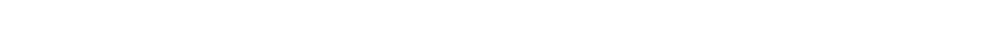

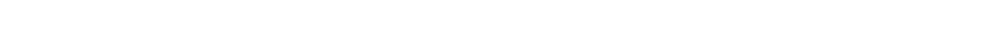

Waller County ................................. 393

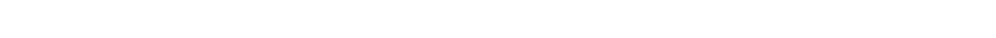

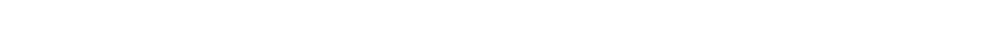

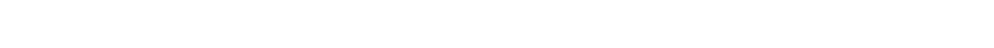

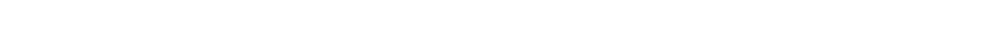
western ......................A 21 Iv c, 22 Iv c: B 780 b Wharton County ............................... 393

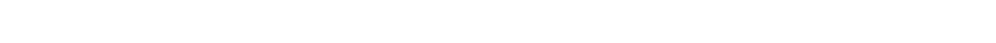


Texas, areas, Williamson County ................... 298; C 398

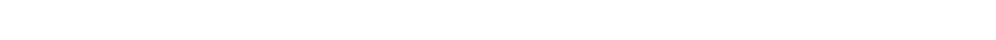

Winkler County .............................. 384

Winter Garden district ....................... 414

Wood County ................................. 393

Yoakum County ........................... 393

Zavala County .................... 298; C 393; D 51 artesian water in ...W 13,66, 71, 190, 191, 276, 335, $375 \mathrm{~g}, 660,773 \mathrm{~b}, \mathrm{~d}$, 849 a; A 11 II c, 18 II b, 21 vIl B 164; GF 42, 64, 76, 194; C 256, $381,392,401,402,408 ;$ D 19, 38, 46; J 132, 202 bibliography of ground water in .....W 61, 120, 149, 163; C 403, 401, 414

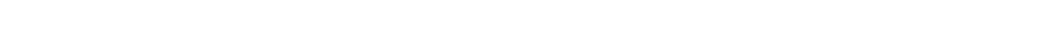
development of ground water in $\ldots \ldots \ldots \ldots \ldots \ldots \ldots \ldots \ldots \ldots \ldots$ C 400

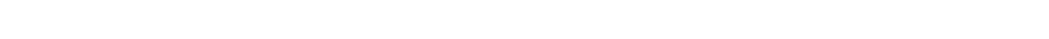

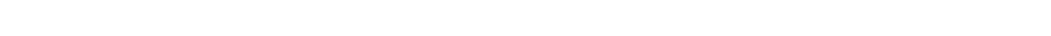
with other ground water in ..W 5, 13, 66, 71, 140, 141, 154, 190, 191, $375 \mathrm{~g}, 676$; A 11 II c, 16 II e, 21 IV c, 22 IV c; C 256, 382, 391; $397,405,411,413,416$; D 19, 38, 40, 51; J 132, 203 large flowing well in .......................... 401 leakage of gas in well in ....................... 337 mineral waters in ..............W 66; B 32; MR 1883-1923; D 55 public water supplies in .....W 13, 190, 335, 343, $889 \mathrm{~d}, 919$; A 18 II b; GF 166; C 396, 404, 405, 408, 412, 413, 415; D 39; J 202 pumping in $\ldots \ldots \ldots \ldots \ldots \ldots \ldots W$ 13, 140, 141, 411, 416, 418; J 294, 317

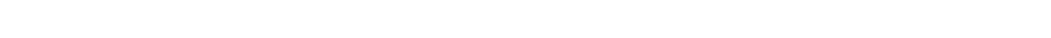
quality of ground water in ..W $66,141,190,276,317,335,343,364,375 \mathrm{~g}$, $660,676,773 \mathrm{~d}, 839,849$ a, 913, 919; A 18 II b, 21 vII; P 46; P 32; GF 166, 194; C 381, 388, 390, 396, 398, 399, 402, 407, 413, 415, 417, 418;

D $40,46,55 ; \mathrm{J} 198,202$ quantity of ground water in ...W 141, 660; C 256, 405, 407, 409, 411, 412, $413,417,418 ; \mathrm{J} 132,170,186$ rice irrigation with ground water in $\ldots \ldots \ldots \ldots \ldots \ldots \ldots . \mathrm{W} 71 ; \mathrm{C} 413$ salt water in ..W 154, 317, 335, 364, $375 \mathrm{~g}$; B 282, 669, $715 \mathrm{~m} \cdot 736 \mathrm{e}, 785$ b; C 381, 382; D 19, 40, 151; J 117, 132 170, 176, 202 spring discharge measurements in .W 28, 37, 66, 84, 132, 174, 288, 508, 528, $548,568,587,588,608,628,648,668,688,688,703,718 ; 733,748,763$, $788,808,828,850,858,878,898,958,977,978$ springs in ...W $71,105,154,190,191,317,335,557,679 \mathrm{~b}, 773 \mathrm{~b}, 849 \mathrm{c}$; A II b, 18 II b; P 187; B 32, 131, 140, $661 \mathrm{~g}, 736 \mathrm{~g}, 902$; GF 42, 64, 183; C 381, 386, 390, 397; D 19; J 292

thermal W $679 \mathrm{~b}$ temperature of ground water in $\ldots \ldots \ldots \ldots \ldots \ldots \ldots \ldots \ldots \ldots$ 413, 418

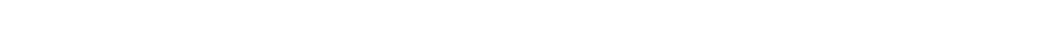

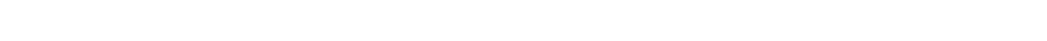
water levels in .....W 777, 817, 840, 845, 886, 909, 919, 939, 947, 989 water table in ...W 141, 335, 773 b; C 256, 383, 384, 385, 386, 387, 388, 389, $394,395,396,397,402,405,411,413,415,416$; D 19, 39,

$51,66,74 ; \mathrm{J} 132,203,241,242,337$ well records for ... .W 13, 61, 149, $190,276,317,335,343,375 \mathrm{~g}, 676,678$, 773 d, 776, 849 a, c, 913, 919; A 18 II b, 21 vII; P 46; B 264, 2?8, 669, 736 a,

e, g, 780 b, 837; GF 166; C 256, 381, 390, 399, 407, 415, 417, 418; J 188. wells in, construction of $\ldots \ldots \ldots \ldots \ldots \ldots \ldots \ldots$ W $660,676,773 \mathrm{~d}, 889 \mathrm{e}$ 
Texas, wells in, cost of $\ldots \ldots \ldots \ldots \ldots \ldots \ldots \ldots \ldots \ldots \ldots$ A 11 Ir c; B 282

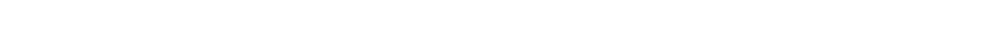

Thallium in ground water $\ldots \ldots \ldots \ldots \ldots \ldots \ldots \ldots \ldots \ldots \ldots \ldots \ldots \ldots$

Theis, C. V., Decline of ground-water level in Portales Valley,

N. Mex., 1932-41 ...................................D 149

Decline of ground-water levels in New Mexico, 1930-41 ......... 148

Decline of water level in Portales Valley, N. Mex ............. 125

Earth tides expressed in fluctuations of the water level in

artesian wells in New Mexico ........................J 209

Effect of a well on the flow of a nearby stream ............J 238

Equation for lines of flow in vicinity of discharging artesian well... . 86

Geology and ground-water, Pecos River Basin, N. Mex '......... 256

Ground-water conditions in the middle Rio Grande Valley, N. Mex. .C 254

Ground-water hydrology of areas in the Pecos Valley, N. Mex . . : C 257

Ground water in Curry and Roosevelt Counties, N. Mex ......... 241

Ground water in south-central Tennessee ..............W 677

Ground water in the middle Rio Grande Valley, N. Mex ........ 255

Ground water in the southern High Plains ............. 66

Ground-water recharge in the southern High Plains ...........J 180

Ground-water supply of Lea County, N. Mex., (progress report) .C 247, 250

Ground-water supply of Mimbres Valley, N. Mex.,

(progress report) ..................... 251; D 108

Ground-water supply of Portales Valley, N. Mex., (progress report) ........................ 245, 249

Method for determining transmissibility- and storage-coefficients

by tests of multiple well systems (discussion) ...........J 311

Origin of water in Major Johnson Springs, N. Mex ......... 253

Relation between the lowering of the piezometric surface anc'

the discharge of a well using ground-water storage ........J 133

Significance and nature of the cone of depression in ground-

water bodies ................................. 199

Sources of water derived from wells ................... 219

Water in wells in New Mexico during $1941 \ldots \ldots \ldots \ldots \ldots \ldots$ D 176

Water levels and artesian pressure in the United States..... $W^{\top 777,817}$,

941,949

Therapeutic properties of water ..W 31, 164, 195, 233, 254, 259, 29£. 335, 338, 341, 398; A 14 II b; P 46; MR 1911 II r. 1913 li h

Thermal movements of ground water ................. 19 II b

Thermal springs. See Springs, thermal; specific States.

Thiem method of determining permeability .........W 679 a. 887; J 85

Thom, W. T., Jr., Geology of Big Horn County and the Crow Indian

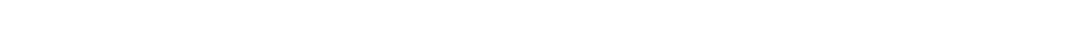

Oil and gas prospects in the Crow Indian Reservation, Mont ... $736 \mathrm{~b}$

Significance of geologic conditions in Naval Petroleum Reserve

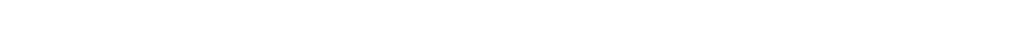

Thomas, A. O., Underground water resources of Iowa .........W 293

Thomas, H. E., Artesian water in the vicinity of Woods Cross, Utah ...D 83

Artesian water levels in the vicinity of Lehi, Utah .......W \&36 c; D 90

Fluctuations in ground-water levels .................J 218

Geology and ground-water hydrology of the Mokelumne area, Calif. W 780

Geology and ground-water resources of Cedar City and Parowan

Valleys, Iron County, Utah ................W \& 
Thomas, H. E., Geology and water resources of Tooele Valley, 'Tooele County, Utah .................................. D 186

Grou.id-water dams created by faulting in Hurricane fault zone,

Utah ....................................... 244

Ground water in the Walla Walla basin, Oreg.-Wash ........... 44

Ground-water investigations in Utah to June 30, $1936 \ldots \ldots \ldots$ C 421

Ground-water levels in Utah ...........D 86, 93, 112, 122, 145, 167

Ground-water resources of Salt Lake City, Utah .............. 183

Manganese in a thermal spring in west-central Utah ...........J.211

Ogden Valley artesian reservoir, Utah .............. 424; D 170

Saline ground-water conditions in Utah .................. 151

Water levels and artesian pressure in the United States ...W 777, 817,

$840,845,886,910,940$

Thompson, D. G., Administrative control of underground water; physical

and legal aspects (discussion) .......................... 182

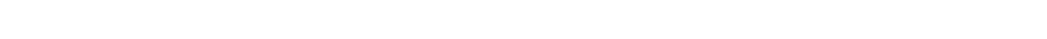

Effect of a sea-level canal on the ground-water level of Florida ...J 185

Geologic studies on Long Island with respect to ground-water

supplies $\ldots \ldots \ldots \ldots \ldots \ldots \ldots \ldots \ldots \ldots \ldots \ldots \ldots \ldots \ldots . . . \ldots \ldots$ J 146, 169

Ground water for irrigation near Gage, Okla $\ldots \ldots \ldots \ldots \ldots \ldots$ W 500 b

Ground water in Lanfair Valley, Calif ................W $450 \mathrm{~b}$

Ground-water investigation in Butler and Hamilton Counties, Ohio

(progress report) ............................. 311

Ground-water levels in Grand Prairie region, Ark ............. 23

Ground-water problems in the southeastern States ...........J 81

Ground-water problems on the barrier beaches of New Jersey .....J 44

Ground-water resources of Florida $\ldots \ldots \ldots \ldots \ldots \ldots \ldots \ldots \ldots \ldots \ldots \ldots$

Ground-water resources of Long Island, N. Y., (investigation

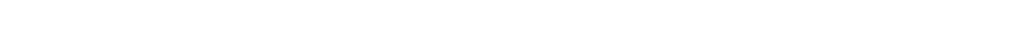

Ground-water supplies for rice irrigation in the Grand Prairie region,

Ark .................................. 20 e; D 18

Ground-water supplies in the vicinity of Asbury Park, N. $5 \ldots \ldots$ C 213

Ground-water supplies of the Atlantic City region, N. J.........C 212

Ground-water supplies of Mill Creek Valley and the Norwoot Trough, Ohio .D 87,88

Ground-water supplies of the Camden area, N. J............C 215

Ground-water supplies of the Passaic River Valley, N. J.........C 214

Investigation of ground-water resources of Long Island, N. Y.....D 41

Investigation of the ground-water resources of Long Island $\mathbf{N}$. Y.

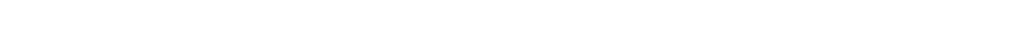

Mohave Desert region, Calif ........................W 578

Municipal and industrial water supplies from wells in Butler and

Hamilton Counties, Ohio ......................... 120

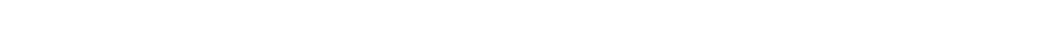

Problems of ground-water supply in Florida ................ 80

Problems relating to fluctuations of ground-water level .........J 149

Problems relating to legal control of use of ground water. .....J 190

Quantities of ground water available for public and industrial

supplies in New Jersey ............................ 211

Relations between ground-water hydrology and oceanography.......J 94

Repoit of the committee on underground waters ...J 82, 96:110, 127, 148, 171, 192, 205, 227, 247, 262 
Thompson, D. G., Routes to desert watering places in the Mohave Desert region, Calif. ............................ 490 b Salt water in seacoast and island wells .................... 104 Source of ground-water supply for Atlantic City, N. J. . .........J 32 Studies of ground water in New Jersey ................J 90 Submergence of a pump ........................... 60 Subsurface water in research on agricultural watersheds (discussion)

Symposium on ground-water levels $\ldots \ldots \ldots \ldots \ldots \ldots \ldots \ldots \ldots$ D 73

Ten years of ground-water records in the Grand Prairie region, Ark J 196 Watch well supplies ...........................J 232 Water levels and artesian pressure in the United States...W 777, 817, $840,845,886,909$

Withdrawal of ground water on Long Island, N. Y ........... 274 Thomson, M. T., Water levels and artesian pressure in the United States

Thorium in ground water $\ldots \ldots \ldots \ldots \ldots \ldots \ldots \ldots \ldots \ldots \ldots \ldots . \ldots \ldots$ Tides, fluctuations of ground-water levels caused by .....W 155, 232, 659 b, See also Water table. 836 d; P 44; GF 193; C 92, 99, 212, 216; J 20", 209, 230

Till, drainage into wells in-

Connecticut. .W 232, 374, 397, 449, 466, 470, 540, 597 b; C 41, 42, 43, 44, 45 general $\ldots \ldots \ldots \ldots \ldots \ldots \ldots \ldots \ldots \ldots \ldots \ldots \ldots W$ 114, 255, 25r, 258, 489 Illinois $\ldots \ldots \ldots \ldots \ldots \ldots \ldots \ldots \ldots \ldots \ldots \ldots \ldots \ldots \ldots$. GF 18?, 213, 216

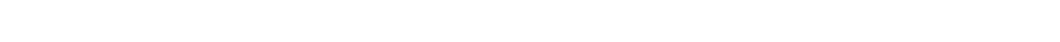

Maine ................................ 2a.3; GF 149

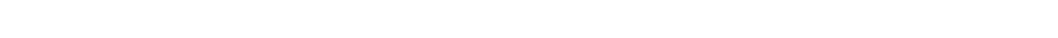

Montana ................................... 400 b

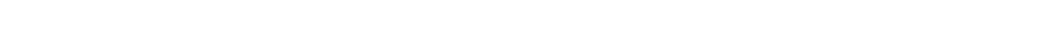

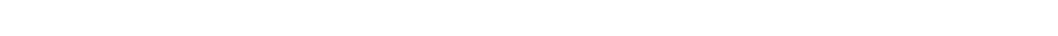

South Dakota ....................GF 96, 97, 100, 113, 114, 156

See also Glacial drift.

Tilton, J. L., Underground water resources of Iowa ...........W 293

Tin in ground water $\ldots \ldots \ldots \ldots \ldots \ldots \ldots \ldots \ldots \ldots \ldots \ldots \ldots \ldots \ldots \ldots$

Titanate in ground water $\ldots \ldots \ldots \ldots \ldots \ldots \ldots \ldots \ldots \ldots \ldots \ldots \ldots \ldots \ldots$ B 47

Todd, J. E., Aberdeen-Redfield folio, S. Dak ...............GF 165

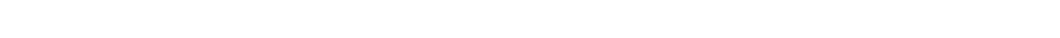

De Smet folio, S. Dak .......................... 114

Elk Point folio, S. Dak.-Nebr.-Iowa ................... 156

Geology and water resources of southeastern South Dakota.......W 34 Geology and water resources of the lower James River Valley, S. Dák.

W 90

Huron folio, $\mathbf{S}$. Dak ...........................FF 113

Mitchell folio, S. Dak ........................GF 99

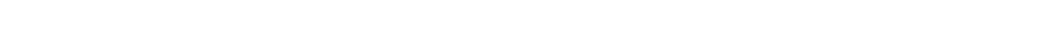

Parker folio, S. Dak ..........................GF 97

Tolman, C. F., Ground water, salt-water inflitration, and ground-surface recession in Santa Clara Valley, Calif ....................J 225

Top water in relation to oil $\ldots \ldots \ldots \ldots \ldots \ldots \ldots \ldots \ldots \ldots \ldots \ldots \ldots \ldots$

Topography, thermal springs in relation to ............... 14 II b water table in relation to ...........W 67, 159, 254, 374; A 19 II b Torchlight sand, water in, in Wyoming ................. 656 
Torpedoing of wells

W 233, 255, 257

Transmissibility, coefficient of $\ldots \ldots \ldots \ldots \ldots \ldots \ldots$ D 205; J 294, 311, 326, 342

Transmission constant ........................W 67, 140

Transpiration .. W 7, 153, 294, 320, 375 d, 423, 577, 638 c, 836 d; C 15, 20, 22;

D $8,16^{n} ; \mathrm{P} 231,240$

Trap rock, water in.$\ldots \ldots \ldots \ldots \ldots$ W 110, 160, 223, 232, 374, 449, 489; B 319 Trask, P. D., Hydrogical investigative work by petroleum companies....J 83 Trautwine, J. C., on flow of water through soils............. 19 in b Traverse formation, water in, in Michigan..........W 30, 114; GF 205 Travertine deposited by ground water.....W 338, 343, 423; A 9 d, 18 II b; P 170 e; B 330, 491, 616, 711 d, 803, 877; C 131, 235

Travis Peak sand, water in, in Texas ...................... 42 Trent formation, water in, in North Carolina ............... 291 Trenton limestone, water in-

Illinois

Indiana W 114, 254

Iowa .W 293

Michigan W 114

Ohio W 114; A 19 Iv b; GF 197

Wisconsin W 114; C 451

See also Platteville limestone.

Triassic formations, water in-

Arizona W 380,836 b; B 435

Colorado A 16 II f, 17 II f, P 52

Connecticut W $110,114,232,374,449,466,470,540,597$ b

Kansas ................................... 16 II f; C 145 Massachusetts .................................... 110

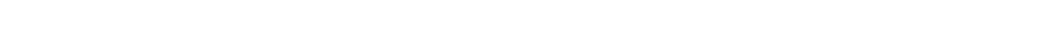

Nebraska ................................ 16 II $f$

New Jersey $\ldots \ldots \ldots \ldots \ldots \ldots \ldots \ldots \ldots \ldots \ldots \ldots$ W 114; GF 157, 167, 191

New Mexico ...................W 380; B 435, 620; C 241

New York .......................... W 114; GF 157

North Carolina ............................ 114

Oklahoma ................................. 213

Pennsylvania W 106, 114 ; B 828, 840, 891; GF 162, 167, 225; C 342, 347, 349

South Dakota .........................GF 107, 164

Texas ......................W 154, 191, 913; В 780 b

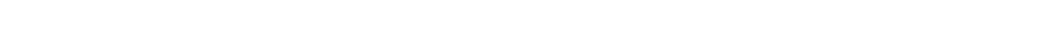

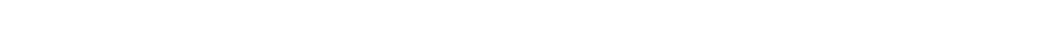

Wyoming ...................... 364; GJ 107, 150, 173

See also specific formations.

Trinity formation, water in-

Arkansas .P 46; B 691 j, 808

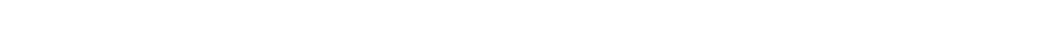

Kansas $\ldots \ldots \ldots \ldots \ldots \ldots \ldots \ldots \ldots \ldots \ldots \ldots \ldots \ldots \ldots$ A 16 in $f$

Nebraska ................................... 16 if $\mathrm{f}$

Texas ..............W 276, 913; A 21 vII; B 780 b; GF 42, 76, 183

Trowbridge, A. C., Galena-Elizabeth folio, Ill.-Iowa............GF 200

Tertiary and Quaternary geology of the lower Rio Grande region, Tex 
Troxell, H. C., Diurnal fluctuation in the ground water, and flow of

Santa Ana River, Calif ............................ 160

Ground-water supply in the valley of Santa Ana River, Calif...... 23

Tufa deposited by grqund water......W 338, 343, 423; A 9 d, 18 II b; B 330, 491,$616 ; \mathrm{C} 131$

Tuff, water in ................W 375 a, 489, $637 \mathrm{~d}$; GF 138; C 92, 99

Tunnels for recovering ground water. See Infiltration ditches and tunnels.

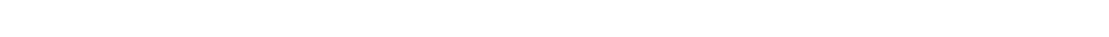

Turbidity of ground water $\ldots \ldots \ldots \ldots \ldots \ldots \ldots \ldots \ldots \ldots \ldots$ 341, 39s; C 131

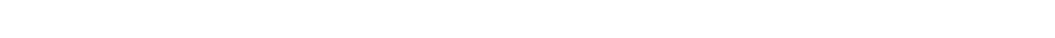

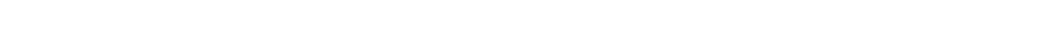

Turkestan, bibliography of ground water in ................... 163

Turner, H. W., Marysville folio, Calif ................... 17

Turner, S. F., County reports on ground-water surveys in Texas by

Works Progress Administration ...................... 384

County reports on ground-water surveys in Texas, in cooperation

with Texas State Board of Water Engineers .............. 393

Design and use of maximum-minimum water-level gage ........ 155

Distribution of Texas ground-water publications (progress report) C $38 \%$

Duncan-Virden Valley, Greenlee County, Ariz., and Hidalgo County,

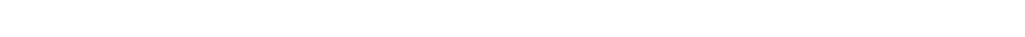

Geological survey of Texas ground waters (progress report).......J 188

Ground-water conditions and pumpage in Arizona in 1943 ...... 196

Ground-water conditions in Arizona in $1941 \ldots \ldots \ldots \ldots \ldots \ldots$ D 171

Ground water in Dimmit and Zavala Counties, Tex ........... 51

Ground water in parts of the Texas Coastal Plain ............J 132

Ground-water inventory in upper Gila River Valley, N. Mex. and Ariz.

J 240

Ground-water investigations by the United States Geological Sirvey

in cooperation with the State of Arizona .............. 11

Ground-water levels and pumpage in Arizona in 1939-40 ........ 14

Ground-water levels in Arizona in $1939-40 \ldots \ldots \ldots \ldots \ldots \ldots \ldots$ D 146

Ground-water resources of Texas, their conservation and development

C 400

Ground-water resources of the Houston district, Tex. (progress report)

C 388

Ground-water resources of the Houston-Galveston area, Tex .......D 39

Ground-water resources of the Santa Cruz River Basin, Ariz .C 2.0; D 185

In-entory of wells and springs, Tex. (progress report) .......... 386

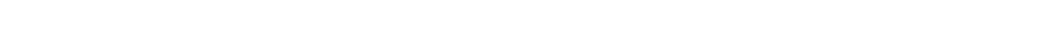

Mineral-water supply of the Mineral Wells area, Tex .......... 55

Observation wells, manual of methods ................... 60

Progress report (on cooperative water-level surveys in Texas) . . . C 389

Pumpage from wells in southern Arizona in $1944 \ldots \ldots \ldots \ldots \ldots$. . . 203

Queen Creek area, Maricopa and Pinal Counties, Ariz........... 18

Report on cooperative ground-water investigations ............ 19

Review of the States' cooperation in ground-water observation and in-

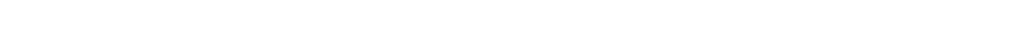

Safford Valley, Graham County, Ariz., records of wells and springs ..C 16

Salt-water enoroachment in the Galveston area, Tex ..........J 117

Salt-water problems in Arizona $\ldots \ldots \ldots \ldots \ldots \ldots \ldots \ldots \ldots \ldots \ldots \ldots \ldots$ 
Turner, S. F., State-wide inventury of ground-water resources, Tex.

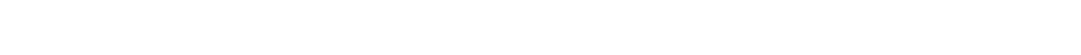

Surveys by Works Progress Administration, county reports on wells

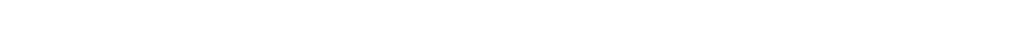

Value of long-time records of ground water $\ldots \ldots \ldots \ldots \ldots \ldots \ldots$ J 186

Water-level recovery curve, form ................... 96

Water levels and artesian pressure in the United States. . W 840, 845, 886,

91.. 941, 949, 991

Water resources of Safford and Duncan-Virden Valleys, Ariz. and N. Mex

C $15 ; \mathrm{D} 160$

Water-stage recorder, self-starting ................... 139

Tuscahoma formation, water in, in Alabama $\ldots \ldots \ldots \ldots \ldots \ldots \ldots$. 1

Tuscaloosa formation, water in-

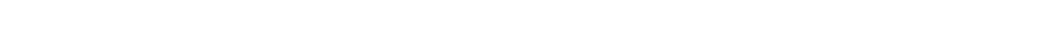

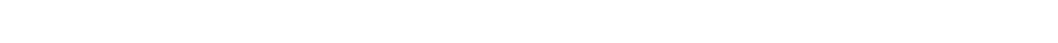

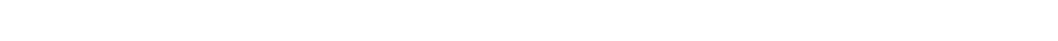

North Carolina ..........................C 293; J 334

South Carolina .............................. 867

Tennessee ..............................W 638 a; C 372

Tuscan tuff, water in, in California ..............W 375 a; GF 138

$\mathbf{U}$

Udden, J. A., Belleville-Breese folio, Ill ..................GF 195

Geology and mineral resources of the Peoria quadrangle, Ill ....... 506

Umpleby, J. B., Geology and ore deposits of the Mackay region, Idaho..P 97

Geology and ore deposits of the Wood River region, Idaho......... 814

Underflow dams. See Dams.

Underflow ditches. See Infiltration ditches and tunnels.

Underflow measurements.. W 112, 140, 141, 153, 184, 258, 494, 637 b; A 19 II b;

P 44; J 194

cost of

W 112

methods for making $\ldots \ldots \ldots \ldots \ldots \ldots \ldots \ldots \ldots \ldots$ 112, 140, 638 c; $P 44$

Underflow meters $\ldots \ldots \ldots \ldots \ldots \ldots \ldots \ldots \ldots \ldots \ldots \ldots \ldots$ W 112, 140, 141; P 44

See also Movements of ground water.

Underground dams. See Dams.

Underground streams ........W 233, 258, 494; A 18 Iv b, 21 iv c; C 81,431

Uniformity coefficient of water-bearing materials ........W 67; P 44

United States, ground-water conditions in ................ 181

water levels in $\ldots . W$ W 777, 817, 840, 845, 886, 906, 907, 909, 909, 910, 911, $936,937,938,939,940,941,944,945,946,947,948,949,986 ; 987,988$,

See also specific States.

$989,990,991$

United States Geological Survey, ground-water work of. .W 427, 991; B 227;

D 116, 133, 161, 172, 187, 198, 209; J 5

United States history, ground water in relation to ............. 14 in a

Unklesbay, A. G., Artificial recharge of artesian límestone at Orlando, Fla.

Ground-water conditions in Orlando and vicinity, Fla $\ldots . . . . . . .64$

Unkpapa sandstone, water in, in South Dakota ................ 65

water in, in Wyoming ............................... 65

Upham, Warren, Glacial Lake Agassiz .................... 25 
Upsōn, J. E., Water levels and artesian pressure in the United States

W 910, 910, 949, 991

Water levels in observation wells in Santa Barbara County Calif....C 28 Water resources of Santa Barbara County, Calif .............. 27 Water wells and water levels in Carpinteria, Goleta, and Sant Ynez

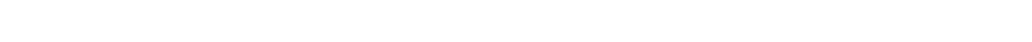
Water wells and water levels in San Antonio, Santa Maria, and Cuyama Valleys, Calif $\ldots \ldots \ldots \ldots \ldots \ldots \ldots \ldots \ldots \ldots \ldots \ldots \ldots$ b $30 \ldots \ldots$

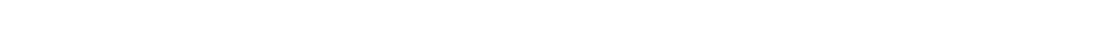

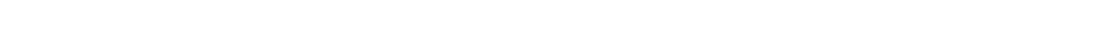

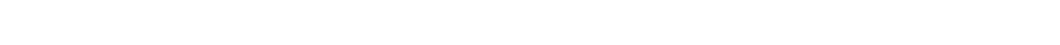

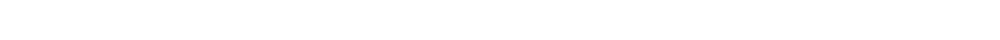

Blue Spring Valley $\ldots \ldots \ldots \ldots \ldots \ldots \ldots \ldots \ldots \ldots \ldots \ldots \ldots \ldots \ldots \ldots \ldots$

Box Elder County .......................... 333

Cedar City Valley ......................W 993; D 179

central Sevier Valley ..........................W 199

Curlew Valley .............................. 333

east-central .............................. 628

Escalante Desert ................W 277, 659 a; D 8; J 48

Fish Springs Valley .......................W 277

Flowell area $\ldots \ldots \ldots \ldots \ldots \ldots \ldots \ldots \ldots \ldots \ldots \ldots \ldots \ldots \ldots \ldots \ldots \ldots$ C 423

Grand County ......................... 541 d, 908

Grouse Creek Valley ......................... 333

Hansel Valley ...............................W 333

Hurricane fault zone $\ldots \ldots \ldots \ldots \ldots \ldots \ldots \ldots \ldots \ldots \ldots \ldots$. 244

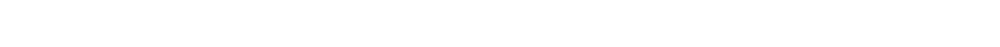

Jordan River Valley ..................W 157; D 36, 183

Juab County $\ldots \ldots \ldots \ldots \ldots \ldots \ldots \ldots \ldots \ldots \ldots \ldots \ldots \ldots \ldots \ldots$ W 277

Lehi and vicinity $\ldots \ldots \ldots \ldots \ldots \ldots \ldots \ldots \ldots \ldots \ldots \ldots$ W 836 c; D 90

Millard County .........................W 277

Moab district ......................... 841 ; D 71

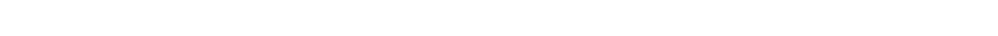

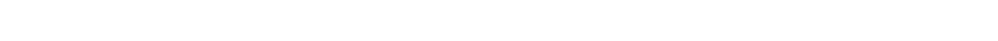

Ogden Valley ...................W 796 d; C 424; D 65, 170

Park Valley ............................... 333

Parowan Valley ...................W 277, 993; D 179

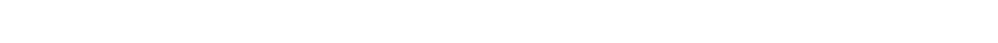

Randolph quadrangle $\ldots \ldots \ldots \ldots \ldots \ldots \ldots \ldots \ldots \ldots \ldots \ldots$ B 923

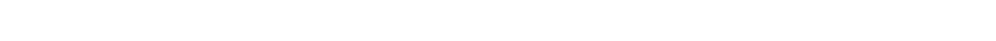

Rush Valley . ............................. 333

Salt Lake City ............................ 183

Salt Lake County ....................... 298; J 135

Salt Valley anticline $\ldots \ldots \ldots \ldots \ldots \ldots \ldots \ldots \ldots \ldots \ldots \ldots \ldots$. 863

San Juan country ...................P 188; B 908

San Juan River Valley ........................ 538

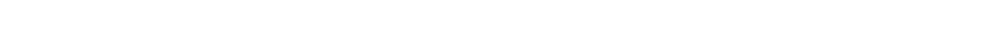

San Rafael Swell ......................... 806 c

Sevier County ......................... 796 c

Sevier Valley $\ldots \ldots \ldots \ldots \ldots \ldots \ldots \ldots \ldots \ldots \ldots \ldots \ldots \ldots \ldots$ W 199, 277

Skull Valley $\ldots \ldots \ldots \ldots \ldots \ldots \ldots \ldots \ldots \ldots \ldots \ldots \ldots \ldots \ldots \ldots$ W 333

Snake Valley $\ldots \ldots \ldots \ldots \ldots \ldots \ldots \ldots \ldots \ldots \ldots \ldots \ldots \ldots \ldots \ldots$ W 277

southeastern $\ldots \ldots \ldots \ldots \ldots \ldots \ldots \ldots \ldots \ldots \ldots \ldots \ldots \ldots$ W 380; D 71 


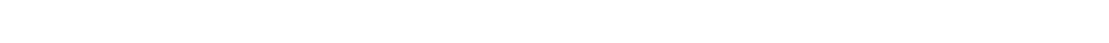

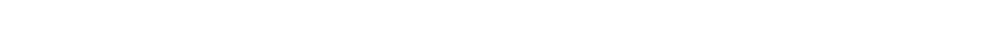

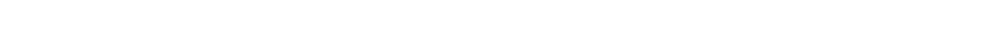

Tooele Valley ....................................... 186

Utah Lake Valley ..............................W 157

White River Valley ............................W 277

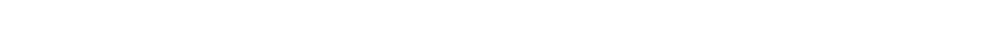

Woods Cross ................................... 83 artesian water in..W 157, 199, 217, 277, 333, $796 \mathrm{~d}, 836$ c; B $751 \mathrm{~d}, 796 \mathrm{c}$; C 423, 424; D 36, 65, 71, 83, 90, 170, 183, 186

bibliography of ground water in....................W 120, 163

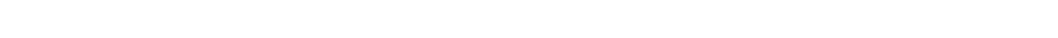

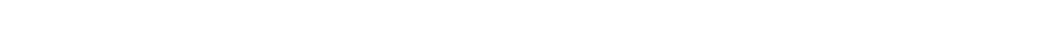

guides to watering places in.....................W 277, 338

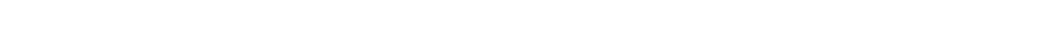

irrigation with artesian water in...W 157, 217, 277, 333, 659 a, $836 \mathrm{c} ; 423$

with other ground water in ...............W 217, 277, 333, 395

leakage from artesian wells in $\ldots \ldots \ldots \ldots \ldots \ldots \ldots \ldots \ldots \ldots \ldots . . .6423$

mine waters in $\ldots \ldots \ldots \ldots \ldots \ldots \ldots \ldots \ldots \ldots \ldots \ldots \ldots \ldots \ldots \ldots \ldots \ldots \ldots \ldots$ W 364

mineral waters in ....................... 32; MR 1883-1916

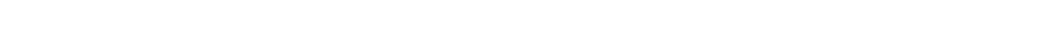

quality of ground water in....W 157, 199, 217, 277, 333, 364; B 32; D 36 quantity of ground water in .......................W 659 a salt water in ....................... 711 a, 785 b, 863; D 151

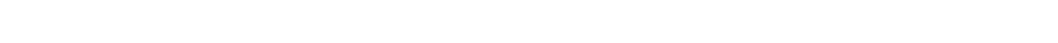
spring discharge measurements in..W 133, 212, 359, 360, 3?9, 390, 440. $460,479,510,529,549,750,765,860 ;$ B 32 springs in .....W 157, 199, 217, 277, 333, 364, 538, 557, 679 b; P 80, 153 164,188 ; B 32, 725 c, 795 b, 819, 841, 865, 908, 923; J 34, 211

thermal .............W 217, 277, 333, 364, 679 b; P 153; J 34, 211 water levels in........W 777, 817, 840, 845, 886, 910, 940, 948, 990, 993 water table in....W 157, 199, 217, 277, 333, 836 c; C 421, 424; D 8, 36, 86, $90,93,110,112,122,137,138,145,167,179 ; \mathrm{J} 115,124,156,179$ well records for ....W 61, 149, 157, 199, 217, 277, 333, 380; F 188; B 264, $298,541 \mathrm{~d}, 751 \mathrm{~d}, 8 \mathrm{r}$ 's é, 841,863

wells in, cost of ............................ 277; J 200

Utica shale, water in, in Michigan .......................W 114

water in, in Ohio ............................... 259

Utilization of ground water $\ldots \ldots \ldots \ldots \ldots \ldots \ldots \ldots \ldots \ldots \ldots \ldots \ldots \ldots$

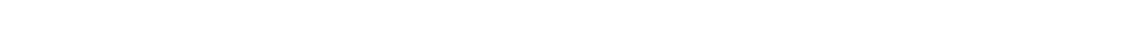

Vacuum in pumps, methods of determining . . . . . . . . . . . . W 141

Vadose circulation of ground water ......................... 529

Vadose water . . . . . . . . . . . . . . . . .W 489, 494; B 330, 491, 529, 616

Vaksvik, K. N., Geology and ground-water resources of Oahu, Hawaü...C 92

Records of drilled wells on Oahu, Hawaii .................... 94

Valley fill, interbedded with lava, water in............... 54 ; B 199 water-bearing capacity of ....................... 423; 16 
Yalley fill, water in-

Arizona .......W 104, 136, 320, 375 b, 380, 425 a, 499, 796 f; B 352;

GF 111,112 ; C 12, 13, 15, 16; D $82 ; \mathrm{J} \mathrm{240,279}$

California ..W 89, 137, 138, 139, 142, 219, 222, 225, 278, 294.375 a, h, 398,400 e, 446, 495, 519; GF 163, 193; C 21, 22

Colorado ..............................W 240; C 32

Idaho $\ldots \ldots \ldots \ldots \ldots \ldots \ldots \ldots \ldots \ldots \ldots \ldots \ldots \ldots \ldots . . \ldots \ldots$ W $78 ; C 114$

Montana ...........................W 345 g, 400 b

Nevada .....................W 365, $375 \mathrm{~d}, 423 ;$ B $530 \mathrm{r}$

New Mexico .. W 123, 158, 188, 260, 275, 343, 345 c, 425 a, f20, 637 b;

B 618; GF 199, 207; C 231 236, 237, 238, 240, 241, 252

Oregon ..................W 78, 220, 231; B 252; D 24, 62

Texas .................W 343; GF 166, 194; C 381; D 31

Utah .....................W 157, 199, 217, 277, 333

See also Debris-filled basins.

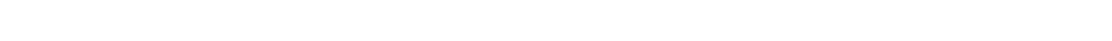

Vanderwilt, J. W., Geology and mineral deposits of the Snowmass

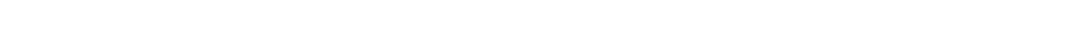

Van Hise, C. R., Geology of the Lake Superior region . . ...........M 52

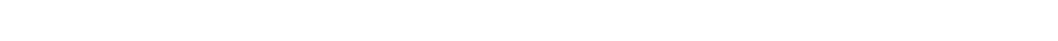

Van Horn, F. R., Geology and mineral resources of the Cleveland district,

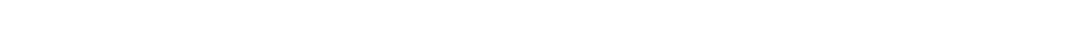

Van Orstrand, C. E., Apparatus for measurement of temperatures in deep

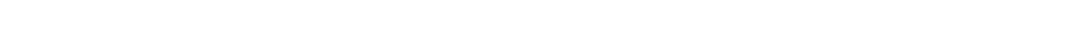

Vaughan, T. W., Austin folio, Tex ....................... 76

Geology and 'underground waters of the Edwards Plateau and Rio

Grande Plain, Tex ........................... 18 In b

Geology of the ground waters of Antigua, B. W. I............ 71

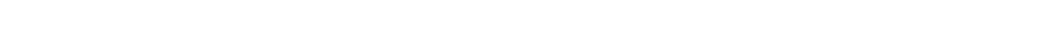

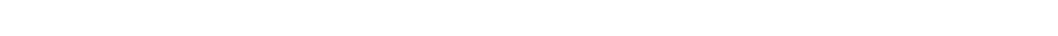

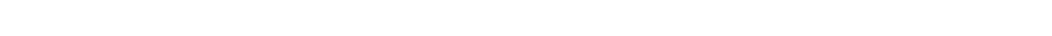

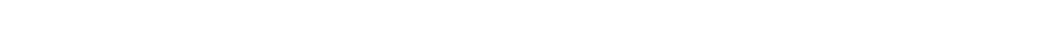

Veatch, A. C., Coal and oil in Uinta County, Wyo ................ 285

Fluctuations of water levels in wells ..................... 155

Geography and geology of southwestern Wyoming............P 56

Geology and underground water resources of northern Louisiana ..C 161

Geology and underground water resources of northern Louisiana and

southern Arkansas.$\ldots \ldots \ldots \ldots \ldots \ldots \ldots \ldots \ldots \ldots \ldots \ldots \ldots$

Peculiar artesian conditions on Long Island, N. Y.............J 3

Records of deep wells, $1904 \ldots \ldots \ldots \ldots \ldots \ldots \ldots \ldots \ldots \ldots \ldots \ldots$. . 264

Underground water resources of Long Island, N. Y............ 44

Underground waters of Louisiana and southern Arkansas ......W 114

Veatch, F. M., Surface water supply of the United States. W 902, 904, 964, 984

Veatch, J. O., Underground waters of the Coastal Plain of Georgia ....W 341

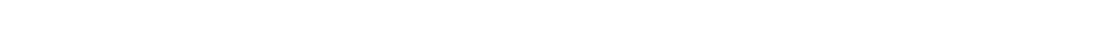

as indicator of ground water. W 294, $375 \mathrm{~d}, 423,467,489,494,497,499,577$

carbonate in water in relation to .................... 9 d

crenothrix in ground water ....................... 338

discharge of water by ......W $7,153,294,320,375 \mathrm{~d}, 423,489,494,577$,

638 c, $796 \mathrm{f} ; \mathrm{C} \mathrm{11}, 15,20,22 ; \mathrm{D} \mathrm{160} ; \mathrm{J} 240$

ground water in relation to.....W 30, 224, 277, 294, 320, 343, $375 \mathrm{~d}, 380$, $423,489,494,577,638$ c; B 308 ; C 15 
Vegetation, hot springs in relation to $\ldots \ldots \ldots \ldots \ldots \ldots \ldots \ldots \ldots \ldots . . .9$ d quality of ground water in relation to ............W 343, 423, 577 sulfuraria in ground water $\ldots \ldots \ldots \ldots \ldots \ldots \ldots \ldots \ldots \ldots \ldots \ldots \ldots \ldots \ldots$ W 338 water table in relation to..........W 320, 343, 423,489, $4^{\wedge} 4,577$; C 15 zones of ground water in relation to ............... 320, 577

Veins, artesian water in .................................. 319

Velocity of ground water. See Movements of ground water; Underflow measurements.

Vermont, areas, all of State ..................... 102, 114 areas, Taconic quadrangle $\ldots \ldots \ldots \ldots \ldots \ldots \ldots \ldots \ldots \ldots \ldots \ldots$ W 110

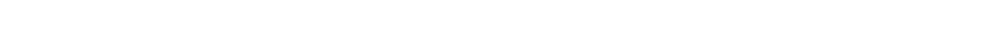

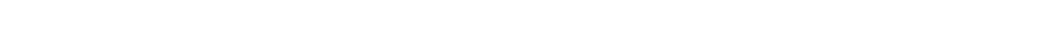
bibliography of ground water in ...............W 114, 120, 163 mineral waters in ..................W 114; B 32; In $1883-1923$ public water supplies in ..................... 102, 114 quality of ground water in $\ldots \ldots \ldots \ldots \ldots \ldots \ldots \ldots$ W 102, 114, 144; B 32 springs in $\ldots \ldots \ldots \ldots \ldots \ldots \ldots \ldots \ldots \ldots \ldots \ldots$ 102, 114; A 14 II b; B 32

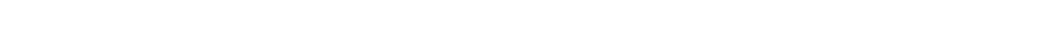
well records for $\ldots \ldots \ldots \ldots \ldots \ldots \ldots \ldots \ldots \ldots \ldots \ldots$. W 102, 110, 149; B 298

Vertical drainage. See Drainage into wells.

Vesicles in rocks, artesian water in................. 319; C 92 Vicksburg group, water in, in Florida .........W 319; C 51, 52, 53, 54 water in, in Georgia .......................W 341; C 81

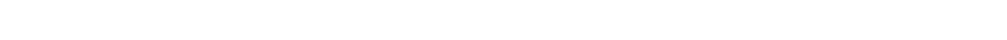

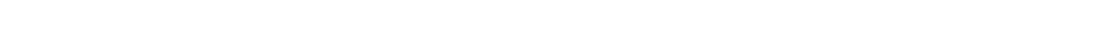
areas, Arlington County ...................... 7 Coastal Plain ......B 138; C 431, 437, 439, 440, 441, 442; J 197, 235

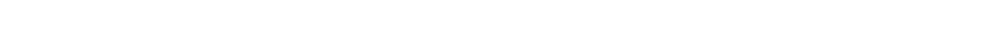
Fall Zone $\ldots \ldots \ldots \ldots \ldots \ldots \ldots \ldots \ldots \ldots \ldots \ldots \ldots \ldots \ldots \ldots \ldots \ldots$

Franklin .................................... 250

Fredericksburg quadrangle $\ldots \ldots \ldots \ldots \ldots \ldots \ldots \ldots \ldots \ldots$. 13

Great Valley ............................. 432

Isle of Wight County ......................... 97

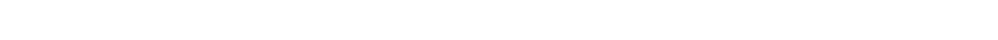

Nomini quadrangle $\ldots \ldots \ldots \ldots \ldots \ldots \ldots \ldots \ldots \ldots \ldots \ldots \ldots$ GF 23

Norfolk area $\ldots \ldots \ldots \ldots \ldots \ldots \ldots \ldots \ldots \ldots \ldots \ldots \ldots \ldots$. 438

Norfolk quadrangle $\ldots \ldots \ldots \ldots \ldots \ldots \ldots \ldots \ldots \ldots \ldots \ldots \ldots$. 6 . 80 northern $\ldots \ldots \ldots \ldots \ldots \ldots \ldots \ldots \ldots \ldots \ldots \ldots \ldots \ldots \ldots$ C 434, 436

St. Marys quadrangle ........................FF 136

Shenandoah County ..........................W 596 c

Sheriandoah Valley ........................ 435

Southampton County $\ldots \ldots \ldots \ldots \ldots \ldots \ldots \ldots \ldots \ldots \ldots \ldots$

southeastern ....................... 442; J 332

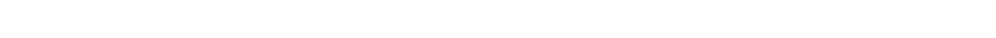

Washington quadrangle $\ldots \ldots \ldots \ldots \ldots \ldots \ldots \ldots \ldots \ldots \ldots \ldots$ GF 70

Woodstock area ........................W 596 c artesian water in....W 596 c; B 138; GF 23, 70, 80; C 431. 437, 438, 440;

D 97; J 1, 197, 295

bibliography of ground water in. ..........W 61, 114,120,149, 163 industrial use of ground water in $\ldots \ldots \ldots \ldots \ldots \ldots \ldots \ldots \ldots \ldots$ J 322 infiltration tunnels in ......................... 431 mineral waters in .................. 32; MR 1883-1923; C 431 
Virginia, public water supplies in .......GF 80; C 431, 435, 436; D 7; J 322 quality of ground water in....W 258, 364, $596 \mathrm{c}$; B 32; GF 80; C 431, 432, 433, 435, 436, 437, 438, 439, 440, 442; D 97; J 68, 197, 295 quantity of ground water in .................... 439,442 salt water in .................W 258; B 669, C 431, 43c . 440; D 151 spring discharge measurements in...W $643,661,663,682,6 \bumpeq 9,697,712$, $713,726,727,742,757,782,802,822,852,872,892,952,972$ springs in ...W 114, 364, $596 \mathrm{c}, 679$ b; A 14 II b; B $32 ;$ C 431, 432, 433, $435 ; \mathrm{J} 68$

thermal W 364,679 b; C 432, 433; J 68 water levels in $\ldots \ldots \ldots \ldots \ldots$ W $777,817,840,845,886,907,937,945,987$ water table in....W 820; C 431, 442; D 22, 29, 37, 42, 107, 121, 130, 152, $190 ; \mathrm{J} 87$ well records for. $W$ W $61,114,149,258,596$ c; B 138, 298, 596 c. 669; GF 70, $80 ; \mathrm{C} 431,435,436,438,439,441,442 ; \mathrm{J} 1$

wells in, construction and cost of .................. 431 yield of $\ldots \ldots \ldots \ldots \ldots \ldots \ldots \ldots \ldots \ldots \ldots \ldots \ldots \ldots \ldots .6438,439$ Viscosity of water, coefficient of $\ldots \ldots \ldots$ W 67, 494, 887; A 19 II b; D 84, 182 Vitruvius, on origin of ground water .................. 14 in b Voedisch, F. W., Water levels and artesian pressure in the United States

W 840,$845 ; 886$

Volcanic rocks See Lava.

Volcanism, quality of ground water in relation to ....... $330,491,616$ thermal springs in relation to .............W 181; B 330, 491, 616

Von Hein, G. H., Water levels and artesian pressure in the Unitid States

W 886, 938

\section{W}

Waite, H. A., Decline in ground-water levels in Scott County, K₹ns ....J 243 Geology and ground-water resources of Ford County, Kans.......C 153 Geology and ground-water resources of Scotts Bluff County, ITebr ..W 943 Ground water in Keith County, Nebr ..................W 848 Ground water in the Republican River Basin in Nebraska . .C 202, 203, 204 Ground water in the San Luis Valley, Colo ............... 32 Ground water in the Scott district, Kans................ 142 Ground water in the southern High Plains ............... 66 Ground water level survey in Nebraska ................. 201 Ground-water resources of Scotts Bluff County, Nebr. ........D 163 Ground-water resources of the Arkansas Valley in Ford Co'unty, Kans.

D 111

Ground water supplies in Kansas available for national defense....C 151 Occurrence of ground water in Ford County, Kans........... 142 Water levels and artesian pressure in the United States....W 845, 886, $908,938,946,988$

Wall Creek sandstone, water in, in Wyoming.......B 471 a, 670, 756, $806 \mathrm{~d}$

Wallace, D. S., Surface water supply of the United States...W 757, 782, 802, $822,852,872,892, \mathrm{n} 52,972 ; \mathrm{C} 62$

Waring, G. A., Features of the geology of northeastern Brazil.......J 285 Geology and its relation to ground-water supplies in Grornd-water resources of the Santa Cruz Basin, Ariz................ 20 Geology and water resources of a portion of south-central 0 "egon . W 220 
Waring, G. A., Geology and water resources of a portion of south-

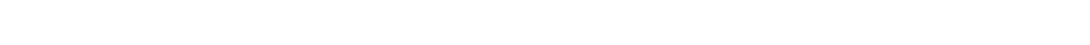
Geology and water resources of the Harney basin region, Oreg ....W 231 Geology of the Anthracite Ridge coal district, Alaska ........... 861 Geology of the island of Trinidad, British West Indies...........J 286 Ground water in Pahrump, Mesquite, and Ivanpah Valleys, Nev. and Calif.

W 450 c

Ground water in Reese River Valley and adjacent areas, Nev...W 425 d Ground water in San Jacinto and Temecula basins, Calif ........W 429 Ground water in the Meriden area, Conn ...............W 449 Ground water resources of Mississippi ...............W 576 Ground water resources of northwestern New Mexico ........... 68

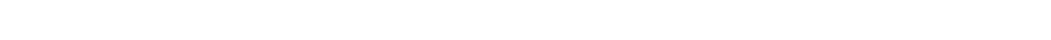
Mineral springs of Alaska ....................... 418

Reef formations of the northeast coast of Brazil ............J 284

Springs of California ......................... 338

Suporimento d'agua no nordeste do Brasil ...............J 283 Thermal springs in the United States ...............W 679 b Two thermal springs in Idaho and Oregon ................. 147 Water supplies from wells in southeastern Utah and southwertern

Colorado ................................... 71

Wells on the public range $\ldots \ldots \ldots \ldots \ldots \ldots \ldots \ldots \ldots \ldots \ldots \ldots$ J 200 Warm springs. See Springs, thermal.

Warren, M. A., Artesian water in southeastern Georgia .......... 83, 84

Artesian water in the coastal area of Georgia ............ 129, 134

Artesian water in the coastal area of Georgia and northeast Florida J 248

Artesian water in the coastal area of Georgia with special reference

to salt-water encroachment in the Savannah area .......... 151

Perennial yield of artesian water in coastal area of Georgia and

northeastern Florida .........................J 353

Water levels and artesian pressure in the United States. . W 845, 886, 907, 937, 945, 987

Warsaw formation, water in, in Missouri ................ 195

Wasatch formation, water in, in Montana ................. 856

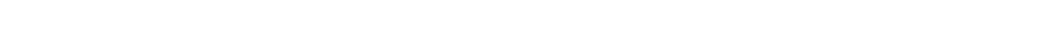

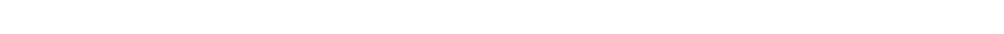

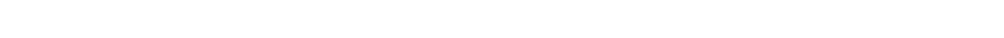

Washburne, C. W., Chlorides in field waters ................... 15

Washing down test pipe ............................ 141

Washington, H. S., Composition of the earth's crust ...........P 127

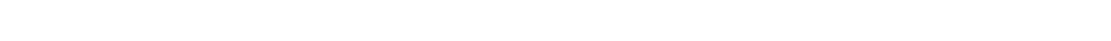

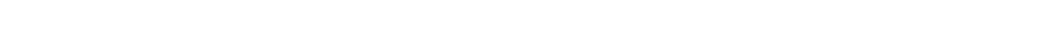

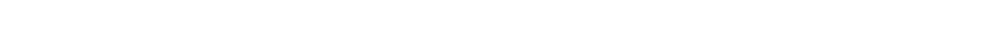

central $: \ldots \ldots \ldots \ldots \ldots \ldots \ldots \ldots \ldots \ldots \ldots \ldots \ldots \ldots$ W 425 e; B 108

Columbia River Basin $\ldots \ldots \ldots \ldots \ldots \ldots \ldots \ldots \ldots \ldots \ldots$ C 446

Columbia River Plains $\ldots \ldots \ldots \ldots \ldots \ldots \ldots \ldots \ldots \ldots \ldots \ldots$ W 316

east-central .............................. 118

Ellensburg quadrangle $\ldots \ldots \ldots \ldots \ldots \ldots \ldots \ldots \ldots \ldots \ldots \ldots$ GF 86

Grant County ............................. 425 e

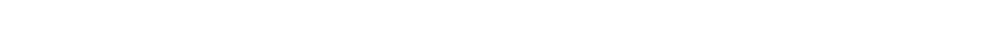

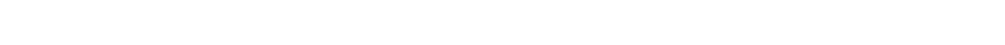

Mount Stuart quadrangle .....................F 106 
Washington, areas, Quincy Valley $\ldots \ldots \ldots \ldots \ldots \ldots \ldots \ldots \ldots \ldots \ldots$ W 425 e

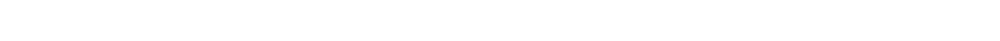

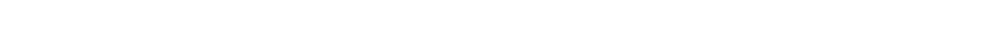

southeastern ..................................W 4

Spokane Valley ......................W 889 b; D 102, 118

Sunnyside Valley ................................W 316

Walla Walla basin ................................ 44

Walla Walla County $\ldots \ldots \ldots \ldots \ldots \ldots \ldots \ldots \ldots \ldots \ldots \ldots \ldots \ldots \ldots \ldots$ B 298

Yakima and vicinity $\ldots \ldots \ldots \ldots \ldots \ldots \ldots \ldots \ldots \ldots \ldots \ldots \ldots \ldots \ldots \ldots \ldots, 75$ artésian water in ...........W 4, 55, 75, 118, 316; B 108; GF 86, 106 bibliography of ground water in....................W 120, 163 irrigation with artesian water in......................W 55

with other ground water in ...........W 55, 316, 425 e; A 16 II e laws relating to ground water in..............W 55, 78, 122, 152 mineral waters in $\ldots \ldots \ldots \ldots \ldots \ldots \ldots \ldots \ldots \ldots . . .632$; MR 1883-1923 public water supplies $\ldots \ldots \ldots \ldots \ldots \ldots \ldots \ldots \ldots \ldots \ldots$ W 111; D 102 pumping in ...................................... $425 \mathrm{e}$ quality of ground water in $\ldots \ldots \ldots \ldots \ldots \ldots$ W 111, 364, 425 e; B 32; C 446 quantity of ground water in.......................... 425 e spring discharge measurements in...W 332, 362, 394, 632, 634, 834, 864, $882,884,902,904,964,984$ springs in .....W 111, 118, 294, 316, 425 \&, 557, 679 b; A 14 II b; B 32; GF 86, 106; C 446

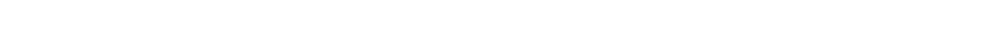

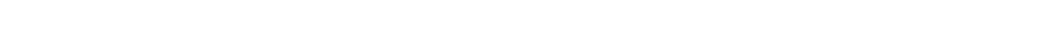
temperature of artesian water in.. $\ldots \ldots \ldots \ldots \ldots \ldots \ldots \ldots \ldots \ldots \ldots$ W 55 water levels in $\ldots \ldots \ldots \ldots \ldots W$ W 777, 817, 840, 845, 886, 910, 940, 948, 990 water table in ................W 316, 425 e, 889 b; D 44.74, 118 well records for W 55, 61, 111, 118, 149, 316; B 264, 298; GF 86, 106; C 446 wells in, construction of ..........................W 118

Washington limestone, water in, in Pennsylvania ................GF 121

Washita formation, water in, in Texas $\ldots \ldots \ldots \ldots \ldots \ldots \ldots \ldots \ldots$ W 276

Waste-filled basins. See Debris-filled basins.

Waste of ground water. See Conservation.

Water-bearing material, effective size of $\ldots \ldots \ldots \ldots \ldots . W 67,140,596 \mathrm{f} ; \mathrm{P} 44$ uniformity coefficient of granular materials in.........W 59 i f; P 44

Water finders .......................W 416; MR $1882 \mathrm{k} ; \mathrm{J} 324$ Water level, instruments for measuring....D 127, 139; 142, 153, 155, 188, 194;

Water levels. See specific States.

Water rights. See Law relating to ground water.

Water spreading in California

Water-stage recorders used in wells..W 155; A 19 il b; D 127, 139, 142, 188 Water supplies. See Irrigation; Public water supplies. ..

Water table, definition of $\ldots \ldots \ldots \ldots \ldots \ldots \ldots \ldots \ldots \dot{W} 67,489,494,836 \mathrm{~d}$ fluctuations of ..W 10, 12, 18, 29, 30,58, 67, 137, 138, 139, 142, 153, 155, $164,213,219,232,251,256,258,294,319,320,331,343,345 \mathrm{~g}, \mathrm{~h}, 375$ a, 400 e, 423, 446, 489, 495, 597 b, 619, 637 b, 680, 774, 818; A $19 \mathrm{rr} \mathrm{b}, 21 \mathrm{rv}$ a, M 47; P 44; GF 120, 193; C 15, 16, 21, 92, 98, 99, 431, 451; D 27; J 338 air in soil in relation to ........................ 19 II $\mathbf{b}$ barometric pressure in relation to.......W $155,258,638 \mathrm{c}, 836 \mathrm{~d}$; A 19 II b; M 47; P 44 
Water table, fluctuations of, capillarity in relation to $\ldots \ldots \ldots \ldots \ldots$ W 155 causes of ....................W 155, $5971.836 \mathrm{~d} ; \mathrm{M} 47$ dams in relation to $\ldots \ldots \ldots \ldots \ldots \ldots \ldots \ldots \ldots \ldots$ 155, 597 a; P 44

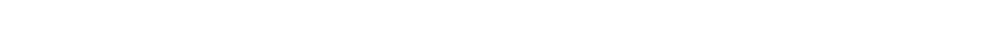
denudation and valley filling in relation to $\ldots \ldots \ldots \ldots \ldots \ldots . \ldots . \ldots$ discharge of ground water in relation to...W 155, 294, $597 \mathrm{~b}, 638 \mathrm{c}$ earthquakes causing ...............W 619; C 92; J 218, 237 evaporation in relation to .........W 294, 423, $597 \mathrm{~b} ; \mathrm{C} 15 ; \mathrm{J} 240$ human agencies in relation to ..............W 155; M 47 irrigation in relation to........W 142, 155, 219, 345 $\mathrm{h}, 774 ; \mathrm{C} 15$ precipitation in relation to $\ldots \ldots W$ W $137,138,139,142,219,345 \mathrm{~h}, 375$ a, 400 e, 597 b, 911, 941; A 19 r b; P 44; C 15 principles of ....W 155; B 529; D 59, 73, 96; J 10, 57, 112, 123, 133, 144, $149,157,158,160,162,186,199238,239,268$ pumping in relation to $W 142,155,219,345 \mathrm{~h}, 911,941 ; \mathrm{P} 44 ; \mathrm{C} 14 ; \mathrm{J} 168$ quantity of ground water indicated by......W $345 \mathrm{~h}, 400 \mathrm{e}, 597 \mathrm{~b}, 638 \mathrm{c}$ railroad trains in relation to ............W 155, 619, $638 \mathrm{c} ; \mathrm{J} 207$ streams in relation to ................W 155, $597 \mathrm{~b}, 849 \mathrm{~b}$; C 15 temperature in relation to ................W 155; M 47; P 44 tides in relation to ....W 155, 232, $836 \mathrm{~d} ; \mathrm{P} 44$; GF 193; C 92, 99; J 209 uplift and subsidence in relation to ................... 47 perched $\ldots \ldots \ldots \ldots \ldots$ W 164, 233, 258, 320, 335, 494, 616; P 44, 46; C 431 relation of, artesian head to ...........W 256, 293, 494 ; A 5 c; C 451 discharge of ground water to..W 155, 294, 320, 423, $597 \mathrm{~b}, 638 \mathrm{a} ; \mathrm{C} 22$

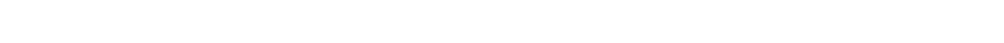
oil and gas to $\ldots \ldots \ldots \ldots \ldots \ldots \ldots \ldots \ldots \ldots \ldots \ldots \ldots . \ldots \ldots$ B 658 . J 337 ore deposits to ...M 47; P $68,80,94,96,97,107,111,115,122,139$, $148,169,177$; B 529, 625, 677, 681, $710 \mathrm{~b}, \mathrm{~d}, 715 \mathrm{l}, 718,725 \mathrm{c}, 735 \mathrm{e}$, 750 b, 762, 782, 787, 814, 842,846 a, 847 a, $849 \mathrm{~g}, 853,870,877$, $879,884,885,902,922 \mathrm{~g}$; GF 112, 120, 129 .

sulfide to ............................ 529,625 topography to ...............W 67, 159, 254.374; A 19 II b vegetation to $\ldots \ldots \ldots \ldots \ldots \ldots \ldots \ldots \ldots \ldots W 294,320,343,423,577,638$ c shape of $\ldots \ldots \ldots \ldots \ldots \ldots \ldots \ldots \ldots \ldots \ldots \ldots \ldots$ 67, 494; $\mathbf{A} 19$ n b Water wheels for lifting water $\ldots \ldots \ldots \ldots \ldots \ldots \ldots \ldots \ldots \ldots \ldots \ldots \ldots, 4,13,29$ Water witching ............W 255, 278, 416; P 128 d; MJ 1882 a; J 222 Watering places on routes of travel-

Arizona $\ldots \ldots \ldots \ldots \ldots \ldots \ldots \ldots \ldots \ldots \ldots \ldots W$ 380, $490 \mathrm{c}, \mathrm{d}, 498,499$; B 352 California $\ldots \ldots \ldots \ldots \ldots \ldots \ldots \ldots \ldots \ldots \ldots \ldots \ldots \ldots$ W 2424,$497 ;$ B 308 Nevada ...........................W 224, 365; B 308 New Mexico ..............................W 343, 380

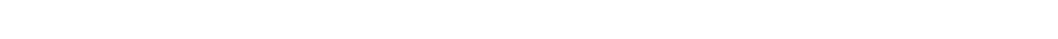

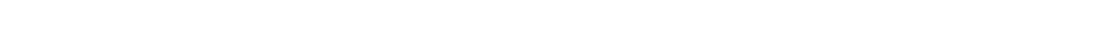

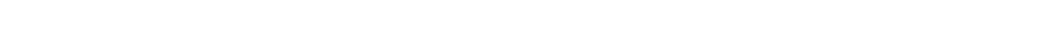

Waynesburg sandstone, water in, in Pennsylvania .............. 121 Weather effects of, on wells. See Water table; Wells.

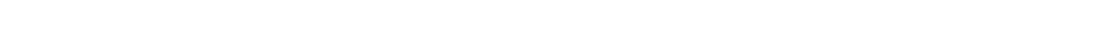
Weathering produced by ground water $\ldots \ldots \ldots \ldots \ldots \ldots \ldots \ldots$ M 47; P 96 Weed, W. H., Fort Benton folio, Mont .................GF 55

Geology and ore deposits of the Butte district, Mont...........P 74 
Weed, W. $\dot{H}$., Hot springs of southern United States ...........W 145 Little Belt Mountains folio, Mont $\ldots \ldots \ldots \ldots \ldots \ldots \ldots \ldots \ldots \ldots$ GF 56

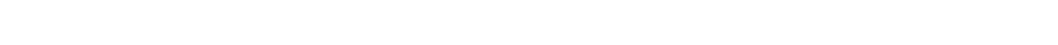
Weeks, F. D., Underground waters of New York ..............W 114 Well and spring records for New York .................W 102

Wegemann, C. H., Geology of Big Horn County and the Crow Intian

Reservation, Mont .................................. 856 Oil and gas in Palo Pinto County, Tex .................. 621 e Powder River oil field, Wyo ......................... 471 a Pumpkin Buttes coal field, Wyo ...................... B 806 a Salt Creek oil field, Wyo ........................... B 670 Weidman, Samuel, Water supplies of Wisconsin ................. 451

Weirs, coefficients, formulas, and tables relating to $\ldots \ldots \ldots \ldots \ldots$ W 150, 200

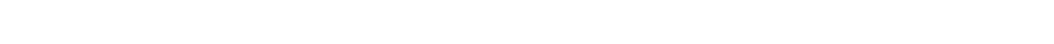

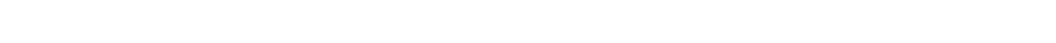

Welitschkowsky, D., on flow of water and air through soils........A 19 in b Well casings ................................W 145; J 64, 105

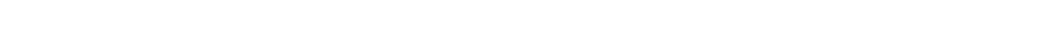

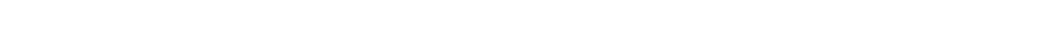

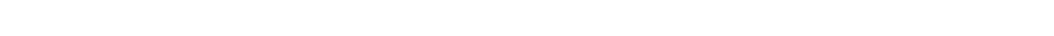

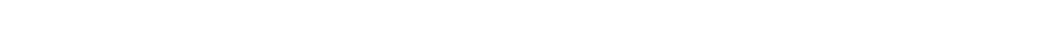
effect of mineralized water on $\ldots \ldots \ldots \ldots \ldots \ldots \ldots \ldots \ldots$ W 293; C 21

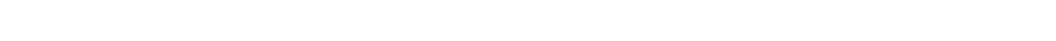
methods of inserting $\ldots \ldots \ldots \ldots \ldots \ldots \ldots \ldots \ldots \ldots \ldots$ W 223, 257, 293 perforation of $\ldots \ldots \ldots \ldots \ldots \ldots \ldots \ldots \ldots \ldots \ldots \ldots \ldots \ldots \ldots \ldots \ldots \ldots, 110,257$

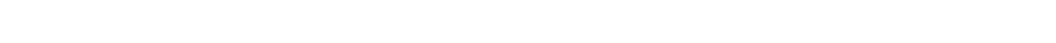

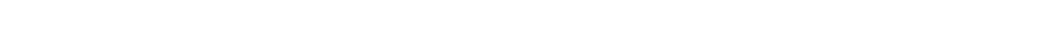
stovepipe $\ldots \ldots \ldots \ldots \ldots \ldots \ldots \ldots \ldots \ldots$ W 110, 140, 255, 257, 446, 495, 498

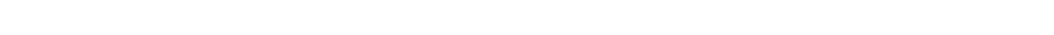
types of $\ldots \ldots \ldots \ldots \ldots \ldots \ldots \ldots \ldots \ldots \ldots \ldots \ldots \ldots \ldots \ldots \ldots \ldots \ldots \ldots \ldots, 233,255,257,494$ uses of $\ldots \ldots \ldots \ldots \ldots \ldots \ldots \ldots \ldots \ldots \ldots \ldots \ldots \ldots \ldots \ldots \ldots \ldots \ldots \ldots \ldots \ldots \ldots \ldots, 223,257,293$

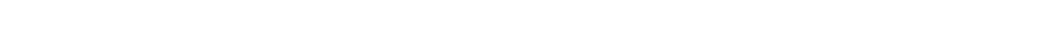

Well construction, accidents in .....................W 257, 293 artesian .W 118, 227, 257; A 5 c, $17 \mathrm{~m} \mathrm{~g}$; C 451 augers for $\ldots \ldots \ldots \ldots \ldots \ldots \ldots \ldots W$ W $231,257,375 \mathrm{a}, 495 ; \mathrm{P} 46$; D 126

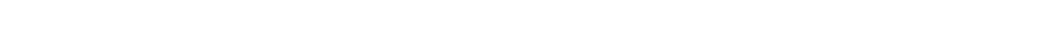
California method of.........W 110, 140, 220, 231, 255, 257, 446, 467, 495,$498 ; \mathrm{J} 92$

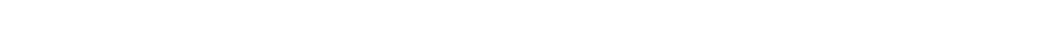

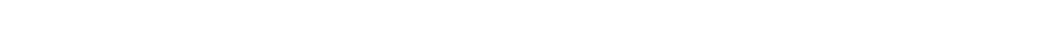

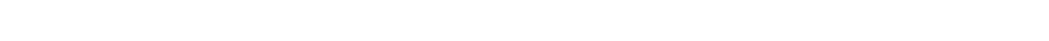
churn drills for $\ldots \ldots \ldots \ldots \ldots \ldots \ldots \ldots \ldots \ldots \ldots \ldots \ldots$ W 232, 257

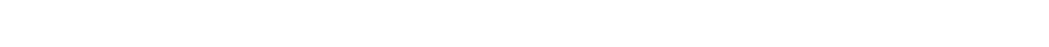

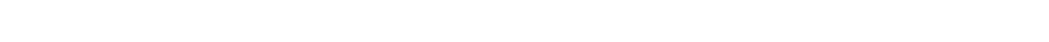
crooked holes in $\ldots \ldots \ldots \ldots \ldots \ldots \ldots \ldots \ldots \ldots \ldots \ldots \ldots$ W 256, 257, 293 deepedrilling methods of $\ldots \ldots \ldots \ldots \ldots \ldots \ldots \ldots \ldots \ldots \ldots$ W 257, 293 detecting flows in .............................. $118, \ldots$ c diamond drills for $\ldots \ldots \ldots \ldots \ldots \ldots \ldots \ldots \ldots \ldots \ldots$ W 146, 255, 257

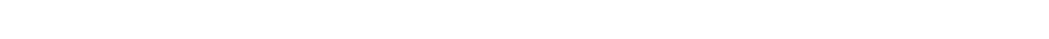

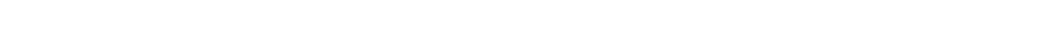

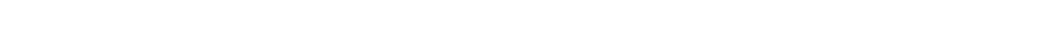
driving method of..W 140, 145, 232, 254, 255, 257; A 19 In k; P 46; C 431 
Well construction, explosives used in $\ldots \ldots \ldots \ldots \ldots \ldots \ldots W$ 22.3, 255, 257 finishing methods of $\ldots \ldots \ldots \ldots \ldots \ldots \ldots$ 255, 256, 293, 343, $597 \mathrm{c}$; P 46 fishing tools for ............................. 77 gravel screens developed in ........W 255, 256, 293, 343, $345 \mathrm{~g}, 597 \mathrm{c}$

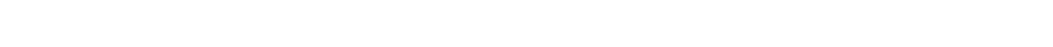

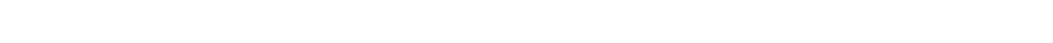
hydraulic method of $\ldots \ldots \ldots \ldots \ldots \ldots \ldots \ldots \ldots$ 255, 256, 257; P $90 \mathrm{~h}$ jetting method of.......W 101, 164, 231, 254, 255, 256, 257; P 46; C 431 methods of $\ldots \ldots \ldots \ldots \ldots \ldots \ldots W 257$; D $43 ; \mathrm{J} 67,70,71,78,105,184,306$ oil well, to exclude water from $\ldots \ldots \ldots \ldots \ldots \ldots \ldots \ldots \ldots \ldots \ldots$ B 658 oil well rigs used in $\ldots \ldots \ldots \ldots \ldots \ldots \ldots \ldots \ldots \ldots \ldots \ldots$ W 257; B 282

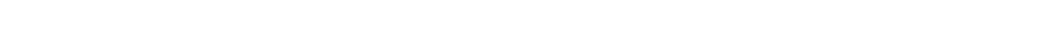
packers used in .............W $54,118,160,257,293$; A 5 c; C 451 percussion drills for $\ldots \ldots \ldots \ldots \ldots \ldots \ldots \ldots \ldots \ldots \ldots \ldots \ldots$. 257; C 431

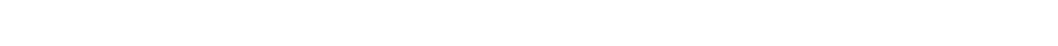

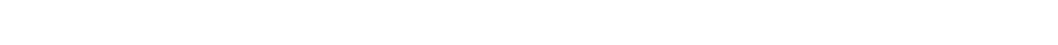

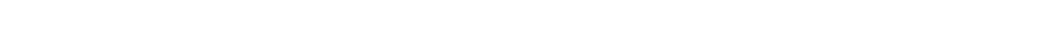
quicksand interfering with $\ldots \ldots \ldots \ldots \ldots \ldots \ldots \ldots$ w 30, 257, $375 \mathrm{~d}, 423$ rotary drills for ............W 101, 232, 255, 257; P 46, $90 \mathrm{~h}$; C 431

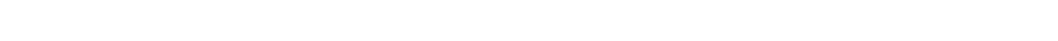
sand pumping in connection with...W 231, 256, 258, 293, 343, 597 c; P 46 seed-bag packers used in ..................W 54, 118; A 5 c specifications for $\ldots \ldots \ldots \ldots \ldots \ldots \ldots \ldots \ldots \ldots . \ldots \ldots 9 . \ldots \ldots, 71,78,184,233$ ständard drills for $\ldots \ldots \ldots \ldots \ldots \ldots \ldots \ldots \ldots \ldots \ldots \ldots \ldots \ldots$ 255, 257

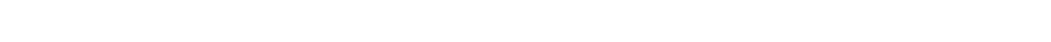
stove-pipe method of $\ldots \ldots \ldots \ldots \ldots \ldots \ldots \ldots$ W 110, 140, 220, $231,255,257$

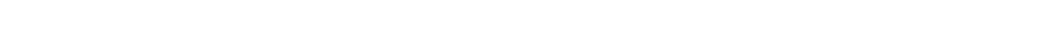
See also specific States.

Well data, symbols for, on maps ...................... 160 Well discharge, dome method of measuring ..W 67, 110, 157, 219, 240; D 195 Well drilling. See Well construction.

Well drillings, fossils in $\ldots \ldots \ldots \ldots \ldots \ldots \ldots \ldots \ldots \ldots \ldots$ W 293,$489 ; \mathrm{P} 90 \mathrm{~h}$ interpretation of $\ldots \ldots \ldots \ldots \ldots \ldots \ldots \ldots \ldots$ W 293, 489; P $90 \mathrm{~h} ; \mathrm{C} 451$ methods of collecting ............W 489; P $90 \mathrm{~h} ; \mathrm{B} 264,298 ;$ C 451 methods of examining ..................W 293, 489; P $90 \mathrm{~h}$

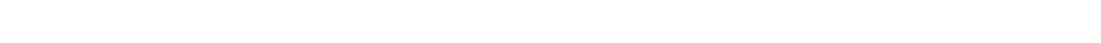
Well packers .................W 54, 118, 160, 257, 293; A 5 c; C 451 Well records, correlation by means of $\ldots \ldots \ldots \ldots \ldots \ldots \ldots \ldots$ W 293; P $90 \mathrm{~h}$ forecasting ground water by means of $\ldots \ldots \ldots \ldots \ldots \ldots \ldots \ldots \ldots$ W 293

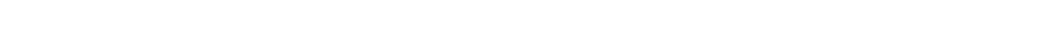
methods of making and obtaining ...W 293; B 264; D 60, 153; J 186, 269 preservation of $\ldots \ldots \ldots \ldots \ldots \ldots \ldots \ldots \ldots \ldots \ldots \ldots \ldots \ldots \ldots \ldots \ldots \ldots, 256$ See also specific States.

Well screens, construction of $\ldots \ldots \ldots \ldots \ldots \ldots \ldots \ldots \ldots \ldots \ldots$ 101, 597 c

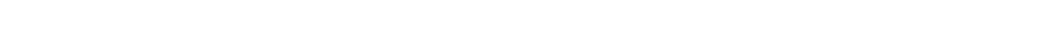
gravel ..............W 255, 256, 293, 343, 345 a, g, 375 a, 597 c

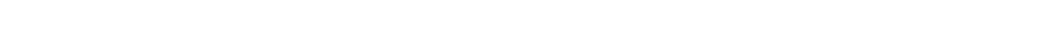

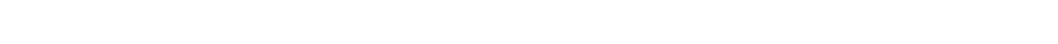

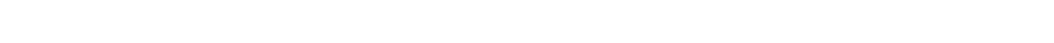
natural .....................W 256, 293, 343, $345 \mathrm{~g}, 375$ a

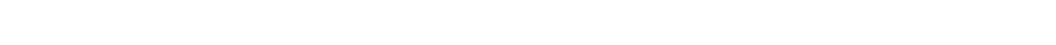


Well screens, sand points as W 145 types of W 71, 255, 257, ₹75 a; P 46

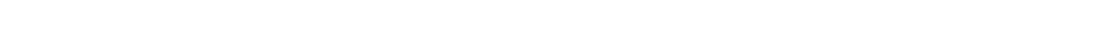

Wells, F. G., Artesian water supply of Memphis and other parts of

western Tennessee .................................. 25

Artesian water supply of Memphis, Tenn ...WW 638 a; C 372; D 14; J 65 Geologic studies on Long Island with respect to ground-water supplies

Geology and ore deposits of the southwestern Arkansas quicksilver district .................................... $886 \mathbf{c}$ Ground-water resources of western Tennessee .............W 656 Investigation of ground-water resources of Long Island, N. Y......D 41

Wells, R. C., Evaporation and concentration of water associated with petroleum and natural gas ............................ B 693 Evaporation of water at depth by natural gases ..............J 17 Sodium sulfate, its sources and uses.................... 717 Wells, barometric effects on....W 29, 155, 195, 215, 216, 256, 258, 317, $836 \mathrm{~d}$; A 19 II b; M 47; P 44; B 19, 319; GF 156; C 92 barometric effects on, bibliography of $\ldots \ldots \ldots \ldots \ldots \ldots \ldots \ldots \ldots$ W 155 blowing, in -

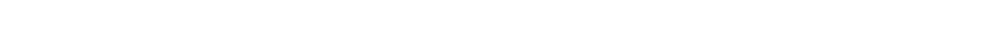

Arkansas ........................................ 258

Colorado ...................................... 16 In f

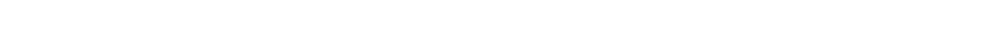

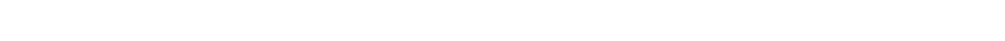

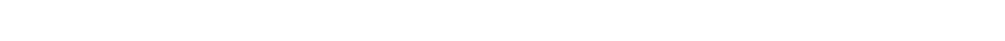
Kansas .................................... 16 it f Louisiana $\ldots \ldots \ldots \ldots \ldots \ldots \ldots \ldots \ldots \ldots \ldots \ldots \ldots$ W 101, 258 Michigan ...........................W 30, 258; GF 205 Minnesota ................................. 256, 258

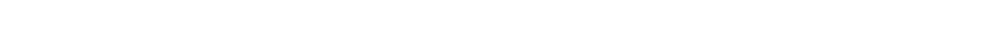
Missouri .................................. 195, 258 Nebraska .....................W 29, 215, 216, 2E8; A 16 II f New York .............................. $\nabla^{\top} 258 ; \mathbf{P} 44$

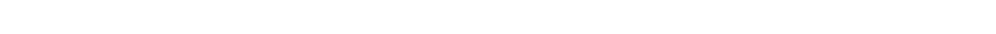

South Carolina ..................................W 258

Texas .......................................W 258

Washington $\ldots \ldots \ldots \ldots \ldots \ldots \ldots \ldots \ldots \ldots \ldots \ldots \ldots \ldots \ldots \ldots \ldots \ldots, 258,316$

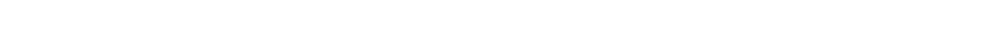

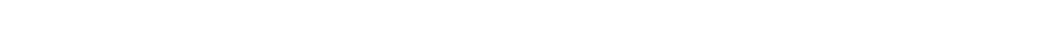
chlorination of $\ldots \ldots \ldots \ldots \ldots \ldots \ldots \ldots \ldots \mathrm{D} 43 ; \mathrm{J} 64,7 \theta, 71,78,105,184$

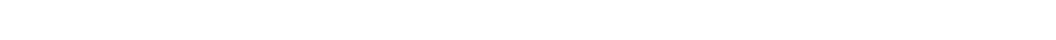

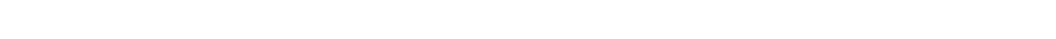
to develop gravel screens ..............W 256, 293, ₹43, 345 a, g

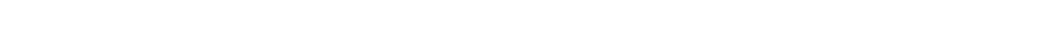

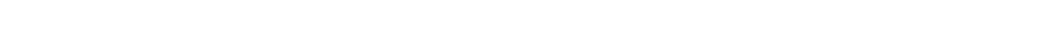

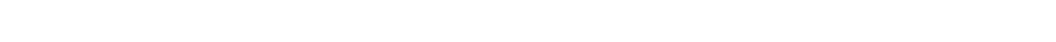
construction of. See Well construction.

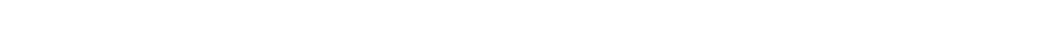

drilled by jetting process $\ldots \ldots \ldots \ldots \ldots \ldots \ldots \ldots \ldots \ldots, 255,277$ 
Wells, cost of, drilled in crystalline rocks $\ldots \ldots \ldots \ldots \ldots \ldots \ldots \ldots$ 160, 258

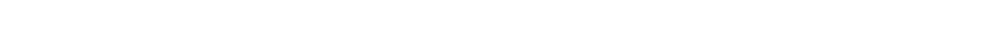
See also specific States.

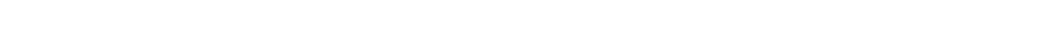
list of $\ldots \ldots \ldots \ldots \ldots \ldots \ldots \ldots \ldots \ldots \ldots \ldots \ldots \ldots \ldots \ldots \ldots \ldots \ldots \ldots, 149,257,489$ diameters of, yield and efficiency in relation to ...........W 293 drainage into .........W 145, 160, 256, 258, 293, 774, 818; C 64; J 363 explosives used in $\ldots \ldots \ldots \ldots \ldots \ldots \ldots \ldots \ldots \ldots \ldots \ldots \ldots W$ 293, 255, 257

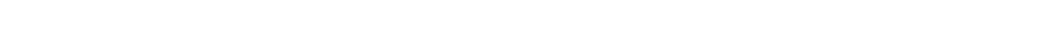
horizontal type of. See Infiltration ditches and tunnels.

improvement of water in ......................... 160 interference of ....W 59, 67, 122, 142, 184, 223; A 19 II b; M 27; GF 97; C 431,$451 ; \mathrm{J} \mathrm{11,} \mathrm{115,} 177$

Lanai-type $\ldots \ldots \ldots \ldots \ldots \ldots \ldots \ldots \ldots \ldots \ldots \ldots \ldots \ldots \ldots \ldots$. 97,98 magnetism in ........................... Maui-type $\ldots \ldots \ldots \ldots \ldots \ldots \ldots \ldots \ldots \ldots \ldots \ldots \ldots \ldots$ C 92, 97, 98, 99; J 165

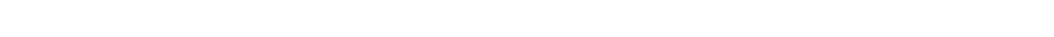
natural, caused by sinkholes ................. 21 Iv c; C 2

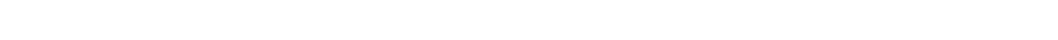
observation $\ldots \ldots \ldots \ldots \ldots \ldots \ldots \ldots \ldots \ldots \ldots \ldots$ 59, 60, 75, 76, 207; J 186 packing of $\ldots \ldots \ldots \ldots \ldots \ldots \ldots \ldots W \cdot 54,118,160,257,293$; A 5 c; C 451 rise of water in, methods of measuring rate of....W $140,155, A 19$ II b

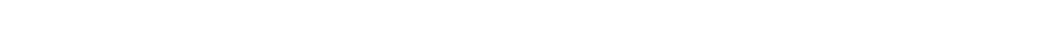
screening of. See Well screens.

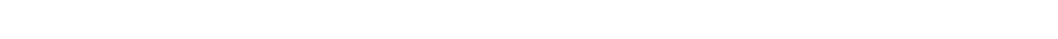
specific capacity of ......W 140,141, 153, 258, $400 \mathrm{~b}, 425$ I. 494, 520 e; P $44 ;$ C $82 ; \mathrm{J} 195$

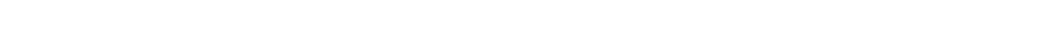
yield of, depth in relation to $\ldots \ldots \ldots \ldots \ldots \ldots \ldots \ldots \ldots \ldots \ldots$ W 160, 232

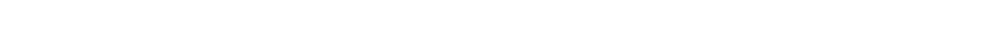

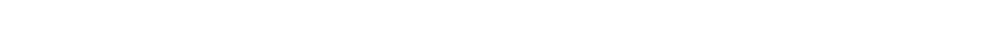
methods for measuring . .....W $67,110,150,157,200,219,240,320$ methods of increasing ................ 255, 257, 343 principles of ........W 67, 140, 293; A $19 \mathrm{II} \mathrm{b;} \mathrm{D} \mathrm{56;} \mathrm{J} \mathrm{24,} \mathrm{195,} 219$ temperature of water in relation to ..........W 215, 256, 258 weather in relation to ...................W 215, 256, 258

See also Artesian water; Artesian wells; Well casings; Well construction;

Well screens; specific States.

Wenzel, L. K., Artesian water conservation in North Dakota has beneficial

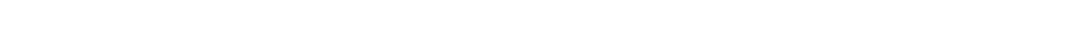

Decline of ground-water level in central Nebraska ............ 58

Durchflussmenge und physikalische Erscheinungen in naturlichen un

Kunstlichen Bodenschichten ....................J 288

Effect of a well on the flow of a nearby stream (discussion) .......J 239 Geology and ground-water resources of Scotts Bluff County, Nebr.. W 943 Geology and ground-water resources of south-central Nebrarka....W 779 Ground water, in Hydrology (Physics of the Earth, IX) ..J 255 (ehap. 10) Ground water as a source of public water supplies ..........J 122 Ground-water conditions in the United States, monthly repcrts on. . D 181 Ground water in Keith County, Nebr .................W 848 Ground-water levels declined in North Dakota in 1938 .......... 109 Ground-water levels in Platte River Valley, Nebr............ 49 
Wenzel, L. K., Ground-water resources of Scotts Bluff County, Nel r. ..D 163

Ground-water resources of south-central Nebr. .............. 64

Local overdevelopment of groundwater supplies, with special reference to Grand Island, Nebr. . . . . . . . . . . . . . . . . . . . 836 e

Method for determining transmissibility and storage-coefficients by tests of multiple well systems ......................... 311

Methods for determining permeability of water-bearing materials .W 887

Notes on salt-water problems ..................... 151

Observation wells, manual of methods $\ldots \ldots \ldots \ldots \ldots \ldots \ldots \ldots$ D 60

Present status of our knowledge regarding the hydraulics of ground water

$\mathrm{J} 236$

Recent investigation of Thiem's method for determining permability of water-bearing materials $\ldots \ldots \ldots \ldots \ldots \ldots \ldots \ldots \ldots \ldots \ldots \ldots . \ldots \ldots$

Recovery of ground-water levels in Nebraska in $1935 \ldots \ldots \ldots \ldots$. . J J 154

Replenishment of underground reservoirs ...............J 320

Salt-water problems and methods of investigation (introductory) ..D 151

Several methods of studying fluctuations of ground-water levels....J 158

Specific yield determined from a. Thiem's pumping test.........J 101

Statewide program of periodic measurements of ground-wat $>$ level

in Nebraska ..................................J 129

Substantial replenishment creates generally favorable outlook for ground-water supplies ......................... 304

Subsurface water in research on agricultural watersheds (discussion) $\mathrm{J} 268$

Thiem method for determining permeability of water-bearing materials

Water levels and artesian pressure in the United States. . W 777, 817, 840 . 845,886

Water levels and artesian pressure in the United States in 1937. . . D 99

Water levels and artesian pressure in the United States, 1940

W 906, 907, 908, 909, 910, 911

Water levels and artesian pressure in the United States, 1941

W 936, 937, 938, ؟39, 940, 941

Water levels and-artesian pressure in the United States, 1942.

W 944, 945, 946, $\ 17,948,949$

Water levels and artesian pressure in the United States, 1943

W 986, 987, 988, 989, 990, 991

Water supply of the Dakota sandstone ................W 889 a

Well discharge, a method of computing the quantity of water derived

from storage $\ldots \ldots \ldots \ldots \ldots \ldots \ldots \ldots \ldots \ldots \ldots \ldots \ldots \ldots \ldots \ldots . \ldots \ldots$

Wesbrook, F. F., Quality of surface waters in Minnesota ........W 193

West Indies, bibliography of ground water in...............W 163 ground water in-

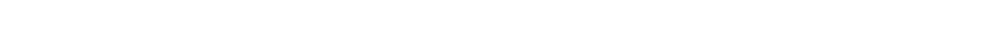

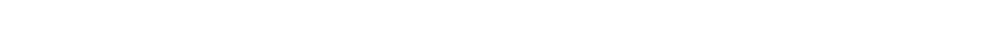

Guantanamo area, Cuba ...................... 287

St. Croix, Virgin Islands ......................... 289

Trinidad, British West Indies ..................... 286

West Virginia, areas, Accident quadrangle ...............GF 160 areas, all of State ..............W 114; C 448; J 251, 256, 356

Cabell County ............................. 298

Flintstone quadrangle $\ldots \ldots \ldots \ldots \ldots \ldots \ldots \ldots \ldots \ldots \ldots \ldots$ W 110

Frostburg quadrangle .......................W 110 
West Virginia, areas, Hancock quadrangle ............W 145; GF 179

Kenova quadrangle ..............................GF 184

Nicholas quadrangle $\ldots \ldots \ldots \ldots \ldots \ldots \ldots \ldots \ldots \ldots \ldots \ldots$ W 145

Ohio River Valley ........................... 449; J 333

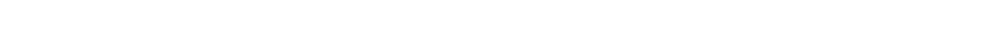

Pawpaw quadrangle $\ldots \ldots \ldots \ldots \ldots \ldots \ldots \ldots \ldots \ldots$ W 145; GF 179

artesian water in ..........................F 160, 179; J 20

bibliographyे of ground water in.............W $61,114,120,149,163$

- ground water for industrial use in....................... 333

mineral waters in ..................W 114; B 32; MR 1883-1923

public water supplies in ..................... 449; J 251, 333

quality of ground water in..W 145, 364; B 32, $530 \mathrm{~b}$; GF 179, 184; C 449;

quantity of ground water in..................... 449; J 357

salt water in ....................... 530 b, 669, 693; GF 184

springs in .......W 114, 145, $679 \mathrm{~b}$; A 14 II b; B 32; GF 160, 179; C 433

thermal ......................W $679 \mathrm{~b}$; G厂 179; C 433

temperature of ground water in ...................... 447

water levels in .............................. 987, 945, 987

water table in ..................................... 356

well records for ...............W 61, 149; B 264, 298, 669; GF 184

Westendick, F. C., Artesian water in the Florida Peninsula..........J 137

Westgate, L. G., Geology and ore deposits of the Pioche district, Nev..P 171

Geology and ore deposits of the Wood River region, Idaho......... B 814

White, D. E., Antimony deposits of the Wildrose Canyon area, Cr.lif.. B 922 k

White, W. F., Jr., Chemical analyses of surface waters of Pennsyl "ania. C 352

Quality of water, Pecos River Basin, N. Mex ............... 398

White, W. N., County reports on ground-water surveys in Texas by Works

Progress Administration ............................. 384

County reports on ground-water surveys in Texas, in cooperation with

Texas State Board of Water Engineers .................. 393

Discharge method of estimating ground-water supplies .........J 48

Exploratory water-well drilling in Houston district, Tex..W 889 e; C 406

Geology and ground-water resources of the Balmorhea area, western

Texas ...................................... $849 \mathrm{c}$

Geology and ground-water resources of the Lufkin area, Tex ....W 849 a

Ground water (in certain parts of Texas) ................. 414

Ground water in Dimmit and Zavala Counties, Tex ............ 51

Ground water in Mimbres Valley, N. Mex.................... 15

Ground water in Texas and principles governing the occurrerse of

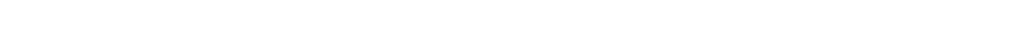

Ground water in Texas, list of published and unpublished reports ..C 410

Ground water in High Plains in Texas. W 889 c; C 391, 395, 397, 405, 411

Ground-water problems in the southern High Plains ...........J 203

Ground-water resources in the vicinity of Vernon, Tex,......... 409

Ground-water resources of the Balmorhea area, Tex............ 390

Ground-water resources of the Houston district, Tex ....W 889 d; C 388, $3 ? 4,396 ; \mathrm{D} 46$

Ground-water resources of the Houston-Galveston area, Tex.......D 39

Ground-water supply of Mimbres Valley, N. Mex..W 67 b; C 238, 243, 246

Investigation in the Escalante Desert, Utah, on discharge method of estimating water supplies $\ldots \ldots \ldots \ldots \ldots \ldots \ldots \ldots \ldots \ldots \ldots, D$ 
White, W. N., Method of estimating ground-water supplies based on discharge by plants and evaporation from soil ..........W 659 a Published reports on Texas ground-water resources ........... 403 Records of wells and springs, county reports, Texas........... 393 Storage, surface and underground ................... 77 Surface run-off control (discussion) $\ldots \ldots \ldots \ldots \ldots \ldots \ldots \ldots \ldots . \ldots \ldots$ J 167 Survey of the underground waters of Texas ............ $382 ;$ D 19 Surveys by Works Progress Administration, county reports on wells .

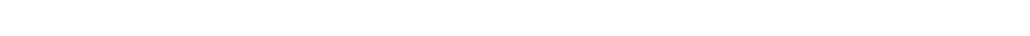
Water levels and artesian pressure in the United States.....W 777, 817 Water resources of the Edwards limestone in the San Antonio area, Tex. W $773 \mathrm{~b}$

White River group, water in, in Nebraska, South Dakota and Wyoming. . P 32 Whitfield, J. E., Analyses of waters of Yellowstone National Park...... 47 Whitney, F. L., Artesian water at Ithaca, N. Y .............W 110

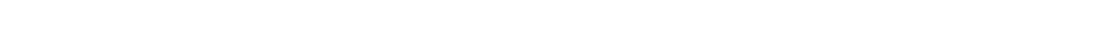
Wicomico formation, water in, in Delaware ................ 137 water in, in Maryland ........................... 137 Wilcox formation, water in-

Arkansas .............................W 39?; B $691 \mathrm{j}$

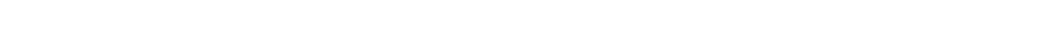
Louisiana ........................W 986 c; C 169; J 331 Mississippi .......................W 159; C 192; J 346 Tennessee ...................W 638 a; C 372, 37í; D 14, 25 Texas ....................W 276, 335; C 399, 417, 412, 417 See also Sabine formation.

Willard, D. E., Casselton-Fargo folio, N. Dak.-Minn...........GF 117

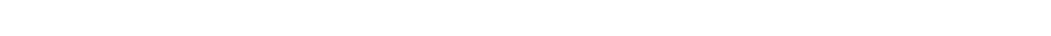

Williams, C. C., Ground-water conditions in the Neosho River Valley, Kans.

Water levels and artesian pressure in the United States........W 938. Williams, E. L., Surface water supply of the United States W 526, 547, 566, 567 Williams, H. S., Eastport folio, Maine ..................GF 192

Watkins Glen-Catatonk folio, N. Y...................FF 169

Willis; Bailey, New York City folio N. Y.-N. J.............GF 83 Wilson, H. M., American irrigation engineering...........A 13 III b

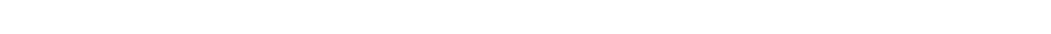
Wilson, W. T., Water levels and artesian pressure in the United St tes

W 845,886

Winchester, D. E., Geology of Alamosa Creek Valley, N. Mex., with special reference to the occurrence of oil and gas................ 716 a Lignite field of northwestern South Dakota................ 627

Winchester limestone, water in, in Kentucky $\ldots \ldots \ldots \ldots \ldots \ldots \ldots \ldots$ W 233

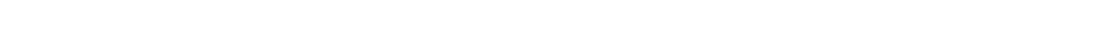

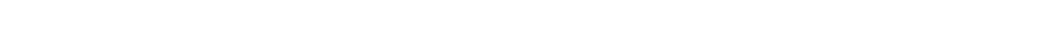

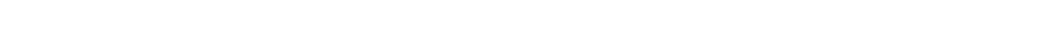

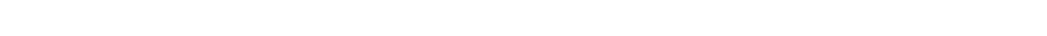

efficiency of $\ldots \ldots \ldots \ldots \ldots \ldots \ldots \ldots \ldots \ldots \ldots \ldots \ldots \ldots \ldots \ldots T^{* 7} 8,41,42$

experiments with $\ldots \ldots \ldots \ldots \ldots \ldots \ldots \ldots \ldots \ldots \ldots \ldots \ldots \ldots \ldots, 20,41,42$

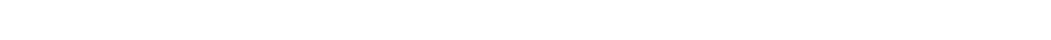

for pumping ...........W 1, 8, 12, 13, 14, 20, 29, 41, 42, 26n, 270, 343;

A 19 IV c, 22 Iv c; P 17; GF 103 
Windmills, testing of $\ldots \ldots \ldots \ldots \ldots \ldots \ldots \ldots \ldots \ldots \ldots \ldots W$ $\varepsilon, \mathbf{2 0}, \mathbf{4 1}, \mathbf{4 2}$ types of $\ldots \ldots \ldots \ldots \ldots \ldots \ldots \ldots \ldots \ldots \ldots \ldots \ldots \ldots W$ 2r. $29, \mathbf{4 1}, \mathbf{4 2}$

Wingate sandstone, water in, in Arizona..................W 836 b Winslow formation, water in, in Oklahoma ...............FF 132154 Wiringa, L. O., Records of wells and water analyses for Caddo and

Bossier Parishes, La ................................. C 168 Wisconsin, areas, all of State $\ldots \ldots \ldots \ldots \ldots \ldots \ldots \ldots \ldots . . .6114 ; C 451$

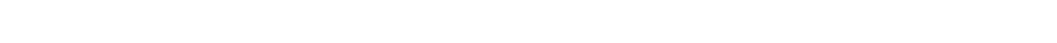

Manitowoc County .............................. 298

Milwaukee quadrangle ................................ 140

Mineral Point quadrangle $\ldots \ldots \ldots \ldots \ldots \ldots \ldots \ldots \ldots$. 145; GF 145 artesian water in $\ldots \ldots \ldots \ldots \ldots \ldots \ldots \ldots \ldots \ldots \ldots$. GF 140, 145; C 451 bibliography of ground water in...........W $61,114,120,149,163$ mineral waters in .........W 114; B 32; MR 1883-1923; GF 140; C 451 public water supplies in .......................GF 140; C 451 quality of ground water in ................ 32; GF 140; C 451 springs in ............W 114, 145; A 14 II b; B 32; GF 140, 145; C 451 water levels in $\ldots \ldots \ldots \ldots \ldots \ldots$ W $777,817,840,845,886,908,938,946,988$

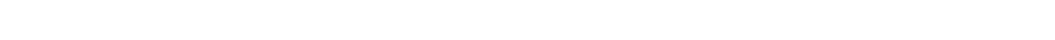
well records for ...............W 61, 149; B 264, 298; GF 140; C 451 wells in, construction of ........................... 451

Wissahickon gneiss, water in, in Delaware ...................GF 223 water in, in Pennsylvania ................W 106; GF 223; C 342

Wolff, H. C., Underflow near St. Francis, Kans. ..............W 258 underflow of South Platte Valley (Colo. and Nebr.) ............W 184

Wolff, J. E., Franklin Furnace folio, N. J...................GF 161

Wollny, E., on flow of water and air through soils ............. 19 in b

Wood, B. D., Publications (of United States Geological Survey) r?lating to

water resources, $1885-1913 \ldots \ldots \ldots \ldots \ldots \ldots \ldots \ldots \ldots \ldots \ldots$ W 340

Woodbine sand, water in, in Arkansas ..................... 808 water in, in Texas ........................ 276; A 21 vir

Woodring, W. P., Geology and oil resources of the Elk Hills, Calif......B 835

Woodruff, E. G., Geology and petroleum resources of the De Beque oil

fields, Colo ..................................... 530 c Woolen mills, quality of water for $\ldots \ldots \ldots \ldots \ldots \ldots \ldots \ldots \ldots \ldots \ldots \ldots \ldots \ldots \ldots$

Woolsey, L. H., Bull Mountain coal. field, Mont ............... 647

Worts, G. F., Jr., Water levels and artesian pressure in the United

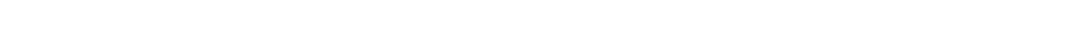
Water levels in observation wells in Santa Barbara County, Calif..C 28 Water wells and water levels in Carpinteria, Goleta, and Santa Ynez

Valley areas, Calif ............................. 30 a

Water wells and water levels in San Antonio, Santa Maria, and

Cuyama Valleys, Calif ............................ 30 b

Wyoming, areas, Aladdin quadrangle $\ldots \ldots \ldots \ldots \ldots \ldots \ldots \ldots \ldots \ldots \ldots \ldots \ldots$ GF 128

areas, Albany County ............................ 806 d

Bald Mountain quadrangle $\ldots \ldots \ldots, \ldots \ldots \ldots \ldots \ldots \ldots$, GF 141

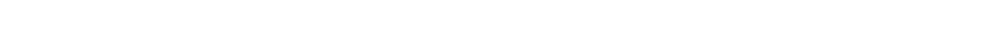

Baxter Basin ........................... 702, 781 b

Bighorn Basin ............................ 53; B 656

Bighorn County .............................. 621 l

Bighorn Mountains $\ldots \ldots \ldots \ldots \ldots \ldots \ldots \ldots \ldots \ldots \ldots \ldots \ldots \ldots$. 51

Black Hills region $\ldots \ldots \ldots \ldots \ldots \ldots \ldots \ldots \ldots \ldots$ A 21 rv b; $\mathbf{P} 65$ 
Wyoming, areas, Carbon County B $796 \mathrm{~d}, 804,806 \mathrm{~d}$ Carpenter area ........................... 456

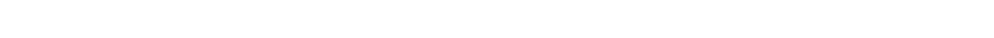
Cheyenne area $\ldots \ldots \ldots \ldots \ldots \ldots \ldots \ldots \ldots \ldots \ldots \ldots \ldots \ldots \ldots$ C 455, 456

Cloud Peak quadrangle $\ldots \ldots \ldots \ldots \ldots \ldots \ldots \ldots \ldots \ldots \ldots$ GF 142

Dayton quadrangle .........................GF 141

Devils Tower quadrangle .......................GF 150 eastern ......................... 21 iv c, 22 iv c; $P 32$ Egbert-Pine Bluffs area $\ldots \ldots \ldots \ldots \ldots \ldots \ldots \ldots \ldots \ldots \ldots \ldots$ 455, 456

Fort McKinney quadrangle $\ldots \ldots \ldots \ldots \ldots \ldots \ldots \ldots \ldots \ldots$ GF 142

Fremont County ......................... 641 i

Goshen Hole quadrangle ...................... 70

Grass Creek Basin quadrangle ..................... 145

Lance Creek oil and gas field ...................... 716 e

Laramie area .......................... 455, 456

Laramie Basin ............................ B 364

Laramie quadrangle $\ldots \ldots \ldots \ldots \ldots \ldots \ldots \ldots \ldots \ldots \ldots$ GF 173

Lincoln County ............................... 543

Lodgepole Valley ............................ 425 b

Lost Soldier-Ferris district $\ldots \ldots \ldots \ldots \ldots \ldots \ldots \ldots \ldots \ldots \ldots \ldots$

Meeteetse quadrangle $\ldots \ldots \ldots \ldots \ldots \ldots \ldots \ldots \ldots \ldots \ldots \ldots$ P 145

Natrona County ......................... 641 i

Naval Petroleum Reserve No. 3...................P 163

Newcastle quadrangle $\ldots \ldots \ldots \ldots \ldots \ldots \ldots \ldots \ldots \ldots \ldots \ldots$ GF 107

northeastern ............................ 796 a

Oregon Basin quadrangle $\ldots \ldots \ldots \ldots \ldots \ldots \ldots \ldots \ldots \ldots \ldots$ P 145

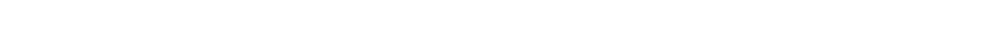

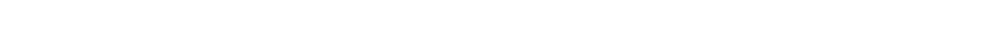

Powder River oil field $\ldots \ldots \ldots \ldots \ldots \ldots \ldots \ldots \ldots \ldots \ldots \ldots$ B 471 a

Randolph quadrangle ........................ 923

Salt Creek oil field $\ldots \ldots \ldots \ldots \ldots \ldots \ldots \ldots \ldots \ldots \ldots \ldots \ldots$ B 670

Salt Creek-Teapot Dome area .................... 163

Sherman quadrangle ........................... 173

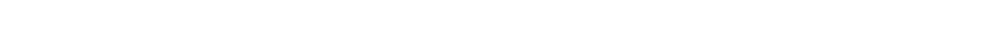

southwestern $\ldots \ldots \ldots \ldots \ldots \ldots \ldots \ldots \ldots \ldots \ldots \ldots \ldots \ldots \ldots \ldots$. 53

Sundance quadrangle $\ldots \ldots \ldots \ldots \ldots \ldots \ldots \ldots \ldots \ldots \ldots \ldots$ GF 127

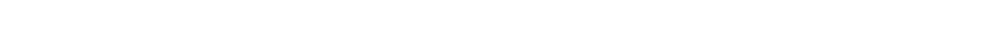

Uinta County .............................. 285

Yellowstone National Park .......W 364; A 9 d, 14 in $k:$ B 47, 395 artesian water in....W 425 b; A 21 Iv b; P 32, 51, 53, 65; B 285, 364, 543, $641 \mathrm{i}, 656,702,711 \mathrm{~h}, 781 \mathrm{~b}, 796$ a; GF 107, 127, 128, 141, 142, 150, 173 bibliography of ground water in .............W 61, 120, 149, 163 irrigation with ground water in ..........W 425 b; A 21 IV c, 22 IV.c mineral waters in ..............P 53; B 32, 641 ; $M$ ? 1883-1928 pumping in ................................... 425 b quality of ground water in. .W 364, 425 b; A 9 d, 21 iv b; P \&?; B 32, 47, 285, 364, 471 a, 641 i, 656; GF 107, 173

quantity of ground water in $\ldots \ldots \ldots \ldots \ldots \ldots \ldots \ldots \ldots \ldots \ldots \ldots \ldots$ salt water in $\ldots \ldots \ldots \ldots \ldots \ldots \ldots \ldots \ldots \ldots \ldots \ldots \ldots$ W $364 ;$ B 659,711 e, $h$ spring discharge measurements in $\ldots \ldots \ldots \ldots \ldots \ldots \ldots \ldots \ldots$ W 456 
Wyoming, springs in W 70,364, $679 \mathrm{~b} ; \mathrm{A} 9 \mathrm{~d}, 14 \mathrm{II} \mathrm{b}$; P 53, 145; J 32, 47, 364, $395,641 \mathrm{i}, 656,680,702,711 \mathrm{~h}, 717,781 \mathrm{~b}, 796 \mathrm{~d}, 806$ a, $921 \mathrm{~b}$; GF $173 ; \mathrm{J} 6,25,91$ thermal ........W 364, 679 b; A 9 d; P 53; B 32, 47, 395, 641 i, 680, $\mathrm{c} 21 \mathrm{~b} ; \mathrm{J} 6,25$

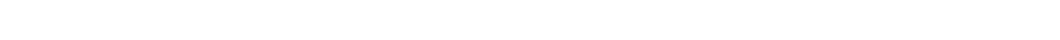
water table in ......................W 425 b; C 456; J 266 well records for ....W 61, 149; A $21 \mathrm{Iv} \mathrm{b;} \mathrm{P} \mathrm{32,} \mathrm{56,} \mathrm{65;} \mathrm{B} \mathrm{2£?,} \mathrm{364,} \mathrm{621} \mathrm{l,}$ $702,711 \mathrm{e}, 716 \mathrm{~b}, \mathrm{c}, 736 \mathrm{~d}, 781 \mathrm{~b}, 796 \mathrm{~d}, 804$; GF 107, 173

$\mathbf{Y}$

Yakima basalt, water in, in Washington. See Lava, water in.

Yates, R. G., Coso quicksilver district in Inyo County, Calif......... 936 q

Quicksilver deposits in San Luis Obispo County and southvestern

Monterey County, Calif ....................... 922 r

Yegua formation, water in, in Texas ............W 335, $375 \mathrm{~g}, 849$ a

Yellowstone National Park, quality of water in.....W 364; A 9 d; B 32, 47 radioactive waters in .................. 395; I $\mathrm{R} 1913$ II $\mathrm{h}$ springs and geysers in ...........W 364; A 9 d, 14 If b; B 47, 395

Yield of wells. See Wells.

Yonker, C. C., Water levels and artesian pressure in the United States

W $817,840,845,886$

Yorktown formation, water in, in North Carolina ............. 291

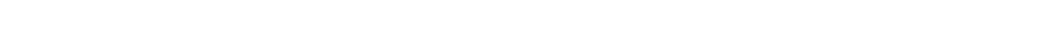
See also Chesapeake group.

$\mathbf{Z}$

Zinc in ground water W 254, 27?, 399; B 606

Zone of flowage, ground water in relation to $\ldots \ldots \ldots \ldots \ldots$ W 499, 494; M 47 Zone of fracture, ground water in relation to $\ldots \ldots \ldots \ldots . W 489,494 ; M 47$ Zone of saturation $\ldots \ldots \ldots \ldots \ldots \ldots \ldots \ldots \ldots \ldots \ldots \ldots \ldots \ldots$ W 335, 489, 494 Zones, deep, of ground water .........W 67, 489, 494; A 14 II b; M 47 